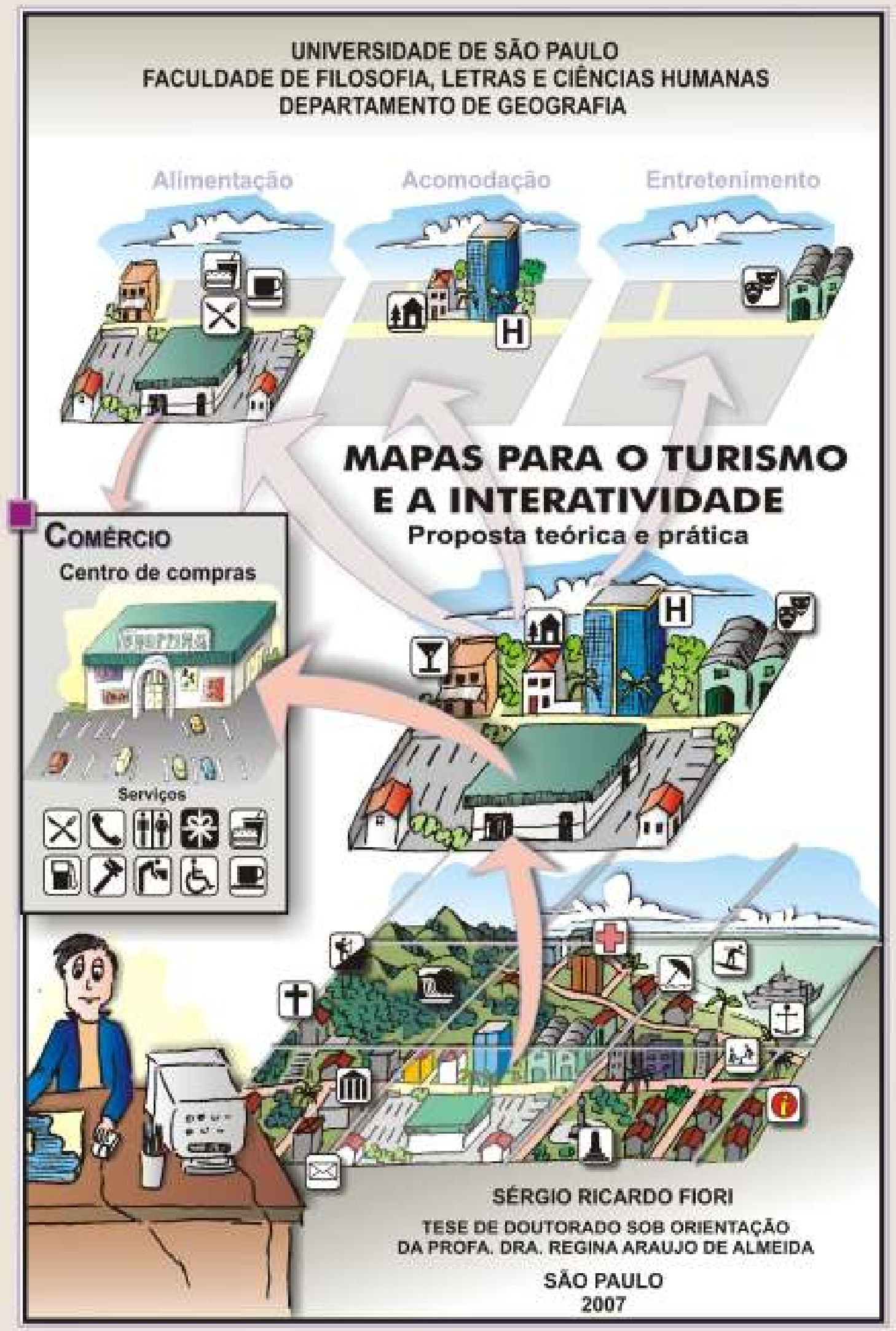




\author{
Universidade de São Paulo \\ Faculdade de Filosofia, Letras e Ciências Humanas \\ Departamento de Geografia \\ Programa de Pós-Graduação em Geografia Física
}

\title{
MAPAS PARA O TURISMO E A INTERATIVIDADE \\ Proposta teórica e prática
}

\author{
SÉRGIO RICARDO FIORI
}

TESE DE DOUTORADO SOB ORIENTAÇÃO DA PROFA. DRA. REGINA ARAUJO DE ALMEIDA

\section{SÃO PAULO}




\author{
Universidade de São Paulo \\ Faculdade de Filosofia, Letras e Ciências Humanas \\ Departamento de Geografia \\ Programa de Pós-Graduação em Geografia Física
}

\title{
MAPAS PARA O TURISMO E A INTERATIVIDADE
}

Proposta teórica e prática

\author{
SÉRGIO RICARDO FIORI
}

Tese apresentada ao Programa de Pós-Graduação em Geografia Física do Departamento de Geografia da Faculdade de Filosofia, Letras e Ciências Humanas da Universidade de São Paulo, para obtenção do título de Doutor em Geografia.

Orientadora: Profa. Dra. Regina Araujo de Almeida

SÃO PAULO 
Finalmente, a viagem conduz à cidade de Tâmara. Penetra-se por suas ruas cheias de placas que pendem das paredes. Os olhos não vêem coisas, mas figuras de coisas que significam outras coisas: a torquês indica a casa do tira-dentes; o jarro, a taberna; as alabardas, o corpo de guarda; a balança, a quitanda. (...) Se um edifício não contém nenhuma insígnia ou figura, a sua forma e o lugar que ocupa na organização da cidade bastam para indicar a sua função: o palácio real, a prisão, a casa da moeda a escola pitagórica, o bordel. Mesmo as mercadorias que os vendedores expõem em suas bancas valem não por si próprias, mas como símbolos de outras coisas: a tira bordada para a testa significa elegância; a liteira dourada, poder; os volumes de Averróis, sabedoria; a pulseira para o tornozelo, voluptuosidade (...) O olhar percorre as ruas como se fossem páginas escritas (Calvino, 1999, p.18, 19). 


\section{AGRADECIMENTOS}

Mais uma vez agradeço a Deus por ter me concedido paciência durante a espera. Como resposta às inúmeras orações, recebi maturidade, mas também realizações e alegrias ao longo de minha carreira acadêmica e profissional.

À minha orientadora, Regina Araujo de Almeida que, ao longo de oito anos, me mostrou o que é ser uma pessoa generosa, amiga, presente, possibilitando que minhas aspirações e sonhos se tomassem reais, verdadeiros. Obrigado por sua proximidade, seus estímulos e conselhos, viagens e trabalhos, e por abraçar desde sempre o meu tema de pesquisa.

À professora doutora Maria de Lourdes Beldi de Alcântara, por sua importante presença em minha pesquisa desde o mestrado, pois, sem o seu auxílio, muitos fundamentos teóricos passariam desapercebidos. Além disso, levo como aprendizado seu grande amor pelo outro, seu desprendimento, sua simplicidade, alegria e profissionalismo.

Aos professores doutores Ailton Luchiari e Alfredo Pereira de Queiroz Filho, respectivamente pelo apoio e compreensão.

A CAPES (Coordenação de Aperfeiçoamento de Pessoal de Nível Superior), pela importante e fundamental ajuda financeira, pois, sem essa base, teria sido muito difícil a realização de boa parte do trabalho.

À Silvânia Soares, que tenho a impressão de conhecer há anos apesar do pouco tempo de amizade. Obrigado pela ótima companhia de viagem, pelas inúmeras e infindáveis conversas, a camaradagem e a ajuda incondicional, quando necessária.

As amigas Aline Alves Bittencourt e Rosiane da Silva Mateus, pelas conversas e ajuda na elaboração dos vários mapas realizados ao longo da pesquisa.

A cinco pessoas essenciais na fase de finalização do trabalho: Silvânia Soares, Vanda Bartalini Baruffaldi, Magda Araújo, Vera Jordan Aguiar e Sidnei Ono.

Aos amigos que ajudaram ou se fizeram presentes em algum momento desta tese. Em especial, gostaria de registrar o nome de alguns deles: Waldirene Ribeiro, Carmem Marega, Aline Souza, Daniel Zungolo Teixeira, Giovanni Ballarin e todos os professores que participaram do Projeto Caminhos do Futuro.

A meus pais, Antônio e Cleuza, pelas conversas, proteção, carinho e amor sempre constantes. Vocês são um grande exemplo para nova etapa da minha vida que se inicia.

À Letícia pela compreensão, apoio, amizade, companheirismo e amor que me transforma em um ser melhor, mais feliz e completo. Brindo ao futuro que nos espera.

A todos muito obrigado! 


\section{RESUMO}

Os mapas inserem-se no dia-a-dia das pessoas de forma cada vez mais presente. A mídia - telejornais, revistas, anúncios de propaganda imobiliária, internet, jornais, mapas artísticos e de propaganda, etc. - ao utilizá-los como um meio de comunicação, na maioria das vezes, ignora algumas regras básicas na relação produtor e público usuário.

No bojo desses materiais cartográficos, encontram-se os mapas turísticos, que usualmente são confeccionados por artistas e ilustradores e não por geógrafos ou cartógrafos.

Esta pesquisa, fundamentada essencialmente na cartografia temática, propõe aprofundar e estreitar a metodologia iniciada e experimentada no mestrado, que abordou o uso das representações pictóricas e da visão oblíqua em mapas direcionados a turistas e leigos em cartografia. Tal recurso gráfico possibilita um menor nível de abstração da representação gráfica, trazendo comprovadamente uma maior facilidade de leitura da informação cartográfica. Além disso, é visualmente mais atrativa, por evocar conotações visuais, afetivas e emotivas.

Ainda utilizando a pictografia e os símbolos de informação pública, é proposta uma legenda específica aos mapas turísticos, símbolos esses que são elaborados para que as pessoas os vejam e os interpretem/ compreendam sem nunca tê-los visto antes.

Entretanto, é bom frisar que os símbolos e mapas convencionais também farão parte do produto cartográfico final, até porque, mesmo trabalhando potencialmente com mapas pictóricos para o setor do turismo, algumas informações são particularmente mais apropriadas e diretas se feitas por meio da convencionalidade.

Soma-se a esta discussão, o desenvolvimento de mapas temáticos para o turismo em meio digital. Esses novos recursos técnicos possibilitam o desenvolvimento de mapas não-limitados a uma folha de papel, proporcionando representações interativas, animadas, sonorizadas, em diferentes idiomas, entre outras possibilidades.

Nesse item, além da elaboração e uso do produto em si, há uma preocupação particular em encontrar relações entre o mapa, a mencionada interatividade e o usuário, nunca esquecendo que o material temático dirigido ao turismo deve não só se preocupar em fazer com que a informação seja adequadamente apreendida pela leitura como também se esmerar em ser atrativo, sedutor, a fim de estimular a curiosidade sobre a localidade representada.

Palavras-chave: Cartografia, Pictografia, Confecção de Mapas, Interatividade e Turismo. 


\begin{abstract}
The maps are going into people's day-to-day on an increasingly basis. The media (telenews, magazines, real estate advertisements, the Internet, newspapers, artistic and advertising maps, etc.), when using them as a communication means, most of times pays no attention to some basic rules in the user-producer relation.

In the heart of these cartographic materials are the tourist maps usually elaborated by artists and illustrators, instead of geographers and/or cartographers. Therefore, this research based essentially on the thematic cartography, aims at going deeper and narrower into the methodology initiated and experienced in the master degree, which dealt with the use of pictoric representations and the oblique vision in maps oriented specifically to tourists and laymen in cartography. The reason is that such graphics resources allow a lower level of abstraction of the graphics representation, bringing unmistakably a higher simplicity to the cartographic reading. Besides, it is visually more attractive as it evokes visual, affective and emotive connotations.

In addition, a specific subtitle is suggested to the tourist maps by making use of the pictography and symbols of public information. Such symbols are elaborated in order for people to see them, interpret them and understand them without have never seem them before.

However, it's important to emphasize that the conventional symbols and maps will also be part of the final cartographic product, because even working potentially with pictoric maps to the tourism sector, some information is especially more adequate and obvious trough the conventionality.

The development of thematic tourism maps for use in the digital media is also added to this study. These new technical resources allow the development of maps which are not limited to a sheet of paper, providing interactive, animated, sonorized representations, in different languages, among many other resources.

In this item, besides the elaboration and use of the product itself, there is a special concern on the map, the interactivity and the user, without never forgetting that the thematic material - tourism - must always bring a good understanding of the information (reading), and motivation (attractiveness, curiosity) towards the locality represented.
\end{abstract}

Key-words: Cartography, Pictography, Elaboration of Maps, Interactivity and Tourism. 


\section{SUMÁRIO}

Índice das figuras

\section{CAPÍTULO 1: Uma cartografia para o turismo: pictografia e interatividade}

1.1 - As novas possibilidades de se conceber um mapa:

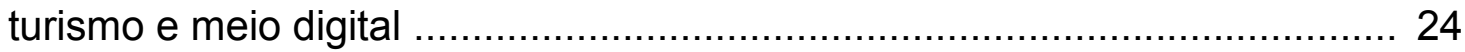

1.2 - O ato de cartografar: cultura e a representação do outro ............................ 29

1.3 - Quando as tradições se institucionalizam:

a semântica para iniciados versus o senso comum................................... 45

1.4 - O mapa, o tempo e as diferentes formas de se representar o espaço ............ 65

1.5 - As bases semiológica e cartográfica:

proposta de um mapa temático para o setor do turismo

1.6 - O processo perceptivo: recolhendo imagens e elaborando representações. 101

1.7 - A arte e o desenho como recurso à cartografia

\section{CAPÍTULO 2: Técnicas e procedimentos utilizados na elaboração dos mapas turísticos e do protótipo mapa-site turístico}

2.1 - As mídias e suas respectivas técnicas: trabalhando a forma e o conteúdo.. 147

2.2 - Símbolos de informação pública:

pictogramas utilizados em mapas turísticos

2.3 - Elementos que compõem a multimídia interativa: aplicação em um mapa .. 193

2.4 - Breve crítica e proposta para a elaboração dos mapas e

o protótipo de um mapa-site turístico do município de Caxambu ................. 218

2.5 - Processo de elaboração dos mapas e do mapa-site turístico 


\section{CAPÍTULO 3: Avaliação e análise dos mapas, dos símbolos de informação pública e do mapa-site turístico de Caxambu}

3.1 - Desenvolvimento do estudo empírico .................................................... 240

3.2 - O material cartográfico em avaliação ................................................... 242

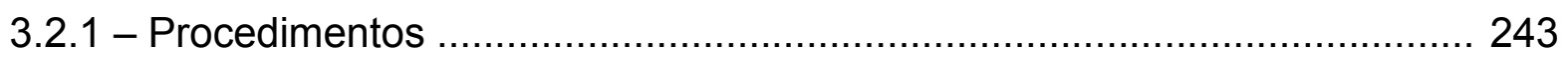

3.2.2 - Coleta e processamento das informações ………................................. 254

3.2.3 - Apresentação e discussão dos resultados ........................................... 261

3.2.4 - Análise dos resultados ............................................................ 280

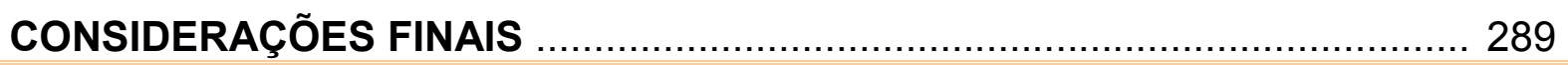

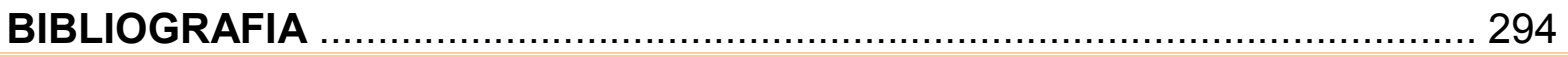

\section{CD - ANEXOS}

Pasta 1 - Mapas pictóricos - Trabalho de Graduação Individual (TGI) - 1999:

"Atlas Pictórico - proposta metodológica para a confecção e uso didático".

Pasta 2 - Mapas convencionais e pictóricos de llhabela (SP) e São Vicente (SP) Dissertação de Mestrado - 2003:

"Mapas turísticos: o desafio do uso da arte na era digital".

Pasta 3 - Mapas convencionais e pictóricos desenvolvidos durante a pesquisa:

Foz do Iguaçu (PR), Caxambu (MG), Manaus (AM) e

São Raimundo Nonato (PI).

Pasta 4 - Mapa turístico (escaneado) de Caxambu - Edição janeiro de 2003.

Todos os direitos reservados a Editora Buz.

Pasta 5 - O site elaborado para a pesquisa.

Pasta 6 - O protótipo mapa-site turístico de Caxambu elaborado para a pesquisa. 


\section{ÍNDICE DE FIGURAS}

01 - Perspectivas e dimensões da cartografia .......................................... 31

02 - Naturezas-culturas: quatro tipos de relação ……................................. 32

03 - $\mathrm{O}$ contexto e a escala do relativismo ……...................................... 34

04 - O arco interpretativo entre a natureza, o mediador e a cultura ................. 37

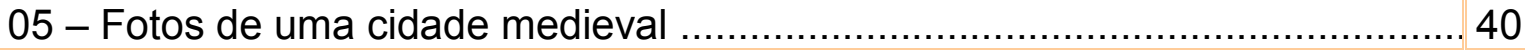

06 - Pictografia usada em mapas político e físico ........................................ 50

07 - Traços visuais: o conceito da girafa ................................................. 52

08 - Traços característicos do elemento representado: a schemata .................. 52

09 - Mapas e símbolos convencionais .................................................... 57

10 - Níveis de abstração do símbolo ........................................................ 57

11 - Mapas e símbolos pictóricos ......................................................... 58

12 - Símbolos superficiais ................................................................ 59

13 - Símbolos profundos ................................................................. 59

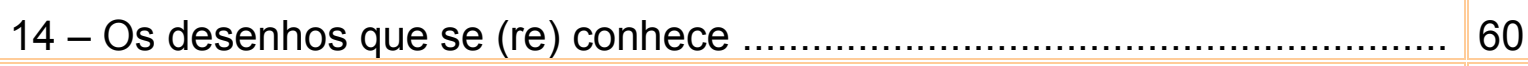

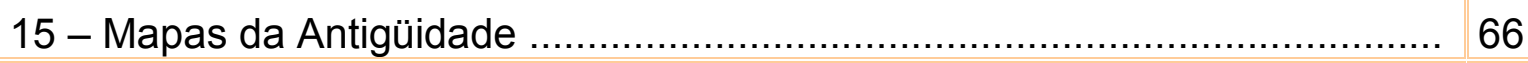

16 - A simplicidade do mapa Orbis Terrarum ........................................... 67

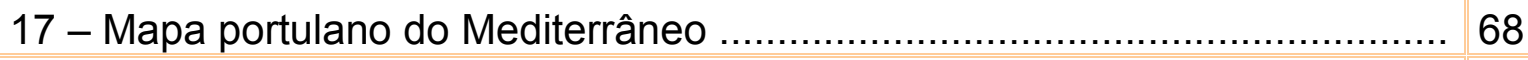

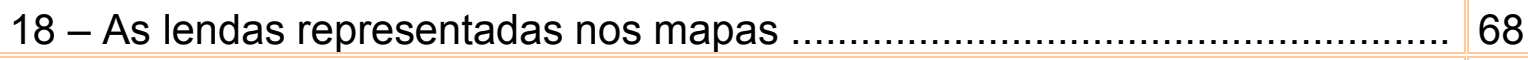

\begin{tabular}{|l|l}
19 - Exemplo de desenhos pictóricos encontrados em guias náuticos & 70
\end{tabular}

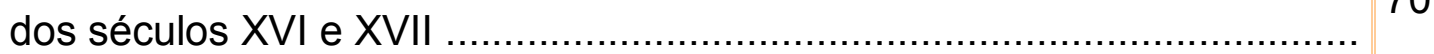

20 - Mapas com base na triangulação ....................................................... 71

21 - A evolução no processo do sensoriamento remoto …........................... 73

22 - As projeções de Mercator e Peters .................................................. 76

23 - Representações gráficas de Nova lorque ............................................ 81

24 - Comunicação em cibercartografia ................................................... 82

25 - Perfil e informação apropriada: o usuário e a multimídia interativa ........... 83

26 - $O$ ato de cartografar: as relações e interesses que envolvem um mapa turístico 85

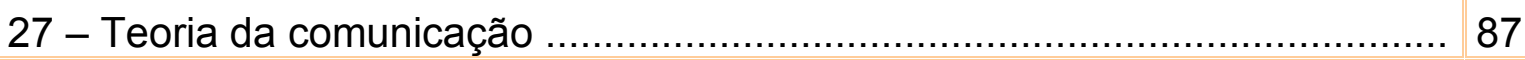

28 - A mensagem denotada e conotada ................................................ 90

29 - Signos dominante e especificador ……………............................. 92

30 - O ícone: o desenho fala por si ........................................................ 93

\begin{tabular}{|l|l|}
\hline 31 - O índice: o desenho não guarda semelhança direta com o & 94
\end{tabular} que representa 
32 - Símbolo: o desenho desenvolvida através de normas e convenções ....... 95

33 - Símbolos cartográficos .................................................................. 95

34 - Dois níveis de representação da mesma realidade .............................. 96

35 - As variáveis visuais segundo Bertin e MacEachren ............................. 98

36 - Exemplos de variáveis visuais ....................................................... 99

37 - "Captando" a imagem ...................................................................... 103

38 - Motivações para se viajar: fatores "push"e "pull" .................................. 109

39 - Atividade da oficina do Projeto Caminhos do Futuro:

o espaço e a sua imagem

40 - Representações materiais e imateriais representativas da paisagem ....... 119

41 - Estabelecimento de três níveis de dificuldade para as trilhas em Ilhabela 122

42 - Alguns ícones do patrimônio cultural de São Paulo ............................... 124

43 - As formas substitutas da paisagem ............................................... 126

44 - Maneiras de se abordar o desenho ................................................. 136

45 - Três tipos de representações pictóricas ……..................................... 137

46 - A mudança das representações icônicas ao longo do tempo e da cultura 140

47 - Maneiras de se elaborar um pássaro ................................................... 142

48 - O experimento de Ryan e Schwarz ................................................. 144

49 - Esquema dos tipos de signos gráficos............................................ 148

50 - As qualidades sintático-semânticas dos signos gráficos ......................... 149

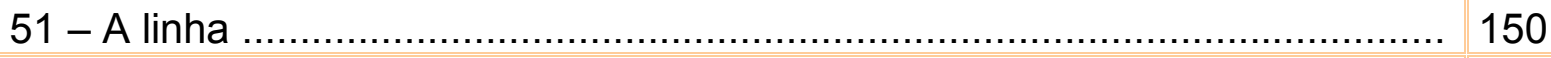

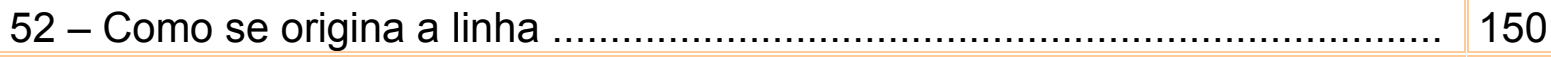

53 - A linha e suas possibilidades de expressão ...................................... 151

\begin{tabular}{|l|l|l|}
\hline 54 - Feira livre: formas básicas de uma representação gráfica ................ & 152 \\
\hline
\end{tabular}

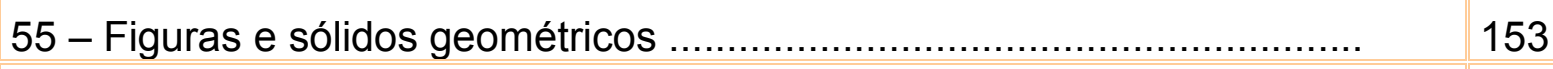

\begin{tabular}{|l|l|}
56 - Exemplos de planos pictóricos em perspectiva ................................. & 154
\end{tabular}

\begin{tabular}{|l|l|l}
57 - Luz e sombra proporcionando o efeito tridimensional................................ & 154
\end{tabular}

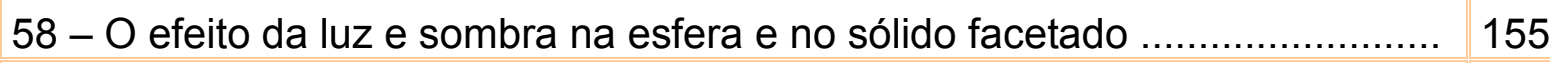

59 - Composições em luz e sombra ......................................................... 156

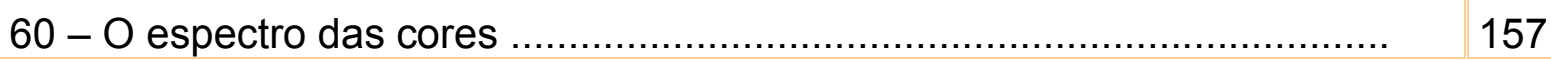

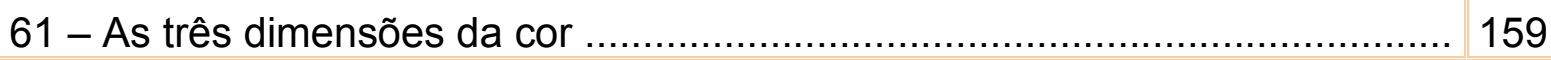

62- Busca de cores similares para os mapas dispostos em um monitor de computador (RGB) e impressos (CMYK)

63 - O "volume" das cores .............................................................. 165

64 - Transparência e sombreamento de ilustrações e objetos ........................ 166 
65 - A textura e suas qualidades visuais ............................................... 168

66 - Proporção e escala ..................................................................... 169

67 - Vocação turística: primeiro impacto visual........................................... 171

68 - Composição de um mapa pictórico com variáveis e elementos visuais .... 172

69 - Articulação texto e imagem .............................................................. 173

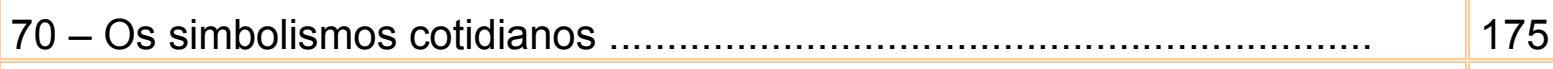

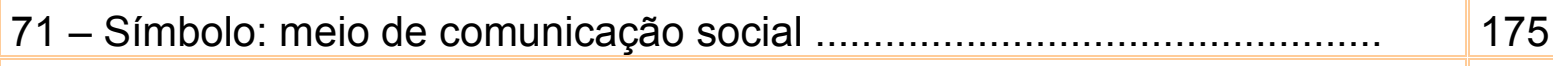

\begin{tabular}{|l|l|l|}
72 - Que representam e o que dizem essas formas gráficas? ..................... & 178
\end{tabular}

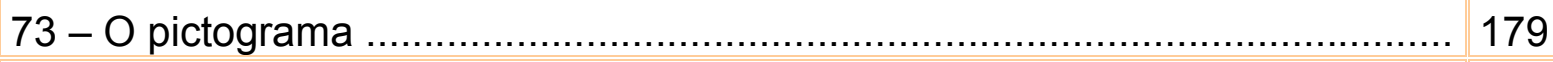

74 - Estrutura inicial de um sistema de sinalização turística ............................ 180

\begin{tabular}{ll|l}
75 - As modificações das representações gráficas ao longo do tempo ............ & 181
\end{tabular}

76 - Pictogramas: versões de um mesmo conceito ...................................... 182

77 - Os três níveis de pictogramas ........................................................... 183

78 - Componentes típicos de um título em multimídia interativa ...................... 195

79 - Os três níveis de conteúdo do mapa interativo ...................................... 200

80 - Simcity $\AA$ : referência para os mapas turísticos interativos........................ 200

81 - Legendas minterativas pop up ...................................................... 203

82 - Exemplo de um fundo-cenário: Caxambu ......................................... 203

83 - Linhas e as figuras geométricas básicas para elaborar um cenário ......... 204

84 - A perspectiva isométrica e cavaleira ............................................... 205

85 - A perspectiva cônica .............................................................. 205

86 - As três posições da perspectiva ................................................... 206

87 - Desenhos com um ou dois pontos de fuga ......................................... 207

88 - São Vicente: desenho confeccionado em perspectiva paralela ............... 207

89 - Os diferentes tipos de símbolos pontuais interativos ............................. 208

90 - Conceito de hipermapa pela hipermídia geo-referenciada .................... 212

91 - A escolha de imagens e o resultado no processo de zoom ..................... 213

92 - Pré-estabelecendo os níveis de zoom ............................................ 214

93 - O site do DG-USP: um exemplo de zoom dinâmico ............................. 215

94 - As barras de rolagem: o recurso pan ................................................ 216

95 - Tipos de pop up ............................................................... 220

96 - Mapas turísticos e a despreocupação com as regras cartográficas ......... 221

97 - O mapa-site turístico de Caxambu e alguns outros exemplos .................. 226

98 - A pictografia sob uma planta cadastral e uma carta topográfica .............. 226

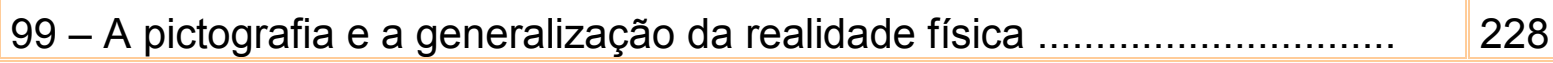


100 - llustrações dos atrativos naturais, culturais e de ação nos mapas turísticos

101 - Direcionamento da informação: ilustração e o complemento texto 229

102 - A legenda geral e turística 230

103 - A legenda: redundância e sedução 231

104 - Bordas ilustradas 232

105 - Os layers dos mapas 233

106 - Seqüência de confecção da base ilustrada 235

107 - Readequação gráfica e digitalização dos SIPs 236

108 - As quatro etapas de zoom do protótipo mapa-site de Caxambu 237

109 - Exemplos de elementos interativos do protótipo mapa-site de Caxambu 238

110 - A advertência para acesso no tema 3 do site 286 


\section{ÍNDICE DE TABELAS}

1 - Principais grupos de necessidades e empresas de turismo ..................... 80

2 - Acomodação e hospedagem ............................................................ 186

3 - Serviços turísticos .................................................................. 187

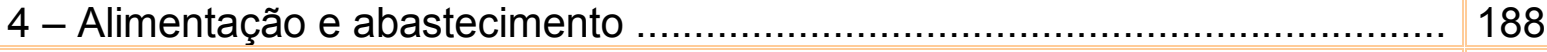

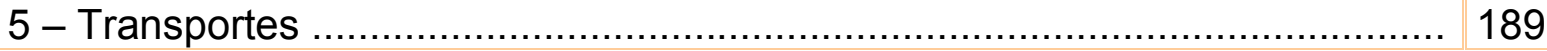

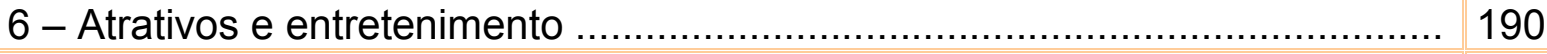

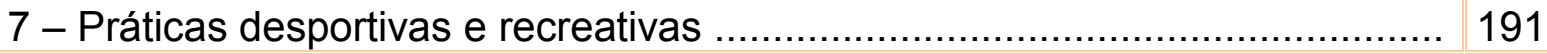

8 - Pictogramas usados pelo site do albergue da juventude internacional ....... 192

9 - Discriminação dos sujeitos que responderam o questionário in loco segundo a idade, o grau de escolaridade e a profissão

10 - Discriminação dos sujeitos que responderam o questionário pelo site segundo a idade, o grau de escolaridade e a profissão

11 - Questionários respondidos e aceitos para a tabulação

12 - Respostas ao se olhar os símbolos de informação pública (respostas dissertativas)

13 - Respostas referentes a dualidade: convencional e pictórico .................. 257

14 - Respostas dadas aos símbolos de informação pública e a escala numérica (respostas alternativas)

15 - Respostas referentes ao protótipo mapa-site turístico de Caxambu ........ 260

16 - Médias amostrais dos símbolos de informação pública (respostas dissertativas)

17 - Valores amostrais quanto a preferência entre o mapa convencional ou pictórico

18 - Médias amostrais dos símbolos de informação pública e a escala numérica 


\section{INTRODUÇÃO}

Desde o primeiro ano de minha graduação no Departamento de Geografia da Universidade de São Paulo, sempre tive um interesse especial pela cartografia, mais especificamente, pela cartografia temática. A partir daí, iniciei uma trajetória como pesquisador. Durante a graduação, por um período de 18 meses (03/1997 a 08/1998), contei com uma bolsa de Iniciação Científica concedida pela FAPESP (processo 96/1054-1). Posteriormente, tal pesquisa foi complementada em meu TGI (Trabalho de Graduação Individual), recebendo o título final de Atlas Pictórico proposta metodológica para a confecção e uso didático. Em síntese, essa pesquisa buscou formas de estimular e motivar crianças à leitura do mapa (alunos de $5^{\mathrm{a}}$ e $6^{\mathrm{a}}$ séries do ensino fundamental, cuja faixa etária oscilava entre os 11 e 12 anos).

Para atingir meus objetivos, iniciei os estudos tendo como base teórica a semiologia gráfica proposta por J.Bertin. Neles enfatizei as seguintes variáveis visuais: tamanho; cor (buscando um suposto volume) e forma (grande uso da perspectiva).

Desde o princípio, tinha muito interesse em trabalhar com as representações nãoconvencionais, ou seja, fazer uso do desenho pictórico que, somado à visão oblíqua, pudesse facilitar o processo de abstração do usuário, gerando um maior interesse e apreensão das informações contidas no mapa.

A pesquisa de Iniciação Científica possibilitou a elaboração de dezenove mapas ilustrados em tamanho de folha A2 $(420 \times 594 \mathrm{~mm})$ e A3 $(297 \times 420 \mathrm{~mm})$ a partir da técnica da aquarela para acabamento (ver mapas em CD - anexos - pasta 1).

Os resultados dessa primeira pesquisa confirmaram a aceitação dos produtos cartográficos propostos. Um exemplo foi o comentário de uma professora que aplicou o teste com os mapas a 120 crianças: Elas demoraram mais para responder o questionário dos mapas pictóricos, por ficar um tempo maior observando, conversando entre eles. Ficaram muito interessados. Mesmo em relação à quantidade de respostas satisfatórias, os mapas pictóricos obtiveram uma média percentual muito positiva quanto à sua avaliação: $78,5 \%$ das respostas estavam corretas.

Sendo assim, o objetivo foi alcançado, principalmente por conceber um tipo de representação que motivou o aluno à leitura do mapa. Além disso, a decodificação das representações elaboradas conseguiu ser eficaz aos estudantes, devido ao fato de a informação estar mais próxima da realidade do público potencial. Os resultados possibilitaram dar continuidade à pesquisa criando condições para um aprofundamento da proposta teórico-metodológica.

O mestrado foi iniciado em março de 2000 e, por diversas razões, acima de tudo acadêmicas e metodológicas, optei por trabalhar com a confecção de mapas voltados a um outro tipo de público, o turista, que se caracteriza por ser um grupo muito 
heterogêneo quanto à idade, grau de escolaridade, capacidade de decodificação da informação cartográfica, entre outros aspectos.

Continuei motivado a aprofundar o estudo sobre as diferentes formas de representação dos símbolos empregados em mapas, ainda evidenciando o uso das figuras pictóricas, devido à sua capacidade de possibilitar algumas semelhanças físicas com o fenômeno representado e, portanto, dispondo de um tipo de informação mais acessível ao usuário leigo em Cartografia. Até porque, além de a representação pictórica caracterizar-se por um baixo nível de abstração e uma informação voltada ao olhar mais atrativa, pode evocar conotações visuais, afetivas e emotivas. Esses fatos possibilitam condições de valorização da paisagem, que é utilizada com freqüência na consolidação e difusão da atividade turística, associada à idéia do lazer e do prazer.

Em julho de 2000, obtive uma nova bolsa de pesquisa pela FAPESP (processo 00/03940-4) por um período de 24 meses (07/2000 a 07/2002), para desenvolver um trabalho de mestrado. A dissertação final foi intitulada: "Mapas turísticos: o desafio do uso da arte na era digital".

A pesquisa resultou na confecção de seis mapas, dois convencionais e quatro pictóricos, em tamanho de folha A1 (594 x $841 \mathrm{~mm})$. Os produtos representaram duas cidades do litoral paulista: Ilhabela e São Vicente.

Essa etapa proporcionou uma discussão referente ao uso dos formatos analógico com todo o processo técnico de confecção desenvolvido manualmente (uso de lápis colorido, caneta nanquim e a tinta aquarela) - e digital - utilização do computador (programas Corel DRAW e Adobe Photoshop).

O desenvolvimento empírico da pesquisa resultou da aplicação de 160 questionários, voltados a tipos de públicos distintos: o morador local (cidades de llhabela e São Vicente) e o turista (pessoas que não moravam em algumas cidades da grande São Paulo). Seguiu-se, então, a tabulação das respostas colhidas, permitindo uma análise crítica quanto à eficácia dos símbolos propostos e a identificação da preferência quanto ao tipo de mapa confeccionado (convencional ou pictórico). De forma geral, no que diz respeito ao produto cartográfico para o turismo, houve uma aceitação expressiva dos mapas pictóricos $(87 \%)$ em relação aos convencionais $(13 \%)$. É importante ressaltar que $73 \%$ dos usuários optaram pela visão oblíqua quanto ao tipo de representação da morfologia do terreno (ver mapas em CD - anexos - pasta 2).

Durante esses anos, o trabalho como pesquisador possibilitou ricas experiências acadêmicas como, por exemplo, qualificação de professores em muitas cidades brasileiras, encontros nacionais e internacionais, produção de materiais, etc. $O$ destaque maior foram as oficinas de qualificação a professores da rede pública, onde se trabalharam conteúdos referentes à cartografia temática direcionada ao setor do turismo. Inicialmente as atividades ocorriam por intermédio de uma parceria entre 0 LEMADI (Laboratório de Ensino e Material Didático), a AVT (Academia de Viagens e 
Turismo) e o IAP (Instituto de Academias Profissionalizantes). Posteriormente, fui convidado a participar do Projeto Caminhos do Futuro - parceria do Ministério do Turismo, do IAP, da AVT e do Núcleo de Turismo da Universidade de São Paulo. A última oportunidade possibilitou aplicar, de maneira prática, alguns pontos de minha pesquisa em dezesseis municípios brasileiros. Tudo isso só fez aumentar meu interesse pela busca teórica e prática quanto à maior e mais eficaz utilização do recurso pictográfico na cartografia atual.

Enfim, as pesquisas teóricas e práticas evidenciam que as representações pictóricas e o uso da visão oblíqua têm uma preferência significativa do turista e do público leigo na semântica cartográfica. Por causa disso, continuo a discussão, que considera o mapa como um produto cultural, e todas as implicações advindas da relação: tempo, formas de representar o espaço e tipos de usuários para o mapa.

Desse modo, esta etapa marca o aprofundamento teórico-metodológico da pesquisa. Efetiva-se a utilização da pictografia na elaboração de mapas. Ela pode representar desde a morfologia do terreno, ilustrações diversas sobre vários temas contidos no espaço (atrativos naturais e culturais), até a idealização de uma legenda coerente e eficaz ao público potencial por meio dos símbolos de informação pública.

Muehrcke (1986) corrobora que o grau de abstração dos símbolos pictóricos apresenta um maior apelo estético e parece ser mais apreciado e mais bem decodificado por crianças e usuários que tenham pouco contato com materiais cartográficos.

Soma-se ainda que, devido à forma de apresentação do futuro material cartográfico o protótipo de um mapa-site turístico - o público-alvo precisa ter conhecimentos mínimos sobre o ambiente Windows e a Internet.

Em verdade, a cartografia, não diferente de outras disciplinas da era da informação, vem sofrendo uma mudança substancial conduzida, principalmente, pelo desenvolvimento tecnológico nos campos da computação e da telecomunicação. Hoje os cartógrafos têm a grande oportunidade de utilizar as novas ferramentas disponibilizadas pela multimídia, o que possibilita um novo e excitante caminho. Essa mudança gerou uma interação dinâmica entre o usuário e o produto, a qual nunca havia sido possível anteriormente (Taylor, 1996). Todavia, ressalte-se que aproximadamente $90 \%$ do trabalho desenvolvimento pelo SIG (Sistema de Informação Geográfica) está de alguma maneira associado à simples digitalização de mapas já existentes.

Contudo, essas novas técnicas de produção oferecem novas oportunidades de pensar o mapa e, no caso específico dos mapas turísticos, deve-se levar em consideração fatores essenciais, relacionados às questões da apresentação gráfica do material e do marketing turístico. Brown, Emmer e Worm (2001) ratificam que a qualidade do design é vital nesse veículo, que precisa ser eficaz ao usuário (indicar a 
localização no espaço, ser motivador), além de servir como material de divulgação turística.

Kokkonen e Peltonen (1999) nos ensinam que um bom mapa turístico deve permitir que o usuário planeje e prepare suas atividades, além de se caracterizar como um produto funcional e esteticamente prazeroso, podendo contribuir com a expectativa dos visitantes e em uma total satisfação pela viagem.

Os futuros mapas turísticos e aqueles adaptados e elaborados ao meio digital interativo deverão servir tanto ao turista (nacional e internacional) quanto ao morador da cidade que queira conhecer a disponibilidade das inúmeras atividades de lazer do município, como, por exemplo, museus, centros de convivência, teatros, parques, feiras, shoppings, restaurantes, etc. Também se deve dispor, por exemplo, de informações úteis e curiosas, que vão desde um breve histórico sobre a cidade e de alguns dos seus bairros, até a confecção de mapas da rede de ônibus, metrô e trem, localização de hotéis e hospitais, entre outros equipamentos urbanos.

Encontram-se, a seguir, a exposição de elementos que direcionaram a pesquisa.

\section{A justificativa e o tema}

Como todas as outras áreas que atuam na construção do conhecimento contemporâneo, a cartografia não pode ser tratada apenas com os olhos da tradição. Sem que se pretenda menosprezar as conquistas até aqui obtidas, é imprescindível que se lance aos mapas um olhar de modernidade o que, para esta pesquisa, significa buscar novas estratégias de representar os mesmos fenômenos geográficos.

A necessidade de recortar o vasto campo oferecido pelo estudo dos mapas forçou o estabelecimento de limites à área de atuação. Assim, circunscreve-se o interesse aos mapas turísticos, justificando que:

a. Diferentes tipos de usuários merecem diferentes tipos de mapas.

b. Os mapas pictóricos são muito utilizados pelo setor do turismo e por turistas, cuja maioria é constituída por leigos em semântica cartográfica.

O tema central deste trabalho é o estudo das formas de representação convencional e pictórica. Enfatiza, porém, o uso da pictografia e, por conseqüência, da visão oblíqua em mapas temáticos para o turismo.

Nesse tema, podem-se ainda identificar sub-temas:

a. O mapa e o marketing turístico.

b. Proposta de uma legenda específica para mapas turísticos.

c. A cartografia em meio digital interativo. 


\section{A hipótese e o problema}

A hipótese segundo a qual os mapas com grande uso da pictografia têm mais aceitabilidade tanto por leigos na semântica cartográfica quanto por turistas, já havia sido considerada em trabalhos anteriores (Fiori 1999 e 2003). Além dessa, pressupõem-se outras hipóteses:

a. Os mapas pictóricos são mais adequados para incentivar o turismo.

b. O usuário prefere utilizar os mapas turísticos pictóricos na destinação.

c. Os símbolos de informação pública podem ser adaptados em legendas de mapas turísticos.

d. É possível a inserção dos mapas turísticos em meio digital e interativo.

A feitura desse tipo de objeto, entretanto, não é simples. O questionamento parte de problemas como:

a. Aprofundamento do uso da pictografia e da visão oblíqua em mapas temáticos para o turismo.

b. De que forma desenvolver um mapa turístico em meio digital, transmitindo de maneira interativa os elementos espaciais e as inúmeras atividades de uma localidade.

c. De que maneira conferir a ele o mencionado caráter interativo.

d. Quais recursos devem ser utilizados para que se atinjam pessoas de perfis diversificados.

A tese

Neste trabalho, defende-se a idéia de que, não obstante o grau de complexidade, é possível formular um mapa turístico pictórico e interativo, dirigido a indivíduos de exigências diversas, sendo capaz de expor as várias opções de lazer oferecidas por uma dada localidade.

Objeto e objetivo de estudo

Conforme tem sido registrado, esta pesquisa focaliza o desenvolvimento de mapas para o setor do turismo, passíveis de serem veiculados pelos ambientes digitais.

Relacionam-se, a seguir, os propósitos a serem perseguidos neste trabalho.

a. Aprofundar a metodologia que focaliza o uso das representações pictóricas e da visão oblíqua em mapas destinados a turistas e a leigos em cartografia. 
b. Oferecer subsídios para facilitar o processo de abstração do usuário pelo emprego do desenho pictórico somado à visão oblíqua.

c. Estudar a relação entre cultura e trabalho cartográfico.

d. Estimular a criação de mapas pictóricos.

e. Mostrar a necessidade de relacionar a confecção de mapas a seus usuários.

f. Formular uma legenda específica para esse tipo de material a fim de facilitar a leitura ao usuário.

g. Incrementar a proposta de desenvolver, em meio digital, mapas temáticos destinados ao turismo.

h. Buscar um modo eficaz e eficiente de realizar a interação entre usuário e mapa.

\section{Fundamentação teórica}

Alguns modelos teóricos servirão de apoio ao desenvolvimento desta pesquisa.

Inicialmente, conforme já se fez referência, serão utilizados os princípios da Teoria da Comunicação, uma vez que se parte da premissa de que o objeto cartográfico permite a interlocução entre dois indivíduos: o que produz o mapa e aquele que o lê.

O fato de partir do princípio de que os sujeitos que atuam no processo comunicativo são fruto de coordenadas espaciais e temporais, faz com que esta pesquisa parta de autores como Harley e Woodward (1987), Monmonier (1996), Latour (1994), Canclini (2003) e Barthes (1971, 1990 e 1995) dentre outros, que enfatizam a impossibilidade de negar a relação entre cultura, produtos híbridos e forma de leitura na confecção do mapa. Um dos fortes argumentos em favor dessa afirmação se baseia em como o sujeito adquire a informação espacial, que se caracteriza por uma imagem seletiva do espaço. Um outro fator não menos importante refere-se à subjetividade das representações gráficas, tanto de quem as vê quanto de quem as produz.

Acreditar que o produto cartográfico preenche um espaço intersubjetivo significa concebê-lo como um objeto significativo. Vale dizer: não se escolheram nem se usaram de modo aleatório os traços que compõem um mapa. Ao contrário, eles foram orquestrados com cuidado para servir de instrumento de comunicação. Esse esforço de olhar o mapa como um elemento de significação mostra a influência de um modelo semiótico, aqui representado pelo pensamento de Roland Barthes.

É importante considerar ainda que, para atingir a contento seu objetivo, a cartografia não deve relevar cuidados com a estética. A lembrança evoca, portanto, referências feitas a teorias que se preocupam com o belo. 


\section{Metodologia}

Relacionam-se abaixo as etapas seguidas para a elaboração desta tese. Nela se encontra não apenas o viés quantitativo como o qualitativo: o primeiro por registrar dados obtidos em pesquisa de campo; o segundo pelo trabalho de análise desenvolvido no objeto de estudo.

Leia-se então a seqüência de atividades que culminaram com a elaboração deste trabalho.

a. Estudo das representações gráficas presentes em todas as etapas do protótipo mapa-site turístico.

b. Seleção dos recursos técnicos necessários para a criação dos mapas e do protótipo mapa-site turístico.

c. Elaboração dos produtos. Emprego dos programas CorelDRAW, Adobe Photoshop e Dreamweaver.

d. Concepção digital dos símbolos convencionais e pictóricos.

e. Concepção analógica das ilustrações a serem digitalizadas.

f. Produção dos mapas em português e inglês.

g. Avaliação do produto cartográfico desenvolvido.

h. Aplicação de duas pesquisas paralelas, com dois tipos de público pesquisados:

- Professores da rede pública de 14 estados brasileiros.

- Pessoas que acessaram o site elaborado para a pesquisa.

\section{Estrutura da tese}

A tese é composta por três capítulos:

O primeiro capítulo trata dos fundamentos teóricos de uma pesquisa interdisciplinar, estabelecida em cinco áreas do conhecimento: Geografia, Cartografia, Antropologia, Lingüística e Turismo. $O$ intuito é desenvolver um embasamento racional para que se elaborem dois tipos distintos de representação cartográfica caracterizadas por um maior ou menor nível de abstração da realidade:

$\checkmark$ Os símbolos convencionais, geométricos ou abstratos - que não possuem semelhança com o elemento representado, apresentando um alto grau de abstração. A esse tipo pertence a maior parte dos mapas, para a leitura dos quais o usuário necessita de convenções e da(s) legenda(s) para (re) conhecer os inúmeros elementos. 
$\checkmark$ Os símbolos pictóricos e as ilustrações - que possuem alguma(s) semelhança(s) física(s) com o elemento representado, devendo apresentar um baixo nível de abstração. Neste item, a questão da arte e da cultura tem relevância, pois os desenhos confeccionados resultam de um conjunto de contextos culturais e históricos, até porque todo processo comunicativo é dependente de uma interação entre expectativas, observações e hábitos que constituem a vida cotidiana.

Essas formas de representação passaram por um processo de adaptação devido a sua utilização em meio digital e dos possíveis recursos interativos.

O segundo capítulo se dedica à elaboração prática dos mapas turísticos (convencionais e pictóricos) e do protótipo mapa-site turístico.

Inicialmente, são inventariadas e apresentadas diferentes técnicas de representação como, por exemplo, os tipos de linha, as figuras e os sólidos geométricos, os diferentes tipos de perspectivas, a cor, a luz e sombra, a textura e a proporção. Somam-se ainda, os recursos em meio digital que possibilitam a interatividade com o produto como o zoom estático em etapas, os recursos pop up, pan, etc.

Outro tópico do capítulo discorre sobre os símbolos de informação pública. Trata-se ali desde sua conceituação, de seus tipos e faz-se um inventário de pictogramas recolhidos em mapas turísticos de vários países.

Por fim, apresenta-se o passo a passo de todo o processo de confecção do protótipo mapa-site (ver os mapas e o protótipo mapa-site no CD - anexos - pasta 3 e 6).

No terceiro e último capítulo, elabora-se um teste empírico a partir de um conjunto de questionários, que procuram avaliar e analisar a aceitação, a preferência e o nível de compreensão dos vários tipos de representações desenvolvidas ao longo da pesquisa.

A aplicação dos questionários ocorre de duas maneiras:

$\checkmark$ In loco - durante uma das atividades oferecidas em um curso de qualificação de professores (Projeto Caminhos do Futuro) em 14 estados brasileiros.

$\checkmark$ Internet - um site é desenvolvido para que o questionário alcance o maior e mais diversificado número de pessoas e culturas. Por isso, o material é disponibilizado em dois idiomas: português e inglês (ver o site em CD - anexos - pasta 5).

Tem-se, por fim, as considerações finais em que se retomam alguns aspectos desenvolvidos na tese e procura-se enfatizar a necessidade de prosseguir a investigação que busca aliar a cartografia com os recursos oferecidos pela arte e pela tecnologia moderna. 


\section{CAPÍTULO 1}

Uma cartografia para o turismo: pictografia e interatividade 


\section{1- As novas possibilidades de se conceber um mapa: turismo e meio digital}

A década de noventa do século XX marca grandes transformações e perspectivas à Cartografia, tanto com relação às bases teóricas quanto às do design e suas variadas técnicas. Isso porque atualmente se vive o franco crescimento da cartografia em meio digital, interativa, com destaque para as áreas de sensoriamento remoto, telecomunicações e informática (hardware e software). O cartógrafo então tem, pela frente, um instigante e desafiador caminho a ser trilhado.

Com isso, a inovação estética também foi deslocada para as tecnologias eletrônicas, tornando a comunicação mais fácil e rápida. Antes havia formas artesanais ou eruditas, porém hoje os recursos técnicos geram hipertextos e rápidas edições audiovisuais ou eletrônicas. Por volta de dez anos atrás, conhecer as inovações de diferentes países, utilizá-las e compor com elas requeria viagens freqüentes, assinaturas de revistas estrangeiras e vultosas contas telefônicas. Atualmente, basta renovar periodicamente o equipamento do computador e ter um bom serviço de Internet para solucionar os problemas (Canclini, 2003: XXXVI).

Assim, tomando como base a esfera teórica e a função prática da cartografia, menciona-se o objeto de estudo desta pesquisa: o mapa turístico interativo. Este é o objeto de estudo.

A tese se propõe investigar as maneiras diferenciadas de se apresentar um importante produto de comunicação cotidiana: o mapa, sempre tendo como preocupação primordial a maior aceitação e compreensão do(s) produto(s) desenvolvido(s) para os usuários potenciais, que, neste caso, continua a ser constituído por um grupo muito heterogêneo (idade, grau de escolaridade, interesse, capacidade de decodificação, acesso à tecnologia digital, etc) e essencialmente leigo em cartografia: turista ${ }^{1}$ e usuário da Web (rede mundial de computadores).

Os resultados empíricos apresentados nas pesquisas anteriores (Fiori 1999 e 2003) evidenciaram a maior compreensão e aceitação dos mapas que ofereceram uma maior quantidade de representações pictóricas, quando comparadas às representações abstratas ou geométricas. Isto porque tal forma de representação tem características muito distintas por serem capazes de apresentar semelhança física com o fenômeno representado, proporcionando, em linhas gerais, uma menor

\footnotetext{
${ }^{1}$ Segundo Beni $(1998: 37 ; 149)$ são aqueles visitantes temporários que permanecem pelo menos vinte e quatro horas no país visitado. A viagem pode ser classificada em vários tipos: lazer - descanso, recreação, férias - de negócios e compras, desportivo, ecológico, rural, de aventura, religioso, cultural, gastronômico, estudantil, de congressos - convenções, encontros e encontros similares - familiar e de amigos, de saúde ou médico-terapêutico. Existem ainda, os excursionistas, que são os visitantes temporários que permanecem menos de vinte e quatro horas no país visitado - incluindo viajantes de cruzeiros marítimos. Contudo, nesta pesquisa o usuário dos mapas turísticos pictóricos interativos podem ser tanto os turistas e excursionistas internacionais quanto nacionais.
} 
abstração ${ }^{2}$ da realidade; logo, um menor esforço para adquirir a informação que permeia a representação e a realidade. Ainda se comprovou empiricamente que as representações pictóricas possuem uma grande capacidade de motivar a decodificação e leitura das imagens contidas nos mapas. Isto se deve, em grande parte, ao seu poder de evocar conotações visuais, afetivas e emotivas.

Essa etapa da pesquisa enfatiza o uso das representações pictóricas em mapas temáticos voltados ao setor do turismo e do lazer. Potencializam-se alguns tópicos teórico-metodológicos iniciados no trabalho de mestrado (Fiori, 2003) como, por exemplo, a abordagem de questões que estabelecem o contexto como agente facilitador na leitura dos códigos, além do recurso artístico que possibilita formas alternativas de persuadir o usuário que o mapa pode ser mais que simplesmente funcional sendo capaz de auxiliar na procura de uma determinada localidade ou distância desejada, ou então comparar informações referentes à população, economia, vegetação, etc, transformando-se em um produto que apresente um design motivador ${ }^{3}$ e cuidadosamente pensado para o público potencial e, além disso, que traga outros tipos de informações - úteis e complementares a este usuário tendo como meta um serviço rico e diferenciado. A contribuição maior é pensar a função do mapa voltado especificamente ao turismo.

De maneira breve, é necessário estabelecer o conceito de design que será utilizado durante toda a pesquisa. Para isso, conta-se com Souza (1992: 12), ao explicar que design, na língua portuguesa, é uma palavra sem tradução. Desenho, em tese, deveria ser o termo equivalente ao conceito de design, pois, quando a palavra apareceu, significava tanto risco, traçado, técnica, quanto desígnio, intenção, projeto. Contudo, pelo uso social, o termo desenho passou a significar somente uma técnica de representação.

Galeffi (1977: 90) então esclarece que atualmente, em português, a palavra design não significa desenho, mas sim desígnio, ou seja, plano ou projeto de intenção. Aliás, o mesmo problema de conceituação ocorre na língua francesa, italiana e alemã. Desse modo, houve uma internacionalização da palavra design, sendo adotada principalmente nos meios profissional e acadêmico (Souza, 1992: 12).

Design, então, passa a significar internacionalmente a manipulação de elementos visuais; é um processo fluido, porém constitui-se como o método de pré-visualização e de planejamento que ilustra o caráter da mensagem sintetizada. Caracteriza-se por um tipo especial de inteligência não-verbal e sua natureza está ligada à emissão de

\footnotetext{
${ }^{2}$ É um processo de "destilação", ou seja, de redução dos fatores visuais múltiplos aos traços mais essenciais e característicos daquilo que está sendo representado (Dondis, 1991: 91). O conceito é mais bem explicado entre as páginas $49-51$.

${ }^{3}$ Em geral, o ato de motivar ocorre quando um indivíduo quer satisfazer uma necessidade. Os motivos implicam ação, ou seja, o indivíduo é movido a fazer alguma coisa. Já (em relação à) a motivação turística - que é o caso desta pesquisa - canaliza e desencadeia um processo de decisão (Goossens, 2000).
} 
conteúdo (o que se quer dizer) em uma forma (meio de expressão), por meio do controle exercido pela técnica (Dondis, 1991: 135). Souza (1992: 12) conclui que:

As diferentes formas de manifestação do design revelam uma espacialidade visual e/ou tátil especialmente projetada para solucionar os diversos problemas de habitação, de locomoção, de lazer e de comunicação, próprios da vida em sociedade.

Partindo de Souza (1992: 32), pode-se afirmar que o trabalho a ser desenvolvido nessa pesquisa tem a ver com o design gráfico, pois trabalha com a informação e com os veículos de comunicação. Diferentemente do desenho industrial, que lida com objetos e equipamentos. A autora (1992: 56) conceitua design gráfico como uma das formas de conversação social em que as pessoas partilham informações e instruções por intermédio dos estímulos visuais gráficos. Portanto, a comunicação pode resultar das várias modalidades do desenho (desenho gráfico, técnico, ilustrativo, publicitário, etc), isto é, a comunicação visual também está sujeita a algumas condições básicas:

> É necessário que o designer conheça estruturalmente o fenômeno da comunicação;

> Utilização dos mesmos códigos de linguagem;

$>$ Busca do máximo de objetividade dos signos utilizados em um ato comunicativo, a fim de assegurar eficiência de comunicação e ausência de falsas interpretações;

> Familiaridade do agente emissor (designer) com as possibilidades expressivas das técnicas de comunicação empregadas e sua adequação às condições fisiológicas, psicológicas e culturais dos agentes receptores (segmentos sociais).

Dito isso, os mapas turísticos pictóricos devem atentar a duas peculiaridades importantes a serem ressaltadas: a primeira refere-se ao interesse e concepção de um produto que busque uma maior e melhor visibilidade do local representado, ou seja, é necessária a busca de formas de representação que forneçam uma série de atividades e funções (materiais) de localização, distâncias, orientação (a rua, o hotel, a cachoeira, a morfologia do terreno) e culturais (o "causo", curiosidades, o imaginário, as histórias) visando gerar relações afetivas com o local de destino. A segunda peculiaridade diz respeito à procura de formas criativas e corretas de representação e construções cartográficas que possam ser facilmente consumidas, "lidas" e estejam adaptadas às necessidades do grupo heterogêneo de usuários. Acrescente-se que haverá uma inovação se consideradas as pesquisas anteriores (Fiori 1999, 2003), isso porque, a apresentação dos futuros produtos cartográficos se dará totalmente em forma digital e, por isso, o público alvo deverá ter conhecimentos mínimos sobre o ambiente Windows e a Internet. 
Ao se pensar em determinados objetos, momentos, paisagens, é comum virem à mente imagens, sons, cheiros, nomes, entre outras sensações que aguçam os cinco sentidos. Tais sensações podem se transformar em desejos, vontades, recordações, deslumbramento, motivações; que por sua vez, poderão ser transformados em representações gráficas, ou seja, em telas, ilustrações, textos, croquis, símbolos e mapas.

Como foi dito anteriormente, o tipo de material cartográfico proposto implica situar, tornar acessível a localização e o reconhecimento de pontos e áreas de uma determinada localidade no espaço. Todavia, pretende-se ir além, ou seja, fazer com que o mapa temático traga o máximo de boas sensações e recordações possíveis. $\mathrm{E}$, para isso, conta-se com o uso da pictografia.

Como demonstração das sensações e possibilidades de representações pretendidas nesta nova etapa da pesquisa, é citado o livro As cidades invisíveis de Ítalo Calvino (1999), que aborda seu fascínio pela complexa simbologia das cidades. Leia-se, por exemplo, o trecho abaixo:

\section{Desejos}

A três dias de distância, caminhando em direção ao sul, encontra-se Anastácia, cidade banhada por canais concêntricos e sobrevoada por pipas. Eu deveria enumerar as mercadorias que aqui se compram a preços vantajosos: ágata, ônix, crisópraso e outras variedades de calcedônia; deveria louvar a carne do faisão dourado que aqui se cozinha na lenha seca de cerejeira e se salpica com muito orégano (Calvino, 1999: 16).

\section{$\underline{\text { Memórias }}$}

Ao se transportarem seis rios e três cadeias de montanhas surge Zora, cidade que quem viu uma vez nunca mais consegue esquecer. Mas não porque deixe, como outras cidades memoráveis, uma imagem extraordinária de recordações. Zora tem a propriedade de permanecer na memória ponto por ponto, na sucessão das ruas e das casas ao longo das ruas e das portas e janelas das casas, apesar de não demonstrar particular beleza ou raridade (op. cit.:19).

\section{$\underline{\text { Trocas }}$}

Em Esmeraldina, cidade aquática, uma rede de canais e uma rede de ruas sobrepõem-se e entrecruzam-se. Para ir de um lugar a outro, pode-se sempre escolher entre o percurso terrestre e o de barco: e, como em Esmeraldina, a linha mais curta entre dois pontos não é uma reta, mas um zigue-zague que se ramifica em tortuosas variantes, os caminhos que se abrem para o transeunte não são dois, mas muitos, e aumentam ainda mais para quem alterna trajetos de barcos e transbordos em terra firme (op. cit.: 83).

\section{Olhares:}


Ao chegar a Fílide, tem-se o prazer de observar quantas pontes diferentes entre si atravessam os canais: pontes arqueadas, cobertas, sobre pilares, sobre barcos, suspensas, com parapeitos perfurados; quantas variedades de janelas apresentam-se diante das ruas: bífores, mouriscas, lanceoladas, ogivais, com meias-luas e florões sobrepostos (op. cit:: 85).

\section{Diferenças}

Presume-se que Isaura, cidade dos mil poços, esteja situada em cima de um profundo lago subterrâneo. A cidade se estendeu exclusivamente até os lugares em que os habitantes conseguiram extrair água, escavando na terra longos buracos verticais (op. cit.: 24).

\section{$\underline{\text { Nomes }}$}

A minha mente continua a conter um grande número de cidades que não vi e não verei, nomes que trazem consigo uma figura ou fragmento ou ofuscação de figura imaginada: Getúlia, Odila, Eufrásia, Margara (op.cit. 87, 88).

\section{$\underline{\text { Símbolos }}$}

Finalmente, a viagem conduz à cidade de Tâmara. Penetra-se por suas ruas cheias de placas que pendem das paredes. Os olhos não vêem coisas, mas figuras de coisas que significam outras coisas: a torquês indica a casa do tiradentes; o jarro, a taberna; as alabardas, o corpo de guarda; a balança, a quitanda. (...) Se um edifício não contém nenhuma insígnia ou figura, a sua forma e o lugar que ocupa na organização da cidade bastam para indicar a sua função: o palácio real, a prisão, a casa da moeda a escola pitagórica, o bordel. Mesmo as mercadorias que os vendedores expõem em suas bancas valem não por si próprias, mas como símbolos de outras coisas: a tira bordada para a testa significa elegância; a liteira dourada, poder; os volumes de Averróis, sabedoria; a pulseira para o tornozelo, voluptuosidade (...) O olhar percorre as ruas como se fossem páginas escritas (op. cit.:18, 19)

Os fragmentos de cada conto exemplificam sensações e possibilidades de representação de vários espaços. Segundo Santos (2002:233), o povo, ao utilizar o território, cria o espaço. Detalhando melhor, o território é imutável em seus limites, que pode ser uma linha traçada de comum acordo ou então pela força. O território, em um dado momento da História, representa um dado fixo, contudo, não possui necessariamente a mesma extensão através dos tempos. Ele se torna espaço através das sucessões históricas da efetiva ocupação por um povo. A ação e o trabalho resultam de regras fundamentadas no modo de produção adotado, tendo como orientação o poder soberano (sistema político), que instalado determina os tipos de relações entre classes sociais e as formas de ocupação desse território.

O espaço, então, é uma constante junção e complementação de elementos materiais 
e imateriais contidos em uma história, que traz diferenças e singularidades, mas também semelhanças quando comparados a outros espaços. Portanto, o grande desafio desta pesquisa é pensar que cada localidade tem singularidades que a faz única, e o mapa, pelo seu poder e formas de representação, pode destacar uma infinidade desses elementos - atrativos materiais e imateriais - dispostos no espaço, tanto em meios analógicos quanto digitais.

A expectativa que se estabelece para este trabalho, fundamentado na Cartografia Temática, vislumbra maneiras inovadoras e originais de conceber produtos que possam ser tanto de interesse do setor turístico e de lazer quanto do usuário que, por sua vez, requer e merece novas formas de representar a informação espacial.

A preocupação inicial do cartógrafo é pensar o mapa a partir de uma situação previamente estabelecida, pois é a partir de um dado contexto (para quem e qual o propósito) que se determinam (codificação e confecção) as expectativas (interesse, motivação) e a capacidade (facilidade de decodificação) de assimilar a informação pelo público-alvo. E é por isso que este trabalho busca captar a essência, o espírito da localidade.

Some-se à discussão, Leung e Li (2002: 12) ao ressaltarem que a qualidade do serviço no turismo é essencial para que ocorra o crescimento do setor, situando o mapa como um importante instrumento nesse sentido. Por conseqüência, a eficácia do produto precisa ser incessantemente buscada.

Um bom mapa turístico deve permitir que o usuário planeje e prepare suas atividades, além de se caracterizar como um produto funcional e esteticamente prazeroso, podendo contribuir com a expectativa dos visitantes e uma total satisfação pela viagem (Kokkonen e Peltonen, 1999).

\section{2 - $O$ ato de cartografar: cultura e a representação do outro}

Wagner e Mikesell (2000:111) afirmam que a cultura resulta da capacidade de os seres humanos se comunicarem entre si por meio de símbolos. Quando as pessoas parecem pensar e agir de maneira igual, elas o fazem porque vivem, aprendem, trabalham e conversam juntas, atribuindo o mesmo significado aos objetos feitos pela humanidade. Além disso, participam dos mesmos rituais e recordam o mesmo passado. Inversamente, quando há grandes diferenças em pontos de vista e atividades, em geral se reflete a ausência de símbolos e língua comuns. A cultura também está assentada numa base geográfica, pois é provável que só ocorra comunicação regular e compartilhada entre pessoas que ocupam uma área comum.

Canclini (2003: 274) continua a reflexão dizendo que a cultura é o capital pertencente a toda e qualquer sociedade, sendo interiorizada pela prática. É produto de uma encenação, na qual se escolhe e se adapta o que vai ser representado, de acordo com o que os receptores possam escutar, ver e compreender. Todo ato de transmissão cultural implica necessariamente a afirmação do valor da própria cultura 
transmitida, em detrimento de uma desvalorização implícita ou explicita das outras culturas. Tal exigência se faz presente no próprio ato da transmissão, pois os indivíduos condenados por sua formação sentem-se inclinados a identificar seu próprio valor com o valor de sua cultura, vendo uma outra cultura muitas vezes como estranha, concorrente (Bourdieu, 1974: 218). Ratifica Tuan (1980:285): o grupo expressa e reforça padrões culturais da sociedade, o que afeta decisivamente a percepção, a atitude e o valor que seus membros atribuem ao meio ambiente.

O pertencer a um grupo traz implícito um conjunto de significados, ou seja, uma nação (e em menor grau um estado/província, cidade, bairro) não é apenas uma entidade política, mas também algo que produz sentidos, conformando-se em um sistema de representação social (Hall, 2003: 49).

Por exemplo, museus, relatos populares, mapas, nunca apresentam os fatos, o cotidiano em sua totalidade; são sempre re-apresentações, simulacros. Só a fé cega fetichiza os objetos e as imagens, acreditando que neles está depositada a verdade (Canclini, 2003: 201). E, para que isto ocorra, constitui-se, então, um conjunto comum de esquemas fundamentais, que são previamente assimilados (Bourdieu, 1974: 208).

Sobre os mapas em particular, Harley (1991) informa que, desde tempos mais remotos até os dias de hoje, a humanidade das mais diversas culturas representa o espaço. Contudo, durante um longo período, os mapas de culturas não-européias só receberam certa atenção quando apresentavam alguma semelhança com os mapas europeus.

Felizmente, a história da cartografia começa a tomar um novo rumo, no qual cada cultura manifesta sua particularidade, permitindo que se entenda muito melhor o objetivo da criação dos mapas (Harley, 1991).

Sendo assim, a fundamentação teórico-metodológica continua focada em estabelecer o mapa como produto cultural (Fiori, 2003). Para isso, conta novamente com a concepção de cartografia expressa na figura 1, definindo suas perspectivas e dimensões. Segundo Vasconcellos (1993: 82), o centro do esquema apresenta a cartografia como um processo que parte da realidade, englobando as etapas de produção e utilização do mapa.

Desse modo, o ato de cartografar disseca várias relações em uma sociedade.

Segundo a professora Regina Araujo de Almeida (Departamento de Geografia da USP) acerca da concepção do Atlas Indígena do estado do Acre (Comissão PróÍndio: 1996), o azul, a cor convencionada para representar a hidrografia na maioria dos mapas da cultura ocidental, teve de ser mudada para o amarelo, porque tal cor não fazia sentido para os indígenas das etnias Arara, Ashaninka, Kaxinawa e Manchineri, os usuários potenciais dos Atlas.

A partir do exemplo acima, cita-se Collins-Kreiner (1997) ao afirmar que os mapas 
são desenvolvidos levando em consideração propósitos específicos. Não são seres passivos; pelo contrário, suas mensagens implícitas sempre precisam ser descobertas. Além do mais, o produto cartográfico precisa satisfazer as necessidades e interesses do usuário, pois se não, provavelmente ele procurará outro que melhor o atenda (Kolacny, 1994 e Benkenstein, Yavas e Forberger, 2003). Kolacny (1994) ainda ressalta que os requisitos básicos de um mapa é ser atraente, devendo ter uma concepção racional e boa impressão emotiva, somando-se a facilidade de leitura e compreensão.

Figura 1 - Perspectivas e dimensões da Cartografia

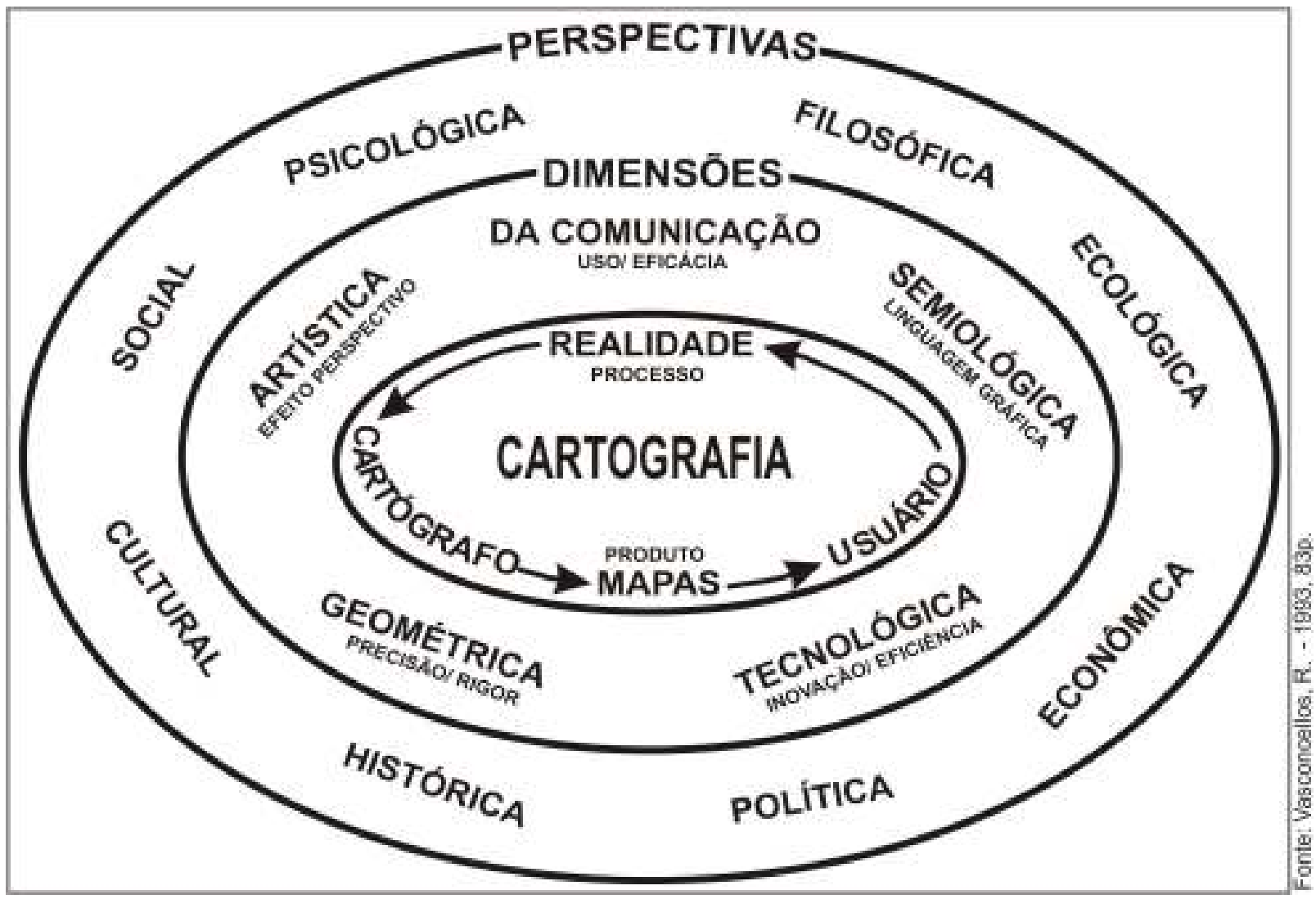

Collins-Kreiner (1997) complementa, em citação, que os geógrafos devem se relacionar com o mapa da mesma forma que um sociólogo se relaciona com um suvenir, ou seja, como uma unidade simbólica, um objeto - no caso para o setor do turismo e lazer - que revela influências, interesses sociais, políticos, forças ideológicas e relações de poder. Dessa forma, os mapas podem ser usados como ferramentas analíticas para entender processos e seus significados, atuando como lentes através das quais a cultura e a sociedade são vistas.

Segundo Harley (1994: 277-278), talvez a grande questão não seja responder categoricamente se os mapas são verdadeiros ou falsos, precisos ou imprecisos, objetivos ou subjetivos, geométricos ou pictóricos, ou se são baseados na integridade científica e contrários à distorção ideológica. $\mathrm{O}$ autor aponta ainda outros elementos 
que influenciam na veracidade de um mapa, como os níveis de carto-alfabetização dos usuários, a autoria e procedência dos mapas, os segredos, as censuras e, finalmente, a natureza das instituições políticas para as quais os mapas são feitos. Com tudo isso, o fato contundente está em saber que o material sempre transmitirá imagens com alguma importância e mensagens direcionadas a algum grupo. Até porque o mapa é uma das fontes de comunicação, articulação e estruturação do conhecimento da humanidade.

A pesquisa, então, procura compreender todo o processo de desenvolvimento de mapas temáticos, potencialmente aqueles direcionados ao setor do turismo.

Todo ato de cartografar gera sempre a representação de um determinado espaço. Sendo o geógrafo/cartógrafo o produtor, ele na maioria das vezes representa o outro (em diferentes escalas), ou melhor, somente a representação externa desse outro, resultado da cultura local, da tradição.

Latour (1994:102) afirma que não existem nem culturas (diferentes ou universais) nem uma natureza universal. O que existem apenas são naturezas-culturas, as quais constituem a única base possível para comparações. O autor (op. cit:: 102-104), então, apresenta quatro maneiras (figura 2) para conceituá-las:

Figura 2 - Naturezas-culturas: quatro tipos de relação

Relativismo Absoluto
Culturas sem bierarquia e sem contatos,
todas incomensuráveis; a natureza foi
colocada à parte.

19) Relativismo absoluto: supõe culturas separadas e incomensuráveis que nenhuma hierarquia seria capaz de ordenar. Coloca a natureza de lado. 
$2^{\mathrm{a}}$ ) Relativismo cultural: é mais sutil. A natureza é considerada, mas permanece à parte das culturas. Esta se reparte em diversos pontos de vista mais ou menos precisos sobre uma natureza única, igual para todos.

$\left.3^{a}\right)$ Universalismo particular: ocorre quando a natureza é vista sem estar atrelada a uma cultura em particular. Logo, uma das sociedades - que é sempre a nossa define o quadro geral da natureza em relação ao qual as outras estarão situadas. Dito isso, projeta-se um argumento dividido em suas partes: o primeiro permite um relativismo modesto - somos apenas uma cultura entre outras; o segundo permite um relativismo arrogante - continuamos a ser absolutamente diferentes dos outros.

$4^{a}$ ) Antropologia simétrica: Todas as naturezas-culturas são parecidas. São formadas ao mesmo tempo pelos seres humanos, divinos e não-humanos.

Mesmo com as diferentes definições sobre as naturezas-culturas, todas possuem um traço comum: constroem ao mesmo tempo os coletivos - humanos e não-humanos (Latour, 1994:104).

Esses coletivos - produções de naturezas-culturas - se definem por relativismos ${ }^{4}$ absolutos e relativos. Latour (op.cit.:110) sustenta que o primeiro limita as culturas ao exotismo e à estranheza, pois, se não existe nenhum instrumento de medida comum, único e transcendental, então todas as linguagens são intraduzíveis, todas as emoções incomunicáveis, todos os ritos igualmente respeitáveis, todos os paradigmas incomensuráveis. Portanto, de gosto e de cor não se discute. $O$ relativismo absoluto, assim como seu franco opositor, o racionalismo:

esquece que os instrumentos de medida devem ser montados e que, ao esquecer o trabalho da instrumentação, não é possível compreender mais nada sobre a própria noção de comensurabilidade. Esquece, mais ainda, o enorme trabalho dos ocidentais para "tirarem a medida" dos outros povos, tornando-os comensuráveis e criando, através do fogo, do saber e do sangue, padrões de medida que não existiam anteriormente (Latour, op.cit.:111).

Já o relativismo relativista traz de volta a compatibilidade que se julgava perdida. É mais modesto, porém mais empírico. Mostram os instrumentos e as cadeias usadas para criar assimetrias e igualdades, hierarquias e diferenças. Os mundos só parecem comensuráveis e incomensuráveis quando ficam presos a medidas que puderam ser medidas. A possibilidade de relacionar vem pelo intermédio do trabalho e de montagem, de prática e controvérsia, de conquista e de dominação.

... todas as medidas, tanto na ciência rígida quanto na ciência flexível, são sempre medidas medidoras e estas constroem uma comensurabilidade que não existia

\footnotetext{
${ }^{4}$ Alguns dos sentidos da palavra relativismo: estabelecer relações; tornar comensurável; regular instrumentos de medida; instituir cadeias metrológicas (estudos de descrição dos povos); redigir dicionários de correspondências; discutir sobre a compatibilidade das normas e dos padrões; estender redes calibradas; montar e negociar os valorímetros (Latour, op.cit.:111).
} 
antes que fossem desenvolvidas. Nenhuma coisa é, por si só, redutível ou irredutível a qualquer outra. Nunca por si mesma, mas sempre por intermédio de uma outra que a mede e transfere esta medida à coisa. Como acreditar que os mundos não podem ser traduzidos quando a tradução é o próprio cerne das relações estabelecidas entre eles? Como dizer que os mundos são dispersos quando nós os totalizamos o tempo todo? (Latour, 1994:111).

Latour (1994: 112) cita a etnologia como uma destas medidas medidoras que pode solucionar na prática a questão do relativismo, pois cotidianamente constrói certa comensurabilidade, sendo que o relativismo relativista pode se tornar um dos recursos essenciais na relação entre os diferentes coletivos, por servir como um negociador planetário sobre os universais relativos que são construídos aos poucos.

A mobilização dos coletivos e do mundo - e em uma escala cada vez maior multiplica os atores que compõem as naturezas e as sociedades (Latour, op. cit.: 71). Isto traz desafios quanto ao coletivo-relativismo que deve ser enfrentado ao se desenvolver um mapa turístico, que representa somente uma pequena parcela espacial (o município de Caxambu, ao sul do estado de Minas Gerais, Brasil), que fica exposta e disponível na internet, alcançando sociedades e culturas ao redor do mundo inteiro.

Neste trabalho, o desafio maior é avaliar até que ponto o mapa-site pode ser compreendido (lido, decodificado) e aceito (pela atratividade, motivação) levando-se em consideração desde um contexto local (município, estado, país) até global (outros países) a partir de itens como simbologia utilizada (convencionais e pictóricas) e a posterior inserção na Web (rede mundial computadores). Por exemplo, tendo como base os diferentes coletivos, a figura 3 apresenta graus de relativismo menores ou maiores, decorrentes do contexto local-global.

Figura 3 - 0 contexto e a escala do relativismo

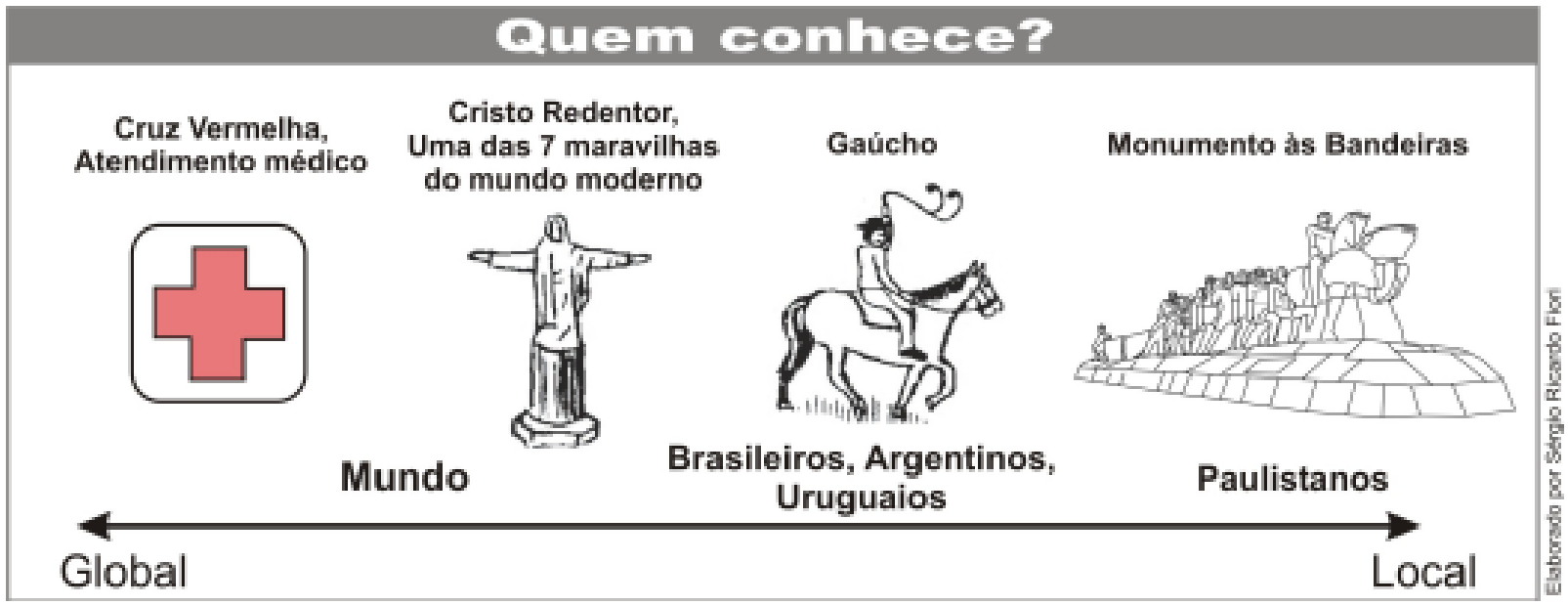

Portanto, a passagem do local ao global, do humano ao não-humano, é feita pela rede de práticas e de instrumentos, de conhecimentos, de documentos e traduções. 
$\mathrm{Na}$ verdade, essas redes não são, por natureza, nem locais nem globais, sendo melhor dizer redes, mais ou menos longas, mais ou menos conectadas (Latour, 1994: 119-120). Com base em Latour (1994), a seguir, detalham-se melhor essas relações de escala.

Primeiro, é preciso dizer que o coletivo é resultado do laço social que une os humanos entre si. Nele atuam paixões, interesses, desejos, entre outros sentimentos. São essas forças personificadas que estruturam uma sociedade. A partir das histórias contadas (o sistema da língua) de uns para outros, geram-se processos de significação a partir de narrativas, textos e discursos - estes são alguns dos elementos que designam o império dos signos (Latour, op. cit.: 63; 87).

O mapa convencional, mas principalmente o pictórico, com seus universos de símbolos, ilustrações e textos está imerso em um coletivo. E, dentro deste coletivo, estão os produtores dos mapas, os quais procuram caminhos para compor, da melhor maneira possível, a relação significante-significado, ou seja, o signo que, precisa ser eficaz (lido, denota algo), mas deve ir além, pois, no caso de um mapa temático para o turismo, o mesmo signo pode ser também associado a conotações de prazer, de emoção, de excitação, de relaxamento, de contemplação, de familiaridade, de tradição entre outras sensações humanas.

Neste instante, justifica-se a posição do mapa como ser intermediário, mediador, quase-objeto; um ser híbrido que se constitui tanto da natureza (o que representa) quanto da cultura.

Dito isso, como pensar o mapa e o seu universo de símbolos disponíveis na rede mundial de computadores, que pode alcançar desde os coletivos locais até os globais?

E é exatamente por isso que as informações disponibilizadas nos mapas turísticos e no mapa-site turístico devem ser claras e objetivas, sendo assim compreendidas e consumidas rapidamente pelo maior número de pessoas. Latour (op. cit.: 52) completa que, em rede, o mundo moderno permite prolongamentos de suas práticas, acelera a circulação dos conhecimentos, havendo uma extensão das sociedades.

Entretanto, os diferentes coletivos podem vir a se estranhar. É o que Latour (op. cit: 99) denomina de exotismo, ou seja, as diversidades das culturas, como, por exemplo, o sistema de crenças, técnicas, hábitos, jogos de poder, familiaridades e similaridades, economias, em suma, a totalidade da existência de um sujeito.

As palavras local e global possibilitam pontos de vista sobre redes que não são, por natureza, nem locais nem globais, mas que são mais ou menos longas e mais ou menos conectadas. O exotismo moderno consiste em tomar estas duplas de oposições como sendo aquilo que define nosso mundo e que nos tornaria distintos de todos os outros (Latour, op. cit.:120). 
O exotismo na elaboração dos mapas turísticos tem duplo direcionamento. O exótico de querer conhecer as outras naturezas-culturas: o coletivo diferente. Por outro lado, o exótico na elaboração de um mapa turístico, deve ser olhado com diligência pois, se, de um lado, ele constitui um estímulo, de outro, ele pode se tornar entrave, já que muitas vezes, ele não é devidamente explicitado. Em outros termos: o usuário que procure pelo exótico quer também compreendê-lo. A convergência do interesse e da explicitação possibilita uma maior eficiência.

Sendo assim, o relativismo relativista ajuda a justificar de maneira mais adequada a proposição e análise - vinda de testes empíricos - das formas de representação que sejam mais convenientes ao turismo/turista, ou seja, que instigue, motive, atraia o turista a conhecer o lugar exótico, além de ser um produto de fácil compreensão, feito para pessoas leigas na leitura de mapas.

Neste momento, é importante pensar no produtor-mediador, um ser não alheio ao processo, pois, na maioria das vezes, ele próprio acaba representando o exótico, por conceber um quase-objeto que não faz parte de sua realidade cotidiana.

O produtor cunha um arco interpretativo entre o "estar lá" - criação feita a partir de inúmeras informações coletadas sobre a localidade, em folderes, sites, livros, por informações repassadas por pessoas que habitam a localidade - e o "representar aqui" - trabalho de gabinete (normalmente distante da localidade representada). $\mathrm{Na}$ verdade, então, o produtor representa o outro a partir de uma visão externa - não é seu coletivo, sua realidade - tal como na tradição, no folclore.

O organograma abaixo (Figura 4) mostra esquematicamente as várias relações e conexões que se estabelecem entre a natureza, o mediador e a cultura.

A seguir, disserta-se sobre dois tópicos conceituais, essenciais na elaboração e compreensão de um mapa temático para o turismo: lugar e paisagem. Entretanto, é o segundo item que recebe a real atenção desta pesquisa, pois trabalha questões de como uma coletividade vê a outra e as subseqüentes expectativas, estranhezas, familiaridade, exotismos, subjetividades, etc.

O próprio ato da coleta dos dados de uma localidade, realizada pelo produtor do mapa, ocorre de diferentes maneiras, isto é, ele pode ou não ter um contato direto com a coletividade representada, assim, pode conhecê-la porque vive no local ou porque realizou nela um trabalho de campo. Mas, pode também conhecê-la por meio de conversas, internet, correio, etc. - materiais e informações (mapas-base, inventário turístico - destaques da história e cultura, arquitetura, hábitos, serviços, atrativos naturais) da coletividade que não é a sua.

Outro ponto a ser destacado é que se elabora o produto (mapa temático turístico) sempre pensando no estrangeiro, isto é, aquele indivíduo que não mora na cidade representada e que precisa ser atraído, motivado a querer conhecê-la, saber mais sobre ela, para que, a partir daí, quem sabe, ter vontade de visitá-la e indicá-la a 
outras pessoas.

Figura 4 - 0 arco interpretativo entre a natureza, o mediador e a cultura

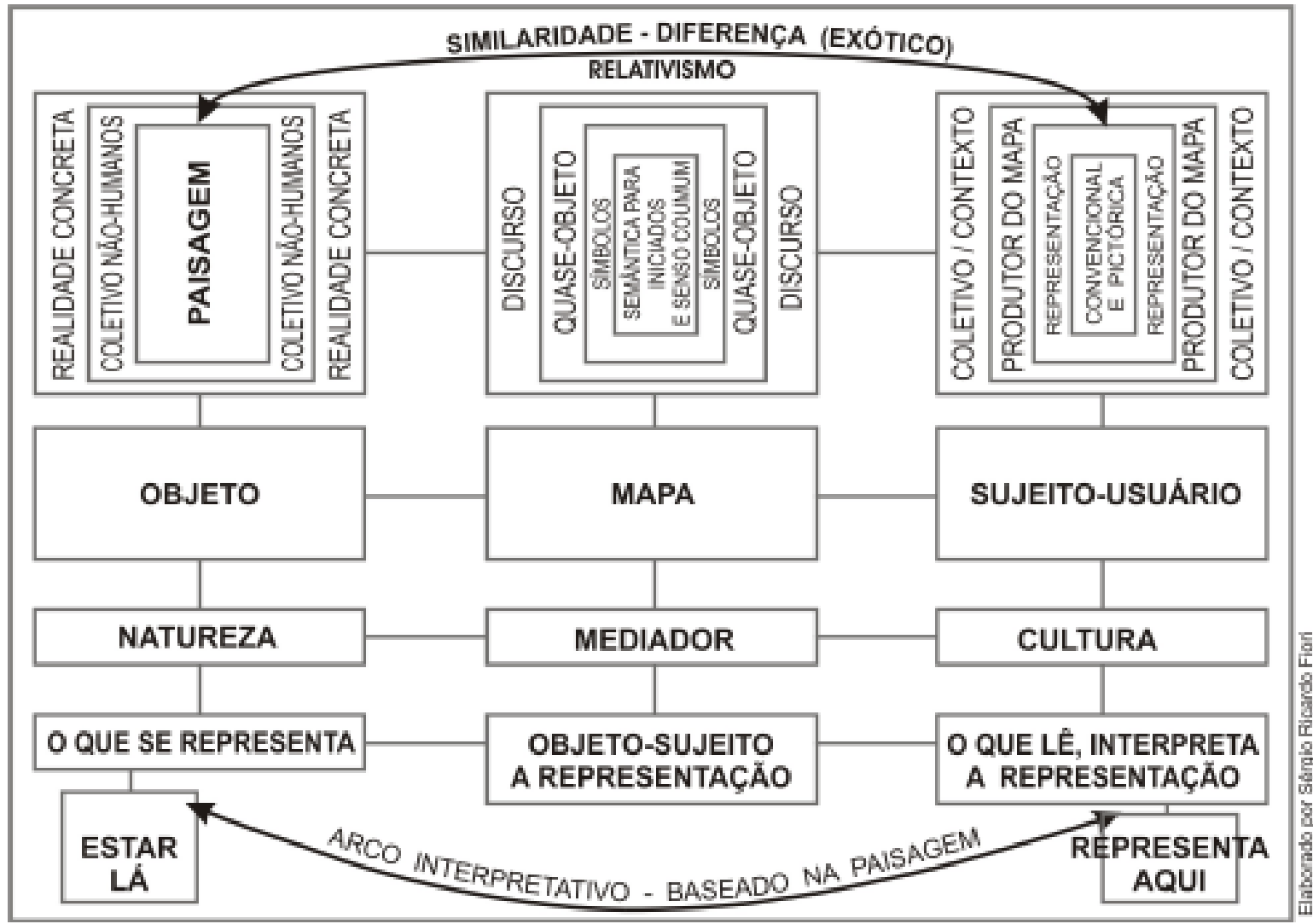

Rapidamente, aborde-se o conceito lugar: é aquele onde o indivíduo se encontra ambientado, familiarizado, integrado. É o espaço-coletivo vivido, íntimo, experimentado; espaço que faz parte do seu mundo, dos seus sentimentos e afeições. Conseqüentemente, o lugar não é toda e qualquer localidade, mas aquela que tem significância afetiva para uma pessoa ou grupo de pessoas. E será a partir dele que decorre a preocupação de verificar os gostos, as preferências, as características e as particularidades que são distintas de cada lugar. Nesse sentido, ocorre também uma valorização do contexto ambiental e dos aspectos que redundam no encanto e na magia do lugar - único - na sua personalidade e distinção (Christofoletti,1985).

Cite-se novamente a dissertação de Rodrigues (2001) pela ilustração prática do conceito de lugar. A autora colhe informações de pessoas que moram nos arredores da Serra da Canastra, em Minas Gerais. Uma delas fala que:

a paisagem era bonita demais, antes quando queimava dava para ver o Chapadão. Os animais foram espantados após a formação do Parque. Quando não havia o Parque havia o fogo e os animais gostavam dos brotos das plantas.

(alfaiate, morador há mais de 55 anos) 
Neste caso, o uso da palavra paisagem na verdade conota o conceito de lugar. Rodrigues (2001: 71) apresenta definições de lugar como espaço do dia-a-dia. O armazenamento, detalhamento, associações de imagens mentais está diretamente relacionada ao tempo da duração da residência (moradia) das pessoas. Em tese se conhece melhor um lugar tendo como referencial a aprendizagem, a aquisição de valores, entre muitas outras experiências cotidianas in loco; e isso demanda tempo.

$\mathrm{O}$ conceito de paisagem foi criado no século XVI, visando gerar um modelo visual, ou seja, a invenção pictórica da natureza. Com isso, os elementos do espaço passaram por um processo de dessacralização, por remeterem a outras coisas que não a eles próprios (seres únicos), tornando-se imagens plenamente significantes por si mesmas. Por exemplo, ao se desenhar uma árvore, um rio, uma montanha, está subentendido que esses elementos são parte constituinte da paisagem, fazendo-a existir com tal (Alcântara e Sader, 1999). As autoras continuam esclarecendo que o termo paisagem é definido por possuir uma realidade material, pois é uma extensão de espaço oferecida ao olhar. Mostra-se como uma realidade é subjetiva, pois ela simplesmente não existiria se não existisse um observador. É um espaço enquadrado, um recorte significativo do mundo, logo, a percepção de um fragmento do espaço, ao ser percebido é automaticamente interpretada. O objeto percebido é um objeto refigurado, provido de atributos anteriormente sabidos, tanto que, quando a percepção transforma um recorte do espaço em paisagem, ela está aplicando-Ihe julgamentos de conformidade, realidade e identificação. Por isso, a paisagem caracteriza-se como:

produto de um olhar estranho ao lugar, de alguma forma liberado. É preciso de um outro para conferir à minha parcela do espaço a qualidade de paisagem, cuja percepção entra numa lógica de diferenciação social e cultural em função de um movimento de distância crítica, transformando elementos do espaço em espetáculo" (Alcântara e Sader, 1999).

Santos (1996: 61 e 2002:103) define e complementa paisagem como uma parte da configuração territorial que é vista, que o olho abarca, com seus volumes, cores, movimentos, odores, sons, etc. Logo, a percepção ${ }^{5}$ e a cognição ${ }^{6}$ têm um papel fundamental na apreensão do conjunto heterogêneo de formas naturais e artificiais (objetos reais-concretos) ${ }^{7}$ encontrados em uma área e que a caracterizam fisicamen-

\footnotetext{
${ }^{5}$ É sempre um processo seletivo da apreensão. Mesmo se as pessoas partem de uma única realidade, cada uma a vê de maneira diferenciada. Isso faz com que a visão do homem em relação às coisas materiais seja sempre deformada. A percepção não é tida como conhecimento - pois depende da interpretação - e terá maior validade quanto mais limitar o risco de tomar por verdadeiro o que é só aparência (Santos: 1996: 62).

${ }^{6} \mathrm{O}$ aparelho cognitivo tem um papel crucial na apreensão da paisagem, pelo fato de que toda educação (formal e informal) é feita de forma seletiva, ou seja, pessoas diferentes apresentam diversas versões para o mesmo fato (Santos: 1996: 62).

${ }^{7}$ A paisagem compreende dois tipos distintos de elementos: os objetos naturais, que não são obra do homem nem jamais foram tocados por ele. $\mathrm{E}$ os objetos sociais, testemunhas do trabalho humano tanto no passado como no presente (Santos, 2004: 54).
} 
te. Como, por exemplo, uma região produtora de algodão, café, trigo ou, então, uma paisagem urbana - cidade, centros, periferias - de tipo européia, americana ou asiática. Todas são paisagens e concentram formas mais ou menos duráveis, possuindo um traço comum: a combinação de objetos naturais e fabricados, que em conjunto formam os objetos sociais, resultado da acumulação da atividade humana por muitas gerações (Santos: 2004: 53).

Nesse processo, Cavalcanti (1997) admite que a compreensão do conceito de paisagem trabalha tanto com a ciência (caráter funcional), quanto com a arte (caráter estético: caso, por exemplo, dos paisagistas). A junção desses dois caracteres revela não só as relações de produção e estrutura da sociedade no espaço mas também o imaginário ${ }^{8}$ social, as crenças, os valores, os sentimentos das pessoas que a constroem. Em suma, espaço e paisagem resultam de um mosaico de relações, formas e sentidos (Santos, 1996: 62).

Pensando mais especificamente no turista e no próprio produtor do mapa, é fundamental esclarecer que eles percebem o lugar em sua "aparência". Segundo Beni (1998: 361), a paisagem se vai com o observador, porque não é mais que uma idéia da realidade que este elabora quando interpreta esteticamente o que está vendo.

O outro - tanto o turista quanto o produtor - não se envolve nem se relaciona com as vidas e os valores dos habitantes locais. Já o morador da localidade representada tem uma atitude mais complexa, resultado de sua imersão no ambiente (Tuan: 1980: 72; 74). O autor ainda exemplifica a postura superficial do turista em relação a uma cidade medieval européia - ver também a figura 4.

Manifestam seu deleite sobre as ruas escuras, calçadas com seixos, as esquinas e recantos íntimos, as pitorescas construções compactadas de casas e as encantadoras lojas antigas, sem parar para pensar como as pessoas realmente viveram. Ou então, um turista em Chinatown fica encantado com o estímulo de seus sentidos da visão e do olfato; ele sai com uma feliz ignorância do apinhamento, das vidas apáticas, do jogo atrás das vistosas fachadas (Tuan: op.cit.: 74).

Mas, por outro lado, o mesmo turista é capaz de perceber méritos e defeitos em um meio ambiente que já não são mais visíveis ao residente (Tuan, op.cit.:75).

Uma abordagem mais gráfica em relação à paisagem é retirada da geografia cultural. Esta conceitua paisagem como um modo especial de compor, estruturar e dar significado ao mundo externo, que é possuidor de uma história que precisa ser

\footnotetext{
${ }^{8}$ Segundo Lacan (apud Gomes, 1996) é uma ficção real e vivida. Para compreender o imaginário, é necessário nos colocar em consonância com o outro mesmo quando a comunicação ultrapassa as possibilidades de interpretação racional. A função empática da arte inscreve-se neste gênero de comunicação, por utilizar um vocabulário inconsciente para fazer transitar sensações reais e vividas sob a aparência de irrealidades. A valorização da arte pelos geógrafos humanistas explica-se exatamente por esta dimensão do conhecimento espontâneo, inconsciente e não racional.
} 
entendida em relação à apropriação da terra. Para isso, são produzidas qualidades simbólicas da paisagem, que ajudam a sustentar seu significado social considerada, a partir de então, uma imagem cultural, um meio pictórico de representar ou simbolizar tudo que rodeia o ser humano. Isso é feito por intermédio da pintura, desenho, imagens gravadas. Cada um desses meios revela significados que os grupos humanos atribuem às áreas e lugares, e permite relacionar esses significados a outros aspectos e condições da existência humana (Cosgrove e Jackson: 2000: 18).

\section{Figura 5 - Fotos de uma cidade medieval}

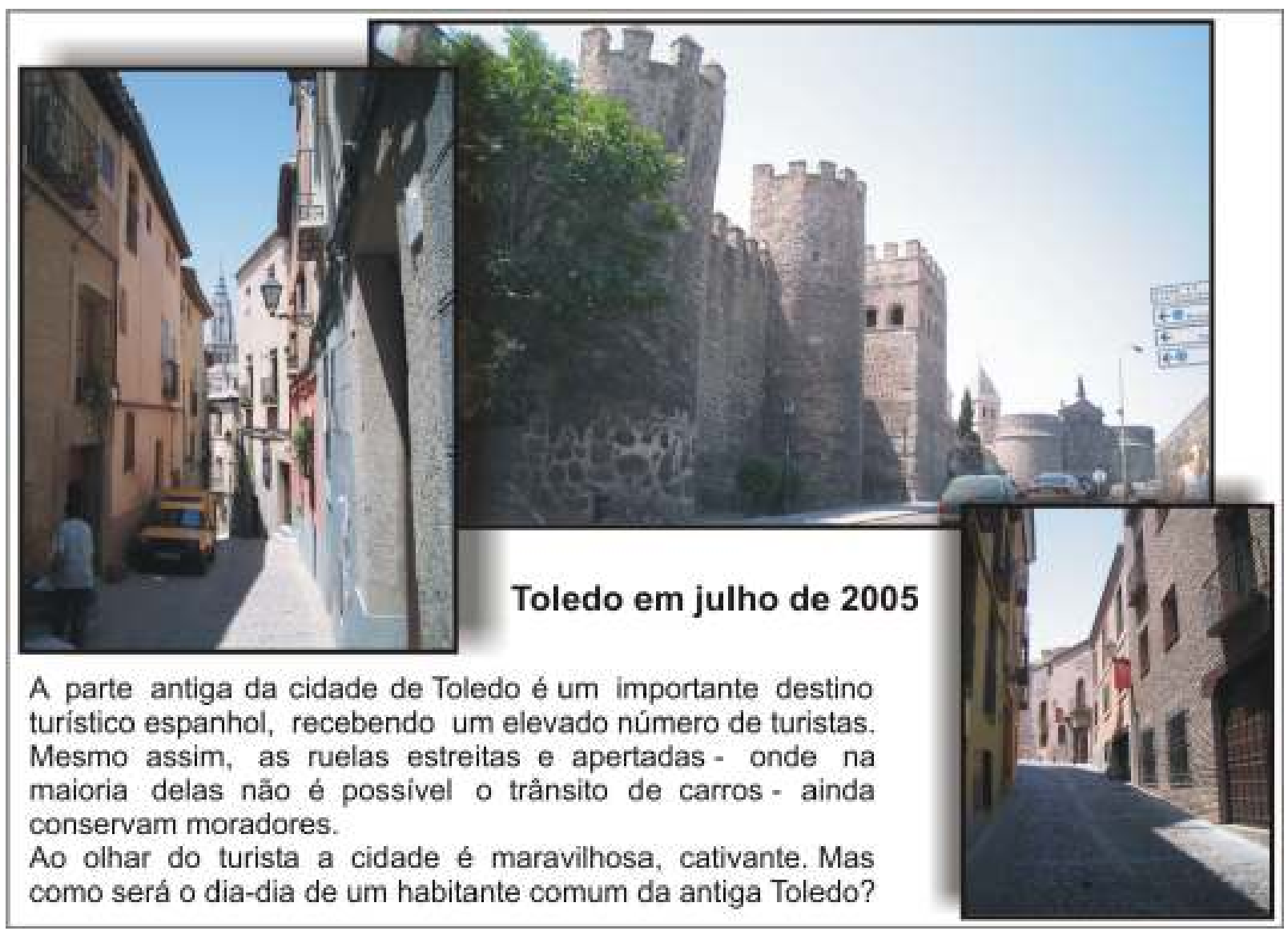

Conceituar paisagem pela representação de símbolos e signos conduz a estudos mais interpretativos como a lingüística e a semiótica. Os autores (Cosgrove e Jackson: 2000: 19) afirmam que esta linha de pesquisa desenvolve a metáfora da paisagem como "texto" que é lido e interpretado como documento social.

Cosgrove e Jackson (2000: 22) ainda ressaltam que a analogia da paisagem-texto é valiosa, pois preserva o significado da ação humana, da criatividade e da sobreposição de camadas de significado. Todavia, apresenta limitações, na medida em que a paisagem é concebida com a história de um modo de ver e de representar.

Por isso, em sociedades primitivas, com menor comércio, os códigos simbólicos eram mais estáveis do que nas sociedades contemporâneas. Hoje, o mundo é marcado 
pela liberdade de atribuir significados e pela intertextualidade, com a qual se invertem os signos e símbolos para adaptá-los a diversos contextos, transformando a referência e enfatizando somente a superfície e não a profundidade (Cosgrove e Jackson, 2000: 23).

Sendo assim, as representações gráficas para mapas turísticos resultam da combinação espaço-tempo. Espaço onde se encontram as diferentes naturezasculturas, que se modificam e se inter-relacionam, em diferentes níveis, no tempo. Relembra-se a definição de território, imutável em seus limites (o que se dá por intermédio da força ou acordo), não possuindo necessariamente a mesma extensão através dos tempos. Ele se torna espaço devido às inúmeras sucessões históricas e conseqüentes ocupações por um povo.

O espaço é resultado de um matrimônio ou encontro, sagrado enquanto dura, entre a configuração territorial, a paisagem e a sociedade. $O$ espaço é a totalidade verdadeira, porque dinâmica, resultado da geografização da sociedade sobre a configuração territorial. Podem as formas, durante muito tempo, permanecer as mesmas, mas, como a sociedade está sempre em movimento, a mesma paisagem, a mesma configuração territorial, nos oferecem, no transcurso histórico, espaços diferentes (Santos: 1996: 77).

O espaço é composto por várias paisagens (materializações de vários instantes históricos), resultado de um conjunto de objetos (materiais e não-materiais), formas e momentos com heranças distintas (Santos, 1996: 66). Conseqüentemente, a paisagem é um registro de época e um documento de cultura (Moraes, 2002: 23).

Wagner e Mikesell (2000: 141) completam que o processo gradual e cumulativo da paisagem, relacionada aos respectivos estágios históricos, traz significados tanto para a paisagem de hoje quanto para as do passado. E, atualmente, as paisagens do mundo não refletem apenas evoluções locais, devido ao grande número de influências resultantes das migrações, difusão (mídias), comércio e trocas.

Essa dinâmica dá à paisagem um sentido móvel, isto é, cada vez que a sociedade passa por um processo de mudança, também mudam, em ritmo variado, a economia, as relações sociais e políticas. Por conseguinte, o mesmo fenômeno acontece com o espaço e a paisagem, que se transformam, buscando se adaptar às novas necessidades da sociedade (Santos, 2004: 54).

Ratifique-se, portanto, que paisagem e espaço não são sinônimos, sendo a primeira um conjunto de formas, contextualizada em recorte temporal, cumulativo e substitutivo, resultado da lógica de produção do espaço. As paisagens se formam umas sobre as outras, sendo constituídas pelo conjunto de objetos de diferentes idades, que representam as sucessivas relações entre a humanidade e a natureza. Reafirme-se, então, que a paisagem é transtemporal, juntando objetos passados e presentes, ou seja, suas formas ocorrem em momentos históricos diferentes - 
rugosidades ${ }^{9}-$, porém coexistem no momento vivido, atual. Já o espaço ${ }^{10}$ são todas essas formas mais a vida - sociedade presente e agente nas formas-objetos - que as anima (Santos, 2002:103-104).

Assim, o mapa pictórico turístico trabalha conjuntamente os conceitos: paisagem configurada por um sistema material - que, entre outras coisas, pode ser graficamente representado e espaço, onde as formas que hoje compõem a paisagem têm uma função, ou seja, respondem às necessidades prementes da sociedade - no caso, foca-se sobre os mapas que apresentam atrações, naturais e culturais, atividades e serviços disponibilizados por localidade e atual destinação turística. Por isso, leva-se ainda em conta a definição de espaço turístico de Boullón (apud Beni: 1998: 56):

é resultado da presença e distribuição territorial dos atrativos ${ }^{11}$ turísticos que, não podemos esquecer, são a matéria-prima do Turismo. Este elemento ou componente do patrimônio turístico, mais o mapeamento, são suficientes para definir o espaço turístico de qualquer país.

Santos (op.cit::104) constata que o espaço se caracteriza por um sistema de valores instáveis, resultado de sua permanente transformação.

Visto de maneira mais direta, o espaço do local trabalhado pelo setor do turismo, concentra um determinado número de objetos reais-concretos e paisagens, que são "filtradas" e aproveitadas no desenvolvimento dos mapas. Isto decorre das diversas parcelas e maneiras de utilização do espaço, que se constituem por um conjunto de mercadorias que recebem valores - maiores ou menores - em um dado momento, pela sociedade, refletido em cada fração da paisagem. O que significa que os objetos não mudam de lugar, mas de função, isto é, de significação, de valor sistêmico (Santos, op.cit::103-104).

Citem-se então alguns exemplos: um rio, que antes servia somente para a pesca de subsistência e irrigação de lavouras, hoje oferece um grande potencial aos esportes de aventura como o rafting, o bóia-cross ou o canyoning. Um antigo galpão, que

\footnotetext{
${ }^{9}$ É o que fica do passado como forma, espaço construído, paisagem, ou seja, são reminiscências dos processos de supressão, acumulação e superposição, com que as coisas se substituem e acumulam em todos os lugares. O tempo atual se defronta com o tempo passado, cristalizado em formas (Santos, 2002: 140).

${ }^{10}$ Deve ser considerado como um conjunto indissociável de que participam, de um lado, certo arranjo de objetos geográficos, objetos naturais e objetos sociais e, de outro, a vida que preenche e os anima, ou seja, a sociedade em movimento (Santos, 1996:26). Por trás dos padrões sociais, das formas criadas, dos usos do solo, das repartições e distribuições, dos arranjos locacionais, estão concepções, valores, interesses, mentalidades, visões de mundo. Enfim, todo o complexo universo da cultura, da política e das ideologias (Moraes: 2002: 16). O autor ainda alerta (op. cit.: 19) que não se deve perder o contexto histórico, pois o sujeito exprime uma época, sendo estruturado dentro de limites e possibilidades.

11 Também chamado de recursos turísticos, os quais constituem o patrimônio turístico. Esses elementos são passíveis de provocar deslocamentos de pessoas e integram o marco geográficoecológico-cultural de um lugar, podendo, por sua origem, ser subdivididos em naturais e culturais (Beni: 1998: 57).
} 
antes abrigava uma tecelagem, hoje pode ser um espaço cultural, como um teatro. Cite-se hipoteticamente o centro urbano de uma cidade qualquer, que outrora fora rico, ativo e efervescente, porém com o tempo se tornou inóspito, perigoso. No entanto, com um trabalho de restauração e incentivo governamental (arquitetura, infra-estrutura, volta de moradores, etc) pôde se tornar um importante e atrativo destino turístico da cidade. Desse modo, o que hoje é valorizado por determinada parcela da sociedade (material acumulado das ações humanas através do tempo) amanhã pode não ser (animado pelas ações atuais) e vice-versa. Santos (2002: 105) complementa que, só por sua presença, os objetos técnicos não têm outro significado senão o paisagístico. Mas eles aí estão também em disponibilidade, à espera de um conteúdo social.

Tal movimento ininterrupto da sociedade traz novas funções às formas geográficas, que possuem vida pelo processo sempre renovado de seu poder representativo, seu conteúdo ${ }^{12}$. Tal conteúdo corporificado, ou seja, já transformado em existência, traz intrinsecamente a sociedade nas formas geográficas: é a sociedade transformada em espaço (Santos, 1996: 27). A forma contém em si a memória viva, imagens do presente e/ou de um passado que não existe mais (Santos, 2002:106).

O mesmo autor exemplifica (Santos, 2002:109) que um conjunto de prédios históricos, uma praia, uma floresta, entre outros elementos paisagísticos, participam desse processo dialético quando Ihes são atribuídos determinados valores, ao serem transformados em espaço. O simples fato de existirem como formas, isto é, como paisagem, não basta. A forma já utilizada é coisa diferente, pois seu conteúdo é social. Ela se torna espaço, porque forma conteúdo.

Neste processo, o espaço tornou-se mercadoria universal por excelência, sendo convertido em uma gama de especulações de ordem econômica, ideológica, política, seja de forma isolada seja em conjunto (Santos, 2004: 30). Kotler (apud Santos, 2004:30) defende a idéia de um marketing das localidades, que procura maneiras para influenciar as atitudes das pessoas e estabelecer trocas de domicílios, de locais industriais e comerciais, de terrenos, de viagens e imagens nacionais.

Dentro dessa lógica, pode-se trabalhar a paisagem como conjuntos, como se fossem cartões postais, ou seja, trazer ao olhar um conjugado de formas ou formas isoladas. Até porque, de um modo ou de outro, temos a tendência de negligenciar o todo; mesmo os conjuntos que se encontram em nosso campo de visão nada mais são do que frações de um todo (Santos, 2004: 35). O autor continua esclarecendo que a percepção que se tem da paisagem está longe de englobar o objeto em sua realidade profunda: o que se capta é uma aparência. O objeto caracteriza-se por duas faces: a verdadeira, que não se dá diretamente ao observador; e a face visível, amoldada pela

${ }^{12} \mathrm{O}$ conteúdo (da sociedade) e a forma (objetos geográficos) são dependentes entre si. Até porque, cada forma encerra uma fração do conteúdo, que pode ser comparado a uma sociedade em andamento, em evolução, em movimento. Ou, melhor ainda, ao seu presente ainda não realizado (Santos, 1996: 27). 
ideologia $^{13}$.

A ideologia é objetiva, por dissimular o real, tentando impor-lhe a sua significação no momento crucial da objetivação da totalidade, ou seja, o que está na forma-objeto como significante, encontra-se em sua totalidade como significado (Santos, 2004: 37). A partir desta dualidade (significante-significado), o símbolo se faz presente, contudo a realidade à qual ele remete pode estar presente ou ausente, ser passado ou futuro, existente ou somente possível (Fraisse apud Santos, 2004: 37). Conseqüentemente, os símbolos são formações que representam objetos; que estão em relação entre si, ao mesmo tempo em que são distintos, que dependem de si próprios assim como os objetos dependem deles, constituindo, porém, entidades autônomas (Lorenzer apud Santos, 2004: 38). Some-se, ainda, que os símbolos adquirem vida própria, tornandose mais eficazes quando há a fetichização da matéria inerte. Isso faz com que, no caso dos objetos que compõem a destinação turística, eles sejam concebidos como mercadorias para seduzir e atrair o turista-consumidor.

Como resultado, as formas (em si), os objetos geográficos, passam a ter mais do que um papel funcional, pois são preenchidos de simbolismo, representatividade, intencionalidade. Impõe-se sobre eles um conteúdo e um valor que na realidade não têm; logo, seu significado é deformado por sua aparência (Santos, 2004: 59).

E a compreensão dos vários níveis de simbolismos é preocupação essencial na pesquisa, pois os mapas turísticos serão oferecidos a uma gama muito heterogênea de usuários (idade, grau de escolaridade, diferentes nacionalidades, níveis de compreensão e utilização de um computador, etc) que precisam compreender e interagir com as informações recebidas Já o produtor procura trabalhar a emoção e a motivação do usuário primeiro pelo produto (mapa turístico em meio digital e interativo) e logo depois, e não menos importante, pela destinação representada.

A universalização do mundo apontada por Santos (1996:14) nos ajuda a supor como se constata empiricamente ao final deste trabalho - que boa parte das pessoas que entram em contato com o produto são capazes de compreendê-lo, por já fazerem parte do processo de universalização das trocas, do mercado, da mercadoria, das técnicas, dos gostos, do consumo.

Cabe então ao produtor representar graficamente, e da melhor maneira possível, o espaço e algumas de suas peculiaridades ao outro turista. Para isso, ele conta com a localização geográfica circunscrita e diferente de outras, com seus atrativos naturais, culturais, serviços, acessos, constituídos ao longo do tempo (movimento). É importante ressaltar que existe um grau de similaridade-diferença (relatividade) entre os diversos espaços e coletividades. Isto faz com que algumas paisagens e sociedades sejam mais ou menos atraentes e mais ou menos compreendidas do que

13 Os construtores do espaço estão atrelados à ideologia dominante ao conceber uma casa, uma estrada, um mapa, uma cidade. $O$ ato de construir está submetido a regras que procuram nos modelos de produção e nas relações de classe suas possibilidades atuais (Santos: 2004: 36-37). 
outras.

Todo o processo de criação tem como base a diversidade cultural, trazendo à tona informações que precisam ser interessantes, de fácil reconhecimento e leitura ao maior número de pessoas. Conseqüentemente, procura-se um tipo de representação cartográfica com grande apelo ao senso comum, ao imaginário coletivo e também ao lúdico. O intuito é gerar sempre a dualidade: traços de identidade, igualdade, visando à leitura, compreensão do mapa; e de diferença, como o exotismo, que motivam, instigam o querer conhecer, viajar.

Para que isso ocorra, o mapa turístico deve se tornar natural e naturalizado, criando possibilidades com base nos mapas já existentes, ou seja, aqueles constituídos por uma semântica para iniciados como os provenientes do ensino formal: os mapas e símbolos convencionais. Estes podem ser retrabalhados e adaptados ao público potencial: o leigo em cartografia e que deseja conhecer novos lugares. Nesse caso, ocorre um hibridismo, resultante da composição entre símbolos pictóricos e ilustrações: os chamados "símbolos culturais" familiares ao senso comum. Contudo, deve-se sempre estar atento aos itens fundamentais da composição de um mapa convencional, como escala, legenda, título e sistema de referências (indicação de norte, latitude, longitude).

A pesquisa empírica auxilia na medição e na verificação analítica do produto, que contém assimetrias, igualdades, hierarquias e diferenças.

\section{3 - Quando as tradições se institucionalizam:}

\section{a semântica para iniciados versus o senso comum}

Referenciados no relativismo cultural e no empirismo, introduz-se Pierre Bourdieu, que discorre sobre os jogos de poder na sociedade. Ele teoriza sobre uma relação mais individualizada entre a tradição e o costume privado que pode vir a se tornar público.

Tendo como parâmetro o mapa para o setor do turismo e com base no capital cultural e suas nuances - grande variedade e níveis de relações entre coletivos - surgem muitas preocupações referentes à boa funcionalidade do produto, devido à diversidade do público usuário e, portanto, à necessidade de uma instrução prévia.

A finalidade é criar convenções com base no que já existe, ou seja, nos mapas convencionais que trazem uma semântica para iniciados. A partir daí adaptar, adequar e elaborar os mapas temáticos para o turismo, que mesclam o convencional (símbolos abstratos, normas mais rígidas, representações e leitura mais simples e direta) com a pictografia (símbolos pictóricos, suposta tridimensão, ilustrações, leitura mais lenta, lúdica). Procurando referenciar (restringir minimamente) o público a ser pesquisado e analisado, é importante esclarecer que os mapas turísticos são disponibilizados na Web. Isso faz com que o usuário do então mapa-site turístico 
precise ter contato com computadores - ambiente Windows ou similar e a internet.

Inicialmente aborda-se o tópico relativo a padronizações, normas.

As relações políticas e acadêmicas procuram "domesticar" o caos, buscando uma ordenação do mundo. Atualmente, o Estado, a escola e a mídia são os principais atores de reprodução das práticas sociais. Bourdieu (1974: XIV-XVI) sustenta que é pelas alegorias (discursos, mensagens e representações) que são simuladas as estruturas reais das relações sociais. A busca de tal organização é gerada por meio de funções ideológicas e políticas de uma cultura dominante numa dada formação social.

O Estado, como autoridade máxima, institucionaliza, à vista de todos e em nome de todos; publica e torna oficial, procurando subtrair o arbitrário. Tal processo se dá de maneira particular ou por intermédio de ações e imposições ao longo do tempo, buscando uma identidade legítima do grupo, a fim de gerar uma unidade real (Bourdieu, 2000:114).

Focalizando o tema desta pesquisa, a cartografia e o turismo, tem-se que os mapas, quando bem executados, tornar-se-iam, por exemplo, uma das primeiras e das mais importantes fontes de informação - principalmente ao turista - e de divulgação do potencial da localidade.

Nesse contexto, conceitua-se o habitus ${ }^{14}$, que exige dos grupos e/ou classes sociais o controle e domínio mínimo de um código comum, mesmo que ainda não seja um registro consciente. Carneiro (2001:31) complementa que o uso de códigos facilita o processo de comunicação das informações semânticas a partir do momento em que utiliza unidades ou elementos significativos que são de conhecimento prévio do receptor-usuário.

Primeiramente, o habitus é adquirido por via inculcação familiar (Bourdieu, 1974: XLVII); contudo, será a escola a força formadora dele, propiciando aos indivíduos um corpo comum de categorias de pensamento, que trazem consigo seus modelos, regras, tornando possível a comunicação. O conceito escolástico para habitus é, sobretudo, um conjunto de esquemas fundamentais que são previamente assimilados, a partir dos quais se produzem, segundo uma arte da invenção.

\footnotetext{
${ }^{14}$ Toda a ação histórica reflete dois estados do social: o Habitat - estado objetivado - história acumulada ao longo do tempo nos objetos, nas máquinas, edifícios, monumentos, livros, teorias, costumes, direito, etc. E o Habitus - estado incorporado. Por exemplo: Quando um homem tira o chapéu para cumprimentar alguém, está reativando, sem saber, um sinal convencional herdado da Idade Média, pois este gesto remonta aos homens de armas, que costumavam tirar o seu elmo para manifestações pacíficas. Esta atualização da história é conseqüência do habitus, isto é, produto de uma aquisição histórica que permite a apropriação do adquirido histórico (Bourdieu, 2000: 82). Por outro lado, quando duas pessoas são dotadas de habitus diferentes, isto é, não foram expostas às mesmas situações e aos mesmos estímulos, terão razões para fazer julgamentos de valor de maneiras diferentes (Bourdieu, 1996: 333).
} 
Esquemas particulares diretamente aplicados a situações particulares (Bourdieu, 1974: 349).

O sistema de ensino tradicional tende a assumir uma função de integração lógica, de legitimação cada vez mais necessária à perpetuação da ordem social. Preocupa-se em elaborar um programa homogêneo de percepção, de pensamento e de ação, assegurando, assim, àqueles indivíduos pertencentes a uma mesma geração ou história, uma homogeneidade própria que facilita a comunicação, a comunhão (Bourdieu, 1974: 206). Em uma disposição geral, ocasiona esquemas capazes de serem aplicados em campos diferentes do pensamento e da ação, aos quais se pode dar o nome de habitus cultivado (Bourdieu, 1974: 211).

Ocorre, então, que o sistema de ensino é umas das instituições mais preocupadas em transmitir a cultura, por desenvolver um papel fundamental quanto à participação de um senso comum, entendido como um fundamento comunicação. A escola dá ao indivíduo primordialmente um repertório para abordar os problemas de maneira comum. Bourdieu (1974: 288) trata de tal relação ao afirmar que, para que os homens cultivados de uma época possam discordar a respeito das questões que discutem, devem ao menos estar de acordo com certas questões, para assim, discutir sobre outras. Até porque o processo de transformações e reestruturações do campo cultural é contínuo e não radical, abraçando os mais variados temas. Assegura também a continuidade da comunicação entre as gerações intelectuais. E, em todos os casos, é o sistema escolar que torna inteiramente compreensível os esquemas que organizam o pensamento de uma época, consagrando-os e constituindo-os, pelo exercício, como hábitos de pensamentos comuns a toda uma geração (Bourdieu, 1974: 208).

Pensando no ensino da linguagem cartográfica, observam-se duas grandes linhas de pesquisa:

$\checkmark$ A Cartografia Sistemática ou topográfica - responsável pela produção e divulgação de documentos cartográficos elaborados a partir de rígidos parâmetros técnicos. Os elementos visíveis da paisagem são representados, efetuando-se medições precisas relacionadas aos ângulos, direções, distâncias, desníveis e superfícies (Guerrero \& Fiori, 2005: 141). Objetivam a representação exata e detalhada da superfície terrestre no que se refere à posição, à forma, às dimensões e à identificação dos acidentes do terreno, assim como dos objetos concretos que aí se encontram permanentemente (Joly, 1990: 54).

$\checkmark$ Cartografia Temática - está relacionada à elaboração e disseminação de documentos cartográficos que representam temas específicos (vegetação, população, clima, etc), relacionados às particularidades da superfície terrestre. Os mapas temáticos são os produtos mais conhecidos da sociedade em geral, sendo utilizados em diferentes contextos. Comumente estão em Atlas escolares, como também em revistas, na Internet, na televisão, etc. Resultam 
principalmente da seleção de dados estatísticos, posteriormente submetidos à representação cartográfica pelo uso de diferentes metodologias (Guerrero \& Fiori, 2005: 141).

Esta pesquisa parte de bases topográficas (sistemáticas), que são o pano de fundo para que se instaure e aprofunde uma metodologia voltada à cartografia temática, objetivando a elaboração de mapas turísticos.

É imprescindível relembrar que os mapas direcionados à divulgação turística e disponibilizados na internet devem ser cuidadosamente pensados, devido à grande heterogeneidade e aos níveis de interesse do público, que apresentam diferentes idades, graus de escolaridade, conhecimentos gerais, afinidades, conhecimentos em cartografia - escala que vai desde aqueles que compreendem a leitura dos mapas e conhecem a semântica para iniciados até aqueles que não têm conhecimento formal da disciplina, etc. Portanto, a elaboração de mapas voltados ao setor do turismo deve levar em consideração o usuário que tem apenas um conhecimento mínimo dos conceitos e noções relativas à comunicação cartográfica.

Neste instante, é importante citar Guerrero (2004: 43), que trata do ato de aprendizagem. $O$ ato ocorre de maneiras diferentes entre os sujeitos. Tal diferenciação está intrinsecamente ligada às estruturas cognitivas, às experiências de vida e ao aprofundamento da significação, resultante do maior ou menor contato com a informação que proporciona maior ou menor conhecimento dos seres humanos em relação aos mais diversos temas de seu cotidiano.

Abordando especificamente a utilização de mapas, relata-se em linhas gerais a pesquisa de Simielli $(1986,1996)$ ao ressaltar que o público não especializado apresenta muitas dificuldades com relação à leitura do material cartográfico. Esse problema histórico ocorre devido à baixa qualidade da educação cartográfica presente no ambiente escolar, que deveria se preocupar, por exemplo, em esclarecer conceitos da visão vertical e oblíqua, imagem bidimensional e tridimensional, noção de proporção e escala, alfabeto cartográfico e legenda, orientação, localização espacial, etc. Entretanto, na maior parte das vezes, conceitos e noções são mal assimilados ou pouco praticados, gerando um baixo índice de compreensão e interesse pela leitura dos mapas.

Torna-se oportuna a apresentação de alguns resultados empíricos obtidos na pesquisa de Guerrero (2004: 220-227), que trabalhou com professores de geografia do ensino fundamental e médio do município de São Paulo (Núcleo de ação educativa 05 - Prefeitura de São Paulo, região político-administrativa do Campo Limpo) em cursos de formação continuada. As atividades foram aplicadas uma a uma, em módulos mensais de aula para cada grupo de professores. Os resultados abaixo demonstram a elaboração de representações cartográficas equivocadas, oriundas de uma alfabetização cartográfica inexistente ou pouco eficiente dos docentes. Observou-se: 
$\checkmark$ Dificuldade na utilização de cartas topográficas, devido a sua linguagem técnica e mais específica, de leitura mais demorada e complexa do que um mapa temático. Acrescenta-se que, quanto maior a escala, maior a dificuldade do pesquisado para ler e compreender as curvas de nível. Aliás, verificou-se que muitos docentes não tinham aprendido os conceitos de curvas de nível e altitude;

$\checkmark$ A maioria dos professores nunca havia manuseado mapas temáticos e cartas topográficas, e, portanto, não conheciam seus signos, símbolos e a linguagem;

$\checkmark$ A presença de um ruído conceitual ao representar os fenômenos de manifestação linear e zonal. Na maioria das atividades realizadas, os professores contavam com informações lineares, mas, ao elaborarem a legenda do mapa, representaram tal informação como zonal;

$\checkmark$ Uso da cor de maneira indevida;

$\checkmark$ Dificuldade de identificar os cursos fluviais, pois eram confundidos com curvas de nível;

$\checkmark$ Problemas para indicar o título, a legenda, a escala;

$\checkmark$ Identificação correta do sistema viário e pontos de referência.

O pequeno exemplo detectou que, mesmo professores de geografia, depararam-se com lacunas conceituais básicas referentes aos conceitos cartográficos e iconográficos. E o que dizer então da população em geral?

A pesquisa empírica inicial de Fiori (1999: 99-106) já dava indícios de que, dependendo do público com o qual o produtor trabalha, a maneira como se concebem os mapas é muito importante. O teste empírico desenvolvido com cento e vinte crianças do ensino fundamental $\left(5^{\mathrm{a}}\right.$. e $6^{\mathrm{a}}$. séries) constatou que esse grupo de usuários sentiu-se motivados à leitura e conseguiu entender melhor a informação constatada a maior quantidade de respostas corretas quando ela trazia um apelo maior dos recursos pictóricos, em vez dos usuais símbolos abstratos ou geométricos. Por exemplo: as figuras pictóricas nos mapas políticos auxiliaram efetivamente a localização dos países, pois o produtor buscou supostas referências (imagens mentais) aprendidas pelo receptor ao longo de sua vida. O mesmo fato aconteceu com as representações da morfologia do terreno. Isso ocorreu porque, enquanto o usuário do mapa convencional tem somente a cor como grande apoio à interpretação - relaciona-se a realidade, que é o espaço geográfico -, à representação - o usuário do mapa pictórico "vê desenhada a altitude" sobre o mapa (Figura 6). Ver também os mapas em formato digital no CD - anexos - pasta 1. 
Figura 6 - Pictografia usada em mapas políticos e físicos
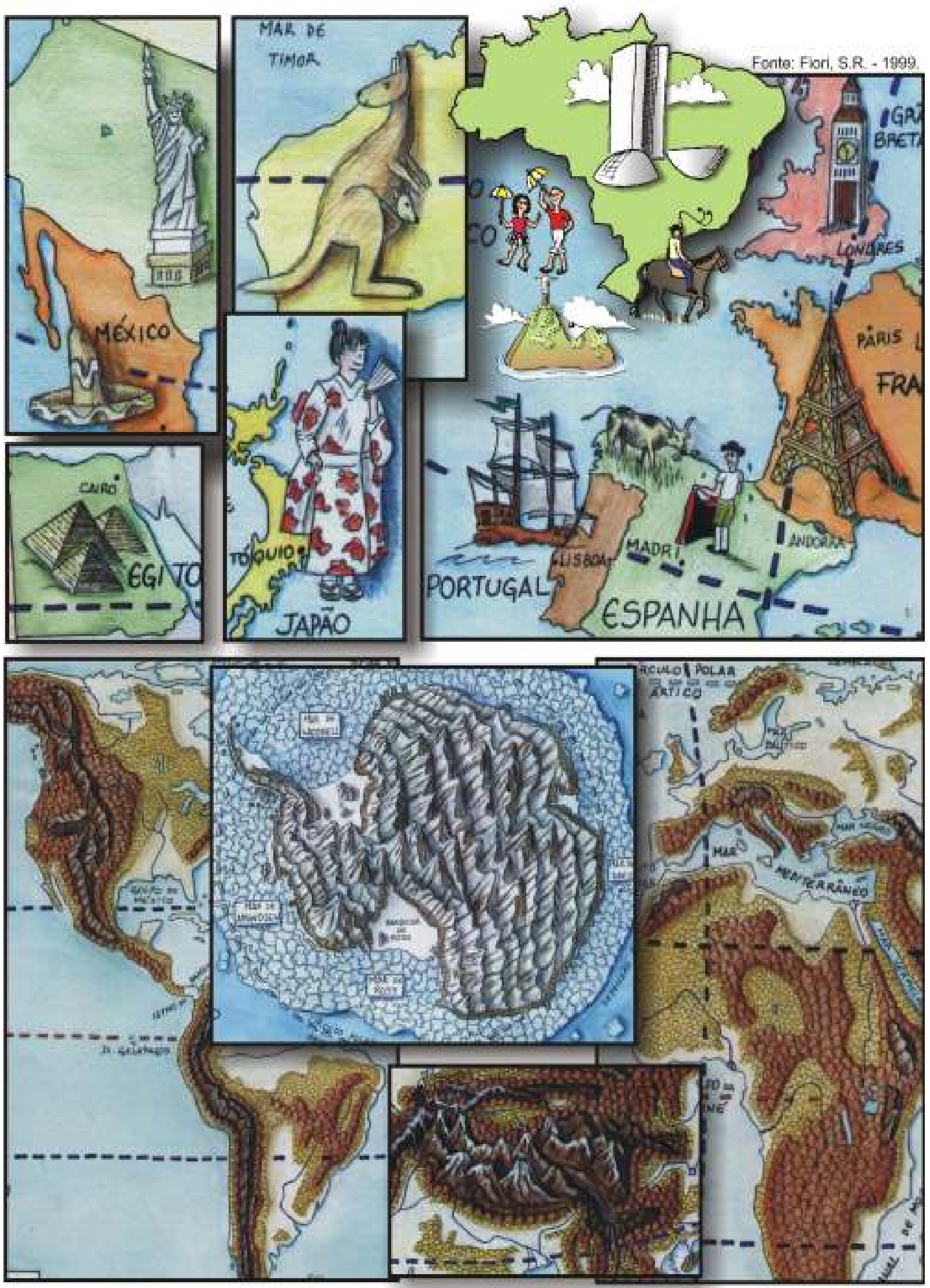

Fonte: Fiori, S.R. - 1999. 
Mesmo na pesquisa seguinte (Fiori: 2003: 180-183), já direcionada ao desenvolvimento de mapas voltados ao setor turístico, é flagrante a opção do usuário leigo pela pictografia. Pôde-se perceber que o segredo do maior sucesso relacionado aos mapas pictóricos - tanto em relação à quantidade de respostas satisfatórias quanto à aceitação do produto - está em sua maior proximidade com a imagem encontrada na realidade havendo, portanto, uma menor exigência de abstração. $O$ estilo artístico adequado, tendo sempre em evidência o tipo de público e a finalidade do produto, também auxilia e muito o aumento do desempenho do material cartográfico.

É necessário deixar mais claro o conceito de abstração utilizado neste trabalho. Ele é definido por deixar de lado os "detalhes irrelevantes" da realidade, enfatizando os traços distintos do elemento real-concreto. De acordo com Dondis (1991: 91), esse é um processo de "destilação", ou seja, de redução dos elementos visuais a traços mais essenciais e característicos. A graduação ligada à eliminação dos detalhes segue dois caminhos: a abstração voltada ao simbolismo que, às vezes, proporciona um significado identificável, e, outras vezes, um significado arbitrariamente atribuído; e a abstração pura, ou redução da manifestação visual aos elementos básicos, que não conserva relação alguma com qualquer representação representacional extraída da experiência do meio ambiente.

Aliás, mesmo a abstração voltada para o simbolismo requer uma simplificação radical, ou seja, a redução dos detalhes visuais do elemento disposto no espaço a seu mínimo irredutível. Além disso, para ser eficaz, um símbolo não deve apenas ser visto e reconhecido; deve também ser lembrado, e até reproduzido (Dondis, op.cit:: 91).

Tal processo de esquematização do desenho é chamado de generalização estrutural, pois, em síntese, consiste em apagar ou atenuar características desprezíveis da realidade, acentuando as importantes que, com a redução, correriam o risco de desaparecer. Quando a escala diminui radicalmente, apela-se para a generalização conceitual, ou seja, há uma mudança radical da representação cartográfica, utilizando-se símbolos mais sintéticos e menos numerosos (Joly, 1990: 22-23).

Souza (1992:193-194) observa que, ao se olhar para um objeto, é possível reconhecer vários traços visuais que o caracterizam enquanto modelo de uma determinada categoria conceitual: forma, tamanho, cor, textura, orientação, movimento, tom, ângulo de visão, etc. Entretanto somente alguns desses traços servirão como base para o reconhecimento perceptivo do objeto. Isso acontece devido à habilidade do ser humano de retificar ou normatizar a percepção segundo expectativas adquiridas ao longo de sua vida como ser cognitivo. Por exemplo: ao se falar em uma girafa, imediatamente vem à cabeça a imagem de um animal de pernas e pescoço longos, manchas na pele, etc. Mesmo que esses itens atributivos sejam um tanto vagos, os três exemplos gráficos demonstrados na figura 7 são capazes de trazer semanticamente o conceito de girafa, pois o processo de conhecimento e reconhecimento dos estímulos visíveis faz uso normalmente de um número reduzido, 
essencial, de atributos definidores.

Figura 7 - Traços visuais: o conceito de uma girafa

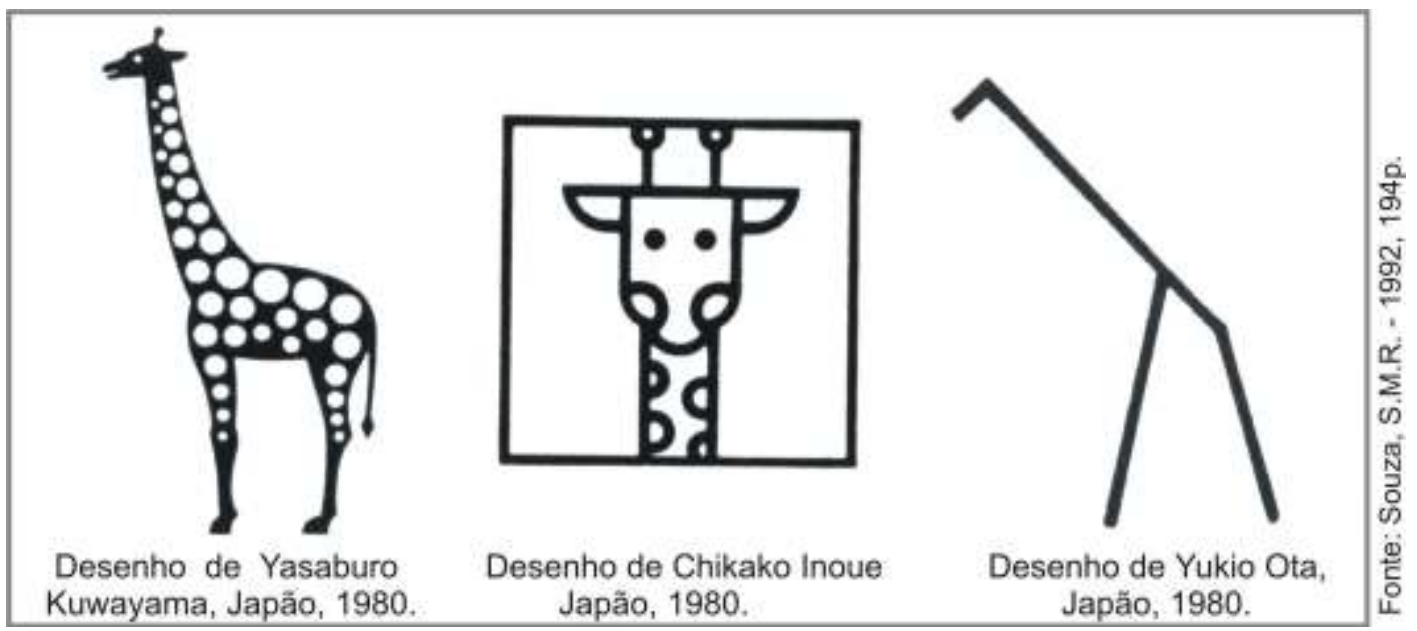

Portanto, a pesquisa enfatizou aquelas representações que tendem ao simbolismo (menor abstração em relação à realidade), por sua qualidade de conservar algumas das qualidades reais do elemento representado (Figura 8).

\section{Figura 8 - Traços característicos do elemento representado: a schemata}

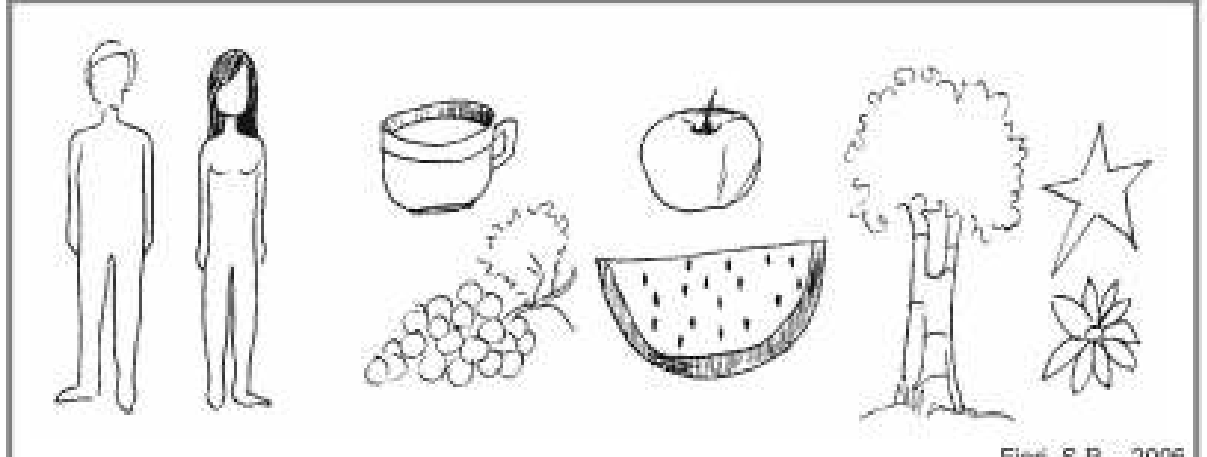

Servem de apoio as imagens da memória, pois é graças a ela que se retiram os traços característicos dos objetos/elementos encontrados no plano concreto, ou seja, aqueles aspectos que revelam a forma mais Fian, S.R.-2006 típica.

É fato que, quanto mais abstrato for o símbolo, mais intenso deve ser o trabalho de educação do público em relação ao significado da representação (Dondis, 1991: 92).

Como argumenta Guerrero (2004: 34), a aceitação e a compreensão de um ou outro tipo de representação é decorrente do ato cognitivo, que atribui significados aos objetos, fenômenos, pessoas, lugares. É um processo contínuo, dinâmico no qual a estrutura cognitiva responde pela aprendizagem de novas idéias, informações, conceitos, contemplando modificações quando necessárias, à medida que os sujeitos realizam essas ações sobre os objetos e materiais.

Isso faz com que as representações não tenham limites muito precisos e uniformes 
entre as pessoas. Wollheim (2002: 60-61) questiona se os sinais internacionais de trânsito, os logotipos, os adesivos, os pictogramas dos banheiros públicos são ou não são representações. $\mathrm{Na}$ verdade serão quando coincidir com as intuições preexistentes de uma determinada pessoa ou grupo. A compreensão de um mapa, por exemplo, está apoiada em um conjunto de habilidades que são paulatinamente aprendidas, criando-se então, condições de leitura.

O aprendizado do indivíduo é resultado de um conjunto de esquemas fundamentais que vão sendo formados ao longo de sua vida, e que servirão de base para a seleção e aquisição das próximas informações. A assimilação dos bens simbólicos só pode ser apreendida por aqueles que já detêm o código e, então, os decifram; ou seja, a apropriação dos bens supõe a posse prévia dos instrumentos de apropriação (Bourdieu, 1974: 210; 297).

Com base nesse autor (1974: 290-291) pode-se concluir que aqueles indivíduos que têm a possibilidade de convívio prolongado com os mapas, trazem consigo uma interiorização consciente e inconsciente das regras de produção e um sentimento de familiaridade e de maior compreensão do objeto. Conseqüentemente, não há uma escala possível para se quantificar qual o maior ou menor grau de compreensão da leitura cartográfica. $O$ que se pode apontar são algumas situações sociais facilitadoras como: os pais mostrarem e incentivarem o uso do mapa, o gosto pessoal, o acesso facilitado, a educação formal, etc. Dessa mesma perspectiva, pode-se justificar que o uso e compreensão das representações se ajustam à visão de mundo da experiência prática.

O grande desafio da pesquisa é pensar possibilidades de elaboração de um produto cartográfico para aqueles usuários que têm pouca familiaridade com o mapa. $O$ objetivo é ampliar ao máximo o sentimento de familiaridade, compreensão, motivação e eficácia, ao maior e mais diversificado número de usuários, objetivando sempre um alto nível quanto à aceitação e uso do produto.

Por fim, insere-se a mídia (jornal, rádio, televisão, Internet, etc.) como um dos principais atores de reprodução das práticas sociais, consagrando, ao longo do tempo, sua grande força na transmissão da comunicação de massa. Gombrich (1991: 129) ilustra a seguir essa forte influência sobre a sociedade contemporânea:

Pela manhã, abre-se o jornal e vêem-se fotografias de homens e mulheres que são notícia e, correndo os olhos por esse mesmo jornal, encontra-se a imagem de uma caixa de cereais. Entre as correspondências do dia, estão brilhantes folhetos e suas imagens de tentadoras paisagens, além de belas mulheres tomando sol, o que incita a se sair de férias em um cruzeiro e, para isso, é preciso comprar um elegante terno feito sob medida. Ao sair de casa, nota-se ao longo da estrada outdoors que perseguem a atenção jogando com os desejos de fumar, beber ou comer. Já no trabalho, é bem provável que se tenha que manejar algum tipo de informação gráfica: fotografias, croquis, catálogos, projetos, mapas ou, ao menos, 
gráficos. À noite, ao se descansar, senta-se à frente da televisão - a nova janela do mundo - e assiste-se às imagens de prazer, horror, tempos passados e países distantes. Hoje as imagens destes lugares conseguem ser mais acessíveis do que foram para o público que viveu naquela época. As casas acumulam livros ilustrados, cartões postais, slides e fotos que sempre ao serem olhados trazem boas recordações de viagens entre amigos e familiares.

O que dizer então do novo e rápido crescimento do mundo digital, com as imagens de satélite, a internet, os cds interativos, a realidade virtual e a inserção de sons, cheiros, entre outros recursos tecnológicos? Brown, Emmer \& Worm (2001) complementam que há grandes progressos em várias áreas da comunicação, como, por exemplo, navegadores (browser) com vozes, o que aumentará a utilização do som. De fato, a alta condição de interatividade é uma revolução quando comparada aos métodos mais tradicionais (imprensa escrita, rádio e televisão) de se comunicar a informação.

No caso da cartografia, o meio mais comum de se informar era por meio da impressão em papel, mas isto também vem sendo paulatinamente mudado a partir da revolução do computador e da Internet.

O ininterrupto processo de aquisição e acúmulo de conhecimento teórico e concomitantemente de tecnologia (materiais e suas funções) favorece o surgimento dos novos produtos, que oferecem mais possibilidades tanto de escolha (para quem e para quê) quanto de compreensão pelo receptor.

Na cartografia, recorda-se Oliveira (1977:15) - que demonstrou, há quase trinta anos, preocupações quanto à elaboração dos mapas escolares - havia:

reproduções dos mapas geográficos. O que ocorre é que os pequenos "lêem" os mapas dos grandes, os quais são generalizações da realidade que implicam uma escala, uma projeção e uma simbologia especiais e que não têm significação nenhuma para as crianças.

De lá para cá, contata-se uma crescente preocupação com o assunto, evidenciando trabalhos relacionados à funcionalidade na elaboração do mapa, que tem a obrigação de ser compatível - oferecendo boa compreensão, leitura, sendo motivador - com usuário potencial. No Brasil, por exemplo, podem ser citadas as pesquisas de Simielli (1986, 1997) sobre cartografia e ensino e as de Vasconcelos (1993), que desenvolveu um estudo de produção e uso de mapas para deficientes visuais. Contudo, existem poucos estudos no país sobre a elaboração e uso de mapas voltados ao setor do turismo. Além disso, abre-se uma nova e enorme possibilidade de se criarem materiais cartográficos em multimídia interativa, que possibilita apresentar uma mesma informação em um mesmo mapa, porém de diferentes maneiras, permitindo uma chance maior de compreensão do conteúdo proposto.

Bourdieu (1974: 105) define o modo de produção e circulação de bens simbólicos como um sistema de relações objetivas entre as várias instâncias determinadas pela 
função que cumprem na divisão do trabalho, seja na produção, reprodução e difusão dos bens simbólicos. Especificamente no campo da produção, decorre uma estrutura específica, estabelecendo uma oposição entre:

- O campo da produção erudita, caracterizado por um sistema produtor de bens culturais (e os instrumentos de apropriação destes bens), objetivamente destinados ao público produtor dos bens culturais.

- O campo da indústria cultural, sistema especificamente organizado com vistas à produção de bens culturais destinados a não-produtores desses bens - 0 grande público - os quais podem ser recrutados tanto nas frações não-intelectuais das classes dominantes (o público cultivado) como nas demais classes sociais.

Há de se atentar que mesmo os usuários pertencentes ao mesmo círculo social apresentam diferentes nuances - estilo de vida, atitudes, conhecimentos, entre outros traços característicos (Bourdieu, 1974: 166).

Destarte, cabe ao produtor do mapa - campo da produção erudita - estabelecer as regras, criando ferramentas que proporcionem a elaboração de mapas temáticos a partir de interesses e públicos distintos, sempre buscando adaptar o desenvolvimento do material ao usuário preferencialmente potencial, que deve ser cultivado.

O profissional deve estar sempre alerta para saber como será concebido o mapa para a indústria cultural. $O$ ato de concepção do material passa primeiramente por um processo de interiorização (realidade-mapa), ou seja, é por intermédio do produtor que acontece uma espécie de filtragem das imagens, impressões e sentimentos naturais. Segundo Galeffi (1977: 148), aquilo que pertencia à vida real ou prática, transforma-se em experiência contemplada - característica distintiva e imprescindível - essência da verdadeira criação estética.

O habitus faz o produtor do mapa ser parte integrante de uma coletividade, de uma época. E, sem que ele tenha consciência, seus atos de criação aparentemente mais especiais, individuais, são orientados e dirigidos (Bourdieu, 1974: 242). Segundo, Canclini (2003: 195) a relação que se tem com os atrativos naturais e culturais - e sua representação técnica e artística: o mapa turístico - ocorre a partir de um determinado capital cultural que não dispõe do conjunto de bens estáveis e neutros, com valores e sentido fixos. Isto significa que, por fazer parte de um processo social, o ato de cartografar se apropria de forma diferenciada e desigual do capital cultural, devido aos diversos setores, que se acumulam e se reestruturam ao longo do tempo.

A noção de indústria cultural continua servindo como referência ao fato de que cada vez mais os bens culturais não são gerados de maneira artesanal ou individual, mas sim por meio de procedimentos técnicos, máquinas e relações de trabalho equivalente àqueles produtos gerados pela indústria (Canclini, 2003: 257).

Os produtores do sistema da indústria cultural possuem uma posição subordinada à 
dos detentores dos instrumentos de produção e difusão, obedecendo basicamente aos imperativos da concorrência pela conquista de mercado, ao passo que a estrutura de seu produto decorre das condições econômicas e sociais de sua produção. Trabalham com um público muitas vezes medianamente qualificado socialmente heterogêneo, os quais se encontram submetidos a sanções do mercado. A cultura média apresenta ainda procedimentos e efeitos estéticos imediatamente acessíveis, excetuando-se todos os temas capazes de provocar controvérsia ou chocar alguma fração do público. Procura o lugar-comum que possibilita a projeção das mais diferentes categorias de usuários (Bourdieu, 1974: 137).

Para haver um maior sucesso quanto ao consumo de um produto, Bourdieu (1996, 289) ressalta aspectos que devem ser levados em conta: os campos de produção (que apresentam suas próprias leis de mudança) e o espaço social. Os dois juntos determinam uma situação na estrutura social. Os gostos vêm por meio dos condicionamentos sociais relacionados às condições materiais de vida do indivíduo.

A partir de tudo que foi exposto até aqui e pensando na cultura de massa ${ }^{15}$, a elaboração do mapa turístico em meio digital traz muitos questionamentos. Desde já fica evidente a aproximação e as combinações entre algumas dualidades, a saber:

\section{» Mapas convencionais e pictóricos}

Os mapas denominados convencionais são compostos por símbolos e formas geométricas (quadrados, círculos, etc.) e abstratos (manchas e áreas sem uma forma definida). Não possuem semelhança com o fenômeno representado e, portanto, apresentam um alto nível de abstração da realidade. Por exemplo: ao olhar um mapa topográfico (relevo) - Figura $9 \mathrm{~A}$ - vê-se um degradê de cores que indica maior ou menor altitude. Ou então, na legenda de um mapa temático convencional, observa-se a representação dos tipos de indústrias (Figura 9 B) com símbolos geométricos.

Nesta modalidade de mapa faz-se uso da semântica formal - que é ensinada - e do discurso da neutralidade, pois, sendo os símbolos abstratos, é imprescindível se recorrer à legenda.

Os mapas pictóricos têm como referência os mapas convencionais, contudo, são adaptados àqueles usuários que conhecem muito pouco ou desconhecem os fundamentos cartográficos. Esse tipo de mapa é composto de símbolos pictóricos (ilustrações, desenhos), devendo possuir alguma(s) semelhança(s) física(s) com o fenômeno representado. Segundo Moscardo (1999:53), quanto mais parecido for o símbolo com o que ele representa, mais fácil será interpretá-lo, compreendê-lo. A figura 10 mostra uma série de símbolos, com maior ou menor grau de abstração. Os símbolos da esquerda requerem uma maior energia mental dos usuários do que

\footnotetext{
${ }^{15}$ É impossível sintetizar formatos e processos tão variados sob um único nome. Alguns rótulos, os de cultura de massa ou para massa, podem ser usados com a precaução de que designam um único aspecto e não o mais recente. As noções de indústria cultural, cultura eletrônica ou tele-informação são pertinentes para designar aspectos técnicos ou pontuais da cultura de massa (Canclini, 2003: 258).
} 
aqueles da direita.

Figura 9 - Mapa e símbolos convencionais
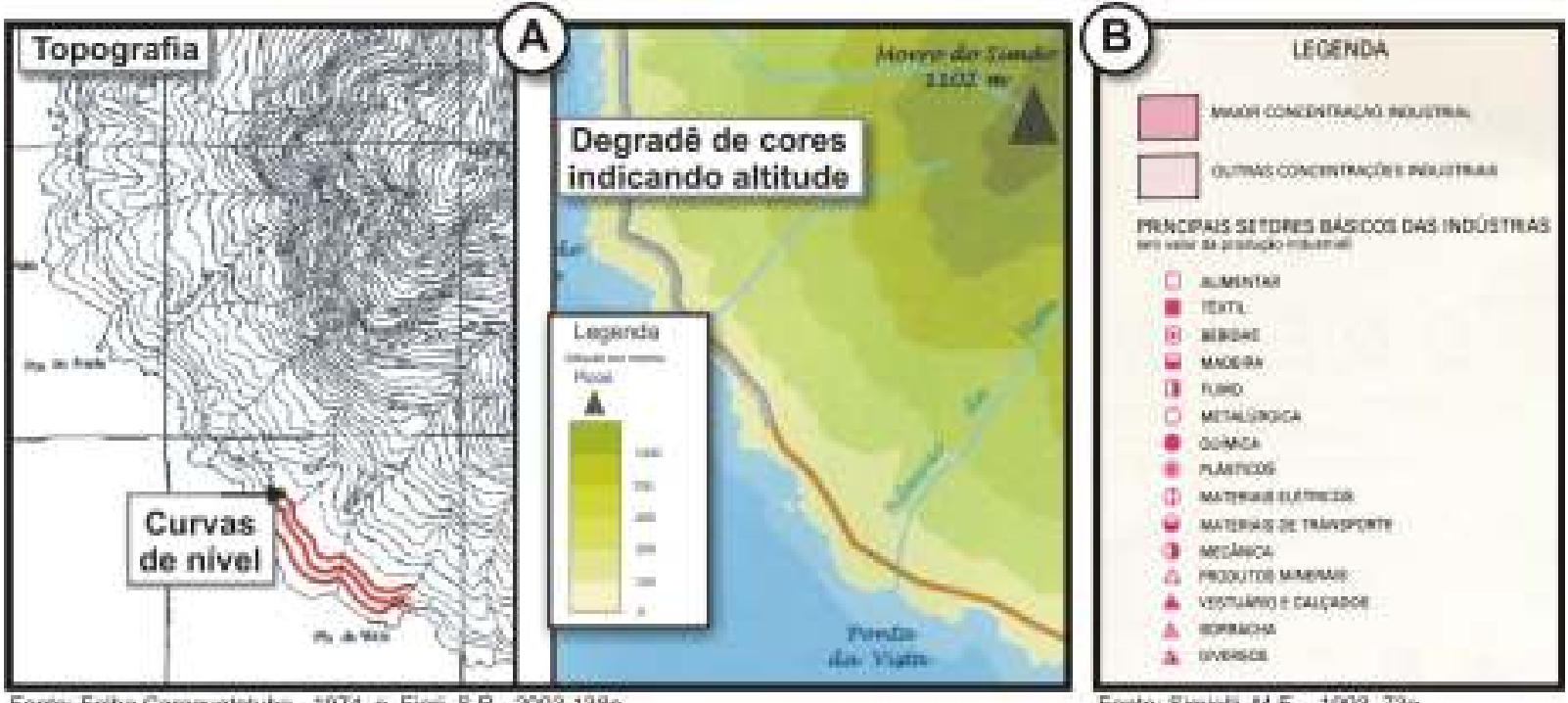

Figura 10 - Níveis de abstração do símbolo

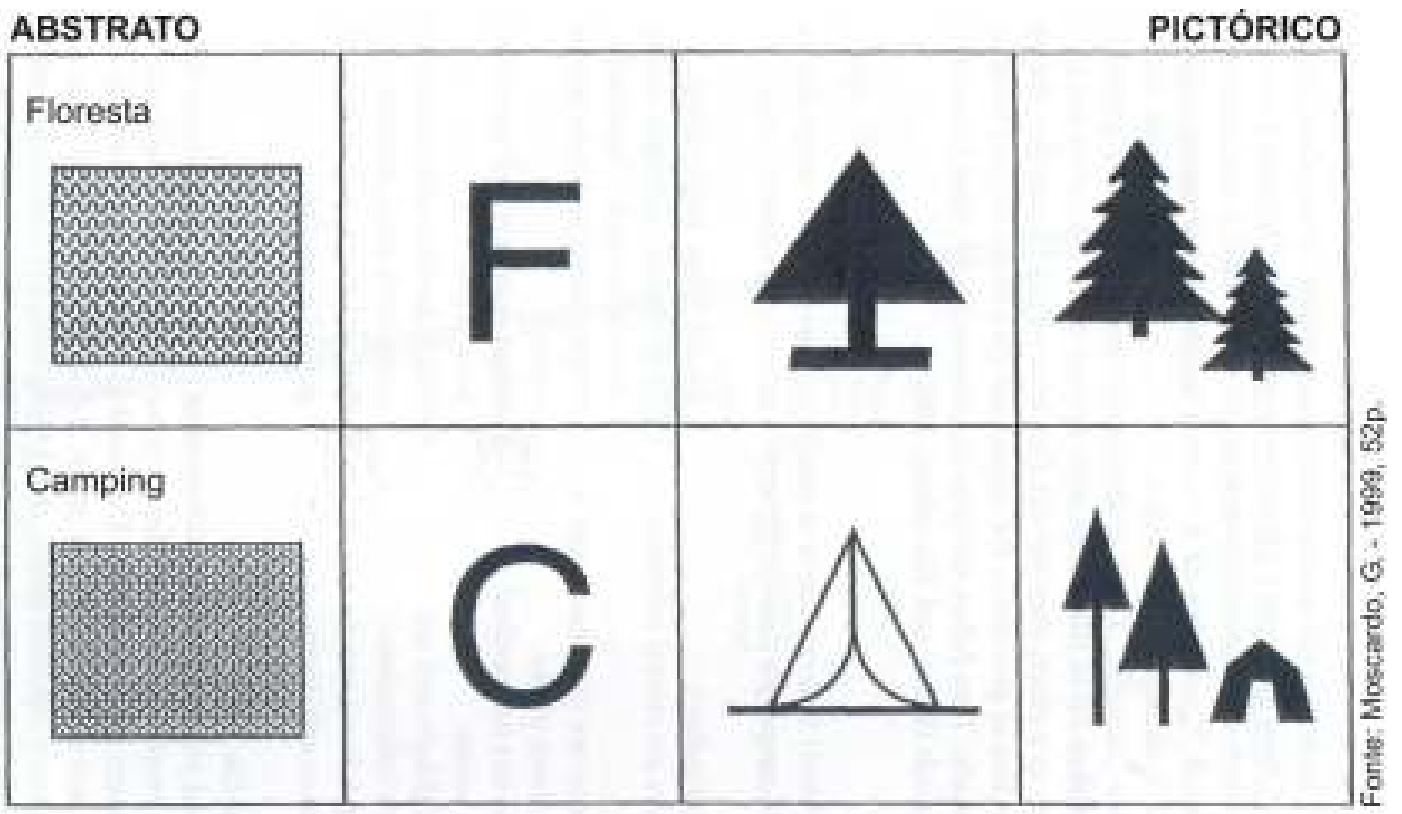

A partir dos mesmos exemplos utilizados para o mapa convencional, a figura $11 \mathrm{~A}$ representa a topografia (relevo) do terreno, usando a pictografia-ilustração. Veja também a legenda da figura $11 \mathrm{~B}$, que utilizou ilustrações para representar os tipos de indústria. É por esse motivo que este tipo de representação gráfica apresenta um baixo nível de abstração da realidade. 


\section{Figura 11 - Mapa e símbolos pictóricos}
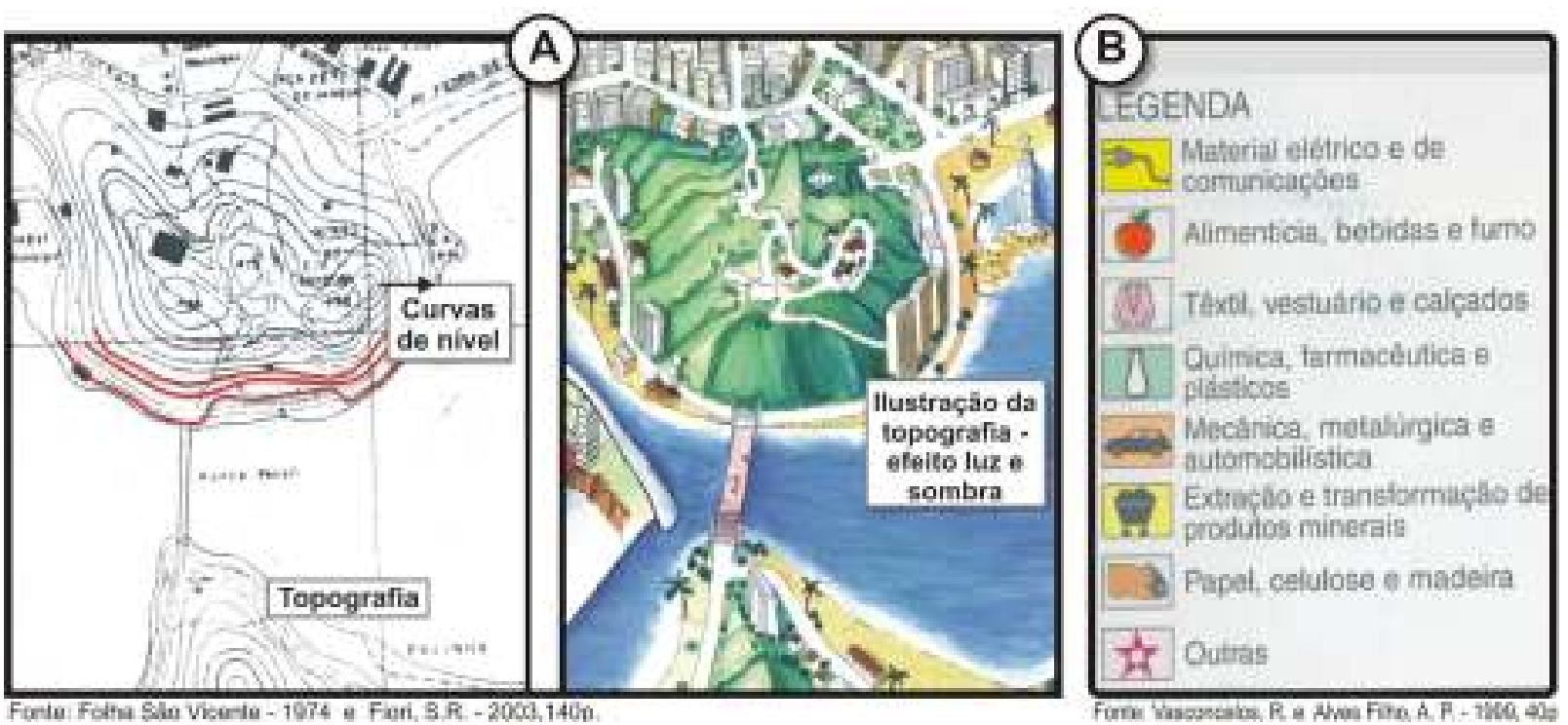

Nesse tipo de mapa, trabalha-se mais o senso comum, sendo que temas como arte e cultura recebem uma importância preponderante, pois os desenhos idealizados, selecionados e confeccionados são resultado de um conjunto de contextos mentais de uma dada sociedade.

Em suma, o mapa turístico é uma junção de duas formas de representar a mesma realidade. Primeiro, a convencional, com preocupações formais, normas técnicas mais rígidas e segundo, a pictórica, caracterizada por símbolos culturais, uma maior expressividade gráfica e proximidade com a realidade representada. O que se espera é um produto que possa ser consumido sem que necessariamente o usuário-turista conheça a semântica formal.

\section{» Simbologia superficial ou profunda}

Este outro tópico tem a ver com o que se pretende e com a intenção de cada símbolo e ilustração dispostos sobre um mapa temático para o turismo, já pensando no uso efetivo da pictografia. As simbologias também se dividem em dois tipos: as denominadas superficiais, que são aquelas reconhecidas mais rapidamente, sendo diretas, simples, rasas; com elas, busca-se uma padronização. Como exemplos citam-se os símbolos para sinalização do trânsito, em estrada, turística, em área pública e privada, entre outros. Mesmo assim, não são alheias às influências culturais (Figura 12).

Já os símbolos profundos são aqueles que valorizam a diversidade cultural e, no caso desta pesquisa, mais especificamente a paisagem, o olhar do outro (figura 13). As ilustrações e símbolos ajudam a explorar o exótico de uma maneira lúdica, buscando a intenção de motivar, atrair o usuário-turista a querer conhecer a dada localidade.

Todavia, as simbologias de uma coletividade precisam ser assimiladas por outras. 
Figura 12 - Símbolos superficiais

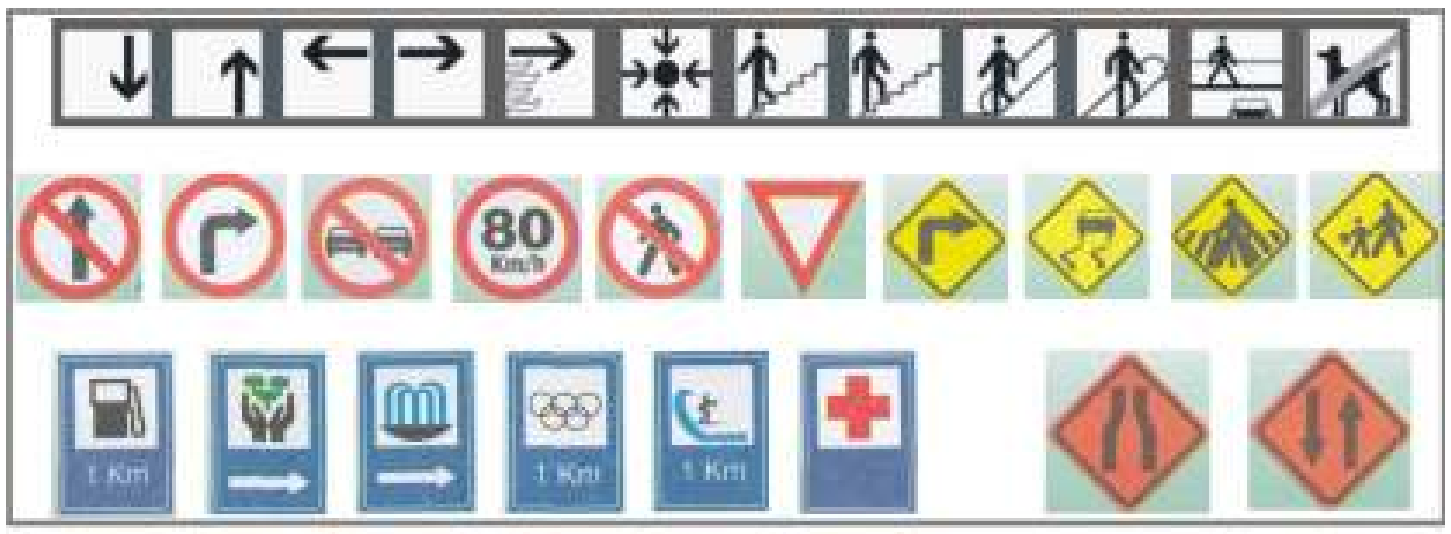

Fonte: Erco - 2005 e Bruns, C, B, - 2000, 28-33p,

Figura 13 - Símbolos profundos

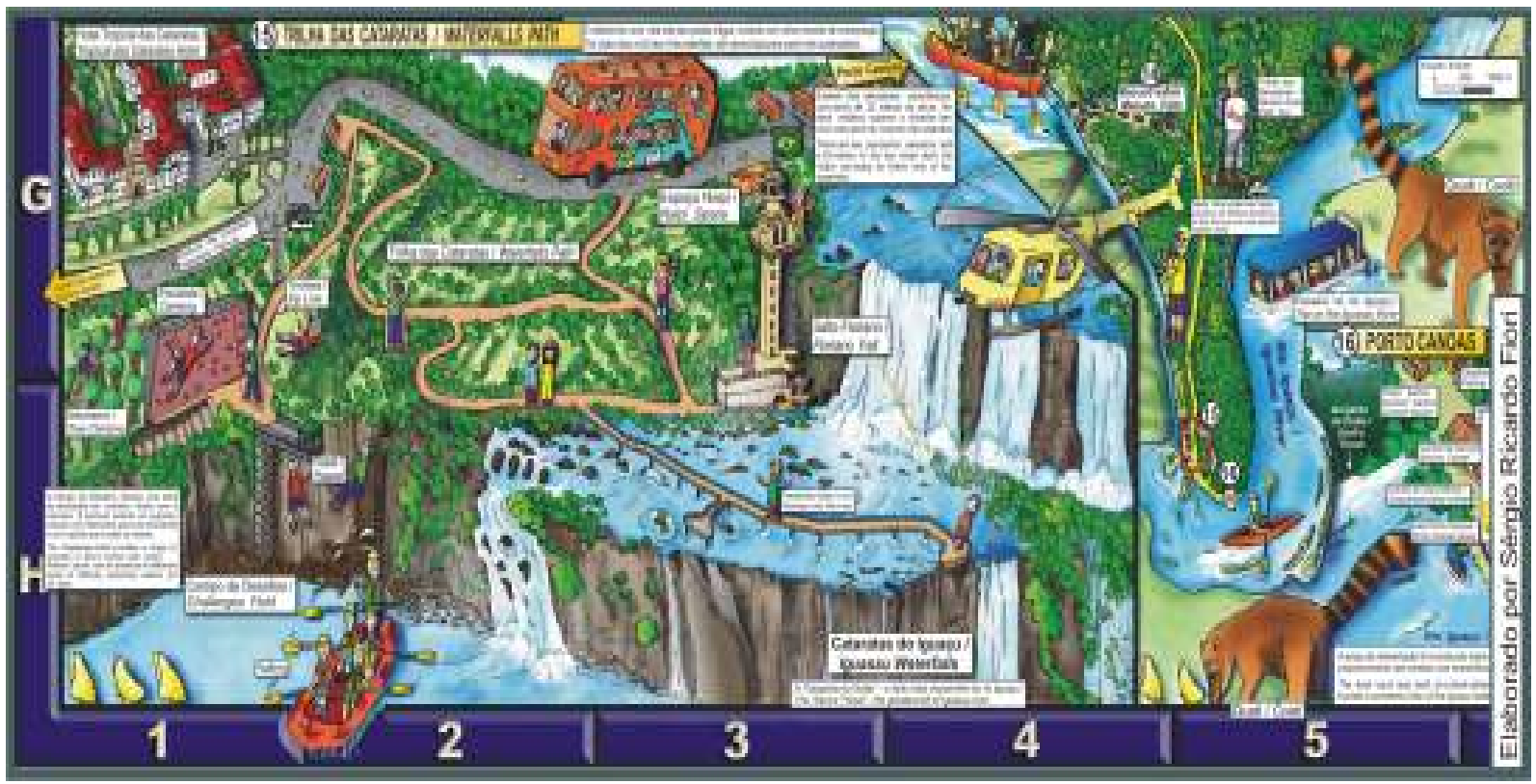

Cabe então ao produtor do mapa, que também não faz parte da coletividade representada, procurar formas de conhecê-la, coletando dados dentro de um contexto O produtor filtra e direciona as informações, preocupado com o efeito que se quer dar da localidade ao turista.

Conseqüentemente, além dos traços diferentes, o produtor do mapa deve trabalhar símbolos, ilustrações que possuam um sincretismo capaz de ser comuns entre as diferentes culturas, ou seja, serem superficiais e profundas ao mesmo tempo.

A figura 14 demonstra que, quando uma ilustração é bem elaborada, o usuário consegue compreender boa parte da informação, mesmo não conhecendo, por exemplo, a escrita japonesa, finlandesa ou húngara! 
Figura 14 - Os desenhos que se (re)conhece

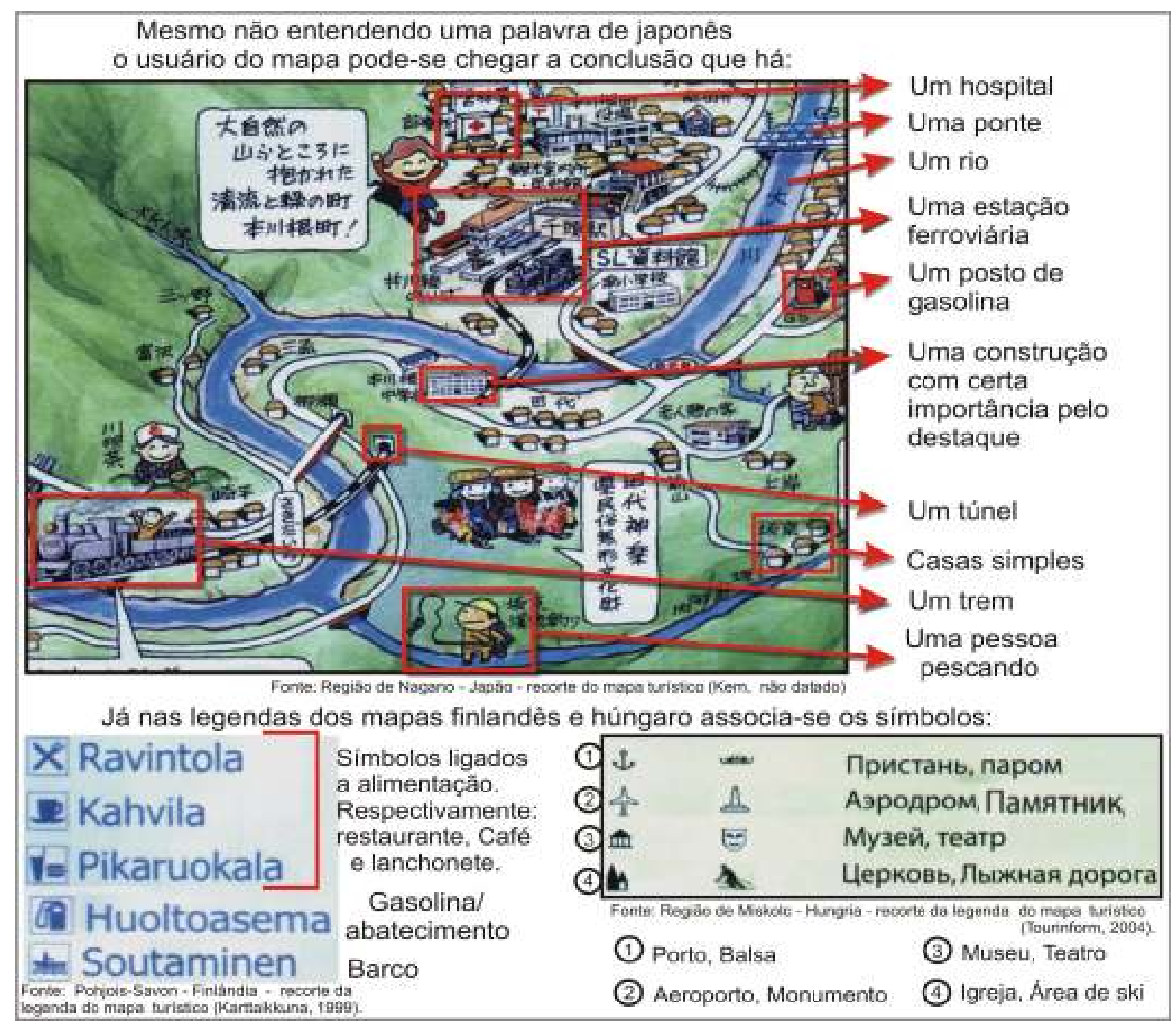

Esse fenômeno ocorre porque as artes visuais trabalham com a capacidade construtiva e imaginativa do usuário, o qual precisa mobilizar suas habilidades cognitivas e afetivas durante o ato de reconhecimento das ilustrações, ícones e símbolos. Guerrero (2004: 162) pontua a possibilidade de utilização de técnicas e de recursos visuais que permitam aos alunos - e por que não falar do público leigo? identificar e desenvolver habilidades e competências que antes desconheciam.

Nota-se ali uma importante consideração: a necessidade de desenvolver um mapa que produza informação de fácil leitura e acesso aos diferentes povos e, para isso, exige-se certa "homogeneização" da representação. Segundo Hall (2003: 77), o fascínio que o usuário-consumidor também pode ter pela diferença traz uma mercantilização da etnia, do particular, ou seja, o interesse pelo local. Portanto, a mídia globalizada deve fornecer especialização flexível e estratégias de criação aos diferentes tipos e interesses do público visitante.

Assim, a elaboração de um mapa-site turístico sempre trabalha a dualidade: cultura de massa, ou seja, fácil acesso, apreensão da informação ao maior número de 
pessoas (meio digital e a internet), aliada aos traços característicos das coletividades. Neste segundo item, cite-se Canclini (2003: 256-257), ao partir do pressuposto de que a construção de uma nação requer um projeto político e cultural unificado, um consumo simbólico compartilhado que favoreça o desenvolvimento do mercado. Os meios de comunicação integrados traduzem a idéia de nação por estabelecer um sentimento e cotidianidade, por exemplo, por meio da mídia.

No Brasil, principalmente a televisão tem um alto apelo comunicativo, mostrando as várias e distintas regiões e povos que formam o país, com seus modos de falar, vestir, gostos e código de costumes. Outrora esses elementos estavam distantes e dispersos, porém hoje os povos juntam suas várias linguagens por meio da mídia, que representa as massas, dando uma síntese da identidade nacional.

Nesse aspecto, os mapas pictóricos seriam de grande valia, pois, além da ação fundamental de auxiliar o usuário a se localizar, pode compor maneiras de representar os atrativos natural e cultural.

Sugere-se um modelo de apresentação pictórica - mapa como "vitrine" - das informações de outros destinos, criando, assim, um modo de perceber as diferenças dos vários e ricos espaços que se somam e geram a identidade nacional.

Finaliza-se esta exposição sobre as diferentes influências e sincretismos ligados ao ato cartográfico com uma citação de Bourdieu (1974: 136), que apresenta um exemplo singelo para o que seria a cultura média, que estaria ao alcance de todos. Um roteirista, escritor de folhetins, autor de vinte romances e premiado pelo Interallié e pelo Grande Prêmio da Academia Francesa na categoria de romance revelou:

Minha única ambição é a de ser lido com facilidade pelo maior público possível. Eu nunca almejo a "obra-prima" e não escrevo para intelectuais. Deixo esta tarefa para outros. Para mim, um bom livro é aquele que nos cativa ao fim de três páginas.

Faça-se aqui apenas uma consideração: esta pesquisa é feita para intelectuais preocupados em encontrar novos caminhos que levem o mapa a resultados práticos, para que, assim, prontamente informe e posteriormente motive sobretudo o público não-familiarizado com a semântica formal dos mapas a querer conhecer, saber mais sobre a localidade retratada.

A essência híbrida do mapa-site turístico é discutida, testada e analisada ao longo deste trabalho, que faz uma reflexão tanto das potencialidades e perspectivas futuras, quanto dos problemas e limitações do produto cartográfico finalizado.

Para que se analise o discurso ${ }^{16}$ - mapas turísticos e os seus respectivos sincretismos mos, com o convencional e o pictórico, com a superficialidade e a profundidade - é preciso atentar a três elementos: o imaginário (real e simbólico) em

\footnotetext{
${ }^{16} \mathrm{~A}$ análise do discurso não trabalha com o que a linguagem quer dizer, mas como o que a linguagem diz (Orlandi, 2004: 20).
} 
relação à ideologia e a determinação histórica. Assim, a análise do discurso trata do domínio do imaginário e dos seus efeitos da evidência produzidos pelos mecanismos ideológicos. A unidade é tida como um fato, é construída de modo imaginário, indicando posteriormente os modos de existência e de relação com o múltiplo (Orlandi, 1997: 16-18).

É ainda Orlandi (op.cit:: 20-21), quem esclarece ser a ideologia obra justamente do ponto de encontro da materialidade da língua com a materialidade da história, sendo que é pelo discurso que se dá o encontro. No discurso - onde está a materialidade especifica da ideologia - é que melhor se pode observar esse ponto de articulação. Compreender o que é efeito de sentidos, em suma, é compreender a necessidade da ideologia na constituição dos sentidos e dos sujeitos. Logo, é da relação regulada historicamente entre múltiplas formações discursivas que se constituem os diferentes efeitos de sentidos entre locutores.

A ideologia ainda é percebida como o processo de produção de um imaginário, isto é, produção de uma interpretação particular que vem ao mundo e se torna necessária, atribuindo sentidos fixos às palavras em um dado contexto histórico (Orlandi, op. cit.: 100).

É por isso que um mesmo símbolo pode ter diferentes sentidos, por sofrer influências diretas de seus coletivos (ideologias, imaginários) e da História. Segundo a mesma autora (op.cit:: 22) os discursos estão duplamente determinados: de um lado, pelas formações ideológicas que relacionam os discursos a formações discursivas definidas e, de outro, pela autonomia relativa da língua. São ainda de Orlandi as seguintes palavras:

O homem está "condenado" a significar. Com ou sem palavras, diante do mundo, há uma injunção à "interpretação": tudo tem de fazer sentido (qualquer que seja). O homem está irremediavelmente constituído pela relação com o simbólico. Numa certa perspectiva, a dominante nos estudos dos signos, se produz uma sobreposição entre a linguagem (verbal e não-verbal) e a significação (Orlandi, op. cit.: 31-32).

Estando os sujeitos condenados a significar, a interpretação é sempre regida por condições de produção específicas que, no entanto, aparecem como universais e eternas, daí resultando a impressão do sentido único e verdadeiro (Orlandi, op. cit.: 100).

A "letra", o "desenho" significa. Nada é indiferente na instância do significante (Orlandi, 2004: 121).

A autora (1997:81) aborda a completude e a incompletude do sujeito frente à ideologia. A completude é a vocação totalizante, ou seja, proporciona sentimentos de identidade e literalidade - unidade que permite ao sujeito identificar-se - no domínio do sentido. A completude produz o efeito de "evidência", sustentando-se sobre o já 
dito, os sentidos institucionais, admitidos por todos como "natural" (Orlandi, 1997: 100), sendo fabricada pela história. Já a incompletude é característica de todo o processo de significação. Isto porque a relação linguagem-pensamento-mundo é aberta e, vendo pela perspectiva discursiva, é também o lugar do possível (Orlandi: 2004:19). A incompletude é o indício da abertura do simbólico, do movimento do sentido e do sujeito, da falha do sentido (Orlandi: 2005:114). Além disso, sem ela apagamento necessário para a constituição do sujeito - haveria a asfixia do sujeito e do sentido, pois o sujeito não poderia atravessar, e não seria atravessado pelos diferentes discursos (Orlandi: 1997:81).

A imprevisibilidade da relação entre os sujeitos e seus sentidos é minorada pela formação social, que tem formas de controle da interpretação, mais ou menos desenvolvidas institucionalmente, sendo historicamente determinadas. Orlandi (2004:25) completa que, de um lado, os fatos reclamam sentidos; de outro, os sujeitos não podem não interpretar, estão condenados a significar. Contudo, existem necessidades que regem essas relações: de um lado, é preciso que todo sujeito domine sua relação com os sentidos, mesmo que imaginariamente e, de outro, a necessidade que tem toda sociedade de administrar esta relação do sujeito sobre a "divisão social do trabalho da leitura".

O analista deve ser cuidadoso em relação a todos estes aspectos da interpretação, levando em conta a linguagem tanto como estrutura quanto como acontecimento. Conseqüentemente ela pode trabalhar com aspectos heterogêneos que tocam a ordem, a regra e também o acaso, o equívoco, a forma histórica da interpretação no entendimento da produção dos sentidos. Deste modo, o analista do discurso não pretende chegar à verdade do sentido, mas permanece atento a suas diferenças e a seus movimentos (Orlandi, 2004:26).

Todos estes aspectos fazem do produtor do mapa um ser mergulhado na história e inserido em um coletivo, com todos os comprometimentos que possam vir dessas circunstâncias. Todavia, diz Orlandi (2004:19), não é porque o processo de significação é aberto que ele não pode ser regido, administrado.

O que deve ficar claro é que o produto final (o mapa-site turístico) tem que fazer sentido para quem o utiliza, consome, isto tanto em relação ao entendimento da informação (leitura) quanto à motivação, de querer conhecer a localidade. E Orlandi (2005:19) deixa claro que não há sentido sem a interpretação. Contudo, faz uma ressalva: a interpretação é posta em questão pela análise do discurso, pois reiterando o que já foi dito, ela não se fecha. $O$ que se tem é a ilusão de seu fechamento, pois o sujeito...

... se submete à ideologia, ao efeito da literalidade, à ilusão do conteúdo, à construção da evidência dos sentidos, à impressão do sentido já-lá. A ideologia se caracteriza assim pela fixação de um conteúdo, pela impressão do sentido literal, pelo apagamento da materialidade da linguagem e da história, pela estruturação 
ideológica da subjetividade (Orlandi, 2005: 21-22).

Partindo da afirmação de que o sujeito está condenado a significar e faz parte de um tempo histórico, constitui-se o tema: a elaboração de mapas turísticos, em diferentes escalas e tipos de representação, e a futura inserção na internet.

O próximo passo é estruturar de que maneira o mapa alcança o usuário-turista, que é caracterizado por coletivos e imaginários diferentes. A interpretação e o sentido mesmo que relativos, admitidos como natural - são necessários para que haja a aceitação e o consumo do produto.

Elaborar, então, uma linguagem carregada de uma significação que abranja um número tão grande e diversificado de pessoas não é uma tarefa fácil. Contudo, aí fazse uma ressalva: por serem pessoas que já têm acesso à Web, mesmo sendo de diferentes culturas, em tese, já compartilham informações comuns.

Tratando mais especificamente do mapa, estudos anteriores (Fiori 1999, 2003) e trabalhos recentes ${ }^{17}$ mostram que o sincretismo entre os mapas convencionais e os pictóricos - semântica formal e senso comum - tem uma boa aceitação e assimilação pelo público leigo em cartografia, possibilitando também um produto mais adequado ao turista (público leigo caracterizado pelo querer conhecer, viajar).

Portanto, a produção de um material cartográfico menos formal vem da necessidade de que diferentes usuários merecem diferentes tipos de mapas.

Ainda não se pode esquecer que, na interação usuário-mapa-produtor, o último colhe, filtra, representa graficamente, interpreta e analisa as informações a serem dispostas sobre o mapa. O produtor está envolvido (por um coletivo) e envolve outras pessoas (do seu e de outros coletivos) estabelecendo maiores ou menores graus de supostas "verdades". Trabalha o tempo inteiro com recortes das paisagens, ilustrando suas identidades e diferenças, abarcando diferentes discursos ligados de alguma forma ao mercado global - trocas, economia, mídia.

Isso faz com que o produto mapa-site turístico trabalhe uma visão mais superficial, genérica, funcional, de fácil leitura e compreensão, e ao meso tempo motivadora, lúdica da informação. Orlandi (2005: 52) resume todo o processo buscado pelo pesquisador:

Há um dispositivo teórico estabelecido pela teoria do discurso e há o dispositivo analítico construído pelo pesquisador em seu campo de pesquisa, sua filiação

17 Como exemplo, cite-se uma oficina de mapas para alunos de escolas públicas, realizada em Brasília: Amanda Cardoso, 13 anos, recortou a gravura de uma plataforma de petróleo e colou no mapa da Venezuela. Sem perceber, ela estava estudando geografia e aprendendo a cultura daquele país com a ajuda de jogos e atividades lúdicas desenvolvidas pelo projeto Caminhos do Futuro. (...) "É bem melhor do que aprender nos livros. Eu gravei o conteúdo rapidinho", conta Amanda, que cursa a sétima série do ensino fundamental no Centro de Educação Fundamental Incra 8, em Brazlândia, a 45 quilômetros de Brasília (MEC, 2007). 
disciplinar, onde contam: a questão que ele formulou, o material coletado (superfície lingüística), a maneira como foi construído o objeto discursivo a partir do corpus constituído, a delimitação e montagem do material de análise, as noções que vão ser mobilizadas, orientadas pela pergunta que faz o analista na compreensão de seu objeto de estudos, em vista de sua finalidade. É a escrita do analista, face ao dispositivo analítico, que dará (ou não) a consistência da análise. Através do dispositivo analítico - cuja forma é determinada pela relação entre a natureza do material analisado, a questão posta pelo pesquisador e os procedimentos analíticos escolhidos - o analista vai formular os resultados no batimento entre descrição e interpretação.

Dito isso, e pensando no trabalho do pesquisador, vinculado a seu tempo e espaço, e na cartografia, busca-se sempre a completude, mas é a incompletude que faz inovar e descobrir novos caminhos e soluções no árido campo das adversidades científicas.

\section{4 - O mapa, o tempo e as diferentes formas de se representar o espaço}

A história da cartografia ao redor do mundo registra inúmeras e distintas formas de representação do espaço, o que justifica dar a devida importância ao contexto cultural em que o produtor do mapa estava e está inserido.

Três itens são fundamentais para justificar o conteúdo de um mapa: a universalidade dos contextos políticos na história do mapeamento; o poder estabelecido, que direciona e estrutura o conteúdo dos mapas; e como a comunicação cartográfica que constitui um nível simbólico, é capaz de reforçar a estrutura de poder a partir da relação usuário-mapa (Harley, 1994: 280). Aliás, em um estudo detalhado da cartografia ao longo dos séculos, demonstrou-se que a elaboração de mapas foi uma das armas intelectuais especializadas que pôde aumentar, administrar, dar legitimidade e codificar o poder. Os conhecimentos contidos nos mapas sempre foram concentrados em poucas mãos, comumente ligadas às elites religiosas (Egito antigo e baixa Idade Média), intelectuais (Grécia e Roma) ou comerciais (cidadesestado de Veneza e Gênova). A seguir demonstram-se alguns exemplos da cultura ocidental.

Inicialmente, Harley (1991) evidencia que a história da cartografia surge com o ato do desenho de um mapa (representação do espaço) sobre um suporte disponível (pedra, barro) possibilitando uma existência concreta à antiga abstração. Esse processo de transposição do espaço real para o analógico gera um domínio intelectual do universo.

A figura 15 mostra exemplares de mapas da Antigüidade. O primeiro (Figura 15 A) é datado em 5.000 anos a.C., onde a representação de uma aldeia foi gravada em uma elevação rochosa, localizada onde hoje está o centro da península itálica (Oliveira, 1978:26). Já a figura 15 B ilustra um mapa confeccionado em um pedaço de barro cozido, com a borda cheia de reentrâncias e marcado por rugosidades, circulo e 
linhas. O mapa certamente representa uma área de várzea do rio Eufrates, ao norte da Mesopotâmia, datado de 2.500 a.C. (Raisz, 1969:9).

\section{Figuras 15 - Mapas da Antigüidade}

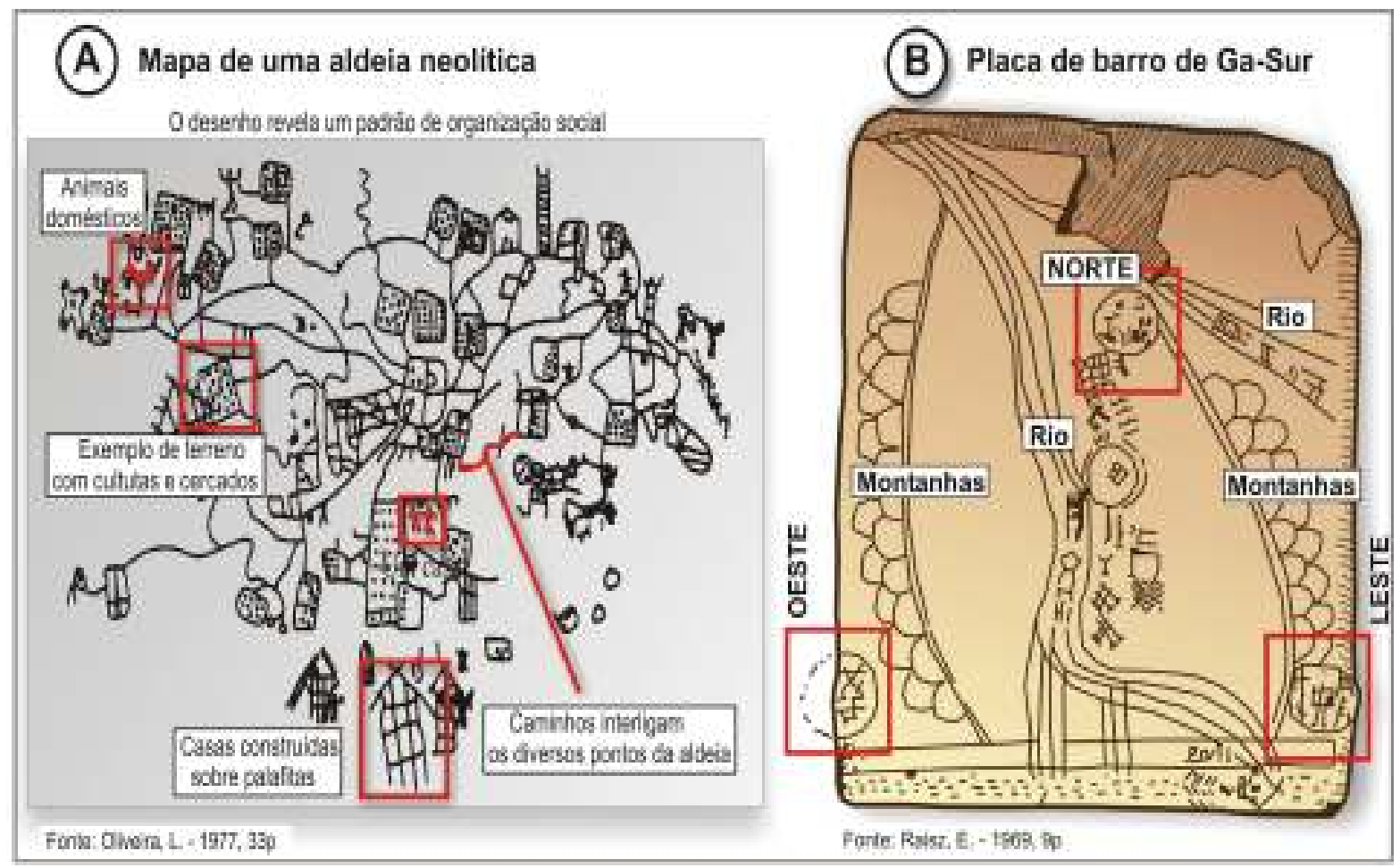

A cartografia desenvolvida por povos desta época (babilônicos, egípcios, fenícios, entre outros) era feita por agricultores ligados à terra e era elaborada por representações esquemáticas de cadastramento. Essas representações expunham subdivisões dos campos e das plantas das cidades e comumente eram confeccionadas em tábuas de argila. Para esses povos, o "documento" era muito importante, pois marcava a propriedade da área cultivável, especialmente no Egito, onde as inundações do rio Nilo exigiam a cada ano a redistribuição das terras (Dreyer-Eimbcke, 1992).

$\mathrm{Na}$ Idade Média, a cartografia do ocidente latino se orientava segundo uma visão teocêntrica. Nessa época, há uma rejeição quanto à esfericidade do mundo, retornando efetivamente a ser usado o formato em disco. Os mapas não visavam representar a configuração física da superfície terrestre, uma vez que as características topográficas ficaram em segundo plano. Um bom exemplo do tipo de mapa realizado nesse período era os $\mathrm{T}$ em $\mathrm{O}$ (Orbis Terrarum). As representações de um mundo simbólico eram percebidas pela localização de Jerusalém, que sempre ocupava o lugar de destaque - centro - no mapa (Figura 16). 
Figura 16 - A simplicidade do mapa Orbis Terrarum

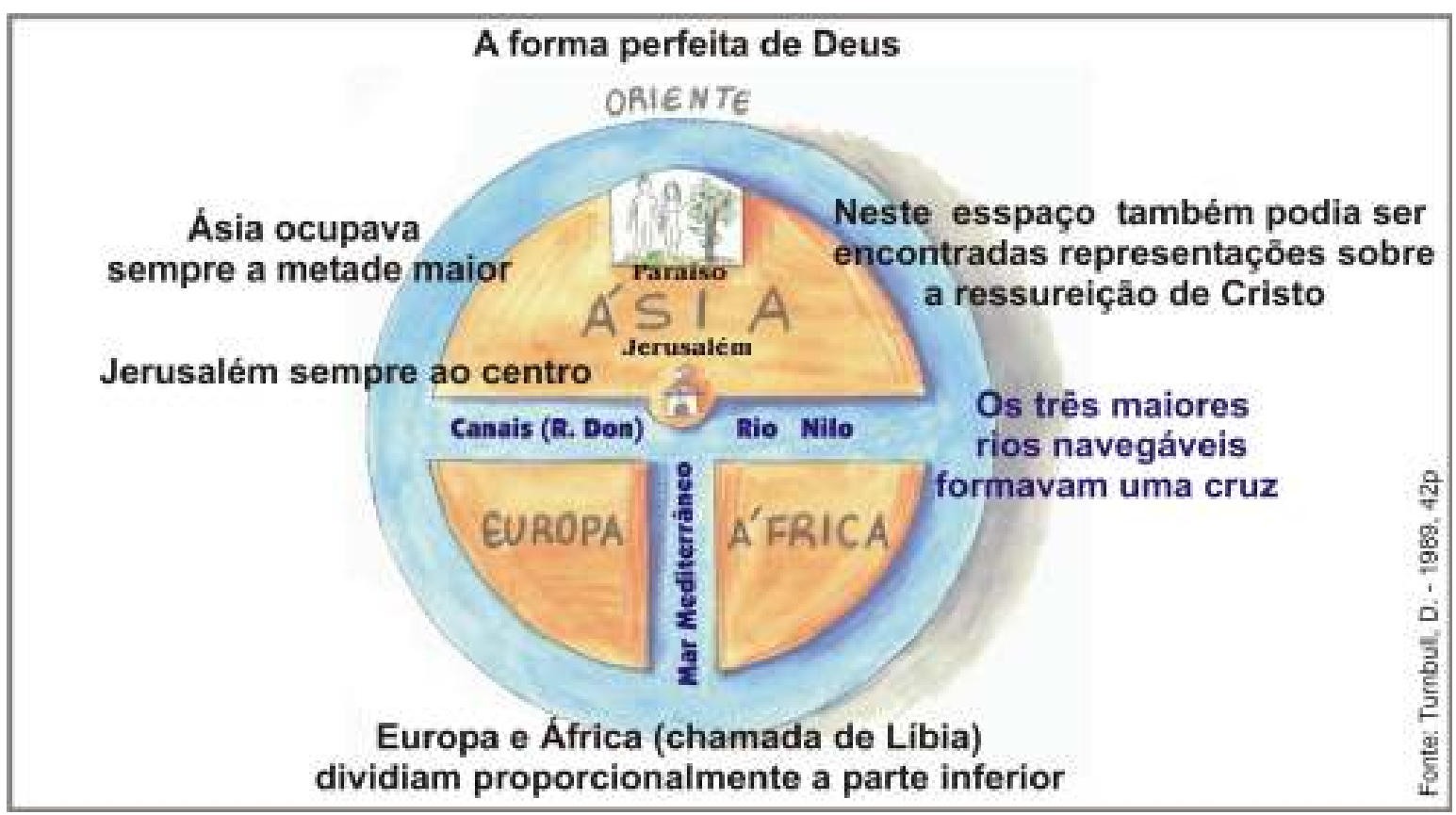

Quando se representava à fauna, consideravam-se sempre os animais típicos da respectiva região, como: o bisão e o alce (leste da Europa), o camelo (oriente), o cavalo (Capadócia), leões, tigres e ursos (Pártia) e o elefante (Marrocos). Contudo, desenhos revelavam a pouca familiaridade que o artista devia ter com a maioria desses animais. Entretanto, é importante ressaltar que continuou viva durante toda a Idade Média a idéia grega de que o mundo era uma esfera. (Dreyer-Eimbcke, 1992).

Em outro momento histórico, a segunda metade do século XIII, marcado pelo aumento da atividade comercial, surge um tipo diferente de mapa: as Cartas Portulanas. Esses mapas, segundo Raisz (1969: 21-22), teriam sido idealizados por almirantes e capitães da frota genovesa, apresentando fins práticos de navegação pelo Mediterrâneo, ou seja, baseados em medições feitas à bússola e a toponímia era estritamente disposta nas áreas de portos, cabos e outros detalhes da costa (Figura 17).

Podem ser citados outros rápidos exemplos de relação entre mapas e a História. Em Ramos (2000:35), lê-se que, se não fosse o forte imaginário popular ibérico, a viagem às Índias poderia ter ocorrido antes. A igreja estimulava ainda mais esse medo. A figura 18 mostra um mapa do período, repleto de representações dos supostos elementos misteriosos.

Quando se representava à fauna consideravam sempre os animais típicos da respectiva região, como: o bisão e o alce (leste da Europa), o camelo (oriente), o cavalo (Capadócia), leões, tigres e ursos (Pártia) e o elefante (Marrocos). Contudo, desenhos revelavam a pouca familiaridade que o artista devia ter com a maioria desses animais. Entretanto, é bom ressaltar, que continuou viva durante toda a Idade Média a idéia grega de que o mundo era uma esfera. (Dreyer-Eimbcke, 1992). 
Figura 17 - Mapa portulano do Mediterrâneo

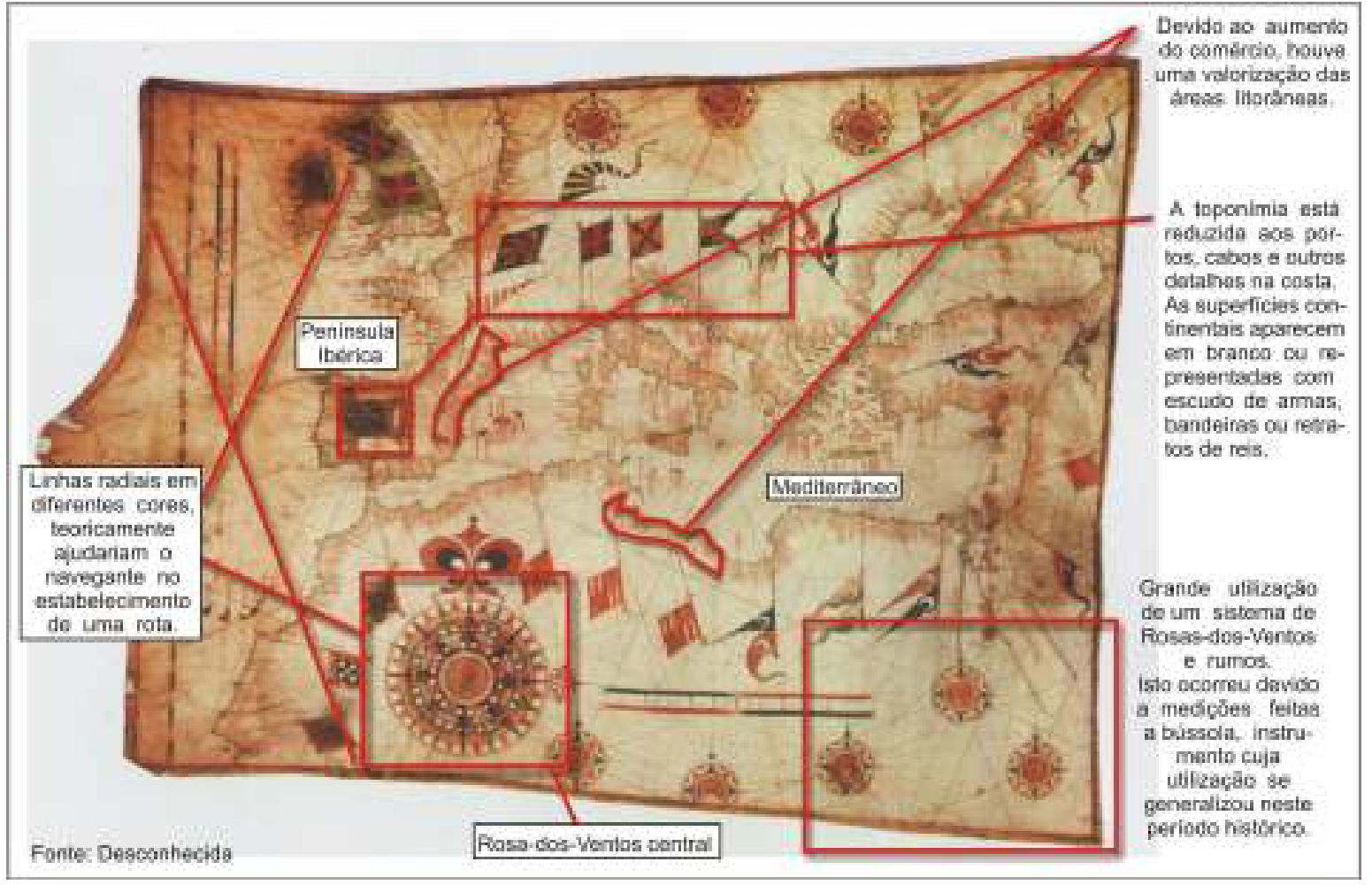

Figura 18 - As lendas representadas nos mapas

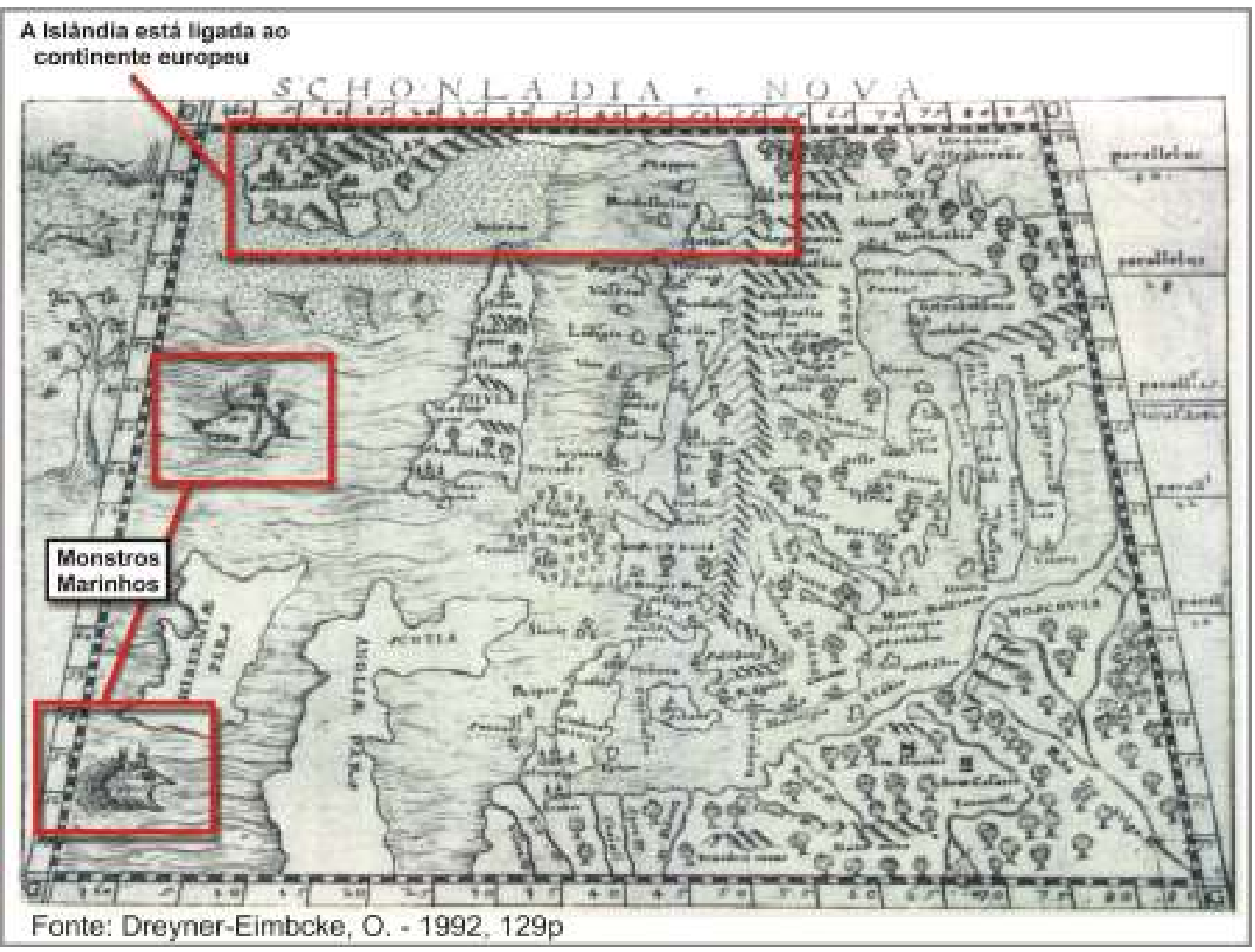


Nos séculos $\mathrm{XV}$ e $\mathrm{XVI}$, o material cartográfico foi utilizado com vários fins: como suporte à reivindicação de terras antes da efetiva ocupação e, logo em seguida, o mapeamento, que servia ao reconhecimento, informações gerais e legitimava a realidade da conquista do império. Eventualmente era usado como dispositivo de pacificação, civilização, de exploração das colônias então definidas, e como instrumento de divulgação das terras do Novo Continente (Harley, 1994: 281-282). Acerca do último caso citado, Delano-Smith (1991) conta que, durante a elaboração dos mapas, os cartógrafos europeus representavam o Novo Mundo à imagem do Velho. Ilustrações procuravam não desestimular as futuras imigrações de colonos. Desse modo, sobre a base do mapa, eram confeccionadas paisagens aprazíveis e iguais às européias. Quanto aos habitantes nativos, os índios, quase nunca eram lembrados, para que se alimentasse o mito de uma América européia.

Nos séculos XVI e XVII, as figuras pictóricas foram providenciais e importantes em guias náuticos, sendo utilizadas no reconhecimento de algumas terras e ilhas. Os guias acompanhavam os pilotos e continham textos sobre rotas, latitudes e desenhos esquemáticos das feições dos lugares já conhecidos (Albuquerque, 1989: 79). A figura 19 do manuscrito de Gaspar (1594) exemplifica a importância do desenho pictórico, auxiliador na orientação e localização das terras. Os mapas também representavam os medos, perigos, mitos e imaginações.

Ainda no século XVII, a cidade de Amsterdã era o maior centro de produção de mapas no mundo ocidental. Existiam inúmeros estabelecimentos comerciais que se dedicavam à produção de mapas, atlas e globos. Destacam-se os cartógrafos holandeses Jan Janszoon e Guilherme Janszoon Blaeus, sucessores de Mercator. Tais produtores preocupavam-se particularmente com a expressão e a representação dos mapas, que segundo Raisz (1969: 42):

constituíam um conjunto harmônico; as terras, os mares, os letreiros e a decoração, tudo é cuidadosamente disposto e ponderado. Mercator introduziu um tipo de letreiro mais legível (...) O título, a escala e as notas esclarecedoras ficam dentro de um quadro, formado por figuras de animais e produtos do país. Estas decorações nem sempre foram felizes; o desenhista provavelmente nunca havia saído da Holanda, e sua concepção era muito ingênua como, por exemplo, eram vistos figuras de reis africanos vivendo em palácios holandeses. O maior defeito dos mapas holandeses.

Outro ponto deficiente nos mapas holandeses está na transmissão de informações, resultado de fatores econômicos. Tanto que espaços em branco nos mapas refletiam uma venda menor do material cartográfico; por isso, eles eram prontamente preenchidos com qualquer tipo de informação, mesmo que não fosse verdadeira.

No século XVIII, os ideais iluministas trouxeram uma significativa transformação de como proceder na confecção dos mapas. Os holandeses, como foi exposto, valorizavam muito a estética, fazendo uso de informações ultrapassadas. Isso 
acontecia porque as medições e estudos teóricos oneravam o trabalho e diminuíam os lucros. O novo momento histórico valorizou os mapas com base científica. $O$ retorno financeiro não era mais o fator preponderante na confecção, mas sim a reputação científica. É bom frisar que os produtores dos novos mapas, na maioria das vezes, pertenciam à nobreza, ou eram subvencionados pelo rei e pela Academia (Raisz, 1969: 42).

Figura 19 - Exemplo de desenhos pictóricos encontrados em guias náuticos dos séculos XVI e XVII
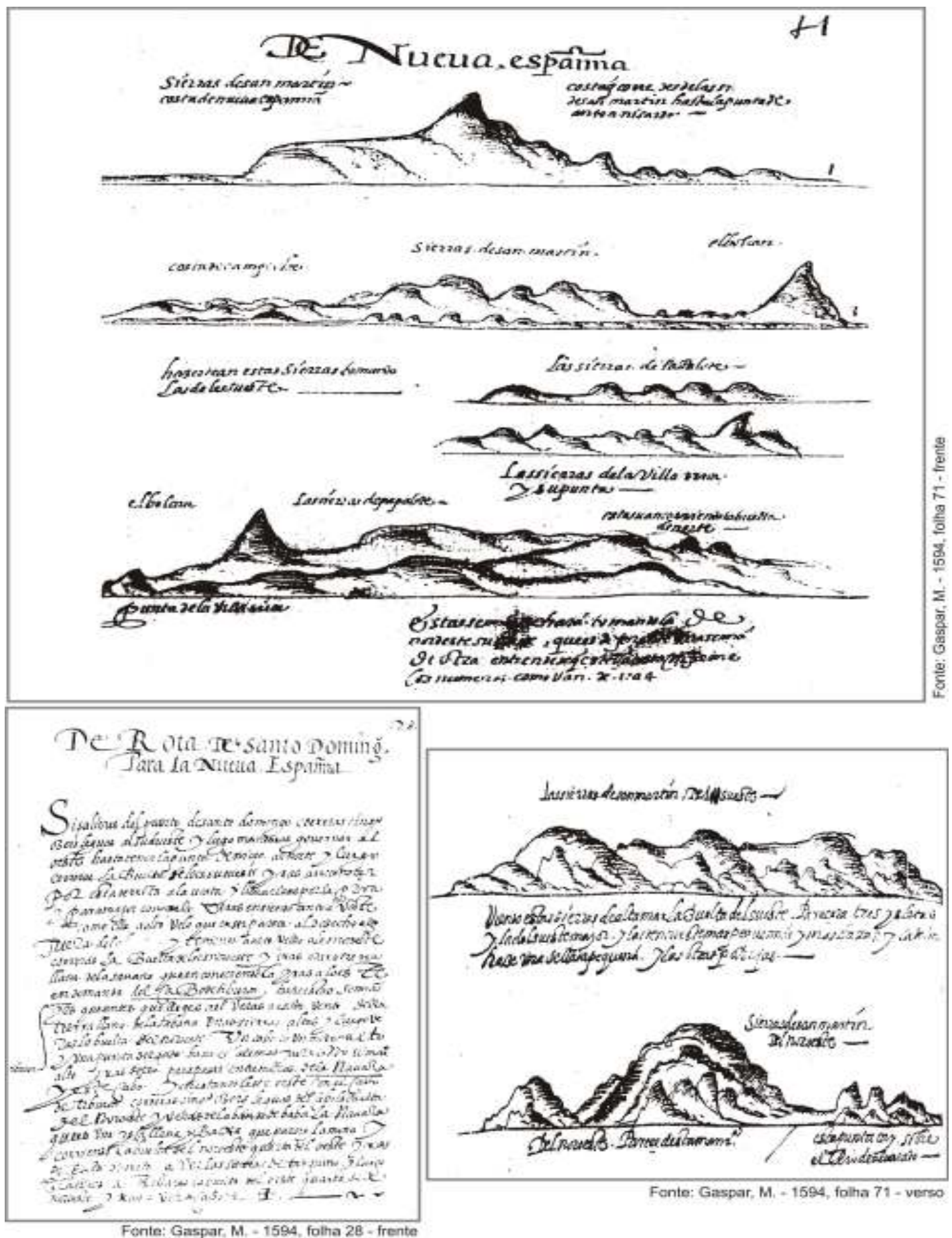
Essa nova cartografia teve sua expressão maior na França, tanto que o país foi o primeiro a confeccionar um mapa preciso e detalhado de seu território (com importante precisão topográfica), baseando-se na triangulação (um conjunto de pontos que servem de referência) e símbolos codificados (figura 20). Para confeccionar esse tipo de mapa se tornava indispensável conhecer a real forma da Terra (Thrower, 1991).

\section{Figura 20 - Mapas com base na triangulação}

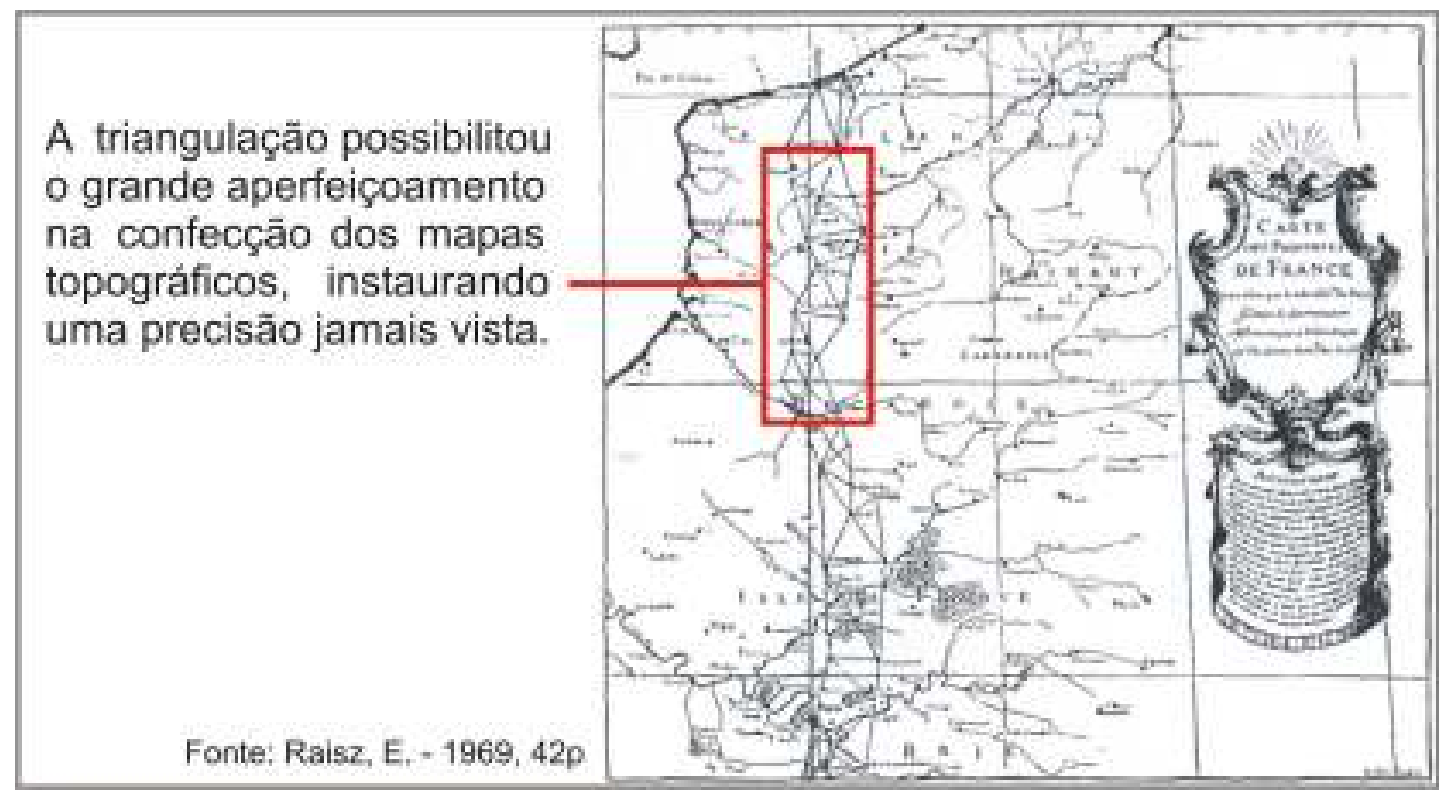

Já na segunda década do século XX, com a invenção do avião somada ao uso da câmera fotográfica, surge o sensoriamento remoto ${ }^{18}$, marcando assim o fim do levantamento dos dados de forma direta no terreno (triangulação) para dar início às técnicas de aerofotogrametria (figura 21). Essa nova forma de captação dos elementos do espaço gerou uma revolução quanto à coleta dos dados, por proporcionar uma grande facilidade de captação (Cruz, 1981).

Em 1972, o sensoriamento remoto passou por um significativo aprimoramento, devido ao lançamento do primeiro satélite artificial (Earth Resources Technology Satellite ERTS); depois vieram, os LANDSAT, SPOT, NOAA e METEOSAT. Efetivou-se então, uma nova e promissora tecnologia: o geoprocessamento ${ }^{19}$ (Figura $21 \mathrm{~A}$ ), que é formado por um conjunto de tecnologias voltadas à coleta e tratamento das

\footnotetext{
${ }^{18}$ Grava a energia eletromagnética (a mais evidente é a luz refletida, natural ou artificial) que emana dos corpos na superfície terrestre. O olho é um perfeito exemplo de sensor remoto, sendo que a câmara fotográfica é provavelmente o mais familiar tipo de sensor remoto; logo, a fotografia nada mais é que uma gravação gráfica de intensidade de energia (Cruz, 1981).

19 Destina-se ao processamento informatizado de dados georeferenciados, desde a sua coleta até a geração de saídas na forma de mapas, relatórios, arquivos digitais, etc., devendo prever recursos para a estocagem, gerenciamento, manipulação e análise (INPE, 2004).
} 
informações espaciais visando a um objetivo específico. As atividades de geoprocessamento são obtidas pelos Sistemas de Informação Geográfica (SIG) ${ }^{20}$, que estão integradas a uma única base de dados de informações espaciais, provenientes de dados cartográficos, dados de censo, cadastro urbano e rural, sensoriamento remoto (imagens aerofotogramétricas e satélites), redes e modelos numéricos de terrenos (INPE, 2004). A figura $21 \mathrm{~B}$ demonstra que a cartografia digital também pode conceber uma síntese visual e informativa de áreas de interesse, possibilitando um melhor planejamento. Por exemplo, mapas urbanos podem dispor de diversos mapas que comporiam as redes de esgoto, água, elétrica, gás, tevê a cabo que estão dispostas em espaço comum. Já no setor agrícola, se aplica ao estudo do uso de ocupação do solo e aos métodos de cultura, controle do estado vegetal e à avaliação das conseqüências dos imprevistos climáticos (secas, inundações) ou dos acidentes previstos (epidemias, incêndios) (Grelot, 1991).

Os acontecimentos históricos brevemente expostos deixam claro que, ao contrário da arte, o mapa demonstra ser pouco popular, ou então, não se configura como um produto de expressão subversiva (Harley, 1994:303). O autor justifica a afirmação, explicando que os mapas são preliminarmente uma linguagem de poder, não de protesto.

Este tipo de linguagem faz uso do espaço-mapa, apreendendo e selecionando a realidade (natureza-cultura), elaborando, então, uma representação em escala muitíssimo reduzida. Fiori (2003: 20-24), Muehrcke (1986: 392-400), Vasconcellos (1993: 21-22), Wood (1994: 17-19), Monmonier (1996: 87-122) apontaram algumas implicações que envolvem, de maneira prática, o processo cartográfico de redução dessa realidade: exagero, erros, distorções, falta de precisão, falsificações, manipulações, etc. Vasconcellos (1993: 22) sintetiza algumas razões que determinam o surgimento das falhas levantadas:

$\checkmark$ Desconhecimento - falta de preparo e treinamento para a utilização da linguagem gráfica;

$\checkmark$ Questões técnicas (treinamento cartográfico adequado) ou financeiras (equipamentos e recursos humanos disponíveis);

$\checkmark$ Questões ideológicas e políticas;

$\checkmark$ Desonestidade.

Ramires (1996) sustenta que o processo de representar a realidade tridimensional em um plano bidimensional - no caso o mapa - causa perdas que são sanadas por quatro bases técnicas:

${ }^{20}$ É um sistema que processa dados gráficos e não-gráficos (alfanuméricos) com ênfase a análises espaciais e modelagens de superfícies (INPE, 2004). 
Figura 21 - A evolução no processo do sensoriamento remoto

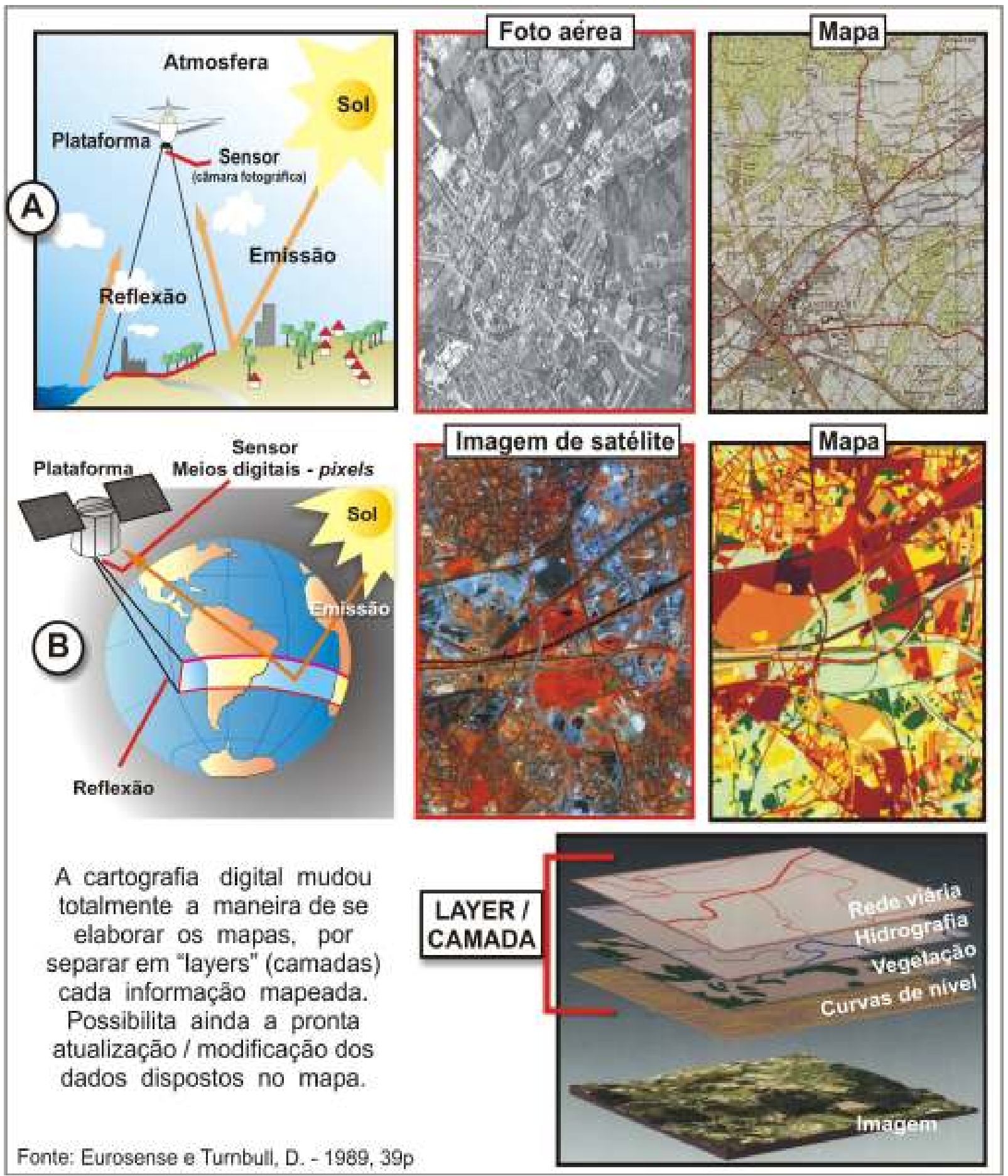

1a) A escolha da projeção cartográfica mais adequada para a representação do mapa.

$2^{a}$ ) O sistema de referências, que se divide em dois grupos: o primeiro parte dos mapas de pequenas e médias escalas mas que abrangem grande extensão de terra, sofrendo interferência da curvatura do planeta. Esse conjunto utiliza as coordenadas geográficas, em que o "x" determina a longitude e o "y" a latitude. Do segundo grupo, 
fazem parte os mapas com grande escala - abrangem uma quantidade de terra pequena em relação ao tamanho do planeta, sendo consideradas porções de espaços planos. Esse conjunto utiliza as coordenadas retangulares, em que o eixo "x" determina as letras para as coordenadas horizontais e o "y" determina os números para as coordenadas verticais do plano cartesiano. Além disso, o sistema de referências permite-nos o processo de orientação espacial geográfica, determinada em graus, obedecendo às direções cardeais Norte, Sul, Leste e Oeste.

$\left.3^{a}\right)$ A utilização da escala, que é muito importante para a confecção de um mapa, pois, como a representação do planeta será feita de forma reduzida, a escala mostra a proporção entre a realidade mapeada e sua representação. Logo, quanto menor for a escala do mapa, maior será a porção do espaço abrangida e, conseqüentemente, os elementos representados terão um menor detalhamento.

$4^{a}$ ) Ainda durante o processo realidade-mapa, Ramires (1996) discorre sobre as etapas da generalização cartográfica, que possibilita eliminar informações da realidade desnecessárias ao mapa, a saber:

$\checkmark$ Simplificação - remove informações excedentes;

$\checkmark$ Exagero - destaca os elementos importantes da realidade no mapa. Isso porque, devido ao enorme processo de redução da realidade, algumas informações imprescindíveis como, por exemplo, um rio, uma cidade, etc, quase não são notados ou somem literalmente do mapa;

$\checkmark$ Hierarquização - reposiciona os elementos no mapa;

$\checkmark$ Deslocamento - ocorre para evitar a visualização confusa de elementos distintos no mapa quando estão muito próximos. Aliás, as generalizações devem ocorrer, quando for possível o agrupamento das informações, permitindo uma análise do espaço abordado. Gerada a nova simbologia, já na forma reduzida da realidade, deve-se analisar a informação antes de implantála no mapa.

$\checkmark$ Os elementos simbólicos do mapa e, em conseqüência da legenda, expressam os resultados do espaço real que sofreu uma considerável redução, organizando-se graficamente pelas técnicas, com a finalidade de transmitir uma mensagem previamente estabelecida. $O$ usuário não precisa ser obrigatoriamente especializado, porém deve reter a informação essencial para que haja entendimento do mapa.

Exemplos encontrados em Muehrcke (1986: 392-400), MacEachren (1994: 19), Collins-Kreiner (1997), Fiori (2003: 25) e em grande parte do livro de Monmonier (1996) ilustram tal processo de generalização e representação construído através dos tempos. 
Criou-se, assim, o imaginário sobre qual seria a forma mais correta de elaborar um produto cartográfico, associando o mapa às disciplinas modernas, somada à visão eurocêntrica e ao crescente avanço tecnológico. Isso fez com que fossem desconsideradas a maiorias dos mapas produzidos até então, purgando-os a ponto de atingir um padrão considerado aceitável. $O$ crivo era estabelecido pelo tempo (história), cultura e uso da matemática no traçado dos mapas. Essa é a cartografia científica que valoriza:

os planos quadriculados, escalas regulares, signos abstratos convencionais e até curvas de nível, ou seja, todos os aspectos correspondentes ao modelo ocidental de excelência cartográfica (...) Os mapas eram considerados marcos significativos da evolução da humanidade; por conseguinte, aqueles que não indicassem algum progresso rumo à objetividade deixavam de ser seriamente estudados (Harley: 1991).

Harley (1991) continua relatando que os mapas da baixa Idade Média (o Hereford e o Ebstorf) foram chamados de monstruosidades não-científicas e absolutamente inúteis. Já mapas elaborados na Índia antes da ocupação britânica, com signos desconhecidos e estilo pictórico, eram considerados simples curiosidades cartográficas. Nesse mesmo caso estão os mapas dos índios americanos, os planos de batalha traçados no solo pelos guerreiros maoris da Nova Zelândia, entre muitos outros. Todos eram meros objetos de coleções etnográficas.

Os mapas de culturas não-européias só recebiam alguma atenção da parte dos historiadores ocidentais quando apresentavam certas semelhanças com os mapas europeus, devendo apresentar, por exemplo, orientação, escalas regulares e elementos da geometria euclidiana. Analisar o porquê das diferenças não era uma tarefa cogitada.

Nesse ínterim, deu-se atenção às tradições "científicas" da cartografia chinesa e aos efeitos de sua difusão no Japão e na Coréia (Harley, 1991).

Seemann (2006) faz um contraponto crítico à cartografia considerada inquestionavelmente científica e objetiva na criação do conhecimento, monitorada pelos órgãos oficiais e suas convenções e normas técnicas. Contudo, o que dizer, por exemplo, sobre as diversas possibilidades da projeção de globo terrestre em um plano? A Groenlândia pode ter o tamanho da América do Sul, embora seja oito vezes menor, quando se faz uso da projeção de Mercator. Já a projeção de Peters deforma (reduz) as regiões polares, tendo uma distorção muito menor (2-1) se comparada à de Mercador (4 -1) figura 22.

As projeções mais usadas condicionam os nossos pensamentos, de modo que qualquer representação do mundo fora do padrão acaba sendo julgada como "esquisita" ou "errada". As projeções dominantes também determinam o traçado dos meridianos e paralelos. (...) À pergunta da Narizinho sobre quantos meridianos havia, Dona Benta responde: "Quantos você quiser. Desde que são 
círculos imaginários, você poderia traçar milhões de milhões deles, cada qual cortando o Equador num pontinho" (Seemann, 2006).

\section{Figura 22 - As projeções de Mercator e Peters}
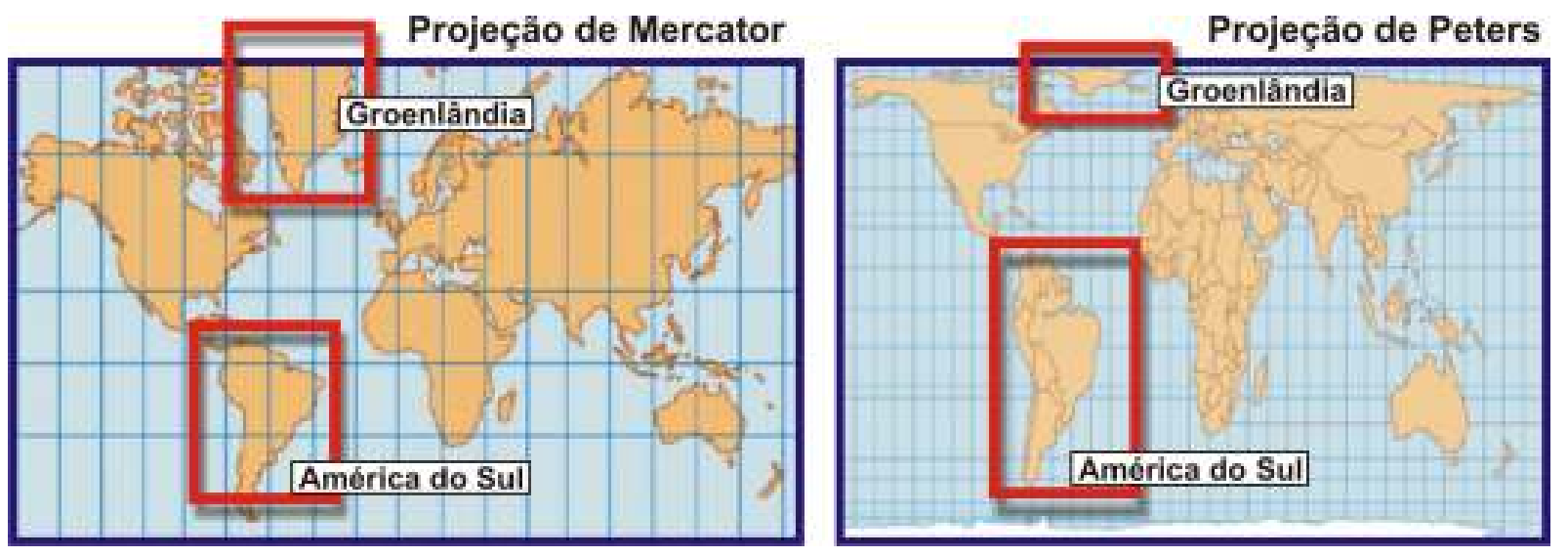

Até que ponto as sociedades produzem mapas objetivos, precisos, em oposição aos aspectos simbólicos, subjetivos, míticos ${ }^{21}$, psicológicos? Kozel (2006) salienta que este aporte cartográfico é identificado como instrumento de dominação e manipulação, ancorada na conotação cientificista da verdade ou representação real.

Aprende-se a ler criticamente os textos, destrinchando suas ideologias, intenções e opções teórico-metodológicas. Já os mapas são literalmente copiados ou elaborados sob um rígido conjunto de técnicas. Todavia, o mapa não se aparta de um conteúdo ideológico e, às vezes, até mitológico do que está sendo reproduzido (Girardi, 1997: 15). A autora continua propondo que não é para se deixar de lado a acurácia, a escala, orientação, etc., mas alerta que esse não deve ser o único critério para avaliar um mapa. Aprender cartografia é aprender regras de construção de mapas, suas diferenças, o uso de cada tipo de produto. O conteúdo técnico é importante, mas não é o bastante.

Essa visão cientificista começou a mudar em 1987 com J. B. Harley e D. Woodward, que, no primeiro dos quatro volumes da História da Cartografia, adotam uma definição de mapa que permitiu introduzir um possível relativismo no estudo histórico das cartas geográficas. Isso faz com que se reconheça a grande diversidade de formas de representação do espaço no grande mosaico da cultura humana universal. Os autores partem da convicção de que como:

\footnotetext{
${ }^{21}$ Mito é uma mensagem sob a qual incide um uso social. Qualquer mensagem poderia, a rigor, ser um mito, porém, consideram-se como mito mensagens que visem à naturalização da cultura. Todo sistema semiológico é um sistema de valores, porém o consumidor do mito considera a significação como um sistema de fatos (Girardi, 2006).
} 
cada sociedade tem ou teve sua própria forma de perceber e produzir imagens espaciais, chegamos a esta definição de mapa: "representação gráfica que facilita a compreensão espacial de objetos, conceitos, condições, processos e fatos do mundo humano". O motivo de uma definição tão ampla é facultar sua ampliação a todas as culturas de todos os tempos, e não apenas às da era moderna. Além disso, ao considerar os mapas uma forma de "saber" em geral, ao invés de meros produtos de uma prolongada difusão tecnológica a partir de um foco europeu, tal definição permite escrever uma história muito mais completa.

Isso faz com que a velha história da cartografia passe por uma constante revisão. Além disso, a nova história da cartografia permite que se entenda muito melhor o objetivo da criação dos mapas. Voltando ao exemplo dos mapas chineses, é comprovada a utilidade dos mapas como instrumento de poder: cadastral e demarcatório de fronteiras, plano de conservação das águas, meios de fixar impostos, etc. Contudo, os mapas chineses também recebiam influência da literatura, da pintura, desempenhavam uma função ritual (comprovada pela presença em túmulos), serviam como instrumento de adivinhação, predição astrológica, de fenômenos celestes ou de proteção contra forças invisíveis (Harley, 1991).

Taylor (1991) alerta que, atualmente, o desenvolvimento conceitual e teórico da cartografia como disciplina tem sido retardado, se não desviado, devido ao grande entusiasmo e interesse suscitado pelo mapeamento automático e pelo SIG. Portanto, um número excessivo de cartógrafos modernos são fundamentalmente especialistas tecnológicos, possuindo uma visão limitada da cartografia.

O que se percebe nesta breve apresentação da cartografia ao longo da história, independente dos discursos e formalismos (suposta certeza e erro), é que cada mapa tem um porquê existencial, isto é, um contexto que está diretamente relacionado com a sua função. Conseqüentemente, a elaboração de mapas temáticos voltados ao setor do turístico só está sendo colocada em pauta, devido a questionamentos e à necessidade de pensar em um material cartográfico mais adequado ao público usuário (turista) e à localidade turística, que quer ser conhecida, desejada, prestigiada.

No Brasil, esse tipo de material já é produzido há muito tempo, contudo, não por profissionais especializados no assunto (como geógrafos e cartógrafos), o que acarreta em materiais "cartográficos" de baixa qualidade.

A elaboração dos mapas turísticos não descarta a cartografia convencional e abstrata; pautada nas convenções matemáticas e novas tecnologias. Pelo contrário, todo esse conteúdo será utilizado e readaptado, procurando um resgate histórico, ou seja, reviver aquela época em que se fazia um uso muito maior da pictografia. Devese ter em mente para que, para quem e como esse tipo de mapa temático será feito. Até porque é o público potencial que faz o produtor escolher quais representações serão mais eficazes que outras. A eficácia se resume em dois tópicos: conseguir aliar 
a clareza do material cartográfico às expectativas do público para quem o mapa é elaborado.

Dondis (1991: 131-133) esclarece que, na comunicação visual, o conteúdo nunca está dissociado da forma. Os dois elementos juntos geram uma manifestação e mudam sutilmente de um meio a outro e de um formato a outro, adaptando-se às circunstâncias de cada um, sendo o mecanismo perceptivo, o meio para sua interpretação.

Aliás, a percepção sofre com as fortes restrições e dependências em relação ao sistema socioestético, que acaba reduzindo as pretensões dos criadores. Mesmo assim, cada vez mais as sociedades modernas procuram abrir e pluralizar possibilidades de escolha não-convencionais de produção, interpretação e comunicação. Acrescente-se o aumento de difusão de novas técnicas, motivo pelo qual existe uma maior diversidade de tendências do que no passado (Canclini, 2003: 39).

Dessa maneira, pretende-se discutir a elaboração de mapas temáticos para o turismo, o qual são portadores de um contexto e um conteúdo próprios, sendo que cabe ao cartógrafo vislumbrar os anseios desses usuários. Por essa razão, é necessário citar Beni (1998: 216-217), que aponta a necessidade de considerar os fatores que atuam na escolha feita pelo turista quando decide viajar. As duas decisões mais comuns são aquelas referentes à decisão de rotina ou decisão por impulso, explicitadas abaixo:

$\checkmark$ Decisão de rotina - turista que se fundamenta em um inventário de conhecimentos e atitudes já existentes em seu pensamento. Em outras palavras, ele possui um estoque de informações úteis (em qual hotel ficar, em que locadora alugar o carro, que restaurantes freqüentar, qual a praia mais adequada, etc), válidas no momento da escolha, sendo que essas informações pré-existentes influenciam a escolha entre uma ou outra destinação. Neste item, o marketing em turismo torna-se um instrumental importante, sugestionando o consumidor a conhecer uma nova destinação e/ou serviço.

$\checkmark$ Decisão por impulso - turista que age de maneira rápida, impulsiva, ou seja, o consumidor muitas vezes atraído por folhetos, por material audiovisual, vídeos, imagens na internet, programas de TV, filmes de roteiros. Logo, a conduta impulsiva pode ser provocada a partir do uso adequado desses materiais de comunicação informativa e publicidade, divulgação. As sugestões de viagens não-consideradas pelo turista-cliente fazem parte de um segmento da técnica de marketing do turismo, utilizadas nessas tomadas de decisões impulsivas.

O autor (Beni: 1998: 218) apresenta ainda, nove fases que o turista levará em conta em seu processo de decisão quanto à escolha de um serviço e localidade, sendo essencial serem conhecidas ao se elaborar um mapa direcionado ao setor do turismo: 
1. Estímulo inicial, que pode se fundamentar em desejos e necessidade provocados pela publicidade e promoção de um país, de um centro de polarização turística, um hotel, uma destinação em geral, por uma literatura especializada de turismo, ou por sugestões e informações de outros viajantes.

2. Estabelecimento de uma referência conceitual - turismo cultural, esportivo, ecoturismo, etc. - referindo-se, então, à pré-escolha de um conjunto de produtos oferecidos ao consumidor que corresponda as suas expectativas, consideradas suas características pessoais e socioeconômicas.

3. Relação a fatos que intervenham: custo de elementos, fatores de perfil da clientela e da pesquisa de mercados.

4. Fixação de pressupostos, extraindo deduções de todos os fatos, além de se obter dados dos pontos-de-vendas (hotéis, agências de viagem) e dos processos de intermediação de serviços turísticos.

5. Quadro de alternativas, ordenando as possíveis compras que possa efetuar.

6. Previsão de conseqüências, com a avaliação dos riscos - objetivos e subjetivos - que possam se apresentar.

7. Análise do custo/benefício - tangível e intangível - que o turista possa obter.

8. Decisão de compra em função de todas as fases anteriores.

9. Conseqüências dessa decisão a fim de proporcionar uma real satisfação do consumidor ou evitando sua decepção.

A partir do que foi exposto, reitera-se o que já dito anteriormente: um mapa voltado ao setor turístico deve ser funcional - indicar localizações, proporcionar aos turistas conhecimento sobre as distâncias entre atrativos, ter símbolos eficazes, etc. Entretanto, além disso, têm que apresentar um tipo de design que cumpra a função de divulgar a localidade turística, e, por esta razão, sua aparência estética é fundamental.

Dentro do complexo Sistema de Turismo - Sistur - criado por Beni (1998: 177), o mapa turístico pode participar da política de distribuição, tanto como material informativo (pontos e referências das atrações, distâncias, etc) quanto como material de divulgação que é enviado aos intermediários (postos de vendas e central de reservas, como hotéis, empresas de transporte, agências de viagens) e transmitido aos consumidores.

Os dados da tabela 1 atestam que o mapa turístico se insere no item Informação e organização de viagens; todavia o produto em si trará dados referentes aos outros quatro itens dos principais grupos de necessidades. 
Tabela 1 - Principais grupos de necessidades e empresas de turismo

\begin{tabular}{|ll|}
\hline $\begin{array}{ll}\text { PRINCIPAIS GRUPOS } \\
\text { DE NECESSIDADES }\end{array}$ & EMPRESAS DE TURISMO \\
\hline - Deslocamento & $\begin{array}{l}\text { Transportadoras para curtas, médias e longas distâncias, oferecendo transporte } \\
\text { ferroviário, rodoviário, aéreo, maritimo, fluvial, lacustre, etc. } \\
\text { Locadoras de veículos. }\end{array}$ \\
\hline \begin{tabular}{ll} 
- Alojamento & Hotéis, motéis, camping, imobiliárias para locaçäo de férias, etc. \\
- Alimentação & Restaurantes, lanchonetes, hotéis, motéis, supermercados, etc. \\
\hline - Recreação e & Hotéis, boates, bares, cinemas, teatros, cassinos e outras instalaçốes de lazer \\
entretenimento & e entretenimento. \\
\hline - Saúde, convalescença & Policlínicas, balneários, sanatórios, termas, estações de águas, spas, etc. \\
e restabelecimento & \\
\hline - Informação e \\
organização de viagens
\end{tabular} & $\begin{array}{l}\text { Agências de viagens e operadoras de turismo, transportadoras, hotéis, } \\
\text { organizaçōes corporativas, etc. }\end{array}$ \\
\hline
\end{tabular}

Neste instante, é oportuno ser citada a pesquisa de Collins-Kreiner (1997), que analisou vinte e um mapas especialmente elaborados para peregrinos que visitavam Israel ${ }^{22}$. Conseqüente-mente, tais produtos eram caracterizados por um status cartográfico especial, devido a sua natureza subjetiva: a fé. Além disso, havia o esforço em combinar a realidade contemporânea com a tradição dos mapas da antiga Terra Santa. Pode-se dizer que tais produtos pertencem a um subtipo de mapa que objetiva comunicar uma mensagem particular e predeterminada da localidade (Collins-Kreiner, 1997).

O exemplo acima ilustra um entre uma grande variedade de contextos que procuram métodos que disponibilizem maneiras distintas de visualização e experimentação dos dados e das informações. Segundo Cartwright \& Heath (2002), como resultado, temse a possibilidade de várias interpretações de uma mesma informação, pois diferentes usuários merecem diferentes estilos de representação. Faça aqui uma ressalva: o estilo do cartógrafo deverá sempre respeitar as reais condições do usuário em ter acesso à informação pelo usuário que ainda pode preferir usar somente um ou diferentes tipos de mapa da mesma localidade, buscando, assim, um melhor entendimento da destinação representada.

A metáfora do mapa é aumentada ao se utilizarem outras metáforas que podem ser facilmente oferecidas pela tecnologia e pela comunicação. E é por tudo isso que os mapas contemporâneos deveriam dispor de mais de uma metáfora para que houvesse uma maior flexibilidade com relação aos diferentes tipos de usuários

\footnotetext{
${ }^{22}$ Pesquisa desenvolvida em 1995, que analisou mapas de visitação confeccionados em Israel entre os anos de 1984 e 1994. Os mapas foram coletados nos escritórios de Informação Turística Cristã de Jerusalém e de Turismo do Governo, hotéis, albergues, lojas de suvenir, livrarias, igrejas, e editoras de mapas. Os mapas continham fundamentalmente representações de igrejas, locais sagrados e para compras, ou seja, informações que interessam potencialmente a peregrinos e turistas (Collins-Kreiner, 1997).
} 
(Cartwright \& Heath, 2002), o que também facilitaria a compreensão (leitura), graças ao recurso da redundância de informações.

A figura 23, retirada de Cartwright \& Heath (2002), demonstra representações diferenciadas de Nova York. Os autores argumentam que existe a necessidade de se investigar a reação dos usuários a partir de métodos que possuam representações cartográficas menos rígidas, além de verificar nesses materiais como são construídas as imagens mentais da realidade.

Figura 23 - Representações gráficas de Nova lorque
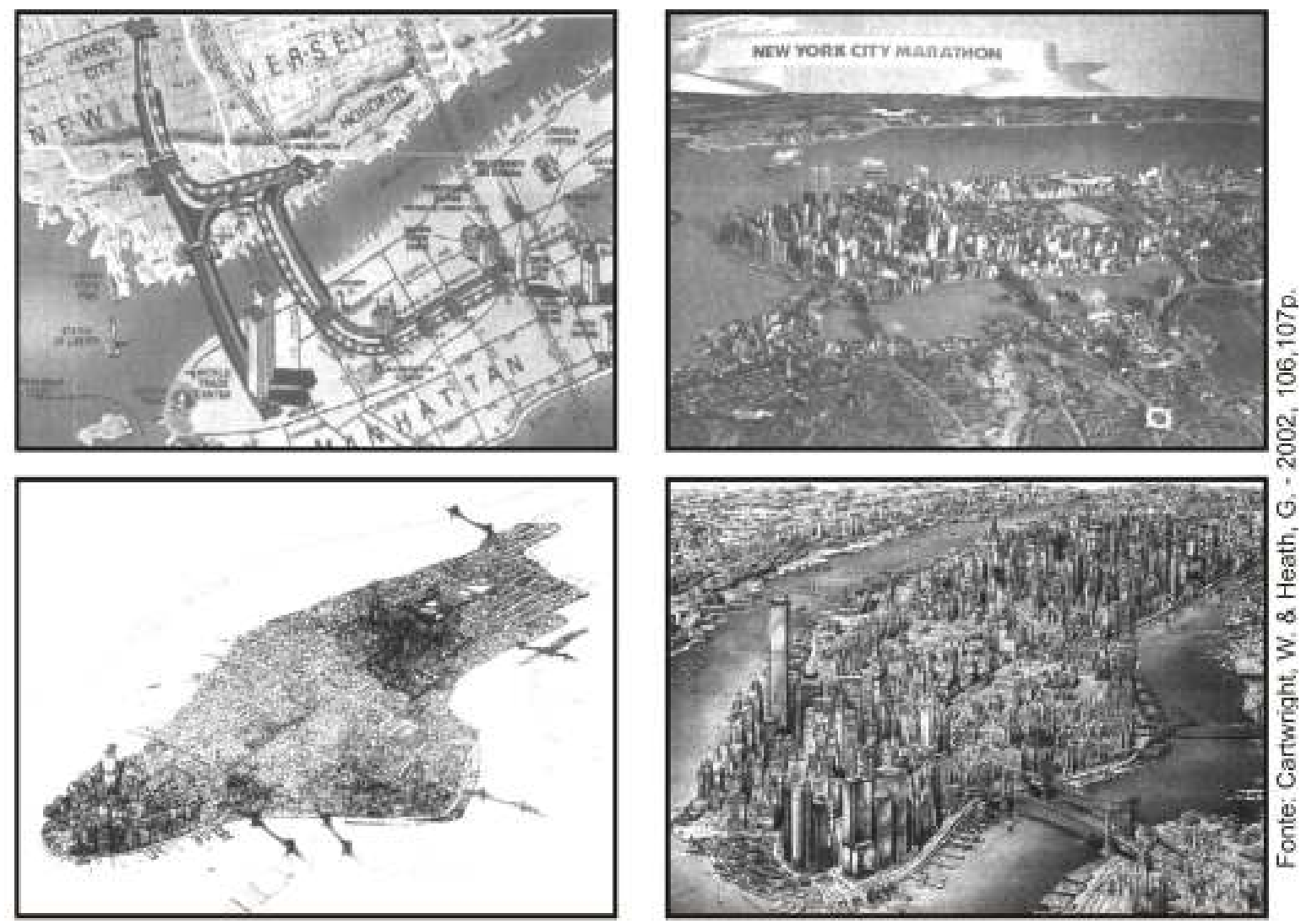

Neste instante, aborda-se a problemática da elaboração de mapas em meio digital, que traz a vantagem de dispor, em um mesmo material cartográfico, diferentes níveis de generalização e abstração de um mesmo conteúdo.

Inicialmente, é importante frisar que, com o rádio e o cinema, iniciou-se uma fase decisiva na formação de símbolos de identificação coletiva (Canclini, 2003: 196-197). $E$, após o advento do satélite, as possibilidades de comunicação instantânea tornarem-se um fato, com destaque à televisão e à rede mundial de computadores.

Assim, as últimas décadas do século $X X$ e início do $X X I$ vêem o surgimento de um novo tipo de cartografia que instiga ainda mais 0 ato criativo do produtor do mapa, pois, como frisa Kraak (1998), o meio digital e a internet não somente permitem uma 
apresentação dinâmica dos mapas como também possibilitam uma participação efetiva (acesso em tempo real aos dados dispostos) do usuário na apresentação de um mapa final.

A Cibercartografia - termo introduzido em junho de 1997 na $18^{a}$ Conferência Cartográfica Internacional, em Estocolmo, Suécia - situa o mapeamento na era da Informação. Neste momento histórico, incorporam-se importantes elementos do passado, redefinem-se outros e se introduzem novas idéias e abordagens tanto em relação à cartografia prática quanto à teórica. Nesta etapa evolutiva, a cartografia trabalha temas como: a multisensorialidade (uso da visão, audição, tato e eventualmente o olfato e o paladar); o uso de formatos em multimídia e novas telecomunicações; a interatividade e novos caminhos, tópicos de interesse da sociedade que não se refiram somente à localização no espaço; utilização de diferentes disciplinas, etc (Taylor, 2005: 2-3).

Segundo Reyes (2005: 75), na cibercartografia usam-se diversas fontes na elaboração de um mesmo material, incluindo diversas áreas do conhecimento como: a cartografia, a lingüística, a matemática, a estatística, a música e as linguagens visuais (figura 24).

Figura 24 - Comunicação em cibercartografia

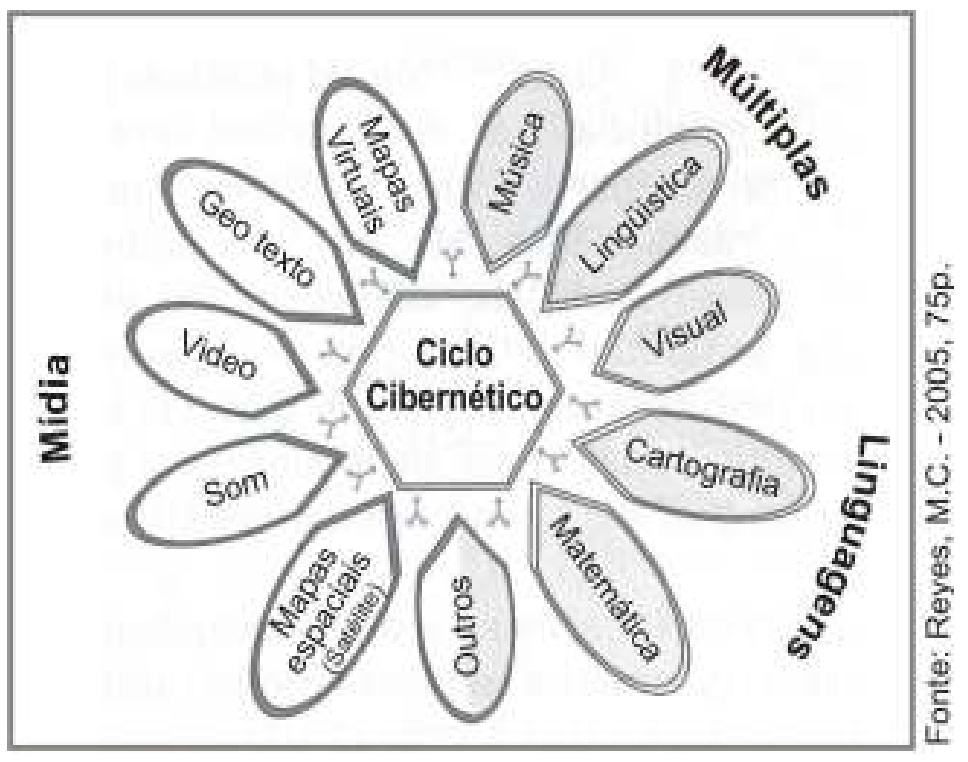

O cartógrafo, então deve definir parâmetros com respeito ao que Canclini (2003: 152) chama de comunidade hermenêutica possivel em uma sociedade e seu tempo, permitindo aos designers saber que graus de variabilidade e inovação podem manejar, que públicos se relacionarão, definindo, assim, políticas de comunicação para que os receptores entendam da melhor forma possível a atividade produtora de sentido.

Cartwright \& Heath (2002) apresentam quatro perfis de usuários quanto à elaboração 
do design que prima pelo acesso a um protótipo de mapa em multimídia interativa. Os usuários são definidos e divididos em quatro gerações: 1) Nintendo - acessa a informação usando a metáfora dos jogos, 2) Computador, 3) Vídeo - (televisão), e 4) Imprensa, Áudio - jornal, rádio. Uma vez identificados esses grupos empregam-se itens específicos no desenvolvimento das diferentes interfaces para o material (Figura 25).

Figura 25 - Perfil e informação apropriada: o usuário e multimídia interativa

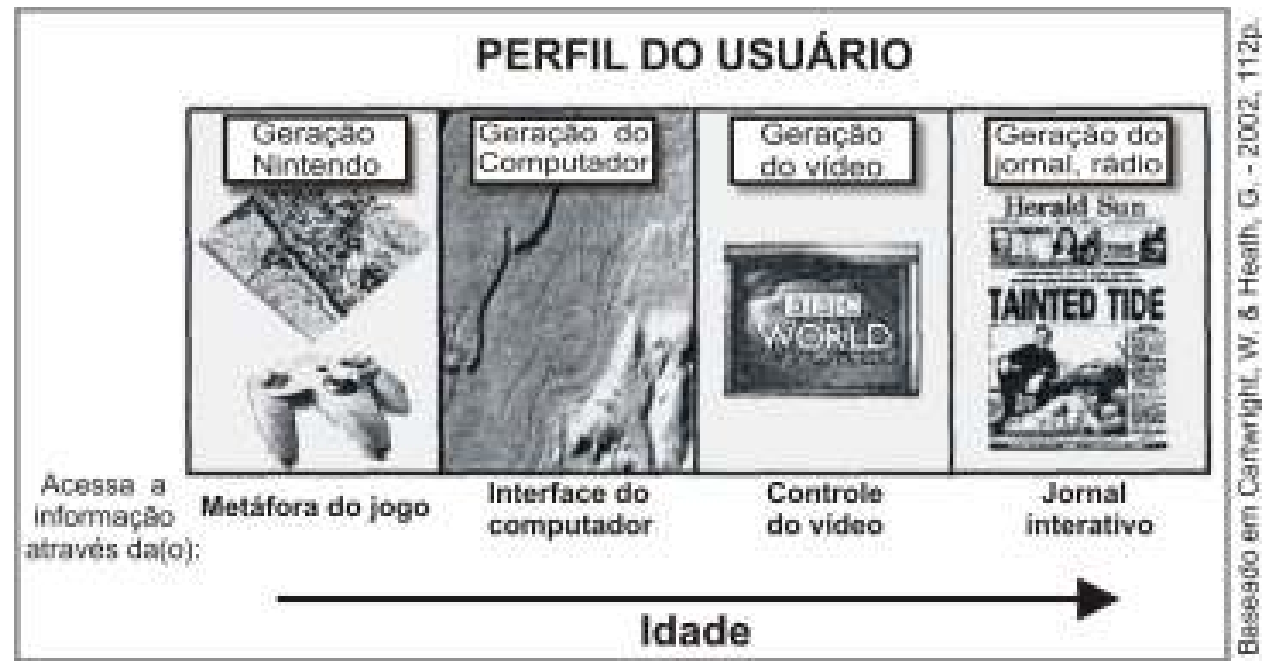

Tendo como referência o que foi exposto acima, conceitua-se o recurso comunicativo da multimídia como o único produto que congrega o conjunto de várias mídias agrupadas. Em Cartwright (1993), encontram-se algumas definições para multimídia. Destacam-se aqui duas:

$\checkmark$ É a integração de duas ou mais formas de mídias como, por exemplo, vídeo, som, texto, gráfico e animação, que são controladas a partir de um computador pessoal (Bahman Dara, APPLE).

$\checkmark$ Já Iggy Pintado da IBM, vê a multimídia como uma grande revolução na maneira de representar a informação no século XX. Ela capacita acessar e expressar a informação além de somente textos e gráficos no computador, incluindo também imagens, animação, vídeo, som estéreo e interação com um simples toque na própria imagem da tela. Em suma, é a combinação de mídias: o áudio visual da televisão e a interatividade do computador pessoal.

É inegável que tal tecnologia favorece e cria enormes possibilidades aos cartógrafos na elaboração de inúmeros tipos de representações e interpretações dos fenômenos espaciais nos novos mapas (Cartwright, 1993). As áreas discretas dos gráficos, outrora representadas de uma forma mais singela, atualmente, podem fazer uso de imagens, animação, filme, vídeo (Cartwright, 1996).

Tais recursos também fazem com que a tecnologia em multimídia permita o controle 
de mais emoções do que qualquer outro meio de comunicação já existente. Devido à variedade de emoções que podem ser influenciadas, o valor comunicativo da multimídia deve ser muito superior à dos métodos anteriores (Cartwright, 1993).

Posto isso, ao pensar na elaboração de um mapa turístico, compartilha-se a idéia de Carneiro (2001: 4) que afirma notar

atualmente uma tendência muito forte de se pensar o processo turístico enquanto, e tão somente, atividade comercial, despida de qualquer outro objetivo que não seja o lucro imediato. E é por esta imediatez que se desperdiçam oportunidades à realização de um trabalho profissional, onde o turista seja bem atendido, na medida em que seja bem informado, se sinta seguro e satisfeito em seus desejos e necessidades.

A afirmação proporciona um parâmetro de qualidade, principalmente ao se pensar que a grande maioria dos mapas turísticos produzidos no país apresenta muitas e algumas graves deficiências cartográficas, tais como: ausência de escala, desconhecimento do sistema de referências (latitude/longitude e direções cardeais) e de legendas bem estruturadas, que cumpram sua função. Some-se ainda o nãoconhecimento ou a descaracterização da base cartográfica, sendo flagrante a omissão de grande parte das ruas e hidrografia. Todos esses itens somados dificultam enormemente a deslocamento e a localização dos diversos pontos turísticos in loco.

Podem ser citados também - como já analisado em Fiori (2003: 125-127) - trabalhos artísticos com mapas turísticos pictóricos, que empregam ilustrações de uma maneira pobre e sem criatividade. É comum ver ilustrações que são simplesmente retiradas de algum arquivo de figuras, sendo em seguida copiadas e coladas.

Fundamentalmente, a qualidade deste tipo de trabalho precisa ser buscada devido à importância que o setor do turismo vem galgando nas últimas décadas. No mesmo grau de importância estão os visitantes, que precisam de mapas que ofereçam o maior número de informações, mas que sejam de fácil compreensão e agradáveis de usar. Além disso, existe o morador local da destinação que, em linhas gerais, precisaria se aproximar, ter afinidade com o mapa que representa sua realidadelocalidade. Cabe então ao cartógrafo estabelecer, da melhor forma possível, uma relação positiva entre todas as forças mencionadas; jamais esquecendo a eficiência do material elaborado.

Finaliza-se esta parte com Vasconcellos (1993: 47) que, ao longo de anos de experiência prática e de resultados concretos, relata: acredito que é preciso mais do que motivar, despertar o interesse e conquistar... É fundamental "seduzir"... Um caminho é desenvolver a percepção, usando todos os sentidos para aprender.

A figura 26 a seguir resume as relações e interesses envolvidos no processo de desenvolvimento de mapas convencional e pictórico e do protótipo mapa-site turístico. 
Figura 26 - 0 ato de cartografar: as relações que envolvem um mapa turístico

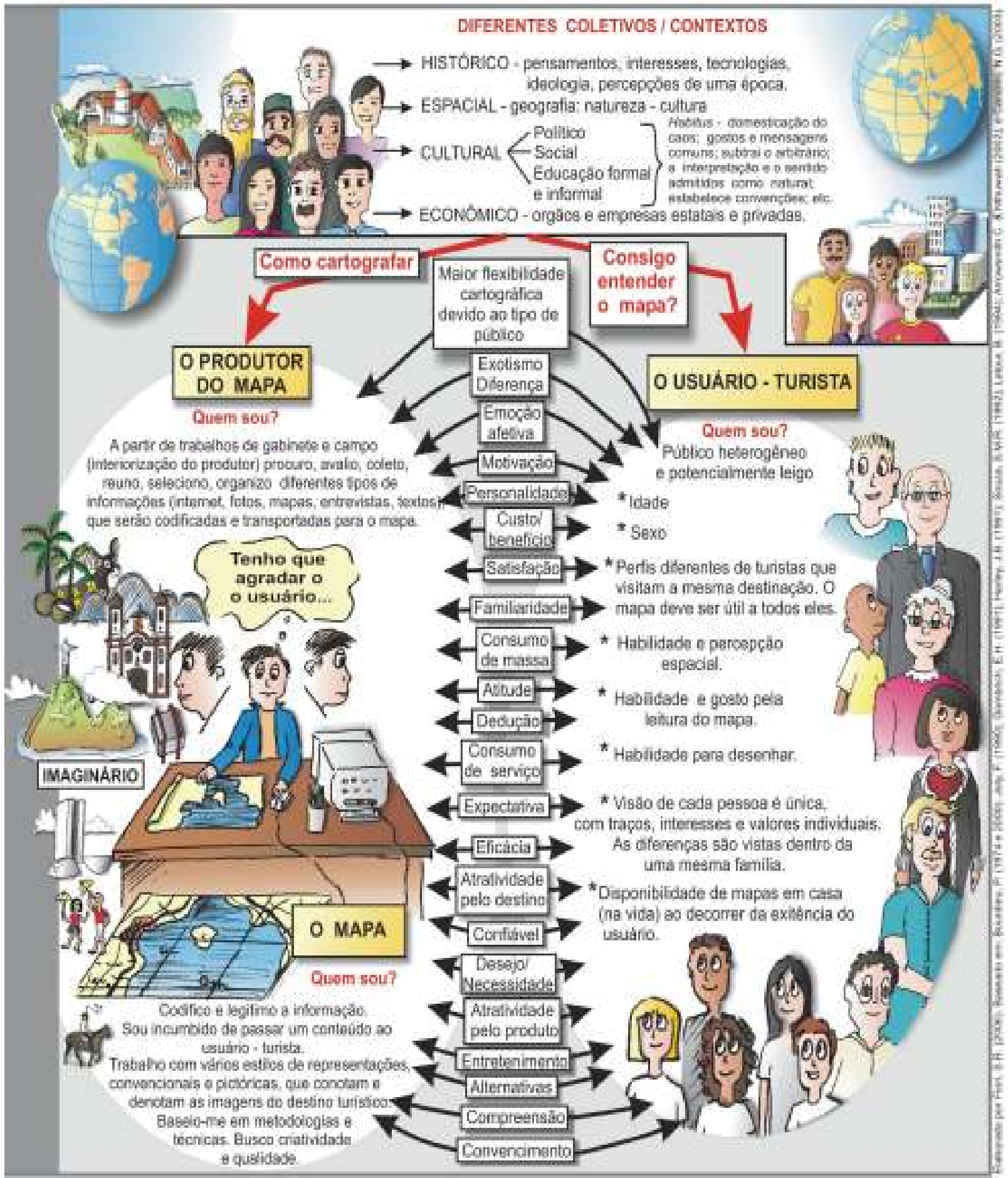




\section{5 - As bases semiológica e cartográfica: \\ proposta de um mapa temático para o setor do turismo}

Como foi dito anteriormente, a dificuldade em representar o espaço geográfico tridimensional - sobre o mapa é que tal representação se faz sobre uma superfície plana bidimensional (folha de papel, monitor de vídeo), simplificada e convencional, do todo ou de parte da superfície terrestre, tendo como base uma relação de semelhança convincente, denominada escala (Joly, 1990: 7). Para isso, conta-se com o processo seqüencial da generalização cartográfica, que traz a simplificação, o exagero, a hierarquização, o deslocamento e os elementos simbólicos do espaço geográfico - realidade para o mapa (Ramires, 1996).

Tal processo resulta em imagens incompletas, seletivas e representativas do terreno; logo, é preocupação primordial, em um mapa, a elaboração de sinais e símbolos apropriados (Joly: op.cit:: 8). O autor continua esclarecendo que as regras para que se estabeleça tal simbologia pertencem ao domínio da semiologia gráfica, que proporciona uma espécie de gramática da linguagem cartográfica.

Segundo Joly (op.cit:13), partindo do pressuposto que a linguagem exprime, por meio da utilização de um sistema de signos, um pensamento e um desejo de comunicação entre as pessoas, a cartografia pode, de maneira legítima, ser considerada como linguagem.

Os fundamentos sobre o estudo da lingüística e do signo ocorrem em meados da segunda metade do século XIX. Charles Sanders Pierce, filólogo e lógico americano e Ferdinand de Saussure, lingüista suíço, iniciam cada um a sua maneira, um estudo sobre o signo.

Santaella (1983: 58) brevemente conceitua o signo como um elemento que sempre representa outro (coisa): seu objeto. Ele só pode funcionar como signo se carregar esse poder de representar, substituir algo diferente dele. Conseqüentemente, o signo não é o objeto, apenas está no lugar dele, representando-o de um certo modo e numa certa capacidade. Ele pode ser interpretado por experiências concretas, sentimentos ou pensamentos. Tudo dependerá da natureza e do potencial do signo, além das condições intrínsecas de vivência de cada pessoa. O signo ainda é composto de duas partes:

$\checkmark$ Significante: caracteriza-se pelo plano da expressão, revelando o aspecto concreto/material do signo.

$\checkmark$ Significado: caracteriza-se pelo plano do conteúdo do elemento, transmitindo o aspecto abstrato/conceitual do signo.

Sendo que o significado do signo não está no próprio signo, mas nos conceitos ou imagens formadas na mente das pessoas. Isto nos faz supor que o significado de um signo é outro signo, ou seja, uma imagem mental ou real, uma ação ou mera reação 
gestual, uma palavra, um sentimento de alegria, e assim por diante (Santaella, 1983: 58).

Sendo assim, a comunicação só é conseguida quando o receptor-usuário associa ao sinal recebido a mesma intenção gerada pelo emissor. Tal processo é fundamentalmente baseado em duas condições: o canal deve ser rico o bastante para não ter ruídos, e o sinal deve fazer parte de um repertório comum à fonte produtora e receptora (Carneiro, 2001:22) - figura 27.

\section{Figura 27 - Teoria da Comunicação}

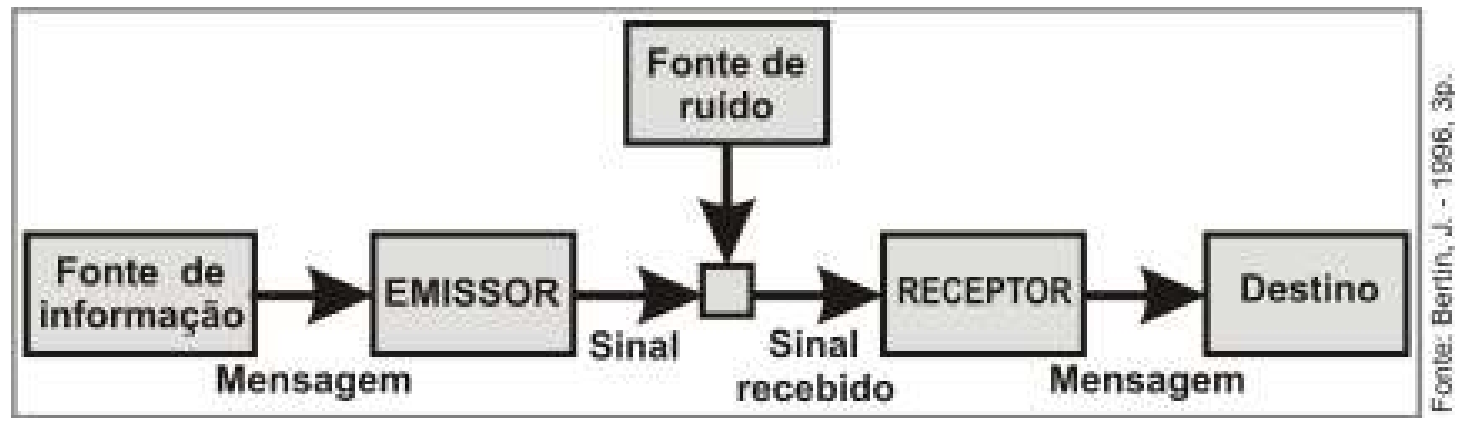

Dondis (1991: 26) deixa claro não haver nenhuma maneira fácil, milagrosa, de se desenvolver o alfabetismo visual. No entanto, atualmente ele é tão vital para o ensino e acesso aos modernos meios de comunicação, quanto a escrita e a leitura foram para o texto impresso.

O contato com o texto de Barthes $(1964,1984,1989)$ permite concluir que os mesmos conceitos trabalhados para a lingüística ajudaram a trazer uma maior familiarização a outros níveis de comunicação referentes a mensagem gráfica. Por exemplo: o autor fez formulações sobre a natureza da mensagem produzida pela pintura, pelo desenho e pela fotografia, apresentando diferenças em relação à mensagem escrita.

Em seus primeiros estudos sobre a semiologia e a vida cotidiana, Barthes demonstrava como imagens intencionais veiculadas pela imprensa, cinema, artes e demais veículos de comunicação eram consumidas inocentemente pelo público, que não as vê como um sistema de valores, mas sim, como sistema factual que exprime relações naturais (Porto Alegre, 1988: 78).

Barthes é citado nesta pesquisa porque seus trabalhos permitem estabelecer um paralelo entre suas idéias e o mapa turístico - potencialmente o pictórico. $\mathrm{O}$ autor (1990: 28-40) aponta três tipos de mensagens distintas que compõem a comunicação: a icônica codificada, a icônica não-codificada e a lingüística. Nesse processo, o espectador da imagem recebe ao mesmo tempo a mensagem perceptiva e a cultural. Cada tipo de mensagem será explorado em sua generalidade, procurando compreender a estrutura da imagem em seu conjunto, ou seja, a relação 
final das três mensagens entre si.

\section{a) A icônica codificada (mensagem denotada)}

Conforma-se pela imagem pura, podendo estar ou não ordenada. Neste caso, pode ser linear - a,b,c.. 1,2,3 ou não linear - desenhos, mapas. As letras, os números, as linhas, as formas e cores são os primeiros elementos visuais a serem compreendidos.

Carneiro (2001: 38) restringe-se aos sinais gráficos, os quais se conformam em imagens representadas por traços (linhas) em uma superfície (papel, monitor de computador). Não possuem valor fonético e comumente não fazem uso dos recursos da lingüística. Sua natureza é então icônica figurativa, pois suas formas se assemelham aos elementos que representam, dentro de uma abordagem de repertórios ou códigos, que é direcionada a um público. A eficácia do sinal o fará conhecido e memorável.

Embora denotado, o desenho - quando busca reproduzir a realidade não deixa de ser uma mensagem literal codificada, pois a natureza codificada do desenho aparece em três níveis (Barthes, 1990):

$\checkmark$ Ao reproduzir um objeto ou uma cena por meio de um desenho, o produtor é obrigado a fazer uso de um conjunto de transposições regulamentadas (técnicas, regras, estilos, etc.). Logo, a cópia pictórica não possui apenas uma única natureza, fazendo uso de códigos de transposição históricos (sobretudo no que tange à perspectiva).

$\checkmark O$ ato de desenhar (a codificação) obriga uma certa divisão do que é significante e do que é insignificante no elemento real-concreto, pois o desenho não reproduz tudo o que é visto na realidade. Freqüentemente, são reproduzidas somente poucas características encontradas no elemento real, mesmo assim, quando o desenho é bem elaborado, sua mensagem não deixa de ser forte e eficaz. Assim, a denotação do desenho é menos pura do que, por exemplo, uma denotação fotográfica.

$\checkmark$ Como todos os códigos, a utilização do desenho exige uma aprendizagem, tanto do produtor quanto do usuário.

\section{b) A icônica não-codificada (retórica da imagem)}

Os signos desse tipo de mensagem são denominados de simbólicos culturais ou conotados. Por meio deles é possível saber, por exemplo, o que alguém pensa de um conjunto de ilustrações como sol e mar, por exemplo, cuja resposta seria, férias ou praia. Mesmo quando o significante parece abranger toda a imagem, é, ainda assim, um signo separado dos outros, pois só a composição tem um significado estético (Citelli, 1985). 
Segundo Barthes (1990), tais signos são extraídos de um código cultural. A diversidade das leituras não é, no entanto, anárquica; depende do saber investido na imagem - saberes práticos, nacionais, culturais, estéticos. Cada pessoa possui uma pluralidade de léxicos ${ }^{23}$, logo, a imagem, em sua conotação, seria, assim, constituída por uma arquitetura de signos provindos de uma profundidade variável de léxicos.

O imenso sistema de conotação apresenta significantes constituídos por outros tipos de expressão como, por exemplo, o desenho, a palavra, os objetos, os comportamentos; não se restringindo somente a imagem. Portanto, a mesma conotação pode ser conseguida a partir da imprensa escrita, em uma imagem na televisão ou no gesto do comediante, todas possuindo um significado comum. Esta é a razão pela qual a semiologia só pode ser concebida em um todo (Barthes, 1990).

Esse domínio comum dos significados de conotação é o da ideologia, que deve ser único em uma mesma sociedade, levando em consideração qualquer um dos significantes de conotação ao qual recorra. Barthes (1990) continua esclarecendo que a ideologia geral corresponde na verdade, a significantes de conotação chamados de conotadores, sendo que o conjunto dos conotadores foram uma retórica, a qual aparece, como a face significante da ideologia.

As retóricas variam fatalmente em razão de sua forma: som, imagem, gesto, etc. Já a retórica da imagem - isto é, a classificação de seus conotadores - é, assim, específica na medida em que é submetida às imposições físicas da visão (diferentes, por exemplo, das imposições auditivas, táteis, etc). Em geral, as figuras nunca são mais do que relações formais dos elementos; e esta retórica só poderá ser constituída a partir de um inventário suficientemente vasto (Barthes, 1990).

A figura 28 exemplifica as duas mensagens - denotativa e conotativa - inerentes ao ato de representação da realidade, a arte imitativa, a qual será usada durante o desenvolvimento dos mapas turísticos.

\section{c) A lingüística}

A lingüística constitui-se na dualidade contraditória: unidade e diversidade, contradição esta inscrita em seu próprio objeto - as diferentes línguas - havendo uma relação necessária entre o formalismo do sistema e a diversidade história concreta. $A$ Lingüística é afetada em sua constituição por essa contradição que se inscreve na sua própria histórica e na história das alianças que ela vai promovendo com diferentes campos do conhecimento como, por exemplo, o logicismo, o psicologismo, o sociologismo, o cognitivismo, etc (Orlandi: 2004:17).

\footnotetext{
${ }^{23}$ Parte do plano simbólico da linguagem que corresponde a um conjunto de práticas e de técnicas. É o caso de diferentes leituras da imagem, onde cada signo corresponde a um conjunto de "atitudes", como por exemplo, o turismo, a vida doméstica, o conhecimento no campo da arte, as leis de trânsito, etc. (Barthes, 1990: 38).
} 
Figura 28 - A mensagem denotada e conotada

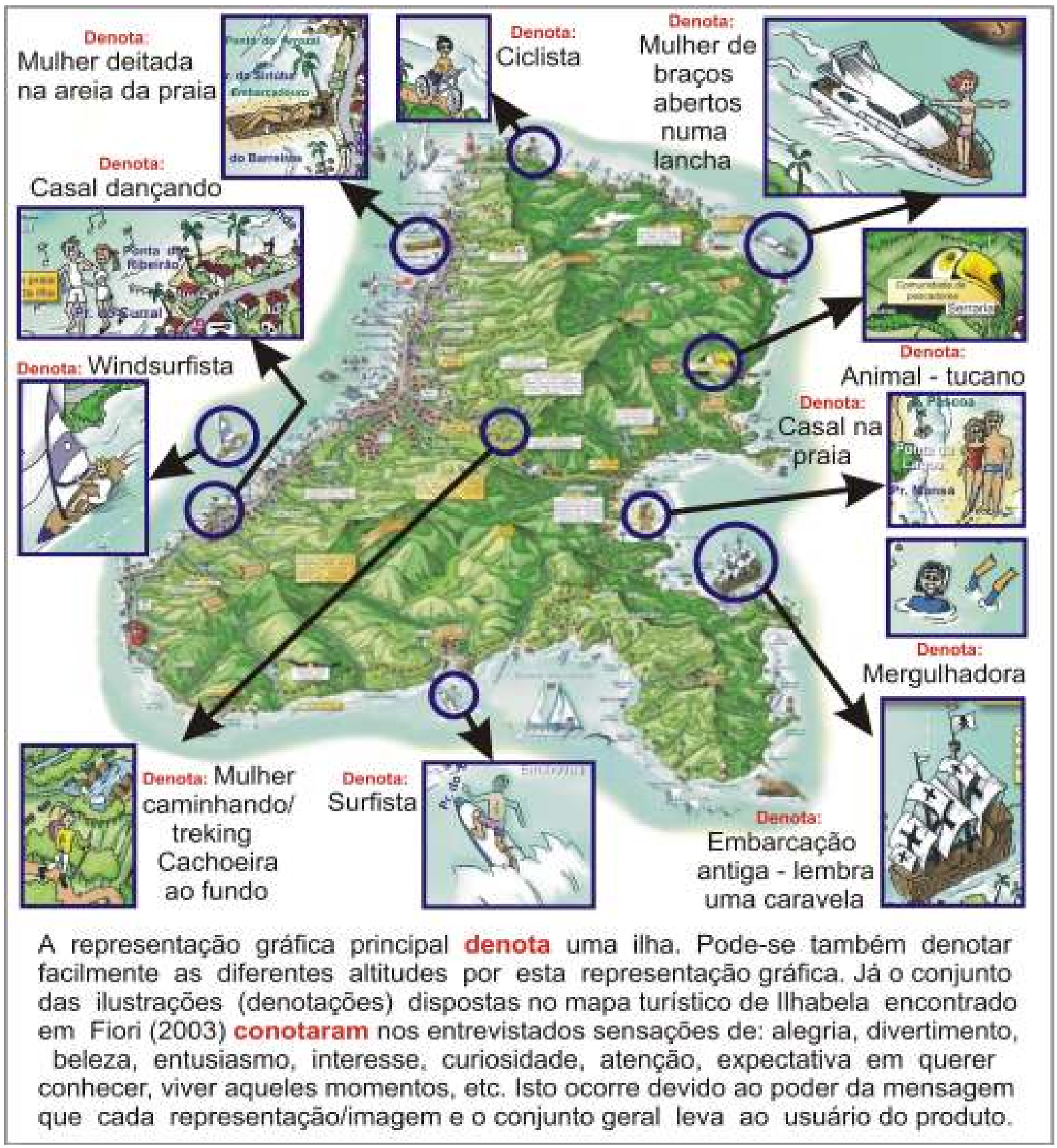

A mensagem lingüística volta-se mais à interpretação e não à identificação, constituindo uma espécie de barreira que impede a proliferação dos sentidos conotados, simbólicos. As mensagens tanto podem estar relacionadas a áreas individuais, limitando o poder de projeção da imagem, quanto relacionadas aos valores, onde os elementos dispostos na cena-imagem utilizam a legenda, orientando a interpretação da imagem.

A fixação pode ser ideológica e esta é, sem dúvida, sua função principal; o texto conduz o leitor entre os significados da imagem, fazendo com que se desvie de alguns significados e assimilem outros (Barthes, 1990). 
O autor esclarece que a palavra, vista em sua forma literal, ou seja, denotada, responde de maneira mais ou menos direta e parcial a pergunta: "o que é?", auxiliando pura e simplesmente na identificação dos elementos contidos na cena e na própria cena. A função denominativa corresponde a uma fixação de todos os sentidos possíveis (denotados) do objeto. Por exemplo, havendo um cartaz que representa um determinado prato de um restaurante, o consumidor pode hesitar na identificação das formas e volumes dispostos pela representação. Contudo, havendo um texto: "arroz e atum com cogumelos", aumenta-se consideravelmente o nível da percepção, permitindo adaptar o olhar e a compreensão.

Um segundo ponto muito importante da semiologia também aplicado à cartografia refere-se às três dimensões do signo: sintática, semântica e pragmática. $O$ trabalho preocupado com essas dimensões permite estruturar e melhorar a qualidade do repertório gráfico voltado à elaboração de mapas para o setor turístico e do lazer.

\section{1) A dimensão sintática:}

\section{estudo das relações dos signos com outros signos}

Preocupa-se com problemas relativos à forma da representação - como dizer ao usuário? - estudando itens estruturais e técnicas de composição, as quais geram regras de formação e codificação visual de um elemento, além de examinar sua interação com outras representações (o conjunto de elementos), que também possuem regras referentes à linguagem e repertórios (Carneiro, 2001:33).

Souza (1992: 72) informa que, estando a sintaxe preocupada em estudar a estrutura lógico-gramatical da linguagem, - as qualidades materiais do signo em seu jeito concreto e particular de existir - os elementos gráficos de preocupação do designer são: a forma, a cor, a textura, a magnitude, a intensidade, o movimento, o ritmo, a composição, a pertinência a um sistema, etc.

Essa etapa da composição visual é vital a todo processo criativo, e é onde o comunicador visual exerce maior controle sobre o seu trabalho, tendo a oportunidade de expressar, em plenitude, o espírito de sua obra. No contexto do alfabeto visual, a sintaxe significa a disposição ordenada de partes (linhas, cores, tons, proporções), não havendo regras absolutas:

o que existe é um alto grau de compreensão do que vai acontecer em termos de significado, se fizermos determinadas ordenações das partes que nos permitam organizar e orquestrar os meios visuais (Dondis, 1991: 29).

Souza (1992: 73,74) complementa afirmando existirem duas regras sintáticas básicas: a formação, que determina combinações independentes e permitidas entre os signos de um sistema e a transformação, que determina as combinações que podem ser obtidas a partir de outras combinações. Neste contexto, o autor ainda subdivide os signos de linguagem em três funções designadoras ou denotadoras, separadas a partir do grau de expectativas concretas que podem determinar no 
intérprete, a saber:

$\checkmark$ Indéxico - pode denotar um objeto individualmente, chamando para este a atenção de intérprete. Por exemplo, a palavra este, o signo gráfico da flecha, o gesto de apontar com o dedo indicador.

$\checkmark$ Caracterizador - pode denotar uma pluralidade de coisas e ter sua designação explicada ou restringida em virtude da presença de outros signos que o especificam. Por exemplo, a palavra homem, as silhuetas de homens.

$\checkmark$ Universal - pode denotar qualquer coisa, pois tem uma significação universal. Por exemplo, a palavra algo, o pictograma de masculino, de hospital, etc.

Normalmente, signos caracterizadores, indéxicos e universais se combinam, buscando um esforço para referenciar o objeto que está sendo aludido, para assim determinar - com maior ou menor precisão - as expectativas do intérprete em relação às possibilidades semânticas dos signos utilizados. Posto isso, na combinação dos signos, existem aqueles que funcionam como dominantes e outros como especificadores daqueles (Souza, 1992: 75) - Figura 29.

\section{2) A dimensão semântica:}

estudo das relações dos signos com os objetos a que se referem

Segundo Souza (1992: 46), é nesta dimensão que os profissionais em design gráfico deveriam despender noventa por cento de seu tempo.

\section{Figura 29 - Signos dominante e especificador}

No exemplo abaixo, o icone de um homem em uma única postura funciona como um signo dominante. Já os desenhos dos objetos: acessórios da cabeça e das mãos, funcionam como especificadores das diversas profissőes (Souza, S.M.R. - 1992, 75p).

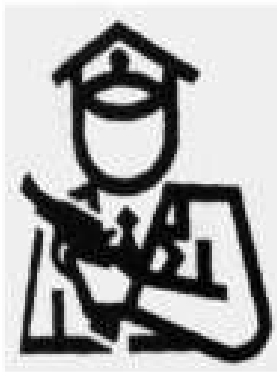

1- Policial

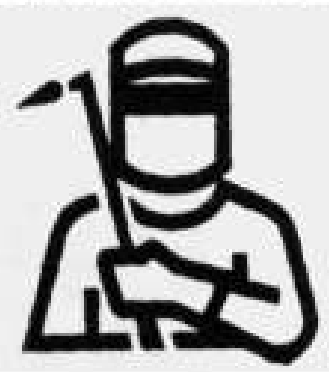

2 - Metalúrgico

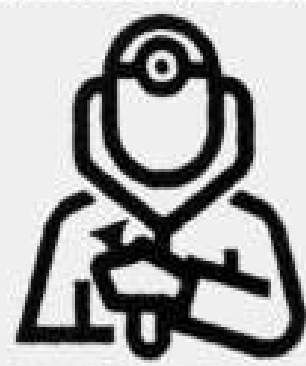

3-Médico

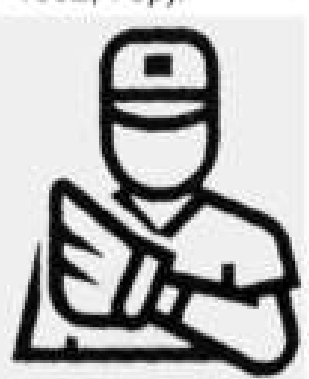

4- Jogador de beisebol

Este item preocupa-se com problemas relativos ao conteúdo da representação, buscando desenvolver formas que se caracterizem sempre pelo menor ruído, ou seja, maior clareza possível. A pergunta semântica é: o que dizer sobre.

$\mathrm{Na}$ verdade, as regras semânticas são muito mais estabelecidas por hábitos de conduta do que por proposições cientificamente provadas. Isso porque elas se 
configuram como modelos ou são aprendidas culturalmente, transmitidas por tradição (Carneiro, 2001: 34 e Souza, 1992: 76).

A opção por um código é feita a partir de uma escolha que tem como referência o meio de comunicação que transmitirá a mensagem (neste caso, um mapa) a alguém (turista) através de um canal (folha de papel e tela de computador). Tal escolha não é aleatória, pois analisa a natureza da mensagem e as particularidades do canal e do meio de comunicação, para que, assim, os sinais ou unidades de significação (signos, representações potencialmente pictóricas) sejam transmitidos da melhor maneira.

Oliveira (1977: 23), Santaella (1990: 63-68), Souza (1992: 73-83) e Carneiro (2001: 31-36) apontam três tipos de relações semânticas que se estabelecem entre o signo e seu referente.

"O ícone - deve denotar alguma característica ou conjunto pré-estabelecido de características do elemento representado, de modo que a imagem se assemelhe àquilo que significa. $\mathrm{O}$ ícone mostra em si mesmo propriedades do objeto por ele denotado, apresentando um alto poder de sugestão, devido a sua capacidade de produzir em nossa mente relações de comparação. Há uma semelhança entre a imagem e o referente. (Souza, 1992: 143) complementa que as codificações icônicas podem ir desde aquelas que apresentam um maior número de propriedades visíveis ou atributos do objeto representado (efeito de réplica, mimético, ilusão de estar diante da própria realidade), até aquelas que reduzem ao mínimo o número e a variedade dos atributos percebidos e selecionados como relevantes para a representação, apresentando-os de maneira esquemática ou convencionalizada como, por exemplo, charges, desenhos infantis, esquemáticos, etc (Figura 30).

Figura 30 - 0 ícone: o desenho fala por si

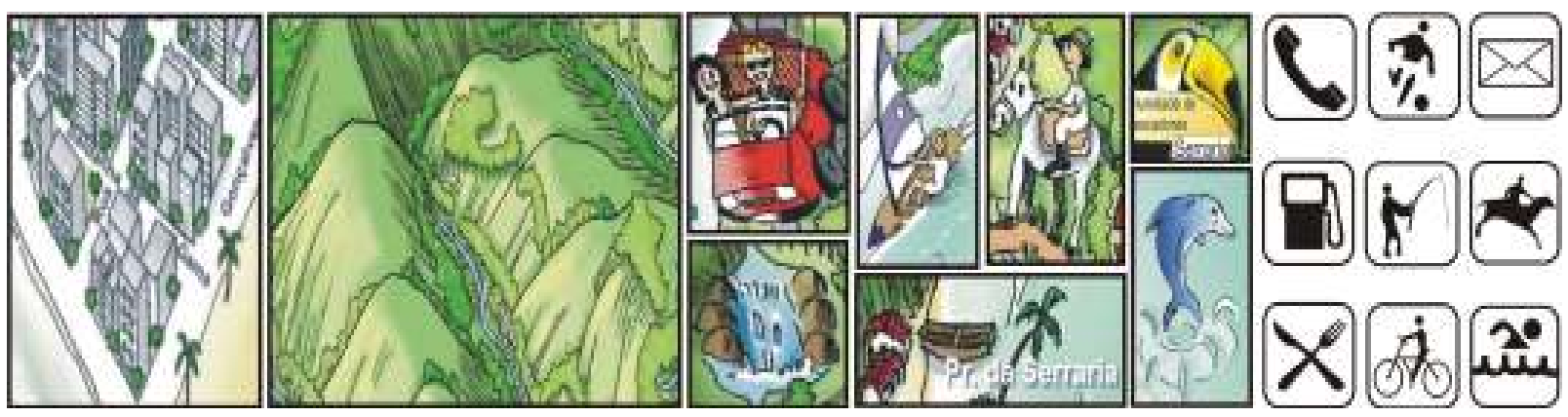

"O índice (ou indicador) - geralmente, dirige a atenção para aquilo que representa, porém não se caracteriza por propriedades de semelhança com o objeto/idéia. É um tipo de signo que funciona quando a mente interpretadora estabelece uma conexão dual, ou seja, o interpretante do índice constata apenas a existência dos elementos físicos: o real-concreto e a representação, normalmente tendendo a um maior nível de abstração. O raciocínio não ultrapassa a compreensão do signo como existência 
concreta, por interpretar simplesmente o que vê, sem maiores implicações quanto a querer identificar, particularizar uma imagem. Por exemplo, ao se elaborarem representações para caracterizar a morfologia do terreno, pode-se trabalhar com as técnicas de sombreamento - simulando uma tridimensionalmente das formas, mas não buscando uma ilustração particular, única e sim genérica - ou então, com cores e tons identificam-se as diferentes altitudes do terreno (Figura 31).

\section{Figura 31 - 0 índice: o desenho não guarda}

\section{semelhança direta com o que representa}
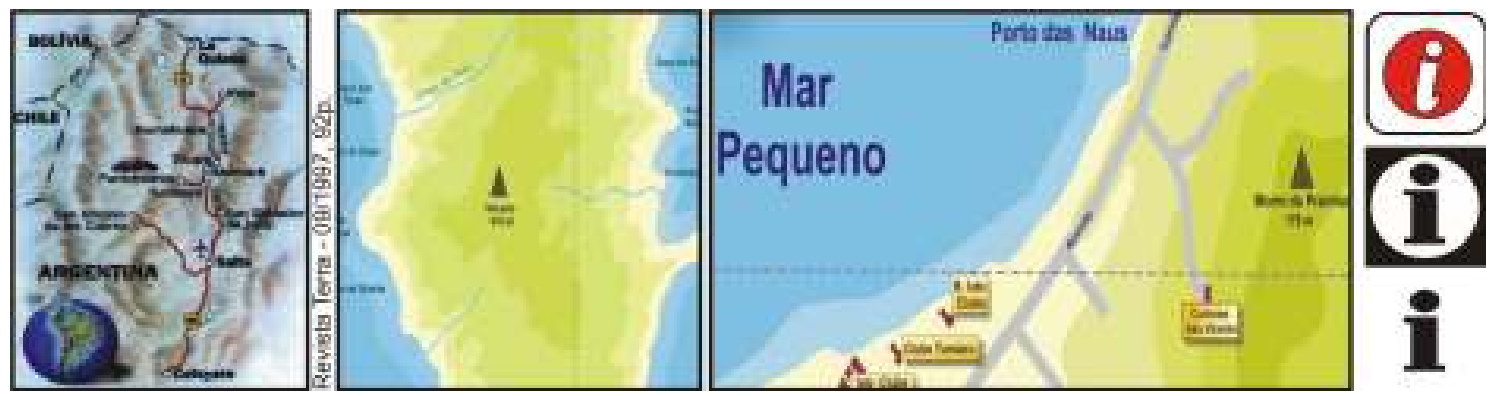

" O símbolo - representa e designa os objetos similares a um modelo, tendo como referência normas e usos convencionais não-questionáveis, sendo simplesmente aceitos. Conseqüentemente, a representação é portadora de uma lei que, por convenção ou pacto coletivo, determina que o signo represente o objeto. Deste modo, o símbolo não representa um tipo individual, mas, sim, geral. É o caso da cruz, que representa o sofrimento; da pomba que representa e paz.

Possibilitam-se ainda dois níveis distintos de convenção: a analógica (motivada) e a arbitrária. Na primeira, a significação cumpre seu papel à medida que o observador reconhece no signo as propriedades do elemento representado (Figura 32 A). Já na convenção arbitrária, a significação só é conseguida graças à existência de regras associativas convencionalmente estabelecidas e adquiridas pelo aprendizado (Figura $32 \mathrm{~B})$.

Essa dimensão faz com que o produtor se preocupe mais com a representação e com o fato de ela ser compreendida e aceita, desenvolvendo símbolos que sejam eficientes aos mais diferentes tipos de pessoas (pertencentes ou não a mesma cultura).

O mapa a seguir representa uma contigüidade instituída, regra convencional entre o significado e o significante - mapas que apresentam legenda: o intérprete precisa recorrer à convenção para haver o entendimento do significado geral (Figura 32 C). 
Figura 32 - Símbolo: o desenho desenvolvido através de normas convenções
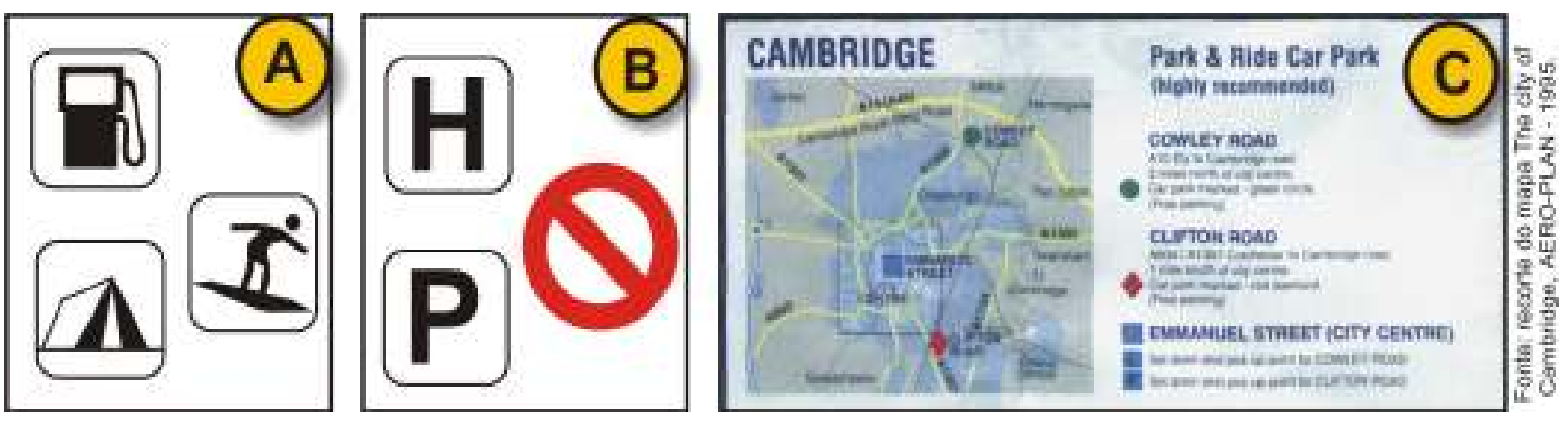

Por fim, Joly $(1990,18,19)$ divide os símbolos em várias categorias (Figura 33):

$\checkmark$ Sinais convencionais - são esquemas gráficos centrados na posição real do elemento representado, permitindo assim que este seja identificado mesmo que sua superfície, na escala, seja muito pequena.

$\checkmark$ Sinais simbólicos - são signos evocadores, localizados ou cuja posição é facilmente determinável.

$\checkmark$ Pictogramas - são símbolos figurativos facilmente reconhecíveis.

$\checkmark$ Ideogramas - são pictogramas que representam um conceito, uma idéia.

$\checkmark$ Símbolo regular - é uma estrutura constituída pela repetição regular de um elemento gráfico sobre uma superfície delimitada.

$\checkmark$ Símbolo proporcional - é um símbolo quantitativo, cuja dimensão varia com o valor do fenômeno representado.

O autor (1990: 19) complementa que o uso dos símbolos naturais, figurativos ou analógicos tem sido a tendência histórica mais antiga na elaboração de mapas.

Figura 33 - Símbolos cartográficos

\begin{tabular}{|l|l|}
1 - Sinais convencionais \\
2 - Sinais simbólicos \\
3 - Pictogramas \\
4 - Ideogramas \\
5 - Símbolos regulares \\
6 - Símbolos proporcionais
\end{tabular}

3) A dimensão pragmática: estudo das relações dos signos com os usuários

Essa dimensão com problemas relativos à função da representação - para que e qual 
usuário se dirige a mensagem - voltando-se a escolhas feitas previamente, na elaboração de um signo (fenômenos psicológicos, biológicos e sociológicos), enfatizando ou eliminando qualidades e/ou atributos para o melhor entendimento do usuário.

Nesta dimensão, estão as regras que relacionam os signos e os objetos representados, de forma a causar uma mudança de comportamento nos usuários, reflexo dos tipos de conduta referenciados pelo uso. Deve-se aqui levar em consideração que, quanto mais abstrata ou convencionalizada for a relação entre o signo e aquilo que designa, tanto maior será a necessidade desses hábitos serem consolidados por algum tipo de aprendizado.

Desse modo, o desenvolvimento de um sistema de repertório utilizado especificamente para mapas turísticos tem como preocupação representações eficazes quanto à comunicação dos elementos dispostos no espaço como localização e distância. E, além disso, algumas vezes pode apresentar o propósito de divulgar alguma informação que motive o visitante, sempre respeitando as condições deste usuário quanto à assimilação da informação que foi consolidada pelo aprendizado formal e informal.

A figura 34 exemplifica graus diferentes de abstração: o usuário só entenderá as mensagens a partir do conhecimento (habitus acumulado) anterior.

Figura 34 - Dois níveis diferentes de representação da mesma realidade
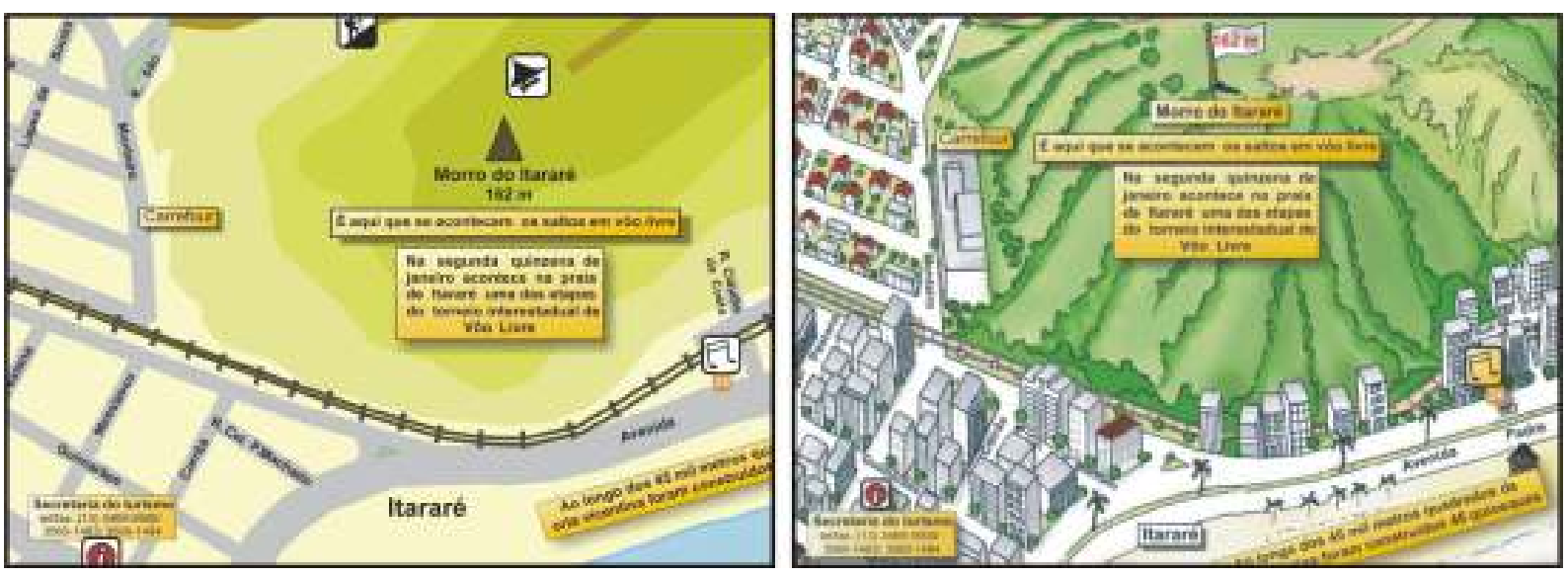

Enfim, as variações das manifestações visuais sempre dependerão da expressão subjetiva do artista, obtida pela ênfase de alguns elementos visuais em detrimento de outros, sendo que a manipulação desses elementos se dá pela opção estratégica de inúmeras técnicas. É nessas opções que o artista encontra seu significado. $O$ resultado final é a verdadeira manifestação do artista. Contudo, é fundamental não esquecer que o significado de sua obra depende da resposta do usuário, que também a modifica e interpreta pela rede de seus próprios critérios subjetivos (Dondis, 1991: 31). 
O terceiro e último ponto a ser abordado tem a preocupação de focalizar a semiologia direcionada ao desenvolvimento de mapas. Esse campo da comunicação - que parte da premissa de que a cartografia é uma forma de linguagem - foi inicialmente trabalhado por Bertin (1967), que estruturou a semiologia gráfica, área ligada ao mesmo tempo às diversas teorias das formas e suas representações e não só estudada pela psicologia contemporânea como pelas teorias da informação. O autor continua dizendo que a semiologia gráfica aplicada à cartografia permite:

avaliar as vantagens e os limites das variáveis visuais empregadas na simbologia cartográfica e, portanto, formular as regras de uma utilização racional da linguagem cartográfica. Encerrada durante muito tempo dentro de limites técnicos bastante restritos, porém magnificamente superados, hoje essa linguagem se vê rápida e consideravelmente modificada pela introdução vigorosa dos métodos da informática e da automação (Joly, 1990: 13-14).

Bertin (1996) afirma que o emprego das variáveis visuais no plano bidimensional faz uso das propriedades perceptivas de cada uma delas. Neste momento, é importante ressaltar que MacEachren $(1994,1995)$ vem trabalhando e aumentando a relação das variáveis visuais, tendo como base as duas dimensões do plano, uma perpendicular à outra: a longitude $(\mathrm{X})$ e latitude $(\mathrm{Y})$. Elas originam as coordenadas geográficas, também chamadas de componentes de localização, determinando uma superfície. Some-se ainda o componente de qualificação $(Z)$, que permite uma modulação do fundo do mapa por uma mancha (cor ou sinal) - característica do lugar representado - que pode ser qualitativa, quantitativa ou ambas. A extensão (mancha) do objeto ou fenômeno divide-se em três modos de implantação: pontual, linear e zonal (Joly, 1990: 14) - Figura 35. É importante ressaltar que Fiori (2003: 72-88) já apresentou detalhadamente cada uma das variáveis visuais.

Bertin $(1996,1988)$ informa que o esquema de representação monossêmica é obtido ao se juntarem as três dimensões do mapa $(X, Y, Z)$ com as três relações fundamentais entre os conceitos a serem transcritos: 1) a associação, semelhança (三), que se contrapõe à seleção, diferença $(\neq)$; 2) a ordem, (O); e 3) a quantidade, proporção (Q). Nesse processo, o emissor e o receptor estão exatamente na mesma situação perceptiva por fazerem uso e obedecerem ao mesmo esquema monossêmico: Ator $\longleftrightarrow(\equiv$ e $\neq, \mathbf{O}, \mathbf{Q})$. Tornar-se ator significa tomar conhecimento - em apenas um instante de percepção, sempre instantânea - da informação contida num gráfico ou mapa, sendo um receptor ativo e não passivo.

$\mathrm{E}$, para que isso aconteça, o redator gráfico (cartógrafo) precisa analisar a natureza quantitativa, ordenada ou diferencial dos dados a serem transcritos, selecionando a variável visual correspondente. Deste modo, o processo de escolha dos signos condiciona-se pelas propriedades limitadas das variáveis visuais, permitindo assim uma leitura de conjunto - mapas para ver - o principal objetivo da representação gráfica (Vasconcellos, 1993: 35). 
Figura 35 - As variáveis visuais segundo Bertin e MacEachren

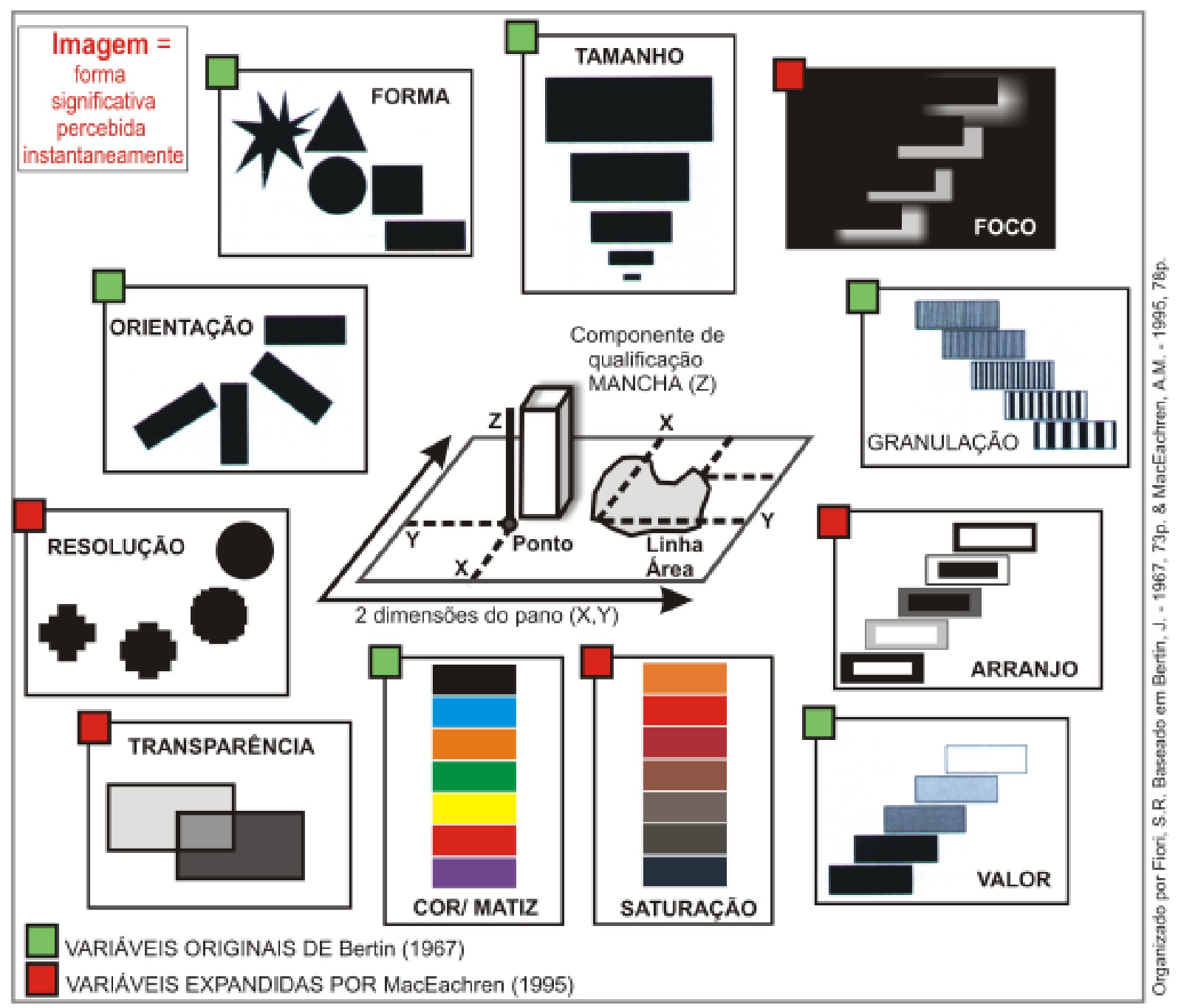

Bertin (1983: 78) ratifica que a:

liberdade não existe em cartografia! É por esta razão que a cartografia é uma linguagem universal, uma linguagem finita e rigorosa que tem apenas UMA ORDEM VISUAL. Adotar qualquer convenção, outra que não imposta pela fisiologia é afirmar que 2 é igual a $5 \ldots$ é ser cego!

Aceita-se somente a normalização de signos convencionais, procurando economizar tempo a fim de obter rápida compreensão da mensagem. Para isso, conta-se inicialmente com a lei básica da representação gráfica (graphique), que objetiva não destruir as relações entre os elementos representados, além da lei de memorização, proporcional ao número de repetições da convenção, sendo inversamente proporcional ao número de convenções (Bertin: 1983: 78) - Figura 36.

Dacey (1978) finaliza que a linguagem das informações geográficas e dos modelos cartográficos tradicionalmente se caracteriza pela linguagem dos símbolos (usualmente abstratos, fisiológicos) de maneira multidirecional, necessitando, assim, 
de uma estrutura organizada com conceitos de ordem. Essa estrutura faz a junção dos símbolos entre dois mapas ou entre os símbolos de vários mapas de um modelo cartográfico, e é denominada de linguagem bidimensional.

\section{Figura 36 - Exemplos de variáveis visuais}

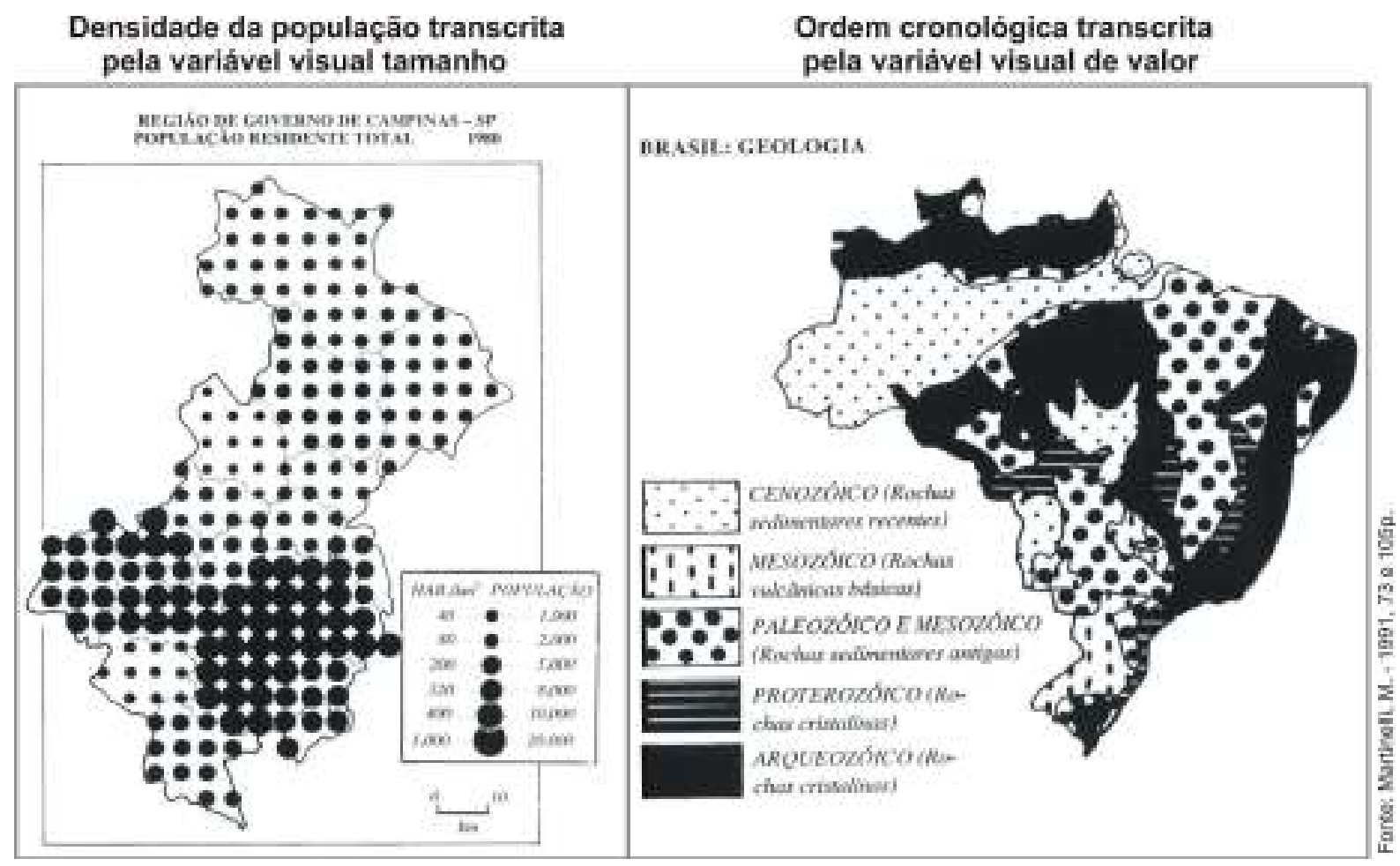

Já o esquema de comunicação polissêmico caracteriza-se por uma constante ambigüidade. Objetiva definir conjuntos ou conceitos levando em consideração uma infinidade de outros conjuntos e signos, ou seja, é um problema sem solução. Mesmo assim, buscam-se imagens possíveis, aproximações, que são conseguidas pela limitação do contexto temporal, espacial e conceitual em que o receptor se insere para receber um sinal. Por exemplo: os sinais de trânsito são polissêmicos, não são sinais universais, pois, para decodificá-los, precisa-se conhecer o Código Nacional de Trânsito (Bertin, 1996). Tais símbolos dependem do esquema polissêmico: "Emissor (cartógrafo) $\leftrightarrow$ Código (mensagem cartográfica) $\leftrightarrow$ Receptor (usuário do mapa)" fundamentos da teoria da comunicação, que é criticada por Bertin (1996) exatamente por seu conteúdo polissêmico. Segundo o autor, nessa teoria é necessário que o emissor leve em conta o conhecimento do receptor para limitar a ambigüidade da comunicação. O objetivo da comunicação será pleno quando o receptor identificar o conceito.

Assim, o emissor é livre para escolher os signos do mapa que elabora, devendo encontrar o caminho mais eficaz em sua comunicação com o receptor, logo o produtor deve levar em consideração: 
a arte de imaginar o conhecimento de todo e qualquer receptor, isto é, o universo de associações significante-significado onde persiste, em geral, um hábito, do qual ele lançará mão em dada situação. A solução, a menos duvidosa, é a que estabelece uma convenção. E azarem-se aqueles que a desconheçam (Bertin, 1996).

Vasconcellos (1993: 34) constata haver várias divergências ao se compararem os pontos de vista dos teóricos da comunicação e da semiologia gráfica, especialmente ao se tratar da linguagem gráfica. Saussure, por exemplo, define a linguagem com um sistema estruturado de signos, ou seja, o signo lingüístico engloba o significado (conceito) e o significante (imagem acústica), sendo caracterizado por dois princípios fundamentais: a arbitrariedade (convenção) e a linearidade (a, b, c... 1, 2, 3...). Já Bertin, partindo desses mesmos conceitos, formula a linguagem gráfica como um sistema de signos gráficos - variáveis visuais - com significado (conceito) e significante (imagem gráfica), contudo o signo gráfico não é arbitrário (convencional) nem linear $(X, Y, Z)$ e, por isso, a representação gráfica é monossêmica.

As principais divergências entre os teóricos da comunicação e da semiologia gráfica se referem aos fatores econômicos e sociais, à experiência (fundamentalmente em relação ao uso dos mapas) e à possibilidade ou mesmo necessidade de normalizar os signos cartográficos - no sentido de torná-los convencionais - incluindo aqui, a utilização de símbolos (Vasconcellos, 1993: 36).

Ao pensar em mapas para o turismo, o intuito é continuar trabalhando um possível sincretismo entre as duas vertentes teóricas: a da comunicação e a da linguagem gráfica. A pesquisa empírica em Fiori (1999) e outros trabalhos práticos ${ }^{24}$ permitiram verificar que as variáveis visuais podem ser adaptadas, reestruturadas, por exemplo, utilizando-se a variável forma em vez da variável cor (ou as duas juntas) para representar a topografia. O resultado foi uma maior eficácia do produto. Entender o processo abstrativo de olhar a cor e imaginar a altitude não é tão simples assim para o leigo na leitura de mapas; logo, ele precisa, sim, ser iniciado nesta semântica.

Por outro lado, é possível trabalhar a pictografia em mapas turísticos, diminuindo consideravelmente a polissemia. Além disso, este tipo de representação teve uma aceitação muito maior do público leigo quando comparado ao mapa feito na versão convencional (Fiori, 2003: 187).

\footnotetext{
${ }^{24}$ Realização de cursos e oficinas com alunos e, principalmente, professores da rede pública, trabalhando conteúdos referentes à cartografia temática e ao turismo. Inicialmente as atividades ocorriam por meio de uma parceria entre o LEMADI (Laboratório de Ensino e Material Didático), a AVT (Academia de Viagens e Turismo) e o IAP (Instituto de Academias Profissionalizantes). Posteriormente, fui convidado a participar do Projeto Caminhos do Futuro - parceria do Ministério do Turismo com o IAP, a AVT e o Núcleo de Turismo da Universidade de São Paulo - onde continuei realizando oficinas. A oportunidade possibilitou aplicar alguns pontos de minha pesquisa em cidades de 16 estados brasileiros (Caminhos do futuro, 2007).
} 


\section{6 - O processo perceptivo: recolhendo imagens e elaborando representações}

Grosso modo, pode-se definir a imagem como um ato fisiológico, ou seja: surge de um feixe de luz que entra pelo olho e chega até a retina, sendo capaz de se adaptar a graus de iluminação e diferenças de intensidade de radiação da luz a partir dos diferentes pontos do campo visual (Keates, 1982: 15). Entretanto, agregam-se a esse ato perceptivo implicações mais profundas envolvendo, por exemplo, valores sociais e culturais, que imprimirão percepções e impressões à imagem, tornando-a afetiva, imprecisa e estabelecida em campo semântico não-delimitado (Coelho, 1993: 21).

Beni (1998: 220) ratifica o que foi dito acima, afirmado que a percepção é um processo pelo qual o indivíduo apreende a realidade pelos sentidos, selecionando, organizando e interpretando a informação. Há uma interação entre o estímulo do entorno físico (fisiológico) e o estímulo social (experiências já vividas e armazenadas na memória, com as do presente), criando assim quadros do mundo e fazendo da percepção um contínuo fluxo de idéias.

O dia-a-dia ajuda efetivamente na multiplicação das imagens presentes na vida de um indivíduo, facilitando a criação de um "museu cotidiano". Por exemplo: em um quarto, pode-se encontrar pregado na parede um pôster com uma reprodução de Matisse, lembranças de viagens, recortes de jornal, um mapa-mundi, o desenho de um amigo, enfim, um patrimônio próprio que é renovado conforme flui a vida (Canclini, 2003: 199).

Os significados dessas imagens resultam em grande parte da experiência e do saber que a pessoa que a contempla adquiriu anteriormente. Portanto, a imagem visual não é uma simples representação da realidade, mas sim um sistema simbólico (Samain, 1988). Conseqüentemente, o estudo da imagem é fundamental para o entendimento dos múltiplos pontos de vista que os homens estabelecem a respeito de si mesmos e dos outros, de seus comportamentos, pensamentos, emoções em diferentes experiências de tempo e espaço. Trata-se, agora, de tomar a imagem como objeto, procurando compreender o lugar dos ícones como parte constitutiva dos sistemas simbólicos, estendendo a eles as mesmas preocupações teóricas e metodológicas presentes no estudo das representações sociais (Porto Alegre, 1988).

Rocha-Trindade (1988) afirma que, em algumas disciplinas, a imagem se constitui como apoio temático, caso da geometria, do desenho técnico, da pintura, da topologia, etc. Em outros casos, a imagem real é um componente indispensável para a compreensão e a integração do objeto de estudo: os exemplos da biologia, da geografia, da história da arte ou da medicina aparecem como imediatos.

Os artistas - e também os cartógrafos - têm dado as maiores contribuições para o desenvolvimento das iconografias nacionais, por documentarem períodos e lugares, projetarem percepções e os valores da sociedade patrocinadora. Pontue-se que alguns artistas são conscientes das implicações culturais e nacionais de seu trabalho. 
O resultado é que as figuras de lugares, pessoas e eventos têm tornado parte da identidade coletiva (Osborne, 1994).

Já o marketing ligado ao comportamento do consumidor-turista empenha-se em projetar imagens e intenções favoráveis de destinações turísticas, objetivando promovê-las aos visitantes (Mackay \& Fesenmaier, 2000). Uma perspectiva do imaginário é valiosa para entender o impacto das mensagens publicitárias. As ilustrações, fotografias, filmes não somente divulgam a localidade, mas podem ainda comunicar atributos, características, conceitos, valores e idéias. Os estudos nesta linha sugerem que tanto as variáveis pessoais (população, cultura e familiaridade, etc.), quanto os atributos visuais (características físicas) são relevantes na avaliação de uma imagem (Mackay, Fesenmaier, 1997).

Segundo Souza (1992: 43-44), o acervo de imagens de uma pessoa só tende a crescer. É um processo contínuo e cumulativo ao longo de sua vida. Tais imagens podem ser conscientes e inconscientes, da primeira infância, mais próximas do presente, do ser amado, subjetivas, entre outras. E é exatamente esse conjunto de imagens que estabelece a ponte entre do mundo interior, subjetivo do indivíduo, e a realidade objetiva que o cerca e sobre a qual ele atua. Sendo assim, o designer deve procurar, entre todas estas imagens, aquelas objetivas ${ }^{25}$, capazes de processar a comunicação entre as mentes humanas por serem imagens comuns a uma grande quantidade de pessoas. A autora então elabora as seguintes questões: Que formas e/ou cores...

... podem intencionalmente comunicar certa informação, sensação ou ordem a um determinado conjunto de pessoas que integram o público receptor da mensagem visual emitida? Que imagem pode sensibilizar positivamente o espectador, fazendo com que este reaja da forma esperada?

Até porque, a polissemia é inerente à imagem, que tem como característica uma "cadeia flutuante" de significados entre a linguagem literal denotada e a linguagem simbólica conotada (figura 37). Como reação à incompreensão, as sociedades produzem diversas técnicas destinadas a fixar tal cadeia de significados (Barthes, 1990: 32).

Souza (1992: 45) detalha melhor o problema da função comunicativa atribuída às imagens objetivas do design gráfico, dividindo-as em natureza:

$\checkmark$ Informativa - onde a mensagem visual intenciona mudar a forma de pensar ou sentir do receptor e/ou grupo de receptores, aumentando-lhes o estado de conhecimentos, de habilidades;

\footnotetext{
${ }^{25}$ A busca da objetividade na comunicação visual faz com que o produtor pesquise - incessantemente - o universo de imagens de cada indivíduo extraindo somente aquelas que são comuns a todos num dado momento e local, independentemente do gosto pessoal do seu criador (Souza, 1992: 44).
} 
$\checkmark$ Persuasiva - onde a comunicação visual pretende modificar as atitudes dos receptores, intensificando a preferência ou valor por um objeto, destinação.

Figura 37 - "Captando" a imagem

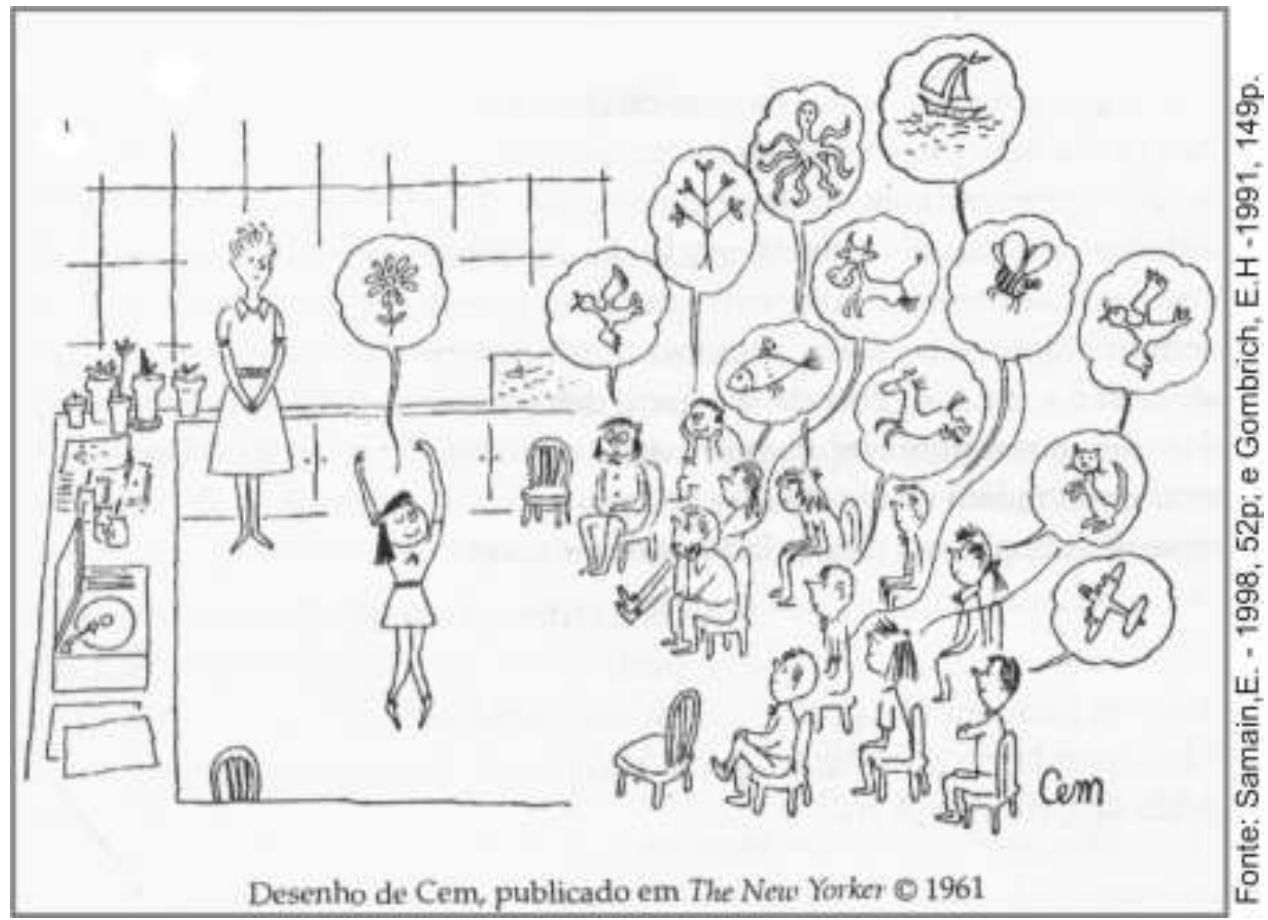

Nessas duas naturezas, a comunicação visual cumpre sua finalidade comunicativa, atingindo de maneira concreta o olhar aleatório e nem sempre atento do usuário, levando-o a reagir positivamente em relação à intenção original da mensagem concebida: compre o mapa, escolha esta destinação, entenda este conceito, preste atenção neste texto, use o produto desta maneira, etc.

Desse modo, os mapas turísticos, além de prestarem serviços de orientação e acessibilidade aos destinos turísticos, podem ir mais longe, auxiliando na projeção de imagens relacionadas à promoção turística. Segundo a Internationale Tourismus Börse (1987), os materiais ligados à comercialização do turismo estão preponderantemente relacionados a prospectos e catálogos, pôsteres, jornais, guias, livros de geografia regional e de viagens. Entre todos esses materiais, os prospectos e catálogos de mapas e para-mapas são os mais importantes. Estes últimos se dividem em produtos que vão desde esboços ("mapas" sem preocupação cartográfica), àqueles ligados à rede de transporte (rodovia, ferrovia, metrô) e à orientação com base topográfica (trekking e outros esportes de aventura), até aqueles mapas especiais relacionados a rotas (maratonas, ciclismo, cultural, vinhedos), cavernas, compras, etc.

Por fim, o artigo da Tourismus Börse (1987) discorre sobre os denominados mapas 
panorâmicos, em visão oblíqua ou pictórica, ou seja, mapas que fazem uso da imagem da localidade e são concebidos em perspectiva geral ${ }^{26}$, os quais informam fundamentalmente sobre as atividades e atrações da destinação. Esse tipo de mapa - que será desenvolvido nesta pesquisa - é mais bem concebido por artistas gráficos do que por cartógrafos, pois os últimos têm dificuldade em negligenciar a precisão em favor da atratividade. Todavia, o futuro da cartografia turística tenderá a um aumento cada vez maior na demanda do tipo de produto cartográfico (panorâmicos e com símbolos pictóricos), em detrimento daqueles com maior precisão e símbolos abstratos. Tal processo de diferenciação e especialização da cartografia vem ocorrendo devido à crescente diferenciação dos grupos de turistas e sua demanda por serviços especiais.

Assim, para se iniciar o processo de desenvolvimento dos mapas pictóricos turísticos, o primeiro estágio para o produtor é compreender, captar e levantar a grande variedade de imagens "oferecidas" pela destinação. Posteriormente, essas imagens são selecionadas e utilizadas em detrimento do objetivo do produto, estabelecido pelo empreendedor. Para isso, recorre-se à teoria push ${ }^{27}$ e pull ${ }^{28}$ trabalhada por Chon (1989) e Goossens (2000), os quais afirmam que a construção das imagens primárias resulta do contexto cultural na associação e preferência da destinação. Quando o indivíduo está motivado a viajar, vêm a sua mente imagens iniciais - mapas mentais - sobre a destinação pensada. Isso faz com que ele selecione certos destinos como possíveis escolhas. A motivação para viajar e o processo de construção das imagens primárias começa quando o indivíduo toma consciência de certas necessidades e percebe que tais destinações podem ter a capacidade para satisfazer suas necessidades (Chon, 1989).

Em seu estudo, Lubbe (1988) exemplifica que as imagens primárias são concebidas em diferentes perspectivas, contudo, foca-se na cultura. A autora apresenta e compara dois tipos distintos de visão: os sauditas (moradores locais da Arábia Saudita) e os visitantes (moradores não-nativos do país). Entre vários resultados de sua pesquisa, Lubbe apresenta diferenças significativas relacionadas à motivação e seleção do destino, pois estes dois públicos constroem suas imagens primárias baseadas em diferentes fatores push e pull. A principal diferença percebida pelos agentes de viagem sauditas é que os não-nativos (e particularmente os ocidentais) são um público mais aventureiro, desejam ver, experimentar novos lugares, com menor familiaridade. Em contrapartida, os sauditas são geralmente motivados a

${ }^{26}$ É um novo estilo cartográfico, que consiste em uma adaptação moderna do antigo estilo tridimensional. A visão oblíqua favorece uma rápida compreensão da geografia e suas várias "texturas" - grafismo da paisagem - (bairros, monumentos e edifícios significativos e de interesse) resultando em uma fácil localização (Guia T de Barcelona, 1992).

${ }^{27}$ Está relacionado aos serviços de lazer que geram sentimentos de prazer rápido, que emocionam e por fim, motivam. Qualidades díspares como excitação e relaxamento são imprescindíveis aos fatores push (Chon, 1989).

${ }^{28}$ Está relacionada aos fatores onde a familiaridade, a similaridade de cultura, de tradição ou da alimentação é maior (Chon, 1989). 
procurarem viagens experimentais em destinos onde se sintam confortáveis e onde a língua, cultura e comida também sejam familiares.

Deste modo, a campanha de divulgação da localidade turística deve ser idealizada de formas diferentes, respeitando as visões distintas dos públicos. No caso dos sauditas, que tendem a construir as imagens primárias baseadas em fatores familiares (pull), a estratégia da mensagem enfatiza aquelas atrações que relatam similaridades na cultura, tradição ou comida. Mas e quanto àqueles visitantes que estão à procura de emoções fortes e do prazer rápido (fatores push)?

Segundo Goossens (2000), o que conectaria dois perfis de turistas tão distintos é o conceito da emoção. Os consumidores, e em particular os turistas, são "empurrados" por suas necessidades (emocionais) e "puxados" (emocionalmente) pelos benefícios dos serviços de lazer. Portanto, as necessidades emocionais e de experimentação ${ }^{29}$ são relevantes na procura do prazer e no comportamento de escolha da destinação. Isto faz com que o lazer seja uma experiência positiva e subjetiva, acompanhada de satisfatórios e agradáveis humores, emoções e sentimentos.

Wolfgram (1994: 7) complementa que, para gerar uma resposta emocional, é preciso estimular os sentidos apropriados. Até porque,

o conteúdo intelectual é importante em uma troca de dados, mas a comunicação verdadeira requer uma troca emocional.(...) E quanto mais você conseguir atingir as emoções da sua platéia, mais eficaz será sua comunicação (Wolfgram, 1994: $\mathrm{XXI})$.

As emoções sinalizam um estado de necessidade que prepara certas tendências de ação no indivíduo. Em teoria, existem oito tipos de emoções essenciais a qualquer pessoa e cultura: alegria, aprovação, medo, surpresa, tristeza, irritação, aborrecimento e expectativa (Gnoth, Zins, Lengmueller \& Boshoff, 2000). Goossens (2000) assinala que a eficácia da "informação emocional" no estímulo promocional pode ser testada e mensurada em três dimensões (que compõem cada emoção):

$\checkmark$ O prazer - descreve sentimentos de felicidade, satisfação, contentamento, agrado.

$\checkmark$ O estímulo e/ou apreciação - representa sentimentos de excitação, animação/ alegria, inteligência/ vivacidade ou surpresa. A pessoa reage ao estímulo baseada em suas primeiras experiências emocionais e sociais. As imagens personalizadas são produtoras do estímulo e estão associadas ao uso do produto. A intensidade do afeto pode ser descrita pela diferença na intensidade das respostas emocionais dadas em níveis de estímulo do afeto.

\footnotetext{
${ }^{29}$ Os processos de experimentação, tais como a imaginação, devaneio, emoções e desejos possuem um importante papel no consumo hedonista (Goossens, 2000).
} 
$\checkmark$ A dominância - refere-se aos sentimentos de domínio, competência, poder e capacidade. Estudos sobre as emoções relacionadas ao consumo alertam que é preciso pensar na expressividade dos produtos, pois a partir do modo de escolha afetiva quanto mais expressivo o produto, maior será a probabilidade de causar estímulo e/ou apreciação do usuário (Mittal apud Goossens, 2000).

Goossens, 2000 complementa que os estímulos, mas também as informações, trazem fortes experiências emocionais e intenções de comportamento. Já as emoções vivenciadas pelos turistas na destinação referem-se às imagens multisensoriais, fantasias, emoções vivenciadas.

Tais emoções podem ser operacionalizadas por experiências subjetivas ${ }^{30}$, avaliação afetiva e relatos de sentimentos sobre os produtos de lazer e atrações turísticas. No entanto, a motivação traz intenções comportamentais em direção às atrações turísticas (Goossens, 2000).

Some-se ainda que as emoções do visitante são realmente obtidas durante o período de consumo, quando sinais afetivos na memória integram-se aos sinais de satisfação, gerando assim a possibilidade de julgamento, escolha (Gnoth, Zins, Lengmueller \& Boshoff, 2000).

Um modelo testado por Benkenstein, Yavas e Forberger (2003) considerou o contexto do zoológico de Rostock na Alemanha. O resultado proveniente da satisfação dos consumidores em relação aos serviços de lazer revelou fatores cognitivos ${ }^{31} \mathrm{e}$ afetivos ${ }^{32}$. Entretanto, os fatores afetivos tiveram um maior impacto se comparados aos cognitivos. Soma-se ainda, que as informações visuais e vivas ${ }^{33}$ de uma destinação quando vinculadas ao prazer fazem aumentar o envolvimento do consumidor e sua capacidade para perceber mais diferenças no fornecimento no

\footnotetext{
${ }^{30}$ A questão da grande subjetividade da imagem de uma destinação turística é resultado da existência dos diferentes tipos de públicos: residentes, vendedores, turistas, planejadores, etc., somada à intangibilidade do serviço turístico, que depende de uma visita e/ou gosto pessoal em relação a uma destinação. Portanto, são as percepções que motivam os consumidores a viajar (Gallarza, Saura \& Garcia, 2002).

${ }^{31}$ Referem-se às representações mentais, sendo um processo lento, onde ocorre o conhecimento que se tem de uma classe de objetos ou de fenômenos que possuem uma característica comum, apoiando-se no concreto. Por exemplo: para saber o que é um homem, nada melhor que vê-lo (fisicamente) ou por meio de uma foto/desenho, pois assim se perceberá que existem homens de tamanhos e cores diferentes, mas que não deixaram de ser homens, pois todos possuem características comuns; por exemplo, todos têm duas pernas e variáveis a cor dos olhos (Falcão, 1988).

${ }^{32}$ É freqüentemente descrito por sentimentos intensos, associado a um estímulo específico. Refere-se ao impulso, sentimentos e instintos (Goossens, 2000). Todos os indivíduos têm sentimentos, valores, atitudes, emoções, etc., em relação a estímulos ambientais. Por exemplo: um indivíduo sente-se bem ao ver seu quarto limpo, arrumado, porque ele aprendeu a gostar da limpeza: a sujeira para ele é vista de forma desprazerosa. Dessa forma, também pode se apresentar graus de afetividade em relação à democracia, ao gosto pelo estudo, a ideais de vida, ao tipo de destino das férias e assim por diante (Falcão, 1988).

${ }^{33}$ A informação pode ser descrita como viva quando atrai, mantém a atenção e excita a imaginação de forma emocionalmente interessante, concreta e desencadeadora de imagens. Está relacionada a uma aproximação das vias sensoriais, temporais ou espaciais (Goossens, 2000).
} 
serviço. Os autores complementam que a natureza dos componentes cognitivos e emocionais interage a partir de elementos:

$\checkmark$ Tangíveis - a satisfação do consumidor é baseada em fatores cognitivos, visuais, como, por exemplo, o meio físico, serviços (playground, restaurantes). O usuário toma consciência da comunicação recebida, que é concreta.

$\checkmark$ Intangíveis - a satisfação do consumidor é baseada em fatores emocionais. 0 usuário expressa seus interesses, desejos, gostos e preferências por conhecimentos adquiridos por meio da comunicação.

Arrowsmith \& Ntuwah (2002) acrescentam que banheiros, lugares de compras, quiosques, centros de informação, pistas para caminhada, terrenos para piquenique e camping são considerados infra-estrutura de apoio, fundamental às atrações turísticas. Mesmo não atuando como atração ao destino, pesam na decisão de uma futura visita.

Beni (1998: 39) complementa que os bens subjetivos, de difícil valoração ou imateriais não-apropriáveis, por exemplo, hoje o ar puro, o mar, as belezas naturais estão adquirindo altos valores econômicos. Isso acontece em contraposição aos conglomerados humanos sempre crescentes, ao estresse, etc., buscando assim, um estilo de vida natural. $\mathrm{O}$ autor divide os bens turísticos em:

$\checkmark$ Materiais - monumentos, museus, galerias de arte, praias e outros; e Imateriais - clima, paisagem e outros;

$\checkmark$ Imóveis - terrenos, casas, hotéis, museus, galerias e outros; e Móveis produtos gastronômicos, artísticos e artesanais;

$\checkmark$ Duráveis - artesanais, e Perecíveis - produtos gastronômicos;

$\checkmark$ De consumo - bens que satisfaçam diretamente as necessidades dos turistas; e De capital - os que são utilizados para a produção dos bens;

$\checkmark$ Básicos, complementares e interdependentes;

$\checkmark$ Naturais ou artificiais.

Já os serviços turísticos, voltados à satisfação das motivações, necessidades e preferências do turista classificam-se em (Beni: 1998: 40):

$\checkmark$ Receptivos - ligados às atividades hoteleiras e extra-hoteleiras,

$\checkmark$ De alimentação;

$\checkmark$ De transporte - da residência à destinação turística e no próprio centro receptor;

$\checkmark$ Públicos - administração turística, postos de informação, funcionários de 
restaurantes, parques, etc;

$\checkmark$ De recreação e entretenimento na área receptora.

Sirgy \& Su (2000) ressaltam, pela longa tradição em pesquisas com consumidores, que as idéias que os turistas têm sobre uma destinação são usadas como uma forma de referência cognitiva na avaliação da memória dos símbolos da localidade. Essas lembranças dos produtos simbólicos referem-se a imagens estereotipadas ${ }^{34}$ - não controláveis pelos planejadores do turismo - dos usuários sobre o destino turístico, como por exemplo: está na moda, é excitante, é moderno, é novo, é ultrapassado, etc.

Os turistas ainda podem avaliar as destinações baseadas em atributos funcionais ou utilitários, denominados de símbolos controláveis pelos administradores do turismo, relacionados aos aspectos estéticos da destinação (produto), preço da viagem (preço), localização (acessibilidade) e à promoção do destino (propaganda) (Sirgy \& Su, 2000). Contudo, as imagens da destinação turística são um fator decisivo na escolha da viagem pelo turista. A atratividade de um destino é baseada no potencial das motivações e necessidades compostas por várias atrações e seus atributos ${ }^{35}$ característicos, responsáveis pela impressão da localidade pelo turista. Um indivíduo motivado a viajar, inicialmente seleciona certas destinações como possíveis escolhas.

O modelo conceitual estruturado na figura 38 expõe as preocupações prévias do grupo-alvo a uma política mercadológica fundamentada na motivação do turista em viajar, tendo como apoio um material de informação promocional. Neste contexto, evidenciam-se respostas quanto a imagens mentais e emocionais dos turistas.

Mackay \& Fesenmaier (1997), Lubbe (1998) e Gallarza, Saura \& Garcia (2002) balizam ainda a imagem da localidade em três níveis de variáveis:

$\checkmark$ Orgânica - é formada por meio das percepções do indivíduo. A mensuração se dá baseada no que se aprende de uma localidade a partir da primeira idade.

$\checkmark$ Induzida - é resultado de uma promoção da localidade como um destino turístico.

$\checkmark$ Complexa - quando o turista tem uma experiência direta com a destinação.

Portanto, a oferta da localidade e seus respectivos atributos apresentam diferenças relacionadas ao significado, ao número e a importância dos elementos que compõem a localidade. Assim, a promoção do local poderá ser percebida a partir de um trabalho de destaque ou exclusão de certos elementos a ela vinculados (Mackay \& Fesenmaier, 1997). Brown, Emmer \& Worm (2001) complementam que a viagem de

\footnotetext{
${ }^{34}$ Apresenta duas formas positivas de aproveitamento: atua como atrativo turístico e revaloriza a cultura local (Norrild, 2001).

${ }^{35}$ Refere-se a atratividade vem da complexidade do espaço, como por exemplo: suavidade, excitação, conhecido/desconhecido e natural/antropomorfizado, etc. (Mackay \& Fesenmaier, 2000).
} 
férias é planejada com base nas informações disponíveis da localidade turística. Logo, quanto mais direcionada for a informação aos clientes potenciais, melhores serão os resultados da divulgação.

Figura 38 - Motivações para se viajar: fatores "push e pull"

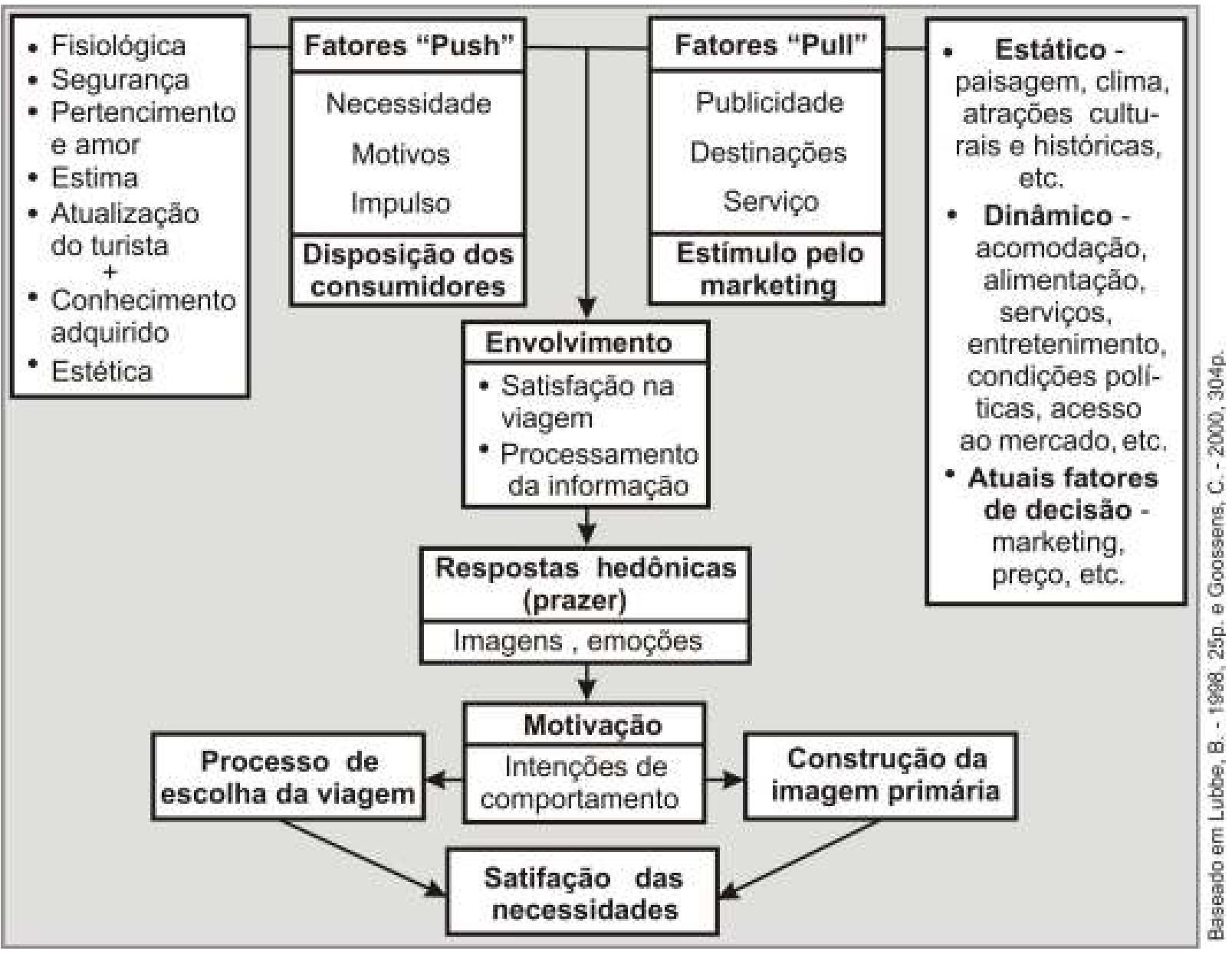

Por isso, o emissor da mensagem (no caso, o cartógrafo), deve estar muito consciente da imagem que quer comunicar e quais serão os receptores da imagem. Até porque ele funciona como um "porta-voz", por transmitir características culturais pertencentes a um grupo social (Norrild, 2001).

Goossens (2000) sugere que sejam dadas instruções claras quanto ao contexto que fará uso da imaginação. Considerando o processamento das informações turísticas e as necessidades relacionadas à visão de consumo, propõem-se duas situações distintas:

$\checkmark$ Imagens não-representativas - são formas de representação na qual o consumidor é envolvido em um baixo nível emocional. 
$\checkmark$ Imagens representativas - são formas de representação na qual o consumidor é altamente envolvido com a informação turística. É uma força que motiva o cognitivo-afetivo, mediando o comportamento do consumidor. Intensifica as respostas emocionais, de apreciação e intenções de comportamento dos consumidores, sendo interessante para os profissionais de marketing investigar quais fatores estimulam e desencadeiam as imagens mentais. Portanto, pode-se fornecer tanto materiais promocionais com um variado leque de propagandas (estímulos de informação: como slides, scripts, figuras, vídeos) quanto os atributos da destinação e seus serviços, trabalhando com as informações de respostas relacionadas às visões dos consumidores, imagens mentais, sentimentos, humores, experiências emocionais.

A partir do que foi exposto até aqui, passa-se a outra questão: como transformar as imagens percebidas na realidade em representações gráficas pictóricas eficazes. Carneiro (2001: 26; 29) afirma que pelos canais de percepção - os cinco sentidos básicos (visão, audição, tato, olfato e paladar) - o ser humano pode decodificar uma idéia e, a seguir, codificá-la novamente em uma nova estrutura - mensagem transmitindo finalmente a um receptor que a perceberá por meio de seus sentidos. $\mathrm{O}$ sucesso quanto à compreensão da mensagem virá desde que o repertório ${ }^{36}$ seja conhecido. A autora ressalta ainda, que grande desafio da comunicação é que...

... o emissor deverá produzir mensagens que possuam um repertório rico e conhecido o bastante para, em consonância com o meio apropriado, alcançar o maior número de receptores e o máximo de modificações (incluindo aquelas de comportamento).

Segundo Cabanellas (1976: 60), o processo perceptivo é dinâmico e arraigado ao comportamento humano, ou seja, desde que nasce e durante toda a sua vida, a pessoa recebe estímulos dos mais variados e, pela inteligência, concentra sua atenção, tem expectativas, relaciona emoções e impulsos ao que a rodeia. A percepção sofre ainda, a influência direta de fatores individuais tais como a aprendizagem, a experiência, a motivação e emoção. Esse processo ocorre graças à ação combinada de três unidades funcionais do cérebro (Cabanellas, 1976), onde é necessário que o "perceptor":

$\checkmark$ Esteja exposto e disposto (é vital) a perceber a informação;

$\checkmark$ Realize uma análise e uma síntese da informação, sendo esse um processo inteligente no qual detecta, discrimina e ordena os estímulos;

\footnotetext{
${ }^{36}$ São coleções, compilações de itens de mesma natureza que, reunidos, conformam um conjunto (Carneiro, 2001:8). Pode-se entender como um conjunto ou estoque de símbolos conhecidos (uma espécie de vocabulário) utilizados por um ou mais indivíduos. (...) Quanto mais rico for o repertório da mensagem e o número de seus elementos, maior será o seu alcance, ainda que não existam repertórios de extensões idênticas, em virtude das diferentes experiências pessoais (Carneiro, 2001: 26-27).
} 
$\checkmark$ Controle seus movimentos oculares de busca. Isso faz com que o exercício da percepção ocorra de um modo ativo, pois os olhos realizam uma espécie de varredura visual. Explicando melhor, o observador sem que se dê conta, em um lance de visão pode registrar, passear por algo que está percebendo e, nesse acontecido, pára e recolhe os elementos que o são importantes.

Em qualquer uma das três unidades funcionais do cérebro, o observador sempre tem uma intenção em sua maneira de perceber, pois vê o que o interessa, o assombra, Ihe agrada. O passo seguinte é identificar, acomodar e até - quem sabe - modificar tais percepções condicionadas pelas experiências anteriores. Neste momento se faz presente a importância da intervenção da inteligência, do estabelecimento de juízos, de comparações, que vão situando com maior objetividade o que é percebido.

Já Cressy e Laudadio (apud Beni: 1998: 220-221) identificam na percepção três características distintas, que consideram o interesse pela localidade ou serviço turístico:

$\checkmark$ Subjetividade - o observador vê o que se quer e ouve o que se deseja ouvir. Cada um dos segmentos da população é atraído por diferentes motivos, que são os que o impulsionam ao ato de compra.

$\checkmark$ Seletividade - o observador seleciona o que considera interessante e relevante. O objeto não será percebido se não corresponder a uma motivação profunda. Os estímulos podem ser muitos, porém a percepção realiza o papel de filtro com relação à amplitude de informações recebidas. É importante ressaltar que as pessoas - mesmo aquelas mais sensíveis à publicidade de viagens - apreendem um número limitado de idéias de uma só vez; logo, estímulos demasiados podem causar confusão e o processo de decisão de compra será mais difícil para o consumidor.

$\checkmark$ Ponderação - o observador, depois de passar pelo processo de seleção, faz uma reavaliação do valor dos elementos que por ele foram escolhidos, sempre em função da sua personalidade. $O$ conceito se enriquece de elementos já existentes na memória, atitudes e juízos do indivíduo-turista, assim como opiniões e recordações de outras pessoas. O objeto ganha então uma estrutura e um peso muito distintos do que realmente apresenta.

Numerosos estudos empíricos confirmam que a percepção tem papel fundamental no processo de criação das imagens que os indivíduos atribuem às destinações turísticas. Os principais modelos estatísticos, que avaliam o comportamento deste tipo de consumidor, relacionam a percepção como um dos fatores condicionantes de decisão na escolha do destino pelo visitante (Valdes, 1997).

Tuan (1980: 71) aponta vários estudos realizados acerca das diferenças de percepção diante dos valores ambientais. $O$ autor exemplifica que, em seu cotidiano, cada membro de uma família ocidental possui diferentes mapas mentais. Isto ocorre 
devido aos distintos e triviais caminhos de circulação de seus membros: percurso da escola, das compras, da empresa, do mercado. Ou mesmo por preferências, isto é, mesmo quando saem juntos às compras: o homem, a mulher, a criança, o adolescente, vão querer olhar lojas, locais e ter experiências diferentes. Eles poderão ir até de braço dado, porém não vão ver, escutar as mesmas coisas.

Pensando para a elaboração de um mapa temático para o turismo, cite-se Jackson, White \& Gronn (apud Arrowsmith \& Ntuwah, 2002) que, com base em questionários e outros fatores de análise sobre o comportamento e preferências dos turistas pontuam quatro perfis de personalidades:

$\checkmark$ O explorador: faz seu próprio horário e tempo. Adquire conhecimento pelo anfitrião. Não é organizado nem direcionado. Procura destinações remotas, isoladas, enriquecendo seu próprio conhecimento. Entusiasmado, procura desafios. Reservado e silencioso em grupos, evita multidão.

$\checkmark$ O aventureiro: viaja com amigos e não com turistas, desconhecidos, porém faz amizade com novas pessoas. Viagem não-organizada; valoriza atividades opcionais. Não é disciplinado, organizado. Evita aborrecimento e tédio pela parada em muitos lugares. Explora diferentes culturas, busca atividades estimulantes, tem senso de liberdade.

$\checkmark$ O orientado: sentido de isolamento. Viaja somente com a esposa ou amigos íntimos. Tudo é organizado para evitar preocupações, mal-entendidos ou gastos em demasia. Visita novamente as destinações favoritas. Foge dos problemas da vida procurando descontração e relaxamento. Gosta de luxo, e prefere a família aos estranhos.

$\checkmark$ O agrupador: viaja em grupo de amigos ou se junta a outros turistas em pacotes de viagem. Reúne-se com turistas e anfitriões, tanto homens como mulheres. Vai a destinações de sol, praia e vida noturna, onde estão outros turistas. Participa de muitas atividades, incluindo esportes e parques temáticos. Vai onde existam muitas pessoas e ação.

E é exatamente a estas nuances que o produtor-cartógrafo deve estar atento. Um bom mapa turístico deve perceber e captar (por vários trabalhos de campo e gabinete) imagens emotivas, interessantes, prazerosas e, por fim, motivadoras, ao maior número de pessoas, para depois representá-las no mapa.

Outro ponto observado diz respeito às atitudes e reações, inclusive estéticas, que se tem com relação ao meio ambiente estabelecido em um tempo e espaço. Tuan (1980: 81-85) aborda as mudanças de atitude em relação às montanhas. Na Antiguidade, eram vistas com aversão e terror pelos gregos, ou mistério e divindade pelos chineses. No século XVIII, por se tornarem acessíveis, perdem muito de sua 
aparência proibida e de medo, mistério. Posteriormente, os teóricos e médicos constataram que $o$ ar leve da montanha era bom para saúde e recuperação de doentes. Tem-se aí o primeiro mote utilizado pelo setor hoteleiro. Sanatórios, hotéis e infra-estrutura turística foram levados até as montanhas e obtiveram um êxito tão grande que, para os muito ricos, a Suíça era uma casa de repouso e um campo de esporte. Como resultado, a imagem em relação às montanhas em meados do século XIX é completamente inversa à de outros tempos.

Sendo assim, a partir do tripé: valores ambientais, condicionamento da percepção e principalmente da cultura, apresenta-se outro exemplo constituído pelo ambiente praia. Antigamente, as praias não eram valorizadas como hoje em dia. Muitas vezes os terrenos próximos ao mar tinham pouco interesse, valor. Até porque, nas sociedades ocidentais, o padrão de beleza era a pele clara, não-bronzeada, com corpos devidamente cobertos. Contudo hoje, em grande parte das culturas, a imagem associada à praia mudou radicalmente: corpos bronzeados estão relacionados à saúde, vigor, e as praias são um dos destinos mais procurados por turistas. Faça-se aqui uma ressalva a vários países do Oriente Médio e Extremo Oriente, onde a praia ainda continua a ser desvalorizada por seus nativos.

Um último tópico destacado por Tuan (1980: 236) refere-se a imagem que promove favoravelmente um destino, mas que pouco respeita a complexidade, a verdade local, deixando clara a preocupação de grupos que desejam chamar a atenção do público externo a localidade - para uma característica particular dela. Isso pode ocorrer a partir de um epíteto ou frase atraente, como: a Cidade luz (Paris), a Capital da vela (llhabela), Cidade maravilhosa (Rio de Janeiro), etc. Ou por uma cena ou fotografia de uma vista panorâmica de Nova Iorque, São Paulo, Ouro Preto, Brasília, e assim por diante. Entretanto, é bom ressaltar que essa imagem, para ser eficaz, deve estar fundamentada em alguns fatos. $O$ autor frisa que cidades dos Estados Unidos - 0 mesmo pensamento pode ser aplicado às cidades brasileiras - carecem de uma identidade visual, existindo, porém, algumas exceções. No entanto, mesmo as cidades menores vendem cartões postais, que valorizam aspectos de suas localidades, aceitos por favorecê-la, divulgando seus monumentos, parques, ruas principais, proporcionando um direciona-mento quanto ao imaginário local.

A figura 39 apresenta uma atividade aplicada a alunos, mas principalmente professores na oficina de cartografia oferecida pelo Projeto Caminhos do Futuro ${ }^{37}$. Recebem-se duas folhas: uma com o mapa da América do Sul e a outra com várias figuras que devem ser recortadas e coladas no mapa. O exemplo demonstra que uma "simples" imagem - uma representação icônica - é associada e incorporada a um espaço, possibilitando vários níveis perceptivos.

${ }^{37}$ Detalhes sobre o Projeto Caminhos do Futuro nas páginas 16 - 17. 
Figura 39 - Atividade da oficina do Projeto "Caminhos do Futuro":

o espaço e sua imagem
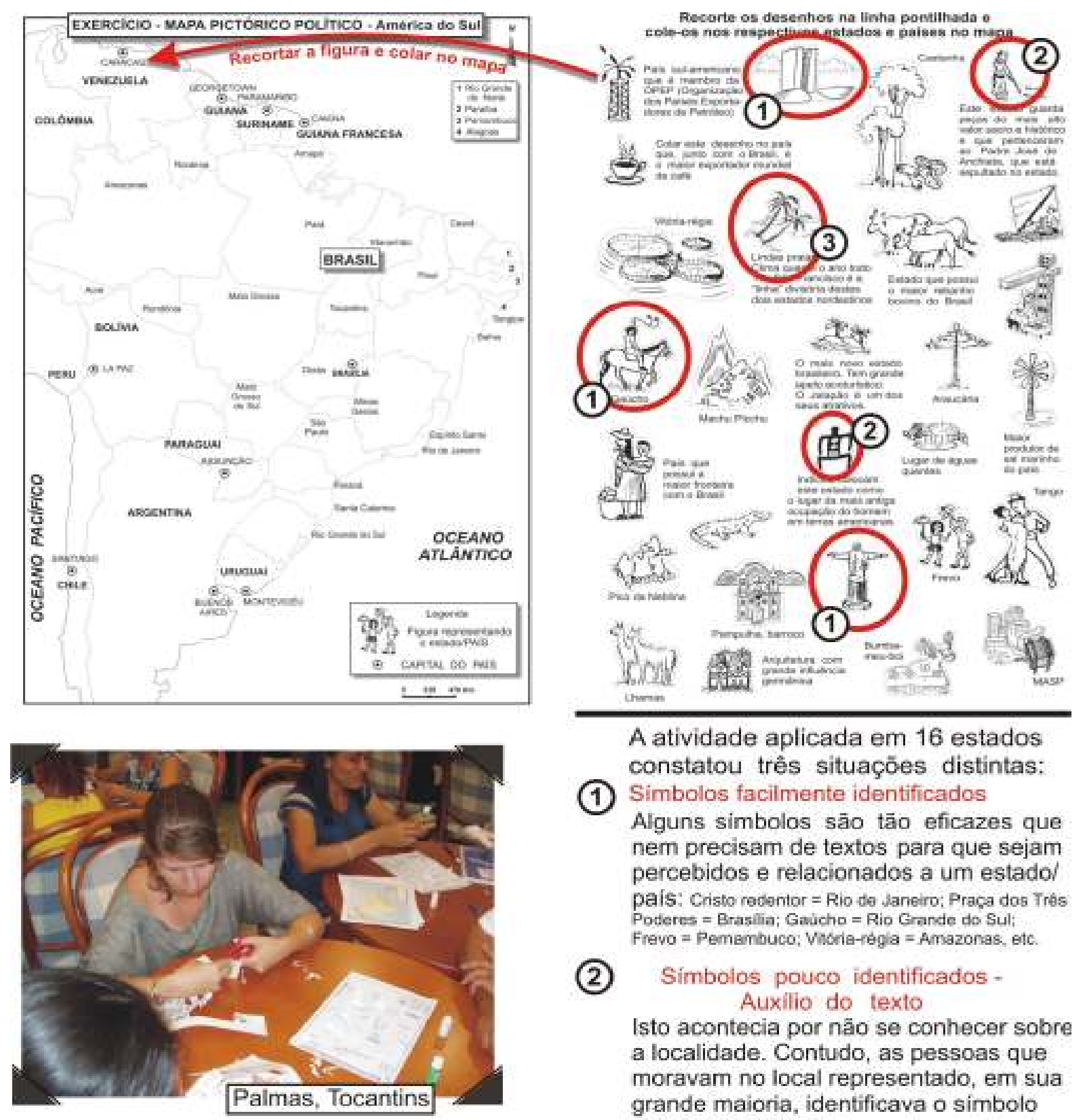

A atividade aplicada em 16 estados constatou três situações distintas:

(1) Simbolos facilmente identificados Alguns simbolos sāo tāo eficazes que nem precisam de textos para que sejam percebidos e relacionados a um estado/ país: Cristo redentor $=$ Rio de janeiro: Praca dos Tres Poderes = Brasflia; Gaùcho = Rio Grande do Sul; Frevo $=$ Pemambuco: Vhorie-régia = Amazonas, etc

Simbolos pouco identificados Auxilio do texto

Isto acontecia por não se conhecer sobre a localidade. Contudo, as pessoas que moravam no local representado, em sua grande maioria, identificava o simbolo "desconhecido": Pintura rupestre - estado onde esta a ocupacao mais antiga do homem em terras. americanas = Piaul; Padre Anchieta - estado onde esta seu tùmulo $=$ Esplitito Sinto.

(3) Estados questionam o porquê de nåo terem um simbolo expressivo

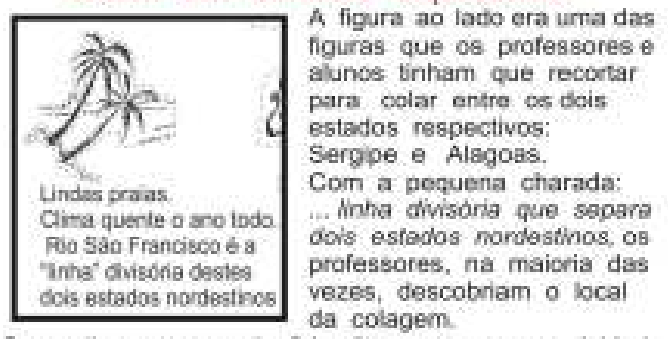

O questionamento maior foi aplicar esta mesma atividade nos estados representados com a figura - Sergipe e Alagoas. A discussão de um simbolo que melhor representasse seus estados era fervorosamente discutida 
Deste modo, o meio ambiente pode não ser a causa direta da topofilia ${ }^{38}$, mas fornece estímulo sensorial que, ao agir como imagem percebida, dá forma às nossas alegrias e ideais (Tuan, 1980: 129). O autor prossegue afirmando que os estímulos sensoriais são potencialmente infinitos, por existirem valores subjetivos, individuais àquilo que a pessoa decide prestar atenção, valorizar. A época histórica e as respectivas forças culturais têm papel preponderante nessas escolhas.

Os mapas turísticos pictóricos trabalham exatamente o papel da paisagem como doadora de imagens topofilíticas, isto é, o coletor, produtor dessas imagens faz uso daqueles aspectos do meio ambiente que lhe inspiram respeito ou the prometem sustento e satisfação no contexto das finalidades pretendidas. Tuan (1980: 137) ratifica que essas imagens mudam à medida que as pessoas adquirem novos interesses e poder, porém continuam a surgir do meio ambiente.

Posto isso, Souza (1992: 97) divide a imagem em dois tipos básicos:

$\checkmark$ As que procedem do mundo natural, visível;

$\checkmark$ As geradas artificialmente pelas atividades de design - são como produtos culturais destinadas fundamentalmente à comunicação visual, povoando o mundo artificial da chamada iconosfera. Essas imagens abrangem desde os objetos dispostos no cotidiano (edifícios, roupas, ferramentas), até as imagens pictográficas, ideográficas, icônicas e sinaléticas.

Souza (1992:97-98) ainda esclarece que as imagens feitas pela humanidade são uma elaboração gráfica, cultural e povoam um mundo artificial denominado iconosfera, sendo produto do design gráfico. As imagens são todas aquelas desenhadas para serem apresentadas em formato digital ou impressas e capazes de serem decodificadas pelo maior número de pessoas. Quanto às técnicas de produção, podem ser feitas à mão - desenho, pintura, grafite - ou podem ser resultado de procedimentos mais complexos pertencentes ao domínio da tecnografia - fotografia, computação gráfica. As imagens ainda podem ser:

$\checkmark$ Físicas: são bidimensionais e tridimensionais (a dimensão tátil se associa de alguma maneira à dimensão óptica);

$\checkmark$ Temporais: são fixas (desenho, fotografia), seqüenciais (histórias em quadrinhos) e móveis (televisão, cinema, vídeo, animação).

\footnotetext{
${ }^{38}$ Associa sentimento ao lugar. Inclui todos os laços afetivos e emocionais que os seres humanos têm com o meio ambiente. Os laços diferem profundamente em intensidade, sutileza e modo de expressão, ou seja, pode-se olhar para o meio ambiente de forma estética, variando desde o prazer efêmero de uma vista até a sensação de beleza, igualmente fugaz, mas com maior intensidade, até uma resposta tátil-contato físico: o deleite do sentir a ar, a água, a terra. Já mais difícil é expressar os sentimentos que se nutre pelo lugar, lar, o locus de reminiscências (passado que evoca orgulho) e o meio de ganhar a vida. Contudo, quando o lugar ou o meio ambiente é irresistível, eles se tornam veículos de acontecimentos emocionalmente fortes ou são percebidos como símbolos (Tuan, 1980: 107).
} 
A preocupação com a subjetividade relacionada à expressão artística das imagens gráficas utilizadas nos mapas, mesmo os altamente pictóricos, deve ser constante. Como alerta Souza (1992: 98), a imagem, ao assumir uma função social, procura comunicar mensagens objetivas voltadas à sociedade e público aos quais se destina.

Conseqüentemente, o estabelecimento de conjuntos simbólicos a partir das imagens expressa uma retórica na qual os símbolos mais fortes de uma cultura são adotados em um discurso icônico que os naturaliza. Daí as imagens se prestarem tão bem ao uso político e à persuasão mercadológica, sendo empregadas com tanta facilidade $e$ sucesso a serviço das ideologias e da propaganda (Barthes, 1989).

Por fim, focaliza-se o processo de representação gráfica das imagens percebidas. Segundo Salvia Coelho (1993: 45), o ato de representar ocorre porque as imagens mentais e os signos em geral ativam processos psicológicos complexos - e já expostos aqui - como a percepção, a memória, a emoção, o imaginário, julgamentos de valor e de realidade, constituindo-se temas de pesquisas na área da cognição. No trabalho com mapas pictóricos voltados ao setor turístico, o pesquisador-cartógrafo faz uso direto de conceitos relativos ao símbolo, ao sinal, à imagem, aos esquemas mentais, aos protótipos - e suas respectivas representações proposicionais - sempre fundamentado no saber organizado.

O próximo passo então é a apropriação e escolha dessas imagens para que se inicie o estágio da codificação direcionada à mensagem gráfica. Brill (1988: 35) parte do princípio de que o homem é um ser racional, o que o torna capaz de simbolizar sua própria experiência vivida. Essa função simbólica possibilita captar a sua vivência, expressando-a, podendo memorizá-la para si mesmo ou transmiti-la a outras pessoas. $O$ ato de comunicação entre os homens está na base da função simbólica, possibilitando trocas de idéias entre indivíduos do mesmo grupo social, por meio dos códigos encontrados, por exemplo, na linguagem falada, escrita e nas artes (como o desenho). Tal recurso da comunicação codificável faz com que os grupos possam constituir-se em sociedades, estabelecendo funções que caibam a cada indivíduo, e regras que regem a comunidade. Pelo processo de ação dos códigos, regras e costumes, há uma cristalização de formas relativamente permanentes, o que determina o aparecimento da tradição.

Souza (1992: 221) ratifica que, quando o designer passa pelo processo de escolha dos traços visíveis do objeto (enfatizando-os ou excluindo-os propositalmente), ele exprime um saber não apenas pessoal, mas também social. Isso ocorre porque traz consigo um jeito convencional de observação da realidade, profundamente governada pela intenção comunicativa que deseja transmitir pelo desenho. Portanto, a imagem funcional mostra não somente a maneira como o designer vê o mundo: vai além, mostrando de que maneira ele traduz o modo de a sociedade ver o mundo.

A estrutura do mapa turístico calcado na pictografia trabalha com sentimentos, conhecimentos, experimentações, convenções que uma pessoa adquire ao longo de 
sua vida. E é a partir daí que as formas gráficas são percebidas, cabendo, então, ao cartógrafo trabalhar incansavelmente com o poder denotativo e conotativo das representações.

Para isso, ele tem o dever de dominar o uso das linhas, formas (seus limites e texturas), cores, da luz, volumes e perspectivas, possibilitando várias sensações visuais e emocionais ao espectador. Cabanellas (1976: 17) complementa que esses elementos plásticos básicos se desenvolvem sobre uma superfície, sendo dispostos em uma determinada ordem, de modo que, paralelamente ao ato compositivo ${ }^{39}$, cria um espaço plástico - que é a obra propriamente dita.

Assim, a geração e a estruturação de práticas e de representações podem ser objetivamente reguladas e regulares, porém não deixam de ser um processo contínuo de transformação onde são criadas naturalmente condições de atualização do habitus $^{40}$, que deve ser encarado como:

um sistema de disposições duráveis e transferíveis que, integrando todas as experiências passadas, funciona a cada momento como uma matriz de percepções, apreciações e ações, e torna possível a realização de tarefas infinitamente diferenciadas, graças às transferências analógicas de esquemas (Bourdieu, 1974: XL e XLI).

O habitus confere à prática social um espaço de liberdade, configurando-se como um princípio gerador que impõe, ao mesmo tempo, um esquema durável, reproduzindo regularidades inscritas em condições objetivas e estruturais; mas também flexível, permitindo ajustamentos e inovações às exigências postas pelas situações concretas que põem à prova sua eficácia (Bourdieu, 1974: XLI).

De acordo com Bourdieu (1974: 293), uma obra contemporânea - que pode ser o mapa turístico - é assimilada a partir da relação que os produtores mantêm com uma determinada época e sociedade, gerando, assim, códigos. Esse contexto é fruto da relação que o produtor do mapa possui com o restante da sociedade e, em particular, com as demais células das classes dominantes, ou seja, os consumidores, com seus gostos e suas demandas.

\footnotetext{
${ }^{39}$ Com base em Cabanellas (1976: 45), pode-se dizer que a composição do mapa pictórico é uma disposição ordenada dos elementos plásticos - visuais - tendo como referência o espaço. Dada uma composição, as formas são subordinadas a um esquema, situadas umas ao lado das outras em ordem mais ou menos complexas. Portanto, ao olhar para as várias ilustrações em um mapa pictórico, o observador agrupa mentalmente as formas, selecionando-as em ordem de modo que sua visão possa percorrê-las com facilidade. Ás vezes, os elementos são agrupados por similaridade de direção, forma, semelhança de cor, textura, etc.

${ }^{40}$ É um conjunto de esquemas implantados desde a primeira educação familiar, sendo continuamente repostos e reatualizados ao longo da vida social do indivíduo (Bourdieu, 1974: XLII). Toda ação histórica e/ou social reflete $(\mathrm{m})$ dois estados: o objetivado, que é a história acumulada ao longo do tempo nos objetos, nas máquinas, edifícios, monumentos, livros, teorias, costumes, direito, etc., e o incorporado: podendo se tornar um habitus, que constitui a matriz que dá conta de uma série de estruturações e reestruturações pelas quais passam as diversas modalidades de experiências diacronicamente (evolução de fatos no tempo) determinadas pelos agentes (Bourdieu, 2000: 83).
} 
Tendo como princípio que se vive num mundo socialmente construído, os principais elementos relacionados à produção e ao consumo dos mapas são a identidade - dos produtores dos mapas e usuários - e as percepções relacionadas tanto ao ato de desenvolvimento quanto à utilização desse tipo de material cartográfico. Esses itens podem esclarecer não somente os motivos encontrados por trás dos eventos cartográficos, mas também o quanto o mapa pode ser eficaz em comunicar a informação (Harley, 1994: 281).

O desafio maior é representar as "informações culturais" de uma maneira genérica, utilizando-se do senso comum para criar ilustrações simples, diretas. Busca-se um direcionamento da atmosfera subjetiva do turista quando vê o mapa (paisagem representada). Para isso, o produtor particulariza, articula ilustrações de forma a tornar as representações gráficas acessíveis à compreensão, procurando diminuir, o grau de polissemia.

É fato que a elaboração do mapa turístico, ao utilizar grandemente da pictografia, jamais estará pautado sobre as bases monossêmicas de Bertin (1967, 1983, 1988 1996), pois os ícones e os símbolos vêem carregados de emoções e percepções. Tudo acontece de maneira premeditada, pois é oferecido outro tipo de produto - o mapa pictórico, menos árido visualmente; que não objetiva somente uma linguagem normatizada - com propósito definido - o turismo - e um usuário leigo, ávido por conhecer outras culturas, ser seduzido que busca mais do que um mapa convencional.

A figura 40 apresenta representações da paisagem divididas em dois aspectos de atrativos: materiais e imateriais. Note-se os poucos, enfáticos e diretos traços gráficos, muitas vezes acompanhados de um texto para situar e referenciar melhor o usuário.

Para entender melhor o que seriam estes aspectos materiais e imateriais, introduz-se o conceito de patrimônio, estabelecido pela UNESCO (2007): é o legado que recebemos do passado, vivemos no presente e transmitimos às futuras gerações. Nosso patrimônio cultural e natural é fonte insubstituível de vida e inspiração, nossa pedra de toque, nosso ponto de referência, nossa identidade.

Canclini (2003: 160) reitera e complementa o conceito de patrimônio informando que é um conjunto de bens e práticas tradicionais que identificam uma nação, um povo, sendo recebido do passado com um dado prestígio, que não cabe aqui discuti-lo.

Assim, procuram-se possíveis operações de sua preservação, restauração e difusão, por ser a base mais discreta da simulação social. A perenidade desses bens pirâmides, palácios, monumentos - leva a imaginar que seu valor é inquestionável e os torna fontes de consenso coletivo, estando além das divisões entre classes, etnias e grupos que formam uma sociedade. A UNESCO (2007) divide o patrimônio em três aspectos: 
Figura 40 - Representações materiais e imateriais da paisagem
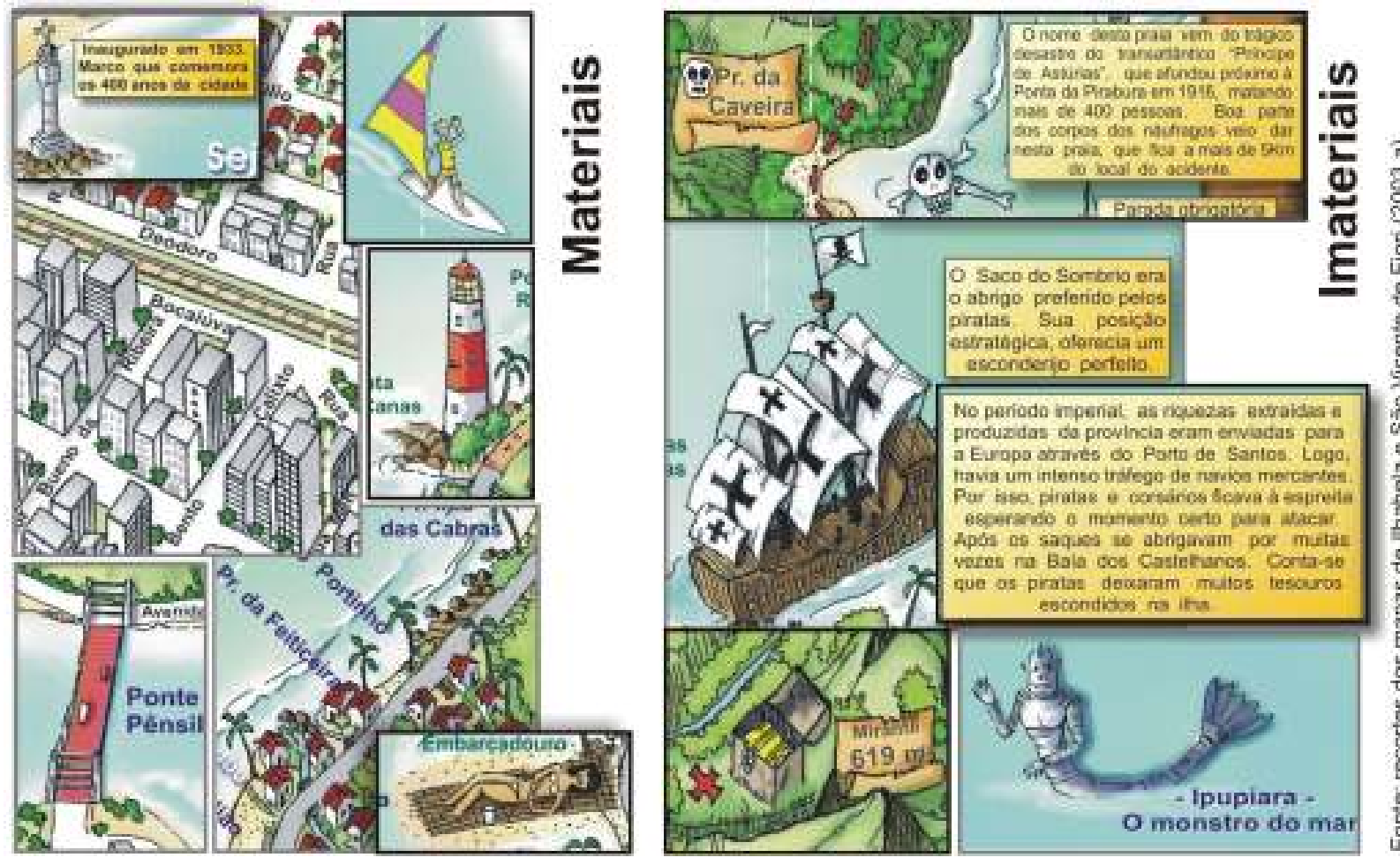

\section{$\checkmark$ Natural}

São áreas que apresentam um valor excepcional no que tange à diversidade biológica e à paisagem. Nesses ambientes, procura-se o respeito à diversidade cultural e as populações tradicionais merecem atenção especial. Os Sítios do Patrimônio Mundial Natural geram, além de benefícios à natureza, uma importante fonte de renda oriunda do desenvolvimento do ecoturismo.

\section{$\checkmark$ Cultural}

É de fundamental importância à memória e à identidade, que é perpetuada por aspectos físicos da criatividade e da riqueza cultural dos diferentes povos. Estes legados são monumentos, grupos de edifícios ou sítios que tenham valor: histórico, estético, arqueológico, científico, etnológico ou antropológico.

\section{$\checkmark$ Imaterial}

Além das manifestações culturais materiais, perpetuadas a partir dos monumentos, sítios históricos e paisagens culturais, existe também o patrimônio imaterial. Este se estabelece por tradições (também orais), folclore, saberes, línguas, festas e em diversos outros aspectos e manifestações, recriados coletivamente e modificados ao longo do tempo. A essa porção intangível da herança cultural dos povos. Num mundo de crescentes interações globais, a revitalização de culturas tradicionais e populares assegura a sobrevivência da diversidade de culturas dentro de cada comunidade, contribuindo para o alcance de um mundo plural. 
Lima (2002: 14) esclarece que, no contexto do turismo internacional, os ambientes naturais, de grande beleza cênica e relativamente bem preservados se valorizam cada vez mais. Este importante setor mercadológico atrai, entre outros, visitantes cada vez mais sensibilizados pelas questões ambientais. Em contrapartida, a gestão de áreas protegidas busca estratégias que aliem a conservação dos ecossistemas, dos recursos naturais e da biodiversidade; às necessidades das populações locais, ampliando as atividades estritamente protecionistas àquelas voltadas ao desenvolvimento, integrando-as à realidade local e regional. Isso faz com que haja um enorme movimento em viabilizar o ecoturismo. Furlan $(2000,187)$ refere-se a uma divulgação do IBAMA de 1998, relativa à abertura de licitação para que empresas privadas explorem o ecoturismo nas Unidades de Conservação (UC) ${ }^{41}$ federais, como, por exemplo, agências de turismo e ONGs, que trabalham com grupos de visitantes de hotéis, escolas, empresas, entre outros.

Em alguns países, a atividade do ecoturismo desenvolvido em unidades de conservação é de grande importância. Veja-se o caso dos Estados Unidos: o Sistema Nacional de Parques é composto de 376 áreas protegidas, recebendo por ano mais de 270 milhões de visitantes, gerando uma receita de 10 bilhões de dólares e 200 mil empregos (IUCN apud Lima, 2002: 97).

A natureza e sua respectiva fauna, flora, ecossistema e paisagem - esta última sendo a principal variável como ponto de confluência entre os fatores ambientais e antrópicos - são atrativos por excelência do ecoturismo, que tem maior importância quanto mais elevado for o seu grau de intocabilidade e de aspectos singulares e únicos. Portanto, o ecoturismo prioriza a preservação do espaço natural onde é realizado, e seu projeto contempla a conservação diante de qualquer outra atividade. Por sua vez, a população autóctone, sua cultura e seu modo de vida estreitamente apegados à natureza que lhes serve de meio de vida e de entorno é o foco de uma abordagem ecoturística que valoriza a autenticidade e a dignidade dessas populações e sua cultura. Além disso, essa população local participa dos serviços prestados aos turistas (Pires, 1998: 76;157-158).

Posto isso, deve-se levar em consideração que, na última década do século passado, visitantes e turistas que nunca haviam pensado em sair dos roteiros convencionais ou mesmo do meio urbano, começaram a se interessar por atividades que antes (décadas de 60, 70 e 80 do século XX) eram desenvolvidas principalmente por pessoas caracterizadas pelo alto espírito de aventura, desprendimento quanto ao

\footnotetext{
${ }^{41}$ Podem estar relacionadas ao uso indireto e direto. As UCs de uso indireto referem-se às áreas destinadas somente à conservação integral da biodiversidade, à pesquisa científica, à educação ambiental e à recreação. É terminantemente proibido explorar os recursos naturais desse tipo de UC. Esta categoria abrange os parques (Nacionais, Estaduais e Municipais), as estações ecológicas, reservas biológicas e ecológicas, áreas de relevante interesse ecológico, reservas particulares do Patrimônio Nacional e áreas sob proteção especial. Já as UCs de uso direto são as "áreas destinadas à proteção e manejo de recursos naturais", como: as florestas nacionais, as áreas de proteção ambiental e as reservas extrativistas (Furlan, 2000: 195-196).
} 
conforto, sem preocupação quanto à infra-estrutura, ou seja, acomodação, alimentação e outras facilidades e ávido de experiências alternativas: os ecoturistas ${ }^{42}$.

Pires (1998: 59) cita o novo ecoturista como possuidor de uma menor informação e experiência do/no meio natural. Podem ser qualificados como curiosos que têm poder aquisitivo para comprar pacotes atrativos, motivados pela onda ecológica ou ainda pela simples influência de conhecidos que experimentaram a atividade. De acordo com Lima (2002: 94), ocorre uma adaptação desse tipo de viagem, não dirigida a especialistas.

O interesse crescente atinge vários países da América Latina (entre eles o Brasil), África e Ásia (Pires, 1998: 58). Nessas áreas, há um apelo do turismo de aventura e esportivo, que envolve uma atmosfera de descobertas, desafios, isolamento e contato com o inusitado, no qual se desenvolvem as mais diversas modalidades e riscos dos chamados esportes da natureza entre eles, a escalada, o trekking, o canyoning, o rafting, o vôo livre, o rapel, o surfe, o windsurfe, o mergulho, o esqui-aquático, a motocross, etc. (Pires, op. cit::122).

No mesmo autor (op. cit:: 59), destaca-se o aumento do número de participantes do ecoturismo e, conseqüentemente, o surgimento daquelas pessoas "menos ecoturistas", a quem se pensar em proporcionar certas facilidades e níveis de sofisticação. Como exemplos, são citadas: as caminhadas mais curtas, que exigem menor esforço; a implantação de centros de informação; de trilhas autointerpretativas, serviços de animação turística, meios de hospedagens confortáveis e guias especializados no manejo de um ecoturista cujo interesse prioritário não é o estudo ou conhecimento da natureza.

Neste aspecto, enfatiza-se a preocupação de como e o que pode ser disponibilizado em um mapa turístico. Dependendo da intenção do usuário, ele achará interessante ou não a representação das curvas de nível. Todavia, existem informações que são importantes tanto em um mapa pictórico quanto em um convencional, como, por exemplo, a importância em se facilitar a informação da escala para que o usuário tenha uma noção prévia da distância e, conseqüentemente, do tempo gasto para o percurso, em informações sobre trilhas, onde conseguir guias (profissionais especializados) para as caminhadas, etc. Ilustram-se esses exemplos a partir de uma legenda que foi elaborada para o mapa de Ilhabela encontrada em Fiori (2003), onde, a partir dos trabalhos de campo, se estabeleceram-se três principais tipos (níveis de

\footnotetext{
${ }^{42}$ Excursionistas, alpinistas, aventureiros, naturalistas, cientistas, estudiosos, estudantes (universitários ou participantes de excursões escolares voltadas ao estudo do meio) e aficionados. Seja qual for à categoria de ecoturista, este só pode ser considerado como tal desde que seja envolvido ou que se envolva com aspectos conservacionistas e educativos que dão a verdadeira dimensão ao ecoturismo, sem a qual serão considerados simplesmente turistas (Pires, 1998: 15). Entretanto, na década de 90 do século $\mathrm{XX}$, houve uma evolução do ecoturismo, visando a um melhor atendimento ao público mais geral, isto é, o empreendedor, mesmo mantendo sua capacitação para atender o segmento do mercado puro, original, também teve que se adaptar à nova tendência, passando a oferecer um tipo de produto compatível com as preferências do novo ecoturista (Pires, op. cit.: 58-59).
} 
dificuldade) de trilhas para llhabela (Figura 41).

Figura 41- Estabelecimento de três níveis de dificuldade

para as trilhas em Ilhabela

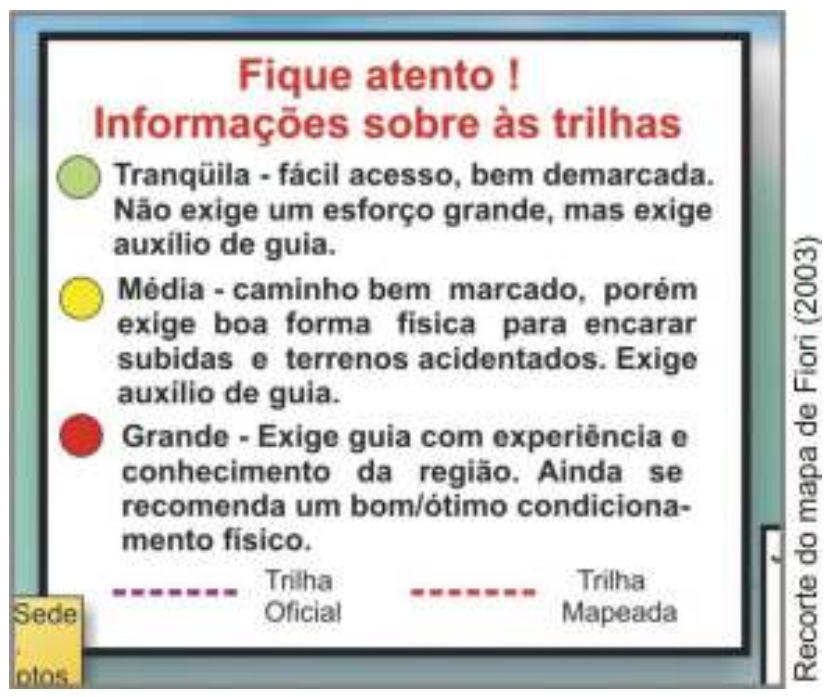

O outro tópico já relacionado e que pode ser representado sobre o mapa são os atrativos culturais, sejam materiais sejam imateriais.

Nos últimos vinte anos do século $X X$, os atrativos culturais vêm recebendo uma maior atenção do público-turista no plano mundial (Patin, 2005).

Alzua, O'Leary, Morrison (1998) reiteram que a cultura e, por conseguinte, todo o seu patrimônio está se transformando nas duas maiores forças de revitalização urbana e econômica. O turismo cultural torna-se cada vez mais importante às destinações preocupadas em atrair mais visitantes internacionais.

O termo turismo cultural e patrimonial tem sido usado para descrever não somente o consumo da arte, monumentos, folclore, mas também para tratar de experiências e motivações dos turistas no local da destinação escolhida. Em um sentido amplo, o significado da cultura e do patrimônio é resultado da estrutura étnica e social. E, em um sentido particularizado, são as influencias provenientes da experiência familiar, do grau de escolaridade, da vizinhança e de muitas outras experiências do dia-a-dia. $\mathrm{O}$ patrimônio e a cultura, quando combinados com o lazer e o turismo, podem ser considerados um dos fenômenos mais significativos ao rápido crescimento do turismo (Alzua, O'Leary, Morrison, 1998).

Segundo Canclini (2003: 202-203) e tendo em mente a proposta de elaboração de mapas turísticos pictóricos, busca-se uma forma de representação dos atrativos materiais e imateriais. $\mathrm{O}$ ato reconstrói uma possível verossimilhança histórica, ao 
estabelecer bases comuns para a re-elaboração de acordo com as necessidades do presente. Até porque,

assim como o conhecimento científico não pode refletir a vida, tampouco a restauração, nem a museografia, nem a difusão mais contextualizada e didática conseguirá abolir a distância entre a realidade e a representação. Toda a operação científica ou pedagógica sobre o patrimônio é uma metalinguagem, não faz com que as coisas falem, mas fala delas e sobre elas.

Dessa maneira, o produtor do mapa turístico deve estar atento a todas as possibilidades da destinação (materiais e imateriais), encontrando maneiras criativas e eficientes para a transmissão destes atrativos. Para isso, o mapa precisa contar com vários níveis de imagens da paisagem, ampliando dessa forma seu leque de opções e contemplando diferenças de interesses em um mesmo grupo social ou entre outros grupos. A figura 42 mostra alguns ícones culturais elaborados para a Secretaria de Turismo da Prefeitura de São Paulo (SPTuris).

O estudo da representação pictórica da paisagem relaciona-se a uma nova área interdisciplinar. Caberá ao pesquisador procurar entender as peculiaridades da linguagem visual, para que, então, analise o efeito das imagens sobre a vida social, seu lugar nas representações e nos sistemas simbólicos. Discute também as implicações da disseminação dos usos da imagem, as suas funções no mundo contemporâneo, o valor dos meios técnicos de produção e reprodução visual e outros tantos temas de interesse e questionamento (Porto Alegre, 1988).

Quando alguém (artista, artesão, desenhista, produtor do mapa, etc.) transforma a realidade em representações gráficas, está na verdade utilizando um schemata, que são os pontos de partida do seu vocabulário gráfico (ver figura 14). Tal schemata é formado a partir de uma seqüência de culturas e tempos ${ }^{43}$, a qual desenvolvendo formas de representação da realidade, até porque a assimilação de qualquer nova forma é resultado da apreensão e da manipulação de modelos esquemáticos (copiados e recopiados por todos ${ }^{44}$ ) utilizados pelos produtores. Esse recurso também serve de apoio à formação das imagens da memória (Gombrich, 1995). O autor continua esclarecendo que é pela percepção e pelo pensamento que se aprende a particularizar, a articular e a fazer distinções onde antes havia apenas uma massa diferenciada.

\footnotetext{
${ }^{43}$ As dimensões temporais estão no âmago da compreensão das estruturas cognitivas. Toda a vida social com suas múltiplas manifestações culturais é antes a orquestração da diversidade do que a réplica da uniformidade (Coelho, 1993: 20).

${ }_{44}$ Pessoas no mundo inteiro (crianças e adultos) adquirem a schemata por meio da arte conceitual, que parte da premissa de que todo o registro visual não é uma certeza, mas uma conjectura condicionada a um público e uma tradição. Portanto, julgando a arte de maneira conceitual, não se pode afirmar se as pinturas ou os conceitos (substantivos comuns que representam, classificam algo, como, por exemplo, um homem, um cachorro ou uma flor) são verdadeiros ou falsos, pois podem ser apenas mais ou menos úteis à formação de descrições (Gombrich, 1995).
} 
Figura 42 - Alguns ícones do patrimônio cultural de São Paulo

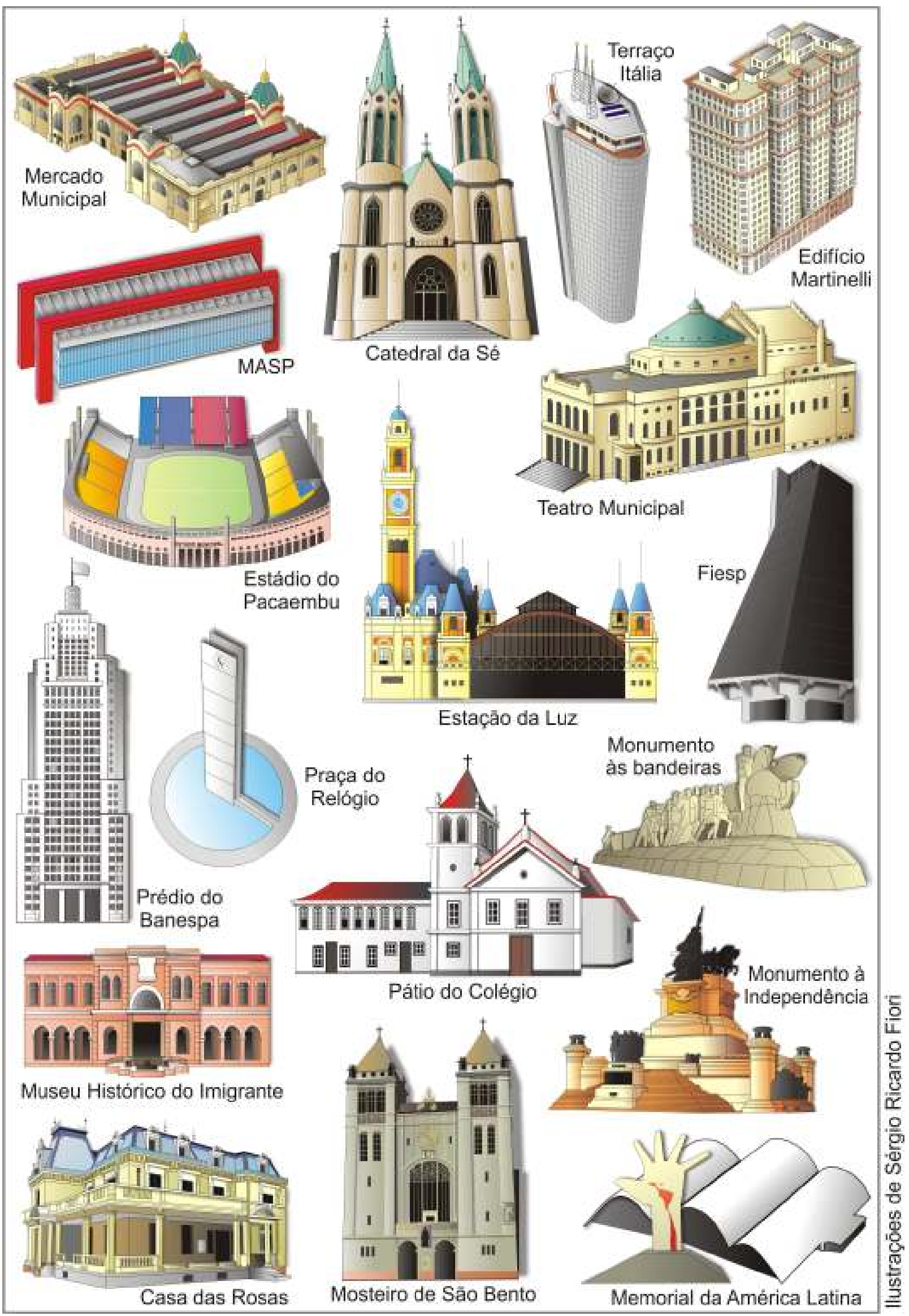


Um artista gráfico treinado possui uma grande quantidade de schematas que servem de apoio para as representações das imagens que estão em sua memória. $E$, logicamente, esses registros jamais serão uma réplica, pois a quantidade de informações que chega do mundo visível é incalculavelmente grande, e os meios à disposição do artista são restritos. Conseqüentemente, as formas de arte, antigas e modernas, não são mais do que as duplicações as quais o homem vê do mundo exterior. Essas transcrições são feitas a partir de um dado veículo adquirido, que se desenvolveu pela da tradição e habilidade. A representação não sendo, portanto, uma réplica, constata sua eficácia, desde que retenha a natureza eficaz do protótipo, isto é, deve funcionar tão bem, ou melhor que o real (Gombrich, 1995). Assim, o grande desafio do cartógrafo é inventar representações gráficas da realidade que funcionem para o maior número de pessoas.

A questão central a enfrentar está relacionada à subjetividade, uma vez que muitos materiais visuais, como o desenho documental e a fotografia, costumam ser associados a um grau de autenticidade da informação que, na verdade, não possuem. As ciências sociais tratam as imagens de forma positivista, como descrições da realidade e não como representações simbólicas, cuja leitura não apenas varia segundo o olhar do espectador como também é decorrente da própria natureza construída da imagem (Porto Alegre, 1988: 75-76).

Esse autor (op. cit: $80-81$ ) ressalta, então, os cuidados que devem ser tomados em uma pesquisa iconográfica:

$\checkmark$ Implica estabelecer classificações e tipologias, identificando diferentes gêneros de produção e seus conteúdos. No caso da iconografia gráfica, é preciso diferenciar a pintura, o desenho, a gravura, a fotografia e, agora, a computação gráfica, como formas distintas de expressão.

$\checkmark$ Definir critérios de classificação dos conteúdos temáticos, que podem ser de natureza estética, histórica, científica, jornalística e publicitária, procurando distinguir principalmente o valor de documento da pura ficção criativa.

$\checkmark$ Cada gênero e cada conteúdo obedecem a condições de realização que interferem no resultado final da imagem produzida e, portanto, naquilo que ela comunica. Por essa razão, o trabalho com materiais iconográficos requer não só um conhecimento da linguagem visual e de suas particularidades como, por exemplo, uma certa familiaridade com a história da arte, as escolas, os estilos artísticos e as técnicas de produção e reprodução, para que o pesquisador não se deixe levar por falsas premissas ou uma perspectiva ingênua da problemática visual. É importante conhecer as características de um quadro a óleo, da aquarela, do desenho, a composição simbólica e a psicológica, o retrato, a montagem e a trucagem fotográficas, a simulação e assim por diante, de modo a obter uma leitura mais acurada da imagem e seus significados. 
$\checkmark$ É desnecessário enfatizar que as escolas e os estilos de criação artística guardam estreita relação com o contexto social, o mundo das idéias e dos valores da época e do local em que a obra foi produzida, e que a consideração de tais elementos é essencial quando se trata de avaliar os valores documental e histórico e relacioná-los com a estética e a expressão artística.

Cite-se ainda Pires (1996), ao afirmar que as qualidades visuais do território são compostas de elementos naturais e artificiais, sendo que é pela visão que se percebem e se discriminam quatro grandes componentes paisagísticos no território: 0 relevo, a água, a vegetação e as atuações humanas ${ }^{45}$, que são capturados da realidade. Para isso, utiliza-se das mais variadas técnicas - representações artísticas tais como gravuras, quadros e ilustrações, documentos históricos, fotografias e filmagens - gerando assim formas substitutas da paisagem. A figura 43 apresenta dois exemplos do trabalho de Pires (1996), que utilizou as imagens turísticas de cartões postais da região litorânea de Santa Catarina.

\section{Figura 43 - As formas substitutas da paisagem}

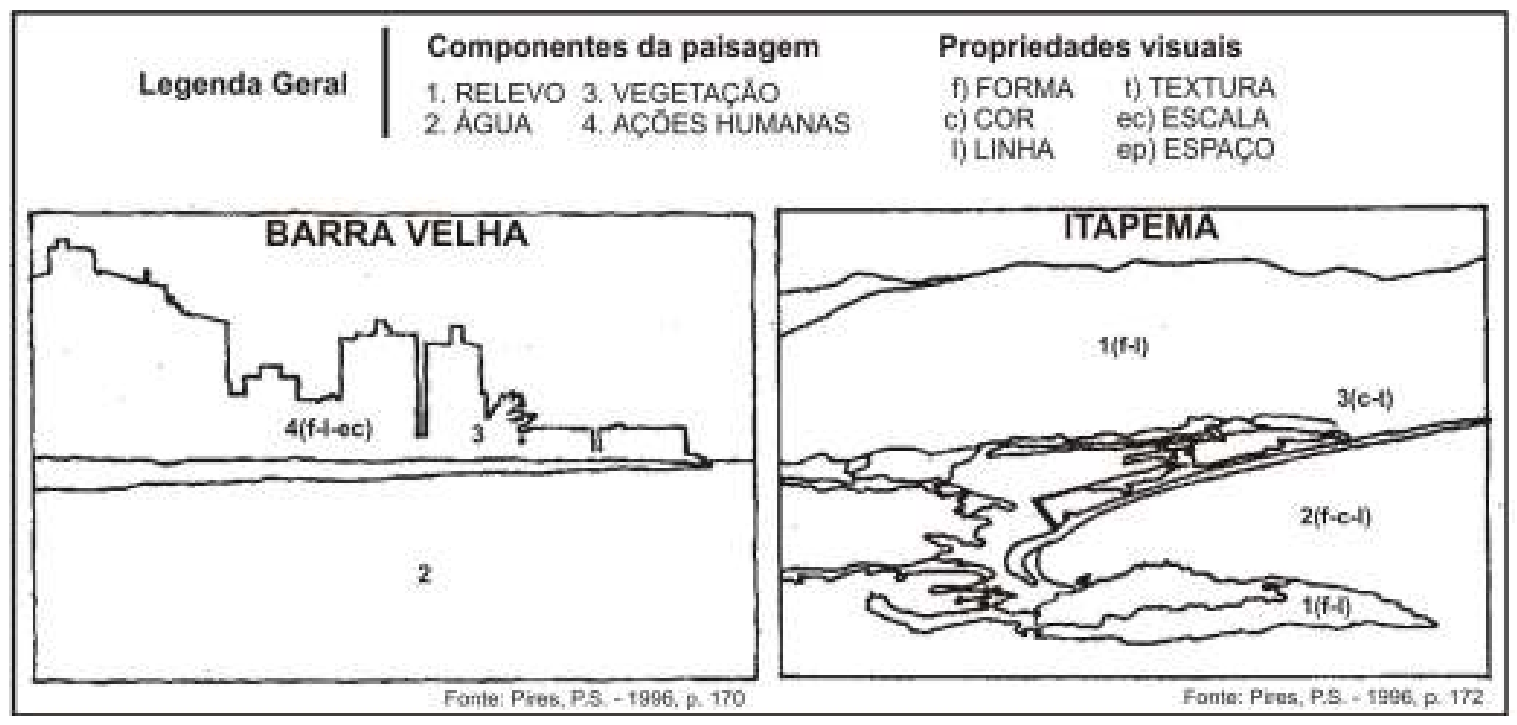

Os componentes paisagísticos ainda são portadores de propriedades e de elementos visuais ${ }^{46}$ particulares e constituem-se por um número de substâncias básicas daquilo que se vê em uma obra pictórica: a linha (seqüência de pontos, formas em 2D); a

\footnotetext{
${ }^{45}$ Os componentes da paisagem mais detalhados são: 1) Forma da terra: é o aspecto exterior da superfície terrestre representado pelo relevo, pelas formas do terreno, por sua disposição e por sua natureza. 2) Água: caracteriza-se pelas formas em superfície (mares, rios, lagos, neve e gelo), sua disposição, monotonia e movimento. 3) Vegetação: apresentam distintas formas de vida vegetal (árvores, arbustos e vegetação herbácea) com suas características específicas, sua distribuição, densidade, etc. 4) Estruturas e elementos artificiais: são criadas por diferentes tipos de usos do solo ou concentrações diversas de caráter pontual, linear ou superficial (Pires, 1996).

${ }^{46}$ São os tipos diferentes de formas das quais o desenhista dispõe para fazer uma ilustração. É importante frisar que apenas um único elemento visual, ou a composição com outros, configuram o plano pictórico.
} 
forma (volume, formas em 3D, dimensão); a luz e sombra (profusão de tons, sombreamento); a cor (reforço emocional expressivo); a textura (proximidade maior da superfície dos elementos representados) e a escala (o espaço). Esses dados fazem com que uma paisagem observada possa ser projetada, esboçada, pintada, desenhada, rabiscada, ou seja, podem-se elaborar representações a partir de expressões plásticas básicas. E é a partir desses elementos visuais que se obtém a matéria-prima para a comunicação visual, podendo assim planejar e expressar todas as variedades de manifestações visuais, objetos, ambientes e experiências. Dondis (1991: 23; 51-52) esclarece que a estrutura da obra visual é a força que determina quais propriedades e elementos visuais estão presentes, e com qual ênfase ocorre essa presença. Portanto, a escolha das propriedades e dos elementos visuais enfatizados e sua manipulação ficam a critério do artista (no caso, o cartógrafo), pois este dará os efeitos pretendidos. Ele é o visualizador.

Mukarovsky (1981: 308) complementa que nenhum desses elementos visuais, nem mesmo os mais simples de todos, como a linha e a cor, são meros fatos de percepção sensorial, pois sempre têm uma determinada relação com a realidade representada, isto é, cada um desses elementos significa de alguma maneira a realidade, por trazer referência, destacar alguns de seus aspectos. Estabelecem, no interior da obra pictórica, relações mútuas, pois as suas significações parciais unemse para formar a significação final e as suas relações parciais com a realidade dão, como resultado, a referência global a ela.

Uma pesquisa realizada por Fiori (2003: 173-191) com os mapas turísticos pictóricos de Ilhabela e São Vicente, constatou empiricamente que por volta de $85 \%$ de 160 entrevistados, aprovaram a escolha das imagens percebidas nos mapas. $O$ resultado descrito abaixo relaciona a preocupação do cartógrafo e a reação dos usuários:

$\checkmark$ A transmissão da informação - o autor-cartógrafo procurou oferecer signos cartográficos (índice, ícones e símbolos) eficazes aos diferentes e ao maior número de usuários, buscando a menor subjetividade possível. Houve então um trabalho de percepção (referência cognitiva) das imagens em dois níveis: primeiro o cartógrafo filtrou e transformou a realidade em imagens representativas. O usuário então precisou compreender tais imagens pictográficas desenvolvidas, que auxiliaram na procura e comunicação das atrações em sua estada no destino.

$\checkmark$ A motivação causada pelas imagens - fez com que se optasse propositalmente pelo estilo pictográfico, devido aos seus recursos gráficos que oferecem maior riqueza de detalhes visuais e despertam reações emocionais como, por exemplo, a memória afetiva e a lembrança. Durante o desenvolvimento do mapa, buscou-se inicialmente uma imagem-representação geral da localidade, sua vocação turística, (balneário, histórico, serrano, etc), por meio de um conjunto de representações como signos cartográficos e desenhos, que destrincharam os vários elementos espaciais e as várias atividades inseridas 
no mapa-destino. Por se tratar de um produto voltado ao turismo, procurou-se levantar as imagens representativas da localidade, tendo, como princípio, o desafio de desenvolver imagens de uma forma estimulante, não tediosa, objetivando valorizar as imagens representativas. A idéia era a de viajar ou relembrar o destino por meio do mapa, mesmo não estando in loco.

llustrando tudo o que foi dito acima, a seguir serão são apresentadas algumas respostas dissertativas retiradas de Fiori (2003: 181-183). Elas exemplificam a reação dos usuários que utilizaram o mapa turístico pictórico, caracterizado pela grande quantidade de imagens representativas:

Porque se eu me perder (o que acontece sempre!) fica mais fácil de localizar algum lugar para pedir ajuda" (usuário 119). Mostra de maneira mais didática os pontos comerciais e locais úteis a serem visitados e ou utilizados por turistas (usuário 130). (...) visualmente eles são mais atraentes e as informações essenciais não são comprometidas por conta disto (usuário 140). Fazer turismo é sair do convencional, da rotina; por isso prefiro o mapa pictórico (usuário 142). Por causa das figuras, os turistas sempre vão ficar curiosos para conhecer mais a cidade (usuário $3,4,5,26$ ). (...) possui um visual que atrai os turistas (usuário 48). 0 turista ao chegar sabe onde poderá se divertir (usuário 62). Porque é uma forma mais alegre de visualizar nossa cidade (usuário 67). Mostra muitas coisas interessantes aos olhos dos turistas (usuário, 72). Porque a ilustração ajuda na compreensão imediata (usuário 81). (...) podemos dizer que dá um espírito de aventura e curiosidade para conhecer a cidade (usuário 93). Pela forma criativa e alegre que o mapa ilustra do lugar (usuário 96). Por causa dos animais, o mar, os navios, os mergulhadores, etc (usuário 102). A visualização cria uma expectativa do lugar (usuário 109). Porque com os pequenos resumos sobre os pontos importantes e com a facilidade de compreender os caminhos, o turista se anima a visitar não só a cidade e pontos mais conhecidos como outros lugares interessantes (sic usuário 119). (...) mostra a região montanhosa (morros, vegetação, rios, cachoeiras) (usuário 122). Por ele ser ilustrativo, realmente dá vontade de ir e não voltar mais (usuário 152). Os mapas têm uma representação gráfica agradável e atrativa (usuário 156).

Essas respostas comprovam a eficácia quanto ao grande uso da pictografia utilizada em mapas voltados ao setor do turismo. Primeiro porque tais representações são mais próximas do usuário potencialmente leigo em cartografia e de cujo cotidiano os mapas não fazem parte. Segundo, porque o usuário, tendo ou não conhecimento da utilização de mapas, é atraído por esse tipo de material cartográfico temático que gera nele expectativa, interesse, curiosidade, espírito de aventura, vontade de conhecer o local.

Dondis (1991: 136) corrobora a preocupação acadêmica relacionada ao desenvolvimento de mapas mais adequados à atividade turística, ao afirmar que a inspiração súbita e irracional não é uma forma aceitável no design. Pelo contrário, 
planejamento cuidadoso, indagação intelectual e conhecimento técnico são necessários tanto ao pré-planejamento visual quanto ao design propriamente dito. Como conseqüência, o designer constrói estratégias compositivas, buscando estabelecer soluções a problemas de beleza e funcionalidade, de equilíbrio e do reforço mútuo entre a forma e o conteúdo do produto. Todo o transcorrer do processo é extremamente científico, ou seja, suas opções, por meio de escolhas das técnicas, devem ser racionais e controladas.

Neste momento, é oportuno citar Arnold (1992), ao testemunhar que a ênfase dada aos símbolos pictóricos no Pilbara Street Smart Touring Map ${ }^{47}$ não foi por acaso, pois tal recurso estilístico possibilitou o desenvolvimento de um mapa sem uma legenda extensa, satisfazendo ainda aos visitantes que não tinham o idioma inglês como língua mãe. A pictografia gerou um processo de simplificação da leitura do mapa, provendo uma comunicação visual eficaz. Além disso, buscou estimular a atividade turística naquele local pela descrição visual da paisagem, criando uma atmosfera de aventura.

Esse tipo de recurso vem sendo usado, como aponta Harley (1994: 296), desde a Renascença, quando a imagem do mapa vinha acompanhada por uma grande quantidade de símbolos decorativos, presentes nos títulos e letras, na vinheta, na rosa-dos-ventos e nas bordas. Todos esses elementos decorativos formavam o vocabulário expressivo do artista e somavam-se ao assunto principal representado, no caso, ajudando a fortalecer e focalizar os significados políticos do mapa.

Essa forma de representação gráfica exprime o modo de percepção, de pensamento e de captação próprio de uma época, de uma classe ou de um agrupamento artístico (Bourdieu, 1974: 284).

Atualmente, sendo bem trabalhada, a pictografia tem grande possibilidade de se firmar como um conveniente e atraente estilo artístico voltado à concepção de mapas para o setor turístico.

A definição de estilo pode ser uma tarefa complexa e difícil de descrever com clareza. Dondis (1991: 161) sugere que talvez a melhor maneira de estabelecer uma definição seja vê-lo como uma categoria ou classe de expressão visual, modelada pela plenitude de um ambiente cultural. Isto porque o estilo é uma síntese visual de elementos representados, a escolha e utilização de técnicas, a sintaxe adequada, o processo de inspiração, a forma de expressão e a finalidade básica do produto.

Segundo Wolfgram (1994: 104-110), pode-se dividir em: desenho livre (cartoon, caricaturas, etc.); tradicional (é informativo, não muito interessante visualmente, mas franco e informativo); alta tecnologia (focaliza ilustrações contemporâneas e imagens

\footnotetext{
${ }^{47}$ Foi publicado em 1992 por órgãos públicos australianos; o Western Australian Departament of Land Administration, Cartographic Services Branch e Department of Conservation and Land Management. A confecção desse mapa turístico tinha como característica fundamental procurar atrair aqueles usuários que não têm familiaridade com as técnicas de leitura de mapas (Arnold, 1992).
} 
geradas no computador); técnico (relaciona-se a assuntos como arquitetura e modelos tridimensionais), natural e floreado (refere-se mais a conjuntos de cores do que a estilos artísticos) e outros estilos de ilustração, podendo se usar pinturas a óleo, pastéis, lápis de cor e aquarelas.

Dondis (1991: 163) complementa afirmando que, em um primeiro momento, escolhese o meio no qual se fará a comunicação, o qual sofrerá influência da forma e do conteúdo. Depois se coloca o objetivo, razão pela qual o material, objeto está sendo feito: sobrevivência, comunicação - caso da informação e publicidade - expressão pessoal. Por fim, ocorre o desenvolvimento, que dispõe de uma série de opções: a busca de decisões compositivas pela escolha de elementos (no caso, visuais) e pelo reconhecimento do caráter elementar, a manipulação dos elementos por meio da escolha das técnicas apropriadas, etc. O resultado final tanto para os artistas quanto para as pessoas em geral é uma expressão individual e, às vezes, coletiva, regida pelos elementos já apontados e que sofre influencia especial e profunda da política, da economia, do meio ambiente e dos padrões sociais, que criam uma psiquê coletiva. Portanto, o estilo é culturalmente condicionado, ou seja, as categorias mais amplas de expressão visual ajudam a entender a escolha e/ou preferência do produtor por um determinado estilo individual.

A pesquisa em questão defende uma concepção de estilo que possa encontrar maneiras de aumentar e melhorar o êxito das representações pictóricas em mapas temáticos específicos ao público e ao setor do turismo.

Bourdieu (1996: 323) enfatiza a necessidade de se ter cuidados ao utilizar a pictografia, devido aos seus recursos de sentido e valor, provenientes do acordo entre as duas faces da mesma instituição histórica: o habitus cultivado e o campo artístico, faces que se fundem. O cartógrafo deve ter em mente que os elementos pictóricos só possuirão sentido e valor se puderem ser apreendidos pelos receptores que, por sua vez, precisam estar dotados da disposição e da competência estéticas exigidas. Por exemplo, Whitehead (apud Porto Alegre, 1988: 85) observa que o desenho ajuda a acentuar os objetos e, ainda hoje, é muitas vezes preferido à fotografia no campo das ciências naturais e biológicas, por poder isolar e acentuar aspectos especiais do objeto estudado, assim como omitir o que não interessa. A fotografia apresenta, simultaneamente, um grande número de elementos dificultando o registro da observação. Entretanto, quem se utiliza da pictografia deve levar em consideração a subjetividade, resultado do estilo e visão de mundo de cada artista e de seu tempo.

Veja-se, por exemplo, o caso dos pintores-etnográficos realistas citados por Porto Alegre (1988: 88); o autor destaca o grande e rico acervo desses artistas que, mesmo procurando não cunhar uma interpretação arbitrária e fantasiosa a suas representações, apresentam certa ambigüidade nas imagens, devido à tensão entre o realismo (mundo concreto) e o não-realismo (pictografia). Essa relação é intrínseca ao processo de criação e interpretação vivida pelos artistas. 


\section{7 - A arte e o desenho como recurso à cartografia}

John Keates, em seu livro Understanding maps (1982), discute extensamente a questão se os mapas podem ser considerados um trabalho artístico.

O tema é de grande interesse, porque a arte consegue reter o elemento sensorial. $\mathrm{O}$ prazer proporcionado por uma ilustração vai além de seu conteúdo, pois possibilita ao espectador combinar, juntar, derivar algo pela justaposição de experiências ou aspectos de uma única experiência. O prazer que uma representação é capaz de nos proporcionar é originado por motivos e imagens que estimulam a lembrança de sensações de cheiro, gosto, audição, lembranças (Wollheim, 2002: 98-100). O autor ressalta mais especificamente o prazer encontrado na apreciação de uma pintura, porém esta observação adapta-se perfeitamente à concepção artística referente aos mapas turísticos, que utilizam da pictografia.

Em 1966, a Associação Cartográfica Internacional apresentou a primeira definição para cartografia, considerando-a:

o conjunto de estudos e operações científicas, artísticas e técnicas que intervêm a partir de resultados de observações diretas ou da exploração de uma documentação existente, tendo em vista a elaboração e a preparação de plantas, mapas e outras formas de expressão, assim como sua utilização.

Entre outras áreas de estudo, essa definição coloca a cartografia muito próxima do design, da comunicação e da arte.

Galeffi (1977: 41) ensina que uma obra de arte tem o poder de encantar, arrebatar o observador que se dispõe a contemplá-la. Naquele instante de graça, não se pensa em outra coisa: é como se vivesse num mundo ideal. Só depois, ao despertar do sonho, é que o observador pode tornar-se crítico e, assim, analisar a mensagem que o artista conseguiu transmitir.

Uma obra de arte se divide em dois aspectos (Bosi, 2002: 7):

$\checkmark$ Primeiro, pode ser vista como um objeto, por exemplo, um artesanato, uma música, um quadro, um desenho, um discurso, que geram um efeito psicológico, pois a obra é percebida, sentida e apreciada pelo receptor. Ela visa tanto comover a alma quanto aliar utilidade ao belo.

$\checkmark$ Segundo, o fator temporal, ou seja, alguém que cresceu após a Revolução Industrial tende a ver em todas as coisas possibilidades de consumo e fruição. Ter ou desejar uma gravura, um cd (compact disc) ou um livro finamente ilustrado é o seu modo habitual de relacionar-se com o que todos chamam de arte.

O mundo da arte faz-se então pela cooperação material e social, a partir do grau de 
adesão às convenções ${ }^{48}$ que regulamentam uma prática (Canclini, 2003: 39).

Conseqüentemente, a arte está inserida em um contexto, onde o artista e suas obras resultam de um acervo de experiências psico-fisiológicas, técnicas, filosóficas, científicas, históricas, morais, políticas, etc., que poderão constituir o motivo de inspiração para toda nova criação, nunca, porém sem serem antes refundidas e regeneradas no mágico crisol da fantasia criadora de cada personalidade artística (Galeffi, 1977: 142).

Sendo assim, ao longo da história, cada tipo de arte produziu suas técnicas e, por conseqüência, um conjunto de regras úteis ao processo de execução da obra. Desde a Antigüidade, formou-se uma tradição normativa. Na realidade, é correto dizer que foram gerados certos padrões estilísticos na vida simbólica de todos os povos, que resistiram durante os séculos, resultado da regularidade interna e do enraizamento comunitário (Bosi, 2000:17).

Bourdieu (1974: 293) cita que há períodos de ruptura, correspondentes àqueles períodos em que as obras são elaboradas sob a influência de um novo modo de produção, contudo, vistas durante certo tempo por meio dos antigos instrumentos de percepção.

O principal objetivo do artista é proporcionar e provocar experiência e prazer ao espectador (Wollheim, 2002: 44). A maior parte do material gráfico produzido prima pela necessidade de registrar, preservar, reproduzir e identificar pessoas, lugares, objetos ou classes de dados visuais. Tais dados, por sua vez, procuram transmitir informação por meio de mensagens específicas ou sentimentos expressivos, tanto intencionalmente, isto é, com objetivo definido, quanto obliquamente, sendo um subproduto da utilidade (Dondis, 1991: 183). Isto acontece devido ao fato de que um meio visual pode desempenhar vários papéis ao mesmo tempo. Por exemplo, um pôster que se destina basicamente a anunciar um concerto de piano, pode acabar servindo para decorar a parede de um estúdio, superando assim, a finalidade comunicativa que motivou a sua criação.

Brill (1988: 76) complementa que a função do artista deve ser a do mediador entre a arte e a técnica, ambas indispensáveis e complementares. Para poder ser veículo legítimo da expressividade de sua época e de seu meio, o artista deve estar arraigado nesse meio. Logo, na época da cultura de massa, é justificável uma arte reproduzível, seriada, divulgada. Todavia, não se pode esquecer que a arte é uma linguagem de descoberta, e que também tem uma função conscientizadora, devendo ser sempre renovada na mesma medida em que a sociedade se renova.

De tal modo, o almejado êxito da comunicação, que procura abolir simbolicamente as

${ }^{48}$ Segundo a sociologia e a antropologia são normas de ação ou costumes - aproxima-se do que Bourdieu (1974) designa de capital cultural - ou seja, as convenções tornam possível que uma orquestra funcione com coerência e se comunique com o público (Canclini, 2003: 39). Ou então: regras e normas para o desenvolvimento de um mapa, entre tantos outros exemplos. 
diferenças e os conflitos da existência cotidiana - buscando a acessibilidade do usuário - não priva o artista de constituir sua maneira, seu estilo próprio de representar o mundo, e essas são marcas infalíveis no domínio que exerce sobre os diferentes tipos de arte. Aliás, os princípios estilísticos são cada vez mais redutíveis a princípios técnicos, possuindo um sistema convencional de procedimentos nas diferentes formas de produção erudita - pintura, música, romance, escultura estando fadadas à dialética do refinamento. Essa constatação se refere ao princípio do esforço que os artistas desenvolvem a fim de explorar e esgotar todas as possibilidades técnicas e estéticas de sua arte (Bourdieu, 1974: 111).

Assim sendo, a obra do produtor-artista pode apresentar uma certa segurança estilística, flexível quanto ao entendimento de seu trabalho, que pode ou não ser compreendido pela sociedade em maior ou menor grau.

No caso específico desta pesquisa, o teor de flexibilidade deverá se ater ao contexto histórico atual que vê, entre outras coisas, o grande crescimento e valorização do serviço voltado ao setor turístico, posicionando o mapa - por definir a posição geográfica em que se encontra o local e por atuar como seu divulgador - como um dos grandes aliados (localização e marketing) da localidade. Ainda dentro do contexto histórico, está o estudo cartográfico, que, em sua evolução metodológica e prática, cria, restringe, preocupa-se, experimenta e aprimora tipos de representações que sejam mais favoráveis às capacidades e habilidades do usuário potencial, sempre contando com novos recursos técnicos e materiais.

Desse modo, existe uma justificativa coerente para que se trabalhe com mapas turísticos que utilizam amplamente os símbolos pictóricos, índices e ícones, mesmo havendo uma resistência teórico-metodológica quando comparados aos mapas convencionais. Todavia, é fato a existência e produção desse tipo de "mapa artístico". Tal material, na maioria das vezes, é desenvolvido por pessoas que não têm preocupação com a qualidade cartográfica, tanto que freqüentemente, tais materiais nem poderiam ser chamados de mapa ${ }^{49}$. Por isso, ninguém melhor que um cartógrafo para buscar soluções coerentes a esse tipo de material utilizado pelas destinações turísticas.

Fiori (1999 e 2003) pôde perceber que o uso da pictografia, quando bem utilizada, configura-se como uma forma de comunicação cartográfica alternativa para o mapa. O mais importante é que o cartógrafo tenha consciência, respeito pelo limites estilísticos idealizados durante a elaboração de suas representações. Logo, a

\footnotetext{
${ }^{49}$ Grande parte dos "mapas" apresenta muitas deficiências cartográficas tais como: ausência de escala, deficiência no sistema de referências (latitude/longitude e direções cardeais), legendas pobres ou confusas, descaracterização da base cartográfica (sendo flagrante, por exemplo, a omissão de grande parte das ruas, rios, trilhas); as ilustrações são empregadas de uma maneira pobre e sem criatividade (pois provavelmente foram tiradas de algum arquivo de figuras, sendo, em seguida, copiadas e coladas várias vezes), etc. Ver Fiori, 2003: 125-127.
} 
prioridade é oferecer ao usuário códigos estéticos que sejam pré-conhecidos por ele, mesmo que superficialmente.

O mapa turístico é configurado por uma dualidade: primeiro objetiva informar sobre as atrações - quer naturais quer culturais - as atividades e as áreas de apoio (infraestrutura) de uma determinada destinação, localizando-as no espaço. Contudo, como já citado anteriormente, também pode ser um subproduto de sua utilidade, servindo como instrumento publicitário ou pôster (suvenir) para decorar um quarto, um restaurante, uma loja, etc.

A autora ainda pontifica (Dondis, 1991: 184) que os objetivos dos meios visuais se misturam, interagem e se transformam. Para que se compreendam os meios de comunicação visuais, é preciso haver um conhecimento sobre eles, fundamentandose num critério de grande amplitude. As respostas a questionamentos sobre as motivações que levaram o artista a conceber e produzir um dado objeto são fluidas e, portanto, as perguntas também devem ser. O idealizador ou o artista deve, então, interrogar a natureza de cada meio de comunicação que utiliza em seu trabalho, a função ou níveis de função, a adequação, a clientela a que se destina e, por último, o porquê histórico do produto.

Um outro ponto ressaltado por Canclini (1984: 54) deixa claro que a arte, como toda a linguagem que quer ser comunicada, deve ater-se a códigos produzidos e manejados socialmente. Deste modo, sendo a arte ${ }^{50}$ resultado da vida em sociedade, pelo menos desde as vanguardas do século XIX - por um lado participando da marcha histórica e, de outro, pelo simples prazer da invenção - sofre condicionamentos, leis, necessárias à ordem vigente. No entanto, mesmo condicionada, o que a distingue de outros modos de transformação da realidade material e cultural é que a arte não resulta só de privações, sendo foco de criatividade e de iniciativa social. Procura mudar a realidade, indo além das leis, contribuindo, assim, para a ampliação no campo do possível (Canclini, op.cit.:33).

O autor (Canclini, op.cit::35) ainda enfatiza que a atividade artística é produtiva por se apropriar da realidade por meio do trabalho, buscando satisfazer uma necessidade social, de acordo com a ordem vigente de cada sociedade. Essa definição parece-nos a mais válida em razão de sua capacidade de abarcar a totalidade do processo artístico e de suas modalidades em diferentes sistemas econômicos e culturais.

Baseando-se em um exemplo do autor, pode-se presumir que um mapa turístico pictórico interativo procura ser bem aceito pela sociedade. Para isso, faz uso e se apropria de algum modo da matéria-prima - imagens, sons, fatos históricos, paisagens - e a reelabora com seu trabalho, que, no caso desta pesquisa, configurase em um meio digital da localidade turística.

50 Dondis (1991: 9) apresenta os "extremos" representativos de artes, ou seja, de um lado àqueles referentes às belas-artes até as artes aplicadas: pintura, escultura, arquitetura, artesanato, fotografia, artes gráficas e desenho industrial. 
O trabalho ainda é fixado em padrões formais, como acesso rápido a cada link (tempo), características técnicas padronizadas (como se dá apresentação no monitor do computador, acesso pela linha discada ou banda larga), custo, etc.

Segundo Canclini (1984: 103), esse momento histórico permite que os artistas vivam de seu trabalho. Em contrapartida, precisam submeter suas obras à homogeneidade dos preços e às determinações estéticas dos usuários. Esta homogeneização resulta do processo sócio-econômico que acabou sujeitando o artista ao intercâmbio comercial, ou seja, um mesmo tipo de produto feito em São Paulo se parece com o de Nova York, Roma ou Tóquio. Nessa perspectiva, é evidente que a arte é produzida sob uma máscara promissora de uma expressão universal, porém sofrendo forte influência da arte dominante, cuja universalidade é a do sistema capitalista. Outrora os artistas sujeitavam-se às igrejas e às cortes, hoje dependem do mercado.

Deste modo, é essencial que o produtor do mapa tenha a clara consciência de como seu material será utilizado pelo usuário e deve procurar maneiras para que ele seja aceito e compreendido por diferentes povos e culturas. Contudo, deve busca ir além, fazendo uso de seu conhecimento científico e técnico na área da cartografia e de sua criatividade como artista, buscando encontrar um meio termo, senso comum na elaboração de mapas específicos para o setor do turismo não partindo daquelas idéias já usuais dos mapas convencionais.

Entretanto, é bom frisar que o cartógrafo do mapa turístico - que busca um produto híbrido entre as técnicas convencionais e a pictografia - deve estar sempre atento e preocupado com as regras cartográficas essenciais, como a escala, referências geográficas e legendas coerentes. Levando-se em consideração pesquisas anteriores (Fiori 1999 e 2003), justifica-se que o atual trabalho enfatize o uso da pictografia e seu recurso de tornar as informações mais emotivas, atrativas, sedutoras.

Wolfgram (1994: 104) concorda que o desenho reflete a emoção da mensagem de maneira muito mais rápida do que as palavras, quase sempre garantindo sem interrupções a atenção do usuário em uma apresentação. Mesmo assim, o desenho é um dos recursos mais negligenciados. Porém se alguém é compelido a apreciar uma apresentação visual, a mensagem tem muito mais oportunidade de ser transmitida.

Em geral, o desenho é um meio de conhecimento do mundo, ou seja, de tudo o que se representa. Também pode ser chamado de ilustração ou pictografia. Constitui-se um meio de expressão, um tipo de linguagem, que possui como característica fundamental alguma(s) semelhança(s) física(s) com o fenômeno representado, isto é, com formas que estão no mundo real como, por exemplo: um objeto ou uma paisagem. Cabanellas (1976: 5) sustenta que o desenhista desenvolve esses conteúdos, tendo consciência de que não são uma réplica do real, mas sim uma expressão equivalente, formal, de alguns fenômenos que são sentidos ou percebidos.

O desenho possibilita uma forma de manifestar as relações, sensações do eu com o ambiente. Permite ao desenhista representar parcialmente o que sabe do mundo que 
o rodeia, expressando atitudes, sentimentos, conhecimentos. Contudo, devem-se encontrar maneiras que sejam capazes de produzir essas mesmas "sensações" no expectador, fazendo uso das linhas, formas, perspectivas, cores, manchas agitadas ou serenas, espaços abertos ou fechados, etc (Cabanellas, 1976: 5).

Desenhar é um ato de criação, onde o artista busca soluções novas e coerentes para se comunicar, e é esta sua faceta humana mais importante, porque não se pode esquecer que a humanidade sempre contribuiu com novas soluções para aquilo que se apresenta. De acordo com Cabanellas (op.cit:: 6), na intenção representativa da realidade, 0 produtor escolhe 0 tipo de desenho mais adequado, tendo como referência uma determinada finalidade. Assim, a ilustração pode ter um caráter estético ou representativo e, dentro deste último caso, pode estar ou não sujeito a normas e convenções. A representação obedece ainda a leis distintas segundo as formas que se desenham: geométricas ou naturais (figura 44). O mapa pictórico trará em seu desenvolvimento tanto intenções estéticas quanto representativas.

Figura 44 - Maneiras de se elaborar um desenho

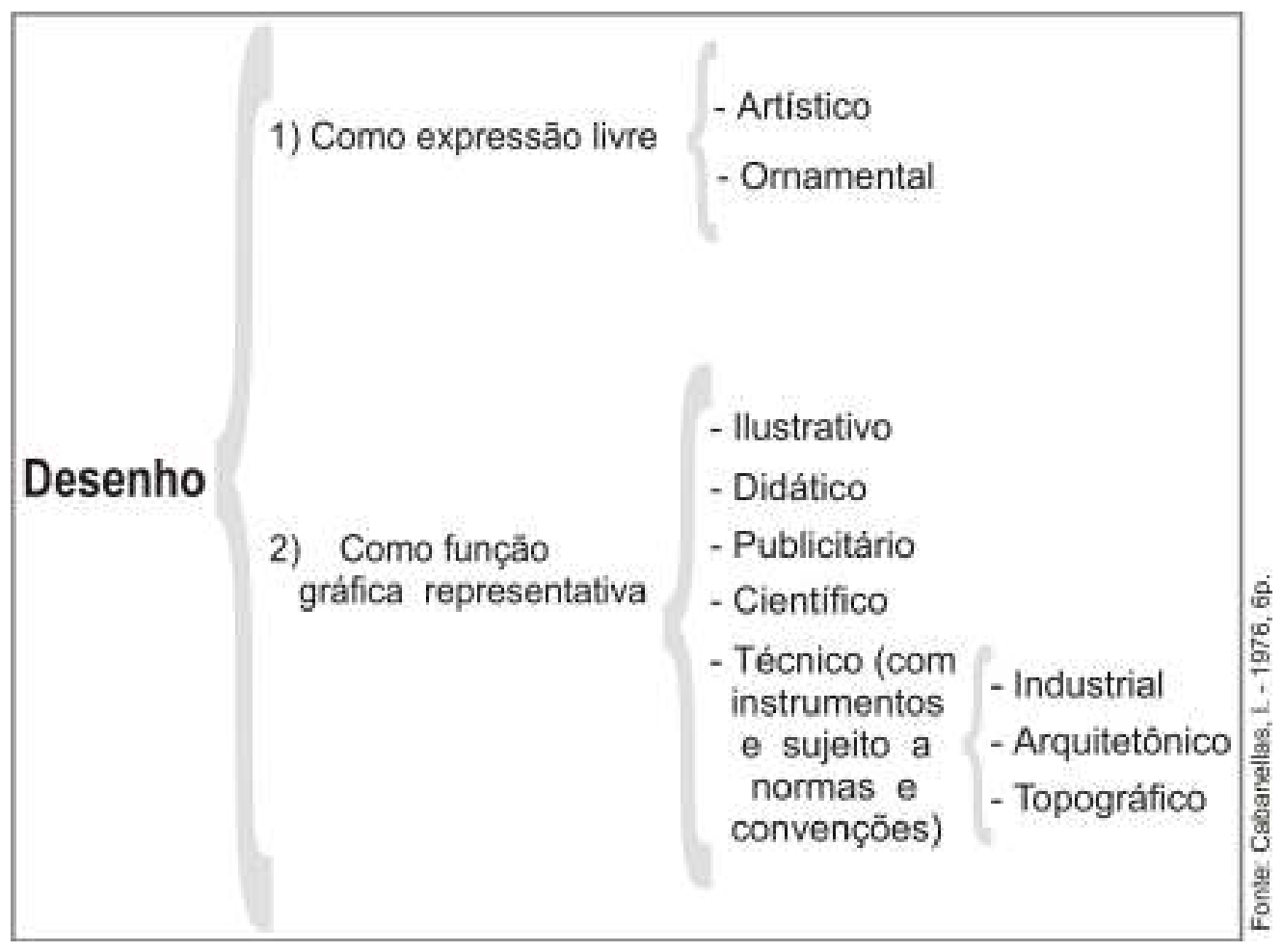

E, em todo o processo de idealização e confecção de um ou um conjunto de desenhos, a arte e a cultura são itens preponderantes, pois o plano pictórico - uma folha de papel, por exemplo - faz uso de leis e princípios voltados ao plano da linguagem para que a ilustração possa ser confeccionada - é resultado do conjunto de contextos mentais de uma dada época e sociedade. Isto porque, como foi abordado, a cultura e a comunicação são dependentes de uma interação entre as expectativas, observações, hábitos e padronizações que fazem parte do cotidiano 
humano.

Fica evidente que qualquer forma de ilustração resulta de escolhas, recortes e enfoques de porções da realidade (plano concreto) que são previamente estabelecidas pelo desenhista. Feito isso, inicia-se um processo de representação, procurando conceber as melhores relações de proporção, angulação e simplificação do elemento focalizado. A seguir se demonstram três tipos diferentes de representação pictográfica (Figuras 45 A, 45 B e 45 C).

Figura 45 - Três tipos de representações pictóricas

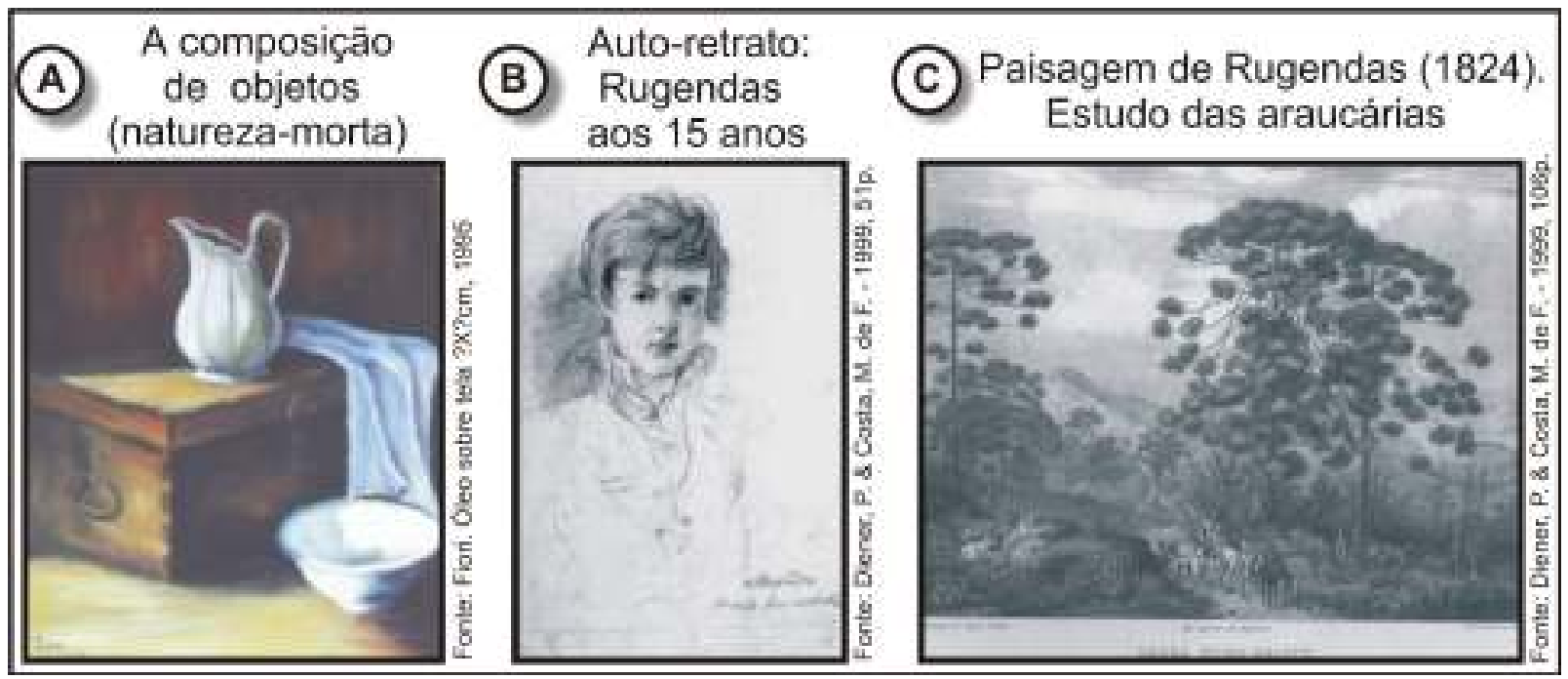

De acordo com trabalhos anteriores (Fiori, 1999 e 2003), e sempre buscando um maior aperfeiçoamento para os mapas turísticos pictóricos, a atual pesquisa preocupa-se em elaborar desde representações pictográficas nomeadas de naturais e relacionadas à topografia (apoiada em bases sistemáticas - convenções), à geomorfologia, à hidrografia (referindo-se principalmente à morfologia do terreno) e à biogeografia (desenhos e ilustrações da fauna e flora), até as representações nomeadas de culturais, relacionadas à história (também lendas e curiosidades), à arquitetura, ao artesanato, à culinária típica e à infra-estrutura de lazer (tipos de esportes, vistas panorâmicas, etc.). Acrescentem-se os símbolos de informação pública, comuns a qualquer tipo de localidade, os quais informam, por exemplo, sobre locais de hospedagem, abastecimento, locadoras de veículos, comércio em geral entre outros dados. Por fim, as representações gráficas da paisagem, com seus ícones e símbolos, terão ainda o apoio de texto, legendas, o título central, as referências geográficas, as bordas e os mapas-detalhe.

Neste momento, é necessário abordar, mesmo que brevemente, mais um conceito: a estética. Canclini (1984: 32) afirma que a estética se preocupa em como as representações serão "materializadas", sempre levando em consideração as culturas, os modos de produção e as classes sociais. O tempo (história) proporciona outras 
descobertas estéticas, nutridas e geradas pelo desenvolvimento social e tecnológico, sendo a inspiração resultado da interação dialética com o meio. Sendo a estética condicionada pela História, os limites entre o "bom e o mau gosto" são por vezes ditados unicamente pelas convenções de uma época (Mukarovsky, 1981:128).

Ao tratar das escolhas e da elaboração dos vários itens que culminam no mapa final, Mukarovsky (op. cit.:125) ressalta a importância da estética, que se configura como atriz coadjuvante da função prática, por sua capacidade de atenuar conflitos e, por conseqüência, buscar o aperfeiçoamento do aspecto técnico. Todos esses elementos encontram apoio nessa espécie de prazer desinteressado e plácido que acompanha a atitude estética.

Desde Kant até Umberto Eco, a maioria das teorias estéticas afirma que a experiência artística é produzida na relação direta entre um sujeito e um objeto. Nesse diálogo, prevalece à função. Por exemplo, ao pedir um lápis emprestado para anotar um endereço, uma pessoa é atraída por um instante e se detém somente à forma (design) do objeto. Esta percepção é propriamente estética, pois se posterga o ato prático, ou seja, elimina-se momentaneamente a função do lápis. Faça-se aqui uma ressalva à afirmativa feita anteriormente, segundo a qual a forma predomina sobre a função, pois ela não é válida para todas as épocas. Refere-se somente a trabalhos artísticos produzidos a partir do sistema capitalista, que proporcionou a autonomia de certos objetos ou de certas qualidades de alguns objetos (Canclini, 1984: 10-12).

Canclini (1984: 25) prosseguiu informando que devido à facilidade de produzir vários tipos de formas para uma mesma função - por exemplo, diversos mapas de uma mesma localidade que a divulgam como localidade turística - o estilo e a freqüência das obras do artista são determinados pelas exigências do planejador e do usuário.

A inovação estética também foi deslocada para as tecnologias eletrônicas, tornando a comunicação mais fácil e rápida. Antes havia formas artesanais ou eruditas, porém hoje se oferecem recursos técnicos que podem gerar hipertextos e rápidas edições audiovisuais ou eletrônicas. Há dez anos, conhecer, utilizar e misturar as inovações de diferentes países resultava em viagens freqüentes, assinaturas de revistas estrangeiras e vultosas contas telefônicas. Atualmente, deve-se renovar periodicamente o equipamento do computador e ter um bom serviço de Internet (Canclini, 2003: XXXVI). Assim:

as modalidades clássicas de fusão, derivadas de migrações, intercâmbios comerciais e das políticas de integração educacional impulsionadas pelos Estados nacionais, acrescentam-se às misturas geradas pelas indústrias culturais (Canclini, 2003: XXXI).

Isto faz com que o ser humano viva cada vez mais em um mundo fluido, interconectado por conjuntos históricos com maior ou menor estabilidade, que se reestruturam em meio a conjuntos interétnicos, transclassistas e transnacionais. Acentua-se a interculturalidade (migratória, econômica e midiática) gerando mercados 
de bens materiais, mensagens e migrantes, propiciando mais formas de hibridismo produtivo, de comunicação e de estilos de consumo (Canclini, 2003: XXIII, XXIV).

A arte e o seu significado mudaram profundamente na era tecnológica: o grande problema é que a estética da arte não deu resposta às modificações. Ocorreu exatamente o contrário, enquanto o caráter das artes visuais e sua relação com a sociedade modificaram-se drasticamente, a estética da arte tornou-se ainda mais estacionária (Dondis, 1991: 27).

Nesse momento, torna-se importante introduzir o conceito de hibridação, ou seja, parte-se do pressuposto de que os processos socioculturais nos quais as estruturas ou práticas discretas ${ }^{51}$ - que existem de forma separada - se combinam para gerar novas estruturas, objetos e práticas. Aborda-se a produtividade e o poder inovador de muitas misturas interculturais, acostumadas a receber diferentes nomes como: sincretismo entre o artesanal e o industrial, o culto e o popular, o escrito e o visual, entre outros temas. Por exemplo, pode-se citar a mudança de imaginário e, conseqüentemente, das representações pictóricas entre as realidades dos períodos pré-colombiano e novo-hispano (figura 46). E posteriormente, com o surgimento das indústrias culturais, o website (o hybridspace) cruza a multimídia e as múltiplas culturas apresentando em um ambiente comum a todos: a Internet, a diversidade cultural de países como Argentina, Brasil e Estados Unidos (Canclini, 2003: XIX, XX).

Freqüentemente a hibridação surge da criatividade individual e coletiva. Não só nas artes, mas também na vida cotidiana e no desenvolvimento tecnológico. Busca-se reconverter ${ }^{52}$ um patrimônio (uma fábrica, uma capacitação profissional, um conjunto de saberes e técnicas) para reinseri-lo em novas condições de produção e mercado (Canclini, 2003: XXII).

Propõe-se, então, reconverter o design cartográfico dos mapas holandeses do século XVII, somando-o á utilização de bases topográficas sistemáticas - já produzidas no século XVIII - e às pinturas panorâmicas do século XIX. Adicionando, finalmente, o uso dos recursos informacionais advindos dos satélites, os digitais e os audiovisuais, explorados principalmente nos últimos vinte anos; com o progressivo aumento da internet e da animação em todo o mundo. Enfim, mesmo fazendo uso de toda a tecnologia possível, o produto final a ser elaborado nesta pesquisa deve manter um ar de artesanal, único, gerando um produto de grande auxílio - prático e promocional - ao setor do turismo.

Recorde-se palavras de Canclini (2003: 253) ao abordar a problemática pós-moderna, no sentido de que o moderno se fragmenta e se mistura com o que não é moderno.

\footnotetext{
${ }^{51}$ É resultado de hibridação, pois não podem ser consideradas fontes puras. Isto porque, ao longo da história, o ser humano passa de formas mais homogêneas a outras mais heterogêneas e vice-versa, sem que nenhuma seja plenamente pura (Canclini, 2003: XIX, XX).

${ }^{52} \mathrm{O}$ termo é usado para explicar as estratégias mediante as quais um pintor se converte em designer, os operários que reformulam sua cultura de trabalho ante as novas tecnologias produtivas, etc. (Canclini, 2003: XXII).
} 
Atualmente, os artistas usam tecnologias avançadas e, ao mesmo tempo, olham para o passado no qual buscam certa densidade histórica ou estímulos para imaginar.

\section{Figura 46 - A mudança das representações icônicas ao longo do tempo e cultura}

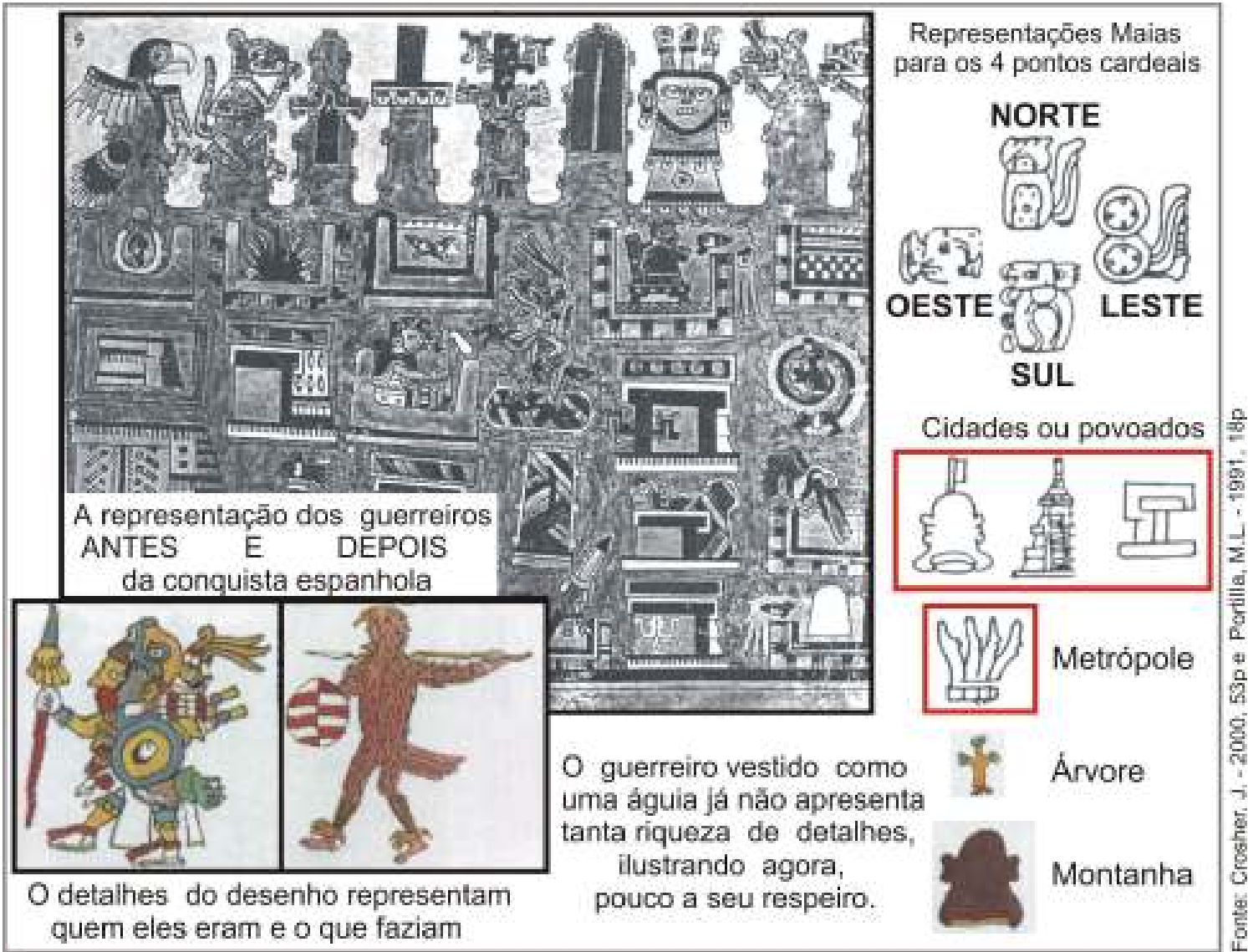

Por essas razões, sustenta-se que o objeto de estudo nesta pesquisa não é a hibridez, mas sim, os processos de hibridação. A análise empírica desses processos, articulados com estratégias de reconversão, demonstra que a hibridação interessa tanto aos setores hegemônicos como aos populares, pois ambos querem se apropriar dos benefícios da modernidade (Canclini, 2003: XXII).

Um último e importante enfoque a ser exposto tendo como resposta o grande uso da pictografia em mapas turísticos diz respeito ao problema da subjetividade, problema apontado ao longo de todo o trabalho como potencial e inerente a este tipo de representação gráfica.

Partindo desta afirmação, pode-se afirmar que a alfabetização pela linguagem verbal (aprendizagem da leitura e escrita) é mais eficaz do que a linguagem visual?

De uma maneira geral, Dondis (1991: 15) ressalta que, devido a sua estrutura sintética, pela linguagem verbal as pessoas se alfabetizam em um processo dividido 
em etapas, contando com uma estrutura relativamente bem organizada. Primeiro se aprende um sistema de símbolos, representados por formas abstratas de determinados sons (grupo de símbolos sonoros): o alfabeto. $O$ segundo passo é aprender as combinações das letras e de seus sons, formando assim as palavras, que se constituem como representantes ou substitutos das coisas, idéias e ações. Por fim, aprende-se uma sintaxe comum (língua específica: português, inglês, japonês, húngaro) que limita o alfabetismo verbal e, mesmo em sua forma mais simplificada, representa uma estrutura dotada de planos técnicos e definições consensuais.

Entretanto, é exatamente aí que o alfabetismo visual tem uma força especial, pois a linguagem verbal encerra-se em um grupo de pessoas que compartilha o significado atribuído a um corpo comum de informações. Todavia, de acordo com Dondis (1991: 16) existem mais de três mil línguas em uso corrente no mundo, todas elas mais ou menos independentes e únicas. Conseqüentemente, em termos comparativos, a linguagem visual é considerada mais universal, por fazer uso de conjuntos lógicos. Faça-se aqui um destaque quanto à enorme importância que esta autora confere ao uso da palavra alfabetismo em conjunção com a palavra visual. Segundo suas palavras, mesmo a visão sendo natural, a criação e compreensão da mensagem visual são naturais até certo ponto, pois sua total eficácia só pode ser alcançada por meio do aprendizado. Expandir a capacidade de "ver" (formar imagens mentais) significa ampliar a capacidade de entender e criar uma mensagem visual.

A informação visual advém de significados obtidos pelo ensino formal e informal, que são paulatinamente incorporados pelo indivíduo a partir de experiências compartilhadas no ambiente e na vida, fazendo com que ele possa manter uma relação mais competente com o mundo. Compartilha-se, por exemplo, o mundo da natureza: o céu azul, o mar verde-esmeralda, as árvores verticais, a areia áspera, a terra úmida, o fogo vermelho-alaranjado-amarelo, a noite e o dia (claro-escuro).

Essas são apenas algumas qualidades denotativas possíveis de serem indicadas e que são compartilhadas visualmente em sociedade. Existe também o mundo criado: as cidades, os aviões, as casas e as máquinas, as manufaturas e outras tecnologias modernas. A humanidade aprende instintivamente a compreender e a atuar psicologicamente nesses mundos e, intelectualmente, convive e opera com esses ambientes e objetos necessários a sua sobrevivência. Deste modo, conscientemente ou não, a sociedade responde com alguma conformidade o significado desses elementos (Dondis, op. cit.: 32; 85).

Dondis (op. cit: $85-86$ ) ratifica que tanto instintiva quanto intelectualmente grande parte do processo de aprendizagem é visual. A reprodução desse tipo de informação deve ser acessível a todos, sendo ensinada e podendo, portanto, ser aprendida. Porém é preciso sempre observar que, na aprendizagem visual, não existe um sistema estrutural arbitrário e externo semelhante ao da linguagem verbal. Então, de que maneira a comunicação visual pode ser entendida, aprendida e expressa? 
Parte-se do pressuposto de que a informação visual é facilmente obtida por meio dos diversos níveis de experiência direta ao ato de ver e reconhecer (Dondis, 1991: 8687), como, por exemplo, um pássaro, uma casa, uma bicicleta, uma árvore, uma montanha, uma praia, etc. Essa capacidade ainda amplia o conhecimento da realidade-concreta do indivíduo, que generaliza toda uma espécie a seus atributos básicos, ou seja, o tipo pássaro, casa, homem, mulher, bicicleta, são definidas em termos visuais elementares, podendo ser identificados de uma forma geral. Isto significa que todos os elementos compartilham referências visuais comuns dentro de uma categoria mais ampla. Apesar disso, ao querer representar um elemento em classificações individuais, deve-se trabalhar com os detalhes mais sutis de cor, proporção, tamanho, movimento e sinais específicos (mais linhas) para que se possa distinguir, por exemplo, uma gaivota de uma pomba ou uma cegonha (Figura 29).

\section{Figura 47 - Maneiras de se representar um pássaro}

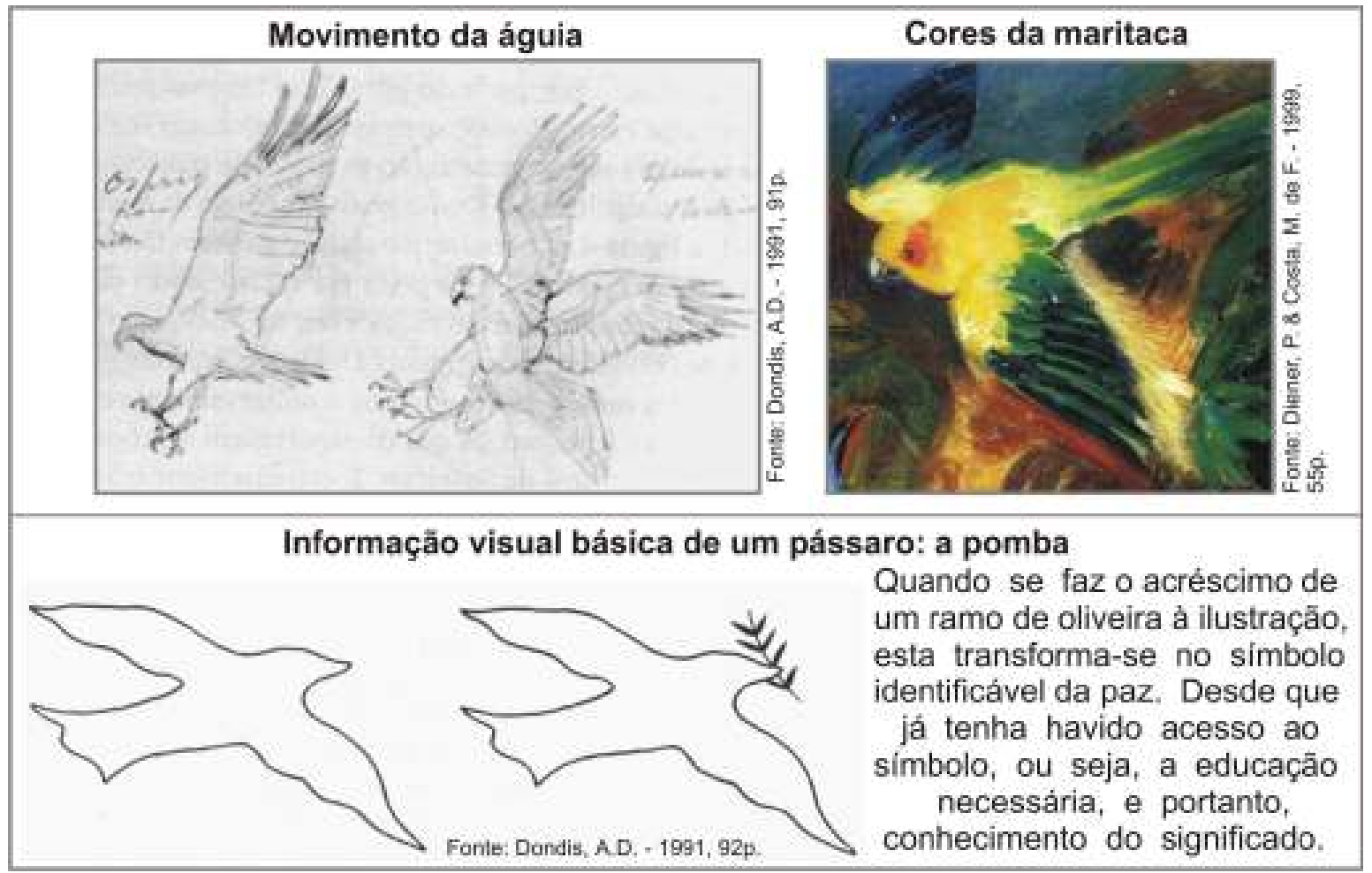

Em relação ao ensino formal, Dondis (1991: 17) critica o sistema educacional (em todos os níveis) por tratar a abordagem visual com quase desinteresse. Métodos construtivos de aprendizagem visual são pouco explorados e ficam a critério da intuição e do acaso, a não ser quando se trata daqueles alunos especialmente interessados e talentosos para o desenho. A sociedade persiste ainda em conferir mais importância à expressão verbal, excluindo o restante da sensibilidade humana. No caso da criança, a experiência visual é fundamental em sua aprendizagem. Posteriormente, a utilização de recursos visuais - filmes, slides, projeções 
audiovisuais - carecem de rigor e objetivos bem definidos no ensino, sendo usados somente como apresentações que reforçam sua experiência passiva. Em suma:

a comunicação visual ficou ao sabor das fantasias e de amorfas definições de gosto, quando não da avaliação subjetiva e auto-reflexiva do emissor ou do receptor, sem que se tente ao menos compreender alguns dos níveis recomendados que esperamos encontrar naquilo que chamamos de alfabetismo no modo verbal (Dondis, 1991: 17).

Todo esse desinteresse atribuído ao sistema visual pode ter como causa dominante a complexidade, pois, mesmo sendo composto de um sistema perceptivo básico (linha, forma, luz e sombra, cor, textura e proporção) comum a todos os seres humanos, tal sistema está sujeito a variações nos temas estruturais básicos. De maneira simplista, pode-se exemplificar o que foi dito acima, pontuando que ninguém desenha da mesma forma um elemento ou ação encontrada na realidade, sem contar as outras nuances constitutivas do desenho, como a perspectiva, a cor, etc.

Segundo Dondis (1991: 19) uma coisa é certa, no geral: o alfabetismo visual jamais poderá ser um sistema tão lógico e preciso quanto a linguagem verbal, pois sua estrutura tem uma lógica que o alfabetismo visual é incapaz de alcançar.

Por outro lado, a compreensão visual é um processo natural. O que precisa ser feito é um refinamento de percepção permitido pelo alfabetismo visual. O caminho não é o mesmo que o da linguagem verbal, onde existe um substituto que precisa ser reduzido de um estado para outro. No ato perceptivo visual ${ }^{53}$, uma maçã é a mesma coisa tanto para um inglês quanto para um francês, ainda que o primeiro a chame de apple, e o segundo de pomme, e assim por diante. Dentro desse contexto, o que a linguagem verbal difere da comunicação visual é a possibilidade de evitar a ambigüidade das pistas visuais, tentando então, expressar as idéias de modo mais simples e direto. Sofisticação excessiva e a escolha de um simbolismo complexo podem trazer dificuldades na comunicação visual intercultural (Dondis, op. cit::186).

Por isso, faz-se necessário cada vez mais o entendimento sobre a comunicação visual, devido a sua inegável força como meio de comunicação. Não se poderá manter por muito mais tempo uma posição de ignorância diante do alfabetismo visual. Dondis (op. cit.: 11; 185) aclara sobre o poder constituído à mensagem visual a partir de alguns casos históricos:

\footnotetext{
${ }^{53}$ Pela percepção visual, a pessoa vivencia uma interpretação direta daquilo que está vendo. Todas as unidades individuais dos estímulos visuais interagem, criando um mosaico de forças saturadas de significado, exclusivo do alfabetismo visual e passível de ser diretamente absorvido com muito pouco esforço, se comparado à lenta decodificação da linguagem vebal (Dondis, 1991: 188). A inteligência visual transmite informação em uma extraordinária velocidade, tanto que, estando os dados claramente organizados e formulados, a informação fica mais fácil de ser absorvida, retida e utilizada referencialmente (Dondis, op.cit::188).
} 
$\checkmark$ Os afrescos de Michelangelo no teto da Capela Sistina foram diretamente influenciados pelo papa, pois as pinturas representam as necessidades que a igreja tinha de informar seus fiéis sobre a história bíblica. Procurou-se, então, uma maneira de explicação visual sobre a "Criação" a um público que, em sua maior parte, era analfabeto; logo, incapaz de ler sobre a história bíblica.

$\checkmark$ Meios visuais com finalidades educativas também foram utilizados na campanha de controle demográfico na Índia, na doutrinação política em Cuba e na identificação de partidos políticos no mundo inteiro.

O exemplo da figura 48 ilustra a importância do elemento visual em uma representação. Portanto, é inquestionável a eficácia da mensagem visual entre as populações que não compartilham da mesma linguagem verbal.

Figura 48 - 0 experimento de Ryan e Schwarz

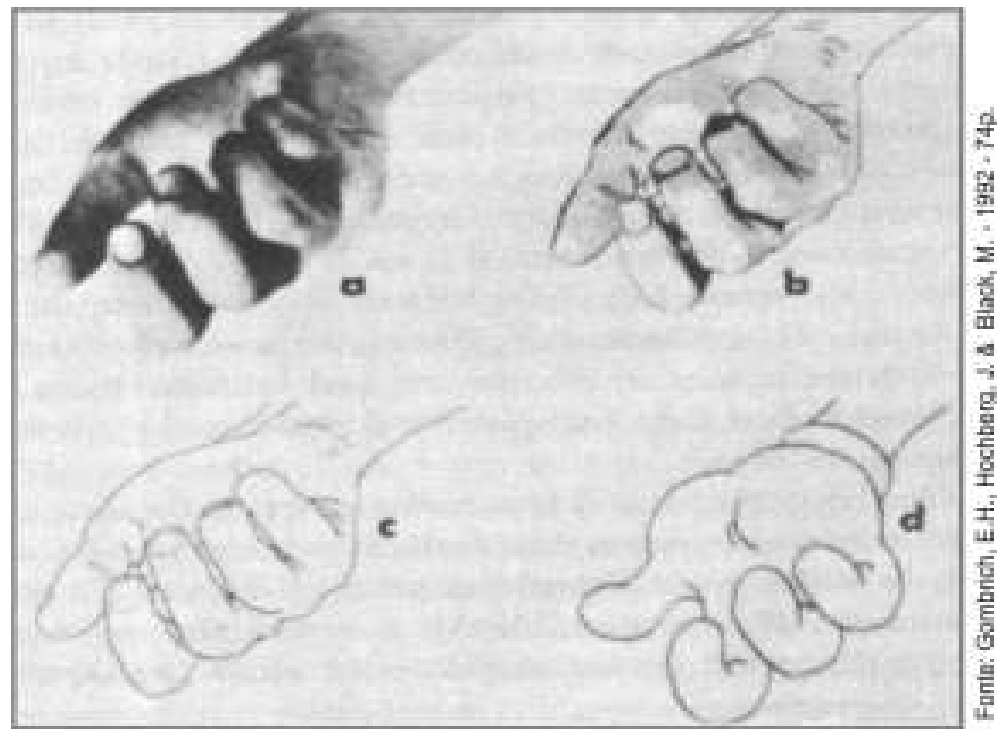

O que deve ser feito é adaptar, aproveitar e melhorar este certo alfabetismo visual buscando abranger o maior número de culturas possíveis. Abre-se então um outro questionamento, alusivo ao tipo de representação que seria mais bem aproveitada na elaboração dos mapas pictóricos turísticos.

Deve-se levar em consideração a experiência direta do observador em qualquer nível da escala de expressão visual - da foto ao esboço impressionista - onde toda experiência do "ver" está fortemente sujeita à interpretação individual, subjetiva. A idéia é utilizar aquelas composições estilísticas mais simples, diretas, genéricas, que possam ter o mesmo tipo de compreensão pelo maior número de pessoas. Pesquisas anteriores (Fiori 1999 e 2003) indicam que o estilo artístico da caricatura de traços simples é um dos recursos visuais mais adequados para a elaboração de mapas pictóricos para destinações turísticas. 
A caricatura tem sido definida desde o século XVII como um modo de representação que objetiva a semelhança em relação ao elemento contido na realidade. Entretanto, nesse processo de transformação, todas as partes componentes - propriedades físicas dos objetos - passam por mudanças. Tanto que a caricatura captura somente a essência do objeto representado - faz possível um vocabulário visual mais compacto - sendo a prova de que as imagens da arte podem ser convincentes sem serem objetivamente realistas (Gombrich, Hochberg \& Black, 1992:1).

Ryan e Schwarz (apud Gombrich, Hochberg \& Black, 1992:74) compararam quatros tipos de representações, tendo como referência o mesmo elemento - uma mão (figura 30), que foi representada em fotografia (a), em desenho sombreado (b), em contorno traçado diretamente de uma fotografia (somente linhas) (c) e em cartoons (desenho, caricatura) (d). As representações eram expostas e recolhidas em pequenos espaços de tempo. O resultado foi o seguinte:

$\checkmark$ O cartoon precisou do menor tempo de exposição se comparado aos outros tipos de representação, obtendo o maior índice de correção quanto a sua percepção. Trouxe uma representação com características marcantes, simples e simplificada do elemento.

$\checkmark$ A fotografia, por possuir um alto grau de fidelidade com o mundo real-concreto, apresenta formas mais complexas e desnecessárias à compreensão do elemento. Por isso, obteve um resultado intermediário, como também o desenho sombreado.

$\checkmark$ Já a representação, que contou somente com o contorno traçado (linha), precisou de maior tempo de exposição para ser compreendida.

A partir de agora serão abordadas as técnicas e elementos gráficos necessários ao desenvolvimento do mapa turístico pictórico. 


\section{CAPÍTULO 2}

Técnicas e procedimentos utilizados na elaboração dos mapas turísticos e do protótipo mapa-site turístico 


\section{1 - As mídias e suas respectivas técnicas: trabalhando a forma e o conteúdo}

A partir das três dimensões do signo: sintática (forma), semântica (conteúdo) e pragmática (função) - ver páginas 91 a 100 - serão realizados estudos, buscando elaborar imagens gráficas eficazes ao desenvolvimento do mapa turístico pictórico. Enfocam-se neste momento somente as duas primeiras dimensões; entretanto, julgase importante destacar que, mesmo com o estabelecimento dos valores sintáticos, semânticos e pragmáticos na elaboração de um mapa turístico pictórico, o material cartográfico não fica imune à subjetividade, pois é uma confecção gráfica cultural.

Para fundamentar a proposta de trabalho, cita-se Souza (1992), que apresenta os signos gráficos em quatro grupos específicos: os diagramas, as redes, as cartas (mapas) e o grupo dos simbólicos. Os três primeiros itens fazem parte de um mesmo grupo, nomeado por Bertin (1967) de Graphique (Gráfica); já o último item está no campo do grafismo. Em essência, esses dois grupos apresentam objetivos e métodos de transcrição distintos ao comunicarem a informação. Devido aos fins buscados por esta pesquisa, serão ressaltados somente dois grupos: o mapa e grafismo (Figura 49).

O desenvolvimento do mapa turístico pictórico se utilizará principalmente das funções caracterizadoras e universais do signo, objetivando um sistema de linguagem que traga boas expectativas de interpretação pelo usuário potencial. A criação de todo o repertório simbólico e gráfico a ser elaborado deve ser denotado satisfatoriamente, buscando atingir o maior número de usuários - o que revela seu caráter universal por serem apreendidos enquanto códigos (Carneiro, 2001:33).

Souza (1992: 123) sustenta que existem técnicas visuais para controle do significado icônico fundamentadas em uma poderosa ferramenta de expressão, que é o contraste entre dois opostos semânticos. Isso porque, o contraste tem a capacidade de intensificar e simplificar a comunicação. Dondis (1991: 129-147) apresenta e Souza (1991: 124-126) sistematiza então as vinte técnicas de composição dotadas de qualidades sintático-semânticas mais habitualmente utilizadas na relação harmonia contraste (figura 50).

Ao se abordar mais especificamente a elaboração de representações gráficas eficazes, um outro recurso essencial é a categorização. Segundo Souza (1992: 129):

Em termos de design gráfico, o processo de categorização atende à necessidade de buscar um efeito visual máximo com um mínimo de elementos estruturais (o ponto, a linha, a superfície...). Descobrindo ou inventando equivalências, o designer conforma os signos gráficos aos atributos que o senso comum, a convenção ou os seus próprios critérios pessoais selecionam como relevantes para a representação de algo. 
Figura 49 - Esquema dos tipos de signos gráficos

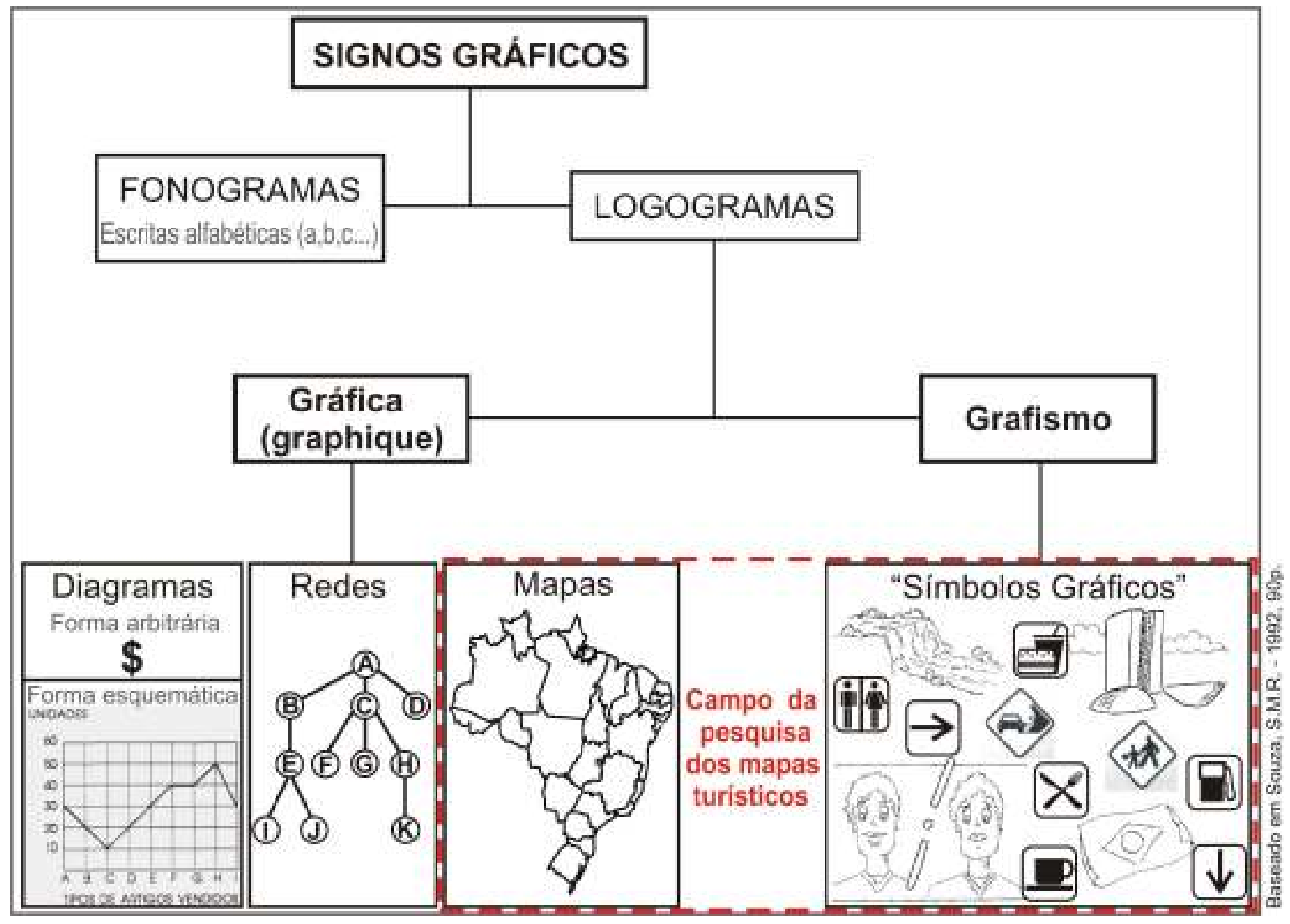

Em um outro momento, Souza (1992: 236) complementa que essa concisão gráfica é resultado de uma redução semântica do conceito aos seus atributos mínimos de discriminação.

Posto isso, leva-se em consideração majoritariamente Dondis (1991: 51-82), Cabanellas (1976), SENAI (1984) e anotações feitas ao longo de cursos de desenho e pintura ${ }^{54}$. Apontam-se, a seguir, a sintaxe básica dos elementos visuais.

\section{1) A linha}

A linha é um dos elementos visuais básicos em uma obra plástica. Suas características intervêm diretamente em uma representação. Cabanellas (1976: 22) afirma que, sendo a linha um instrumento gráfico, ela habilita o produtor a comunicar a situação exata do corpo no espaço, além de auxiliar a criação dos campos de ação e de movimentos. Por meio das linhas, pode-se ainda definir, limitar, de maneira fluente e incansável, infinitos tipos de formas: reta ou ondulada, fina ou delgada, precisa ou indefinida, etc.

${ }^{54}$ Por um ano e meio, tive aulas regulares de desenho mecânico em um curso do SENAI. Posteriormente, ao longo de alguns três anos fiz parte de cursos de pintura (óleo sobre tela). E, já no mestrado, por quase um ano fiz um curso de história em quadrinhos. 
Figura 50 - As qualidades sintático-semânticas dos signos gráficos

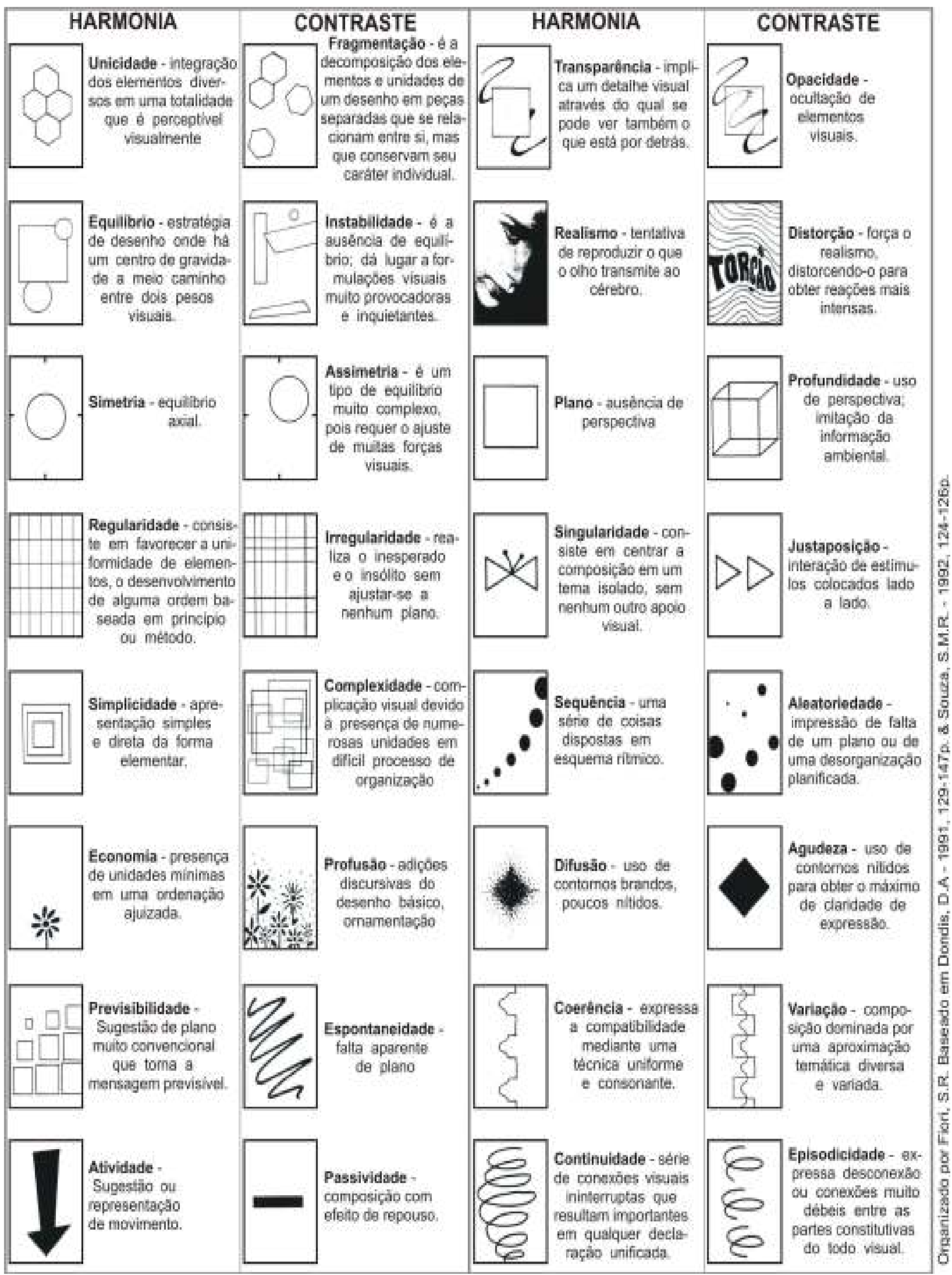


Essa flexibilidade inerente à linha faz com que se possa elaborar desde um solto e despreocupado esboço, até a rigidez de um desenho técnico (Figura 51).

Figura 51 - A linha

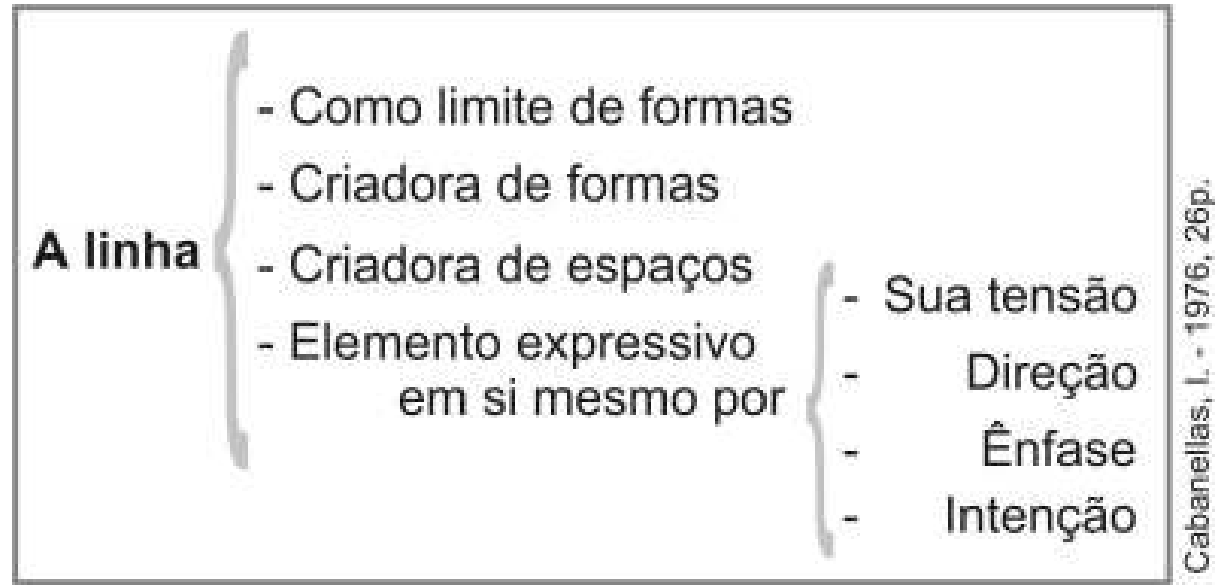

Mesmo com toda sua importância, a linha é o único dos elementos visuais aqui abordados que não existe no plano concreto, existindo verdadeiramente somente no plano pictórico.

$\mathrm{Na}$ verdade, aprende-se a ver as linhas por conseqüência de um aprendizado intelectual, resultado da autoridade institucionalizada (no caso, a escola) apontada por Bourdieu (2000). Ela tem origem em uma seqüência de pontos (reta) - Figura 52 - apresentando apenas uma dimensão, o que já a capacita estabelecer a diferenciação entre fundo e a figura, relação essencial da linguagem visual.

Figura 52 - Como se origina uma linha

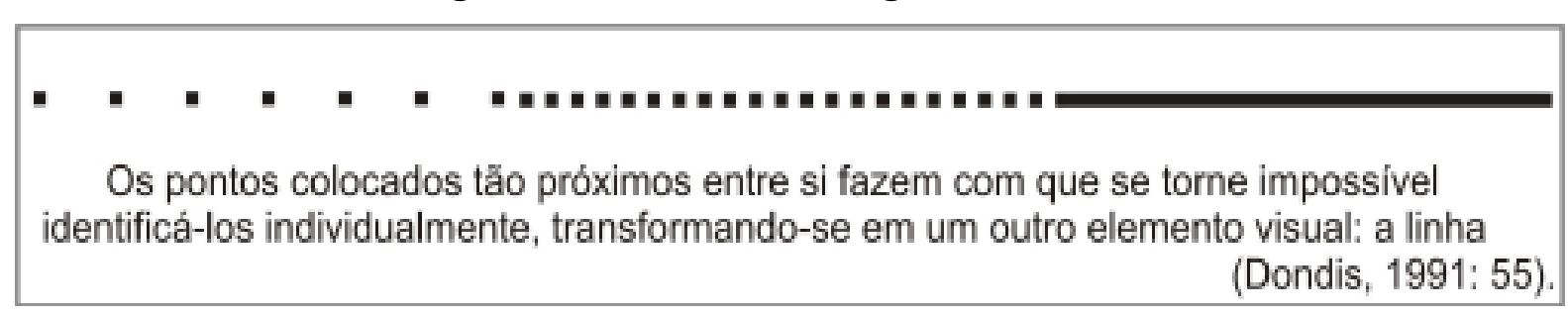

Dondis (1991: 56) refere-se à linha como um instrumento fundamental à prévisualização por ser um meio que apresenta, em forma palpável, aquilo que ainda só existe na imaginação. Contribui, portanto, sobremaneira para o processo visual. $\mathrm{Na}$ arte, a linha é o elemento fundamental ao desenho, por capturar a informação visual, reduzindo e eliminando toda informação visual supérflua. A figura 53 apresenta exemplos distintos de como a linha pode ser trabalhada. 
Figura 53 - A linha e suas possibilidades de expressão
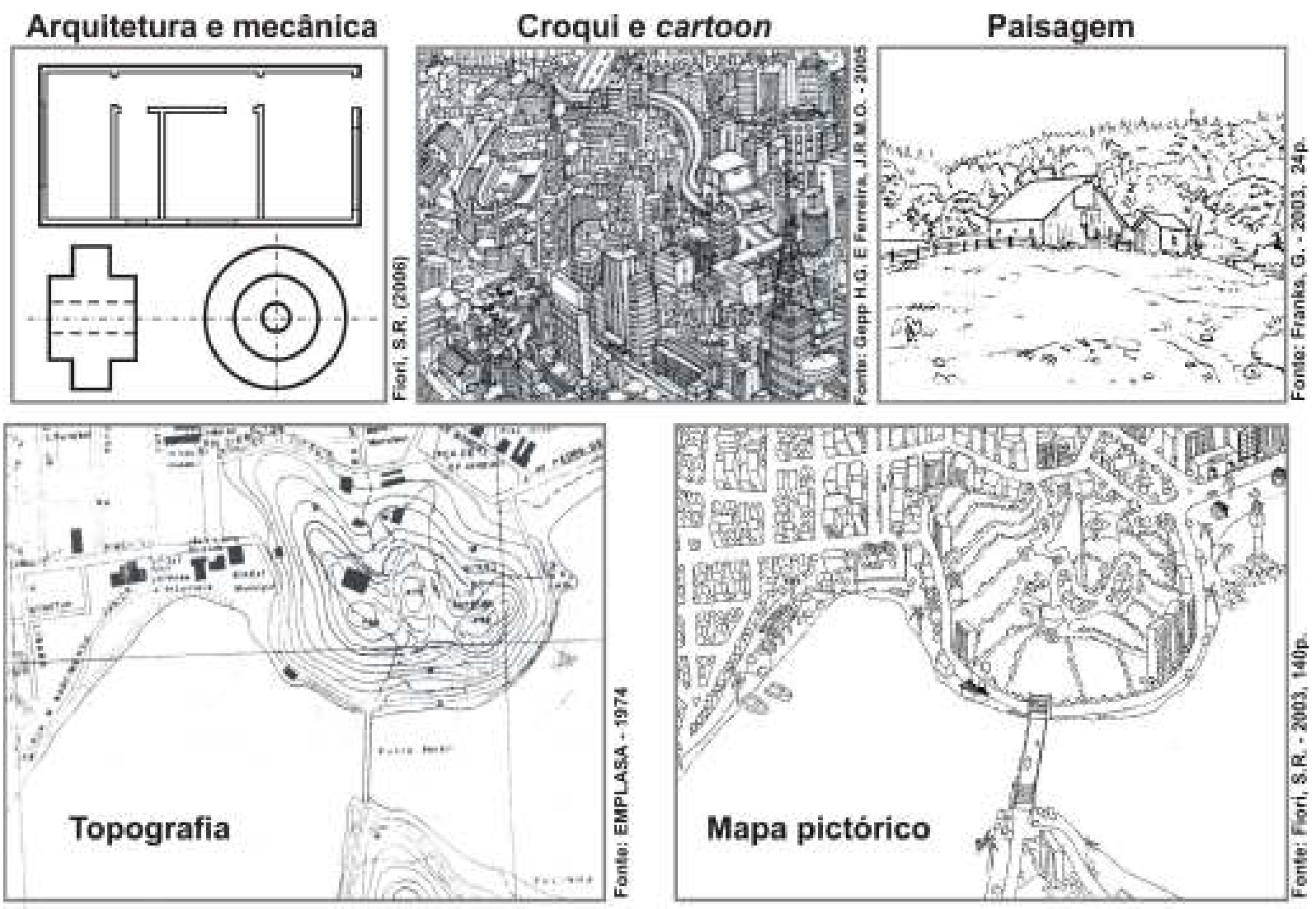

\section{2) A forma: o plano, o volume e a sensação de dimensão}

Como ficou sugerido acima, a linha é capaz de conceber formas. E essas formas já vêm carregadas de significação, pois não são simplesmente observadas, vistas, mas sim lidas, traduzidas, reproduzidas. Conseqüentemente, a impressão que se tem das coisas é terciária e nos vem indiretamente, já manipulada, pela memória ou pelo hábito (Pedrosa \& Arantes, 1996: 142,143).

Dondis (1991: 57) distingue três formas básicas: o quadrado, o círculo e o triângulo eqüilátero, as quais possuem características específicas, e a cada uma atribui uma grande quantidade de significados, alguns por associação, outros por vinculação arbitrária, e outros, ainda, através de nossas próprias percepções psicológicas e fisiológicas. Essas formas permitem combinações e variações infinitas e possibilitam compor outras formas físicas da natureza e da imaginação humana (Dondis, 1991: 59). O exemplo a seguir (Figura 54) remete à cena de em uma feira livre.

Esse discurso ainda leva em consideração que é inerente, à maior parte das formas, apresentar a dimensão e o volume ocupado no espaço, ou seja, a representação de um elemento necessita de técnicas preocupadas em ilustrar as formas tridimensionais (comprimento, largura e altura), mesmo que estejam compreendidas em um plano 2D, 
onde só possuem comprimento e largura, caso dos mapas pictóricos turísticos.

Figura 54 - Feira livre: formas básicas de uma representação gráfica

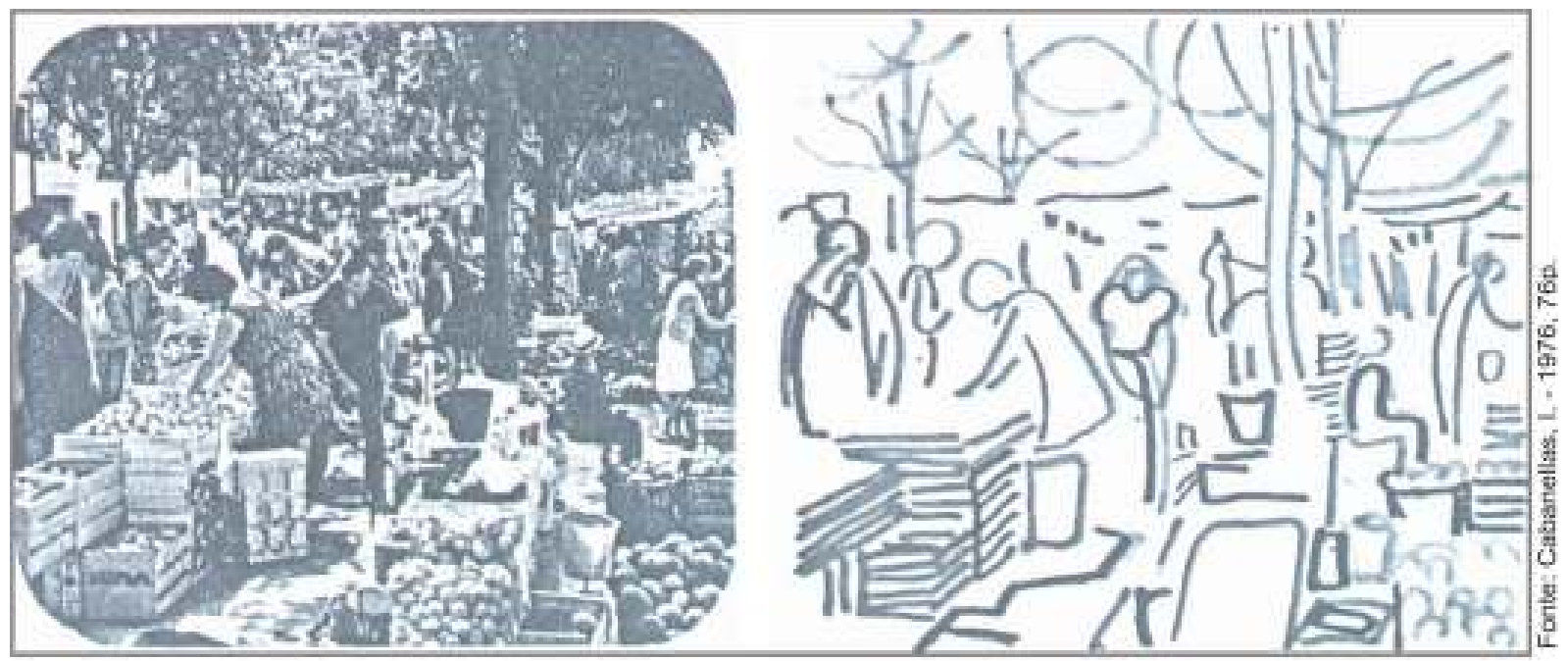

Dondis (1991: 75) esclarece, então, que o ilustrador faz uso do ilusório para dimensionar a representação em formatos visuais de natureza bidimensional. Graças a esse recurso, que é subentendido pelo observador uma vez que ele não possui uma dimensão real da representação, o aspecto ilusório pode ser reforçado de muitas maneiras. O principal artifício para simulá-lo é a convenção técnica da perspectiva, sendo que a intensificação da ilusão pode ocorrer de forma ainda mais forte ao se fazer uso da variação tonal (claro-escuro), enfatizando a luz e a sombra.

Dessa maneira, apoiados no desenho linear plano (bidimensional) e, portanto nas formas geométricas básicas, geram-se os sólidos geométricos e de revolução. Eles são compostos pelas três dimensões: comprimento, altura e largura, concebendo assim o cubo, o prisma, a esfera e o cilindro. A figura 55 mostra desenhos confeccionados em 2D (figuras) e em 3D (sólidos).

Tuan (1980: 155) data o uso desse tipo de representação somente a partir do século XIV. As primeiras experiências com profundidade espacial se deram na França e na Inglaterra. A nova técnica era então utilizada nas paredes das vilas italianas no período Renascentista, onde se pintavam paisagens que serviam tanto para alardear as riquezas de seus proprietários como para permitir o desfrute da ilusão de perspectiva panorâmica.

Essa técnica produz o efeito de representar o plano pictórico tal como é visto no plano concreto, ou seja, o(s) elemento(s) ocupa $(\mathrm{m})$ e define $(\mathrm{m})$ determinado lugar no espaço: vertical, horizontal, oblíquo, caracterizando-se por uma determinada posição, forma e tamanho. O produtor, ainda auxiliado pelas formas em três dimensões, cria possibilidades de sensações espaciais 3D em representações 2D (Cabanellas: 1976: 
40). Entretanto, é importante ressaltar que um objeto único é infinitamente mais fácil de ser representado se comparado a um recorte da paisagem.

Figura 55 - Figuras e sólidos geométricos

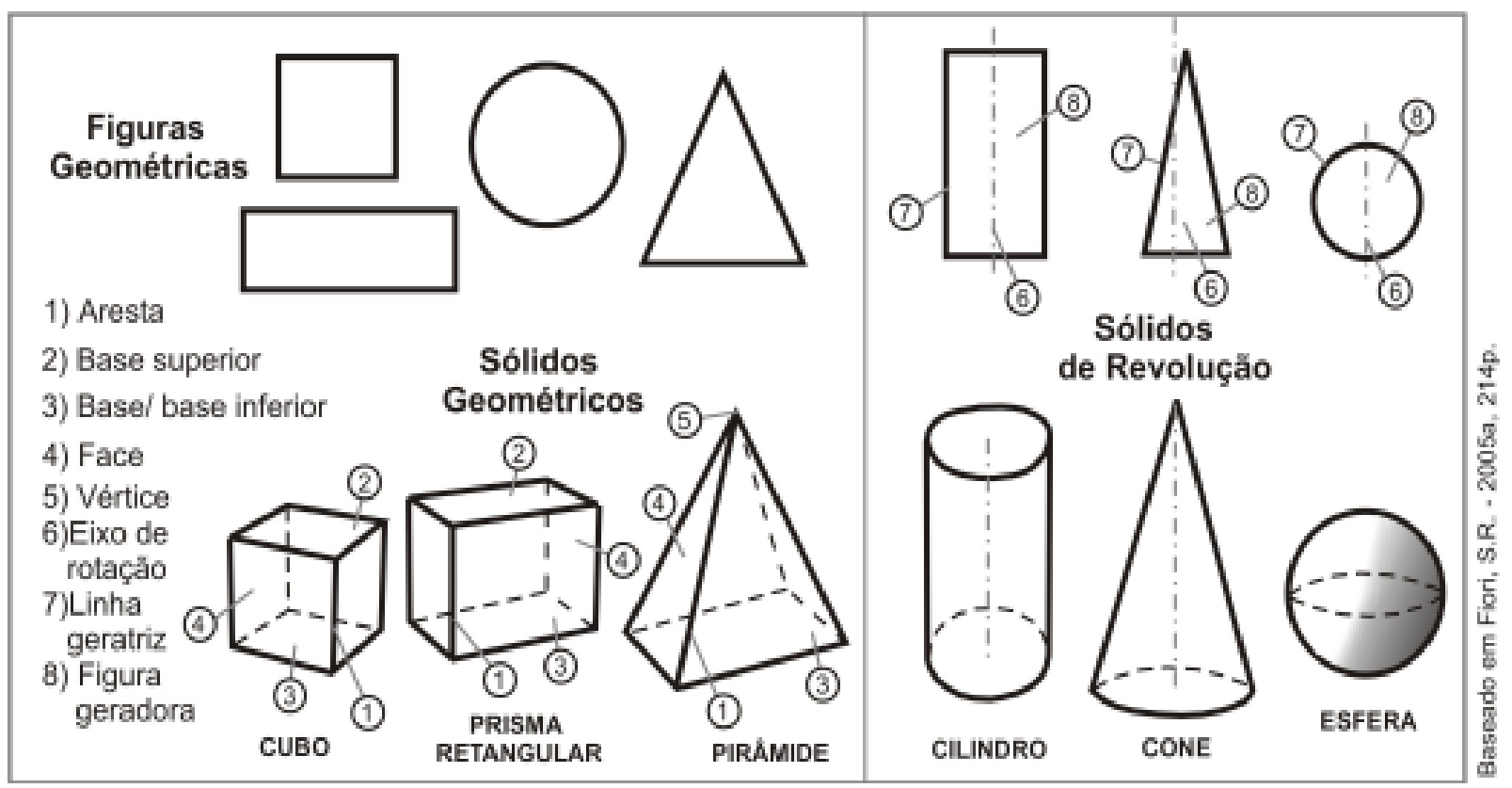

O desenhista mais atento, por exemplo, irá se defrontar com diferentes tipos de formas do terreno (vales, colinas, morros, falésias), de vegetação, da hidrografia, de ações humanas, etc. Enfim, abstrair, suprimir, ressaltar e estilizar os elementos contidos na paisagem faz parte da realidade do mais meticuloso ilustrador, que sempre recorrerá a uma técnica que lhe possibilite dar, a um desenho, a sensação de realismo ou a "caricatura" de uma realidade.

Segundo Cabanellas: 1976: 40), as formas a serem desenvolvidas e distribuídas sobre o mapa pictórico devem ser criadas e carregadas de intenção, tendo em si mesmas uma força expressiva que seja capaz de atrair a atenção do espectador sem nenhuma outra mediação.

A figura 56 exemplifica alguns planos pictóricos em perspectiva que podem ser usados para se confeccionar esboços e croquis, ilustrações, perfis, esquemas e blocos-diagrama. No item 2.3, em que se trata dos elementos que compõem a multimídia interativa, demonstra-se de maneira prática como produzir ilustrações e cenários a partir de diferentes tipos de perspectivas.

\section{3) Luz e sombra}

Só se percebem plenamente as formas que compõem os elementos do plano concreto, como os sólidos e representações tridimensionais, graças à relação complementar que ocorre entre a luz e a sombra, até porque a luz não se irradia com uniformidade no meio ambiente. As variações de luz (refletida pelo sol, lua ou alguma 
fonte artificial) ou de tom são os meios pelos quais o observador percebe, distingue oticamente, a complexidade da informação visual do ambiente (Figura 57).

Figura 56 - Exemplos de planos pictóricos em perspectiva
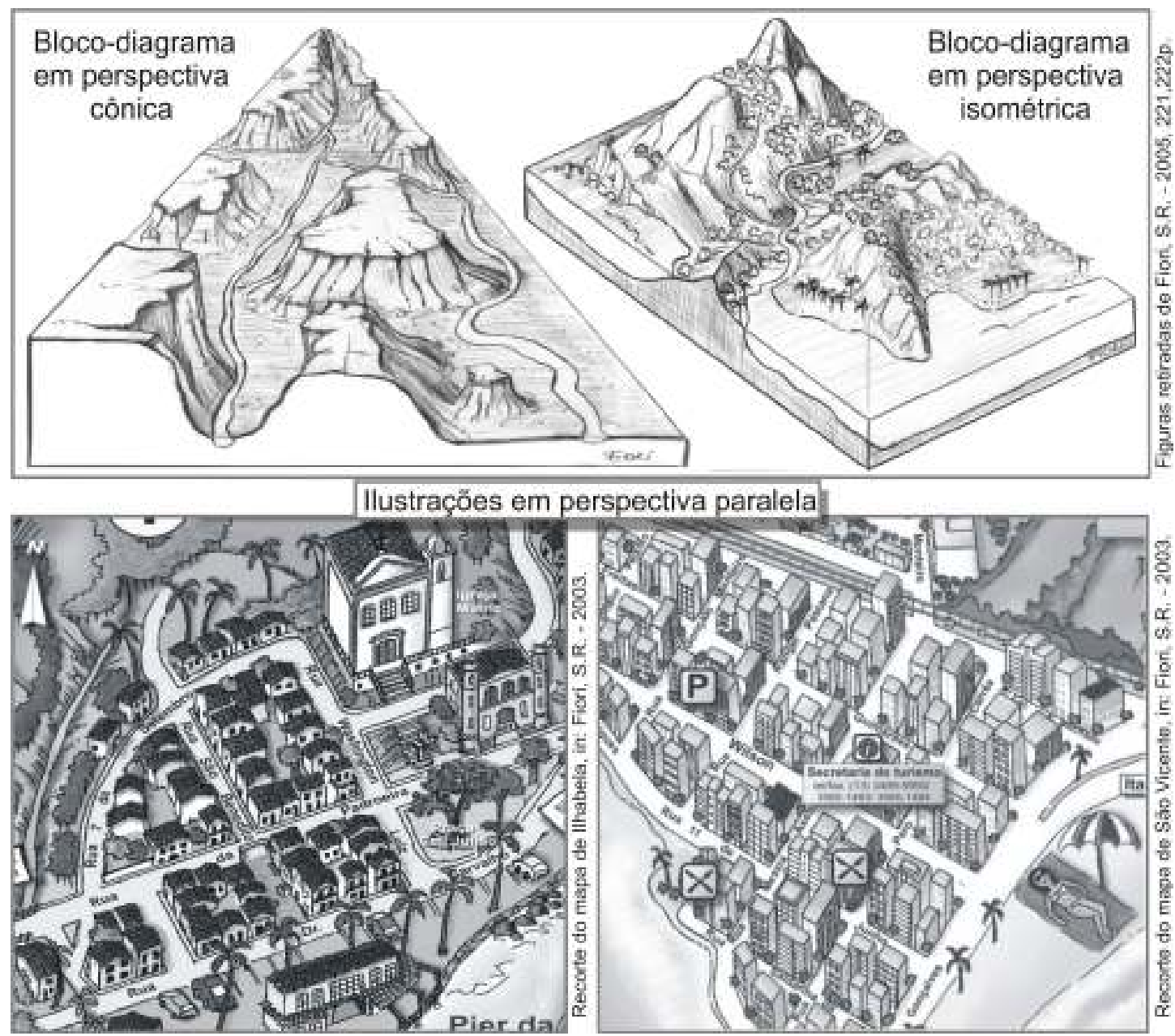

Figura 57 - Luz e sombra proporcionando o efeito tridimensional

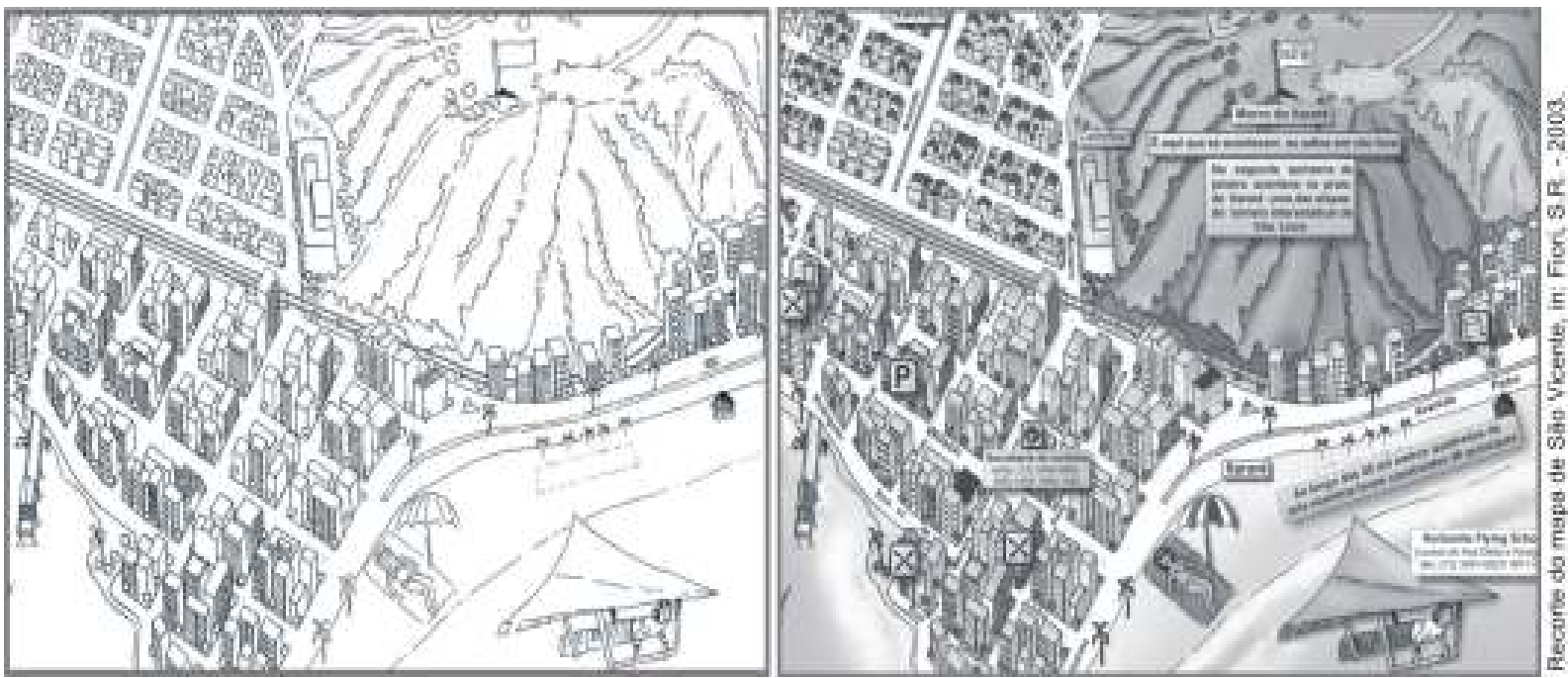


O ato de visualização está diretamente vinculado à fisiologia, ou seja, a visão proporciona um efeito no qual as áreas mais claras avançam, saltam aos olhos, ao passo que as áreas escuras retraem. Um ilustrador, então, faz uso efetivo do recurso avanço-recuo de acordo com o que quer representar. A partir de dois extremos: claro e escuro, trabalham-se outras intensidades, que combinadas a tons intermediários, envolvem o decodificador, ou seja, aquele que vê a ilustração, em uma atmosfera que previamente se idealiza (Figura 58).

\section{Figura 58 - 0 efeito luz e sombra na esfera e no sólido facetado}

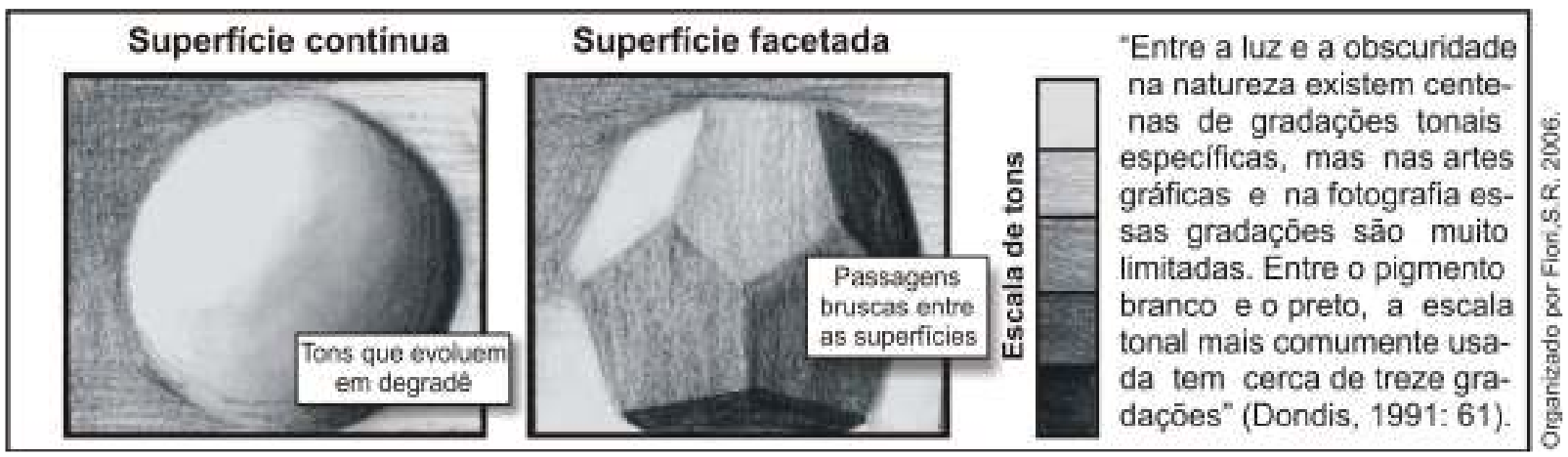

Sendo assim, o tom conforma-se como um importantíssimo recurso visual na composição de alternativas para se indicar e expressar as dimensões da paisagem. Até porque o uso da perspectiva, somente apoiada nas linhas, não consegue criar uma ilusão tão convincente da realidade. As nuances entre tons claros e escuros é de tal maneira importante na percepção do ambiente, que o usuário acolhe facilmente uma representação monocromática da realidade.

Ainda dentro do tema claro-escuro, não se pode deixar de lembrar que, ao compor uma ilustração, também se trabalham os contrastes que, sem dúvida, é um poderoso instrumento de expressão, por ter a capacidade de intensificar o significado, e, portanto, facilitar a comunicação. O contraste é uma força de oposição tonal que desequilibra, choca, estimula, chama a atenção (Dondis, 1991:108). A autora finaliza, na página 109 dizendo que, no alfabetismo visual, a importância do significado do contraste começa no nível básico da visão ou da ausência desta, através da presença ou da ausência de luz.

Após a elaboração do plano pictórico, onde se desenham linhas, figuras e formas tridimensionais, escolhe-se a direção da fonte de luz, enquadrando quais áreas da ilustração a receberão, buscando, então, um sombreado apropriado (Figura 59). 
Figura 59- Composições em luz e sombra

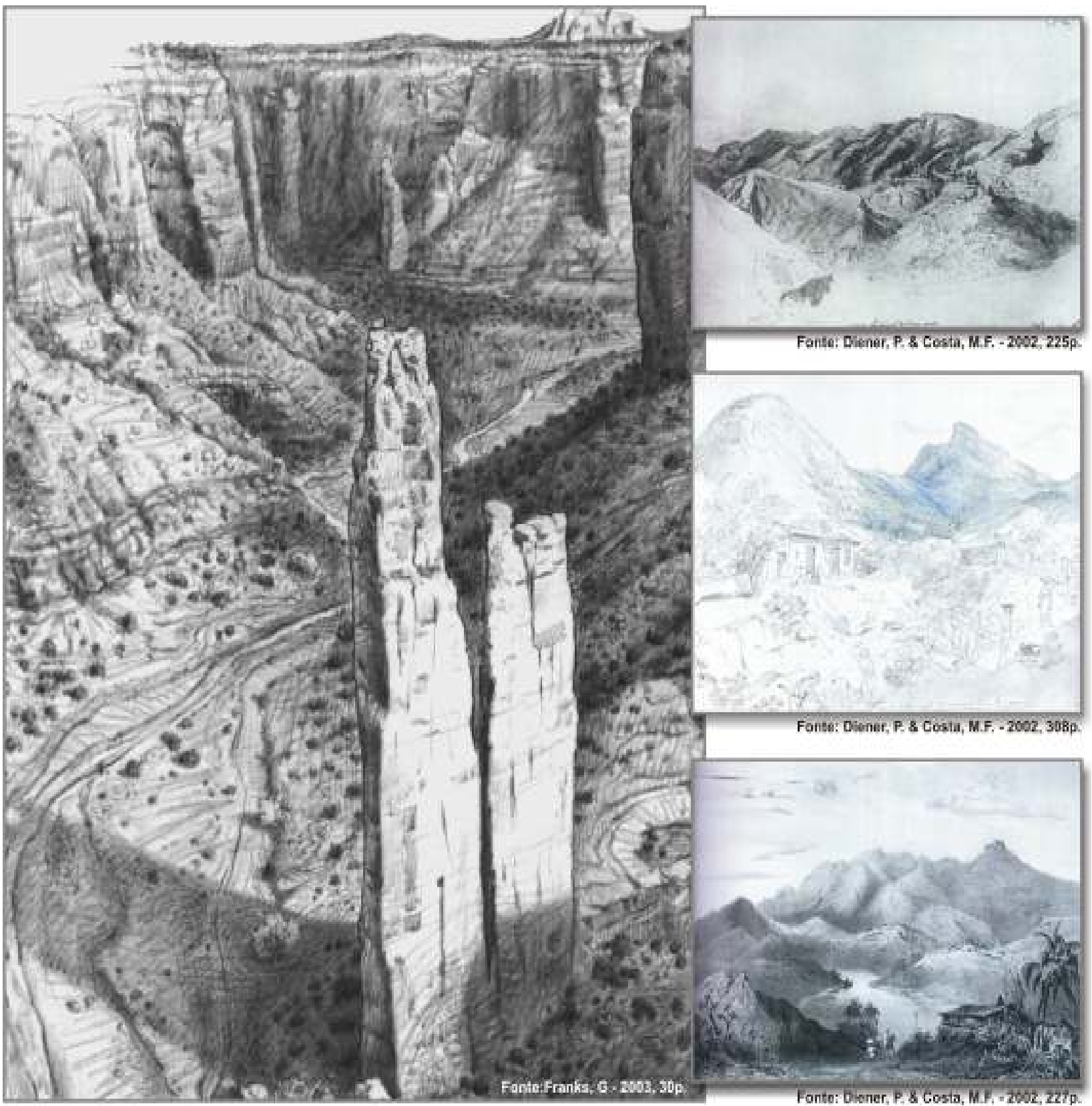

\section{4) Cor}

O autor de uma obra gráfica tem, na cor, um dos recursos fundamentais ao desenvolvimento de seu trabalho. Entretanto, é importante saber como melhor utilizála, pois quando as cores não estão corretas podem dificultar, ou mesmo invalidar, a aquisição do que se informa.

Segundo o site Desenhador Virtual (2005), encontrar a cor perfeita para uma representação gráfica não é tarefa fácil. Por exemplo, é importante saber utilizar o verde mais adequado para representar uma floresta que remeta à grandiosidade da natureza, a aparência "sadia" da paisagem. Contudo, ao se recorrer a um tom verde mais amarelado e/ou fraco, é bem provável que esse esplendor desapareça. Efeito 
semelhante aconteceria com os tons vermelhos, que deveriam ser resplandecentes e brilhantes, ou seja, se os tons forem enfraquecidos, será transmitida uma imagem apática e deprimente da vegetação, ao invés de excitação.

Inicialmente, pode-se dizer que a cor é um fenômeno biofísico, sendo uma resposta sensorial, relacionada à radiação eletromagnética. $O$ espectro do comprimento de ondas visível ao olho humano está entre 0,4 e 0,7 mícrons (banda visível). Isto quer dizer que, entre esses limites, o olho e o cérebro conseguem distinguir facilmente os comprimentos de ondas associados a cores denominadas: violeta, azul, verde, amare-lo, laranja e vermelho - Figura 60 (Monmonier, 1996: 164).

Figura 60 - 0 espectro das cores

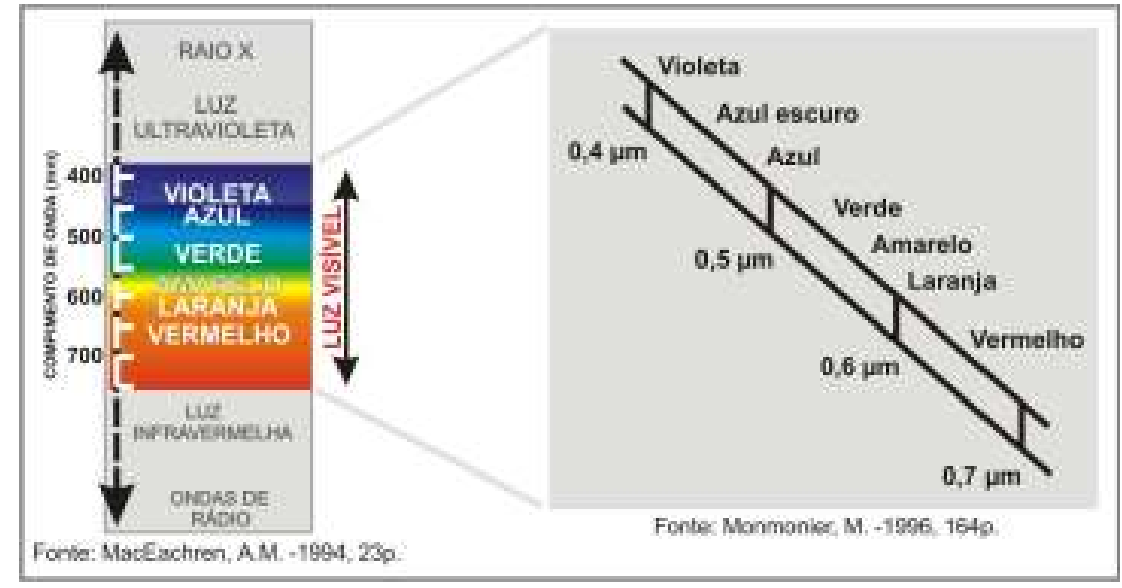

A confecção do mapa pictórico turístico e interativo trabalha com duas formas características da cor, ou seja, existe uma diferenciação muito grande em relação à cor-luz e cor-matéria (Cabanellas, 1976: 55). Segundo Dondis (1991: 109), tudo o que é visto reveste-se de, pelo menos, de duas propriedades: uma qualidade pigmentaria, que tende mais ao branco ou ao preto (relativo ao tom, cor-matéria), e a qualidade física da luminosidade ou da obscuridade (cor-luz). Esses dois tipos de composição tonal trazem características muito distintas, pois a luz física possui uma vasta gama de intensidade tonal, enquanto o pigmento costuma ser utilizado num âmbito limitado de oito a quatorze graus tonais.

A preocupação em entender as duas formas características da cor tem a ver diretamente com o tipo de mapa produzido que, na maior parte do tempo, é visto pela tela do computador, mas também pode ser impresso e utilizado durante viagens e atividades de lazer. E é aí que se estabelece o problema, pois as cores que compõem o mapa sobre o monitor do computador não serão as mesmas encontradas no mapa impresso.

Deste modo, o intuito é trabalhar com cores que possam trazer a mínima diferença 
possível entre o mapa na tela (cor-luz) e o mapa impresso (cor matéria, pigmento ${ }^{55}$ ).

Posto isso, Dondis (1991: 65-66) e Monmonier (1996: 164-167) afirmam que, sendo a cor um fenômeno perceptivo e da arte gráfica, ela é gerada tanto pela luz quanto pelo pigmento. A cor apresenta um comportamento único, possuindo três dimensões, que podem ser definidas e medidas:

$\checkmark$ A matiz é a cor em si e refere-se ao comprimento de onda da radiação eletromagnética. Existe uma grande variedade de tipos, cada qual com características individuais. Os grupos ou categorias de cores compartilham efeitos comuns, e as formulações mais simples podem ser ensinadas pelo círculo cromático (Figura $61 \mathrm{~A}$ ).

$\checkmark$ A saturação, também chamada de croma, preocupa-se com a pureza relativa de uma cor, do matiz ao cinza. É explicita e compõe-se dos matizes primários e secundários. Logo, quanto maior for a intensidade ou saturação de cor ao se elaborar um objeto ou acontecimento visual, mais carregado estará de expressão e emoção (Figura 61 B).

$\checkmark$ Acromática é o brilho relativo, do claro ao escuro, das gradações tonais ou de valor. Neste item, a presença ou ausência de cor não afeta o tom, que é constante. Por exemplo: ao se manipular o botão da cor em um monitor de computador, pode-se deixar a imagem mais ou menos colorida, ou seja, mais ou menos saturada de cor. Essa experimentação jamais afetará os valores tonais da imagem. Portanto, aumentar ou diminuir a saturação, demonstra a constância do tom, provando que a cor e o tom coexistem na percepção, não se modificam entre si. A negritude ou claridade podem ser aplicadas tanto para as cores quanto para os tons de cinza (Figura $61 \mathrm{C}$ ).

A figura $61 \mathrm{D}$ demonstra esquematicamente as variáveis visuais: cor, valor e saturação referenciadas a partir da cor.

A seguir Monmonier (1996: 165, 166), Desenhador Visual (2005) e Macmania (2005) expõem as diferenças básicas entre a cor-luz e a cor-pigmento, divididas respectivamente em cores primárias aditivas e subtrativas.

\footnotetext{
${ }^{55} \mathrm{O}$ pigmento fornece cor a tudo que é material, podendo ser conseguido por vários meios. Os índios o retiram de sementes (urucum), mas também está nas folhas verdes (clorofila), nos minerais (o amarelo/vermelho do óxido de ferro, azul do cobalto, no roxo da terra), etc. O homem então, extrai os pigmentos da natureza, utilizando-os como tinta. Contudo, o desenvolvimento tecnológico fez surgir os pigmentos sintéticos, ou seja, cores conseguidas graças a produtos químicos. Já a tinta é formada pela combinação de resinas, solventes, pigmentos e aditivos. O pigmento dá a cor, o solvente a viscosidade, os aditivos o brilho, opacidade e consistência, e as resinas são responsáveis pelo transporte físico (Macmania, 2005).
} 
Figura 61 - As três dimensões da cor

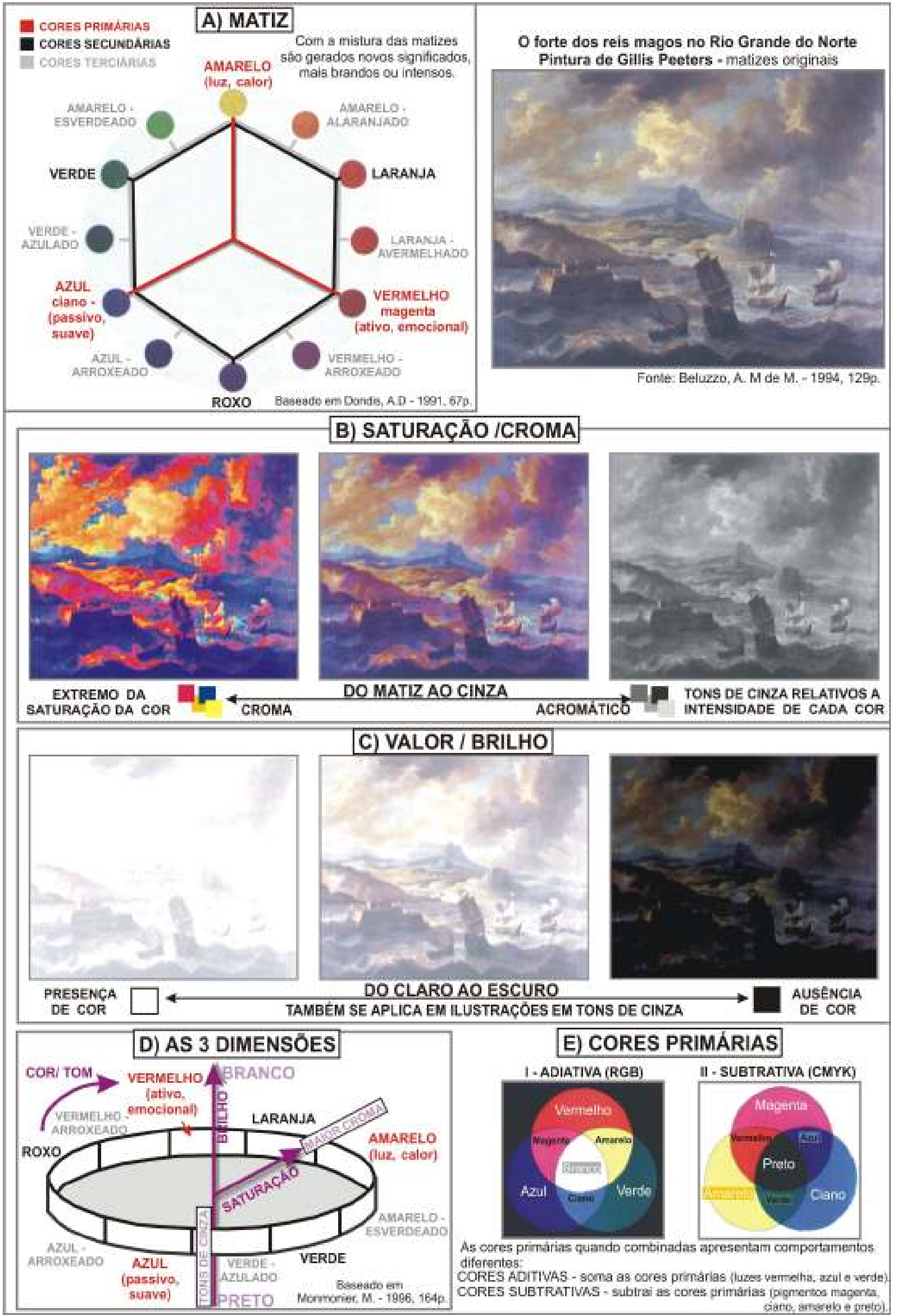


O processo de misturada das cores pode ser feito desde a utilização de luzes até pigmentos extraídos das tintas, vegetais, minerais e produtos químicos (Figura $61 \mathrm{E}$ ).

\section{a) Cor- luz-aditiva (RGB)}

Fundamenta-se em três cores básicas: a vermelha, a verde e a azul que, quando sobrepostas (processo aditivo), formam a luz branca. Ao misturar essas cores duas a duas, geram-se as cores secundárias aditivas (vermelho + verde $=$ amarelo, vermelho + azul $=$ magenta, verde + azul $=$ ciano $)$.

Veja os exemplos: ao apanhar uma maçã vermelha num ambiente claro, a luz que bate e brilha sobre a fruta e o comprimento de onda de vermelho da luz refletem-se da maçã para os olhos do observador, enquanto os comprimentos de onda azul e verde são absorvidos pela maçã. Sensores nos olhos do observador reagem à luz refletida, enviando uma mensagem que é interpretada pelo cérebro como sendo a cor vermelha. Já ao olhar para um girassol, vê-se a cor amarela, pois os comprimentos de onda da luz vermelha e verde são refletidos de volta ao observador, enquanto o azul é absorvido pela planta. E, por fim, quando se vê uma folha branca, todos os comprimentos de onda são refletidos ao observador, porém uma folha preta absorve todos os comprimentos de onda.

O sistema usado para a criação de cores encontradas em um monitor de computador, ou tela de televisão está baseado nas mesmas propriedades fundamentais da luz que ocorrem na natureza. O monitor, tela de TV, cria uma enorme variedade de cores e tons através da emissão de três feixes de luz com diferentes intensidades, advindas da mistura das cores primárias aditivas: vermelha, verde e azul. Para isso, usa o modelo RGB ${ }^{56}$ (vermelho, verde e azul). Nesse modelo, as cores dos pixels podem ser mudadas, combinando-se os vários tons de vermelho, verde e azul.

Uma rápida explicação técnica é que, por exemplo, quando o observador vê a cor vermelha, isso significa que o monitor ativou o feixe de luz vermelha, ascendendo um pixel vermelho na tela.

\section{b) Cor-pigmeto-subtrativa (CMYK)}

Fundamenta-se em três cores básicas: ciano (azul turquesa), magenta e amarelo, funcionando como filtros que subtraem da luz branca certas cores e refletem suas cores complementares. Até porque, sem a luz, nenhuma cor dos elementos encontrados no espaço é percebida. Assim, ao se misturarem às cores primárias subtrativas - duas a duas - geram-se as cores secundárias subtrativas (magenta + ciano $=$ azul, magenta + amarelo $=$ vermelho, amarelo + ciano $=$ verde $).$ Logo, percebe-se que as cores primárias subtrativas são as secundárias aditivas e viceversa.

${ }^{56} \mathrm{O}$ modelo RGB refere-se àqueles equipamentos que emitem luz própria quando mostram suas imagens, como o CRT (tubo de raios catódicos) ou o LCD (cristal líquido); ou seja, monitores e aparelhos de TV (Macmania, 2005). 
O processo de subtração das cores consiste em suprimir um ou mais componentes da luz. Em outras palavras, pode-se dizer que a mistura de tintas equivale subtrair cores. Por exemplo, ao se misturar à tinta azul com a tinta amarela, será gerada a tinta verde. Isso ocorre devido à absorção dos componentes do lado vermelho pelos pigmentos da tinta azul e os componentes do lado azul pelos pigmentos da tinta amarela, sobrando finalmente as componentes intermediárias, que geram o verde.

Vale aqui ressaltar que a dualidade: a mistura de pigmentos está diretamente ligada à quantidade de luz absorvida e refletida pelos objetos. Por exemplo, o pigmento branco não absorve, mas reflete todas as cores. Portanto, a cor-luz é a soma de todas as cores, que é refletida pelos elementos iluminados pela luz branca. Conseqüentemente, ao se misturar um pigmento preto a uma tinta branca, obtêm-se diferentes tons de cinza.

Partindo para o processo efetivo da impressão dos mapas, tendo como fato que a folha de papel não emite luz, só absorve e reflete, uma impressora não pode usar as cores RGB. O cartógrafo, então, necessita de um outro modelo que transporte as cores do monitor para o papel: o CMYK. Ele está baseado em quatro cores: ciano, magenta, amarelo e preto; usadas na mistura de pigmentos, principalmente para imprimir imagens de tons contínuos como fotos e ilustrações digitalizadas, etc. Tais cores combinadas podem reproduzir uma parte significativa do espectro visível de cores.

Em princípio, a combinação das tintas $100 \%$ de ciano, $100 \%$ de magenta e $100 \%$ de amarelo deveriam reproduzir sozinhas todas as cores subtrativas. No entanto, por causa da impureza das tintas, não é possível produzir a cor preta, e sim um marrom turvo. E ainda visando a não sobrecarregar a impressora, geralmente é adicionada uma quarta tinta de impressão: a cor preta; que substitui parcialmente as outras três (cores) nos tons mais escuros e cinza das imagens.

Por causa da dualidade ocorrida entre as cores luz-RGB e pigmento-CMYK, há uma grande dificuldade em estabelecer imagens que possam ter o mesmo resultado visual - aparência das cores - no monitor do computador e posteriormente quando impressas. Em Fiori (2003), relata-se a realização de um teste prático, voltado à colorização dos mapas de llhabela e São Vicente, que visou encontrar cores visualmente compatíveis na relação: cor-luz (que aparece no monitor) e cor-pigmento (que aparece no mapa impresso). Tal resultado, porém, não foi disponibilizado pela dissertação. A seguir, a figura 62 apresenta um pequeno inventário das cores testadas e utilizadas. 
Figura 62 - Busca de cores similares para mapas dispostos em um monitor de computador (RGB) e impressos (CMYK)

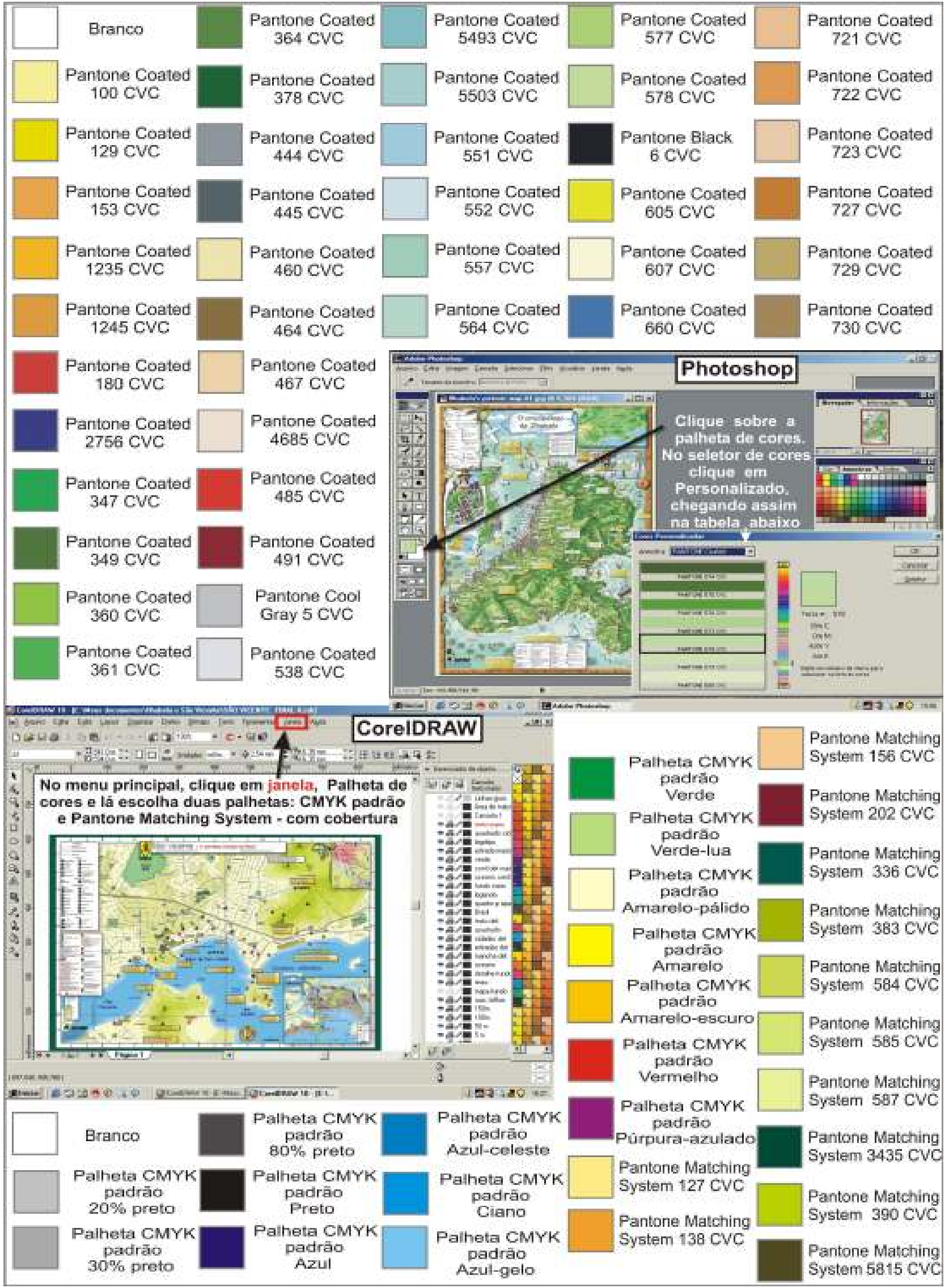


O trabalho de relação entre as cor-luz e cor-pigmento ainda será aplicado e discutido nesta pesquisa, buscando cores que sejam compatíveis, como um todo, aos mapas turísticos pictóricos. Isto é, mesmo estando em ambientes distintos - RGB e CMYK a cor refletida via monitor deve ser parecida com a do pigmento impresso.

Além dos aspectos fisiológicos relacionados às três dimensões das cores, devido à linha de pensamento seguida, não se pode ignorar que a percepção da cor esteja impregnada de emoção. A força intrínseca a essa variável visual pode ser usada com muito proveito na expressão e intensificação do conteúdo informado (Dondis, 1991:67).

Em Farina (1990) encontra-se a ratificação de que, quando o indivíduo recebe a comunicação através da cor, o processo se dá em três níveis:

1. A cor é vista e impressiona a retina;

2. É sentida, provoca e expressa uma emoção;

3. É construtiva e, por possuir um significado próprio, tem valor de símbolo, tendo a capacidade de construir uma linguagem que comunique uma idéia.

A cor faz parte do cotidiano, tanto que muitas vezes se estabelecem até regras de harmonia para utilizá-las. Por exemplo, na moda, na decoração, etc., procura-se uma estética coletiva. Por meio dela, o homem se manifesta, e não somente pela transmissão de sensações, como também pelo estabelecimento de códigos completos para a liturgia, para o trânsito, para a publicidade, etc (Cabanellas, 1976: 75).

Outras vezes, por meio da experiência, o significado simbólico da cor pode ser compartilhado de maneira particular ou universal, sempre apresentando um valor informativo. Levando-se em consideração o meio ambiente, o sujeito compartilha significados associativos da cor das árvores, do céu, da terra e de inúmeros elementos dispostos no espaço, nos quais vêem-se as cores como estímulo. Tudo é coligado a significados associativos e simbólicos (Dondis, 1991: 69).

Mukarovsky (1981:260) exemplifica que a cor vermelha produz no receptor efeitos e sensações diferentes daquelas encontradas nas cores azul, verde ou amarela. Isso porque desencadeia diferentes associações, despertando sentimentos, reações motoras, etc. Essa significação própria da cor por vezes é tão forte que chega a concretizar-se: o azul pode insinuar o céu ou a água, mesmo sendo utilizado como mera qualidade de cor e não para representar o céu ou água.

Monmonier (1996: 171) complementa o que foi dito até aqui, relatando que através da história, as cores dispostas sobre os mapas, por exemplo, reforçaram uma certa metáfora da paisagem. Por muitos séculos, os cartógrafos exploraram e encorajaram a associação do verde à vegetação, do azul à água, do vermelho às altas temperaturas e do amarelo ao ambiente desértico. Contudo, essa associação 
somente pode ser considerada segundo um contexto que seja correto e apropriado, gerando, então, associações que promovam uma eficiente decodificação.

Cita-se novamente que, por convenção, durante o desenvolvimento do Atlas Indígena do estado do Acre (Comissão Pró-Índio: 1996), a cor amarela foi escolhida para representar a rede hidrográfica nos mapas, pois a cor azul, usualmente encontrada na maioria dos mapas da cultura ocidental, não fazia sentido à compreensão dos usuários potenciais: os índios.

Pouco se conhece sobre os efeitos e reações subjetivas que os usuários dos mapas têm em relação às cores. É fato que a maioria delas estão relacionadas a várias sensações. A cor vermelha, por exemplo, está associada a fogo, perigo, calor, sangue, raiva, amor e também ao comunismo. Logo, deve-se estar atento ao contexto ao qual a cor está inserida. Alguns produtores de mapas procuram cores que reforcem - de forma inteligente ou óbvia - os símbolos pictóricos. Como, por exemplo, o amarelo pode reforçar símbolos que exemplificam a riqueza. Outros símbolos que valorizam as cores são os trevos (verdes), as cruzes simétricas e vermelhas das ambulâncias e hospitais, as cruzes pretas dos cemitérios e igrejas (Monmonier, 1996:171).

Portanto, Robinson, Morrison, Muehrcke, Kimerling e Guptill (1995) sustentam que a significação das cores pode variar culturalmente, sendo que, na cultura ocidental, associa-se comumente as cores aos mais diferentes fenômenos físicos, sensações e emoções. As associações evocadas podem ser usadas para retratar certas características a serem representadas. A seguir expõem-se algumas importantes conotações simbólicas dadas à cor:

$\checkmark$ Azul: os corpos d'água, os rios, a alguma coisa molhada ou fria.

$\checkmark$ Verde: as áreas de vegetação viçosa.

$\checkmark$ Amarelo ou castanho-amarelado: as áreas secas ou que apresentam vegetações esparsas.

$\checkmark$ Marrom: o solo nu.

$\checkmark$ Vermelho e laranja: o calor.

Tuan (1980: 27) disserta sobre as cores avançadas e recuadas. O vermelho, laranja e amarelo parecem mais próximas do expectador, por estimular o sistema nervoso e fazer com que o objeto pareça mais quente, mais pesado do que é. Já o verde, azul e o azul esverdeado promovem distância aos olhos, sugerem frieza, o objeto é julgado mais leve do que é. Como visto, as cores afetam o sentido de peso e também o sentido de indicação acima e abaixo, pois quando os elevadores possuem luzes coloridas, a seta vermelha invariavelmente indica descida, a seta azul subida. 
A figura 63 demonstra-nos que a cor possui uma ação móvel. As distâncias visuais tornam-se relativas. O próprio volume de qualquer elemento pode ser alterado pelo uso da cor sendo que a superfície mais clara sempre aparecerá maior, pois a luz que reflete the confere amplidão.

Figura 63 - 0 "volume" das cores

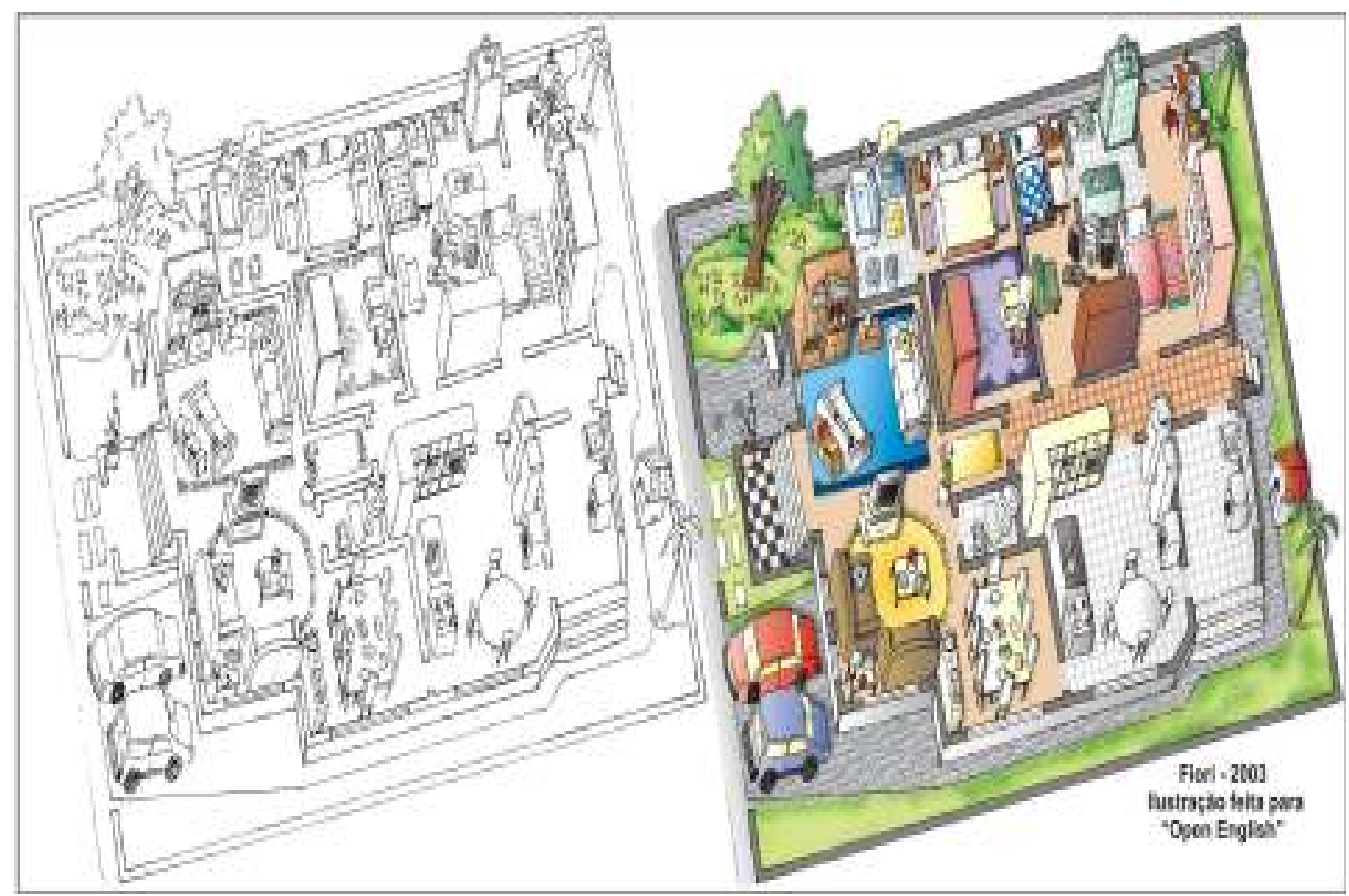

Além das possibilidades do uso da cor referentes as suas qualidades culturais e de motivação, apontam-se outros recursos nos quais o uso da cor pode realçar ou deixar em segundo plano uma informação. Por exemplo, a variável visual transparência (voltar à figura 35 e ver figura $64 \mathrm{~A}$ ) pode ajudar a representar um tipo de névoa pelo qual um tema abordado no mapa pode ficar encoberto ou desbotado.

A transparência também é usada para descrever características do mapa que se sobrepõem. O recurso é aplicado, por exemplo, para esconder o fundo de um mapa ou para trazer ao primeiro plano o tema principal. Nos mapas turísticos interativos, essa variável proporciona a impressão de profundidade ou distância à visão oblíqua. Contudo, ela deve ser usada com muito cuidado, pois, quanto maior a nevoa, menor a possibilidade de distinção da figura do fundo. $O$ assunto é abordado rapidamente por MacEachren (1994: 31,32) ao dissertar sobre a variável visual foco. Também já abordado em Fiori (2003: 87, 88). 
Outro recurso que se deve mencionar é o sombreamento de um objeto no mapa. De acordo com o ângulo, direção e intensidade de uma iluminação imaginária, pode-se criar volumes e planos às ilustrações e, conseqüentemente, o mapa como um todo (Figuras $64 \mathrm{~B}$ ).

Figura 64 - Transparência e sombreamento de ilustrações e objetos

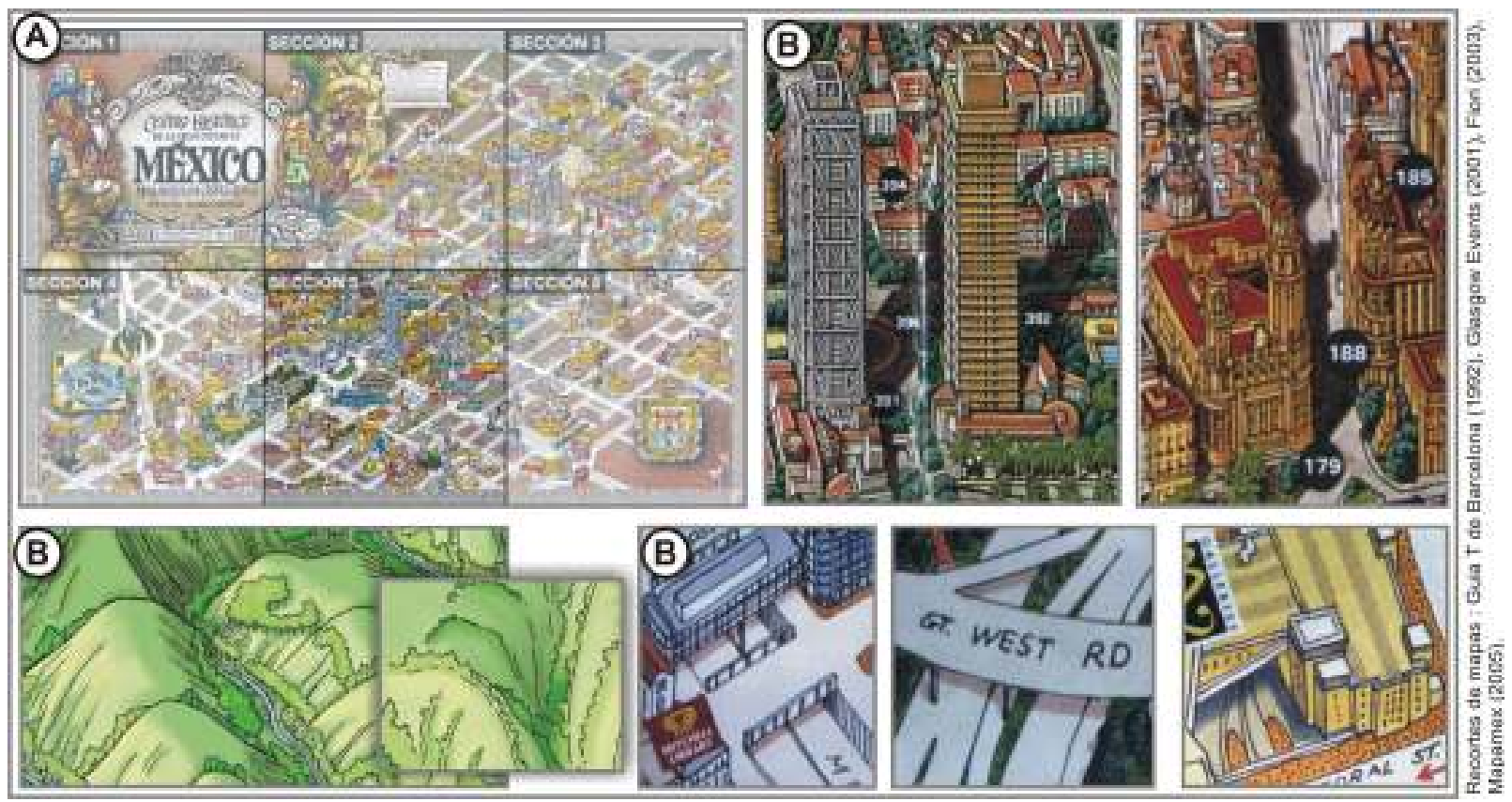

Por fim, Mayhew (1992) apresenta alguns itens que merecem destaque em relação aos princípios e diretrizes das cores:

$\checkmark$ Devem ser usadas de acordo com a necessidade, valor e não com exagero ou substitutas de outras técnicas mais eficazes para a representação.

$\checkmark$ É preferível trabalhá-las em conjunto com outra variável visual (redundância), por causa de problemas como daltonismo (monocromatas, dicromatas e tricomatas) e pessoas com idade avançada.

$\checkmark$ Devem avisar (amarelo), diferenciar (cores distintas), enfatizar (vermelho) e relacionar (cores comuns) as informações.

$\checkmark$ Devem identificar estruturas e subdivisões - sempre usando as mesmas regras para aplicação de cores em todo o sistema.

$\checkmark$ Podem retratar os objetos naturais de forma realista, ou então, buscar uma certa caricatura funcional.

$\checkmark$ O azul deve ser evitado em textos, detalhes e símbolos pequenos. Essa cor é boa para fundos e áreas grandes. 
$\checkmark$ Cores quentes devem ser utilizadas para criar uma aparência de aumento das imagens.

$\checkmark$ Recomenda-se utilizar cores para a percepção de profundidade. Tons azuis parecem estar um pouco mais longe do que os tons vermelhos.

$\checkmark$ Deve-se buscar reduzir "erros" de interpretação relacionados principalmente à associação cultural das cores.

$\checkmark$ Podem aumentar a compreensão, a credibilidade, a aparência e a satisfação.

$\checkmark$ Propiciam melhor captação de memória,

$\checkmark$ Cores contrastantes entre $\circ$ fundo e o destaque devem ser empregadas. Geralmente, aconselha-se utilizar imagens coloridas em fundos acromáticos (preto, branco ou cinza). No caso de um formato em meio digital, o fundo branco constante pode cansar os olhos.

\section{5) Textura}

Esse elemento visual é muito útil na substituição ou complementação das qualidades de um outro sentido, o tato. Ao se abordar a produção de um material fundamentalmente visual como mapas impressos ou elaborados para telas de computador, Dondis (1991: 70) é categórica ao afirmar que é possível uma textura apresentar somente qualidades óticas e não táteis como, por exemplo, no caso dos padrões de um determinado tecido ou dos traços superpostos de um esboço. Havendo...

... uma textura real, as qualidades táteis e óticas coexistem, não como tom e cor, que são unificados em um valor comparável e uniforme, mas de uma forma única e especifica, que permite à mão e ao olho uma sensação individual, ainda que projetemos sobre ambos um forte significado associativo (Dondis, op.cit::70).

Aliás, a maior parte da experiência vivenciada com relação à textura é ótica e não tátil. llustrações e pinturas muitas vezes proporcionam aparências convincentes de uma ou mais texturas (Dondis, op.cit.: 71).

MacEachren (1994: 27) pontua que o atributo mais importante da textura é que esta variável visual gráfica, já à primeira vista, facilita a percepção dos diferentes tipos de texturas.

Isso quer dizer que a elaboração de um mapa turístico deve valorizar e criar texturas convincentes e diretas da paisagem que contém: vegetações (florestas, savanas, climas temperados e frios), tipos de morfologia de terreno (montanhas, vales, planícies, praias), presença do homem (cidades, aldeias, tribos), etc (Figura 65). E essas "qualidades" de separação visual entre camadas de informação da paisagem se mostram por meio de características gráficas de suavidade, aspereza, volume, 
sinuosidade, precisão, entre outras. Pode-se sugerir ainda tipos de materiais constitutivos dos elementos visuais como pedra, madeira, areia, tecido, água.

Figura 65 - A textura e suas qualidades visuais

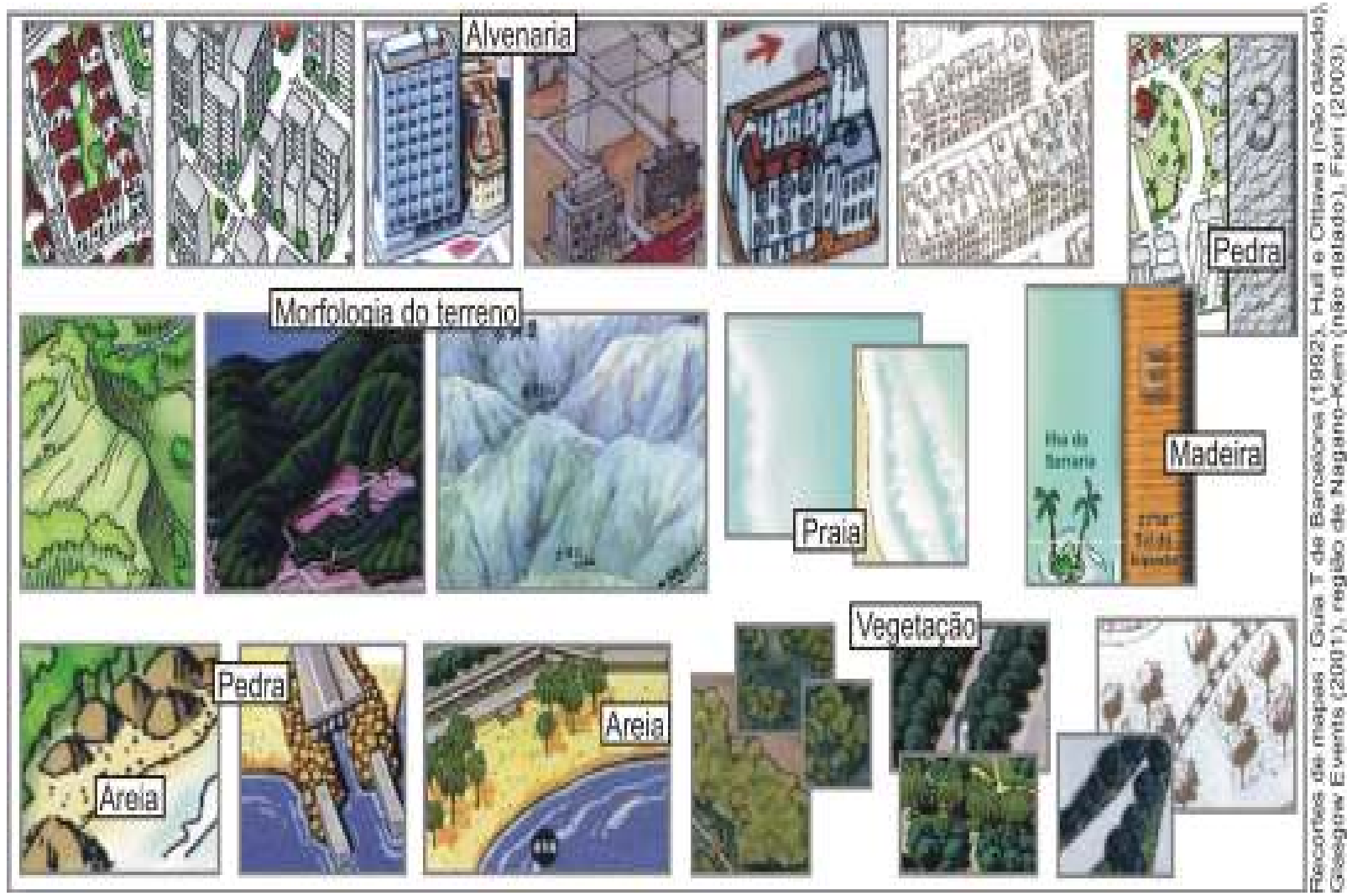

\section{6) Escala e proporção}

A primeira etapa, antes de iniciar um desenho, é reconhecer e trabalhar a partir de dois itens fundamentais: o tamanho da área de ilustração como, por exemplo, uma folha de papel ou a tela de computador, e as informações que se deseja representar. Nessa relação, a escala auxiliará na composição dos tamanhos e as proporções entre dois ou mais elementos visuais presentes na ilustração. Dondis (1991: 73) complementa que a medida é parte integrante da escala, porém sua importância não é crucial.

A preferência de uma escala para a ilustração é feita por elaborações visuais fluidas, não absolutas e sujeitas a muitas variáveis modificadoras a partir da composição pretendida pelo ilustrador. Nessa pesquisa, a escala torna-se muito útil na definição dos vários planos da paisagem, sendo trabalhada conforme as referências que são pré-estabelecidas. A figura 66 exemplifica claramente essa relação. 
Figura 66 - Proporção e escala

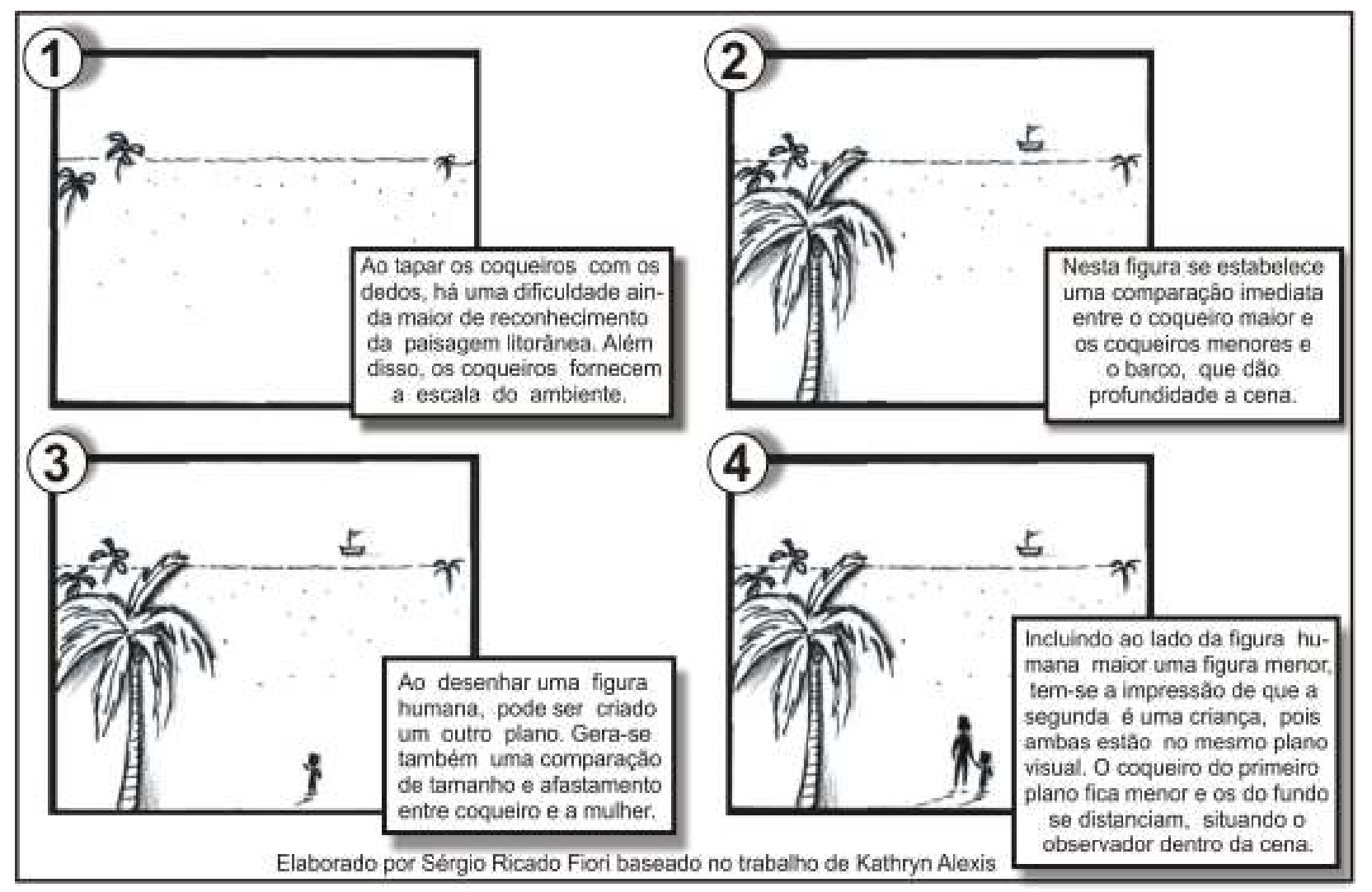

Aprender a construir a relação tamanho-objetivo-significado é essencial na estruturação da mensagem visual. $\mathrm{O}$ controle da escala faz, por exemplo, que uma paisagem ampla torne-se visualmente fácil de ser apreendida. Já o enfoque a um ambiente específico, pequeno, pode trazer riqueza de detalhes sem que haja uma poluição visual, com a escolha dos elementos pertinentes à proposta do tema a ser representado.

Ainda durante a escolha da escala na composição de um desenho, é importante utilizar representações de fácil identificação para o decodificador. Isso quer dizer que nunca se deve esquecer de incluir uma referência básica de tamanho, ou seja, algum elemento cujas dimensões de tamanho o observador esteja habituado a perceber no plano concreto. No geral, qualquer pessoa sabe e pode comparar o tamanho de uma árvore, uma pessoa, uma casa. Com isso, trabalhando com algum elemento "conhecido" presente em uma ilustração, torna-se mais fácil identificar, confeccionar e comparar dimensões com outros elementos. A figura humana, por exemplo, fornece as determinações essenciais da escala, sendo um ótimo elemento visual. É como utilizar uma caneta ao lado de um perfil de solo ao ser fotografado.

Todos os elementos já apresentados - o ponto e a linha, a forma, o tom, a cor, a textura e a escala - são componentes irredutíveis dos meios visuais, configurando-se como itens básicos com os quais o observador conta para desenvolver o pensamento e a comunicação visual. Apresentam o dramático potencial de transmitir informações 
de forma fácil e direta, mensagens que podem ser aprendidas com naturalidade por qualquer pessoa capaz de ver (Dondis, 1991: 82).

Focalizando mais diretamente o desenvolvimento dos mapas pictóricos turísticos, todos os elementos visuais apresentados serão utilizados, tendo como base cartas topográficas (que dispõem de escala métrica), que sofrerão diferentes recortes, dependendo do enfoque a ser dado à localidade turística.

Desde já, é certo que todo o processo de colorização será feito em meio digital, por sua maior praticidade e menor custo, como comprovado em Fiori (2003:147). Além disso, a idealização dos inúmeros tipos de ilustrações pictóricas trabalhadas sobre uma base topográfica tem o intuito de causar um forte impacto visual - imagem inicial - buscando enfatizar a vocação turística do destino representado - balneário, histórico, rural, saúde, ecoturismo, religioso, etc. Posteriormente, virão outras "imagens menores", auxiliares e complementares, que apresentarão os patrimônios natural, cultural e a infra-estrutura presente na localidade.

Essas observações remetem aos fatores push e pull (item 1.6: 109), ou seja, o cartógrafo pode pensar em criar inicialmente um primeiro impacto visual ao mapa. Tal impressão objetivaria enfatizar a principal vocação turística do destino representado, configurando a localidade, por exemplo, como balneária, histórica, rural, serrana, cosmopolita, de instância, de atração singular, etc. A figura 67 exemplifica mapas panorâmicos que fornecem tal atmosfera.

A próxima parte do desafio é explicitar claramente no mapa, as atrações e atividades encontradas na localidade, possibilitando assim, opções de escolha ao usuárioturista. Por exemplo, destacando os tipos de restaurantes, expondo e criando uma hierarquia quanto ao grau de facilidade-dificuldade das trilhas usadas para caminhadas e outros esportes, localização e o tipo de acomodações, apresentação das tradições (arquitetura, artesanato, religiões) e curiosidades (histórias, lendas) do destino, além de alguns tipos de texto e legendas com informações utilizando um ou mais idiomas, etc.

Devido às respostas anteriores (Fiori: 1999 e 2003), a concepção dos mapas turísticos utiliza basicamente os recursos do índice, dos ícones e dos símbolos pictográficos. Primeiramente por atingirem um maior número de usuários, devido a sua configuração estético-visual. E, em seguida, pelo fato de tal estilo acentuar a resposta emocional (alegria, surpresa, expectativa) relacionada ao prazer e apreciação do usuário. A dimensão emocional de dominância estará mais vinculada à capacidade de transmitir a informação do mapa como produto em si. 
Figura 67 - Vocação turística: primeiro impacto visual

Localidade: balneária, urbana

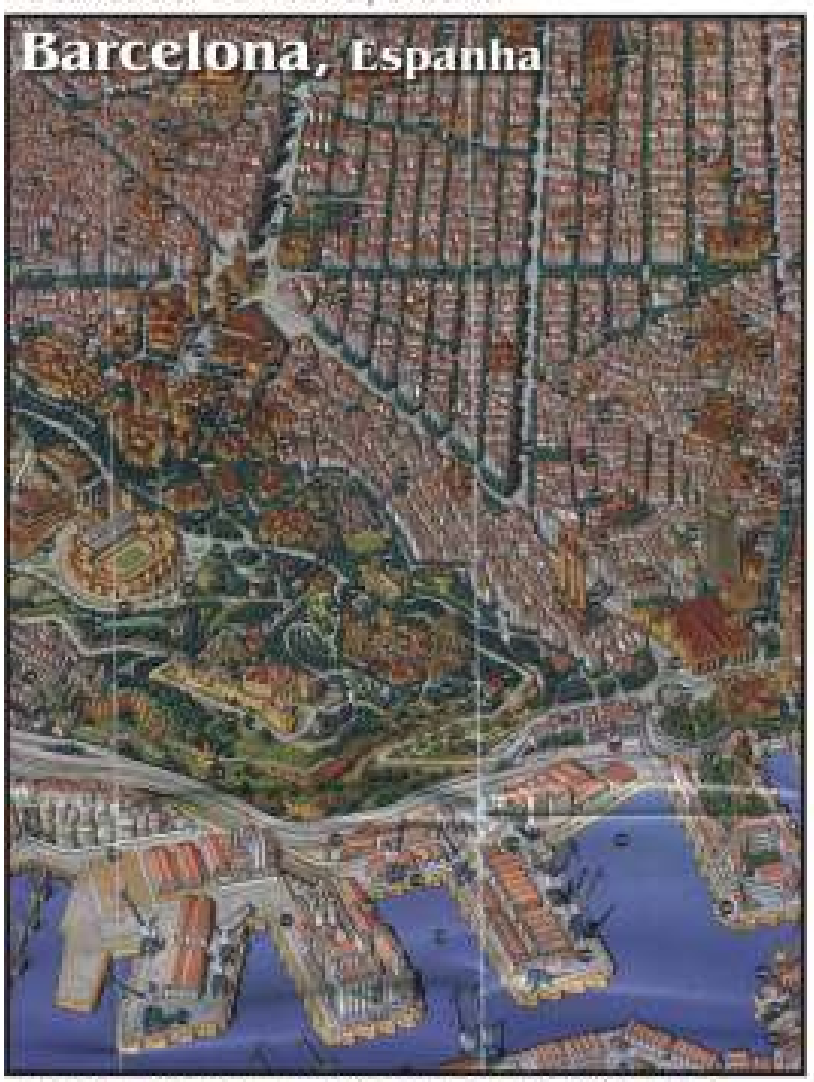

Forka: Gua T de Earcolona. produrido por Planografico - N.G Ediciones

Localidade: serrana, alpina

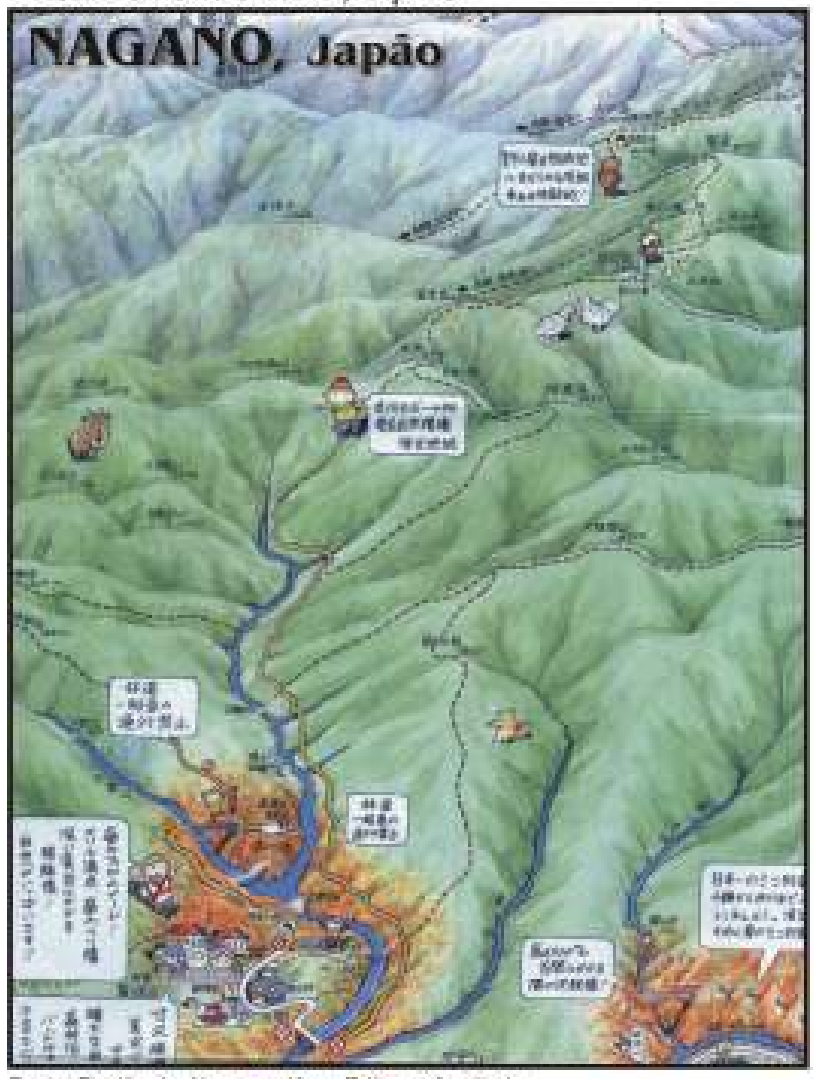

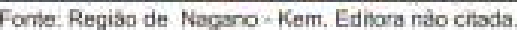

Localidade: histórica

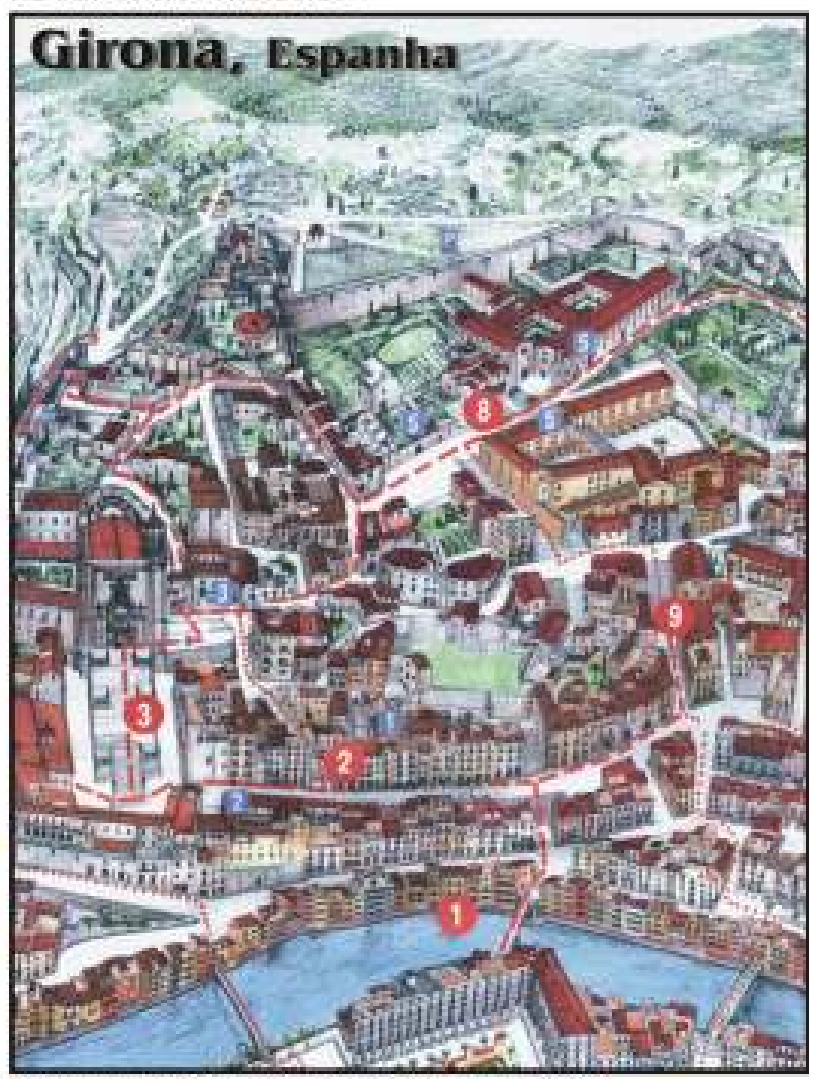

Fonte Maca de Girona, Glorecido peio Ayuntament de Grana

Localidade: de águas, cachoeiras

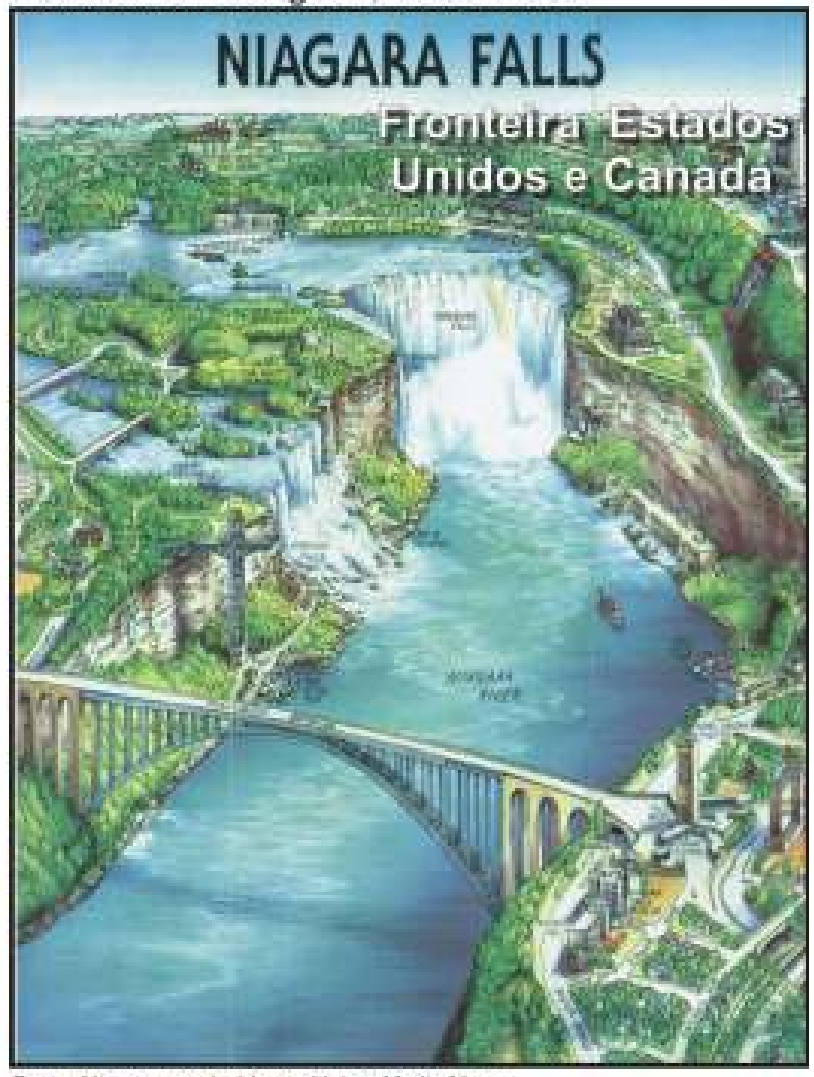

Fonte: Nagara, produzido por Uniquellodia Mass. 
Some-se ainda, uma junção entre as variáveis visuais de Bertin (1967), com atualização de MacEachren (1995), e os elementos visuais até agora descritos em suas qualidades sintático-semânticas. Todos esses recursos gráficos possibilitam representar o espaço por meio do mapa, proporcionando ao plano bidimensional uma aparente tridimensio-nalidade, como demonstrado na figura 68 .

Figura 68 - Composição de um mapa pictórico com variáveis e elementos visuais

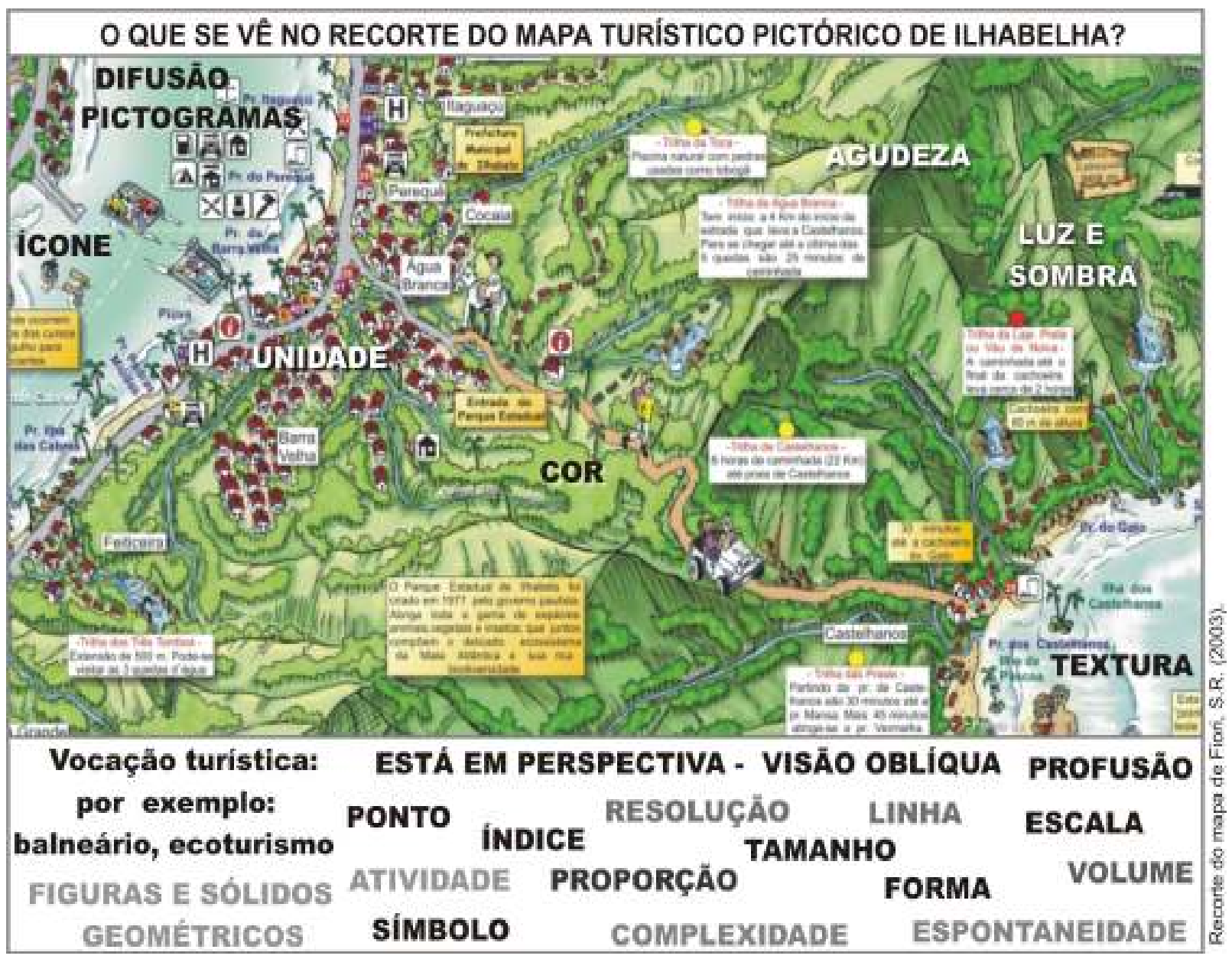

E, por se tratar de um mapa, não se poderia deixar de abordar que sempre haverá algum tipo de texto, pois a palavra escrita é um recurso eficiente e a articulação desenho / texto verbal constitui uma técnica importante para facilitar a decodificação de uma mensagem.

O texto verbal aparece, no mapa pictórico turístico, por exemplo, no título, em algumas legendas e etiquetas que apresentam um determinado assunto e são inseridos de forma natural à cena: uma folha de papel ou monitor do computador. No caso desta pesquisa, o código de expressão da mensagem é a língua portuguesa idioma oficial do país e compreendido pela imensa maioria das pessoas alfabetizadas, porém é importante frisar que o produto também será disponibilizado em inglês - de tal modo que, para que se compreendam plenamente as informações 
dispostas sobre o mapa, é necessário compreender o código de expressão da mensagem.

O texto usado no mapa turístico pictórico serve tanto para reforçar a representação pictórica quanto para enriquecê-la com outras informações complementares (Figura 69). Aliás, a divulgação pelo marketing turístico tem o poder de influenciar, direcionar, informar, facilitar a seleção ou escolha do usuário sobre uma determinada destinação, que conta com diferentes propostas paisagísticas ao turista, como rotas, lugares, áreas, atividades específicas da localidade.

Figura 69 - Articulação texto e imagem

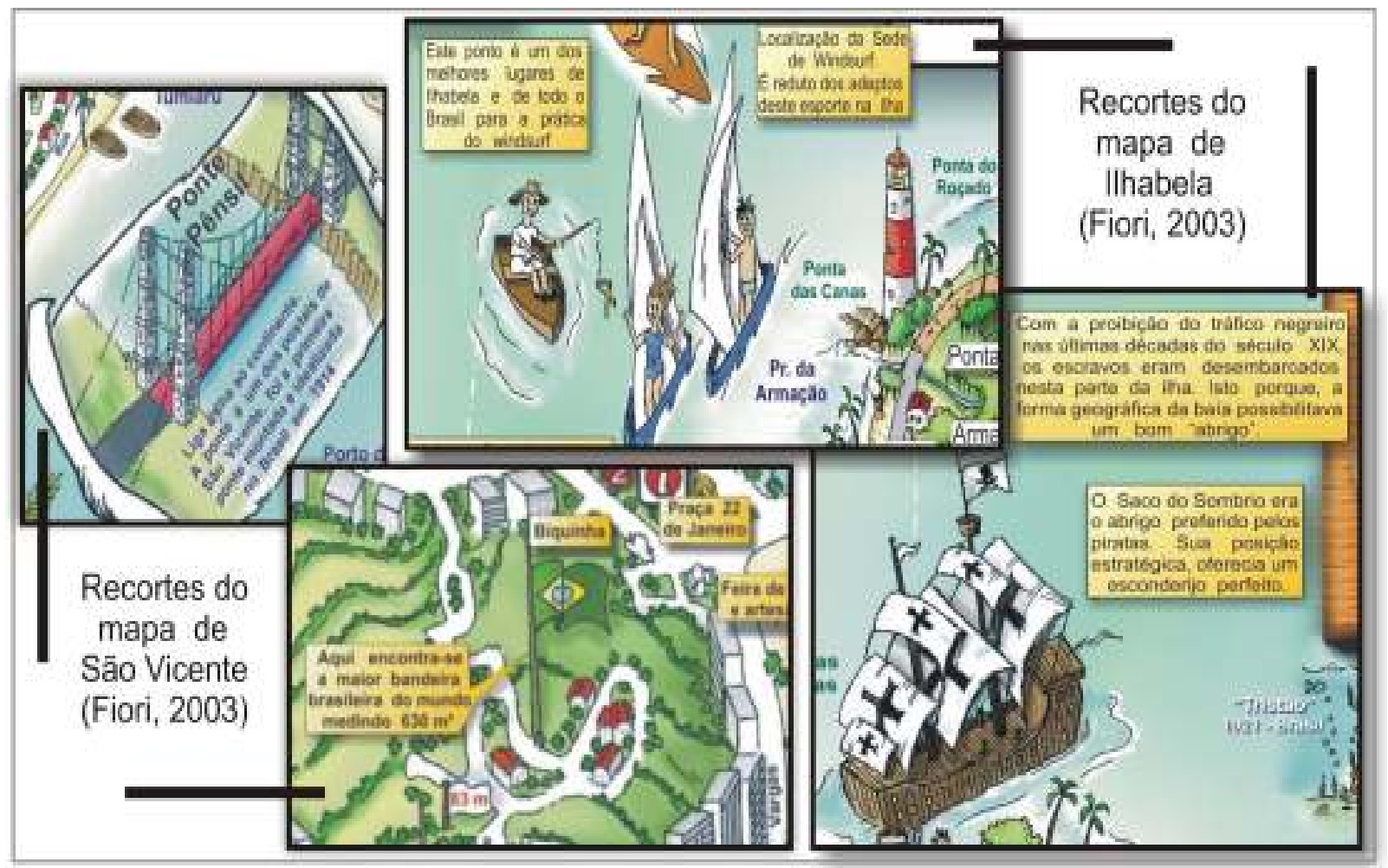

Moreira Leite (1998: 44) complementa que, embora habitualmente a linguagem visual seja considerada de transmissão direta, pode apresentar uma postura parasitária em relação à linguagem verbal. As imagens visuais precisam das palavras para que sejam transmitidas e, freqüentemente, a palavra já inclui em si um valor figurativo a ser considerado. Entretanto, em grande parte das vezes, as palavras não conseguem evocar exatamente o que a imagem propõe.

Barthes (1990: 33, 34) reitera que, de um lado, o texto verbal traz a possibilidade de o criador, e também de a sociedade, exercer um controle sobre a imagem: a fixação é o controle, detém uma responsabilidade sobre o uso da mensagem frente ao poder de projeção das ilustrações. Mostra-se como um valor repressivo em relação à liberdade dos significados da imagem. Por outro lado, a mensagem icônica possibilita que o leitor apressado não tenha que se incomodar com as descrições verbais, acreditando 
que as imagens constituem um sistema menos trabalhoso para assimilar a informação. Porto Alegre (1988: 80) complementa que, intuitivamente, um indivíduo é capaz de entender certas imagens sem passar à palavra e, mais do que isso, se tentar recorrer à fala, o sentido do que é puramente imagem não conseguirá existir, uma vez que se trata de um sentido irredutível.

Por tudo que foi exposto, pode-se estabelecer que não existe um tipo de mensagem lingüística, verbal, visual ou icônica absoluta. A idéia, então, é utilizar da melhor forma possível as três possibilidades de elaboração da mensagem: icônica codificada, icônica não-codificada e lingüística, apontadas por Barthes (1990: 28-40), para que, assim, o mapa pictórico se torne mais facilmente compreendido. Até porque os três tipos de mensagens apresentadas capacitam a trabalhar a redundância, podendo tornar o mapa mais informativo e esteticamente mais rico e agradável.

\section{2 - Símbolos de informação pública: pictogramas utilizados em mapas turísticos}

Até o momento, a pesquisa tratou particularmente do uso das representações pictóricas, objetivando justificar sua importância estética e informativa, onde todo o processo de design está essencialmente vinculado a um tipo de mapa preocupado em satisfazer as necessidades do setor do turismo.

Este setor de consumo ocorre em meio à infra-estrutura urbana ou rural, estando sujeito a condições de uma sinalização própria aos equipamentos, serviços e atrativos turísticos. Entre outras condicionantes, é importante que a destinação proporcione orientação ao turista, resultando em algum tipo de serviço de guia pela própria sinalização existente no local (Carneiro, 2001:5).

No caso do serviço aqui ressaltado, o mapa turístico, a comunicação almejada para os símbolos das legendas encerra-se em uma dualidade apresentada por Carneiro (2001:14): devem ser claros o bastante para serem globais, mesmo incorporando um certo grau de subjetividade; e personalizados, para atingirem os objetivos individuais do receptor, relacionando-se à atual tendência de uma comunicação plural de pessoas e gostos.

Como já visto anteriormente, o símbolo tem o poder de sugerir a parte de um todo, por exemplo, a cruz para a cristandade, a coroa para a monarquia, o círculo para a harmonia e perfeição. Um objeto, quando projetado traz à mente uma sucessão de idéias relacionadas entre si, analógica ou metaforicamente. O costume de estruturar o mundo em substâncias, cores, direções, animais e traços humanos, estimula uma visão simbólica do mundo (Tuan, 1980: 26).

Neste momento, discrimina-se uma grande variedade de símbolos, os quais denotam e conotam atividades, atrativos e serviços encontrados nas mais variadas destinações. 
De maneira geral, o simbolismo é utilizado corriqueiramente no dia-a-dia. Dondis (1991: 94), por exemplo, lembra que as datas festivas como o Natal, a Páscoa, o Dia dos Namorados, entre outras aproveitam os simbolismos sensíveis ao efeito publicitário (Figura 70). Até mesmo as empresas de grande porte adeririam aos símbolos visuais para representar sua identidade e seus objetivos.

Figura 70 - Os simbolismos cotidianos

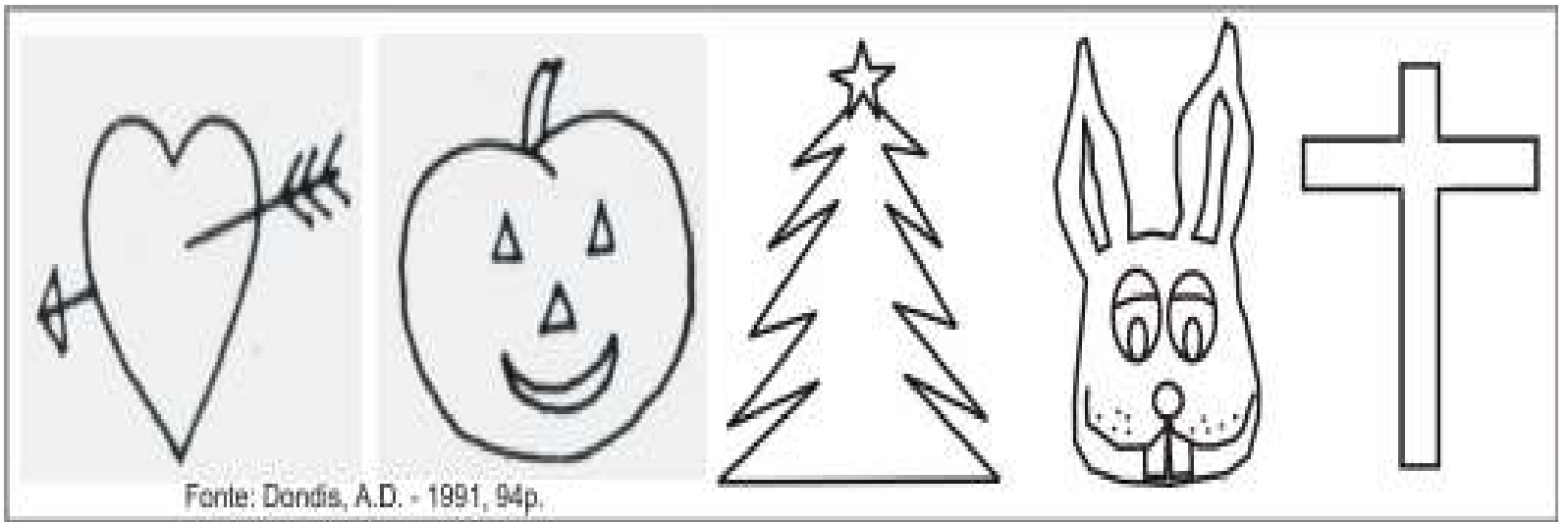

Portanto, o símbolo se configura como um meio de comunicação visual: deve ser simples, impregnado de informação de significado universal. Ele não existe apenas na linguagem verbal e visual: seu uso é muito mais abrangente, referindo-se a um grupo, idéia, atividade comercial, instituição ou partido político (Figura 71).

Figura 71 - Símbolo: meio de comunicação social

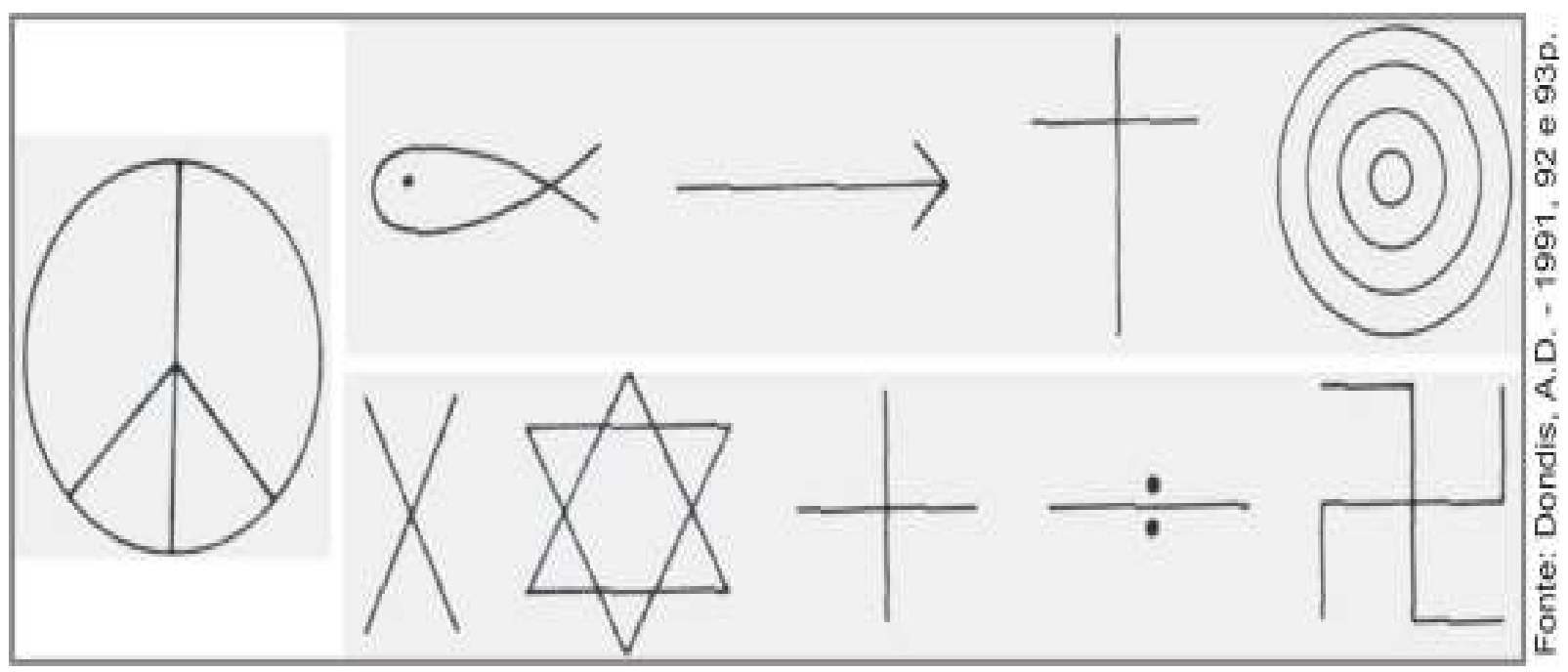

A interação entre propósito e composição de um lado e entre estrutura sintática e substância visual de outro deve ser mutuamente reforçada para que atinja uma maior eficácia em termos visuais. Constituem, em conjunto, a força mais importante de toda comunicação visual, a anatomia da mensagem (Dondis, 1991: 105). 
Isso posto, busca-se utilizar simbologias já existentes e desenvolver outras, quando necessário, que sejam bem aceitas e interpretadas em vários níveis e tipos de representação, pelo maior número de pessoas, as quais compõem o heterogêneo nicho de mercado relacionado ao setor do turismo.

Este momento focaliza e aprofunda os desenhos e símbolos pictóricos a serem dispostos nas legendas de mapas turísticos. O estudo empírico iniciado em Fiori (2003: 157 - 179) sobre a pictografia utilizada em símbolos de informação pública, somado às leituras de outros trabalhos - Forrest e Castner (1985), Clarke (1989), Forrest (1998), Gerber, Burgen \& Stanton (1990), Leung e Li (2002) - deixam claro o valor deste tipo de representação quando relacionado à compreensão da mensagem pelo usuário não especializado.

Muehrcke (1986:84) é relembrado ao afirmar que os símbolos pictóricos oferecem um maior apelo estético, além de serem lidos e apreciados mais facilmente por crianças e usuários não habituados a semântica cartográfica.

Em contrapartida, como também se firma desde o início desta pesquisa, é flagrante, principalmente às representações pictóricas, o contexto cultural que, por exemplo, gera e possibilita a escolha do estilo artístico; familiariza o usuário, capacitando-o a compreender a representação; valoriza certos elementos em detrimento de outros, etc. A preocupação está no olhar, que é condicionado por hábitos e expectativas, tanto que, ao se romper este vínculo, a comunicação tem grande possibilidade de falhar.

Em relação aos símbolos de informação pública (SIP), Carneiro (2001:14) ressalta que, devido ao momento histórico e econômico, torna-se cada vez mais necessária uma simbologia padronizada, na medida em que a qualidade do produto ou serviço passa a ser um atributo imprescindível à sua venda. $O$ público consumidor tende a ser por natureza frio e objetivo, exigindo a eficácia do produto e/ou serviço no qual está investindo seu tempo e dinheiro, não aceitando mais promoções mentirosas.

Conseqüentemente, a seleção e/ou desenvolvimento de SIPs e pictogramas ${ }^{57}$, dispostos em mapas turísticos impressos ou em meio digital, devem estabelecer um design eficiente e capaz de abranger o contexto mental de sociedades de diferentes tradições e culturas podendo ser consumidos, por exemplo, por brasileiros, europeus, australianos chineses ou japoneses.

Partindo do pressuposto de que o usuário só entende uma mensagem quando o repertório disponível é igual ao que ele conhece, até porque o contrário inviabiliza qualquer iniciativa de criação e implantação de um sistema de sinalização turística,

\footnotetext{
${ }^{57}$ A popularização do turismo e das viagens internacionais ocorreu principalmente após a Primeira Guerra Mundial, fazendo com que houvesse a necessidade de se criar um sistema de comunicação que não fosse limitado pela fronteira da língua. Gerou-se então, o interesse pela linguagem dos signos: o pictograma (Carneiro, 2001: 1), denominado por Frutiger (apud Carneiro, 2001: 25) como signo de segurança, possibilitando ao usuário apreender a informação com maior rapidez e facilidade.
} 
torna-se extremamente necessário o esforço continuado de um inventário, ordenação, padronização e divulgação, em escala internacional, de sistemas de sinalização. Assim, ao longo dos anos, poderá se vislumbrar a composição de um sistema único, normatizado, pelo menos no que se refere a ações, situações e locais de senso comum. A partir daí, os manuais de sinalização, ditos oficiais, reveriam suas posições, pois ser oficial não é uma qualidade imposta pelos órgãos ou entidades, mas sim uma condição legítima de uso e inteligibilidade (Carneiro, 2001:193).

Baseado em Souza (1992:2-5), inicia-se a discussão sobre os Símbolos de Informação Pública (SIP). As imagens dispostas na figura 72 são caracterizadas por sua funcionalidade, ou seja, são produzidas e criadas com um único intuito: a comunicação social. Devido a sua função sinalética ${ }^{58}$, excluem-se de sua natureza todas as imagens produzidas apenas com a intenção ornamental ou estética.

Esse tipo de imagem funcional, sinalética, gráfica, sem valor fonético, de natureza icônica é conhecida no âmbito da comunicação visual pelo nome de pictogramas, símbolos de sinalização, ou ainda, SIPs. Além disso, é auto-explicativo, devendo apresentar como características básicas a concisão gráfica, a densidade semântica e uma funcionalidade comunicativa que ultrapasse as barreiras comunicativas (Souza, 1992:6).

Entre os vários tipos de imagens gráficas já abordadas até aqui - representações pictóricas, mapas, plantas, etc - Souza (1992: 6) destaca os pictogramas como signos que comunicam mensagens primordiais à prática e a organização da vida pública, procurando superar as barreiras lingüísticas, reforçando, ampliando e, até mesmo, substituindo a palavra escrita e falada. De maneira simplificada, a autora (Souza, 1992: 141) conceitua pictograma como:

signos de comunicação visual, gráficos e sem valor fonético, de natureza icônica figurativa e de função sinalética. São auto-explicativos e apresentam como principais características: concisão gráfica, densidade semântica e uma funcionalidade comunicativa que ultrapassa as barreiras lingüísticas.

\footnotetext{
${ }^{58}$ Sinaléticos - compreende os signos gráficos - tais como: os pictogramas, os códigos gráficos de âmbito profissional, as marcas e logotipos institucionais, a sinalização viária (Souza, 1992: 132) - que transmitem informações essenciais a um grande número de pessoas, inclusive de línguas diferentes, para orientar o seu comportamento social.Tais imagens indicam reações comportamentais apropriadas em determinada situação social. Na tabela 72 podem-se classificar as imagens por sinais indicativos (fig. 3,14), designativos (fig. 1, 2, 4, 5, 6, 7, 8, 10, 11, 12, 13, 15, 16) e proibitivos (fig.9) (Souza, 1992: 5).
} 
Tabela 72 - 0 que representam e o que dizem essas formas gráficas?

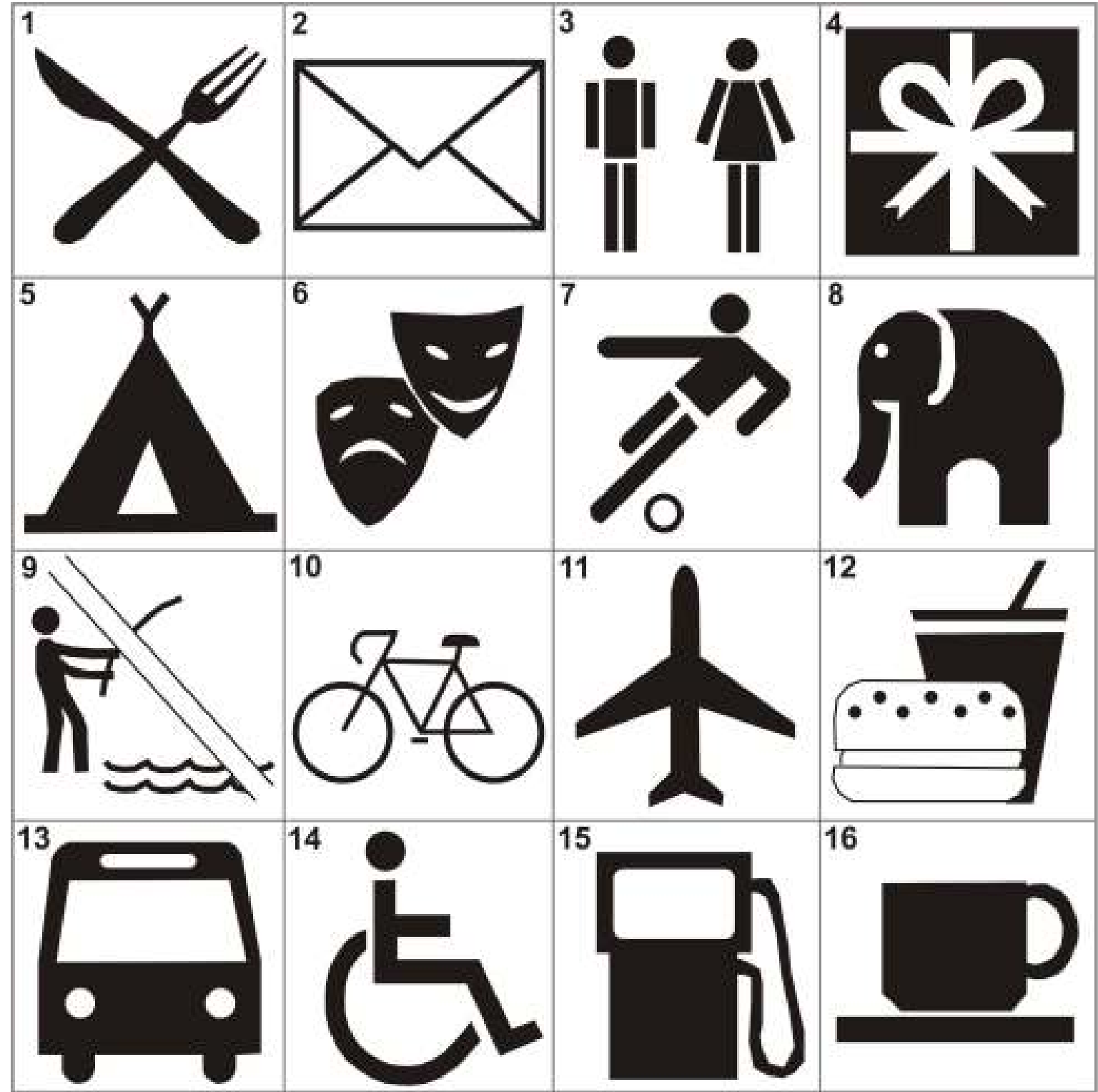

\begin{tabular}{|c|l|l|}
\hline $\begin{array}{c}\text { Forma } \\
\text { gráfica }\end{array}$ & \multicolumn{1}{|c|}{ Que representam ? } & \multicolumn{1}{|c|}{ Que dizem? } \\
Que mensagens comunicam? \\
\hline 1 & Garfo e faca & Restaurante \\
\hline 2 & Carta & Correio \\
\hline 3 & Homem, mulher & Porta de recinto (banheiro) \\
\hline 4 & Pacote decorado, presente & Local de compras (shopping) \\
\hline 5 & Tenda, cabana, barraca & Local para camping \\
\hline 6 & Duas máscaras (triste e alegre) & Teatro \\
\hline 7 & Jogando futebol & Evento esportivo, campo para esporte \\
\hline 8 & Elefante & Zoológico \\
\hline 9 & Homem pescando com barra diagonal & Proibido pescar \\
\hline 10 & Bicicleta & Ciclovia, aluguel de bicicleta \\
\hline 11 & Aviăo & Aeroporto \\
\hline 12 & Pão (hambürguer) e copo \{de suco, rétrigerante) & Lanchonete, fast-food \\
\hline 13 & Ónibus & Estação rodoviária, parada de ônibus \\
\hline 14 & Homem em uma cadeira de rodas & Local acessivel a deficientes fisicos \\
\hline 15 & Bomba de gasolina & Local de abastecimento, posto \\
\hline 16 & Pires e xicara & Local onde se encontra café \\
\hline
\end{tabular}


Já Carneiro (2001: 2) estabelece o pictograma por meio do conceito de ideograma, ou seja, desenho que representa uma idéia. Logo, o pictograma é uma espécie de ideograma que simboliza, representa uma idéia ou elemento em particular, sem que para isso necessite da palavra. Por exemplo, um objeto concreto - o telefone - ou um fato - alimentação - pode ser representado pelo pictograma, que estará no lugar do objeto, do fato. Esse tipo de comunicação é aplicado na maioria dos países, mesmo que seus traços gráficos sejam elaborados de maneiras e formas diversas (Figura 73 A). Some-se aqui que, quanto mais abstrata for uma imagem, maior será a necessidade de aprendizagem do seu significado, ou seja, o pictograma só se terá significado a partir do momento em que for reconhecido como sinal de comunicação Figura 73 B (Souza, 1992: 148).

\section{Figura 73 - 0 pictograma}

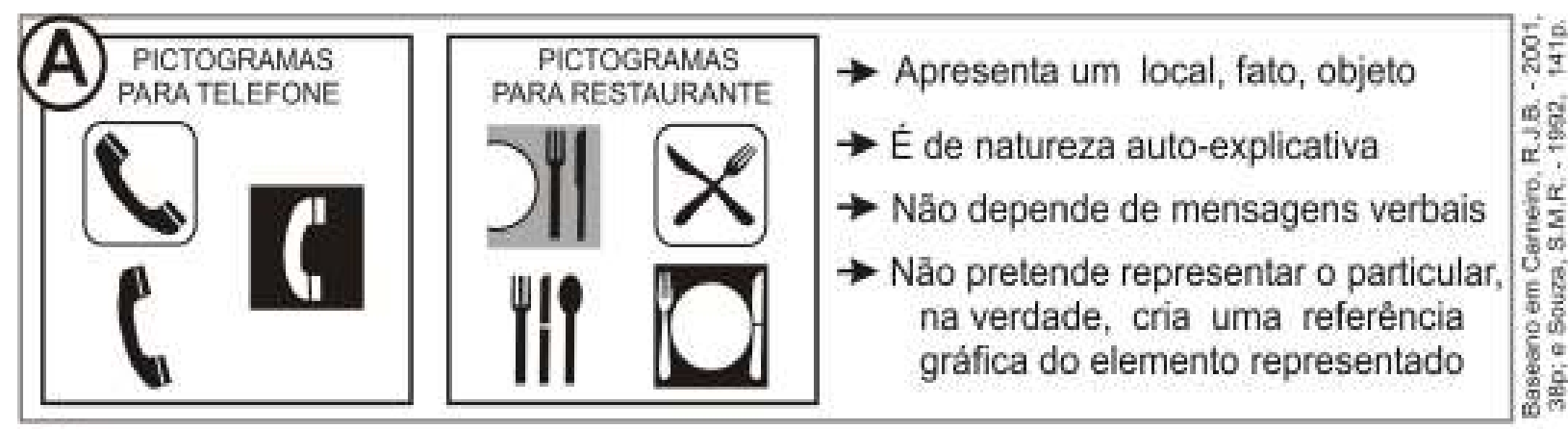

(B) Cinco graus de abstração dos pictogramas referentes a masculino e feminino
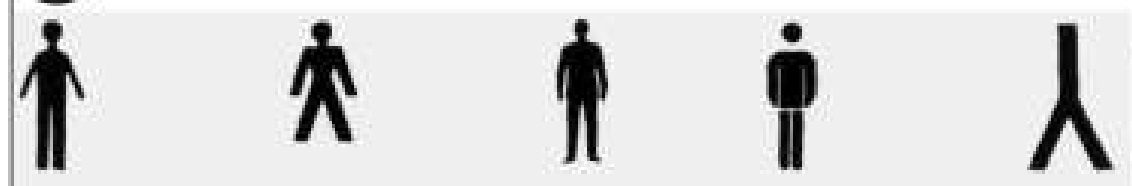

A natureza icônica dos pictogramas admite

graus de esquematização do desenho, correspondendo a diferentes graus

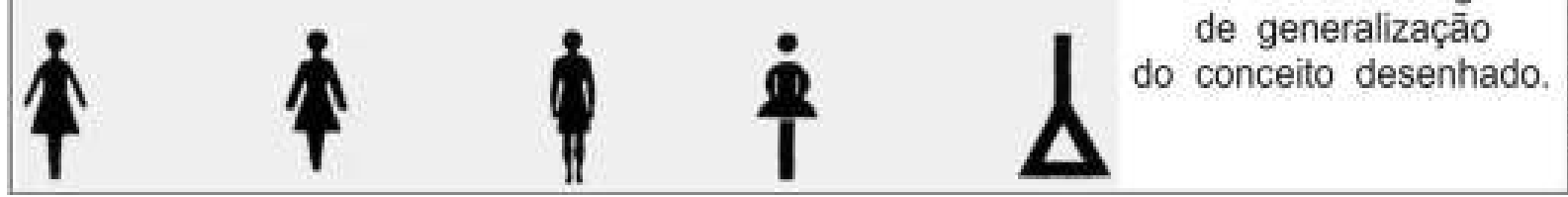

Os pictogramas têm ilustrado sinais ou mensagens de trânsito, os mais variados eventos esportivos, feiras mundiais, aeroportos entre outras atividades cotidianas. Encontra-se, por exemplo, em equipamentos eletrodomésticos, no zoológico, na sinalização turística, adaptando-se a distintas culturas e situações (Carneiro, 2001: 2). Existem, ainda, alguns símbolos que representam objetos e locais do cotidiano humano, como aqueles pictogramas utilizados para indicar locais públicos (hospital, banheiro, vestiários, restaurantes) e serviços (telefonia, transportes, informações, estacionamento). No entanto, tais pictogramas não são suficientes para garantir o aprendizado de toda gama de sinais inseridos na simbologia usada na comunicação visual (Carneiro, 2001:191). 
No que diz respeito ao programa de uma sinalização turística, a autora complementa (op.cit.: 2001:196) que se devem levar em conta as sinalizações (Figura 74):

$\checkmark$ Externas: inseridas em ambientes urbanos e rurais - referem-se aos equipamentos e serviços atrativos do cenário representado,

$\checkmark$ Internas: referem-se especificamente aos equipamentos, apontando as suas facilidades, serviços e locais especiais,

$\checkmark$ De uso comum: orientações de cunho genérico, dirigidas a turistas, como advertências, proibições e regulamentações.

Figura 74 - Estrutura inicial de um sistema de sinalização turística

\begin{tabular}{|c|c|c|c|c|}
\hline & & $\begin{array}{l}\text { Vias de } \\
\text { Acesso } \\
\text { em consonância } \\
\text { com Contran e }\end{array}$ & $\begin{array}{l}\text { Rodoviári } \\
\text { Ferroviárił } \\
\text { Aérea }\end{array}$ & \\
\hline & EXTERNA & & & $\begin{array}{l}\text { Parques estaduais } \\
\text { Áreas de proteção }\end{array}$ \\
\hline & & Atrativos & Histórico- & culturais \\
\hline & & & Artificiais & $\begin{array}{l}\text { Parques temáticos } \\
\text { de diversäo }\end{array}$ \\
\hline & & $\begin{array}{l}\text { Serviços/ Equ } \\
\text { Indicação e Or }\end{array}$ & $\begin{array}{l}\text { (Turisticos } \\
\text { ntaçäo). }\end{array}$ & e Não-Turísticos \\
\hline SINALIZAÇÃO & INTERNA & $\begin{array}{l}\text { Equipamentos } \\
\text { de apoio }\end{array}$ & $\begin{array}{l}\text { Hotéis } \\
\text { Eventos/F } \\
\text { Restaurar }\end{array}$ & $\begin{array}{l}\text { eiras } \\
\text { ites }\end{array}$ \\
\hline & & Serviços & $\begin{array}{l}\text { Todos os } \\
\text { não só os }\end{array}$ & $\begin{array}{l}\text { serviços, } \\
\text { turisticos }\end{array}$ \\
\hline & & Comunicações & $\begin{array}{l}\text { Sinais de } \\
\text { em emb } \\
\text { produtos }\end{array}$ & $\begin{array}{l}\text { advertência } \\
\text { alagens de } \\
\text { manuais, etc. }\end{array}$ \\
\hline & & Educação & $\begin{array}{l}\text { Sinais edu } \\
\text { escolas, bi } \\
\text { museus, c }\end{array}$ & $\begin{array}{l}\text { Icativos em } \\
\text { ibliotecas, } \\
\text { ampus universitário }\end{array}$ \\
\hline & OUTRAS & Facilidades & $\begin{array}{l}\text { Médicas, } \\
\text { manutenç } \\
\text { transporte }\end{array}$ & $\begin{array}{l}\text { nospitalares, } \\
\text { âo de } \\
\text { s, etc. }\end{array}$ \\
\hline & & $\begin{array}{l}\text { Segurança } \\
\text { Industrial }\end{array}$ & $\begin{array}{l}\text { Prevenção } \\
\text { incêndios, } \\
\text { saidas de }\end{array}$ & $\begin{array}{l}\text { e combate a } \\
\text { radioatividade, } \\
\text { emergência, etc. }\end{array}$ \\
\hline
\end{tabular}


A figura 75 refere-se ao fato de que, além do princípio básico de que todo pictograma deve ser compatível a várias culturas, faz-se ainda uma segunda ressalva: devido ao desenvolvimento natural da sociedade, correlacionado ao tempo e sua dinâmica, é bem provável que alguns símbolos necessitem de uma reavaliação periódica de suas representações. Por exemplo, citam-se as diferentes formas - reflexo do processo evolutivo - de representação para telefone, isto é, será que o pictograma elaborado para as Olimpíadas de 1968 no México não está ultrapassado? Até porque, atualmente, é raro se deparar com um telefone discado.

Figura 75 - As modificações das representações gráficas ao longo do tempo

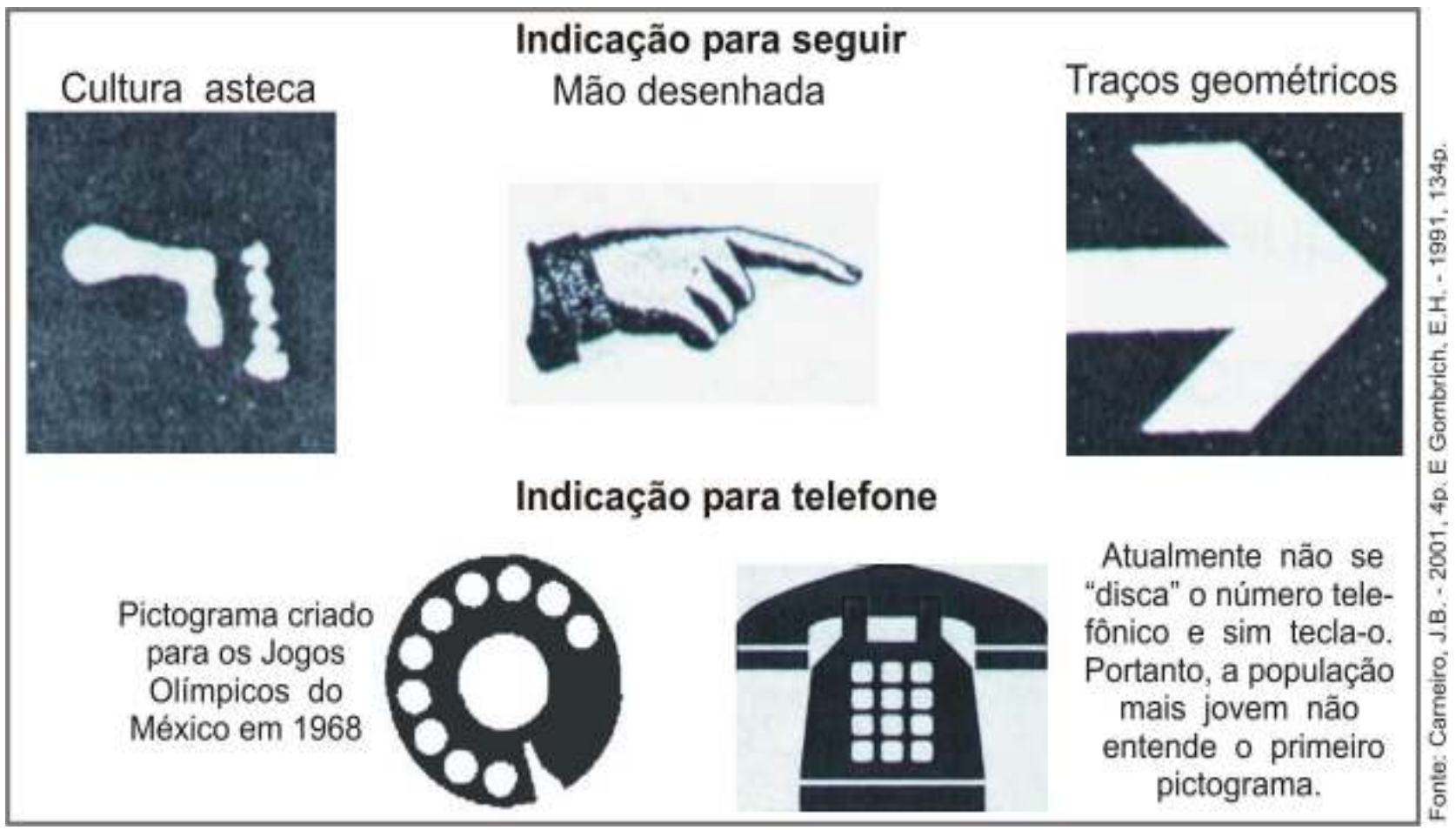

A figura 76 exemplifica o processo essencialmente dinâmico referente à evolução dos traços gráficos para os sinais de orientação.

Souza (1992: 178; 182) ainda lembra que, mesmo havendo um princípio normativo para a criação de pictogramas, é comum surgirem várias versões do mesmo conceito, isto é, o mesmo pictograma pode apresentar diferenças gráficas sem que isso altere sua significação (Figura 76A). Acrescente-se que, embora o plano de representação do pictograma seja preferencialmente frontal, ainda existem os pictogramas longitudinais e, mais raramente, os em perspectiva (Figura 76B). 
Figura 76 - Pictogramas: versões de um mesmo conceito

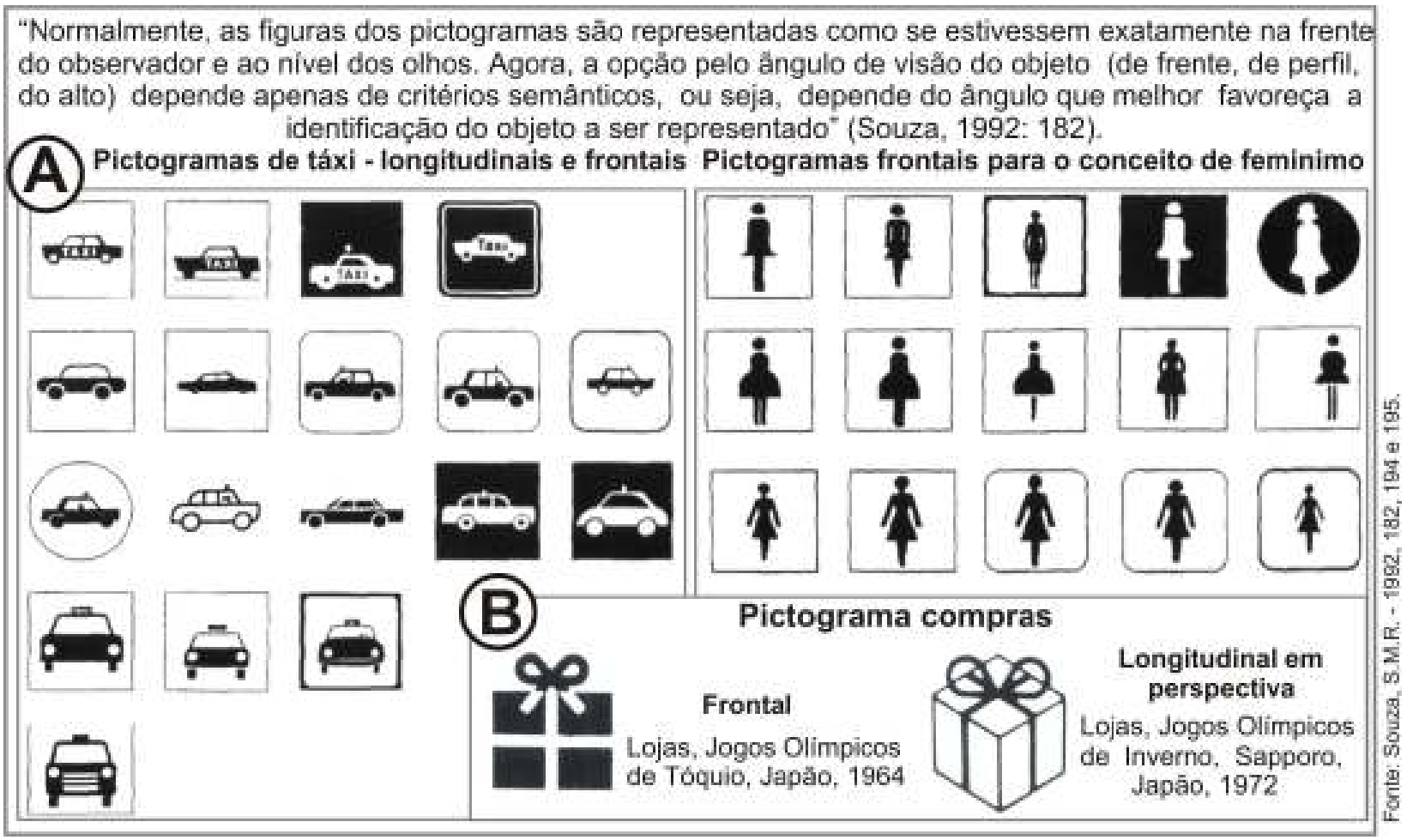

Carneiro, 2001:3) lista três tipos diferentes de pictogramas (Figura 77):

$\checkmark$ O figurativo - caracteriza-se pela vocação mimética de sua imagem, não deixando dúvidas quanto ao seu significado para o observador. Representa o objeto, ação ou idéia por meio de um desenho com peculiaridades aproximadas do elemento representado. Informa de maneira imediata; logo, não necessita de uma aprendizagem especial.

$\checkmark$ O semântico - abrange os esquemas cuja mensagem gráfica do objeto, ação ou idéia não é compreensível à primeira vista, exigindo um certo esforço de reflexão. O reconhecimento deste tipo de pictograma exige um período de aprendizagem específico. Logo, busca-se elaborar uma imagem gráfica por meio de contornos simples, suficientemente claros e inteligíveis na relação entre a representação e seu símbolo para que, assim, as pessoas entendam pelo aprendizado do uso constante.

$\checkmark$ O abstrato - compreende signos que possuem um alto grau de abstração, ou seja, não apresentam o objeto, ação ou idéia. É um código que será entendido apenas por aquelas pessoas que aprenderam como utilizá-lo. No entanto, quando incorporados ao conhecimento, sendo empregados de modo inconsciente, a informação que prestam é imediata e espontânea, tal como acontece aos signos alfabéticos. 
Figura 77 - Os três níveis de pictogramas

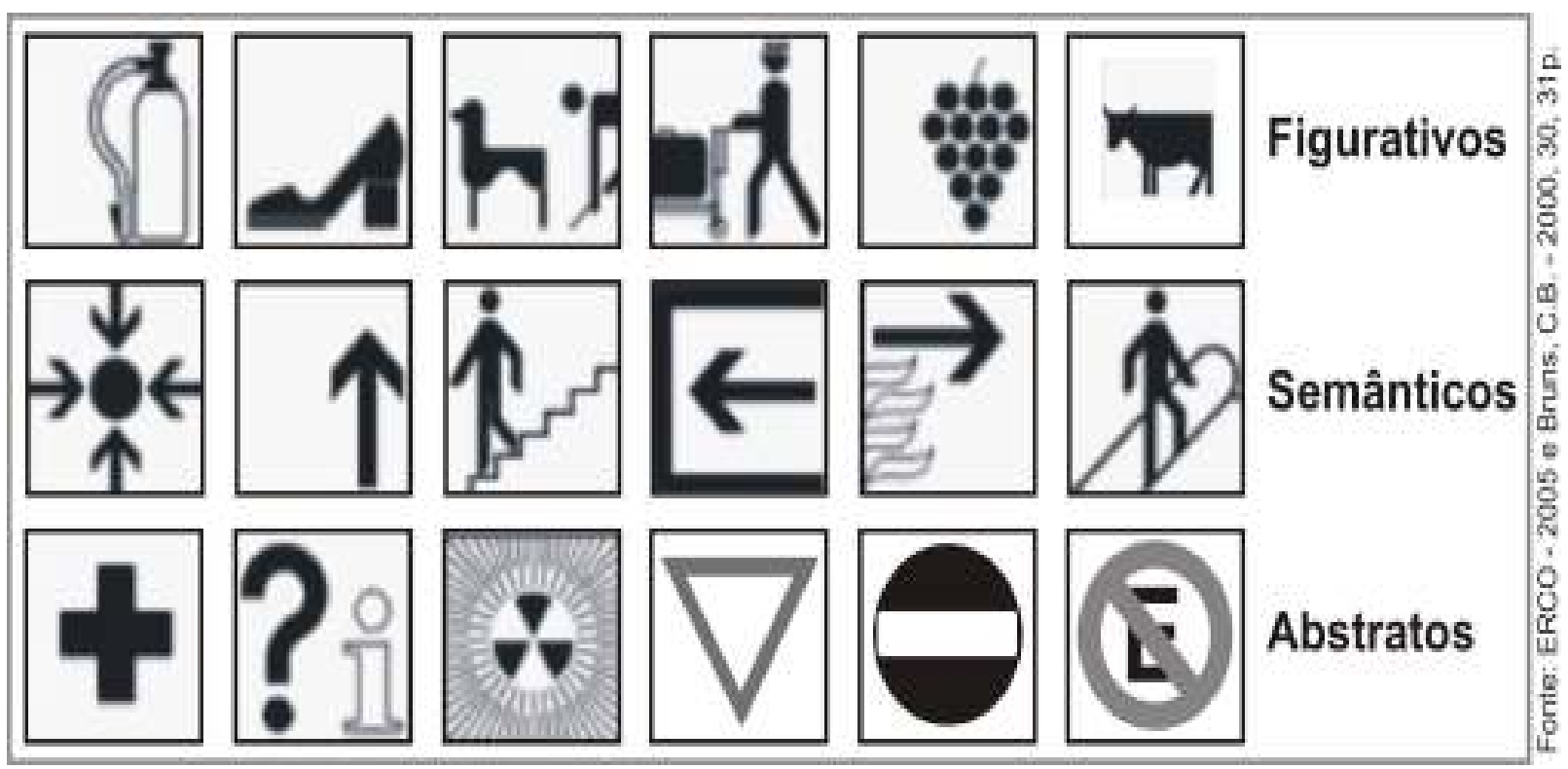

Para finalizar, Souza (1992:193) descreve as etapas do processo de categorização para a produção de pictogramas, que compreende as seguintes etapas:

a) reconhecer atributos (gestuais ou formais) invariantes distintivos que um ser, objeto ou situação possuem para pertencer a esta ou àquela classe; b) valorar os atributos reconhecidos; c) selecionar os atributos mais significativos para uma correta identificação semântica do ser, objeto ou situação; d) traduzir os atributos selecionados para a linguagem gráfica, observando as normas ou padrões sintáticos já estabelecidos pelo uso.

Carneiro (2001: 7) expõe a flagrante falta de estudos e pesquisas de caráter científico sobre a implantação, o uso e compreensão dos pictogramas em um sistema de sinalização turística ${ }^{59}$. E isso se traduz em uma escassa bibliografia disponível no Brasil e mesmo no exterior.

Como se pôde notar, a continuidade na elaboração de uma simbologia voltada aos mapas pictóricos turísticos conta com a valiosa dissertação de Carneiro (2001) intitulada: Sinalização Turística - diretórios e sistemas nacionais e internacionais, por desenvolver um trabalho apurado ao longo de quatro anos sobre o uso de pictogramas no setor turístico. A autora escolheu os diretórios (ou sistemas) do

\footnotetext{
${ }^{59}$ Compreende todo sinal gráfico (lingüístico, pictórico ou misto) que promova a correta orientação do usuário/ turista dentro de uma destinação ou equipamento turísticos (Carneiro, 2001: 11).
} 
Instituto Americano de Artes Gráficas ${ }^{60}$ (A/GA) e do japonês de Kuwayama ${ }^{61}$ Pictogramas e Fontes do Mundo Inteiro $n^{\circ}$. 2, por serem fontes bibliográficas constantes nos sistemas oficiais brasileiros e também por constituírem-se fontes referenciais em publicações nacionais e internacionais. Ao mesmo tempo, analisou alguns sistemas de sinalização turística, como o da Portland Oregon Visitors Association $^{62}$ (POVA), das cidades de Navarra, Ibiza (Espanha) e Alentejo (Portugal), da empresa alemã ERCO e das Olimpíadas de 2000 em Sidney, Austrália.

Quanto a fontes nacionais, a autora optou por aqueles sistemas elaborados por órgãos oficiais de turismo, federal e estadual: o CONTRAN (Conselho Nacional de Trânsito), a EMBRATUR (Instituto Brasileiro de Turismo) e a Secretaria Estadual de Esportes e Turismo do Estado de São Paulo (SEET), o sistema de sinalização do Código de Transito Brasileiro, além do Guia Quatro Rodas Brasil, reeditado anualmente pela Editora Abril.

Posto isso, concorda-se com Carneiro (2001: 30) no tocante ao desafio que os comunicadores têm quanto ao coeficiente de repetição da informação - no caso, os pictogramas - em um determinado tempo, ou seja, quanto mais um mesmo Símbolo de Informação Pública for usado, mais haverá a probabilidade de ser conhecido por um maior número de pessoas. Cresce, dessa forma, a inteligibilidade.

O desenvolvimento ou a escolha de uso de um pictograma já elaborado deve sempre respeitar as três dimensões de projeção de um signo e deixar-se guiar por elas: a sintática (como dizer ao usuário = técnicas e regras), a semântica (o que dizer ao usuário = clareza, influência da cultura) e a pragmática (para que dizer e a qual usuário dizer = enfatiza ou elimina elementos caracterizadores do signo para melhor entendimento), procurando sempre a maior eficiência do pictograma - detalhes sobre as três dimensões estão no item 1.5 .

Neste momento, apresenta-se o recolhimento de pictogramas utilizados em várias partes do mundo. As tabelas de 2 a 8 mostram uma série de símbolos de informação pública encontrados em publicações referentes a sistemas de sinalização turística, mapas turísticos e sites do Brasil e de outros países - mais aqueles já testados empiricamente em Fiori (2003) - demonstrando que se pode almejar uma possível

\footnotetext{
${ }^{60}$ Associação sem fins lucrativos fundada em 1914. Desenvolve nos E.U.A. um programa que inclui eventos, publicações, exposições e atividades educativas, com a finalidade de promover a qualidade e a excelência no terreno do desenho ou design gráfico. Ao longo deste tempo, elaboraram, por exemplo, sistemas gráficos de sinalização e programas de identificação para clientes na Europa, África, Ásia e Estados Unidos (Carneiro, op.cit.:46).

${ }^{61}$ Coletou e inventariou pictogramas ao longo de sete anos (1980 a 1987) em 76 cidades de 39 países da Europa, Ásia e Américas (incluindo São Paulo e Rio de Janeiro), resultando na publicação desse diretório. Em 1993, foi lançado o segundo diretório (Carneiro, op.cit.:65).

${ }^{62}$ Essa associação requisitou de Todd Pierce (presidente da empresa Design Pacifica International LLC) e sua equipe a criação e organização de um repertório de pictogramas. Em 1996, foi publicado um livro com a intenção de ser um indicador de sinalização completo para a cidade de Portland (E.U.A.).
} 
homogeneidade em relação aos pictogramas, mesmo havendo a factual heterogeneidade intercultural.

Ao término do inventário, percebeu-se que:

A mesma aparência gráfica de um pictograma é utilizada por diferentes culturas. Como é o caso, por exemplo, dos pictogramas de abastecimento, informação, café, hospital, aeroporto, natação, teatro, camping, entre outros.

> Implicações culturais puderam ser evidenciadas em alguns casos. Primeiro: todos os países já arrolados ilustram pictograficamente o item restaurante a partir de representações gráficas compostas por um garfo, uma faca, uma colher e/ou um prato. Contudo, no Japão, esse item é representado por meio de um "rashi". Outro caso: o Brasil é o único país que não utiliza a letra "P" (parking) para se referir a estacionamento, preferindo a letra "E". Talvez a solução seja colocar o pictograma de um "carrinho" (redundância ao lado da letra), como utilizado no mapa de Glasgow, Inglaterra. O mesmo fato acontece com o SIP para Hotel. Uma observação final refere-se aos países do norte europeu (Alemanha, Finlândia, Suécia) que utiliza um "olho" para representar correio.

Alguns pictogramas são mais facilmente compreendidos e interpretados que outros, ou seja, existem pictogramas potencialmente mais usados em mapas turísticos e, por conseguinte, pelos usuários enquanto outros se referem a atividades e atrações turísticas específicas e restritas a poucas destinações. $O$ exemplo pode ser retirado dos pictogramas de arquitetura histórica, tipos de templos religiosos (igreja, mesquita, sinagoga), ou de atividades esportivas não muito conhecidas como: paraglider, rafting, windsurfe ou rapel.

A terceira etapa da pesquisa, como já foi realizada em Fiori (2003), propôs um repertório maior de pictogramas a serem testados empiricamente por intermédio da aplicação de questionários, tendo como referencial os símbolos de informação pública das tabelas de 2 a 8.

A análise ocorre basicamente se averiguando a eficácia da representação gráfica de cada pictograma, ou seja, quantificando e qualificando a compreensão e aceitação pelo público potencial. 
Tabela 2 - Acomodaçāol Hospedagem

\begin{tabular}{|c|c|c|c|c|c|}
\hline Coluna 11 & $\begin{array}{l}\text { 蹗 } \\
\text { 品 }\end{array}$ & 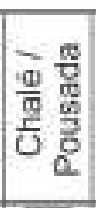 & 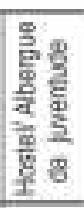 & $\frac{\frac{D}{C}}{\frac{\mathrm{C}}{\mathrm{B}}}$ & 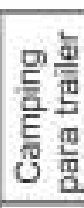 \\
\hline Fiori $(2003)^{*}$ & H] & 다 & & & \\
\hline $\begin{array}{l}\text { Secretaria do } \\
\text { turismo (Săo Paulo) }\end{array}$ & & & & & \\
\hline CONTRAN & & & & & IF \\
\hline Guia 4 rodas & (6) & & & & \\
\hline IPHAN & & & & & \\
\hline ERCO & 10 & & & & \\
\hline Rügen & & & IR & & \\
\hline Dusseldorf & & & & & \\
\hline Buenos Aires & $\mathrm{H}$ & & & & \\
\hline Mendoza & $\theta$ & & & & \\
\hline Hull e Ottawa & & & & & \\
\hline Ottawa & & & & & \\
\hline Chile & [a] & ill & & $\mathbf{A}$ & \\
\hline Cuba & TI & & & & \\
\hline Barcelona & $\mathrm{H}$ & & & & \\
\hline La Coruna & H & & & & \\
\hline Madri & $\mathrm{H}$ & & & & \\
\hline Toledo & & & & & \\
\hline AIGA & $\stackrel{6}{n}$ & & & & \\
\hline Filadélfia & {$[\mathbf{E}]$} & & & & \\
\hline $\begin{array}{c}\text { Williamsburg } \\
\text { (Vrginia) }\end{array}$ & & & & & \\
\hline Manhattan & & & & & \\
\hline Finlândia & 复 & E & If & $\mathbf{A}$ & $\underline{\underline{O}}$ \\
\hline $\int_{\text {França }}^{\text {coshi }}$ & & & & & \\
\hline Milskolc & & & & & \\
\hline Budapeste & & & & & \\
\hline
\end{tabular}

\begin{tabular}{|c|c|c|c|c|c|}
\hline 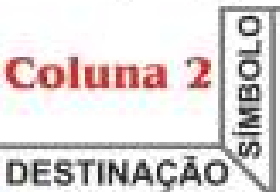 & $\begin{array}{l}\text { 명 } \\
\text { 옹 }\end{array}$ & 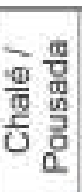 & 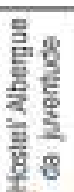 & $\frac{\text { 噼 }}{\text { E }}$ & 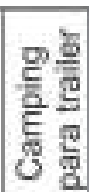 \\
\hline $\begin{array}{l}\text { entur } \\
\text { Israel }\end{array}$ & & & Aก & & \\
\hline Killarney & & & 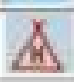 & & \\
\hline Camboubge e Glasgow & {$[1]$} & & & & \\
\hline Nagano e Oyama & & & & 1 & 8 \\
\hline Estocolmo & 障 & & in & $\boldsymbol{\Lambda}$ & 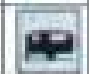 \\
\hline & & & & & \\
\hline & & & & & \\
\hline & & & & & \\
\hline & & & & & \\
\hline & & & & & \\
\hline & & & & & \\
\hline & & & & & \\
\hline & & & & & \\
\hline & & & & & \\
\hline & & & & & \\
\hline & & & & & \\
\hline & & & & & \\
\hline & & & & & \\
\hline & & & & & \\
\hline & & & & & \\
\hline & & & & & \\
\hline & & & & & \\
\hline & & & & & \\
\hline & & & & & \\
\hline & & & & & \\
\hline & & & & & \\
\hline
\end{tabular}


Tabela 3 - Serviços turísticos

\begin{tabular}{|c|c|c|c|c|c|c|c|c|c|c|c|c|c|c|}
\hline 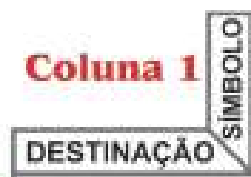 & 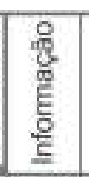 & 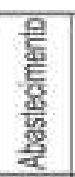 & : & & 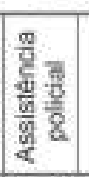 & $\frac{\mathscr{0}}{\frac{\delta}{\omega}}$ & 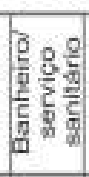 & $\frac{8}{\frac{8}{2}}$ & 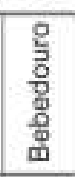 & 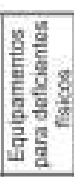 & 这 & 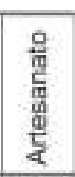 & 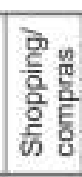 & 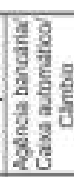 \\
\hline Fiori (2003)* & (4) & 믈 & 四 & 5 & $\mathbf{P}$ & 6 & & $\varnothing$ & & & & 8 & & \\
\hline $\begin{array}{l}\text { Secretaria do } \\
\text { turismo (S3so Pauto) }\end{array}$ & i & & & 40 & 2 & & 巾े & & & & & & 㱐 & \\
\hline CONTRAN & (i) & 용 & & 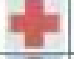 & & 1 & 筮 & $>$ & & G. & & is & & \\
\hline Guia 4 rodas & i & & 2 & 4 & & 6 & & & & & & & & \$ \\
\hline IPHAN & i & Q & 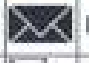 & 4 & & & ia & $>$ & & & & 28 & & $\$$ \\
\hline ERCO & $?$ & Q & 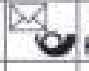 & $\infty$ & $\underline{x^{n}=}$ & 6 & $\dot{\varphi} \dot{\varphi}$ & $\overline{\mathbf{T}}$ & & $\dot{\xi}$ & 司 & & (18) & $\$$ \\
\hline Rügen & & & & & & & & & & & & & & \\
\hline Dusseldorf & i & & (2) & $\boldsymbol{\theta}$ & 3 & & wC & & & b & & & & \\
\hline Buenos Aires & $\mathbf{E}$ & 8 & ब & & & & & & & & & & Ed & \\
\hline Mendoza & (i) & & & & & & & & & & & & & \\
\hline Hull e Ottawa & $?$ & & & & & 6 & AB & & Niv & 5 & & & & \\
\hline Ottawa & $?$ & & & 4 & & & & & & & & & & \\
\hline Chile & I? & ? & a & 4 & & 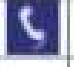 & & & & & & 3 & s & 5 \\
\hline Cuba & & 89 & 20 & Fis & & & & & & & & & हี่ & 5 \\
\hline Barcelona & in & f & 国 & 5 & 2 & C & & & & E & & & & \\
\hline La Conuña & 2 & D & 国 & 5 & & & & & & & & & & \\
\hline Madri & i & & & & & & & & & b & & & & \\
\hline Toledo & i) & & & & & & & & & & & & & \\
\hline AIGA & (2) & & 四 & & & C & Itis & & 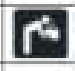 & & 菌 & & 兑券 & 需 \\
\hline Filadélfia & & & & H & & & & & & & & & & \\
\hline $\begin{array}{c}\text { Williamsburg } \\
\text { (Mirginia) }\end{array}$ & & & & & & $C$ & +4 & & 0 & 5 & & & & \\
\hline Manhattan & & & & & & & & & & & & & & \\
\hline Finlândia & & (1) & a. & & & & & 1 & & & & & 8 & $\$$ \\
\hline França & & & & & & & & & & & & & & \\
\hline Milskolc & $\mathbf{E}$ & & & & & & & & & & & & & \\
\hline Budapeste & i & di & & 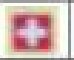 & & & & & & & & & & \\
\hline
\end{tabular}

\begin{tabular}{|c|c|c|c|c|c|c|c|c|c|c|c|c|c|c|}
\hline Coluna 2 DESTINAÇĀO & 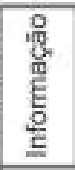 & 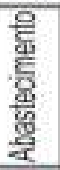 & 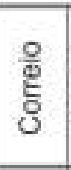 & 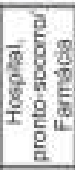 & 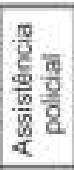 & 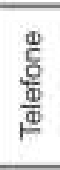 & 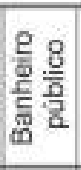 & 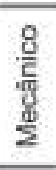 & 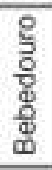 & 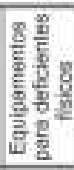 & 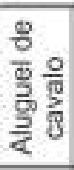 & 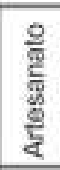 & 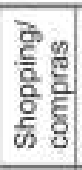 & \\
\hline Israel & & D & & & & & & & & & & & & \\
\hline $\begin{array}{l}\text { Rewas } \\
\text { Killarney }\end{array}$ & {[} & & & & & & WC & & & & & & & \\
\hline $\begin{array}{l}\text { Hountemen } \\
\text { Cambridge }\end{array}$ & $\bar{l}$ & & (2) & & & 6 & 둔후 & & & 5 & & & & \\
\hline Nagano e Oyama & & 䨘 & & 7 & & 8 & W.c & & & & & & & \\
\hline $\begin{array}{l}\text { Sulciv } \\
\text { Estocolmo }\end{array}$ & E & & $\infty$ & 4 & 2 & & WC & & & & & & & \\
\hline
\end{tabular}


Tabela 4 - Alimentação e Abastecimento

\begin{tabular}{|c|c|c|c|c|c|c|c|}
\hline 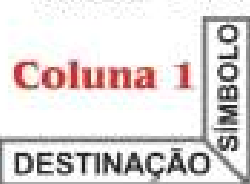 & 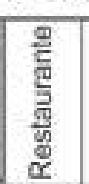 & లু & 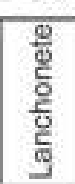 & 高 & $\begin{array}{l}\frac{\pi}{\frac{\pi}{2}} \\
\frac{\pi}{2} \\
\frac{8}{8}\end{array}$ & 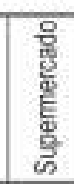 & 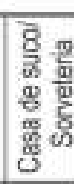 \\
\hline Fiori $(2003)^{*}$ & $x$ & & & (1) & & & \\
\hline $\begin{array}{l}\text { Secretaria do } \\
\text { turismo (Sao Paub) }\end{array}$ & IIP & III & 5 & 1 & 而 & 쁄 & 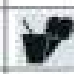 \\
\hline CONTRAN & $x$ & & & & & & \\
\hline Guia 4 rodas & $\%$ & & & & & & \\
\hline IPHAN & $x$ & & & & & & \\
\hline ERCO & 211 & 표 & $\rightarrow$ & E & D & = & $P$ \\
\hline Rügen & x & & & & & & \\
\hline Dusseldorf & & & & & & & \\
\hline Buenos Aires & {$[1$} & & & $Y$ & & & \\
\hline Mendoza & (6) & 8 & & & & & \\
\hline Hull e Ottawa & b] & E & & & & & \\
\hline Ottawa & & & & & & & \\
\hline $\int_{\text {Chan }}^{\text {Conile }}$ & 80 & 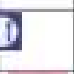 & & E & & & \\
\hline Cuba & $\mathbf{E}$ & $\square$ & & $\mathrm{I}$ & & & \\
\hline Barcelona & & & & & & & \\
\hline La Coruña & & & & & & & \\
\hline Madri & & & & & & & \\
\hline Toledo & & & & & & & \\
\hline AIGA & II & P & & $Y$ & & & \\
\hline Filadélfia & & & & & & & \\
\hline $\begin{array}{c}\text { Williamsburg } \\
\text { (Virginia) }\end{array}$ & & & & & & & \\
\hline Manhattan & & & & & & & \\
\hline Finlândia & $x$ & 표 & $V=$ & $\mathbf{I}$ & & wi & \\
\hline$\llbracket$ França & & & & & & & \\
\hline Milskolc & & & & & & & \\
\hline Budapeste & & & & & & & \\
\hline
\end{tabular}

\begin{tabular}{|c|c|c|c|c|c|c|c|}
\hline Coluna 2 & 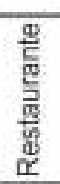 & $\frac{\Phi}{\tilde{N}}$ & 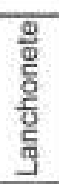 & 蹗 & 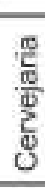 & 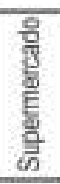 & 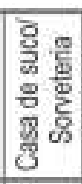 \\
\hline $\begin{array}{l}\text { oeens } \\
\text { istael }\end{array}$ & & & & & & & \\
\hline Killarney & & & & & & & \\
\hline Cambridge & & & & & & & \\
\hline $\int_{\text {Naghano e Oyama }}^{1 \text { Nodo }}$ & (a. & $\theta$ & & & & & \\
\hline
\end{tabular}


Tabela 5 - Transportes

\begin{tabular}{|c|c|c|c|c|c|c|c|c|c|c|c|}
\hline Coluna 1 DESTINAÇAO & 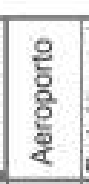 & 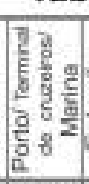 & & & 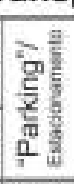 & $\stackrel{\mathrm{g}}{\mathrm{g}}$ & $\bar{x}$ & 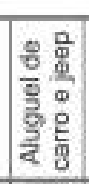 & 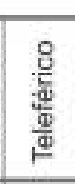 & $\frac{9}{\frac{8}{5}}$ & $\begin{array}{l}\frac{2}{\circ} \\
\frac{2}{9} \\
\frac{2}{x}\end{array}$ \\
\hline Fiori (2003) & & \pm & & & $E$ & & & 成 & & $\theta$ & \\
\hline $\begin{array}{l}\text { Secretaria do } \\
\text { turismo (Saco Pavulo) }\end{array}$ & + & & $\theta$ & 且 & & & 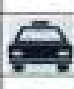 & $\sum_{\infty}^{\circ}$ & $\pi$ & 息 & E् \\
\hline CONTRAN & T & \pm & $\Rightarrow$ & & E & & & & & $t$ & \\
\hline Guia 4 rodas & A & & $\operatorname{men}$ & aㅔ & [E] & & & 咸 & & & \\
\hline IPHAN & & & & & & & & & & & \\
\hline ERCO & & & & & & & & & & & \\
\hline Rügen & $\Psi$ & \pm & & & $\mathbf{P}$ & & & & & & \\
\hline Dusseldorf & & & & & $P$ & & & & & & \\
\hline Buenos Aires & P & & & & $P$ & & & & & & \\
\hline Mendonça & & & & & & & & & & & \\
\hline Hull e Ottawa & & & & & $\mathbf{P}$ & & & & & & \\
\hline Ottawa & & & & & & & & & & & \\
\hline Chile & & & & & & & & & & & \\
\hline Cuba & & & & & & & & & & & \\
\hline Barcelona & $t$ & 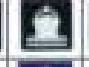 & - & B & $P$ & (4) & & & 몸 & & \\
\hline La Coruña & & $\underline{z}$ & $\Theta$ & $\theta$ & $\mathbf{P}$ & & $\mathrm{T}$ & & & & \\
\hline Madri & $x$ & & E & & $P$ & $\infty$ & & & & & \\
\hline Toledo & & & & & P & & & & & & \\
\hline AIGA & & & & & & & & & & & \\
\hline Filadelfia & (x) & & E & & P. & & & & & & \\
\hline $\begin{array}{c}\text { Williamsburg } \\
\text { (Nirginia) }\end{array}$ & & & & & & & & & & & \\
\hline Manhattan & & & & & & & & & & & \\
\hline Finlândia & A & 2 & & & & & & & N & & \\
\hline França & + & & & & & & & & & & \\
\hline Milskolc & $\hat{1}$ & 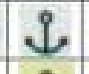 & & & & & & & & 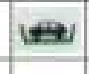 & \\
\hline Budapeste & & $\downarrow$ & 田 & & $\mathbf{P}$ & Q & & & & & \\
\hline $\begin{array}{l}\text { Coluna } 2 \mid \frac{\mathrm{m}}{\mathrm{m}} \\
\text { DESTINAÇĀO }\end{array}$ & \begin{tabular}{|l|}
8 \\
$\frac{8}{2}$ \\
8 \\
$\frac{2}{2}$ \\
8 \\
\end{tabular} & 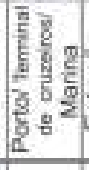 & 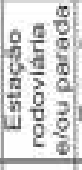 & 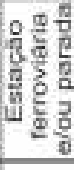 & 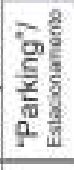 & $\frac{\mathrm{g}}{2}$ & 준 & 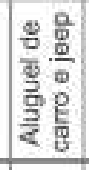 & 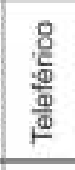 & 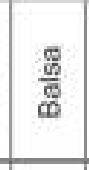 & $\begin{array}{l}\frac{0}{8} \\
\frac{\circ}{\overline{5}} \\
\end{array}$ \\
\hline \begin{tabular}{|l|} 
oesti \\
Israel \\
\end{tabular} & 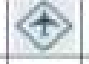 & & & & & & & & & & \\
\hline \begin{tabular}{|l|l|} 
Imunou \\
\end{tabular} & & & & & (P) & & & & & & \\
\hline \multirow{2}{*}{ 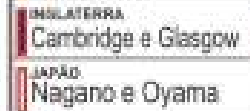 } & \pm . & 它 & $=$ & & 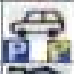 & & & & & & \\
\hline & & & & Bast & (P) & & & & & 8 & \\
\hline Estocolmo & & & & (J) & $P$ & (T) & & & & & \\
\hline
\end{tabular}


Tabela 6 - Atrativos turísticos e entretenimento

\begin{tabular}{|c|c|c|c|c|c|c|c|c|c|c|c|c|c|c|c|c|c|c|c|}
\hline Coluna 1 DESTINAÇAO & 梠 & 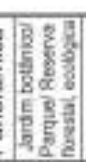 & 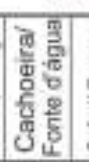 & 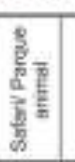 & $\begin{array}{l}\frac{8}{0} \\
\frac{8}{8} \\
\end{array}$ & 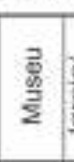 & 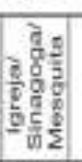 & 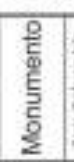 & 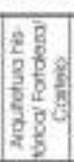 & 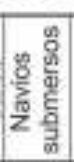 & $\frac{\pi}{80}$ & 를 & 要 & 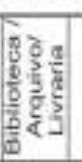 & 兽 & 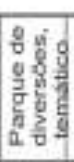 & $\begin{array}{l}\frac{8}{0} \\
\frac{8}{8} \\
\frac{3}{2}\end{array}$ & $\begin{array}{l}\text { 总 } \\
\frac{p^{2}}{I}\end{array}$ & 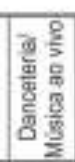 \\
\hline Fion $(2003)^{*}$ & & & 대요 & & (7) & (IIII) & $\Phi$ & (1) & A & $\infty$ & $\lambda$ & TT & & $\theta$ & & & & $\infty$ & E. \\
\hline 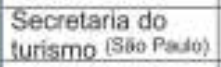 & & & & & & & & & & & & & & & te & Q & $\rightarrow$ & के & \\
\hline CONTRAN & E: & 뚜 & & & 国 & IIII & 1 & 1 & A & & $\lambda$ & 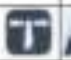 & $A$ & & & & & & \\
\hline Guia 4 rodas & + & & & & & & ed & & & & & & & & & & & & \\
\hline IPHAN & to & 8 & ne & & P. & IIII & & 1 & 댐에 & & $\lambda$ & $\overline{1}$ & 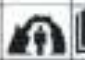 & [L] & 疍 & sin & \% & $x$ & \\
\hline ERCO & & & & & & 藏 & $1+{ }^{+}+$ & & 口 & & & & & IIII & $\because 0^{\circ}$ & & & & $a_{x}$ \\
\hline Rügen & 洸 & & & 6 & एव० & IIII & की & & $\mathbf{H}$ & & & ic & & & & & & & \\
\hline Dusseldarf & & & & & & & 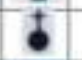 & & & & & & & & & & & & \\
\hline Buenos Aires & & T) & & & 4 & & tha & & & & 2 & & & & & & & ER & \\
\hline Mendoza & & & & & $70^{\circ}$ & (1) & 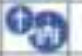 & & & & & & & & (6) & & & & \\
\hline Hull e Ottawa & & & & & & Iiii & & & & & & & & & & & & & \\
\hline Ottawa & & & & & & & & & & & & & & & & & & & \\
\hline Chile & L & 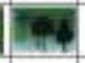 & & & $\pi / 2$ & & $A$ & & $\circ$ & & & & & & (2) & & & 8 & $\%$ \\
\hline Cuba & & & & & & [iii] & $\boldsymbol{\theta}$ & $\Omega$ & & & 5 & & & $\mathrm{\theta}$ & $\theta$ & & & & (1) \\
\hline Barcelona & 36 & & & & & $M$ & & & & & & & & B & & & & & \\
\hline La Coruña & & & & & & 0 & & & & & $\infty$ & & & & & & & & \\
\hline Madri & & & & & & & & & & & & & & & & & & & \\
\hline Toledo & & & & & & & & & & & & & & & & & & & \\
\hline AIGA & & & & & & & & & & & & & & & & & & & \\
\hline Filadelfia & & & & & & & $\pm \%$ & & & & & & & & & & & & \\
\hline $\begin{array}{c}\text { Williamsburg } \\
\text { (Nininie) }\end{array}$ & & & & & & & & & & & & & & & & & & & \\
\hline Manhattan & & & & & & & & & & & & & & & & & & & \\
\hline Finnlândia & $*$ & & & & & $\mathbf{M}$ & $\mathrm{b}$ & & & & & & & & $\Theta$ & & & & \\
\hline Franca & $\Delta !$ & & & $n^{\prime}$ & & & H & & $\mathbf{d}$ & & & & $n$ & & & 조 & & & \\
\hline Milskolc & ㄴ. & 4: & & & & 業 & $M$ & $\Lambda$ & $\mathbf{H}$ & & & & $\Omega$ & & (ㄷ) & & & & \\
\hline Budapeste & & 乎 & & & & 요 & $4 *$ & 1 & & & & & $\Omega$ & & $\theta$ & & & & \\
\hline Coluna 2 DESTINAC,AO O & 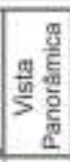 & & 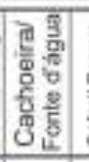 & 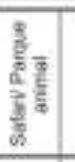 & $\begin{array}{l}\frac{8}{10} \\
\frac{8}{8} \\
N\end{array}$ & 想, & 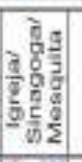 & 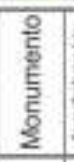 & 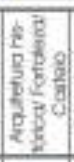 & 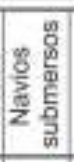 & $\frac{m}{2}$ & 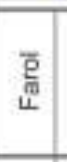 & 票 & 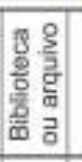 & $\frac{2}{2}$ & 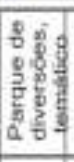 & है & $\begin{array}{l}\frac{\text { है }}{\text { 奠 }} \\
\frac{1}{1}\end{array}$ & 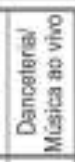 \\
\hline Israel & $\psi$ & 9 & & & & $\mathrm{~m}$ & 24 & & $z$ & & $\cong$ & & n & & & & & & \\
\hline Kinatamey & $21 / 6$ & 49 & & & & & + & & & & & & & & & & & & \\
\hline 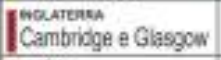 & & & & & & Givi & 60 & & & & & & & & 89 & & & & \\
\hline Nagano e Oyame & & & 20 & & & & & & & & & & & & & & & & a \\
\hline Esten & $\%$ & & & (9) & & & & & & & & & & & (5) & & & & \\
\hline
\end{tabular}


Tabela 7 - Práticas desportivas e recreativas

\begin{tabular}{|c|c|c|c|c|c|c|c|c|c|c|c|c|c|c|c|c|c|c|c|c|c|c|c|c|c|}
\hline 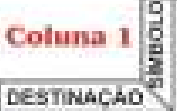 & $\frac{2}{E}$ & $\frac{8}{2}$ & 要 & 党 & है & हैं & & E. & $\frac{3}{8}$ & & $\frac{E}{3}$ & कै & & & $\frac{8}{2}$ & 量 & & & & 离 & $\frac{b}{8}$ & $\frac{2}{2}$ & & & 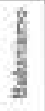 \\
\hline Five (20031" & 2xin & & & & (ब) & (x) & $\$$ & 9 & 8 & (I) & & II & (a) & $=11$ & I & A & & $F$ & (2) & & & 조 & & & \\
\hline 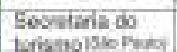 & & & & & & & $\bar{k}$ & & & $E$ & & & & & & & & & a. & F & $\widehat{F}$ & & d & & $\%$ \\
\hline Gua 4 rodas & a. & th & \#ึ & 9 & $\rho$ & & & & & & & $-x$ & & & lot & 1. & 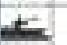 & & dito & & & & 1 & & \\
\hline DONTFWN & 2 & & & & & & & b) & & I & & ce & 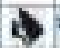 & 51 & $t$ & A & 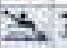 & $\$$ & & & & $h^{3}$ & & $P_{m}$ & \\
\hline IFHAN & & $\not h$ & & & & 6 & $\$ 1$ & & & & & (t) & 3 & $\Rightarrow$ & $t$ & A & & 3 & A & & & & & 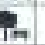 & \\
\hline EACO & $m$ & $\not h$ & $\$$ & c) & $x$ & $y$ & k & 乘 & & $z$ & 7 & $x$ & $P_{n}$ & 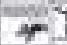 & B. & $*$ & $*$ & 8 & dकी & ţ & $\nabla$ & & & & 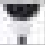 \\
\hline Fuger & & & & & & & & & & & & & & & & $\approx$ & & & & & & & & & \\
\hline Dussuldat & & & & & & & & & & & & & & & & & & & & & & & & & \\
\hline Buenos Arou & & & & & & & & & & & & & & & & & & & & & & & & & \\
\hline Menososos & & & & & & & & & & & & & & & & & & & & & & & & & \\
\hline Hat cotama & Da & & & & & & & & & & & & & & & & & & & & & & & & \\
\hline Glawa & & & & & & & 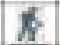 & & & & $t$ & & & & & \pm & \pm & & a & & & & & 五 & \\
\hline çate & & & & & & 嘼 & [1] & & & & t1 & & & & E & 2 & A & & & & 해 & & & 물 & \\
\hline Dons & & & & & & & & & & & & & & 5.4 & (2) & & & & & & & & & & \\
\hline Barsotions & & & & & & & & & & & & & & & & & & & a & & & & & & \\
\hline Lo chensts & & & & & & & & & & & & & & & & & & & Q & & & & & & \\
\hline Masin & & & & & & & & & & & & & & & & & & & & & & & & & \\
\hline funto & & & & & & & & & & & & & & & & & & & & & & & & & \\
\hline AMOA & & & & & & & & & & & & & & & & & & & & & & & & & \\
\hline Fandefa & & & & & & & & & & & & & & & & & & & & & & & & & \\
\hline $\begin{array}{l}\text { Wharrodury } \\
\text { Murpara }\end{array}$ & & & & & & & & & & & & & & & & & & & & & & & & & \\
\hline Marhanen & & & & & & & & & & & & & & & & & & & & & & & & & \\
\hline Finstinde & $\underline{1}$ & & & & & 6. & Mx & & & & & & a) & & 2 & $\neq$ & 3 & & do & $x$ & & s): & A & & \\
\hline Ftianca & & & & & & & & & & & & & & & & & & & & & & & & & \\
\hline Matric: & & & & & & & & & & & 2 & & & & & & & & & & & & & & \\
\hline Buctapeste & & & & & & & & & & & & & & & & & & & & & & & & & \\
\hline $\begin{array}{c}\text { Coluna } 2 \text {. } \\
\text { DESInNAC,AO }\end{array}$ & $\frac{\frac{\pi}{2}}{6}$ & $\frac{8}{6}$ & $\frac{\pi}{3}$ & $\frac{z}{2}$ & है & $\frac{\frac{2}{6}}{6}$ & Pह & $\frac{\pi}{2}$ & $\frac{8}{8}$ & $\frac{d}{3}$ & $\frac{\tilde{c}}{3} \frac{1}{3}$ & $\frac{8}{2}$ & 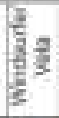 & है: & $\frac{b}{2}$ & $\frac{8}{9}$ & & & 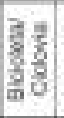 & $\frac{8}{8}$ & 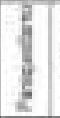 & $\frac{2}{2}$ & $\frac{8}{8}$ & & $\frac{8}{3}$ \\
\hline Isrant & & & & & & & & & & & 3 & & & 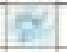 & & 3 & & & & & & & & 9 & \\
\hline Thimey & & & & & & & & & & & & & & & & & & & & & & & & & \\
\hline 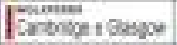 & & & & & & & & & & & & & & & & & & & dse & & & & & & \\
\hline 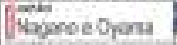 & 69 & & & & 2 & & 9 & & & & bi & & II & & 63 & & & & 30 & & & 8 & & & \\
\hline Estoonimo & 1 & & & & & & & & & & & & & & & & & & & & & & & & \\
\hline
\end{tabular}


Tabela 8 - Pictogramas usados pelo site do Albergue da Juventude Internacional

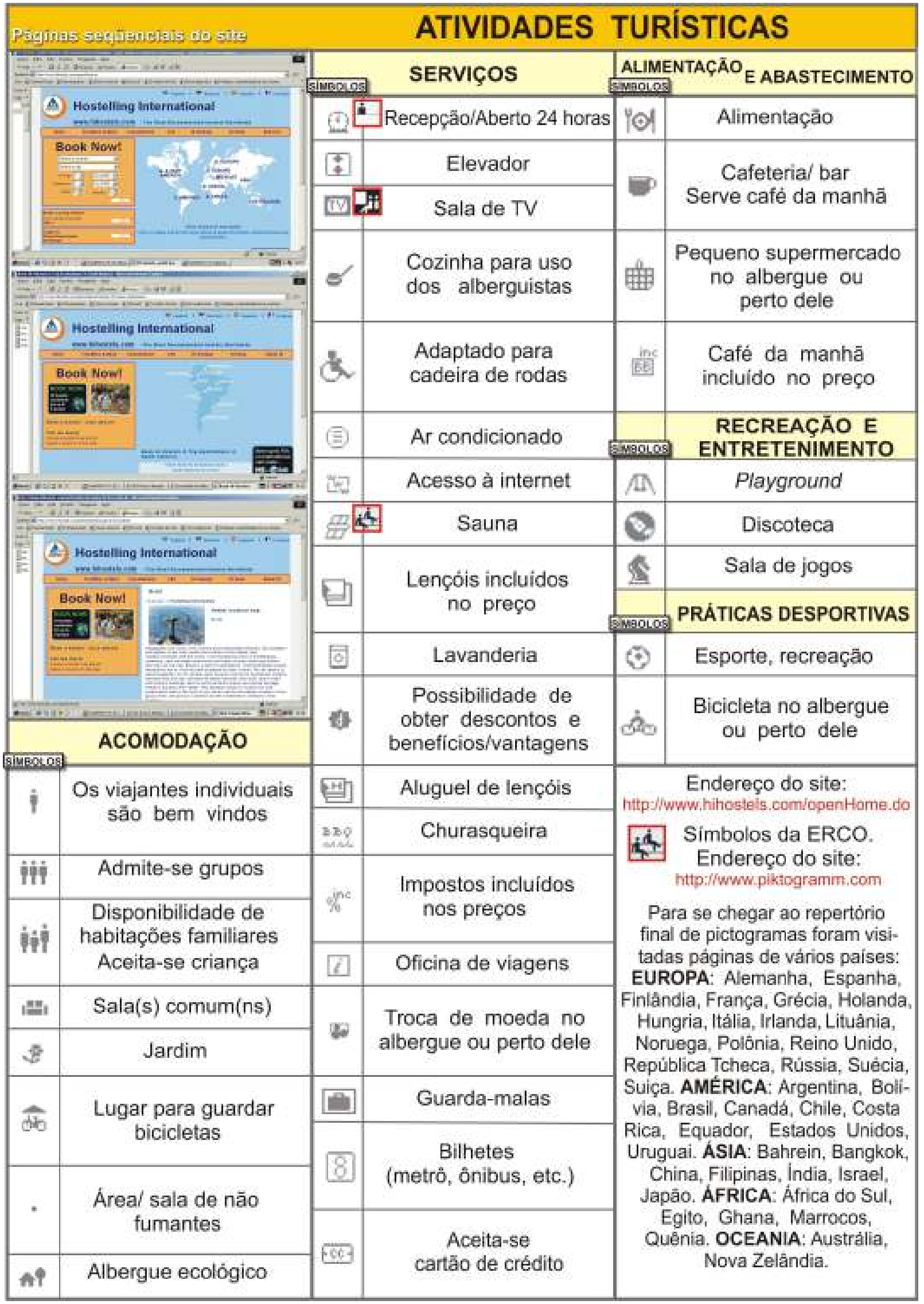




\section{3 - Elementos que compõem a multimídia interativa: aplicação em um mapa}

No setor do turismo, o mapa tradicional impresso é usado em conjunto com outros produtos gráficos, como guias e folhetos. Em geral, é um produto que ocupa pouco espaço físico como, por exemplo, o bolso da calça ou pequeno espaço na mochila. É de fácil manipulação, pois é dobrável, podendo ainda ser consultado em várias situações: ao andar, sentado no banco de uma praça, na areia da praia, em uma mesa, em pé, etc.

Entretanto, o mapa turístico em meio digital pode ser mais atrativo por poder incluir uma quantidade enorme de informações se comparado aos tradicionais mapas impressos, pois utilizar recursos como: vídeo clips, composição de vários layers camadas e possibilidade de representar uma mesma informação de diferentes formas - textos em pop up, que não poluem visualmente o mapa, indicação de links, entre outros recursos.

Apoiando-se na idéia de Emmer \& Worm (2001), um mapa turístico em multimídia interativa tem a capacidade de transformar um único mapa em muitos outros, sempre referenciado na mesma função inicial: o setor do turismo. Isso porque, um mesmo produto pode oferecer um mapa itinerário que se faz necessário às viagens de carro; o mapa da cidade e turístico, representando os cenários, as ruas, os hotéis, os restaurantes, os pontos atrativos, etc; o mapa rural, essencial para a viagem de férias no campo onde existam escaladas, caminhadas, ciclismo, etc neste seria interessante disponibilizar um mapa topográfico - e mais quantos mapas desejarem o planejador e o usuário.

Além disso, a multimídia interativa proporciona uma terceira opção, possibilitando que seus usuários "montem" e imprimam seus próprios mapas, personalizados, antes de saírem de casa (Brown, Emmer \& Worm, 2001).

Toda essa remodelação tecnológica ajudou a expandir, por exemplo, o uso dos bens patrimoniais e o campo da criatividade. Assim como o vídeo game tornou trivial as batalhas históricas, e alguns videoclipes ofereceram tendências experimentais à arte, os computadores e outros usos do vídeo facilitaram a obtenção de dados, a visualização e inovação gráfica. Isso permitiu simular o uso de novas peças e informações, reduziu a distância entre concepção e execução, conhecimento e aplicação, informação e decisão. Essa apropriação múltipla de produtos culturais abre as possibilidades originais de experimentação e comunicação (Canclini, 2003: 308). Entretanto, é necessário se fazer uma ressalva, apoiada no mesmo autor (Canclini, op.cit::150), que coloca a noção de público como sendo muito perigosa se caracterizada como um conjunto homogêneo e de comportamentos constantes. Deve-se levar em consideração que a sociedade está dividida em estratos econômicos e educacionais diversos, com hábitos de consumo 
cultural e disponibilidades diferentes para se relacionar com os bens oferecidos no mercado.

A partir daí, quem serão potencialmente os usuários dos produtos desenvolvidos nesta pesquisa? Pode-se supor que são aquelas pessoas com maior nível de educação tanto informal, isto é, aprenderam a lidar com o computador com os pais, amigos, filhos ou netos, quanto formal, por freqüentarem diversos graus e tipos de escolas, curso de computação, etc; além de possuir um poder aquisitivo para possuir, por exemplo, um computador e ter acesso à Internet.

O produtor de mapas em um site, então, terá dois grandes desafios: primeiro, desenvolver produtos no formato digital, de maneira que possam ser navegados de maneira simples e rápida. Em seguida, voltar-se para as preocupações primordiais abordadas por Gerber, Burgen \& Stanton (1990) sobre as oito características quanto à maior ou menor possibilidade de adquirir a informação cartográfica pelos usuários, que dependem de sua habilidade e percepção espacial, capacidade de leitura, idade, habilidade para desenhar mapas, experiência prévia quanto ao uso dos mapas, gosto pela leitura e a disponibilidade de mapas em casa no decorrer da vida de modo que eles não sejam vistos como objetos estranhos.

Posto isso, sabe-se que existe a possibilidade de reconhecer, identificar um novo caminho de ver a informação geográfica, fornecendo enfoques e pontos de vista diferentes e, assim, esperançosamente, assegurar que o vazio do entendimento geográfico possa ser preenchido com informações reunidas a partir de outras perspectivas, trazendo, dessa forma, uma compreensão mais completa da realidade (Cartwright \& Heath, 2002).

Ao se trabalhar com produtos disponibilizados em ambiente virtual, uma outra questão a ser abordada diz respeito à plataforma mínima necessária para que o produto possa ser acessado. Cartwright (1996) destaca que cada título em multimídia apresenta uma necessidade específica para sua confecção, que se conformam em:

$\checkmark$ Espaço suficientemente extenso para armazenamento no disco rígido (hard disk drives) ou CD.

$\checkmark$ Memória RAM que permita movimentos e manipulações eficazes de imagens digitais, animação e vídeo.

$\checkmark$ Uma unidade de CD.

$\checkmark$ CDs para usar na confecção dos protótipos e cópias short-run.

$\checkmark$ Interatividade, isto é, o usuário - que é o agente - determina por onde e como navegar. $O$ acesso às informações deve ser rápido e fácil. 
$\checkmark$ Provisão de uma estrutura eficiente, a partir da qual os usuários possam ao mesmo tempo transitar e fazer escolhas sensatas e criativas (Figura 78).

Figura 78 - Componentes típicos de um título em multimídia

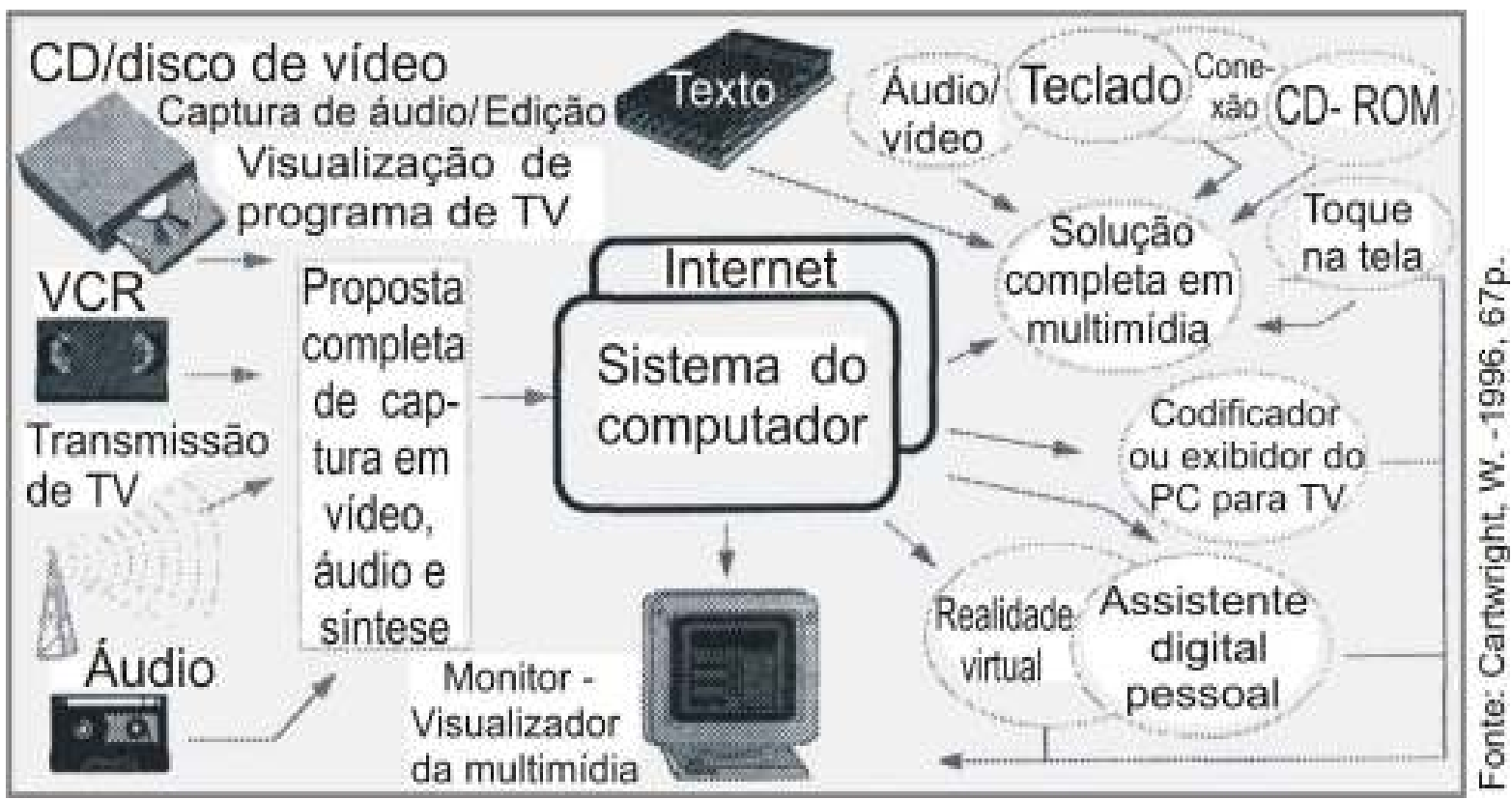

Inclui-se aos itens acima, um importante recurso não-material, ou seja, um conjunto de respostas emocionais que sejam o resultado das possibilidades de escolhas, caracterizando um acesso pessoal e personalizado com relação às diferentes mídias de um mesmo produto: a interação, ou seja, o controle da situação. Nos sistemas interativos, o espectador torna-se parte ativa da apresentação em vez de ser meramente um observador passivo. A interação possibilita ao usuário escolher o que fazer com o vídeo, o áudio e o texto. Com isso, os resultados da interatividade são mais individuais e imprevisíveis. Wolfgram (1994: 87) afirma que se você puder dar poderes à sua platéia, mesmo que seja da forma mais tímida, então poderá manter a sua atenção pelo tempo que precisar para transmitir a sua mensagem.

Romanov (apud Cartwright \& Heath, 2002) lembrou que, na Quarta Conferência Anual sobre World Wide Web, sustentou-se que a questão-chave na interatividade inteligente está no conteúdo emocional, que fundamenta a elaboração de produtos aos usuários. A promessa de novas tecnologias para artefatos cognitivos, como os mapas, tem proporcionado e aumentado a interação da comunicação contemporânea. Todavia, essas novas formas de representação e artefatos trarão novos questionamentos relacionados, por exemplo, ao entendimento e à eficácia da informação geográfica retratada, visualizada e percebida. A cartografia contemporânea precisa, então, encontrar maneiras de avaliar esse tipo de 
visualização, que dispõe de novas e diferentes ferramentas, providenciando representações inovadoras das imagens advindas da realidade.

Todavia se, de um lado, a grande variedade de recursos disponíveis como: ilustrações, áudio, vídeo, gráficos, textos, fotos, diferentes graus de representação da mesma informação, interatividade; num primeiro momento, fascina e dá a oportunidade de belas apresentações e possibilidades, de outro, traz também o problema da alta complexidade e imenso banco de dados. Logo, é papel do produtor desenvolver um material cartográfico e de multimídia-interativa eficaz em sua comunicação, ou seja, o usuário deve assimilar facilmente a informação, além de esta ser esteticamente motivadora. O consumidor não deve se sentir intimidado pela tecnologia, senão provavelmente não passará da demonstração inicial (Wolfgram, 1994).

Segundo Brown, Emmer \& Worm (2001) o grande negócio da interação é capacitar o usuário a encontrar e reagir às informações gráficas e textuais disponibilizadas. A cartografia, do mesmo modo que outras áreas do conhecimento, está sendo amplamente afetada pela revolução dos computadores e da Internet.

Desse modo, a produção de mapas turísticos interativos é um excitante desafio para o profissional em cartografia. Miller \& Pupedis (2002) afirmam que muitas vezes existe um enfoque maior nos aspectos técnicos (estruturação, integração e distribuição das bases de dados dos mapas) do que nos objetivos, necessidades e preferências dos usuários.

Entender como se trabalha com a tecnologia é fundamental, mas associações e contribuições da arte e da ciência para a cartografia são ainda mais importantes. $\mathrm{Na}$ opinião de Cartwright \& Heath (2002), a arte fornece a face pública da cartografia em multimídia (e a paixão, talvez a alma, do cartógrafo ao elaborar os produtos), e a ciência a complementa, garantindo a precisão e o rigor.

Sabe-se que, durante a elaboração do produto, agregam-se intrinsecamente técnicas e estéticas cartográficas, porém, para que se faça um produto esteticamente agradável, o talento artístico e o senso estético são de fundamental necessidade. Aliás, talento e senso estético não podem ser ensinados; por essa razão, alguns produtores de mapas são talentosos e outros, não (Brown, Emmer \& Worm, 2001).

Brown, Emmer \& Worm (2001) acrescentam serem poucas as vezes em que se encontram mapas que combinam elementos atrativos, de motivação e interativos. $E$ nos casos em que se aplica especificamente a interatividade, ela é, em sua maior parte, limitada a ações como zoom, pan e acesso a outros sites. Essas falhas ocorrem mesmo havendo programas que possibilitem a criação de uma grande variedade de formas interativas e de apresentação, trabalhadas por meio do design cartográfico. Especificamente, a produção de mapas para a Web, incluindo os turísticos, ainda continua muito restrito a reproduções feitas em papel, isto é, 
grande parte dos mapas turísticos disponíveis são simplesmente escaneados de outros já impressos.

Outro ponto a ser ressaltado sobre tipos de meios de apresentação no formato digital diz respeito à preocupação com o tempo de download do produto na Web. Isso porque, o desenvolvimento dos mapas turísticos precisa respeitar a qualidade da conexão - discada ou banda larga - que o usuário utiliza quando adquire a informação. Assim, o produto elaborado para a Web merece uma atenção redobrada quanto à funcionalidade das simbologias e à hierarquia visual da informação, por exemplo, buscando uma comunicação ágil e diminuindo a dificuldade em entender seqüências de acesso no site.

Wolfgram (1994) ratifica a proposta, a idéia de que o objetivo principal é não deixar que a apresentação pare de fluir, disponibilizando, por exemplo, recursos para informar ao usuário que o programa está rodando, ou para que ele saiba que, ao pressionar uma determinada tecla, aparecerá um determinado assunto. Deve-se evitar a demora no reconhecimento das informações: o usuário não pode, por exemplo, ficar parado por muito tempo em frente ao monitor do computador só para entender o que acontece no site. Todos esses fatores vão causando aborrecimento ao usuário, fazendo com que o produtor corra um sério risco de gerar perda das emoções e da motivação.

Miller \& Pupedis (2002), ao verificar outros sites, chegaram a algumas conclusões: normalmente, o produtor é muito técnico e, na maioria das vezes, faz suposições que generalizam o público alvo. Eles enfatizam que a implementação técnica, ou seja, acreditam que o produtor está muito mais preocupado com o tempo de download do que com a eficaz navegação do site pelo usuário. Além disso, devido ao custo, muitos produtores acabam desenvolvendo o site sem fazer um reconhecimento mais aprofundado e experimentado de seu usuário potencial.

Os autores (Miller \& Pupedis, 2002) ainda alertam para o fato de que pesquisas relacionadas ao uso dos mapas para $W e b$ - e, por que não dizer, os mapas interativos em geral - ligados às ciências geoespaciais estão normalmente focados em ferramentas de geovisualização voltadas àqueles usuários que já dominam o Sistema de Informação Geográfica (GIS). Por isso, os pesquisadores também precisam se preocupar com o uso do design daqueles sites elaborados para os usuários não-especializados, leigos em cartografia e/ou GIS. Os autores terminam a explanação, apontando alguns problemas de sites baseados em GIS:

$\checkmark$ Níveis inapropriados de generalização e escala.

$\checkmark$ Má elaboração do conteúdo temático dos mapas.

$\checkmark$ Precária legibilidade de leitura dos mapas.

$\checkmark$ Simbolização inconsistente. 
$\checkmark$ Uso confuso entre a escala e o zoom.

$\checkmark$ Uso de conceitos GIS não-familiares ao público em geral.

$\checkmark$ Procura confusa das estruturas espaciais.

$\checkmark$ Falta de clareza dos objetivos.

$\checkmark$ Excesso de níveis para obter a informação desejada.

$\checkmark$ Apresentação e navegação confusas.

$\checkmark$ Baixa motivação do usuário diante das informações oferecidas.

Em Cartwright \& Heath (2002) se acrescenta que a avaliação também deve envolver dimensões de interesse, que precisariam ser pensadas a partir dos projetos individuais, podendo incluir: a eficácia de aprendizado, o custo, a interatividade, os estilos de interação, a sincronicidade, a continuidade, a coesão, a qualidade na interface, a facilitação no uso, a disponibilidade, a facilidade de acesso, a natureza do produto, a fixação e a sustentação da informação, a eficácia na utilização da mídia e a complexidade dos elementos distribuídos.

Enfim, é óbvia a riqueza de conteúdo do novo meio de comunicação denominado hipermídia. Todavia, é prudente advertir sobre a enorme complexidade de elaboração desse tipo de produto, que necessita de um longo tempo para ser desenvolvido, é dispendioso e necessita de estudos que averigúem sua eficácia. Entretanto, estudos já apontam um inquestionável potencial de motivação do material disponibilizado em hipermídia, advindo tanto da diversidade de discursos disponíveis, como da flexibilidade dos percursos de exploração. Torna-se então necessário prever um mínimo de coerência pedagógica no projeto da correspondente navegação para que o usuário não se sinta perdido no hiperespaço (Rocha-Trindade, 1998: 169).

Faz-se justo afirmar que a boa transmissão da informação, além da alta tecnologia e suas respectivas facilidades técnicas, jamais deve dispensar um profissional especializado e competente preocupado em estabelecer um processo de desenvolvimento compatível com o produto idealizado.

Conseqüentemente, a concepção de todo o processo de design estará centrada no usuário, objetivando primordialmente que ele reconheça a idéia principal: no caso, a vocação turística (balneário, rural, estância, etc.) do município representado nos mapas turísticos interativos. O usuário-internauta deve se envolver a cada ação/clique no site, por meio dos botões, pop ups e outros recursos só existentes em meio digital.

O então mapa-site pode proporcionar a apresentação de atrativos, atividades e serviços, que é, por sua vez, atrelado a ciclos - grupos de temas distintos: 
arquitetura, esportes, acomodação, informações úteis, etc. - os quais em conjunto geram muitas e variadas informações sobre o destino. Some-se ainda a particularidade de que, por ser um produto constituído em ambiente virtual, tem a capacidade de ser renovado e realimentado, de tempos em tempos.

Escolhido a idéia principal e o público, inicia-se o processo desenvolvimento do produto. A primeira etapa é encontrar um estilo de arte mais condizente com as expectativas do usuário (Wolfgram, 1994: 103).

Desse modo, na elaboração dos mapas turísticos pictóricos interativos, é necessário que o produtor conheça as várias técnicas e formas de uso dos materiais já disponíveis. Wolfgram (op.cit:16) informa que as possibilidades de design incluem o projeto, o texto, as ilustrações, as animações, o vídeo, a música e, em alguns casos, a programação. Um bom projeto em multimídia deve sustentar uma boa apresentação, tendo como principais elementos a clareza, a simplicidade e a seqüência lógica e coerente. O autor (Wolfgram, op.cit.:122) ainda divide os componentes do projeto em: layout básico, cabeçalhos, texto principal, figuras adicionais, botões, tipografia, fundos e texturas.

O primeiro nível do conteúdo é formado pelo tema principal e os objetos interativos que podem ser, por exemplo, os símbolos acessíveis pelo mouse. O segundo nível refere-se à base da informação do mapa, muitas vezes consistindo em uma topografia simplificada. Pode conter também menus pop ups (com textos, filmes, tabelas, som, etc.), os quais fornecem informações adicionais sobre o tema principal. Existe ainda um terceiro nível, ligado às informações-suporte (aquelas não-diretamente relacionadas - marginais - ao tema principal) como legendas, bordas (moldura), ilustrações, gráficos ou menus pop up, como ilustra a figura 79 (Brown, Emmer \& Worm, 2001).

Wolfgram (op.cit:121) acrescenta que o projeto precisa buscar a união da arte, animação, ilustração e texto de forma que, efetivamente, comunique a mensagem. Cada linha, forma, fragmento de texto e cor precisa ter intenção e propósitos previamente direcionados. Fontes, estilos de fundo, e motivos musicais juntam-se aos já citados, proporcionando o impacto emocional e/ou auxiliar na comunicação. Trabalhar corretamente com estes parâmetros faz com que o projeto tenha uma possibilidade muito maior de eficácia.

Sendo assim, a elaboração dos mapas turísticos pictóricos e interativos apóia-se inicialmente na apresentação estilística (layout) do jogo SimCity ${ }^{\circledR}{ }^{63}$ (Figura 80), que parte de uma base - porção de terra - onde o jogador vai aos poucos construindo sua própria cidade. O SimCity ${ }^{\circledR}$ possui uma importante legenda

\footnotetext{
${ }^{63}$ Diferente da maioria dos jogos de computador, o SimCity 2000 ® não foi concebido com o intuito de vencer ou perder, pelo contrário; invoca um pensamento construtivo para educar o usuário sobre os conceitos geográficos e espaciais associados ao desenvolvimento urbano (Johnston \& Cartwright, 2000).
} 
Figura 79 - Os três níveis de conteúdo do mapa interativo

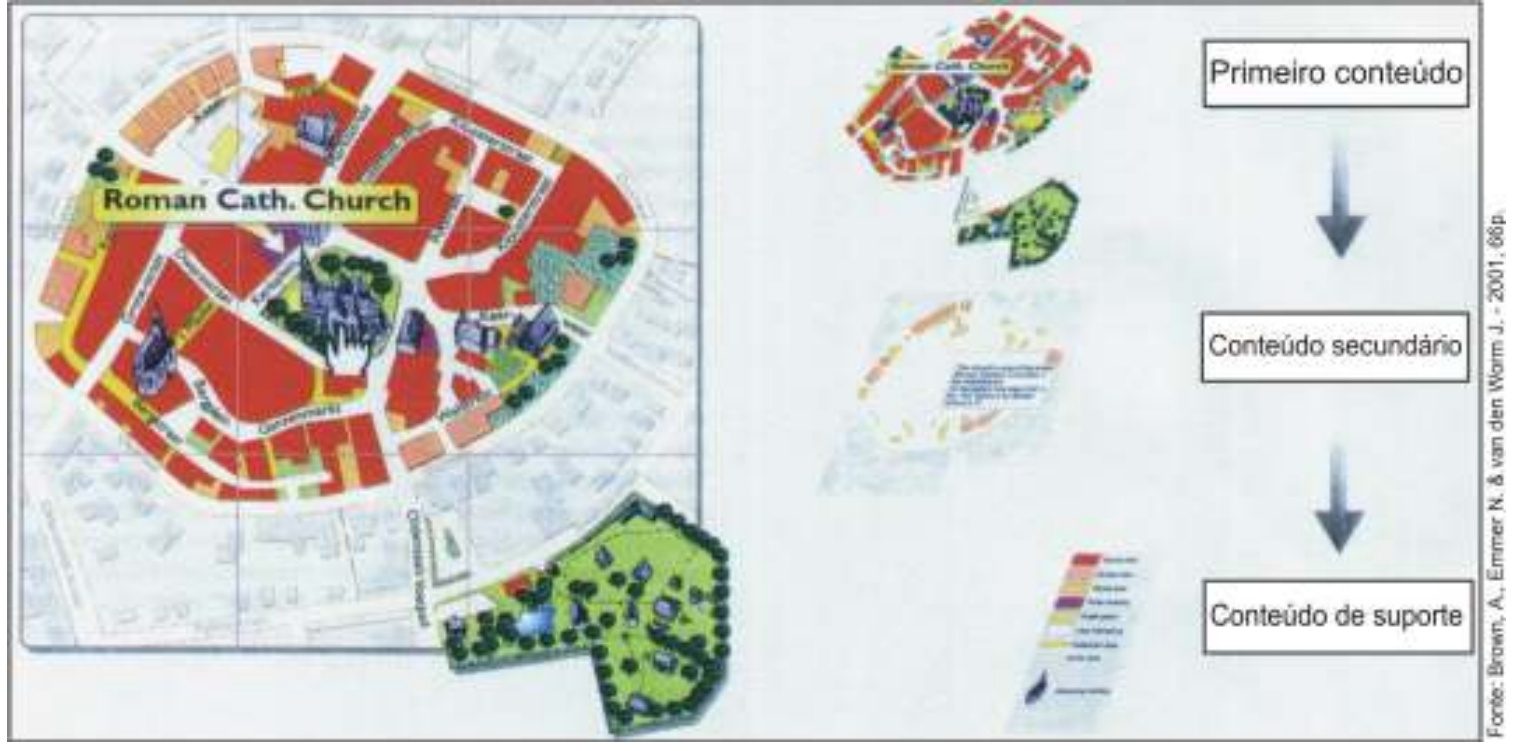

Figura 80: Simcity $®$ :referência para os mapas turísticos interativos

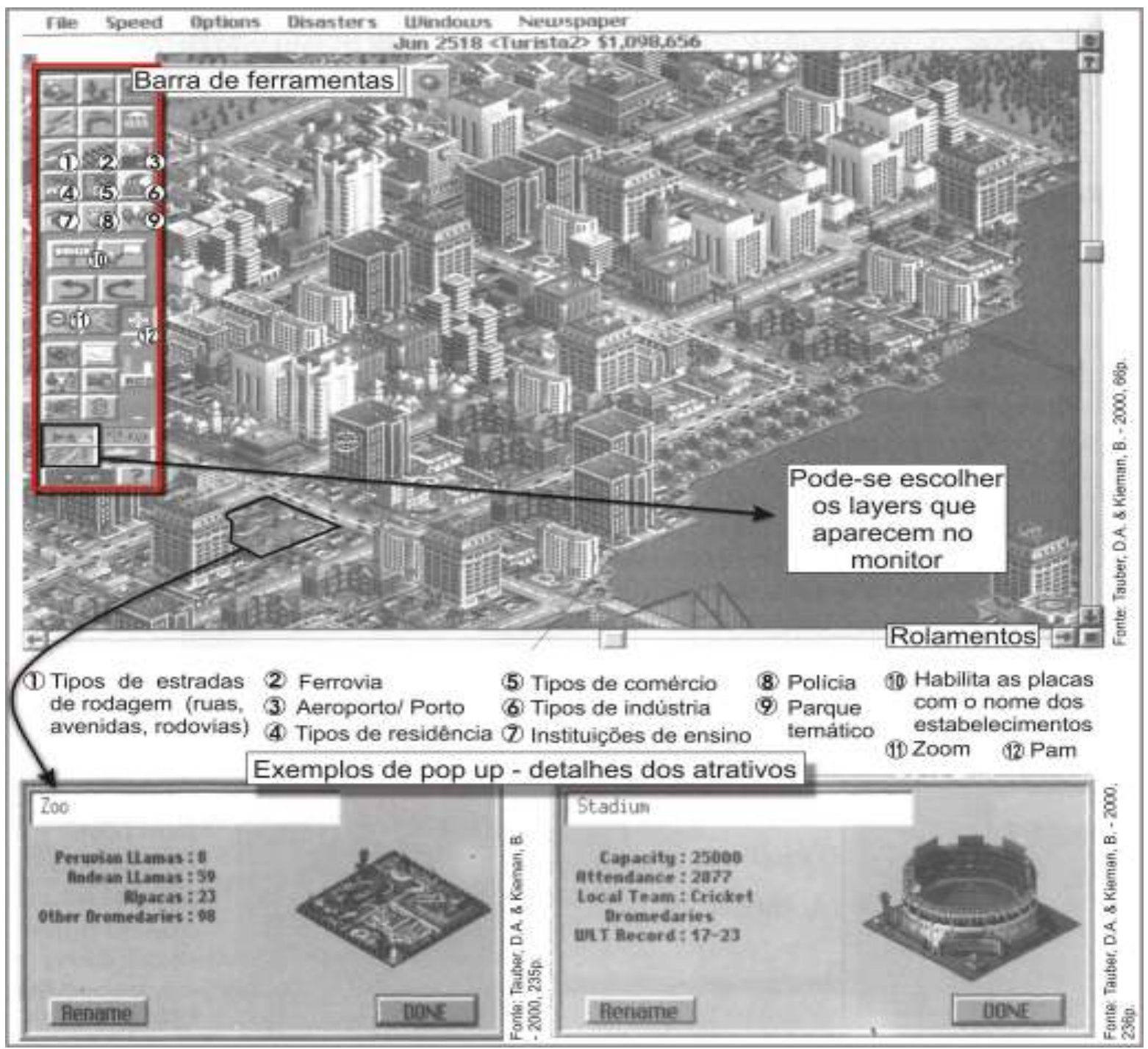


interativa que, entre seus inúmeros recursos, tem como principais elementos:

$>$ O zoom e o pan em vários níveis (sem escala formal).

> Uma rede de layers interativos que representam vários elementos espaciais de uma cidade como: residências, conglomerados comerciais (shoppings, restaurantes, parques de diversão) serviços (biblioteca, hospital, polícia), tipos de indústrias, meios de transporte, etc.

Acesso a informações importantes por meio de pop ups.

Todos esses recursos são facilmente habilitados e desabilitados pelo jogadorusuário.

Posto isso, a partir de agora são arroladas e exemplificadas as técnicas ainda não abordadas pelo item 2.1. Ao final, todas as técnicas apresentadas comporão um só conjunto que vão auxiliar no desenvolvimento dos mapas turísticos pictóricos interativos. Até porque, como enfatiza Dondis (1991: 24), as técnicas são os agentes do processo de comunicação visual e é por meio da sua energia que o caráter de solução visual adquire forma.

Referenciando-se na estrutura de projeto de Wolfgram (1994) e, até o momento, em autores como Menno-Jan \& Driel (1997), Brown, Emmer \& Worm (2001), detalham-se oito recursos de elaboração, transmissão e motivação de mensagens em multimídia interativa: o texto, o fundo-cenário, os elementos particulares (ilustrações, ícones e pictogramas), a animação, o áudio, o vídeo, a interatividade e o download e a impressão.

\subsection{1 - O texto}

Como já foi abordado anteriormente, mesmo com todas as novas tecnologias disponíveis para fazer uma boa apresentação, o texto ainda continua sendo um dos recursos mais importantes de comunicação. Entretanto, para que haja a transmissão da mensagem, ele deve ser representado de forma a provocar sua leitura.

Um bom texto deve sempre estar bem escrito, ser interessante e fácil de ler; precisa ainda prender a atenção, mesmo que não esteja acompanhado de animações ou efeitos de imagens. Na elaboração do mapa no formato digital, pontua-se que:

$\checkmark$ Trabalhe-se inicialmente com letras maiúsculas.

$\checkmark$ Mudem as dimensões das letras para explorar diferentes climas emocionais.

$\checkmark$ Usem-se fontes diferentes para transmitir a sensação de história, maciez, firmeza, ventos agitados e tundras congeladas. 
$\checkmark$ Cuide-se do tamanho dos caracteres que deve estar intrinsecamente ligado à escolha da fonte selecionada.

Já os textos referentes aos mapas disponibilizados para o computador distinguemse por duas aplicações principais:

$\checkmark \quad O$ texto aplicado nas bordas do mapa pode ser tratado como qualquer outro tipo de aplicação de texto em um mapa interativo ou página da Web. Deve haver precauções quanto ao controle do texto "flutuante" (onde e como localizá-lo nos pontos extremos do mapa), espaçamento e tamanho das letras, o tipo de fonte mais adequada, etc. Esse conjunto de texto comporá a(s) legenda(s), a(s) escala(s), o título, a borda (moldura) e outros itens complementares do mapa.

$\checkmark$ Em geral, o texto interno do mapa é usado para as informações geográficas, como os símbolos e uma série limitada de informações descritivas (rios, estradas, acidentes geográficos, etc.). As fontes devem buscar uma fácil legibilidade, principalmente aquelas relacionadas aos tamanhos menores $\mathrm{e}$, neste caso, os estilos simples, como a serifa e as fontes abertas são particularmente indicadas. $O$ texto em negrito pode melhorar a legibilidade, como também melhorar o espaçamento entre as letras. Uma regra é que a fonte não deve ter um tamanho menor que 10.

A quantidade de textos sobre o mapa deve se conservar baixa, porém, havendo a necessidade de grande uso deste recurso, a aplicação de um painel de controle habilita/desabilita para a legenda poderia permitir ao usuário mudar as camadas de texto ou desligá-los. Pode-se também utilizar o recurso do pop up: ele permite que, com um clique sobre uma determinada figura por meio do mouse, abra-se uma caixa de textos. Essa técnica permite ao produtor usar com freqüência, outros tamanhos e tipos de fontes, possibilitando uma leitura mais fácil e agradável (Figura 81).

O contraste entre a fonte e o fundo do mapa também afeta a legibilidade. Evita-se mais freqüentemente a seleção de texto claro sobre um fundo saturado (escuro) ou com muitas informações.

O contraste pode ser melhorado, se possível, pela adição de um fino contorno branco na fonte escura. Outra opção é aplicar uma sombra transparente projetada. Esta alternativa tem uma melhor aplicação em um texto importante e sóbrio, pois a sombra projetada pode gerar tanto um ruído quanto o aumento do tamanho do arquivo trabalhado.

\subsection{2 - O fundo-cenário}

E a maior ilustração do mapa pictórico interativo. Provém de um mapa-base topográfico em escala. $O$ fundo-cenário detalha pictograficamente e em visão 
oblíqua a morfologia do terreno da localidade turística, além de outros itens como vias de acesso (trilhas, ruas, avenidas, rodovias), rede hidrográfica (rios e córregos importantes) e caracterização de zonas urbanas, rurais e matas (figura 82).

Figura 81 - Legendas interativas pop up

As legendas interativas pop up podem ser utilizadas, por exemplo nas legendas secundárias, que são disponibilizadas quando o usuário seleciona ou passa o mouse por cima de um determinado objeto sobre o mapa

(Brown, Emmer \& Worm, 2001).

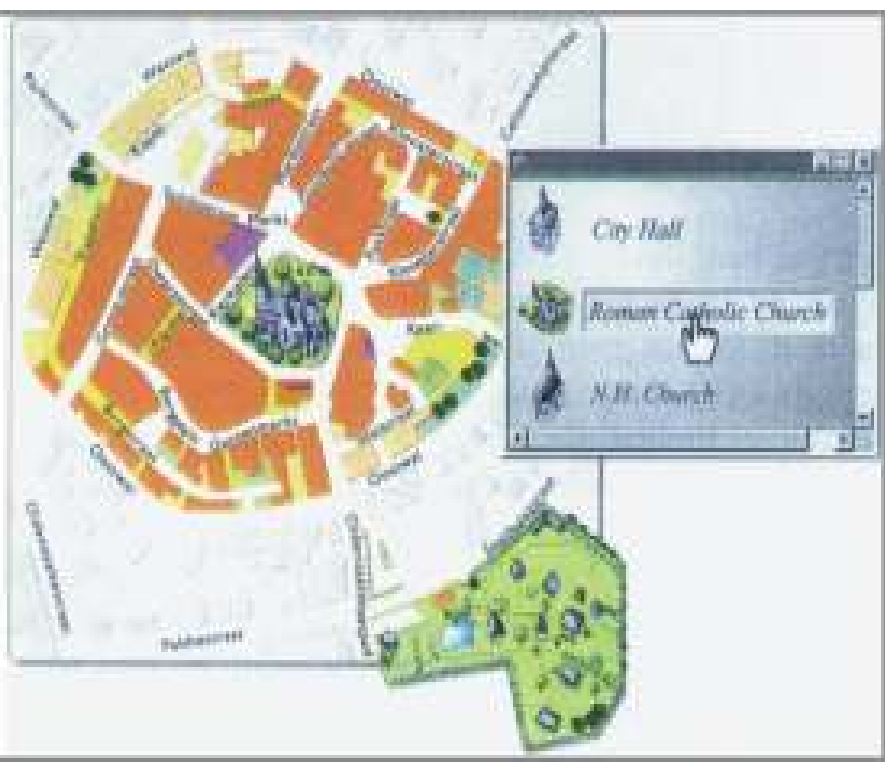

Figura 82 - Exemplo de um fundo-cenário: Caxambu

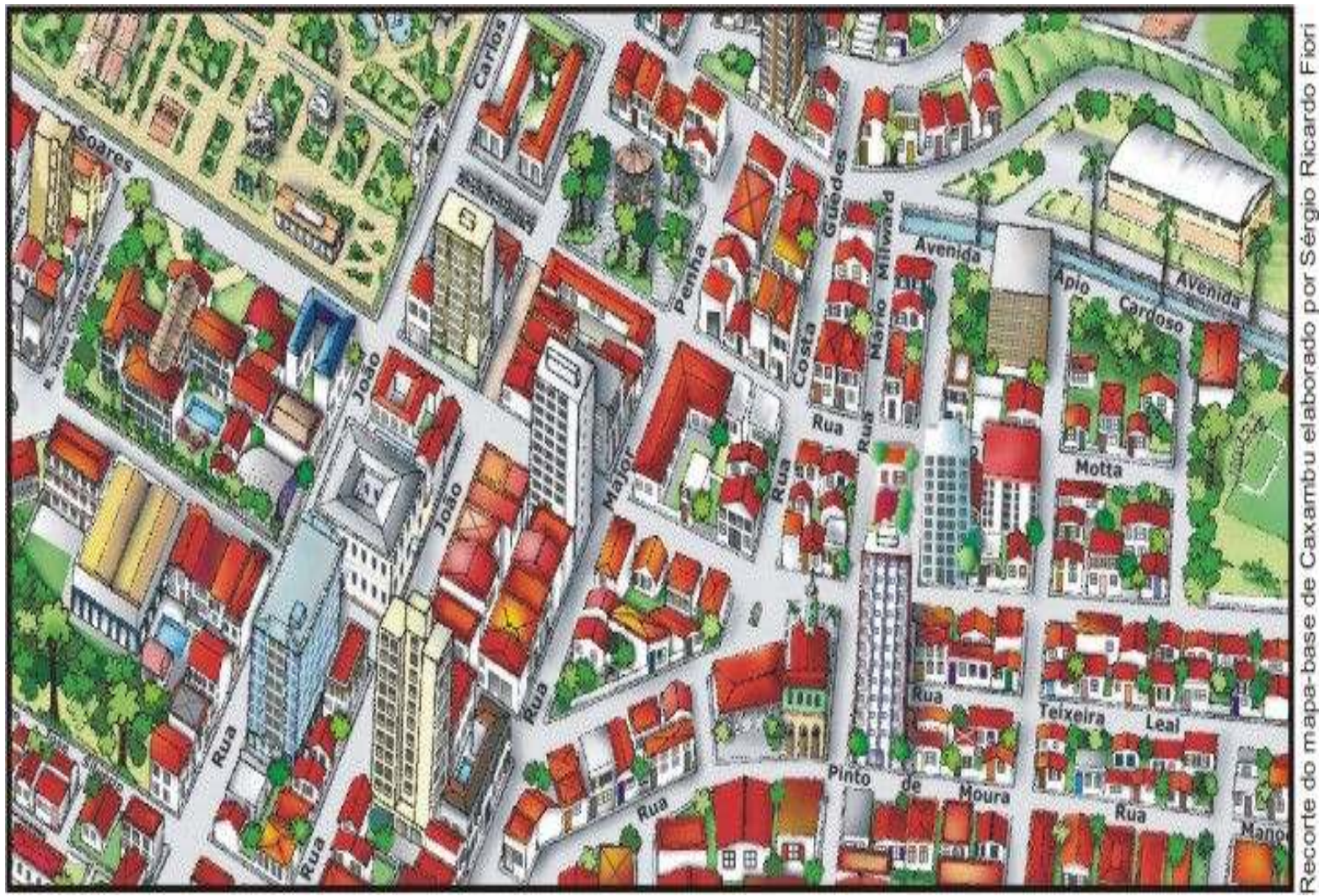

É primordial exemplificar pragmaticamente como se constrói este tipo de representação pictórica. 
Antes de iniciar o desenho, é preciso se preocupar com a proporção dos elementos dispostos na paisagem. Criam-se então alguns apoios, esquemas, utilizando as figuras geométricas básicas: o quadrado, o retângulo, o triângulo e a circunferência, que servem de guias para a construção das inúmeras figuras que compõem a paisagem, como exemplificado na figura $83 \mathrm{~A}$.

É aconselhável utilizar um lápis/grafite macio (6B, HB) em papel sulfite comum. Primeiramente, o ideal é traçar várias linhas sobre uma mesma área ainda não é importante atentar para o fato de as linhas estarem certas ou erradas; a preocupação maior deve estar na pressão que se faz com o lápis sobre a folha de papel, que deve ser leve. Até então não é necessário utilizar a borracha.

$\mathrm{Na}$ fase seguinte, deve-se procurar, entre as linhas desenhadas, o delineado mais preciso para a confecção do modelo. Agora, os movimentos das mãos são mais lentos e a pressão do lápis sobre o papel deve ser mais forte (ver figura 83 B).

$\mathrm{Na}$ finalização, utiliza-se uma borracha macia ou um limpa-tipo para apagar os traços em excesso. Pode-se passar uma caneta hidrográfica ou nanquim antes de apagar o excesso de linhas (Ver figura 83 final).

Figura 83 - Linhas e as figuras geométricas básicas para elaborar um cenário
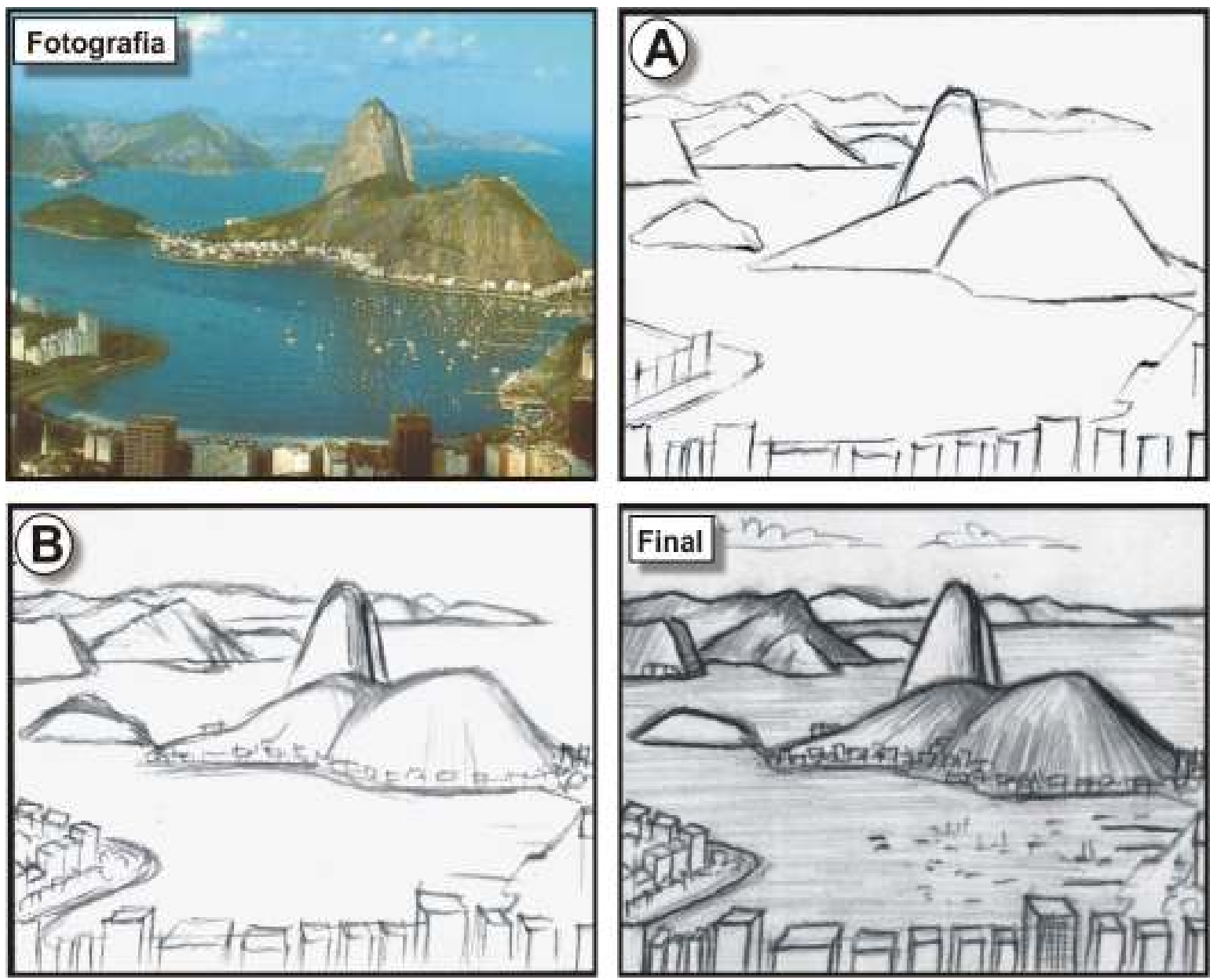
Neste momento, é imprescindível abordar o tema da perspectiva. Basicamente pode-se dividi-la em dois tipos distintos: paralela e cônica.

A perspectiva paralela acontece quando as arestas de um objeto formam feixe de linhas paralelas (figura 84 A). São subdivididas em: isométrica (figura 84 B) e cavaleira (figura $84 \mathrm{C}$ ). Ver também exemplo: figura 56.

Figura 84 - A perspectiva paralela isométrica e cavaleira

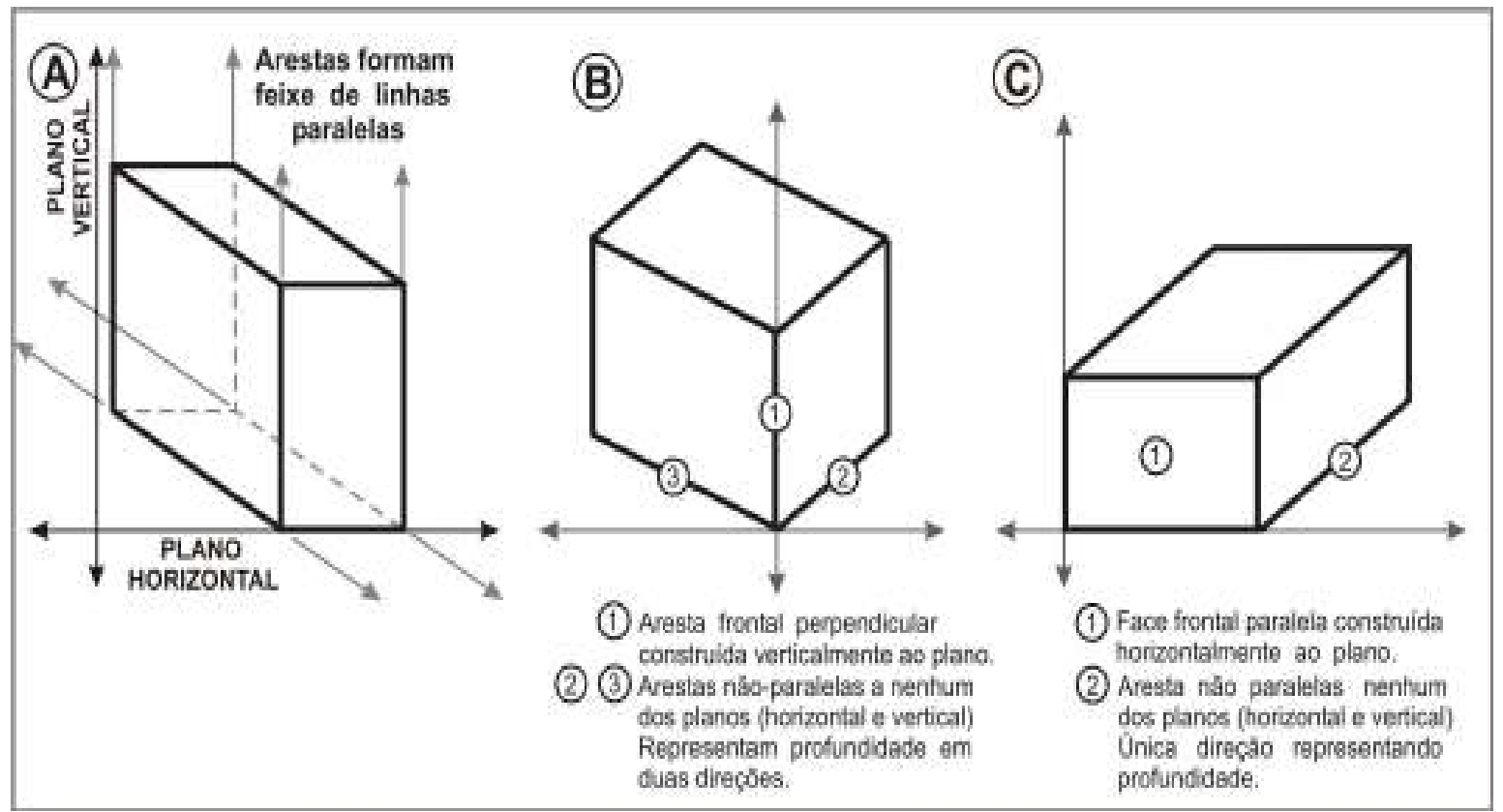

Já a perspectiva cônica é resultado das arestas de um objeto que convergem para um ponto pré-determinado, denominado ponto de fuga (PF) - Figura 85.

Figura 85 - A perspectiva cônica

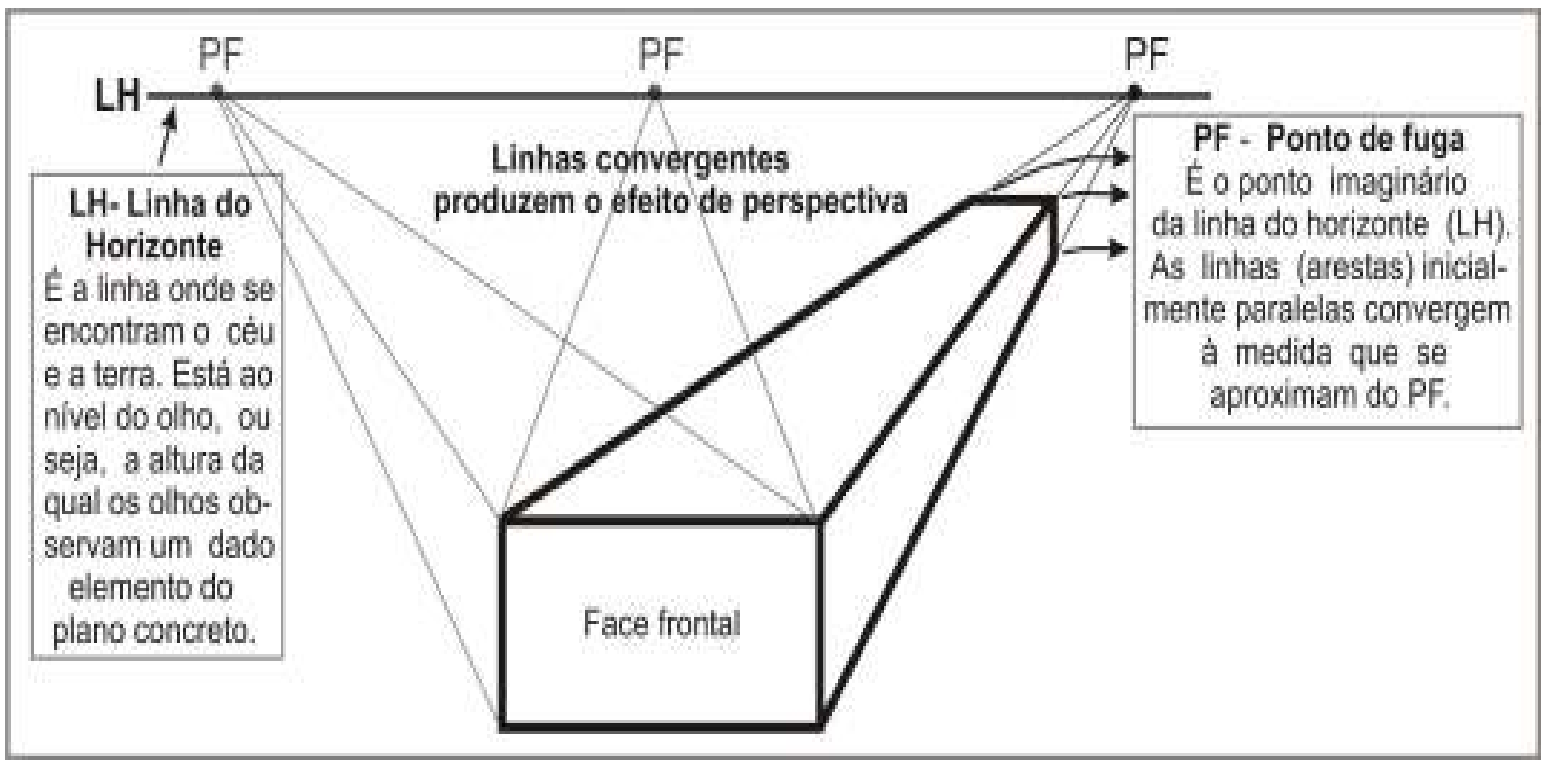


Qualquer forma em perspectiva é representada em três posições: acima, no nível e abaixo da linha do horizonte (LH), que são os níveis de visão de um observador. Cosgrove \& Daniels (1994:1) ensinam que a perspectiva busca transpor a superfície bidimensional à estrutura tridimensional do espaço, tal como o olho humano o percebe. Logo, a terceira dimensão (profundidade) tem que ser fingida pelo desenhista e pelo pintor. O que fica em primeiro plano na ilustração é o que está mais próximo do olho do pintor e do observador; portanto, deve ser representada em proporções maiores do que se desenha em segundo plano e assim por diante. Quanto mais distante estiver o objeto, menor será a figura representada e mais alta a sua base na tela (Figura 86). Já as imagens laterais devem estar acomodadas à pirâmide visual, cujo vértice coincide com o olho do pintor. O que está fora do campo de observação dos olhos (a cabeça deve estar imóvel e central - olhando para frente), não pode ser pintado, pois não existe naquele espaço.

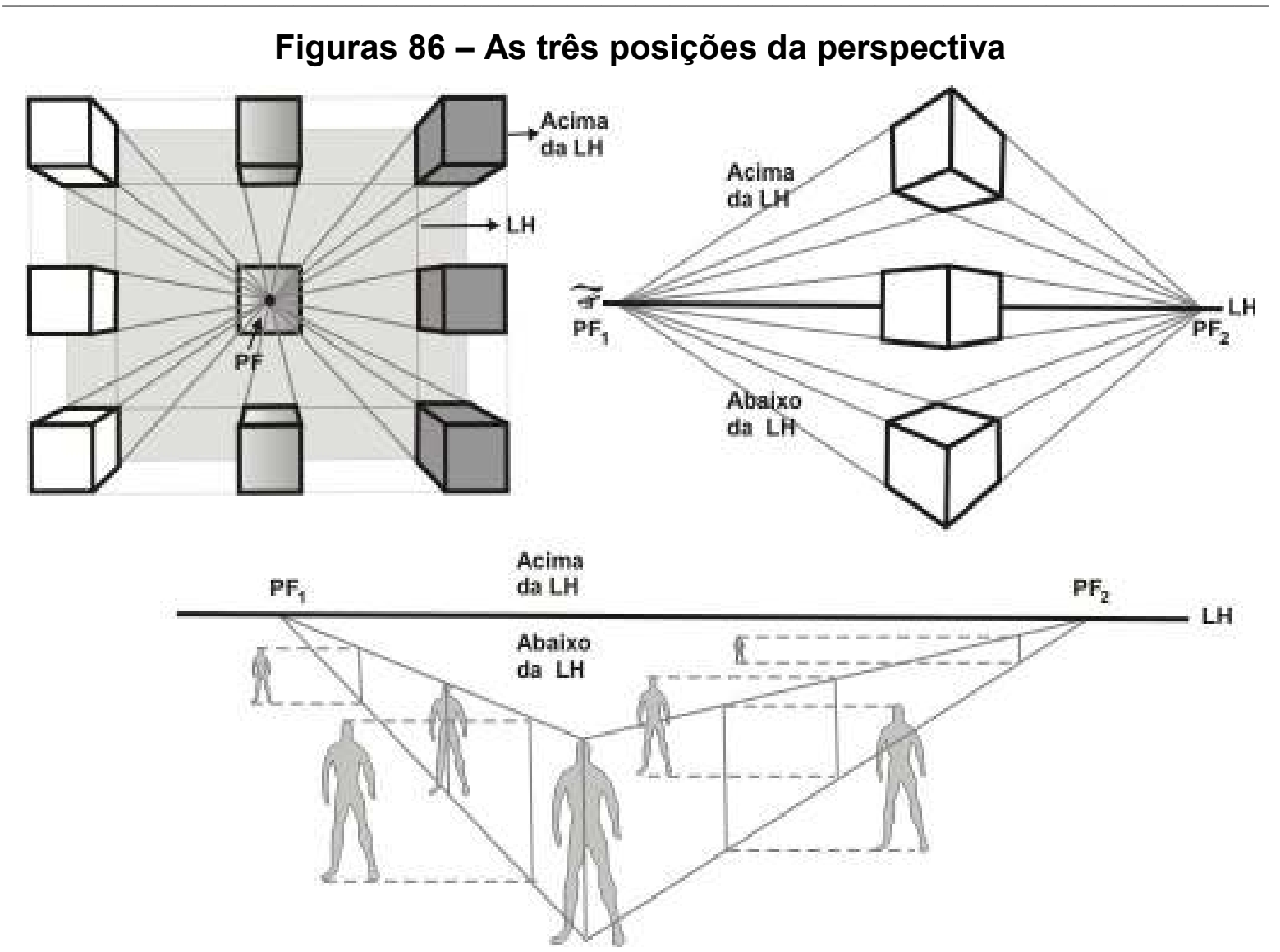

Os exemplos da figura 87 exemplificam ilustrações com um ou dois pontos de fuga.

Finalizando esta parte, ressalte-se que, muitas vezes, não é necessário utilizar a linha do horizonte e pontos de fuga para compor uma ilustração. A técnica da perspectiva paralela, além de ser mais simples, também proporciona bons efeitos visuais. A figura 88 demonstra que tanto os lados verticais como os horizontais são feitos a partir de linhas paralelas. 
Figura 87 - Desenhos com um ou dois pontos de fuga

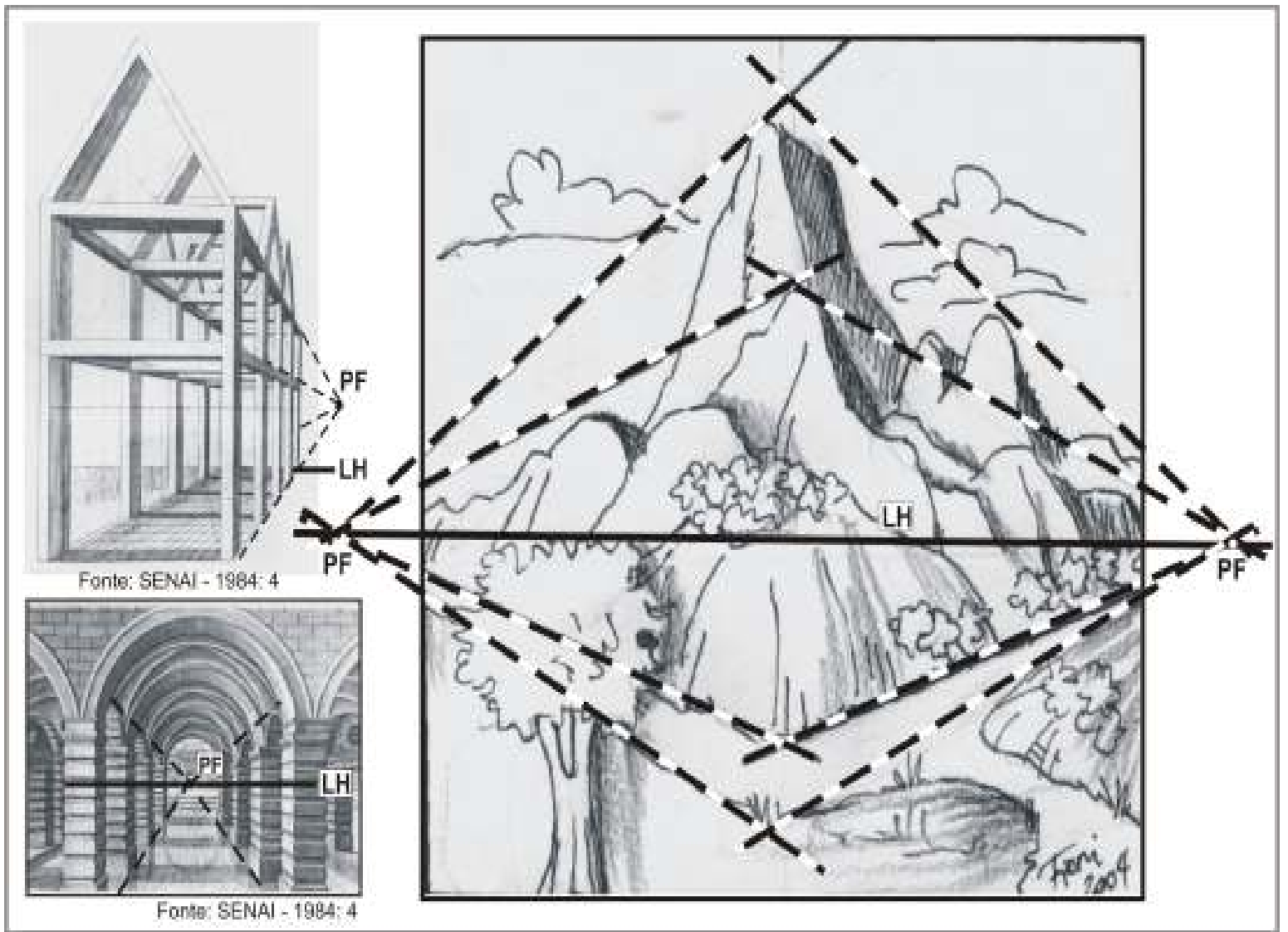

Figura 88 - São Vicente: desenho confeccionado em perspectiva paralela

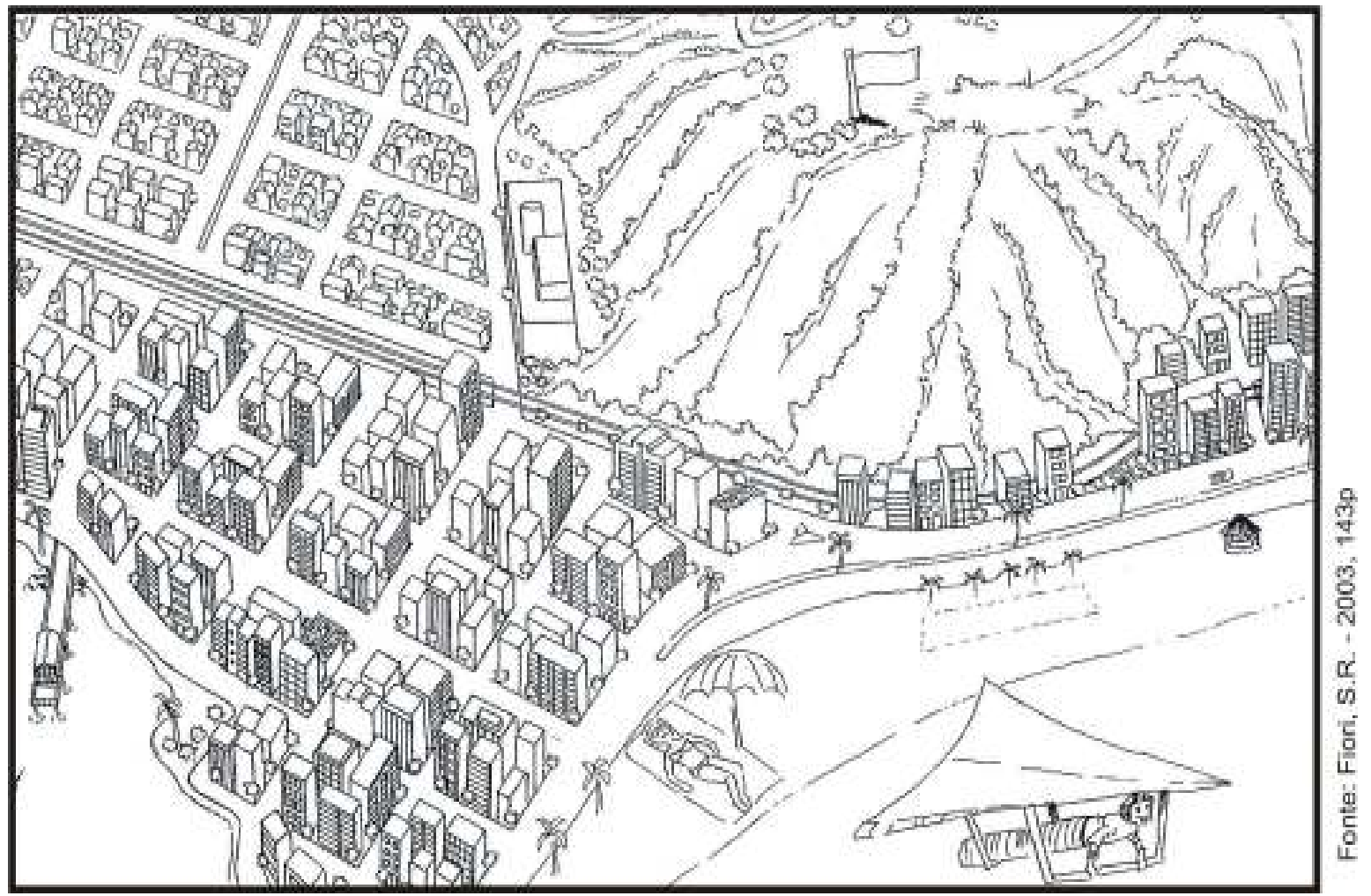




\subsection{3 - Elementos particulares}

Ao longo dos séculos, cartógrafos têm representado os fenômenos geográficos em mapas a partir de três formas básicas: o ponto, a linha e a área. Contudo, daqui para frente, serão destacados recursos de visualização ainda não abordados pela pesquisa de Fiori $(1999,2003)$, por se tratar de ferramentas elaboradas e utilizadas em ambientes interativos.

Nos mapas interativos, um ponto pode ser transformado em ícone ou símbolo, funcionando como um objeto que recebe uma ação graças ao clique do mouse, que permite funções, como, por exemplo, hiperlinks ou aberturas de menus pop up (Brown, Emmer \& Worm, 2001).

A interação em um mapa traz, então, um novo elemento complicador, atrelado ao trabalho do cartógrafo, porque o usuário pode perder uma informação por não perceber que alguns símbolos eram, na realidade, interativos. Assim, o mapa, ao ser manipulado, precisa deixar claro quais são os símbolos interativos e quais são os não-interativos.

Brown, Emmer \& Worm (2001) enfatizam que uma convenção parece estar se formando em torno dos símbolos pontuais interativos. Ela busca um efeito tridimensional para que eles pareçam flutuar sobre o fundo do mapa. O sombreamento é grandemente aplicado no desenvolvimento dos mapas interativos e da Web para criar objetos em 3D clicáveis, ou seja, acionados por meio de botões. O uso da sombra projetada sobre os objetos cria a impressão de estarem projetados sobre o fundo (Figura 89).

Figura 89 - Os diferentes tipos de símbolos pontuais interativos

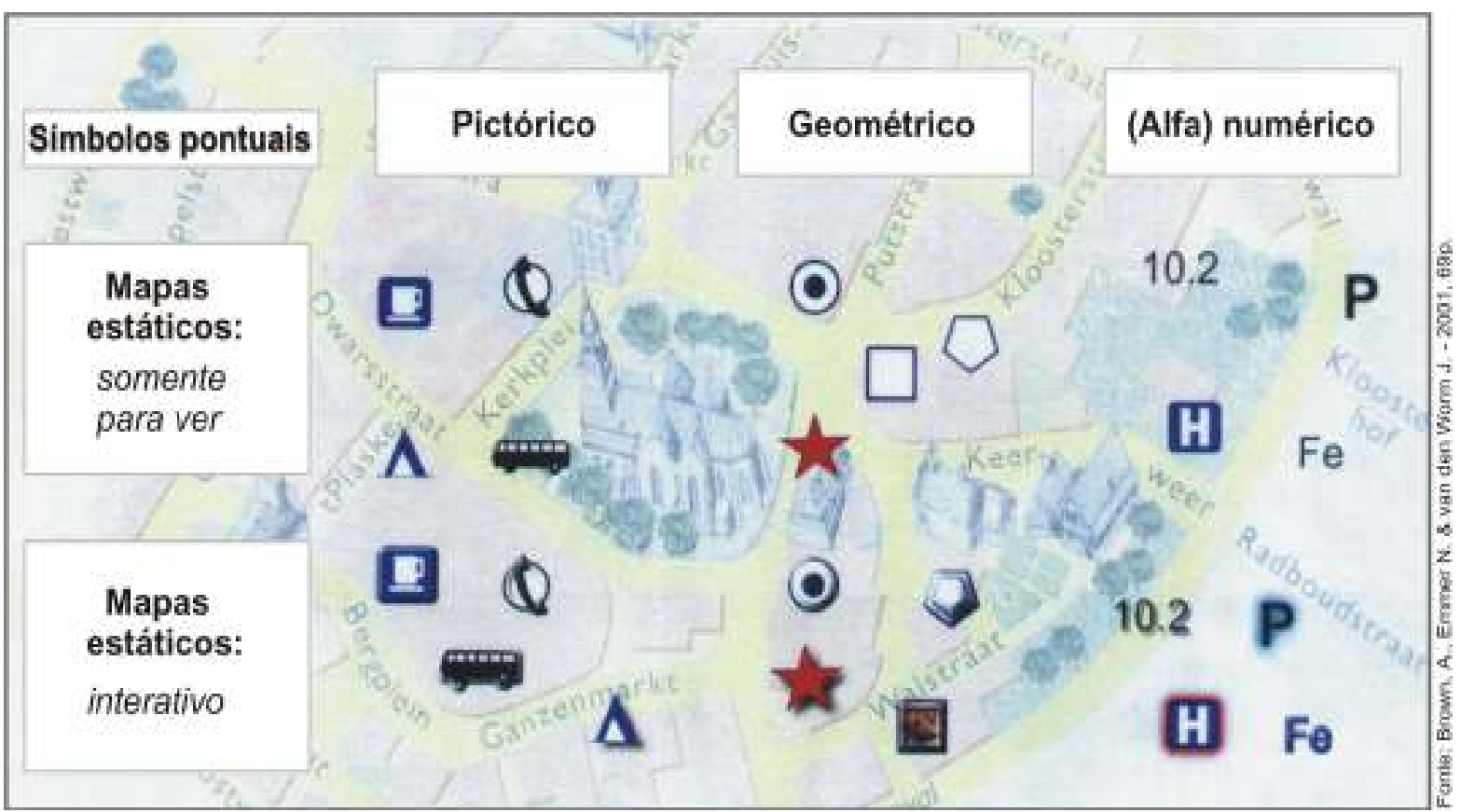


Os autores (Brown, Emmer \& Worm, 2001) ainda alertam para o cuidado em relação àquelas "legendas interativas" que são meramente escaneadas ao lado do mapa, não oferecendo nenhuma possibilidade de interação. Aliás, um dos grandes problemas associados à simples escanerização das legendas em mapas ocorre quando o usuário utiliza recursos como o zoom ou o pan e a legenda normalmente desaparece. Não se pode esquecer que a legenda é parte importante e fundamental do processo informativo de um mapa e, portanto, deve ser tratada como um objeto separado e móvel, o que possibilitará sempre seja vista na tela.

\subsection{4 - Animação}

Brown, Emmer \& Worm (2001) esclarecem que as animações podem ser aplicadas em símbolos:

$\checkmark$ Pontuais: rotacionar, pulsar, mudar de forma, alinhar símbolos, dar um efeito de algo movendo ao longo de uma linha, etc.

$\checkmark$ Areais: pequena mudança das cores do "verão" para o "inverno", movimento de setas ao longo de todos os itinerários de transporte ou o (um) modelo de uma suave ondulação azul para o mar.

A seguir, Wolfgram (1994) apresenta tipos de animações:

$\checkmark$ Personagem - busca a humanização de um desenho, isto é, significa que o personagem deve ter olhos, andar ou, de alguma forma, locomover-se como um ser humano faria, não havendo a necessidade de uma réplica perfeita. No caso de um mapa turístico, pode-se criar uma personagem que possua uma forte relação com o destino que ela representa, podendo ser naturalmente uma figura humana, como um pirata, um mártir; uma personagem típica - gaúcho, baiana, sambista, pantaneiro. Contudo, também pode ser uma personagem de uma lenda, um animal - jacaré ou o tuiuiú estilizado e usado para o Pantanal ou o golfinho para Fernando de Noronha - uma planta ou um objeto inanimado.

$\mathrm{Na}$ representação das personagens, devem ser ainda consideradas as emoções que possam caracterizá-las como tristeza, alegria, paixão, seriedade, etc.

A partir de pesquisas de gabinete e de campo, o produtor chega à conclusão de qual elemento seria o mais recomendado para representar a destinação.

$\checkmark$ Ping e pong - representam objetos em movimentos constantes, repetitivos, efeitos cintilantes e luminosos, capazes de destacar um objeto na imagem. Não devem prender a atenção por muito tempo; apenas o suficiente para que o produtor tenha a certeza de que público os percebeu. Como exemplos 
citam-se: o logotipo, diferentes tipos de botões - da legenda, de informações, da locomoção entre as páginas, etc.

A movimentação de objetos precisar ter sempre uma finalidade pré-estabelecida, ocorrendo somente se necessária, pois, quando uma apresentação é preenchida com movimentos sem sentido, os pontos-chave são perdidos e o usuário fica confuso. A movimentação da animação tem como finalidade acentuar o impacto emocional, melhorar a transmissão da mensagem, além de produzir uma transição eficaz entre um e outro segmento da apresentação.

\subsection{5 - Áudio}

Wolfgram (1994) divide-se o áudio em três categorias: música, efeitos sonoros e narrativa. Esses três elementos são parte importante do planejamento.

$\checkmark$ Música - é utilizada para criar um clima, uma atmosfera que deve envolver o espectador, influenciando a marcha das cenas seguintes. Tem diversas funções em uma apresentação, podendo determinar o início da exibição, enfatizar emoções ou ilustrar pontos particulares.

$\checkmark$ Efeitos sonoros - ranger de portas, chuva, sons de campainha são alguns exemplos desse tipo de áudio. Cada efeito sonoro precisa ter um propósito específico e deve ser adequado ao propósito do trabalho. Os efeitos sonoros nunca devem ser usados apenas para fazer um barulho de fundo, a menos que seja necessário.

$\checkmark$ Narrativa - usa a voz humana para apresentações em multimídia. O produtor que decide usar a voz deve ter cuidado com as possíveis reações a esse recuso. O sexo, a idade, a raça, a região e a atitude pessoal são características que se manifestam pela voz de uma pessoa. Nota-se, portanto, uma vez mais, a necessidade de conhecer bem o público-alvo e planejar a matéria de acordo com ele.

\subsection{6 - Interatividade}

É a forma como um usuário progride e se movimenta em uma apresentação nãolinear, não-seqüencial, ou seja, o usuário escolhe o seu próprio caminho quando utiliza o mapa. Logo, é importante considerar que tipo de usuário fará uso do produto e qual seu estado de ânimo nesse momento.

Segundo Wolfgram (1994:15), estatisticamente, as pessoas lembram-se apenas de cerca de $15 \%$ do que escutam, $25 \%$ do que vêem e mais de $60 \%$ das situações em que interagem. Em uma apresentação em multimídia, a interatividade aloca-se 
como a forma mais poderosa de provocar emoções, trazendo à tona todo um nível de controle implícito do produtor.

No entanto, esse recurso exige que o usuário sempre saiba onde está, como chegou ali e como deve proceder para ir de um lugar a outro; caso contrário, o produtor o perde. Portanto, a comunicação bem-sucedida sempre depende de manter a atenção do usuário ao assunto exposto.

A interatividade segue modelos diferentes, que podem ser previamente escolhidos. A forma mais comum de apresentações em multimídia ocorre por meio da estrutura hierárquica da organização dos dados. Normalmente, são utilizadas pequenas caixas retangulares em que se inserem palavras, porém, em geral, são pouco atrativas e não estimulam o interesse do usuário. Muitas vezes, botões de menu na forma de ícones contendo desenhos, sem legendas, são mais atraentes.

As aplicações em hipermídia - os hiperlinks, hipertextos e hipermapas - têm como princípio básico centenas de ligações cruzadas entre sessões sobre um mesmo assunto de forma que o usuário, tendo o controle interativo, pode pesquisar sem precisar passar por menus. De certa forma, uma apresentação em hipermídia é, na verdade, uma rede de informações com muitos caminhos por meio dos quais podese navegar.

Ao se abordar o tema principal desta pesquisa, o mapa pictórico turístico e interativo, a hipermídia habilita agregar e oferecer um grande e variado número de informações (Figura 90).

Baseado no exemplo de Menno-Jan \& Driel (1997), o turista, ao utilizar o hipermapa ${ }^{64}$, com sua coleção de mapas em diferentes escalas da destinação, tem a possibilidade de localizar todos os restaurantes num raio de dois quilômetros de seu hotel. Por exemplo, o mapa indica três: um de comida mineira, outro de comida internacional e um terceiro de comida árabe. O turista, então, ao clicar sobre o restaurante de sua preferência: o restaurante de comida mineira. Por meio do zoom, pode obter outras informações, como conhecer os diferentes ambientes (plantas) do edifício, fotografias do local e dos pratos, ver um vídeo da última festa de fim de ano, etc. Assim, todas as informações buscadas partem diretamente do hipermapa, definido como uma janela de procura dos elementos espaciais contidos na área representada, tendo como base o banco de dados já disponibilizado ao usuário.

\footnotetext{
${ }^{64} \mathrm{Na}$ literatura especializada, o termo hipermapa não é usado somente em sistemas de hipermídia geo-referenciada, mas também em mapas dinâmicos mais elementares, que apresentam uma exibição mais simples, com um número limitado de links. Já os mapas "clicáveis" são sistemas hierarquicamente orientados e proporcionam uma flexibilidade limitada, porém geo-referenciados. Menno-Jan, K. \& VAN DRIEL, R. (1997).
} 
Figura 90 - Conceito de hipermapa pela hipermídia geo-referenciada

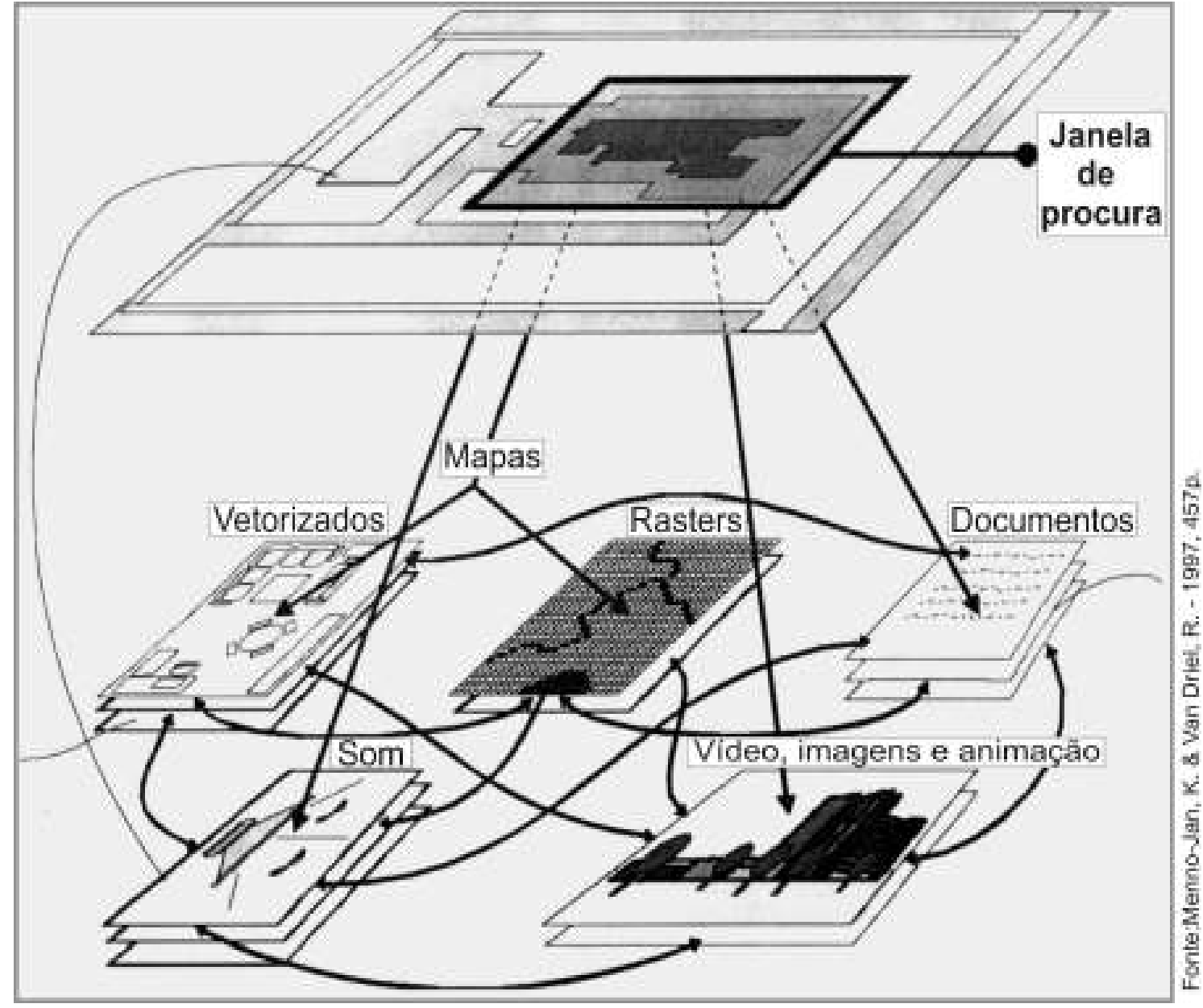

O tipo de acesso da informação exposto acima é conhecido como interno, porém existem outros links que se destacam fora da área do mapa, ou seja, o usuário pode clicar sobre um botão no site que está e este o liga a outros sites, fornecendo outras possibilidades de informação. Por exemplo, querendo saber mais informações sobre um hotel representado no mapa, o usuário pode ter acesso ao endereço/site do próprio hotel, que dará informações mais detalhadas sobre a acomodação: tipos de quartos e seus preços, planta de detalhamento de todos os serviços da instalação, a aceitação ou não de animais, tour virtual.

O site também pode ser enriquecido, se oferecer importantes informações sobre atividades e serviços que estão próximos ao destino representado, mas que não aparecem no mapa, como restaurantes na estrada, postos de gasolina e mecânicos, hospitais, parques de diversão, praias, monumentos históricos e arquitetônicos, entre outros. Este segundo tipo de acesso é conhecido como externo, ou seja, são aquelas informações obtidas além do site inicialmente acessado.

Os hipermapas são essencialmente constituídos pelo recurso do zoom, responsável por habilitar o usuário a focalizar ou ampliar, por meio de escalas, sua 
visão de um ou mais elementos dispostos no mapa. Desse modo, uma informação inicialmente dispersa e pequena no mapa, com o recurso zoom, pode ser ampliada, fazendo com que textos e ilustrações se tornem visíveis e compreensíveis. É claro que, para que uma informação seja bem transmitida, as mudanças de escala devem ser rápidas.

Comumente, encontram-se mapas na tela sem uma escala fixa, porém o produtor tem que decidir sobre alguns tipos de escalas "ideais", e isso depende da quantidade e precisão dos detalhes que quer apresentar. Brown, Emmer \& Worm (2001) distinguem três estratégias de zooms que podem ser aplicadas:

1) Zoom linear estático - Neste caso, a relação entre o zoom e o conteúdo do mapa é estática, sendo apenas ampliada ou reduzida linearmente, não havendo uma mudança de conteúdo do mapa. Pode-se conceber o processo de redução e ampliação do mapa a partir de dois tipos de comportamento:

$\checkmark$ Imagem raster - conforma-se no aumento ou diminuição de seus pixe/s, se caracterizam pelo formato analógico (folha de papel) e quando digitalizados são salvos em arquivos JPG, TIF, GIF, EPS.

$\checkmark$ Imagem vetorial - conserva seus detalhes em qualquer porcentagem de zoom, pois são elaborados em formato digital que, por exemplo, podem estar em arquivos DXF, DWG, CDR, Al (Figura 91).

Figura 91 - A escolha das imagens e o resultado no processo de zoom

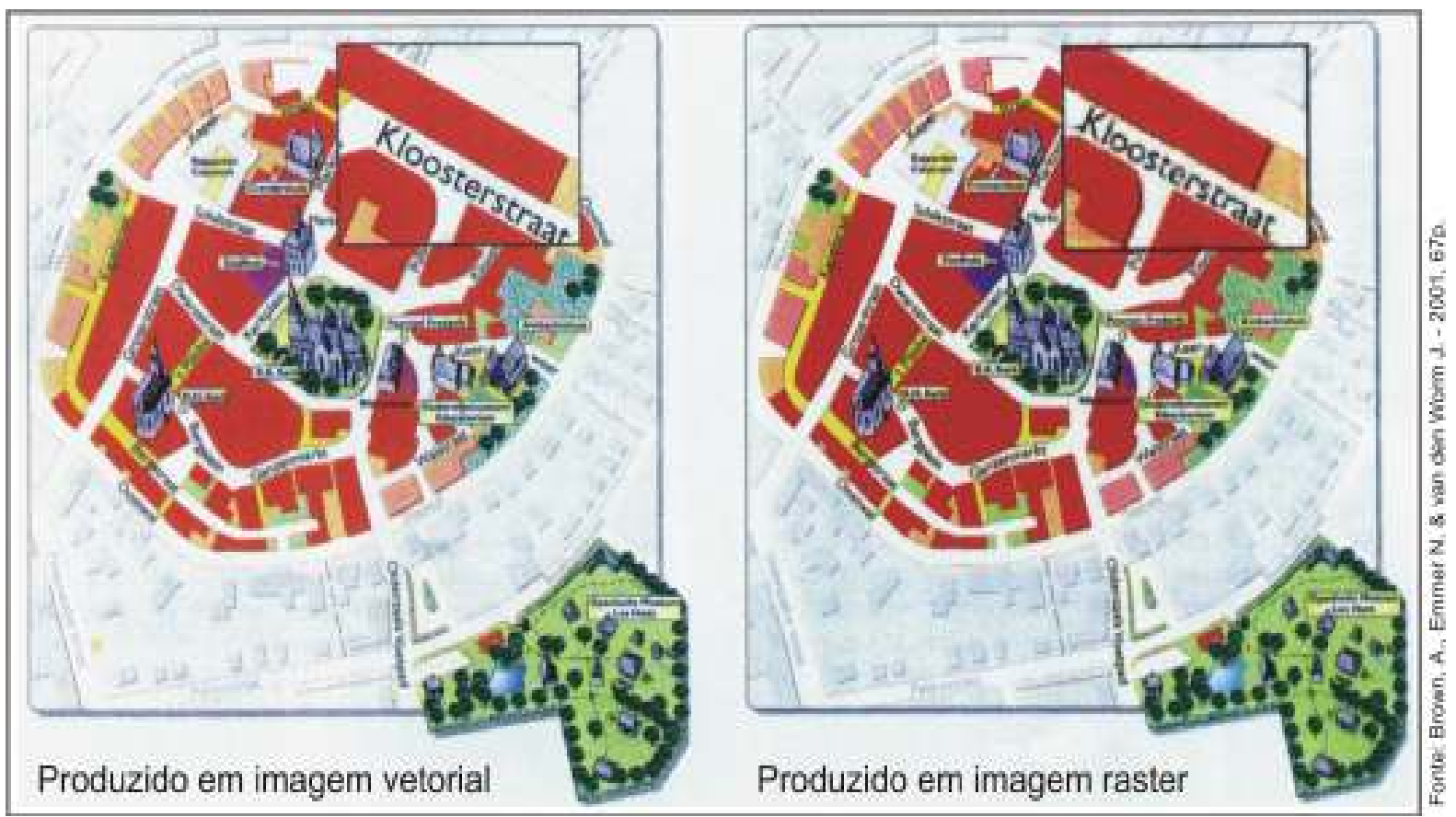


2) Zoom estático em etapas - Aqui se oferece uma série de mapas de um mesmo destino, os quais são armazenados em uma biblioteca de imagens gráficas, sendo cada mapa individualmente editado em seu conteúdo-escala, e desenvolvido a partir de imagens raster/vetorial reelaboradas para cada escala. Logo, quando o usuário utiliza o zoom (in ou out), há um processo de realocação, onde um mapa se sobrepõe ao outro, que o usuário havia inicialmente clicado. Este sistema é grandemente usado em sites de percursos projetados (Figura 92).

Figura 92 - Pré-estabelecendo os níveis de zoom

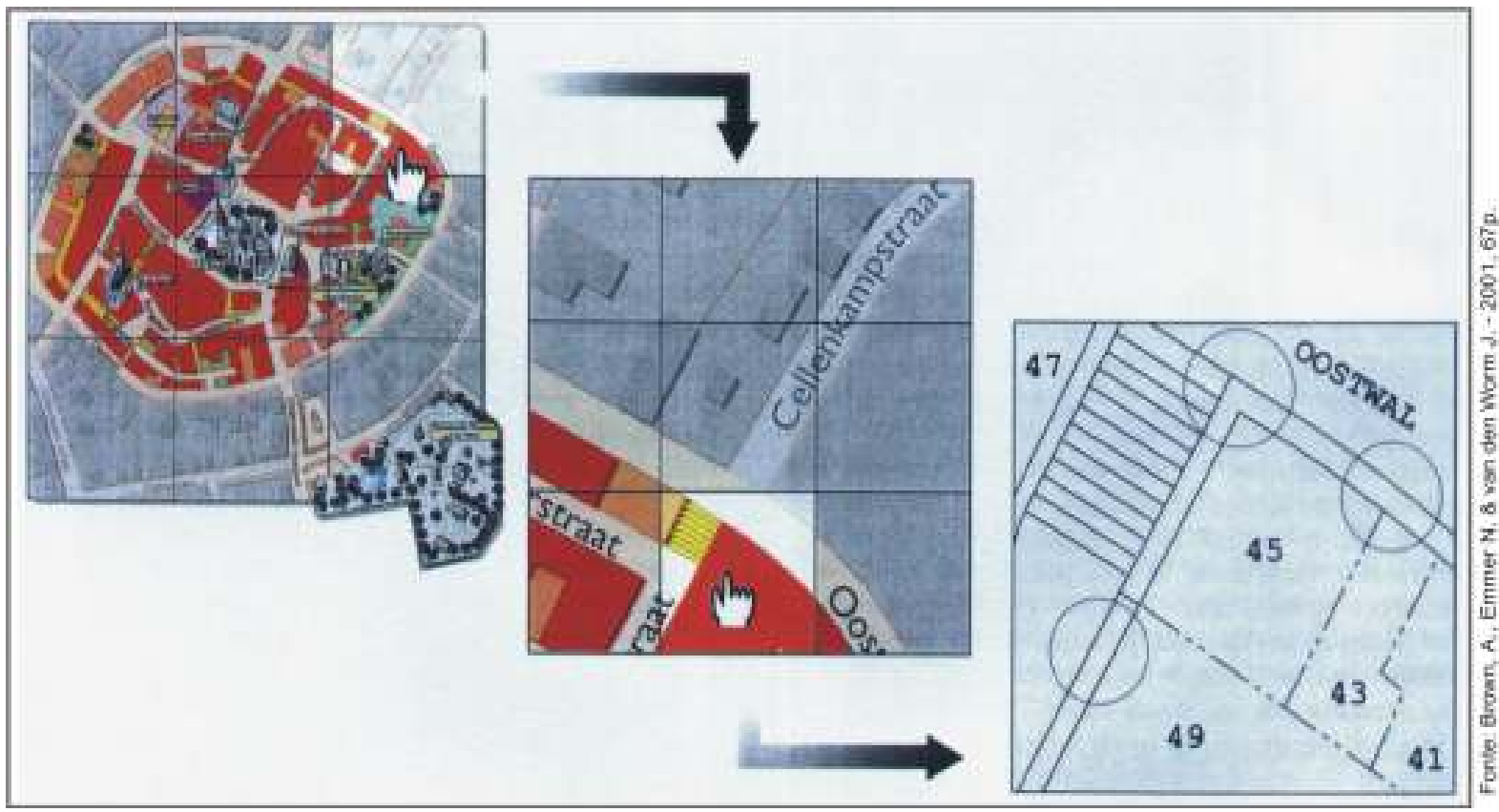

3) Zoom dinâmico (escala animada) - Este sistema apresenta um elo em tempo real entre a escala e o conteúdo do mapa; logo, quanto mais se aumenta a área de abrangência do mapa (zoom out), maior é o conteúdo automaticamente incluído. Para que isso ocorra são necessárias informações on-line da base de dados espaciais ligadas entre si. Como o tamanho do mapa não é fixo, a escala numérica não é o recurso mais recomendado para indicar a escala nos mapas confeccionados para Web. O mapa encontrado no site do departamento de Geografia da Universidade de São Paulo é um bom exemplo deste tipo de apresentação em zoom (Figura 93).

Aliás, ao abordar o tema escala, é necessário lembra que, historicamente e em uma grande variedade de aplicações, a hipermídia tem fornecido a seus usuários acesso a dados não-geo-referenciados. Em contrapartida, ao trabalhar fundamentalmente com mapas, abre-se essa nova fronteira. Nos campos de aplicação voltados às ciências da Terra, como o planejamento (cidades), o gerenciamento do meio ambiente e o setor do turismo, existe uma necessidade 
intrínseca de se combinarem dados geo-referenciados e não-geo-referenciados. Essa dualidade introduz o conceito de hipermapa, que permite ao usuário navegar por uma série de dados: não somente pelo tema, mas também espacialmente.

Figura 93 - O site do DG-USP: um exemplo de zoom dinâmico

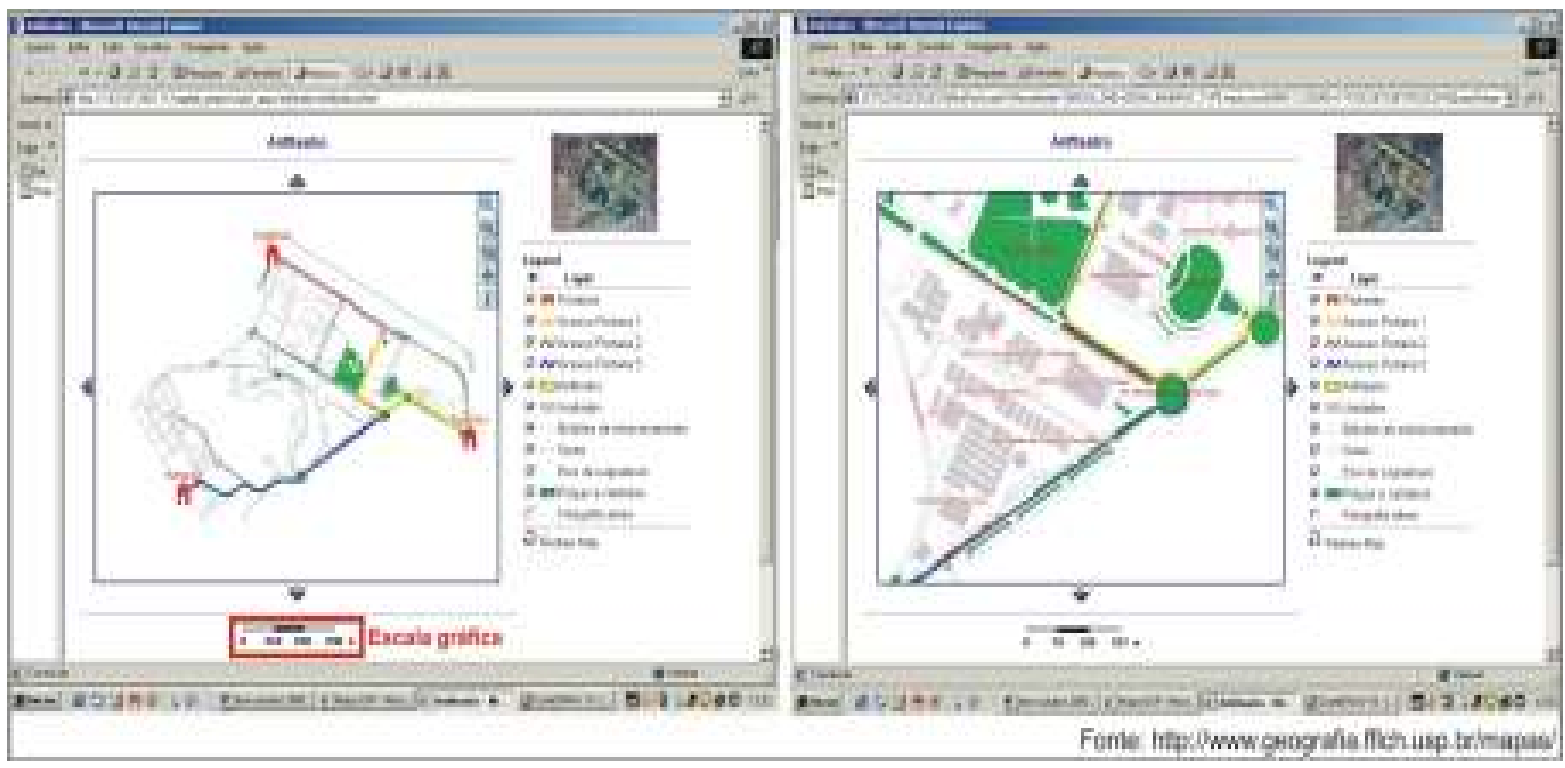

4) Pan - decorre da inserção de barras de rolagem no lado direito e/ou na parte inferior da tela. Estas barras surgem automaticamente toda vez que 0 tamanho da janela não suporta o seu conteúdo disponibilizado. A barra à direita é usada para deslocar o conteúdo da janela verticalmente, e a barra inferior para mover o conteúdo horizontalmente. Ao clicar nas setas das barras, o conteúdo da janela também é movimentado (Figura 94).

Figura 94 - As barras de rolagem: o recurso pan

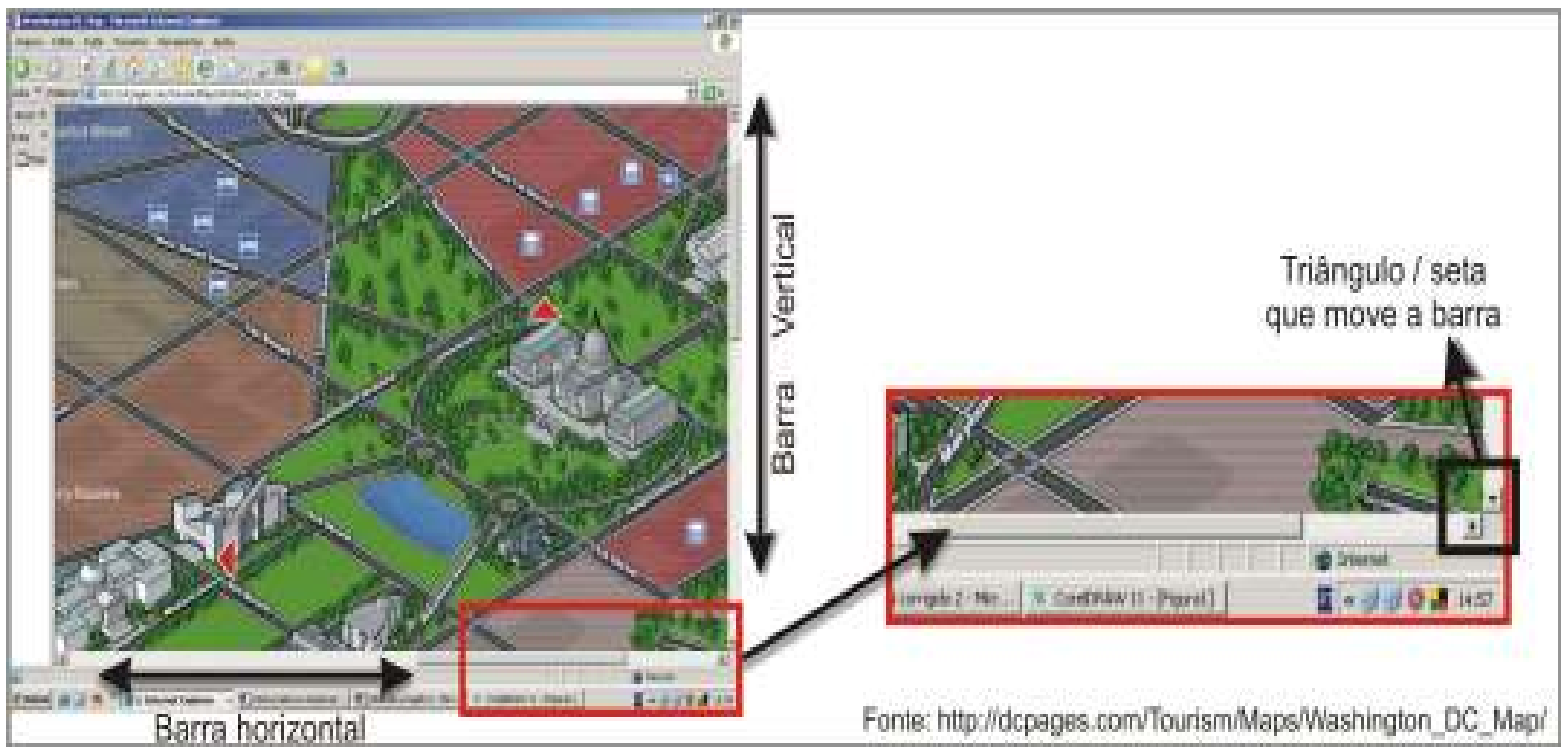


5) Pop up - é muito utilizado para solucionar o problema de acomodação de uma grande quantidade de links de navegação em um espaço reduzido. $O$ pop up surge e desaparece de maneira automática, rápida e temporária sobrepondo-se a pagina que se visualiza na tela do computador. Resulta da ação: clicar ou simplesmente passar o cursor em cima de algum elemento figura, texto, legenda, barra horizontal com submenus, etc. - com o auxílio mouse, liberando assim, a informação suplementar (Figura 95).

\section{Figura 95 - Tipos de pop up}

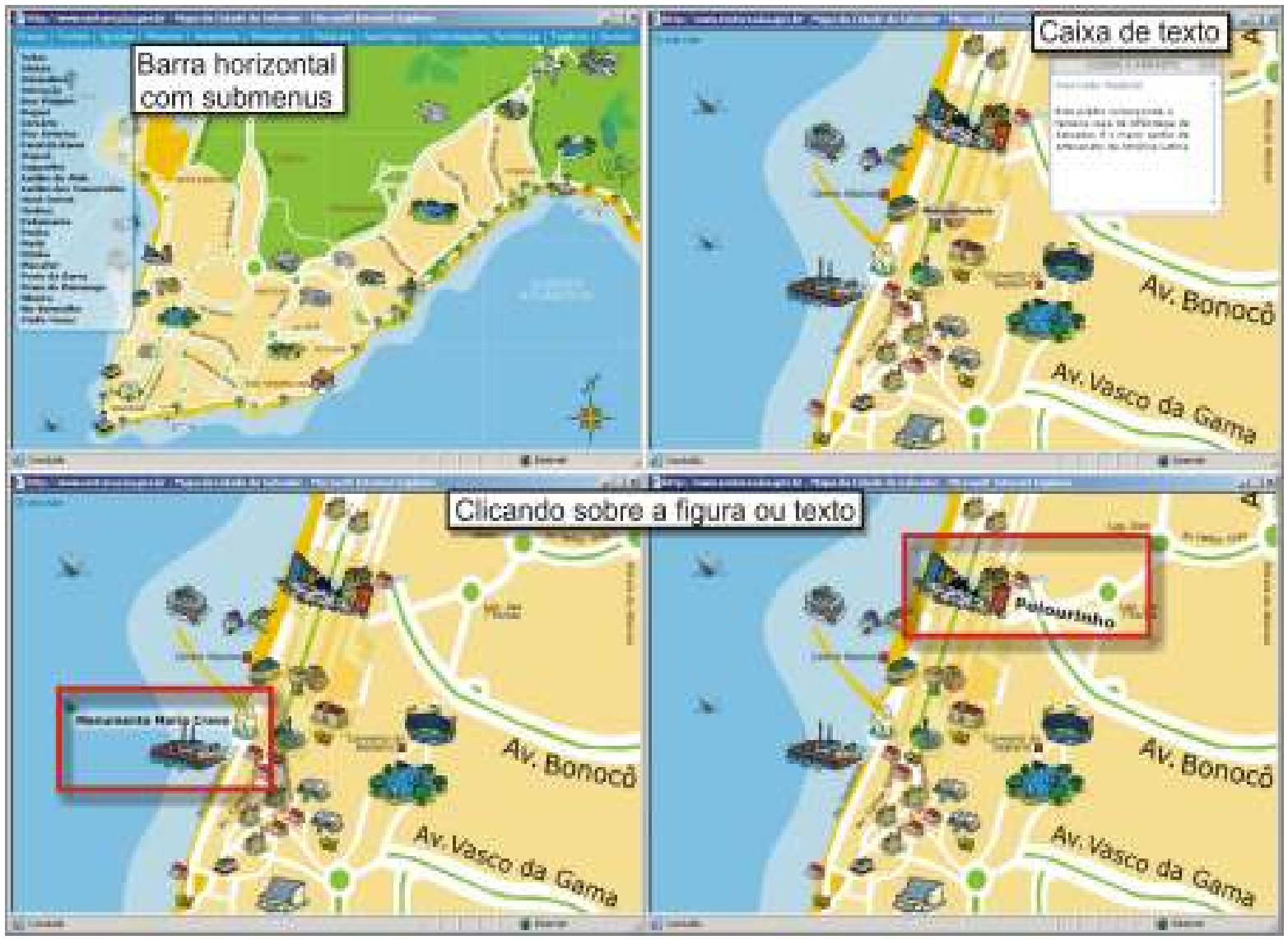

\subsection{7 - Download}

No caso dos mapas desenvolvidos especificamente para a Web, os cartógrafos precisam estar atentos a um item vital para seu sucesso: o tempo de download. Obviamente, o mapa deve motivar e ser cartograficamente eficaz, porém deve ter a obrigação de gerar apresentações, como páginas e animações, que sejam baixadas em um tempo que não as torne enfadonhas e desinteressantes. Inicialmente pela demora e posteriormente pelo custo da ligação telefônica, sobretudo a que se relaciona às conexões discadas ( $56 \mathrm{Kbps})$. Entretanto, mesmo a conexão em banda larga apresenta diferentes velocidades de downloads - 150, 250, 500 e $750 \mathrm{Kbps}, 1$ e 2 Mbps. 
Por isso, é importante levar em consideração o tipo de conexão de que o usuário faz uso. Em um levantamento da European Intelligence Unit (EIU), constatou-se que países como o Chile, Brasil, México e Argentina crescem rapidamente em número de internautas. No entanto, só o Chile possui penetração em banda larga superior a 3\% (IDG now!, 04/2005).

Em outra reportagem da IDG now! (06/2005), lê-se que, no Brasil, de cada dez internautas domésticos, quase cinco já possuem conexão em banda larga. A tendência é que, até 2009, por volta de 7,4 milhões de brasileiros estarão conectados a alta velocidade.

Diante dessas informações, fazem-se duas ressalvas: em primeiro lugar, mesmo com o crescimento apontado das conexões em banda larga, a porcentagem, ao se pensar no Brasil, país com mais de cento e oitenta milhões de habitantes, é muito pequena. Outra peculiaridade no que diz respeito à eficácia de um produto cartográfico feito para Web, é pensar que o download deve ser satisfatório a todos os usuários de Internet, sejam eles da conexão discada ou das várias possibilidades de conexões em banda larga.

Finaliza-se este capítulo com referências ao pensamento de Wolfgram (1994: 214), que aponta alguns itens que devem ser analisados ao finalizar o desenvolvimento de um trabalho em multimídia interativa:

$\checkmark$ Mensuração de quanto da memória do computador (CPU) é utilizada.

$\checkmark$ Qualidade das transições que devem acontecer de maneira suave e eficientemente.

$\checkmark$ Eficácia da comunicação da mensagem: o usuário deve compreender a mensagem desde a primeira vez que vê a apresentação.

$\checkmark$ Equilíbrio entre ritmo e andamento, ou seja, o trabalho interativo deve ser (está) lento o suficiente para ser confortável, mas não moroso e enfadonho.

$\checkmark$ Conteúdo da apresentação: todos os objetivos foram alcançados?

$\checkmark$ Satisfação do usuário: as mensagens estão sendo transmitidas do jeito que o cliente queria?

$\checkmark$ Preservação e/ou melhora da imagem do cliente.

$\checkmark$ Capacidade de medida: estão prontos os veículos que avaliarão o sucesso do projeto?

$\checkmark$ Expectativa dos usuários: Se os clientes gostaram do produto, o que mais os atraiu? 


\section{4 - Breve crítica e proposta para a elaboração dos mapas}

\section{e o protótipo de um mapa-site turístico do município de Caxambu}

Na última semana do mês de março de 2006, ocorreu um trabalho de campo no município de Caxambu, sul do estado de Minas Gerais. Durante a estada, foram travadas algumas conversas com funcionários da prefeitura, resultando na coleta de dados: o inventário turístico do município, folderes, fotos e visitas guiadas ao teleférico e Parque das Águas. Recolheu-se também o mapa turístico mais usado pela cidade (ver o mapa em CD - anexos - pasta 4), elaborado pela Editora Buz (C) em 2003, sendo disponibilizado à Prefeitura Municipal de Caxambu. O produto era encontrado facilmente em hotéis, no Parque das Águas e no Posto de Informação Turística.

Levando-se em conta o momento histórico pelo qual a correção dos mapas convencio-nais se pauta - por exemplo, na geometria euclidiana e no atual desenvolvimento tecnológico - o mapa de Caxambu não se diferencia da grande parte dos "mapas" que prestam serviço ao setor do turismo / turista.

Apresenta muitas deficiências cartográficas, como: ausência de título, de escala e do sistema de referências ${ }^{65}$. A base cartográfica referente ao arruamento foi distorcida, e aparecem apenas poucos nomes de ruas - somente aquelas próximas ao Balneário. Além disso, a legenda poderia estar mais bem sinalizada, e não há citação sobre as fontes utilizada. Já os símbolos, sob o mapa-fundo, são poucos, mas claros, graficamente bem representados e de bom tamanho. É importante ressaltar que o fundo do mapa mantém relação harmônica com os símbolos, até porque o segundo elemento destacado deve sempre sobressair, não disputando a atenção com o fundo.

O mapa de Caxambu disponibiliza ainda um detalhe do Parque das Águas, o maior atrativo turístico da cidade. Contudo, seria muito oportuno existir também um mapa em menor escala, que indicasse acesso a rodovias e a localização de Caxambu entre outras cidades. Ainda poderia se fazer um pequeno mapa do Brasil, destacando o estado de Minas Gerais.

Por todos esses elementos inexistentes no mapa turístico do município de Caxambu, pode-se afirmar seguramente que o material não pode ser caracterizado como um mapa, mas sim como uma ilustração ou uma representação gráfica de uma parte do município.

Os cartunistas Gepp e Maia constituem um bom exemplo de profissionais que trabalham a arte como uma representação simbólica do espaço. No site www.geppemaia.com.br e em Gepp e Ferreira (2002), encontram-se ilustrações que representam o futuro Rodoanel, bairros como a Vila Madalena, Pinheiros,

\footnotetext{
${ }^{65}$ São as coordenadas geográficas e/ou UTM (Projeção Universal Transversa de Mercator) que revelam a latitude, longitude; indicação do Norte.
} 
Morumbi, região da Avenida Paulista, pontos históricos do centro da cidade de São Paulo, entre outras.

A figura 96 demonstra recortes de mapas turísticos ilustrados em diferentes escalas, que não apresentam nenhuma preocupação com as regras cartográficas essenciais. Outro item a ser observado é o espaço reservado à propaganda comercial, comum a esse tipo de representação, até porque, na grande maioria das vezes, são os comerciantes que custeiam a confecção do produto. Torna-se importante destacá-los, mas isso pode ser feito de uma maneira mais sutil e que não agrida a diagramação e o trabalho estético referente a compreensão do mapa.

A figura 96 exemplifica as deficiências cartográficas a partir de quatro mapas turísticos:

$\checkmark$ Não possuem escala,

$\checkmark$ O titulo é pequeno, sem destaque ou visualmente confuso em A e B;

$\checkmark$ Não há indicação de Norte em B e C;

$\checkmark$ Os mapas fazem uso de símbolos pictóricos; destaca-se o D, por sua visão oblíqua bem elaborada;

$\checkmark$ Os textos acompanham muitas ilustrações;

$\checkmark$ A legenda inexiste em $C$ e $D$, e é muito mal elaborada em A;

$\checkmark$ Todos possuem propaganda comercial; destaca-se o A pela poluição visual causada pelos anúncios que não estão nas bordas, mas inseridos dentro do próprio mapa.

O outro tópico é a discussão do mapa-site turístico de Caxambu, disponível no endereço: www.caxambu.mg.gov.br (Figura 97), que utiliza como apoio o material impresso ante-riormente citado: o mapa de Caxambu, ou seja, com todas as deficiências já relaciona-das. Ele é então adaptado ao meio digital e moldado como um mapa estático interativo.

A partir do fundo-mapa-base, são compostos símbolos e caixas de texto interativos, devido a alguns recursos "clicáveis", que possibilitam diferentes formas de apresentação visual do mapa. É de fácil acessibilidade, por ter um rápido download da página, mesmo em conexões de baixa velocidade. A navegação é simples e de boa compreensão por disponibilizar poucos símbolos pontuais. A legenda, em pop up, traz textos dos principais atrativos do município. Não é possível utilizar o recurso pan e não há uma rede de layers. O recurso zoom é disponível em um só nível - zoom em etapas com imagens raster. Há uma pequena animação em flash: o teleférico mas é esteticamente pobre.

A figura 97 ainda apresenta outros tipos de mapas-site encontrados na Internet. 
Figura 96 - Mapas turísticos e a despreocupação com as regras cartográficas
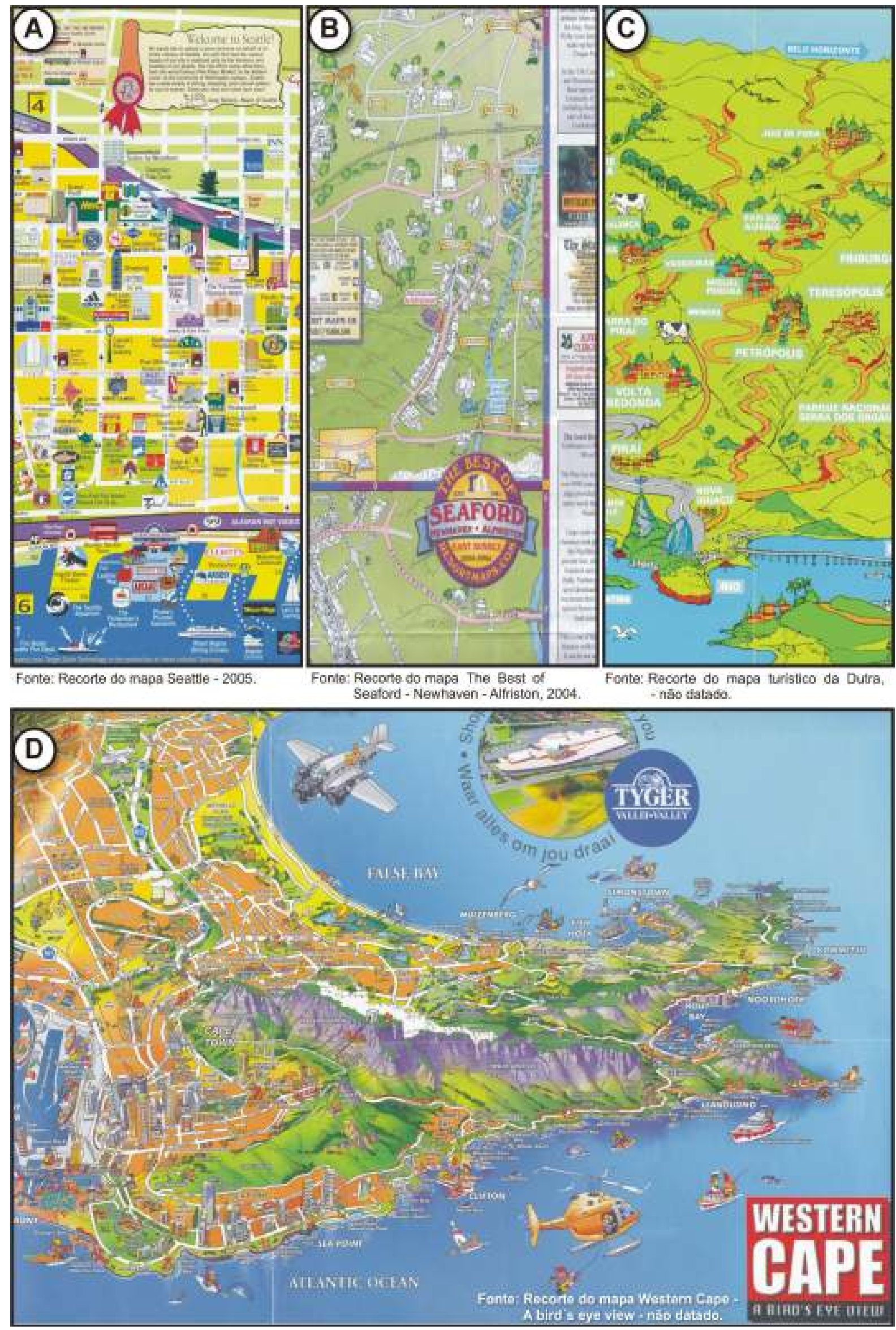
Figura 97 - O mapa-site turístico de Caxambu e alguns outros exemplos

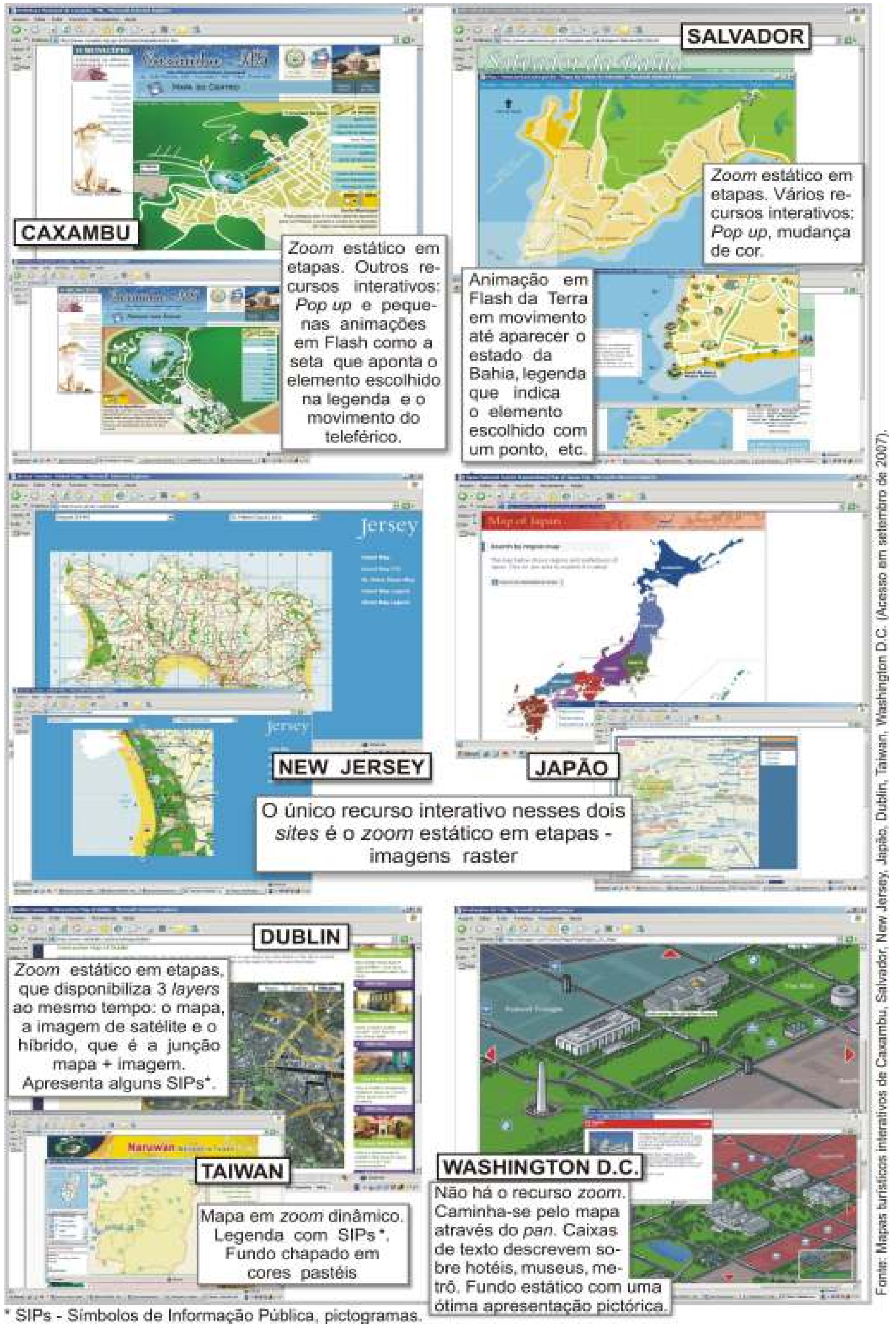


Todas essas observações refletem o desenvolvimento de vários tipos de mapas: convencionais, pictóricos e de mapas-site voltados ao setor do turismo.

Nesse momento, trabalha-se, na prática, o mapa híbrido, ou seja, aquele que tanto faz uso das regras cartográficas básicas, da semântica para iniciados e da semiologia gráfica de Bertin, quanto da teoria da comunicação, do senso comum e da pictografia.

É fundamental justificar que o mapa pictórico jamais conseguirá conceber uma linguagem finita, rigorosa, fisiológica e ordenada, como estabelece a semiologia gráfica. Até porque a teoria da comunicação estuda o signo lingüístico, que engloba o significante e o significado, e é caracterizado pela arbitrariedade por influencia das coordenadas histórico-culturais.

Em suma, a elaboração dos mapas convencionais tende a uma maior aproximação da semiologia gráfica: os denominados mapas para ver, enquanto os mapas pictóricos se configuram como mapas para ler (Bertin, 1983: 78).

Fiori $(1999,2003)$ e outros trabalhos empíricos evidenciam que, em geral, o público leigo em cartografia e o turista tendem a optar pelos mapas pictóricos, mesmo que a compreensão do conteúdo ocorra mais lentamente. Isso acontece devido ao melhor entendimento da informação, à atratividade e ao poder de sedução exercido pelo produto pictórico.

Ao se reportar ao tema central: diferentes tipos de usuários merecem diferentes tipos de mapas e, não ignorando o vertiginoso aumento dos "mapas" turísticos, resultado do crescimento das viagens pelo mundo, continua-se a pesquisa quanto à eficácia e eficiência de materiais cartográficos com grande apelo pictográfico.

Conseqüentemente, é proposital a elaboração de mapas para ler e não para ver, pois, considerando tudo que foi dito até aqui, o mapa para ler faz com que o usuário viaje à localidade representada antes mesmo de conhecê-la, possibilitando o devaneio, entre outras reações. $O$ marketing turístico também pode tornar 0 mapa um suvenir.

Levando em conta a elaboração do mapa-site turístico pictórico e o acesso por pessoas de profissões, idades, mas principalmente culturas diferentes, é impossível não existir um rico questionamento quanto à maneira de representar a realidade, de modo que um maior número de pessoas possa ler e se interessar pelo material desenvolvido.

Como já se registrou anteriormente, os símbolos e ícones devem procurar uma feição simples, sem muitos traços. A legenda, textos e outros elementos ilustrativos são recursos que ajudam a aumentar a informação cartográfica. 
Faz-se aqui uma ressalva: os usuários que acessam o mapa-site turístico conhecem, sem mensurar o quanto, o meio digital e a Internet, supondo ainda conhecimentos formais e informais.

Além disso, é instigante pensar que o mapa pictórico possibilita uma maior visão do outro, ao enfatizar símbolos locais e nacionais, atrativos naturais e culturais, fornecendo ao usuário da Internet - "o turista virtual" - informações de que ele pode se apropriar e que é capaz de adaptar com o propósito de conceber um senso distinto de nacionalidade. Palmer (1999) afirma que a idéia de nação está poderosamente presente na linguagem do turismo patrimonial. A apropriação da identidade nacional para o turismo - e, por que não inserir o mapa turístico? - vai além do interesse comercial: perpassa o coração do povo e serve para definir uma identidade tanto para os que são representados quanto os que devem entender a representação.

A importância de um castelo vai além da estrutura física que atrai os turistas. Ele também significa a nação como anciã, poderosa, majestosa, forte e duradoura e, desse modo, representa tudo o que é apreciado sobre a nação (Palmer, 1999).

Assim, ao propor um mapa-site turístico, devem-se considerar não só os elementos essenciais de um mapa (título, escala, referências geográficas), mas ir além, estudando formas de representar graficamente alguns elementos característicos da identidade local e nacional.

\section{5 - Processo de elaboração dos mapas e do mapa-site turístico}

Elaboram-se dez mapas: cinco convencionais e cinco pictóricos de cinco municípios brasileiros. Os mapas em formato digital estão disponíveis CD - anexos - pasta 3.

\section{$1^{\circ}$ passo: o trabalho de campo}

Os trabalhos de campo foram realizados em Ilhabela (SP); em Foz do Iguaçu (PR), em fevereiro de 2006; Caxambu (MG), em março de 2006; Manaus (AM), em abril de 2006 e São Raimundo Nonato (PI), em junho de 2006. A estada nos municípios foi importante para recolher informações como: inventários turísticos, folderes, mapas, fotos, textos, entre outras fontes de dados.

\section{$2^{\circ}$ passo: a base cartográfica}

Utilizam-se cartas do IBGE em escalas 1:1.000.000, 1:250.000 e 1:50.000 (relacionadas na bibliografia), plantas cadastrais analógicas e digitais, Guia Brasil Quatro Rodas e os Atlas de Simielli (1993), Vasconcellos e Alves Filho (1999).

Entretanto, é necessário registrar que as cartas do IBGE foram produzidas há aproximadamente 20 anos, o que acarreta problemas quanto à defasagem das 
informações nelas dispostas. Por isso, foi necessário consultar outros materiais visando à atualização das bases, como imagens de satélite (Google Earth) e principalmente outros "mapas" sem escala, que forneceram subsídios para referências como hidrografia, estradas, curvas de nível, etc. As bases cartográficas, principalmente aquelas usadas nos mapas pictóricos, passaram por ampliações, com tamanho suficiente para a caracterização das ilustrações, símbolos e textos em geral.

Alguns mapas já vieram em formato digital (programa AutoCAD), mas a maioria foi escaneada e posteriormente digitalizada em AutoCAD ou CorelDraw.

O formato final do mapa temático turístico é o tamanho A1 (584 X $841 \mathrm{~mm})$.

\section{$3^{\circ}$ passo: a elaboração dos mapas}

A partir de uma mesma base cartográfica, elaboram-se dois mapas que, entretanto, apresentaram diferentes versões de representação para a mesma localidade: um mapa convencional e um mapa pictórico. A seguir, destacam-se os itens comuns às duas versões:

\section{1 - Um título com um tema em destaque disposto na parte superior do mapa}

Seguem-se os títulos: O arquipélago de llhabela; Foz do Iguaçu - Terra das Cataratas; Caxambu - A maior concentração de fontes carbogasosas do planeta; Manaus - Coração da Amazônia; e Parque Nacional Serra da Capivara - A maior concentração de sítios arqueológicos do mundo.

\section{2 - A base temática: o fundo do mapa}

Como se sabe, ao levar em conta o usuário, o fundo de um mapa nunca deve chamar mais a atenção do que as informações realmente importantes. Entretanto, devido à temática do turismo, fazem-se três ponderações:

$\checkmark$ Durante o processo de tematização, o produtor do mapa escolhe e adapta as informações contidas na base cartográfica. No caso desta pesquisa, as bases em escala menor são normalmente topográficas ou cadastrais (arruamento), e as bases em escala maior vêm fundamentalmente de guias e Atlas.

$\checkmark \mathrm{O}$ fundo do mapa turístico pode conter representações caracterizadas por espaços urbanos ou rurais e diferentes feições de morfologia do terreno. Contudo, a forma de representação visual desenvolvida pelos mapas convencionais é muito diferente se comparada aos mapas pictóricos. $\mathrm{O}$ primeiro tipo apresenta a vantagem de conseguir compor um mapa abstrato essencialmente por meio das cores, das linhas e do uso efetivo da visão vertical. O mapa convencional, referenciado no discurso da neutralidade, tende a ser visualmente mais claro, direto e possibilitar o domínio da 
informação de maneira mais rápida. São os mapas para ver.

$\checkmark$ Mesmo os mapas pictóricos sendo mais poluídos visualmente, apresentam a grande vantagem de compor representações que atraem o olhar da maioria das pessoas, em particular, os leigos em cartografia. Esse público, embora demore mais tempo para interpretar o que vê, consegue um melhor resultado quanto ao entendimento da informação. São os mapas para ler. Além disso, o recurso da ilustração e da visão oblíqua possibilita apresentar os temas de maneira mais lúdica, sedutora e atrativa, um aspecto a ser considerado quando se pensa desenvolver um mapa temático para o turismo.

A figura 98 demonstra o processo de elaboração dos mapas convencionais e pictóricos, referenciados em uma planta cadastral (98 A) e uma carta topográfica (98 B).

Para finalizar, é necessário que se faça uma ressalva quanto à elaboração das bases temáticas pictóricas. Mesmo que o grau de abstração da realidade seja menor, se comparado aos mapas convencionais, a base pictográfica continua sendo uma representação gráfica muito reduzida da realidade.

Ao olhar novamente para a figura $98 \mathrm{~A}$, pode-se afirmar que a representação é uma imagem genérica e geral dos quarteirões e suas construções. No caso do mapa de Caxambu, ainda devido à boa dimensão de sua escala foi possível até representar os principais prédios e atrativos do Parque das Águas, como as fontes e o Balneário. Todavia, é quase impossível compor ilustrações que representem o tamanho real ou apresentar todas as construções contidas em um quarteirão. $O$ que o mapa pictórico mantém são as distâncias, ou seja, as ilustrações consideram rigorosamente a base cadastral, topográfica.

O mesmo caso é percebido nas representações morfológicas do terreno, pois é impossível caracterizar a vegetação tal com ela é na realidade. Dessa forma, mesmo que a representação busque seguir as curvas de nível para moldar a morfologia do terreno, o modo como se caracteriza a vegetação é caricata. A figura 99 demonstra outro exemplo. Rever também as figuras $96 \mathrm{~B}, \mathrm{C}$ e D.

\section{3 - O sistema de referências}

Os mapas convencionais e ilustrados desenvolvidos possuem a indicação de Norte e a coordenada geográfica representando uma latitude e uma longitude.

Outro ponto de referência é conseguido graças à composição: mapa principal e outros mapas em escala menor. Os mapas-detalhe situam as cidades turísticas em relação a vias de acesso, a outras cidades e a capitais. Um pequeno mapa do Brasil ainda informa em qual estado brasileiro está a cidade representada. 
Figura 98 - A pictografia sob uma planta cadastral e uma carta topográfica
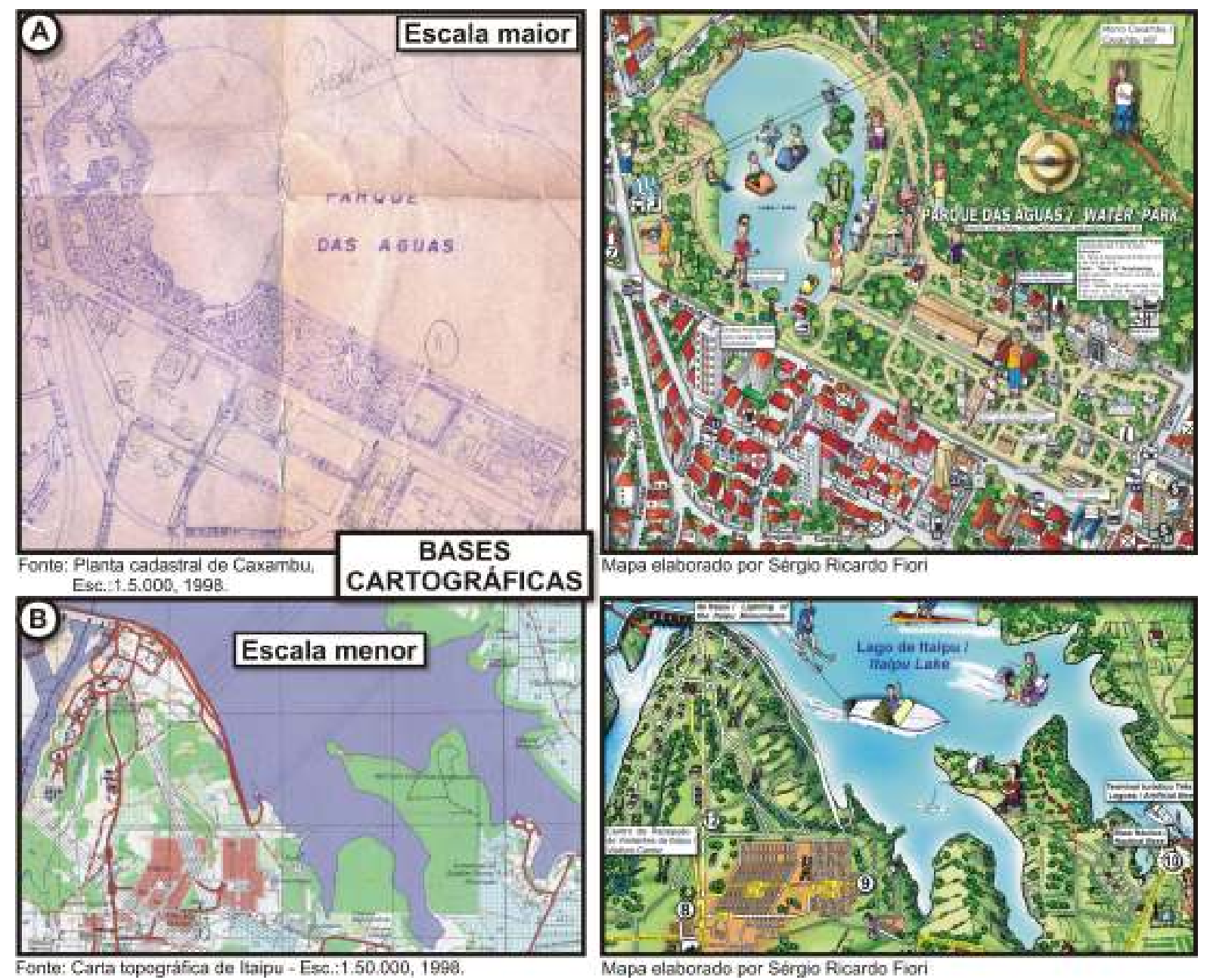

Figura 99 - A pictografia e a generalização da realidade física

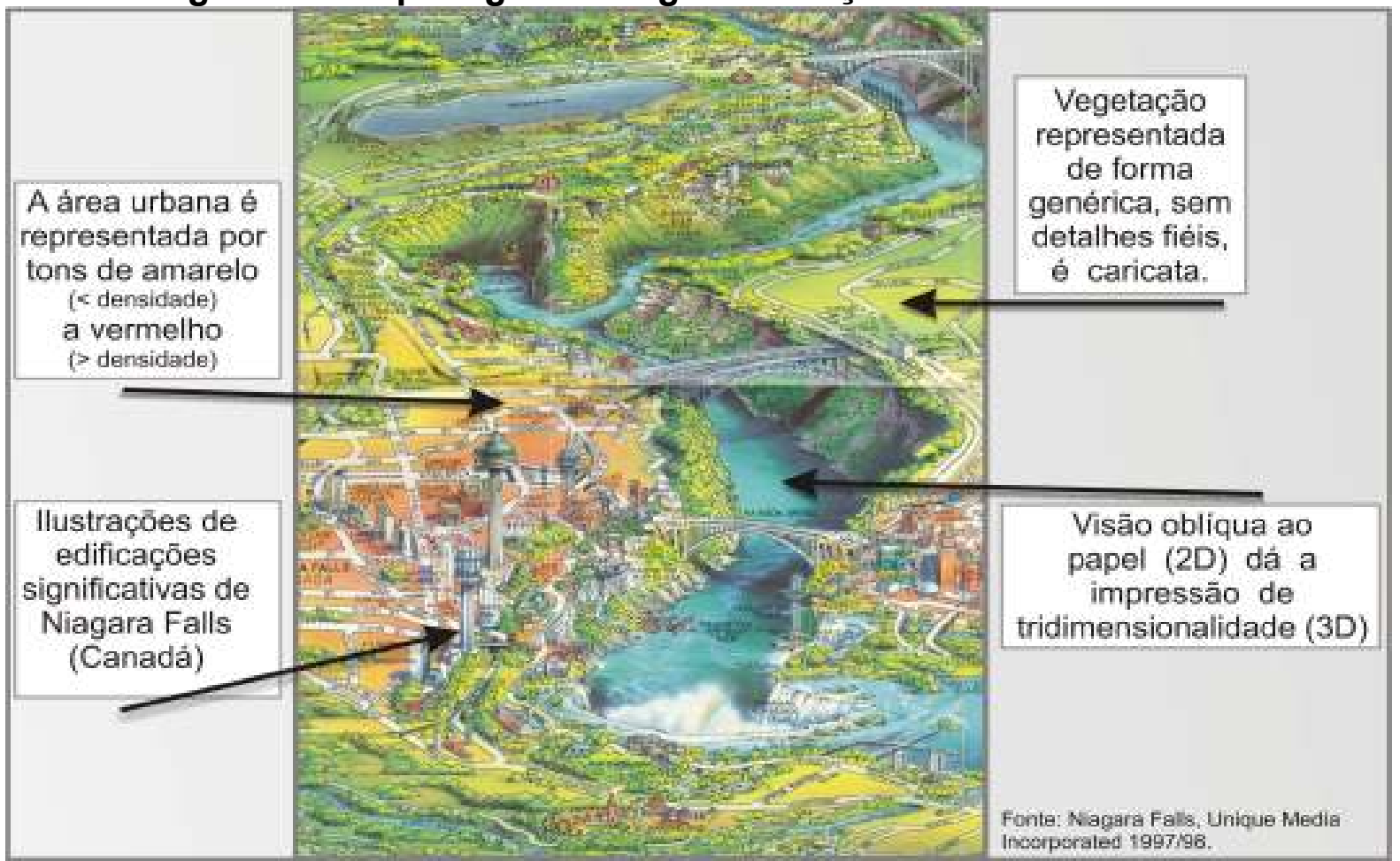




\section{4 - 0 símbolo}

A elaboração dos símbolos utiliza os mesmos fundamentos teóricos relatados no item 3.2 - base temática, ou seja, estão divididos em dois tipos: convencionais e pictóricos.

Os símbolos convencionais, também chamados de geométricos ou abstratos, caracterizam-se por círculos, quadrados, triângulos entre outras figuras, não conservando nenhuma relação com o elemento espacial representado.

Nos mapas temáticos turísticos convencionais, também é fundamental se representarem as vias de acesso (rodovias, ferrovias, ruas, trilhas, pontes) e a hidrografia (rios intermitentes e perenes). Esse é um tipo de simbologia de nível intermediário de abstração. Os símbolos são denominados de associativos (Gerber, Burden, Stanton, 1990) seminaturais (Oliveira, 1978:23) ou motivados (Forest e Castner, 1985).

Posto isso, os mapas convencionais tendem a uma simbologia voltada ao ver, à relação fisiológica da imagem. Mesmo assim, os mapas convencionais não estão livres de tradições, códigos e convenções estabelecidas a partir do tratamento gráfico da informação. Por exemplo, a cor: convencionou-se o verde para vegetação; o sépia para curvas de nível; o marrom para as maiores altitudes e o azul para hidrografia. Essa codificação resulta da cultura, ao empregar, no caso a cor, como uma metáfora natural, comum. Além disso, nos mapas com o grande uso de representações abstratas, a legenda é um elemento indispensável, mas o texto verbal também; logo, o usuário que desconhece aquela língua e sua escrita certamente terá problemas para decodificar as informações contidas no mapa.

Já os símbolos pictóricos exacerbam, em suas representações, os fatores tempo e cultura, porque as ilustrações sempre apresentam alguma semelhança física com o fenômeno representado. Como já foi visto anteriormente, é nesse instante que a arte e a cultura revelam uma importância preponderante, pois o ato da criação resulta de um conjunto de contextos mentais. Dessa forma, ao desenvolver os cinco mapas pictóricos (Ilhabela, Foz do Iguaçu, Caxambu, Manaus e São Raimundo Nonato), inúmeras figuras compõem, individualizam e ilustram os atrativos naturais (fauna, flora), culturais (arquitetura, artesanato) e alguns imateriais. Este último tipo de atrativo é bem mais complexo de ilustrar, pois, na maior parte das vezes, a compreensão do símbolo ultrapassa as referências físicas, necessitando de um conhecimento além da paisagem (Figura 100). Existem, ainda, símbolos e ilustrações que representam ações mais comuns, como personagens fazendo compras, praticando algum tipo de esporte ou serviço.

Registra-se aqui o cuidado que se deve ter quanto à concepção de ilustrações e imagens que, de apelo duvidoso, "venderiam" a destinação a qualquer preço. 
Figura 100 - llustrações dos atrativos

naturais, culturais e de ação nos mapas

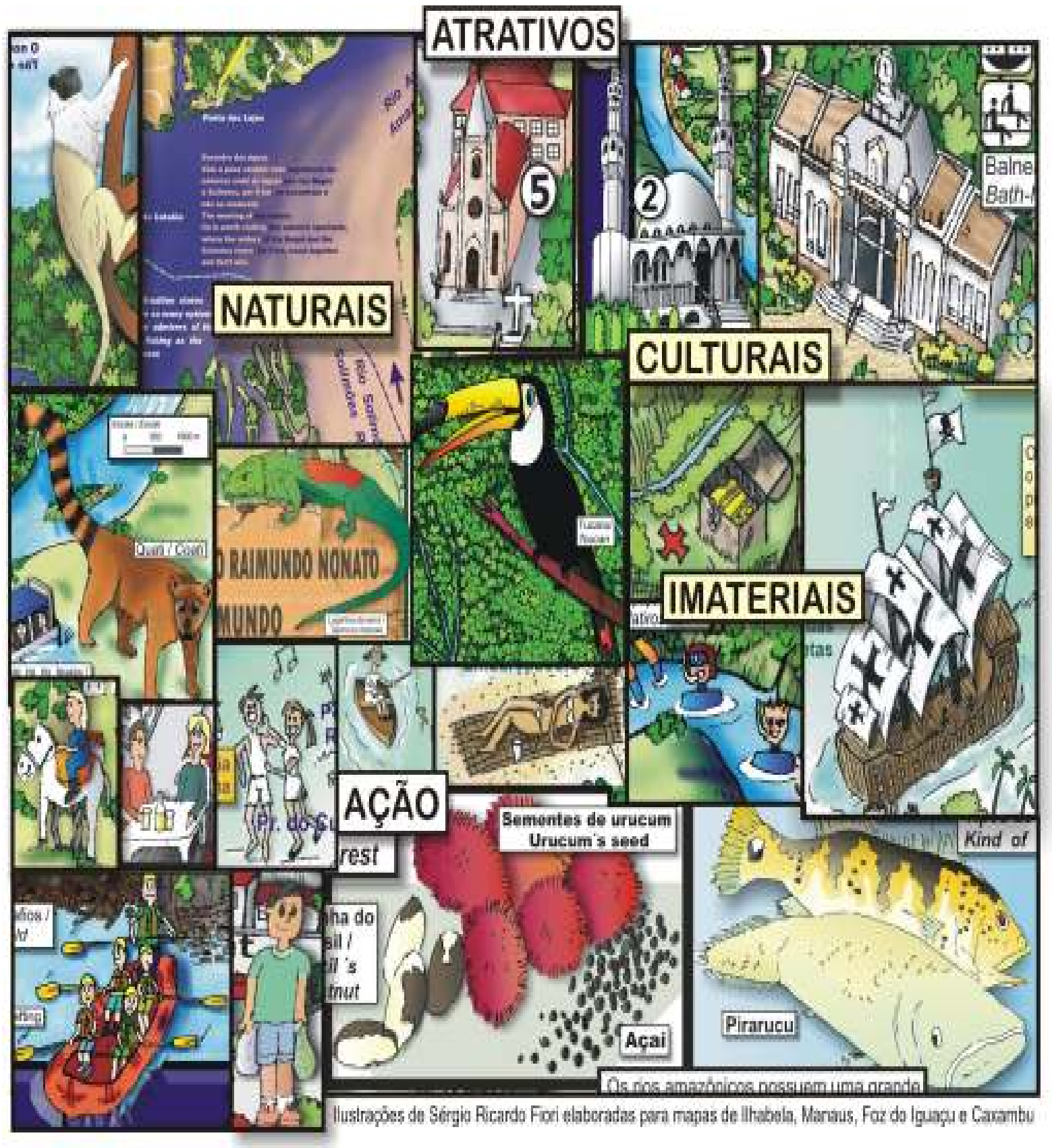

\section{5 - 0 texto}

O texto é um recurso fundamental a qualquer mapa. No caso particular dos turísticos convencionais e pictóricos, serve para compor o título, as caixas informativas - serviços, história, curiosidades - os nomes de praias, das serras, dos bairros, das ruas, dos rios, etc. Também é o elo entre a representação gráfica e a legenda - texto verbal. A harmonia estética e funcional entre os vários elementos gráficos e os textos possibilita composições com fontes de estilos e tamanhos diferentes, resultado de o que e como se quer informar (Figura 101). 
Figura 101 - Direcionamento da informação: ilustração e complemento texto

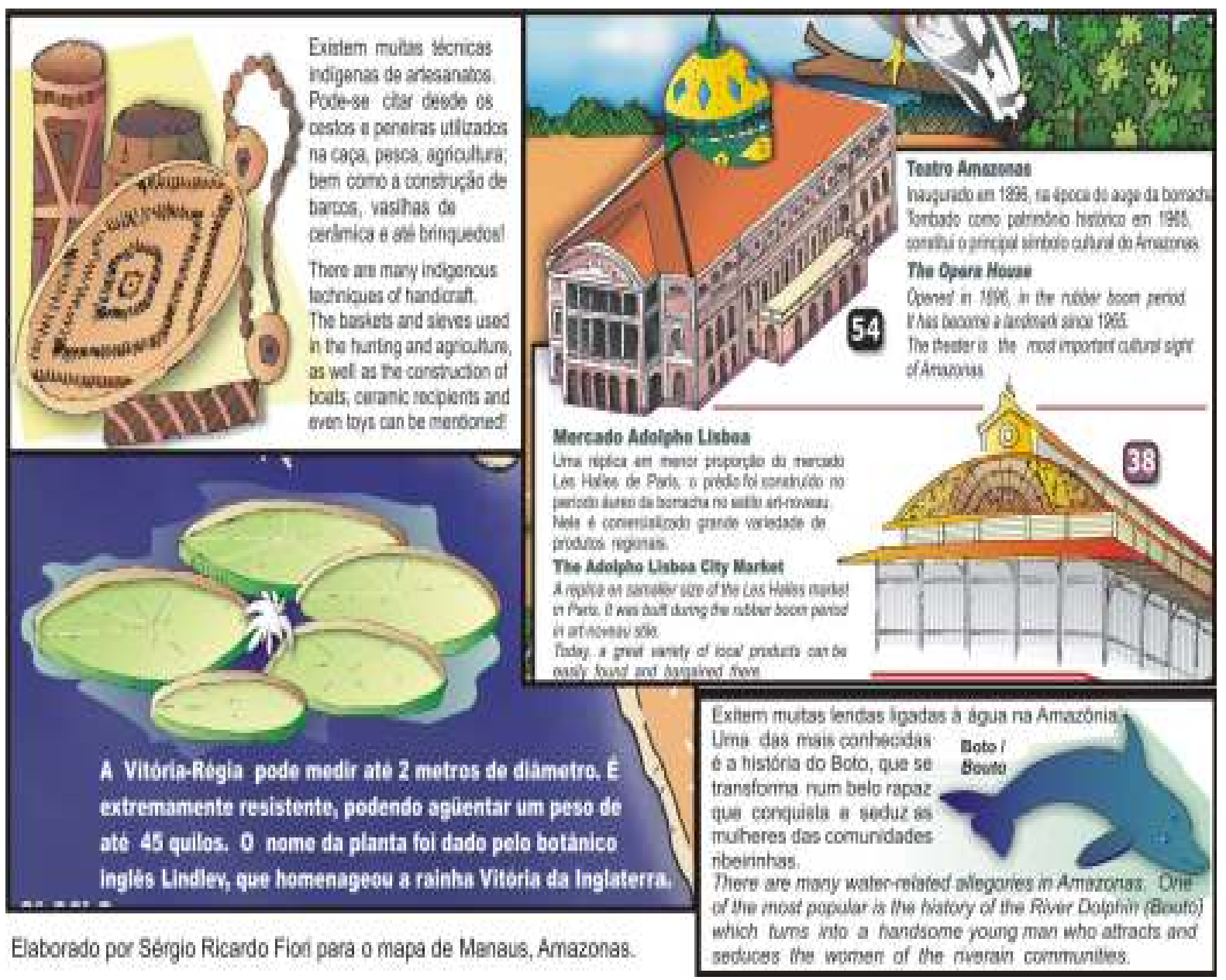

\section{6 - A legenda}

A legenda faz parte do processo de leitura, decodificação e compreensão do mapa. O maior ou menor uso desse recurso está intrinsecamente ligado à escolha do tipo de representação gráfica, pois, como visto no item 3.4, os mapas que contêm símbolos abstratos se caracterizam pela não referência ou semelhança com a informação que representam, pressupondo, assim, um uso maior da legenda.

O mapa turístico divide a legenda em dois tipos: geral, caracterizado por elementos usualmente encontrados em qualquer mapa como, por exemplo, o símbolo de capital, cidade, rodovia pavimentada ou sem pavimentação, hidrografia, limites municipal, estadual e federal entre outros do mesmo gênero. E a legenda turística, com símbolos relacionados à acomodação, alimentação, hospedagem, serviços, atrativos naturais e culturais, entretenimento, práticas desportivas, recreação e transporte (Figura 102).

Aliás, esta pesquisa continua o estudo de Fiori (2003), que propõe a elaboração de uma legenda para mapas turísticos, utilizando-se dos Símbolos de Informação Pública (SIPs). A escolha dos símbolos empregados nas legendas dos dez mapas desenvolvidos ao longo deste trabalho seguiu alguns critérios: 
102 - A legenda geral e turística

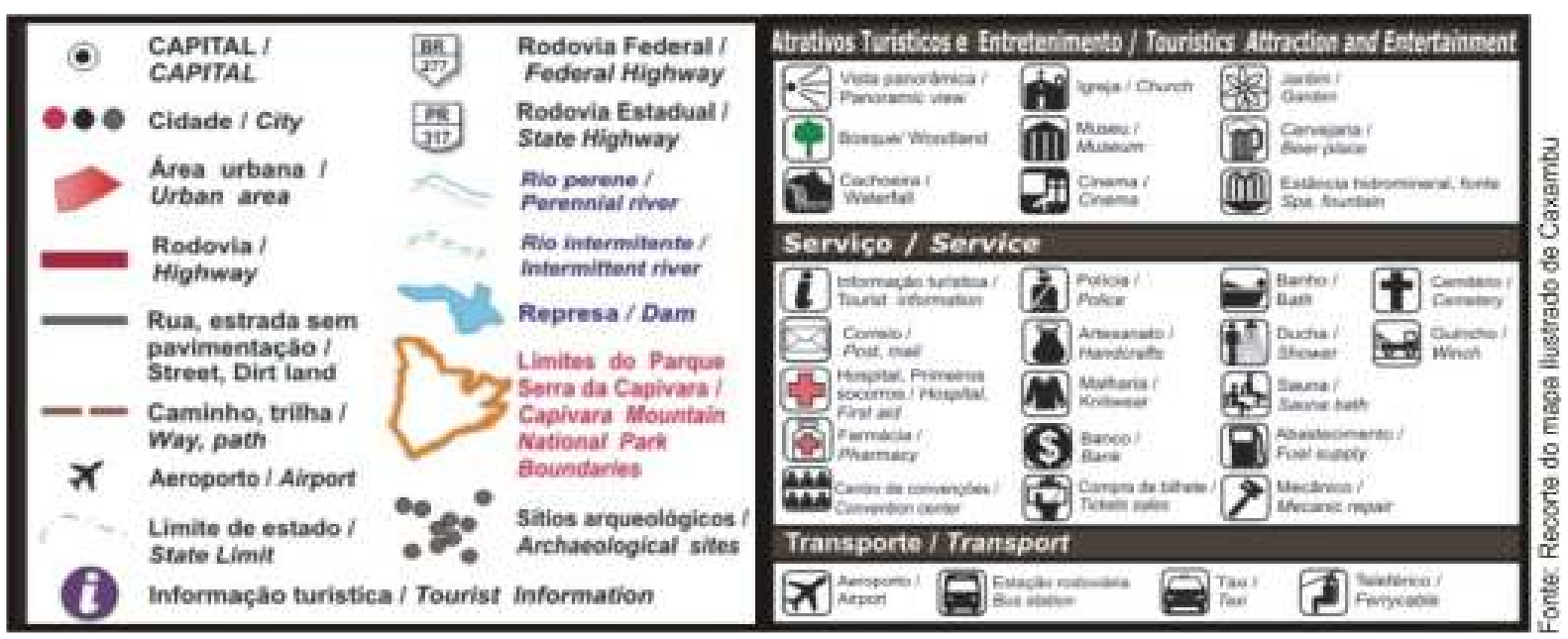

$\checkmark$ Utilizar os SIPs que já aparecem usualmente em mapas nacionais e internacionais, guias turísticos como, por exemplo, o guia Quatro Rodas ou em padronizações (AIGA, ERCO, EMBRATUR); por apresentarem uma generalização pictográfica já estabelecida na sociedade, o que facilitaria a descoberta do significado, permitindo, ao turista, uma maior familiaridade com os símbolos.

$\checkmark$ Tomar como referência e utilizar alguns dos símbolos propostos em uma pesquisa realizada em 1987 e 1989 por Stanton (apud Gerber, Burgen \& Stanton,1990), que selecionou mapas turísticos da Austrália, Inglaterra, Suíça, Dinamarca, Nova Zelândia e Espanha. Depois disso, o autor desenvolveu uma série de SIPs, tendo como base um modelo australiano (AS 2342), que é equivalente ao modelo britânico (BS 6034) e ao da Organização Internacional (ISO 7001). Outra referência é o trabalho de Clarke (1989), que selecionou duas séries de símbolos comumente usados e disponíveis em mapas turísticos pertencentes às instituições da GrãBretanha ("Ordnance Survey") e dos Estados Unidos ("Estate Publications").

$\checkmark$ Havendo a necessidade de confeccionar um SIP, procurou-se elaborar uma representação gráfica que tendesse a concentrar um número pequeno de características gráficas da referência, simplificando ao máximo o código. A intenção é levar o usuário a recorrer à legenda somente para assimilar o novo ícone-símbolo, tornando-o tão natural quanto aqueles já usados pela mídia.

Durante o desenvolvimento dos mapas, foram elaborados alguns símbolos, como: rapel, pizzaria, jardim, confeitaria, vôos de trike, feira-mercado municipal, espaço cultural.

Proporcionar à identificação dos símbolos de uma maneira rápida e direta é muito importante; logo, é preciso que eles estejam emoldurados em um fundo chapado 
na cor branca. O intuito é permitir um destaque dos símbolos em relação ao fundo do mapa, tornando-os visualmente mais claros. A moldura deve ter o tamanho adequado para possibilitar que as figuras sejam facilmente identificadas.

Observa-se que os mapas convencionais tendem a ter um número maior de símbolos em suas legendas do que os mapas pictóricos. Quando isso não acontece, é porque o produtor do mapa opta por trabalhar a redundância, ou seja, representa a mesma informação mais de uma vez (Figura 103 A). As duas situações podem ser notadas em oito dos dez mapas produzidos, pois, naqueles de Ilhabela e Foz do Iguaçu, há uma redução do número de símbolos na legenda dos mapas pictóricos se comparado ao dos mapas convencionais. Já nos de Manaus e São Raimundo Nonato, a legenda é a mesma nas duas versões do mesmo mapa.

Rever novamente a figura 103 A, que exemplifica o porquê da ocorrência de menos SIPs nas legendas dos mapas pictóricos - as ilustrações falam por si. Já a figura 103 B demonstra a maneira enfática e sedutora de uma informação contida na legenda.

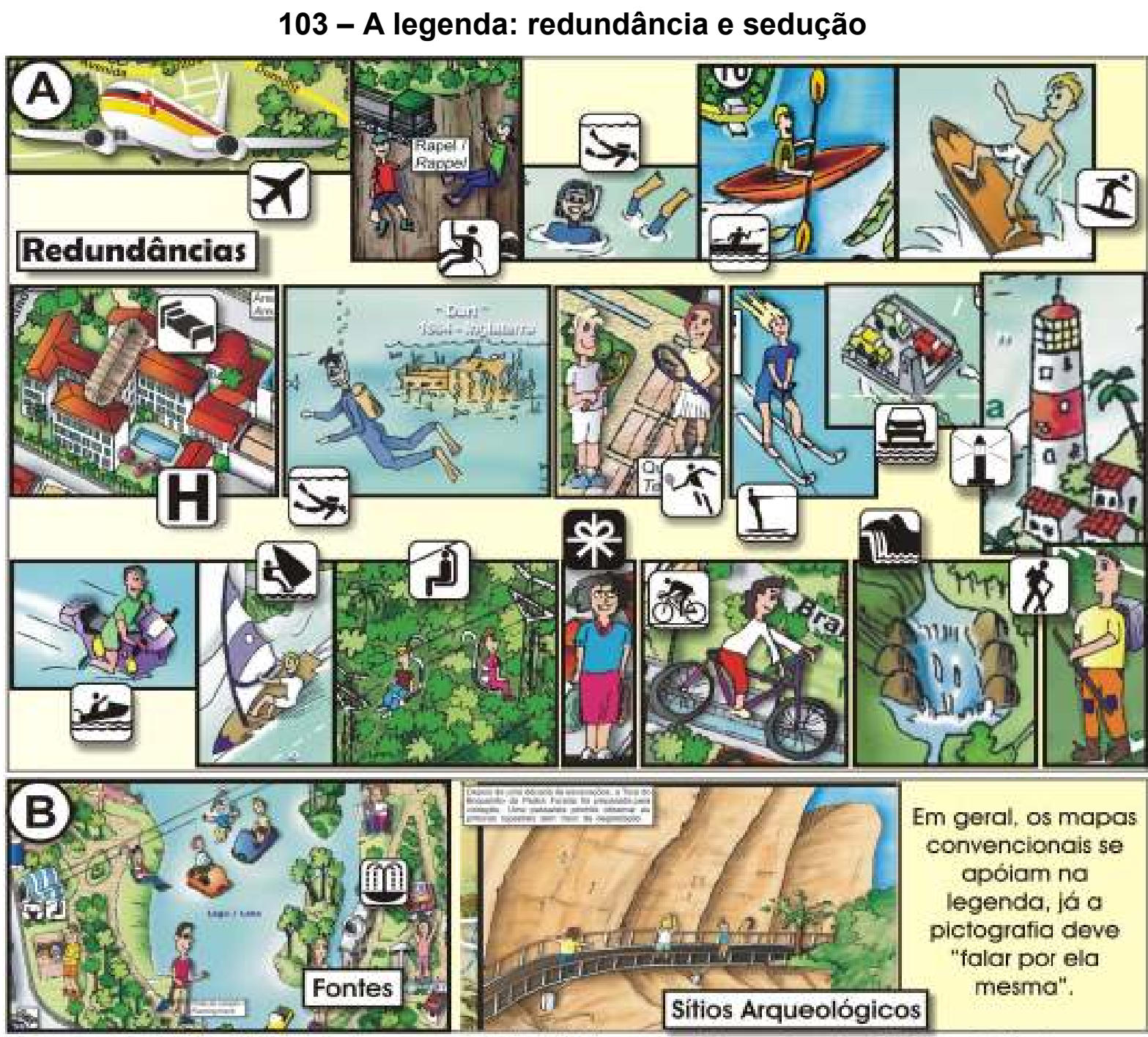

liustraçōes de Sérgio Ricardo Ficri elaborados para mapas de llhabela, Manaus, Foz do lquaçu, Caxambu e São Raimundo Nonato 


\section{7 - A borda}

A borda em um mapa turístico serve para auxiliar o usuário que procura relacionar o item da legenda com sua localização no mapa. Por exemplo: como encontrar no mapa um hotel que se vê na legenda. Nesse caso, o simples e já usado processo de dividir a borda do mapa com letras e números resolve de maneira eficaz o problema (104 A).

Nos mapas pictóricos, as bordas recebem uma personalização, pois "encarna" algum tema referente à destinação turística (Figura 104 B). A idéia de confeccionar esse tipo de borda faz referência aos mapas do século XVII, quando os profissionais ilustravam as bordas das legendas com animais e produtos típicos da localidade mapeada.

Figura 104 - Bordas ilustradas

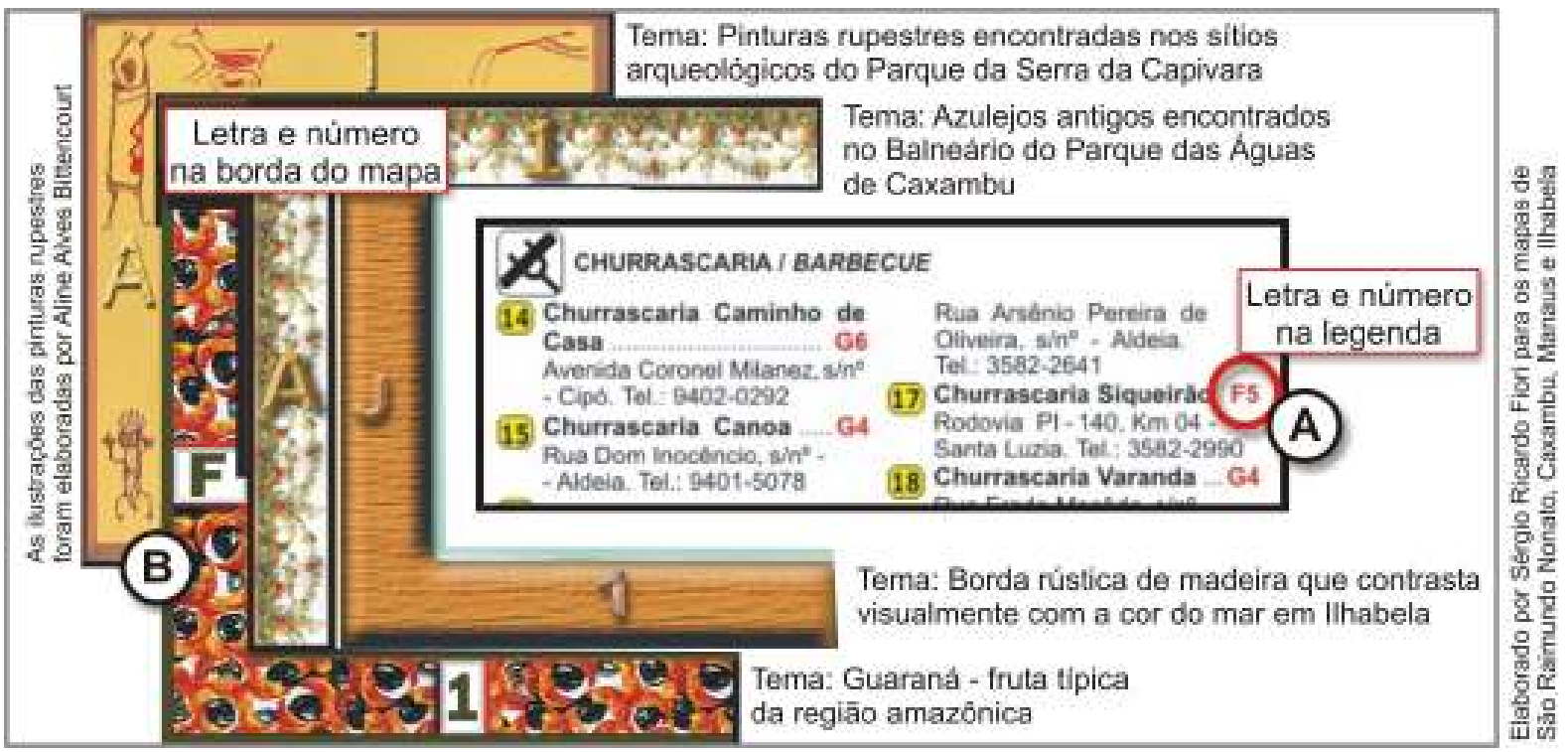

\section{8 - 0 processo de confecção dos mapas}

Inicialmente é necessário que todos os mapas recolhidos estejam em formato digital. Na maioria das vezes, a ação seguinte é unir e compor os vários mapas para que ocorra a atualização e eles fiquem adequados ao tamanho de folha A1 $(584 \times 841 \mathrm{~mm})$. A partir de então, tem-se a base cartográfica para o desenvolvimento dos mapas turísticos convencionais e pictóricos. As duas versões representativas da mesma localidade passam por um processo de confecção diferente:

Os mapas convencionais - transporta-se a base ao programa CorelDRAW, onde se realiza todo o processo de digitalização e diagramação das linhas, polígonos e manchas e textos dos vários elementos espaciais como, por exemplo, a indicação de área urbana ou rural, a hidrografia, a topografia, a rede viária, os diversos 
símbolos, etc. Cada elemento é ordenado em layers (camadas) - Figura 105. No caso específico da morfologia do terreno, levando em consideração a heterogeneidade do público alvo, opta-se por reduzir a quantidade do número de curvas de nível encontradas na base cartográfica. Utiliza-se uma seqüência monocromática de cor (verde) para obter uma impressão visual de altitude. Um símbolo geométrico (triângulo) marca os pontos mais altos (picos) da topografia.

Figura 105 - Os layers dos mapas

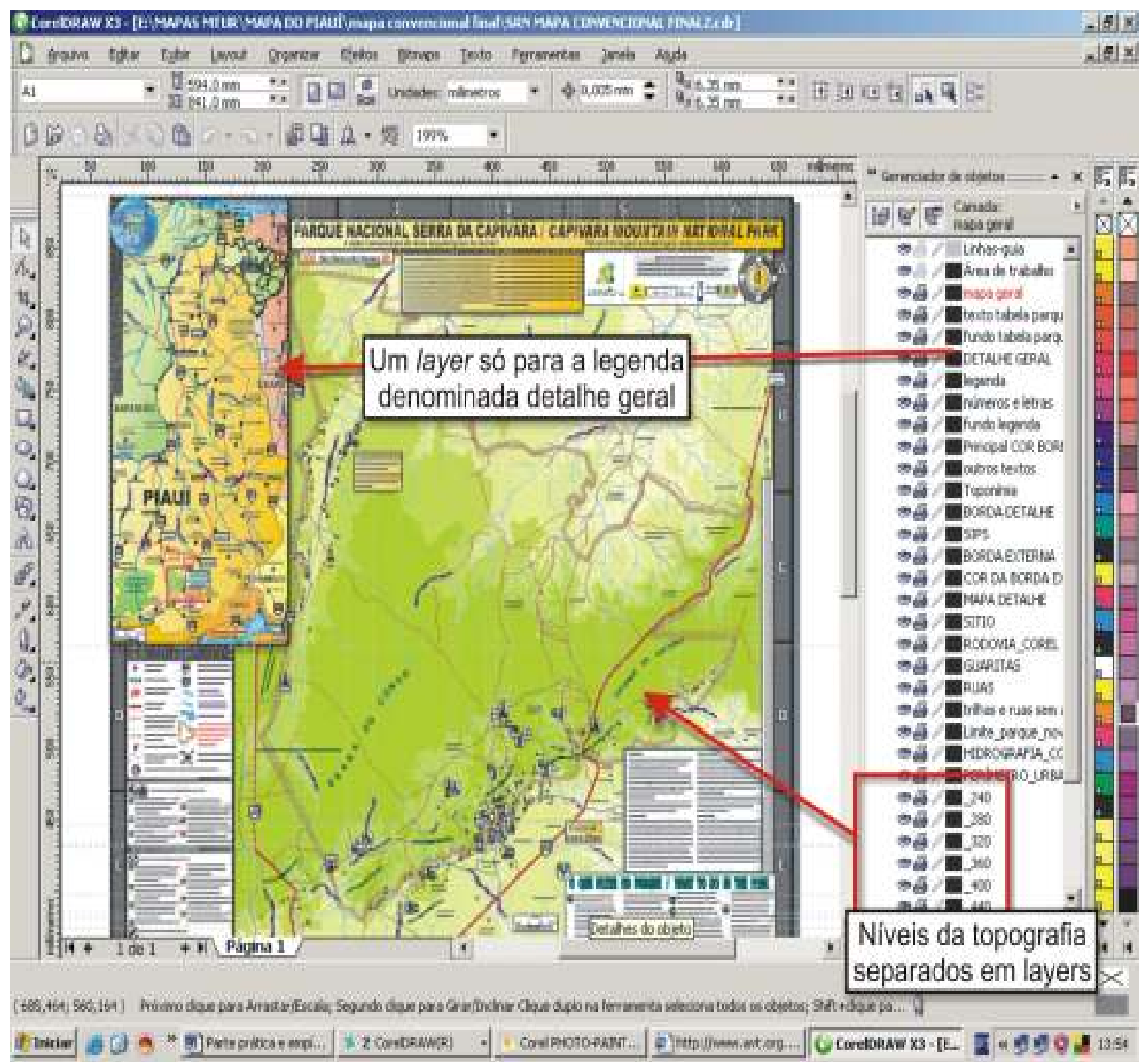

- Os mapas pictóricos - partem da base cartográfica (unida e atualizada) do mapa convencional, contudo, é necessário imprimi-la. Posteriormente, utiliza-se um papel vegetal para copiar linhas e áreas do mapa que servem de apoio ao processo ilustrativo (Figura 106 A). Neste momento, pode-se escolher ou não copiar, no papel vegetal, elementos como o arruamento, a rodovia, a hidrografia, etc. Por exemplo, nos mapas pictóricos de Ilhabela e Caxambu, o arruamento foi copiado e transferido para o papel vegetal; já nos mapas de Manaus e São Raimundo Nonato, utilizam-se as bases digitalizadas do mapa convencional. 
Em seguida, transportam-se as informações coletadas no papel vegetal para uma folha de papel branca (preferencialmente verge ou canson). A confecção da base ilustrada apóia-se nas referências (linhas) transferidas, sendo que a ilustração é realizada a partir da técnica da visão oblíqua, que proporciona um aspecto de perspectiva ao desenho (Figura $106 \mathrm{~B}$ ).

É Importante ressaltar que, mesmo utilizando a visão oblíqua para a confecção dos mapas pictóricos, estes foram concebidos sobre uma base cartográfica em escala, o que possibilitou a inserção do sistema de referências geográficas (latitude, longitude e pontos cardeais).

Todo o processo de confecção nesta parte do trabalho é feito manualmente. $O$ desenho é concluído ao se passar a caneta nanquim sobre as linhas em grafite.

A próxima etapa é a digitalização da base ilustrada e seu transporte ao Adobe Photoshop. Parte-se então para o processo de colorização digital por meio da técnica da luz e sombra, o que possibilita o suposto volume; a tridimensionalidade. No programa, é realizado todo o processo de colorização, utilizando principalmente o recurso da ferramenta aerógrafo (Figura 106 C).

No final do processo de confecção, transporta-se o mapa ao CorelDRAW para sejam acrescidas as legendas, os mapas-detalhe e os textos. No mesmo programa, elaboraram-se ilustrações em outro layer, disposto acima do mapa-base. É o caso, por exemplo, das atividades esportivas, do imaginário local (lendas), curiosidades, construções históricas, etc (Figura 106 D). As ilustrações mais significativas dos mapas desenvolvidos são o centro de Ilhabela, a trilha das Cataratas em Foz do Iguaçu, o Parque das Águas de Caxambu, o centro de Manaus e a Toca do Boqueirão da Pedra Furada no Parque da Serra da Capivara.

- A legenda - grande parte dos símbolos de informação pública foi recolhida da Internet - ERCO, AIGA e GUIA BRASILEIRO DE SINALIZAÇÃO TURÍSTICA. A outra parte foi retirada e digitalizada do Guia Quatro Rodas, da apostila do Curso de Formação de Condutores (Bruns, 2000) e de vários mapas recolhidos e analisados ao longo da pesquisa (ver tabelas 2 a 8 ).

Os símbolos escolhidos para compor os mapas passaram por um processo de uniformização visual por meio do programa CorelDRAW - Figura 107. 
Figura 106 - Seqüência de confecção da base ilustrada
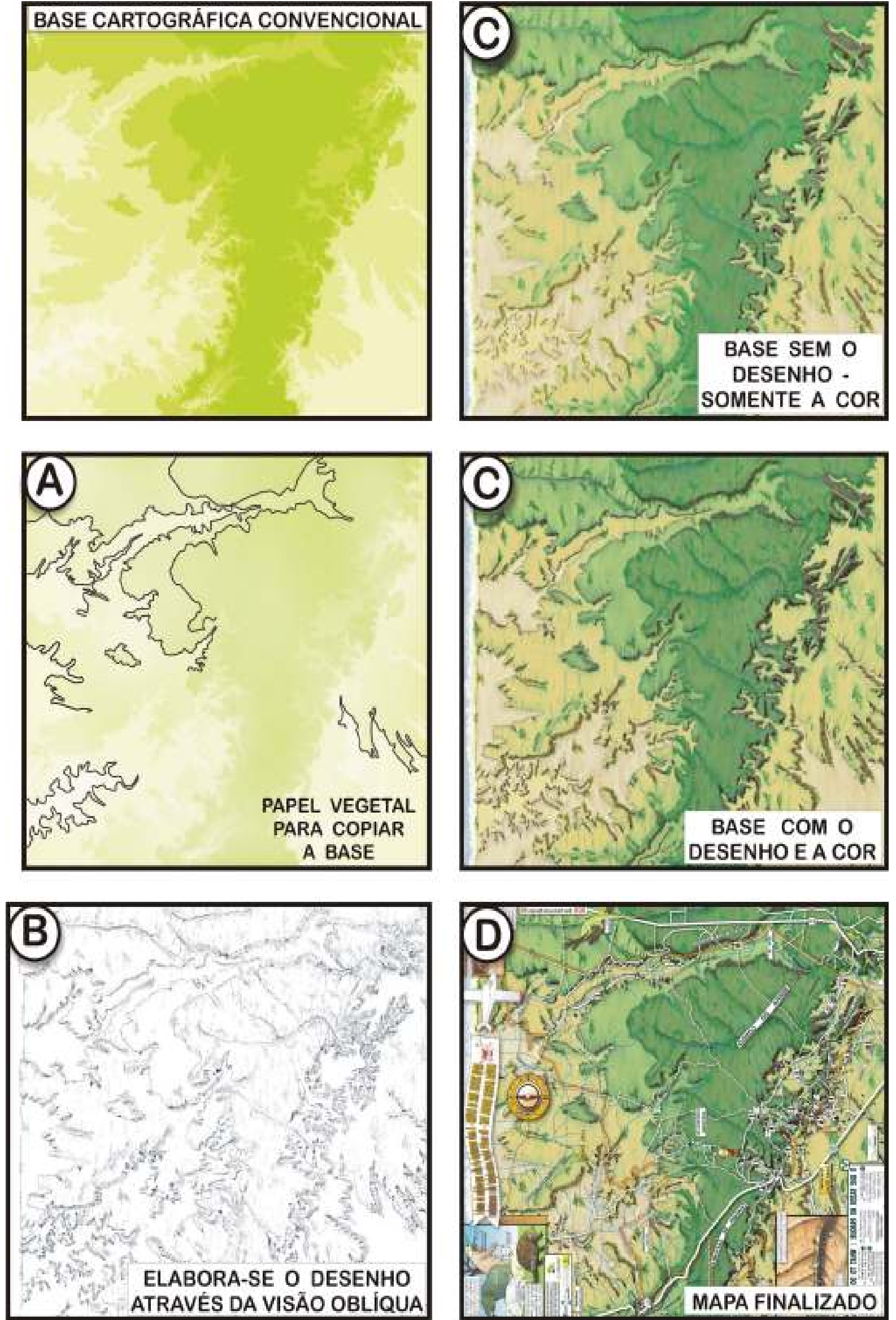
Figura 107 - Readequação gráfica e digitalização dos SIPs

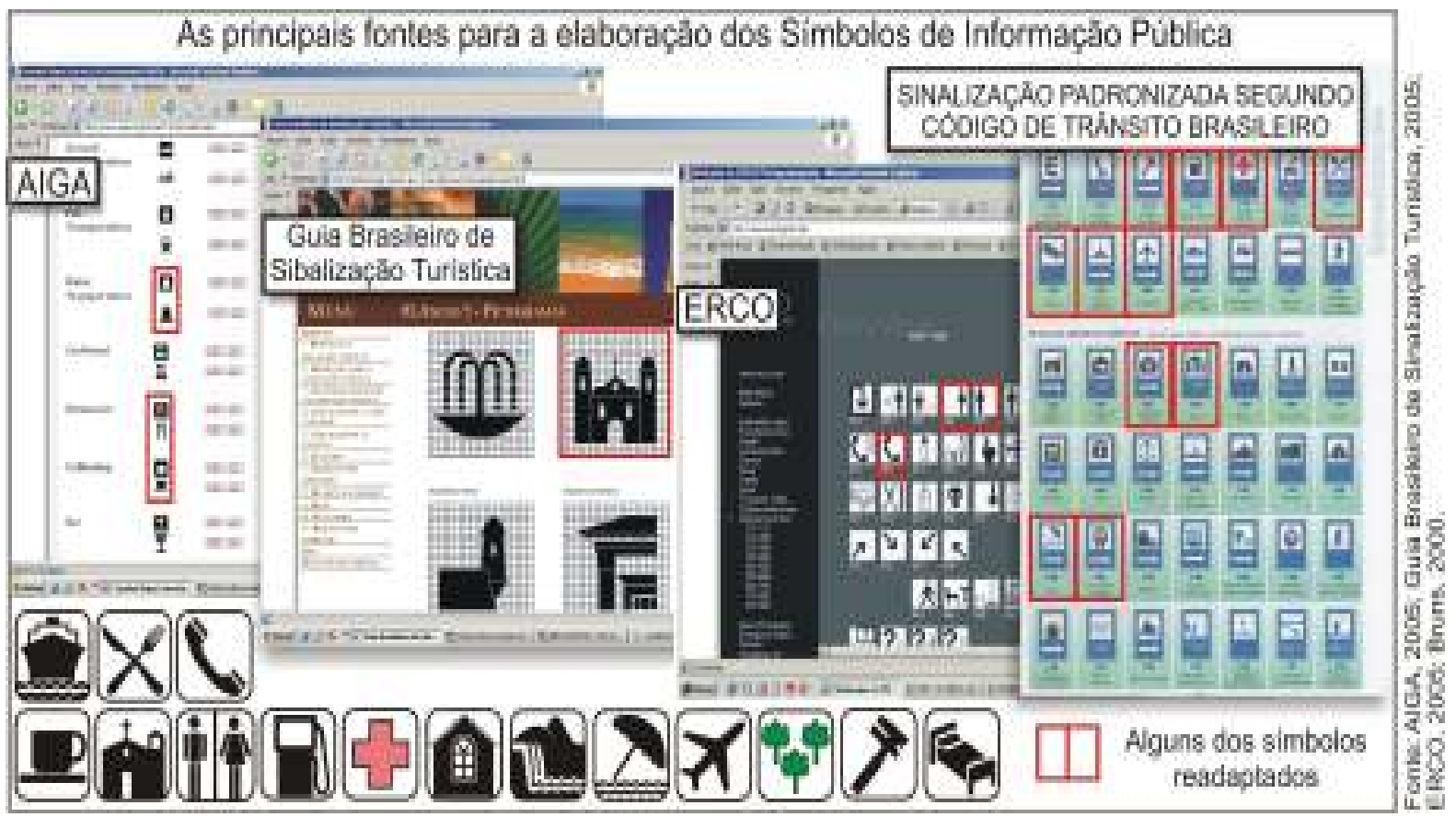

\section{$4^{\circ}$ passo: a elaboração do protótipo mapa-site turístico de Caxambu}

Após a confecção dos mapas turísticos de llhabela (SP), Foz do Iguaçu (PR), Caxambu (MG), Manaus (AM) e São Raimundo Nonato (PI): cinco convencionais e cinco pictóricos (ver mapas em CD - anexos - pasta 3), Caxambu foi selecionada para o desenvolvimento de um protótipo para um mapa-site turístico. A escolha se deve ao processo de elaboração dos dez mapas turísticos, ou seja, se comparado às outras cidades, Caxambu dispõe de uma maior quantidade de mapas convencionais e pictóricos e, ainda, escalas mais diversificadas, divididas em:

- Escala menor - globo terrestre focando a América do Sul, mapa da região Sudeste com destaque ao sul de Minas Gerai, e o mapa da Estrada Real.

- Escala intermediária - mapa do Circuito das Águas e do município de Caxambu.

- Escala maior - mapa do Parque das Águas.

O site foi confeccionado no programa Dreamweaver, sendo disponibilizado em dois idiomas: português e inglês. Compõe-se de quatro etapas em zoom estático com escalas gráficas pré-estabelecidas em imagem raster. As informações da legenda mudam, dependendo do mapa-zoom escolhido. Os mapas também oferecem ao usuário o recurso pan (Figura 108). 
Figura 108 - As quatro etapas de zoom do protótipo mapa-site de Caxambu

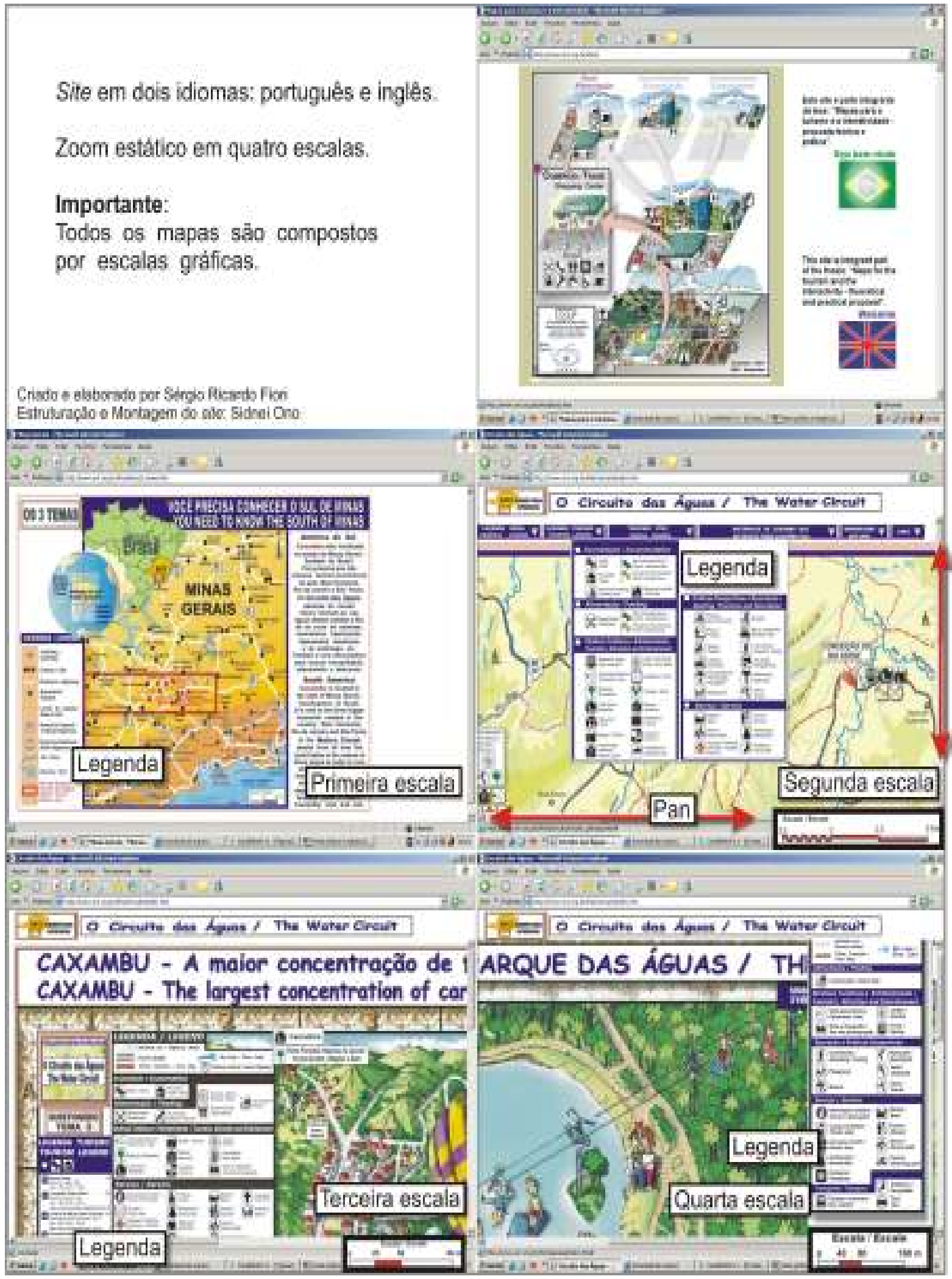

A interatividade do site aconteceu nos vários tipos de caixas de texto e botões que, ao serem clicados, abrem legendas, proporcionam informações direcionadas (entrar, ir até, voltar), apresentam alguns atrativos como as igrejas, o centro 
comercial de artesanato e o lago. Já os textos relatam sobre a história, a arquitetura, as fontes, horários de funcionamento do balneário e do Parque das Águas, curiosidades, etc. No mapa do Circuito das Águas, ainda se disponibilizam links para outros sites que se reportam a Caxambu e ao Circuito (Figura 109).

Figura 109 - Exemplos de elementos interativos do protótipo mapa-site de Caxambu

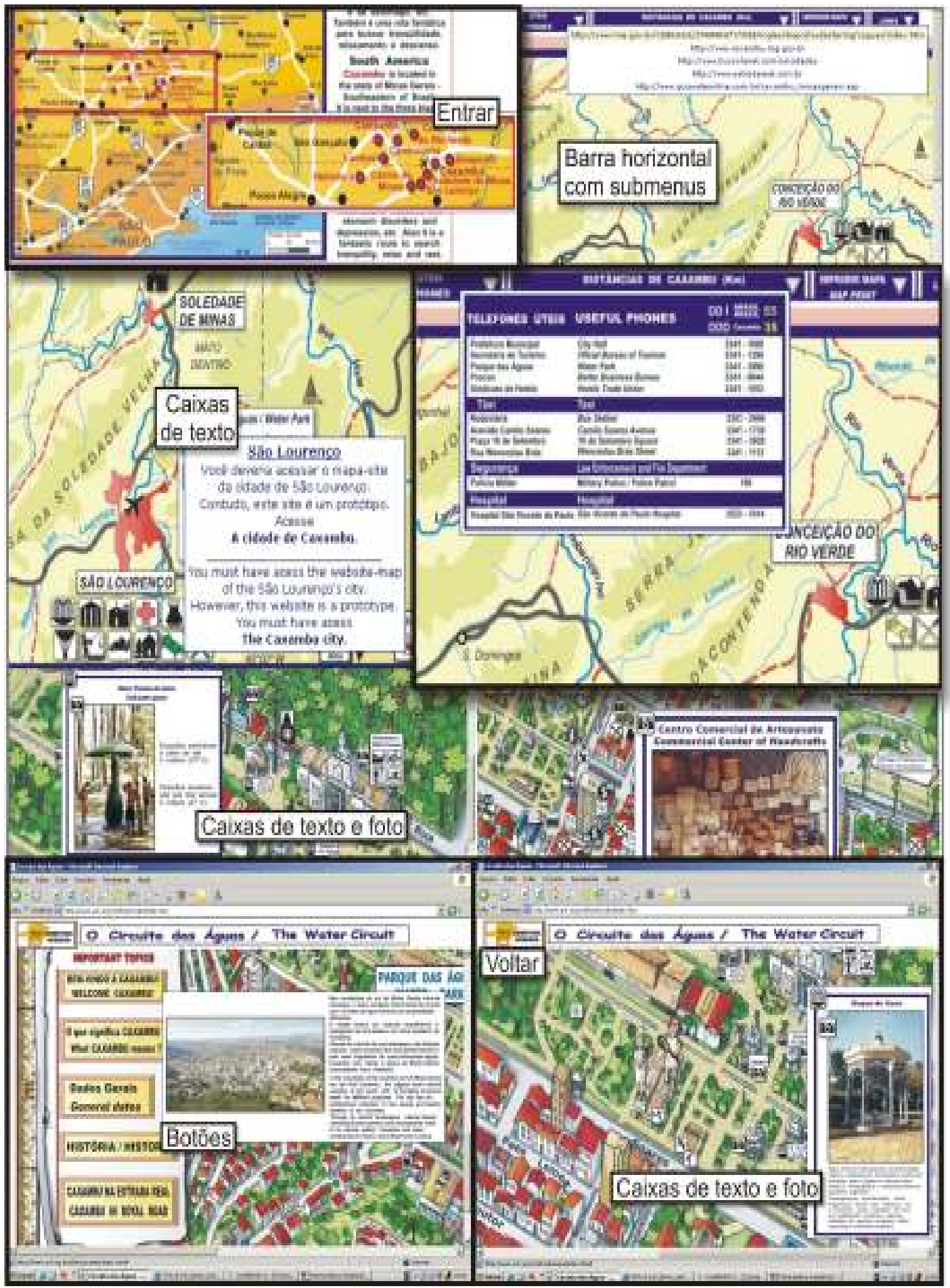




\section{CAPÍTULO 3}

Avaliação e análise dos mapas, dos símbolos de informação pública e do protótipo mapa-site turístico de Caxambu 


\section{1 - Desenvolvimento do estudo empírico}

Vários pesquisadores relacionados à produção cartográfica atestam que, durante a elaboração de um mapa, o qual comunica os inúmeros elementos materiais e imateriais contidos no espaço, é desencadeada uma problemática da informação, inicialmente representada / codificada para posteriormente ser lida / decodificada.

Portanto, a relação entre produtor e o receptor deve estar sempre harmonizada. Para que isto ocorra, deve-se respeitar uma regra básica da linguagem cartográfica: é imprescindível que o código construído pelo produtor seja captado de maneira plena pelo receptor, pois só desta maneira haverá a correta transmissão da informação e, conseqüentemente, a verdadeira comunicação.

A linguagem específica da cartografia é a linguagem gráfica e, com o auxilio de métodos próprios para a representação, se chega ao mapa, que terá a função de fazer o leitor retornar à realidade no seu sentido mais amplo. Assim, quanto melhor for representado o mapa e quanto mais adequado à clientela a que se destina, melhor será a visão do leitor sobre a realidade representada (Simielli, 1996).

Fica evidente, nesse sistema de informação visual, que, além da confecção de um mapa correto, segundo as tradições, normas e padrões cartográficos, deve-se satisfazer as expectativas do usuário potencial em relação ao material proposto.

E é por isso que esta pesquisa, fundamentada em Fiori (2003), apresenta uma dualidade crítica quanto a dois tipos distintos de mapas para o setor do turismo: o convencional e o pictórico, por proporcionarem graus diferentes de abstração e formas distintas de representar a informação. Portanto, três tópicos são averiguados:

1) Eficácia: identificar que tipo de mapa é mais eficaz para comunicar a informação representada.

2) Estética: qual dos mapas tem um maior grau de empatia - emotiva, sedutora - e atração quando expostos aos turistas.

3) Inteligibilidade: ao se propor a adaptação dos símbolos de informação pública em legendas de mapas temáticos para o setor do turismo, verifica-se quais símbolos possuem uma maior facilidade de leitura pelo usuário. Ressalta-se que os SIPs são elaborados para serem compreendidos sem a necessidade do ensino formal.

Os procedimentos e cuidados tomados até o momento em relação a um embasamento teórico, e posterior desenvolvimento prático - a elaboração dos mapas (convencionais e pictóricos) e do site - são discutidos e avaliados neste capítulo. 
A elaboração das questões empíricas leva em consideração o conceito de paisagem, ou seja, os mapas se pautam por uma realidade material, pela extensão de espaço que é vista, recortada, pictórica, oferecida ao olhar. Conseqüentemente, ao se pensar na elaboração dos mapas turísticos, o interesse está na visão do estrangeiro, que é aquele que interpreta superficialmente e esteticamente o que vê, dando significado ao mundo externo. Assim, os mapas são feitos para aquele indivíduo que não mora na cidade representada e que precisa ser atraído, motivado a querer conhecê-la, saber mais sobre a ela, para que, a partir daí, quem sabe, tenha vontade de visitá-la e indicá-la a outras pessoas.

Lowenthal (1985) afirma que cada indivíduo percebe diferencialmente a paisagem. Essa diferenciação se dá devido a fatores culturais, condições sócioeconômicas, crenças, sexo e idade. Além disso, ele aponta mais um item fundamental, pois o nativo do lugar adquire e assimila informações de forma diferente daquela pessoa que está em trânsito - aquele que viaja, o turista.

Gerber, Burgen \& Stanton (1990) identificam oito aspectos que atuam sobre as pessoas quando adquirem informação cartográfica: a habilidade espacial, a percepção espacial, a habilidade de leitura, a idade, a habilidade para desenhar, a experiência prévia quanto ao uso dos mapas, a atitude (pessoas que gostam de observar mapas) e a disponibilidade de mapas em casa ao decorrer da vida, ou seja, o mapa não é visto como um objeto estranho. A apreensão dessas características determinará o maior ou menor grau de abstração dos símbolos pelo usuário.

Somam-se ainda as preocupações sobre os problemas referentes à elaboração do site:

$\checkmark$ A diagramação e a facilidade de navegação.

$\checkmark$ A funcionalidade dos recursos zoom e pan, possibilitando vários ângulos e enfoques de uma mesma localidade.

$\checkmark$ A arte, o conteúdo e a motivação.

$\checkmark$ A objetividade, riqueza e não poluição visual do mapa possibilitada pelo recurso do pop up.

$\checkmark$ O tempo de download.

Enfim, a etapa empírica volta-se à dimensão pragmática, devendo se preocupar com o usuário-turista que, em geral, é o indivíduo caracterizado por ter pouco ou nenhum conhecimento cartográfico.

Em relação ao acesso / navegação do protótipo mapa-site turístico, o usuário necessita de um conhecimento mínimo do ambiente Windows e da Internet. Esse contexto é formado por um grupo de indivíduos com perfis muito heterogêneos, 
devido às diferentes idades, ao grau de escolaridade, à maior ou menor facilidade de abstração, à diversidade sócio-econômico-cultural, entre outros aspectos.

Devido a todos esses fatores, costuma-se estabelecer apenas uma idade mínima para a aplicação dos questionários: as pessoas deveriam ter uma idade acima dos quinze anos. Sem entrar no mérito da discussão, a escolha da idade mínima é apoiada em Cavalcanti (1996). Segundo o estudioso, somente aos onze, doze anos um indivíduo, uma pessoa é capaz de realizar abstrações que vão além dos significados ligados a suas práticas imediatas. Contudo, o autor ressalta ainda que essa competência não se consegue simplesmente pela idade: é preciso levar em conta a experiência do usuário. Isso quer dizer que, se o ambiente no qual o adolescente vive não oferece desafios e tarefas necessárias para estimular seu intelecto, seu raciocínio poderá não alcançar o nível adequado para sua faixa etária.

\section{2 - O material cartográfico em avaliação}

A pesquisa empírica conta com os seguintes produtos desenvolvidos para análise:

a) Um mapa convencional e um mapa turístico de Ilhabela, município do estado de São Paulo.

b) Um mapa convencional e um mapa turístico de Foz do Iguaçu, município do estado do Paraná.

c) Um mapa convencional e um mapa turístico da cidade de Caxambu, município do estado de Minas Gerais.

d) Um mapa convencional e um mapa turístico de Manaus, capital do estado do Amazonas.

e) Um mapa convencional e um mapa turístico de São Raimundo Nonato, município do estado do Piauí.

f) Um protótipo de um mapa-site turístico do município de Caxambu.

g) Uma relação de oitenta e dois símbolos de informação pública adaptados para a legenda de mapas turísticos.

A aplicação dos questionários ocorreu de duas maneiras:

$\checkmark$ O questionário in loco, referente aos oitenta e dois símbolos de informação pública, passou por um pré-teste em outubro de 2005. A aplicação efetiva ocorreu entre os meses de fevereiro de 2006 e setembro de 2007. 
$\checkmark$ Os questionários via Internet - site - dividem-se em três temas:

$\left.1^{\circ}\right)$ Duas maneiras de elaborar o mapa turístico.

$2^{\circ}$ ) Os oitenta e dois símbolos de informação pública.

$\left.3^{\circ}\right)$ Protótipo para um mapa-site turístico.

Os questionários não passaram por pré-testes. A aplicação ocorreu entre os meses de setembro e outubro de 2007.

\subsection{1 - Procedimentos}

\section{$\underline{\text { População }}$}

Destaca-se o público pesquisado em dois grandes grupos:

- Os participantes das qualificações do Projeto Caminhos do Futuro ${ }^{68}$, divididos em professores do ensino fundamental e médio da rede pública e profissionais das secretarias da educação e turismo.

- Qualquer pessoa que tivesse tido acesso ao questionário do site da pesquisa (que se está em dois idiomas: português e inglês) no endereço: www. avt.org.br/sfiori.

A única ressalva quanto à aceitação do questionário preenchido esteve relacionada à idade do sujeito, que deveria ter, no mínimo, 15 anos, isto é, deveria ter nascido em 1992.

\section{Sujeitos}

Os sujeitos que responderam os questionários apresentam características muito heterogêneas. Discrimina-se, na tabela abaixo, somente o local de origem, a idade, o grau de escolaridade e a profissão - ver as tabelas 9 e 10.

68 O projeto Caminhos do Futuro é uma parceria do Ministério do Turismo com o Instituto de Academias Profissionalizantes (IAP), a Academia de Viagens e Turismo (AVT) e o Núcleo de Turismo da Universidade de São Paulo (USP). Essa parceria resultou em qualificações em 16 estados brasileiros, nos principais temas ligados ao turismo (Caminhos do Futuro, 2007). 
Tabela 9 - Discriminação dos sujeitos que responderam o questionário in loco segundo a idade, o grau de escolaridade e a profissão

\begin{tabular}{|c|c|c|c|c|c|c|c|}
\hline \multirow{2}{*}{ ESTADO } & \multicolumn{5}{|c|}{ Idade } & \multirow{2}{*}{$\begin{array}{l}\text { Escola- } \\
\text { ridade }\end{array}$} & \multirow{2}{*}{ Profissão } \\
\hline & $20-30$ & $31-40$ & $41-50$ & $>50$ & $\begin{array}{c}\text { Total } \\
\text { Sujeitos }\end{array}$ & & \\
\hline 1- ALAGOAS & 9 & 16 & 14 & 4 & 43 & \multirow{15}{*}{ Superior } & \multirow{15}{*}{$\begin{array}{c}\text { Professores } \\
\text { de escolas } \\
\text { públicas do } \\
\text { ensino } \\
\text { fundamental } \\
\text { e médio. } \\
\text { Outros } \\
\text { profissionais } \\
\text { ligados às } \\
\text { secretarias } \\
\text { da educação } \\
\text { e do turismo. }\end{array}$} \\
\hline 2- AMAZONAS & 6 & 9 & 18 & 12 & 45 & & \\
\hline 3- BAHIA & 4 & 16 & 14 & 6 & 40 & & \\
\hline 4- CEARÁ & 14 & 21 & 11 & 7 & 53 & & \\
\hline 5- DISTRITO FEDERAL & 5 & 15 & 6 & 8 & 34 & & \\
\hline 6- ESPÍRITO SANTO & 12 & 15 & 12 & 4 & 43 & & \\
\hline 7- GOIÁS & 6 & 22 & 8 & 10 & 46 & & \\
\hline 8- MARANHÃO & 20 & 18 & 8 & 2 & 48 & & \\
\hline 9- PERNAMBUCO & 13 & 10 & 13 & 8 & 44 & & \\
\hline 10- PIAUÍ & 11 & 15 & 16 & 10 & 52 & & \\
\hline 11- RIO GRANDE DO SUL & 8 & 8 & 15 & 9 & 40 & & \\
\hline 12- SANTA CATARINA & 12 & 9 & 13 & 6 & 40 & & \\
\hline 13- SERGIPE & 4 & 11 & 14 & 5 & 34 & & \\
\hline 14- TOCANTINS & 9 & 19 & 15 & 4 & 47 & & \\
\hline TOTAL GERAL & 133 & 204 & 177 & 95 & 609 & & \\
\hline
\end{tabular}

Municípios que participaram da pesquisa (in loco)

1- Maragogi (AL), Manaus (AM), Mata de São João (BA), Jijoca (CE), Brasília (DF), São Mateus (ES), Caldas Novas (GO), Barreinhas (MA), Cabo de Santo Agostinho $(\mathrm{PE})$, São Raimundo Nonato (PI), Pelotas (RS), Balneário de Camboriú (SC), Aracaju (SE) e Palmas (TO). 
Tabela 10 - Discriminação dos sujeitos que responderam o questionário pelo site segundo a idade, o grau de escolaridade e a profissão

\begin{tabular}{|c|c|c|c|c|c|c|c|c|c|c|c|}
\hline \multirow{2}{*}{\multicolumn{2}{|c|}{ PAÍS }} & \multicolumn{6}{|c|}{ Idade } & \multicolumn{3}{|c|}{ Escolaridade } & \multirow{2}{*}{$\begin{array}{l}\text { Profissão } \\
\text { Ver área de } \\
\text { atuação }\end{array}$} \\
\hline & & $<20$ & $\begin{array}{l}21 \\
30\end{array}$ & $\begin{array}{l}31 \\
40\end{array}$ & $\begin{array}{l}41 \\
50\end{array}$ & $>50$ & $\begin{array}{c}\text { Total } \\
\text { Sujeitos }\end{array}$ & Médio & Superior & $\begin{array}{c}\text { Pós- } \\
\text { graduado }\end{array}$ & \\
\hline \multicolumn{2}{|c|}{$\begin{array}{l}\text { BRASIL } \\
\text { (Total) }\end{array}$} & 7 & 20 & 15 & 9 & 5 & 56 & 5 & 32 & 19 & \multirow{8}{*}{1} \\
\hline \multicolumn{2}{|c|}{$\begin{array}{l}\text { Distrito } \\
\text { Federal }\end{array}$} & - & 2 & - & - & - & 2 & - & 2 & - & \\
\hline \multicolumn{2}{|c|}{ Mato Grosso } & - & 2 & - & - & - & 2 & - & 1 & 1 & \\
\hline \multicolumn{2}{|c|}{ Minas Gerais } & - & 1 & - & 3 & 1 & 5 & - & 3 & 2 & \\
\hline \multicolumn{2}{|c|}{ Pará } & - & 3 & - & 1 & - & 4 & - & 2 & 2 & \\
\hline \multicolumn{2}{|c|}{ Paraná } & - & 2 & 1 & - & 1 & 4 & - & 2 & 2 & \\
\hline \multicolumn{2}{|c|}{$\begin{array}{l}\text { Rio de } \\
\text { Janeiro }\end{array}$} & - & 1 & - & - & 1 & 2 & - & 1 & 1 & \\
\hline \multicolumn{2}{|c|}{ São Paulo } & 7 & 9 & 14 & 5 & 2 & 37 & 5 & 21 & 11 & \\
\hline \multicolumn{2}{|c|}{$\begin{array}{l}\text { ESTRANGEIROS } \\
\text { (Total) }\end{array}$} & - & 8 & 7 & 3 & 5 & 23 & - & 6 & 17 & 2 a 10 \\
\hline \multicolumn{2}{|c|}{ Alemanha } & - & 3 & 1 & - & - & 4 & - & 2 & 2 & 2 \\
\hline \multicolumn{2}{|c|}{ Áustria } & - & 2 & 1 & - & 1 & 4 & - & 1 & 3 & 3 \\
\hline \multicolumn{2}{|c|}{ Canadá } & - & - & 2 & - & - & 2 & - & 1 & 1 & 4 \\
\hline \multicolumn{2}{|c|}{ China } & - & - & - & 1 & - & 1 & - & 1 & - & 5 \\
\hline \multicolumn{2}{|c|}{ Espanha } & - & 1 & - & - & 1 & 2 & - & - & 2 & 6 \\
\hline \multicolumn{2}{|c|}{ E.U.A. } & - & 1 & 3 & - & 1 & 5 & - & 1 & 4 & 7 \\
\hline \multicolumn{2}{|c|}{ Holanda } & - & - & - & 1 & 2 & 3 & - & - & 3 & 8 \\
\hline \multicolumn{2}{|c|}{ México } & - & - & - & 1 & - & 1 & - & - & 1 & 9 \\
\hline \multicolumn{2}{|c|}{ Suíça } & - & 1 & - & - & - & 1 & - & - & 1 & 10 \\
\hline \multicolumn{2}{|c|}{ TOTAL GERAL } & 7 & 28 & 22 & 12 & 10 & 79 & 5 & 38 & 36 & 1 a 10 \\
\hline \multicolumn{12}{|c|}{ Área de atuação profissional daqueles que responderam os questionários } \\
\hline \multicolumn{12}{|c|}{$\begin{array}{l}\text { Estudante, química, artesanato, vendas, turismo, informática, marketing, setor } \\
\text { administrativo, geografia, pesquisa, magistério, psicologia, compras, consultoria, } \\
\text { odontologia, arquitetura, gestão ambiental, comércio, autônomo, designer gráfico. }\end{array}$} \\
\hline 2 & \multicolumn{11}{|c|}{ Cartografia, geo informática e mídia. } \\
\hline 3 & Cartograf & a, ge & info & rmát & ca e & nídia. & & & & & \\
\hline 4 & Cartograf & & & & & & & & & & \\
\hline 5 & Cartograf & & & & & & & & & & \\
\hline 6 & Geografia & e ca & togr & & & & & & & & \\
\hline 7 & Geografia & , cart & ograt & a, ps & colog & ia e c & onsultor & & & & \\
\hline 8 & Consulto & ia, ca & ttogr & fia e & magi & stério & & & & & \\
\hline 9 & Magistéri & & & & & & & & & & \\
\hline 10 & Engenha & & & & & & & & & & \\
\hline
\end{tabular}


$\underline{\text { Instrumento de medida }}$

Nessa etapa da pesquisa, são reapresentadas e resumidas cinco questões importantes quanto à confecção dos mapas, tendo sempre como cuidado principal a adequação do usuário aos produtos finais desenvolvidos - mapas e mapa-site turístico de Caxambu:

1a.) A leitura do artigo de Kokkoken e Peltonen (1999) desafia a elaborar mapas, tendo o turista como usuário potencial. Castner (1987), ao trabalhar na elaboração de um Atlas para crianças (e pode-se pensar no leigo em cartografia), afirma que se deve diminuir a atenção dada aos elementos convencionais e estruturais dos mapas, enfatizando descobertas, descrições, classificações e símbolos de informações, pois o entretenimento passivo está por toda parte.

À preocupação de confeccionar um tipo de produto cartográfico funcional, que possibilite ao turista planejar e preparar suas atividades em seu tempo de descanso, soma-se a preocupação de um maior apelo estético. E é graças à pictografia que se dispõe do lúdico, tentando seduzir o turista tanto em relação ao destino turístico quanto ao produto-mapa.

O grau de abstração dos símbolos pictóricos apresenta um maior apelo estético e parece ser mais apreciado e lido por crianças e usuários que tenham pouco contato com materiais cartográficos (Muehrcke, 1986).

Para oferecer um contraponto e uma complementação ao material pictográfico, foram confeccionados mapas que fazem uso dos símbolos convencionais (abstratos, geométricos), devido à forma de representação mais objetiva e neutra.

É imprescindível frisar que, na proposta desenvolvida pela Semiologia Gráfica, as imagens necessitam somente de um momento de percepção; portanto, são imagens para "ver" - fisiológicas, entendidas à primeira vista - e não para "ler" condicionadas pela cultura, contexto, hábito, expectativas, etc. Contudo, o produto desenvolvido nesta pesquisa teve o propósito de enquadrar-se melhor na segunda opção, por objetivar propositalmente um produto de leitura mais lenta, levando o turista a viajar pelo mapa. Acredita-se que o intuito dos mapas turísticos não é obter uma resposta rápida, mas sim, permitir que o usuário compreenda e viaje pela informação.

2a.) Ao abordar mais especificamente o produto-mapa, deve-se estar constantemente preocupado com a percepção do usuário diante dos vários elementos gráficos representados no mapa. Robinson, Morrison, Muehrcke, Kimerling e Guptill (1995), e Fiori (2003) ressaltam quesitos como:

$\checkmark$ Legibilidade: uso de símbolos claros, familiares.

$\checkmark$ Contraste visual entre os símbolos e o fundo do mapa. 
$\checkmark$ Organização entre a figura e a base: saber distinguir entre a terra e a água, reconhecer contornos de cidades, ilhas, portos, etc.

$\checkmark$ Organização hierárquica: saber separar as características significativas, para poder descrever suas semelhanças, diferenças e inter-relações. Por exemplo, reconhecer diferentes espessuras de linhas, contrastes e tons das cores, hachuras, etc.

Esses itens são fundamentais na busca de um material cartográfico bem sucedido. Tem-se que é imprescindível facilitar e tornar atraente o processo visual de decodificação pelo usuário leigo em cartografia, possibilitando, assim, uma maior apreensão da informação e um menor esforço mental.

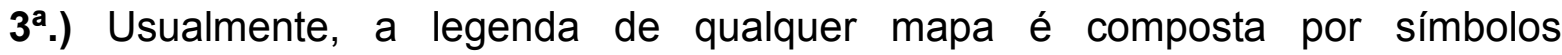
geométricos e intermediários, que representam elementos espaciais como cidades, rodovias pavimentadas ou sem pavimentação, hidrografia, limites municipal, estadual, federal, entre outros aspectos. Entretanto, durante a elaboração dos mapas para o setor do turismo, faz-se necessária a representação de outros tipos de elementos espaciais como: acomodação, alimentação, hospedagem, serviços, atrativos naturais e culturais, entretenimento, práticas desportivas, recreação e transporte. Aliás, na maior parte das vezes, os mapas analógicos e digitais para o setor representam todos esses itens por meio de símbolos pictográficos.

Propõe-se, então, um tipo de legenda para mapas turísticos que se baseie nos símbolos de informação pública. Para isso, é necessário adaptar, melhorar graficamente e avaliar, por pesquisas empíricas, os vários pictogramas já existentes. É preciso que se mantenha o esforço de formular um inventário, de ordenar, padronizar e divulgar, em escala internacional, um sistema de sinalização para o setor. Desse modo, pode-se vislumbrar a composição de um sistema único, normatizado, pelo menos no que se refere a ações, situações e locais de senso comum. Carneiro (2001:193) complementa que, ser oficial, não é uma qualidade imposta pelos órgãos ou entidades, mas sim a condição legítima de uso e inteligibilidade.

4a.) $O$ texto deve ser direto e objetivo, trazendo informações úteis - serviços, curiosidades, história, referências - aos turistas. A escala precisa ser adequada aos elementos que serão dispostos sobre o mapa-base. A orientação (pontos cardeais, latitude e longitude) é necessária, pois é um item que traz referências ao turista.

5.) O processo do desenvolvimento de mapas para o setor do turismo deve considerar o modo de adaptá-los ao meio digital interativo. A atenção se volta a itens como:

$\checkmark$ A facilidade de navegação e transição entre as páginas. 
$\checkmark$ O conteúdo e a apresentação visual (estética).

$\checkmark$ O equilíbrio entre ritmo e andamento, ou seja, a preocupação em gerar uma interatividade confortável (tempo de download) de recursos como o zoom, pan, pop up, etc.

Os itens acima constatam se as mensagens desenvolvidas pelo produtor ao longo do mapa-site foram transmitidas de maneira satisfatória. Verifica-se também a motivação, expectativas e a satisfação dos usuários, auxiliando na mensuração de que mais os atraiu e do que gostaram no produto.

Inicia-se o trabalho empírico, a partir da seguinte afirmação: fazendo uso da mesma base cartográfica e de outras informações comuns, elaboram-se duas formas de representação para um mapa turístico, possibilitando uma comparação entre os mapas convencionais e pictóricos, e uma posterior locação em meio digital e interativo, possibilitando uma situação de comparação, que:

$\checkmark$ Verifica as preferências do sujeito ao apresentar dois tipos de representação - convencional e pictórica - para um mesmo tema: o mapa turístico.

$\checkmark$ Verifica as preferências do sujeito quanto à utilização de símbolos convencionais e pictóricos.

$\checkmark$ Questiona a inserção de caixas de textos distribuídas sob o mapa.

$\checkmark$ Questiona a aceitação dos materiais cartográficos desenvolvidos.

$\checkmark$ Quantifica o grau de reconhecimento dos símbolos de informação pública.

$\checkmark$ Verifica a interatividade e a aceitação do mapa-site turístico de Caxambu por meio de itens como acesso, navegação, arte, conteúdo, motivação e o tempo de download.

Formularam-se questões com alternativas e outras dissertativas, com perguntas curtas, objetivas e de rápida compreensão, sempre levando em conta a heterogeneidade do usuário. É importante ressaltar a não-obrigatoriedade em se responder as questões dissertativas. 
Questionário 1 - in loco em quatorze municípios brasileiros

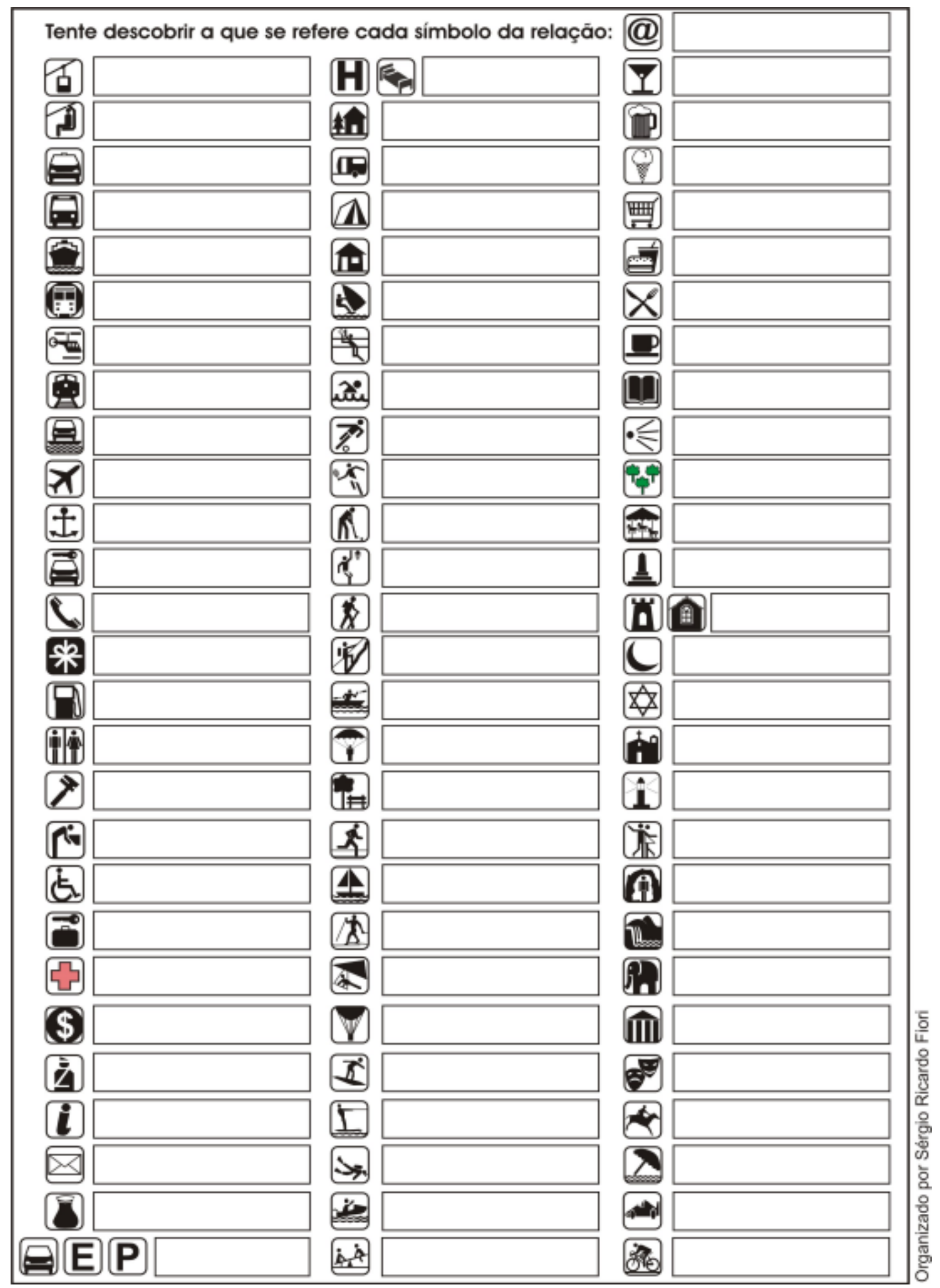


Questionário 2 - site (versão em português)

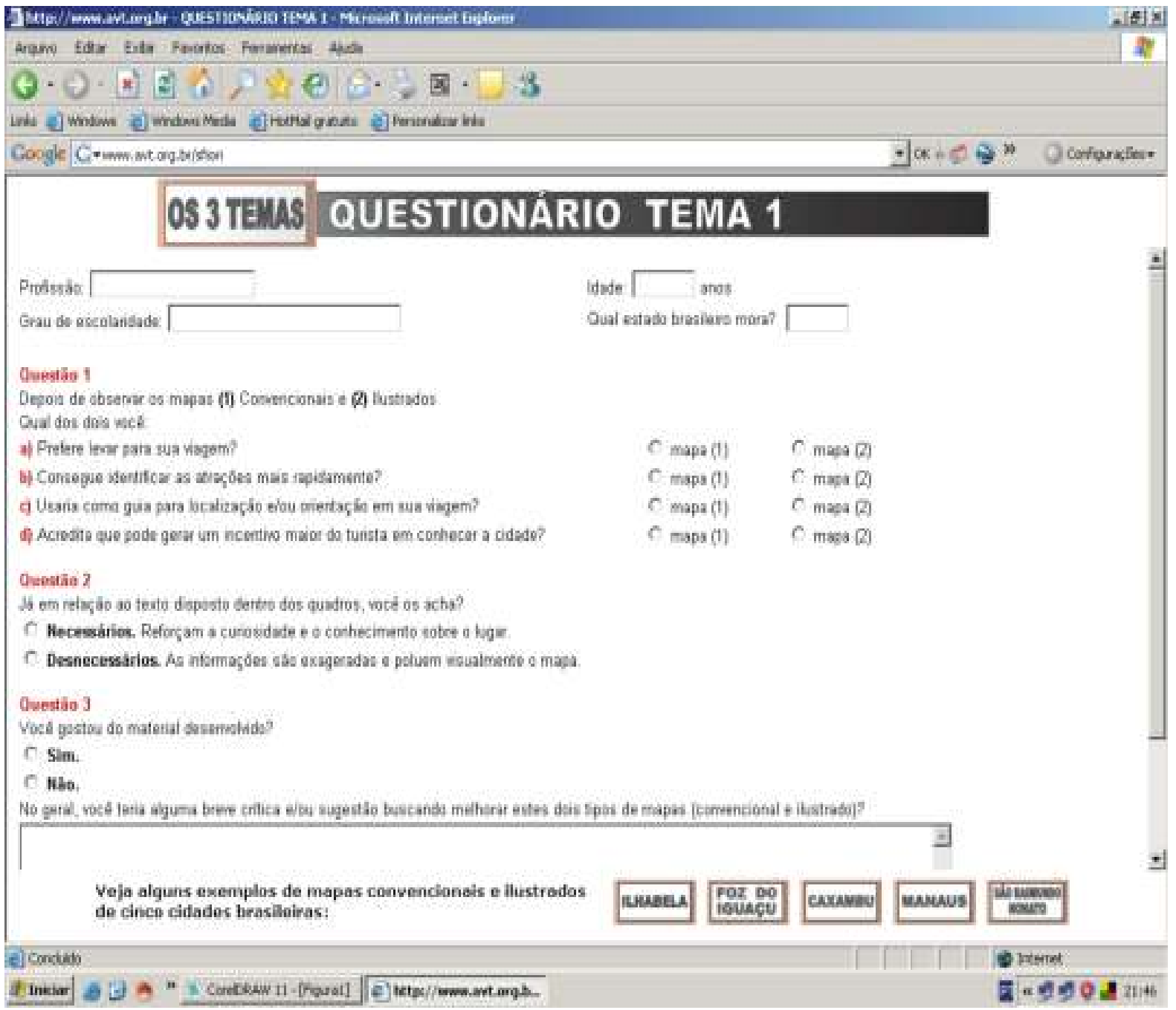

Elaborado por Sérgio Ricardo Fiori 
Questionário 3 - site (versão em português)

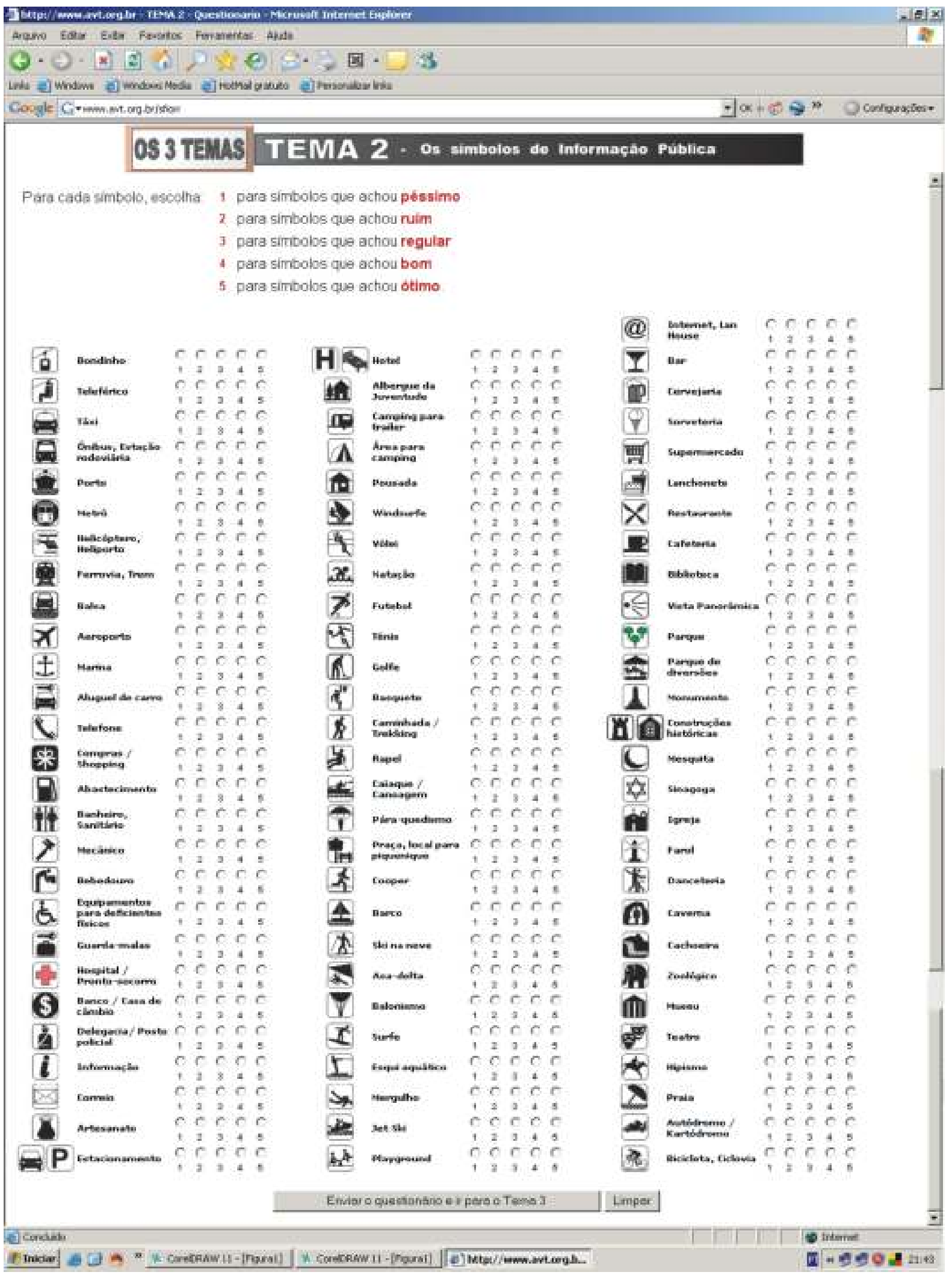


Questionário 4 - site (versão em inglês)

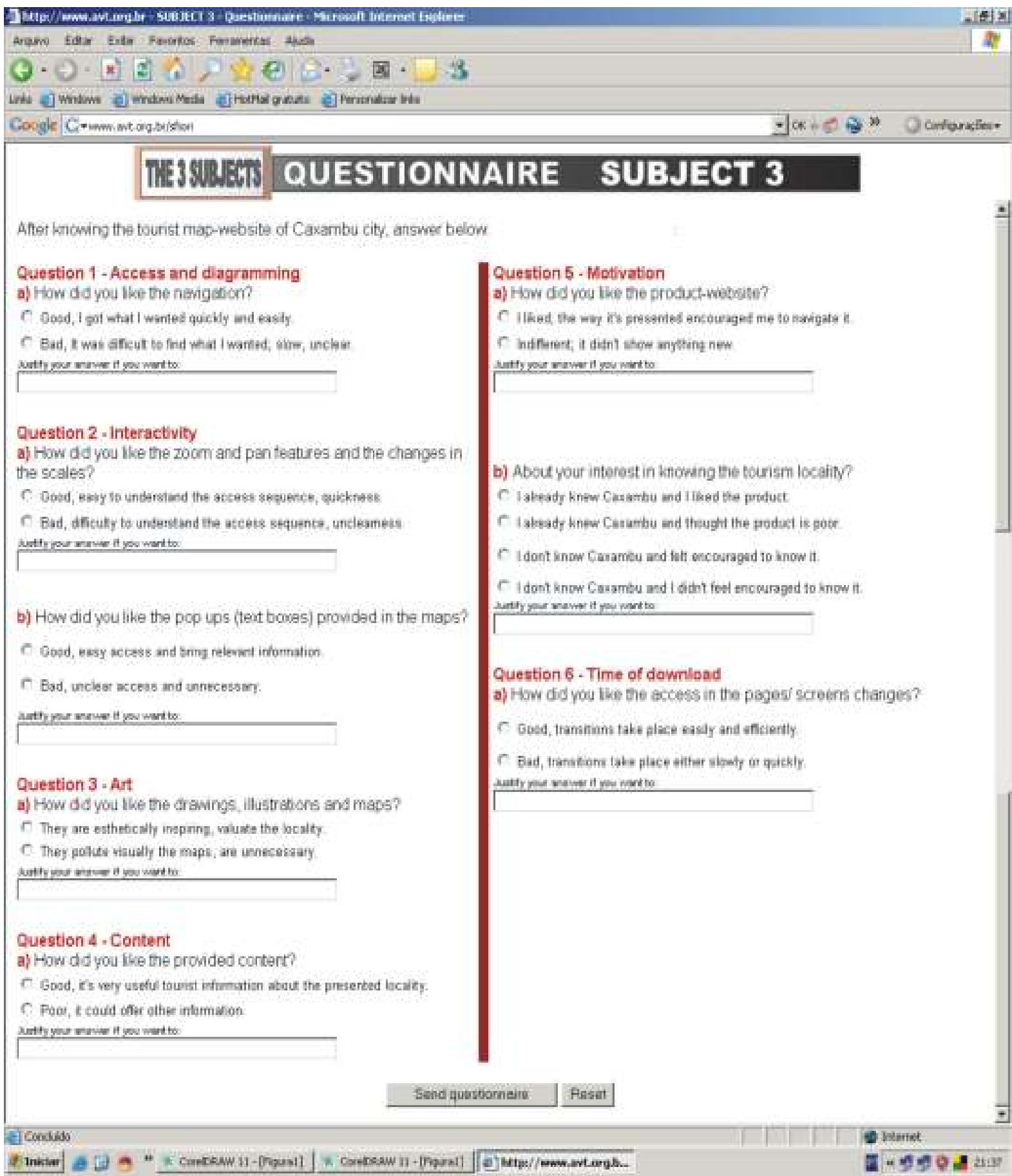


A aplicação dos questionários ocorreu de duas maneiras diferentes:

$\checkmark$ In loco - Entre as atividades de um curso de qualificação de professores, aplicou-se um questionário em que se utilizaram oitenta e seis símbolos de informação publica. O sujeito deveria olhar o símbolo (um por um) e, logo em seguida, escrever em um espaço em branco, na frente do próprio símbolo, o que aquilo significava, ou seja, qual a primeira palavra que vinha a sua mente ao se deparar com aquele símbolo.

$\checkmark$ Internet - Os outros três questionários (três temas distintos) eram respondidos quando o sujeito acessava o site da pesquisa no endereço: www. avt.org.br/sfiori. No tema 1, ele contava com dois mapas de cada destinação: um pictórico e um convencional, num total de dez mapas, indo logo em seguida ao questionário para responder três questões. No tema 2, o sujeito via a relação dos oitenta e seis símbolos de informação publica, mas, desta vez, contava com uma grade numérica para cada símbolo que ia de um a cinco, relacionados, em uma escala, aos conceitos, de péssimo a ótimo. O sujeito, então, avaliava cada um dos símbolos. E, no tema três, depois de navegar pela mapa-site turístico de Caxambu, dirigia-se ao questionário para responder seis questões.

\section{Atribuição de pontos}

$\checkmark$ O questionário que dispõe dos oitenta e seis símbolos de informação publica, respondido de forma dissertativa, resultou de uma avaliação em quatro níveis: símbolos que foram interpretados plenamente (sentido de coletivo); símbolos que foram interpretados fora do contexto (interpretação ao "pé da letra"); não foi respondido, e não se conseguiu interpretar o símbolo. Neste último caso, citam-se os casos mais relevantes para discussão.

$\checkmark$ Nos questionários do site: o Tema 1 e o Tema 3 se apresentaram em respostas optativas, ou seja, não corresponderam a respostas certas ou erradas, mas sim à escolha entre a primeira ou segunda preferência. Já as respostas dissertativas foram opcionais.

$\checkmark$ No questionário do site, o Tema 2 também utilizou os oitenta e seis Símbolos de Informação Publica respondidos, mas a aplicação do questionário ocorreu de forma alternativa. Na frente de cada símbolo, há uma grade numérica com números inteiros que vai de 1 (péssimo) a 5 (ótimo). Cada número inteiro equivale a um ponto. 


\subsection{2 - Coleta e processamento das informações}

Ao final dos 782 questionários aplicados, obtiveram-se os seguintes resultados:

$\checkmark 79$ sujeitos responderam sobre o tema Mapas convencionais e pictóricos.

$\checkmark 675$ sujeitos responderam sobre o tema Símbolos de Informação Pública; nesse caso, foram registradas 596 respostas dissertativas e 79 respostas alternativas.

$\checkmark 28$ sujeitos responderam sobre o tema Protótipo de um mapa-site turístico.

É fundamental registrar que, no caso das perguntas específicas ao site, o sujeito nem sempre respondeu os três temas propostos; na verdade, não era obrigado. A única condição para desconsiderar o questionário respondido ocorreu quando o sujeito não respondia as perguntas referentes à vida pessoal: profissão, idade, anos, grau de escolaridade e em qual estado brasileiro ou em qual país mora. As tabelas $11 \mathrm{~A}, 11 \mathrm{~B}$ e $11 \mathrm{C}$ mostram a diferenciação entre temas e divide os sujeitos em brasileiros e estrangeiros - sujeitos que moram em outros países.

As tabelas 12, 13, 14 e 15 apresentam os dados brutos, ou seja, respostas dadas por cada sujeito referentes aos questionários 1 (in loco) e 2, 3 e 4 (os três temas encontrados no site).

Tabela 11 - Questionários respondidos e aceitos para a tabulação

\section{A) BRASIL}

\begin{tabular}{|c|c|c|c|}
\hline $\begin{array}{r}\text { TEMA } \\
\text { RESPOSTA }\end{array}$ & 1 & 2 & 3 \\
\hline Aceita & 56 & 56 & 28 \\
\hline Rejeitada & 3 & 8 & 0 \\
\hline TOTAL & 59 & 64 & 28 \\
\hline
\end{tabular}

B) ESTRANGEIROS

\begin{tabular}{|c|c|c|c|}
\hline $\begin{array}{l}\text { TEMA } \\
\text { RESPOSTA }\end{array}$ & 1 & 2 & 3 \\
\hline Aceita & 23 & 23 & 13 \\
\hline Rejeitada & 1 & 5 & 0 \\
\hline TOTAL & 24 & 28 & 13 \\
\hline
\end{tabular}

\begin{tabular}{|r|c|c|c|}
\hline C) BRASIL + ESTRANGEIROS \\
\hline TEMA & $\mathbf{1}$ & $\mathbf{2}$ & $\mathbf{3}$ \\
\hline RESPOSTA & 56 & 56 & 28 \\
\hline Aceita & 56 & 8 & 0 \\
\hline Rejeitada & 3 & $\mathbf{6 4}$ & $\mathbf{2 8}$ \\
\hline TOTAL & $\mathbf{5 9}$ & & \\
\hline
\end{tabular}


Tabela 12 - Repostas ao se olhar os símbolos de informação pública (respostas dissertativas)

\begin{tabular}{|c|c|c|c|c|}
\hline $\begin{array}{ll} & \text { Resposta } \\
\text { Símbolo }\end{array}$ & $\begin{array}{l}\text { Acertaram o } \\
\text { Contexto }\end{array}$ & $\begin{array}{l}\text { Acertaram o } \\
\text { Símbolo }\end{array}$ & $\begin{array}{l}\text { Não } \\
\text { responderam }\end{array}$ & $\begin{array}{l}\text { Erraram os } \\
\text { dois }\end{array}$ \\
\hline 1) Bondinho & 254 & 0 & 37 & 305 \\
\hline 2) Teleférico & 456 & 0 & 93 & 47 \\
\hline 3) Táxi & 478 & 0 & 24 & 94 \\
\hline 4) Rodoviária & 58 & 355 & 30 & 153 \\
\hline 5) Porto & 281 & 225 & 27 & 66 \\
\hline 6) Metrô & 426 & 0 & 40 & 130 \\
\hline 7) Heliponto & 22 & 212 & 39 & 323 \\
\hline 8) Estação ferroviária & 67 & 271 & 25 & 233 \\
\hline 9) Balsa & 371 & 0 & 91 & 134 \\
\hline 10) Aeroporto & 513 & 66 & 5 & 12 \\
\hline 11) Marina / Atracadouro & 80 & 60 & 50 & 406 \\
\hline 12) Locação / Aluguel de carro & 256 & 0 & 86 & 254 \\
\hline 13) Telefone público & 87 & 387 & 1 & 121 \\
\hline 14) Shopping / Compras & 204 & 91 & 97 & 204 \\
\hline 15) Posto de gasolina / Abastecimento & 417 & 4 & 14 & 161 \\
\hline 16) Banheiro público / WC & 62 & 402 & 42 & 90 \\
\hline 17) Oficina mecânica / Mecânico & 303 & 18 & 109 & 166 \\
\hline 18) Bebedouro & 227 & 0 & 153 & 216 \\
\hline 19) Acesso para deficiente físico & 102 & 33 & 22 & 439 \\
\hline 20) Guarda malas / Volumes & 316 & 0 & 118 & 162 \\
\hline 21) Hospital / Pronto Socorro & 546 & 2 & 6 & 42 \\
\hline 22) Banco & 461 & 48 & 26 & 61 \\
\hline 23) Delegacia & 21 & 174 & 60 & 341 \\
\hline 24) Informação / Informação Turística & 252 & 0 & 161 & 183 \\
\hline 25) Correio & 559 & 11 & 3 & 23 \\
\hline 26) Artesanato & 260 & 3 & 201 & 132 \\
\hline 27) Estacionamento & 387 & 0 & 161 & 48 \\
\hline 28) Hotel & 492 & 4 & 8 & 92 \\
\hline 29) Albergue da juventude & 63 & 0 & 175 & 358 \\
\hline 30) Trailer & 361 & 0 & 138 & 97 \\
\hline 31) Camping & 322 & 38 & 29 & 207 \\
\hline 32) Pousada & 91 & 40 & 198 & 267 \\
\hline 33) Wind surf & 272 & 2 & 81 & 241 \\
\hline 34) Vôlei & 450 & 7 & 38 & 101 \\
\hline 35) Natação & 501 & 0 & 38 & 57 \\
\hline 36) Futebol & 521 & 0 & 18 & 57 \\
\hline 37) Tênis & 497 & 0 & 29 & 70 \\
\hline 38) Golfe & 500 & 0 & 24 & 72 \\
\hline 39) Basquete & 475 & 0 & 44 & 77 \\
\hline 40) Trekking / Caminhada & 127 & 0 & 140 & 329 \\
\hline 41) Rapel / Alpinismo & 407 & 5 & 61 & 123 \\
\hline 42) Caiaque / Canoagem & 272 & 0 & 94 & 230 \\
\hline
\end{tabular}


Tabela 12 - Repostas ao se olhar os símbolos de informação pública (continuação)

\begin{tabular}{|c|c|c|c|c|}
\hline Resposta & $\begin{array}{c}\text { Acertaram o } \\
\text { Contexto }\end{array}$ & $\begin{array}{l}\text { Acertaram o } \\
\text { Símbolo }\end{array}$ & $\begin{array}{c}\text { Não } \\
\text { responderam }\end{array}$ & $\begin{array}{l}\text { Erraram os } \\
\quad \text { dois }\end{array}$ \\
\hline 43) Pára-quedismo & 326 & 130 & 54 & 86 \\
\hline 44) Praça / Área p/ piquenique & 460 & 0 & 45 & 91 \\
\hline 45) Cooper / Corrida & 334 & 0 & 54 & 208 \\
\hline 46) Barco / Barco a vela & 151 & 0 & 126 & 319 \\
\hline 47) Esqui na neve & 405 & 1 & 106 & 84 \\
\hline 48) Asa delta & 462 & 0 & 47 & 87 \\
\hline 49) Balonismo & 299 & 184 & 53 & 60 \\
\hline 50) Surfe & 411 & 4 & 75 & 106 \\
\hline 51) Esqui aquático & 416 & 0 & 115 & 65 \\
\hline 52) Mergulho & 378 & 72 & 98 & 48 \\
\hline 53) Jet Ski & 443 & 0 & 83 & 70 \\
\hline 54) Playground & 141 & 93 & 50 & 312 \\
\hline 55) Bar & 272 & 10 & 105 & 209 \\
\hline 56) Cervejaria & 62 & 58 & 20 & 456 \\
\hline 57) Sorveteria & 542 & 49 & 2 & 3 \\
\hline 58) Supermercado & 554 & 4 & 7 & 31 \\
\hline 59) Lanchonete & 477 & 41 & 19 & 59 \\
\hline 60) Restaurante & 572 & 0 & 4 & 20 \\
\hline 61) Cafeteria & 201 & 299 & 45 & 51 \\
\hline 62) Biblioteca & 301 & 240 & 28 & 27 \\
\hline 63) Vista panorâmica & 48 & 0 & 261 & 287 \\
\hline 64) Parque & 48 & 24 & 45 & 479 \\
\hline 65) Parque de diversão & 363 & 60 & 30 & 143 \\
\hline 66) Monumento & 204 & 1 & 165 & 226 \\
\hline 67) Construção histórica & 42 & 96 & 208 & 250 \\
\hline 68) Mesquita & 142 & 67 & 187 & 200 \\
\hline 69) Sinagoga & 208 & 38 & 172 & 178 \\
\hline 70) Igreja & 557 & 0 & 13 & 26 \\
\hline 71) Farol & 482 & 0 & 80 & 34 \\
\hline 72) Danceteria / Salão de dança & 333 & 2 & 28 & 233 \\
\hline 73) Caverna & 225 & 0 & 164 & 207 \\
\hline 74) Cachoeira & 495 & 2 & 38 & 61 \\
\hline 75) Zoológico & 383 & 58 & 63 & 92 \\
\hline 76) Museu & 116 & 0 & 91 & 389 \\
\hline 77) Teatro & 404 & 11 & 31 & 150 \\
\hline 78) Hipismo & 346 & 5 & 30 & 215 \\
\hline 79) Praia & 555 & 5 & 17 & 19 \\
\hline 80) Autódromo / Cartódromo & 296 & 48 & 77 & 175 \\
\hline 81) Ciclismo / Ciclovia & 417 & 32 & 11 & 136 \\
\hline 82) Internet * & 71 & 57 & 6 & 33 \\
\hline
\end{tabular}

* O símbolo Internet só foi utilizado em quatro dos quatorze municípios que se aplicou o questionário 
Tabela 13 - Respostas referentes a dualidade: convencional ou pictórico

\begin{tabular}{|c|c|c|c|c|}
\hline A) BRASIL & \multicolumn{3}{|c|}{} \\
\hline $\begin{array}{c}\text { QUESTÃO } \\
\text { TIPO DE } \\
\text { MAPA }\end{array}$ & a & B & c & d \\
\hline $\begin{array}{c}\text { Convencional } \\
\text { (1) }\end{array}$ & 15 & 6 & 23 & 4 \\
\hline $\begin{array}{c}\text { Pictórico } \\
\text { (2) }\end{array}$ & 41 & 50 & 33 & 52 \\
\hline $\begin{array}{c}\text { Total Geral } \\
(1+2)\end{array}$ & & & 56 & \\
\hline
\end{tabular}

B) ESTRANGEIROS

\begin{tabular}{|c|c|c|c|c|}
\hline QUESTÃO & \multicolumn{4}{|c|}{1} \\
\hline $\begin{array}{c}\text { TIPO DE } \\
\text { MAPA }\end{array}$ & A & B & C & d \\
\hline $\begin{array}{c}\text { Convencional } \\
\text { (1) }\end{array}$ & 6 & 12 & 13 & 5 \\
\hline $\begin{array}{c}\text { Pictórico } \\
(\mathbf{2})\end{array}$ & 17 & 11 & 10 & 18 \\
\hline $\begin{array}{c}\text { Total Geral } \\
(1+2)\end{array}$ & \multicolumn{4}{|c|}{23} \\
\hline
\end{tabular}

\section{C) BRASIL + ESTRANGEIROS}

\begin{tabular}{|c|c|c|c|c|}
\hline QUESTÃO & \multicolumn{4}{|c|}{1} \\
\hline $\begin{array}{c}\text { TIPO DE } \\
\text { MAPA }\end{array}$ & a & B & c & d \\
\hline $\begin{array}{c}\text { Convencional } \\
\text { (1) }\end{array}$ & 21 & 18 & 36 & 9 \\
\hline $\begin{array}{c}\text { Pictórico } \\
(\mathbf{2})\end{array}$ & 58 & 61 & 43 & 70 \\
\hline $\begin{array}{c}\text { Total Geral } \\
(1+2)\end{array}$ & & \multicolumn{2}{|c|}{79} & \\
\hline
\end{tabular}

\section{QUESTÃO 2}

\begin{tabular}{l|l|l}
$\mathbf{N}$ & Dn & $\mathrm{N}=$ Necessário \\
$\mathbf{6 6}$ & $\mathbf{1 3}$ & $\mathrm{Dn}=$ Desnecessário
\end{tabular}

\section{QUESTÃO 3}

\begin{tabular}{c|c|l|}
$\mathbf{N}$ & Dn & $\mathrm{N}=$ Necessário \\
\cline { 1 - 2 } & $\mathbf{1}$ & $\mathrm{Dn}=$ Desnecessário \\
\hline
\end{tabular}

Tabela XX.2 - Disponibilidade de textos (total geral = Brasil + estrangeiros) 72 questionários aplicados

Tabela XX.2 - Aceitação do material (total geral = Brasil + estrangeiros) 72 questionários aplicados 
Tabela 14 - Repostas dadas aos símbolos de informação pública e a escala numérica (respostas alternativas)

\begin{tabular}{|c|c|c|}
\hline Símbolo $\quad$ Resposta & $\begin{array}{l}\text { BRASIL - média } \\
\text { Total bruto - } 56 \text { sujeitos }\end{array}$ & $\begin{array}{l}\text { ESTRANGEIROS - média } \\
\text { Total bruto - } 23 \text { sujeitos }\end{array}$ \\
\hline 1) Bondinho & 4,2 & 4,2 \\
\hline 2) Teleférico & 4,2 & 4,3 \\
\hline 3) Táxi & 4,3 & 4,2 \\
\hline 4) Rodoviária & 4,3 & 4,2 \\
\hline 5) Porto & 4,2 & 4,3 \\
\hline 6) Metrô & 3,8 & 3,3 \\
\hline 7) Heliponto & 4,4 & 4,4 \\
\hline 8) Estação ferroviária & 4,2 & 3,6 \\
\hline 9) Balsa & 3,2 & 3,0 \\
\hline 10) Aeroporto & 4,7 & 4,9 \\
\hline 11) Marina / Atracadouro & 3,9 & 3,4 \\
\hline 12) Locação / Aluguel de carro & 3,2 & 3,5 \\
\hline 13) Telefone público & 4,6 & 4,6 \\
\hline 14) Shopping / Compras & 3,2 & 3,0 \\
\hline 15) Posto de gasolina / Abastecimento & 4,4 & 4,4 \\
\hline 16) Banheiro público / WC & 4,5 & 4,6 \\
\hline 17) Oficina mecânica / Mecânico & 3,5 & 3,4 \\
\hline 18) Bebedouro & 3,7 & 3,3 \\
\hline 19) Acesso para deficiente físico & 4,5 & 4,8 \\
\hline 20) Guarda malas / Volumes & 3,9 & 4,0 \\
\hline 21) Hospital / Pronto Socorro & 4,8 & 4,8 \\
\hline 22) Banco & 4,5 & 4,2 \\
\hline 23) Delegacia & 3,7 & 3,5 \\
\hline 24) Informação / Informação Turística & 4,2 & 4,4 \\
\hline 25) Correio & 4,4 & 4,5 \\
\hline 26) Artesanato & 3,1 & 2,8 \\
\hline 27) Estacionamento & 4,3 & 4,2 \\
\hline 28) Hotel & 4,4 & 4,4 \\
\hline 29) Albergue da juventude & 3,4 & 3,6 \\
\hline 30) Trailer & 3,6 & 3,9 \\
\hline 31) Camping & 4,3 & 4,0 \\
\hline 32) Pousada & 3,3 & 2,9 \\
\hline 33) Windsurf & 4,4 & 4,4 \\
\hline 34) Vôlei & 4,0 & 3,9 \\
\hline 35) Natação & 4,2 & 4,4 \\
\hline 36) Futebol & 4,5 & 4,6 \\
\hline 37) Tênis & 4,4 & 4,2 \\
\hline 38) Golfe & 4,4 & 4,3 \\
\hline 39) Basquete & 4,1 & 4,0 \\
\hline 40) Trekking / Caminhada & 3,8 & 3,8 \\
\hline 41) Rapel / Alpinismo & 4,1 & 3,7 \\
\hline 42) Caiaque / Canoagem & 4,3 & 3,9 \\
\hline
\end{tabular}


Tabela 14 - Respostas dos símbolos de informação pública e a escala numérica (continuação)

\section{Símbolo}

43) Pára-quedismo

44) Praça / Área p/ piquenique

45) Cooper / Corrida

46) Barco / Barco a vela

47) Esqui na neve

48) Asa delta

49) Balonismo

50) Surfe

51) Esqui aquático

52) Mergulho

53) Jet Ski

54) Playground

55) Bar

56) Cervejaria

57) Sorveteria

58) Supermercado

59) Lanchonete

60) Restaurante

61) Cafeteria

62) Biblioteca

63) Vista panorâmica

64) Parque

65) Parque de diversão

66) Monumento

67) Construção histórica

68) Mesquita

69) Sinagoga

70) Igreja

71) Farol

72) Danceteria / Salão de dança

73) Caverna

74) Cachoeira

75) Zoológico

76) Museu

77) Teatro

78) Hipismo

79) Praia

80) Autódromo / Cartódromo

81) Ciclismo / Ciclovia

82) Internet
BRASIL - média

Total bruto - 56 sujeitos

4,4

3,9

4,1

4,1

4,2

4,5

4,2

4,1

4,1

3,8

4,0

4,3

4,0

4,4

4,6

4,7

4,4

4,8

4,5

3,8

2,7

4,0

4,0

3,6

3,5

3,4

3,9

4,3

4,3

3,7

3,5

4,2

3,9

3,2

4,5

4,4

4,3

3,8

4,7

4,7
ESTRANGEIROS - média Total bruto - 23 sujeitos

4,3

3,8

3,6

3,9

3,9

4,2

4,1

3,3

3,9

3,3

3,3

4,2

3,8

4,0

4,8

4,6

4,3

4,8

4,6

3,8

2,7

3,8

3,8

3,5

3,3

3,2

3,9

3,9

4,3

3,5

3,3

3,3

3,8

3,3

4,2

3,8

4,5

3,5

4,3

4,5 
Tabela 15 - Respostas referentes ao protótipo mapa-site turístico de Caxambu

\begin{tabular}{|c|c|c|c|c|c|c|c|c|c|c|c|}
\hline \multicolumn{12}{|l|}{ A) BRASIL } \\
\hline \multirow{3}{*}{$\begin{array}{l}\text { QUESTÃO } \\
\text { RESPOSTA } \\
\text { Positiva }\end{array}$} & \multirow{3}{*}{$\begin{array}{c}1 \\
\\
19\end{array}$} & \multicolumn{2}{|c|}{2} & \multirow[t]{2}{*}{3} & \multirow[t]{2}{*}{4} & \multicolumn{3}{|c|}{5} & \multirow[t]{2}{*}{6} & \multicolumn{2}{|c|}{$\begin{array}{c}\text { Detalhe } \\
\text { Questão } 5 \text { b }\end{array}$} \\
\hline & & A & b & & & $\mathbf{a}$ & & & & \multirow{2}{*}{6} & \multirow{2}{*}{4} \\
\hline & & 17 & 26 & 28 & 28 & 17 & 1 & II & 16 & & \\
\hline Negativa & 9 & 11 & 2 & 0 & 0 & 11 & III & IV & 12 & & \\
\hline $\begin{array}{c}\text { TOTAL } \\
\text { (Positiva + } \\
\text { negativa) }\end{array}$ & \multicolumn{9}{|c|}{28} & & \\
\hline
\end{tabular}

\section{B) ESTRANGEIROS}

\begin{tabular}{|c|c|c|c|c|c|c|c|c|c|c|c|}
\hline \multirow{3}{*}{$\begin{array}{l}\text { QUESTÃO } \\
\text { RESPOSTA } \\
\text { Positiva }\end{array}$} & \multirow[b]{3}{*}{5} & \multicolumn{2}{|c|}{2} & \multirow[t]{2}{*}{3} & \multirow[t]{2}{*}{4} & \multicolumn{3}{|c|}{5} & \multirow[t]{2}{*}{6} & \multicolumn{2}{|c|}{$\begin{array}{c}\text { Detalhe } \\
\text { Questão } 5 \text { b }\end{array}$} \\
\hline & & A & b & & & a & & & & & \\
\hline & & 6 & 7 & 12 & 12 & 10 & 1 & II & 6 & & \\
\hline Negativa & 8 & 7 & 6 & 1 & 1 & 3 & III & IV & 7 & & \\
\hline $\begin{array}{c}\text { TOTAL } \\
\text { (Positiva + } \\
\text { negativa) }\end{array}$ & & & & & 13 & & & & & & \\
\hline
\end{tabular}

\section{C) BRASIL + ESTRANGEIROS}

\begin{tabular}{|c|c|c|c|c|c|c|c|c|c|c|c|}
\hline \multirow{3}{*}{$\begin{array}{l}\text { QUESTÃO } \\
\text { RESPOSTA } \\
\text { Positiva }\end{array}$} & \multirow[t]{2}{*}{1} & \multicolumn{2}{|c|}{2} & \multirow[t]{2}{*}{3} & \multirow[t]{2}{*}{4} & \multicolumn{3}{|c|}{5} & \multirow[t]{2}{*}{6} & \multicolumn{2}{|c|}{$\begin{array}{c}\text { Detalhe } \\
\text { Questão } 5 \text { b }\end{array}$} \\
\hline & & A & b & & & a & & & & \multirow{3}{*}{20} & \multirow{2}{*}{4} \\
\hline & 24 & 23 & 33 & 40 & 40 & 27 & I & II & 22 & & \\
\hline Negativa & 17 & 18 & 8 & 1 & 1 & 14 & III & IV & 19 & & \\
\hline $\begin{array}{l}\text { TOTAL } \\
\text { (Positiva + } \\
\text { negativa) }\end{array}$ & & & & & 41 & & & & & & \\
\hline
\end{tabular}




\section{3 - Apresentação e discussão dos resultados}

A realização dos questionários procurou conhecer o ponto de vista dos usuários potenciais de um mapa temático para o setor do turismo. Buscou-se saber se a preferência recaía sobre a utilização de mapas convencionais ou de mapas pictóricos, com seus respectivos símbolos, com a inserção de textos - informativos, serviços, curiosidades, etc. Buscava verificar também se há ou não aceitação desse tipo de produto por turistas e pessoas leigas em cartografia. Além disso, analisou-se uma relação de oitenta e seis símbolos de informação pública e propôs-se um tipo de legenda que adaptasse tais símbolos aos mapas turísticos.

Foram utilizadas, como parâmetros duas visões distintas em relação ao material cartográfico elaborado: a do brasileiro e a do estrangeiro. Neste caso, requisitaramse sujeitos que moram em outros países.

A seguir, apresentam-se as tabelas 16, 17, 18 e 19 com as médias percentuais referentes aos quatro questionários (in loco e no site), realizados ao longo da pesquisa. 
Tabela 16 - Médias amostrais dos símbolos de informação pública in loco (\%)

\begin{tabular}{|c|c|c|c|c|}
\hline \multirow{2}{*}{ Símbolo } & \multirow[b]{2}{*}{$\begin{array}{c}\text { Acertaram o } \\
\text { Contexto }\end{array}$} & \multirow[b]{2}{*}{$\begin{array}{c}\text { Acertaram o } \\
\text { Símbolo }\end{array}$} & \multicolumn{2}{|c|}{ Pontuação mais alta } \\
\hline & & & $\begin{array}{c}\text { Não } \\
\text { responderam }\end{array}$ & $\begin{array}{l}\text { Erraram os } \\
\text { dois }\end{array}$ \\
\hline 1) Bondinho & 42,6 & 0 & 6,2 & 51,2 \\
\hline 2) Teleférico & 76,5 & 0 & 15,6 & 7,9 \\
\hline 3) Táxi & 80,2 & 0 & 4,0 & 15,8 \\
\hline 4) Rodoviária & 9,7 & 59,6 & 5,0 & 25,7 \\
\hline 5) Porto & 47,1 & 37,8 & 4,5 & 11,1 \\
\hline 6) Metrô & 71,5 & 0 & 6,7 & 21,8 \\
\hline 7) Heliponto & 3,7 & 35,6 & 6,5 & 54,2 \\
\hline 8) Estação ferroviária & 11,2 & 45,7 & 4,2 & 39,1 \\
\hline 9) Balsa & 62,2 & 0 & 15,3 & 22,5 \\
\hline 10) Aeroporto & 86,1 & 11,1 & 0,8 & 2,0 \\
\hline 11) Marina / Atracadouro & 13,4 & 10,1 & 8,4 & 68,1 \\
\hline 12) Locação / Aluguel de carro & 43,0 & 0 & 14,4 & 42,6 \\
\hline 13) Telefone público & 14,6 & 65,0 & 0,2 & 20,2 \\
\hline 14) Shopping / Compras & 34,2 & 15,3 & 16,3 & 34,2 \\
\hline 15) Posto de gasolina / Abastecimento & 70,0 & 0,7 & 2,3 & 27,0 \\
\hline 16) Banheiro público / WC & 10,4 & 67,4 & 7,0 & 15,2 \\
\hline 17) Oficina mecânica / Mecânico & 50,2 & 3,0 & 18,3 & 27,7 \\
\hline 18) Bebedouro & 38,1 & 0 & 25,7 & 36,2 \\
\hline 19) Acesso para deficiente físico & 17,1 & 5,5 & 3,7 & 73,7 \\
\hline 20) Guarda malas / Volumes & 53,0 & 0 & 19,8 & 27,2 \\
\hline 21) Hospital / Pronto Socorro & 91,6 & 0,3 & 1,0 & 7,1 \\
\hline 22) Banco & 77,4 & 8,0 & 4,4 & 10,2 \\
\hline 23) Delegacia & 3,5 & 29,2 & 10,1 & 57,2 \\
\hline 24) Informação / Informação Turística & 42,3 & 0 & 27,0 & 30,7 \\
\hline 25) Correio & 93,8 & 1,8 & 0,5 & 3,9 \\
\hline 26) Artesanato & 43,6 & 0,5 & 33,7 & 22,1 \\
\hline 27) Estacionamento & 64,9 & 0 & 27,0 & 8,1 \\
\hline 28) Hotel & 82,6 & 0,7 & 1,3 & 15,4 \\
\hline 29) Albergue da juventude & 10,6 & 0 & 29,4 & 60,1 \\
\hline 30) Trailer & 60,2 & 0 & 23,3 & 16,5 \\
\hline 31) Camping & 54,0 & 6,4 & 4,9 & 34,7 \\
\hline 32) Pousada & 15,3 & 6,7 & 33,2 & 44,8 \\
\hline 33) Wind surf & 45,6 & 0,3 & 13,6 & 40,4 \\
\hline 34) Vôlei & 75,5 & 1,2 & 6,4 & 16,9 \\
\hline 35) Natação & 84,1 & 0 & 6,4 & 9,5 \\
\hline 36) Futebol & 87,4 & 0 & 3,0 & 9,6 \\
\hline 37) Tênis & 83,5 & 0 & 4,8 & 11,7 \\
\hline 38) Golfe & 83,9 & 0 & 4,0 & 12,1 \\
\hline 39) Basquete & 79,7 & 0 & 7,4 & 12,9 \\
\hline 40) Trekking / Caminhada & 21,3 & 0 & 23,5 & 55,2 \\
\hline 41) Rapel / Alpinismo & 68,3 & 0,8 & 10,3 & 20,6 \\
\hline 42) Caiaque / Canoagem & 47,8 & 0 & 15,7 & 38,5 \\
\hline
\end{tabular}


Tabela 16 - Médias amostrais dos símbolos de informação pública in loco (\%) (continuação)

\begin{tabular}{|c|c|c|c|c|}
\hline Resposta & $\begin{array}{l}\text { Acertaram o } \\
\text { Contexto }\end{array}$ & $\begin{array}{l}\text { Acertaram o } \\
\text { Símbolo }\end{array}$ & $\begin{array}{c}\text { Não } \\
\text { responderam }\end{array}$ & $\begin{array}{l}\text { Erraram os } \\
\quad \text { dois }\end{array}$ \\
\hline 43) Pára-quedismo & 54,7 & 21,8 & 9,1 & 14,4 \\
\hline 44) Praça / Área para piquenique & 77,2 & 0 & 7,6 & 15,2 \\
\hline 45) Cooper / Corrida & 56,0 & 0 & 9,1 & 34,9 \\
\hline 46) Barco / Barco a vela & 25,4 & 0 & 21,1 & 53,5 \\
\hline 47) Esqui na neve & 68,0 & 0,2 & 17,7 & 14,1 \\
\hline 48) Asa delta & 77,5 & 0 & 7,9 & 14,6 \\
\hline 49) Balonismo & 50,2 & 30,8 & 8,9 & 10,1 \\
\hline 50) Surfe & 69,0 & 0,7 & 12,6 & 17,8 \\
\hline 51) Esqui aquático & 70,0 & 0 & 19,2 & 10,8 \\
\hline 52) Mergulho & 63,4 & 12,1 & 16,4 & 8,1 \\
\hline 53) Jet Ski & 74,4 & 0 & 13,9 & 11,7 \\
\hline 54) Playground & 23,7 & 15,6 & 8,4 & 52,3 \\
\hline 55) Bar & 45,6 & 1,7 & 17,6 & 35,1 \\
\hline 56) Cervejaria & 10,4 & 9,7 & 3,4 & 76,5 \\
\hline 57) Sorveteria & 91,0 & 8,2 & 0,3 & 0,5 \\
\hline 58) Supermercado & 93,0 & 0,7 & 1,1 & 5,2 \\
\hline 59) Lanchonete & 80,0 & 6,9 & 3,2 & 9,9 \\
\hline 60) Restaurante & 96,0 & 0 & 0,6 & 3,4 \\
\hline 61) Cafeteria & 33,7 & 50,2 & 7,5 & 8,6 \\
\hline 62) Biblioteca & 51,0 & 40,2 & 4,5 & 4,3 \\
\hline 63) Vista panorâmica & 8,1 & 0 & 43,8 & 48,1 \\
\hline 64) Parque & 8,1 & 4,0 & 7,5 & 80,4 \\
\hline 65) Parque de diversão & 61,0 & 10,0 & 5,0 & 24,0 \\
\hline 66) Monumento & 34,2 & 0,2 & 27,7 & 37,9 \\
\hline 67) Construção histórica & 7,0 & 16,1 & 34,9 & 42,0 \\
\hline 68) Mesquita & 23,8 & 11,2 & 31,4 & 33,6 \\
\hline 69) Sinagoga & 34,9 & 6,4 & 28,9 & 29,8 \\
\hline 70) Igreja & 93,4 & 0 & 2,3 & 4,3 \\
\hline 71) Farol & 80,9 & 0 & 13,4 & 5,7 \\
\hline 72) Danceteria / Salão de dança & 55,9 & 0,3 & 4,7 & 39,1 \\
\hline 73) Caverna & 37,8 & 0 & 27,5 & 34,7 \\
\hline 74) Cachoeira & 83,1 & 0,3 & 6,4 & 10,2 \\
\hline 75) Zoológico & 64,3 & 9,7 & 10,6 & 15,4 \\
\hline 76) Museu & 19,5 & 0 & 15,3 & 65,2 \\
\hline 77) Teatro & 67,8 & 1,8 & 5,2 & 25,2 \\
\hline 78) Hipismo & 58,1 & 0,8 & 5,0 & 36,1 \\
\hline 79) Praia & 93,1 & 0,8 & 2,9 & 3,2 \\
\hline 80) Autódromo / Cartódromo & 49,7 & 8,1 & 12,9 & 29,3 \\
\hline 81) Ciclismo / Ciclovia & 70,0 & 5,4 & 1,8 & 22,8 \\
\hline 82) Internet * & 42,6 & 34,2 & 3,7 & 19,5 \\
\hline
\end{tabular}


E quando o sujeito não acertava o contexto do símbolo de informação pública, quais foram as respostas mais freqüentes?

A estrutura é a seguinte:

\begin{tabular}{|c|c|c|}
\hline \multicolumn{3}{|c|}{$\begin{array}{l}\text { O PICTOGRAMA } \\
\text { ANALISADO }\end{array}$} \\
\hline 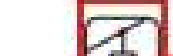 & O NOME, C & CONTEXTO CORRETO \\
\hline (1) & 1) Bondinho & \\
\hline Bond & $\theta$, teleférico, pằ & de açúcar, transporte por cabo \\
\hline $\begin{array}{l}\text { RESF } \\
\text { COLC }\end{array}$ & $\begin{array}{l}\text { OSTAS MAIS FR } \\
\text { PCAVA O CONTE }\end{array}$ & $\begin{array}{l}\text { REQUENTES QUANDO NĀO SE } \\
\text { XXTO CORRETO DO PICTOGRAMA }\end{array}$ \\
\hline
\end{tabular}

1) Bondinho

Bonde, teleférico, pão de açúcar, transporte por cabo.

\section{2) Teleférico}

Estação de esqui, poltrona, esqui, trem de esqui.

\section{3) Táxi}

Ponto de táxi, carro, polícia, ambulância, locação de veículos, parada de táxi.

\section{4) Rodoviária}

Ônibus, ponto de ônibus, transporte coletivo, transporte rodoviário.

\section{5) Porto}

Navio, embarcação, transporte fluvial, área portuária, transporte marítimo, viagem marítima, hidrovia.

\section{6) Metrô}

Estação de trem, trem-metrô, bonde, estação de metrô.

7) Heliponto

Helicóptero, heliporto, táxi aéreo, aeroclube, local de pouso.

\section{8) Estação ferroviária}

Trem, Ferrovia, Estação de trem, Linha de trem, linha férrea, locomotiva, metrô, trem de superfície.

\section{9) Balsa}

Carro, transporte fluvial, transporte aquático de carro, transporte por barca, carro na balsa. 
10) Aeroporto

Avião, transporte aéreo, aeroporto-avião.

11) Marina / Atracadouro

Âncora, porto, Marinha do Brasil, marinha, ancoradouro, cais.

12) Locação / Aluguel de carro

Chaveiro, garagem, oficina, estacionamento.

\section{3) Telefone público}

Telefone, orelhão, telecomunicações, cabine telefônica, posto telefônico.

\section{4) Shopping / Compras}

Presente, souvenir, loja comercial, conveniência, loja.

15) Posto de gasolina / Abastecimento

Posto, posto de combustível, gasolina.

\section{6) Banheiro público / WC}

Banheiro, ele-ela, toalete, unisex, maculino-feminino, sanitário.

\section{7) Oficina mecânica / Mecânico}

Oficina, borracharia, ferramenta, oficina de ferragem, chave, encanador.

18) Bebedouro

Lavatório, lixo, lixeira, pia, lavatório, limpeza, lavabo.

\section{9) Acesso para deficiente físico}

Cadeirante, deficiente, local para deficiente, vaga reservada para deficiente, cadeira de rodas, acessibilidade.

\section{0) Guarda malas / Guarda volumes}

Chaveiro, cofre, bagagem, viagem, armário, maleiro, porta bagagem. 
21) Hospital / Pronto Socorro

Ambulatório, primeiros socorros, saúde, posto de saúde, posto médico, cruz.

\section{2) Banco}

Dinheiro, empréstimo, câmbio, financeira, cifrão.

\section{3) Delegacia}

Policial, segurança, guarda de trânsito, área militar, posto policial, guarda, policiamento.

\section{4) Informação / Informação Turística}

Letra i, Internet, Itaú, banco Itaú, cyber café.

\section{5) Correio}

Correspondência, carta, serviço postal.

\section{6) Artesanato}

Cerâmica, utensílio, jarra, laboratório, vinho, louça, indústria química, artesanato-cerâmica, química, farmácia, ciência, pote, vaso.

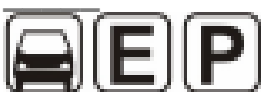

27) Estacionamento

Permitido estacionar, parada, estacionamento proibido, permitido estacionar, estacionamento privado.

\section{H] 28) Hotel}

Hospedagem, dormitório, repouso, pernoite, hospital.

29) Albergue da juventude

Chalé, pousada, casa de campo, pousada nos Alpes, Natal.

\section{0) Camping para trailer}

Reboque, camping móvel, área de trailer, camping.

\section{1) Camping}

Acampamento, barraca, local para acampamento, cabana, área de camping.

\section{2) Pousada}

Chalé, casa de aluguel, casa, casa na praia, residência, guarita, moradia, área residencial.

\section{3) Windsurfe}

Velejar, barco a vela, vela, surfe, jangadeiro, regata, prática de iatismo. 


\section{4) Vôlei}

Quadra de vôlei, Pólo aquático, basquete.

\section{5) Natação}

Piscina, área para nadar.

\section{6) Futebol}

Quadra de Futebol, campo de futebol, jogo de futebol.

\section{7) Tênis}

Quadra de tênis, ping-pong.

\section{8) Golfe}

Campo de golfe.

39) Basquete

Quadra de basquete.

40) Trekking / Caminhada

Trilha, alpinismo, idoso, passagem para cegos, trilha de eco-turismo.

41) Rapel / Alpinismo

Escalada, montanhismo, escalar montanha, escalagem.

\section{2) Caiaque / Canoagem}

Remo, windsurfe, pescaria, iatismo, área de canoagem, regata.

\section{3) Pára-quedismo}

Pára-quedas, pára-quedista.

44) Praça / Área para piquenique

Parque, fazenda, pracinha, parque para recreação.

\section{5) Cooper / Corrida}

Atletismo, atleta, caminhar, pista de corrida, pista de Cooper, maratona.

46) Barco / Barco a vela

latismo, vela, marina, jangada, veleiro.

Esquiar, esqui no gelo, deficiente visual, trenó, patinador. 
48) Asa delta

Vôo livre, área de salto, ultra-leve.

49) Balonismo

Balão, pára-quedismo, balonista, baloagem.

\section{0) Surfe}

Surfista, skate, skatista.

51) Esqui aquático

Windsurfe, pescaria, esqui na água.

\section{2) Mergulho}

Mergulhador, área de mergulho, prática submarina, nadador.

53) Jet Ski

Lancha, bote, moto-náutica.

54) Playground

Gangorra, parque, parquinho, parque infantil, balanço.

55) Bar

Drink, taça, frágil, adega, bebida, taça de vinho.

56) Cervejaria

Choperia, chope, bar, milk shake, bar.

\section{7) Sorveteria}

Sorvete.

58) Supermercado

Carrinho de supermercado, mercado.

59) Lanchonete

Lanche, fast food, lancharia.

60) Restaurante

Refeição, talheres. 


\section{1) Cafeteria}

Café, casa de chá, café expresso.

\section{2) Biblioteca}

Livraria, leitura, livro, jornal.

\section{3) Vista panorâmica}

Farol alto, luz alta, luz, lanterna, autofalante, som, farol-sinaleiro, mirante, cinema, acenda o farol, buzina.

\section{4) Parque}

Floresta, árvores, bosque, reserva florestal, parque natural, campo, mata, área verde.

\section{5) Parque de diversão}

Carrossel, parque.

\section{6) Monumento}

Farol, marco, obelisco.

\section{iif 67) Construção histórica}

Castelo, patrimônio histórico, torre, patrimônio cultural, centro histórico.

\section{8) Mesquita}

Noite, lua, lua crescente, boate, templo islã, místico, lual, lua minguante, muçulmanos, símbolo do islã.

\section{9) Sinagoga}

Estrela de Davi, judaísmo, templo judeu, judeu, israelense, maçonaria, pentagrama.

\section{0) Igreja}

Catedral, cristão, igreja católica, igreja cristã, templo cristão.

\section{1) Farol}

Farol alto, porto, foguete.

\section{2) Danceteria / Salão de dança}

Dança, festa, baile, boate, pista de dança, clube, discoteca. 
Catarata, cascata, corredeira.

\section{5) Zoológico}

Animal selvagem, elefante, safári, selva, circo, cuidado: animais.

\section{6) Museu}

Circo, palácio, mesquita, teatro, ruínas, Grécia.

\section{7) Teatro}

Carnaval, museu, máscara do teatro, baile de máscara.

\section{8) Hipismo}

Hipódromo, rodeio, corrida de cavalo, hípica, jóquei, corrida de cavalo, equitação, festa de rodeio, haras.

\section{9) Praia}

Chuva, sombrinha, balneário, guarda-sol, área para banhista.

\section{0) Autódromo / Cartódromo}

Fórmula 1, automobilismo, pista de corrida, carte, corrida de automóvel.

\section{1) Ciclismo / Ciclovia}

Ciclista, bicicleta, velódromo, via de bicicleta.

\section{2) Internet}

Arroba, cyber café, e-mail, endereço eletrônico, informática, lan house, acesso a Internet.

Pelas respostas dissertativas de 596 sujeitos inventariadas na tabela 16, pôde-se averiguar que:

\section{Acertaram o contexto}

$\checkmark 11$ símbolos $(12,8 \%)$ foram identificados corretamente por mais de 500 sujeitos;

$\checkmark 32$ símbolos $(37,2 \%)$ foram identificados corretamente por mais de 400 sujeitos; 
$\checkmark 48$ símbolos $(55,8 \%)$ foram respondidos corretamente por mais de 300 sujeitos.

\section{Acertaram o contexto ou o símbolo}

$\checkmark 19$ símbolos $(23,2 \%)$ foram respondidos corretamente por mais de 500 sujeitos.

$\checkmark 45$ símbolos $(52,3 \%)$ foram respondidos corretamente por mais de 400 sujeitos.

$\checkmark 56$ símbolos $(68,3 \%)$ foram respondidos corretamente por mais de 300 sujeitos.

O próximo item merece destaque pela alta quantidade de respostas corretas acerto do contexto (sem contar o acerto do símbolo):

- Restaurante - 572; Correio - 559; Supermercado - 554; Igreja - 557; Praia - 555; Hospital, Pronto-Socorro - 546; Sorveteria - 542.

A partir dos 56 símbolos já inclusos, ainda restam 26 com índice menor de acerto que 300 sujeitos. Desses 26, 12 símbolos foram respondidos corretamente por menos de 200 sujeitos - acerto do contexto (incluindo-se o acerto do símbolo):

- Delegacia - 195; Marina, atracadouro - 140; Acesso para deficiente físico -135; Pousada - 131; Trekking, caminhada - 127; Barco, barco à vela - 151; Construção histórica - 138; Cervejaria - 120; Museu - 116; Albergue da juventude - 63; Parque - 72, Vista panorâmica - 48 .

Um dado curioso é que mais de $50 \%$ dos entrevistados interpretaram o símbolo Museu, mesmo sendo muito utilizado em placas de sinalização turística, como Circo. 
Tabela 17 - Valores amostrais quanto a preferência entre o mapa convencional ou pictórico

\begin{tabular}{|c|c|c|c|c|}
\hline A) BRASIL & \multicolumn{3}{|c|}{} \\
\hline $\begin{array}{c}\text { QUESTÃO } \\
\text { TIPO DE } \\
\text { MAPA }\end{array}$ & a & B & C & D \\
\hline $\begin{array}{c}\text { Convencional } \\
\text { (1) }\end{array}$ & 26,8 & 10,7 & 41,0 & 7,0 \\
\hline $\begin{array}{c}\text { Pictórico } \\
\text { (2) }\end{array}$ & 73,2 & 89,3 & 59,0 & 93,0 \\
\hline $\begin{array}{c}\text { Total Geral } \\
\text { (1+2) }\end{array}$ & & $\mathbf{1 0 0}$ & \\
\hline
\end{tabular}

\begin{tabular}{|c|c|c|c|c|}
\hline \multirow{2}{*}{$\begin{array}{l}\text { QUESTÃO } \\
\text { TIPO DE } \\
\text { MAPA }\end{array}$} & \multicolumn{4}{|c|}{$1(\%)$} \\
\hline & A & b & C & d \\
\hline $\begin{array}{l}\text { Convencional } \\
\text { (1) }\end{array}$ & 26,1 & 52,2 & 56,5 & 21,7 \\
\hline $\begin{array}{c}\text { Pictórico } \\
\text { (2) }\end{array}$ & 73,9 & 47,8 & 43,5 & 78,3 \\
\hline $\begin{array}{l}\text { Total Geral } \\
\quad(1+2)\end{array}$ & \multicolumn{4}{|c|}{100} \\
\hline
\end{tabular}

\begin{tabular}{|c|c|c|c|c|}
\hline C) BRASIL + ESTRANGEIROS \\
\hline $\begin{array}{c}|c| \\
\text { QUESTÃO }\end{array}$ & \multicolumn{4}{|c|}{$\mathbf{( \% )}$} \\
\hline $\begin{array}{c}\text { TIPO DE } \\
\text { MAPA }\end{array}$ & A & B & C & d \\
\hline $\begin{array}{c}\text { Convencional } \\
\text { (1) }\end{array}$ & 26,6 & 22,8 & 45,6 & 11,4 \\
\hline $\begin{array}{c}\text { Pictórico } \\
\text { (2) }\end{array}$ & 73,4 & 72,2 & 54,4 & 86,6 \\
\hline $\begin{array}{c}\text { Total Geral } \\
\text { (1+2) }\end{array}$ & & 100 & \\
\hline
\end{tabular}
QUESTÃO 2 Tabela D - Valores amostrais: Disponibilidade de textos \begin{tabular}{cc|l} 
N & Dn & $\begin{array}{l}\mathrm{N}=\text { Necessário } \\
\text { Dn = Desnecessário }\end{array}$ \\
\hline $\mathbf{8 3 , 5}$ & $\mathbf{1 6 , 5}$ &
\end{tabular} (total geral $=$ Brasil + estrangeiros) $100 \%$

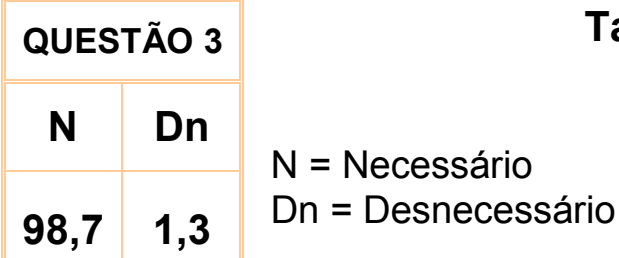
Tabela E - Valores amostrais: Aceitação do material (total geral $=$ Brasil + estrangeiros) $100 \%$ 
Ao observar as tabelas $17 \mathrm{~A}, \mathrm{~B}, \mathrm{C}, \mathrm{D}$ e $\mathrm{E}$, onde se registram os resultados dos questionários referentes ao tema 1 do site (ver site em CD - anexos - pasta 4), pôde-se averiguar que:

\section{Questão 1 (tema 1)}

Depois de observar os mapas (1) convencional e (2) ilustrado:

a) Qual dos dois prefere levar para sua viagem?

b) Em qual consegue identificar as atrações mais rapidamente? Note que a regência do verbo é diferente da dos demais.

c) Qual usaria como guia para localização e/ou orientação em sua viagem?

d) Qual você credita que pode gerar um incentivo maior ao turista que pretende conhecer a cidade?

$\left.1^{\circ}\right)$ As respostas dadas às questões formuladas com alternativas mostraram que, em resposta à questão $1 \mathrm{a}$ e $1 \mathrm{~d}, 80 \%$ dos entrevistados (brasileiros e estrangeiros) optaram pelos mapas pictóricos, que alcançaram os $93 \%$ na preferência dos brasileiros. Já na questão $1 \mathrm{~b}$, mesmo com a preferência geral dada aos mapas pictóricos, $52,2 \%$ dos estrangeiros optaram pelos mapas convencionais. A questão 1c apresentou os valores mais elevados a favor dos mapas convencionais $(45 \%)$, alcançando o pico de $56,5 \%$ entre os estrangeiros.

$\mathbf{2}^{\circ}$ ) As respostas dissertativas indicaram que os mapas convencionais são mais práticos, menos poluídos, preferidos quando em trânsito; proporcionam fácil localização, leitura imediata, melhor orientação no dia-a-dia. Já em relação aos mapas pictóricos, os termos usados para avaliá-los foram: oferecem ótima orientação, são atrativos, chamam mais a atenção, são preferidos quando já se está na localidade, são bons para planejar a viagem, aguçam a curiosidade e a querer conhecer o local, dão referências de localização, despertam o sentimento de pré-felicidade, são claros, confiáveis, dão uma visão mais aprofundada dos locais, permitem uma leitura mais lenta, são mais coloridos e adequados para os turistas.

Ressaltam-se a seguir algumas respostas dadas pelos entrevistados, que ilustram o que foi dito acima: "quando falamos de viagens turísticas, é claro que o mapa ilustrado é a melhor opção, pois te dá uma visão mais aprofundada dos locais a serem conhecidos, já os mapas convencionais tb são importantes, mas para localização do dia-a-dia" (Técnico em informática, 29, SP). "Map 2 is really colorful and perfect for tourists while Map 1 is much better for an overview or to orientate in the city. I think they are for different purposes..." (Engenheiro, 28, Suíça)."Para pedestres o ilustrado é interessante e motivador, porém a leitura é mais lenta, para motoristas o convencional permite uma leitura mais imediata" (Arquiteta, 43, SP). "Quality should be a main topic - especially in a time where computer tend to focus less on quality and loss of cartographic esthetics - type 1 has also its use in tourism, but would probably be better with a shaded relief in the background, then it could be 
perfect for hikink with the shown contour lines etc... there we need precise scales e.g. for measuring and suggesting the time for trips - type 2 seems to me being good for planning trips and getting to know the main features - told with pictures it attracts the visitors and helps the tourist in setting priorities. Maybe he sees which atractions are in a near surroundings and its importance for the family trip that could be made in a specific time - tourist maps should give a feeling of prehappyness of the upcoming trip" (geo informática e mídia, 30, Alemanha). "...em alguns momentos seria interessante levar os dois mapas...” (professora, 29, MT).

\section{Questão 2 (tema 1)}

Já em relação ao texto disposto dentro dos quadros, você os acha:

a) Necessários. Reforçam a curiosidade e o conhecimento sobre o lugar.

b) Desnecessários. As informações são exageradas e poluem visualmente o mapa.

$\left.1^{\circ}\right)$ As respostas baseadas nas questões apresentadas com alternativas revelaram que tanto os brasileiros quanto os estrangeiros vêem como necessária a disponibilidade de informações (caixas de texto) escritas sob o mapa turístico. A afirmação é ratificada por $83,5 \%$ dos entrevistados.

$2^{\circ}$ ) As respostas dissertativas mostraram que pode haver um excesso de informações. Leiam-se algumas declrações: "The text written in boxes is sometimes necessary, sometimes not. There is always some information obliterated by it. I like the material developed, but see it as additional information, not as a complete substitute" (cartógrafo, 64, Holanda). "O material é ótimo, o que pode ser melhorada levemente é a poluição visual, que, em certos casos, se faz presente, como em alguns trechos do mapa de Manaus, por exemplo. Mas é apenas em alguns casos" (Estudante, 15, SP). "... should be as attractive as possible but not overloaded with information - keep to details but don't get lost in them (geo informática e mídia, 30, Alemanha).

\section{Questão 3 (tema 1)}

\section{Você gostou do material desenvolvido?}

As respostas, dadas a questões baseadas em alternativas indicaram que tanto os brasileiros quanto os estrangeiros aprovaram de forma expressiva o material produzido para o setor do turismo (98,7 \%). Dos 79 entrevistados, houve apenas uma resposta negativa. 
Tabela 18 - Médias amostrais dos símbolos de informação pública e a escala numérica (\%)

Porcentagem igual ou menor que $70 \%$

\begin{tabular}{|c|c|}
\hline $\begin{array}{ll}\text { Símbolo } & \text { Resposta }\end{array}$ & $\begin{array}{l}\text { BRASIL } \\
\text { porcentagem (\%) }\end{array}$ \\
\hline 1) Bondinho & 84 \\
\hline 2) Teleférico & 84 \\
\hline 3) Táxi & 86 \\
\hline 4) Rodoviária & 86 \\
\hline 5) Porto & 84 \\
\hline 6) Metrô & 76 \\
\hline 7) Heliponto & 88 \\
\hline 8) Estação ferroviária & 84 \\
\hline 9) Balsa & 64 \\
\hline 10) Aeroporto & 94 \\
\hline 11) Marina / Atracadouro & 78 \\
\hline 12) Locação / Aluguel de carro & 64 \\
\hline 13) Telefone público & 92 \\
\hline 14) Shopping / Compras & 64 \\
\hline 15) Posto de gasolina / Abastecimento & 88 \\
\hline 16) Banheiro público / WC & 90 \\
\hline 17) Oficina mecânica / Mecânico & 70 \\
\hline 18) Bebedouro & 74 \\
\hline 19) Acesso para deficiente físico & 90 \\
\hline 20) Guarda malas / Volumes & 78 \\
\hline 21) Hospital / Pronto Socorro & 96 \\
\hline 22) Banco & 90 \\
\hline 23) Delegacia & 74 \\
\hline 24) Informação / Informação Turística & 84 \\
\hline 25) Correio & 88 \\
\hline 26) Artesanato & 62 \\
\hline 27) Estacionamento & 86 \\
\hline 28) Hotel & 88 \\
\hline 29) Albergue da juventude & 68 \\
\hline 30) Trailer & 72 \\
\hline 31) Camping & 86 \\
\hline 32) Pousada & 66 \\
\hline 33) Windsurf & 88 \\
\hline 34) Vôlei & 80 \\
\hline 35) Natação & 84 \\
\hline 36) Futebol & 90 \\
\hline 37) Tênis & 88 \\
\hline 38) Golfe & 88 \\
\hline 39) Basquete & 82 \\
\hline 40) Trekking / Caminhada & 76 \\
\hline
\end{tabular}

Tabela 18 - Respostas dos Símbolos de Informação

Pública e a escala numérica (\%)

\begin{tabular}{|c|}
\hline \begin{tabular}{|c|} 
ESTRANGEIROS \\
porcentagem (\%)
\end{tabular} \\
\hline 84 \\
\hline 86 \\
\hline 84 \\
\hline 84 \\
\hline 86 \\
\hline 66 \\
\hline 88 \\
\hline 72 \\
\hline 60 \\
\hline 98 \\
\hline 68 \\
\hline 70 \\
\hline 92 \\
\hline 80 \\
\hline 92 \\
\hline 68 \\
\hline 66 \\
\hline 96 \\
\hline 80 \\
\hline 96 \\
\hline 84 \\
\hline 70 \\
\hline 88 \\
\hline 90 \\
\hline 56 \\
\hline 84 \\
\hline 72 \\
\hline 78 \\
\hline 80 \\
\hline 88 \\
\hline 78 \\
\hline 98 \\
\hline continuação) \\
\hline
\end{tabular}




\begin{tabular}{|c|c|c|}
\hline $\begin{array}{ll} & \text { Resposta } \\
\text { Símbolo } & \end{array}$ & $\begin{array}{c}\text { BRASIL } \\
\text { porcentagem (\%) }\end{array}$ & $\begin{array}{l}\text { ESTRANGEIROS } \\
\text { porcentagem (\%) }\end{array}$ \\
\hline 41) Rapel / Alpinismo & 82 & 74 \\
\hline 42) Caiaque / Canoagem & 86 & 78 \\
\hline 43) Pára-quedismo & 88 & 86 \\
\hline 44) Praça / Área p/ piquenique & 78 & 76 \\
\hline 45) Cooper / Corrida & 82 & 72 \\
\hline 46) Barco / Barco a vela & 82 & 78 \\
\hline 47) Esqui na neve & 84 & 78 \\
\hline 48) Asa delta & 90 & 84 \\
\hline 49) Balonismo & 84 & 82 \\
\hline 50) Surfe & 82 & 66 \\
\hline 51) Esqui aquático & 82 & 78 \\
\hline 52) Mergulho & 76 & 66 \\
\hline 53) Jet Ski & 80 & 66 \\
\hline 54) Playground & 86 & 84 \\
\hline 55) Bar & 80 & 76 \\
\hline 56) Cervejaria & 88 & 80 \\
\hline 57) Sorveteria & 92 & 96 \\
\hline 58) Supermercado & 94 & 92 \\
\hline 59) Lanchonete & 88 & 86 \\
\hline 60) Restaurante & 96 & 96 \\
\hline 61) Cafeteria & 90 & 92 \\
\hline 62) Biblioteca & 76 & 76 \\
\hline 63) Vista panorâmica & 54 & 54 \\
\hline 64) Parque & 80 & 76 \\
\hline 65) Parque de diversão & 80 & 76 \\
\hline 66) Monumento & 72 & 70 \\
\hline 67) Construção histórica & 70 & 66 \\
\hline 68) Mesquita & 68 & 64 \\
\hline 69) Sinagoga & 78 & 78 \\
\hline 70) Igreja & 86 & 78 \\
\hline 71) Farol & 86 & 86 \\
\hline 72) Danceteria / Salão de dança & 74 & 70 \\
\hline 73) Caverna & 70 & 66 \\
\hline 74) Cachoeira & 84 & 66 \\
\hline 75) Zoológico & 78 & 76 \\
\hline 76) Museu & 64 & 66 \\
\hline 77) Teatro & 90 & 84 \\
\hline 78) Hipismo & 88 & 76 \\
\hline 79) Praia & 86 & 90 \\
\hline 80) Autódromo / Cartódromo & 76 & 70 \\
\hline 81) Ciclismo / Ciclovia & 94 & 86 \\
\hline 82) Internet & 94 & 90 \\
\hline
\end{tabular}

Ao observar a tabela 18, referente aos oitenta e dois Símbolos de Informação Pública (site), e a escala numérica, pôde-se averiguar o seguinte a partir das médias gerais (somadas todas as idades):

\section{1) Entre os brasileiros}

$\checkmark 15$ símbolos obtiveram uma média superior a $90 \%$ de aceitação.

$\checkmark 55$ símbolos obtiveram uma média superior a $80 \%$ de aceitação; 
$\checkmark 74$ símbolos obtiveram uma média superior a $70 \%$ de aceitação.

Neste item abaixo, merecem destaque os símbolos que obtiveram a média de aceitação igual ou superior a $92 \%$ :

- Restaurante - 96\%; Supermercado - 94\%; Ciclismo, ciclovia - 94\%; Internet - 94\%; Aeroporto - 94\%; Telefone público - 92\%; Sorveteria $92 \%$.

A partir dos 74 símbolos já inclusos, ainda restam 8 com índice de aceitação menor que $70 \%$ entre os sujeitos, a saber:

- Albergue da juventude - 68\%; Mesquita - 68; Pousada - 66\%; Shopping, compras - 64\%; Balsa - 64\%; Locação, aluguel de carro $64 \%$; Museu - 64\%; Artesanato - $62 \%$; Vista panorâmica - $54 \%$.

\section{2) Entre os estrangeiros}

$\checkmark 13$ símbolos obtiveram uma média superior a $90 \%$ de aceitação.

$\checkmark 40$ símbolos obtiveram uma média superior a $80 \%$ de aceitação.

$\checkmark 65$ símbolos obtiveram uma média superior a $70 \%$ de aceitação.

No item abaixo, merecem destaque os símbolos que obtiveram a média de aceitação igual ou superior a $92 \%$ :

- Aeroporto - 98\%; Restaurante - 96\%; Sorveteria - 96\%; Supermercado - 92\%; Banheiro público, WC - 92\%; Futebol - 92\%; Telefone público $92 \%$; Cafeteria - $92 \%$.

Dos 65 símbolos já inclusos, ainda restam 17 com índice de acerto menor que 70\% entre os sujeitos, a saber:

- Marina, atracadouro - $68 \%$; Oficina mecânica, mecânico - 68\%; Museu - 66\%; Bebedouro - 66\%; Surfe - 66\%; Mergulho - 66\%; Jet ski - 66\%; Construção histórica - 66\%, Caverna - 66\%; Cachoeira - 66\%; Metrô $66 \%$; Mesquita - 64\%; Balsa - 60\%; Shopping, compras - 60\%; Pousada $-58 \%$; Artesanato - $56 \%$; Vista panorâmica $-54 \%$. 
Tabela 19 - Respostas referentes ao protótipo mapa-site turístico de Caxambu

\begin{tabular}{|c|c|c|c|c|c|c|c|c|c|c|c|}
\hline \multicolumn{12}{|l|}{ A) BRASIL } \\
\hline \multirow{2}{*}{$\begin{array}{l}\text { QUESTÃO } \\
\text { RESPOSTA }\end{array}$} & \multirow[t]{2}{*}{1} & \multicolumn{2}{|c|}{2} & \multirow[t]{2}{*}{3} & \multirow[t]{2}{*}{4} & \multicolumn{3}{|c|}{5} & \multirow[t]{2}{*}{6} & \multicolumn{2}{|c|}{$\begin{array}{c}\text { Detalhe } \\
\text { Questão } 5 \text { b }\end{array}$} \\
\hline & & $\mathbf{a}$ & b & & & $\mathbf{a}$ & & & & \multirow{3}{*}{$\begin{array}{r}21,4 \\
53,6\end{array}$} & \multirow{2}{*}{14,3} \\
\hline Positiva & $\begin{array}{c}67 \\
6\end{array}$ & $\begin{array}{c}60 \\
7\end{array}$ & $\begin{array}{c}92 \\
9\end{array}$ & 100 & 100 & $\begin{array}{c}60 \\
7\end{array}$ & 1 & II & $\begin{array}{c}57 \\
1\end{array}$ & & \\
\hline Negativa & $\begin{array}{c}32 \\
1\end{array}$ & $\begin{array}{c}39 \\
3\end{array}$ & 7,1 & 0 & 0 & $\begin{array}{c}39, \\
3\end{array}$ & III & IV & $\begin{array}{c}42, \\
9\end{array}$ & & 10,7 \\
\hline $\begin{array}{c}\text { TOTAL } \\
\text { (Positiva + } \\
\text { negativa) }\end{array}$ & & & & & 100 & & & & & & \\
\hline
\end{tabular}

\section{B) ESTRANGEIROS}

\begin{tabular}{|c|c|c|c|c|c|c|c|c|c|c|c|}
\hline \multirow{3}{*}{$\begin{array}{l}\text { QUESTÃO } \\
\text { RESPOSTA } \\
\text { Positiva }\end{array}$} & \multirow[t]{2}{*}{1} & \multicolumn{2}{|c|}{2} & \multirow[t]{2}{*}{3} & \multirow[t]{2}{*}{4} & \multicolumn{3}{|c|}{5} & \multirow[t]{2}{*}{6} & \multicolumn{2}{|c|}{$\begin{array}{c}\text { Detalhe } \\
\text { Questão } 5 \text { b }\end{array}$} \\
\hline & & a & b & & & a & & & & & \\
\hline & $\begin{array}{c}38, \\
5\end{array}$ & $\begin{array}{c}46 \\
2\end{array}$ & $\begin{array}{c}53 \\
8\end{array}$ & $\begin{array}{c}92 \\
3\end{array}$ & $\begin{array}{c}92, \\
3\end{array}$ & 77 & I & II & $\begin{array}{c}46, \\
2\end{array}$ & - & - \\
\hline Negativa & $\begin{array}{c}61, \\
5\end{array}$ & $\begin{array}{c}53 \\
8\end{array}$ & $\begin{array}{c}46 \\
2\end{array}$ & 7,7 & 7,7 & 33 & III & IV & $\begin{array}{c}53, \\
8\end{array}$ & 38,5 & 61,5 \\
\hline $\begin{array}{c}\text { TOTAL } \\
\text { (Positiva + } \\
\text { negativa) }\end{array}$ & & & & & 100 & & & & & & \\
\hline
\end{tabular}

\section{C) BRASIL + ESTRANGEIROS}

\begin{tabular}{|c|c|c|c|c|c|c|c|c|c|c|c|}
\hline \multirow{2}{*}{$\begin{array}{l}\text { QUESTÃO } \\
\text { RESPOSTA }\end{array}$} & \multirow[t]{2}{*}{1} & \multicolumn{2}{|c|}{2} & \multirow[t]{2}{*}{3} & \multirow[t]{2}{*}{4} & \multicolumn{3}{|c|}{5} & \multirow[t]{2}{*}{6} & \multicolumn{2}{|c|}{$\begin{array}{c}\text { Detalhe } \\
\text { Questão } 5 \text { b }\end{array}$} \\
\hline & & $\mathbf{a}$ & b & & & a & & & & & \\
\hline Positiva & $\begin{array}{c}58, \\
5\end{array}$ & $\begin{array}{c}56 \\
1\end{array}$ & $\begin{array}{c}80 \\
5\end{array}$ & $\begin{array}{c}97, \\
6\end{array}$ & $\begin{array}{c}97 \\
6\end{array}$ & $\begin{array}{c}65 \\
9\end{array}$ & 1 & II & $\begin{array}{c}53 \\
7\end{array}$ & 14,0 & , \\
\hline Negativa & $\begin{array}{c}41 \\
5\end{array}$ & $\begin{array}{c}43 \\
9\end{array}$ & $\begin{array}{c}19, \\
5\end{array}$ & 2,4 & 2,4 & $\begin{array}{c}34, \\
1\end{array}$ & III & IV & $\begin{array}{c}46, \\
3\end{array}$ & 48,8 & 26,8 \\
\hline $\begin{array}{c}\text { TOTAL } \\
\text { (Positiva + } \\
\text { negativa) }\end{array}$ & & & & & 100 & & & & & & \\
\hline
\end{tabular}




\section{Questão 1 (tema 3) \\ O que achou da navegação? \\ Questão 2 (tema 3) \\ a) $\mathrm{O}$ que achou dos recursos zoom, pan e as mudanças de escalas? \\ b) $\mathrm{O}$ que achou dos pop ups (caixas de texto) contidos nos mapas?}

$\left.1^{\circ}\right)$ As respostas dadas às questões baseadas em alternativas mostraram que, na média geral, considerados brasileiros e estrangeiros, a navegação foi considerada positiva, mas apenas regular para $58,5 \%$ dos entrevistados, sendo que $61,5 \%$ dos estrangeiros acharam a navegação ruim. A reação não foi muito diferente quanto à interatividade. A questão 2 a recebeu uma média geral menor ainda $(56,1 \%)$. O melhor resultado conseguido entre os brasileiros não ultrapassou os $61 \%$. Os pop ups obtiveram uma média geral positiva, alcançando $80 \%$.

$\left.2^{\circ}\right)$ Quanto às dissertativas, apesar de respostas como "Adorei ver as fotos da cidade" (Assistente de diretoria, 40, SP), outros entrevistados apontaram falhas ocorridas durante o processo de navegação e interatividade: "Navegação não muito direta - confusa" (consultora, 37, SP); "I didn't know where to click, navigation to the other maps were strange" (cartógrafo, 30, Alemanha); "Alguns detalhes de navegação devem ser revistos"..."um pouco confuso para abrir os pop ups" (arquiteta, 43, SP); "Não foi possível ter uma visão geral do mapa na tela" (psicóloga, 35, SP).

\section{Questão 3 (tema 3) \\ 0 que achou dos desenhos, ilustrações nos mapas? \\ Questão 4 (tema 3) \\ O que achou do conteúdo disponibilizado?}

As respostas a essas questões evidenciaram que, mesmo com ressalvas, tanto brasileiros $(100 \%)$ quanto estrangeiros $(92,3 \%)$ aprovam categoricamente o uso das ilustrações e do tipo de conteúdo disponibilizado nos mapas turísticos.

\section{Questão 5 (tema 3)}

a) $O$ que achou do produto mapa-site?

b) Seu interesse em querer conhecer a localidade turística aumentou? 
$\left.1^{\circ}\right)$ As respostas alternativas revelaram que, na média geral, o produto mapa-site obteve uma aceitação de quase $66 \%$, sendo que as respostas positivas dos estrangeiros alcançaram os $77 \%$.

Já em relação aos entrevistados brasileiros que já conhecem a cidade e que gostaram do produto (questão $5 \mathrm{~b} I-21,4 \%$ ), somada a outra parcela que ficou motivada a conhecer Caxambu (questão $5 \mathrm{~b}$ III - 53,6) totalizam-se $75 \%$ de respostas positivas. Os estrangeiros também esboçaram um certo interesse em conhecer o destino (questões $38,5 \%$ ).

$2^{\circ}$ ) Das respostas dissertativas, uma exemplifica a reação esperada diante de um mapa-site: "Vou passar o carnaval de 2008 na cidade e já vou levar esse mapa comigo, achei tudo de bom e moderno. Aguçou minha curiosidade em conhecer a cidade" (Analista de Marketing, 21, SP).0

\section{Questão 6 (tema 3)}

a) $O$ que achou do acesso na mudança das páginas / telas? (download)

$\left.1^{\circ}\right)$ As respostas às questões formuladas com alternativas revelaram que este item também teve problemas, apresentando uma média geral positiva regular $(53,7 \%)$, sendo que entre os estrangeiros a rejeição chegou a quase $54 \%$.

$\left.2^{\circ}\right)$ Já as respostas dissertativas apontam falhas como: "achei o site um pouco pesado e olhe que tenho uma máquina core duo com 1 giga de memória" (Gestor ambiental, 46, SP). "Very slow through big file sizes" ... "slowly" (Cartógrafo, 30, Alemanha).

\section{4 - Análise dos resultados}

A amostragem estatística apresenta um total de setecentos e oitenta e dois questionários aplicados.

Os dados permitem fazer algumas afirmações quanto à eficácia, preferência e aceitação de três itens complementares, porém distintos, desta pesquisa:

Mapas temáticos para o setor do turismo.

Símbolos de informação pública adaptados às legendas de mapas turísticos.

> Protótipo de um mapa-site turístico. 


\section{Primeira afirmação}

\section{Os entrevistados aprovaram os mapas desenvolvidos.}

\section{Houve uma maior aceitação dos mapas pictóricos em relação aos convencionais}

\section{quanto à preferência do produto cartográfico direcionado ao setor do turismo}

As respostas dadas às questões formuladas com alternativas e as dissertativas ratificam a pesquisa anterior de Fiori (2003:187), que estabelece o mapa pictórico como um produto mais apropriado ao setor do turismo que o mapa convencional. Inicialmente, a preferência resulta do menor nível de exigência de abstração do produto. Isto significa que a pictografia facilita o processo de leitura do conteúdo representado, em especial, para o público leigo em cartografia.

A representação pictórica também consegue obter maior sucesso quando comparada as representações convencionais, devido ao seu poder de sedução gráfica, ou seja, seu traço "menos técnico" e mais rico em detalhes proporciona uma maior atração estética e lúdica ao produto cartográfico. Esses recursos, sendo bem aproveitados, transformam o mapa em um produto de marketing para o turismo.

Kokkoken e Peltonen (1999) ressaltam que, ao promover uma destinação, a cartografia para o turismo deve estar atenta ao olhar do usuário, que vê a localidade como "produto". Logo, o cartógrafo deve fornecer impressões que possam ser convertidas em estímulo, trazendo concepções realistas sobre a qualidade do tipo de lugar e suas oportunidades para férias.

Sendo assim, além da funcionalidade (normas, regras, técnicas), o mapa turístico deve ter um visual prazeroso e remeter a emoções - vontade, curiosidade de conhecer as atrações propositalmente preparadas e ilustradas - permitindo que o turista planeje suas atividades em seu tempo de descanso. A pictografia permite formas de representação bem aceitas tanto pelo turista quanto pelos agentes de viagens. Atualmente, sabe-se que boa parte dos mapas utilizados pelo setor é pictórica. Portanto, pensar em formas de representação, referenciadas na cartografia e produzidas com um uso mais efetivo da pictografia, é uma necessidade.

É importante esclarecer que esta pesquisa não está preocupada em produzir mapas para ver e sim para ler (rever páginas 97-100). Mesmo os denominados mapas convencionais, elaborados ao longo do trabalho fazem uso, em menor grau, da pictografia, e por conseqüência, de padronizações e convenções não impostas pela fisiologia e pela alta abstração. 
No entanto, a aquisição mais lenta do conteúdo é proposital, pois, como já foi mencionado, o leitor precisa se envolver, e literalmente viajar pelo mapa. Todavia, deve compreender o que vê.

Para finalizar, mencione-se que Fiori (1999:106) vivenciou a utilização do recurso pictográfico em uma escola no ensino fundamental. Durante um teste com mapas, uma professora da sala relatou que os alunos demoravam mais tempo para responder o mapa pictórico porque, despendiam um tempo maior observando, admirando, lendo o material. Todavia, conseguiu-se o objetivo principal: atrair, seduzir o aluno à leitura do mapa, conseqüência de uma informação que estava mais próxima da realidade do público escolhido.

\section{Segunda afirmação}

Quase $\mathbf{7 0 \%}$ dos oitenta e dois símbolos de informação pública foram respondidos corretamente (contexto + símbolo)

Na média entre brasileiros e estrangeiros, 70 dos 86 símbolos de informação pública obtiveram uma média de aceitação superior a $\mathbf{7 0 \%}$

As respostas dissertativas (questionário in loco nos quatorze municípios) e as dadas às questões formuladas com alternativas (questionário do site, dividido entre brasileiros e estrangeiros) permitem reflexões quanto referentes aos oitenta e dois símbolos de informação pública analisados.

Em geral, a relação de pictogramas que receberam os maiores ou menores níveis de acerto (questionário respostas dissertativas) e aceitação (questionário respostas alternativas) são os mesmos nos três questionários aplicados.

Fica evidente que o símbolo em conjunto com o texto proporciona um auxílio fundamental a boa parte dos pictogramas, basta comparar a pontuação obtida pelos questionários: in loco e os do site.

No entanto, pode-se afirmar que alguns pictogramas são eficazes, mesmo não utilizando o texto complementar. São eles os que representam o: aeroporto, restaurante, sorveteria, hotel, correio, supermercado, hospital, praia, telefone público, banco, vôlei, natação, futebol, tênis, golfe, basquete, asa delta, igreja, teleférico, táxi, posto de gasolina, lanchonete, e internet. Ao olhar as respostas dissertativas dadas a esses pictogramas, percebe-se que os poucos entrevistados, mesmo que não acertassem exatamente o contexto, chegaram muito próximos do significado pretendido pelo produtor. 
Já outros pictogramas, mesmo recebendo boa pontuação / aceitação, aproximamse mais do que se quer informar quando acompanhados do texto verbal (símbolo + texto $=$ redundância). Logo, o usuário vai a legenda para ler o que o pictograma significa, e posteriormente, não precisa mais do recurso para interpretar a informação, pois o símbolo de informação pública se faz claro e não é mais preciso voltar à legenda.

Nesse caso se destacam os pictogramas de rodoviária, porto, metrô, heliponto, estação ferroviária, balsa, estacionamento, praça / área para piquenique, acesso para deficiente físico, camping, pára-quedismo, balonismo, esqui na neve, cafeteria, mergulho, farol, danceteria / salão de dança, esqui aquático, surfe, caverna, teatro, hipismo, autódromo / cartódromo, ciclismo / ciclovia, cooper / corrida e biblioteca. Outros pictogramas como os que representam o bondinho, parque de diversão, cachoeira, zoológico, trailer, jet ski, parque, delegacia, informação turística, playground, banheiro público, cervejaria e bar encontram-se nesta relação mesmo recebendo uma pontuação menor, porque, com o efetivo auxilio do texto-legenda, recebem um esforço particular para que aconteça uma boa interpretação do símbolo.

Existem ainda os pictogramas específicos, cuja significação requer o conhecimento da cultura, atividade ou serviço que ele representa para que a informação possa ser compreendida. Nesse caso, o texto ao lado do símbolo é mais do que um tradutor, pois também esclarece o que significa o elemento representado. Relacionam-se aqui os pictogramas: rapel / alpinismo, caiaque / canoagem, windsurfe, trekking / caminhada. Já nos símbolos Mesquita e Sinagoga é visível a necessidade de referências culturais para a compreensão do grafismo. Ao ser referenciado no Ocidente, o pictograma Igreja atinge altos valores de compreensão $(93,4 \%)$ e aceitação (82\%) nos dois questionários usados (in loco e site). É seguido pelo pictograma Sinagoga, associado aos judeus, ao judaísmo, Estrela de Davi, Israel $(41,3 \%$ e $78 \%)$. Já o pictograma Mesquita é associado, em sua grande maioria, a lua e a noite, apresentando uma menor compreensão $(23,8 \%)$ e aceitação (66\%).

Por fim, mencionem-se os pictogramas que se referem a conceitos amplos e / ou um traçado distante daquilo que se pretende informar. Nesse caso, além do texto como apoio, dever-se-ia pensar em alguma alteração gráfica no pictograma que pudesse aprimorar seu teor informacional. Enquadram-se ali os símbolos locação / aluguel de carro, shopping / Compras, artesanato, oficina mecânica, guarda malas / guarda volumes, monumento, marina / atracadouro, bebedouro, pousada e barco / barco a vela. 
Quatro símbolos merecem uma consideração especial:

- Construção histórica - o produtor errou ao inserir, na mesma pergunta, dois símbolos que significavam a mesma coisa, mas em locais diferentes, isto é, a "torre" é usada para indicar construções históricas em alguns mapas europeus, enquanto a "casa" é utilizada em placas de sinalização turística no Brasil.

- Albergue da juventude - a confecção do pictograma foi inspirada no símbolo utilizado pela organização dos albergues da juventude, localizados em todo o mundo. Dessa forma, o símbolo não merece correção, mas que deve ser pelos usuários de albergues.

- Vista panorâmica - é um pictograma verdadeiramente ruim, como se pôde comprovar nas duas pesquisas trabalhadas. Os níveis de compreensão (10\%) e aceitação (54\%) foram muito baixos. Deve, portanto, ser elaborado um outro pictograma para o tema.

- Museu - também mereceria reformulação: mesmo sendo um pictograma mundialmente conhecido e utilizado em placas de sinalização turística, apresenta um nível de aceitação e compreensão baixo (65\% e $20 \%)$. Somese ao problema, o fato já mencionado de que mais de $50 \%$ dos entrevistados interpretaram o símbolo referente a museus como se representasse um circo.

Esta pesquisa confirma alguns resultados já registrados em Fiori (2003: 177-178) sobre a utilização dos símbolos de informação pública em legendas para mapas turísticos.

\section{Terceira afirmação}

Há interesse na utilização de textos em mapas turísticos

Corroborando a pesquisa empírica de Fiori (2003:189), a maioria dos entrevistados aprovou a utilização de textos verbais na parte inferior do mapa por proporcionarem informações complementares acerca dos atrativos turísticos. Entretanto, os quase $17 \%$ de rejeição desse recurso, somados aos comentários expostos nas respostas dissertativas, alertam para a necessidade de ter cuidado com a quantidade de caixas-texto, pois informações em demasia podem gerar um resultado inverso, já que a poluição visual é capaz de dificultar e até confundir o usuário, prejudicando a eficiência do produto cartográfico. 


\section{Quarta afirmação}

\section{Os entrevistados acharam o mapa-site regular}

\section{A navegação e a interatividade precisam ser melhoradas no protótipo mapa-site turístico}

Cabe aqui uma justificativa referente à baixa avaliação do protótipo mapa-site turístico. Desde o momento em que o site da pesquisa foi disponibilizado na Internet, percebeu-se que vários itens interativos poderiam e deveriam ser melhorados ou modificados. Entretanto, havia três fatores limitadores:

1) O tempo para o desenvolvimento do mapa-site foi curto (3 semanas).

2) A elaboração do produto necessitava de recursos técnicos e de um profissional mais adequado, o que elevaria o custo do projeto.

3) Não houve tempo suficiente para realizar um pré-teste.

Por exemplo, o modo como foram elaborados os pop ups, onde a informação (texto e/ou figura) só mantinha aberta se o cursor permanecesse sobre a caixa, ou então, a falta de indicações mais claras e diretas ao internauta, o que fez com que grande parte dos entrevistados não conseguisse ou tivesse dificuldades em acessar a seqüência dos quatro mapas em zoom (escala menor para maior) até chegar ao questionário do tema 3 . Essa limitação é flagrante quando se compara a quantidade de sujeitos que responderam os outros temas:1 e 2 (ver tabelas $11 \mathrm{~A}$, B e C).

O acesso ao tema 3 pôde ser melhorado quando foi inserida no site uma página de advertência sobre como prosseguir para chegar ao questionário (Figura 110).

Um último problema apontado foi o tempo de download para abrir principalmente às páginas do mapa-site turístico de Caxambu. $O$ que já se faz é disponibilizar o mesmo mapa em resoluções (dpi) diferentes, ou seja, na página do site (tela do computador), o mapa tem uma resolução menor do que quando disponibilizado para impressão. 
Figura 110 - A advertência para acesso no tema 3 do site

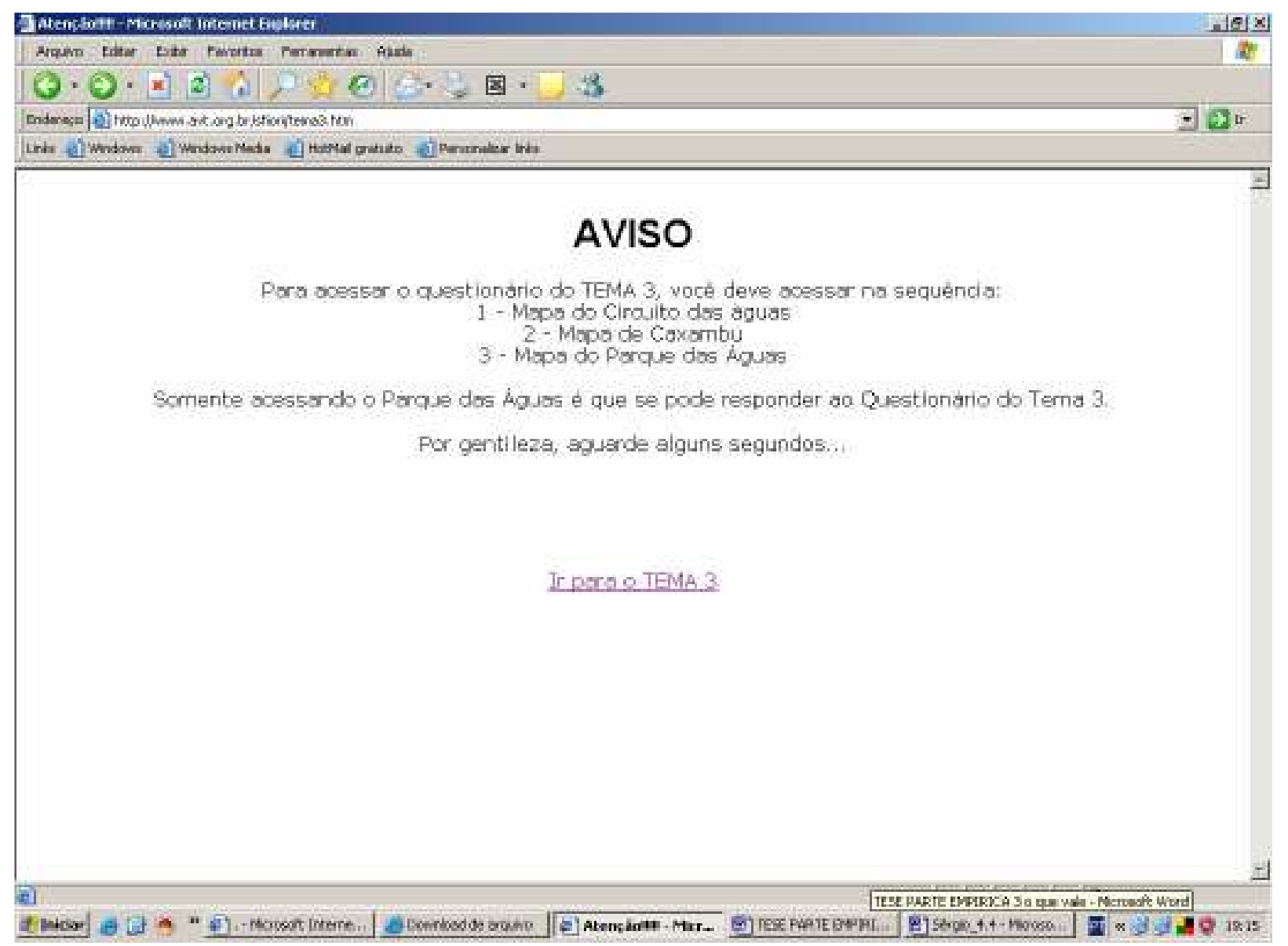

\section{Quinta afirmação}

Os entrevistados aprovaram as formas de

representação (arte) e o conteúdo do protótipo mapa-site

A média geral e particular (brasileiros ou estrangeiros) ultrapassou 90\% de aprovação. $O$ fato só reforça e legitima ainda mais a pictografia como recurso gráfico e visual muito importante em mapas temáticos para o setor do turismo (ver a segunda afirmação) e, neste caso, adaptada ao meio digital e interativo.

Mesmo com a alta aprovação dos itens, os entrevistados alertam para a grande quantidade de informação (textos, ilustrações), que, se reduzidas, podem melhorar ainda mais o produto.

Para serem mais eficientes, os mapas do protótipo mapa-site de Caxambu deveriam ter uma quantidade menor de informações dispostas sobre cada mapafundo. Essas informações poderiam ser distribuídas em pop ups e em uma legenda 
com layers (camadas, tópicos) que seriam habilitados segundo a vontade do usuário.

As cinco afirmações encerram mais uma etapa de pesquisas teórico-aplicadas que articula e analisa a cartografia temática e o uso da pictografia. A disposição e o aprofundamento nesta linha de discussão é decorrente do que autores como Oliveira (1993) e Taylor (1991) destacam ao afirmar que a avaliação do material cartográfico tem início em perguntas simples, porém fundamentais, como:

$\checkmark$ Para que ou por que esse mapa?

$\checkmark$ Que tipos de usuários têm necessidade dele?

$\checkmark$ Qual a finalidade do material a ser confeccionado?

Tais indagações permitem segmentar o público potencial para o material que é proposto, oferecendo orientações para o direcionamento do trabalho.

Kolacny (1994) pondera que o mapa só atinge seu objetivo quando o produtor considera a produção e o consumo como dois processos interligados. Por isso, desde a primeira pesquisa que nos propusemos fazer, sempre foram elaborados testes e análises empíricas após o planejamento e posterior confecção do material idealizado. Acredita-se se essa a maneira mais acertada de quantificar e qualificar a eficácia do produto finalizado. Colocam-se então, duas situações distintas, mas complementares, desenvolvidas durante o processo de comunicação elaborado por Board (1996):

Primeiro, como produtor - o profissional tem a obrigação de desenvolver uma abordagem teórico-metodológica cuidadosa e direcionada. Conseqüentemente, ao estabelecer o setor do turismo a ser atingido e o turista como público potencial, o produtor deve estar habilitado e preocupado (teoria e prática) em elaborar materiais o mais adequado possível ao grupo previamente selecionado.

Segundo, como usuário - auxiliado por questionários, o produtor busca se colocar no lugar do usuário. As análises das respostas ajudam a verificar qual o nível de eficácia obtido durante o processo que transmitiu a informação.

A decisão de privilegiar os símbolos pictóricos não foi tomada ao acaso. Os trabalhos desenvolvidos anteriormente (ver Fiori: 1999) com 120 alunos do ensino fundamental e com 160 pessoas divididas entre moradores locais e turistas (Fiori: 2003) apontam um instigante e desafiador campo de pesquisa: para uma maior discussão do uso da arte e, por conseqüência, da pictografia e da visão oblíqua em mapas para turistas e leigos em cartografia. Some-se ainda, a discussão sobre o mapa impresso e a sua adequação ao meio digital interativo. 


\section{CONSIDERAÇÕES}

FINAIS 


\section{4 - Considerações finais}

De acordo com a linha de estudo adotada, a história da cartografia, em todo registra inúmeras e distintas formas de representação do espaço; logo, é preciso dar à devida importância ao contexto cultural em que o mapa está inserido.

No caso da cultura ocidental, pode-se afirmar que os mapas sempre representaram o espaço com os olhos de um determinado tempo e de uma cultura. Isso ocorreu desde as primeiras representações espaciais feitas em pedra e barro na Antigüidade; passou pelos mapas com visões teocêntricas da Alta Idade Média; por aqueles que serviam como documento de legitimação e conquista de terras nos séculos XV e XVI; pelos utilizados nas guerras européias dos séculos XVIII e XIX, chegando finalmente ao sensoriamento remoto e ao geoprocessamento no século $\mathrm{XX}$.

Entretanto, durante um significativo período do século passado, os mapas de culturas não-européias só receberam alguma atenção da parte dos historiadores ocidentais quando possuíam certas semelhanças com os mapas europeus. Por exemplo: deveriam oferecer um sistema de orientação, escalas regulares e elementos da geometria euclidiana. Analisar o porquê destas diferenças não era uma tarefa cogitada.

Essa visão cientificista começou a mudar em 1987 com J. B. Harley e D. Woodward que, no primeiro dos quatro volumes da História da Cartografia, adotaram uma definição de mapa que permitia introduzir um possível relativismo no estudo histórico das cartas geográficas. A iniciativa fez com que se reconhecesse a diversidade das representações do espaço no grande mosaico da cultura humana universal.

Independentemente dos discursos e formalismos (suposta certeza e erro), cada mapa tem um porquê existencial, isto é, a forma está diretamente relacionada com a sua função. E é por isso que esta pesquisa discute e propõe a elaboração de mapas temáticos voltados ao setor do turístico, e posteriormente, sua adaptação ao meio digital, fazendo uso de recursos interativos. Aliás, a elaboração dos mapas turísticos não descarta a cartografia convencional e abstrata pautada nas convenções matemáticas e nas novas tecnologias do século XXI. Pelo contrário, todo esse conteúdo é utilizado e readaptado, procurando um resgate histórico, ou seja, o reviver daquela época em que se fazia uso mais freqüente da pictografia nos mapas.

Esse resgate acontece em um momento histórico em que as viagens a longas distâncias se tornaram rápidas e comuns, possibilitando que as pessoas conheçam outros atrativos naturais e culturais dentro ou fora de seu país. Portanto, ao pensar na elaboração de um mapa para o setor do turismo, deve-se ter em mente três perguntas essenciais: para que, para quem e como fazer o mapa temático turístico. 
Até porque é o público potencial que deve conduzir o produtor do mapa na escolha de quais representações devem ser mais usadas e eficazes do que outras.

A eficácia do mapa se resume a dois tópicos: conseguir alcançar o entendimento (boa leitura, compreensão) e as expectativas (sedução) do público para quem o mapa é elaborado.

Justifica-se, então, o tema e o problema quanto à elaboração e à eficácia dos mapas e do protótipo mapa-site turístico: diferentes tipos de usuários merecem diferentes tipos de mapas. Sendo assim, os produtos oferecidos (impressos e virtuais) devem ser adequados ao público potencial (turista e leigos na semântica cartográfica) e também servir à destinação turística como um produto de marketing.

O passo seguinte apresenta questões trabalhadas por Fiori (1999 e 2003), que são retomadas e aprofundadas nesta tese, cumprindo três etapas seqüenciais:

\section{O fundamento teórico}

O mapa turístico, seja na versão convencional seja na pictórica, traz reflexões sobre a relação tempo-natureza-cultura. O empirismo do relativismo relativista admite que os instrumentos e as cadeias de comunicação, criadas ao longo do tempo, estabelecem assimetrias e igualdades, hierarquias e diferenças. Logo, os mundos só parecem comensuráveis e incomensuráveis quando ficam presos a "medidas que puderam ser medidas". Essa linha de raciocínio possibilitou o enfoque interdisciplinar da pesquisa, principalmente entre os campos da Antropologia, da Lingüística, da Geografia, da Cartografia e do Turismo, e temas relacionados como o hibridismo, a comunicação, o espaço, a paisagem, a percepção, a leitura e interpretação do mapa, a arte e os símbolos, os atrativos naturais e culturais (material e imaterial), etc.

Em suma, a elaboração de mapas temáticos para o turismo apresentou diferentes graus de representação da mesma realidade selecionada, que se caracteriza por um maior ou menor nível de abstração dos símbolos. Além disso, a posterior elaboração do mapa-site turístico trabalhou a interatividade no meio digital, o que possibilitou a identificação de múltiplas escalas e uma grande quantidade de informações que podem ser habilitadas e desabilitadas por meio de botões, pop ups, entre outros recursos.

\section{O design e as técnicas}

A base teórica orienta o planejamento de como trabalhar o conteúdo, ou seja, o que se quer dizer; a forma, ou o meio de expressão a ser utilizado, graças ao controle exercido pela técnica. Inicialmente se apresentam os elementos visuais e gráficos indispensáveis à elaboração dos mapas, sejam eles convencionais sejam pictóricos, e do protótipo mapa-site como os tipos de linha, as figuras e os sólidos 
geométricos, os diferentes tipos de perspectivas, a cor, a luz e sombra, a textura, a proporção, o zoom estático em etapas, os recursos pop up, pan, etc.

O efetivo processo de representação dos mapas convencionais, dos elementos interativos do protótipo mapa-site turístico e de toda a diagramação final ocorre exclusivamente em meio digital. Já nos mapas pictóricos, a maior parte das ilustrações foram concebidas analogicamente, sendo posteriormente digitalizadas e colorizadas no computador. O procedimento possibilitou ao produtor mesclar técnicas analógicas e digitais na busca de um material diversificado, que permitisse diferentes tipos de representação e esteticamente mais atraente ao público potencial.

Os materiais utilizados vão desde lápis, papel vegetal, folha branca e caneta nanquim, até os recursos encontrados nos programas CorelDRAW, Photoshop e Dreamweaver.

\section{Avaliação empírica}

Após a finalização técnica e prática, partiu-se para a etapa de entrevistas, testes e análises dos mapas e do protótipo mapa-site turístico da cidade de Caxambu.

Os questionários foram desenvolvidos para averiguar três tópicos referentes à eficácia, preferência e aceitação de três itens complementares, porém distintos:

> Mapas temáticos para o setor do turismo.

> Símbolos de Informação Pública adaptados às legendas de mapas turísticos.

Protótipo de um mapa-site turístico.

A aplicação dos questionários ocorreu de duas maneiras diferentes:

> In loco - Durante uma das atividades oferecidas em um curso de qualificação de professores (Projeto Caminhos do Futuro) desenvolvido em 14 estados brasileiros.

$>$ Internet - Acesso ao site da pesquisa.

As três etapas acima ajudaram a investigar três hipóteses, estabelecidas no início da pesquisa, e permitiram fazer as seguintes afirmações:

1) Os mapas pictóricos têm maior aceitabilidade e preferência dos usuários durante a estada na destinação, além de serem mais adequados para incentivar o turismo. A hipótese, construída em trabalhos anteriores, (Fiori: 1990 e 2003), foi novamente confirmada o que estabelece a consistência e o interesse por esse tipo de produto.

2) O Símbolo de Informação Pública é um bom recurso gráfico de reconhecimento do conteúdo que se quer comunicar (atrativo, serviço, 
acomodação, etc), sendo possível uma simbologia padronizada em âmbito mundial. Além disso, pode ser habilmente utilizado e adaptado na elaboração de legendas para mapas turísticos.

3) A inserção dos mapas turísticos (convencionais e pictóricos) em meio digital interativo (protótipo mapa-site turístico) recebeu uma aprovação regular dos entrevistados. O grau de insatisfação pode ter ocorrido em conseqüência de uma finalização não-adequada do produto, que pode ser revisto e reavaliado.

A pesquisa aponta para a necessidade de uma discussão maior do uso da arte e, como conseqüência, da pictografia, da visão oblíqua e dos Símbolos de Informação Pública em mapas turísticos impressos e em meio digital interativo. Até porque, atualmente, é indiscutível que boa parte dos mapas do setor do turismo são pictóricos ou utilizam a pictografia em grande quantidade.

Pensar formas de representação que resultem de uma composição referenciada nas bases e convenções cartográficas praticadas hoje, somada ao uso mais efetivo da pictografia é um fato que precisa continuar a ser investigado. 


\section{5 - Bibliografia}

ALBUQUERQUE, L. Curso de história náutica. Lisboa: Alfa. 1989.

ALCÂNTARA, M. L. B \& SADER, R. T. Paisagem e cultura. Imaginário. São Paulo, n.5, p.83-89. 1999.

ALMEIDA, R. A.; GUERRERO; A. L. e FIORI, S. R. Caminhos do Futuro. Geografia e cartografia para o turismo. São Paulo: Ministério do Turismo, 2007.

ALZUA, A., O'LEARY J.T. \& MORRISON A. M. Cultural and heritage tourism: Identifying niches for international travelers. The Journal of Tourism Studies, v. 9, n.2, p.2-13. 1998.

ANDRÄ, H. \& FALCÃO, E. C. América preterida eventa. São Paulo: Indústria de Papel Leon Feffer S.A., 1966.

ARNOLD, L. M. Western Australia's Pilbara touring map. Cartography, v.21, n.1, p.17-20. 1992.

ARROWSMITH, C. \& NTUWAH, W. Mapping Potencial for tourist segments. Cartography, v.31, n.1, p. 55-61, 2002.

BARBOSA, I. S. Propaganda e significação: do conceito à inscrição psico-cultural. In: CORRÊA, T. G. Comunicação para o mercado. 2.ed. São Paulo: Edicon, p.3150.1995.

BARTHES, R. Crítica e verdade. São Paulo: Editora perspectiva, 1970. . Elementos de Semiologia. São Paulo: Cultrix, Editora da USP, 1971.

O óbvio e o obtuso: ensaios críticos III, Rio de Janeiro: Nova Fronteira, 1990.

BELLUZZO, A. M. M. O Brasil dos viajantes: a construção da paisagem. São Paulo: Metalivros - Fundação Emílio Odebrecht, 1994.

BENI, M. C. Análise estrutural do turismo. São Paulo: Senac, 1998.

BENKENSTEIN, M.; YAVAS, U. \& FORBERGER, D. Emotional and Cognitive antecedents of customer satisfation in leisure services: the case of the Rostok Zoo. Journal of Hospitality \& Leisure Marketing, v.10 (3/4), p.173-184, 2003.

BERTIN, J. New look at cartography. In: D.R.F. Taylor (ed.) Graphic Communication and Design in Contemporary. E.U.A: John Wiley \& Sons, p. 69$86,1983$.

Sémiologie Graphique: les diagrammes, les réseaux, les cartes. Paris: Monton \& Gauthier-Villars, 1967.

. Teoria da comunicação e teoria da representação gráfica.

Geocartografia, n.13, p.1-11,1996. 
. Ver ou ler: um olhar sobre a cartografia. Seleção de textos - Associação dos Geógrafos Brasileiros, n.18, p. 45-53,1988.

BOARD, C. Comunicação e recuperação de informações espaciais de mapas temáticos. Geocartografia, n.7, p.1-9, 1996.

BOSI, A. Reflexões sobre a arte. 7.ed., São Paulo: Ática, 2000.

BOURDIEU, P. A economia das trocas simbólicas. São Paulo: Perspectiva, 1974. . As regras da arte: gênese e estrutura do campo literário. São Paulo: Companhia da Letras, 1996. . O poder simbólico. 3.ed., Rio de Janeiro: Bertrand Brasil, 2000.

BRILL, A. Da arte e da linguagem. São Paulo: Perspectiva, 1988.

BROWN, A.; EMMER, N. \& WORM, J. VAN DEN Cartographic design and production in the Internet Era: the example of tourist web maps. The Cartographic Journal, v.38, n.1, p. 61-72, 2001.

BRUNS, C. B. Curso de formação de condutores. São Paulo, Tecnodata: 2000.

CABANELLAS, I. Dibujo. 2.ed., Espanha: Editorial Magistério Español S.A, 1976.

CALVINO, I. As cidades invisíveis. $12^{\mathrm{a}}$ reimpressão, São Paulo: Companhia das Letras, 1999.

CANCLINI, N. G. A socialização da arte: teoria e prática na América Latina. 2.ed., São Paulo: Cultrix, 1984.

. Culturas híbridas: estratégias para entrar e sair da modernidade.

4.ed., São Paulo: EDUSP, 2003.

CARNEIRO, R. J. B. Sinalização turística: diretórios e sistemas nacionais e internacionais. (Dissertação de Mestrado). Escola de Comunicações e Artes, Programa de Pós-Graduação em Ciências da Comunicação, Universidade de São Paulo, São Paulo. 2001, 206p.

CARTWRIGHT, W. \& HEATH, G. Geography as seen from the window: exploration bout viewpoint-specific images of geography defined by tools of visualization. Cartography, v.31, n.2, p.103-117, 2002.

. Hardware, software and staffing requirements of multimedia cartography: an update. Cartography, v. 25, p.67-80, 1996.

. Multimedia and mapping. Cartography, v. 22, p.25-32. 1993.

CASTNER, H. W. Education throught mapping: a new role for the school Atlas. Cartographica, v.14, p.72-91, 1987. 
CAVALCANTI, L. S. A construção de conceitos geográficos no ensino: Uma análise de conhecimentos geográficos em alunos de $5^{a}$. e $6^{a}$. séries do ensino fundamental. (Tese de Doutorado) Faculdade de Filosofia, Letras e Ciências Humanas, Departamento de Geografia, Universidade de São Paulo, São Paulo. 1997, 118p.

$\mathrm{CHON}, \mathrm{K}$. Understanding recreational traveller's motivation, attitude and satisfation. The Tourist Review, n.1, p. 3-7, 1989.

CHRISTOFOLETTI, A. As perspectivas dos estudos geográficos. In: Perspectivas da Geografia. 2.ed. São Paulo: Difel, p.11-36, 1985.

CITELLI, A. Linguagem e persuasão. São Paulo: Ática, 1985. (série princípios)

CLARKE, L. M. An experimental investigation of communicative eficiency of point symbols on tourist maps. The cartographic Journal, v. 26, p.105-110, 1989.

COELHO, R. Da antropologia simbólica à antropologia cognitiva. Imaginário. n.1. p.11-39, 1993.

COLLINS-KREINER, N. Cartographic characteristics of current Christian pilgrimage maps of the Holy Land. Cartographica, v. 34, p. 45-53, 1997.

COMISSÃO PRÓ-ÍNDIO DO ACRE Atlas geográfico indígena do Acre. Acre: CPI/AC, 1996.

COSGROVE, D. \& DANIELS, S. Introduction: iconography and landscape. In: Theiconography of landscape: essays on the simbolic representation, design and use of past environments. Great Britain: Cambridge University Press, p.1-10, 1994.

. e JACKSON, P. Novos rumos da geografia cultural. In: CORREA, R. L. e ROSENDAHL, Z Geografia Cultural: um século (2). Rio de Janeiro: EdUERJ, p.15-32, 2000.

CROSHER, J. Os astecas. 15 ed., São Paulo: Melhoramentos, 2000.

CRUZ, O. Alguns conhecimentos básicos para fotointerpretação. Aerofotogeografia, v. 25, São Paulo: Instituto de Geografia-USP, p.1-13, 1981.

DACEY, M. F. Aspectos lingüísticos dos mapas e a informação geográfica. Boletim de Geografia Teorética, AGETEO, Rio Claro, v.8, n.15, p. 5-16, 1978.

DELANO-SMITH, C. Cartografia e imaginação. O correio da UNESCO. São Paulo: FGV, v.19, n.8, p.10-13, 1991. (Ed. em português)

DIENER, P. \& COSTA, M. F. A América de Rugendas: obras e Documentos. São Paulo: Kosmos, 1999.

Rugendas e o Brasil. São Paulo: Capivara, 2002.

DONDIS, A. D. (1991) Sintaxe da linguagem visual. São Paulo: Martins Fontes, 1991.

DREYER-EIMBCKE, O. O descobrimento da Terra: histórias da aventura cartográfica. São Paulo: Edusp e Melhoramentos, 1992. 
FALCÃO, G.M. Psicologia de aprendizagem. São Paulo: Ática, 1988.

FARINA, M. Psicodinâmica das cores em comunicação. 4. ed., São Paulo: Edgard Blücher Ltda e Modesto Farina, 1990.

FIORI, S. R. (2005a) Touristic maps: the challenge of using art in the digital era. In: XXII INTERNATIONAL CARTOGRAPHIC CONFERENCE. A Coruña. Mapping Approaches into a changing world. v.1. Espanha: International Cartographic Association, p.1-10, 2005.

- Atlas pictórico: proposta metodológica para a confecção e uso didático. (Trabalho de Graduação Individual) Faculdade de Filosofia, Letras e Ciências Humanas, Departamento de Geografia, Universidade de São Paulo, São Paulo, 1999, 130p.

- Confecção de mapas para o turismo: a "leitura" e as expectativas do público-alvo". Imaginário, n. 9, p.253-270, 2003 b.

Mapas Turísticos: o desafio do uso da arte na era digital. (Dissertação de Mestrado) Faculdade de Filosofia, Letras e Ciências Humanas, Departamento de Geografia, Universidade de São Paulo, São Paulo. 204p, 2003a.

- Técnicas de desenho e elaboração de perfis. In: VENTURI, L.A.B. Praticando Geografia: técnicas de campo e laboratório. 1. ed., São Paulo: Oficina de textos, p.211-223, 2005b.

FORREST, D. \& CASTNER, H. W. The design and perception of point symbols for tourism maps. The cartographic Journal, British Cartographic Society, London, v. 22, p.11-29, 1985.

. On the design of point symbols for tourist maps: enclosed or not enclosed is not the question! The cartographic Journal, v. 35, p. 79-81, 1998.

FRANKS, G. Landscapes: learn to drawn step by step. 3.ed. California: Walter Foster Publishing, Inc, 2003.

FURLAN, S.A. Lugar e cidadania: implicações sócio-ambientais das políticas de conservação ambiental - situação do Parque Estadual de Ilhabela na Ilha de São Vicente. (tese de doutorado - volume 1) Faculdade de Filosofia, Letras e Ciências Humanas, Departamento de Geografia, Universidade de São Paulo, São Paulo, 2000, 277p.

GALEFFI, R. Fundamentos da criação artística. São Paulo: Melhoramentos Edusp, 1977.

GALLARZA, M. G., SAURA, I. G. \& GARCíA, H. C. Destination image: towards a conceptual framework. Annals of tourism research, v. 29, p. 56-78, 2002.

GASPAR, M. (Manuscrito datado de 1594) Livro de Universal de derrotas, alturas, longetudes, e conhencenças. Códice 1507 da Biblioteca Nacional de Lisboa, 112 f. 
GEIGER, P. P. Turismo e espacialidade. In: Congresso Internacional de Geografia e Planejamento do Turismo "Sol e Território", 1995, São Paulo. Turismo e Geografia: reflexões teóricas e enfoques regionais. São Paulo: Hucitec, 1999.

GEPP, H. G. e FERREIRA, J. R. M de O. Um pouco de São Paulo. São Paulo: Imprensa Oficial do Estado, 2002.

GERBER, R.; BURDEN, P. \& STANTON, G. Development of public Information Symbols for tourism and recreational mapping. The cartographic Journal, v. 27: p.92-103, 1990.

GIRARDI, G. A cartografia e os mitos: ensaios de leituras de mapas. (Dissertação de Mestrado). Faculdade de Filosofia, Letras e Ciências Humanas, Departamento de Geografia, Universidade de São Paulo, São Paulo. 1997, 118p.

- Aventuras da leitura de mapas. In: SEEMANN, J. A aventura cartográfica: perspectivas, pesquisas e reflexões sobre a cartografia humana. Fortaleza: Expressão Gráfica e Editora, 2005, p. 61-72.

GNOTH, J, ZINS, A., LENGMUELLER, R. \& BOSHOFF, C. Emotion, mood, flow and motivation to travel. Journal of Travel \& Tourism Marketing, v. 9, n.3, p. 23-34, 2000.

GOLLEDGE, R. G.; JACOBSON, R. D.; KITCHINN, R., BLADES, M. Cognitive maps, spacial abilities, and humam wayfinding. Geographical Review of Japan, v. 73, n.2, p. 93-104, 2000.

GOMBRICH, E. H. Arte e ilusão: um estudo da psicologia da representação pictórica. 3 ed., São Paulo, Martins Fontes, 1995, 473p.

. La imagen y el ojo: nuevos estudios sobre la psicologia de la representación pictórica. 2.ed., Espanha: Alianza Editorial, 1991.

.; HOCHBERG, J. \& BLACK, M. Art, perception and reality. 5.ed.,

Baltimore and London: The Johns Hopkins University Press, 1992.

GOMES, P. C. C. Geografia e Modernidade. Rio de Janeiro: Bertrand Brasil, 1996.

GOOSSENS, C. Tourism information and pleasure motivation. Annals of Tourism Research, v.27, n.2, p.301-321, 2000.

GRELOT, J. P. Os agrimensores do espaço. O correio da UNESCO. São Paulo: FGV, 19(8):29-32, 1991.

GUERRERO, A. L. A. \& FIORI, S. R. A cartografia como elemento no turismo de aventura. In: UVINHA, R. R. Turismo de aventura: reflexões e tendências. São Paulo: Aleph, p.137-152, 2005. (Série turismo)

- A aprendizagem docente de conceitos elementares da

Geografia Física e da Cartografia de Base: um estudo de caso na região de Campo 
Limpo - SP. (Dissertação de Mestrado) Faculdade de Filosofia, Letras e Ciências Humanas, Departamento de Geografia, Universidade de São Paulo, São Paulo, 2004, 283p.

HALL, S. A identidade cultural na pós-modernidade. 8.ed., Rio de Janeiro: DP\&A editora, 2003.

HARLEY, J. B. A nova história da cartografia. O correio da UNESCO. São Paulo: FGV, v.19, n.8, p.4-9, 1991.

. e WOODWARD, D. - The History of Cartography. V.I-IV. Chicago:

The Chicago University Press, 1987.

. Maps, knowledge, and power. In: Cosgrove, D. \& Daniels, S. The iconography of landscape: essays on the simbolic representation, design and use of past environments. Great Britain: Cambridge University Press, p. 277-312, 1994.

INTERNATIONALE TOURISMUS BÖRSE Maps for tourists: a systematic approach to tourist cartography. In: International Tourist Fair, Berlin, p.163-168, 1987.

JOHNSTON, B. \& CARTWRIGHT, W. An historical overview of games and the spatial sciences within the learning environment. Cartography, v.29, n.2, p.65-73, 2000.

JOLY, F. A cartografia. Campinas: Papirus, 1990.

KEATES, J. S. Understanding maps. New York: Longman, 1982.

KOKKONEN, P. \& PELTONEN, A. Mapping lakelands: challenges $f$ map design for tourism. In: International Cartographic Conference, Ottawa, p.1-7, 1999.

KOLACNY, A. Informação cartográfica: conceitos e termos fundamentais na cartografia moderna. Geocartografia, n.2, p. 3-11, 1994.

KOZEL, S. Comunicando e representando: mapas como construções socioculturais. In: SEEMANN, J. A aventura cartográfica: perspectivas, pesquisas e reflexões sobre a cartografia humana. Fortaleza: Expressão Gráfica e Editora, p.131-149, 2005.

KRAAK, M-J. The cartographic visualization process: from presentation to exploration. The cartographic Journal, v. 35: p.11-15, 1998.

LATOUR, B. Jamais fomos modernos: Ensaio de antropologia simétrica. Rio de Janeiro: Ed. 34, 1994. (Coleção Trans)

LEUNG, L-F. \& LI, Z. Experimental evaluation of the effectiveness of graphic symbols on tourist maps. Cartography, v.31, p.11-20, 2002.

LEWIS, M. G. Rhetoric of the western interior: modes of environmental description in American promotional literature of the nineteenth century. In: Cosgrove, D. \& Daniels, S. The iconography of landscape: essays on the simbolic representation, design and use of past environments. Great Britain: Cambridge University Press, 
p.179-193, 1994.

LIMA, M. L. F. C. Eco(turismo) em áreas protegidas: um olhar sobre Fernando de Noronha. (Tese de doutorado) Faculdade de Filosofia, Letras e Ciências Humanas, Departamento de Geografia, Universidade de São Paulo, São Paulo. 2002, 306p.

LOWENTHAL, D. Geografia, experiência e imaginação em direção a uma epistemologia geográfica. In: CHRISTOFOLETTI, A. (Org.) Perspectivas da Geografia. 2.ed. São Paulo: Difel, p.103-141, 1985.

LUBBE B. Primary image as a dimension of destination image: an empirical assessment. Journal of travel \& tourism marketing, v.7, n.4, p.21-42, 1998.

MacEACHREN, A. M. How map work: representation, visualization and design. Guildford Press: New York, 1995.

Some Truth with Maps: a primer on Symbolization and design. Washington, D.C.: Association of American Geographers, 1994.

MACKAY, K. J. \& FESENMAIER, D. R. An exploration of cross-cultural destation image assessment. Journal of travel research, v.38, p.417-423, 2000.

Pictorial element of destination in image formation. Annals of tourism research, v.24, n.3, p.537-565, 1997.

MARTINELLI, M. Curso de cartografia temática. São Paulo: Contexto, 1991. (coleção: manuais contexto)

MAYHEW, D. J. Principles and guidelines in software user interface design. Englewood Cliffs: Prentice Hall, 1992.

MENNO-JAN, K. \& DRIEL, R. V. Principles of hipermaps. Computers \& Geosciences, v.23, n.4, p.457-464, 1997.

MILLER, S. \& PUPEDIS, G. Spatial interface design for the web - a question of usability. Cartography, v.31, n.2, p.119-134, 2002.

MONMONIER, M. How to lie with maps. 2.ed., Chicago and London: The University of Chicago Press, 1996.

MORAES, A. C. R. Ideologias geográficas. 4.ed., São Paulo: Hucitec, 2002. (Série Linha de Frente)

MOREIRA LEITE, M. L. Texto visual e texto verbal. In: FELDMAN-BIANCO, B. \& Desafios da imagem: fotografia, iconografia e vídeo nas ciências sociais. Campinas: Papirus, 1998, p. 37-49.

MOSCARDO, G. Making visitors mindful: principles for creating sustainable visitor experiences through effective communication. USA: Sagamore Publishing, 1999. (Advances in tourism applications series - volume two)

MUEHRCHE, P. C. Map use: reading, analysis, interpretation. 2.ed. Wisconsin: JP Publications, 1986. 
MUKAROVSKY, J. Escritos sobre a semiótica da arte. Lisboa: Editorial Estampa, 1981.

NORRILD, J. Las postales como geradoras de imagen de destino: El gaúcho y la identidad argentina. Estudios y Perspectivas en Turismo, v.10, p.113-130, 2001.

OLIVEIRA, C. Curso de cartografia moderna. Rio de Janeiro: IBGE, 1993.

OLIVEIRA, L. de Estudo metodológico e cognitivo do mapa. São Paulo: IGEOGUSP, 1978, 130p. (Série Teses e Monografias)

ORLANDI, E. P. As formas do silêncio: No movimento dos sentidos. 2.ed., Campinas: Ed. UNICAMP, 1997.

. Cidade dos sentidos. Campinas: Pontes, 2004.

. Discurso e texto: formulação e circulação dos sentidos. 4.ed.,

Campinas: Pontes, 2005.

OSBORNE, B. S. The iconography of nationhood in Canadian art. In: Cosgrove, D. \& Daniels, S. The iconography of landscape: essays on the simbolic representation, design and use of past environments. Great Britain: Cambridge University Press, p.162-178, 1994.

PADILLA, O. T. El Turismo: fenômeno social. 8.ed., México: Fondo de Cultura Económica, 1980.

PALMER, C. Tourism and the symbols of identity. Tourism Management, v.20, p.313-321, 1999.

PATIN, V. Tourisme et patrimoine. Paris: La documentation française, 2005.

PEDROSA, M. \& ARANTES, O. Forma e percepção estética: textos escolhidos II. São Paulo: Edusp, 1996.

PIRES, P. S. Ecoturismo no Brasil: uma abordagem histórica e conceitual na perspectiva ambientalista. (Tese de Doutorado), Faculdade de Filosofia, Letras e Ciência Humanas, Departamento de Geografia, Universidade de São Paulo, São Paulo. 1998. 218p.

Paisagem litorânea de Santa Catarina como recurso turístico. In: Congresso Internacional de Geografia e Planejamento do turismo "Sol e Território", 1995. Turismo - espaço, paisagem e cultura. São Paulo: Hucitec, 1996, p. 161-177.

PORTILLA, M. L. Os arquivos de Montezuma. O correio da UNESCO: São Paulo, FGV, n.8, p. 18-20, 1991.

PORTO ALEGRE M. S. Reflexões sobre iconografia etnográfica: por uma hermenêutica visual. In: FELDMAN-BIANCO, B. \& MOREIRA LEITE, M. L. Desafios da imagem: fotografia, iconografia e vídeo nas ciências sociais. Campinas: Papirus, p. 75-112, 1988. 
POTTER, S. R. () Illustrated maps on public display in Japan: geography and artistic tradition. Geographical Review of Japan, v.76, n.12, p.823-842, 2003.

PRINGLE, T. R. The privation of history: Landseer, Victoria and the highland myth. In: Cosgrove, D. \& Daniels, S. The iconography of landscape: essays on the simbolic representation, design and use of past environments. Great Britain: Cambridge University Press, p.142-161, 1994.

RAISZ, E. Cartografia Geral. 2.ed., Rio de Janeiro: Científica, 1969.

RAMIRES, R. R. Cartografia e cognição: aspectos de aprendizagem do mapa no início do processo de escolarização. (Dissertação de Mestrado) Faculdade de Filosofia, Letras e Ciências Humanas, Departamento de Geografia, Universidade de São Paulo, São Paulo, 1996. 175p.

RAMOS, F. P. Naufrágios e Obstáculos enfrentados pelas armadas da Índia portuguesa (1497-1653). São Paulo: Humanitas, 2000. (Série Iniciação)

REYES, M. C. Cibercartography from a modeling perspective. In: TAYLOR, D. R. F. Cybercartography: theory and practice. The Netherlands: Elsevier B.V., p. 63-97, 2005.

ROBINSON, A. H., MORRISON, J. L., MUEHRCKE, P. C.,KIMERLING, A. J. \& GUPTILL, S. C. Elements of cartography. 6.ed. E.U.A.: John Wiley \& Sons, Inc., 1995.

ROCHA-TRINDADE, M. B. Imagens e aprendizagens na sociologia e na antropologia. In: FELDMAN-BIANCO, B. \& MOREIRA LEITE, M. L. Desafios da imagem: fotografia, iconografia e vídeo nas ciências sociais. Campinas: Papirus, $p$. 159-171, 1988.

RODRIGUES, G. S. S. Representações da paisagem do Parque Nacional da Serra da Canastra - MG: o olhar do viajante, da população local e do geógrafo. (Dissertação de Mestrado) Faculdade de Filosofia, Letras e Ciências Humanas, Departamento de Geografia, Universidade de São Paulo, São Paulo. 2001, 110p.

SALVIA COELHO, L. M. Afinal o que é cognitivismo? Imaginário, n.1, p.41-72, 1993.

SAMAIN, E. Questões heurísticas em torno do uso das imagens nas ciências sociais. In: FELDMAN-BIANCO, B. \& MOREIRA LEITE, M. L. Desafios da imagem: fotografia, Iconografia e vídeo nas ciências sociais. Campinas: Papirus, p.51-62, 1988.

SANCHEZ, M. C. Conteúdo e eficácia da imagem gráfica. Boletim de Geografia Teorética, v.11, p.74-81, 1981.

SANTAELLA, L. O que é semiótica? 9.ed., São Paulo: Brasiliense, 1990.

SANTOS, M. A natureza do espaço: técnica e tempo, razão e emoção. São Paulo:

Edusp, 2002. 
SANTOS, M. Metamorfoses do espaço habitado. 4.ed., São Paulo: Hucitec, 1996. . Pensando o espaço do homem. 5.ed., São Paulo: Hucitec, 2004. . Por uma Geografia Nova: da crítica a geografia a uma gGeografia crítica. São Paulo: Edusp, 2002.

SEEMANN, J. Linhas imaginárias na cartografia: a invenção do primeiro meridiano. In: A aventura cartográfica: perspectivas, pesquisas e reflexões sobre a cartografia humana. Fortaleza: Expressão Gráfica e Editora, p.111-129, 2005.

SENAI - DIVISÃO DE MATERIAL DIDÁTICO. Desenho técnico e artístico. v.1, São Paulo: SENAI/SP, 1984.

SENAI - DIVISÃO DE MATERIAL DIDÁTICO. Perspectiva isométrica. v.4, São Paulo, SENAI/SP, 1984.

SENAI - DIVISÃO DE MATERIAL DIDÁTICO. Sólidos geométricos. v.3, São Paulo: SENAI/SP, 1984.

SEVERINO, A. J. Metodologia do trabalho cinetífico. 22.ed., São Paulo: Cortez, 2002.

SIMIELLI, M. E. Cartografia e ensino: proposta e contraponto de uma obra Didática. (Tese de livre docência) Faculdade de Filosofia, Letras e Ciências Humanas, Departamento de Geografia, Universidade de São Paulo, São Paulo, 1996. . Geoatlas. 12.ed., São Paulo: Ática, 1993.

.O mapa como meio de comunicação: implicações no ensino da geografia de $1^{\circ}$. Grau. (Tese de Doutorado) Faculdade de Filosofia, Letras e Ciências Humanas, Departamento de Geografia, Universidade de São Paulo, São Paulo, 1986. 205p.

SIRGY, M. J \& SU C. Destionation image, self-congruity, and travel behavior: toward an interative model. Journal of travel research, v.38, p.340-352, 2000.

SOUZA, S. R. M. Conteúdo, forma e função no design de pictogramas. In: CORRÊA, T. G. Comunicação para o mercado. São Paulo: Edicon, p.171-192, 1995.

. Do conceito à imagem: fundamentos do design de pictogramas. (Tese de doutorado) Escola de Comunicações e Artes, Programa de PósGraduação em Ciências da Comunicação, Universidade de São Paulo, São Paulo, 1992, 250p.

TANG, H. \& BISHOP, I. D. Integration methodologies for interative forest modeling and visualization systems. The Cartographic Journal, London, 39(1):27-35, 2002.

TAUBER, D. A. \& KIENAN, B. SIMCITY 2000: estratégias e segredos. São Paulo: Makron Books, 1995. 
TAYLOR, D. R. F. A conceptual basis for cartography: new directions for the information era. Cartographica, University Toronto Press, Toronto, 28(4):1-8, 1991.

. Challenge and response in cartographic deseign. In: KELLER,

C. H. \& WOOD, C.P. Cartographic design: theoretical and Practical perspectives. England: John Wiley \& Sons, p. 11-18, 1996.

The theory and practice of cybercartography: an introduction. In: Cybercartography: theory and practice. The Netherlands: Elsevier B.V., p.1-13, 2005.

THROWER, N. J. Uma nova imagem do mundo. O correio da UNESCO. São Paulo: FGV, n.8, p.25-28, 1991. (Ed. em português)

TUAN, Y. F. Topofilia: um estudo da percepção, atitudes e valores do meio ambiente. São Paulo: Difel, 1980.

TURNBULL, D. Maps are territories science is an atlas: a portfolio of exhibits. Austrália: University of Chicago Press, 1989.

VALDES, R. El acceso psicologico y la nocion de posicionamiento en el dominio del turismo. Estudios y Perspectivas en Turismo, v. 6, p. 53-76, 1997.

VASCONCELLOS, R. A cartografia tátil e o deficiente visual: uma avaliação das etapas de produção e uso do mapa. (Tese de doutorado volume I) Faculdade de Filosofia, Letras e Ciências Humanas, Departamento de Geografia, Universidade de São Paulo, São Paulo, 1993, 268p.

e ALVES FILHO, A. P. Novo Atlas geográfico ilustrado e comentado. São Paulo: FTD, 1999.

Tactile mapping design and the visually impaired user. In:

KELLER, C. H. \& WOOD, C.P. Cartographic design: theoretical and practical perspectives. England: John Wiley \& Sons, p.91-102,1996.

WAGNER, P. L. e MIKESELL, M. W. Temas da geografia cultural. In: CORREAA, R. L. e ROSENDAHL, Z. Geografia Cultural: um século (1). Rio de Janeiro: EdUERJ, p.111-167, 2000.

WOLFGRAM, D. E. Criando em multimídia. Rio de Janeiro: Campus, 1994.

WOLLHEIM, R. A pintura como arte. São Paulo: Cosac \& Naify, 2002.

WOOD, H. C. and KELLER, C. P. Design: Its pace in cartography. In: KELLER, C. H. \& WOOD, C.P. Cartographic design: theoretical and practical perspectives. England: John Wiley \& Sons, p.1-9, 1996.

WOOD, M. Visualization in historical context. In: MacEachren, A. M. \& D. R. F. Taylor Visualization in modern cartography. Pergamon, p.13-26, 1994. (Modern cartography, v. two) 
WURMAN, R. S. Ansiedade da informação: como transformar informação em compreensão. São Paulo: Cultura Editores e Associados, 1991.

\section{Sites}

AIGA. Disponível em: <http://www.aiga.org/content.cfm?content/D=147>. Acesso em: 2 set. 2005.

CAMINHOS DO FUTURO. Disponível em: <http://www.caminhosdofuturo.com.br/site/home/> Acesso em: 10 set. 2007.

CENTRO HISTÓRICO DE LA GRAN CIUDAD DE MÉXICO. Disponível em: <http://www.mapamex.com.> Acesso em: 12 dez. 2005.

CONHEÇA SALVADOR. Disponível em: <http://www.emtursa.ba.gov.br/Template.asp?nivel=00010001\&identidade=7>. Acesso em: 13 mar. 2007.

DESENHADOR VIRTUAL. Disponível em: < $<$ http://paginas.terra.com.br/arte/desenhadorvirtualcores/htm> Acesso em: 16 out. 2005.

ERCO. Disponível em <http://www.piktogramm.com> Acesso em: 2 set. 2005.

GEPP, H. G. e FERREIRA, J. R. M de O. Exposição dos mapas ilustrados da cidade de São Paulo. Disponível em: < http://www.geppemaia.com.br/mis/index. htm> Acesso em: 3 nov. 2004.

GUIA BRASILEIRO DE SINALIZAÇÃO TURÍSTICA. Disponível em: $<$ http://institucional.turismo.gov.br/sinalizacao/conteudo/principal.htm/> Acesso em: 28 set. 2005.

IDG NOW! Brasil cai três posições em ranking sobre web. Disponível em <http://idgnow.uol.com.br/AdPortalv5/InternetInterna_200405.htm/> Acesso em: 20 abr. 2005.

IDG NOW! Especial: qual a melhor tecnologia da banda larga? Disponível em: <http://idgnow.uol.com.br/AdPortalv5/Internet/nterna_060705.htm/> Acesso em: 6 set. 2005.

INPE-Manual do software Spring. Disponível em: <http://www.api.inpe.br/spring/teoria/ introd1/teoria1.htm> Acesso em: 25 de set. 2004.

MACMANIA.

$<$ http://www.terra.com.br/macmania/macmania/resenhas/resenhas_dtp.htm> Acesso: em 15 out. 2005.

MEC. Disponível em:<http://www.girus.com.br/noticias/visualiza.php?cod=3627> 
Acesso: em 5 set. 2007.

MAPA DO CENTRO DE CAXAMBU. Disponível em: <http://www.caxambu.mg.gov.br/turismo/mapadocentro.htm> Acesso em: 5 abr. 2006.

MAPA DO PARQUE DE CAXAMBU - Disponível em: <http://www.caxambu.mg.gov.br/turismo/mapadoparque.htm> Acesso em: 5 abr. 2006.

MAPA INTERATIVO DA BAHIA. Disponível em: $<$ ittp://www.emtursa.ba.gov.br/Template.asp? IdEntidade=7\&Nivel=00010001> MAPA INTERATIVO DE NEW JERSEY. Disponível em: <http://www.jersey.com/maps/> Acesso em: 15 set. 2007.

MAPA INTERATIVO DO DEPARTAMENTO DE GEOGRAFIA DA USP. Disponível em: <http://www.geografia.fflch.usp.br/mapas/> Acesso em: 26 jan. 2006.

MAPA INTERATIVO DO JAPÃO. Disponível em: <http://www.jnto.go.jp/eng/map/index_map.htm/\#> Acesso em: 15 set. 2007.

MAPA INTERATIVO DE TAIWAN. Disponível em: <http://202.39.225.132/jsp/Eng/html/map/index.jsp\#> Acesso em: 15 set. 2007.

MAPA INTERATIVO DE DUBLIN. Disponível em: http://www. visitdublin.com/travel/maps/dublin/ Acesso em: 15 set. 2007.

MAPA INTERATIVO DE WASHINGTON D.C.. Disponível em: <http://dcpages.com/cgi-bin/jump.cgi?/D=11576> Acesso em: 15 set. 2007.

UNESCO. Disponível em: <http://www.unesco.org.br/> Acesso em: 10 mai. 2007.

\section{Cartas}

FOLHA ASSUNCIÓN. Rio de Janeiro: IBGE, 1998. Mapa color, 75 x 60 cm, SG-21. Esc. 1:1.000.000.

FOLHA BARBACENA. Rio de Janeiro: IBGE, 1979. Mapa color, 75 x 60 cm, SF-23X-C. Esc. 1: 250.000.

FOLHA BARRAGEM. Recife: DSG, 1974. Mapa color, 72 x 62 cm, SC.23-X-B-VI, MI -1435, 1974, Esc. 1:100.000.

FOLHA CANTO DO BURITI. Recife: DSG, 1974. Mapa color, 72 × 62 cm, SC.23-XB-II, MI - 1356, Esc. 1:100.000.

FOLHA CARAGUATATUBA. Rio de Janeiro: IBGE, 1974. Mapa color, 75 x $60 \mathrm{~cm}$, SF-23-Y-D-VI-1. Esc. 1: 50.000. 
FOLHA CATARATAS DO IGUAÇU. Porto Alegre: DSG, 1997. Mapa color, 72 x 62 cm, SG.21-X-D-VI-1, MI - 2847/1, 1997, Esc. 1:50.000.

FOLHA CHAPADA DOS GERAIS. Recife: DSG, 1974. Mapa color, 72 × $62 \mathrm{~cm}$, SC.23-X-B-IV, MI - 1433, Esc. 1:100.000.

FOLHA CURITIBA. Rio de Janeiro: IBGE, 1998. Mapa color, 75 x 60 cm, SF-22. Esc. 1:1.000.000.

FOLHA FOZ DO IGUAÇU. Porto Alegre: DSG, 1997. Mapa color, 72 × $62 \mathrm{~cm}$, SG 21-X-D-V-2, MI - 2846/2, 1997, Esc. 1:50.000.

FOLHA GUARATINGUETÁ. Rio de Janeiro: IBGE, 1976. Mapa color, $75 \times 60 \mathrm{~cm}$, SF-23-Y-B. Esc. 1: 250.000.

FOLHA ITAIPU. Porto Alegre: DSG, 1998. Mapa color, 72 x 62 cm, SG.21-X-D-II-4, MI - 2831/4, Esc. 1:50.000.

FOLHA MANAUS. Brasília: DSG, 1999. Mapa color, 72 x 62 cm, SA.20-Z-D-II, MI 0578, Esc. 1:100.000.

FOLHA MANAUS-E. Brasília: DSG, 1994. Mapa color, 72 x 62 cm, SA.21-Y-C-I, MI - 0579, Esc. 1:100.000.

FOLHA MANAUS-N. Brasília: DSG, 1994. Mapa color, 72 × $62 \mathrm{~cm}$, SA.20-Z-B-VI, MI - 0517, 1994, Esc. 1:100.000.

FOLHA RIO DE JANEIRO. Rio de Janeiro: IBGE, 1998. Mapa color, 75 x $60 \mathrm{~cm}$, SF-23. Esc. 1:1.000.000.

FOLHA RIO PRETO DA EVA. Brasília: DSG, 1994. Mapa color, 72 × 62 cm, SA.21Y-A-IV, MI - 0518, Esc. 1:100.000.

FOLHA SANTA TERESINHA DE ITAIPU. Porto Alegre: DSG, 1997. Mapa color, 72 x $62 \mathrm{~cm}$, SG.21-X-D- III-3, MI - 2832/3, Esc. 1:50.000.

FOLHA SÃO JOÃO DO PIAUÍ. Recife: DSG, 1974. Mapa color, $72 \times 62 \mathrm{~cm}$, SC.23X-B-III, MI - 1357, Esc. 1:100.000.

FOLHA SÃO RAIMUNDO NONATO. Recife: DSG, 1974. Mapa color, $72 \times 62 \mathrm{~cm}$, SC.23-X-C-V, MI - 1511, 1974, Esc. 1:100.000.

FOLHA SÃO VICENTE. São Paulo: EMPLASA, 1974. Mapa p\&b, $58 \times 81 \mathrm{~cm}$, SF23-Y-D-IV-3-SE-C, Esc. 1: 10.000.

FOLHA SERRA DO CONGO. Recife: DSG, 1974. Mapa color, 72 × $62 \mathrm{~cm}$, SC.23X-B-V, MI - 1434, Esc. 1:100.000.

FOLHA VARGINHA. Rio de Janeiro: IBGE, 1979. Mapa color, 75 × 60 cm, SF-23-VD. Esc. 1: 250.000.

FOLHA VOLTA REDONDA. Rio de Janeiro: IBGE, 1976. Mapa color, $75 \times 60 \mathrm{~cm}$, SF-23-Z-A. Esc. 1: 250.000. 
PLANTA DE REFERÊNCIA CADASTRAL DE CAXAMBU. 1990, Esc. 1:5.000.

PLANTA DE REFERÊNCIA CADASTRAL DE MANAUS. 1998. Esc. 1:5.000.

PLANTA DE REFERÊNCIA CADASTRAL DE SÃO RAIMUNDO NONATO. 1997, Esc. 1:4.000.

\section{Mapas turísticos}

BARCELONA CITY MAP. GREMI d'HOTELS de BARCELONA: Barcelona, 2005.

BARCELONA CITY MAP. PLAN de la ville. Ajuntament de Barcelona: Barcelona, Espanha, 1992.

BARCELONA. Plano Monumental. Rivadeneyra Geoproyectos S.A: España, 1989.

CARTE DE FRANCE. Maison de la France: France, 2000.

CENTER CITY PHILADELPHIA and PHILADELPHIA'S COUNTRYSIDE.

Philadelphia Convention and Visitors Bureau: Philadelphia, 2001.

CIUDAD DE LA HABANA. Mapa turístico. Ediciones GEO: Cuba, 1993.

GIRONA. Ajuntament de Girona: Girona, não datado.

GLASGOW EVENTS. City guide \& map. Mapmasters: Edinburgo, 2001.

GUIA T DE BARCELONA. Barcelona: Planografico - N.G. Ediciones, Espanha, 1992.

GUIA TURÍSTICO DE OYAMA. Oyama: Japão, não datado.

ISRAEL-TOURING MAP. Ministry of Tourism: Jerusalém, 2000.

KILLARNEY Area Guide. Cork Kerry Tourism: Ireland, [s.d.].

LANDESHAUPTSTADT DÜSSELDORF. City-karte. Vermessungs-und Katasteramt Düsseldorf, 1992.

MAPA DE BUDAPEST. Tourism Office of Budapeste: Hungria, 2003.

MAPA DE HULL E OTAWA: WHERE TM Magazine: Ottawa, [s.d.].

MAPA DE LA CIUDAD DE MENDOZA E ALTA MONTANA. Artes Gráficas Unión:

Mendonza, 2004.

MAPA DE MANAUS. Perspectiva: Manaus, 2003.

MAPA SANTIAGO TURÍSTICO. SERNATUR: Santiago do Chile, 2005.

MAPA TURÍSTICO DA REGIÃO DE NAGANO. Kem: Nagano: [s.d.]

MAPA TURÍSTICO DA DUTRA. RDE Empreendimentos Publicitários Ltda: Rio de Janeiro, [s.d.]

MAPA TURÍSTICO DE CAXAMBU. Tour Mapas. Editora Buz: Caxambu, 2003. 
MAPA TURISTICO NACIONAL. Ediciones GEO: Cuba, 1996.

MISKOLC. Borsod-Abaúj-Zemplén. Tourinform: Hungria, 2004.

NIAGARA FALLS (Buffalo, Hamilton). Unique Media Incorporated: Ontário: $1997 / 98$.

OTTAWA VALLEY-VALLÉE DE L'OUTAQUAIS. Canada Centre for mapping: Ottawa, 1993.

PLANO DE MADRID. Cartografia Digital Rugoma: Madrid, 2005.

PLANO JOVEM DE A CORUÑA. Ayuntamiento de La Coruña: Guzman Norte, 2004.

POHJOIS-SAVON VESIRETKEILYREITIT JA-PALVELUT: Karttaikkuna Ou, Finlândia, 1999.

RED CAMINERA PRINCIPAL. Automóvil Club argentino: Argentina, 1988.

RÜGEN. Topographisch-Touristische Karte 1: 100.000: Herausgegeben, 1991.

SEATTLE. Tourmap Company: Seattle, 2005.

SHOPPING MAP. Menzoza: Global Refund, Argentina, 2005.

STORA STOCKHOLMSKARTAN. Stockholm Information Service: Suécia, 1997.

THE BEST OF SEAFORD - NEWHAVEN - ALFRISTON. Resort Maps: United Kingdom, 2004.

THE CITY OF CAMBRIDGE. Map and guide for shoppers \& Tourists. AERO-PLAN: Cambridge, 1995.

THE GOLDEN MAP BUENOS AIRES. Golden Company S. R. L.: Argentina, 1998.

TOLEDO. Junta de Cominidades de Castilla-La Mancha: Espanha, 2004.

VISITOR'S COMPANION. Colonial Williamsburg. The colonial Williamsburg Foundation: Virginia, 2000.

WESTERN CAPE. A bird's eye view. Tyger Valley centre: Durbanville, [s.d.]. datado. 


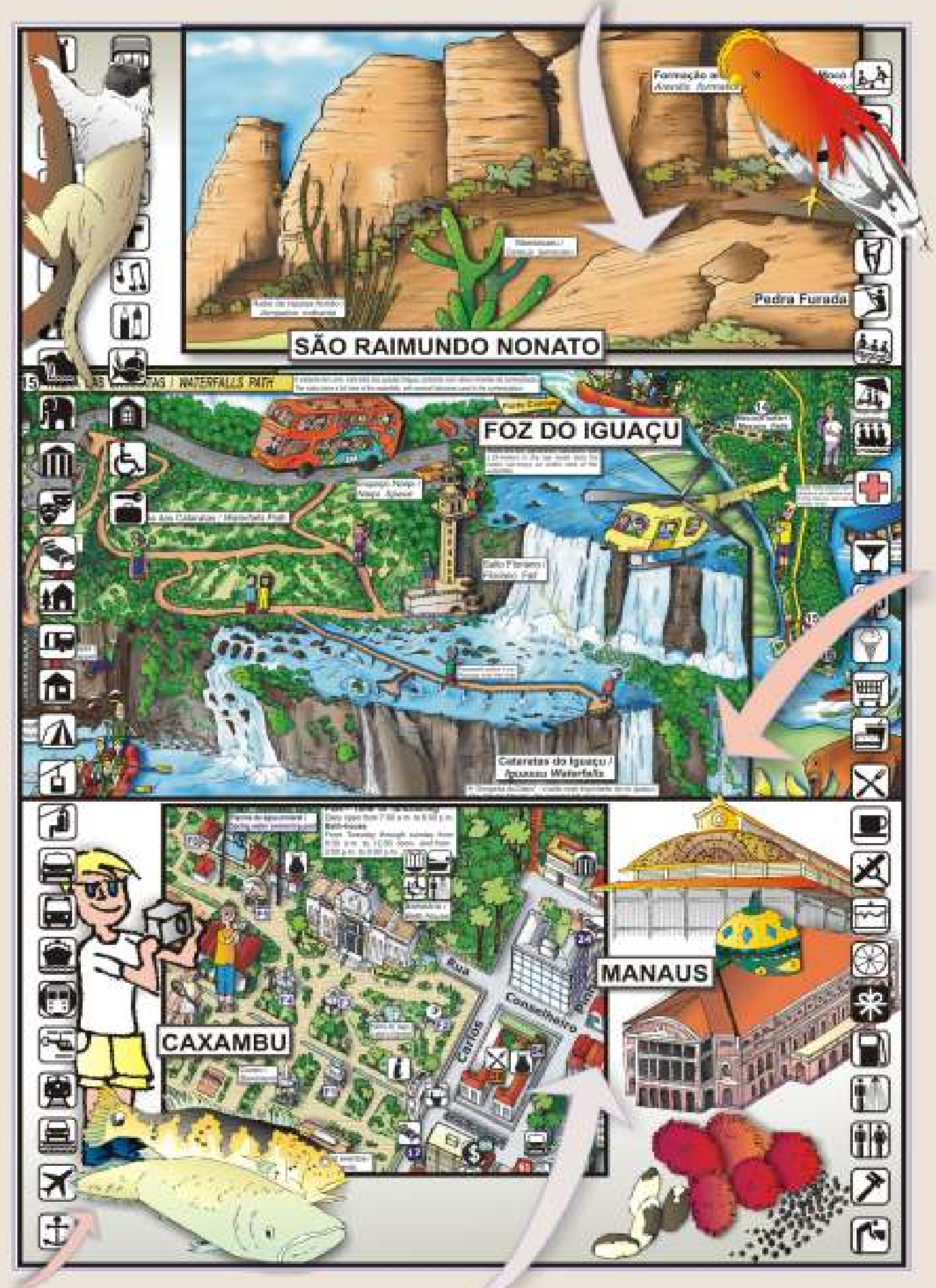




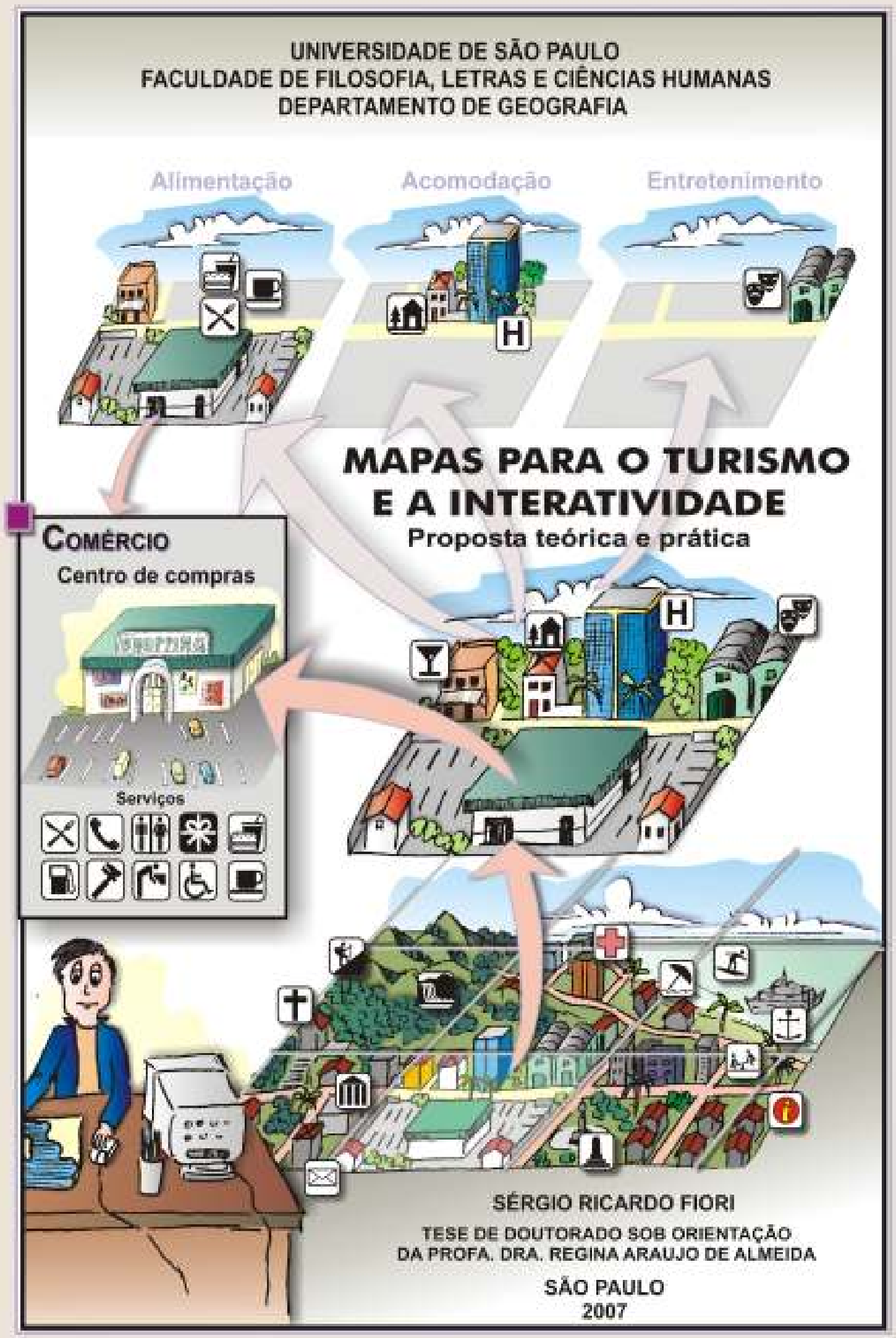




\author{
Universidade de São Paulo \\ Faculdade de Filosofia, Letras e Ciências Humanas \\ Departamento de Geografia \\ Programa de Pós-Graduação em Geografia Física
}

\title{
MAPAS PARA O TURISMO E A INTERATIVIDADE \\ Proposta teórica e prática
}

\author{
SÉRGIO RICARDO FIORI
}

TESE DE DOUTORADO SOB ORIENTAÇÃO DA PROFA. DRA. REGINA ARAUJO DE ALMEIDA

\section{SÃO PAULO}




\author{
Universidade de São Paulo \\ Faculdade de Filosofia, Letras e Ciências Humanas \\ Departamento de Geografia \\ Programa de Pós-Graduação em Geografia Física
}

\title{
MAPAS PARA O TURISMO E A INTERATIVIDADE
}

Proposta teórica e prática

\author{
SÉRGIO RICARDO FIORI
}

Tese apresentada ao Programa de Pós-Graduação em Geografia Física do Departamento de Geografia da Faculdade de Filosofia, Letras e Ciências Humanas da Universidade de São Paulo, para obtenção do título de Doutor em Geografia.

Orientadora: Profa. Dra. Regina Araujo de Almeida SÃo PAULO 
Finalmente, a viagem conduz à cidade de Tâmara. Penetra-se por suas ruas cheias de placas que pendem das paredes. Os olhos não vêem coisas, mas figuras de coisas que significam outras coisas: a torquês indica a casa do tira-dentes; o jarro, a taberna; as alabardas, o corpo de guarda; a balança, a quitanda. (...) Se um edifício não contém nenhuma insígnia ou figura, a sua forma e o lugar que ocupa na organização da cidade bastam para indicar a sua função: o palácio real, a prisão, a casa da moeda a escola pitagórica, o bordel. Mesmo as mercadorias que os vendedores expõem em suas bancas valem não por si próprias, mas como símbolos de outras coisas: a tira bordada para a testa significa elegância; a liteira dourada, poder; os volumes de Averróis, sabedoria; a pulseira para o tornozelo, voluptuosidade (...) O olhar percorre as ruas como se fossem páginas escritas (Calvino, 1999, p.18, 19). 


\section{AGRADECIMENTOS}

Mais uma vez agradeço a Deus por ter me concedido paciência durante a espera. Como resposta às inúmeras orações, recebi maturidade, mas também realizações e alegrias ao longo de minha carreira acadêmica e profissional.

À minha orientadora, Regina Araujo de Almeida que, ao longo de oito anos, me mostrou o que é ser uma pessoa generosa, amiga, presente, possibilitando que minhas aspirações e sonhos se tomassem reais, verdadeiros. Obrigado por sua proximidade, seus estímulos e conselhos, viagens e trabalhos, e por abraçar desde sempre o meu tema de pesquisa.

À professora doutora Maria de Lourdes Beldi de Alcântara, por sua importante presença em minha pesquisa desde o mestrado, pois, sem o seu auxílio, muitos fundamentos teóricos passariam desapercebidos. Além disso, levo como aprendizado seu grande amor pelo outro, seu desprendimento, sua simplicidade, alegria e profissionalismo.

Aos professores doutores Ailton Luchiari e Alfredo Pereira de Queiroz Filho, respectivamente pelo apoio e compreensão.

A CAPES (Coordenação de Aperfeiçoamento de Pessoal de Nível Superior), pela importante e fundamental ajuda financeira, pois, sem essa base, teria sido muito difícil a realização de boa parte do trabalho.

À Silvânia Soares, que tenho a impressão de conhecer há anos apesar do pouco tempo de amizade. Obrigado pela ótima companhia de viagem, pelas inúmeras e infindáveis conversas, a camaradagem e a ajuda incondicional, quando necessária.

As amigas Aline Alves Bittencourt e Rosiane da Silva Mateus, pelas conversas e ajuda na elaboração dos vários mapas realizados ao longo da pesquisa.

A cinco pessoas essenciais na fase de finalização do trabalho: Silvânia Soares, Vanda Bartalini Baruffaldi, Magda Araújo, Vera Jordan Aguiar e Sidnei Ono.

Aos amigos que ajudaram ou se fizeram presentes em algum momento desta tese. Em especial, gostaria de registrar o nome de alguns deles: Waldirene Ribeiro, Carmem Marega, Aline Souza, Daniel Zungolo Teixeira, Giovanni Ballarin e todos os professores que participaram do Projeto Caminhos do Futuro.

A meus pais, Antônio e Cleuza, pelas conversas, proteção, carinho e amor sempre constantes. Vocês são um grande exemplo para nova etapa da minha vida que se inicia.

À Letícia pela compreensão, apoio, amizade, companheirismo e amor que me transforma em um ser melhor, mais feliz e completo. Brindo ao futuro que nos espera.

A todos muito obrigado! 


\section{RESUMO}

Os mapas inserem-se no dia-a-dia das pessoas de forma cada vez mais presente. A mídia - telejornais, revistas, anúncios de propaganda imobiliária, internet, jornais, mapas artísticos e de propaganda, etc. - ao utilizá-los como um meio de comunicação, na maioria das vezes, ignora algumas regras básicas na relação produtor e público usuário.

No bojo desses materiais cartográficos, encontram-se os mapas turísticos, que usualmente são confeccionados por artistas e ilustradores e não por geógrafos ou cartógrafos.

Esta pesquisa, fundamentada essencialmente na cartografia temática, propõe aprofundar e estreitar a metodologia iniciada e experimentada no mestrado, que abordou o uso das representações pictóricas e da visão oblíqua em mapas direcionados a turistas e leigos em cartografia. Tal recurso gráfico possibilita um menor nível de abstração da representação gráfica, trazendo comprovadamente uma maior facilidade de leitura da informação cartográfica. Além disso, é visualmente mais atrativa, por evocar conotações visuais, afetivas e emotivas.

Ainda utilizando a pictografia e os símbolos de informação pública, é proposta uma legenda específica aos mapas turísticos, símbolos esses que são elaborados para que as pessoas os vejam e os interpretem/ compreendam sem nunca tê-los visto antes.

Entretanto, é bom frisar que os símbolos e mapas convencionais também farão parte do produto cartográfico final, até porque, mesmo trabalhando potencialmente com mapas pictóricos para o setor do turismo, algumas informações são particularmente mais apropriadas e diretas se feitas por meio da convencionalidade.

Soma-se a esta discussão, o desenvolvimento de mapas temáticos para o turismo em meio digital. Esses novos recursos técnicos possibilitam o desenvolvimento de mapas não-limitados a uma folha de papel, proporcionando representações interativas, animadas, sonorizadas, em diferentes idiomas, entre outras possibilidades.

Nesse item, além da elaboração e uso do produto em si, há uma preocupação particular em encontrar relações entre o mapa, a mencionada interatividade e o usuário, nunca esquecendo que o material temático dirigido ao turismo deve não só se preocupar em fazer com que a informação seja adequadamente apreendida pela leitura como também se esmerar em ser atrativo, sedutor, a fim de estimular a curiosidade sobre a localidade representada.

Palavras-chave: Cartografia, Pictografia, Confecção de Mapas, Interatividade e Turismo. 


\begin{abstract}
The maps are going into people's day-to-day on an increasingly basis. The media (telenews, magazines, real estate advertisements, the Internet, newspapers, artistic and advertising maps, etc.), when using them as a communication means, most of times pays no attention to some basic rules in the user-producer relation.

In the heart of these cartographic materials are the tourist maps usually elaborated by artists and illustrators, instead of geographers and/or cartographers. Therefore, this research based essentially on the thematic cartography, aims at going deeper and narrower into the methodology initiated and experienced in the master degree, which dealt with the use of pictoric representations and the oblique vision in maps oriented specifically to tourists and laymen in cartography. The reason is that such graphics resources allow a lower level of abstraction of the graphics representation, bringing unmistakably a higher simplicity to the cartographic reading. Besides, it is visually more attractive as it evokes visual, affective and emotive connotations.

In addition, a specific subtitle is suggested to the tourist maps by making use of the pictography and symbols of public information. Such symbols are elaborated in order for people to see them, interpret them and understand them without have never seem them before.

However, it's important to emphasize that the conventional symbols and maps will also be part of the final cartographic product, because even working potentially with pictoric maps to the tourism sector, some information is especially more adequate and obvious trough the conventionality.

The development of thematic tourism maps for use in the digital media is also added to this study. These new technical resources allow the development of maps which are not limited to a sheet of paper, providing interactive, animated, sonorized representations, in different languages, among many other resources.

In this item, besides the elaboration and use of the product itself, there is a special concern on the map, the interactivity and the user, without never forgetting that the thematic material - tourism - must always bring a good understanding of the information (reading), and motivation (attractiveness, curiosity) towards the locality represented.
\end{abstract}

Key-words: Cartography, Pictography, Elaboration of Maps, Interactivity and Tourism. 
SUMÁRIO

Índice das figuras

\section{CAPÍTULO 1: Uma cartografia para o turismo: pictografia e interatividade}

1.1 - As novas possibilidades de se conceber um mapa:

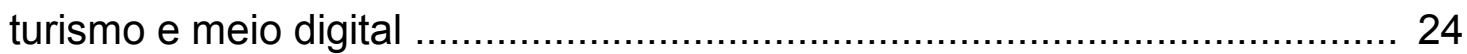

1.2 - O ato de cartografar: cultura e a representação do outro ............................ 29

1.3 - Quando as tradições se institucionalizam: a semântica para iniciados versus o senso comum................................... 45

1.4 - O mapa, o tempo e as diferentes formas de se representar o espaço ............ 65

1.5 - As bases semiológica e cartográfica:

proposta de um mapa temático para o setor do turismo 86

1.6 - O processo perceptivo: recolhendo imagens e elaborando representações. 101 1.7 - A arte e o desenho como recurso à cartografia

\section{CAPÍTULO 2: Técnicas e procedimentos utilizados na elaboração dos mapas turísticos e do protótipo mapa-site turístico}

2.1 - As mídias e suas respectivas técnicas: trabalhando a forma e o conteúdo.. 147

2.2 - Símbolos de informação pública:

pictogramas utilizados em mapas turísticos

2.3 - Elementos que compõem a multimídia interativa: aplicação em um mapa .. 193

2.4 - Breve crítica e proposta para a elaboração dos mapas e

o protótipo de um mapa-site turístico do município de Caxambu ................. 218

2.5 - Processo de elaboração dos mapas e do mapa-site turístico 


\section{CAPÍTULO 3: Avaliação e análise dos mapas, dos símbolos de informação pública e do mapa-site turístico de Caxambu}

3.1 - Desenvolvimento do estudo empírico ..................................................... 240

3.2 - O material cartográfico em avaliação ......................................................... 242

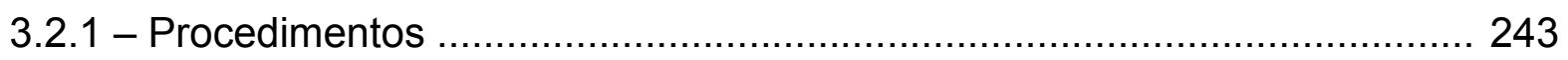

3.2.2 - Coleta e processamento das informações ……….................................. 254

3.2.3 - Apresentação e discussão dos resultados ........................................... 261

3.2.4 - Análise dos resultados ............................................................ 280

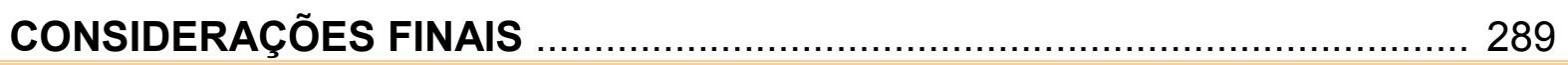

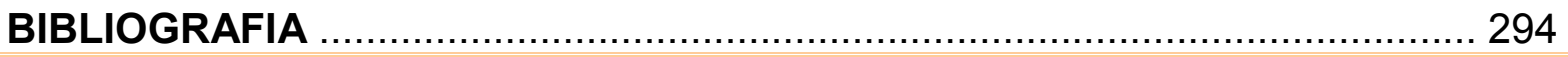

\section{CD - ANEXOS}

Pasta 1 - Mapas pictóricos - Trabalho de Graduação Individual (TGI) - 1999:

"Atlas Pictórico - proposta metodológica para a confecção e uso didático".

Pasta 2 - Mapas convencionais e pictóricos de llhabela (SP) e São Vicente (SP) Dissertação de Mestrado - 2003:

"Mapas turísticos: o desafio do uso da arte na era digital".

Pasta 3 - Mapas convencionais e pictóricos desenvolvidos durante a pesquisa:

Foz do Iguaçu (PR), Caxambu (MG), Manaus (AM) e

São Raimundo Nonato (PI).

Pasta 4 - Mapa turístico (escaneado) de Caxambu - Edição janeiro de 2003.

Todos os direitos reservados a Editora Buz.

Pasta 5 - O site elaborado para a pesquisa.

Pasta 6 - O protótipo mapa-site turístico de Caxambu elaborado para a pesquisa. 


\section{ÍNDICE DE FIGURAS}

01 - Perspectivas e dimensões da cartografia .......................................... 31

02 - Naturezas-culturas: quatro tipos de relação ……................................. 32

03 - $\mathrm{O}$ contexto e a escala do relativismo …............................................... 34

04 - $\mathrm{O}$ arco interpretativo entre a natureza, o mediador e a cultura .................. 37

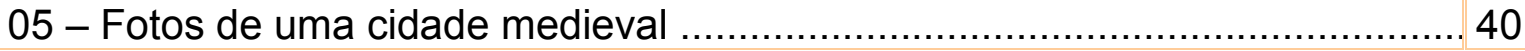

06 - Pictografia usada em mapas político e físico ........................................ 50

07 - Traços visuais: o conceito da girafa ................................................. 52

08 - Traços característicos do elemento representado: a schemata .................. 52

09 - Mapas e símbolos convencionais ................................................... 57

10 - Níveis de abstração do símbolo ..................................................... 57

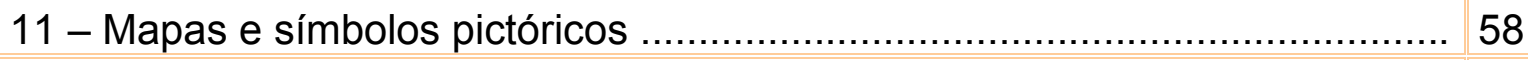

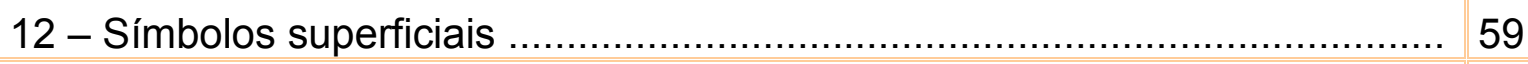

13 - Símbolos profundos ................................................................ 59

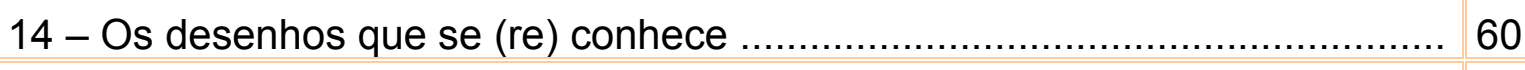

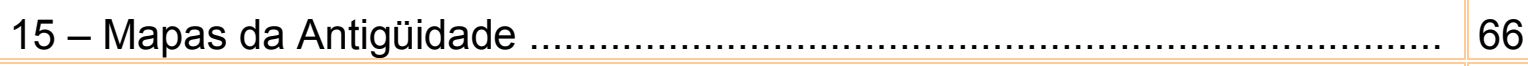

16 - A simplicidade do mapa Orbis Terrarum ........................................... 67

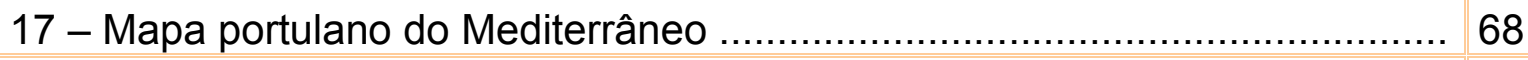

18 - As lendas representadas nos mapas ................................................ 68

\begin{tabular}{|l|l}
19 - Exemplo de desenhos pictóricos encontrados em guias náuticos & 70
\end{tabular}

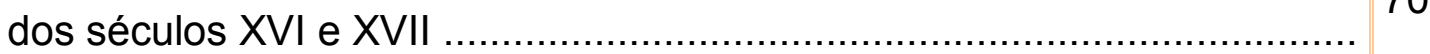

20 - Mapas com base na triangulação ....................................................... 71

21 - A evolução no processo do sensoriamento remoto …........................... 73

22 - As projeções de Mercator e Peters .................................................. 76

23 - Representações gráficas de Nova lorque .......................................... 81

24 - Comunicação em cibercartografia ................................................... 82

25 - Perfil e informação apropriada: o usuário e a multimídia interativa ........... 83

26 - $O$ ato de cartografar: as relações e interesses que envolvem um mapa turístico 85

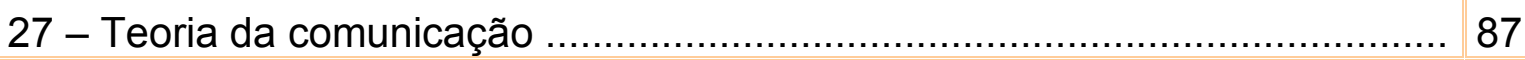

28 - A mensagem denotada e conotada ............................................... 90

29 - Signos dominante e especificador …….......................................... 92

30 - O ícone: o desenho fala por si ...................................................... 93

\begin{tabular}{|l|l|}
\hline 31 - O índice: o desenho não guarda semelhança direta com o & 94
\end{tabular} que representa 
32 - Símbolo: o desenho desenvolvida através de normas e convenções ....... 95

33 - Símbolos cartográficos .................................................................. 95

34 - Dois níveis de representação da mesma realidade ............................... 96

35 - As variáveis visuais segundo Bertin e MacEachren ............................. 98

36 - Exemplos de variáveis visuais ...................................................... 99

37 - "Captando" a imagem ...................................................................... 103

38 - Motivações para se viajar: fatores "push"e "pull" .................................. 109

39 - Atividade da oficina do Projeto Caminhos do Futuro:

o espaço e a sua imagem

40 - Representações materiais e imateriais representativas da paisagem ....... 119

41 - Estabelecimento de três níveis de dificuldade para as trilhas em Ilhabela 122

42 - Alguns ícones do patrimônio cultural de São Paulo ............................... 124

43 - As formas substitutas da paisagem ................................................ 126

44 - Maneiras de se abordar o desenho ................................................. 136

45 - Três tipos de representações pictóricas ……..................................... 137

46 - A mudança das representações icônicas ao longo do tempo e da cultura 140

47 - Maneiras de se elaborar um pássaro ................................................... 142

48 - O experimento de Ryan e Schwarz .................................................. 144

49 - Esquema dos tipos de signos gráficos................................................ 148

50 - As qualidades sintático-semânticas dos signos gráficos ......................... 149

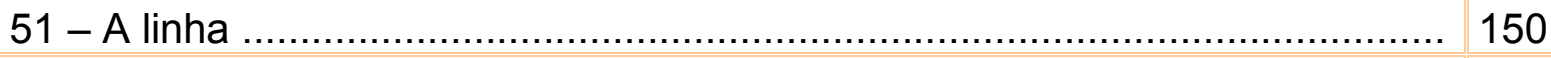

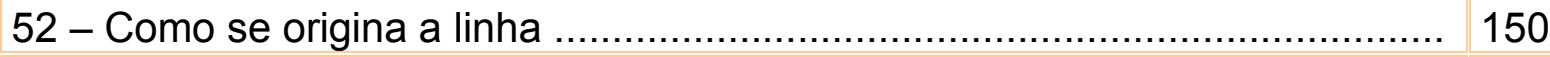

53 - A linha e suas possibilidades de expressão ...................................... 151

\begin{tabular}{|l|l|l|}
\hline 54 - Feira livre: formas básicas de uma representação gráfica ................ & 152 \\
\hline
\end{tabular}

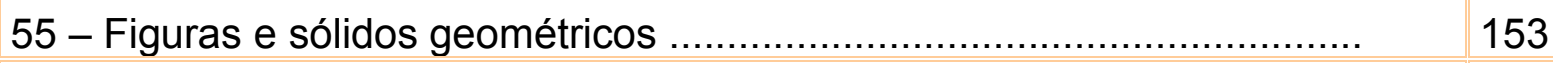

56 - Exemplos de planos pictóricos em perspectiva ................................ 154

\begin{tabular}{|l|l|l|}
57 - Luz e sombra proporcionando o efeito tridimensional................................ & 154
\end{tabular}

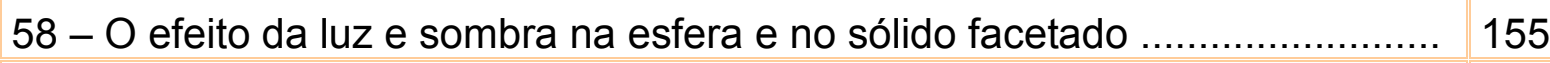

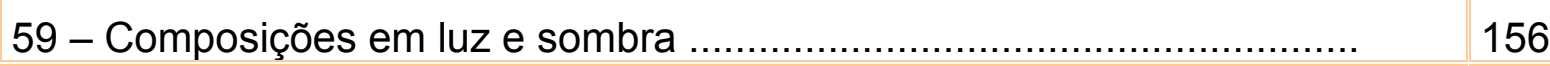

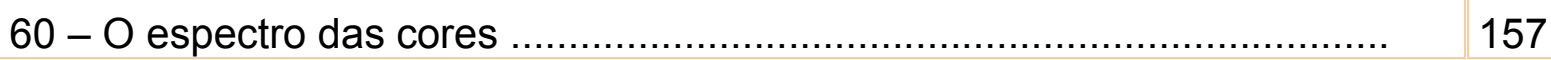

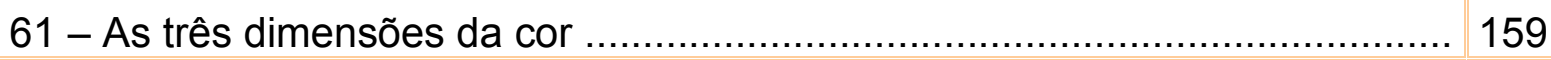

62- Busca de cores similares para os mapas dispostos em um monitor de computador (RGB) e impressos (CMYK)

63 - O "volume" das cores .............................................................. 165

64 - Transparência e sombreamento de ilustrações e objetos ........................ 166 
65 - A textura e suas qualidades visuais ............................................... 168

66 - Proporção e escala ...................................................................... 169

67 - Vocação turística: primeiro impacto visual............................................ 171

68 - Composição de um mapa pictórico com variáveis e elementos visuais .... 172

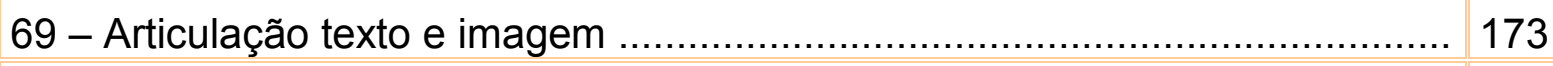

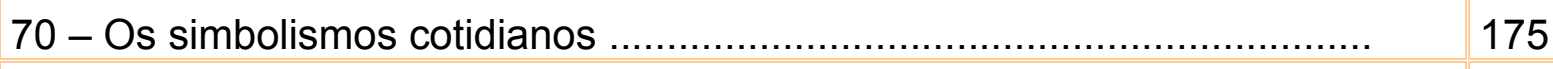

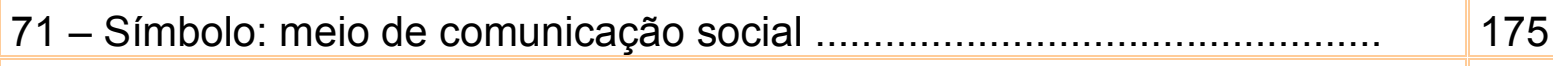

\begin{tabular}{|l|l|l|}
72 - Que representam e o que dizem essas formas gráficas? ..................... & 178
\end{tabular}

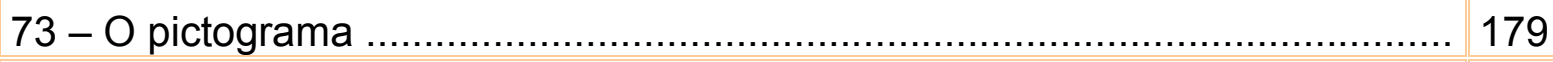

74 - Estrutura inicial de um sistema de sinalização turística ............................ 180

\begin{tabular}{ll|l}
75 - As modificações das representações gráficas ao longo do tempo ............ & 181
\end{tabular}

76 - Pictogramas: versões de um mesmo conceito ..................................... 182

77 - Os três níveis de pictogramas ........................................................... 183

78 - Componentes típicos de um título em multimídia interativa ...................... 195

79 - Os três níveis de conteúdo do mapa interativo ..................................... 200

80 - Simcity $\AA$ : referência para os mapas turísticos interativos........................ 200

81 - Legendas minterativas pop up .................................................... 203

82 - Exemplo de um fundo-cenário: Caxambu .......................................... 203

83 - Linhas e as figuras geométricas básicas para elaborar um cenário ......... 204

84 - A perspectiva isométrica e cavaleira .............................................. 205

85 - A perspectiva cônica .............................................................. 205

86 - As três posições da perspectiva ................................................... 206

87 - Desenhos com um ou dois pontos de fuga ......................................... 207

88 - São Vicente: desenho confeccionado em perspectiva paralela ............... 207

89 - Os diferentes tipos de símbolos pontuais interativos ............................ 208

90 - Conceito de hipermapa pela hipermídia geo-referenciada .................... 212

91 - A escolha de imagens e o resultado no processo de zoom ..................... 213

92 - Pré-estabelecendo os níveis de zoom ............................................ 214

93 - O site do DG-USP: um exemplo de zoom dinâmico ............................. 215

94 - As barras de rolagem: o recurso pan ................................................ 216

95 - Tipos de pop up ............................................................... 220

96 - Mapas turísticos e a despreocupação com as regras cartográficas ......... 221

97 - O mapa-site turístico de Caxambu e alguns outros exemplos .................. 226

98 - A pictografia sob uma planta cadastral e uma carta topográfica .............. 226

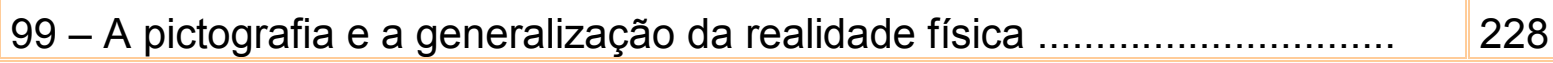


100 - Ilustrações dos atrativos naturais, culturais e de ação nos mapas turísticos

101 - Direcionamento da informação: ilustração e o complemento texto 229

102 - A legenda geral e turística 230

103 - A legenda: redundância e sedução 231

104 - Bordas ilustradas 232

105 - Os layers dos mapas 233

106 - Seqüência de confecção da base ilustrada 235

107 - Readequação gráfica e digitalização dos SIPs 236

108 - As quatro etapas de zoom do protótipo mapa-site de Caxambu 237

109 - Exemplos de elementos interativos do protótipo mapa-site de Caxambu 238

110 - A advertência para acesso no tema 3 do site 286 


\section{ÍNDICE DE TABELAS}

1 - Principais grupos de necessidades e empresas de turismo ..................... 80

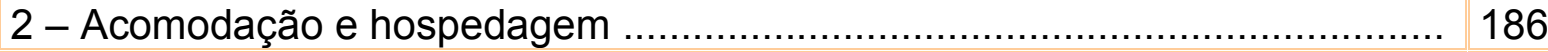

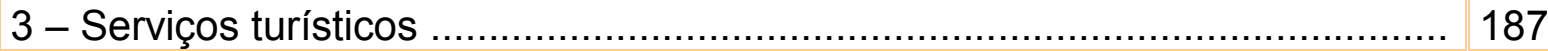

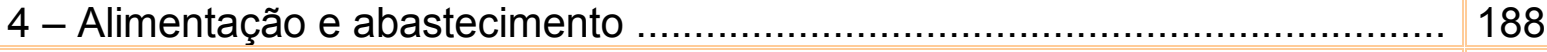

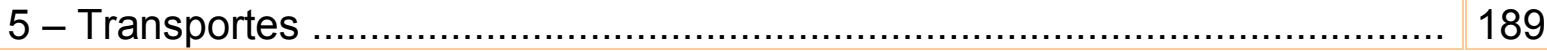

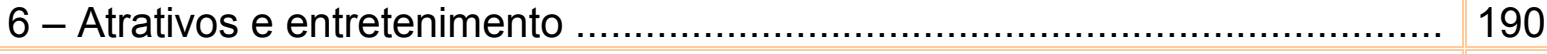

7 - Práticas desportivas e recreativas ....................................................... 191

8 - Pictogramas usados pelo site do albergue da juventude internacional ....... 192

9 - Discriminação dos sujeitos que responderam o questionário in loco segundo a idade, o grau de escolaridade e a profissão

10 - Discriminação dos sujeitos que responderam o questionário pelo site segundo a idade, o grau de escolaridade e a profissão

11 - Questionários respondidos e aceitos para a tabulação

12 - Respostas ao se olhar os símbolos de informação pública (respostas dissertativas)

13 - Respostas referentes a dualidade: convencional e pictórico .................. 257

14 - Respostas dadas aos símbolos de informação pública e a escala numérica (respostas alternativas)

15 - Respostas referentes ao protótipo mapa-site turístico de Caxambu ........ 260

16 - Médias amostrais dos símbolos de informação pública (respostas dissertativas)

17 - Valores amostrais quanto a preferência entre o mapa convencional ou pictórico

18 - Médias amostrais dos símbolos de informação pública e a escala numérica 


\section{INTRODUÇÃO}

Desde o primeiro ano de minha graduação no Departamento de Geografia da Universidade de São Paulo, sempre tive um interesse especial pela cartografia, mais especificamente, pela cartografia temática. A partir daí, iniciei uma trajetória como pesquisador. Durante a graduação, por um período de 18 meses (03/1997 a 08/1998), contei com uma bolsa de Iniciação Científica concedida pela FAPESP (processo 96/1054-1). Posteriormente, tal pesquisa foi complementada em meu TGI (Trabalho de Graduação Individual), recebendo o título final de Atlas Pictórico proposta metodológica para a confecção e uso didático. Em síntese, essa pesquisa buscou formas de estimular e motivar crianças à leitura do mapa (alunos de $5^{\mathrm{a}}$ e $6^{\mathrm{a}}$ séries do ensino fundamental, cuja faixa etária oscilava entre os 11 e 12 anos).

Para atingir meus objetivos, iniciei os estudos tendo como base teórica a semiologia gráfica proposta por J.Bertin. Neles enfatizei as seguintes variáveis visuais: tamanho; cor (buscando um suposto volume) e forma (grande uso da perspectiva).

Desde o princípio, tinha muito interesse em trabalhar com as representações nãoconvencionais, ou seja, fazer uso do desenho pictórico que, somado à visão oblíqua, pudesse facilitar o processo de abstração do usuário, gerando um maior interesse e apreensão das informações contidas no mapa.

A pesquisa de Iniciação Científica possibilitou a elaboração de dezenove mapas ilustrados em tamanho de folha A2 $(420 \times 594 \mathrm{~mm})$ e A3 $(297 \times 420 \mathrm{~mm})$ a partir da técnica da aquarela para acabamento (ver mapas em CD - anexos - pasta 1).

Os resultados dessa primeira pesquisa confirmaram a aceitação dos produtos cartográficos propostos. Um exemplo foi o comentário de uma professora que aplicou o teste com os mapas a 120 crianças: Elas demoraram mais para responder o questionário dos mapas pictóricos, por ficar um tempo maior observando, conversando entre eles. Ficaram muito interessados. Mesmo em relação à quantidade de respostas satisfatórias, os mapas pictóricos obtiveram uma média percentual muito positiva quanto à sua avaliação: $78,5 \%$ das respostas estavam corretas.

Sendo assim, o objetivo foi alcançado, principalmente por conceber um tipo de representação que motivou o aluno à leitura do mapa. Além disso, a decodificação das representações elaboradas conseguiu ser eficaz aos estudantes, devido ao fato de a informação estar mais próxima da realidade do público potencial. Os resultados possibilitaram dar continuidade à pesquisa criando condições para um aprofundamento da proposta teórico-metodológica.

O mestrado foi iniciado em março de 2000 e, por diversas razões, acima de tudo acadêmicas e metodológicas, optei por trabalhar com a confecção de mapas voltados a um outro tipo de público, o turista, que se caracteriza por ser um grupo muito 
heterogêneo quanto à idade, grau de escolaridade, capacidade de decodificação da informação cartográfica, entre outros aspectos.

Continuei motivado a aprofundar o estudo sobre as diferentes formas de representação dos símbolos empregados em mapas, ainda evidenciando o uso das figuras pictóricas, devido à sua capacidade de possibilitar algumas semelhanças físicas com o fenômeno representado e, portanto, dispondo de um tipo de informação mais acessível ao usuário leigo em Cartografia. Até porque, além de a representação pictórica caracterizar-se por um baixo nível de abstração e uma informação voltada ao olhar mais atrativa, pode evocar conotações visuais, afetivas e emotivas. Esses fatos possibilitam condições de valorização da paisagem, que é utilizada com freqüência na consolidação e difusão da atividade turística, associada à idéia do lazer e do prazer.

Em julho de 2000, obtive uma nova bolsa de pesquisa pela FAPESP (processo 00/03940-4) por um período de 24 meses (07/2000 a 07/2002), para desenvolver um trabalho de mestrado. A dissertação final foi intitulada: "Mapas turísticos: o desafio do uso da arte na era digital".

A pesquisa resultou na confecção de seis mapas, dois convencionais e quatro pictóricos, em tamanho de folha A1 (594 x $841 \mathrm{~mm})$. Os produtos representaram duas cidades do litoral paulista: Ilhabela e São Vicente.

Essa etapa proporcionou uma discussão referente ao uso dos formatos analógico com todo o processo técnico de confecção desenvolvido manualmente (uso de lápis colorido, caneta nanquim e a tinta aquarela) - e digital - utilização do computador (programas Corel DRAW e Adobe Photoshop).

O desenvolvimento empírico da pesquisa resultou da aplicação de 160 questionários, voltados a tipos de públicos distintos: o morador local (cidades de llhabela e São Vicente) e o turista (pessoas que não moravam em algumas cidades da grande São Paulo). Seguiu-se, então, a tabulação das respostas colhidas, permitindo uma análise crítica quanto à eficácia dos símbolos propostos e a identificação da preferência quanto ao tipo de mapa confeccionado (convencional ou pictórico). De forma geral, no que diz respeito ao produto cartográfico para o turismo, houve uma aceitação expressiva dos mapas pictóricos $(87 \%)$ em relação aos convencionais $(13 \%)$. É importante ressaltar que $73 \%$ dos usuários optaram pela visão oblíqua quanto ao tipo de representação da morfologia do terreno (ver mapas em CD - anexos - pasta 2).

Durante esses anos, o trabalho como pesquisador possibilitou ricas experiências acadêmicas como, por exemplo, qualificação de professores em muitas cidades brasileiras, encontros nacionais e internacionais, produção de materiais, etc. $O$ destaque maior foram as oficinas de qualificação a professores da rede pública, onde se trabalharam conteúdos referentes à cartografia temática direcionada ao setor do turismo. Inicialmente as atividades ocorriam por intermédio de uma parceria entre 0 LEMADI (Laboratório de Ensino e Material Didático), a AVT (Academia de Viagens e 
Turismo) e o IAP (Instituto de Academias Profissionalizantes). Posteriormente, fui convidado a participar do Projeto Caminhos do Futuro - parceria do Ministério do Turismo, do IAP, da AVT e do Núcleo de Turismo da Universidade de São Paulo. A última oportunidade possibilitou aplicar, de maneira prática, alguns pontos de minha pesquisa em dezesseis municípios brasileiros. Tudo isso só fez aumentar meu interesse pela busca teórica e prática quanto à maior e mais eficaz utilização do recurso pictográfico na cartografia atual.

Enfim, as pesquisas teóricas e práticas evidenciam que as representações pictóricas e o uso da visão oblíqua têm uma preferência significativa do turista e do público leigo na semântica cartográfica. Por causa disso, continuo a discussão, que considera o mapa como um produto cultural, e todas as implicações advindas da relação: tempo, formas de representar o espaço e tipos de usuários para o mapa.

Desse modo, esta etapa marca o aprofundamento teórico-metodológico da pesquisa. Efetiva-se a utilização da pictografia na elaboração de mapas. Ela pode representar desde a morfologia do terreno, ilustrações diversas sobre vários temas contidos no espaço (atrativos naturais e culturais), até a idealização de uma legenda coerente e eficaz ao público potencial por meio dos símbolos de informação pública.

Muehrcke (1986) corrobora que o grau de abstração dos símbolos pictóricos apresenta um maior apelo estético e parece ser mais apreciado e mais bem decodificado por crianças e usuários que tenham pouco contato com materiais cartográficos.

Soma-se ainda que, devido à forma de apresentação do futuro material cartográfico o protótipo de um mapa-site turístico - o público-alvo precisa ter conhecimentos mínimos sobre o ambiente Windows e a Internet.

Em verdade, a cartografia, não diferente de outras disciplinas da era da informação, vem sofrendo uma mudança substancial conduzida, principalmente, pelo desenvolvimento tecnológico nos campos da computação e da telecomunicação. Hoje os cartógrafos têm a grande oportunidade de utilizar as novas ferramentas disponibilizadas pela multimídia, o que possibilita um novo e excitante caminho. Essa mudança gerou uma interação dinâmica entre o usuário e o produto, a qual nunca havia sido possível anteriormente (Taylor, 1996). Todavia, ressalte-se que aproximadamente $90 \%$ do trabalho desenvolvimento pelo SIG (Sistema de Informação Geográfica) está de alguma maneira associado à simples digitalização de mapas já existentes.

Contudo, essas novas técnicas de produção oferecem novas oportunidades de pensar o mapa e, no caso específico dos mapas turísticos, deve-se levar em consideração fatores essenciais, relacionados às questões da apresentação gráfica do material e do marketing turístico. Brown, Emmer e Worm (2001) ratificam que a qualidade do design é vital nesse veículo, que precisa ser eficaz ao usuário (indicar a 
localização no espaço, ser motivador), além de servir como material de divulgação turística.

Kokkonen e Peltonen (1999) nos ensinam que um bom mapa turístico deve permitir que o usuário planeje e prepare suas atividades, além de se caracterizar como um produto funcional e esteticamente prazeroso, podendo contribuir com a expectativa dos visitantes e em uma total satisfação pela viagem.

Os futuros mapas turísticos e aqueles adaptados e elaborados ao meio digital interativo deverão servir tanto ao turista (nacional e internacional) quanto ao morador da cidade que queira conhecer a disponibilidade das inúmeras atividades de lazer do município, como, por exemplo, museus, centros de convivência, teatros, parques, feiras, shoppings, restaurantes, etc. Também se deve dispor, por exemplo, de informações úteis e curiosas, que vão desde um breve histórico sobre a cidade e de alguns dos seus bairros, até a confecção de mapas da rede de ônibus, metrô e trem, localização de hotéis e hospitais, entre outros equipamentos urbanos.

Encontram-se, a seguir, a exposição de elementos que direcionaram a pesquisa.

\section{A justificativa e o tema}

Como todas as outras áreas que atuam na construção do conhecimento contemporâneo, a cartografia não pode ser tratada apenas com os olhos da tradição. Sem que se pretenda menosprezar as conquistas até aqui obtidas, é imprescindível que se lance aos mapas um olhar de modernidade o que, para esta pesquisa, significa buscar novas estratégias de representar os mesmos fenômenos geográficos.

A necessidade de recortar o vasto campo oferecido pelo estudo dos mapas forçou o estabelecimento de limites à área de atuação. Assim, circunscreve-se o interesse aos mapas turísticos, justificando que:

a. Diferentes tipos de usuários merecem diferentes tipos de mapas.

b. Os mapas pictóricos são muito utilizados pelo setor do turismo e por turistas, cuja maioria é constituída por leigos em semântica cartográfica.

O tema central deste trabalho é o estudo das formas de representação convencional e pictórica. Enfatiza, porém, o uso da pictografia e, por conseqüência, da visão oblíqua em mapas temáticos para o turismo.

Nesse tema, podem-se ainda identificar sub-temas:

a. O mapa e o marketing turístico.

b. Proposta de uma legenda específica para mapas turísticos.

c. A cartografia em meio digital interativo. 


\section{A hipótese e o problema}

A hipótese segundo a qual os mapas com grande uso da pictografia têm mais aceitabilidade tanto por leigos na semântica cartográfica quanto por turistas, já havia sido considerada em trabalhos anteriores (Fiori 1999 e 2003). Além dessa, pressupõem-se outras hipóteses:

a. Os mapas pictóricos são mais adequados para incentivar o turismo.

b. O usuário prefere utilizar os mapas turísticos pictóricos na destinação.

c. Os símbolos de informação pública podem ser adaptados em legendas de mapas turísticos.

d. É possível a inserção dos mapas turísticos em meio digital e interativo.

A feitura desse tipo de objeto, entretanto, não é simples. O questionamento parte de problemas como:

a. Aprofundamento do uso da pictografia e da visão oblíqua em mapas temáticos para o turismo.

b. De que forma desenvolver um mapa turístico em meio digital, transmitindo de maneira interativa os elementos espaciais e as inúmeras atividades de uma localidade.

c. De que maneira conferir a ele o mencionado caráter interativo.

d. Quais recursos devem ser utilizados para que se atinjam pessoas de perfis diversificados.

A tese

Neste trabalho, defende-se a idéia de que, não obstante o grau de complexidade, é possível formular um mapa turístico pictórico e interativo, dirigido a indivíduos de exigências diversas, sendo capaz de expor as várias opções de lazer oferecidas por uma dada localidade.

Objeto e objetivo de estudo

Conforme tem sido registrado, esta pesquisa focaliza o desenvolvimento de mapas para o setor do turismo, passíveis de serem veiculados pelos ambientes digitais.

Relacionam-se, a seguir, os propósitos a serem perseguidos neste trabalho.

a. Aprofundar a metodologia que focaliza o uso das representações pictóricas e da visão oblíqua em mapas destinados a turistas e a leigos em cartografia. 
b. Oferecer subsídios para facilitar o processo de abstração do usuário pelo emprego do desenho pictórico somado à visão oblíqua.

c. Estudar a relação entre cultura e trabalho cartográfico.

d. Estimular a criação de mapas pictóricos.

e. Mostrar a necessidade de relacionar a confecção de mapas a seus usuários.

f. Formular uma legenda específica para esse tipo de material a fim de facilitar a leitura ao usuário.

g. Incrementar a proposta de desenvolver, em meio digital, mapas temáticos destinados ao turismo.

h. Buscar um modo eficaz e eficiente de realizar a interação entre usuário e mapa.

\section{Fundamentação teórica}

Alguns modelos teóricos servirão de apoio ao desenvolvimento desta pesquisa.

Inicialmente, conforme já se fez referência, serão utilizados os princípios da Teoria da Comunicação, uma vez que se parte da premissa de que o objeto cartográfico permite a interlocução entre dois indivíduos: o que produz o mapa e aquele que o lê.

O fato de partir do princípio de que os sujeitos que atuam no processo comunicativo são fruto de coordenadas espaciais e temporais, faz com que esta pesquisa parta de autores como Harley e Woodward (1987), Monmonier (1996), Latour (1994), Canclini (2003) e Barthes (1971, 1990 e 1995) dentre outros, que enfatizam a impossibilidade de negar a relação entre cultura, produtos híbridos e forma de leitura na confecção do mapa. Um dos fortes argumentos em favor dessa afirmação se baseia em como o sujeito adquire a informação espacial, que se caracteriza por uma imagem seletiva do espaço. Um outro fator não menos importante refere-se à subjetividade das representações gráficas, tanto de quem as vê quanto de quem as produz.

Acreditar que o produto cartográfico preenche um espaço intersubjetivo significa concebê-lo como um objeto significativo. Vale dizer: não se escolheram nem se usaram de modo aleatório os traços que compõem um mapa. Ao contrário, eles foram orquestrados com cuidado para servir de instrumento de comunicação. Esse esforço de olhar o mapa como um elemento de significação mostra a influência de um modelo semiótico, aqui representado pelo pensamento de Roland Barthes.

É importante considerar ainda que, para atingir a contento seu objetivo, a cartografia não deve relevar cuidados com a estética. A lembrança evoca, portanto, referências feitas a teorias que se preocupam com o belo. 


\section{Metodologia}

Relacionam-se abaixo as etapas seguidas para a elaboração desta tese. Nela se encontra não apenas o viés quantitativo como o qualitativo: o primeiro por registrar dados obtidos em pesquisa de campo; o segundo pelo trabalho de análise desenvolvido no objeto de estudo.

Leia-se então a seqüência de atividades que culminaram com a elaboração deste trabalho.

a. Estudo das representações gráficas presentes em todas as etapas do protótipo mapa-site turístico.

b. Seleção dos recursos técnicos necessários para a criação dos mapas e do protótipo mapa-site turístico.

c. Elaboração dos produtos. Emprego dos programas CorelDRAW, Adobe Photoshop e Dreamweaver.

d. Concepção digital dos símbolos convencionais e pictóricos.

e. Concepção analógica das ilustrações a serem digitalizadas.

f. Produção dos mapas em português e inglês.

g. Avaliação do produto cartográfico desenvolvido.

h. Aplicação de duas pesquisas paralelas, com dois tipos de público pesquisados:

- Professores da rede pública de 14 estados brasileiros.

- Pessoas que acessaram o site elaborado para a pesquisa.

\section{Estrutura da tese}

A tese é composta por três capítulos:

O primeiro capítulo trata dos fundamentos teóricos de uma pesquisa interdisciplinar, estabelecida em cinco áreas do conhecimento: Geografia, Cartografia, Antropologia, Lingüística e Turismo. O intuito é desenvolver um embasamento racional para que se elaborem dois tipos distintos de representação cartográfica caracterizadas por um maior ou menor nível de abstração da realidade:

$\checkmark$ Os símbolos convencionais, geométricos ou abstratos - que não possuem semelhança com o elemento representado, apresentando um alto grau de abstração. A esse tipo pertence a maior parte dos mapas, para a leitura dos quais o usuário necessita de convenções e da(s) legenda(s) para (re) conhecer os inúmeros elementos. 
$\checkmark$ Os símbolos pictóricos e as ilustrações - que possuem alguma(s) semelhança(s) física(s) com o elemento representado, devendo apresentar um baixo nível de abstração. Neste item, a questão da arte e da cultura tem relevância, pois os desenhos confeccionados resultam de um conjunto de contextos culturais e históricos, até porque todo processo comunicativo é dependente de uma interação entre expectativas, observações e hábitos que constituem a vida cotidiana.

Essas formas de representação passaram por um processo de adaptação devido a sua utilização em meio digital e dos possíveis recursos interativos.

O segundo capítulo se dedica à elaboração prática dos mapas turísticos (convencionais e pictóricos) e do protótipo mapa-site turístico.

Inicialmente, são inventariadas e apresentadas diferentes técnicas de representação como, por exemplo, os tipos de linha, as figuras e os sólidos geométricos, os diferentes tipos de perspectivas, a cor, a luz e sombra, a textura e a proporção. Somam-se ainda, os recursos em meio digital que possibilitam a interatividade com o produto como o zoom estático em etapas, os recursos pop up, pan, etc.

Outro tópico do capítulo discorre sobre os símbolos de informação pública. Trata-se ali desde sua conceituação, de seus tipos e faz-se um inventário de pictogramas recolhidos em mapas turísticos de vários países.

Por fim, apresenta-se o passo a passo de todo o processo de confecção do protótipo mapa-site (ver os mapas e o protótipo mapa-site no CD - anexos - pasta 3 e 6).

No terceiro e último capítulo, elabora-se um teste empírico a partir de um conjunto de questionários, que procuram avaliar e analisar a aceitação, a preferência e o nível de compreensão dos vários tipos de representações desenvolvidas ao longo da pesquisa.

A aplicação dos questionários ocorre de duas maneiras:

$\checkmark$ In loco - durante uma das atividades oferecidas em um curso de qualificação de professores (Projeto Caminhos do Futuro) em 14 estados brasileiros.

$\checkmark$ Internet - um site é desenvolvido para que o questionário alcance o maior e mais diversificado número de pessoas e culturas. Por isso, o material é disponibilizado em dois idiomas: português e inglês (ver o site em CD - anexos - pasta 5).

Tem-se, por fim, as considerações finais em que se retomam alguns aspectos desenvolvidos na tese e procura-se enfatizar a necessidade de prosseguir a investigação que busca aliar a cartografia com os recursos oferecidos pela arte e pela tecnologia moderna. 


\section{CAPÍTULO 1}

Uma cartografia para o turismo: pictografia e interatividade 


\section{1- As novas possibilidades de se conceber um mapa: turismo e meio digital}

A década de noventa do século XX marca grandes transformações e perspectivas à Cartografia, tanto com relação às bases teóricas quanto às do design e suas variadas técnicas. Isso porque atualmente se vive o franco crescimento da cartografia em meio digital, interativa, com destaque para as áreas de sensoriamento remoto, telecomunicações e informática (hardware e software). O cartógrafo então tem, pela frente, um instigante e desafiador caminho a ser trilhado.

Com isso, a inovação estética também foi deslocada para as tecnologias eletrônicas, tornando a comunicação mais fácil e rápida. Antes havia formas artesanais ou eruditas, porém hoje os recursos técnicos geram hipertextos e rápidas edições audiovisuais ou eletrônicas. Por volta de dez anos atrás, conhecer as inovações de diferentes países, utilizá-las e compor com elas requeria viagens freqüentes, assinaturas de revistas estrangeiras e vultosas contas telefônicas. Atualmente, basta renovar periodicamente o equipamento do computador e ter um bom serviço de Internet para solucionar os problemas (Canclini, 2003: XXXVI).

Assim, tomando como base a esfera teórica e a função prática da cartografia, menciona-se o objeto de estudo desta pesquisa: o mapa turístico interativo. Este é o objeto de estudo.

A tese se propõe investigar as maneiras diferenciadas de se apresentar um importante produto de comunicação cotidiana: o mapa, sempre tendo como preocupação primordial a maior aceitação e compreensão do(s) produto(s) desenvolvido(s) para os usuários potenciais, que, neste caso, continua a ser constituído por um grupo muito heterogêneo (idade, grau de escolaridade, interesse, capacidade de decodificação, acesso à tecnologia digital, etc) e essencialmente leigo em cartografia: turista ${ }^{1}$ e usuário da Web (rede mundial de computadores).

Os resultados empíricos apresentados nas pesquisas anteriores (Fiori 1999 e 2003) evidenciaram a maior compreensão e aceitação dos mapas que ofereceram uma maior quantidade de representações pictóricas, quando comparadas às representações abstratas ou geométricas. Isto porque tal forma de representação tem características muito distintas por serem capazes de apresentar semelhança física com o fenômeno representado, proporcionando, em linhas gerais, uma menor

\footnotetext{
${ }^{1}$ Segundo Beni $(1998: 37 ; 149)$ são aqueles visitantes temporários que permanecem pelo menos vinte e quatro horas no país visitado. A viagem pode ser classificada em vários tipos: lazer - descanso, recreação, férias - de negócios e compras, desportivo, ecológico, rural, de aventura, religioso, cultural, gastronômico, estudantil, de congressos - convenções, encontros e encontros similares - familiar e de amigos, de saúde ou médico-terapêutico. Existem ainda, os excursionistas, que são os visitantes temporários que permanecem menos de vinte e quatro horas no país visitado - incluindo viajantes de cruzeiros marítimos. Contudo, nesta pesquisa o usuário dos mapas turísticos pictóricos interativos podem ser tanto os turistas e excursionistas internacionais quanto nacionais.
} 
abstração $^{2}$ da realidade; logo, um menor esforço para adquirir a informação que permeia a representação e a realidade. Ainda se comprovou empiricamente que as representações pictóricas possuem uma grande capacidade de motivar a decodificação e leitura das imagens contidas nos mapas. Isto se deve, em grande parte, ao seu poder de evocar conotações visuais, afetivas e emotivas.

Essa etapa da pesquisa enfatiza o uso das representações pictóricas em mapas temáticos voltados ao setor do turismo e do lazer. Potencializam-se alguns tópicos teórico-metodológicos iniciados no trabalho de mestrado (Fiori, 2003) como, por exemplo, a abordagem de questões que estabelecem o contexto como agente facilitador na leitura dos códigos, além do recurso artístico que possibilita formas alternativas de persuadir o usuário que o mapa pode ser mais que simplesmente funcional sendo capaz de auxiliar na procura de uma determinada localidade ou distância desejada, ou então comparar informações referentes à população, economia, vegetação, etc, transformando-se em um produto que apresente um design motivador ${ }^{3}$ e cuidadosamente pensado para o público potencial e, além disso, que traga outros tipos de informações - úteis e complementares a este usuário tendo como meta um serviço rico e diferenciado. A contribuição maior é pensar a função do mapa voltado especificamente ao turismo.

De maneira breve, é necessário estabelecer o conceito de design que será utilizado durante toda a pesquisa. Para isso, conta-se com Souza (1992: 12), ao explicar que design, na língua portuguesa, é uma palavra sem tradução. Desenho, em tese, deveria ser o termo equivalente ao conceito de design, pois, quando a palavra apareceu, significava tanto risco, traçado, técnica, quanto desígnio, intenção, projeto. Contudo, pelo uso social, o termo desenho passou a significar somente uma técnica de representação.

Galeffi (1977: 90) então esclarece que atualmente, em português, a palavra design não significa desenho, mas sim desígnio, ou seja, plano ou projeto de intenção. Aliás, o mesmo problema de conceituação ocorre na língua francesa, italiana e alemã. Desse modo, houve uma internacionalização da palavra design, sendo adotada principalmente nos meios profissional e acadêmico (Souza, 1992: 12).

Design, então, passa a significar internacionalmente a manipulação de elementos visuais; é um processo fluido, porém constitui-se como o método de pré-visualização e de planejamento que ilustra o caráter da mensagem sintetizada. Caracteriza-se por um tipo especial de inteligência não-verbal e sua natureza está ligada à emissão de

\footnotetext{
${ }^{2}$ É um processo de "destilação", ou seja, de redução dos fatores visuais múltiplos aos traços mais essenciais e característicos daquilo que está sendo representado (Dondis, 1991: 91). O conceito é mais bem explicado entre as páginas $49-51$.

${ }^{3}$ Em geral, o ato de motivar ocorre quando um indivíduo quer satisfazer uma necessidade. Os motivos implicam ação, ou seja, o indivíduo é movido a fazer alguma coisa. Já (em relação à) a motivação turística - que é o caso desta pesquisa - canaliza e desencadeia um processo de decisão (Goossens, 2000).
} 
conteúdo (o que se quer dizer) em uma forma (meio de expressão), por meio do controle exercido pela técnica (Dondis, 1991: 135). Souza (1992: 12) conclui que:

As diferentes formas de manifestação do design revelam uma espacialidade visual e/ou tátil especialmente projetada para solucionar os diversos problemas de habitação, de locomoção, de lazer e de comunicação, próprios da vida em sociedade.

Partindo de Souza (1992: 32), pode-se afirmar que o trabalho a ser desenvolvido nessa pesquisa tem a ver com o design gráfico, pois trabalha com a informação e com os veículos de comunicação. Diferentemente do desenho industrial, que lida com objetos e equipamentos. A autora (1992: 56) conceitua design gráfico como uma das formas de conversação social em que as pessoas partilham informações e instruções por intermédio dos estímulos visuais gráficos. Portanto, a comunicação pode resultar das várias modalidades do desenho (desenho gráfico, técnico, ilustrativo, publicitário, etc), isto é, a comunicação visual também está sujeita a algumas condições básicas:

> É necessário que o designer conheça estruturalmente o fenômeno da comunicação;

> Utilização dos mesmos códigos de linguagem;

$>$ Busca do máximo de objetividade dos signos utilizados em um ato comunicativo, a fim de assegurar eficiência de comunicação e ausência de falsas interpretações;

> Familiaridade do agente emissor (designer) com as possibilidades expressivas das técnicas de comunicação empregadas e sua adequação às condições fisiológicas, psicológicas e culturais dos agentes receptores (segmentos sociais).

Dito isso, os mapas turísticos pictóricos devem atentar a duas peculiaridades importantes a serem ressaltadas: a primeira refere-se ao interesse e concepção de um produto que busque uma maior e melhor visibilidade do local representado, ou seja, é necessária a busca de formas de representação que forneçam uma série de atividades e funções (materiais) de localização, distâncias, orientação (a rua, o hotel, a cachoeira, a morfologia do terreno) e culturais (o "causo", curiosidades, o imaginário, as histórias) visando gerar relações afetivas com o local de destino. A segunda peculiaridade diz respeito à procura de formas criativas e corretas de representação e construções cartográficas que possam ser facilmente consumidas, "lidas" e estejam adaptadas às necessidades do grupo heterogêneo de usuários. Acrescente-se que haverá uma inovação se consideradas as pesquisas anteriores (Fiori 1999, 2003), isso porque, a apresentação dos futuros produtos cartográficos se dará totalmente em forma digital e, por isso, o público alvo deverá ter conhecimentos mínimos sobre o ambiente Windows e a Internet. 
Ao se pensar em determinados objetos, momentos, paisagens, é comum virem à mente imagens, sons, cheiros, nomes, entre outras sensações que aguçam os cinco sentidos. Tais sensações podem se transformar em desejos, vontades, recordações, deslumbramento, motivações; que por sua vez, poderão ser transformados em representações gráficas, ou seja, em telas, ilustrações, textos, croquis, símbolos e mapas.

Como foi dito anteriormente, o tipo de material cartográfico proposto implica situar, tornar acessível a localização e o reconhecimento de pontos e áreas de uma determinada localidade no espaço. Todavia, pretende-se ir além, ou seja, fazer com que o mapa temático traga o máximo de boas sensações e recordações possíveis. $\mathrm{E}$, para isso, conta-se com o uso da pictografia.

Como demonstração das sensações e possibilidades de representações pretendidas nesta nova etapa da pesquisa, é citado o livro As cidades invisíveis de Ítalo Calvino (1999), que aborda seu fascínio pela complexa simbologia das cidades. Leia-se, por exemplo, o trecho abaixo:

\section{Desejos}

A três dias de distância, caminhando em direção ao sul, encontra-se Anastácia, cidade banhada por canais concêntricos e sobrevoada por pipas. Eu deveria enumerar as mercadorias que aqui se compram a preços vantajosos: ágata, ônix, crisópraso e outras variedades de calcedônia; deveria louvar a carne do faisão dourado que aqui se cozinha na lenha seca de cerejeira e se salpica com muito orégano (Calvino, 1999: 16).

\section{$\underline{\text { Memórias }}$}

Ao se transportarem seis rios e três cadeias de montanhas surge Zora, cidade que quem viu uma vez nunca mais consegue esquecer. Mas não porque deixe, como outras cidades memoráveis, uma imagem extraordinária de recordações. Zora tem a propriedade de permanecer na memória ponto por ponto, na sucessão das ruas e das casas ao longo das ruas e das portas e janelas das casas, apesar de não demonstrar particular beleza ou raridade (op. cit.:19).

\section{$\underline{\text { Trocas }}$}

Em Esmeraldina, cidade aquática, uma rede de canais e uma rede de ruas sobrepõem-se e entrecruzam-se. Para ir de um lugar a outro, pode-se sempre escolher entre o percurso terrestre e o de barco: e, como em Esmeraldina, a linha mais curta entre dois pontos não é uma reta, mas um zigue-zague que se ramifica em tortuosas variantes, os caminhos que se abrem para o transeunte não são dois, mas muitos, e aumentam ainda mais para quem alterna trajetos de barcos e transbordos em terra firme (op. cit.: 83).

\section{Olhares:}


Ao chegar a Fílide, tem-se o prazer de observar quantas pontes diferentes entre si atravessam os canais: pontes arqueadas, cobertas, sobre pilares, sobre barcos, suspensas, com parapeitos perfurados; quantas variedades de janelas apresentam-se diante das ruas: bífores, mouriscas, lanceoladas, ogivais, com meias-luas e florões sobrepostos (op. cit:: 85).

\section{Diferenças}

Presume-se que Isaura, cidade dos mil poços, esteja situada em cima de um profundo lago subterrâneo. A cidade se estendeu exclusivamente até os lugares em que os habitantes conseguiram extrair água, escavando na terra longos buracos verticais (op. cit.: 24).

\section{$\underline{\text { Nomes }}$}

A minha mente continua a conter um grande número de cidades que não vi e não verei, nomes que trazem consigo uma figura ou fragmento ou ofuscação de figura imaginada: Getúlia, Odila, Eufrásia, Margara (op.cit. 87, 88).

\section{$\underline{\text { Símbolos }}$}

Finalmente, a viagem conduz à cidade de Tâmara. Penetra-se por suas ruas cheias de placas que pendem das paredes. Os olhos não vêem coisas, mas figuras de coisas que significam outras coisas: a torquês indica a casa do tiradentes; o jarro, a taberna; as alabardas, o corpo de guarda; a balança, a quitanda. (...) Se um edifício não contém nenhuma insígnia ou figura, a sua forma e o lugar que ocupa na organização da cidade bastam para indicar a sua função: o palácio real, a prisão, a casa da moeda a escola pitagórica, o bordel. Mesmo as mercadorias que os vendedores expõem em suas bancas valem não por si próprias, mas como símbolos de outras coisas: a tira bordada para a testa significa elegância; a liteira dourada, poder; os volumes de Averróis, sabedoria; a pulseira para o tornozelo, voluptuosidade (...) O olhar percorre as ruas como se fossem páginas escritas (op. cit.:18, 19)

Os fragmentos de cada conto exemplificam sensações e possibilidades de representação de vários espaços. Segundo Santos (2002:233), o povo, ao utilizar o território, cria o espaço. Detalhando melhor, o território é imutável em seus limites, que pode ser uma linha traçada de comum acordo ou então pela força. O território, em um dado momento da História, representa um dado fixo, contudo, não possui necessariamente a mesma extensão através dos tempos. Ele se torna espaço através das sucessões históricas da efetiva ocupação por um povo. A ação e o trabalho resultam de regras fundamentadas no modo de produção adotado, tendo como orientação o poder soberano (sistema político), que instalado determina os tipos de relações entre classes sociais e as formas de ocupação desse território.

O espaço, então, é uma constante junção e complementação de elementos materiais 
e imateriais contidos em uma história, que traz diferenças e singularidades, mas também semelhanças quando comparados a outros espaços. Portanto, o grande desafio desta pesquisa é pensar que cada localidade tem singularidades que a faz única, e o mapa, pelo seu poder e formas de representação, pode destacar uma infinidade desses elementos - atrativos materiais e imateriais - dispostos no espaço, tanto em meios analógicos quanto digitais.

A expectativa que se estabelece para este trabalho, fundamentado na Cartografia Temática, vislumbra maneiras inovadoras e originais de conceber produtos que possam ser tanto de interesse do setor turístico e de lazer quanto do usuário que, por sua vez, requer e merece novas formas de representar a informação espacial.

A preocupação inicial do cartógrafo é pensar o mapa a partir de uma situação previamente estabelecida, pois é a partir de um dado contexto (para quem e qual o propósito) que se determinam (codificação e confecção) as expectativas (interesse, motivação) e a capacidade (facilidade de decodificação) de assimilar a informação pelo público-alvo. E é por isso que este trabalho busca captar a essência, o espírito da localidade.

Some-se à discussão, Leung e Li (2002: 12) ao ressaltarem que a qualidade do serviço no turismo é essencial para que ocorra o crescimento do setor, situando o mapa como um importante instrumento nesse sentido. Por conseqüência, a eficácia do produto precisa ser incessantemente buscada.

Um bom mapa turístico deve permitir que o usuário planeje e prepare suas atividades, além de se caracterizar como um produto funcional e esteticamente prazeroso, podendo contribuir com a expectativa dos visitantes e uma total satisfação pela viagem (Kokkonen e Peltonen, 1999).

\section{2 - $O$ ato de cartografar: cultura e a representação do outro}

Wagner e Mikesell (2000:111) afirmam que a cultura resulta da capacidade de os seres humanos se comunicarem entre si por meio de símbolos. Quando as pessoas parecem pensar e agir de maneira igual, elas o fazem porque vivem, aprendem, trabalham e conversam juntas, atribuindo o mesmo significado aos objetos feitos pela humanidade. Além disso, participam dos mesmos rituais e recordam o mesmo passado. Inversamente, quando há grandes diferenças em pontos de vista e atividades, em geral se reflete a ausência de símbolos e língua comuns. A cultura também está assentada numa base geográfica, pois é provável que só ocorra comunicação regular e compartilhada entre pessoas que ocupam uma área comum.

Canclini (2003: 274) continua a reflexão dizendo que a cultura é o capital pertencente a toda e qualquer sociedade, sendo interiorizada pela prática. É produto de uma encenação, na qual se escolhe e se adapta o que vai ser representado, de acordo com o que os receptores possam escutar, ver e compreender. Todo ato de transmissão cultural implica necessariamente a afirmação do valor da própria cultura 
transmitida, em detrimento de uma desvalorização implícita ou explicita das outras culturas. Tal exigência se faz presente no próprio ato da transmissão, pois os indivíduos condenados por sua formação sentem-se inclinados a identificar seu próprio valor com o valor de sua cultura, vendo uma outra cultura muitas vezes como estranha, concorrente (Bourdieu, 1974: 218). Ratifica Tuan (1980:285): o grupo expressa e reforça padrões culturais da sociedade, o que afeta decisivamente a percepção, a atitude e o valor que seus membros atribuem ao meio ambiente.

O pertencer a um grupo traz implícito um conjunto de significados, ou seja, uma nação (e em menor grau um estado/província, cidade, bairro) não é apenas uma entidade política, mas também algo que produz sentidos, conformando-se em um sistema de representação social (Hall, 2003: 49).

Por exemplo, museus, relatos populares, mapas, nunca apresentam os fatos, o cotidiano em sua totalidade; são sempre re-apresentações, simulacros. Só a fé cega fetichiza os objetos e as imagens, acreditando que neles está depositada a verdade (Canclini, 2003: 201). E, para que isto ocorra, constitui-se, então, um conjunto comum de esquemas fundamentais, que são previamente assimilados (Bourdieu, 1974: 208).

Sobre os mapas em particular, Harley (1991) informa que, desde tempos mais remotos até os dias de hoje, a humanidade das mais diversas culturas representa o espaço. Contudo, durante um longo período, os mapas de culturas não-européias só receberam certa atenção quando apresentavam alguma semelhança com os mapas europeus.

Felizmente, a história da cartografia começa a tomar um novo rumo, no qual cada cultura manifesta sua particularidade, permitindo que se entenda muito melhor o objetivo da criação dos mapas (Harley, 1991).

Sendo assim, a fundamentação teórico-metodológica continua focada em estabelecer o mapa como produto cultural (Fiori, 2003). Para isso, conta novamente com a concepção de cartografia expressa na figura 1, definindo suas perspectivas e dimensões. Segundo Vasconcellos (1993: 82), o centro do esquema apresenta a cartografia como um processo que parte da realidade, englobando as etapas de produção e utilização do mapa.

Desse modo, o ato de cartografar disseca várias relações em uma sociedade.

Segundo a professora Regina Araujo de Almeida (Departamento de Geografia da USP) acerca da concepção do Atlas Indígena do estado do Acre (Comissão PróÍndio: 1996), o azul, a cor convencionada para representar a hidrografia na maioria dos mapas da cultura ocidental, teve de ser mudada para o amarelo, porque tal cor não fazia sentido para os indígenas das etnias Arara, Ashaninka, Kaxinawa e Manchineri, os usuários potenciais dos Atlas.

A partir do exemplo acima, cita-se Collins-Kreiner (1997) ao afirmar que os mapas 
são desenvolvidos levando em consideração propósitos específicos. Não são seres passivos; pelo contrário, suas mensagens implícitas sempre precisam ser descobertas. Além do mais, o produto cartográfico precisa satisfazer as necessidades e interesses do usuário, pois se não, provavelmente ele procurará outro que melhor o atenda (Kolacny, 1994 e Benkenstein, Yavas e Forberger, 2003). Kolacny (1994) ainda ressalta que os requisitos básicos de um mapa é ser atraente, devendo ter uma concepção racional e boa impressão emotiva, somando-se a facilidade de leitura e compreensão.

Figura 1 - Perspectivas e dimensões da Cartografia

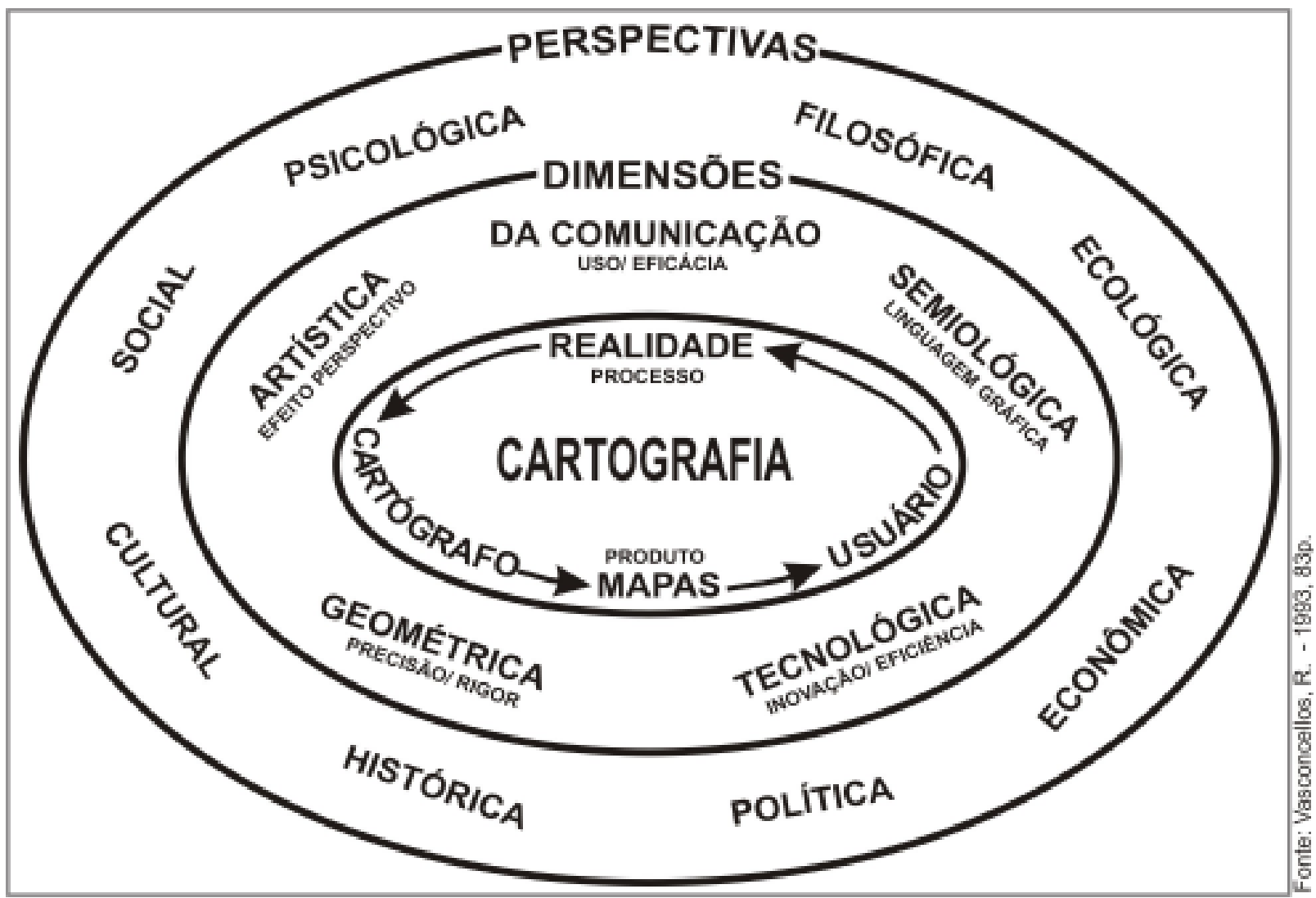

Collins-Kreiner (1997) complementa, em citação, que os geógrafos devem se relacionar com o mapa da mesma forma que um sociólogo se relaciona com um suvenir, ou seja, como uma unidade simbólica, um objeto - no caso para o setor do turismo e lazer - que revela influências, interesses sociais, políticos, forças ideológicas e relações de poder. Dessa forma, os mapas podem ser usados como ferramentas analíticas para entender processos e seus significados, atuando como lentes através das quais a cultura e a sociedade são vistas.

Segundo Harley (1994: 277-278), talvez a grande questão não seja responder categoricamente se os mapas são verdadeiros ou falsos, precisos ou imprecisos, objetivos ou subjetivos, geométricos ou pictóricos, ou se são baseados na integridade científica e contrários à distorção ideológica. $\mathrm{O}$ autor aponta ainda outros elementos 
que influenciam na veracidade de um mapa, como os níveis de carto-alfabetização dos usuários, a autoria e procedência dos mapas, os segredos, as censuras e, finalmente, a natureza das instituições políticas para as quais os mapas são feitos. Com tudo isso, o fato contundente está em saber que o material sempre transmitirá imagens com alguma importância e mensagens direcionadas a algum grupo. Até porque o mapa é uma das fontes de comunicação, articulação e estruturação do conhecimento da humanidade.

A pesquisa, então, procura compreender todo o processo de desenvolvimento de mapas temáticos, potencialmente aqueles direcionados ao setor do turismo.

Todo ato de cartografar gera sempre a representação de um determinado espaço. Sendo o geógrafo/cartógrafo o produtor, ele na maioria das vezes representa o outro (em diferentes escalas), ou melhor, somente a representação externa desse outro, resultado da cultura local, da tradição.

Latour (1994:102) afirma que não existem nem culturas (diferentes ou universais) nem uma natureza universal. O que existem apenas são naturezas-culturas, as quais constituem a única base possível para comparações. O autor (op. cit:: 102-104), então, apresenta quatro maneiras (figura 2) para conceituá-las:

Figura 2 - Naturezas-culturas: quatro tipos de relação

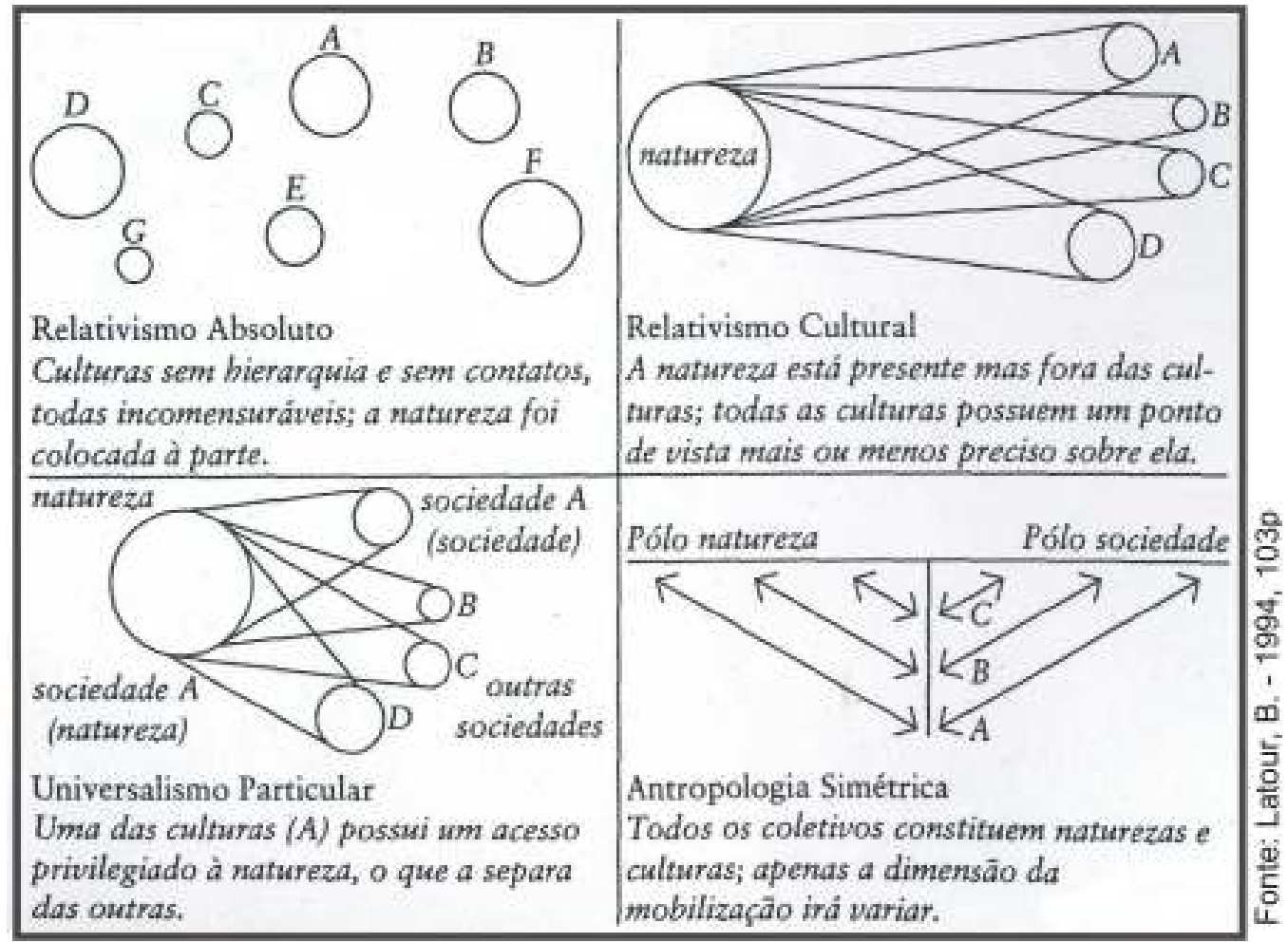

19) Relativismo absoluto: supõe culturas separadas e incomensuráveis que nenhuma hierarquia seria capaz de ordenar. Coloca a natureza de lado. 
$2^{\mathrm{a}}$ ) Relativismo cultural: é mais sutil. A natureza é considerada, mas permanece à parte das culturas. Esta se reparte em diversos pontos de vista mais ou menos precisos sobre uma natureza única, igual para todos.

$\left.3^{a}\right)$ Universalismo particular: ocorre quando a natureza é vista sem estar atrelada a uma cultura em particular. Logo, uma das sociedades - que é sempre a nossa define o quadro geral da natureza em relação ao qual as outras estarão situadas. Dito isso, projeta-se um argumento dividido em suas partes: o primeiro permite um relativismo modesto - somos apenas uma cultura entre outras; o segundo permite um relativismo arrogante - continuamos a ser absolutamente diferentes dos outros.

$4^{\text {a) }}$ Antropologia simétrica: Todas as naturezas-culturas são parecidas. São formadas ao mesmo tempo pelos seres humanos, divinos e não-humanos.

Mesmo com as diferentes definições sobre as naturezas-culturas, todas possuem um traço comum: constroem ao mesmo tempo os coletivos - humanos e não-humanos (Latour, 1994:104).

Esses coletivos - produções de naturezas-culturas - se definem por relativismos ${ }^{4}$ absolutos e relativos. Latour (op.cit.:110) sustenta que o primeiro limita as culturas ao exotismo e à estranheza, pois, se não existe nenhum instrumento de medida comum, único e transcendental, então todas as linguagens são intraduzíveis, todas as emoções incomunicáveis, todos os ritos igualmente respeitáveis, todos os paradigmas incomensuráveis. Portanto, de gosto e de cor não se discute. $O$ relativismo absoluto, assim como seu franco opositor, o racionalismo:

esquece que os instrumentos de medida devem ser montados e que, ao esquecer o trabalho da instrumentação, não é possível compreender mais nada sobre a própria noção de comensurabilidade. Esquece, mais ainda, o enorme trabalho dos ocidentais para "tirarem a medida" dos outros povos, tornando-os comensuráveis e criando, através do fogo, do saber e do sangue, padrões de medida que não existiam anteriormente (Latour, op.cit.:111).

Já o relativismo relativista traz de volta a compatibilidade que se julgava perdida. É mais modesto, porém mais empírico. Mostram os instrumentos e as cadeias usadas para criar assimetrias e igualdades, hierarquias e diferenças. Os mundos só parecem comensuráveis e incomensuráveis quando ficam presos a medidas que puderam ser medidas. A possibilidade de relacionar vem pelo intermédio do trabalho e de montagem, de prática e controvérsia, de conquista e de dominação.

... todas as medidas, tanto na ciência rígida quanto na ciência flexível, são sempre medidas medidoras e estas constroem uma comensurabilidade que não existia

\footnotetext{
${ }^{4}$ Alguns dos sentidos da palavra relativismo: estabelecer relações; tornar comensurável; regular instrumentos de medida; instituir cadeias metrológicas (estudos de descrição dos povos); redigir dicionários de correspondências; discutir sobre a compatibilidade das normas e dos padrões; estender redes calibradas; montar e negociar os valorímetros (Latour, op.cit.:111).
} 
antes que fossem desenvolvidas. Nenhuma coisa é, por si só, redutível ou irredutível a qualquer outra. Nunca por si mesma, mas sempre por intermédio de uma outra que a mede e transfere esta medida à coisa. Como acreditar que os mundos não podem ser traduzidos quando a tradução é o próprio cerne das relações estabelecidas entre eles? Como dizer que os mundos são dispersos quando nós os totalizamos o tempo todo? (Latour, 1994:111).

Latour (1994: 112) cita a etnologia como uma destas medidas medidoras que pode solucionar na prática a questão do relativismo, pois cotidianamente constrói certa comensurabilidade, sendo que o relativismo relativista pode se tornar um dos recursos essenciais na relação entre os diferentes coletivos, por servir como um negociador planetário sobre os universais relativos que são construídos aos poucos.

A mobilização dos coletivos e do mundo - e em uma escala cada vez maior multiplica os atores que compõem as naturezas e as sociedades (Latour, op. cit.: 71). Isto traz desafios quanto ao coletivo-relativismo que deve ser enfrentado ao se desenvolver um mapa turístico, que representa somente uma pequena parcela espacial (o município de Caxambu, ao sul do estado de Minas Gerais, Brasil), que fica exposta e disponível na internet, alcançando sociedades e culturas ao redor do mundo inteiro.

Neste trabalho, o desafio maior é avaliar até que ponto o mapa-site pode ser compreendido (lido, decodificado) e aceito (pela atratividade, motivação) levando-se em consideração desde um contexto local (município, estado, país) até global (outros países) a partir de itens como simbologia utilizada (convencionais e pictóricas) e a posterior inserção na Web (rede mundial computadores). Por exemplo, tendo como base os diferentes coletivos, a figura 3 apresenta graus de relativismo menores ou maiores, decorrentes do contexto local-global.

Figura 3 - 0 contexto e a escala do relativismo

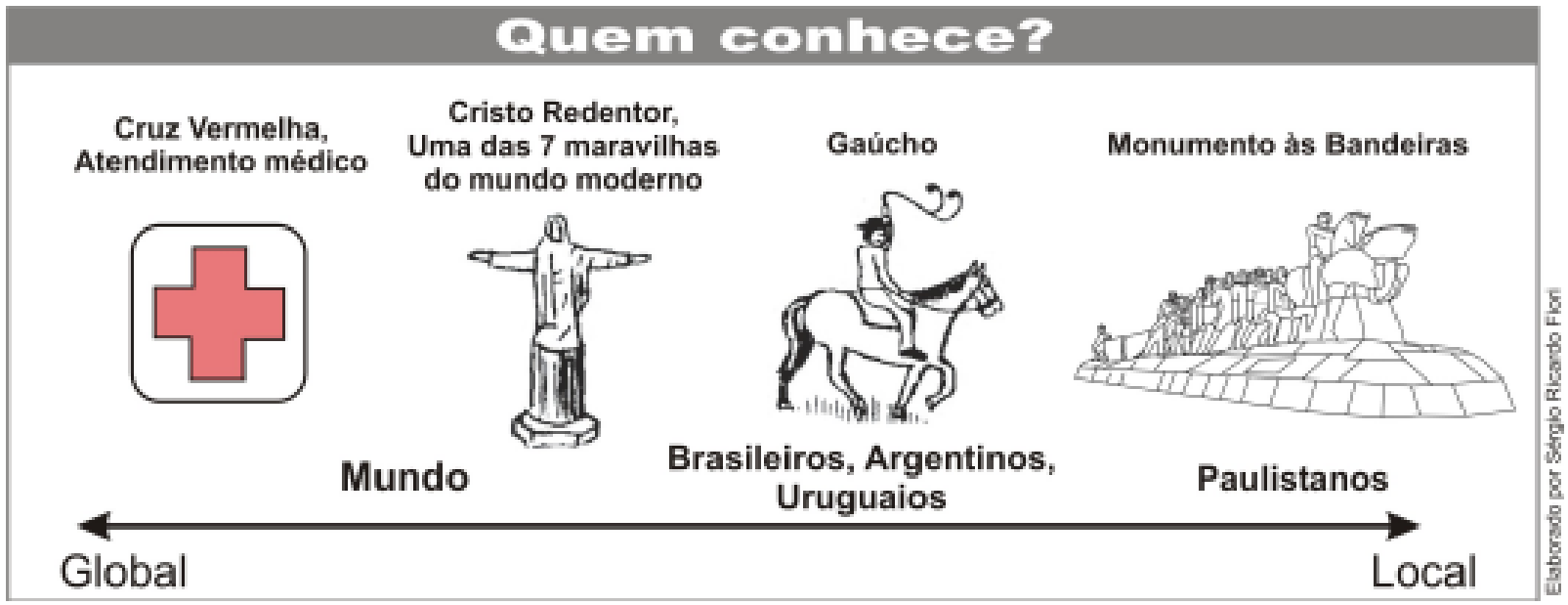

Portanto, a passagem do local ao global, do humano ao não-humano, é feita pela rede de práticas e de instrumentos, de conhecimentos, de documentos e traduções. 
$\mathrm{Na}$ verdade, essas redes não são, por natureza, nem locais nem globais, sendo melhor dizer redes, mais ou menos longas, mais ou menos conectadas (Latour, 1994: 119-120). Com base em Latour (1994), a seguir, detalham-se melhor essas relações de escala.

Primeiro, é preciso dizer que o coletivo é resultado do laço social que une os humanos entre si. Nele atuam paixões, interesses, desejos, entre outros sentimentos. São essas forças personificadas que estruturam uma sociedade. A partir das histórias contadas (o sistema da língua) de uns para outros, geram-se processos de significação a partir de narrativas, textos e discursos - estes são alguns dos elementos que designam o império dos signos (Latour, op. cit.: 63; 87).

O mapa convencional, mas principalmente o pictórico, com seus universos de símbolos, ilustrações e textos está imerso em um coletivo. E, dentro deste coletivo, estão os produtores dos mapas, os quais procuram caminhos para compor, da melhor maneira possível, a relação significante-significado, ou seja, o signo que, precisa ser eficaz (lido, denota algo), mas deve ir além, pois, no caso de um mapa temático para o turismo, o mesmo signo pode ser também associado a conotações de prazer, de emoção, de excitação, de relaxamento, de contemplação, de familiaridade, de tradição entre outras sensações humanas.

Neste instante, justifica-se a posição do mapa como ser intermediário, mediador, quase-objeto; um ser híbrido que se constitui tanto da natureza (o que representa) quanto da cultura.

Dito isso, como pensar o mapa e o seu universo de símbolos disponíveis na rede mundial de computadores, que pode alcançar desde os coletivos locais até os globais?

E é exatamente por isso que as informações disponibilizadas nos mapas turísticos e no mapa-site turístico devem ser claras e objetivas, sendo assim compreendidas e consumidas rapidamente pelo maior número de pessoas. Latour (op. cit.: 52) completa que, em rede, o mundo moderno permite prolongamentos de suas práticas, acelera a circulação dos conhecimentos, havendo uma extensão das sociedades.

Entretanto, os diferentes coletivos podem vir a se estranhar. É o que Latour (op. cit: 99) denomina de exotismo, ou seja, as diversidades das culturas, como, por exemplo, o sistema de crenças, técnicas, hábitos, jogos de poder, familiaridades e similaridades, economias, em suma, a totalidade da existência de um sujeito.

As palavras local e global possibilitam pontos de vista sobre redes que não são, por natureza, nem locais nem globais, mas que são mais ou menos longas e mais ou menos conectadas. O exotismo moderno consiste em tomar estas duplas de oposições como sendo aquilo que define nosso mundo e que nos tornaria distintos de todos os outros (Latour, op. cit.:120). 
O exotismo na elaboração dos mapas turísticos tem duplo direcionamento. O exótico de querer conhecer as outras naturezas-culturas: o coletivo diferente. Por outro lado, o exótico na elaboração de um mapa turístico, deve ser olhado com diligência pois, se, de um lado, ele constitui um estímulo, de outro, ele pode se tornar entrave, já que muitas vezes, ele não é devidamente explicitado. Em outros termos: o usuário que procure pelo exótico quer também compreendê-lo. A convergência do interesse e da explicitação possibilita uma maior eficiência.

Sendo assim, o relativismo relativista ajuda a justificar de maneira mais adequada a proposição e análise - vinda de testes empíricos - das formas de representação que sejam mais convenientes ao turismo/turista, ou seja, que instigue, motive, atraia o turista a conhecer o lugar exótico, além de ser um produto de fácil compreensão, feito para pessoas leigas na leitura de mapas.

Neste momento, é importante pensar no produtor-mediador, um ser não alheio ao processo, pois, na maioria das vezes, ele próprio acaba representando o exótico, por conceber um quase-objeto que não faz parte de sua realidade cotidiana.

O produtor cunha um arco interpretativo entre o "estar lá" - criação feita a partir de inúmeras informações coletadas sobre a localidade, em folderes, sites, livros, por informações repassadas por pessoas que habitam a localidade - e o "representar aqui" - trabalho de gabinete (normalmente distante da localidade representada). $\mathrm{Na}$ verdade, então, o produtor representa o outro a partir de uma visão externa - não é seu coletivo, sua realidade - tal como na tradição, no folclore.

O organograma abaixo (Figura 4) mostra esquematicamente as várias relações e conexões que se estabelecem entre a natureza, o mediador e a cultura.

A seguir, disserta-se sobre dois tópicos conceituais, essenciais na elaboração e compreensão de um mapa temático para o turismo: lugar e paisagem. Entretanto, é o segundo item que recebe a real atenção desta pesquisa, pois trabalha questões de como uma coletividade vê a outra e as subseqüentes expectativas, estranhezas, familiaridade, exotismos, subjetividades, etc.

O próprio ato da coleta dos dados de uma localidade, realizada pelo produtor do mapa, ocorre de diferentes maneiras, isto é, ele pode ou não ter um contato direto com a coletividade representada, assim, pode conhecê-la porque vive no local ou porque realizou nela um trabalho de campo. Mas, pode também conhecê-la por meio de conversas, internet, correio, etc. - materiais e informações (mapas-base, inventário turístico - destaques da história e cultura, arquitetura, hábitos, serviços, atrativos naturais) da coletividade que não é a sua.

Outro ponto a ser destacado é que se elabora o produto (mapa temático turístico) sempre pensando no estrangeiro, isto é, aquele indivíduo que não mora na cidade representada e que precisa ser atraído, motivado a querer conhecê-la, saber mais sobre ela, para que, a partir daí, quem sabe, ter vontade de visitá-la e indicá-la a 
outras pessoas.

Figura 4 - 0 arco interpretativo entre a natureza, o mediador e a cultura

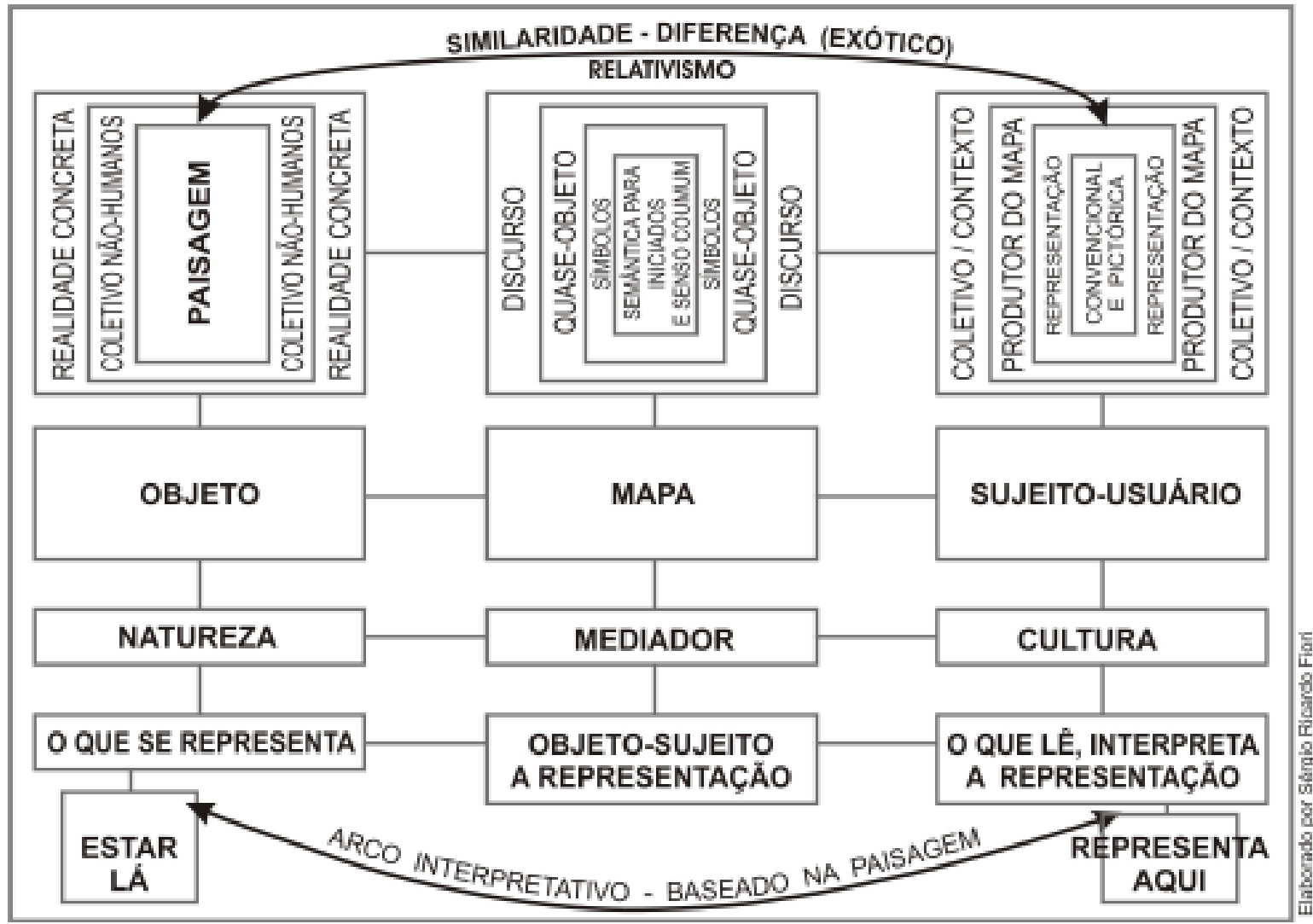

Rapidamente, aborde-se o conceito lugar: é aquele onde o indivíduo se encontra ambientado, familiarizado, integrado. É o espaço-coletivo vivido, íntimo, experimentado; espaço que faz parte do seu mundo, dos seus sentimentos e afeições. Conseqüentemente, o lugar não é toda e qualquer localidade, mas aquela que tem significância afetiva para uma pessoa ou grupo de pessoas. E será a partir dele que decorre a preocupação de verificar os gostos, as preferências, as características e as particularidades que são distintas de cada lugar. Nesse sentido, ocorre também uma valorização do contexto ambiental e dos aspectos que redundam no encanto e na magia do lugar - único - na sua personalidade e distinção (Christofoletti,1985).

Cite-se novamente a dissertação de Rodrigues (2001) pela ilustração prática do conceito de lugar. A autora colhe informações de pessoas que moram nos arredores da Serra da Canastra, em Minas Gerais. Uma delas fala que:

a paisagem era bonita demais, antes quando queimava dava para ver o Chapadão. Os animais foram espantados após a formação do Parque. Quando não havia o Parque havia o fogo e os animais gostavam dos brotos das plantas.

(alfaiate, morador há mais de 55 anos) 
Neste caso, o uso da palavra paisagem na verdade conota o conceito de lugar. Rodrigues (2001: 71) apresenta definições de lugar como espaço do dia-a-dia. O armazenamento, detalhamento, associações de imagens mentais está diretamente relacionada ao tempo da duração da residência (moradia) das pessoas. Em tese se conhece melhor um lugar tendo como referencial a aprendizagem, a aquisição de valores, entre muitas outras experiências cotidianas in loco; e isso demanda tempo.

$\mathrm{O}$ conceito de paisagem foi criado no século XVI, visando gerar um modelo visual, ou seja, a invenção pictórica da natureza. Com isso, os elementos do espaço passaram por um processo de dessacralização, por remeterem a outras coisas que não a eles próprios (seres únicos), tornando-se imagens plenamente significantes por si mesmas. Por exemplo, ao se desenhar uma árvore, um rio, uma montanha, está subentendido que esses elementos são parte constituinte da paisagem, fazendo-a existir com tal (Alcântara e Sader, 1999). As autoras continuam esclarecendo que o termo paisagem é definido por possuir uma realidade material, pois é uma extensão de espaço oferecida ao olhar. Mostra-se como uma realidade é subjetiva, pois ela simplesmente não existiria se não existisse um observador. É um espaço enquadrado, um recorte significativo do mundo, logo, a percepção de um fragmento do espaço, ao ser percebido é automaticamente interpretada. O objeto percebido é um objeto refigurado, provido de atributos anteriormente sabidos, tanto que, quando a percepção transforma um recorte do espaço em paisagem, ela está aplicando-lhe julgamentos de conformidade, realidade e identificação. Por isso, a paisagem caracteriza-se como:

produto de um olhar estranho ao lugar, de alguma forma liberado. É preciso de um outro para conferir à minha parcela do espaço a qualidade de paisagem, cuja percepção entra numa lógica de diferenciação social e cultural em função de um movimento de distância crítica, transformando elementos do espaço em espetáculo" (Alcântara e Sader, 1999).

Santos (1996: 61 e 2002:103) define e complementa paisagem como uma parte da configuração territorial que é vista, que o olho abarca, com seus volumes, cores, movimentos, odores, sons, etc. Logo, a percepção ${ }^{5}$ e a cognição ${ }^{6}$ têm um papel fundamental na apreensão do conjunto heterogêneo de formas naturais e artificiais (objetos reais-concretos) ${ }^{7}$ encontrados em uma área e que a caracterizam fisicamen-

\footnotetext{
${ }^{5}$ É sempre um processo seletivo da apreensão. Mesmo se as pessoas partem de uma única realidade, cada uma a vê de maneira diferenciada. Isso faz com que a visão do homem em relação às coisas materiais seja sempre deformada. A percepção não é tida como conhecimento - pois depende da interpretação - e terá maior validade quanto mais limitar o risco de tomar por verdadeiro o que é só aparência (Santos: 1996: 62).

${ }^{6} \mathrm{O}$ aparelho cognitivo tem um papel crucial na apreensão da paisagem, pelo fato de que toda educação (formal e informal) é feita de forma seletiva, ou seja, pessoas diferentes apresentam diversas versões para o mesmo fato (Santos: 1996: 62).

${ }^{7}$ A paisagem compreende dois tipos distintos de elementos: os objetos naturais, que não são obra do homem nem jamais foram tocados por ele. $\mathrm{E}$ os objetos sociais, testemunhas do trabalho humano tanto no passado como no presente (Santos, 2004: 54).
} 
te. Como, por exemplo, uma região produtora de algodão, café, trigo ou, então, uma paisagem urbana - cidade, centros, periferias - de tipo européia, americana ou asiática. Todas são paisagens e concentram formas mais ou menos duráveis, possuindo um traço comum: a combinação de objetos naturais e fabricados, que em conjunto formam os objetos sociais, resultado da acumulação da atividade humana por muitas gerações (Santos: 2004: 53).

Nesse processo, Cavalcanti (1997) admite que a compreensão do conceito de paisagem trabalha tanto com a ciência (caráter funcional), quanto com a arte (caráter estético: caso, por exemplo, dos paisagistas). A junção desses dois caracteres revela não só as relações de produção e estrutura da sociedade no espaço mas também o imaginário ${ }^{8}$ social, as crenças, os valores, os sentimentos das pessoas que a constroem. Em suma, espaço e paisagem resultam de um mosaico de relações, formas e sentidos (Santos, 1996: 62).

Pensando mais especificamente no turista e no próprio produtor do mapa, é fundamental esclarecer que eles percebem o lugar em sua "aparência". Segundo Beni (1998: 361), a paisagem se vai com o observador, porque não é mais que uma idéia da realidade que este elabora quando interpreta esteticamente o que está vendo.

O outro - tanto o turista quanto o produtor - não se envolve nem se relaciona com as vidas e os valores dos habitantes locais. Já o morador da localidade representada tem uma atitude mais complexa, resultado de sua imersão no ambiente (Tuan: 1980: 72; 74). O autor ainda exemplifica a postura superficial do turista em relação a uma cidade medieval européia - ver também a figura 4.

Manifestam seu deleite sobre as ruas escuras, calçadas com seixos, as esquinas e recantos íntimos, as pitorescas construções compactadas de casas e as encantadoras lojas antigas, sem parar para pensar como as pessoas realmente viveram. Ou então, um turista em Chinatown fica encantado com o estímulo de seus sentidos da visão e do olfato; ele sai com uma feliz ignorância do apinhamento, das vidas apáticas, do jogo atrás das vistosas fachadas (Tuan: op.cit.: 74).

Mas, por outro lado, o mesmo turista é capaz de perceber méritos e defeitos em um meio ambiente que já não são mais visíveis ao residente (Tuan, op.cit.:75).

Uma abordagem mais gráfica em relação à paisagem é retirada da geografia cultural. Esta conceitua paisagem como um modo especial de compor, estruturar e dar significado ao mundo externo, que é possuidor de uma história que precisa ser

\footnotetext{
${ }^{8}$ Segundo Lacan (apud Gomes, 1996) é uma ficção real e vivida. Para compreender o imaginário, é necessário nos colocar em consonância com o outro mesmo quando a comunicação ultrapassa as possibilidades de interpretação racional. A função empática da arte inscreve-se neste gênero de comunicação, por utilizar um vocabulário inconsciente para fazer transitar sensações reais e vividas sob a aparência de irrealidades. A valorização da arte pelos geógrafos humanistas explica-se exatamente por esta dimensão do conhecimento espontâneo, inconsciente e não racional.
} 
entendida em relação à apropriação da terra. Para isso, são produzidas qualidades simbólicas da paisagem, que ajudam a sustentar seu significado social considerada, a partir de então, uma imagem cultural, um meio pictórico de representar ou simbolizar tudo que rodeia o ser humano. Isso é feito por intermédio da pintura, desenho, imagens gravadas. Cada um desses meios revela significados que os grupos humanos atribuem às áreas e lugares, e permite relacionar esses significados a outros aspectos e condições da existência humana (Cosgrove e Jackson: 2000: 18).

\section{Figura 5 - Fotos de uma cidade medieval}

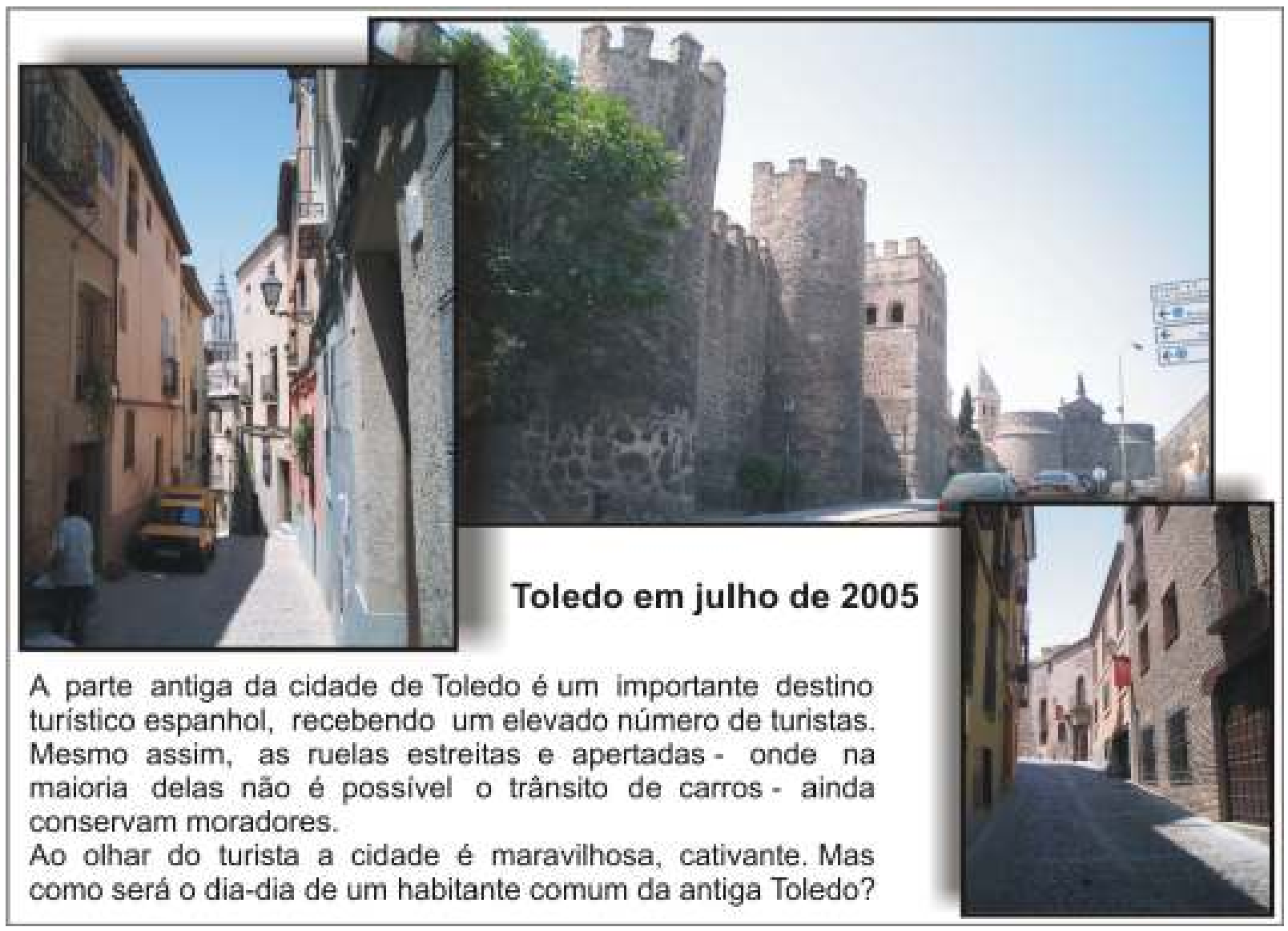

Conceituar paisagem pela representação de símbolos e signos conduz a estudos mais interpretativos como a lingüística e a semiótica. Os autores (Cosgrove e Jackson: 2000: 19) afirmam que esta linha de pesquisa desenvolve a metáfora da paisagem como "texto" que é lido e interpretado como documento social.

Cosgrove e Jackson (2000: 22) ainda ressaltam que a analogia da paisagem-texto é valiosa, pois preserva o significado da ação humana, da criatividade e da sobreposição de camadas de significado. Todavia, apresenta limitações, na medida em que a paisagem é concebida com a história de um modo de ver e de representar.

Por isso, em sociedades primitivas, com menor comércio, os códigos simbólicos eram mais estáveis do que nas sociedades contemporâneas. Hoje, o mundo é marcado 
pela liberdade de atribuir significados e pela intertextualidade, com a qual se invertem os signos e símbolos para adaptá-los a diversos contextos, transformando a referência e enfatizando somente a superfície e não a profundidade (Cosgrove e Jackson, 2000: 23).

Sendo assim, as representações gráficas para mapas turísticos resultam da combinação espaço-tempo. Espaço onde se encontram as diferentes naturezasculturas, que se modificam e se inter-relacionam, em diferentes níveis, no tempo. Relembra-se a definição de território, imutável em seus limites (o que se dá por intermédio da força ou acordo), não possuindo necessariamente a mesma extensão através dos tempos. Ele se torna espaço devido às inúmeras sucessões históricas e conseqüentes ocupações por um povo.

O espaço é resultado de um matrimônio ou encontro, sagrado enquanto dura, entre a configuração territorial, a paisagem e a sociedade. $O$ espaço é a totalidade verdadeira, porque dinâmica, resultado da geografização da sociedade sobre a configuração territorial. Podem as formas, durante muito tempo, permanecer as mesmas, mas, como a sociedade está sempre em movimento, a mesma paisagem, a mesma configuração territorial, nos oferecem, no transcurso histórico, espaços diferentes (Santos: 1996: 77).

O espaço é composto por várias paisagens (materializações de vários instantes históricos), resultado de um conjunto de objetos (materiais e não-materiais), formas e momentos com heranças distintas (Santos, 1996: 66). Conseqüentemente, a paisagem é um registro de época e um documento de cultura (Moraes, 2002: 23).

Wagner e Mikesell (2000: 141) completam que o processo gradual e cumulativo da paisagem, relacionada aos respectivos estágios históricos, traz significados tanto para a paisagem de hoje quanto para as do passado. E, atualmente, as paisagens do mundo não refletem apenas evoluções locais, devido ao grande número de influências resultantes das migrações, difusão (mídias), comércio e trocas.

Essa dinâmica dá à paisagem um sentido móvel, isto é, cada vez que a sociedade passa por um processo de mudança, também mudam, em ritmo variado, a economia, as relações sociais e políticas. Por conseguinte, o mesmo fenômeno acontece com o espaço e a paisagem, que se transformam, buscando se adaptar às novas necessidades da sociedade (Santos, 2004: 54).

Ratifique-se, portanto, que paisagem e espaço não são sinônimos, sendo a primeira um conjunto de formas, contextualizada em recorte temporal, cumulativo e substitutivo, resultado da lógica de produção do espaço. As paisagens se formam umas sobre as outras, sendo constituídas pelo conjunto de objetos de diferentes idades, que representam as sucessivas relações entre a humanidade e a natureza. Reafirme-se, então, que a paisagem é transtemporal, juntando objetos passados e presentes, ou seja, suas formas ocorrem em momentos históricos diferentes - 
rugosidades ${ }^{9}-$, porém coexistem no momento vivido, atual. Já o espaço ${ }^{10}$ são todas essas formas mais a vida - sociedade presente e agente nas formas-objetos - que as anima (Santos, 2002:103-104).

Assim, o mapa pictórico turístico trabalha conjuntamente os conceitos: paisagem configurada por um sistema material - que, entre outras coisas, pode ser graficamente representado e espaço, onde as formas que hoje compõem a paisagem têm uma função, ou seja, respondem às necessidades prementes da sociedade - no caso, foca-se sobre os mapas que apresentam atrações, naturais e culturais, atividades e serviços disponibilizados por localidade e atual destinação turística. Por isso, leva-se ainda em conta a definição de espaço turístico de Boullón (apud Beni: 1998: 56):

é resultado da presença e distribuição territorial dos atrativos ${ }^{11}$ turísticos que, não podemos esquecer, são a matéria-prima do Turismo. Este elemento ou componente do patrimônio turístico, mais o mapeamento, são suficientes para definir o espaço turístico de qualquer país.

Santos (op.cit::104) constata que o espaço se caracteriza por um sistema de valores instáveis, resultado de sua permanente transformação.

Visto de maneira mais direta, o espaço do local trabalhado pelo setor do turismo, concentra um determinado número de objetos reais-concretos e paisagens, que são "filtradas" e aproveitadas no desenvolvimento dos mapas. Isto decorre das diversas parcelas e maneiras de utilização do espaço, que se constituem por um conjunto de mercadorias que recebem valores - maiores ou menores - em um dado momento, pela sociedade, refletido em cada fração da paisagem. O que significa que os objetos não mudam de lugar, mas de função, isto é, de significação, de valor sistêmico (Santos, op.cit::103-104).

Citem-se então alguns exemplos: um rio, que antes servia somente para a pesca de subsistência e irrigação de lavouras, hoje oferece um grande potencial aos esportes de aventura como o rafting, o bóia-cross ou o canyoning. Um antigo galpão, que

\footnotetext{
${ }^{9}$ É o que fica do passado como forma, espaço construído, paisagem, ou seja, são reminiscências dos processos de supressão, acumulação e superposição, com que as coisas se substituem e acumulam em todos os lugares. O tempo atual se defronta com o tempo passado, cristalizado em formas (Santos, 2002: 140).

${ }^{10}$ Deve ser considerado como um conjunto indissociável de que participam, de um lado, certo arranjo de objetos geográficos, objetos naturais e objetos sociais e, de outro, a vida que preenche e os anima, ou seja, a sociedade em movimento (Santos, 1996:26). Por trás dos padrões sociais, das formas criadas, dos usos do solo, das repartições e distribuições, dos arranjos locacionais, estão concepções, valores, interesses, mentalidades, visões de mundo. Enfim, todo o complexo universo da cultura, da política e das ideologias (Moraes: 2002: 16). O autor ainda alerta (op. cit.: 19) que não se deve perder o contexto histórico, pois o sujeito exprime uma época, sendo estruturado dentro de limites e possibilidades.

11 Também chamado de recursos turísticos, os quais constituem o patrimônio turístico. Esses elementos são passíveis de provocar deslocamentos de pessoas e integram o marco geográficoecológico-cultural de um lugar, podendo, por sua origem, ser subdivididos em naturais e culturais (Beni: 1998: 57).
} 
antes abrigava uma tecelagem, hoje pode ser um espaço cultural, como um teatro. Cite-se hipoteticamente o centro urbano de uma cidade qualquer, que outrora fora rico, ativo e efervescente, porém com o tempo se tornou inóspito, perigoso. No entanto, com um trabalho de restauração e incentivo governamental (arquitetura, infra-estrutura, volta de moradores, etc) pôde se tornar um importante e atrativo destino turístico da cidade. Desse modo, o que hoje é valorizado por determinada parcela da sociedade (material acumulado das ações humanas através do tempo) amanhã pode não ser (animado pelas ações atuais) e vice-versa. Santos (2002: 105) complementa que, só por sua presença, os objetos técnicos não têm outro significado senão o paisagístico. Mas eles aí estão também em disponibilidade, à espera de um conteúdo social.

Tal movimento ininterrupto da sociedade traz novas funções às formas geográficas, que possuem vida pelo processo sempre renovado de seu poder representativo, seu conteúdo ${ }^{12}$. Tal conteúdo corporificado, ou seja, já transformado em existência, traz intrinsecamente a sociedade nas formas geográficas: é a sociedade transformada em espaço (Santos, 1996: 27). A forma contém em si a memória viva, imagens do presente e/ou de um passado que não existe mais (Santos, 2002:106).

O mesmo autor exemplifica (Santos, 2002:109) que um conjunto de prédios históricos, uma praia, uma floresta, entre outros elementos paisagísticos, participam desse processo dialético quando Ihes são atribuídos determinados valores, ao serem transformados em espaço. O simples fato de existirem como formas, isto é, como paisagem, não basta. A forma já utilizada é coisa diferente, pois seu conteúdo é social. Ela se torna espaço, porque forma conteúdo.

Neste processo, o espaço tornou-se mercadoria universal por excelência, sendo convertido em uma gama de especulações de ordem econômica, ideológica, política, seja de forma isolada seja em conjunto (Santos, 2004: 30). Kotler (apud Santos, 2004:30) defende a idéia de um marketing das localidades, que procura maneiras para influenciar as atitudes das pessoas e estabelecer trocas de domicílios, de locais industriais e comerciais, de terrenos, de viagens e imagens nacionais.

Dentro dessa lógica, pode-se trabalhar a paisagem como conjuntos, como se fossem cartões postais, ou seja, trazer ao olhar um conjugado de formas ou formas isoladas. Até porque, de um modo ou de outro, temos a tendência de negligenciar o todo; mesmo os conjuntos que se encontram em nosso campo de visão nada mais são do que frações de um todo (Santos, 2004: 35). O autor continua esclarecendo que a percepção que se tem da paisagem está longe de englobar o objeto em sua realidade profunda: o que se capta é uma aparência. O objeto caracteriza-se por duas faces: a verdadeira, que não se dá diretamente ao observador; e a face visível, amoldada pela

${ }^{12} \mathrm{O}$ conteúdo (da sociedade) e a forma (objetos geográficos) são dependentes entre si. Até porque, cada forma encerra uma fração do conteúdo, que pode ser comparado a uma sociedade em andamento, em evolução, em movimento. Ou, melhor ainda, ao seu presente ainda não realizado (Santos, 1996: 27). 
ideologia $^{13}$.

A ideologia é objetiva, por dissimular o real, tentando impor-lhe a sua significação no momento crucial da objetivação da totalidade, ou seja, o que está na forma-objeto como significante, encontra-se em sua totalidade como significado (Santos, 2004: 37). A partir desta dualidade (significante-significado), o símbolo se faz presente, contudo a realidade à qual ele remete pode estar presente ou ausente, ser passado ou futuro, existente ou somente possível (Fraisse apud Santos, 2004: 37). Conseqüentemente, os símbolos são formações que representam objetos; que estão em relação entre si, ao mesmo tempo em que são distintos, que dependem de si próprios assim como os objetos dependem deles, constituindo, porém, entidades autônomas (Lorenzer apud Santos, 2004: 38). Some-se, ainda, que os símbolos adquirem vida própria, tornandose mais eficazes quando há a fetichização da matéria inerte. Isso faz com que, no caso dos objetos que compõem a destinação turística, eles sejam concebidos como mercadorias para seduzir e atrair o turista-consumidor.

Como resultado, as formas (em si), os objetos geográficos, passam a ter mais do que um papel funcional, pois são preenchidos de simbolismo, representatividade, intencionalidade. Impõe-se sobre eles um conteúdo e um valor que na realidade não têm; logo, seu significado é deformado por sua aparência (Santos, 2004: 59).

E a compreensão dos vários níveis de simbolismos é preocupação essencial na pesquisa, pois os mapas turísticos serão oferecidos a uma gama muito heterogênea de usuários (idade, grau de escolaridade, diferentes nacionalidades, níveis de compreensão e utilização de um computador, etc) que precisam compreender e interagir com as informações recebidas Já o produtor procura trabalhar a emoção e a motivação do usuário primeiro pelo produto (mapa turístico em meio digital e interativo) e logo depois, e não menos importante, pela destinação representada.

A universalização do mundo apontada por Santos (1996:14) nos ajuda a supor como se constata empiricamente ao final deste trabalho - que boa parte das pessoas que entram em contato com o produto são capazes de compreendê-lo, por já fazerem parte do processo de universalização das trocas, do mercado, da mercadoria, das técnicas, dos gostos, do consumo.

Cabe então ao produtor representar graficamente, e da melhor maneira possível, o espaço e algumas de suas peculiaridades ao outro turista. Para isso, ele conta com a localização geográfica circunscrita e diferente de outras, com seus atrativos naturais, culturais, serviços, acessos, constituídos ao longo do tempo (movimento). É importante ressaltar que existe um grau de similaridade-diferença (relatividade) entre os diversos espaços e coletividades. Isto faz com que algumas paisagens e sociedades sejam mais ou menos atraentes e mais ou menos compreendidas do que

13 Os construtores do espaço estão atrelados à ideologia dominante ao conceber uma casa, uma estrada, um mapa, uma cidade. $O$ ato de construir está submetido a regras que procuram nos modelos de produção e nas relações de classe suas possibilidades atuais (Santos: 2004: 36-37). 
outras.

Todo o processo de criação tem como base a diversidade cultural, trazendo à tona informações que precisam ser interessantes, de fácil reconhecimento e leitura ao maior número de pessoas. Conseqüentemente, procura-se um tipo de representação cartográfica com grande apelo ao senso comum, ao imaginário coletivo e também ao lúdico. O intuito é gerar sempre a dualidade: traços de identidade, igualdade, visando à leitura, compreensão do mapa; e de diferença, como o exotismo, que motivam, instigam o querer conhecer, viajar.

Para que isso ocorra, o mapa turístico deve se tornar natural e naturalizado, criando possibilidades com base nos mapas já existentes, ou seja, aqueles constituídos por uma semântica para iniciados como os provenientes do ensino formal: os mapas e símbolos convencionais. Estes podem ser retrabalhados e adaptados ao público potencial: o leigo em cartografia e que deseja conhecer novos lugares. Nesse caso, ocorre um hibridismo, resultante da composição entre símbolos pictóricos e ilustrações: os chamados "símbolos culturais" familiares ao senso comum. Contudo, deve-se sempre estar atento aos itens fundamentais da composição de um mapa convencional, como escala, legenda, título e sistema de referências (indicação de norte, latitude, longitude).

A pesquisa empírica auxilia na medição e na verificação analítica do produto, que contém assimetrias, igualdades, hierarquias e diferenças.

\section{3 - Quando as tradições se institucionalizam:}

\section{a semântica para iniciados versus o senso comum}

Referenciados no relativismo cultural e no empirismo, introduz-se Pierre Bourdieu, que discorre sobre os jogos de poder na sociedade. Ele teoriza sobre uma relação mais individualizada entre a tradição e o costume privado que pode vir a se tornar público.

Tendo como parâmetro o mapa para o setor do turismo e com base no capital cultural e suas nuances - grande variedade e níveis de relações entre coletivos - surgem muitas preocupações referentes à boa funcionalidade do produto, devido à diversidade do público usuário e, portanto, à necessidade de uma instrução prévia.

A finalidade é criar convenções com base no que já existe, ou seja, nos mapas convencionais que trazem uma semântica para iniciados. A partir daí adaptar, adequar e elaborar os mapas temáticos para o turismo, que mesclam o convencional (símbolos abstratos, normas mais rígidas, representações e leitura mais simples e direta) com a pictografia (símbolos pictóricos, suposta tridimensão, ilustrações, leitura mais lenta, lúdica). Procurando referenciar (restringir minimamente) o público a ser pesquisado e analisado, é importante esclarecer que os mapas turísticos são disponibilizados na Web. Isso faz com que o usuário do então mapa-site turístico 
precise ter contato com computadores - ambiente Windows ou similar e a internet.

Inicialmente aborda-se o tópico relativo a padronizações, normas.

As relações políticas e acadêmicas procuram "domesticar" o caos, buscando uma ordenação do mundo. Atualmente, o Estado, a escola e a mídia são os principais atores de reprodução das práticas sociais. Bourdieu (1974: XIV-XVI) sustenta que é pelas alegorias (discursos, mensagens e representações) que são simuladas as estruturas reais das relações sociais. A busca de tal organização é gerada por meio de funções ideológicas e políticas de uma cultura dominante numa dada formação social.

O Estado, como autoridade máxima, institucionaliza, à vista de todos e em nome de todos; publica e torna oficial, procurando subtrair o arbitrário. Tal processo se dá de maneira particular ou por intermédio de ações e imposições ao longo do tempo, buscando uma identidade legítima do grupo, a fim de gerar uma unidade real (Bourdieu, 2000:114).

Focalizando o tema desta pesquisa, a cartografia e o turismo, tem-se que os mapas, quando bem executados, tornar-se-iam, por exemplo, uma das primeiras e das mais importantes fontes de informação - principalmente ao turista - e de divulgação do potencial da localidade.

Nesse contexto, conceitua-se o habitus ${ }^{14}$, que exige dos grupos e/ou classes sociais o controle e domínio mínimo de um código comum, mesmo que ainda não seja um registro consciente. Carneiro (2001:31) complementa que o uso de códigos facilita o processo de comunicação das informações semânticas a partir do momento em que utiliza unidades ou elementos significativos que são de conhecimento prévio do receptor-usuário.

Primeiramente, o habitus é adquirido por via inculcação familiar (Bourdieu, 1974: XLVII); contudo, será a escola a força formadora dele, propiciando aos indivíduos um corpo comum de categorias de pensamento, que trazem consigo seus modelos, regras, tornando possível a comunicação. O conceito escolástico para habitus é, sobretudo, um conjunto de esquemas fundamentais que são previamente assimilados, a partir dos quais se produzem, segundo uma arte da invenção.

\footnotetext{
${ }^{14}$ Toda a ação histórica reflete dois estados do social: o Habitat - estado objetivado - história acumulada ao longo do tempo nos objetos, nas máquinas, edifícios, monumentos, livros, teorias, costumes, direito, etc. E o Habitus - estado incorporado. Por exemplo: Quando um homem tira o chapéu para cumprimentar alguém, está reativando, sem saber, um sinal convencional herdado da Idade Média, pois este gesto remonta aos homens de armas, que costumavam tirar o seu elmo para manifestações pacíficas. Esta atualização da história é conseqüência do habitus, isto é, produto de uma aquisição histórica que permite a apropriação do adquirido histórico (Bourdieu, 2000: 82). Por outro lado, quando duas pessoas são dotadas de habitus diferentes, isto é, não foram expostas às mesmas situações e aos mesmos estímulos, terão razões para fazer julgamentos de valor de maneiras diferentes (Bourdieu, 1996: 333).
} 
Esquemas particulares diretamente aplicados a situações particulares (Bourdieu, 1974: 349).

O sistema de ensino tradicional tende a assumir uma função de integração lógica, de legitimação cada vez mais necessária à perpetuação da ordem social. Preocupa-se em elaborar um programa homogêneo de percepção, de pensamento e de ação, assegurando, assim, àqueles indivíduos pertencentes a uma mesma geração ou história, uma homogeneidade própria que facilita a comunicação, a comunhão (Bourdieu, 1974: 206). Em uma disposição geral, ocasiona esquemas capazes de serem aplicados em campos diferentes do pensamento e da ação, aos quais se pode dar o nome de habitus cultivado (Bourdieu, 1974: 211).

Ocorre, então, que o sistema de ensino é umas das instituições mais preocupadas em transmitir a cultura, por desenvolver um papel fundamental quanto à participação de um senso comum, entendido como um fundamento comunicação. A escola dá ao indivíduo primordialmente um repertório para abordar os problemas de maneira comum. Bourdieu (1974: 288) trata de tal relação ao afirmar que, para que os homens cultivados de uma época possam discordar a respeito das questões que discutem, devem ao menos estar de acordo com certas questões, para assim, discutir sobre outras. Até porque o processo de transformações e reestruturações do campo cultural é contínuo e não radical, abraçando os mais variados temas. Assegura também a continuidade da comunicação entre as gerações intelectuais. E, em todos os casos, é o sistema escolar que torna inteiramente compreensível os esquemas que organizam o pensamento de uma época, consagrando-os e constituindo-os, pelo exercício, como hábitos de pensamentos comuns a toda uma geração (Bourdieu, 1974: 208).

Pensando no ensino da linguagem cartográfica, observam-se duas grandes linhas de pesquisa:

$\checkmark$ A Cartografia Sistemática ou topográfica - responsável pela produção e divulgação de documentos cartográficos elaborados a partir de rígidos parâmetros técnicos. Os elementos visíveis da paisagem são representados, efetuando-se medições precisas relacionadas aos ângulos, direções, distâncias, desníveis e superfícies (Guerrero \& Fiori, 2005: 141). Objetivam a representação exata e detalhada da superfície terrestre no que se refere à posição, à forma, às dimensões e à identificação dos acidentes do terreno, assim como dos objetos concretos que aí se encontram permanentemente (Joly, 1990: 54).

$\checkmark$ Cartografia Temática - está relacionada à elaboração e disseminação de documentos cartográficos que representam temas específicos (vegetação, população, clima, etc), relacionados às particularidades da superfície terrestre. Os mapas temáticos são os produtos mais conhecidos da sociedade em geral, sendo utilizados em diferentes contextos. Comumente estão em Atlas escolares, como também em revistas, na Internet, na televisão, etc. Resultam 
principalmente da seleção de dados estatísticos, posteriormente submetidos à representação cartográfica pelo uso de diferentes metodologias (Guerrero \& Fiori, 2005: 141).

Esta pesquisa parte de bases topográficas (sistemáticas), que são o pano de fundo para que se instaure e aprofunde uma metodologia voltada à cartografia temática, objetivando a elaboração de mapas turísticos.

É imprescindível relembrar que os mapas direcionados à divulgação turística e disponibilizados na internet devem ser cuidadosamente pensados, devido à grande heterogeneidade e aos níveis de interesse do público, que apresentam diferentes idades, graus de escolaridade, conhecimentos gerais, afinidades, conhecimentos em cartografia - escala que vai desde aqueles que compreendem a leitura dos mapas e conhecem a semântica para iniciados até aqueles que não têm conhecimento formal da disciplina, etc. Portanto, a elaboração de mapas voltados ao setor do turismo deve levar em consideração o usuário que tem apenas um conhecimento mínimo dos conceitos e noções relativas à comunicação cartográfica.

Neste instante, é importante citar Guerrero (2004: 43), que trata do ato de aprendizagem. $O$ ato ocorre de maneiras diferentes entre os sujeitos. Tal diferenciação está intrinsecamente ligada às estruturas cognitivas, às experiências de vida e ao aprofundamento da significação, resultante do maior ou menor contato com a informação que proporciona maior ou menor conhecimento dos seres humanos em relação aos mais diversos temas de seu cotidiano.

Abordando especificamente a utilização de mapas, relata-se em linhas gerais a pesquisa de Simielli $(1986,1996)$ ao ressaltar que o público não especializado apresenta muitas dificuldades com relação à leitura do material cartográfico. Esse problema histórico ocorre devido à baixa qualidade da educação cartográfica presente no ambiente escolar, que deveria se preocupar, por exemplo, em esclarecer conceitos da visão vertical e oblíqua, imagem bidimensional e tridimensional, noção de proporção e escala, alfabeto cartográfico e legenda, orientação, localização espacial, etc. Entretanto, na maior parte das vezes, conceitos e noções são mal assimilados ou pouco praticados, gerando um baixo índice de compreensão e interesse pela leitura dos mapas.

Torna-se oportuna a apresentação de alguns resultados empíricos obtidos na pesquisa de Guerrero (2004: 220-227), que trabalhou com professores de geografia do ensino fundamental e médio do município de São Paulo (Núcleo de ação educativa 05 - Prefeitura de São Paulo, região político-administrativa do Campo Limpo) em cursos de formação continuada. As atividades foram aplicadas uma a uma, em módulos mensais de aula para cada grupo de professores. Os resultados abaixo demonstram a elaboração de representações cartográficas equivocadas, oriundas de uma alfabetização cartográfica inexistente ou pouco eficiente dos docentes. Observou-se: 
$\checkmark$ Dificuldade na utilização de cartas topográficas, devido a sua linguagem técnica e mais específica, de leitura mais demorada e complexa do que um mapa temático. Acrescenta-se que, quanto maior a escala, maior a dificuldade do pesquisado para ler e compreender as curvas de nível. Aliás, verificou-se que muitos docentes não tinham aprendido os conceitos de curvas de nível e altitude;

$\checkmark$ A maioria dos professores nunca havia manuseado mapas temáticos e cartas topográficas, e, portanto, não conheciam seus signos, símbolos e a linguagem;

$\checkmark$ A presença de um ruído conceitual ao representar os fenômenos de manifestação linear e zonal. Na maioria das atividades realizadas, os professores contavam com informações lineares, mas, ao elaborarem a legenda do mapa, representaram tal informação como zonal;

$\checkmark$ Uso da cor de maneira indevida;

$\checkmark$ Dificuldade de identificar os cursos fluviais, pois eram confundidos com curvas de nível;

$\checkmark$ Problemas para indicar o título, a legenda, a escala;

$\checkmark$ Identificação correta do sistema viário e pontos de referência.

O pequeno exemplo detectou que, mesmo professores de geografia, depararam-se com lacunas conceituais básicas referentes aos conceitos cartográficos e iconográficos. E o que dizer então da população em geral?

A pesquisa empírica inicial de Fiori (1999: 99-106) já dava indícios de que, dependendo do público com o qual o produtor trabalha, a maneira como se concebem os mapas é muito importante. O teste empírico desenvolvido com cento e vinte crianças do ensino fundamental $\left(5^{\mathrm{a}}\right.$. e $6^{\mathrm{a}}$. séries) constatou que esse grupo de usuários sentiu-se motivados à leitura e conseguiu entender melhor a informação constatada a maior quantidade de respostas corretas quando ela trazia um apelo maior dos recursos pictóricos, em vez dos usuais símbolos abstratos ou geométricos. Por exemplo: as figuras pictóricas nos mapas políticos auxiliaram efetivamente a localização dos países, pois o produtor buscou supostas referências (imagens mentais) aprendidas pelo receptor ao longo de sua vida. O mesmo fato aconteceu com as representações da morfologia do terreno. Isso ocorreu porque, enquanto o usuário do mapa convencional tem somente a cor como grande apoio à interpretação - relaciona-se a realidade, que é o espaço geográfico -, à representação - o usuário do mapa pictórico "vê desenhada a altitude" sobre o mapa (Figura 6). Ver também os mapas em formato digital no CD - anexos - pasta 1. 
Figura 6 - Pictografia usada em mapas políticos e físicos
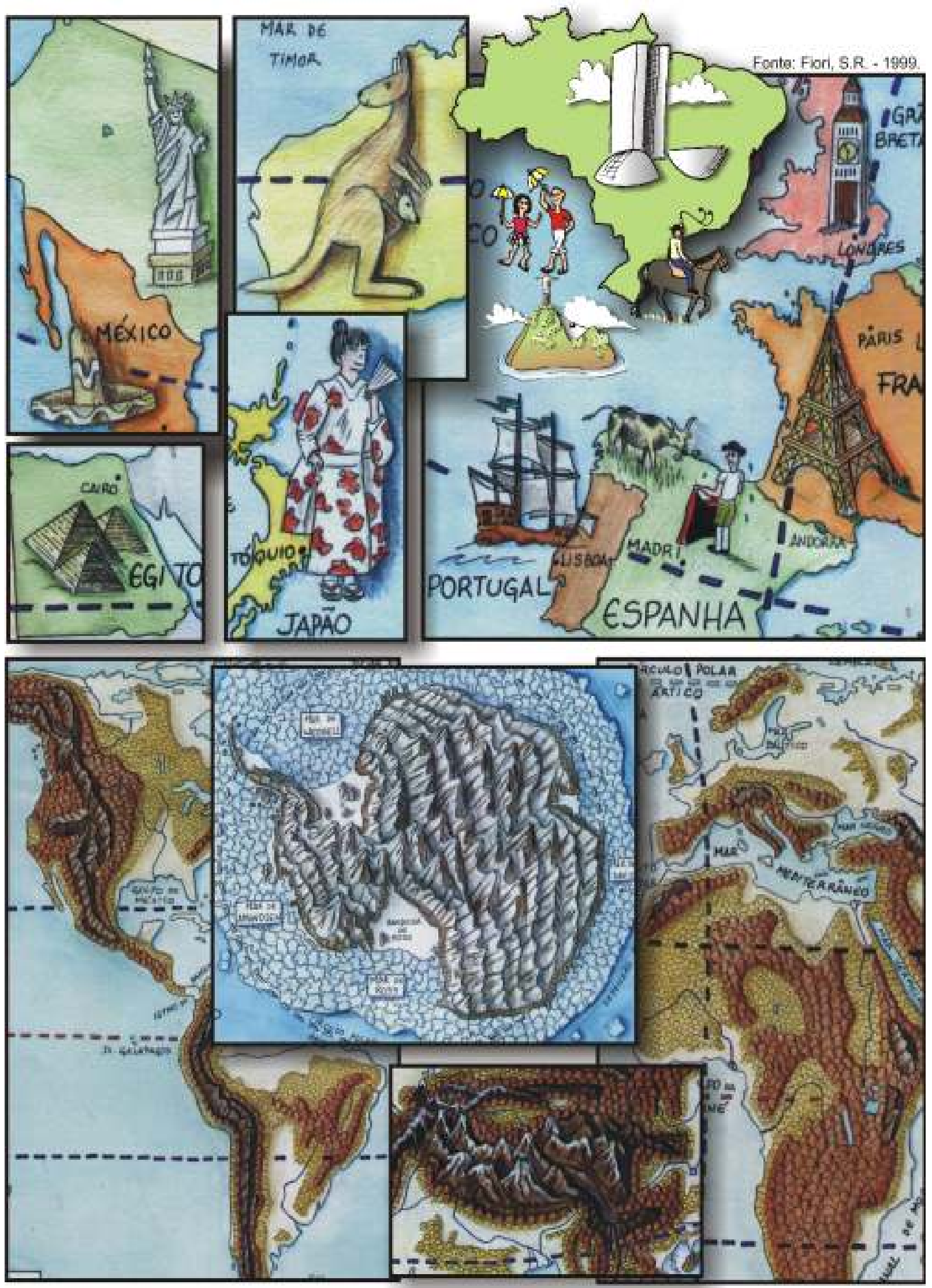

Fonte: Fiori, S.R. - 1999. 
Mesmo na pesquisa seguinte (Fiori: 2003: 180-183), já direcionada ao desenvolvimento de mapas voltados ao setor turístico, é flagrante a opção do usuário leigo pela pictografia. Pôde-se perceber que o segredo do maior sucesso relacionado aos mapas pictóricos - tanto em relação à quantidade de respostas satisfatórias quanto à aceitação do produto - está em sua maior proximidade com a imagem encontrada na realidade havendo, portanto, uma menor exigência de abstração. $O$ estilo artístico adequado, tendo sempre em evidência o tipo de público e a finalidade do produto, também auxilia e muito o aumento do desempenho do material cartográfico.

É necessário deixar mais claro o conceito de abstração utilizado neste trabalho. Ele é definido por deixar de lado os "detalhes irrelevantes" da realidade, enfatizando os traços distintos do elemento real-concreto. De acordo com Dondis (1991: 91), esse é um processo de "destilação", ou seja, de redução dos elementos visuais a traços mais essenciais e característicos. A graduação ligada à eliminação dos detalhes segue dois caminhos: a abstração voltada ao simbolismo que, às vezes, proporciona um significado identificável, e, outras vezes, um significado arbitrariamente atribuído; e a abstração pura, ou redução da manifestação visual aos elementos básicos, que não conserva relação alguma com qualquer representação representacional extraída da experiência do meio ambiente.

Aliás, mesmo a abstração voltada para o simbolismo requer uma simplificação radical, ou seja, a redução dos detalhes visuais do elemento disposto no espaço a seu mínimo irredutível. Além disso, para ser eficaz, um símbolo não deve apenas ser visto e reconhecido; deve também ser lembrado, e até reproduzido (Dondis, op.cit:: 91).

Tal processo de esquematização do desenho é chamado de generalização estrutural, pois, em síntese, consiste em apagar ou atenuar características desprezíveis da realidade, acentuando as importantes que, com a redução, correriam o risco de desaparecer. Quando a escala diminui radicalmente, apela-se para a generalização conceitual, ou seja, há uma mudança radical da representação cartográfica, utilizando-se símbolos mais sintéticos e menos numerosos (Joly, 1990: 22-23).

Souza (1992:193-194) observa que, ao se olhar para um objeto, é possível reconhecer vários traços visuais que o caracterizam enquanto modelo de uma determinada categoria conceitual: forma, tamanho, cor, textura, orientação, movimento, tom, ângulo de visão, etc. Entretanto somente alguns desses traços servirão como base para o reconhecimento perceptivo do objeto. Isso acontece devido à habilidade do ser humano de retificar ou normatizar a percepção segundo expectativas adquiridas ao longo de sua vida como ser cognitivo. Por exemplo: ao se falar em uma girafa, imediatamente vem à cabeça a imagem de um animal de pernas e pescoço longos, manchas na pele, etc. Mesmo que esses itens atributivos sejam um tanto vagos, os três exemplos gráficos demonstrados na figura 7 são capazes de trazer semanticamente o conceito de girafa, pois o processo de conhecimento e reconhecimento dos estímulos visíveis faz uso normalmente de um número reduzido, 
essencial, de atributos definidores.

Figura 7 - Traços visuais: o conceito de uma girafa

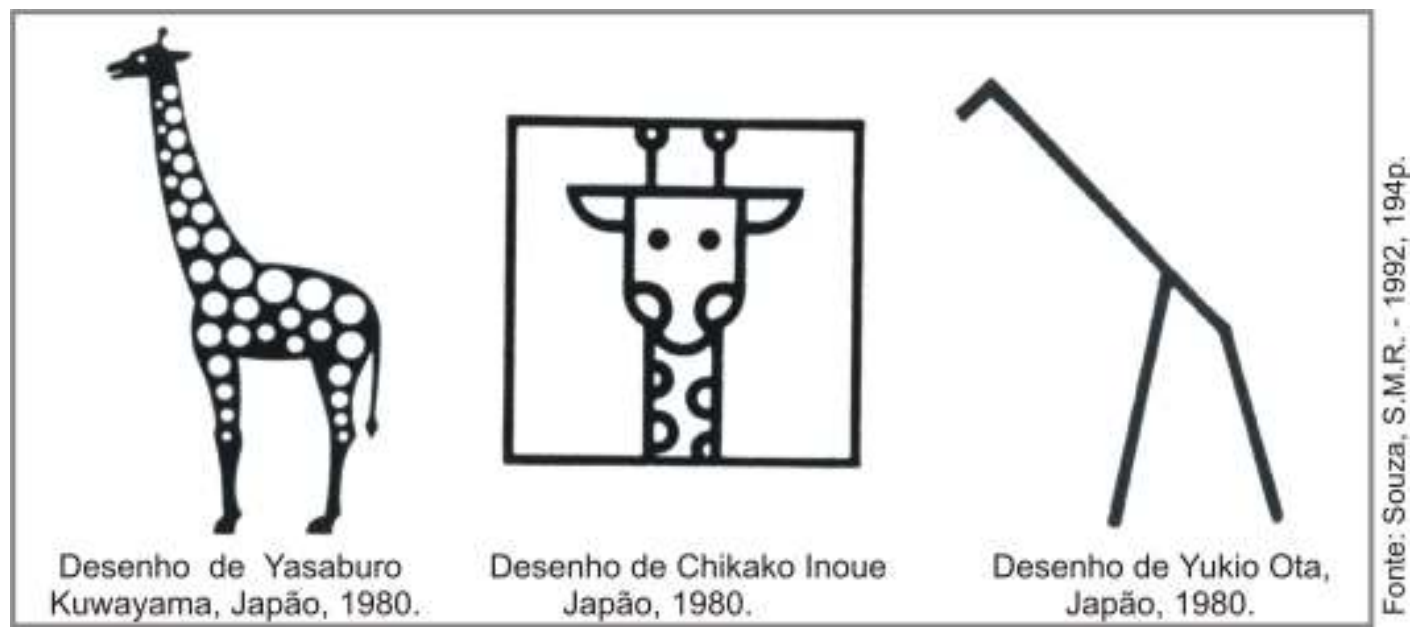

Portanto, a pesquisa enfatizou aquelas representações que tendem ao simbolismo (menor abstração em relação à realidade), por sua qualidade de conservar algumas das qualidades reais do elemento representado (Figura 8).

\section{Figura 8 - Traços característicos do elemento representado: a schemata}

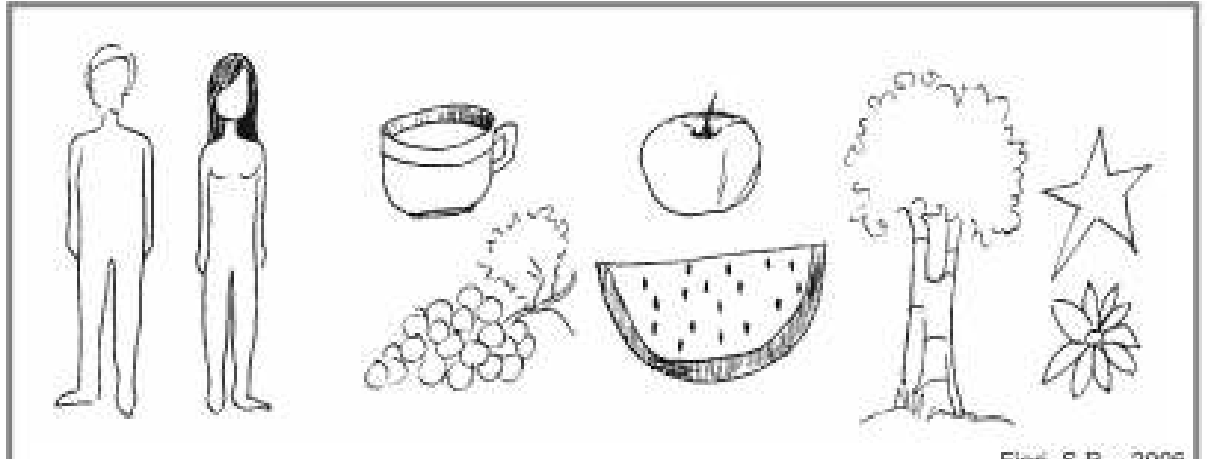

Servem de apoio as imagens da memória, pois é graças a ela que se retiram os traços característicos dos objetos/elementos encontrados no plano concreto, ou seja, aqueles aspectos que revelam a forma mais Fian, S.R. - 2006 típica.

É fato que, quanto mais abstrato for o símbolo, mais intenso deve ser o trabalho de educação do público em relação ao significado da representação (Dondis, 1991: 92).

Como argumenta Guerrero (2004: 34), a aceitação e a compreensão de um ou outro tipo de representação é decorrente do ato cognitivo, que atribui significados aos objetos, fenômenos, pessoas, lugares. É um processo contínuo, dinâmico no qual a estrutura cognitiva responde pela aprendizagem de novas idéias, informações, conceitos, contemplando modificações quando necessárias, à medida que os sujeitos realizam essas ações sobre os objetos e materiais.

Isso faz com que as representações não tenham limites muito precisos e uniformes 
entre as pessoas. Wollheim (2002: 60-61) questiona se os sinais internacionais de trânsito, os logotipos, os adesivos, os pictogramas dos banheiros públicos são ou não são representações. $\mathrm{Na}$ verdade serão quando coincidir com as intuições preexistentes de uma determinada pessoa ou grupo. A compreensão de um mapa, por exemplo, está apoiada em um conjunto de habilidades que são paulatinamente aprendidas, criando-se então, condições de leitura.

O aprendizado do indivíduo é resultado de um conjunto de esquemas fundamentais que vão sendo formados ao longo de sua vida, e que servirão de base para a seleção e aquisição das próximas informações. A assimilação dos bens simbólicos só pode ser apreendida por aqueles que já detêm o código e, então, os decifram; ou seja, a apropriação dos bens supõe a posse prévia dos instrumentos de apropriação (Bourdieu, 1974: 210; 297).

Com base nesse autor (1974: 290-291) pode-se concluir que aqueles indivíduos que têm a possibilidade de convívio prolongado com os mapas, trazem consigo uma interiorização consciente e inconsciente das regras de produção e um sentimento de familiaridade e de maior compreensão do objeto. Conseqüentemente, não há uma escala possível para se quantificar qual o maior ou menor grau de compreensão da leitura cartográfica. $O$ que se pode apontar são algumas situações sociais facilitadoras como: os pais mostrarem e incentivarem o uso do mapa, o gosto pessoal, o acesso facilitado, a educação formal, etc. Dessa mesma perspectiva, pode-se justificar que o uso e compreensão das representações se ajustam à visão de mundo da experiência prática.

O grande desafio da pesquisa é pensar possibilidades de elaboração de um produto cartográfico para aqueles usuários que têm pouca familiaridade com o mapa. $O$ objetivo é ampliar ao máximo o sentimento de familiaridade, compreensão, motivação e eficácia, ao maior e mais diversificado número de usuários, objetivando sempre um alto nível quanto à aceitação e uso do produto.

Por fim, insere-se a mídia (jornal, rádio, televisão, Internet, etc.) como um dos principais atores de reprodução das práticas sociais, consagrando, ao longo do tempo, sua grande força na transmissão da comunicação de massa. Gombrich (1991: 129) ilustra a seguir essa forte influência sobre a sociedade contemporânea:

Pela manhã, abre-se o jornal e vêem-se fotografias de homens e mulheres que são notícia e, correndo os olhos por esse mesmo jornal, encontra-se a imagem de uma caixa de cereais. Entre as correspondências do dia, estão brilhantes folhetos e suas imagens de tentadoras paisagens, além de belas mulheres tomando sol, o que incita a se sair de férias em um cruzeiro e, para isso, é preciso comprar um elegante terno feito sob medida. Ao sair de casa, nota-se ao longo da estrada outdoors que perseguem a atenção jogando com os desejos de fumar, beber ou comer. Já no trabalho, é bem provável que se tenha que manejar algum tipo de informação gráfica: fotografias, croquis, catálogos, projetos, mapas ou, ao menos, 
gráficos. À noite, ao se descansar, senta-se à frente da televisão - a nova janela do mundo - e assiste-se às imagens de prazer, horror, tempos passados e países distantes. Hoje as imagens destes lugares conseguem ser mais acessíveis do que foram para o público que viveu naquela época. As casas acumulam livros ilustrados, cartões postais, slides e fotos que sempre ao serem olhados trazem boas recordações de viagens entre amigos e familiares.

O que dizer então do novo e rápido crescimento do mundo digital, com as imagens de satélite, a internet, os cds interativos, a realidade virtual e a inserção de sons, cheiros, entre outros recursos tecnológicos? Brown, Emmer \& Worm (2001) complementam que há grandes progressos em várias áreas da comunicação, como, por exemplo, navegadores (browser) com vozes, o que aumentará a utilização do som. De fato, a alta condição de interatividade é uma revolução quando comparada aos métodos mais tradicionais (imprensa escrita, rádio e televisão) de se comunicar a informação.

No caso da cartografia, o meio mais comum de se informar era por meio da impressão em papel, mas isto também vem sendo paulatinamente mudado a partir da revolução do computador e da Internet.

O ininterrupto processo de aquisição e acúmulo de conhecimento teórico e concomitantemente de tecnologia (materiais e suas funções) favorece o surgimento dos novos produtos, que oferecem mais possibilidades tanto de escolha (para quem e para quê) quanto de compreensão pelo receptor.

Na cartografia, recorda-se Oliveira (1977:15) - que demonstrou, há quase trinta anos, preocupações quanto à elaboração dos mapas escolares - havia:

reproduções dos mapas geográficos. O que ocorre é que os pequenos "lêem" os mapas dos grandes, os quais são generalizações da realidade que implicam uma escala, uma projeção e uma simbologia especiais e que não têm significação nenhuma para as crianças.

De lá para cá, contata-se uma crescente preocupação com o assunto, evidenciando trabalhos relacionados à funcionalidade na elaboração do mapa, que tem a obrigação de ser compatível - oferecendo boa compreensão, leitura, sendo motivador - com usuário potencial. No Brasil, por exemplo, podem ser citadas as pesquisas de Simielli (1986, 1997) sobre cartografia e ensino e as de Vasconcelos (1993), que desenvolveu um estudo de produção e uso de mapas para deficientes visuais. Contudo, existem poucos estudos no país sobre a elaboração e uso de mapas voltados ao setor do turismo. Além disso, abre-se uma nova e enorme possibilidade de se criarem materiais cartográficos em multimídia interativa, que possibilita apresentar uma mesma informação em um mesmo mapa, porém de diferentes maneiras, permitindo uma chance maior de compreensão do conteúdo proposto.

Bourdieu (1974: 105) define o modo de produção e circulação de bens simbólicos como um sistema de relações objetivas entre as várias instâncias determinadas pela 
função que cumprem na divisão do trabalho, seja na produção, reprodução e difusão dos bens simbólicos. Especificamente no campo da produção, decorre uma estrutura específica, estabelecendo uma oposição entre:

- O campo da produção erudita, caracterizado por um sistema produtor de bens culturais (e os instrumentos de apropriação destes bens), objetivamente destinados ao público produtor dos bens culturais.

- O campo da indústria cultural, sistema especificamente organizado com vistas à produção de bens culturais destinados a não-produtores desses bens - 0 grande público - os quais podem ser recrutados tanto nas frações não-intelectuais das classes dominantes (o público cultivado) como nas demais classes sociais.

Há de se atentar que mesmo os usuários pertencentes ao mesmo círculo social apresentam diferentes nuances - estilo de vida, atitudes, conhecimentos, entre outros traços característicos (Bourdieu, 1974: 166).

Destarte, cabe ao produtor do mapa - campo da produção erudita - estabelecer as regras, criando ferramentas que proporcionem a elaboração de mapas temáticos a partir de interesses e públicos distintos, sempre buscando adaptar o desenvolvimento do material ao usuário preferencialmente potencial, que deve ser cultivado.

O profissional deve estar sempre alerta para saber como será concebido o mapa para a indústria cultural. $O$ ato de concepção do material passa primeiramente por um processo de interiorização (realidade-mapa), ou seja, é por intermédio do produtor que acontece uma espécie de filtragem das imagens, impressões e sentimentos naturais. Segundo Galeffi (1977: 148), aquilo que pertencia à vida real ou prática, transforma-se em experiência contemplada - característica distintiva e imprescindível - essência da verdadeira criação estética.

O habitus faz o produtor do mapa ser parte integrante de uma coletividade, de uma época. E, sem que ele tenha consciência, seus atos de criação aparentemente mais especiais, individuais, são orientados e dirigidos (Bourdieu, 1974: 242). Segundo, Canclini (2003: 195) a relação que se tem com os atrativos naturais e culturais - e sua representação técnica e artística: o mapa turístico - ocorre a partir de um determinado capital cultural que não dispõe do conjunto de bens estáveis e neutros, com valores e sentido fixos. Isto significa que, por fazer parte de um processo social, o ato de cartografar se apropria de forma diferenciada e desigual do capital cultural, devido aos diversos setores, que se acumulam e se reestruturam ao longo do tempo.

A noção de indústria cultural continua servindo como referência ao fato de que cada vez mais os bens culturais não são gerados de maneira artesanal ou individual, mas sim por meio de procedimentos técnicos, máquinas e relações de trabalho equivalente àqueles produtos gerados pela indústria (Canclini, 2003: 257).

Os produtores do sistema da indústria cultural possuem uma posição subordinada à 
dos detentores dos instrumentos de produção e difusão, obedecendo basicamente aos imperativos da concorrência pela conquista de mercado, ao passo que a estrutura de seu produto decorre das condições econômicas e sociais de sua produção. Trabalham com um público muitas vezes medianamente qualificado socialmente heterogêneo, os quais se encontram submetidos a sanções do mercado. A cultura média apresenta ainda procedimentos e efeitos estéticos imediatamente acessíveis, excetuando-se todos os temas capazes de provocar controvérsia ou chocar alguma fração do público. Procura o lugar-comum que possibilita a projeção das mais diferentes categorias de usuários (Bourdieu, 1974: 137).

Para haver um maior sucesso quanto ao consumo de um produto, Bourdieu (1996, 289) ressalta aspectos que devem ser levados em conta: os campos de produção (que apresentam suas próprias leis de mudança) e o espaço social. Os dois juntos determinam uma situação na estrutura social. Os gostos vêm por meio dos condicionamentos sociais relacionados às condições materiais de vida do indivíduo.

A partir de tudo que foi exposto até aqui e pensando na cultura de massa ${ }^{15}$, a elaboração do mapa turístico em meio digital traz muitos questionamentos. Desde já fica evidente a aproximação e as combinações entre algumas dualidades, a saber:

\section{» Mapas convencionais e pictóricos}

Os mapas denominados convencionais são compostos por símbolos e formas geométricas (quadrados, círculos, etc.) e abstratos (manchas e áreas sem uma forma definida). Não possuem semelhança com o fenômeno representado e, portanto, apresentam um alto nível de abstração da realidade. Por exemplo: ao olhar um mapa topográfico (relevo) - Figura $9 \mathrm{~A}$ - vê-se um degradê de cores que indica maior ou menor altitude. Ou então, na legenda de um mapa temático convencional, observa-se a representação dos tipos de indústrias (Figura 9 B) com símbolos geométricos.

Nesta modalidade de mapa faz-se uso da semântica formal - que é ensinada - e do discurso da neutralidade, pois, sendo os símbolos abstratos, é imprescindível se recorrer à legenda.

Os mapas pictóricos têm como referência os mapas convencionais, contudo, são adaptados àqueles usuários que conhecem muito pouco ou desconhecem os fundamentos cartográficos. Esse tipo de mapa é composto de símbolos pictóricos (ilustrações, desenhos), devendo possuir alguma(s) semelhança(s) física(s) com o fenômeno representado. Segundo Moscardo (1999:53), quanto mais parecido for o símbolo com o que ele representa, mais fácil será interpretá-lo, compreendê-lo. A figura 10 mostra uma série de símbolos, com maior ou menor grau de abstração. Os símbolos da esquerda requerem uma maior energia mental dos usuários do que

\footnotetext{
${ }^{15}$ É impossível sintetizar formatos e processos tão variados sob um único nome. Alguns rótulos, os de cultura de massa ou para massa, podem ser usados com a precaução de que designam um único aspecto e não o mais recente. As noções de indústria cultural, cultura eletrônica ou tele-informação são pertinentes para designar aspectos técnicos ou pontuais da cultura de massa (Canclini, 2003: 258).
} 
aqueles da direita.

Figura 9 - Mapa e símbolos convencionais
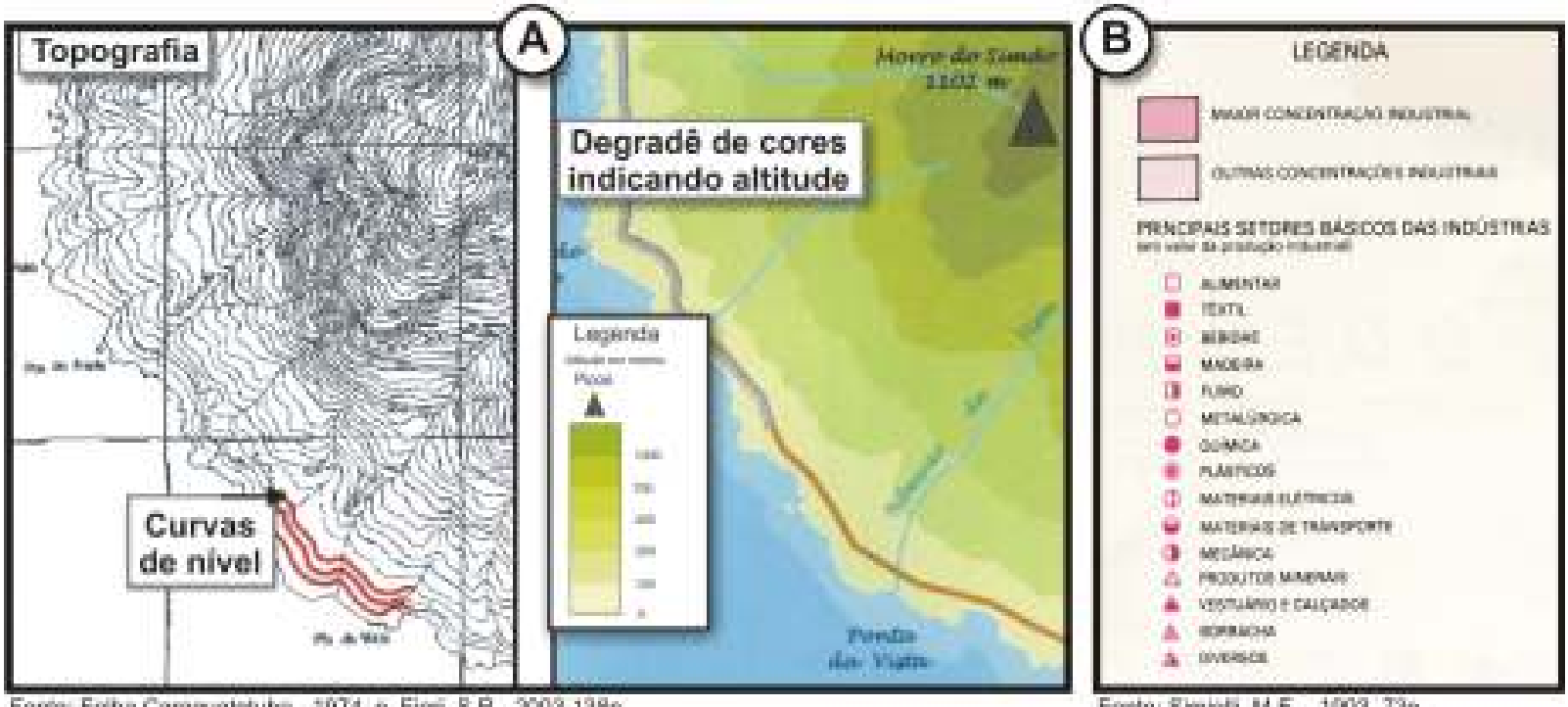

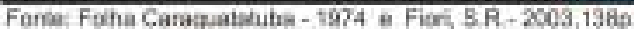

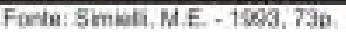

Figura 10 - Níveis de abstração do símbolo

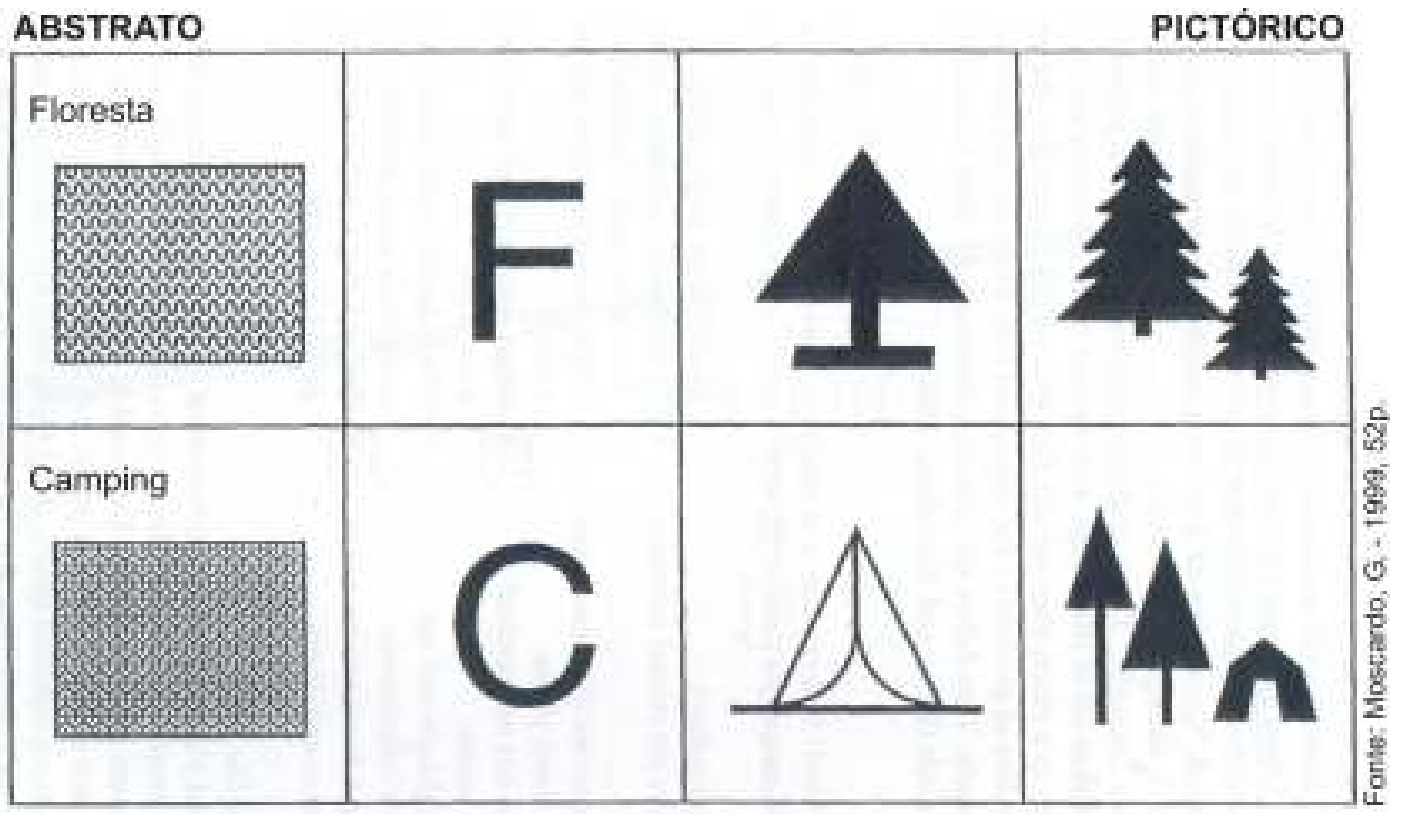

A partir dos mesmos exemplos utilizados para o mapa convencional, a figura $11 \mathrm{~A}$ representa a topografia (relevo) do terreno, usando a pictografia-ilustração. Veja também a legenda da figura $11 \mathrm{~B}$, que utilizou ilustrações para representar os tipos de indústria. É por esse motivo que este tipo de representação gráfica apresenta um baixo nível de abstração da realidade. 


\section{Figura 11 - Mapa e símbolos pictóricos}
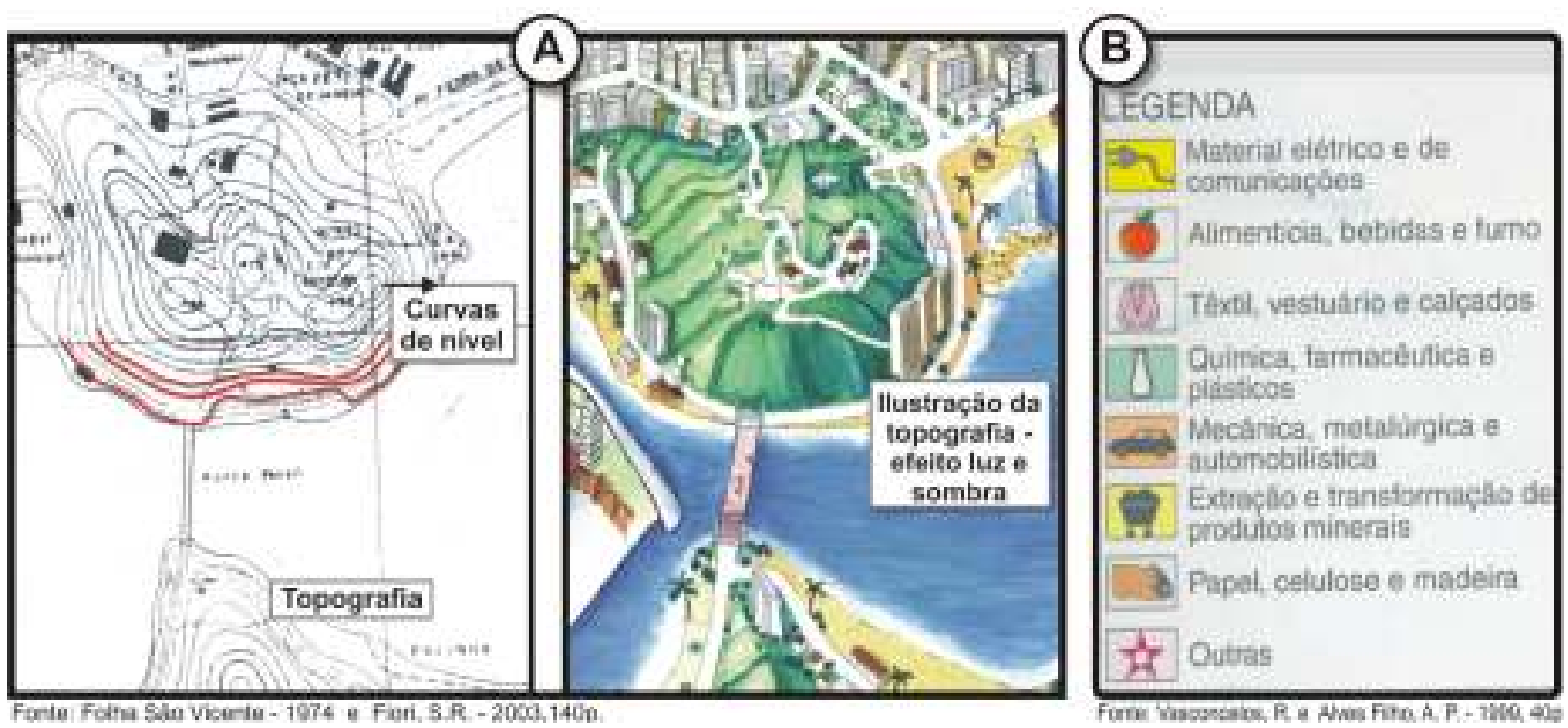

Nesse tipo de mapa, trabalha-se mais o senso comum, sendo que temas como arte e cultura recebem uma importância preponderante, pois os desenhos idealizados, selecionados e confeccionados são resultado de um conjunto de contextos mentais de uma dada sociedade.

Em suma, o mapa turístico é uma junção de duas formas de representar a mesma realidade. Primeiro, a convencional, com preocupações formais, normas técnicas mais rígidas e segundo, a pictórica, caracterizada por símbolos culturais, uma maior expressividade gráfica e proximidade com a realidade representada. O que se espera é um produto que possa ser consumido sem que necessariamente o usuário-turista conheça a semântica formal.

\section{» Simbologia superficial ou profunda}

Este outro tópico tem a ver com o que se pretende e com a intenção de cada símbolo e ilustração dispostos sobre um mapa temático para o turismo, já pensando no uso efetivo da pictografia. As simbologias também se dividem em dois tipos: as denominadas superficiais, que são aquelas reconhecidas mais rapidamente, sendo diretas, simples, rasas; com elas, busca-se uma padronização. Como exemplos citam-se os símbolos para sinalização do trânsito, em estrada, turística, em área pública e privada, entre outros. Mesmo assim, não são alheias às influências culturais (Figura 12).

Já os símbolos profundos são aqueles que valorizam a diversidade cultural e, no caso desta pesquisa, mais especificamente a paisagem, o olhar do outro (figura 13). As ilustrações e símbolos ajudam a explorar o exótico de uma maneira lúdica, buscando a intenção de motivar, atrair o usuário-turista a querer conhecer a dada localidade.

Todavia, as simbologias de uma coletividade precisam ser assimiladas por outras. 
Figura 12 - Símbolos superficiais

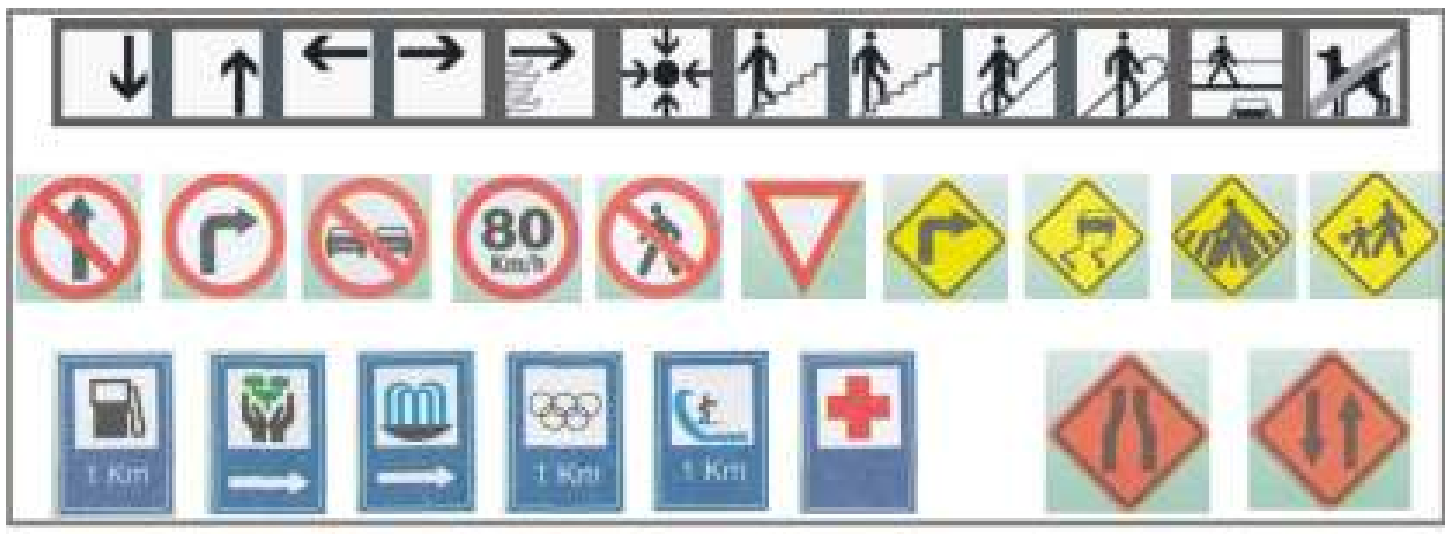

Fonte: Erco - 2005 e Bruns, C. B, - 2000, 28-33p,

Figura 13 - Símbolos profundos

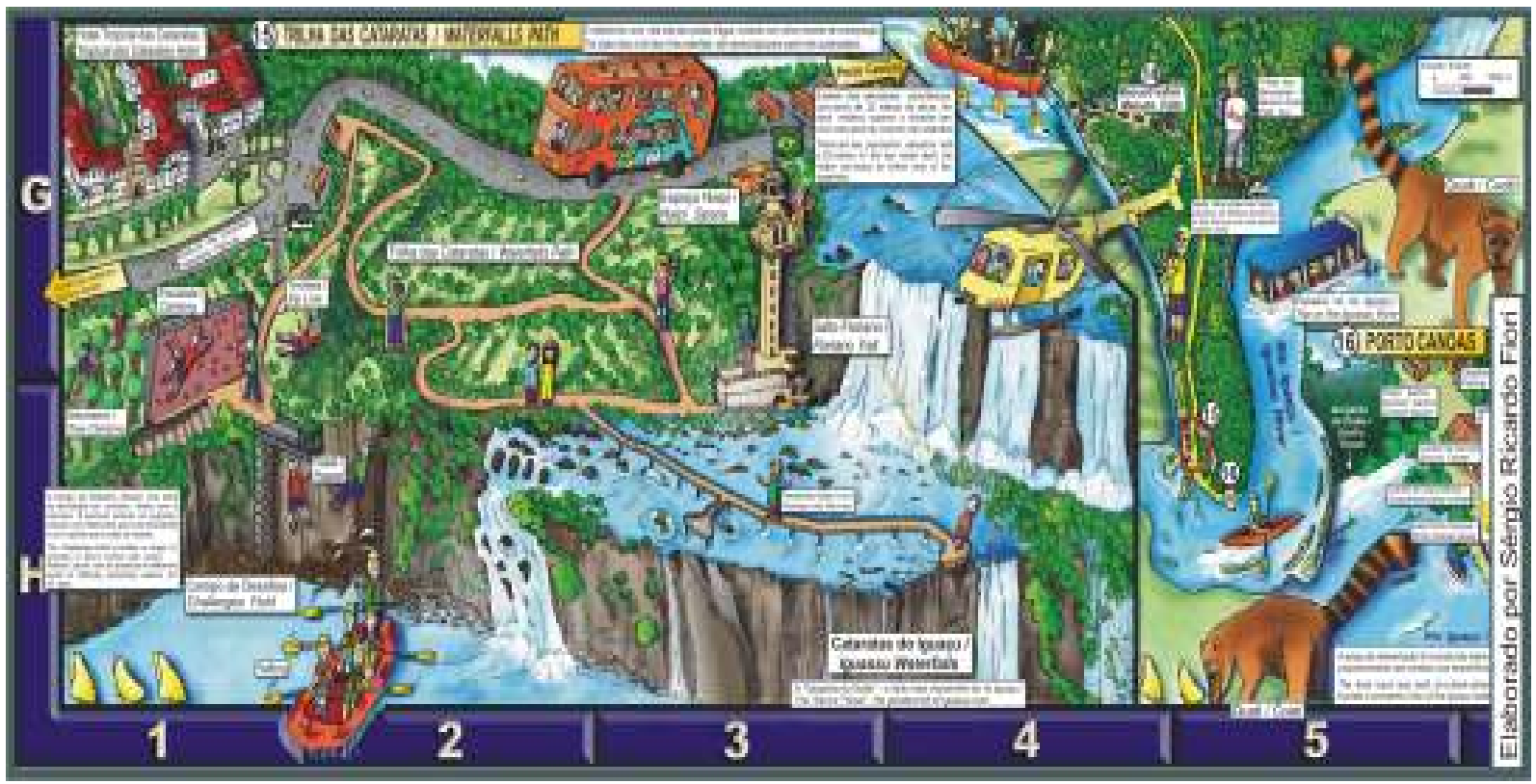

Cabe então ao produtor do mapa, que também não faz parte da coletividade representada, procurar formas de conhecê-la, coletando dados dentro de um contexto O produtor filtra e direciona as informações, preocupado com o efeito que se quer dar da localidade ao turista.

Conseqüentemente, além dos traços diferentes, o produtor do mapa deve trabalhar símbolos, ilustrações que possuam um sincretismo capaz de ser comuns entre as diferentes culturas, ou seja, serem superficiais e profundas ao mesmo tempo.

A figura 14 demonstra que, quando uma ilustração é bem elaborada, o usuário consegue compreender boa parte da informação, mesmo não conhecendo, por exemplo, a escrita japonesa, finlandesa ou húngara! 
Figura 14 - Os desenhos que se (re)conhece

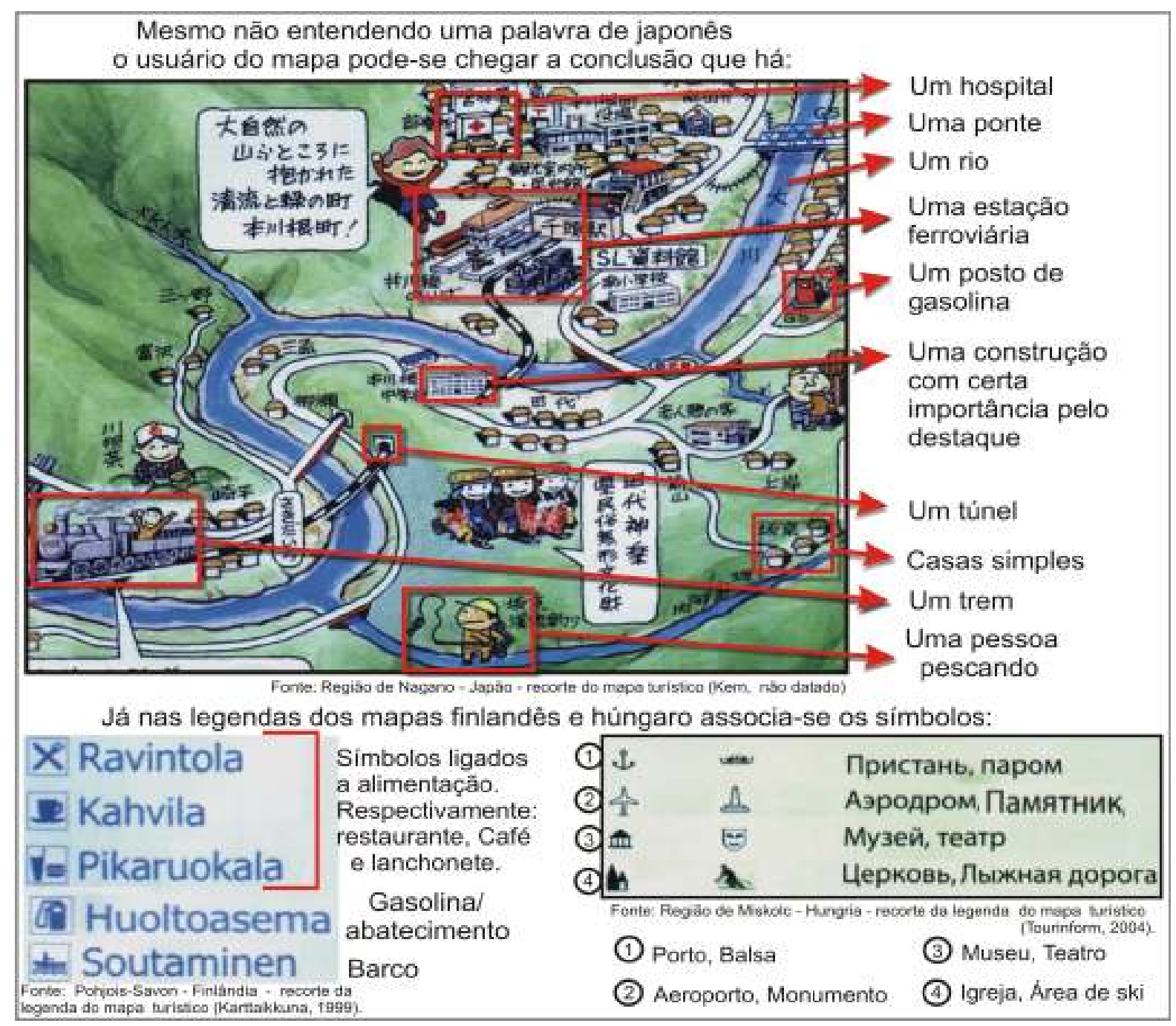

Esse fenômeno ocorre porque as artes visuais trabalham com a capacidade construtiva e imaginativa do usuário, o qual precisa mobilizar suas habilidades cognitivas e afetivas durante o ato de reconhecimento das ilustrações, ícones e símbolos. Guerrero (2004: 162) pontua a possibilidade de utilização de técnicas e de recursos visuais que permitam aos alunos - e por que não falar do público leigo? identificar e desenvolver habilidades e competências que antes desconheciam.

Nota-se ali uma importante consideração: a necessidade de desenvolver um mapa que produza informação de fácil leitura e acesso aos diferentes povos e, para isso, exige-se certa "homogeneização" da representação. Segundo Hall (2003: 77), o fascínio que o usuário-consumidor também pode ter pela diferença traz uma mercantilização da etnia, do particular, ou seja, o interesse pelo local. Portanto, a mídia globalizada deve fornecer especialização flexível e estratégias de criação aos diferentes tipos e interesses do público visitante.

Assim, a elaboração de um mapa-site turístico sempre trabalha a dualidade: cultura de massa, ou seja, fácil acesso, apreensão da informação ao maior número de 
pessoas (meio digital e a internet), aliada aos traços característicos das coletividades. Neste segundo item, cite-se Canclini (2003: 256-257), ao partir do pressuposto de que a construção de uma nação requer um projeto político e cultural unificado, um consumo simbólico compartilhado que favoreça o desenvolvimento do mercado. Os meios de comunicação integrados traduzem a idéia de nação por estabelecer um sentimento e cotidianidade, por exemplo, por meio da mídia.

No Brasil, principalmente a televisão tem um alto apelo comunicativo, mostrando as várias e distintas regiões e povos que formam o país, com seus modos de falar, vestir, gostos e código de costumes. Outrora esses elementos estavam distantes e dispersos, porém hoje os povos juntam suas várias linguagens por meio da mídia, que representa as massas, dando uma síntese da identidade nacional.

Nesse aspecto, os mapas pictóricos seriam de grande valia, pois, além da ação fundamental de auxiliar o usuário a se localizar, pode compor maneiras de representar os atrativos natural e cultural.

Sugere-se um modelo de apresentação pictórica - mapa como "vitrine" - das informações de outros destinos, criando, assim, um modo de perceber as diferenças dos vários e ricos espaços que se somam e geram a identidade nacional.

Finaliza-se esta exposição sobre as diferentes influências e sincretismos ligados ao ato cartográfico com uma citação de Bourdieu (1974: 136), que apresenta um exemplo singelo para o que seria a cultura média, que estaria ao alcance de todos. Um roteirista, escritor de folhetins, autor de vinte romances e premiado pelo Interallié e pelo Grande Prêmio da Academia Francesa na categoria de romance revelou:

Minha única ambição é a de ser lido com facilidade pelo maior público possível. Eu nunca almejo a "obra-prima" e não escrevo para intelectuais. Deixo esta tarefa para outros. Para mim, um bom livro é aquele que nos cativa ao fim de três páginas.

Faça-se aqui apenas uma consideração: esta pesquisa é feita para intelectuais preocupados em encontrar novos caminhos que levem o mapa a resultados práticos, para que, assim, prontamente informe e posteriormente motive sobretudo o público não-familiarizado com a semântica formal dos mapas a querer conhecer, saber mais sobre a localidade retratada.

A essência híbrida do mapa-site turístico é discutida, testada e analisada ao longo deste trabalho, que faz uma reflexão tanto das potencialidades e perspectivas futuras, quanto dos problemas e limitações do produto cartográfico finalizado.

Para que se analise o discurso ${ }^{16}$ - mapas turísticos e os seus respectivos sincretismos mos, com o convencional e o pictórico, com a superficialidade e a profundidade - é preciso atentar a três elementos: o imaginário (real e simbólico) em

\footnotetext{
${ }^{16} \mathrm{~A}$ análise do discurso não trabalha com o que a linguagem quer dizer, mas como o que a linguagem diz (Orlandi, 2004: 20).
} 
relação à ideologia e a determinação histórica. Assim, a análise do discurso trata do domínio do imaginário e dos seus efeitos da evidência produzidos pelos mecanismos ideológicos. A unidade é tida como um fato, é construída de modo imaginário, indicando posteriormente os modos de existência e de relação com o múltiplo (Orlandi, 1997: 16-18).

É ainda Orlandi (op.cit:: 20-21), quem esclarece ser a ideologia obra justamente do ponto de encontro da materialidade da língua com a materialidade da história, sendo que é pelo discurso que se dá o encontro. No discurso - onde está a materialidade especifica da ideologia - é que melhor se pode observar esse ponto de articulação. Compreender o que é efeito de sentidos, em suma, é compreender a necessidade da ideologia na constituição dos sentidos e dos sujeitos. Logo, é da relação regulada historicamente entre múltiplas formações discursivas que se constituem os diferentes efeitos de sentidos entre locutores.

A ideologia ainda é percebida como o processo de produção de um imaginário, isto é, produção de uma interpretação particular que vem ao mundo e se torna necessária, atribuindo sentidos fixos às palavras em um dado contexto histórico (Orlandi, op. cit.: 100).

É por isso que um mesmo símbolo pode ter diferentes sentidos, por sofrer influências diretas de seus coletivos (ideologias, imaginários) e da História. Segundo a mesma autora (op.cit:: 22) os discursos estão duplamente determinados: de um lado, pelas formações ideológicas que relacionam os discursos a formações discursivas definidas e, de outro, pela autonomia relativa da língua. São ainda de Orlandi as seguintes palavras:

O homem está "condenado" a significar. Com ou sem palavras, diante do mundo, há uma injunção à "interpretação": tudo tem de fazer sentido (qualquer que seja). O homem está irremediavelmente constituído pela relação com o simbólico. Numa certa perspectiva, a dominante nos estudos dos signos, se produz uma sobreposição entre a linguagem (verbal e não-verbal) e a significação (Orlandi, op. cit.: 31-32).

Estando os sujeitos condenados a significar, a interpretação é sempre regida por condições de produção específicas que, no entanto, aparecem como universais e eternas, daí resultando a impressão do sentido único e verdadeiro (Orlandi, op. cit.: 100).

A "letra", o "desenho" significa. Nada é indiferente na instância do significante (Orlandi, 2004: 121).

A autora (1997:81) aborda a completude e a incompletude do sujeito frente à ideologia. A completude é a vocação totalizante, ou seja, proporciona sentimentos de identidade e literalidade - unidade que permite ao sujeito identificar-se - no domínio do sentido. A completude produz o efeito de "evidência", sustentando-se sobre o já 
dito, os sentidos institucionais, admitidos por todos como "natural" (Orlandi, 1997: 100), sendo fabricada pela história. Já a incompletude é característica de todo o processo de significação. Isto porque a relação linguagem-pensamento-mundo é aberta e, vendo pela perspectiva discursiva, é também o lugar do possível (Orlandi: 2004:19). A incompletude é o indício da abertura do simbólico, do movimento do sentido e do sujeito, da falha do sentido (Orlandi: 2005:114). Além disso, sem ela apagamento necessário para a constituição do sujeito - haveria a asfixia do sujeito e do sentido, pois o sujeito não poderia atravessar, e não seria atravessado pelos diferentes discursos (Orlandi: 1997:81).

A imprevisibilidade da relação entre os sujeitos e seus sentidos é minorada pela formação social, que tem formas de controle da interpretação, mais ou menos desenvolvidas institucionalmente, sendo historicamente determinadas. Orlandi (2004:25) completa que, de um lado, os fatos reclamam sentidos; de outro, os sujeitos não podem não interpretar, estão condenados a significar. Contudo, existem necessidades que regem essas relações: de um lado, é preciso que todo sujeito domine sua relação com os sentidos, mesmo que imaginariamente e, de outro, a necessidade que tem toda sociedade de administrar esta relação do sujeito sobre a "divisão social do trabalho da leitura".

O analista deve ser cuidadoso em relação a todos estes aspectos da interpretação, levando em conta a linguagem tanto como estrutura quanto como acontecimento. Conseqüentemente ela pode trabalhar com aspectos heterogêneos que tocam a ordem, a regra e também o acaso, o equívoco, a forma histórica da interpretação no entendimento da produção dos sentidos. Deste modo, o analista do discurso não pretende chegar à verdade do sentido, mas permanece atento a suas diferenças e a seus movimentos (Orlandi, 2004:26).

Todos estes aspectos fazem do produtor do mapa um ser mergulhado na história e inserido em um coletivo, com todos os comprometimentos que possam vir dessas circunstâncias. Todavia, diz Orlandi (2004:19), não é porque o processo de significação é aberto que ele não pode ser regido, administrado.

O que deve ficar claro é que o produto final (o mapa-site turístico) tem que fazer sentido para quem o utiliza, consome, isto tanto em relação ao entendimento da informação (leitura) quanto à motivação, de querer conhecer a localidade. E Orlandi (2005:19) deixa claro que não há sentido sem a interpretação. Contudo, faz uma ressalva: a interpretação é posta em questão pela análise do discurso, pois reiterando o que já foi dito, ela não se fecha. $O$ que se tem é a ilusão de seu fechamento, pois o sujeito...

... se submete à ideologia, ao efeito da literalidade, à ilusão do conteúdo, à construção da evidência dos sentidos, à impressão do sentido já-lá. A ideologia se caracteriza assim pela fixação de um conteúdo, pela impressão do sentido literal, pelo apagamento da materialidade da linguagem e da história, pela estruturação 
ideológica da subjetividade (Orlandi, 2005: 21-22).

Partindo da afirmação de que o sujeito está condenado a significar e faz parte de um tempo histórico, constitui-se o tema: a elaboração de mapas turísticos, em diferentes escalas e tipos de representação, e a futura inserção na internet.

O próximo passo é estruturar de que maneira o mapa alcança o usuário-turista, que é caracterizado por coletivos e imaginários diferentes. A interpretação e o sentido mesmo que relativos, admitidos como natural - são necessários para que haja a aceitação e o consumo do produto.

Elaborar, então, uma linguagem carregada de uma significação que abranja um número tão grande e diversificado de pessoas não é uma tarefa fácil. Contudo, aí fazse uma ressalva: por serem pessoas que já têm acesso à Web, mesmo sendo de diferentes culturas, em tese, já compartilham informações comuns.

Tratando mais especificamente do mapa, estudos anteriores (Fiori 1999, 2003) e trabalhos recentes ${ }^{17}$ mostram que o sincretismo entre os mapas convencionais e os pictóricos - semântica formal e senso comum - tem uma boa aceitação e assimilação pelo público leigo em cartografia, possibilitando também um produto mais adequado ao turista (público leigo caracterizado pelo querer conhecer, viajar).

Portanto, a produção de um material cartográfico menos formal vem da necessidade de que diferentes usuários merecem diferentes tipos de mapas.

Ainda não se pode esquecer que, na interação usuário-mapa-produtor, o último colhe, filtra, representa graficamente, interpreta e analisa as informações a serem dispostas sobre o mapa. O produtor está envolvido (por um coletivo) e envolve outras pessoas (do seu e de outros coletivos) estabelecendo maiores ou menores graus de supostas "verdades". Trabalha o tempo inteiro com recortes das paisagens, ilustrando suas identidades e diferenças, abarcando diferentes discursos ligados de alguma forma ao mercado global - trocas, economia, mídia.

Isso faz com que o produto mapa-site turístico trabalhe uma visão mais superficial, genérica, funcional, de fácil leitura e compreensão, e ao meso tempo motivadora, lúdica da informação. Orlandi (2005: 52) resume todo o processo buscado pelo pesquisador:

Há um dispositivo teórico estabelecido pela teoria do discurso e há o dispositivo analítico construído pelo pesquisador em seu campo de pesquisa, sua filiação

17 Como exemplo, cite-se uma oficina de mapas para alunos de escolas públicas, realizada em Brasília: Amanda Cardoso, 13 anos, recortou a gravura de uma plataforma de petróleo e colou no mapa da Venezuela. Sem perceber, ela estava estudando geografia e aprendendo a cultura daquele país com a ajuda de jogos e atividades lúdicas desenvolvidas pelo projeto Caminhos do Futuro. (...) "É bem melhor do que aprender nos livros. Eu gravei o conteúdo rapidinho", conta Amanda, que cursa a sétima série do ensino fundamental no Centro de Educação Fundamental Incra 8, em Brazlândia, a 45 quilômetros de Brasília (MEC, 2007). 
disciplinar, onde contam: a questão que ele formulou, o material coletado (superfície lingüística), a maneira como foi construído o objeto discursivo a partir do corpus constituído, a delimitação e montagem do material de análise, as noções que vão ser mobilizadas, orientadas pela pergunta que faz o analista na compreensão de seu objeto de estudos, em vista de sua finalidade. É a escrita do analista, face ao dispositivo analítico, que dará (ou não) a consistência da análise. Através do dispositivo analítico - cuja forma é determinada pela relação entre a natureza do material analisado, a questão posta pelo pesquisador e os procedimentos analíticos escolhidos - o analista vai formular os resultados no batimento entre descrição e interpretação.

Dito isso, e pensando no trabalho do pesquisador, vinculado a seu tempo e espaço, e na cartografia, busca-se sempre a completude, mas é a incompletude que faz inovar e descobrir novos caminhos e soluções no árido campo das adversidades científicas.

\section{4 - O mapa, o tempo e as diferentes formas de se representar o espaço}

A história da cartografia ao redor do mundo registra inúmeras e distintas formas de representação do espaço, o que justifica dar a devida importância ao contexto cultural em que o produtor do mapa estava e está inserido.

Três itens são fundamentais para justificar o conteúdo de um mapa: a universalidade dos contextos políticos na história do mapeamento; o poder estabelecido, que direciona e estrutura o conteúdo dos mapas; e como a comunicação cartográfica que constitui um nível simbólico, é capaz de reforçar a estrutura de poder a partir da relação usuário-mapa (Harley, 1994: 280). Aliás, em um estudo detalhado da cartografia ao longo dos séculos, demonstrou-se que a elaboração de mapas foi uma das armas intelectuais especializadas que pôde aumentar, administrar, dar legitimidade e codificar o poder. Os conhecimentos contidos nos mapas sempre foram concentrados em poucas mãos, comumente ligadas às elites religiosas (Egito antigo e baixa Idade Média), intelectuais (Grécia e Roma) ou comerciais (cidadesestado de Veneza e Gênova). A seguir demonstram-se alguns exemplos da cultura ocidental.

Inicialmente, Harley (1991) evidencia que a história da cartografia surge com o ato do desenho de um mapa (representação do espaço) sobre um suporte disponível (pedra, barro) possibilitando uma existência concreta à antiga abstração. Esse processo de transposição do espaço real para o analógico gera um domínio intelectual do universo.

A figura 15 mostra exemplares de mapas da Antigüidade. O primeiro (Figura 15 A) é datado em 5.000 anos a.C., onde a representação de uma aldeia foi gravada em uma elevação rochosa, localizada onde hoje está o centro da península itálica (Oliveira, 1978:26). Já a figura 15 B ilustra um mapa confeccionado em um pedaço de barro cozido, com a borda cheia de reentrâncias e marcado por rugosidades, circulo e 
linhas. O mapa certamente representa uma área de várzea do rio Eufrates, ao norte da Mesopotâmia, datado de 2.500 a.C. (Raisz, 1969:9).

\section{Figuras 15 - Mapas da Antigüidade}

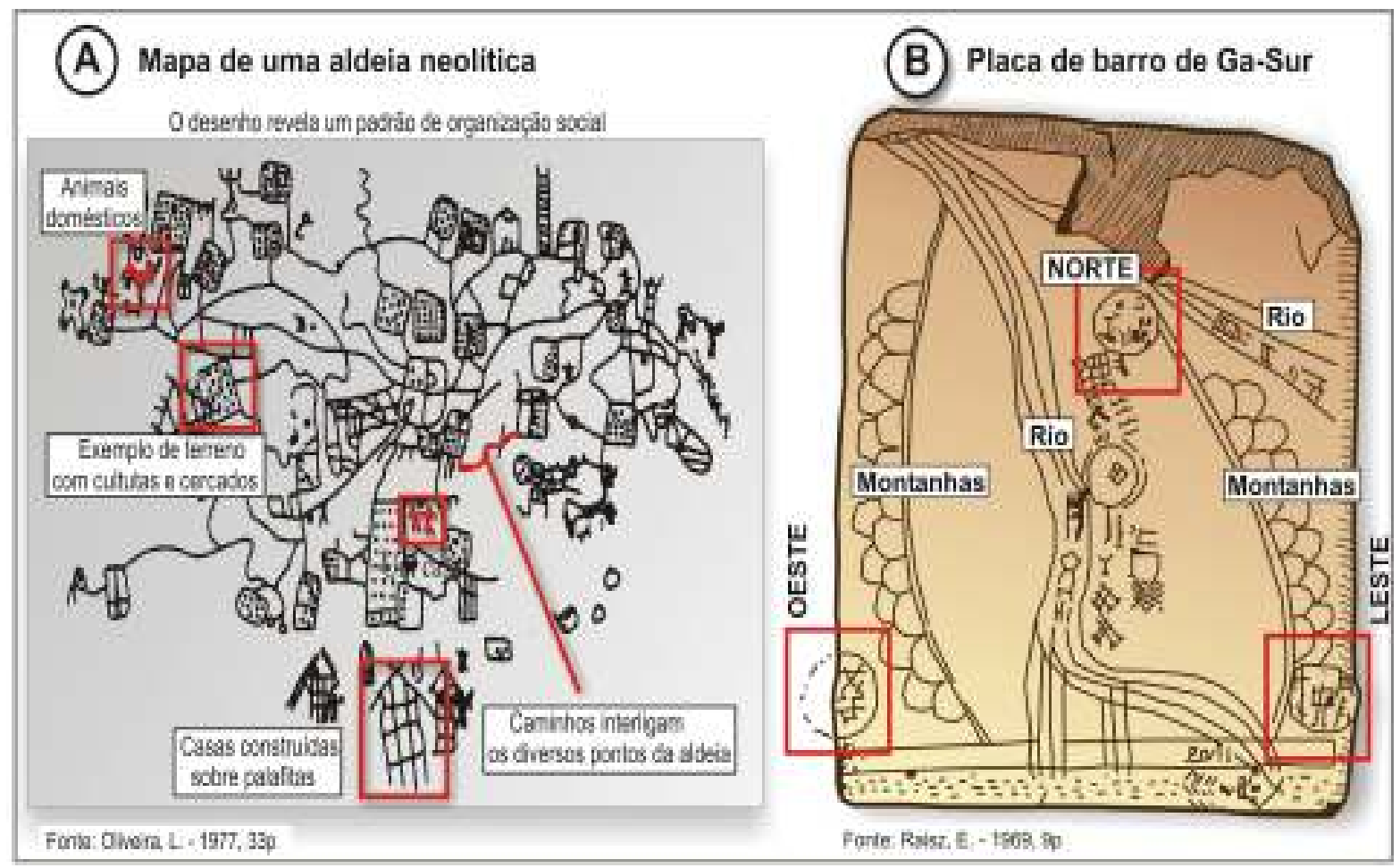

A cartografia desenvolvida por povos desta época (babilônicos, egípcios, fenícios, entre outros) era feita por agricultores ligados à terra e era elaborada por representações esquemáticas de cadastramento. Essas representações expunham subdivisões dos campos e das plantas das cidades e comumente eram confeccionadas em tábuas de argila. Para esses povos, o "documento" era muito importante, pois marcava a propriedade da área cultivável, especialmente no Egito, onde as inundações do rio Nilo exigiam a cada ano a redistribuição das terras (Dreyer-Eimbcke, 1992).

$\mathrm{Na}$ Idade Média, a cartografia do ocidente latino se orientava segundo uma visão teocêntrica. Nessa época, há uma rejeição quanto à esfericidade do mundo, retornando efetivamente a ser usado o formato em disco. Os mapas não visavam representar a configuração física da superfície terrestre, uma vez que as características topográficas ficaram em segundo plano. Um bom exemplo do tipo de mapa realizado nesse período era os $\mathrm{T}$ em $\mathrm{O}$ (Orbis Terrarum). As representações de um mundo simbólico eram percebidas pela localização de Jerusalém, que sempre ocupava o lugar de destaque - centro - no mapa (Figura 16). 
Figura 16 - A simplicidade do mapa Orbis Terrarum

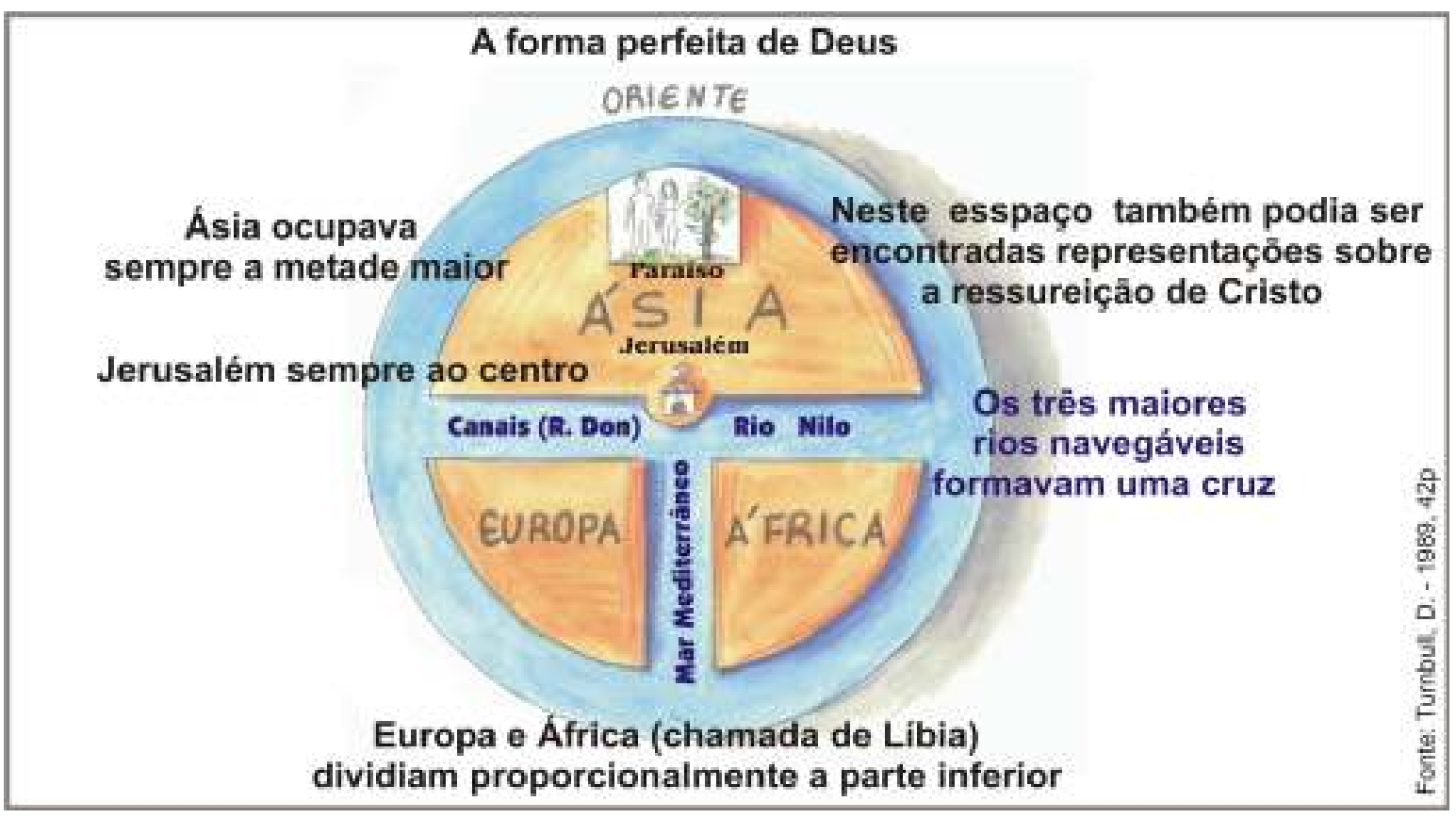

Quando se representava à fauna, consideravam-se sempre os animais típicos da respectiva região, como: o bisão e o alce (leste da Europa), o camelo (oriente), o cavalo (Capadócia), leões, tigres e ursos (Pártia) e o elefante (Marrocos). Contudo, desenhos revelavam a pouca familiaridade que o artista devia ter com a maioria desses animais. Entretanto, é importante ressaltar que continuou viva durante toda a Idade Média a idéia grega de que o mundo era uma esfera. (Dreyer-Eimbcke, 1992).

Em outro momento histórico, a segunda metade do século XIII, marcado pelo aumento da atividade comercial, surge um tipo diferente de mapa: as Cartas Portulanas. Esses mapas, segundo Raisz (1969: 21-22), teriam sido idealizados por almirantes e capitães da frota genovesa, apresentando fins práticos de navegação pelo Mediterrâneo, ou seja, baseados em medições feitas à bússola e a toponímia era estritamente disposta nas áreas de portos, cabos e outros detalhes da costa (Figura 17).

Podem ser citados outros rápidos exemplos de relação entre mapas e a História. Em Ramos (2000:35), lê-se que, se não fosse o forte imaginário popular ibérico, a viagem às Índias poderia ter ocorrido antes. A igreja estimulava ainda mais esse medo. A figura 18 mostra um mapa do período, repleto de representações dos supostos elementos misteriosos.

Quando se representava à fauna consideravam sempre os animais típicos da respectiva região, como: o bisão e o alce (leste da Europa), o camelo (oriente), o cavalo (Capadócia), leões, tigres e ursos (Pártia) e o elefante (Marrocos). Contudo, desenhos revelavam a pouca familiaridade que o artista devia ter com a maioria desses animais. Entretanto, é bom ressaltar, que continuou viva durante toda a Idade Média a idéia grega de que o mundo era uma esfera. (Dreyer-Eimbcke, 1992). 
Figura 17 - Mapa portulano do Mediterrâneo

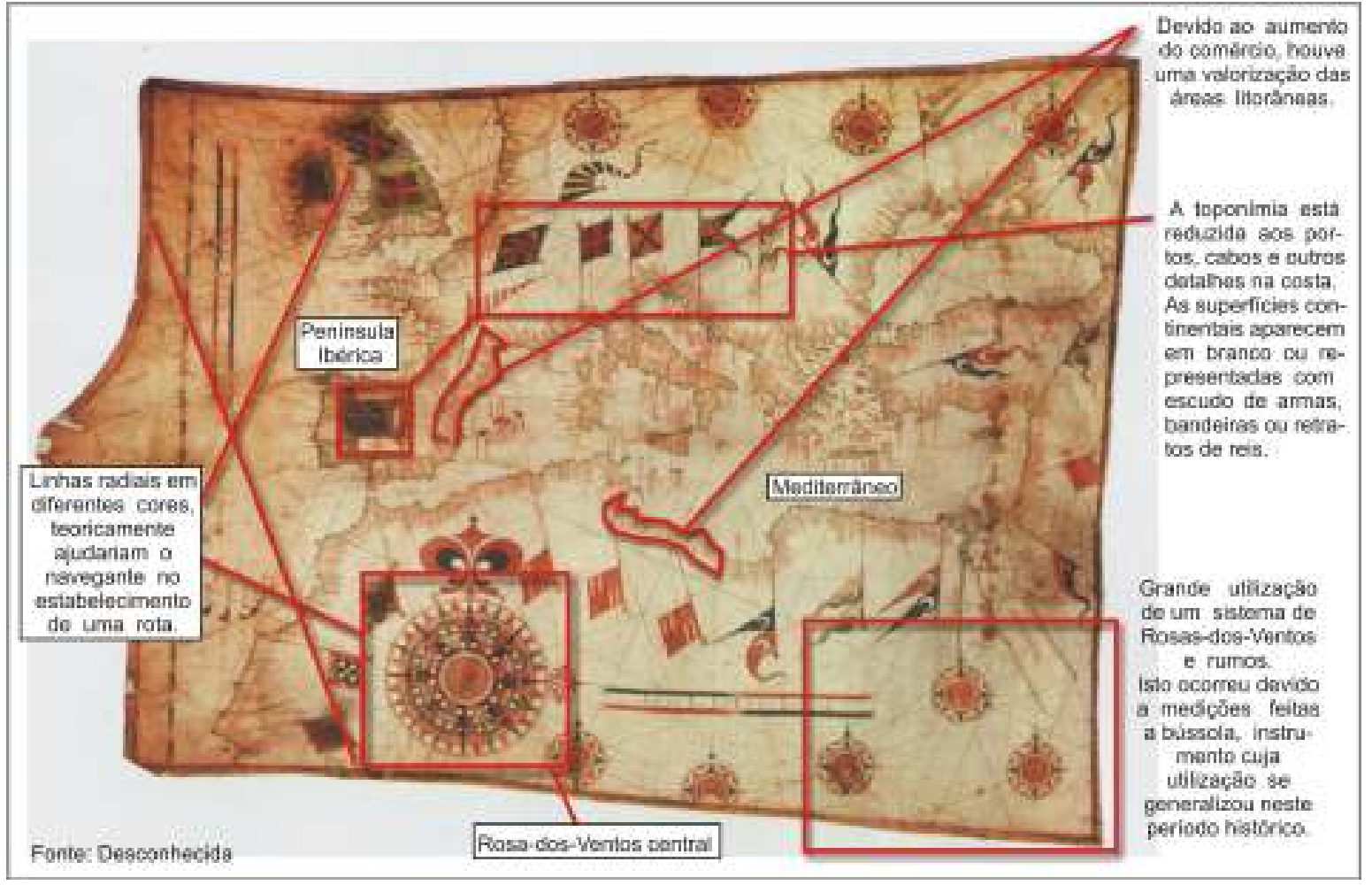

Figura 18 - As lendas representadas nos mapas

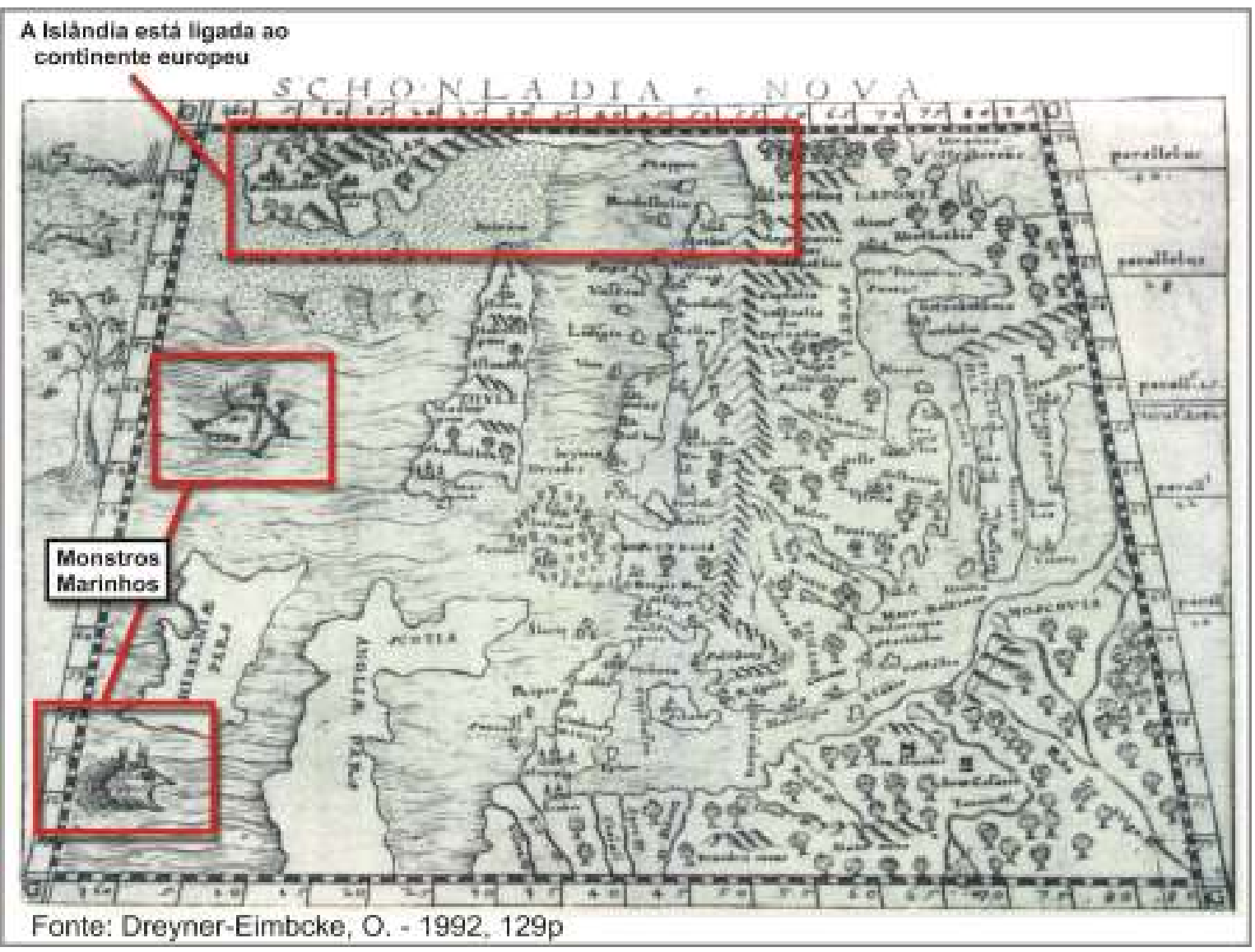


Nos séculos $\mathrm{XV}$ e $\mathrm{XVI}$, o material cartográfico foi utilizado com vários fins: como suporte à reivindicação de terras antes da efetiva ocupação e, logo em seguida, o mapeamento, que servia ao reconhecimento, informações gerais e legitimava a realidade da conquista do império. Eventualmente era usado como dispositivo de pacificação, civilização, de exploração das colônias então definidas, e como instrumento de divulgação das terras do Novo Continente (Harley, 1994: 281-282). Acerca do último caso citado, Delano-Smith (1991) conta que, durante a elaboração dos mapas, os cartógrafos europeus representavam o Novo Mundo à imagem do Velho. Ilustrações procuravam não desestimular as futuras imigrações de colonos. Desse modo, sobre a base do mapa, eram confeccionadas paisagens aprazíveis e iguais às européias. Quanto aos habitantes nativos, os índios, quase nunca eram lembrados, para que se alimentasse o mito de uma América européia.

Nos séculos XVI e XVII, as figuras pictóricas foram providenciais e importantes em guias náuticos, sendo utilizadas no reconhecimento de algumas terras e ilhas. Os guias acompanhavam os pilotos e continham textos sobre rotas, latitudes e desenhos esquemáticos das feições dos lugares já conhecidos (Albuquerque, 1989: 79). A figura 19 do manuscrito de Gaspar (1594) exemplifica a importância do desenho pictórico, auxiliador na orientação e localização das terras. Os mapas também representavam os medos, perigos, mitos e imaginações.

Ainda no século XVII, a cidade de Amsterdã era o maior centro de produção de mapas no mundo ocidental. Existiam inúmeros estabelecimentos comerciais que se dedicavam à produção de mapas, atlas e globos. Destacam-se os cartógrafos holandeses Jan Janszoon e Guilherme Janszoon Blaeus, sucessores de Mercator. Tais produtores preocupavam-se particularmente com a expressão e a representação dos mapas, que segundo Raisz (1969: 42):

constituíam um conjunto harmônico; as terras, os mares, os letreiros e a decoração, tudo é cuidadosamente disposto e ponderado. Mercator introduziu um tipo de letreiro mais legível (...) O título, a escala e as notas esclarecedoras ficam dentro de um quadro, formado por figuras de animais e produtos do país. Estas decorações nem sempre foram felizes; o desenhista provavelmente nunca havia saído da Holanda, e sua concepção era muito ingênua como, por exemplo, eram vistos figuras de reis africanos vivendo em palácios holandeses. O maior defeito dos mapas holandeses.

Outro ponto deficiente nos mapas holandeses está na transmissão de informações, resultado de fatores econômicos. Tanto que espaços em branco nos mapas refletiam uma venda menor do material cartográfico; por isso, eles eram prontamente preenchidos com qualquer tipo de informação, mesmo que não fosse verdadeira.

No século XVIII, os ideais iluministas trouxeram uma significativa transformação de como proceder na confecção dos mapas. Os holandeses, como foi exposto, valorizavam muito a estética, fazendo uso de informações ultrapassadas. Isso 
acontecia porque as medições e estudos teóricos oneravam o trabalho e diminuíam os lucros. O novo momento histórico valorizou os mapas com base científica. $O$ retorno financeiro não era mais o fator preponderante na confecção, mas sim a reputação científica. É bom frisar que os produtores dos novos mapas, na maioria das vezes, pertenciam à nobreza, ou eram subvencionados pelo rei e pela Academia (Raisz, 1969: 42).

Figura 19 - Exemplo de desenhos pictóricos encontrados em guias náuticos dos séculos XVI e XVII
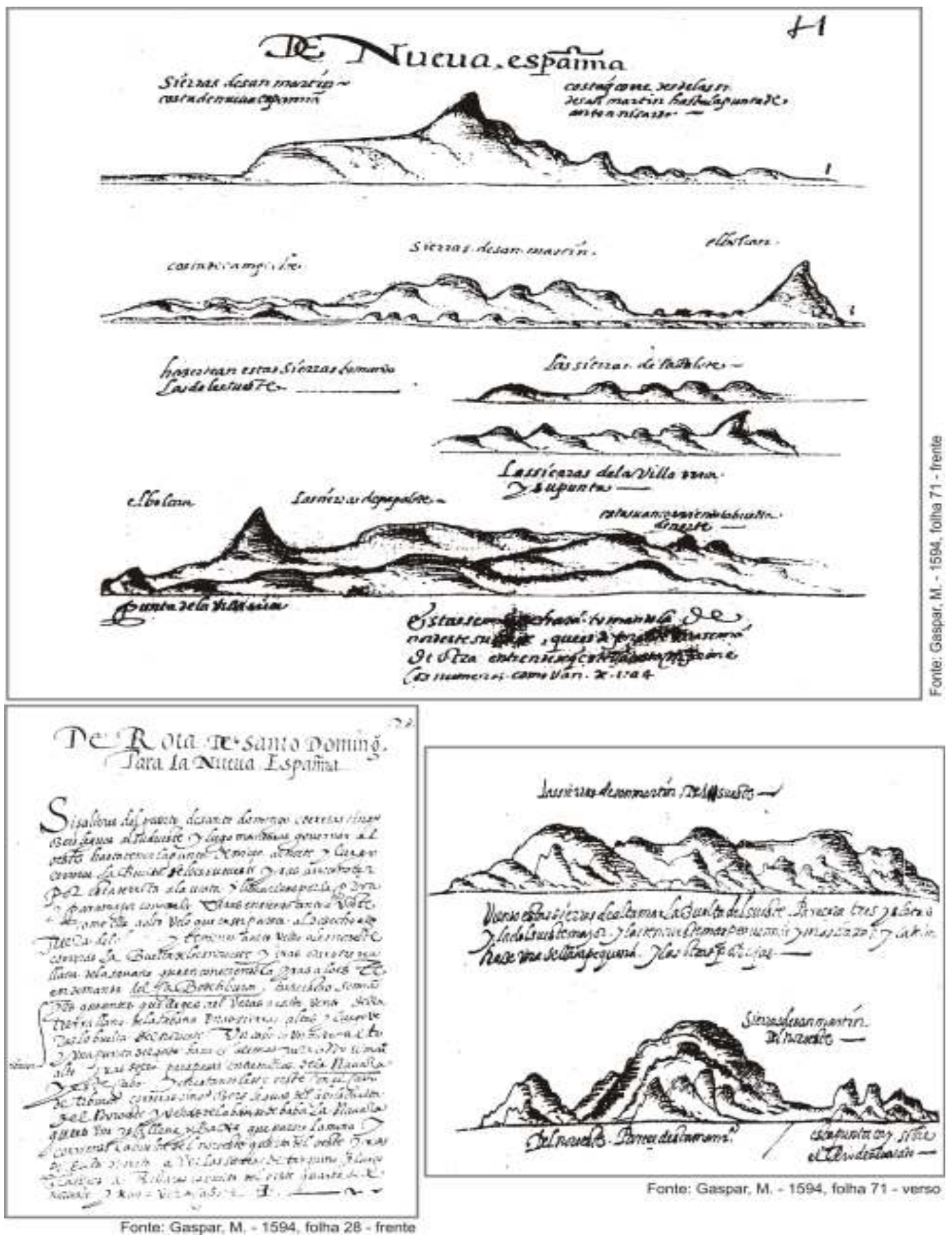
Essa nova cartografia teve sua expressão maior na França, tanto que o país foi o primeiro a confeccionar um mapa preciso e detalhado de seu território (com importante precisão topográfica), baseando-se na triangulação (um conjunto de pontos que servem de referência) e símbolos codificados (figura 20). Para confeccionar esse tipo de mapa se tornava indispensável conhecer a real forma da Terra (Thrower, 1991).

\section{Figura 20 - Mapas com base na triangulação}

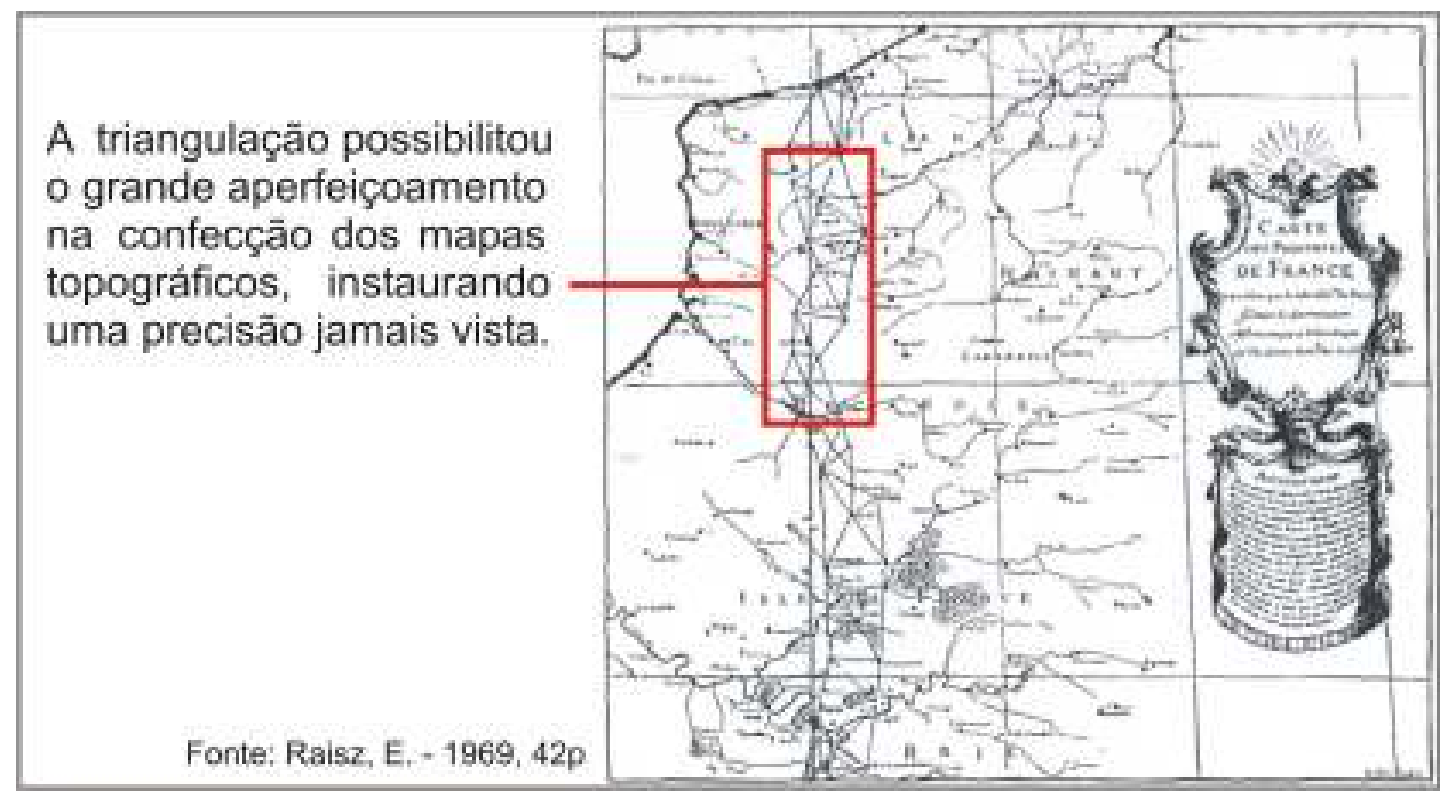

Já na segunda década do século XX, com a invenção do avião somada ao uso da câmera fotográfica, surge o sensoriamento remoto ${ }^{18}$, marcando assim o fim do levantamento dos dados de forma direta no terreno (triangulação) para dar início às técnicas de aerofotogrametria (figura 21). Essa nova forma de captação dos elementos do espaço gerou uma revolução quanto à coleta dos dados, por proporcionar uma grande facilidade de captação (Cruz, 1981).

Em 1972, o sensoriamento remoto passou por um significativo aprimoramento, devido ao lançamento do primeiro satélite artificial (Earth Resources Technology Satellite ERTS); depois vieram, os LANDSAT, SPOT, NOAA e METEOSAT. Efetivou-se então, uma nova e promissora tecnologia: o geoprocessamento ${ }^{19}$ (Figura $21 \mathrm{~A}$ ), que é formado por um conjunto de tecnologias voltadas à coleta e tratamento das

\footnotetext{
${ }^{18}$ Grava a energia eletromagnética (a mais evidente é a luz refletida, natural ou artificial) que emana dos corpos na superfície terrestre. O olho é um perfeito exemplo de sensor remoto, sendo que a câmara fotográfica é provavelmente o mais familiar tipo de sensor remoto; logo, a fotografia nada mais é que uma gravação gráfica de intensidade de energia (Cruz, 1981).

19 Destina-se ao processamento informatizado de dados georeferenciados, desde a sua coleta até a geração de saídas na forma de mapas, relatórios, arquivos digitais, etc., devendo prever recursos para a estocagem, gerenciamento, manipulação e análise (INPE, 2004).
} 
informações espaciais visando a um objetivo específico. As atividades de geoprocessamento são obtidas pelos Sistemas de Informação Geográfica (SIG $)^{20}$, que estão integradas a uma única base de dados de informações espaciais, provenientes de dados cartográficos, dados de censo, cadastro urbano e rural, sensoriamento remoto (imagens aerofotogramétricas e satélites), redes e modelos numéricos de terrenos (INPE, 2004). A figura 21 B demonstra que a cartografia digital também pode conceber uma síntese visual e informativa de áreas de interesse, possibilitando um melhor planejamento. Por exemplo, mapas urbanos podem dispor de diversos mapas que comporiam as redes de esgoto, água, elétrica, gás, tevê a cabo que estão dispostas em espaço comum. Já no setor agrícola, se aplica ao estudo do uso de ocupação do solo e aos métodos de cultura, controle do estado vegetal e à avaliação das conseqüências dos imprevistos climáticos (secas, inundações) ou dos acidentes previstos (epidemias, incêndios) (Grelot, 1991).

Os acontecimentos históricos brevemente expostos deixam claro que, ao contrário da arte, o mapa demonstra ser pouco popular, ou então, não se configura como um produto de expressão subversiva (Harley, 1994:303). O autor justifica a afirmação, explicando que os mapas são preliminarmente uma linguagem de poder, não de protesto.

Este tipo de linguagem faz uso do espaço-mapa, apreendendo e selecionando a realidade (natureza-cultura), elaborando, então, uma representação em escala muitíssimo reduzida. Fiori (2003: 20-24), Muehrcke (1986: 392-400), Vasconcellos (1993: 21-22), Wood (1994: 17-19), Monmonier (1996: 87-122) apontaram algumas implicações que envolvem, de maneira prática, o processo cartográfico de redução dessa realidade: exagero, erros, distorções, falta de precisão, falsificações, manipulações, etc. Vasconcellos (1993: 22) sintetiza algumas razões que determinam o surgimento das falhas levantadas:

$\checkmark$ Desconhecimento - falta de preparo e treinamento para a utilização da linguagem gráfica;

$\checkmark$ Questões técnicas (treinamento cartográfico adequado) ou financeiras (equipamentos e recursos humanos disponíveis);

$\checkmark$ Questões ideológicas e políticas;

$\checkmark$ Desonestidade.

Ramires (1996) sustenta que o processo de representar a realidade tridimensional em um plano bidimensional - no caso o mapa - causa perdas que são sanadas por quatro bases técnicas:

${ }^{20}$ É um sistema que processa dados gráficos e não-gráficos (alfanuméricos) com ênfase a análises espaciais e modelagens de superfícies (INPE, 2004). 
Figura 21 - A evolução no processo do sensoriamento remoto

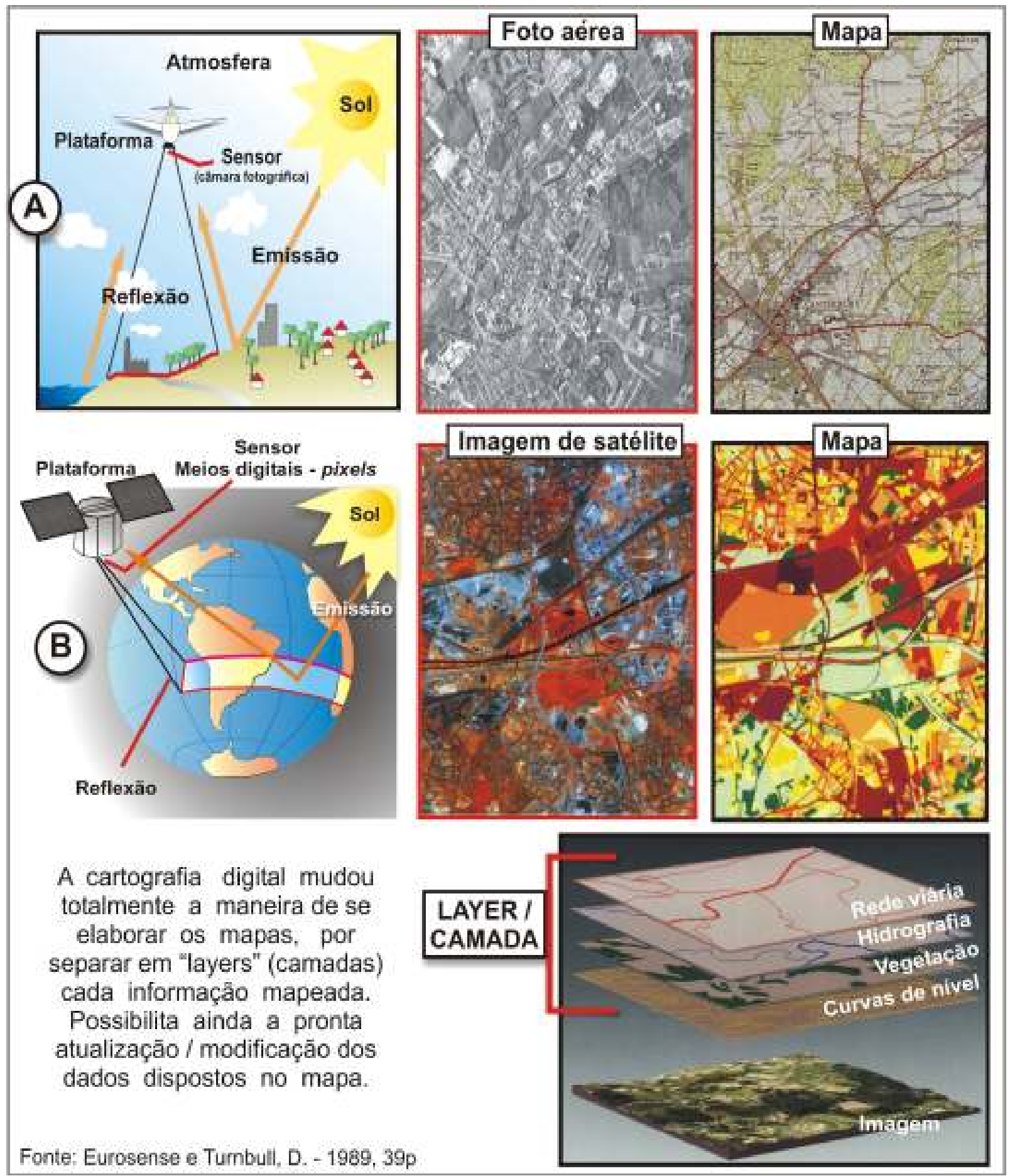

1a) A escolha da projeção cartográfica mais adequada para a representação do mapa.

$2^{a}$ ) O sistema de referências, que se divide em dois grupos: o primeiro parte dos mapas de pequenas e médias escalas mas que abrangem grande extensão de terra, sofrendo interferência da curvatura do planeta. Esse conjunto utiliza as coordenadas geográficas, em que o "x" determina a longitude e o "y" a latitude. Do segundo grupo, 
fazem parte os mapas com grande escala - abrangem uma quantidade de terra pequena em relação ao tamanho do planeta, sendo consideradas porções de espaços planos. Esse conjunto utiliza as coordenadas retangulares, em que o eixo "x" determina as letras para as coordenadas horizontais e o "y" determina os números para as coordenadas verticais do plano cartesiano. Além disso, o sistema de referências permite-nos o processo de orientação espacial geográfica, determinada em graus, obedecendo às direções cardeais Norte, Sul, Leste e Oeste.

$\left.3^{a}\right)$ A utilização da escala, que é muito importante para a confecção de um mapa, pois, como a representação do planeta será feita de forma reduzida, a escala mostra a proporção entre a realidade mapeada e sua representação. Logo, quanto menor for a escala do mapa, maior será a porção do espaço abrangida e, conseqüentemente, os elementos representados terão um menor detalhamento.

$4^{a}$ ) Ainda durante o processo realidade-mapa, Ramires (1996) discorre sobre as etapas da generalização cartográfica, que possibilita eliminar informações da realidade desnecessárias ao mapa, a saber:

$\checkmark$ Simplificação - remove informações excedentes;

$\checkmark$ Exagero - destaca os elementos importantes da realidade no mapa. Isso porque, devido ao enorme processo de redução da realidade, algumas informações imprescindíveis como, por exemplo, um rio, uma cidade, etc, quase não são notados ou somem literalmente do mapa;

$\checkmark$ Hierarquização - reposiciona os elementos no mapa;

$\checkmark$ Deslocamento - ocorre para evitar a visualização confusa de elementos distintos no mapa quando estão muito próximos. Aliás, as generalizações devem ocorrer, quando for possível o agrupamento das informações, permitindo uma análise do espaço abordado. Gerada a nova simbologia, já na forma reduzida da realidade, deve-se analisar a informação antes de implantála no mapa.

$\checkmark$ Os elementos simbólicos do mapa e, em conseqüência da legenda, expressam os resultados do espaço real que sofreu uma considerável redução, organizando-se graficamente pelas técnicas, com a finalidade de transmitir uma mensagem previamente estabelecida. $O$ usuário não precisa ser obrigatoriamente especializado, porém deve reter a informação essencial para que haja entendimento do mapa.

Exemplos encontrados em Muehrcke (1986: 392-400), MacEachren (1994: 19), Collins-Kreiner (1997), Fiori (2003: 25) e em grande parte do livro de Monmonier (1996) ilustram tal processo de generalização e representação construído através dos tempos. 
Criou-se, assim, o imaginário sobre qual seria a forma mais correta de elaborar um produto cartográfico, associando o mapa às disciplinas modernas, somada à visão eurocêntrica e ao crescente avanço tecnológico. Isso fez com que fossem desconsideradas a maiorias dos mapas produzidos até então, purgando-os a ponto de atingir um padrão considerado aceitável. O crivo era estabelecido pelo tempo (história), cultura e uso da matemática no traçado dos mapas. Essa é a cartografia científica que valoriza:

os planos quadriculados, escalas regulares, signos abstratos convencionais e até curvas de nível, ou seja, todos os aspectos correspondentes ao modelo ocidental de excelência cartográfica (...) Os mapas eram considerados marcos significativos da evolução da humanidade; por conseguinte, aqueles que não indicassem algum progresso rumo à objetividade deixavam de ser seriamente estudados (Harley: 1991).

Harley (1991) continua relatando que os mapas da baixa Idade Média (o Hereford e o Ebstorf) foram chamados de monstruosidades não-científicas e absolutamente inúteis. Já mapas elaborados na Índia antes da ocupação britânica, com signos desconhecidos e estilo pictórico, eram considerados simples curiosidades cartográficas. Nesse mesmo caso estão os mapas dos índios americanos, os planos de batalha traçados no solo pelos guerreiros maoris da Nova Zelândia, entre muitos outros. Todos eram meros objetos de coleções etnográficas.

Os mapas de culturas não-européias só recebiam alguma atenção da parte dos historiadores ocidentais quando apresentavam certas semelhanças com os mapas europeus, devendo apresentar, por exemplo, orientação, escalas regulares e elementos da geometria euclidiana. Analisar o porquê das diferenças não era uma tarefa cogitada.

Nesse ínterim, deu-se atenção às tradições "científicas" da cartografia chinesa e aos efeitos de sua difusão no Japão e na Coréia (Harley, 1991).

Seemann (2006) faz um contraponto crítico à cartografia considerada inquestionavelmente científica e objetiva na criação do conhecimento, monitorada pelos órgãos oficiais e suas convenções e normas técnicas. Contudo, o que dizer, por exemplo, sobre as diversas possibilidades da projeção de globo terrestre em um plano? A Groenlândia pode ter o tamanho da América do Sul, embora seja oito vezes menor, quando se faz uso da projeção de Mercator. Já a projeção de Peters deforma (reduz) as regiões polares, tendo uma distorção muito menor (2-1) se comparada à de Mercador (4 -1) figura 22.

As projeções mais usadas condicionam os nossos pensamentos, de modo que qualquer representação do mundo fora do padrão acaba sendo julgada como "esquisita" ou "errada". As projeções dominantes também determinam o traçado dos meridianos e paralelos. (...) À pergunta da Narizinho sobre quantos meridianos havia, Dona Benta responde: "Quantos você quiser. Desde que são 
círculos imaginários, você poderia traçar milhões de milhões deles, cada qual cortando o Equador num pontinho" (Seemann, 2006).

\section{Figura 22 - As projeções de Mercator e Peters}
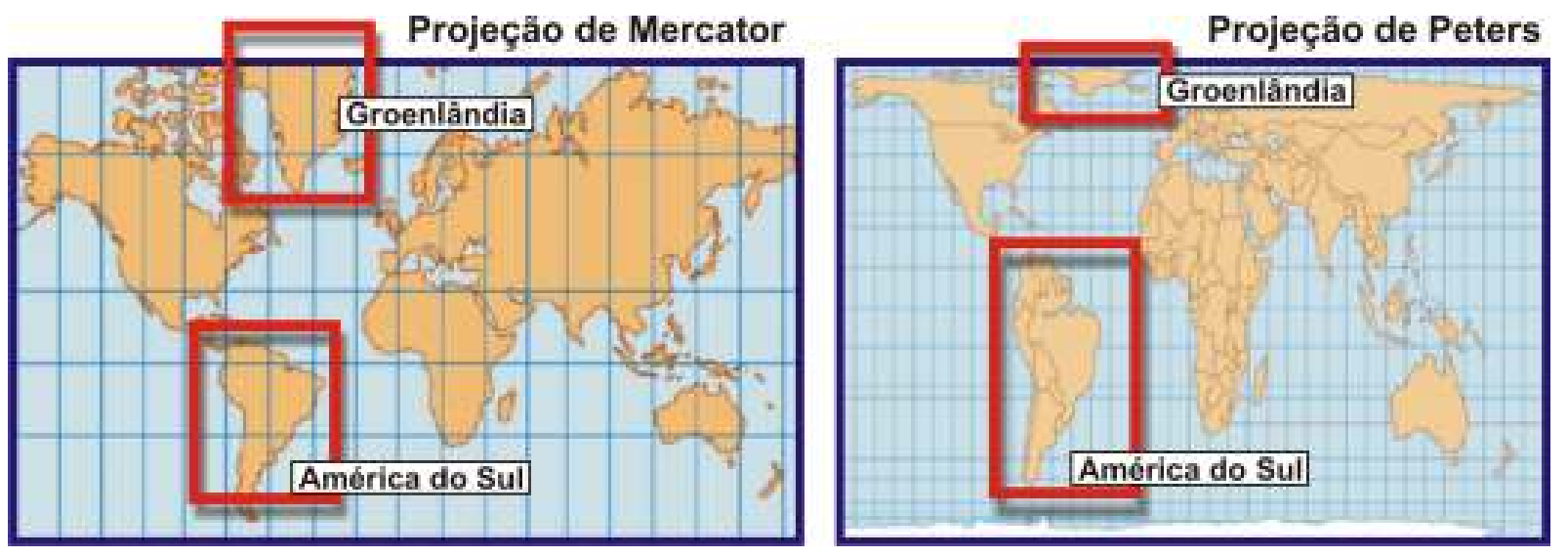

Até que ponto as sociedades produzem mapas objetivos, precisos, em oposição aos aspectos simbólicos, subjetivos, míticos ${ }^{21}$, psicológicos? Kozel (2006) salienta que este aporte cartográfico é identificado como instrumento de dominação e manipulação, ancorada na conotação cientificista da verdade ou representação real.

Aprende-se a ler criticamente os textos, destrinchando suas ideologias, intenções e opções teórico-metodológicas. Já os mapas são literalmente copiados ou elaborados sob um rígido conjunto de técnicas. Todavia, o mapa não se aparta de um conteúdo ideológico e, às vezes, até mitológico do que está sendo reproduzido (Girardi, 1997: 15). A autora continua propondo que não é para se deixar de lado a acurácia, a escala, orientação, etc., mas alerta que esse não deve ser o único critério para avaliar um mapa. Aprender cartografia é aprender regras de construção de mapas, suas diferenças, o uso de cada tipo de produto. O conteúdo técnico é importante, mas não é o bastante.

Essa visão cientificista começou a mudar em 1987 com J. B. Harley e D. Woodward, que, no primeiro dos quatro volumes da História da Cartografia, adotam uma definição de mapa que permitiu introduzir um possível relativismo no estudo histórico das cartas geográficas. Isso faz com que se reconheça a grande diversidade de formas de representação do espaço no grande mosaico da cultura humana universal. Os autores partem da convicção de que como:

\footnotetext{
${ }^{21}$ Mito é uma mensagem sob a qual incide um uso social. Qualquer mensagem poderia, a rigor, ser um mito, porém, consideram-se como mito mensagens que visem à naturalização da cultura. Todo sistema semiológico é um sistema de valores, porém o consumidor do mito considera a significação como um sistema de fatos (Girardi, 2006).
} 
cada sociedade tem ou teve sua própria forma de perceber e produzir imagens espaciais, chegamos a esta definição de mapa: "representação gráfica que facilita a compreensão espacial de objetos, conceitos, condições, processos e fatos do mundo humano". O motivo de uma definição tão ampla é facultar sua ampliação a todas as culturas de todos os tempos, e não apenas às da era moderna. Além disso, ao considerar os mapas uma forma de "saber" em geral, ao invés de meros produtos de uma prolongada difusão tecnológica a partir de um foco europeu, tal definição permite escrever uma história muito mais completa.

Isso faz com que a velha história da cartografia passe por uma constante revisão. Além disso, a nova história da cartografia permite que se entenda muito melhor o objetivo da criação dos mapas. Voltando ao exemplo dos mapas chineses, é comprovada a utilidade dos mapas como instrumento de poder: cadastral e demarcatório de fronteiras, plano de conservação das águas, meios de fixar impostos, etc. Contudo, os mapas chineses também recebiam influência da literatura, da pintura, desempenhavam uma função ritual (comprovada pela presença em túmulos), serviam como instrumento de adivinhação, predição astrológica, de fenômenos celestes ou de proteção contra forças invisíveis (Harley, 1991).

Taylor (1991) alerta que, atualmente, o desenvolvimento conceitual e teórico da cartografia como disciplina tem sido retardado, se não desviado, devido ao grande entusiasmo e interesse suscitado pelo mapeamento automático e pelo SIG. Portanto, um número excessivo de cartógrafos modernos são fundamentalmente especialistas tecnológicos, possuindo uma visão limitada da cartografia.

O que se percebe nesta breve apresentação da cartografia ao longo da história, independente dos discursos e formalismos (suposta certeza e erro), é que cada mapa tem um porquê existencial, isto é, um contexto que está diretamente relacionado com a sua função. Conseqüentemente, a elaboração de mapas temáticos voltados ao setor do turístico só está sendo colocada em pauta, devido a questionamentos e à necessidade de pensar em um material cartográfico mais adequado ao público usuário (turista) e à localidade turística, que quer ser conhecida, desejada, prestigiada.

No Brasil, esse tipo de material já é produzido há muito tempo, contudo, não por profissionais especializados no assunto (como geógrafos e cartógrafos), o que acarreta em materiais "cartográficos" de baixa qualidade.

A elaboração dos mapas turísticos não descarta a cartografia convencional e abstrata; pautada nas convenções matemáticas e novas tecnologias. Pelo contrário, todo esse conteúdo será utilizado e readaptado, procurando um resgate histórico, ou seja, reviver aquela época em que se fazia um uso muito maior da pictografia. Devese ter em mente para que, para quem e como esse tipo de mapa temático será feito. Até porque é o público potencial que faz o produtor escolher quais representações serão mais eficazes que outras. A eficácia se resume em dois tópicos: conseguir aliar 
a clareza do material cartográfico às expectativas do público para quem o mapa é elaborado.

Dondis (1991: 131-133) esclarece que, na comunicação visual, o conteúdo nunca está dissociado da forma. Os dois elementos juntos geram uma manifestação e mudam sutilmente de um meio a outro e de um formato a outro, adaptando-se às circunstâncias de cada um, sendo o mecanismo perceptivo, o meio para sua interpretação.

Aliás, a percepção sofre com as fortes restrições e dependências em relação ao sistema socioestético, que acaba reduzindo as pretensões dos criadores. Mesmo assim, cada vez mais as sociedades modernas procuram abrir e pluralizar possibilidades de escolha não-convencionais de produção, interpretação e comunicação. Acrescente-se o aumento de difusão de novas técnicas, motivo pelo qual existe uma maior diversidade de tendências do que no passado (Canclini, 2003: 39).

Dessa maneira, pretende-se discutir a elaboração de mapas temáticos para o turismo, o qual são portadores de um contexto e um conteúdo próprios, sendo que cabe ao cartógrafo vislumbrar os anseios desses usuários. Por essa razão, é necessário citar Beni (1998: 216-217), que aponta a necessidade de considerar os fatores que atuam na escolha feita pelo turista quando decide viajar. As duas decisões mais comuns são aquelas referentes à decisão de rotina ou decisão por impulso, explicitadas abaixo:

$\checkmark$ Decisão de rotina - turista que se fundamenta em um inventário de conhecimentos e atitudes já existentes em seu pensamento. Em outras palavras, ele possui um estoque de informações úteis (em qual hotel ficar, em que locadora alugar o carro, que restaurantes freqüentar, qual a praia mais adequada, etc), válidas no momento da escolha, sendo que essas informações pré-existentes influenciam a escolha entre uma ou outra destinação. Neste item, o marketing em turismo torna-se um instrumental importante, sugestionando o consumidor a conhecer uma nova destinação e/ou serviço.

$\checkmark$ Decisão por impulso - turista que age de maneira rápida, impulsiva, ou seja, o consumidor muitas vezes atraído por folhetos, por material audiovisual, vídeos, imagens na internet, programas de TV, filmes de roteiros. Logo, a conduta impulsiva pode ser provocada a partir do uso adequado desses materiais de comunicação informativa e publicidade, divulgação. As sugestões de viagens não-consideradas pelo turista-cliente fazem parte de um segmento da técnica de marketing do turismo, utilizadas nessas tomadas de decisões impulsivas.

O autor (Beni: 1998: 218) apresenta ainda, nove fases que o turista levará em conta em seu processo de decisão quanto à escolha de um serviço e localidade, sendo essencial serem conhecidas ao se elaborar um mapa direcionado ao setor do turismo: 
1. Estímulo inicial, que pode se fundamentar em desejos e necessidade provocados pela publicidade e promoção de um país, de um centro de polarização turística, um hotel, uma destinação em geral, por uma literatura especializada de turismo, ou por sugestões e informações de outros viajantes.

2. Estabelecimento de uma referência conceitual - turismo cultural, esportivo, ecoturismo, etc. - referindo-se, então, à pré-escolha de um conjunto de produtos oferecidos ao consumidor que corresponda as suas expectativas, consideradas suas características pessoais e socioeconômicas.

3. Relação a fatos que intervenham: custo de elementos, fatores de perfil da clientela e da pesquisa de mercados.

4. Fixação de pressupostos, extraindo deduções de todos os fatos, além de se obter dados dos pontos-de-vendas (hotéis, agências de viagem) e dos processos de intermediação de serviços turísticos.

5. Quadro de alternativas, ordenando as possíveis compras que possa efetuar.

6. Previsão de conseqüências, com a avaliação dos riscos - objetivos e subjetivos - que possam se apresentar.

7. Análise do custo/benefício - tangível e intangível - que o turista possa obter.

8. Decisão de compra em função de todas as fases anteriores.

9. Conseqüências dessa decisão a fim de proporcionar uma real satisfação do consumidor ou evitando sua decepção.

A partir do que foi exposto, reitera-se o que já dito anteriormente: um mapa voltado ao setor turístico deve ser funcional - indicar localizações, proporcionar aos turistas conhecimento sobre as distâncias entre atrativos, ter símbolos eficazes, etc. Entretanto, além disso, têm que apresentar um tipo de design que cumpra a função de divulgar a localidade turística, e, por esta razão, sua aparência estética é fundamental.

Dentro do complexo Sistema de Turismo - Sistur - criado por Beni (1998: 177), o mapa turístico pode participar da política de distribuição, tanto como material informativo (pontos e referências das atrações, distâncias, etc) quanto como material de divulgação que é enviado aos intermediários (postos de vendas e central de reservas, como hotéis, empresas de transporte, agências de viagens) e transmitido aos consumidores.

Os dados da tabela 1 atestam que o mapa turístico se insere no item Informação e organização de viagens; todavia o produto em si trará dados referentes aos outros quatro itens dos principais grupos de necessidades. 
Tabela 1 - Principais grupos de necessidades e empresas de turismo

\begin{tabular}{|c|c|}
\hline $\begin{array}{l}\text { PRINCIPAIS GRUPOS } \\
\text { DE NECESSIDADES }\end{array}$ & EMPRESAS DE TURISMO \\
\hline - Deslocamento & $\begin{array}{l}\text { Transportadoras para curtas, médias e longas distâncias, oferecendo transporte } \\
\text { ferroviário, rodoviário, aéreo, marítimo, fluvial, lacustre, etc. } \\
\text { Locadoras de veículos. }\end{array}$ \\
\hline $\begin{array}{l}\text { - Alojamento } \\
\text { - Alimentaçã̉o }\end{array}$ & $\begin{array}{l}\text { Hotéis, motéis, camping, imobiliárias para locaçăo de férias, etc. } \\
\text { Restaurantes, lanchonetes, hotéis, motéis, supermercados, etc. }\end{array}$ \\
\hline $\begin{array}{l}\text { - Recreação e } \\
\text { entretenimento }\end{array}$ & $\begin{array}{l}\text { Hotéis, boates, bares, cinemas, teatros, cassinos e outras instalaçóes de lazer } \\
\text { e entretenimento. }\end{array}$ \\
\hline $\begin{array}{l}\text { - Saúde, convalescença } \\
\text { e restabelecimento }\end{array}$ & Policlínicas, balneários, sanatórios, termas, estações de águas, spas, etc. \\
\hline $\begin{array}{l}\text { - Informação e } \\
\text { organização de viagens }\end{array}$ & $\begin{array}{l}\text { Agências de viagens e operadoras de turismo, transportadoras, hotéis, } \\
\text { organizaçôes corporativas, etc. }\end{array}$ \\
\hline
\end{tabular}

Neste instante, é oportuno ser citada a pesquisa de Collins-Kreiner (1997), que analisou vinte e um mapas especialmente elaborados para peregrinos que visitavam Israel ${ }^{22}$. Conseqüente-mente, tais produtos eram caracterizados por um status cartográfico especial, devido a sua natureza subjetiva: a fé. Além disso, havia o esforço em combinar a realidade contemporânea com a tradição dos mapas da antiga Terra Santa. Pode-se dizer que tais produtos pertencem a um subtipo de mapa que objetiva comunicar uma mensagem particular e predeterminada da localidade (Collins-Kreiner, 1997).

O exemplo acima ilustra um entre uma grande variedade de contextos que procuram métodos que disponibilizem maneiras distintas de visualização e experimentação dos dados e das informações. Segundo Cartwright \& Heath (2002), como resultado, temse a possibilidade de várias interpretações de uma mesma informação, pois diferentes usuários merecem diferentes estilos de representação. Faça aqui uma ressalva: o estilo do cartógrafo deverá sempre respeitar as reais condições do usuário em ter acesso à informação pelo usuário que ainda pode preferir usar somente um ou diferentes tipos de mapa da mesma localidade, buscando, assim, um melhor entendimento da destinação representada.

A metáfora do mapa é aumentada ao se utilizarem outras metáforas que podem ser facilmente oferecidas pela tecnologia e pela comunicação. E é por tudo isso que os mapas contemporâneos deveriam dispor de mais de uma metáfora para que houvesse uma maior flexibilidade com relação aos diferentes tipos de usuários

\footnotetext{
${ }^{22}$ Pesquisa desenvolvida em 1995, que analisou mapas de visitação confeccionados em Israel entre os anos de 1984 e 1994. Os mapas foram coletados nos escritórios de Informação Turística Cristã de Jerusalém e de Turismo do Governo, hotéis, albergues, lojas de suvenir, livrarias, igrejas, e editoras de mapas. Os mapas continham fundamentalmente representações de igrejas, locais sagrados e para compras, ou seja, informações que interessam potencialmente a peregrinos e turistas (Collins-Kreiner, 1997).
} 
(Cartwright \& Heath, 2002), o que também facilitaria a compreensão (leitura), graças ao recurso da redundância de informações.

A figura 23, retirada de Cartwright \& Heath (2002), demonstra representações diferenciadas de Nova York. Os autores argumentam que existe a necessidade de se investigar a reação dos usuários a partir de métodos que possuam representações cartográficas menos rígidas, além de verificar nesses materiais como são construídas as imagens mentais da realidade.

Figura 23 - Representações gráficas de Nova lorque
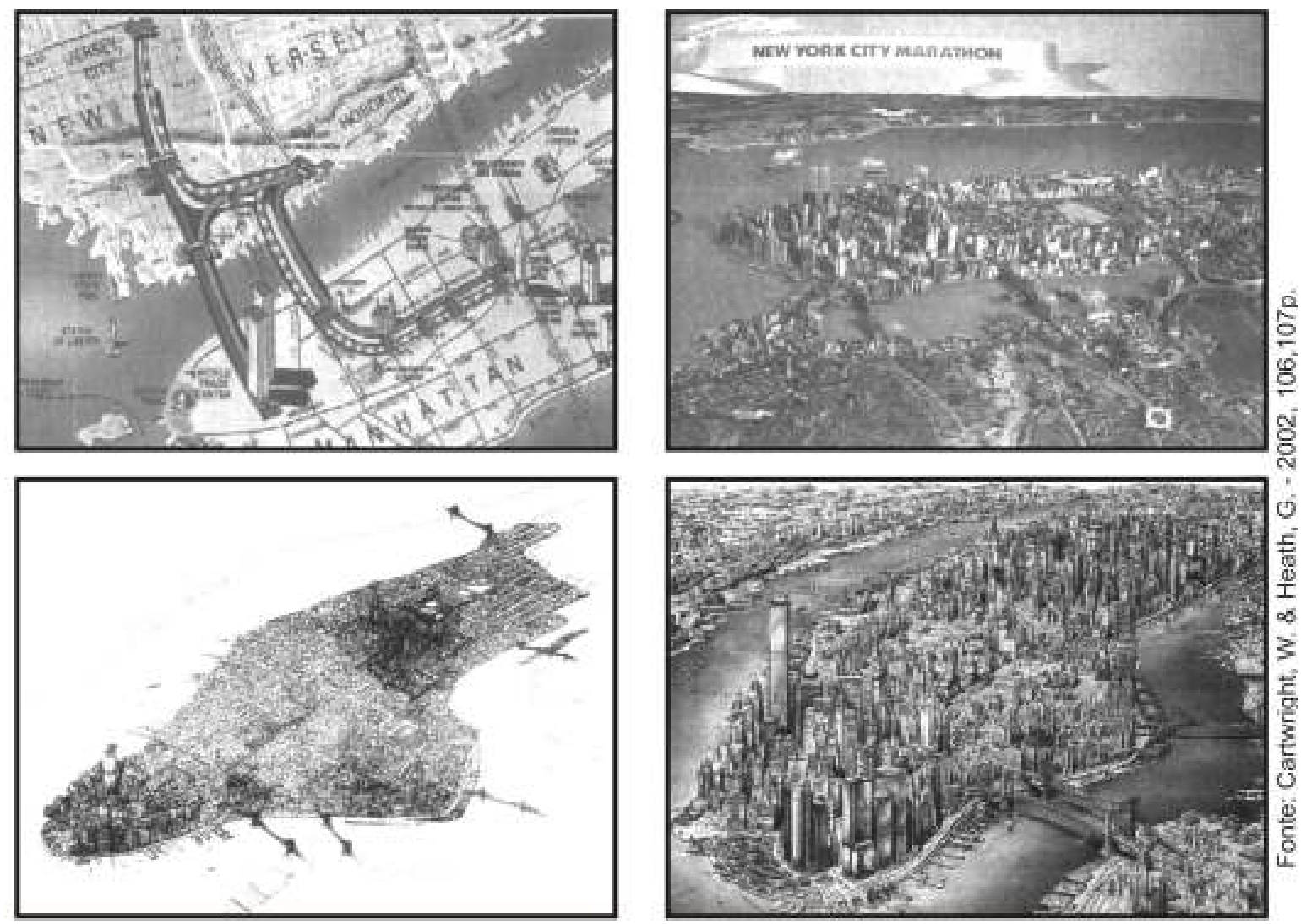

Neste instante, aborda-se a problemática da elaboração de mapas em meio digital, que traz a vantagem de dispor, em um mesmo material cartográfico, diferentes níveis de generalização e abstração de um mesmo conteúdo.

Inicialmente, é importante frisar que, com o rádio e o cinema, iniciou-se uma fase decisiva na formação de símbolos de identificação coletiva (Canclini, 2003: 196-197). $\mathrm{E}$, após o advento do satélite, as possibilidades de comunicação instantânea tornarem-se um fato, com destaque à televisão e à rede mundial de computadores.

Assim, as últimas décadas do século $X X$ e início do $X X I$ vêem o surgimento de um novo tipo de cartografia que instiga ainda mais 0 ato criativo do produtor do mapa, pois, como frisa Kraak (1998), o meio digital e a internet não somente permitem uma 
apresentação dinâmica dos mapas como também possibilitam uma participação efetiva (acesso em tempo real aos dados dispostos) do usuário na apresentação de um mapa final.

A Cibercartografia - termo introduzido em junho de 1997 na $18^{a}$ Conferência Cartográfica Internacional, em Estocolmo, Suécia - situa o mapeamento na era da Informação. Neste momento histórico, incorporam-se importantes elementos do passado, redefinem-se outros e se introduzem novas idéias e abordagens tanto em relação à cartografia prática quanto à teórica. Nesta etapa evolutiva, a cartografia trabalha temas como: a multisensorialidade (uso da visão, audição, tato e eventualmente o olfato e o paladar); o uso de formatos em multimídia e novas telecomunicações; a interatividade e novos caminhos, tópicos de interesse da sociedade que não se refiram somente à localização no espaço; utilização de diferentes disciplinas, etc (Taylor, 2005: 2-3).

Segundo Reyes (2005: 75), na cibercartografia usam-se diversas fontes na elaboração de um mesmo material, incluindo diversas áreas do conhecimento como: a cartografia, a lingüística, a matemática, a estatística, a música e as linguagens visuais (figura 24).

Figura 24 - Comunicação em cibercartografia

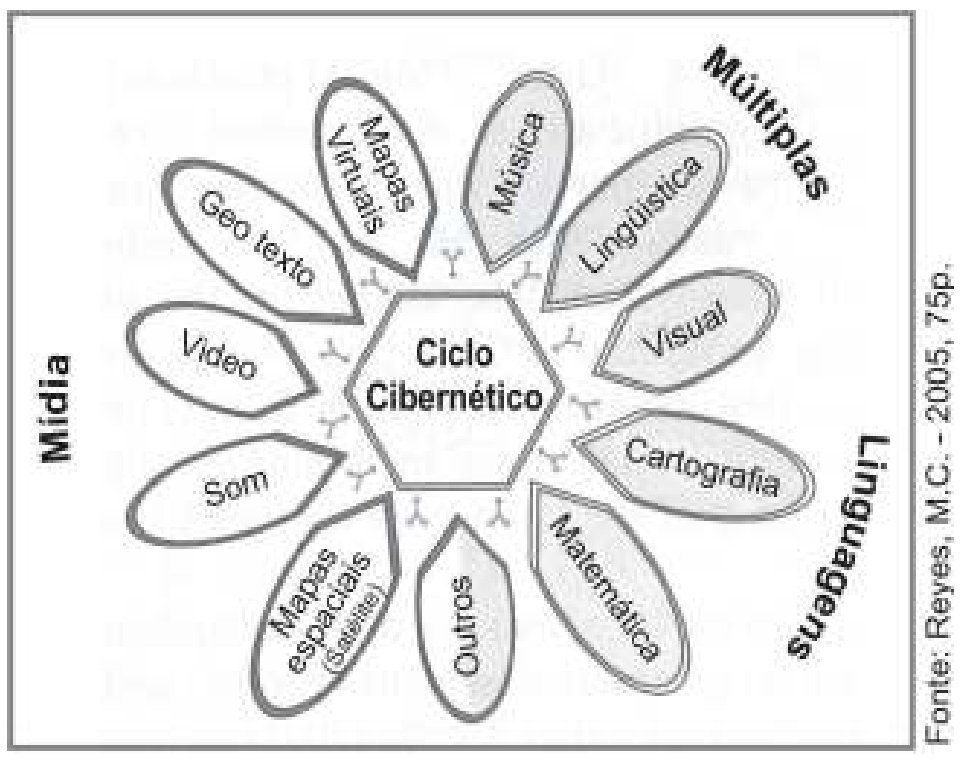

O cartógrafo, então deve definir parâmetros com respeito ao que Canclini (2003: 152) chama de comunidade hermenêutica possivel em uma sociedade e seu tempo, permitindo aos designers saber que graus de variabilidade e inovação podem manejar, que públicos se relacionarão, definindo, assim, políticas de comunicação para que os receptores entendam da melhor forma possível a atividade produtora de sentido.

Cartwright \& Heath (2002) apresentam quatro perfis de usuários quanto à elaboração 
do design que prima pelo acesso a um protótipo de mapa em multimídia interativa. Os usuários são definidos e divididos em quatro gerações: 1) Nintendo - acessa a informação usando a metáfora dos jogos, 2) Computador, 3) Vídeo - (televisão), e 4) Imprensa, Áudio - jornal, rádio. Uma vez identificados esses grupos empregam-se itens específicos no desenvolvimento das diferentes interfaces para o material (Figura 25).

Figura 25 - Perfil e informação apropriada: o usuário e multimídia interativa

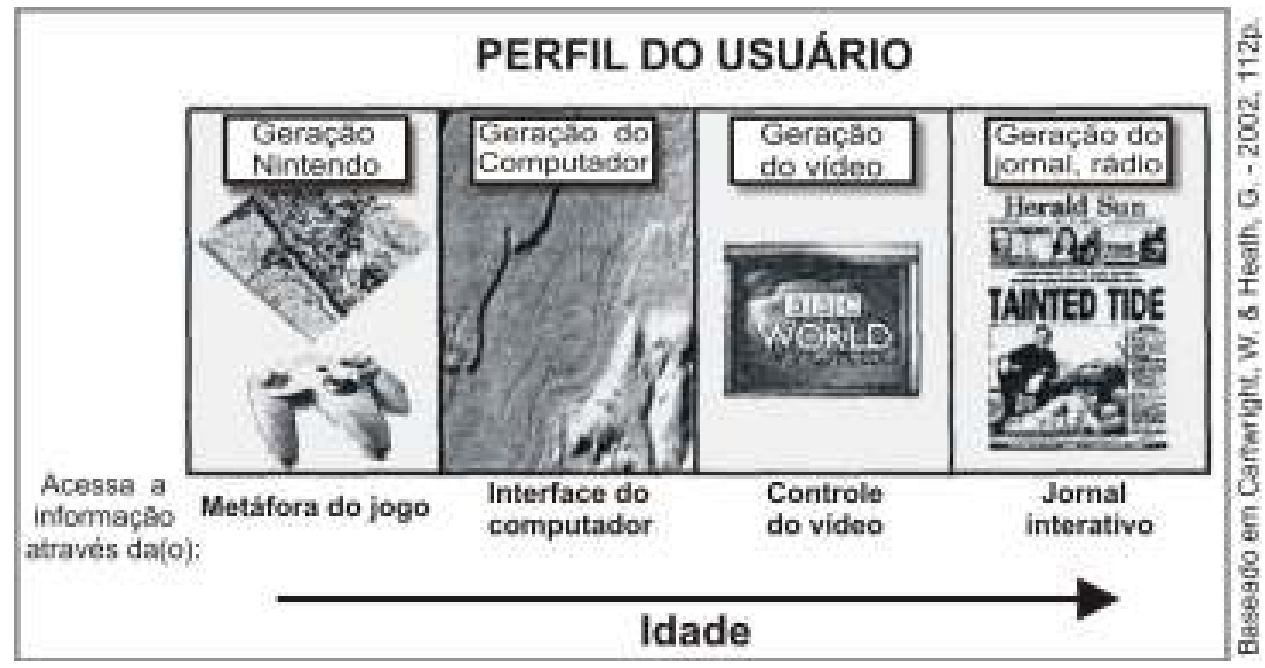

Tendo como referência o que foi exposto acima, conceitua-se o recurso comunicativo da multimídia como o único produto que congrega o conjunto de várias mídias agrupadas. Em Cartwright (1993), encontram-se algumas definições para multimídia. Destacam-se aqui duas:

$\checkmark$ É a integração de duas ou mais formas de mídias como, por exemplo, vídeo, som, texto, gráfico e animação, que são controladas a partir de um computador pessoal (Bahman Dara, APPLE).

$\checkmark$ Já Iggy Pintado da IBM, vê a multimídia como uma grande revolução na maneira de representar a informação no século XX. Ela capacita acessar e expressar a informação além de somente textos e gráficos no computador, incluindo também imagens, animação, vídeo, som estéreo e interação com um simples toque na própria imagem da tela. Em suma, é a combinação de mídias: o áudio visual da televisão e a interatividade do computador pessoal.

É inegável que tal tecnologia favorece e cria enormes possibilidades aos cartógrafos na elaboração de inúmeros tipos de representações e interpretações dos fenômenos espaciais nos novos mapas (Cartwright, 1993). As áreas discretas dos gráficos, outrora representadas de uma forma mais singela, atualmente, podem fazer uso de imagens, animação, filme, vídeo (Cartwright, 1996).

Tais recursos também fazem com que a tecnologia em multimídia permita o controle 
de mais emoções do que qualquer outro meio de comunicação já existente. Devido à variedade de emoções que podem ser influenciadas, o valor comunicativo da multimídia deve ser muito superior à dos métodos anteriores (Cartwright, 1993).

Posto isso, ao pensar na elaboração de um mapa turístico, compartilha-se a idéia de Carneiro (2001: 4) que afirma notar

atualmente uma tendência muito forte de se pensar o processo turístico enquanto, e tão somente, atividade comercial, despida de qualquer outro objetivo que não seja o lucro imediato. E é por esta imediatez que se desperdiçam oportunidades à realização de um trabalho profissional, onde o turista seja bem atendido, na medida em que seja bem informado, se sinta seguro e satisfeito em seus desejos e necessidades.

A afirmação proporciona um parâmetro de qualidade, principalmente ao se pensar que a grande maioria dos mapas turísticos produzidos no país apresenta muitas e algumas graves deficiências cartográficas, tais como: ausência de escala, desconhecimento do sistema de referências (latitude/longitude e direções cardeais) e de legendas bem estruturadas, que cumpram sua função. Some-se ainda o nãoconhecimento ou a descaracterização da base cartográfica, sendo flagrante a omissão de grande parte das ruas e hidrografia. Todos esses itens somados dificultam enormemente a deslocamento e a localização dos diversos pontos turísticos in loco.

Podem ser citados também - como já analisado em Fiori (2003: 125-127) - trabalhos artísticos com mapas turísticos pictóricos, que empregam ilustrações de uma maneira pobre e sem criatividade. É comum ver ilustrações que são simplesmente retiradas de algum arquivo de figuras, sendo em seguida copiadas e coladas.

Fundamentalmente, a qualidade deste tipo de trabalho precisa ser buscada devido à importância que o setor do turismo vem galgando nas últimas décadas. No mesmo grau de importância estão os visitantes, que precisam de mapas que ofereçam o maior número de informações, mas que sejam de fácil compreensão e agradáveis de usar. Além disso, existe o morador local da destinação que, em linhas gerais, precisaria se aproximar, ter afinidade com o mapa que representa sua realidadelocalidade. Cabe então ao cartógrafo estabelecer, da melhor forma possível, uma relação positiva entre todas as forças mencionadas; jamais esquecendo a eficiência do material elaborado.

Finaliza-se esta parte com Vasconcellos (1993: 47) que, ao longo de anos de experiência prática e de resultados concretos, relata: acredito que é preciso mais do que motivar, despertar o interesse e conquistar... É fundamental "seduzir"... Um caminho é desenvolver a percepção, usando todos os sentidos para aprender.

A figura 26 a seguir resume as relações e interesses envolvidos no processo de desenvolvimento de mapas convencional e pictórico e do protótipo mapa-site turístico. 
Figura 26 - 0 ato de cartografar: as relações que envolvem um mapa turístico

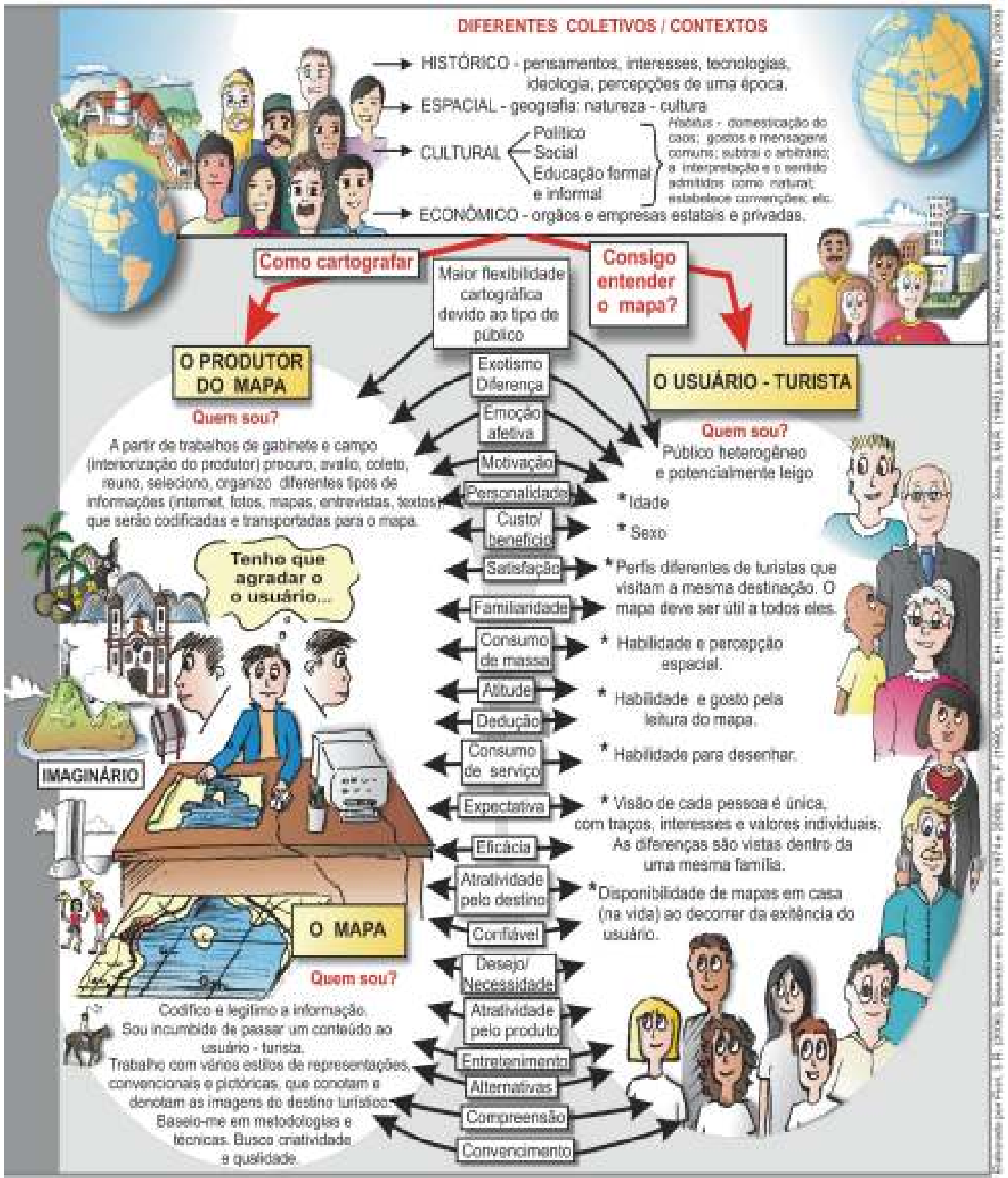




\section{5 - As bases semiológica e cartográfica: \\ proposta de um mapa temático para o setor do turismo}

Como foi dito anteriormente, a dificuldade em representar o espaço geográfico tridimensional - sobre o mapa é que tal representação se faz sobre uma superfície plana bidimensional (folha de papel, monitor de vídeo), simplificada e convencional, do todo ou de parte da superfície terrestre, tendo como base uma relação de semelhança convincente, denominada escala (Joly, 1990: 7). Para isso, conta-se com o processo seqüencial da generalização cartográfica, que traz a simplificação, o exagero, a hierarquização, o deslocamento e os elementos simbólicos do espaço geográfico - realidade para o mapa (Ramires, 1996).

Tal processo resulta em imagens incompletas, seletivas e representativas do terreno; logo, é preocupação primordial, em um mapa, a elaboração de sinais e símbolos apropriados (Joly: op.cit:: 8). O autor continua esclarecendo que as regras para que se estabeleça tal simbologia pertencem ao domínio da semiologia gráfica, que proporciona uma espécie de gramática da linguagem cartográfica.

Segundo Joly (op.cit:13), partindo do pressuposto que a linguagem exprime, por meio da utilização de um sistema de signos, um pensamento e um desejo de comunicação entre as pessoas, a cartografia pode, de maneira legítima, ser considerada como linguagem.

Os fundamentos sobre o estudo da lingüística e do signo ocorrem em meados da segunda metade do século XIX. Charles Sanders Pierce, filólogo e lógico americano e Ferdinand de Saussure, lingüista suíço, iniciam cada um a sua maneira, um estudo sobre o signo.

Santaella (1983: 58) brevemente conceitua o signo como um elemento que sempre representa outro (coisa): seu objeto. Ele só pode funcionar como signo se carregar esse poder de representar, substituir algo diferente dele. Conseqüentemente, o signo não é o objeto, apenas está no lugar dele, representando-o de um certo modo e numa certa capacidade. Ele pode ser interpretado por experiências concretas, sentimentos ou pensamentos. Tudo dependerá da natureza e do potencial do signo, além das condições intrínsecas de vivência de cada pessoa. O signo ainda é composto de duas partes:

$\checkmark$ Significante: caracteriza-se pelo plano da expressão, revelando o aspecto concreto/material do signo.

$\checkmark$ Significado: caracteriza-se pelo plano do conteúdo do elemento, transmitindo o aspecto abstrato/conceitual do signo.

Sendo que o significado do signo não está no próprio signo, mas nos conceitos ou imagens formadas na mente das pessoas. Isto nos faz supor que o significado de um signo é outro signo, ou seja, uma imagem mental ou real, uma ação ou mera reação 
gestual, uma palavra, um sentimento de alegria, e assim por diante (Santaella, 1983: 58).

Sendo assim, a comunicação só é conseguida quando o receptor-usuário associa ao sinal recebido a mesma intenção gerada pelo emissor. Tal processo é fundamentalmente baseado em duas condições: o canal deve ser rico o bastante para não ter ruídos, e o sinal deve fazer parte de um repertório comum à fonte produtora e receptora (Carneiro, 2001:22) - figura 27.

\section{Figura 27 - Teoria da Comunicação}

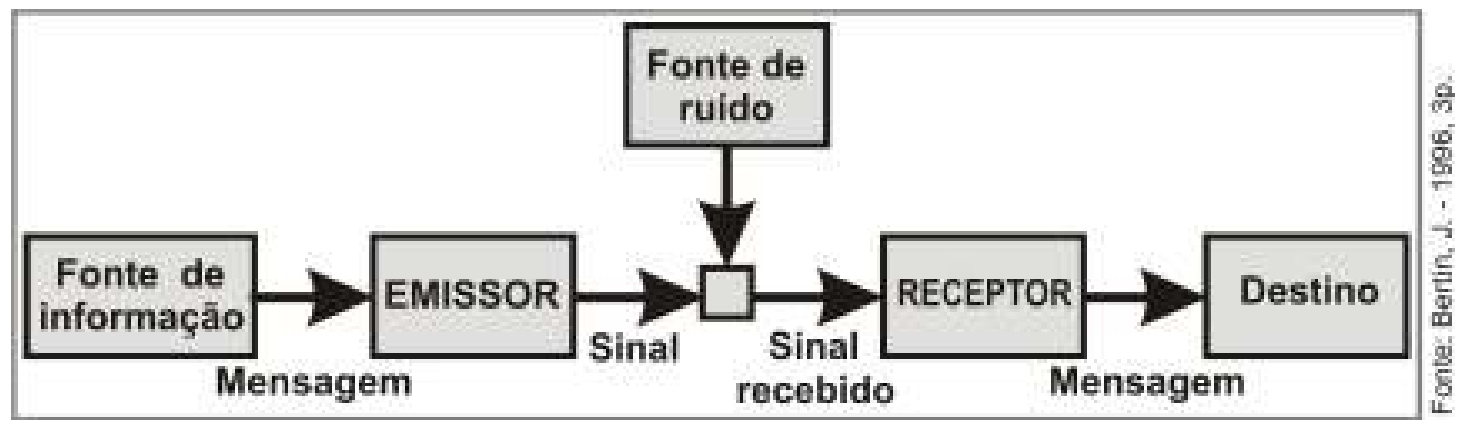

Dondis (1991: 26) deixa claro não haver nenhuma maneira fácil, milagrosa, de se desenvolver o alfabetismo visual. No entanto, atualmente ele é tão vital para o ensino e acesso aos modernos meios de comunicação, quanto a escrita e a leitura foram para o texto impresso.

O contato com o texto de Barthes $(1964,1984,1989)$ permite concluir que os mesmos conceitos trabalhados para a lingüística ajudaram a trazer uma maior familiarização a outros níveis de comunicação referentes a mensagem gráfica. Por exemplo: o autor fez formulações sobre a natureza da mensagem produzida pela pintura, pelo desenho e pela fotografia, apresentando diferenças em relação à mensagem escrita.

Em seus primeiros estudos sobre a semiologia e a vida cotidiana, Barthes demonstrava como imagens intencionais veiculadas pela imprensa, cinema, artes e demais veículos de comunicação eram consumidas inocentemente pelo público, que não as vê como um sistema de valores, mas sim, como sistema factual que exprime relações naturais (Porto Alegre, 1988: 78).

Barthes é citado nesta pesquisa porque seus trabalhos permitem estabelecer um paralelo entre suas idéias e o mapa turístico - potencialmente o pictórico. $\mathrm{O}$ autor (1990: 28-40) aponta três tipos de mensagens distintas que compõem a comunicação: a icônica codificada, a icônica não-codificada e a lingüística. Nesse processo, o espectador da imagem recebe ao mesmo tempo a mensagem perceptiva e a cultural. Cada tipo de mensagem será explorado em sua generalidade, procurando compreender a estrutura da imagem em seu conjunto, ou seja, a relação 
final das três mensagens entre si.

\section{a) A icônica codificada (mensagem denotada)}

Conforma-se pela imagem pura, podendo estar ou não ordenada. Neste caso, pode ser linear - a,b,c... 1,2,3 ou não linear - desenhos, mapas. As letras, os números, as linhas, as formas e cores são os primeiros elementos visuais a serem compreendidos.

Carneiro (2001: 38) restringe-se aos sinais gráficos, os quais se conformam em imagens representadas por traços (linhas) em uma superfície (papel, monitor de computador). Não possuem valor fonético e comumente não fazem uso dos recursos da lingüística. Sua natureza é então icônica figurativa, pois suas formas se assemelham aos elementos que representam, dentro de uma abordagem de repertórios ou códigos, que é direcionada a um público. A eficácia do sinal o fará conhecido e memorável.

Embora denotado, o desenho - quando busca reproduzir a realidade não deixa de ser uma mensagem literal codificada, pois a natureza codificada do desenho aparece em três níveis (Barthes, 1990):

$\checkmark$ Ao reproduzir um objeto ou uma cena por meio de um desenho, o produtor é obrigado a fazer uso de um conjunto de transposições regulamentadas (técnicas, regras, estilos, etc.). Logo, a cópia pictórica não possui apenas uma única natureza, fazendo uso de códigos de transposição históricos (sobretudo no que tange à perspectiva).

$\checkmark \quad \mathrm{O}$ ato de desenhar (a codificação) obriga uma certa divisão do que é significante e do que é insignificante no elemento real-concreto, pois o desenho não reproduz tudo o que é visto na realidade. Freqüentemente, são reproduzidas somente poucas características encontradas no elemento real, mesmo assim, quando o desenho é bem elaborado, sua mensagem não deixa de ser forte e eficaz. Assim, a denotação do desenho é menos pura do que, por exemplo, uma denotação fotográfica.

$\checkmark$ Como todos os códigos, a utilização do desenho exige uma aprendizagem, tanto do produtor quanto do usuário.

\section{b) A icônica não-codificada (retórica da imagem)}

Os signos desse tipo de mensagem são denominados de simbólicos culturais ou conotados. Por meio deles é possível saber, por exemplo, o que alguém pensa de um conjunto de ilustrações como sol e mar, por exemplo, cuja resposta seria, férias ou praia. Mesmo quando o significante parece abranger toda a imagem, é, ainda assim, um signo separado dos outros, pois só a composição tem um significado estético (Citelli, 1985). 
Segundo Barthes (1990), tais signos são extraídos de um código cultural. A diversidade das leituras não é, no entanto, anárquica; depende do saber investido na imagem - saberes práticos, nacionais, culturais, estéticos. Cada pessoa possui uma pluralidade de léxicos ${ }^{23}$, logo, a imagem, em sua conotação, seria, assim, constituída por uma arquitetura de signos provindos de uma profundidade variável de léxicos.

O imenso sistema de conotação apresenta significantes constituídos por outros tipos de expressão como, por exemplo, o desenho, a palavra, os objetos, os comportamentos; não se restringindo somente a imagem. Portanto, a mesma conotação pode ser conseguida a partir da imprensa escrita, em uma imagem na televisão ou no gesto do comediante, todas possuindo um significado comum. Esta é a razão pela qual a semiologia só pode ser concebida em um todo (Barthes, 1990).

Esse domínio comum dos significados de conotação é o da ideologia, que deve ser único em uma mesma sociedade, levando em consideração qualquer um dos significantes de conotação ao qual recorra. Barthes (1990) continua esclarecendo que a ideologia geral corresponde na verdade, a significantes de conotação chamados de conotadores, sendo que o conjunto dos conotadores foram uma retórica, a qual aparece, como a face significante da ideologia.

As retóricas variam fatalmente em razão de sua forma: som, imagem, gesto, etc. Já a retórica da imagem - isto é, a classificação de seus conotadores - é, assim, específica na medida em que é submetida às imposições físicas da visão (diferentes, por exemplo, das imposições auditivas, táteis, etc). Em geral, as figuras nunca são mais do que relações formais dos elementos; e esta retórica só poderá ser constituída a partir de um inventário suficientemente vasto (Barthes, 1990).

A figura 28 exemplifica as duas mensagens - denotativa e conotativa - inerentes ao ato de representação da realidade, a arte imitativa, a qual será usada durante o desenvolvimento dos mapas turísticos.

\section{c) A lingüística}

A lingüística constitui-se na dualidade contraditória: unidade e diversidade, contradição esta inscrita em seu próprio objeto - as diferentes línguas - havendo uma relação necessária entre o formalismo do sistema e a diversidade história concreta. $A$ Lingüística é afetada em sua constituição por essa contradição que se inscreve na sua própria histórica e na história das alianças que ela vai promovendo com diferentes campos do conhecimento como, por exemplo, o logicismo, o psicologismo, o sociologismo, o cognitivismo, etc (Orlandi: 2004:17).

\footnotetext{
${ }^{23}$ Parte do plano simbólico da linguagem que corresponde a um conjunto de práticas e de técnicas. É o caso de diferentes leituras da imagem, onde cada signo corresponde a um conjunto de "atitudes", como por exemplo, o turismo, a vida doméstica, o conhecimento no campo da arte, as leis de trânsito, etc. (Barthes, 1990: 38).
} 
Figura 28 - A mensagem denotada e conotada

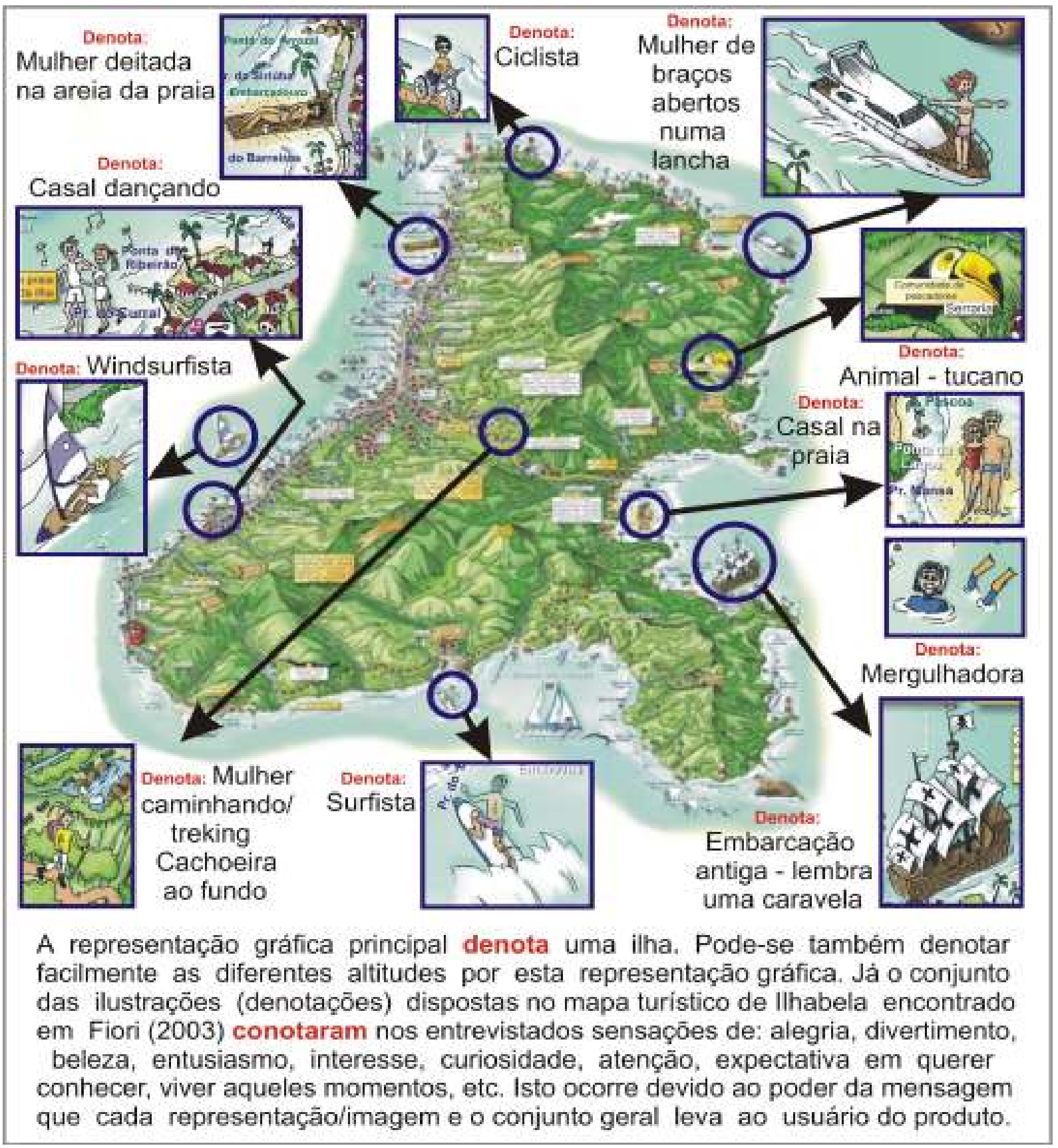

A mensagem lingüística volta-se mais à interpretação e não à identificação, constituindo uma espécie de barreira que impede a proliferação dos sentidos conotados, simbólicos. As mensagens tanto podem estar relacionadas a áreas individuais, limitando o poder de projeção da imagem, quanto relacionadas aos valores, onde os elementos dispostos na cena-imagem utilizam a legenda, orientando a interpretação da imagem.

A fixação pode ser ideológica e esta é, sem dúvida, sua função principal; o texto conduz o leitor entre os significados da imagem, fazendo com que se desvie de alguns significados e assimilem outros (Barthes, 1990). 
O autor esclarece que a palavra, vista em sua forma literal, ou seja, denotada, responde de maneira mais ou menos direta e parcial a pergunta: "o que é?", auxiliando pura e simplesmente na identificação dos elementos contidos na cena e na própria cena. A função denominativa corresponde a uma fixação de todos os sentidos possíveis (denotados) do objeto. Por exemplo, havendo um cartaz que representa um determinado prato de um restaurante, o consumidor pode hesitar na identificação das formas e volumes dispostos pela representação. Contudo, havendo um texto: "arroz e atum com cogumelos", aumenta-se consideravelmente o nível da percepção, permitindo adaptar o olhar e a compreensão.

Um segundo ponto muito importante da semiologia também aplicado à cartografia refere-se às três dimensões do signo: sintática, semântica e pragmática. $O$ trabalho preocupado com essas dimensões permite estruturar e melhorar a qualidade do repertório gráfico voltado à elaboração de mapas para o setor turístico e do lazer.

\section{1) A dimensão sintática:}

\section{estudo das relações dos signos com outros signos}

Preocupa-se com problemas relativos à forma da representação - como dizer ao usuário? - estudando itens estruturais e técnicas de composição, as quais geram regras de formação e codificação visual de um elemento, além de examinar sua interação com outras representações (o conjunto de elementos), que também possuem regras referentes à linguagem e repertórios (Carneiro, 2001:33).

Souza (1992: 72) informa que, estando a sintaxe preocupada em estudar a estrutura lógico-gramatical da linguagem, - as qualidades materiais do signo em seu jeito concreto e particular de existir - os elementos gráficos de preocupação do designer são: a forma, a cor, a textura, a magnitude, a intensidade, o movimento, o ritmo, a composição, a pertinência a um sistema, etc.

Essa etapa da composição visual é vital a todo processo criativo, e é onde o comunicador visual exerce maior controle sobre o seu trabalho, tendo a oportunidade de expressar, em plenitude, o espírito de sua obra. No contexto do alfabeto visual, a sintaxe significa a disposição ordenada de partes (linhas, cores, tons, proporções), não havendo regras absolutas:

o que existe é um alto grau de compreensão do que vai acontecer em termos de significado, se fizermos determinadas ordenações das partes que nos permitam organizar e orquestrar os meios visuais (Dondis, 1991: 29).

Souza (1992: 73,74) complementa afirmando existirem duas regras sintáticas básicas: a formação, que determina combinações independentes e permitidas entre os signos de um sistema e a transformação, que determina as combinações que podem ser obtidas a partir de outras combinações. Neste contexto, o autor ainda subdivide os signos de linguagem em três funções designadoras ou denotadoras, separadas a partir do grau de expectativas concretas que podem determinar no 
intérprete, a saber:

$\checkmark$ Indéxico - pode denotar um objeto individualmente, chamando para este a atenção de intérprete. Por exemplo, a palavra este, o signo gráfico da flecha, o gesto de apontar com o dedo indicador.

$\checkmark$ Caracterizador - pode denotar uma pluralidade de coisas e ter sua designação explicada ou restringida em virtude da presença de outros signos que o especificam. Por exemplo, a palavra homem, as silhuetas de homens.

$\checkmark$ Universal - pode denotar qualquer coisa, pois tem uma significação universal. Por exemplo, a palavra algo, o pictograma de masculino, de hospital, etc.

Normalmente, signos caracterizadores, indéxicos e universais se combinam, buscando um esforço para referenciar o objeto que está sendo aludido, para assim determinar - com maior ou menor precisão - as expectativas do intérprete em relação às possibilidades semânticas dos signos utilizados. Posto isso, na combinação dos signos, existem aqueles que funcionam como dominantes e outros como especificadores daqueles (Souza, 1992: 75) - Figura 29.

\section{2) A dimensão semântica:}

\section{estudo das relações dos signos com os objetos a que se referem}

Segundo Souza (1992: 46), é nesta dimensão que os profissionais em design gráfico deveriam despender noventa por cento de seu tempo.

\section{Figura 29 - Signos dominante e especificador}

No exemplo abaixo, o icone de um homem em uma única postura funciona como um signo dominante. Já os desenhos dos objetos: acessórios da cabeça e das mãos, funcionam como especificadores das diversas profissőes (Souza, S.M.R. - 1992, 75p).

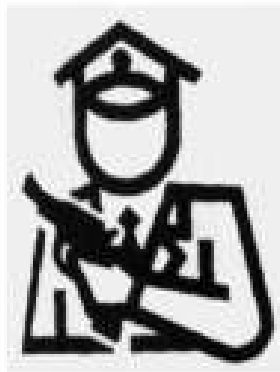

1- Policial

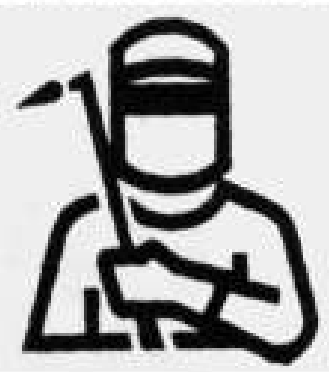

2 - Metalúrgico

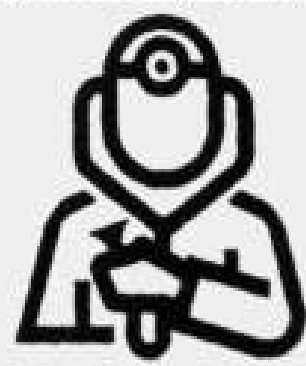

3-Médico

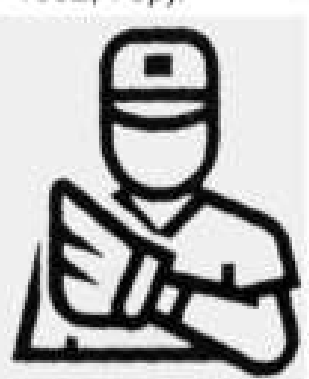

4- Jogador de beisebol

Este item preocupa-se com problemas relativos ao conteúdo da representação, buscando desenvolver formas que se caracterizem sempre pelo menor ruído, ou seja, maior clareza possível. A pergunta semântica é: o que dizer sobre.

$\mathrm{Na}$ verdade, as regras semânticas são muito mais estabelecidas por hábitos de conduta do que por proposições cientificamente provadas. Isso porque elas se 
configuram como modelos ou são aprendidas culturalmente, transmitidas por tradição (Carneiro, 2001: 34 e Souza, 1992: 76).

A opção por um código é feita a partir de uma escolha que tem como referência o meio de comunicação que transmitirá a mensagem (neste caso, um mapa) a alguém (turista) através de um canal (folha de papel e tela de computador). Tal escolha não é aleatória, pois analisa a natureza da mensagem e as particularidades do canal e do meio de comunicação, para que, assim, os sinais ou unidades de significação (signos, representações potencialmente pictóricas) sejam transmitidos da melhor maneira.

Oliveira (1977: 23), Santaella (1990: 63-68), Souza (1992: 73-83) e Carneiro (2001: 31-36) apontam três tipos de relações semânticas que se estabelecem entre o signo e seu referente.

"O ícone - deve denotar alguma característica ou conjunto pré-estabelecido de características do elemento representado, de modo que a imagem se assemelhe àquilo que significa. $\mathrm{O}$ ícone mostra em si mesmo propriedades do objeto por ele denotado, apresentando um alto poder de sugestão, devido a sua capacidade de produzir em nossa mente relações de comparação. Há uma semelhança entre a imagem e o referente. (Souza, 1992: 143) complementa que as codificações icônicas podem ir desde aquelas que apresentam um maior número de propriedades visíveis ou atributos do objeto representado (efeito de réplica, mimético, ilusão de estar diante da própria realidade), até aquelas que reduzem ao mínimo o número e a variedade dos atributos percebidos e selecionados como relevantes para a representação, apresentando-os de maneira esquemática ou convencionalizada como, por exemplo, charges, desenhos infantis, esquemáticos, etc (Figura 30).

Figura 30 - 0 ícone: o desenho fala por si

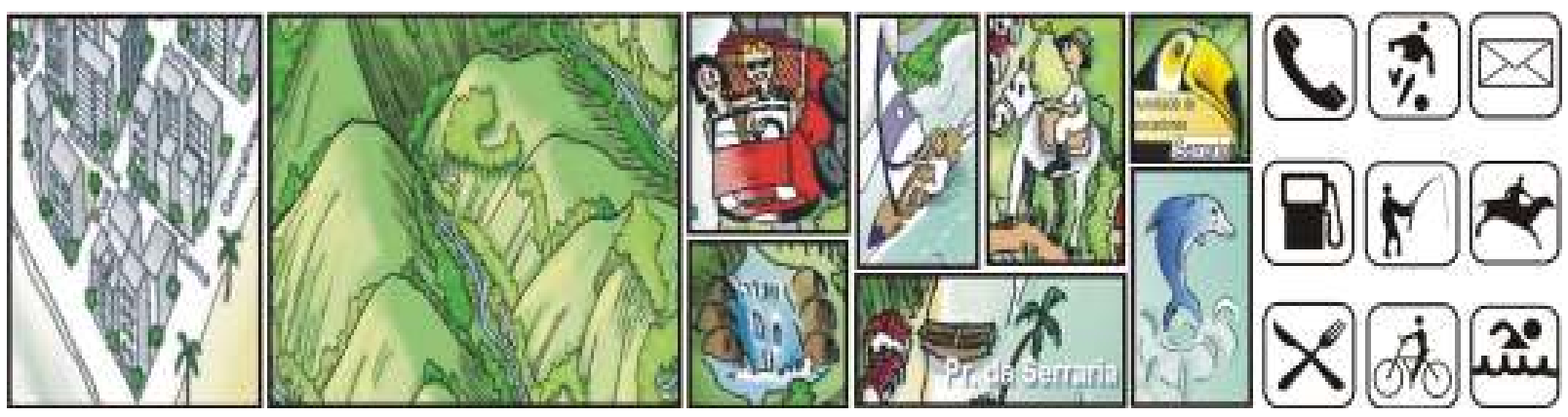

"O índice (ou indicador) - geralmente, dirige a atenção para aquilo que representa, porém não se caracteriza por propriedades de semelhança com o objeto/idéia. É um tipo de signo que funciona quando a mente interpretadora estabelece uma conexão dual, ou seja, o interpretante do índice constata apenas a existência dos elementos físicos: o real-concreto e a representação, normalmente tendendo a um maior nível de abstração. O raciocínio não ultrapassa a compreensão do signo como existência 
concreta, por interpretar simplesmente o que vê, sem maiores implicações quanto a querer identificar, particularizar uma imagem. Por exemplo, ao se elaborarem representações para caracterizar a morfologia do terreno, pode-se trabalhar com as técnicas de sombreamento - simulando uma tridimensionalmente das formas, mas não buscando uma ilustração particular, única e sim genérica - ou então, com cores e tons identificam-se as diferentes altitudes do terreno (Figura 31).

\section{Figura 31 - 0 índice: o desenho não guarda}

\section{semelhança direta com o que representa}
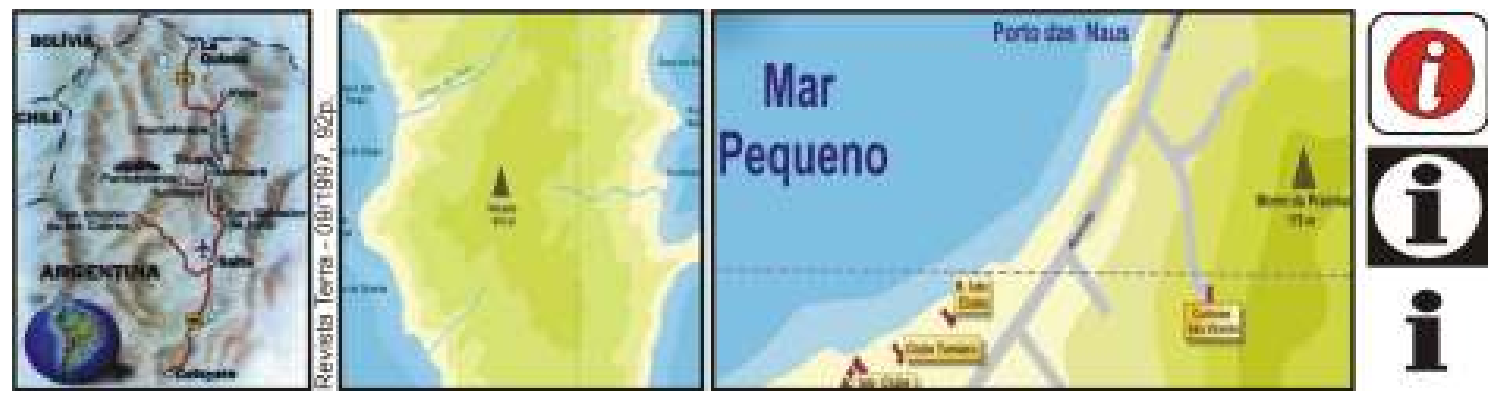

" O símbolo - representa e designa os objetos similares a um modelo, tendo como referência normas e usos convencionais não-questionáveis, sendo simplesmente aceitos. Conseqüentemente, a representação é portadora de uma lei que, por convenção ou pacto coletivo, determina que o signo represente o objeto. Deste modo, o símbolo não representa um tipo individual, mas, sim, geral. É o caso da cruz, que representa o sofrimento; da pomba que representa e paz.

Possibilitam-se ainda dois níveis distintos de convenção: a analógica (motivada) e a arbitrária. Na primeira, a significação cumpre seu papel à medida que o observador reconhece no signo as propriedades do elemento representado (Figura $32 \mathrm{~A}$ ). Já na convenção arbitrária, a significação só é conseguida graças à existência de regras associativas convencionalmente estabelecidas e adquiridas pelo aprendizado (Figura $32 \mathrm{~B})$.

Essa dimensão faz com que o produtor se preocupe mais com a representação e com o fato de ela ser compreendida e aceita, desenvolvendo símbolos que sejam eficientes aos mais diferentes tipos de pessoas (pertencentes ou não a mesma cultura).

O mapa a seguir representa uma contigüidade instituída, regra convencional entre o significado e o significante - mapas que apresentam legenda: o intérprete precisa recorrer à convenção para haver o entendimento do significado geral (Figura $32 \mathrm{C}$ ). 
Figura 32 - Símbolo: o desenho desenvolvido através de normas convenções
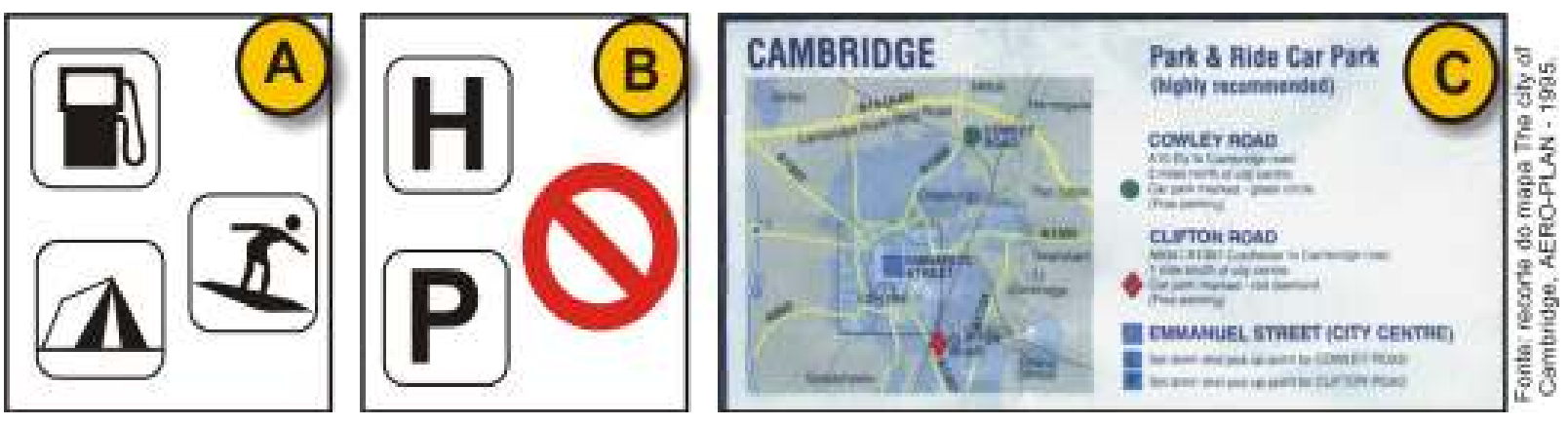

Por fim, Joly $(1990,18,19)$ divide os símbolos em várias categorias (Figura 33):

$\checkmark$ Sinais convencionais - são esquemas gráficos centrados na posição real do elemento representado, permitindo assim que este seja identificado mesmo que sua superfície, na escala, seja muito pequena.

$\checkmark$ Sinais simbólicos - são signos evocadores, localizados ou cuja posição é facilmente determinável.

$\checkmark$ Pictogramas - são símbolos figurativos facilmente reconhecíveis.

$\checkmark$ Ideogramas - são pictogramas que representam um conceito, uma idéia.

$\checkmark$ Símbolo regular - é uma estrutura constituída pela repetição regular de um elemento gráfico sobre uma superfície delimitada.

$\checkmark$ Símbolo proporcional - é um símbolo quantitativo, cuja dimensão varia com o valor do fenômeno representado.

O autor (1990: 19) complementa que o uso dos símbolos naturais, figurativos ou analógicos tem sido a tendência histórica mais antiga na elaboração de mapas.

Figura 33 - Símbolos cartográficos

\begin{tabular}{|l|l|}
1 - Sinais convencionais \\
2 - Sinais simbólicos \\
3 - Pictogramas \\
4 - Ideogramas \\
5 - Símbolos regulares \\
6 - Símbolos proporcionais
\end{tabular}

3) A dimensão pragmática: estudo das relações dos signos com os usuários

Essa dimensão com problemas relativos à função da representação - para que e qual 
usuário se dirige a mensagem - voltando-se a escolhas feitas previamente, na elaboração de um signo (fenômenos psicológicos, biológicos e sociológicos), enfatizando ou eliminando qualidades e/ou atributos para o melhor entendimento do usuário.

Nesta dimensão, estão as regras que relacionam os signos e os objetos representados, de forma a causar uma mudança de comportamento nos usuários, reflexo dos tipos de conduta referenciados pelo uso. Deve-se aqui levar em consideração que, quanto mais abstrata ou convencionalizada for a relação entre o signo e aquilo que designa, tanto maior será a necessidade desses hábitos serem consolidados por algum tipo de aprendizado.

Desse modo, o desenvolvimento de um sistema de repertório utilizado especificamente para mapas turísticos tem como preocupação representações eficazes quanto à comunicação dos elementos dispostos no espaço como localização e distância. E, além disso, algumas vezes pode apresentar o propósito de divulgar alguma informação que motive o visitante, sempre respeitando as condições deste usuário quanto à assimilação da informação que foi consolidada pelo aprendizado formal e informal.

A figura 34 exemplifica graus diferentes de abstração: o usuário só entenderá as mensagens a partir do conhecimento (habitus acumulado) anterior.

Figura 34 - Dois níveis diferentes de representação da mesma realidade
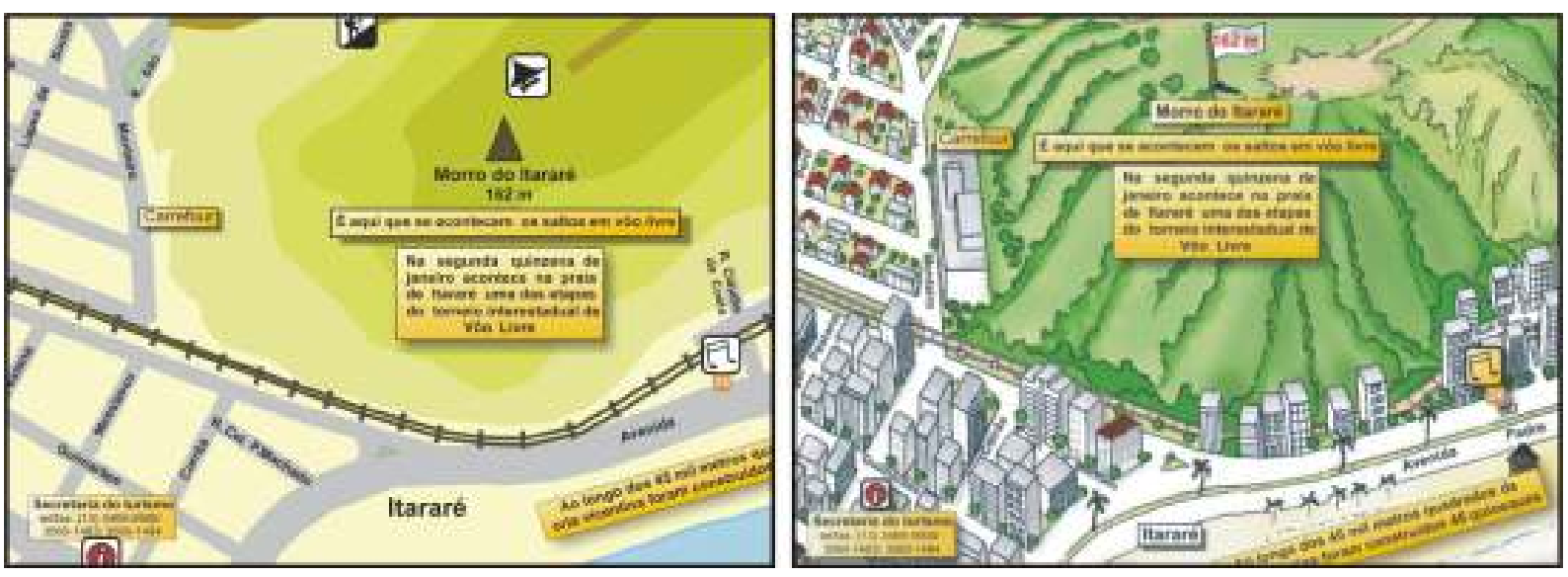

Enfim, as variações das manifestações visuais sempre dependerão da expressão subjetiva do artista, obtida pela ênfase de alguns elementos visuais em detrimento de outros, sendo que a manipulação desses elementos se dá pela opção estratégica de inúmeras técnicas. É nessas opções que o artista encontra seu significado. $O$ resultado final é a verdadeira manifestação do artista. Contudo, é fundamental não esquecer que o significado de sua obra depende da resposta do usuário, que também a modifica e interpreta pela rede de seus próprios critérios subjetivos (Dondis, 1991: 31). 
O terceiro e último ponto a ser abordado tem a preocupação de focalizar a semiologia direcionada ao desenvolvimento de mapas. Esse campo da comunicação - que parte da premissa de que a cartografia é uma forma de linguagem - foi inicialmente trabalhado por Bertin (1967), que estruturou a semiologia gráfica, área ligada ao mesmo tempo às diversas teorias das formas e suas representações e não só estudada pela psicologia contemporânea como pelas teorias da informação. O autor continua dizendo que a semiologia gráfica aplicada à cartografia permite:

avaliar as vantagens e os limites das variáveis visuais empregadas na simbologia cartográfica e, portanto, formular as regras de uma utilização racional da linguagem cartográfica. Encerrada durante muito tempo dentro de limites técnicos bastante restritos, porém magnificamente superados, hoje essa linguagem se vê rápida e consideravelmente modificada pela introdução vigorosa dos métodos da informática e da automação (Joly, 1990: 13-14).

Bertin (1996) afirma que o emprego das variáveis visuais no plano bidimensional faz uso das propriedades perceptivas de cada uma delas. Neste momento, é importante ressaltar que MacEachren $(1994,1995)$ vem trabalhando e aumentando a relação das variáveis visuais, tendo como base as duas dimensões do plano, uma perpendicular à outra: a longitude $(\mathrm{X})$ e latitude $(\mathrm{Y})$. Elas originam as coordenadas geográficas, também chamadas de componentes de localização, determinando uma superfície. Some-se ainda o componente de qualificação $(Z)$, que permite uma modulação do fundo do mapa por uma mancha (cor ou sinal) - característica do lugar representado - que pode ser qualitativa, quantitativa ou ambas. A extensão (mancha) do objeto ou fenômeno divide-se em três modos de implantação: pontual, linear e zonal (Joly, 1990: 14) - Figura 35. É importante ressaltar que Fiori (2003: 72-88) já apresentou detalhadamente cada uma das variáveis visuais.

Bertin $(1996,1988)$ informa que o esquema de representação monossêmica é obtido ao se juntarem as três dimensões do mapa $(X, Y, Z)$ com as três relações fundamentais entre os conceitos a serem transcritos: 1) a associação, semelhança (三), que se contrapõe à seleção, diferença $(\neq)$; 2) a ordem, (O); e 3) a quantidade, proporção (Q). Nesse processo, o emissor e o receptor estão exatamente na mesma situação perceptiva por fazerem uso e obedecerem ao mesmo esquema monossêmico: Ator $\longleftrightarrow(\equiv$ e $\neq, \mathbf{O}, \mathbf{Q})$. Tornar-se ator significa tomar conhecimento - em apenas um instante de percepção, sempre instantânea - da informação contida num gráfico ou mapa, sendo um receptor ativo e não passivo.

$\mathrm{E}$, para que isso aconteça, o redator gráfico (cartógrafo) precisa analisar a natureza quantitativa, ordenada ou diferencial dos dados a serem transcritos, selecionando a variável visual correspondente. Deste modo, o processo de escolha dos signos condiciona-se pelas propriedades limitadas das variáveis visuais, permitindo assim uma leitura de conjunto - mapas para ver - o principal objetivo da representação gráfica (Vasconcellos, 1993: 35). 
Figura 35 - As variáveis visuais segundo Bertin e MacEachren

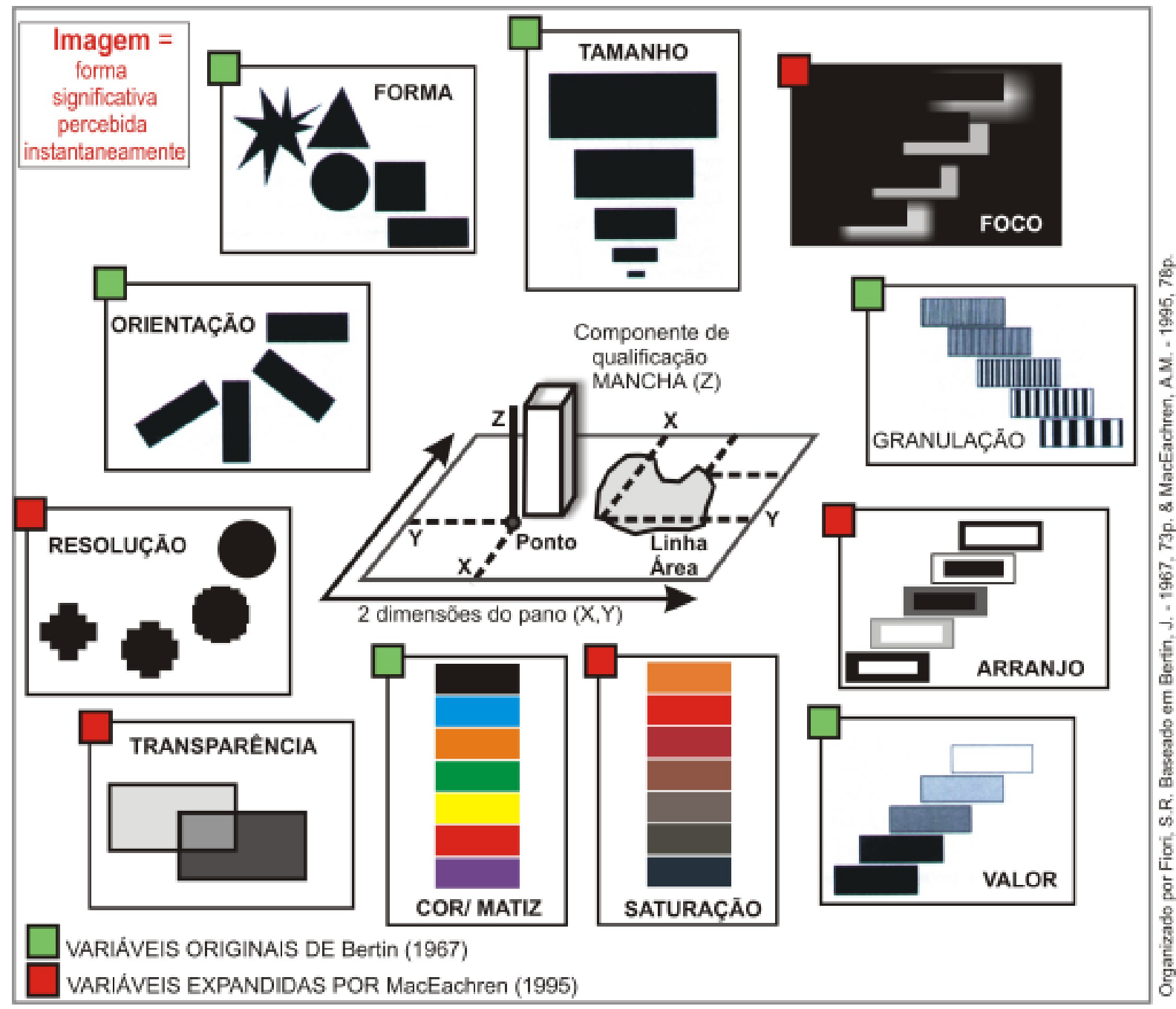

Bertin (1983: 78) ratifica que a:

liberdade não existe em cartografia! É por esta razão que a cartografia é uma linguagem universal, uma linguagem finita e rigorosa que tem apenas UMA ORDEM VISUAL. Adotar qualquer convenção, outra que não imposta pela fisiologia é afirmar que 2 é igual a $5 \ldots$ é ser cego!

Aceita-se somente a normalização de signos convencionais, procurando economizar tempo a fim de obter rápida compreensão da mensagem. Para isso, conta-se inicialmente com a lei básica da representação gráfica (graphique), que objetiva não destruir as relações entre os elementos representados, além da lei de memorização, proporcional ao número de repetições da convenção, sendo inversamente proporcional ao número de convenções (Bertin: 1983: 78) - Figura 36.

Dacey (1978) finaliza que a linguagem das informações geográficas e dos modelos cartográficos tradicionalmente se caracteriza pela linguagem dos símbolos (usualmente abstratos, fisiológicos) de maneira multidirecional, necessitando, assim, 
de uma estrutura organizada com conceitos de ordem. Essa estrutura faz a junção dos símbolos entre dois mapas ou entre os símbolos de vários mapas de um modelo cartográfico, e é denominada de linguagem bidimensional.

\section{Figura 36 - Exemplos de variáveis visuais}

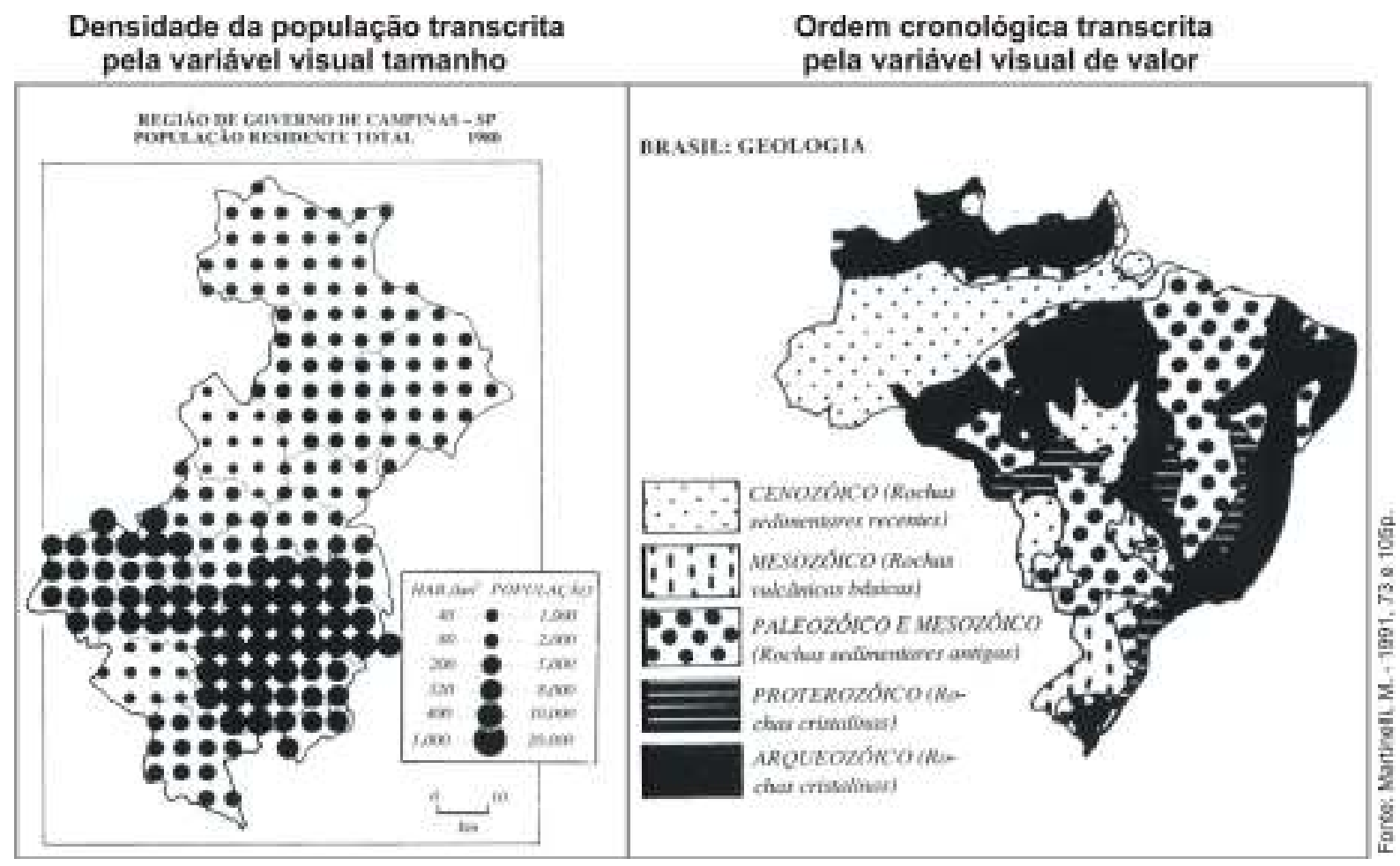

Já o esquema de comunicação polissêmico caracteriza-se por uma constante ambigüidade. Objetiva definir conjuntos ou conceitos levando em consideração uma infinidade de outros conjuntos e signos, ou seja, é um problema sem solução. Mesmo assim, buscam-se imagens possíveis, aproximações, que são conseguidas pela limitação do contexto temporal, espacial e conceitual em que o receptor se insere para receber um sinal. Por exemplo: os sinais de trânsito são polissêmicos, não são sinais universais, pois, para decodificá-los, precisa-se conhecer o Código Nacional de Trânsito (Bertin, 1996). Tais símbolos dependem do esquema polissêmico: "Emissor (cartógrafo) $\leftrightarrow$ Código (mensagem cartográfica) $\leftrightarrow$ Receptor (usuário do mapa)" fundamentos da teoria da comunicação, que é criticada por Bertin (1996) exatamente por seu conteúdo polissêmico. Segundo o autor, nessa teoria é necessário que o emissor leve em conta o conhecimento do receptor para limitar a ambigüidade da comunicação. O objetivo da comunicação será pleno quando o receptor identificar o conceito.

Assim, o emissor é livre para escolher os signos do mapa que elabora, devendo encontrar o caminho mais eficaz em sua comunicação com o receptor, logo o produtor deve levar em consideração: 
a arte de imaginar o conhecimento de todo e qualquer receptor, isto é, o universo de associações significante-significado onde persiste, em geral, um hábito, do qual ele lançará mão em dada situação. A solução, a menos duvidosa, é a que estabelece uma convenção. E azarem-se aqueles que a desconheçam (Bertin, 1996).

Vasconcellos (1993: 34) constata haver várias divergências ao se compararem os pontos de vista dos teóricos da comunicação e da semiologia gráfica, especialmente ao se tratar da linguagem gráfica. Saussure, por exemplo, define a linguagem com um sistema estruturado de signos, ou seja, o signo lingüístico engloba o significado (conceito) e o significante (imagem acústica), sendo caracterizado por dois princípios fundamentais: a arbitrariedade (convenção) e a linearidade (a, b, c... 1, 2, 3...). Já Bertin, partindo desses mesmos conceitos, formula a linguagem gráfica como um sistema de signos gráficos - variáveis visuais - com significado (conceito) e significante (imagem gráfica), contudo o signo gráfico não é arbitrário (convencional) nem linear $(X, Y, Z)$ e, por isso, a representação gráfica é monossêmica.

As principais divergências entre os teóricos da comunicação e da semiologia gráfica se referem aos fatores econômicos e sociais, à experiência (fundamentalmente em relação ao uso dos mapas) e à possibilidade ou mesmo necessidade de normalizar os signos cartográficos - no sentido de torná-los convencionais - incluindo aqui, a utilização de símbolos (Vasconcellos, 1993: 36).

Ao pensar em mapas para o turismo, o intuito é continuar trabalhando um possível sincretismo entre as duas vertentes teóricas: a da comunicação e a da linguagem gráfica. A pesquisa empírica em Fiori (1999) e outros trabalhos práticos ${ }^{24}$ permitiram verificar que as variáveis visuais podem ser adaptadas, reestruturadas, por exemplo, utilizando-se a variável forma em vez da variável cor (ou as duas juntas) para representar a topografia. O resultado foi uma maior eficácia do produto. Entender o processo abstrativo de olhar a cor e imaginar a altitude não é tão simples assim para o leigo na leitura de mapas; logo, ele precisa, sim, ser iniciado nesta semântica.

Por outro lado, é possível trabalhar a pictografia em mapas turísticos, diminuindo consideravelmente a polissemia. Além disso, este tipo de representação teve uma aceitação muito maior do público leigo quando comparado ao mapa feito na versão convencional (Fiori, 2003: 187).

\footnotetext{
${ }^{24}$ Realização de cursos e oficinas com alunos e, principalmente, professores da rede pública, trabalhando conteúdos referentes à cartografia temática e ao turismo. Inicialmente as atividades ocorriam por meio de uma parceria entre o LEMADI (Laboratório de Ensino e Material Didático), a AVT (Academia de Viagens e Turismo) e o IAP (Instituto de Academias Profissionalizantes). Posteriormente, fui convidado a participar do Projeto Caminhos do Futuro - parceria do Ministério do Turismo com o IAP, a AVT e o Núcleo de Turismo da Universidade de São Paulo - onde continuei realizando oficinas. A oportunidade possibilitou aplicar alguns pontos de minha pesquisa em cidades de 16 estados brasileiros (Caminhos do futuro, 2007).
} 


\section{6 - O processo perceptivo: recolhendo imagens e elaborando representações}

Grosso modo, pode-se definir a imagem como um ato fisiológico, ou seja: surge de um feixe de luz que entra pelo olho e chega até a retina, sendo capaz de se adaptar a graus de iluminação e diferenças de intensidade de radiação da luz a partir dos diferentes pontos do campo visual (Keates, 1982: 15). Entretanto, agregam-se a esse ato perceptivo implicações mais profundas envolvendo, por exemplo, valores sociais e culturais, que imprimirão percepções e impressões à imagem, tornando-a afetiva, imprecisa e estabelecida em campo semântico não-delimitado (Coelho, 1993: 21).

Beni (1998: 220) ratifica o que foi dito acima, afirmado que a percepção é um processo pelo qual o indivíduo apreende a realidade pelos sentidos, selecionando, organizando e interpretando a informação. Há uma interação entre o estímulo do entorno físico (fisiológico) e o estímulo social (experiências já vividas e armazenadas na memória, com as do presente), criando assim quadros do mundo e fazendo da percepção um contínuo fluxo de idéias.

O dia-a-dia ajuda efetivamente na multiplicação das imagens presentes na vida de um indivíduo, facilitando a criação de um "museu cotidiano". Por exemplo: em um quarto, pode-se encontrar pregado na parede um pôster com uma reprodução de Matisse, lembranças de viagens, recortes de jornal, um mapa-mundi, o desenho de um amigo, enfim, um patrimônio próprio que é renovado conforme flui a vida (Canclini, 2003: 199).

Os significados dessas imagens resultam em grande parte da experiência e do saber que a pessoa que a contempla adquiriu anteriormente. Portanto, a imagem visual não é uma simples representação da realidade, mas sim um sistema simbólico (Samain, 1988). Conseqüentemente, o estudo da imagem é fundamental para o entendimento dos múltiplos pontos de vista que os homens estabelecem a respeito de si mesmos e dos outros, de seus comportamentos, pensamentos, emoções em diferentes experiências de tempo e espaço. Trata-se, agora, de tomar a imagem como objeto, procurando compreender o lugar dos ícones como parte constitutiva dos sistemas simbólicos, estendendo a eles as mesmas preocupações teóricas e metodológicas presentes no estudo das representações sociais (Porto Alegre, 1988).

Rocha-Trindade (1988) afirma que, em algumas disciplinas, a imagem se constitui como apoio temático, caso da geometria, do desenho técnico, da pintura, da topologia, etc. Em outros casos, a imagem real é um componente indispensável para a compreensão e a integração do objeto de estudo: os exemplos da biologia, da geografia, da história da arte ou da medicina aparecem como imediatos.

Os artistas - e também os cartógrafos - têm dado as maiores contribuições para o desenvolvimento das iconografias nacionais, por documentarem períodos e lugares, projetarem percepções e os valores da sociedade patrocinadora. Pontue-se que alguns artistas são conscientes das implicações culturais e nacionais de seu trabalho. 
O resultado é que as figuras de lugares, pessoas e eventos têm tornado parte da identidade coletiva (Osborne, 1994).

Já o marketing ligado ao comportamento do consumidor-turista empenha-se em projetar imagens e intenções favoráveis de destinações turísticas, objetivando promovê-las aos visitantes (Mackay \& Fesenmaier, 2000). Uma perspectiva do imaginário é valiosa para entender o impacto das mensagens publicitárias. As ilustrações, fotografias, filmes não somente divulgam a localidade, mas podem ainda comunicar atributos, características, conceitos, valores e idéias. Os estudos nesta linha sugerem que tanto as variáveis pessoais (população, cultura e familiaridade, etc.), quanto os atributos visuais (características físicas) são relevantes na avaliação de uma imagem (Mackay, Fesenmaier, 1997).

Segundo Souza (1992: 43-44), o acervo de imagens de uma pessoa só tende a crescer. É um processo contínuo e cumulativo ao longo de sua vida. Tais imagens podem ser conscientes e inconscientes, da primeira infância, mais próximas do presente, do ser amado, subjetivas, entre outras. E é exatamente esse conjunto de imagens que estabelece a ponte entre do mundo interior, subjetivo do indivíduo, e a realidade objetiva que o cerca e sobre a qual ele atua. Sendo assim, o designer deve procurar, entre todas estas imagens, aquelas objetivas ${ }^{25}$, capazes de processar a comunicação entre as mentes humanas por serem imagens comuns a uma grande quantidade de pessoas. A autora então elabora as seguintes questões: Que formas e/ou cores...

... podem intencionalmente comunicar certa informação, sensação ou ordem a um determinado conjunto de pessoas que integram o público receptor da mensagem visual emitida? Que imagem pode sensibilizar positivamente o espectador, fazendo com que este reaja da forma esperada?

Até porque, a polissemia é inerente à imagem, que tem como característica uma "cadeia flutuante" de significados entre a linguagem literal denotada e a linguagem simbólica conotada (figura 37). Como reação à incompreensão, as sociedades produzem diversas técnicas destinadas a fixar tal cadeia de significados (Barthes, 1990: 32).

Souza (1992: 45) detalha melhor o problema da função comunicativa atribuída às imagens objetivas do design gráfico, dividindo-as em natureza:

$\checkmark$ Informativa - onde a mensagem visual intenciona mudar a forma de pensar ou sentir do receptor e/ou grupo de receptores, aumentando-lhes o estado de conhecimentos, de habilidades;

\footnotetext{
${ }^{25}$ A busca da objetividade na comunicação visual faz com que o produtor pesquise - incessantemente - o universo de imagens de cada indivíduo extraindo somente aquelas que são comuns a todos num dado momento e local, independentemente do gosto pessoal do seu criador (Souza, 1992: 44).
} 
$\checkmark$ Persuasiva - onde a comunicação visual pretende modificar as atitudes dos receptores, intensificando a preferência ou valor por um objeto, destinação.

Figura 37 - "Captando" a imagem

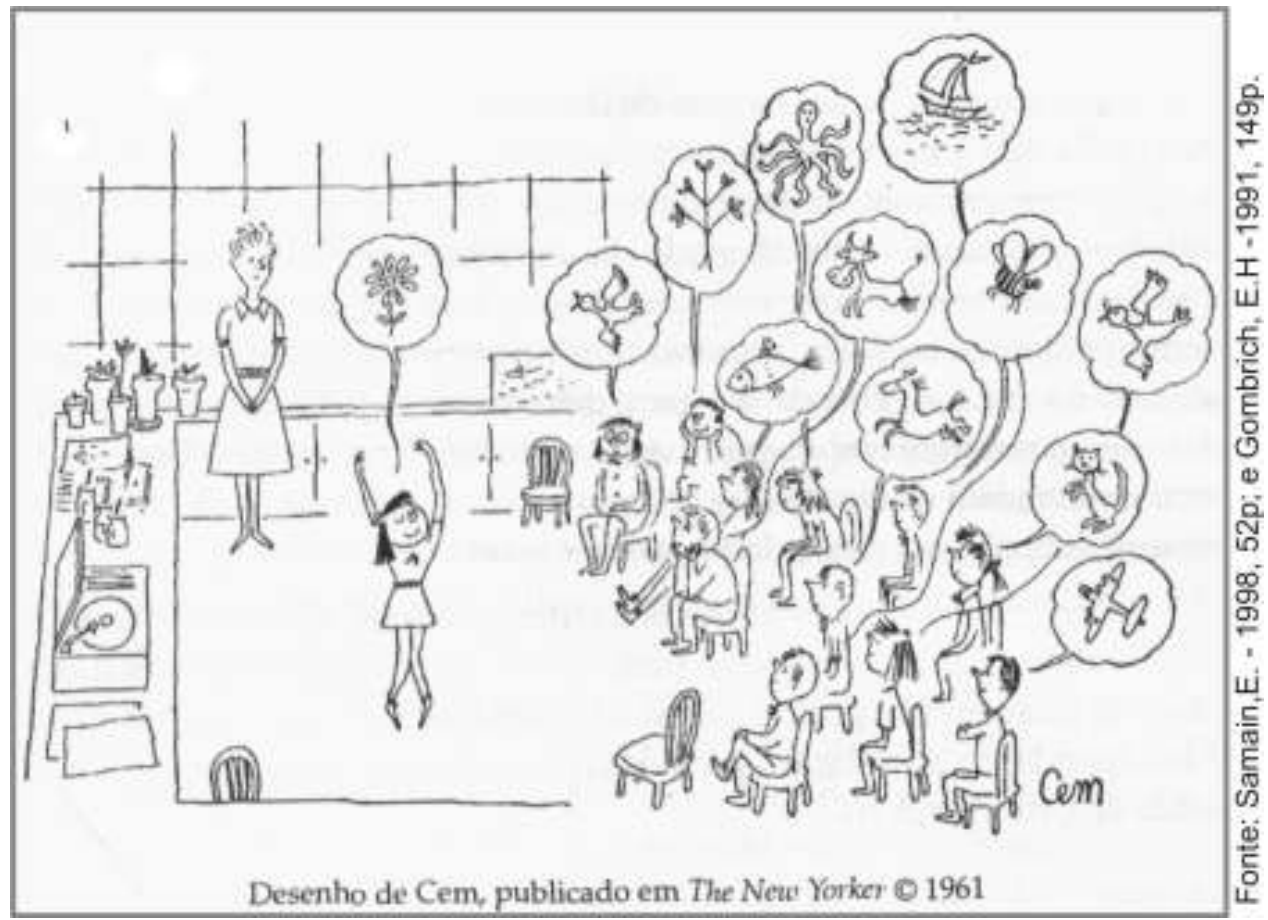

Nessas duas naturezas, a comunicação visual cumpre sua finalidade comunicativa, atingindo de maneira concreta o olhar aleatório e nem sempre atento do usuário, levando-o a reagir positivamente em relação à intenção original da mensagem concebida: compre o mapa, escolha esta destinação, entenda este conceito, preste atenção neste texto, use o produto desta maneira, etc.

Desse modo, os mapas turísticos, além de prestarem serviços de orientação e acessibilidade aos destinos turísticos, podem ir mais longe, auxiliando na projeção de imagens relacionadas à promoção turística. Segundo a Internationale Tourismus Börse (1987), os materiais ligados à comercialização do turismo estão preponderantemente relacionados a prospectos e catálogos, pôsteres, jornais, guias, livros de geografia regional e de viagens. Entre todos esses materiais, os prospectos e catálogos de mapas e para-mapas são os mais importantes. Estes últimos se dividem em produtos que vão desde esboços ("mapas" sem preocupação cartográfica), àqueles ligados à rede de transporte (rodovia, ferrovia, metrô) e à orientação com base topográfica (trekking e outros esportes de aventura), até aqueles mapas especiais relacionados a rotas (maratonas, ciclismo, cultural, vinhedos), cavernas, compras, etc.

Por fim, o artigo da Tourismus Börse (1987) discorre sobre os denominados mapas 
panorâmicos, em visão oblíqua ou pictórica, ou seja, mapas que fazem uso da imagem da localidade e são concebidos em perspectiva geral ${ }^{26}$, os quais informam fundamentalmente sobre as atividades e atrações da destinação. Esse tipo de mapa - que será desenvolvido nesta pesquisa - é mais bem concebido por artistas gráficos do que por cartógrafos, pois os últimos têm dificuldade em negligenciar a precisão em favor da atratividade. Todavia, o futuro da cartografia turística tenderá a um aumento cada vez maior na demanda do tipo de produto cartográfico (panorâmicos e com símbolos pictóricos), em detrimento daqueles com maior precisão e símbolos abstratos. Tal processo de diferenciação e especialização da cartografia vem ocorrendo devido à crescente diferenciação dos grupos de turistas e sua demanda por serviços especiais.

Assim, para se iniciar o processo de desenvolvimento dos mapas pictóricos turísticos, o primeiro estágio para o produtor é compreender, captar e levantar a grande variedade de imagens "oferecidas" pela destinação. Posteriormente, essas imagens são selecionadas e utilizadas em detrimento do objetivo do produto, estabelecido pelo empreendedor. Para isso, recorre-se à teoria push ${ }^{27}$ e pull ${ }^{28}$ trabalhada por Chon (1989) e Goossens (2000), os quais afirmam que a construção das imagens primárias resulta do contexto cultural na associação e preferência da destinação. Quando o indivíduo está motivado a viajar, vêm a sua mente imagens iniciais - mapas mentais - sobre a destinação pensada. Isso faz com que ele selecione certos destinos como possíveis escolhas. A motivação para viajar e o processo de construção das imagens primárias começa quando o indivíduo toma consciência de certas necessidades e percebe que tais destinações podem ter a capacidade para satisfazer suas necessidades (Chon, 1989).

Em seu estudo, Lubbe (1988) exemplifica que as imagens primárias são concebidas em diferentes perspectivas, contudo, foca-se na cultura. A autora apresenta e compara dois tipos distintos de visão: os sauditas (moradores locais da Arábia Saudita) e os visitantes (moradores não-nativos do país). Entre vários resultados de sua pesquisa, Lubbe apresenta diferenças significativas relacionadas à motivação e seleção do destino, pois estes dois públicos constroem suas imagens primárias baseadas em diferentes fatores push e pull. A principal diferença percebida pelos agentes de viagem sauditas é que os não-nativos (e particularmente os ocidentais) são um público mais aventureiro, desejam ver, experimentar novos lugares, com menor familiaridade. Em contrapartida, os sauditas são geralmente motivados a

${ }^{26}$ É um novo estilo cartográfico, que consiste em uma adaptação moderna do antigo estilo tridimensional. A visão oblíqua favorece uma rápida compreensão da geografia e suas várias "texturas" - grafismo da paisagem - (bairros, monumentos e edifícios significativos e de interesse) resultando em uma fácil localização (Guia T de Barcelona, 1992).

${ }^{27}$ Está relacionado aos serviços de lazer que geram sentimentos de prazer rápido, que emocionam e por fim, motivam. Qualidades díspares como excitação e relaxamento são imprescindíveis aos fatores push (Chon, 1989).

${ }^{28}$ Está relacionada aos fatores onde a familiaridade, a similaridade de cultura, de tradição ou da alimentação é maior (Chon, 1989). 
procurarem viagens experimentais em destinos onde se sintam confortáveis e onde a língua, cultura e comida também sejam familiares.

Deste modo, a campanha de divulgação da localidade turística deve ser idealizada de formas diferentes, respeitando as visões distintas dos públicos. No caso dos sauditas, que tendem a construir as imagens primárias baseadas em fatores familiares (pull), a estratégia da mensagem enfatiza aquelas atrações que relatam similaridades na cultura, tradição ou comida. Mas e quanto àqueles visitantes que estão à procura de emoções fortes e do prazer rápido (fatores push)?

Segundo Goossens (2000), o que conectaria dois perfis de turistas tão distintos é o conceito da emoção. Os consumidores, e em particular os turistas, são "empurrados" por suas necessidades (emocionais) e "puxados" (emocionalmente) pelos benefícios dos serviços de lazer. Portanto, as necessidades emocionais e de experimentação ${ }^{29}$ são relevantes na procura do prazer e no comportamento de escolha da destinação. Isto faz com que o lazer seja uma experiência positiva e subjetiva, acompanhada de satisfatórios e agradáveis humores, emoções e sentimentos.

Wolfgram (1994: 7) complementa que, para gerar uma resposta emocional, é preciso estimular os sentidos apropriados. Até porque,

o conteúdo intelectual é importante em uma troca de dados, mas a comunicação verdadeira requer uma troca emocional.(...) $\mathrm{E}$ quanto mais você conseguir atingir as emoções da sua platéia, mais eficaz será sua comunicação (Wolfgram, 1994: $\mathrm{XXI})$.

As emoções sinalizam um estado de necessidade que prepara certas tendências de ação no indivíduo. Em teoria, existem oito tipos de emoções essenciais a qualquer pessoa e cultura: alegria, aprovação, medo, surpresa, tristeza, irritação, aborrecimento e expectativa (Gnoth, Zins, Lengmueller \& Boshoff, 2000). Goossens (2000) assinala que a eficácia da "informação emocional" no estímulo promocional pode ser testada e mensurada em três dimensões (que compõem cada emoção):

$\checkmark$ O prazer - descreve sentimentos de felicidade, satisfação, contentamento, agrado.

$\checkmark$ O estímulo e/ou apreciação - representa sentimentos de excitação, animação/ alegria, inteligência/ vivacidade ou surpresa. A pessoa reage ao estímulo baseada em suas primeiras experiências emocionais e sociais. As imagens personalizadas são produtoras do estímulo e estão associadas ao uso do produto. A intensidade do afeto pode ser descrita pela diferença na intensidade das respostas emocionais dadas em níveis de estímulo do afeto.

\footnotetext{
${ }^{29}$ Os processos de experimentação, tais como a imaginação, devaneio, emoções e desejos possuem um importante papel no consumo hedonista (Goossens, 2000).
} 
$\checkmark$ A dominância - refere-se aos sentimentos de domínio, competência, poder e capacidade. Estudos sobre as emoções relacionadas ao consumo alertam que é preciso pensar na expressividade dos produtos, pois a partir do modo de escolha afetiva quanto mais expressivo o produto, maior será a probabilidade de causar estímulo e/ou apreciação do usuário (Mittal apud Goossens, 2000).

Goossens, 2000 complementa que os estímulos, mas também as informações, trazem fortes experiências emocionais e intenções de comportamento. Já as emoções vivenciadas pelos turistas na destinação referem-se às imagens multisensoriais, fantasias, emoções vivenciadas.

Tais emoções podem ser operacionalizadas por experiências subjetivas ${ }^{30}$, avaliação afetiva e relatos de sentimentos sobre os produtos de lazer e atrações turísticas. No entanto, a motivação traz intenções comportamentais em direção às atrações turísticas (Goossens, 2000).

Some-se ainda que as emoções do visitante são realmente obtidas durante o período de consumo, quando sinais afetivos na memória integram-se aos sinais de satisfação, gerando assim a possibilidade de julgamento, escolha (Gnoth, Zins, Lengmueller \& Boshoff, 2000).

Um modelo testado por Benkenstein, Yavas e Forberger (2003) considerou o contexto do zoológico de Rostock na Alemanha. O resultado proveniente da satisfação dos consumidores em relação aos serviços de lazer revelou fatores cognitivos ${ }^{31} \mathrm{e}$ afetivos ${ }^{32}$. Entretanto, os fatores afetivos tiveram um maior impacto se comparados aos cognitivos. Soma-se ainda, que as informações visuais e vivas ${ }^{33}$ de uma destinação quando vinculadas ao prazer fazem aumentar o envolvimento do consumidor e sua capacidade para perceber mais diferenças no fornecimento no

\footnotetext{
${ }^{30}$ A questão da grande subjetividade da imagem de uma destinação turística é resultado da existência dos diferentes tipos de públicos: residentes, vendedores, turistas, planejadores, etc., somada à intangibilidade do serviço turístico, que depende de uma visita e/ou gosto pessoal em relação a uma destinação. Portanto, são as percepções que motivam os consumidores a viajar (Gallarza, Saura \& Garcia, 2002).

${ }^{31}$ Referem-se às representações mentais, sendo um processo lento, onde ocorre o conhecimento que se tem de uma classe de objetos ou de fenômenos que possuem uma característica comum, apoiando-se no concreto. Por exemplo: para saber o que é um homem, nada melhor que vê-lo (fisicamente) ou por meio de uma foto/desenho, pois assim se perceberá que existem homens de tamanhos e cores diferentes, mas que não deixaram de ser homens, pois todos possuem características comuns; por exemplo, todos têm duas pernas e variáveis a cor dos olhos (Falcão, 1988).

${ }^{32}$ É freqüentemente descrito por sentimentos intensos, associado a um estímulo específico. Refere-se ao impulso, sentimentos e instintos (Goossens, 2000). Todos os indivíduos têm sentimentos, valores, atitudes, emoções, etc., em relação a estímulos ambientais. Por exemplo: um indivíduo sente-se bem ao ver seu quarto limpo, arrumado, porque ele aprendeu a gostar da limpeza: a sujeira para ele é vista de forma desprazerosa. Dessa forma, também pode se apresentar graus de afetividade em relação à democracia, ao gosto pelo estudo, a ideais de vida, ao tipo de destino das férias e assim por diante (Falcão, 1988).

${ }^{33}$ A informação pode ser descrita como viva quando atrai, mantém a atenção e excita a imaginação de forma emocionalmente interessante, concreta e desencadeadora de imagens. Está relacionada a uma aproximação das vias sensoriais, temporais ou espaciais (Goossens, 2000).
} 
serviço. Os autores complementam que a natureza dos componentes cognitivos e emocionais interage a partir de elementos:

$\checkmark$ Tangíveis - a satisfação do consumidor é baseada em fatores cognitivos, visuais, como, por exemplo, o meio físico, serviços (playground, restaurantes). O usuário toma consciência da comunicação recebida, que é concreta.

$\checkmark$ Intangíveis - a satisfação do consumidor é baseada em fatores emocionais. $O$ usuário expressa seus interesses, desejos, gostos e preferências por conhecimentos adquiridos por meio da comunicação.

Arrowsmith \& Ntuwah (2002) acrescentam que banheiros, lugares de compras, quiosques, centros de informação, pistas para caminhada, terrenos para piquenique e camping são considerados infra-estrutura de apoio, fundamental às atrações turísticas. Mesmo não atuando como atração ao destino, pesam na decisão de uma futura visita.

Beni (1998: 39) complementa que os bens subjetivos, de difícil valoração ou imateriais não-apropriáveis, por exemplo, hoje o ar puro, o mar, as belezas naturais estão adquirindo altos valores econômicos. Isso acontece em contraposição aos conglomerados humanos sempre crescentes, ao estresse, etc., buscando assim, um estilo de vida natural. $\mathrm{O}$ autor divide os bens turísticos em:

$\checkmark$ Materiais - monumentos, museus, galerias de arte, praias e outros; e Imateriais - clima, paisagem e outros;

$\checkmark$ Imóveis - terrenos, casas, hotéis, museus, galerias e outros; e Móveis produtos gastronômicos, artísticos e artesanais;

$\checkmark$ Duráveis - artesanais, e Perecíveis - produtos gastronômicos;

$\checkmark$ De consumo - bens que satisfaçam diretamente as necessidades dos turistas; e De capital - os que são utilizados para a produção dos bens;

$\checkmark$ Básicos, complementares e interdependentes;

$\checkmark$ Naturais ou artificiais.

Já os serviços turísticos, voltados à satisfação das motivações, necessidades e preferências do turista classificam-se em (Beni: 1998: 40):

$\checkmark$ Receptivos - ligados às atividades hoteleiras e extra-hoteleiras,

$\checkmark$ De alimentação;

$\checkmark$ De transporte - da residência à destinação turística e no próprio centro receptor;

$\checkmark$ Públicos - administração turística, postos de informação, funcionários de 
restaurantes, parques, etc;

$\checkmark$ De recreação e entretenimento na área receptora.

Sirgy \& Su (2000) ressaltam, pela longa tradição em pesquisas com consumidores, que as idéias que os turistas têm sobre uma destinação são usadas como uma forma de referência cognitiva na avaliação da memória dos símbolos da localidade. Essas lembranças dos produtos simbólicos referem-se a imagens estereotipadas ${ }^{34}$ - não controláveis pelos planejadores do turismo - dos usuários sobre o destino turístico, como por exemplo: está na moda, é excitante, é moderno, é novo, é ultrapassado, etc.

Os turistas ainda podem avaliar as destinações baseadas em atributos funcionais ou utilitários, denominados de símbolos controláveis pelos administradores do turismo, relacionados aos aspectos estéticos da destinação (produto), preço da viagem (preço), localização (acessibilidade) e à promoção do destino (propaganda) (Sirgy \& Su, 2000). Contudo, as imagens da destinação turística são um fator decisivo na escolha da viagem pelo turista. A atratividade de um destino é baseada no potencial das motivações e necessidades compostas por várias atrações e seus atributos ${ }^{35}$ característicos, responsáveis pela impressão da localidade pelo turista. Um indivíduo motivado a viajar, inicialmente seleciona certas destinações como possíveis escolhas.

O modelo conceitual estruturado na figura 38 expõe as preocupações prévias do grupo-alvo a uma política mercadológica fundamentada na motivação do turista em viajar, tendo como apoio um material de informação promocional. Neste contexto, evidenciam-se respostas quanto a imagens mentais e emocionais dos turistas.

Mackay \& Fesenmaier (1997), Lubbe (1998) e Gallarza, Saura \& Garcia (2002) balizam ainda a imagem da localidade em três níveis de variáveis:

$\checkmark$ Orgânica - é formada por meio das percepções do indivíduo. A mensuração se dá baseada no que se aprende de uma localidade a partir da primeira idade.

$\checkmark$ Induzida - é resultado de uma promoção da localidade como um destino turístico.

$\checkmark$ Complexa - quando o turista tem uma experiência direta com a destinação.

Portanto, a oferta da localidade e seus respectivos atributos apresentam diferenças relacionadas ao significado, ao número e a importância dos elementos que compõem a localidade. Assim, a promoção do local poderá ser percebida a partir de um trabalho de destaque ou exclusão de certos elementos a ela vinculados (Mackay \& Fesenmaier, 1997). Brown, Emmer \& Worm (2001) complementam que a viagem de

\footnotetext{
${ }^{34}$ Apresenta duas formas positivas de aproveitamento: atua como atrativo turístico e revaloriza a cultura local (Norrild, 2001).

${ }^{35}$ Refere-se a atratividade vem da complexidade do espaço, como por exemplo: suavidade, excitação, conhecido/desconhecido e natural/antropomorfizado, etc. (Mackay \& Fesenmaier, 2000).
} 
férias é planejada com base nas informações disponíveis da localidade turística. Logo, quanto mais direcionada for a informação aos clientes potenciais, melhores serão os resultados da divulgação.

Figura 38 - Motivações para se viajar: fatores "push e pull"

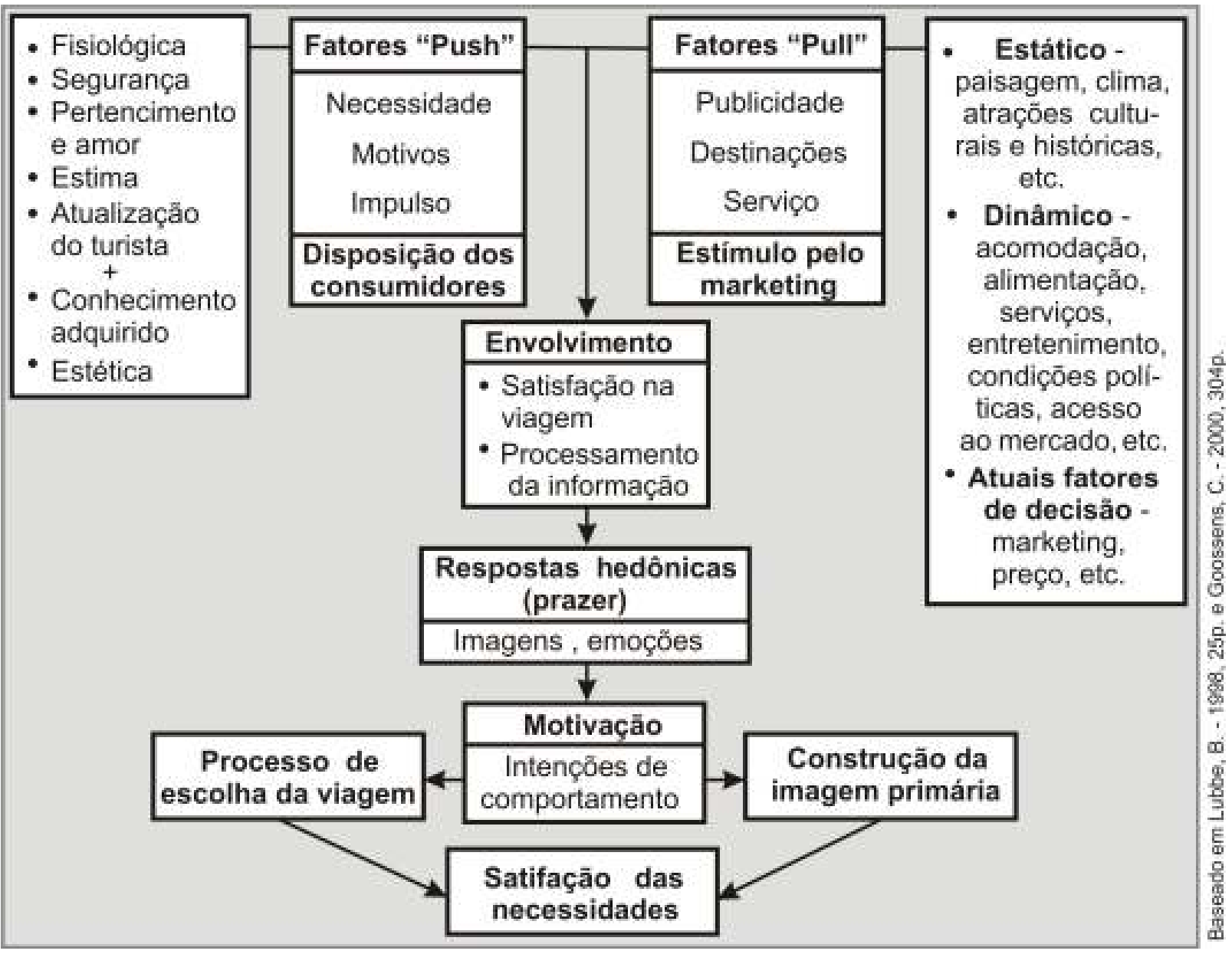

Por isso, o emissor da mensagem (no caso, o cartógrafo), deve estar muito consciente da imagem que quer comunicar e quais serão os receptores da imagem. Até porque ele funciona como um "porta-voz", por transmitir características culturais pertencentes a um grupo social (Norrild, 2001).

Goossens (2000) sugere que sejam dadas instruções claras quanto ao contexto que fará uso da imaginação. Considerando o processamento das informações turísticas e as necessidades relacionadas à visão de consumo, propõem-se duas situações distintas:

$\checkmark$ Imagens não-representativas - são formas de representação na qual o consumidor é envolvido em um baixo nível emocional. 
$\checkmark$ Imagens representativas - são formas de representação na qual o consumidor é altamente envolvido com a informação turística. É uma força que motiva o cognitivo-afetivo, mediando o comportamento do consumidor. Intensifica as respostas emocionais, de apreciação e intenções de comportamento dos consumidores, sendo interessante para os profissionais de marketing investigar quais fatores estimulam e desencadeiam as imagens mentais. Portanto, pode-se fornecer tanto materiais promocionais com um variado leque de propagandas (estímulos de informação: como slides, scripts, figuras, vídeos) quanto os atributos da destinação e seus serviços, trabalhando com as informações de respostas relacionadas às visões dos consumidores, imagens mentais, sentimentos, humores, experiências emocionais.

A partir do que foi exposto até aqui, passa-se a outra questão: como transformar as imagens percebidas na realidade em representações gráficas pictóricas eficazes. Carneiro (2001: 26; 29) afirma que pelos canais de percepção - os cinco sentidos básicos (visão, audição, tato, olfato e paladar) - o ser humano pode decodificar uma idéia e, a seguir, codificá-la novamente em uma nova estrutura - mensagem transmitindo finalmente a um receptor que a perceberá por meio de seus sentidos. $\mathrm{O}$ sucesso quanto à compreensão da mensagem virá desde que o repertório ${ }^{36}$ seja conhecido. A autora ressalta ainda, que grande desafio da comunicação é que...

... o emissor deverá produzir mensagens que possuam um repertório rico e conhecido o bastante para, em consonância com o meio apropriado, alcançar o maior número de receptores e o máximo de modificações (incluindo aquelas de comportamento).

Segundo Cabanellas (1976: 60), o processo perceptivo é dinâmico e arraigado ao comportamento humano, ou seja, desde que nasce e durante toda a sua vida, a pessoa recebe estímulos dos mais variados e, pela inteligência, concentra sua atenção, tem expectativas, relaciona emoções e impulsos ao que a rodeia. A percepção sofre ainda, a influência direta de fatores individuais tais como a aprendizagem, a experiência, a motivação e emoção. Esse processo ocorre graças à ação combinada de três unidades funcionais do cérebro (Cabanellas, 1976), onde é necessário que o "perceptor":

$\checkmark$ Esteja exposto e disposto (é vital) a perceber a informação;

$\checkmark$ Realize uma análise e uma síntese da informação, sendo esse um processo inteligente no qual detecta, discrimina e ordena os estímulos;

\footnotetext{
${ }^{36}$ São coleções, compilações de itens de mesma natureza que, reunidos, conformam um conjunto (Carneiro, 2001:8). Pode-se entender como um conjunto ou estoque de símbolos conhecidos (uma espécie de vocabulário) utilizados por um ou mais indivíduos. (...) Quanto mais rico for o repertório da mensagem e o número de seus elementos, maior será o seu alcance, ainda que não existam repertórios de extensões idênticas, em virtude das diferentes experiências pessoais (Carneiro, 2001: 26-27).
} 
$\checkmark$ Controle seus movimentos oculares de busca. Isso faz com que o exercício da percepção ocorra de um modo ativo, pois os olhos realizam uma espécie de varredura visual. Explicando melhor, o observador sem que se dê conta, em um lance de visão pode registrar, passear por algo que está percebendo e, nesse acontecido, pára e recolhe os elementos que o são importantes.

Em qualquer uma das três unidades funcionais do cérebro, o observador sempre tem uma intenção em sua maneira de perceber, pois vê o que o interessa, o assombra, Ihe agrada. O passo seguinte é identificar, acomodar e até - quem sabe - modificar tais percepções condicionadas pelas experiências anteriores. Neste momento se faz presente a importância da intervenção da inteligência, do estabelecimento de juízos, de comparações, que vão situando com maior objetividade o que é percebido.

Já Cressy e Laudadio (apud Beni: 1998: 220-221) identificam na percepção três características distintas, que consideram o interesse pela localidade ou serviço turístico:

$\checkmark$ Subjetividade - o observador vê o que se quer e ouve o que se deseja ouvir. Cada um dos segmentos da população é atraído por diferentes motivos, que são os que o impulsionam ao ato de compra.

$\checkmark$ Seletividade - o observador seleciona o que considera interessante e relevante. $O$ objeto não será percebido se não corresponder a uma motivação profunda. Os estímulos podem ser muitos, porém a percepção realiza o papel de filtro com relação à amplitude de informações recebidas. É importante ressaltar que as pessoas - mesmo aquelas mais sensíveis à publicidade de viagens - apreendem um número limitado de idéias de uma só vez; logo, estímulos demasiados podem causar confusão e o processo de decisão de compra será mais difícil para o consumidor.

$\checkmark$ Ponderação - o observador, depois de passar pelo processo de seleção, faz uma reavaliação do valor dos elementos que por ele foram escolhidos, sempre em função da sua personalidade. O conceito se enriquece de elementos já existentes na memória, atitudes e juízos do indivíduo-turista, assim como opiniões e recordações de outras pessoas. O objeto ganha então uma estrutura e um peso muito distintos do que realmente apresenta.

Numerosos estudos empíricos confirmam que a percepção tem papel fundamental no processo de criação das imagens que os indivíduos atribuem às destinações turísticas. Os principais modelos estatísticos, que avaliam o comportamento deste tipo de consumidor, relacionam a percepção como um dos fatores condicionantes de decisão na escolha do destino pelo visitante (Valdes, 1997).

Tuan (1980: 71) aponta vários estudos realizados acerca das diferenças de percepção diante dos valores ambientais. $O$ autor exemplifica que, em seu cotidiano, cada membro de uma família ocidental possui diferentes mapas mentais. Isto ocorre 
devido aos distintos e triviais caminhos de circulação de seus membros: percurso da escola, das compras, da empresa, do mercado. Ou mesmo por preferências, isto é, mesmo quando saem juntos às compras: o homem, a mulher, a criança, o adolescente, vão querer olhar lojas, locais e ter experiências diferentes. Eles poderão ir até de braço dado, porém não vão ver, escutar as mesmas coisas.

Pensando para a elaboração de um mapa temático para o turismo, cite-se Jackson, White \& Gronn (apud Arrowsmith \& Ntuwah, 2002) que, com base em questionários e outros fatores de análise sobre o comportamento e preferências dos turistas pontuam quatro perfis de personalidades:

$\checkmark$ O explorador: faz seu próprio horário e tempo. Adquire conhecimento pelo anfitrião. Não é organizado nem direcionado. Procura destinações remotas, isoladas, enriquecendo seu próprio conhecimento. Entusiasmado, procura desafios. Reservado e silencioso em grupos, evita multidão.

$\checkmark$ O aventureiro: viaja com amigos e não com turistas, desconhecidos, porém faz amizade com novas pessoas. Viagem não-organizada; valoriza atividades opcionais. Não é disciplinado, organizado. Evita aborrecimento e tédio pela parada em muitos lugares. Explora diferentes culturas, busca atividades estimulantes, tem senso de liberdade.

$\checkmark$ O orientado: sentido de isolamento. Viaja somente com a esposa ou amigos íntimos. Tudo é organizado para evitar preocupações, mal-entendidos ou gastos em demasia. Visita novamente as destinações favoritas. Foge dos problemas da vida procurando descontração e relaxamento. Gosta de luxo, e prefere a família aos estranhos.

$\checkmark$ O agrupador: viaja em grupo de amigos ou se junta a outros turistas em pacotes de viagem. Reúne-se com turistas e anfitriões, tanto homens como mulheres. Vai a destinações de sol, praia e vida noturna, onde estão outros turistas. Participa de muitas atividades, incluindo esportes e parques temáticos. Vai onde existam muitas pessoas e ação.

E é exatamente a estas nuances que o produtor-cartógrafo deve estar atento. Um bom mapa turístico deve perceber e captar (por vários trabalhos de campo e gabinete) imagens emotivas, interessantes, prazerosas e, por fim, motivadoras, ao maior número de pessoas, para depois representá-las no mapa.

Outro ponto observado diz respeito às atitudes e reações, inclusive estéticas, que se tem com relação ao meio ambiente estabelecido em um tempo e espaço. Tuan (1980: 81-85) aborda as mudanças de atitude em relação às montanhas. Na Antiguidade, eram vistas com aversão e terror pelos gregos, ou mistério e divindade pelos chineses. No século XVIII, por se tornarem acessíveis, perdem muito de sua 
aparência proibida e de medo, mistério. Posteriormente, os teóricos e médicos constataram que $o$ ar leve da montanha era bom para saúde e recuperação de doentes. Tem-se aí o primeiro mote utilizado pelo setor hoteleiro. Sanatórios, hotéis e infra-estrutura turística foram levados até as montanhas e obtiveram um êxito tão grande que, para os muito ricos, a Suíça era uma casa de repouso e um campo de esporte. Como resultado, a imagem em relação às montanhas em meados do século XIX é completamente inversa à de outros tempos.

Sendo assim, a partir do tripé: valores ambientais, condicionamento da percepção e principalmente da cultura, apresenta-se outro exemplo constituído pelo ambiente praia. Antigamente, as praias não eram valorizadas como hoje em dia. Muitas vezes os terrenos próximos ao mar tinham pouco interesse, valor. Até porque, nas sociedades ocidentais, o padrão de beleza era a pele clara, não-bronzeada, com corpos devidamente cobertos. Contudo hoje, em grande parte das culturas, a imagem associada à praia mudou radicalmente: corpos bronzeados estão relacionados à saúde, vigor, e as praias são um dos destinos mais procurados por turistas. Faça-se aqui uma ressalva a vários países do Oriente Médio e Extremo Oriente, onde a praia ainda continua a ser desvalorizada por seus nativos.

Um último tópico destacado por Tuan (1980: 236) refere-se a imagem que promove favoravelmente um destino, mas que pouco respeita a complexidade, a verdade local, deixando clara a preocupação de grupos que desejam chamar a atenção do público externo a localidade - para uma característica particular dela. Isso pode ocorrer a partir de um epíteto ou frase atraente, como: a Cidade luz (Paris), a Capital da vela (llhabela), Cidade maravilhosa (Rio de Janeiro), etc. Ou por uma cena ou fotografia de uma vista panorâmica de Nova Iorque, São Paulo, Ouro Preto, Brasília, e assim por diante. Entretanto, é bom ressaltar que essa imagem, para ser eficaz, deve estar fundamentada em alguns fatos. $O$ autor frisa que cidades dos Estados Unidos - 0 mesmo pensamento pode ser aplicado às cidades brasileiras - carecem de uma identidade visual, existindo, porém, algumas exceções. No entanto, mesmo as cidades menores vendem cartões postais, que valorizam aspectos de suas localidades, aceitos por favorecê-la, divulgando seus monumentos, parques, ruas principais, proporcionando um direciona-mento quanto ao imaginário local.

A figura 39 apresenta uma atividade aplicada a alunos, mas principalmente professores na oficina de cartografia oferecida pelo Projeto Caminhos do Futuro ${ }^{37}$. Recebem-se duas folhas: uma com o mapa da América do Sul e a outra com várias figuras que devem ser recortadas e coladas no mapa. O exemplo demonstra que uma "simples" imagem - uma representação icônica - é associada e incorporada a um espaço, possibilitando vários níveis perceptivos.

${ }^{37}$ Detalhes sobre o Projeto Caminhos do Futuro nas páginas 16 - 17. 
Figura 39 - Atividade da oficina do Projeto "Caminhos do Futuro":

o espaço e sua imagem
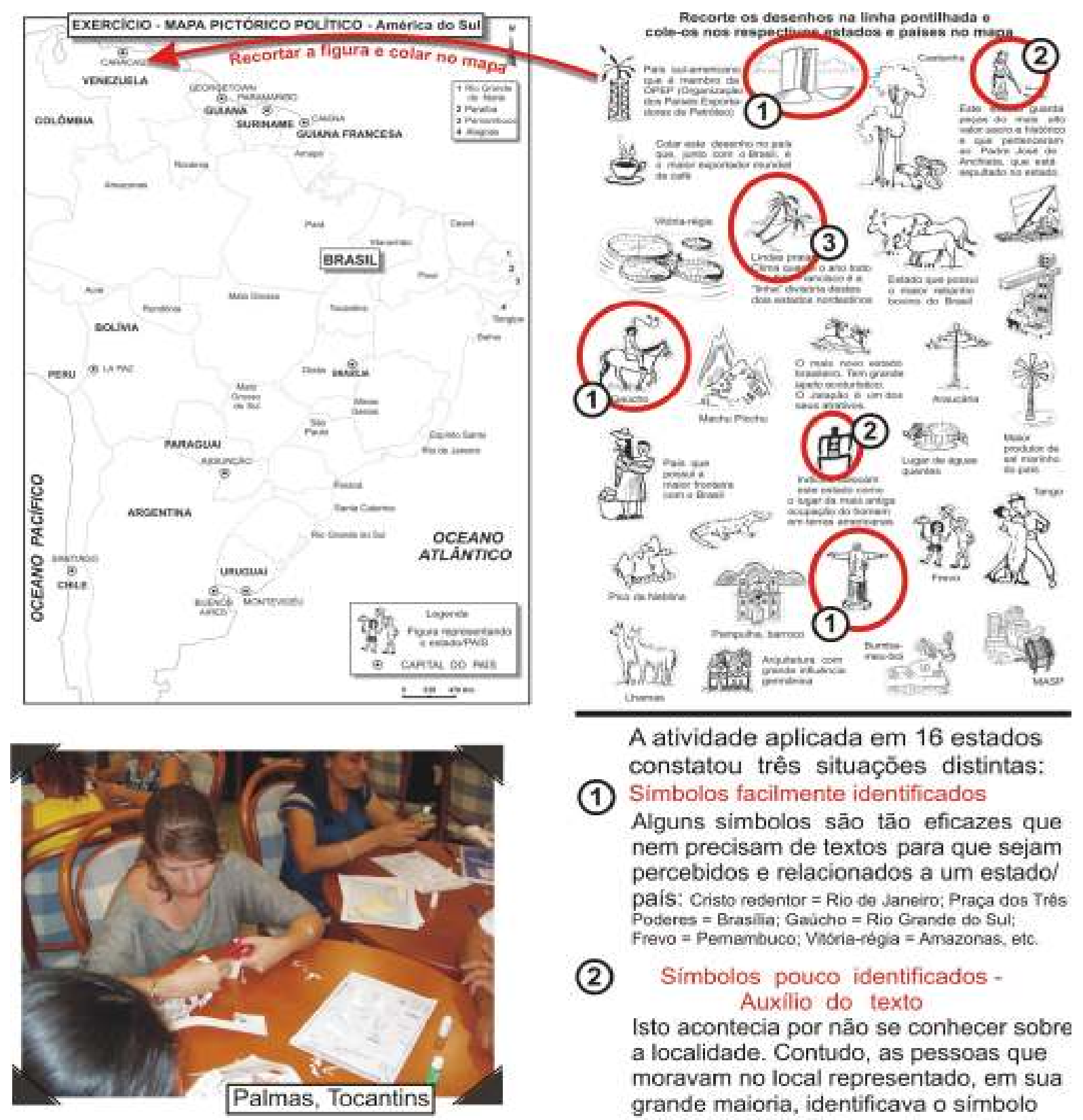

A atividade aplicada em 16 estados constatou três situaçōes distintas:

(1) Simbolos facilmente identificados Alguns simbolos sāo tāo eficazes que nem precisam de textos para que sejam percebidos e relacionados a um estado/ país: Cristo redentor $=$ Rio de vaneiro; Praca dos Tres Poderes = Brasilia; Gaùcho = Rio Grande do Sul; Frevo = Pemambuco; Vhorie-régia = Amazonas, etc.

Simbolos pouco identificados Auxilio do texto

Isto acontecia por não se conhecer sobre a localidade. Contudo, as pessoas que moravam no local representado, em sua grande maioria, identificava o simbolo "desconhecido": Pintura rupestre - estado onde esta a ocupacalo mais antiga do homem em terras. americanas = Piaul; Padre Anchieta - estado onde esta seu tùmulo $=$ Esplitito Santo.

(3) Estados questionam o porquê de não terem um simbolo expressivo

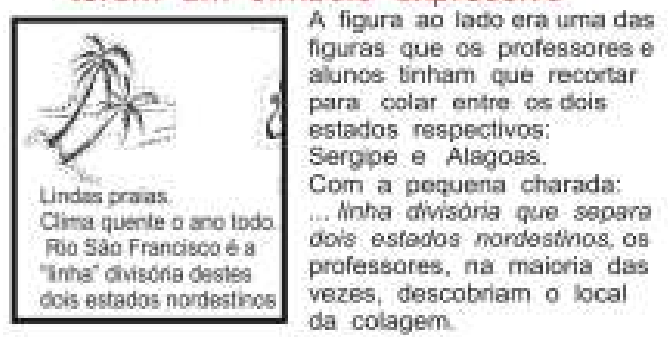

O questionamento maior foi aplicar esta mesma atividade nos estados representados com a figura - Sergipe e Alagoas. A discussão de um simbolo que melhor representasse seus estados era fervorosamente discutida. 
Deste modo, o meio ambiente pode não ser a causa direta da topofilia ${ }^{38}$, mas fornece estímulo sensorial que, ao agir como imagem percebida, dá forma às nossas alegrias e ideais (Tuan, 1980: 129). O autor prossegue afirmando que os estímulos sensoriais são potencialmente infinitos, por existirem valores subjetivos, individuais àquilo que a pessoa decide prestar atenção, valorizar. A época histórica e as respectivas forças culturais têm papel preponderante nessas escolhas.

Os mapas turísticos pictóricos trabalham exatamente o papel da paisagem como doadora de imagens topofilíticas, isto é, o coletor, produtor dessas imagens faz uso daqueles aspectos do meio ambiente que lhe inspiram respeito ou the prometem sustento e satisfação no contexto das finalidades pretendidas. Tuan (1980: 137) ratifica que essas imagens mudam à medida que as pessoas adquirem novos interesses e poder, porém continuam a surgir do meio ambiente.

Posto isso, Souza (1992: 97) divide a imagem em dois tipos básicos:

$\checkmark$ As que procedem do mundo natural, visível;

$\checkmark$ As geradas artificialmente pelas atividades de design - são como produtos culturais destinadas fundamentalmente à comunicação visual, povoando o mundo artificial da chamada iconosfera. Essas imagens abrangem desde os objetos dispostos no cotidiano (edifícios, roupas, ferramentas), até as imagens pictográficas, ideográficas, icônicas e sinaléticas.

Souza (1992:97-98) ainda esclarece que as imagens feitas pela humanidade são uma elaboração gráfica, cultural e povoam um mundo artificial denominado iconosfera, sendo produto do design gráfico. As imagens são todas aquelas desenhadas para serem apresentadas em formato digital ou impressas e capazes de serem decodificadas pelo maior número de pessoas. Quanto às técnicas de produção, podem ser feitas à mão - desenho, pintura, grafite - ou podem ser resultado de procedimentos mais complexos pertencentes ao domínio da tecnografia - fotografia, computação gráfica. As imagens ainda podem ser:

$\checkmark$ Físicas: são bidimensionais e tridimensionais (a dimensão tátil se associa de alguma maneira à dimensão óptica);

$\checkmark$ Temporais: são fixas (desenho, fotografia), seqüenciais (histórias em quadrinhos) e móveis (televisão, cinema, vídeo, animação).

\footnotetext{
${ }^{38}$ Associa sentimento ao lugar. Inclui todos os laços afetivos e emocionais que os seres humanos têm com o meio ambiente. Os laços diferem profundamente em intensidade, sutileza e modo de expressão, ou seja, pode-se olhar para o meio ambiente de forma estética, variando desde o prazer efêmero de uma vista até a sensação de beleza, igualmente fugaz, mas com maior intensidade, até uma resposta tátil-contato físico: o deleite do sentir a ar, a água, a terra. Já mais difícil é expressar os sentimentos que se nutre pelo lugar, lar, o locus de reminiscências (passado que evoca orgulho) e o meio de ganhar a vida. Contudo, quando o lugar ou o meio ambiente é irresistível, eles se tornam veículos de acontecimentos emocionalmente fortes ou são percebidos como símbolos (Tuan, 1980: 107).
} 
A preocupação com a subjetividade relacionada à expressão artística das imagens gráficas utilizadas nos mapas, mesmo os altamente pictóricos, deve ser constante. Como alerta Souza (1992: 98), a imagem, ao assumir uma função social, procura comunicar mensagens objetivas voltadas à sociedade e público aos quais se destina.

Conseqüentemente, o estabelecimento de conjuntos simbólicos a partir das imagens expressa uma retórica na qual os símbolos mais fortes de uma cultura são adotados em um discurso icônico que os naturaliza. Daí as imagens se prestarem tão bem ao uso político e à persuasão mercadológica, sendo empregadas com tanta facilidade $e$ sucesso a serviço das ideologias e da propaganda (Barthes, 1989).

Por fim, focaliza-se o processo de representação gráfica das imagens percebidas. Segundo Salvia Coelho (1993: 45), o ato de representar ocorre porque as imagens mentais e os signos em geral ativam processos psicológicos complexos - e já expostos aqui - como a percepção, a memória, a emoção, o imaginário, julgamentos de valor e de realidade, constituindo-se temas de pesquisas na área da cognição. No trabalho com mapas pictóricos voltados ao setor turístico, o pesquisador-cartógrafo faz uso direto de conceitos relativos ao símbolo, ao sinal, à imagem, aos esquemas mentais, aos protótipos - e suas respectivas representações proposicionais - sempre fundamentado no saber organizado.

O próximo passo então é a apropriação e escolha dessas imagens para que se inicie o estágio da codificação direcionada à mensagem gráfica. Brill (1988: 35) parte do princípio de que o homem é um ser racional, o que o torna capaz de simbolizar sua própria experiência vivida. Essa função simbólica possibilita captar a sua vivência, expressando-a, podendo memorizá-la para si mesmo ou transmiti-la a outras pessoas. $O$ ato de comunicação entre os homens está na base da função simbólica, possibilitando trocas de idéias entre indivíduos do mesmo grupo social, por meio dos códigos encontrados, por exemplo, na linguagem falada, escrita e nas artes (como o desenho). Tal recurso da comunicação codificável faz com que os grupos possam constituir-se em sociedades, estabelecendo funções que caibam a cada indivíduo, e regras que regem a comunidade. Pelo processo de ação dos códigos, regras e costumes, há uma cristalização de formas relativamente permanentes, o que determina o aparecimento da tradição.

Souza (1992: 221) ratifica que, quando o designer passa pelo processo de escolha dos traços visíveis do objeto (enfatizando-os ou excluindo-os propositalmente), ele exprime um saber não apenas pessoal, mas também social. Isso ocorre porque traz consigo um jeito convencional de observação da realidade, profundamente governada pela intenção comunicativa que deseja transmitir pelo desenho. Portanto, a imagem funcional mostra não somente a maneira como o designer vê o mundo: vai além, mostrando de que maneira ele traduz o modo de a sociedade ver o mundo.

A estrutura do mapa turístico calcado na pictografia trabalha com sentimentos, conhecimentos, experimentações, convenções que uma pessoa adquire ao longo de 
sua vida. E é a partir daí que as formas gráficas são percebidas, cabendo, então, ao cartógrafo trabalhar incansavelmente com o poder denotativo e conotativo das representações.

Para isso, ele tem o dever de dominar o uso das linhas, formas (seus limites e texturas), cores, da luz, volumes e perspectivas, possibilitando várias sensações visuais e emocionais ao espectador. Cabanellas (1976: 17) complementa que esses elementos plásticos básicos se desenvolvem sobre uma superfície, sendo dispostos em uma determinada ordem, de modo que, paralelamente ao ato compositivo ${ }^{39}$, cria um espaço plástico - que é a obra propriamente dita.

Assim, a geração e a estruturação de práticas e de representações podem ser objetivamente reguladas e regulares, porém não deixam de ser um processo contínuo de transformação onde são criadas naturalmente condições de atualização do habitus $^{40}$, que deve ser encarado como:

um sistema de disposições duráveis e transferíveis que, integrando todas as experiências passadas, funciona a cada momento como uma matriz de percepções, apreciações e ações, e torna possível a realização de tarefas infinitamente diferenciadas, graças às transferências analógicas de esquemas (Bourdieu, 1974: XL e XLI).

O habitus confere à prática social um espaço de liberdade, configurando-se como um princípio gerador que impõe, ao mesmo tempo, um esquema durável, reproduzindo regularidades inscritas em condições objetivas e estruturais; mas também flexível, permitindo ajustamentos e inovações às exigências postas pelas situações concretas que põem à prova sua eficácia (Bourdieu, 1974: XLI).

De acordo com Bourdieu (1974: 293), uma obra contemporânea - que pode ser o mapa turístico - é assimilada a partir da relação que os produtores mantêm com uma determinada época e sociedade, gerando, assim, códigos. Esse contexto é fruto da relação que o produtor do mapa possui com o restante da sociedade e, em particular, com as demais células das classes dominantes, ou seja, os consumidores, com seus gostos e suas demandas.

\footnotetext{
${ }^{39}$ Com base em Cabanellas (1976: 45), pode-se dizer que a composição do mapa pictórico é uma disposição ordenada dos elementos plásticos - visuais - tendo como referência o espaço. Dada uma composição, as formas são subordinadas a um esquema, situadas umas ao lado das outras em ordem mais ou menos complexas. Portanto, ao olhar para as várias ilustrações em um mapa pictórico, o observador agrupa mentalmente as formas, selecionando-as em ordem de modo que sua visão possa percorrê-las com facilidade. Ás vezes, os elementos são agrupados por similaridade de direção, forma, semelhança de cor, textura, etc.

${ }^{40}$ É um conjunto de esquemas implantados desde a primeira educação familiar, sendo continuamente repostos e reatualizados ao longo da vida social do indivíduo (Bourdieu, 1974: XLII). Toda ação histórica e/ou social reflete $(\mathrm{m})$ dois estados: o objetivado, que é a história acumulada ao longo do tempo nos objetos, nas máquinas, edifícios, monumentos, livros, teorias, costumes, direito, etc., e o incorporado: podendo se tornar um habitus, que constitui a matriz que dá conta de uma série de estruturações e reestruturações pelas quais passam as diversas modalidades de experiências diacronicamente (evolução de fatos no tempo) determinadas pelos agentes (Bourdieu, 2000: 83).
} 
Tendo como princípio que se vive num mundo socialmente construído, os principais elementos relacionados à produção e ao consumo dos mapas são a identidade - dos produtores dos mapas e usuários - e as percepções relacionadas tanto ao ato de desenvolvimento quanto à utilização desse tipo de material cartográfico. Esses itens podem esclarecer não somente os motivos encontrados por trás dos eventos cartográficos, mas também o quanto o mapa pode ser eficaz em comunicar a informação (Harley, 1994: 281).

O desafio maior é representar as "informações culturais" de uma maneira genérica, utilizando-se do senso comum para criar ilustrações simples, diretas. Busca-se um direcionamento da atmosfera subjetiva do turista quando vê o mapa (paisagem representada). Para isso, o produtor particulariza, articula ilustrações de forma a tornar as representações gráficas acessíveis à compreensão, procurando diminuir, o grau de polissemia.

É fato que a elaboração do mapa turístico, ao utilizar grandemente da pictografia, jamais estará pautado sobre as bases monossêmicas de Bertin (1967, 1983, 1988 1996), pois os ícones e os símbolos vêem carregados de emoções e percepções. Tudo acontece de maneira premeditada, pois é oferecido outro tipo de produto - o mapa pictórico, menos árido visualmente; que não objetiva somente uma linguagem normatizada - com propósito definido - o turismo - e um usuário leigo, ávido por conhecer outras culturas, ser seduzido que busca mais do que um mapa convencional.

A figura 40 apresenta representações da paisagem divididas em dois aspectos de atrativos: materiais e imateriais. Note-se os poucos, enfáticos e diretos traços gráficos, muitas vezes acompanhados de um texto para situar e referenciar melhor o usuário.

Para entender melhor o que seriam estes aspectos materiais e imateriais, introduz-se o conceito de patrimônio, estabelecido pela UNESCO (2007): é o legado que recebemos do passado, vivemos no presente e transmitimos às futuras gerações. Nosso patrimônio cultural e natural é fonte insubstituível de vida e inspiração, nossa pedra de toque, nosso ponto de referência, nossa identidade.

Canclini (2003: 160) reitera e complementa o conceito de patrimônio informando que é um conjunto de bens e práticas tradicionais que identificam uma nação, um povo, sendo recebido do passado com um dado prestígio, que não cabe aqui discuti-lo.

Assim, procuram-se possíveis operações de sua preservação, restauração e difusão, por ser a base mais discreta da simulação social. A perenidade desses bens pirâmides, palácios, monumentos - leva a imaginar que seu valor é inquestionável e os torna fontes de consenso coletivo, estando além das divisões entre classes, etnias e grupos que formam uma sociedade. A UNESCO (2007) divide o patrimônio em três aspectos: 
Figura 40 - Representações materiais e imateriais da paisagem
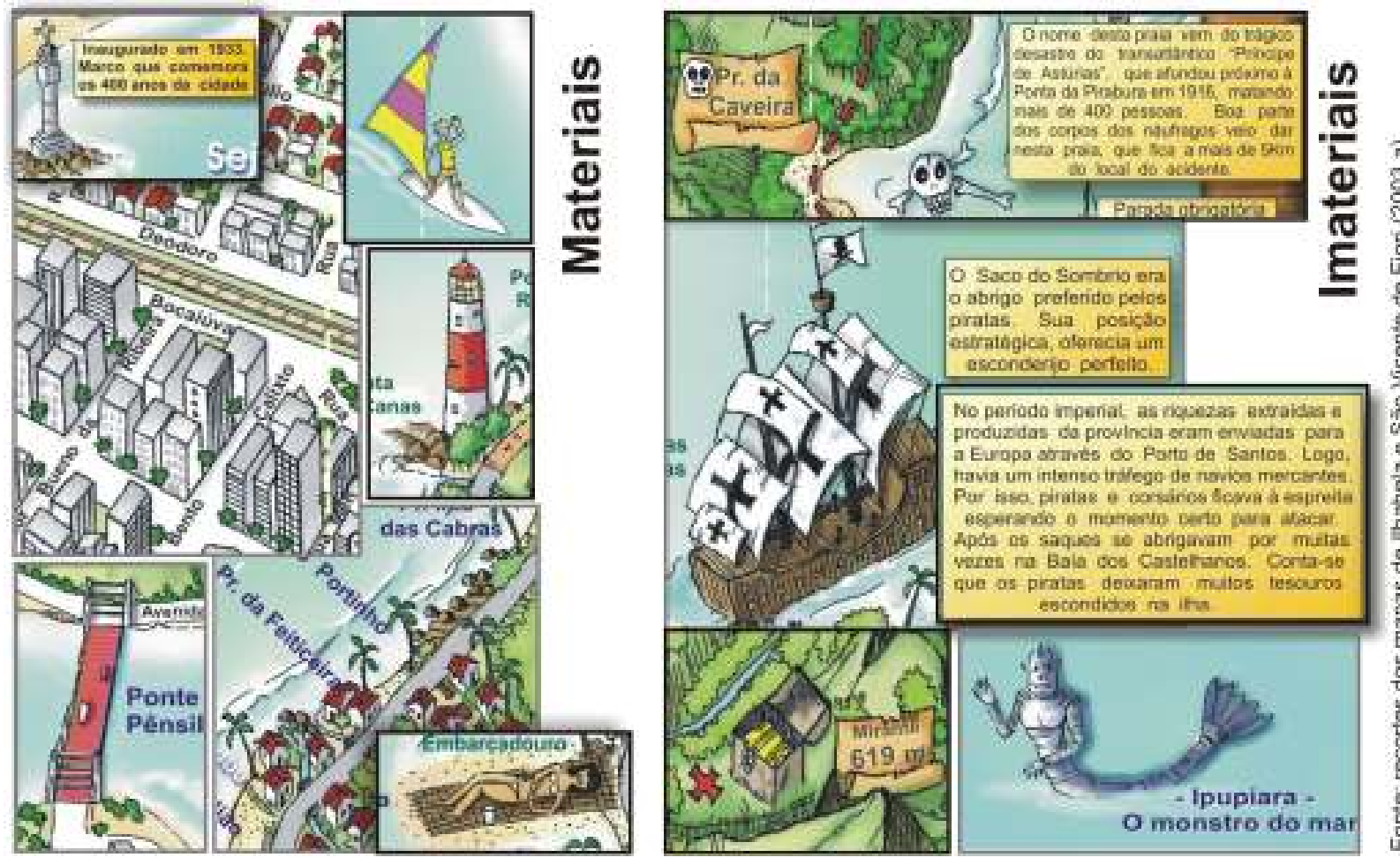

\section{$\checkmark$ Natural}

São áreas que apresentam um valor excepcional no que tange à diversidade biológica e à paisagem. Nesses ambientes, procura-se o respeito à diversidade cultural e as populações tradicionais merecem atenção especial. Os Sítios do Patrimônio Mundial Natural geram, além de benefícios à natureza, uma importante fonte de renda oriunda do desenvolvimento do ecoturismo.

\section{$\checkmark$ Cultural}

É de fundamental importância à memória e à identidade, que é perpetuada por aspectos físicos da criatividade e da riqueza cultural dos diferentes povos. Estes legados são monumentos, grupos de edifícios ou sítios que tenham valor: histórico, estético, arqueológico, científico, etnológico ou antropológico.

\section{$\checkmark$ Imaterial}

Além das manifestações culturais materiais, perpetuadas a partir dos monumentos, sítios históricos e paisagens culturais, existe também o patrimônio imaterial. Este se estabelece por tradições (também orais), folclore, saberes, línguas, festas e em diversos outros aspectos e manifestações, recriados coletivamente e modificados ao longo do tempo. A essa porção intangível da herança cultural dos povos. Num mundo de crescentes interações globais, a revitalização de culturas tradicionais e populares assegura a sobrevivência da diversidade de culturas dentro de cada comunidade, contribuindo para o alcance de um mundo plural. 
Lima (2002: 14) esclarece que, no contexto do turismo internacional, os ambientes naturais, de grande beleza cênica e relativamente bem preservados se valorizam cada vez mais. Este importante setor mercadológico atrai, entre outros, visitantes cada vez mais sensibilizados pelas questões ambientais. Em contrapartida, a gestão de áreas protegidas busca estratégias que aliem a conservação dos ecossistemas, dos recursos naturais e da biodiversidade; às necessidades das populações locais, ampliando as atividades estritamente protecionistas àquelas voltadas ao desenvolvimento, integrando-as à realidade local e regional. Isso faz com que haja um enorme movimento em viabilizar o ecoturismo. Furlan $(2000,187)$ refere-se a uma divulgação do IBAMA de 1998, relativa à abertura de licitação para que empresas privadas explorem o ecoturismo nas Unidades de Conservação (UC) ${ }^{41}$ federais, como, por exemplo, agências de turismo e ONGs, que trabalham com grupos de visitantes de hotéis, escolas, empresas, entre outros.

Em alguns países, a atividade do ecoturismo desenvolvido em unidades de conservação é de grande importância. Veja-se o caso dos Estados Unidos: o Sistema Nacional de Parques é composto de 376 áreas protegidas, recebendo por ano mais de 270 milhões de visitantes, gerando uma receita de 10 bilhões de dólares e 200 mil empregos (IUCN apud Lima, 2002: 97).

A natureza e sua respectiva fauna, flora, ecossistema e paisagem - esta última sendo a principal variável como ponto de confluência entre os fatores ambientais e antrópicos - são atrativos por excelência do ecoturismo, que tem maior importância quanto mais elevado for o seu grau de intocabilidade e de aspectos singulares e únicos. Portanto, o ecoturismo prioriza a preservação do espaço natural onde é realizado, e seu projeto contempla a conservação diante de qualquer outra atividade. Por sua vez, a população autóctone, sua cultura e seu modo de vida estreitamente apegados à natureza que lhes serve de meio de vida e de entorno é o foco de uma abordagem ecoturística que valoriza a autenticidade e a dignidade dessas populações e sua cultura. Além disso, essa população local participa dos serviços prestados aos turistas (Pires, 1998: 76;157-158).

Posto isso, deve-se levar em consideração que, na última década do século passado, visitantes e turistas que nunca haviam pensado em sair dos roteiros convencionais ou mesmo do meio urbano, começaram a se interessar por atividades que antes (décadas de 60, 70 e 80 do século XX) eram desenvolvidas principalmente por pessoas caracterizadas pelo alto espírito de aventura, desprendimento quanto ao

\footnotetext{
${ }^{41}$ Podem estar relacionadas ao uso indireto e direto. As UCs de uso indireto referem-se às áreas destinadas somente à conservação integral da biodiversidade, à pesquisa científica, à educação ambiental e à recreação. É terminantemente proibido explorar os recursos naturais desse tipo de UC. Esta categoria abrange os parques (Nacionais, Estaduais e Municipais), as estações ecológicas, reservas biológicas e ecológicas, áreas de relevante interesse ecológico, reservas particulares do Patrimônio Nacional e áreas sob proteção especial. Já as UCs de uso direto são as "áreas destinadas à proteção e manejo de recursos naturais", como: as florestas nacionais, as áreas de proteção ambiental e as reservas extrativistas (Furlan, 2000: 195-196).
} 
conforto, sem preocupação quanto à infra-estrutura, ou seja, acomodação, alimentação e outras facilidades e ávido de experiências alternativas: os ecoturistas ${ }^{42}$.

Pires (1998: 59) cita o novo ecoturista como possuidor de uma menor informação e experiência do/no meio natural. Podem ser qualificados como curiosos que têm poder aquisitivo para comprar pacotes atrativos, motivados pela onda ecológica ou ainda pela simples influência de conhecidos que experimentaram a atividade. De acordo com Lima (2002: 94), ocorre uma adaptação desse tipo de viagem, não dirigida a especialistas.

O interesse crescente atinge vários países da América Latina (entre eles o Brasil), África e Ásia (Pires, 1998: 58). Nessas áreas, há um apelo do turismo de aventura e esportivo, que envolve uma atmosfera de descobertas, desafios, isolamento e contato com o inusitado, no qual se desenvolvem as mais diversas modalidades e riscos dos chamados esportes da natureza entre eles, a escalada, o trekking, o canyoning, o rafting, o vôo livre, o rapel, o surfe, o windsurfe, o mergulho, o esqui-aquático, a motocross, etc. (Pires, op. cit::122).

No mesmo autor (op. cit:: 59), destaca-se o aumento do número de participantes do ecoturismo e, conseqüentemente, o surgimento daquelas pessoas "menos ecoturistas", a quem se pensar em proporcionar certas facilidades e níveis de sofisticação. Como exemplos, são citadas: as caminhadas mais curtas, que exigem menor esforço; a implantação de centros de informação; de trilhas autointerpretativas, serviços de animação turística, meios de hospedagens confortáveis e guias especializados no manejo de um ecoturista cujo interesse prioritário não é o estudo ou conhecimento da natureza.

Neste aspecto, enfatiza-se a preocupação de como e o que pode ser disponibilizado em um mapa turístico. Dependendo da intenção do usuário, ele achará interessante ou não a representação das curvas de nível. Todavia, existem informações que são importantes tanto em um mapa pictórico quanto em um convencional, como, por exemplo, a importância em se facilitar a informação da escala para que o usuário tenha uma noção prévia da distância e, conseqüentemente, do tempo gasto para o percurso, em informações sobre trilhas, onde conseguir guias (profissionais especializados) para as caminhadas, etc. Ilustram-se esses exemplos a partir de uma legenda que foi elaborada para o mapa de Ilhabela encontrada em Fiori (2003), onde, a partir dos trabalhos de campo, se estabeleceram-se três principais tipos (níveis de

\footnotetext{
${ }^{42}$ Excursionistas, alpinistas, aventureiros, naturalistas, cientistas, estudiosos, estudantes (universitários ou participantes de excursões escolares voltadas ao estudo do meio) e aficionados. Seja qual for à categoria de ecoturista, este só pode ser considerado como tal desde que seja envolvido ou que se envolva com aspectos conservacionistas e educativos que dão a verdadeira dimensão ao ecoturismo, sem a qual serão considerados simplesmente turistas (Pires, 1998: 15). Entretanto, na década de 90 do século $\mathrm{XX}$, houve uma evolução do ecoturismo, visando a um melhor atendimento ao público mais geral, isto é, o empreendedor, mesmo mantendo sua capacitação para atender o segmento do mercado puro, original, também teve que se adaptar à nova tendência, passando a oferecer um tipo de produto compatível com as preferências do novo ecoturista (Pires, op. cit.: 58-59).
} 
dificuldade) de trilhas para llhabela (Figura 41).

Figura 41- Estabelecimento de três níveis de dificuldade

para as trilhas em Ilhabela

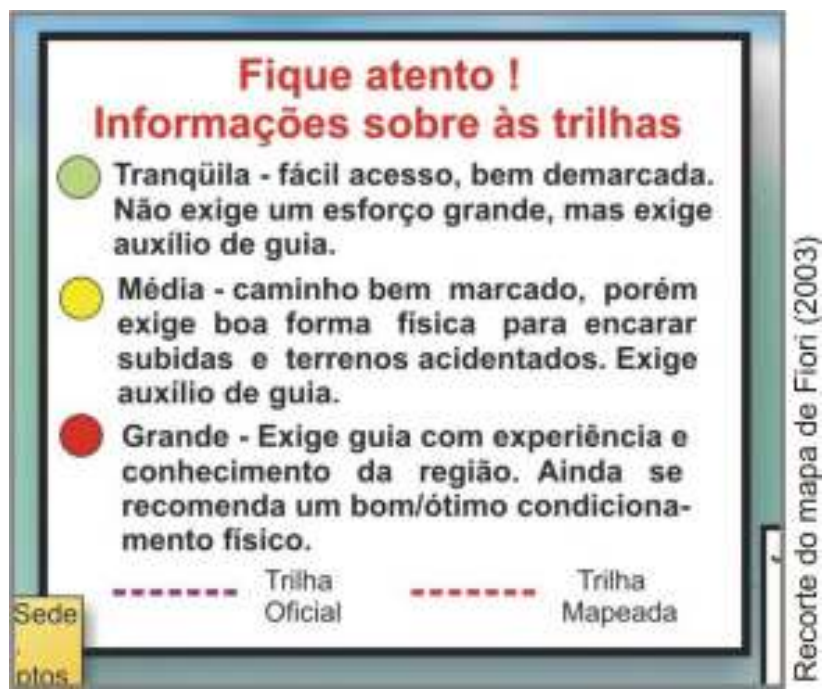

O outro tópico já relacionado e que pode ser representado sobre o mapa são os atrativos culturais, sejam materiais sejam imateriais.

Nos últimos vinte anos do século $X X$, os atrativos culturais vêm recebendo uma maior atenção do público-turista no plano mundial (Patin, 2005).

Alzua, O'Leary, Morrison (1998) reiteram que a cultura e, por conseguinte, todo o seu patrimônio está se transformando nas duas maiores forças de revitalização urbana e econômica. O turismo cultural torna-se cada vez mais importante às destinações preocupadas em atrair mais visitantes internacionais.

O termo turismo cultural e patrimonial tem sido usado para descrever não somente o consumo da arte, monumentos, folclore, mas também para tratar de experiências e motivações dos turistas no local da destinação escolhida. Em um sentido amplo, o significado da cultura e do patrimônio é resultado da estrutura étnica e social. E, em um sentido particularizado, são as influencias provenientes da experiência familiar, do grau de escolaridade, da vizinhança e de muitas outras experiências do dia-a-dia. $\mathrm{O}$ patrimônio e a cultura, quando combinados com o lazer e o turismo, podem ser considerados um dos fenômenos mais significativos ao rápido crescimento do turismo (Alzua, O'Leary, Morrison, 1998).

Segundo Canclini (2003: 202-203) e tendo em mente a proposta de elaboração de mapas turísticos pictóricos, busca-se uma forma de representação dos atrativos materiais e imateriais. $\mathrm{O}$ ato reconstrói uma possível verossimilhança histórica, ao 
estabelecer bases comuns para a re-elaboração de acordo com as necessidades do presente. Até porque,

assim como o conhecimento científico não pode refletir a vida, tampouco a restauração, nem a museografia, nem a difusão mais contextualizada e didática conseguirá abolir a distância entre a realidade e a representação. Toda a operação científica ou pedagógica sobre o patrimônio é uma metalinguagem, não faz com que as coisas falem, mas fala delas e sobre elas.

Dessa maneira, o produtor do mapa turístico deve estar atento a todas as possibilidades da destinação (materiais e imateriais), encontrando maneiras criativas e eficientes para a transmissão destes atrativos. Para isso, o mapa precisa contar com vários níveis de imagens da paisagem, ampliando dessa forma seu leque de opções e contemplando diferenças de interesses em um mesmo grupo social ou entre outros grupos. A figura 42 mostra alguns ícones culturais elaborados para a Secretaria de Turismo da Prefeitura de São Paulo (SPTuris).

O estudo da representação pictórica da paisagem relaciona-se a uma nova área interdisciplinar. Caberá ao pesquisador procurar entender as peculiaridades da linguagem visual, para que, então, analise o efeito das imagens sobre a vida social, seu lugar nas representações e nos sistemas simbólicos. Discute também as implicações da disseminação dos usos da imagem, as suas funções no mundo contemporâneo, o valor dos meios técnicos de produção e reprodução visual e outros tantos temas de interesse e questionamento (Porto Alegre, 1988).

Quando alguém (artista, artesão, desenhista, produtor do mapa, etc.) transforma a realidade em representações gráficas, está na verdade utilizando um schemata, que são os pontos de partida do seu vocabulário gráfico (ver figura 14). Tal schemata é formado a partir de uma seqüência de culturas e tempos ${ }^{43}$, a qual desenvolvendo formas de representação da realidade, até porque a assimilação de qualquer nova forma é resultado da apreensão e da manipulação de modelos esquemáticos (copiados e recopiados por todos ${ }^{44}$ ) utilizados pelos produtores. Esse recurso também serve de apoio à formação das imagens da memória (Gombrich, 1995). O autor continua esclarecendo que é pela percepção e pelo pensamento que se aprende a particularizar, a articular e a fazer distinções onde antes havia apenas uma massa diferenciada.

\footnotetext{
${ }^{43}$ As dimensões temporais estão no âmago da compreensão das estruturas cognitivas. Toda a vida social com suas múltiplas manifestações culturais é antes a orquestração da diversidade do que a réplica da uniformidade (Coelho, 1993: 20).

${ }_{44}$ Pessoas no mundo inteiro (crianças e adultos) adquirem a schemata por meio da arte conceitual, que parte da premissa de que todo o registro visual não é uma certeza, mas uma conjectura condicionada a um público e uma tradição. Portanto, julgando a arte de maneira conceitual, não se pode afirmar se as pinturas ou os conceitos (substantivos comuns que representam, classificam algo, como, por exemplo, um homem, um cachorro ou uma flor) são verdadeiros ou falsos, pois podem ser apenas mais ou menos úteis à formação de descrições (Gombrich, 1995).
} 
Figura 42 - Alguns ícones do patrimônio cultural de São Paulo

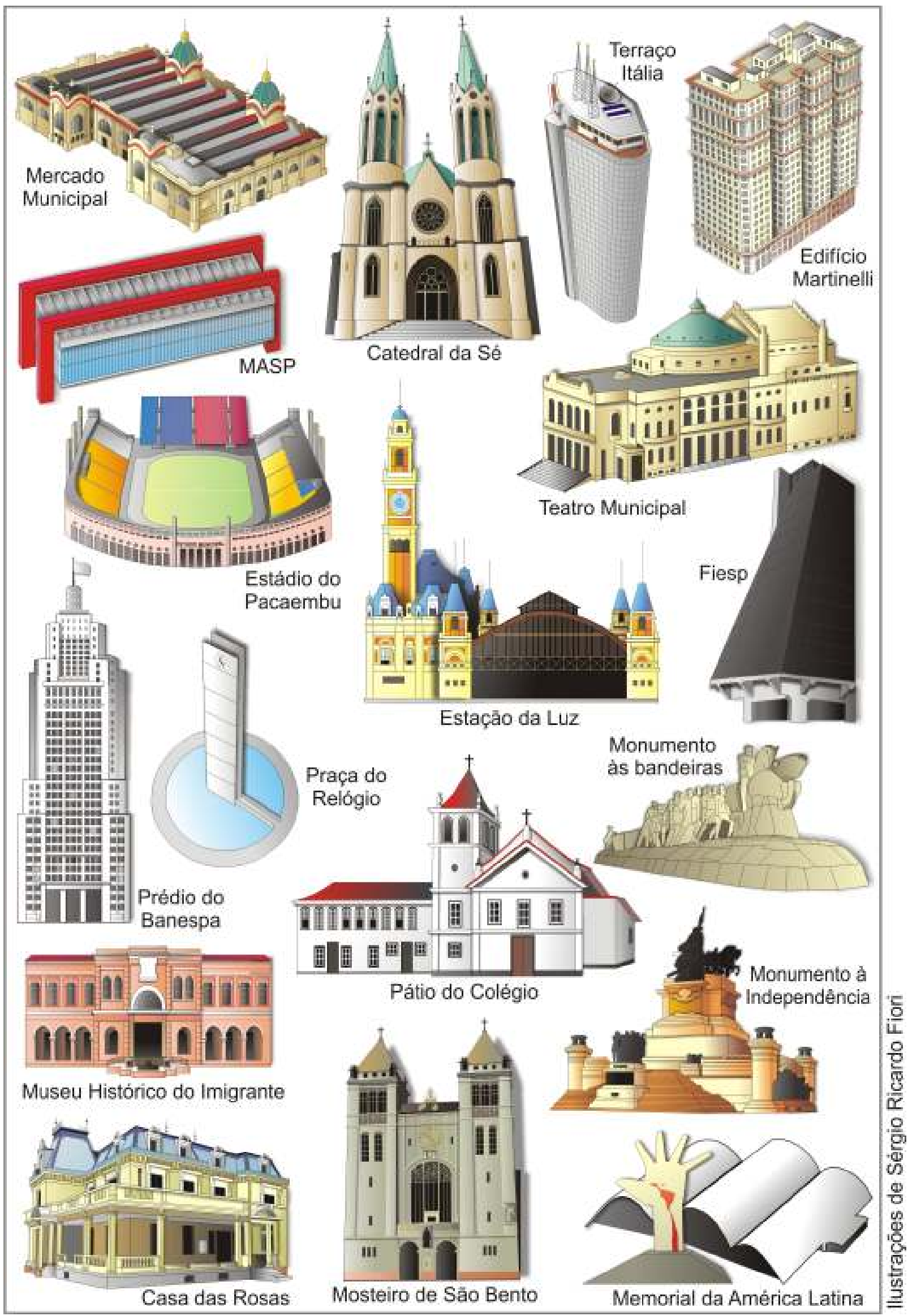


Um artista gráfico treinado possui uma grande quantidade de schematas que servem de apoio para as representações das imagens que estão em sua memória. $E$, logicamente, esses registros jamais serão uma réplica, pois a quantidade de informações que chega do mundo visível é incalculavelmente grande, e os meios à disposição do artista são restritos. Conseqüentemente, as formas de arte, antigas e modernas, não são mais do que as duplicações as quais o homem vê do mundo exterior. Essas transcrições são feitas a partir de um dado veículo adquirido, que se desenvolveu pela da tradição e habilidade. A representação não sendo, portanto, uma réplica, constata sua eficácia, desde que retenha a natureza eficaz do protótipo, isto é, deve funcionar tão bem, ou melhor que o real (Gombrich, 1995). Assim, o grande desafio do cartógrafo é inventar representações gráficas da realidade que funcionem para o maior número de pessoas.

A questão central a enfrentar está relacionada à subjetividade, uma vez que muitos materiais visuais, como o desenho documental e a fotografia, costumam ser associados a um grau de autenticidade da informação que, na verdade, não possuem. As ciências sociais tratam as imagens de forma positivista, como descrições da realidade e não como representações simbólicas, cuja leitura não apenas varia segundo o olhar do espectador como também é decorrente da própria natureza construída da imagem (Porto Alegre, 1988: 75-76).

Esse autor (op. cit: $80-81$ ) ressalta, então, os cuidados que devem ser tomados em uma pesquisa iconográfica:

$\checkmark$ Implica estabelecer classificações e tipologias, identificando diferentes gêneros de produção e seus conteúdos. No caso da iconografia gráfica, é preciso diferenciar a pintura, o desenho, a gravura, a fotografia e, agora, a computação gráfica, como formas distintas de expressão.

$\checkmark$ Definir critérios de classificação dos conteúdos temáticos, que podem ser de natureza estética, histórica, científica, jornalística e publicitária, procurando distinguir principalmente o valor de documento da pura ficção criativa.

$\checkmark$ Cada gênero e cada conteúdo obedecem a condições de realização que interferem no resultado final da imagem produzida e, portanto, naquilo que ela comunica. Por essa razão, o trabalho com materiais iconográficos requer não só um conhecimento da linguagem visual e de suas particularidades como, por exemplo, uma certa familiaridade com a história da arte, as escolas, os estilos artísticos e as técnicas de produção e reprodução, para que o pesquisador não se deixe levar por falsas premissas ou uma perspectiva ingênua da problemática visual. É importante conhecer as características de um quadro a óleo, da aquarela, do desenho, a composição simbólica e a psicológica, o retrato, a montagem e a trucagem fotográficas, a simulação e assim por diante, de modo a obter uma leitura mais acurada da imagem e seus significados. 
$\checkmark$ É desnecessário enfatizar que as escolas e os estilos de criação artística guardam estreita relação com o contexto social, o mundo das idéias e dos valores da época e do local em que a obra foi produzida, e que a consideração de tais elementos é essencial quando se trata de avaliar os valores documental e histórico e relacioná-los com a estética e a expressão artística.

Cite-se ainda Pires (1996), ao afirmar que as qualidades visuais do território são compostas de elementos naturais e artificiais, sendo que é pela visão que se percebem e se discriminam quatro grandes componentes paisagísticos no território: 0 relevo, a água, a vegetação e as atuações humanas ${ }^{45}$, que são capturados da realidade. Para isso, utiliza-se das mais variadas técnicas - representações artísticas tais como gravuras, quadros e ilustrações, documentos históricos, fotografias e filmagens - gerando assim formas substitutas da paisagem. A figura 43 apresenta dois exemplos do trabalho de Pires (1996), que utilizou as imagens turísticas de cartões postais da região litorânea de Santa Catarina.

\section{Figura 43 - As formas substitutas da paisagem}

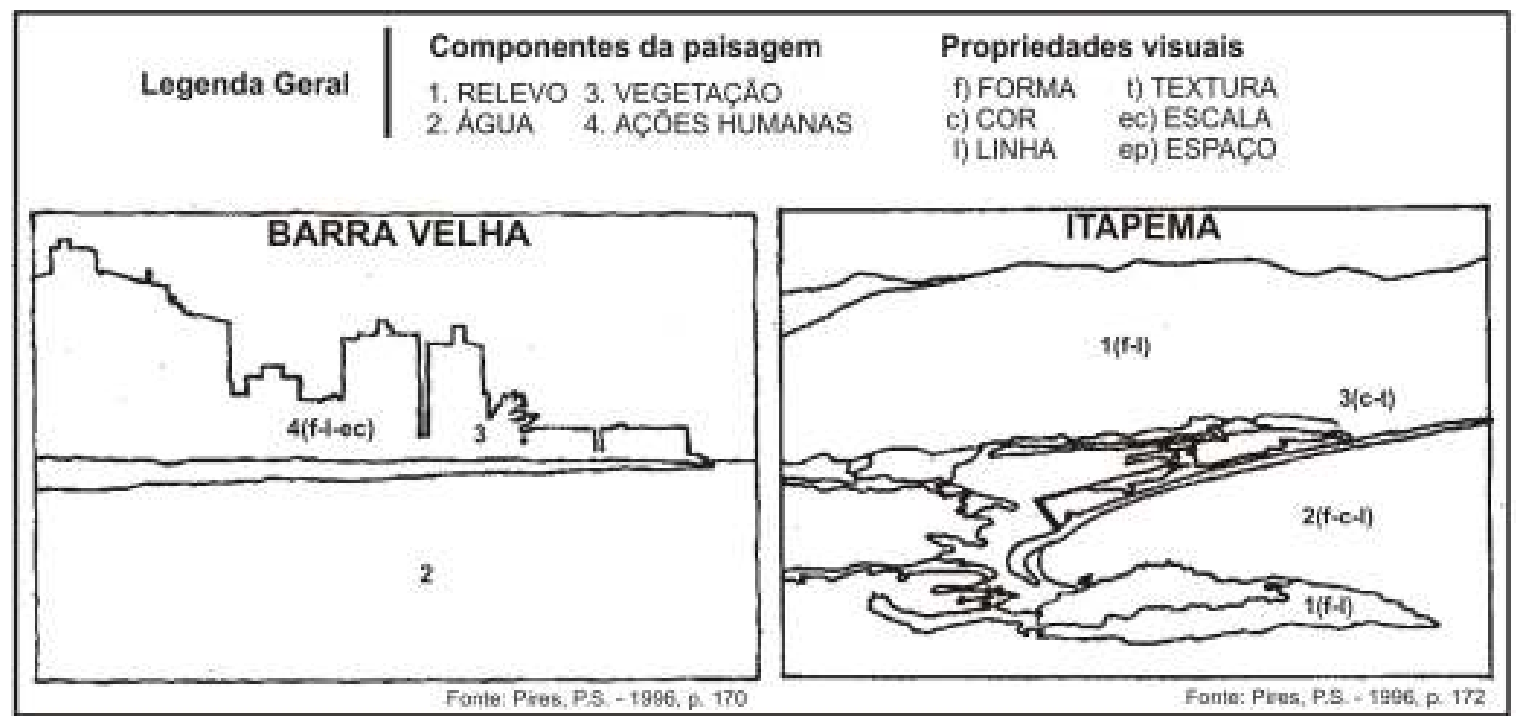

Os componentes paisagísticos ainda são portadores de propriedades e de elementos visuais ${ }^{46}$ particulares e constituem-se por um número de substâncias básicas daquilo que se vê em uma obra pictórica: a linha (seqüência de pontos, formas em 2D); a

\footnotetext{
${ }^{45}$ Os componentes da paisagem mais detalhados são: 1) Forma da terra: é o aspecto exterior da superfície terrestre representado pelo relevo, pelas formas do terreno, por sua disposição e por sua natureza. 2) Água: caracteriza-se pelas formas em superfície (mares, rios, lagos, neve e gelo), sua disposição, monotonia e movimento. 3) Vegetação: apresentam distintas formas de vida vegetal (árvores, arbustos e vegetação herbácea) com suas características específicas, sua distribuição, densidade, etc. 4) Estruturas e elementos artificiais: são criadas por diferentes tipos de usos do solo ou concentrações diversas de caráter pontual, linear ou superficial (Pires, 1996).

${ }^{46}$ São os tipos diferentes de formas das quais o desenhista dispõe para fazer uma ilustração. É importante frisar que apenas um único elemento visual, ou a composição com outros, configuram o plano pictórico.
} 
forma (volume, formas em 3D, dimensão); a luz e sombra (profusão de tons, sombreamento); a cor (reforço emocional expressivo); a textura (proximidade maior da superfície dos elementos representados) e a escala (o espaço). Esses dados fazem com que uma paisagem observada possa ser projetada, esboçada, pintada, desenhada, rabiscada, ou seja, podem-se elaborar representações a partir de expressões plásticas básicas. E é a partir desses elementos visuais que se obtém a matéria-prima para a comunicação visual, podendo assim planejar e expressar todas as variedades de manifestações visuais, objetos, ambientes e experiências. Dondis (1991: 23; 51-52) esclarece que a estrutura da obra visual é a força que determina quais propriedades e elementos visuais estão presentes, e com qual ênfase ocorre essa presença. Portanto, a escolha das propriedades e dos elementos visuais enfatizados e sua manipulação ficam a critério do artista (no caso, o cartógrafo), pois este dará os efeitos pretendidos. Ele é o visualizador.

Mukarovsky (1981: 308) complementa que nenhum desses elementos visuais, nem mesmo os mais simples de todos, como a linha e a cor, são meros fatos de percepção sensorial, pois sempre têm uma determinada relação com a realidade representada, isto é, cada um desses elementos significa de alguma maneira a realidade, por trazer referência, destacar alguns de seus aspectos. Estabelecem, no interior da obra pictórica, relações mútuas, pois as suas significações parciais unemse para formar a significação final e as suas relações parciais com a realidade dão, como resultado, a referência global a ela.

Uma pesquisa realizada por Fiori (2003: 173-191) com os mapas turísticos pictóricos de Ilhabela e São Vicente, constatou empiricamente que por volta de $85 \%$ de 160 entrevistados, aprovaram a escolha das imagens percebidas nos mapas. $O$ resultado descrito abaixo relaciona a preocupação do cartógrafo e a reação dos usuários:

$\checkmark$ A transmissão da informação - o autor-cartógrafo procurou oferecer signos cartográficos (índice, ícones e símbolos) eficazes aos diferentes e ao maior número de usuários, buscando a menor subjetividade possível. Houve então um trabalho de percepção (referência cognitiva) das imagens em dois níveis: primeiro o cartógrafo filtrou e transformou a realidade em imagens representativas. O usuário então precisou compreender tais imagens pictográficas desenvolvidas, que auxiliaram na procura e comunicação das atrações em sua estada no destino.

$\checkmark$ A motivação causada pelas imagens - fez com que se optasse propositalmente pelo estilo pictográfico, devido aos seus recursos gráficos que oferecem maior riqueza de detalhes visuais e despertam reações emocionais como, por exemplo, a memória afetiva e a lembrança. Durante o desenvolvimento do mapa, buscou-se inicialmente uma imagem-representação geral da localidade, sua vocação turística, (balneário, histórico, serrano, etc), por meio de um conjunto de representações como signos cartográficos e desenhos, que destrincharam os vários elementos espaciais e as várias atividades inseridas 
no mapa-destino. Por se tratar de um produto voltado ao turismo, procurou-se levantar as imagens representativas da localidade, tendo, como princípio, o desafio de desenvolver imagens de uma forma estimulante, não tediosa, objetivando valorizar as imagens representativas. A idéia era a de viajar ou relembrar o destino por meio do mapa, mesmo não estando in loco.

Ilustrando tudo o que foi dito acima, a seguir serão são apresentadas algumas respostas dissertativas retiradas de Fiori (2003: 181-183). Elas exemplificam a reação dos usuários que utilizaram o mapa turístico pictórico, caracterizado pela grande quantidade de imagens representativas:

Porque se eu me perder (o que acontece sempre!) fica mais fácil de localizar algum lugar para pedir ajuda" (usuário 119). Mostra de maneira mais didática os pontos comerciais e locais úteis a serem visitados e ou utilizados por turistas (usuário 130). (...) visualmente eles são mais atraentes e as informações essenciais não são comprometidas por conta disto (usuário 140). Fazer turismo é sair do convencional, da rotina; por isso prefiro o mapa pictórico (usuário 142). Por causa das figuras, os turistas sempre vão ficar curiosos para conhecer mais a cidade (usuário $3,4,5,26$ ). (...) possui um visual que atrai os turistas (usuário 48). 0 turista ao chegar sabe onde poderá se divertir (usuário 62). Porque é uma forma mais alegre de visualizar nossa cidade (usuário 67). Mostra muitas coisas interessantes aos olhos dos turistas (usuário, 72). Porque a ilustração ajuda na compreensão imediata (usuário 81). (...) podemos dizer que dá um espírito de aventura e curiosidade para conhecer a cidade (usuário 93). Pela forma criativa e alegre que o mapa ilustra do lugar (usuário 96). Por causa dos animais, o mar, os navios, os mergulhadores, etc (usuário 102). A visualização cria uma expectativa do lugar (usuário 109). Porque com os pequenos resumos sobre os pontos importantes e com a facilidade de compreender os caminhos, o turista se anima a visitar não só a cidade e pontos mais conhecidos como outros lugares interessantes (sic usuário 119). (...) mostra a região montanhosa (morros, vegetação, rios, cachoeiras) (usuário 122). Por ele ser ilustrativo, realmente dá vontade de ir e não voltar mais (usuário 152). Os mapas têm uma representação gráfica agradável e atrativa (usuário 156).

Essas respostas comprovam a eficácia quanto ao grande uso da pictografia utilizada em mapas voltados ao setor do turismo. Primeiro porque tais representações são mais próximas do usuário potencialmente leigo em cartografia e de cujo cotidiano os mapas não fazem parte. Segundo, porque o usuário, tendo ou não conhecimento da utilização de mapas, é atraído por esse tipo de material cartográfico temático que gera nele expectativa, interesse, curiosidade, espírito de aventura, vontade de conhecer o local.

Dondis (1991: 136) corrobora a preocupação acadêmica relacionada ao desenvolvimento de mapas mais adequados à atividade turística, ao afirmar que a inspiração súbita e irracional não é uma forma aceitável no design. Pelo contrário, 
planejamento cuidadoso, indagação intelectual e conhecimento técnico são necessários tanto ao pré-planejamento visual quanto ao design propriamente dito. Como conseqüência, o designer constrói estratégias compositivas, buscando estabelecer soluções a problemas de beleza e funcionalidade, de equilíbrio e do reforço mútuo entre a forma e o conteúdo do produto. Todo o transcorrer do processo é extremamente científico, ou seja, suas opções, por meio de escolhas das técnicas, devem ser racionais e controladas.

Neste momento, é oportuno citar Arnold (1992), ao testemunhar que a ênfase dada aos símbolos pictóricos no Pilbara Street Smart Touring Map ${ }^{47}$ não foi por acaso, pois tal recurso estilístico possibilitou o desenvolvimento de um mapa sem uma legenda extensa, satisfazendo ainda aos visitantes que não tinham o idioma inglês como língua mãe. A pictografia gerou um processo de simplificação da leitura do mapa, provendo uma comunicação visual eficaz. Além disso, buscou estimular a atividade turística naquele local pela descrição visual da paisagem, criando uma atmosfera de aventura.

Esse tipo de recurso vem sendo usado, como aponta Harley (1994: 296), desde a Renascença, quando a imagem do mapa vinha acompanhada por uma grande quantidade de símbolos decorativos, presentes nos títulos e letras, na vinheta, na rosa-dos-ventos e nas bordas. Todos esses elementos decorativos formavam o vocabulário expressivo do artista e somavam-se ao assunto principal representado, no caso, ajudando a fortalecer e focalizar os significados políticos do mapa.

Essa forma de representação gráfica exprime o modo de percepção, de pensamento e de captação próprio de uma época, de uma classe ou de um agrupamento artístico (Bourdieu, 1974: 284).

Atualmente, sendo bem trabalhada, a pictografia tem grande possibilidade de se firmar como um conveniente e atraente estilo artístico voltado à concepção de mapas para o setor turístico.

A definição de estilo pode ser uma tarefa complexa e difícil de descrever com clareza. Dondis (1991: 161) sugere que talvez a melhor maneira de estabelecer uma definição seja vê-lo como uma categoria ou classe de expressão visual, modelada pela plenitude de um ambiente cultural. Isto porque o estilo é uma síntese visual de elementos representados, a escolha e utilização de técnicas, a sintaxe adequada, o processo de inspiração, a forma de expressão e a finalidade básica do produto.

Segundo Wolfgram (1994: 104-110), pode-se dividir em: desenho livre (cartoon, caricaturas, etc.); tradicional (é informativo, não muito interessante visualmente, mas franco e informativo); alta tecnologia (focaliza ilustrações contemporâneas e imagens

\footnotetext{
${ }^{47}$ Foi publicado em 1992 por órgãos públicos australianos; o Western Australian Departament of Land Administration, Cartographic Services Branch e Department of Conservation and Land Management. A confecção desse mapa turístico tinha como característica fundamental procurar atrair aqueles usuários que não têm familiaridade com as técnicas de leitura de mapas (Arnold, 1992).
} 
geradas no computador); técnico (relaciona-se a assuntos como arquitetura e modelos tridimensionais), natural e floreado (refere-se mais a conjuntos de cores do que a estilos artísticos) e outros estilos de ilustração, podendo se usar pinturas a óleo, pastéis, lápis de cor e aquarelas.

Dondis (1991: 163) complementa afirmando que, em um primeiro momento, escolhese o meio no qual se fará a comunicação, o qual sofrerá influência da forma e do conteúdo. Depois se coloca o objetivo, razão pela qual o material, objeto está sendo feito: sobrevivência, comunicação - caso da informação e publicidade - expressão pessoal. Por fim, ocorre o desenvolvimento, que dispõe de uma série de opções: a busca de decisões compositivas pela escolha de elementos (no caso, visuais) e pelo reconhecimento do caráter elementar, a manipulação dos elementos por meio da escolha das técnicas apropriadas, etc. O resultado final tanto para os artistas quanto para as pessoas em geral é uma expressão individual e, às vezes, coletiva, regida pelos elementos já apontados e que sofre influencia especial e profunda da política, da economia, do meio ambiente e dos padrões sociais, que criam uma psiquê coletiva. Portanto, o estilo é culturalmente condicionado, ou seja, as categorias mais amplas de expressão visual ajudam a entender a escolha e/ou preferência do produtor por um determinado estilo individual.

A pesquisa em questão defende uma concepção de estilo que possa encontrar maneiras de aumentar e melhorar o êxito das representações pictóricas em mapas temáticos específicos ao público e ao setor do turismo.

Bourdieu (1996: 323) enfatiza a necessidade de se ter cuidados ao utilizar a pictografia, devido aos seus recursos de sentido e valor, provenientes do acordo entre as duas faces da mesma instituição histórica: o habitus cultivado e o campo artístico, faces que se fundem. O cartógrafo deve ter em mente que os elementos pictóricos só possuirão sentido e valor se puderem ser apreendidos pelos receptores que, por sua vez, precisam estar dotados da disposição e da competência estéticas exigidas. Por exemplo, Whitehead (apud Porto Alegre, 1988: 85) observa que o desenho ajuda a acentuar os objetos e, ainda hoje, é muitas vezes preferido à fotografia no campo das ciências naturais e biológicas, por poder isolar e acentuar aspectos especiais do objeto estudado, assim como omitir o que não interessa. A fotografia apresenta, simultaneamente, um grande número de elementos dificultando o registro da observação. Entretanto, quem se utiliza da pictografia deve levar em consideração a subjetividade, resultado do estilo e visão de mundo de cada artista e de seu tempo.

Veja-se, por exemplo, o caso dos pintores-etnográficos realistas citados por Porto Alegre (1988: 88); o autor destaca o grande e rico acervo desses artistas que, mesmo procurando não cunhar uma interpretação arbitrária e fantasiosa a suas representações, apresentam certa ambigüidade nas imagens, devido à tensão entre o realismo (mundo concreto) e o não-realismo (pictografia). Essa relação é intrínseca ao processo de criação e interpretação vivida pelos artistas. 


\section{7 - A arte e o desenho como recurso à cartografia}

John Keates, em seu livro Understanding maps (1982), discute extensamente a questão se os mapas podem ser considerados um trabalho artístico.

O tema é de grande interesse, porque a arte consegue reter o elemento sensorial. $\mathrm{O}$ prazer proporcionado por uma ilustração vai além de seu conteúdo, pois possibilita ao espectador combinar, juntar, derivar algo pela justaposição de experiências ou aspectos de uma única experiência. O prazer que uma representação é capaz de nos proporcionar é originado por motivos e imagens que estimulam a lembrança de sensações de cheiro, gosto, audição, lembranças (Wollheim, 2002: 98-100). O autor ressalta mais especificamente o prazer encontrado na apreciação de uma pintura, porém esta observação adapta-se perfeitamente à concepção artística referente aos mapas turísticos, que utilizam da pictografia.

Em 1966, a Associação Cartográfica Internacional apresentou a primeira definição para cartografia, considerando-a:

o conjunto de estudos e operações científicas, artísticas e técnicas que intervêm a partir de resultados de observações diretas ou da exploração de uma documentação existente, tendo em vista a elaboração e a preparação de plantas, mapas e outras formas de expressão, assim como sua utilização.

Entre outras áreas de estudo, essa definição coloca a cartografia muito próxima do design, da comunicação e da arte.

Galeffi (1977: 41) ensina que uma obra de arte tem o poder de encantar, arrebatar o observador que se dispõe a contemplá-la. Naquele instante de graça, não se pensa em outra coisa: é como se vivesse num mundo ideal. Só depois, ao despertar do sonho, é que o observador pode tornar-se crítico e, assim, analisar a mensagem que o artista conseguiu transmitir.

Uma obra de arte se divide em dois aspectos (Bosi, 2002: 7):

$\checkmark$ Primeiro, pode ser vista como um objeto, por exemplo, um artesanato, uma música, um quadro, um desenho, um discurso, que geram um efeito psicológico, pois a obra é percebida, sentida e apreciada pelo receptor. Ela visa tanto comover a alma quanto aliar utilidade ao belo.

$\checkmark$ Segundo, o fator temporal, ou seja, alguém que cresceu após a Revolução Industrial tende a ver em todas as coisas possibilidades de consumo e fruição. Ter ou desejar uma gravura, um cd (compact disc) ou um livro finamente ilustrado é o seu modo habitual de relacionar-se com o que todos chamam de arte.

O mundo da arte faz-se então pela cooperação material e social, a partir do grau de 
adesão às convenções ${ }^{48}$ que regulamentam uma prática (Canclini, 2003: 39).

Conseqüentemente, a arte está inserida em um contexto, onde o artista e suas obras resultam de um acervo de experiências psico-fisiológicas, técnicas, filosóficas, científicas, históricas, morais, políticas, etc., que poderão constituir o motivo de inspiração para toda nova criação, nunca, porém sem serem antes refundidas e regeneradas no mágico crisol da fantasia criadora de cada personalidade artística (Galeffi, 1977: 142).

Sendo assim, ao longo da história, cada tipo de arte produziu suas técnicas e, por conseqüência, um conjunto de regras úteis ao processo de execução da obra. Desde a Antigüidade, formou-se uma tradição normativa. Na realidade, é correto dizer que foram gerados certos padrões estilísticos na vida simbólica de todos os povos, que resistiram durante os séculos, resultado da regularidade interna e do enraizamento comunitário (Bosi, 2000:17).

Bourdieu (1974: 293) cita que há períodos de ruptura, correspondentes àqueles períodos em que as obras são elaboradas sob a influência de um novo modo de produção, contudo, vistas durante certo tempo por meio dos antigos instrumentos de percepção.

O principal objetivo do artista é proporcionar e provocar experiência e prazer ao espectador (Wollheim, 2002: 44). A maior parte do material gráfico produzido prima pela necessidade de registrar, preservar, reproduzir e identificar pessoas, lugares, objetos ou classes de dados visuais. Tais dados, por sua vez, procuram transmitir informação por meio de mensagens específicas ou sentimentos expressivos, tanto intencionalmente, isto é, com objetivo definido, quanto obliquamente, sendo um subproduto da utilidade (Dondis, 1991: 183). Isto acontece devido ao fato de que um meio visual pode desempenhar vários papéis ao mesmo tempo. Por exemplo, um pôster que se destina basicamente a anunciar um concerto de piano, pode acabar servindo para decorar a parede de um estúdio, superando assim, a finalidade comunicativa que motivou a sua criação.

Brill (1988: 76) complementa que a função do artista deve ser a do mediador entre a arte e a técnica, ambas indispensáveis e complementares. Para poder ser veículo legítimo da expressividade de sua época e de seu meio, o artista deve estar arraigado nesse meio. Logo, na época da cultura de massa, é justificável uma arte reproduzível, seriada, divulgada. Todavia, não se pode esquecer que a arte é uma linguagem de descoberta, e que também tem uma função conscientizadora, devendo ser sempre renovada na mesma medida em que a sociedade se renova.

De tal modo, o almejado êxito da comunicação, que procura abolir simbolicamente as

${ }^{48}$ Segundo a sociologia e a antropologia são normas de ação ou costumes - aproxima-se do que Bourdieu (1974) designa de capital cultural - ou seja, as convenções tornam possível que uma orquestra funcione com coerência e se comunique com o público (Canclini, 2003: 39). Ou então: regras e normas para o desenvolvimento de um mapa, entre tantos outros exemplos. 
diferenças e os conflitos da existência cotidiana - buscando a acessibilidade do usuário - não priva o artista de constituir sua maneira, seu estilo próprio de representar o mundo, e essas são marcas infalíveis no domínio que exerce sobre os diferentes tipos de arte. Aliás, os princípios estilísticos são cada vez mais redutíveis a princípios técnicos, possuindo um sistema convencional de procedimentos nas diferentes formas de produção erudita - pintura, música, romance, escultura estando fadadas à dialética do refinamento. Essa constatação se refere ao princípio do esforço que os artistas desenvolvem a fim de explorar e esgotar todas as possibilidades técnicas e estéticas de sua arte (Bourdieu, 1974: 111).

Assim sendo, a obra do produtor-artista pode apresentar uma certa segurança estilística, flexível quanto ao entendimento de seu trabalho, que pode ou não ser compreendido pela sociedade em maior ou menor grau.

No caso específico desta pesquisa, o teor de flexibilidade deverá se ater ao contexto histórico atual que vê, entre outras coisas, o grande crescimento e valorização do serviço voltado ao setor turístico, posicionando o mapa - por definir a posição geográfica em que se encontra o local e por atuar como seu divulgador - como um dos grandes aliados (localização e marketing) da localidade. Ainda dentro do contexto histórico, está o estudo cartográfico, que, em sua evolução metodológica e prática, cria, restringe, preocupa-se, experimenta e aprimora tipos de representações que sejam mais favoráveis às capacidades e habilidades do usuário potencial, sempre contando com novos recursos técnicos e materiais.

Desse modo, existe uma justificativa coerente para que se trabalhe com mapas turísticos que utilizam amplamente os símbolos pictóricos, índices e ícones, mesmo havendo uma resistência teórico-metodológica quando comparados aos mapas convencionais. Todavia, é fato a existência e produção desse tipo de "mapa artístico". Tal material, na maioria das vezes, é desenvolvido por pessoas que não têm preocupação com a qualidade cartográfica, tanto que freqüentemente, tais materiais nem poderiam ser chamados de mapa ${ }^{49}$. Por isso, ninguém melhor que um cartógrafo para buscar soluções coerentes a esse tipo de material utilizado pelas destinações turísticas.

Fiori (1999 e 2003) pôde perceber que o uso da pictografia, quando bem utilizada, configura-se como uma forma de comunicação cartográfica alternativa para o mapa. O mais importante é que o cartógrafo tenha consciência, respeito pelo limites estilísticos idealizados durante a elaboração de suas representações. Logo, a

\footnotetext{
${ }^{49}$ Grande parte dos "mapas" apresenta muitas deficiências cartográficas tais como: ausência de escala, deficiência no sistema de referências (latitude/longitude e direções cardeais), legendas pobres ou confusas, descaracterização da base cartográfica (sendo flagrante, por exemplo, a omissão de grande parte das ruas, rios, trilhas); as ilustrações são empregadas de uma maneira pobre e sem criatividade (pois provavelmente foram tiradas de algum arquivo de figuras, sendo, em seguida, copiadas e coladas várias vezes), etc. Ver Fiori, 2003: 125-127.
} 
prioridade é oferecer ao usuário códigos estéticos que sejam pré-conhecidos por ele, mesmo que superficialmente.

O mapa turístico é configurado por uma dualidade: primeiro objetiva informar sobre as atrações - quer naturais quer culturais - as atividades e as áreas de apoio (infraestrutura) de uma determinada destinação, localizando-as no espaço. Contudo, como já citado anteriormente, também pode ser um subproduto de sua utilidade, servindo como instrumento publicitário ou pôster (suvenir) para decorar um quarto, um restaurante, uma loja, etc.

A autora ainda pontifica (Dondis, 1991: 184) que os objetivos dos meios visuais se misturam, interagem e se transformam. Para que se compreendam os meios de comunicação visuais, é preciso haver um conhecimento sobre eles, fundamentandose num critério de grande amplitude. As respostas a questionamentos sobre as motivações que levaram o artista a conceber e produzir um dado objeto são fluidas e, portanto, as perguntas também devem ser. O idealizador ou o artista deve, então, interrogar a natureza de cada meio de comunicação que utiliza em seu trabalho, a função ou níveis de função, a adequação, a clientela a que se destina e, por último, o porquê histórico do produto.

Um outro ponto ressaltado por Canclini (1984: 54) deixa claro que a arte, como toda a linguagem que quer ser comunicada, deve ater-se a códigos produzidos e manejados socialmente. Deste modo, sendo a arte ${ }^{50}$ resultado da vida em sociedade, pelo menos desde as vanguardas do século XIX - por um lado participando da marcha histórica e, de outro, pelo simples prazer da invenção - sofre condicionamentos, leis, necessárias à ordem vigente. No entanto, mesmo condicionada, o que a distingue de outros modos de transformação da realidade material e cultural é que a arte não resulta só de privações, sendo foco de criatividade e de iniciativa social. Procura mudar a realidade, indo além das leis, contribuindo, assim, para a ampliação no campo do possível (Canclini, op.cit.:33).

O autor (Canclini, op.cit::35) ainda enfatiza que a atividade artística é produtiva por se apropriar da realidade por meio do trabalho, buscando satisfazer uma necessidade social, de acordo com a ordem vigente de cada sociedade. Essa definição parece-nos a mais válida em razão de sua capacidade de abarcar a totalidade do processo artístico e de suas modalidades em diferentes sistemas econômicos e culturais.

Baseando-se em um exemplo do autor, pode-se presumir que um mapa turístico pictórico interativo procura ser bem aceito pela sociedade. Para isso, faz uso e se apropria de algum modo da matéria-prima - imagens, sons, fatos históricos, paisagens - e a reelabora com seu trabalho, que, no caso desta pesquisa, configurase em um meio digital da localidade turística.

50 Dondis (1991: 9) apresenta os "extremos" representativos de artes, ou seja, de um lado àqueles referentes às belas-artes até as artes aplicadas: pintura, escultura, arquitetura, artesanato, fotografia, artes gráficas e desenho industrial. 
O trabalho ainda é fixado em padrões formais, como acesso rápido a cada link (tempo), características técnicas padronizadas (como se dá apresentação no monitor do computador, acesso pela linha discada ou banda larga), custo, etc.

Segundo Canclini (1984: 103), esse momento histórico permite que os artistas vivam de seu trabalho. Em contrapartida, precisam submeter suas obras à homogeneidade dos preços e às determinações estéticas dos usuários. Esta homogeneização resulta do processo sócio-econômico que acabou sujeitando o artista ao intercâmbio comercial, ou seja, um mesmo tipo de produto feito em São Paulo se parece com o de Nova York, Roma ou Tóquio. Nessa perspectiva, é evidente que a arte é produzida sob uma máscara promissora de uma expressão universal, porém sofrendo forte influência da arte dominante, cuja universalidade é a do sistema capitalista. Outrora os artistas sujeitavam-se às igrejas e às cortes, hoje dependem do mercado.

Deste modo, é essencial que o produtor do mapa tenha a clara consciência de como seu material será utilizado pelo usuário e deve procurar maneiras para que ele seja aceito e compreendido por diferentes povos e culturas. Contudo, deve busca ir além, fazendo uso de seu conhecimento científico e técnico na área da cartografia e de sua criatividade como artista, buscando encontrar um meio termo, senso comum na elaboração de mapas específicos para o setor do turismo não partindo daquelas idéias já usuais dos mapas convencionais.

Entretanto, é bom frisar que o cartógrafo do mapa turístico - que busca um produto híbrido entre as técnicas convencionais e a pictografia - deve estar sempre atento e preocupado com as regras cartográficas essenciais, como a escala, referências geográficas e legendas coerentes. Levando-se em consideração pesquisas anteriores (Fiori 1999 e 2003), justifica-se que o atual trabalho enfatize o uso da pictografia e seu recurso de tornar as informações mais emotivas, atrativas, sedutoras.

Wolfgram (1994: 104) concorda que o desenho reflete a emoção da mensagem de maneira muito mais rápida do que as palavras, quase sempre garantindo sem interrupções a atenção do usuário em uma apresentação. Mesmo assim, o desenho é um dos recursos mais negligenciados. Porém se alguém é compelido a apreciar uma apresentação visual, a mensagem tem muito mais oportunidade de ser transmitida.

Em geral, o desenho é um meio de conhecimento do mundo, ou seja, de tudo o que se representa. Também pode ser chamado de ilustração ou pictografia. Constitui-se um meio de expressão, um tipo de linguagem, que possui como característica fundamental alguma(s) semelhança(s) física(s) com o fenômeno representado, isto é, com formas que estão no mundo real como, por exemplo: um objeto ou uma paisagem. Cabanellas (1976: 5) sustenta que o desenhista desenvolve esses conteúdos, tendo consciência de que não são uma réplica do real, mas sim uma expressão equivalente, formal, de alguns fenômenos que são sentidos ou percebidos.

O desenho possibilita uma forma de manifestar as relações, sensações do eu com o ambiente. Permite ao desenhista representar parcialmente o que sabe do mundo que 
o rodeia, expressando atitudes, sentimentos, conhecimentos. Contudo, devem-se encontrar maneiras que sejam capazes de produzir essas mesmas "sensações" no expectador, fazendo uso das linhas, formas, perspectivas, cores, manchas agitadas ou serenas, espaços abertos ou fechados, etc (Cabanellas, 1976: 5).

Desenhar é um ato de criação, onde o artista busca soluções novas e coerentes para se comunicar, e é esta sua faceta humana mais importante, porque não se pode esquecer que a humanidade sempre contribuiu com novas soluções para aquilo que se apresenta. De acordo com Cabanellas (op.cit:: 6), na intenção representativa da realidade, 0 produtor escolhe o tipo de desenho mais adequado, tendo como referência uma determinada finalidade. Assim, a ilustração pode ter um caráter estético ou representativo e, dentro deste último caso, pode estar ou não sujeito a normas e convenções. A representação obedece ainda a leis distintas segundo as formas que se desenham: geométricas ou naturais (figura 44). O mapa pictórico trará em seu desenvolvimento tanto intenções estéticas quanto representativas.

Figura 44 - Maneiras de se elaborar um desenho

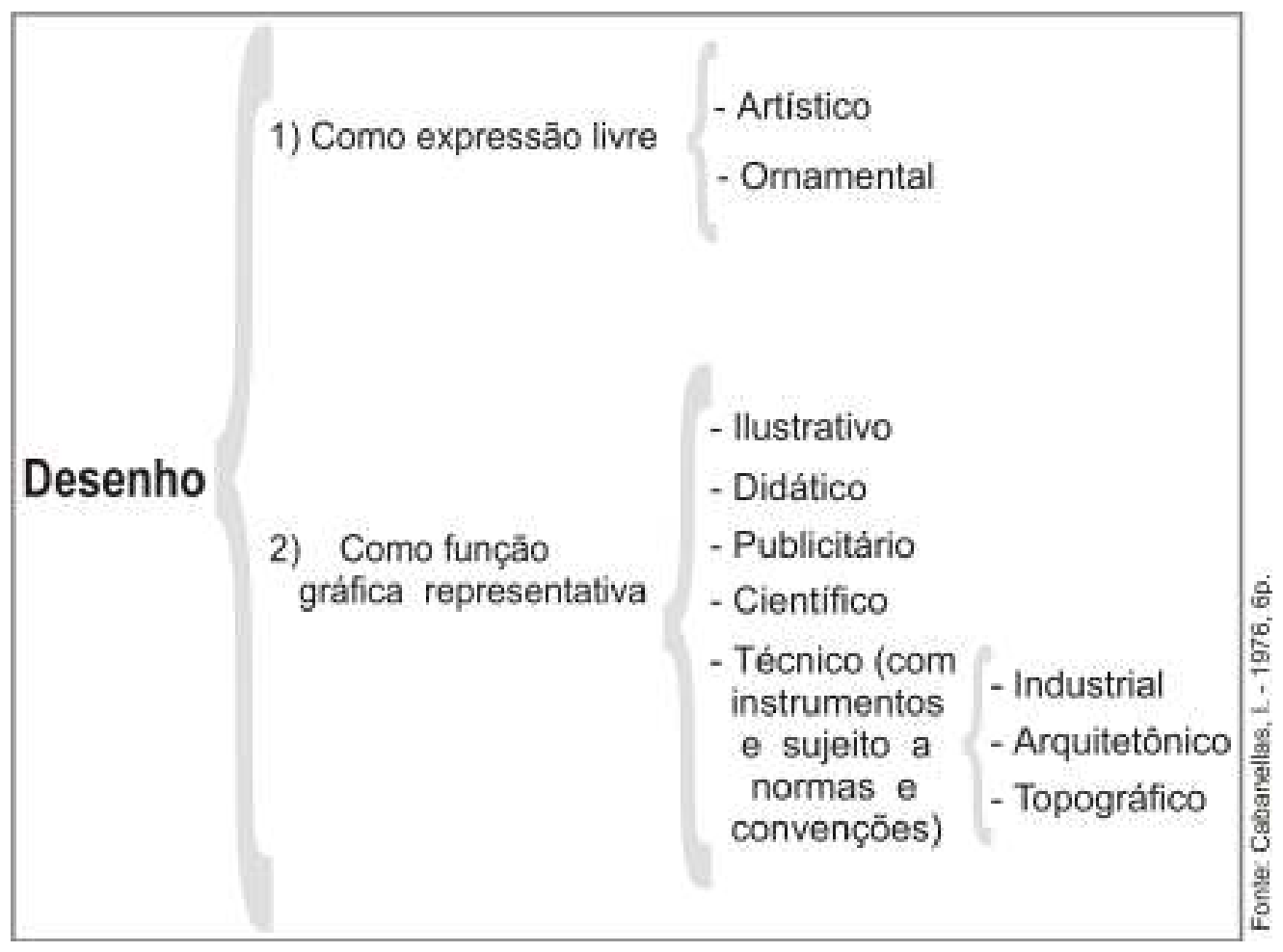

E, em todo o processo de idealização e confecção de um ou um conjunto de desenhos, a arte e a cultura são itens preponderantes, pois o plano pictórico - uma folha de papel, por exemplo - faz uso de leis e princípios voltados ao plano da linguagem para que a ilustração possa ser confeccionada - é resultado do conjunto de contextos mentais de uma dada época e sociedade. Isto porque, como foi abordado, a cultura e a comunicação são dependentes de uma interação entre as expectativas, observações, hábitos e padronizações que fazem parte do cotidiano 
humano.

Fica evidente que qualquer forma de ilustração resulta de escolhas, recortes e enfoques de porções da realidade (plano concreto) que são previamente estabelecidas pelo desenhista. Feito isso, inicia-se um processo de representação, procurando conceber as melhores relações de proporção, angulação e simplificação do elemento focalizado. A seguir se demonstram três tipos diferentes de representação pictográfica (Figuras 45 A, 45 B e 45 C).

Figura 45 - Três tipos de representações pictóricas

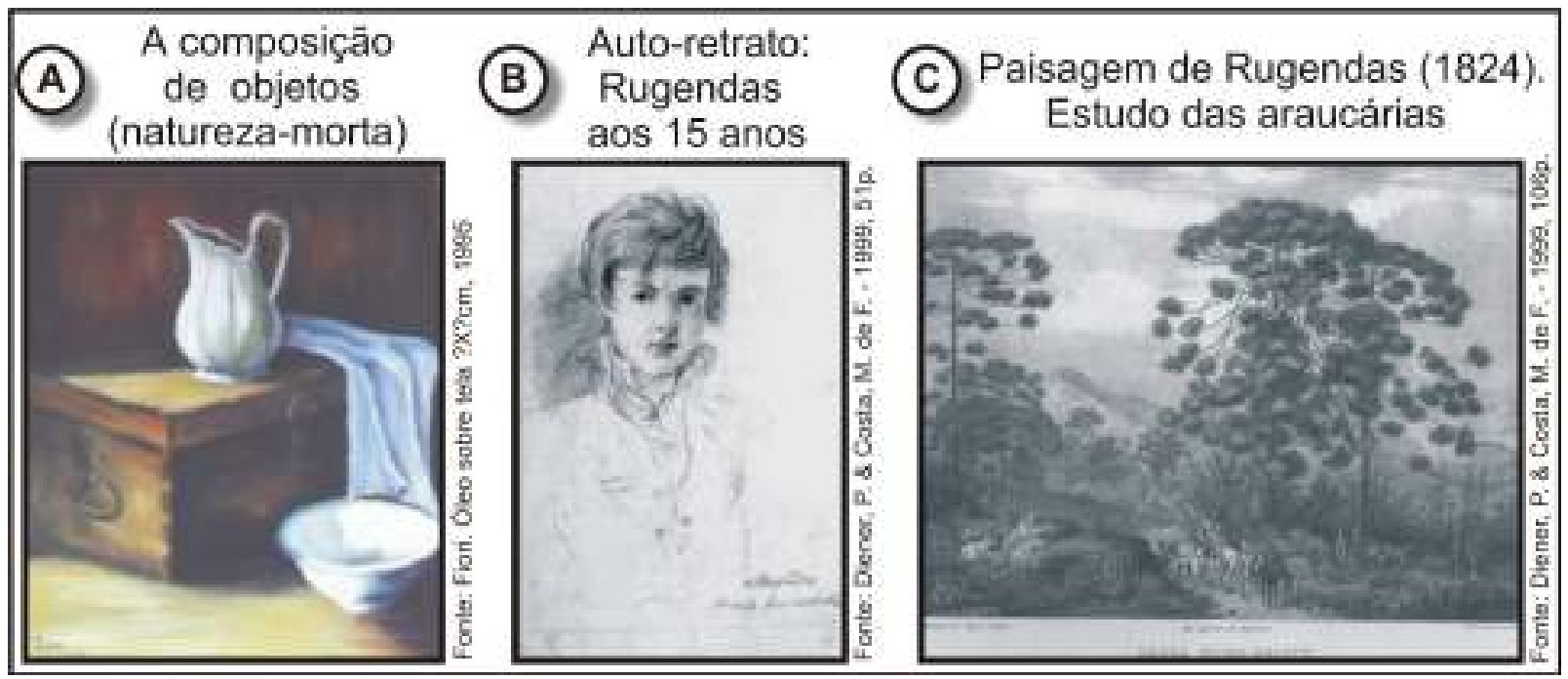

De acordo com trabalhos anteriores (Fiori, 1999 e 2003), e sempre buscando um maior aperfeiçoamento para os mapas turísticos pictóricos, a atual pesquisa preocupa-se em elaborar desde representações pictográficas nomeadas de naturais e relacionadas à topografia (apoiada em bases sistemáticas - convenções), à geomorfologia, à hidrografia (referindo-se principalmente à morfologia do terreno) e à biogeografia (desenhos e ilustrações da fauna e flora), até as representações nomeadas de culturais, relacionadas à história (também lendas e curiosidades), à arquitetura, ao artesanato, à culinária típica e à infra-estrutura de lazer (tipos de esportes, vistas panorâmicas, etc.). Acrescentem-se os símbolos de informação pública, comuns a qualquer tipo de localidade, os quais informam, por exemplo, sobre locais de hospedagem, abastecimento, locadoras de veículos, comércio em geral entre outros dados. Por fim, as representações gráficas da paisagem, com seus ícones e símbolos, terão ainda o apoio de texto, legendas, o título central, as referências geográficas, as bordas e os mapas-detalhe.

Neste momento, é necessário abordar, mesmo que brevemente, mais um conceito: a estética. Canclini (1984: 32) afirma que a estética se preocupa em como as representações serão "materializadas", sempre levando em consideração as culturas, os modos de produção e as classes sociais. O tempo (história) proporciona outras 
descobertas estéticas, nutridas e geradas pelo desenvolvimento social e tecnológico, sendo a inspiração resultado da interação dialética com o meio. Sendo a estética condicionada pela História, os limites entre o "bom e o mau gosto" são por vezes ditados unicamente pelas convenções de uma época (Mukarovsky, 1981:128).

Ao tratar das escolhas e da elaboração dos vários itens que culminam no mapa final, Mukarovsky (op. cit.:125) ressalta a importância da estética, que se configura como atriz coadjuvante da função prática, por sua capacidade de atenuar conflitos e, por conseqüência, buscar o aperfeiçoamento do aspecto técnico. Todos esses elementos encontram apoio nessa espécie de prazer desinteressado e plácido que acompanha a atitude estética.

Desde Kant até Umberto Eco, a maioria das teorias estéticas afirma que a experiência artística é produzida na relação direta entre um sujeito e um objeto. Nesse diálogo, prevalece à função. Por exemplo, ao pedir um lápis emprestado para anotar um endereço, uma pessoa é atraída por um instante e se detém somente à forma (design) do objeto. Esta percepção é propriamente estética, pois se posterga o ato prático, ou seja, elimina-se momentaneamente a função do lápis. Faça-se aqui uma ressalva à afirmativa feita anteriormente, segundo a qual a forma predomina sobre a função, pois ela não é válida para todas as épocas. Refere-se somente a trabalhos artísticos produzidos a partir do sistema capitalista, que proporcionou a autonomia de certos objetos ou de certas qualidades de alguns objetos (Canclini, 1984: 10-12).

Canclini (1984: 25) prosseguiu informando que devido à facilidade de produzir vários tipos de formas para uma mesma função - por exemplo, diversos mapas de uma mesma localidade que a divulgam como localidade turística - o estilo e a freqüência das obras do artista são determinados pelas exigências do planejador e do usuário.

A inovação estética também foi deslocada para as tecnologias eletrônicas, tornando a comunicação mais fácil e rápida. Antes havia formas artesanais ou eruditas, porém hoje se oferecem recursos técnicos que podem gerar hipertextos e rápidas edições audiovisuais ou eletrônicas. Há dez anos, conhecer, utilizar e misturar as inovações de diferentes países resultava em viagens freqüentes, assinaturas de revistas estrangeiras e vultosas contas telefônicas. Atualmente, deve-se renovar periodicamente o equipamento do computador e ter um bom serviço de Internet (Canclini, 2003: XXXVI). Assim:

as modalidades clássicas de fusão, derivadas de migrações, intercâmbios comerciais e das políticas de integração educacional impulsionadas pelos Estados nacionais, acrescentam-se às misturas geradas pelas indústrias culturais (Canclini, 2003: XXXI).

Isto faz com que o ser humano viva cada vez mais em um mundo fluido, interconectado por conjuntos históricos com maior ou menor estabilidade, que se reestruturam em meio a conjuntos interétnicos, transclassistas e transnacionais. Acentua-se a interculturalidade (migratória, econômica e midiática) gerando mercados 
de bens materiais, mensagens e migrantes, propiciando mais formas de hibridismo produtivo, de comunicação e de estilos de consumo (Canclini, 2003: XXIII, XXIV).

A arte e o seu significado mudaram profundamente na era tecnológica: o grande problema é que a estética da arte não deu resposta às modificações. Ocorreu exatamente o contrário, enquanto o caráter das artes visuais e sua relação com a sociedade modificaram-se drasticamente, a estética da arte tornou-se ainda mais estacionária (Dondis, 1991: 27).

Nesse momento, torna-se importante introduzir o conceito de hibridação, ou seja, parte-se do pressuposto de que os processos socioculturais nos quais as estruturas ou práticas discretas ${ }^{51}$ - que existem de forma separada - se combinam para gerar novas estruturas, objetos e práticas. Aborda-se a produtividade e o poder inovador de muitas misturas interculturais, acostumadas a receber diferentes nomes como: sincretismo entre o artesanal e o industrial, o culto e o popular, o escrito e o visual, entre outros temas. Por exemplo, pode-se citar a mudança de imaginário e, conseqüentemente, das representações pictóricas entre as realidades dos períodos pré-colombiano e novo-hispano (figura 46). E posteriormente, com o surgimento das indústrias culturais, o website (o hybridspace) cruza a multimídia e as múltiplas culturas apresentando em um ambiente comum a todos: a Internet, a diversidade cultural de países como Argentina, Brasil e Estados Unidos (Canclini, 2003: XIX, XX).

Freqüentemente a hibridação surge da criatividade individual e coletiva. Não só nas artes, mas também na vida cotidiana e no desenvolvimento tecnológico. Busca-se reconverter ${ }^{52}$ um patrimônio (uma fábrica, uma capacitação profissional, um conjunto de saberes e técnicas) para reinseri-lo em novas condições de produção e mercado (Canclini, 2003: XXII).

Propõe-se, então, reconverter o design cartográfico dos mapas holandeses do século XVII, somando-o á utilização de bases topográficas sistemáticas - já produzidas no século XVIII - e às pinturas panorâmicas do século XIX. Adicionando, finalmente, o uso dos recursos informacionais advindos dos satélites, os digitais e os audiovisuais, explorados principalmente nos últimos vinte anos; com o progressivo aumento da internet e da animação em todo o mundo. Enfim, mesmo fazendo uso de toda a tecnologia possível, o produto final a ser elaborado nesta pesquisa deve manter um ar de artesanal, único, gerando um produto de grande auxílio - prático e promocional - ao setor do turismo.

Recorde-se palavras de Canclini (2003: 253) ao abordar a problemática pós-moderna, no sentido de que o moderno se fragmenta e se mistura com o que não é moderno.

\footnotetext{
${ }^{51}$ É resultado de hibridação, pois não podem ser consideradas fontes puras. Isto porque, ao longo da história, o ser humano passa de formas mais homogêneas a outras mais heterogêneas e vice-versa, sem que nenhuma seja plenamente pura (Canclini, 2003: XIX, XX).

${ }^{52} \mathrm{O}$ termo é usado para explicar as estratégias mediante as quais um pintor se converte em designer, os operários que reformulam sua cultura de trabalho ante as novas tecnologias produtivas, etc. (Canclini, 2003: XXII).
} 
Atualmente, os artistas usam tecnologias avançadas e, ao mesmo tempo, olham para o passado no qual buscam certa densidade histórica ou estímulos para imaginar.

\section{Figura 46 - A mudança das representações icônicas ao longo do tempo e cultura}

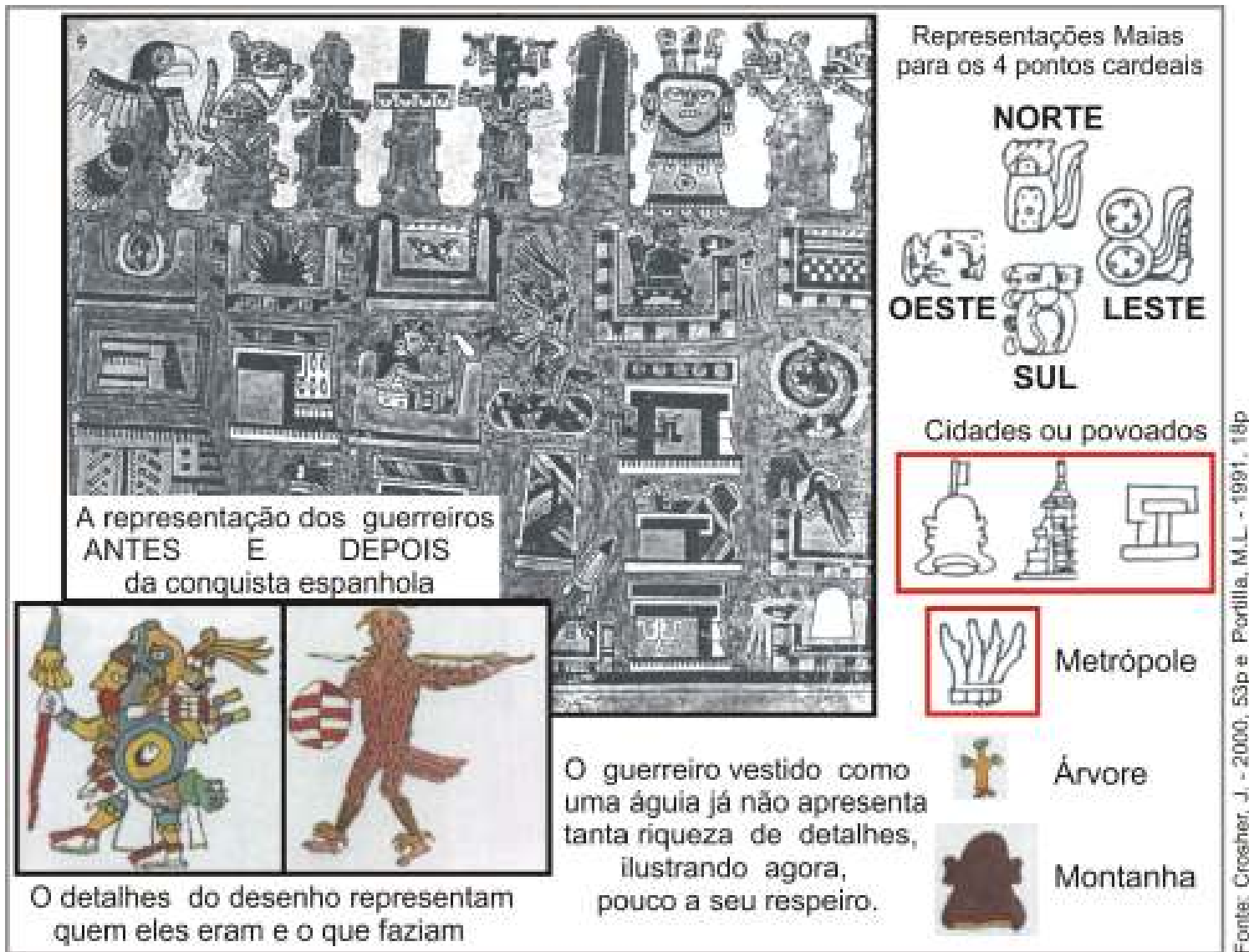

Por essas razões, sustenta-se que o objeto de estudo nesta pesquisa não é a hibridez, mas sim, os processos de hibridação. A análise empírica desses processos, articulados com estratégias de reconversão, demonstra que a hibridação interessa tanto aos setores hegemônicos como aos populares, pois ambos querem se apropriar dos benefícios da modernidade (Canclini, 2003: XXII).

Um último e importante enfoque a ser exposto tendo como resposta o grande uso da pictografia em mapas turísticos diz respeito ao problema da subjetividade, problema apontado ao longo de todo o trabalho como potencial e inerente a este tipo de representação gráfica.

Partindo desta afirmação, pode-se afirmar que a alfabetização pela linguagem verbal (aprendizagem da leitura e escrita) é mais eficaz do que a linguagem visual?

De uma maneira geral, Dondis (1991: 15) ressalta que, devido a sua estrutura sintética, pela linguagem verbal as pessoas se alfabetizam em um processo dividido 
em etapas, contando com uma estrutura relativamente bem organizada. Primeiro se aprende um sistema de símbolos, representados por formas abstratas de determinados sons (grupo de símbolos sonoros): o alfabeto. $O$ segundo passo é aprender as combinações das letras e de seus sons, formando assim as palavras, que se constituem como representantes ou substitutos das coisas, idéias e ações. Por fim, aprende-se uma sintaxe comum (língua específica: português, inglês, japonês, húngaro) que limita o alfabetismo verbal e, mesmo em sua forma mais simplificada, representa uma estrutura dotada de planos técnicos e definições consensuais.

Entretanto, é exatamente aí que o alfabetismo visual tem uma força especial, pois a linguagem verbal encerra-se em um grupo de pessoas que compartilha o significado atribuído a um corpo comum de informações. Todavia, de acordo com Dondis (1991: 16) existem mais de três mil línguas em uso corrente no mundo, todas elas mais ou menos independentes e únicas. Conseqüentemente, em termos comparativos, a linguagem visual é considerada mais universal, por fazer uso de conjuntos lógicos. Faça-se aqui um destaque quanto à enorme importância que esta autora confere ao uso da palavra alfabetismo em conjunção com a palavra visual. Segundo suas palavras, mesmo a visão sendo natural, a criação e compreensão da mensagem visual são naturais até certo ponto, pois sua total eficácia só pode ser alcançada por meio do aprendizado. Expandir a capacidade de "ver" (formar imagens mentais) significa ampliar a capacidade de entender e criar uma mensagem visual.

A informação visual advém de significados obtidos pelo ensino formal e informal, que são paulatinamente incorporados pelo indivíduo a partir de experiências compartilhadas no ambiente e na vida, fazendo com que ele possa manter uma relação mais competente com o mundo. Compartilha-se, por exemplo, o mundo da natureza: o céu azul, o mar verde-esmeralda, as árvores verticais, a areia áspera, a terra úmida, o fogo vermelho-alaranjado-amarelo, a noite e o dia (claro-escuro).

Essas são apenas algumas qualidades denotativas possíveis de serem indicadas e que são compartilhadas visualmente em sociedade. Existe também o mundo criado: as cidades, os aviões, as casas e as máquinas, as manufaturas e outras tecnologias modernas. A humanidade aprende instintivamente a compreender e a atuar psicologicamente nesses mundos e, intelectualmente, convive e opera com esses ambientes e objetos necessários a sua sobrevivência. Deste modo, conscientemente ou não, a sociedade responde com alguma conformidade o significado desses elementos (Dondis, op. cit.: 32; 85).

Dondis (op. cit: $85-86$ ) ratifica que tanto instintiva quanto intelectualmente grande parte do processo de aprendizagem é visual. A reprodução desse tipo de informação deve ser acessível a todos, sendo ensinada e podendo, portanto, ser aprendida. Porém é preciso sempre observar que, na aprendizagem visual, não existe um sistema estrutural arbitrário e externo semelhante ao da linguagem verbal. Então, de que maneira a comunicação visual pode ser entendida, aprendida e expressa? 
Parte-se do pressuposto de que a informação visual é facilmente obtida por meio dos diversos níveis de experiência direta ao ato de ver e reconhecer (Dondis, 1991: 8687), como, por exemplo, um pássaro, uma casa, uma bicicleta, uma árvore, uma montanha, uma praia, etc. Essa capacidade ainda amplia o conhecimento da realidade-concreta do indivíduo, que generaliza toda uma espécie a seus atributos básicos, ou seja, o tipo pássaro, casa, homem, mulher, bicicleta, são definidas em termos visuais elementares, podendo ser identificados de uma forma geral. Isto significa que todos os elementos compartilham referências visuais comuns dentro de uma categoria mais ampla. Apesar disso, ao querer representar um elemento em classificações individuais, deve-se trabalhar com os detalhes mais sutis de cor, proporção, tamanho, movimento e sinais específicos (mais linhas) para que se possa distinguir, por exemplo, uma gaivota de uma pomba ou uma cegonha (Figura 29).

\section{Figura 47 - Maneiras de se representar um pássaro}

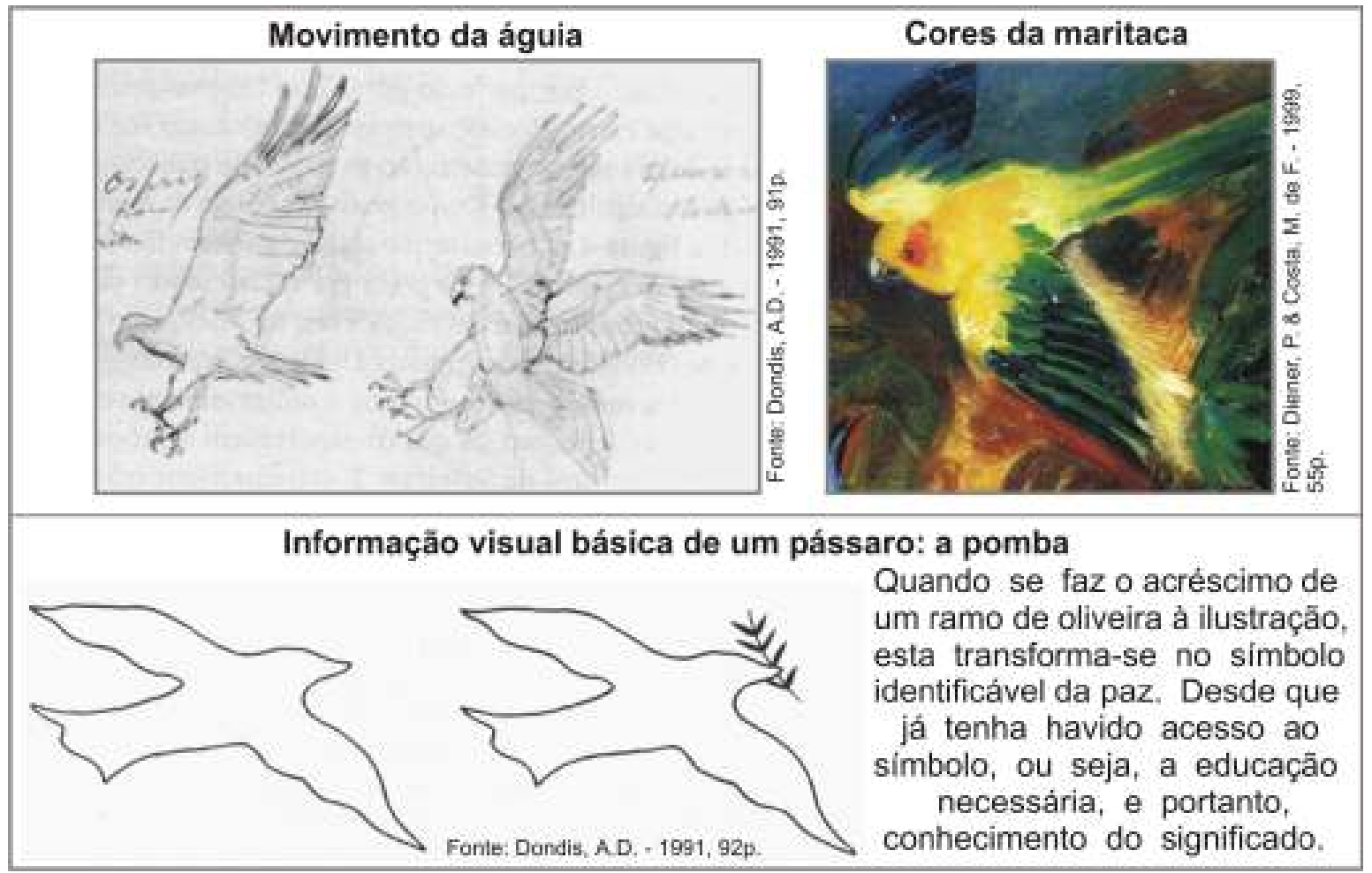

Em relação ao ensino formal, Dondis (1991: 17) critica o sistema educacional (em todos os níveis) por tratar a abordagem visual com quase desinteresse. Métodos construtivos de aprendizagem visual são pouco explorados e ficam a critério da intuição e do acaso, a não ser quando se trata daqueles alunos especialmente interessados e talentosos para o desenho. A sociedade persiste ainda em conferir mais importância à expressão verbal, excluindo o restante da sensibilidade humana. No caso da criança, a experiência visual é fundamental em sua aprendizagem. Posteriormente, a utilização de recursos visuais - filmes, slides, projeções 
audiovisuais - carecem de rigor e objetivos bem definidos no ensino, sendo usados somente como apresentações que reforçam sua experiência passiva. Em suma:

a comunicação visual ficou ao sabor das fantasias e de amorfas definições de gosto, quando não da avaliação subjetiva e auto-reflexiva do emissor ou do receptor, sem que se tente ao menos compreender alguns dos níveis recomendados que esperamos encontrar naquilo que chamamos de alfabetismo no modo verbal (Dondis, 1991: 17).

Todo esse desinteresse atribuído ao sistema visual pode ter como causa dominante a complexidade, pois, mesmo sendo composto de um sistema perceptivo básico (linha, forma, luz e sombra, cor, textura e proporção) comum a todos os seres humanos, tal sistema está sujeito a variações nos temas estruturais básicos. De maneira simplista, pode-se exemplificar o que foi dito acima, pontuando que ninguém desenha da mesma forma um elemento ou ação encontrada na realidade, sem contar as outras nuances constitutivas do desenho, como a perspectiva, a cor, etc.

Segundo Dondis (1991: 19) uma coisa é certa, no geral: o alfabetismo visual jamais poderá ser um sistema tão lógico e preciso quanto a linguagem verbal, pois sua estrutura tem uma lógica que o alfabetismo visual é incapaz de alcançar.

Por outro lado, a compreensão visual é um processo natural. O que precisa ser feito é um refinamento de percepção permitido pelo alfabetismo visual. O caminho não é o mesmo que o da linguagem verbal, onde existe um substituto que precisa ser reduzido de um estado para outro. No ato perceptivo visual ${ }^{53}$, uma maçã é a mesma coisa tanto para um inglês quanto para um francês, ainda que o primeiro a chame de apple, e o segundo de pomme, e assim por diante. Dentro desse contexto, o que a linguagem verbal difere da comunicação visual é a possibilidade de evitar a ambigüidade das pistas visuais, tentando então, expressar as idéias de modo mais simples e direto. Sofisticação excessiva e a escolha de um simbolismo complexo podem trazer dificuldades na comunicação visual intercultural (Dondis, op. cit::186).

Por isso, faz-se necessário cada vez mais o entendimento sobre a comunicação visual, devido a sua inegável força como meio de comunicação. Não se poderá manter por muito mais tempo uma posição de ignorância diante do alfabetismo visual. Dondis (op. cit: $11 ; 185)$ aclara sobre o poder constituído à mensagem visual a partir de alguns casos históricos:

\footnotetext{
${ }^{53}$ Pela percepção visual, a pessoa vivencia uma interpretação direta daquilo que está vendo. Todas as unidades individuais dos estímulos visuais interagem, criando um mosaico de forças saturadas de significado, exclusivo do alfabetismo visual e passível de ser diretamente absorvido com muito pouco esforço, se comparado à lenta decodificação da linguagem vebal (Dondis, 1991: 188). A inteligência visual transmite informação em uma extraordinária velocidade, tanto que, estando os dados claramente organizados e formulados, a informação fica mais fácil de ser absorvida, retida e utilizada referencialmente (Dondis, op.cit::188).
} 
$\checkmark$ Os afrescos de Michelangelo no teto da Capela Sistina foram diretamente influenciados pelo papa, pois as pinturas representam as necessidades que a igreja tinha de informar seus fiéis sobre a história bíblica. Procurou-se, então, uma maneira de explicação visual sobre a "Criação" a um público que, em sua maior parte, era analfabeto; logo, incapaz de ler sobre a história bíblica.

$\checkmark$ Meios visuais com finalidades educativas também foram utilizados na campanha de controle demográfico na Índia, na doutrinação política em Cuba e na identificação de partidos políticos no mundo inteiro.

O exemplo da figura 48 ilustra a importância do elemento visual em uma representação. Portanto, é inquestionável a eficácia da mensagem visual entre as populações que não compartilham da mesma linguagem verbal.

Figura 48 - 0 experimento de Ryan e Schwarz

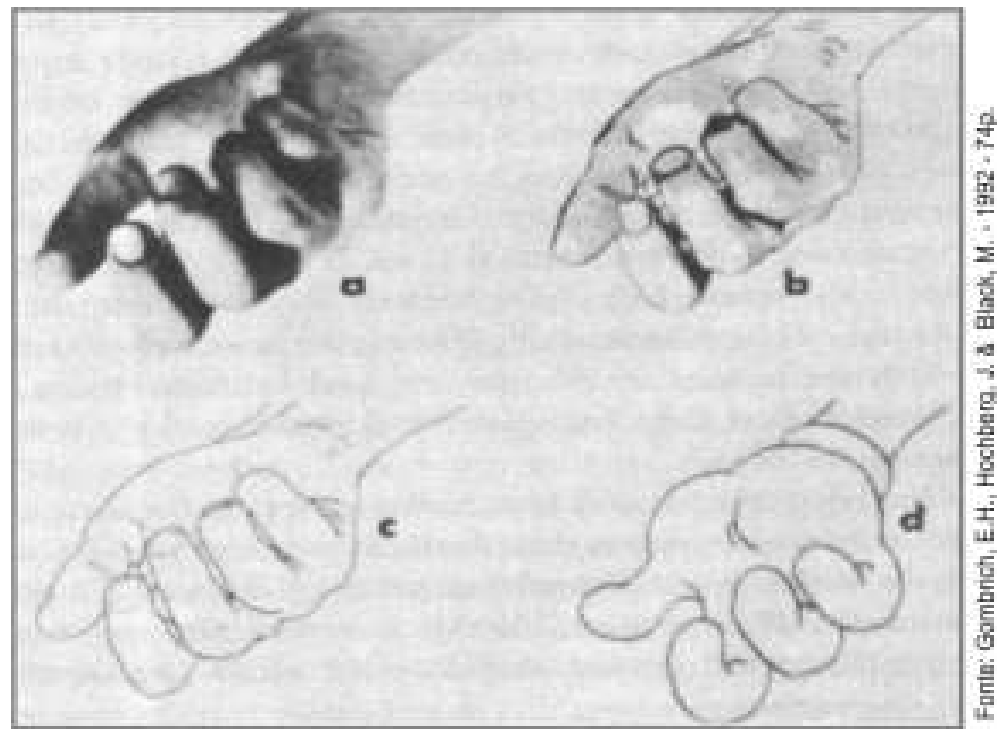

O que deve ser feito é adaptar, aproveitar e melhorar este certo alfabetismo visual buscando abranger o maior número de culturas possíveis. Abre-se então um outro questionamento, alusivo ao tipo de representação que seria mais bem aproveitada na elaboração dos mapas pictóricos turísticos.

Deve-se levar em consideração a experiência direta do observador em qualquer nível da escala de expressão visual - da foto ao esboço impressionista - onde toda experiência do "ver" está fortemente sujeita à interpretação individual, subjetiva. A idéia é utilizar aquelas composições estilísticas mais simples, diretas, genéricas, que possam ter o mesmo tipo de compreensão pelo maior número de pessoas. Pesquisas anteriores (Fiori 1999 e 2003) indicam que o estilo artístico da caricatura de traços simples é um dos recursos visuais mais adequados para a elaboração de mapas pictóricos para destinações turísticas. 
A caricatura tem sido definida desde o século XVII como um modo de representação que objetiva a semelhança em relação ao elemento contido na realidade. Entretanto, nesse processo de transformação, todas as partes componentes - propriedades físicas dos objetos - passam por mudanças. Tanto que a caricatura captura somente a essência do objeto representado - faz possível um vocabulário visual mais compacto - sendo a prova de que as imagens da arte podem ser convincentes sem serem objetivamente realistas (Gombrich, Hochberg \& Black, 1992:1).

Ryan e Schwarz (apud Gombrich, Hochberg \& Black, 1992:74) compararam quatros tipos de representações, tendo como referência o mesmo elemento - uma mão (figura 30), que foi representada em fotografia (a), em desenho sombreado (b), em contorno traçado diretamente de uma fotografia (somente linhas) (c) e em cartoons (desenho, caricatura) (d). As representações eram expostas e recolhidas em pequenos espaços de tempo. O resultado foi o seguinte:

$\checkmark$ O cartoon precisou do menor tempo de exposição se comparado aos outros tipos de representação, obtendo o maior índice de correção quanto a sua percepção. Trouxe uma representação com características marcantes, simples e simplificada do elemento.

$\checkmark$ A fotografia, por possuir um alto grau de fidelidade com o mundo real-concreto, apresenta formas mais complexas e desnecessárias à compreensão do elemento. Por isso, obteve um resultado intermediário, como também o desenho sombreado.

$\checkmark$ Já a representação, que contou somente com o contorno traçado (linha), precisou de maior tempo de exposição para ser compreendida.

A partir de agora serão abordadas as técnicas e elementos gráficos necessários ao desenvolvimento do mapa turístico pictórico. 


\section{CAPÍTULO 2}

Técnicas e procedimentos utilizados na elaboração dos mapas turísticos e do protótipo mapa-site turístico 


\section{1 - As mídias e suas respectivas técnicas: trabalhando a forma e o conteúdo}

A partir das três dimensões do signo: sintática (forma), semântica (conteúdo) e pragmática (função) - ver páginas 91 a 100 - serão realizados estudos, buscando elaborar imagens gráficas eficazes ao desenvolvimento do mapa turístico pictórico. Enfocam-se neste momento somente as duas primeiras dimensões; entretanto, julgase importante destacar que, mesmo com o estabelecimento dos valores sintáticos, semânticos e pragmáticos na elaboração de um mapa turístico pictórico, o material cartográfico não fica imune à subjetividade, pois é uma confecção gráfica cultural.

Para fundamentar a proposta de trabalho, cita-se Souza (1992), que apresenta os signos gráficos em quatro grupos específicos: os diagramas, as redes, as cartas (mapas) e o grupo dos simbólicos. Os três primeiros itens fazem parte de um mesmo grupo, nomeado por Bertin (1967) de Graphique (Gráfica); já o último item está no campo do grafismo. Em essência, esses dois grupos apresentam objetivos e métodos de transcrição distintos ao comunicarem a informação. Devido aos fins buscados por esta pesquisa, serão ressaltados somente dois grupos: o mapa e grafismo (Figura 49).

O desenvolvimento do mapa turístico pictórico se utilizará principalmente das funções caracterizadoras e universais do signo, objetivando um sistema de linguagem que traga boas expectativas de interpretação pelo usuário potencial. A criação de todo o repertório simbólico e gráfico a ser elaborado deve ser denotado satisfatoriamente, buscando atingir o maior número de usuários - o que revela seu caráter universal por serem apreendidos enquanto códigos (Carneiro, 2001:33).

Souza (1992: 123) sustenta que existem técnicas visuais para controle do significado icônico fundamentadas em uma poderosa ferramenta de expressão, que é o contraste entre dois opostos semânticos. Isso porque, o contraste tem a capacidade de intensificar e simplificar a comunicação. Dondis (1991: 129-147) apresenta e Souza (1991: 124-126) sistematiza então as vinte técnicas de composição dotadas de qualidades sintático-semânticas mais habitualmente utilizadas na relação harmonia contraste (figura 50).

Ao se abordar mais especificamente a elaboração de representações gráficas eficazes, um outro recurso essencial é a categorização. Segundo Souza (1992: 129):

Em termos de design gráfico, o processo de categorização atende à necessidade de buscar um efeito visual máximo com um mínimo de elementos estruturais (o ponto, a linha, a superfície...). Descobrindo ou inventando equivalências, o designer conforma os signos gráficos aos atributos que o senso comum, a convenção ou os seus próprios critérios pessoais selecionam como relevantes para a representação de algo. 
Figura 49 - Esquema dos tipos de signos gráficos

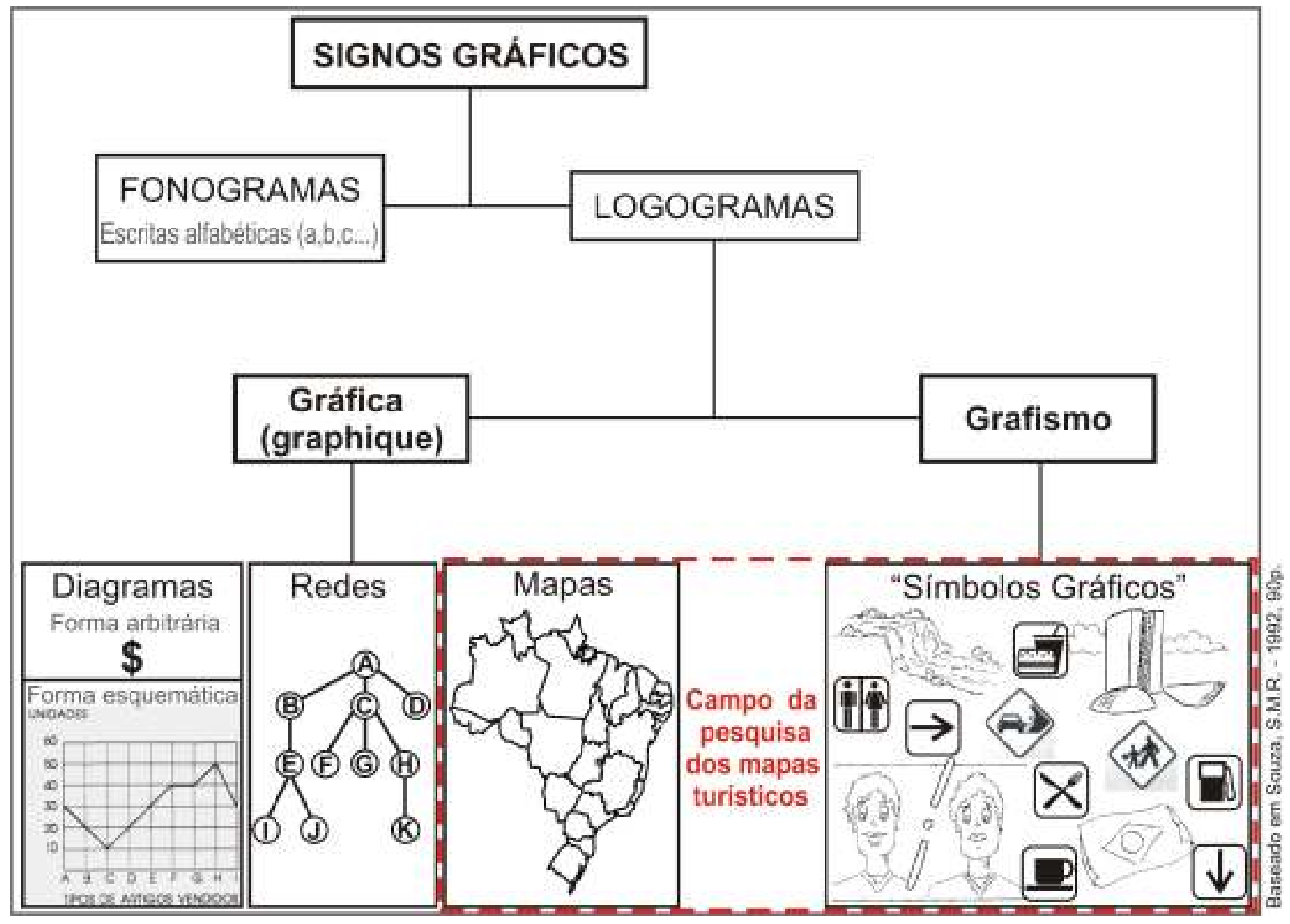

Em um outro momento, Souza (1992: 236) complementa que essa concisão gráfica é resultado de uma redução semântica do conceito aos seus atributos mínimos de discriminação.

Posto isso, leva-se em consideração majoritariamente Dondis (1991: 51-82), Cabanellas (1976), SENAI (1984) e anotações feitas ao longo de cursos de desenho e pintura ${ }^{54}$. Apontam-se, a seguir, a sintaxe básica dos elementos visuais.

\section{1) A linha}

A linha é um dos elementos visuais básicos em uma obra plástica. Suas características intervêm diretamente em uma representação. Cabanellas (1976: 22) afirma que, sendo a linha um instrumento gráfico, ela habilita o produtor a comunicar a situação exata do corpo no espaço, além de auxiliar a criação dos campos de ação e de movimentos. Por meio das linhas, pode-se ainda definir, limitar, de maneira fluente e incansável, infinitos tipos de formas: reta ou ondulada, fina ou delgada, precisa ou indefinida, etc.

${ }^{54}$ Por um ano e meio, tive aulas regulares de desenho mecânico em um curso do SENAI. Posteriormente, ao longo de alguns três anos fiz parte de cursos de pintura (óleo sobre tela). E, já no mestrado, por quase um ano fiz um curso de história em quadrinhos. 
Figura 50 - As qualidades sintático-semânticas dos signos gráficos

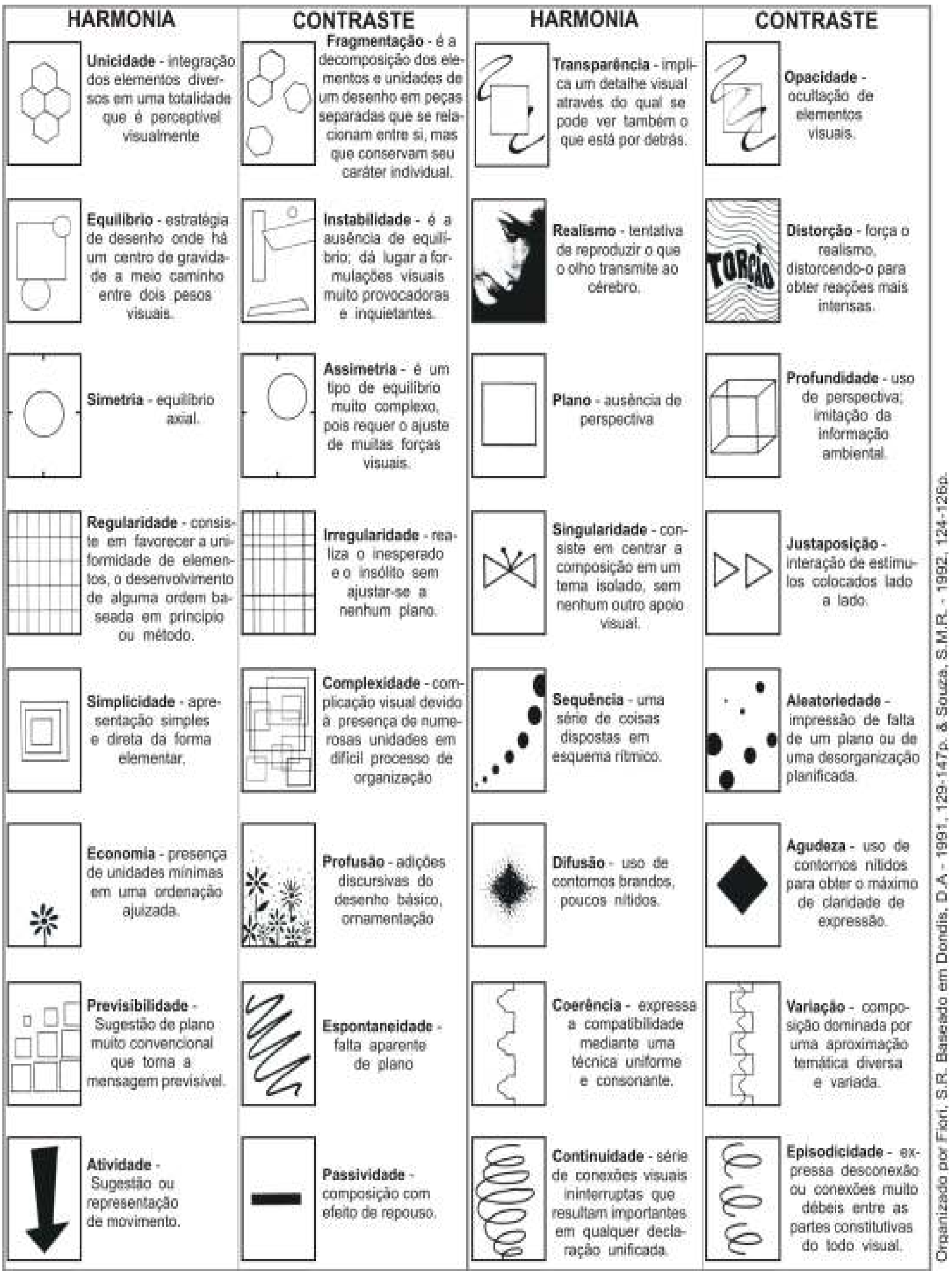


Essa flexibilidade inerente à linha faz com que se possa elaborar desde um solto e despreocupado esboço, até a rigidez de um desenho técnico (Figura 51).

Figura 51 - A linha

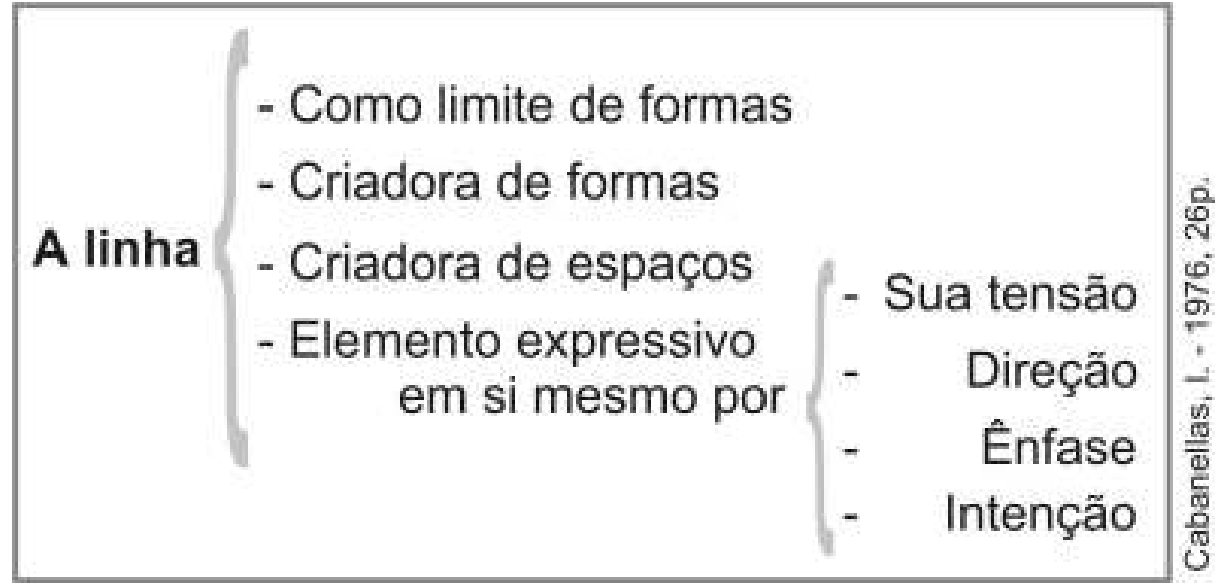

Mesmo com toda sua importância, a linha é o único dos elementos visuais aqui abordados que não existe no plano concreto, existindo verdadeiramente somente no plano pictórico.

$\mathrm{Na}$ verdade, aprende-se a ver as linhas por conseqüência de um aprendizado intelectual, resultado da autoridade institucionalizada (no caso, a escola) apontada por Bourdieu (2000). Ela tem origem em uma seqüência de pontos (reta) - Figura 52 - apresentando apenas uma dimensão, o que já a capacita estabelecer a diferenciação entre fundo e a figura, relação essencial da linguagem visual.

Figura 52 - Como se origina uma linha

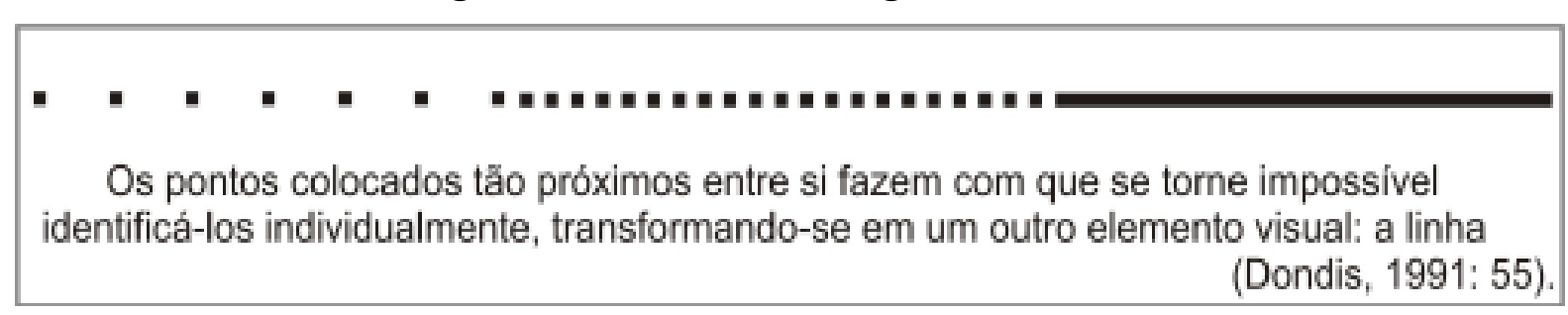

Dondis (1991: 56) refere-se à linha como um instrumento fundamental à prévisualização por ser um meio que apresenta, em forma palpável, aquilo que ainda só existe na imaginação. Contribui, portanto, sobremaneira para o processo visual. $\mathrm{Na}$ arte, a linha é o elemento fundamental ao desenho, por capturar a informação visual, reduzindo e eliminando toda informação visual supérflua. A figura 53 apresenta exemplos distintos de como a linha pode ser trabalhada. 
Figura 53 - A linha e suas possibilidades de expressão
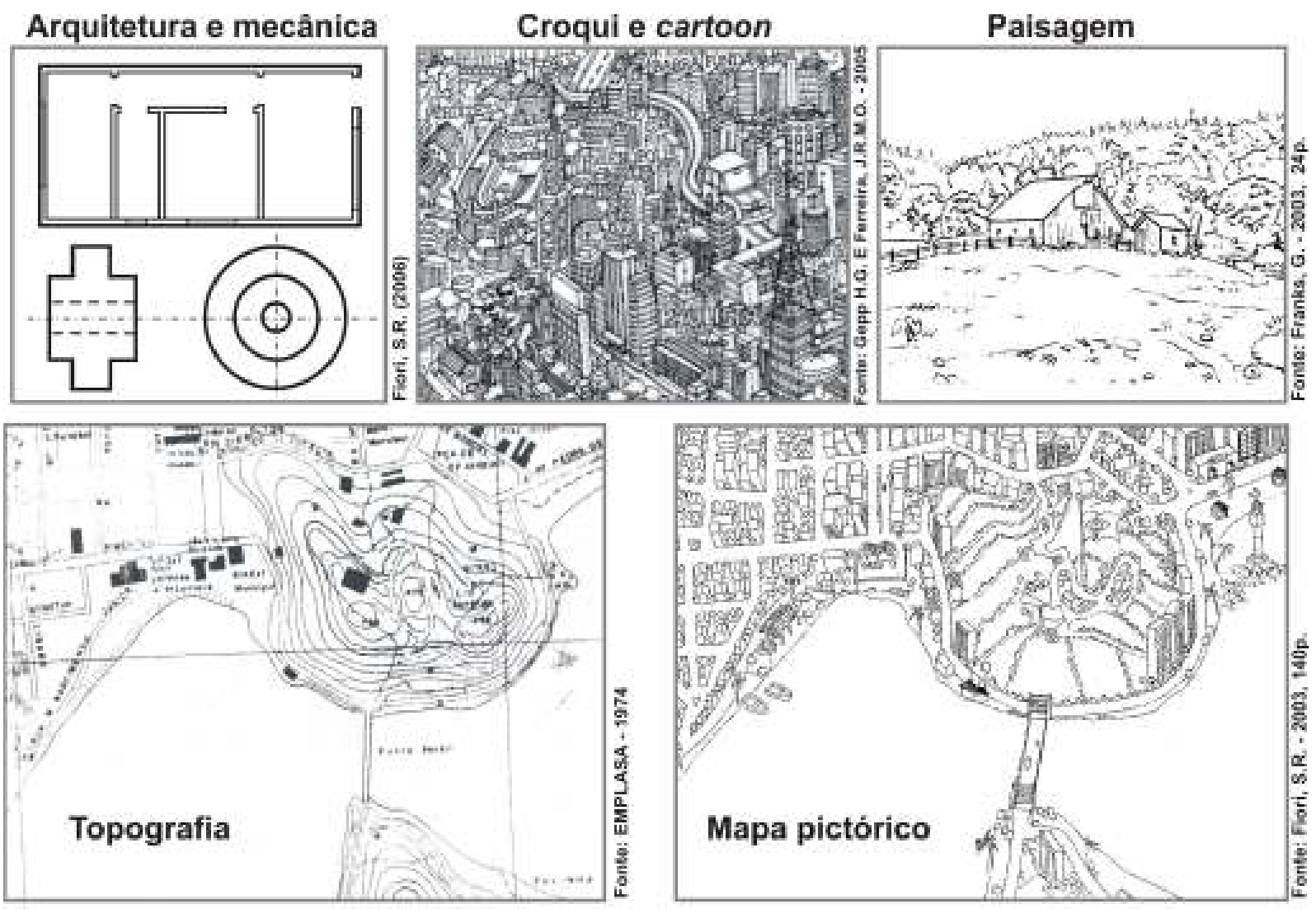

\section{2) A forma: o plano, o volume e a sensação de dimensão}

Como ficou sugerido acima, a linha é capaz de conceber formas. E essas formas já vêm carregadas de significação, pois não são simplesmente observadas, vistas, mas sim lidas, traduzidas, reproduzidas. Conseqüentemente, a impressão que se tem das coisas é terciária e nos vem indiretamente, já manipulada, pela memória ou pelo hábito (Pedrosa \& Arantes, 1996: 142,143).

Dondis (1991: 57) distingue três formas básicas: o quadrado, o círculo e o triângulo eqüilátero, as quais possuem características específicas, e a cada uma atribui uma grande quantidade de significados, alguns por associação, outros por vinculação arbitrária, e outros, ainda, através de nossas próprias percepções psicológicas e fisiológicas. Essas formas permitem combinações e variações infinitas e possibilitam compor outras formas físicas da natureza e da imaginação humana (Dondis, 1991: 59). O exemplo a seguir (Figura 54) remete à cena de em uma feira livre.

Esse discurso ainda leva em consideração que é inerente, à maior parte das formas, apresentar a dimensão e o volume ocupado no espaço, ou seja, a representação de um elemento necessita de técnicas preocupadas em ilustrar as formas tridimensionais (comprimento, largura e altura), mesmo que estejam compreendidas em um plano 2D, 
onde só possuem comprimento e largura, caso dos mapas pictóricos turísticos.

Figura 54 - Feira livre: formas básicas de uma representação gráfica

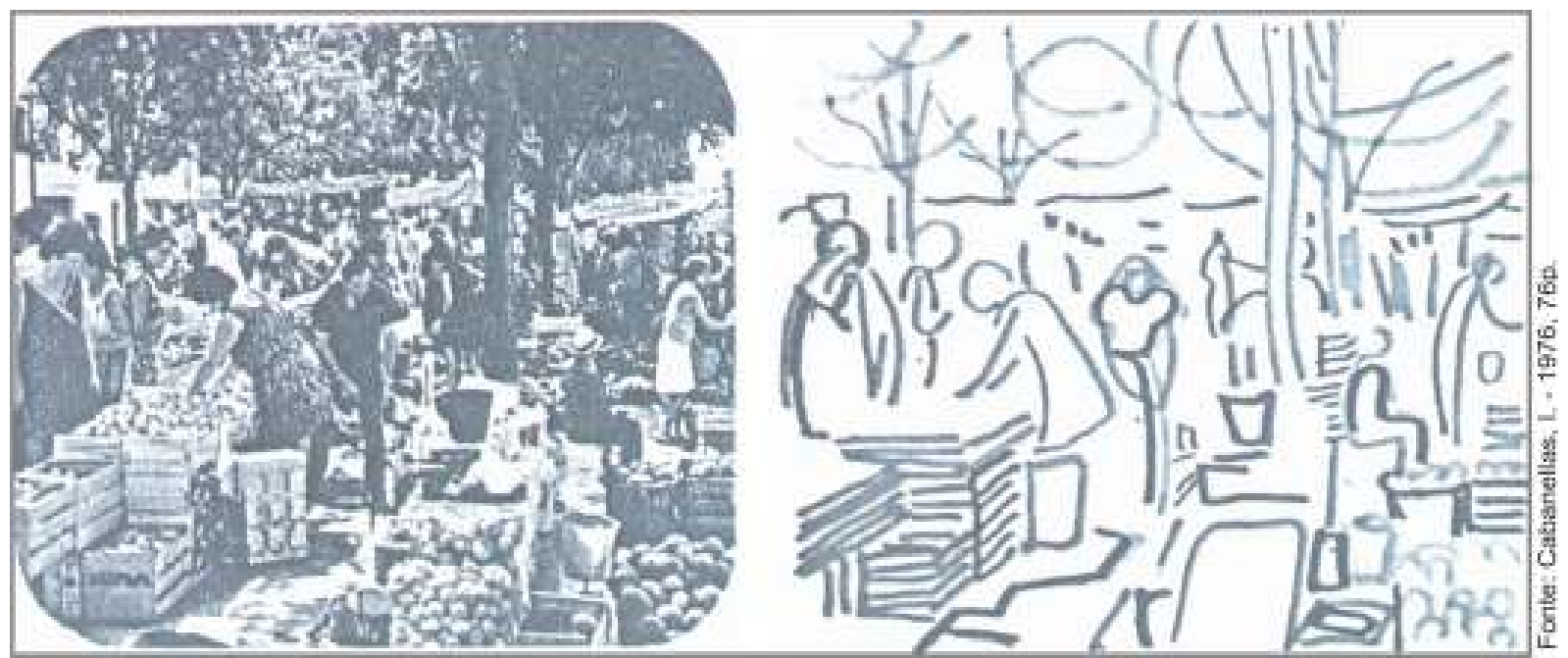

Dondis (1991: 75) esclarece, então, que o ilustrador faz uso do ilusório para dimensionar a representação em formatos visuais de natureza bidimensional. Graças a esse recurso, que é subentendido pelo observador uma vez que ele não possui uma dimensão real da representação, o aspecto ilusório pode ser reforçado de muitas maneiras. O principal artifício para simulá-lo é a convenção técnica da perspectiva, sendo que a intensificação da ilusão pode ocorrer de forma ainda mais forte ao se fazer uso da variação tonal (claro-escuro), enfatizando a luz e a sombra.

Dessa maneira, apoiados no desenho linear plano (bidimensional) e, portanto nas formas geométricas básicas, geram-se os sólidos geométricos e de revolução. Eles são compostos pelas três dimensões: comprimento, altura e largura, concebendo assim o cubo, o prisma, a esfera e o cilindro. A figura 55 mostra desenhos confeccionados em 2D (figuras) e em 3D (sólidos).

Tuan (1980: 155) data o uso desse tipo de representação somente a partir do século XIV. As primeiras experiências com profundidade espacial se deram na França e na Inglaterra. A nova técnica era então utilizada nas paredes das vilas italianas no período Renascentista, onde se pintavam paisagens que serviam tanto para alardear as riquezas de seus proprietários como para permitir o desfrute da ilusão de perspectiva panorâmica.

Essa técnica produz o efeito de representar o plano pictórico tal como é visto no plano concreto, ou seja, o(s) elemento(s) ocupa $(\mathrm{m})$ e define $(\mathrm{m})$ determinado lugar no espaço: vertical, horizontal, oblíquo, caracterizando-se por uma determinada posição, forma e tamanho. O produtor, ainda auxiliado pelas formas em três dimensões, cria possibilidades de sensações espaciais 3D em representações 2D (Cabanellas: 1976: 
40). Entretanto, é importante ressaltar que um objeto único é infinitamente mais fácil de ser representado se comparado a um recorte da paisagem.

Figura 55 - Figuras e sólidos geométricos

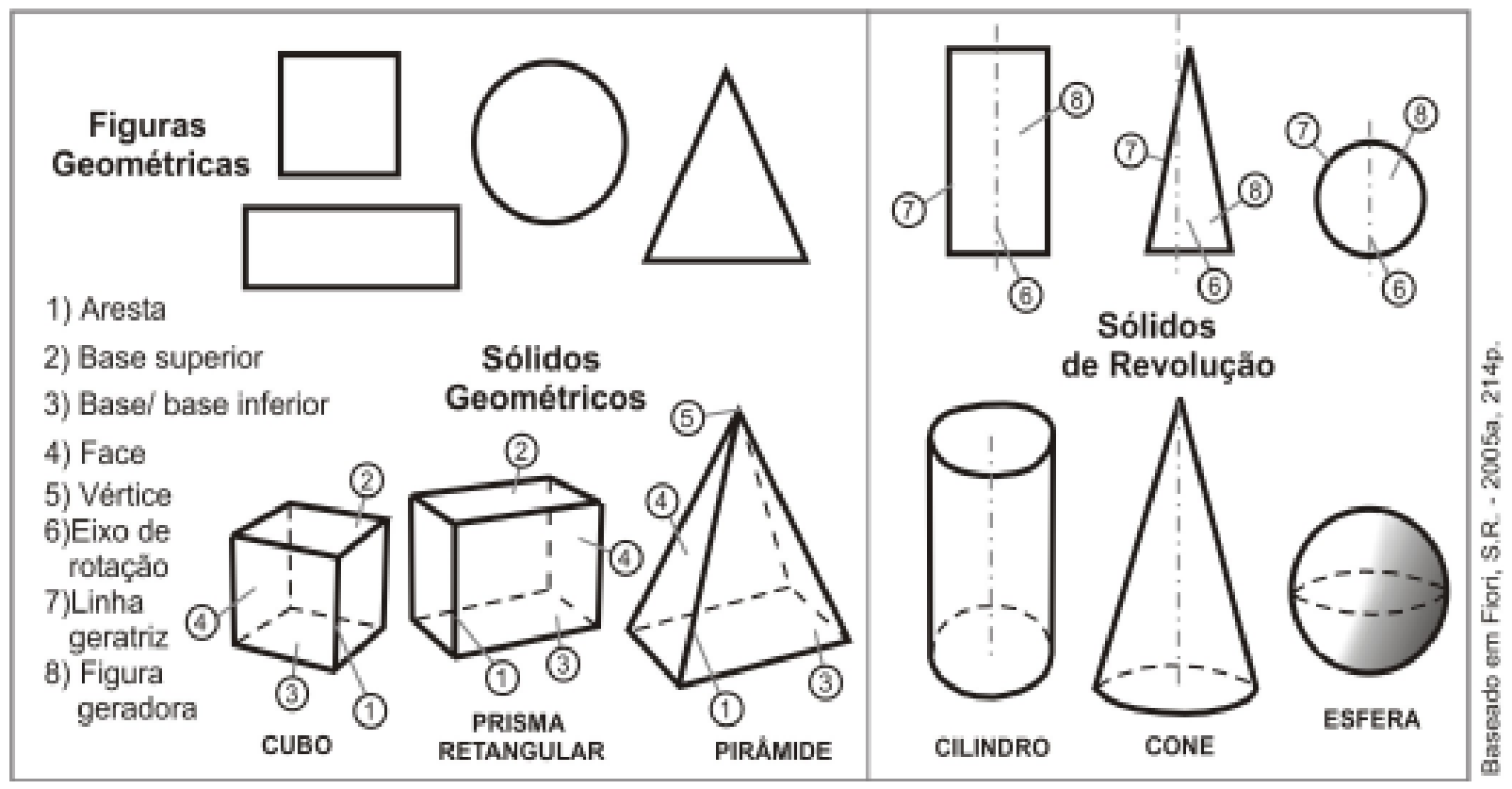

O desenhista mais atento, por exemplo, irá se defrontar com diferentes tipos de formas do terreno (vales, colinas, morros, falésias), de vegetação, da hidrografia, de ações humanas, etc. Enfim, abstrair, suprimir, ressaltar e estilizar os elementos contidos na paisagem faz parte da realidade do mais meticuloso ilustrador, que sempre recorrerá a uma técnica que lhe possibilite dar, a um desenho, a sensação de realismo ou a "caricatura" de uma realidade.

Segundo Cabanellas: 1976: 40), as formas a serem desenvolvidas e distribuídas sobre o mapa pictórico devem ser criadas e carregadas de intenção, tendo em si mesmas uma força expressiva que seja capaz de atrair a atenção do espectador sem nenhuma outra mediação.

A figura 56 exemplifica alguns planos pictóricos em perspectiva que podem ser usados para se confeccionar esboços e croquis, ilustrações, perfis, esquemas e blocos-diagrama. No item 2.3, em que se trata dos elementos que compõem a multimídia interativa, demonstra-se de maneira prática como produzir ilustrações e cenários a partir de diferentes tipos de perspectivas.

\section{3) Luz e sombra}

Só se percebem plenamente as formas que compõem os elementos do plano concreto, como os sólidos e representações tridimensionais, graças à relação complementar que ocorre entre a luz e a sombra, até porque a luz não se irradia com uniformidade no meio ambiente. As variações de luz (refletida pelo sol, lua ou alguma 
fonte artificial) ou de tom são os meios pelos quais o observador percebe, distingue oticamente, a complexidade da informação visual do ambiente (Figura 57).

Figura 56 - Exemplos de planos pictóricos em perspectiva
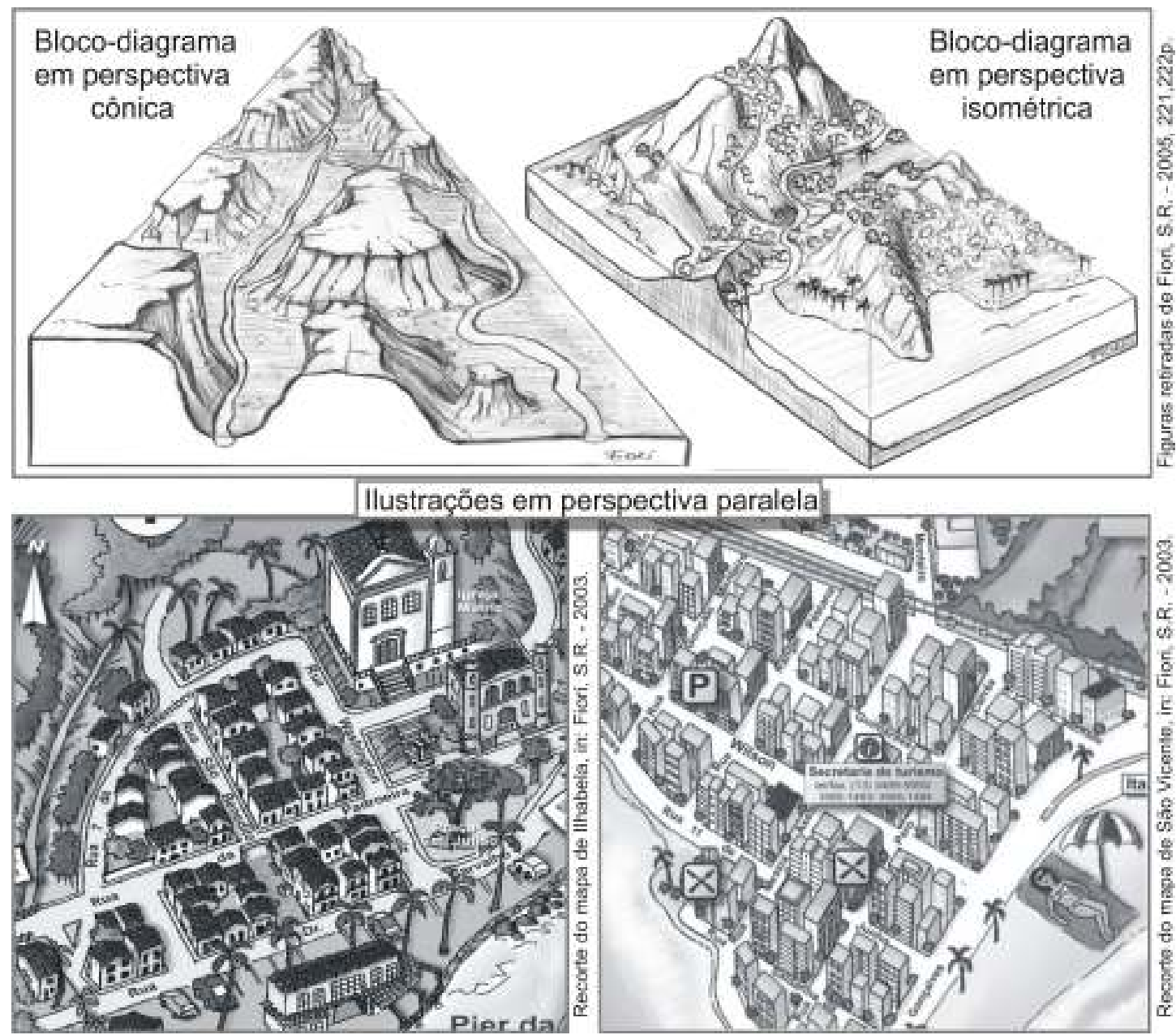

Figura 57 - Luz e sombra proporcionando o efeito tridimensional

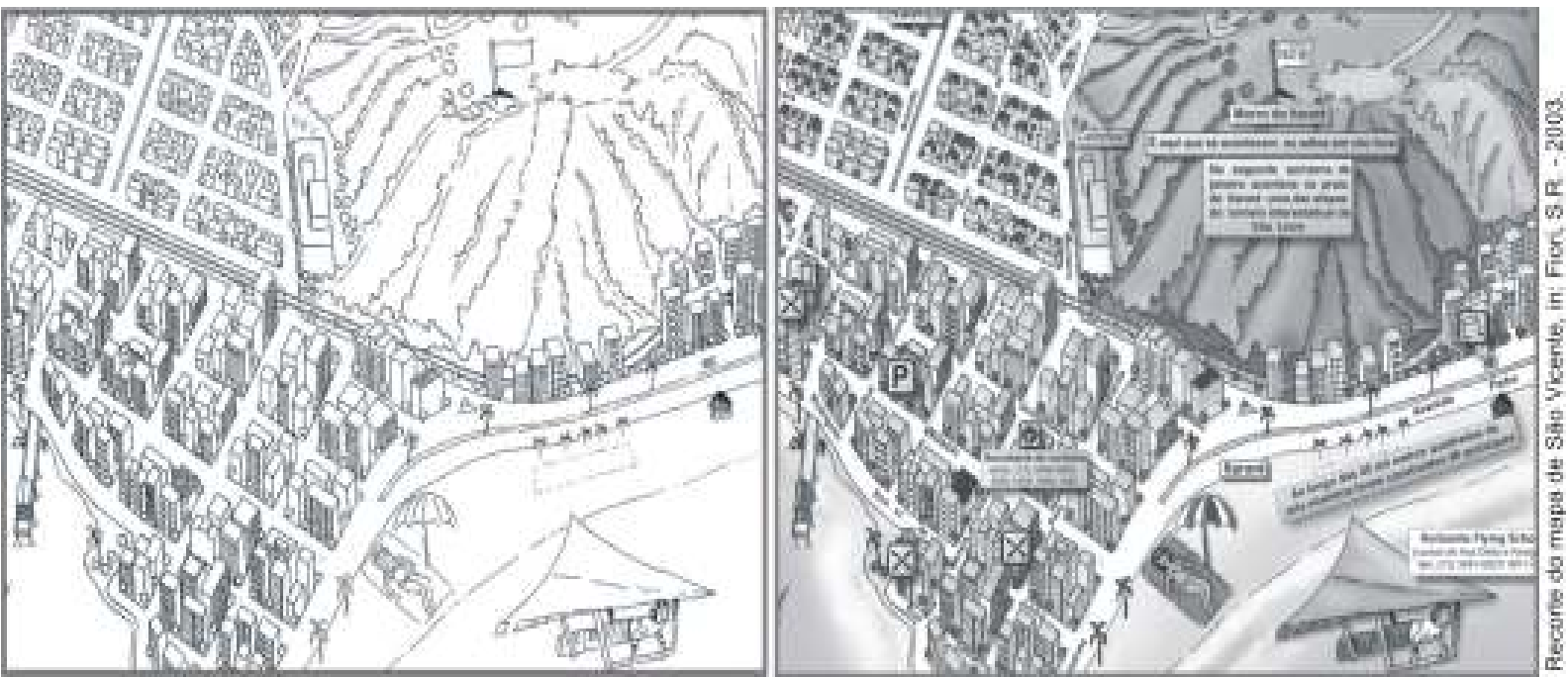


O ato de visualização está diretamente vinculado à fisiologia, ou seja, a visão proporciona um efeito no qual as áreas mais claras avançam, saltam aos olhos, ao passo que as áreas escuras retraem. Um ilustrador, então, faz uso efetivo do recurso avanço-recuo de acordo com o que quer representar. A partir de dois extremos: claro e escuro, trabalham-se outras intensidades, que combinadas a tons intermediários, envolvem o decodificador, ou seja, aquele que vê a ilustração, em uma atmosfera que previamente se idealiza (Figura 58).

\section{Figura 58 - 0 efeito luz e sombra na esfera e no sólido facetado}

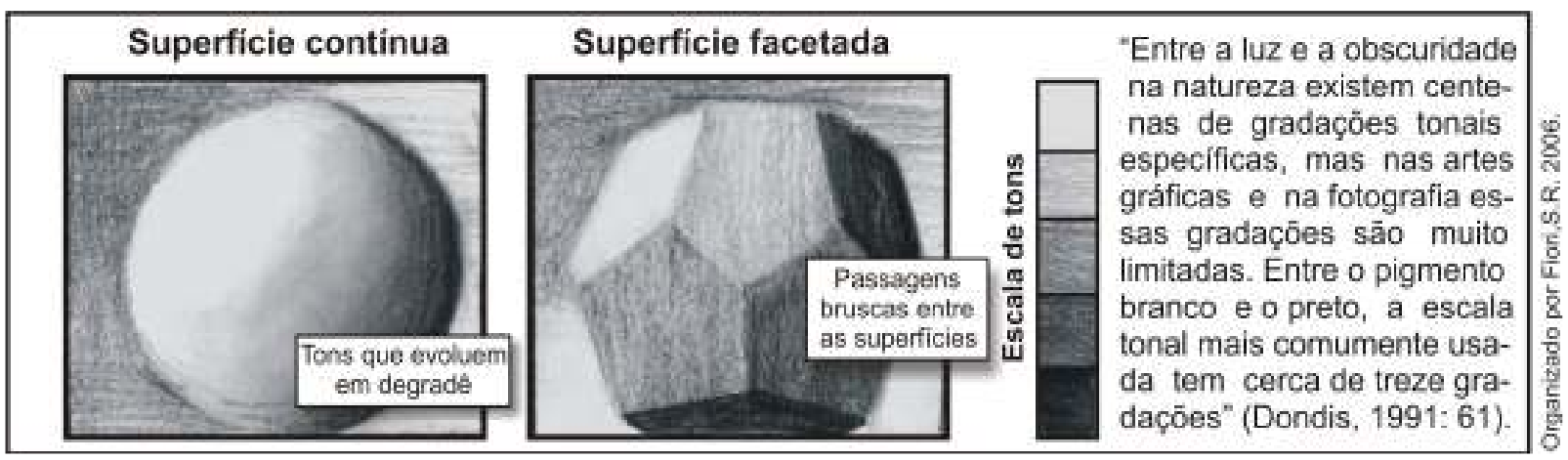

Sendo assim, o tom conforma-se como um importantíssimo recurso visual na composição de alternativas para se indicar e expressar as dimensões da paisagem. Até porque o uso da perspectiva, somente apoiada nas linhas, não consegue criar uma ilusão tão convincente da realidade. As nuances entre tons claros e escuros é de tal maneira importante na percepção do ambiente, que o usuário acolhe facilmente uma representação monocromática da realidade.

Ainda dentro do tema claro-escuro, não se pode deixar de lembrar que, ao compor uma ilustração, também se trabalham os contrastes que, sem dúvida, é um poderoso instrumento de expressão, por ter a capacidade de intensificar o significado, e, portanto, facilitar a comunicação. O contraste é uma força de oposição tonal que desequilibra, choca, estimula, chama a atenção (Dondis, 1991:108). A autora finaliza, na página 109 dizendo que, no alfabetismo visual, a importância do significado do contraste começa no nível básico da visão ou da ausência desta, através da presença ou da ausência de luz.

Após a elaboração do plano pictórico, onde se desenham linhas, figuras e formas tridimensionais, escolhe-se a direção da fonte de luz, enquadrando quais áreas da ilustração a receberão, buscando, então, um sombreado apropriado (Figura 59). 
Figura 59- Composições em luz e sombra

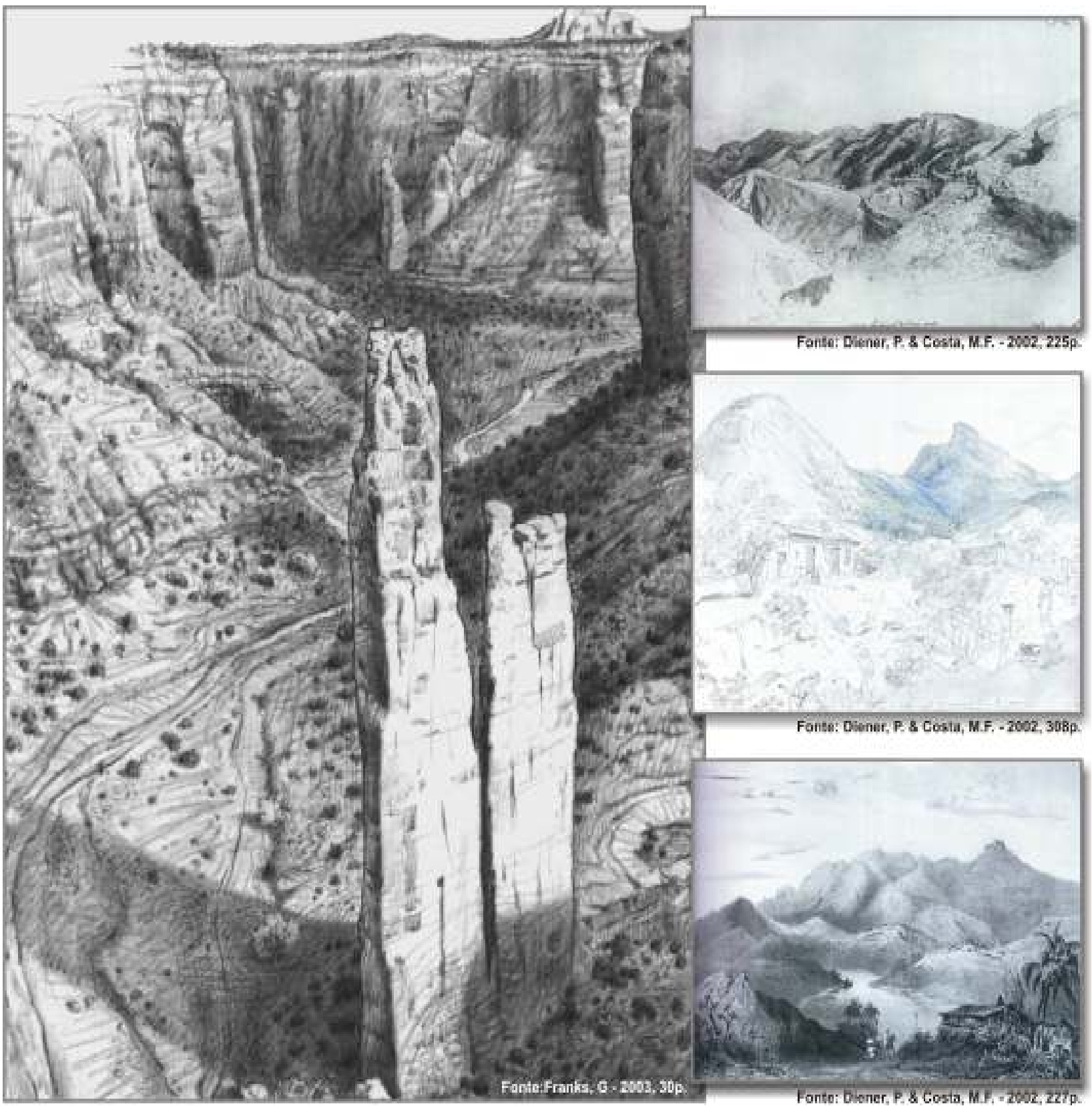

\section{4) Cor}

O autor de uma obra gráfica tem, na cor, um dos recursos fundamentais ao desenvolvimento de seu trabalho. Entretanto, é importante saber como melhor utilizála, pois quando as cores não estão corretas podem dificultar, ou mesmo invalidar, a aquisição do que se informa.

Segundo o site Desenhador Virtual (2005), encontrar a cor perfeita para uma representação gráfica não é tarefa fácil. Por exemplo, é importante saber utilizar o verde mais adequado para representar uma floresta que remeta à grandiosidade da natureza, a aparência "sadia" da paisagem. Contudo, ao se recorrer a um tom verde mais amarelado e/ou fraco, é bem provável que esse esplendor desapareça. Efeito 
semelhante aconteceria com os tons vermelhos, que deveriam ser resplandecentes e brilhantes, ou seja, se os tons forem enfraquecidos, será transmitida uma imagem apática e deprimente da vegetação, ao invés de excitação.

Inicialmente, pode-se dizer que a cor é um fenômeno biofísico, sendo uma resposta sensorial, relacionada à radiação eletromagnética. $O$ espectro do comprimento de ondas visível ao olho humano está entre 0,4 e 0,7 mícrons (banda visível). Isto quer dizer que, entre esses limites, o olho e o cérebro conseguem distinguir facilmente os comprimentos de ondas associados a cores denominadas: violeta, azul, verde, amare-lo, laranja e vermelho - Figura 60 (Monmonier, 1996: 164).

\section{Figura 60 - 0 espectro das cores}

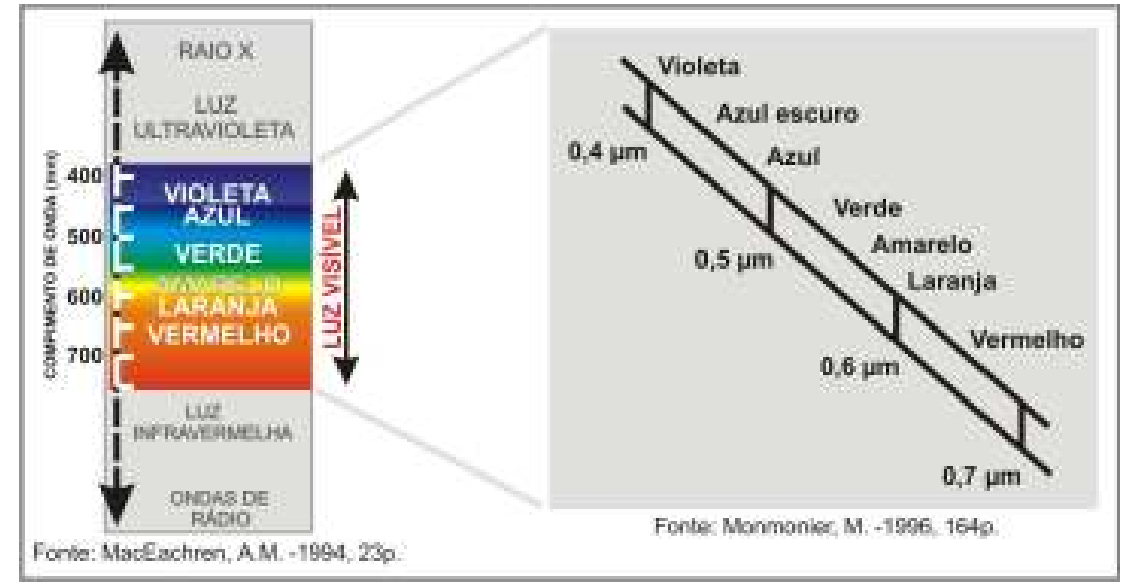

A confecção do mapa pictórico turístico e interativo trabalha com duas formas características da cor, ou seja, existe uma diferenciação muito grande em relação à cor-luz e cor-matéria (Cabanellas, 1976: 55). Segundo Dondis (1991: 109), tudo o que é visto reveste-se de, pelo menos, de duas propriedades: uma qualidade pigmentaria, que tende mais ao branco ou ao preto (relativo ao tom, cor-matéria), e a qualidade física da luminosidade ou da obscuridade (cor-luz). Esses dois tipos de composição tonal trazem características muito distintas, pois a luz física possui uma vasta gama de intensidade tonal, enquanto o pigmento costuma ser utilizado num âmbito limitado de oito a quatorze graus tonais.

A preocupação em entender as duas formas características da cor tem a ver diretamente com o tipo de mapa produzido que, na maior parte do tempo, é visto pela tela do computador, mas também pode ser impresso e utilizado durante viagens e atividades de lazer. E é aí que se estabelece o problema, pois as cores que compõem o mapa sobre o monitor do computador não serão as mesmas encontradas no mapa impresso.

Deste modo, o intuito é trabalhar com cores que possam trazer a mínima diferença 
possível entre o mapa na tela (cor-luz) e o mapa impresso (cor matéria, pigmento ${ }^{55}$ ).

Posto isso, Dondis (1991: 65-66) e Monmonier (1996: 164-167) afirmam que, sendo a cor um fenômeno perceptivo e da arte gráfica, ela é gerada tanto pela luz quanto pelo pigmento. A cor apresenta um comportamento único, possuindo três dimensões, que podem ser definidas e medidas:

$\checkmark$ A matiz é a cor em si e refere-se ao comprimento de onda da radiação eletromagnética. Existe uma grande variedade de tipos, cada qual com características individuais. Os grupos ou categorias de cores compartilham efeitos comuns, e as formulações mais simples podem ser ensinadas pelo círculo cromático (Figura $61 \mathrm{~A}$ ).

$\checkmark$ A saturação, também chamada de croma, preocupa-se com a pureza relativa de uma cor, do matiz ao cinza. É explicita e compõe-se dos matizes primários e secundários. Logo, quanto maior for a intensidade ou saturação de cor ao se elaborar um objeto ou acontecimento visual, mais carregado estará de expressão e emoção (Figura 61 B).

$\checkmark$ Acromática é o brilho relativo, do claro ao escuro, das gradações tonais ou de valor. Neste item, a presença ou ausência de cor não afeta o tom, que é constante. Por exemplo: ao se manipular o botão da cor em um monitor de computador, pode-se deixar a imagem mais ou menos colorida, ou seja, mais ou menos saturada de cor. Essa experimentação jamais afetará os valores tonais da imagem. Portanto, aumentar ou diminuir a saturação, demonstra a constância do tom, provando que a cor e o tom coexistem na percepção, não se modificam entre si. A negritude ou claridade podem ser aplicadas tanto para as cores quanto para os tons de cinza (Figura $61 \mathrm{C}$ ).

A figura $61 \mathrm{D}$ demonstra esquematicamente as variáveis visuais: cor, valor e saturação referenciadas a partir da cor.

A seguir Monmonier (1996: 165, 166), Desenhador Visual (2005) e Macmania (2005) expõem as diferenças básicas entre a cor-luz e a cor-pigmento, divididas respectivamente em cores primárias aditivas e subtrativas.

\footnotetext{
${ }^{55} \mathrm{O}$ pigmento fornece cor a tudo que é material, podendo ser conseguido por vários meios. Os índios o retiram de sementes (urucum), mas também está nas folhas verdes (clorofila), nos minerais (o amarelo/vermelho do óxido de ferro, azul do cobalto, no roxo da terra), etc. O homem então, extrai os pigmentos da natureza, utilizando-os como tinta. Contudo, o desenvolvimento tecnológico fez surgir os pigmentos sintéticos, ou seja, cores conseguidas graças a produtos químicos. Já a tinta é formada pela combinação de resinas, solventes, pigmentos e aditivos. O pigmento dá a cor, o solvente a viscosidade, os aditivos o brilho, opacidade e consistência, e as resinas são responsáveis pelo transporte físico (Macmania, 2005).
} 
Figura 61 - As três dimensões da cor

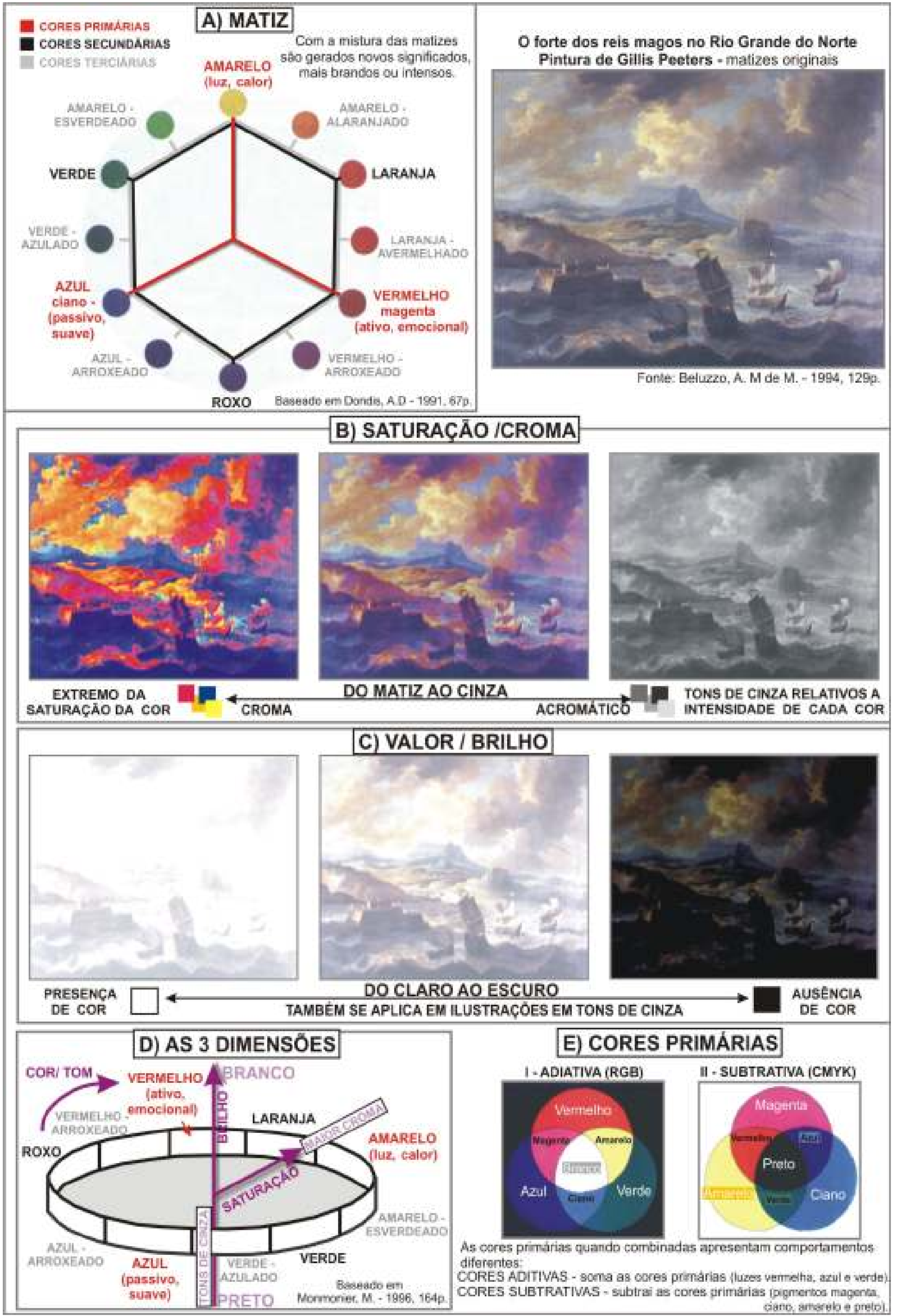


O processo de misturada das cores pode ser feito desde a utilização de luzes até pigmentos extraídos das tintas, vegetais, minerais e produtos químicos (Figura $61 \mathrm{E}$ ).

\section{a) Cor- luz-aditiva (RGB)}

Fundamenta-se em três cores básicas: a vermelha, a verde e a azul que, quando sobrepostas (processo aditivo), formam a luz branca. Ao misturar essas cores duas a duas, geram-se as cores secundárias aditivas (vermelho + verde $=$ amarelo, vermelho + azul $=$ magenta, verde + azul $=$ ciano $)$.

Veja os exemplos: ao apanhar uma maçã vermelha num ambiente claro, a luz que bate e brilha sobre a fruta e o comprimento de onda de vermelho da luz refletem-se da maçã para os olhos do observador, enquanto os comprimentos de onda azul e verde são absorvidos pela maçã. Sensores nos olhos do observador reagem à luz refletida, enviando uma mensagem que é interpretada pelo cérebro como sendo a cor vermelha. Já ao olhar para um girassol, vê-se a cor amarela, pois os comprimentos de onda da luz vermelha e verde são refletidos de volta ao observador, enquanto o azul é absorvido pela planta. E, por fim, quando se vê uma folha branca, todos os comprimentos de onda são refletidos ao observador, porém uma folha preta absorve todos os comprimentos de onda.

O sistema usado para a criação de cores encontradas em um monitor de computador, ou tela de televisão está baseado nas mesmas propriedades fundamentais da luz que ocorrem na natureza. O monitor, tela de TV, cria uma enorme variedade de cores e tons através da emissão de três feixes de luz com diferentes intensidades, advindas da mistura das cores primárias aditivas: vermelha, verde e azul. Para isso, usa o modelo RGB ${ }^{56}$ (vermelho, verde e azul). Nesse modelo, as cores dos pixels podem ser mudadas, combinando-se os vários tons de vermelho, verde e azul.

Uma rápida explicação técnica é que, por exemplo, quando o observador vê a cor vermelha, isso significa que o monitor ativou o feixe de luz vermelha, ascendendo um pixel vermelho na tela.

\section{b) Cor-pigmeto-subtrativa (CMYK)}

Fundamenta-se em três cores básicas: ciano (azul turquesa), magenta e amarelo, funcionando como filtros que subtraem da luz branca certas cores e refletem suas cores complementares. Até porque, sem a luz, nenhuma cor dos elementos encontrados no espaço é percebida. Assim, ao se misturarem às cores primárias subtrativas - duas a duas - geram-se as cores secundárias subtrativas (magenta + ciano $=$ azul, magenta + amarelo $=$ vermelho, amarelo + ciano $=$ verde $).$ Logo, percebe-se que as cores primárias subtrativas são as secundárias aditivas e viceversa.

${ }^{56} \mathrm{O}$ modelo RGB refere-se àqueles equipamentos que emitem luz própria quando mostram suas imagens, como o CRT (tubo de raios catódicos) ou o LCD (cristal líquido); ou seja, monitores e aparelhos de TV (Macmania, 2005). 
O processo de subtração das cores consiste em suprimir um ou mais componentes da luz. Em outras palavras, pode-se dizer que a mistura de tintas equivale subtrair cores. Por exemplo, ao se misturar à tinta azul com a tinta amarela, será gerada a tinta verde. Isso ocorre devido à absorção dos componentes do lado vermelho pelos pigmentos da tinta azul e os componentes do lado azul pelos pigmentos da tinta amarela, sobrando finalmente as componentes intermediárias, que geram o verde.

Vale aqui ressaltar que a dualidade: a mistura de pigmentos está diretamente ligada à quantidade de luz absorvida e refletida pelos objetos. Por exemplo, o pigmento branco não absorve, mas reflete todas as cores. Portanto, a cor-luz é a soma de todas as cores, que é refletida pelos elementos iluminados pela luz branca. Conseqüentemente, ao se misturar um pigmento preto a uma tinta branca, obtêm-se diferentes tons de cinza.

Partindo para o processo efetivo da impressão dos mapas, tendo como fato que a folha de papel não emite luz, só absorve e reflete, uma impressora não pode usar as cores RGB. O cartógrafo, então, necessita de um outro modelo que transporte as cores do monitor para o papel: o CMYK. Ele está baseado em quatro cores: ciano, magenta, amarelo e preto; usadas na mistura de pigmentos, principalmente para imprimir imagens de tons contínuos como fotos e ilustrações digitalizadas, etc. Tais cores combinadas podem reproduzir uma parte significativa do espectro visível de cores.

Em princípio, a combinação das tintas $100 \%$ de ciano, $100 \%$ de magenta e $100 \%$ de amarelo deveriam reproduzir sozinhas todas as cores subtrativas. No entanto, por causa da impureza das tintas, não é possível produzir a cor preta, e sim um marrom turvo. E ainda visando a não sobrecarregar a impressora, geralmente é adicionada uma quarta tinta de impressão: a cor preta; que substitui parcialmente as outras três (cores) nos tons mais escuros e cinza das imagens.

Por causa da dualidade ocorrida entre as cores luz-RGB e pigmento-CMYK, há uma grande dificuldade em estabelecer imagens que possam ter o mesmo resultado visual - aparência das cores - no monitor do computador e posteriormente quando impressas. Em Fiori (2003), relata-se a realização de um teste prático, voltado à colorização dos mapas de llhabela e São Vicente, que visou encontrar cores visualmente compatíveis na relação: cor-luz (que aparece no monitor) e cor-pigmento (que aparece no mapa impresso). Tal resultado, porém, não foi disponibilizado pela dissertação. A seguir, a figura 62 apresenta um pequeno inventário das cores testadas e utilizadas. 
Figura 62 - Busca de cores similares para mapas dispostos em um monitor de computador (RGB) e impressos (CMYK)

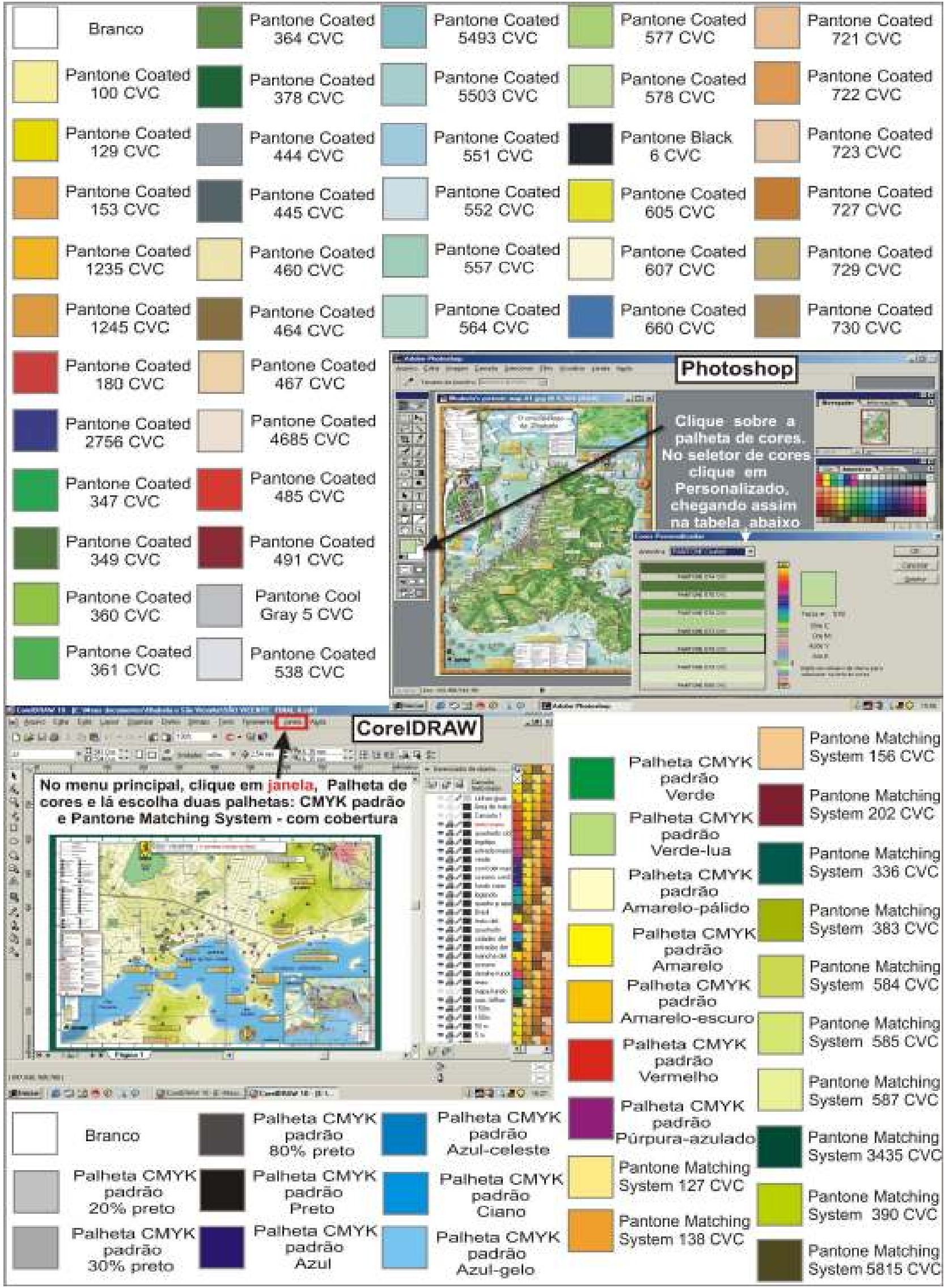


O trabalho de relação entre as cor-luz e cor-pigmento ainda será aplicado e discutido nesta pesquisa, buscando cores que sejam compatíveis, como um todo, aos mapas turísticos pictóricos. Isto é, mesmo estando em ambientes distintos - RGB e CMYK a cor refletida via monitor deve ser parecida com a do pigmento impresso.

Além dos aspectos fisiológicos relacionados às três dimensões das cores, devido à linha de pensamento seguida, não se pode ignorar que a percepção da cor esteja impregnada de emoção. A força intrínseca a essa variável visual pode ser usada com muito proveito na expressão e intensificação do conteúdo informado (Dondis, 1991:67).

Em Farina (1990) encontra-se a ratificação de que, quando o indivíduo recebe a comunicação através da cor, o processo se dá em três níveis:

1. A cor é vista e impressiona a retina;

2. É sentida, provoca e expressa uma emoção;

3. É construtiva e, por possuir um significado próprio, tem valor de símbolo, tendo a capacidade de construir uma linguagem que comunique uma idéia.

A cor faz parte do cotidiano, tanto que muitas vezes se estabelecem até regras de harmonia para utilizá-las. Por exemplo, na moda, na decoração, etc., procura-se uma estética coletiva. Por meio dela, o homem se manifesta, e não somente pela transmissão de sensações, como também pelo estabelecimento de códigos completos para a liturgia, para o trânsito, para a publicidade, etc (Cabanellas, 1976: 75).

Outras vezes, por meio da experiência, o significado simbólico da cor pode ser compartilhado de maneira particular ou universal, sempre apresentando um valor informativo. Levando-se em consideração o meio ambiente, o sujeito compartilha significados associativos da cor das árvores, do céu, da terra e de inúmeros elementos dispostos no espaço, nos quais vêem-se as cores como estímulo. Tudo é coligado a significados associativos e simbólicos (Dondis, 1991: 69).

Mukarovsky (1981:260) exemplifica que a cor vermelha produz no receptor efeitos e sensações diferentes daquelas encontradas nas cores azul, verde ou amarela. Isso porque desencadeia diferentes associações, despertando sentimentos, reações motoras, etc. Essa significação própria da cor por vezes é tão forte que chega a concretizar-se: o azul pode insinuar o céu ou a água, mesmo sendo utilizado como mera qualidade de cor e não para representar o céu ou água.

Monmonier (1996: 171) complementa o que foi dito até aqui, relatando que através da história, as cores dispostas sobre os mapas, por exemplo, reforçaram uma certa metáfora da paisagem. Por muitos séculos, os cartógrafos exploraram e encorajaram a associação do verde à vegetação, do azul à água, do vermelho às altas temperaturas e do amarelo ao ambiente desértico. Contudo, essa associação 
somente pode ser considerada segundo um contexto que seja correto e apropriado, gerando, então, associações que promovam uma eficiente decodificação.

Cita-se novamente que, por convenção, durante o desenvolvimento do Atlas Indígena do estado do Acre (Comissão Pró-Índio: 1996), a cor amarela foi escolhida para representar a rede hidrográfica nos mapas, pois a cor azul, usualmente encontrada na maioria dos mapas da cultura ocidental, não fazia sentido à compreensão dos usuários potenciais: os índios.

Pouco se conhece sobre os efeitos e reações subjetivas que os usuários dos mapas têm em relação às cores. É fato que a maioria delas estão relacionadas a várias sensações. A cor vermelha, por exemplo, está associada a fogo, perigo, calor, sangue, raiva, amor e também ao comunismo. Logo, deve-se estar atento ao contexto ao qual a cor está inserida. Alguns produtores de mapas procuram cores que reforcem - de forma inteligente ou óbvia - os símbolos pictóricos. Como, por exemplo, o amarelo pode reforçar símbolos que exemplificam a riqueza. Outros símbolos que valorizam as cores são os trevos (verdes), as cruzes simétricas e vermelhas das ambulâncias e hospitais, as cruzes pretas dos cemitérios e igrejas (Monmonier, 1996:171).

Portanto, Robinson, Morrison, Muehrcke, Kimerling e Guptill (1995) sustentam que a significação das cores pode variar culturalmente, sendo que, na cultura ocidental, associa-se comumente as cores aos mais diferentes fenômenos físicos, sensações e emoções. As associações evocadas podem ser usadas para retratar certas características a serem representadas. A seguir expõem-se algumas importantes conotações simbólicas dadas à cor:

$\checkmark$ Azul: os corpos d'água, os rios, a alguma coisa molhada ou fria.

$\checkmark$ Verde: as áreas de vegetação viçosa.

$\checkmark$ Amarelo ou castanho-amarelado: as áreas secas ou que apresentam vegetações esparsas.

$\checkmark$ Marrom: o solo nu.

$\checkmark$ Vermelho e laranja: o calor.

Tuan (1980: 27) disserta sobre as cores avançadas e recuadas. O vermelho, laranja e amarelo parecem mais próximas do expectador, por estimular o sistema nervoso e fazer com que o objeto pareça mais quente, mais pesado do que é. Já o verde, azul e o azul esverdeado promovem distância aos olhos, sugerem frieza, o objeto é julgado mais leve do que é. Como visto, as cores afetam o sentido de peso e também o sentido de indicação acima e abaixo, pois quando os elevadores possuem luzes coloridas, a seta vermelha invariavelmente indica descida, a seta azul subida. 
A figura 63 demonstra-nos que a cor possui uma ação móvel. As distâncias visuais tornam-se relativas. O próprio volume de qualquer elemento pode ser alterado pelo uso da cor sendo que a superfície mais clara sempre aparecerá maior, pois a luz que reflete the confere amplidão.

Figura 63 - 0 "volume" das cores

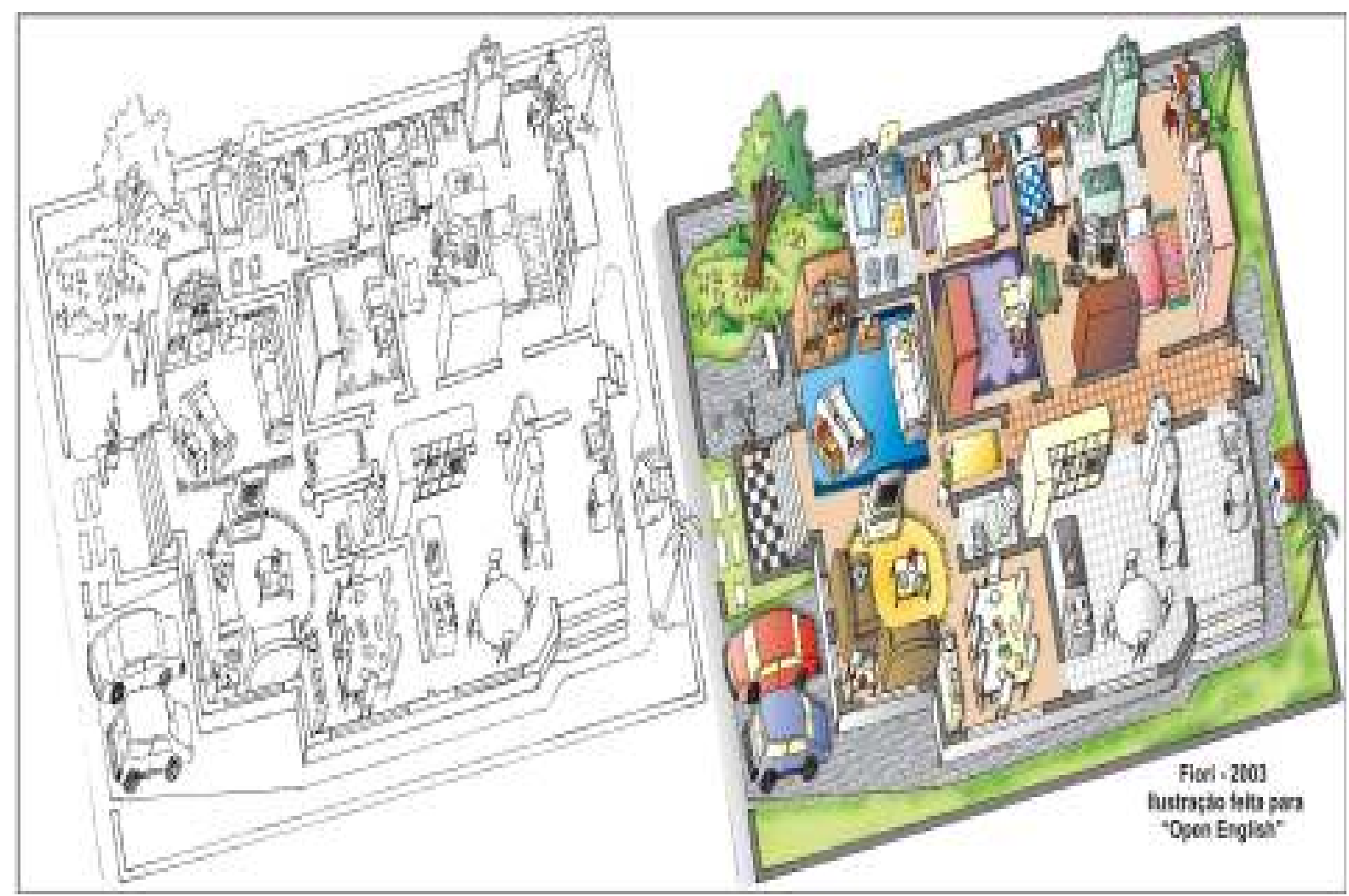

Além das possibilidades do uso da cor referentes as suas qualidades culturais e de motivação, apontam-se outros recursos nos quais o uso da cor pode realçar ou deixar em segundo plano uma informação. Por exemplo, a variável visual transparência (voltar à figura 35 e ver figura $64 \mathrm{~A}$ ) pode ajudar a representar um tipo de névoa pelo qual um tema abordado no mapa pode ficar encoberto ou desbotado.

A transparência também é usada para descrever características do mapa que se sobrepõem. O recurso é aplicado, por exemplo, para esconder o fundo de um mapa ou para trazer ao primeiro plano o tema principal. Nos mapas turísticos interativos, essa variável proporciona a impressão de profundidade ou distância à visão oblíqua. Contudo, ela deve ser usada com muito cuidado, pois, quanto maior a nevoa, menor a possibilidade de distinção da figura do fundo. $O$ assunto é abordado rapidamente por MacEachren (1994: 31,32) ao dissertar sobre a variável visual foco. Também já abordado em Fiori $(2003:$ 87, 88). 
Outro recurso que se deve mencionar é o sombreamento de um objeto no mapa. De acordo com o ângulo, direção e intensidade de uma iluminação imaginária, pode-se criar volumes e planos às ilustrações e, conseqüentemente, o mapa como um todo (Figuras $64 \mathrm{~B}$ ).

Figura 64 - Transparência e sombreamento de ilustrações e objetos

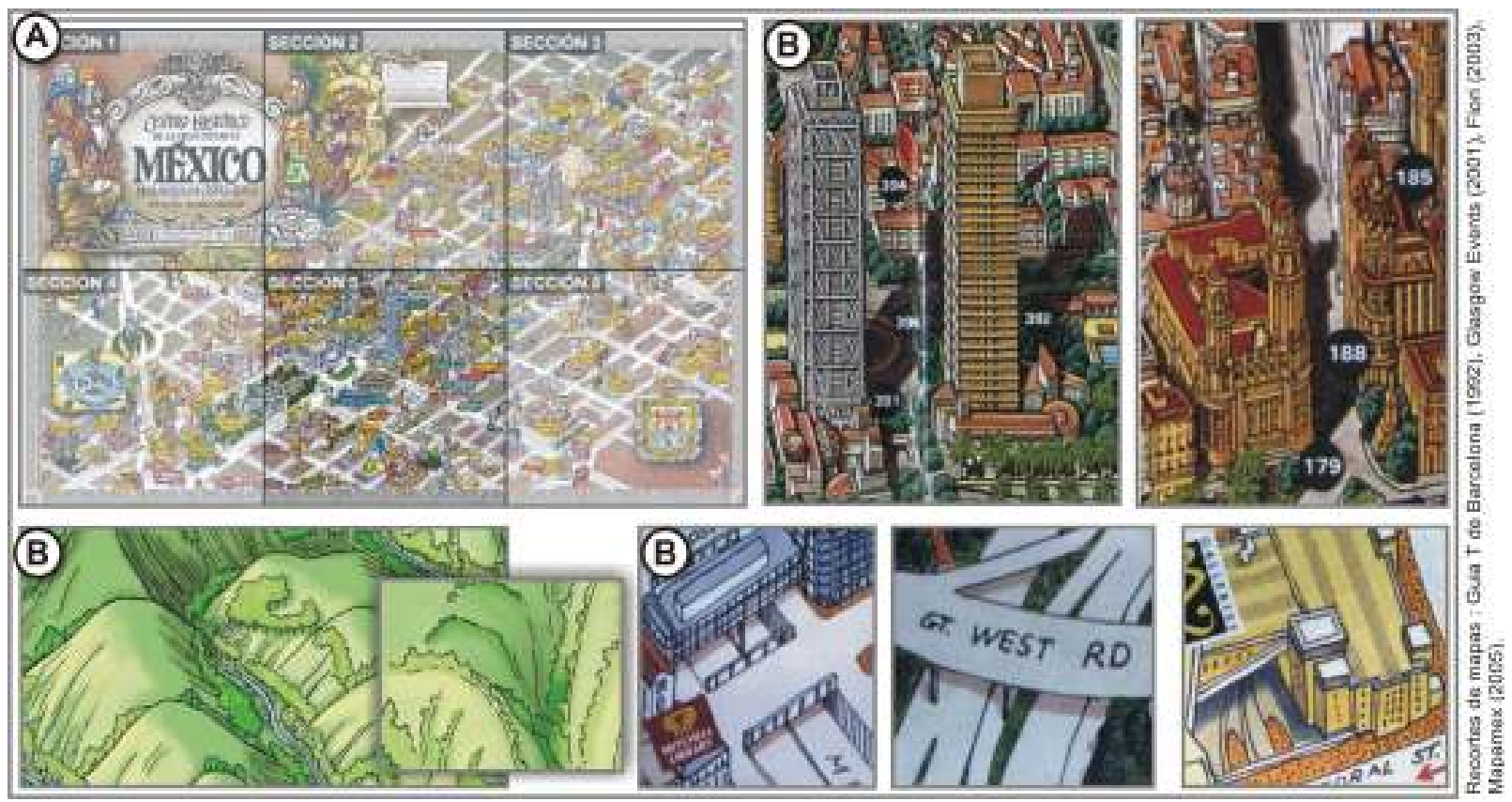

Por fim, Mayhew (1992) apresenta alguns itens que merecem destaque em relação aos princípios e diretrizes das cores:

$\checkmark$ Devem ser usadas de acordo com a necessidade, valor e não com exagero ou substitutas de outras técnicas mais eficazes para a representação.

$\checkmark$ É preferível trabalhá-las em conjunto com outra variável visual (redundância), por causa de problemas como daltonismo (monocromatas, dicromatas e tricomatas) e pessoas com idade avançada.

$\checkmark$ Devem avisar (amarelo), diferenciar (cores distintas), enfatizar (vermelho) e relacionar (cores comuns) as informações.

$\checkmark$ Devem identificar estruturas e subdivisões - sempre usando as mesmas regras para aplicação de cores em todo o sistema.

$\checkmark$ Podem retratar os objetos naturais de forma realista, ou então, buscar uma certa caricatura funcional.

$\checkmark$ O azul deve ser evitado em textos, detalhes e símbolos pequenos. Essa cor é boa para fundos e áreas grandes. 
$\checkmark$ Cores quentes devem ser utilizadas para criar uma aparência de aumento das imagens.

$\checkmark$ Recomenda-se utilizar cores para a percepção de profundidade. Tons azuis parecem estar um pouco mais longe do que os tons vermelhos.

$\checkmark$ Deve-se buscar reduzir "erros" de interpretação relacionados principalmente à associação cultural das cores.

$\checkmark$ Podem aumentar a compreensão, a credibilidade, a aparência e a satisfação.

$\checkmark$ Propiciam melhor captação de memória,

$\checkmark$ Cores contrastantes entre $\circ$ fundo e o destaque devem ser empregadas. Geralmente, aconselha-se utilizar imagens coloridas em fundos acromáticos (preto, branco ou cinza). No caso de um formato em meio digital, o fundo branco constante pode cansar os olhos.

\section{5) Textura}

Esse elemento visual é muito útil na substituição ou complementação das qualidades de um outro sentido, o tato. Ao se abordar a produção de um material fundamentalmente visual como mapas impressos ou elaborados para telas de computador, Dondis (1991: 70) é categórica ao afirmar que é possível uma textura apresentar somente qualidades óticas e não táteis como, por exemplo, no caso dos padrões de um determinado tecido ou dos traços superpostos de um esboço. Havendo...

... uma textura real, as qualidades táteis e óticas coexistem, não como tom e cor, que são unificados em um valor comparável e uniforme, mas de uma forma única e especifica, que permite à mão e ao olho uma sensação individual, ainda que projetemos sobre ambos um forte significado associativo (Dondis, op.cit::70).

Aliás, a maior parte da experiência vivenciada com relação à textura é ótica e não tátil. llustrações e pinturas muitas vezes proporcionam aparências convincentes de uma ou mais texturas (Dondis, op.cit.: 71).

MacEachren (1994: 27) pontua que o atributo mais importante da textura é que esta variável visual gráfica, já à primeira vista, facilita a percepção dos diferentes tipos de texturas.

Isso quer dizer que a elaboração de um mapa turístico deve valorizar e criar texturas convincentes e diretas da paisagem que contém: vegetações (florestas, savanas, climas temperados e frios), tipos de morfologia de terreno (montanhas, vales, planícies, praias), presença do homem (cidades, aldeias, tribos), etc (Figura 65). E essas "qualidades" de separação visual entre camadas de informação da paisagem se mostram por meio de características gráficas de suavidade, aspereza, volume, 
sinuosidade, precisão, entre outras. Pode-se sugerir ainda tipos de materiais constitutivos dos elementos visuais como pedra, madeira, areia, tecido, água.

Figura 65 - A textura e suas qualidades visuais

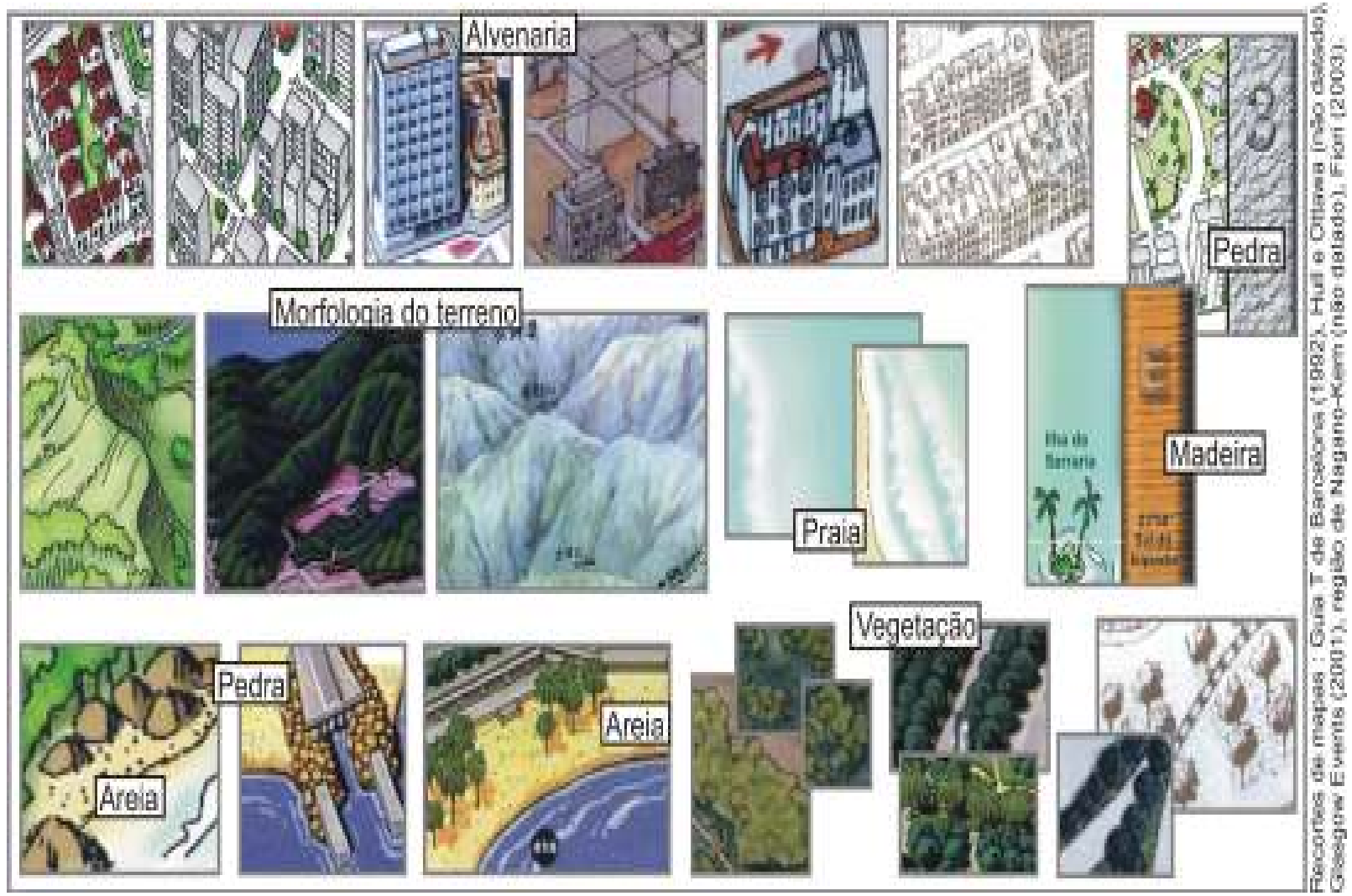

\section{6) Escala e proporção}

A primeira etapa, antes de iniciar um desenho, é reconhecer e trabalhar a partir de dois itens fundamentais: o tamanho da área de ilustração como, por exemplo, uma folha de papel ou a tela de computador, e as informações que se deseja representar. Nessa relação, a escala auxiliará na composição dos tamanhos e as proporções entre dois ou mais elementos visuais presentes na ilustração. Dondis (1991: 73) complementa que a medida é parte integrante da escala, porém sua importância não é crucial.

A preferência de uma escala para a ilustração é feita por elaborações visuais fluidas, não absolutas e sujeitas a muitas variáveis modificadoras a partir da composição pretendida pelo ilustrador. Nessa pesquisa, a escala torna-se muito útil na definição dos vários planos da paisagem, sendo trabalhada conforme as referências que são pré-estabelecidas. A figura 66 exemplifica claramente essa relação. 
Figura 66 - Proporção e escala

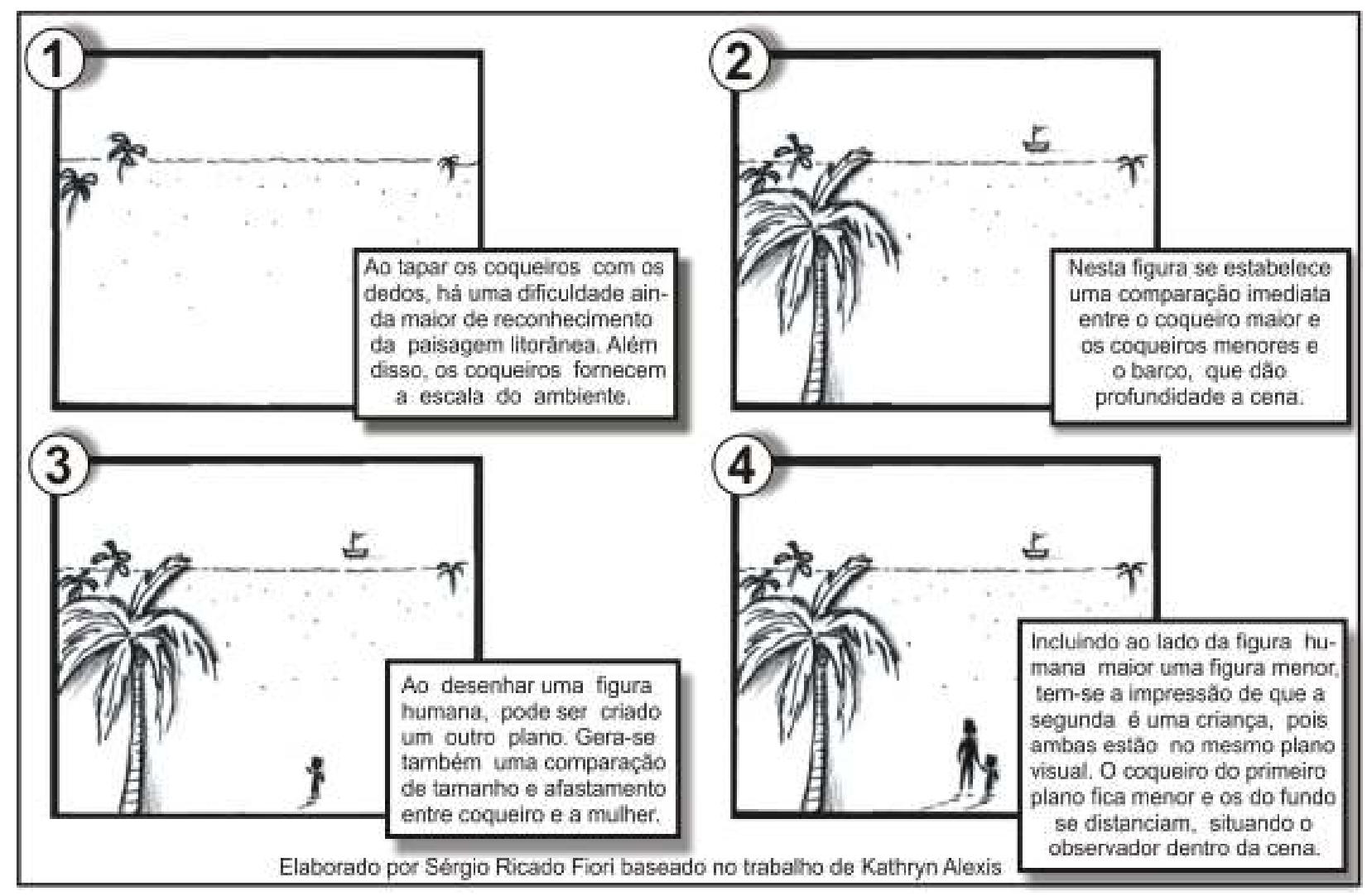

Aprender a construir a relação tamanho-objetivo-significado é essencial na estruturação da mensagem visual. $\mathrm{O}$ controle da escala faz, por exemplo, que uma paisagem ampla torne-se visualmente fácil de ser apreendida. Já o enfoque a um ambiente específico, pequeno, pode trazer riqueza de detalhes sem que haja uma poluição visual, com a escolha dos elementos pertinentes à proposta do tema a ser representado.

Ainda durante a escolha da escala na composição de um desenho, é importante utilizar representações de fácil identificação para o decodificador. Isso quer dizer que nunca se deve esquecer de incluir uma referência básica de tamanho, ou seja, algum elemento cujas dimensões de tamanho o observador esteja habituado a perceber no plano concreto. No geral, qualquer pessoa sabe e pode comparar o tamanho de uma árvore, uma pessoa, uma casa. Com isso, trabalhando com algum elemento "conhecido" presente em uma ilustração, torna-se mais fácil identificar, confeccionar e comparar dimensões com outros elementos. A figura humana, por exemplo, fornece as determinações essenciais da escala, sendo um ótimo elemento visual. É como utilizar uma caneta ao lado de um perfil de solo ao ser fotografado.

Todos os elementos já apresentados - o ponto e a linha, a forma, o tom, a cor, a textura e a escala - são componentes irredutíveis dos meios visuais, configurando-se como itens básicos com os quais o observador conta para desenvolver o pensamento e a comunicação visual. Apresentam o dramático potencial de transmitir informações 
de forma fácil e direta, mensagens que podem ser aprendidas com naturalidade por qualquer pessoa capaz de ver (Dondis, 1991: 82).

Focalizando mais diretamente o desenvolvimento dos mapas pictóricos turísticos, todos os elementos visuais apresentados serão utilizados, tendo como base cartas topográficas (que dispõem de escala métrica), que sofrerão diferentes recortes, dependendo do enfoque a ser dado à localidade turística.

Desde já, é certo que todo o processo de colorização será feito em meio digital, por sua maior praticidade e menor custo, como comprovado em Fiori (2003:147). Além disso, a idealização dos inúmeros tipos de ilustrações pictóricas trabalhadas sobre uma base topográfica tem o intuito de causar um forte impacto visual - imagem inicial - buscando enfatizar a vocação turística do destino representado - balneário, histórico, rural, saúde, ecoturismo, religioso, etc. Posteriormente, virão outras "imagens menores", auxiliares e complementares, que apresentarão os patrimônios natural, cultural e a infra-estrutura presente na localidade.

Essas observações remetem aos fatores push e pull (item 1.6: 109), ou seja, o cartógrafo pode pensar em criar inicialmente um primeiro impacto visual ao mapa. Tal impressão objetivaria enfatizar a principal vocação turística do destino representado, configurando a localidade, por exemplo, como balneária, histórica, rural, serrana, cosmopolita, de instância, de atração singular, etc. A figura 67 exemplifica mapas panorâmicos que fornecem tal atmosfera.

A próxima parte do desafio é explicitar claramente no mapa, as atrações e atividades encontradas na localidade, possibilitando assim, opções de escolha ao usuárioturista. Por exemplo, destacando os tipos de restaurantes, expondo e criando uma hierarquia quanto ao grau de facilidade-dificuldade das trilhas usadas para caminhadas e outros esportes, localização e o tipo de acomodações, apresentação das tradições (arquitetura, artesanato, religiões) e curiosidades (histórias, lendas) do destino, além de alguns tipos de texto e legendas com informações utilizando um ou mais idiomas, etc.

Devido às respostas anteriores (Fiori: 1999 e 2003), a concepção dos mapas turísticos utiliza basicamente os recursos do índice, dos ícones e dos símbolos pictográficos. Primeiramente por atingirem um maior número de usuários, devido a sua configuração estético-visual. E, em seguida, pelo fato de tal estilo acentuar a resposta emocional (alegria, surpresa, expectativa) relacionada ao prazer e apreciação do usuário. A dimensão emocional de dominância estará mais vinculada à capacidade de transmitir a informação do mapa como produto em si. 
Figura 67 - Vocação turística: primeiro impacto visual

Localidade: balneária, urbana

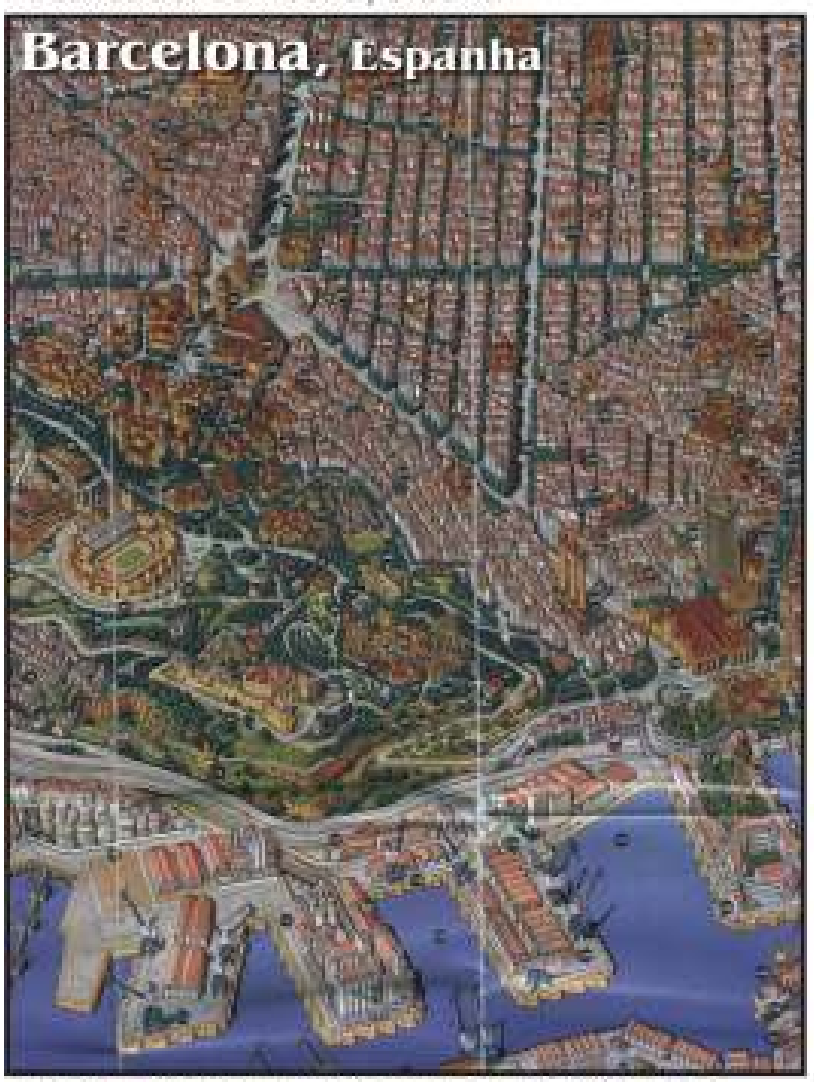

Forla: Gua T de Earoolona. produzido por Planografico - N.Gi Ediciones

Localidade: serrana, alpina

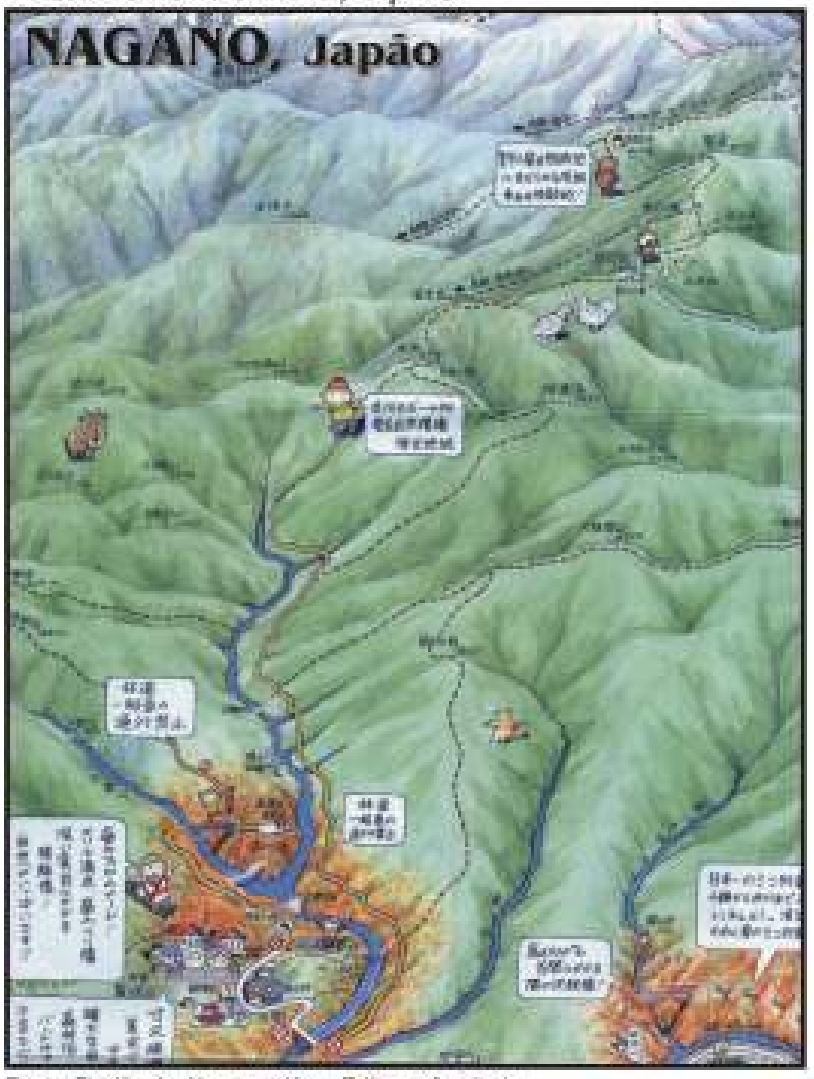

Fonte: Reqiấo de Naçano - Kem, Edinara nâo cilada.
Localidade: histórica

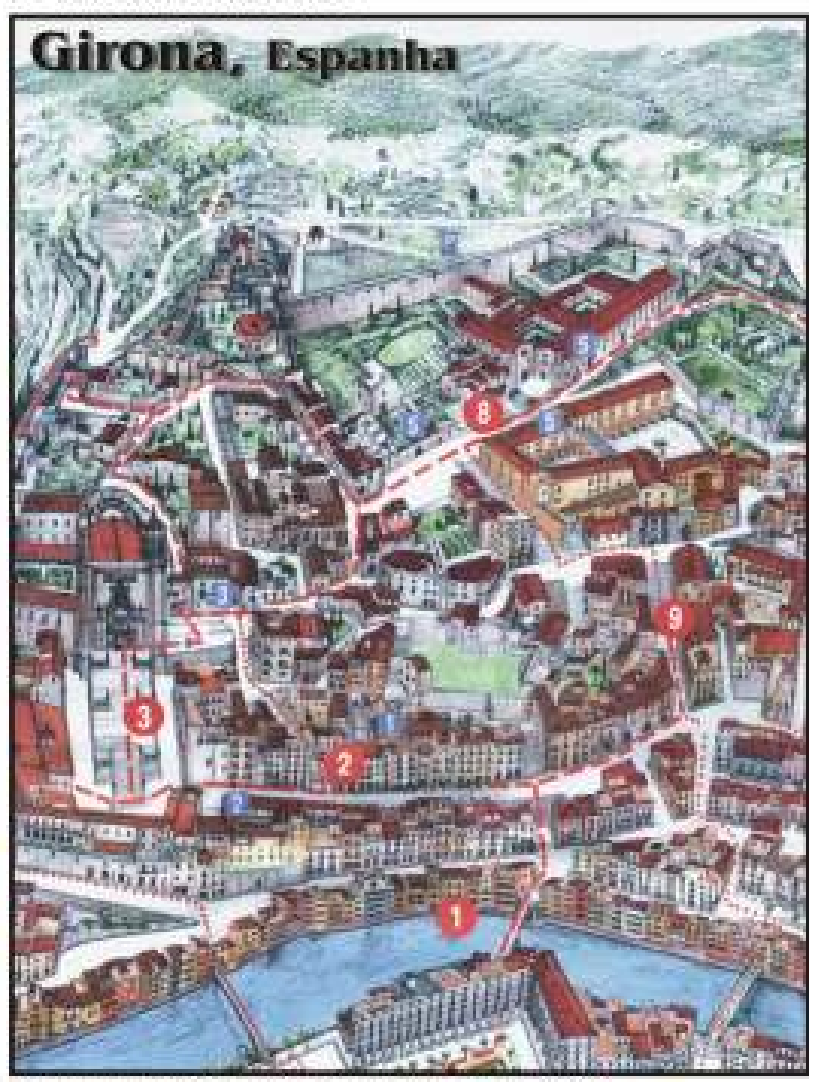

Fonte Mapa de Girona, Glerecido polo Ajuntament de Grana

Localidade: de águas, cachoeiras

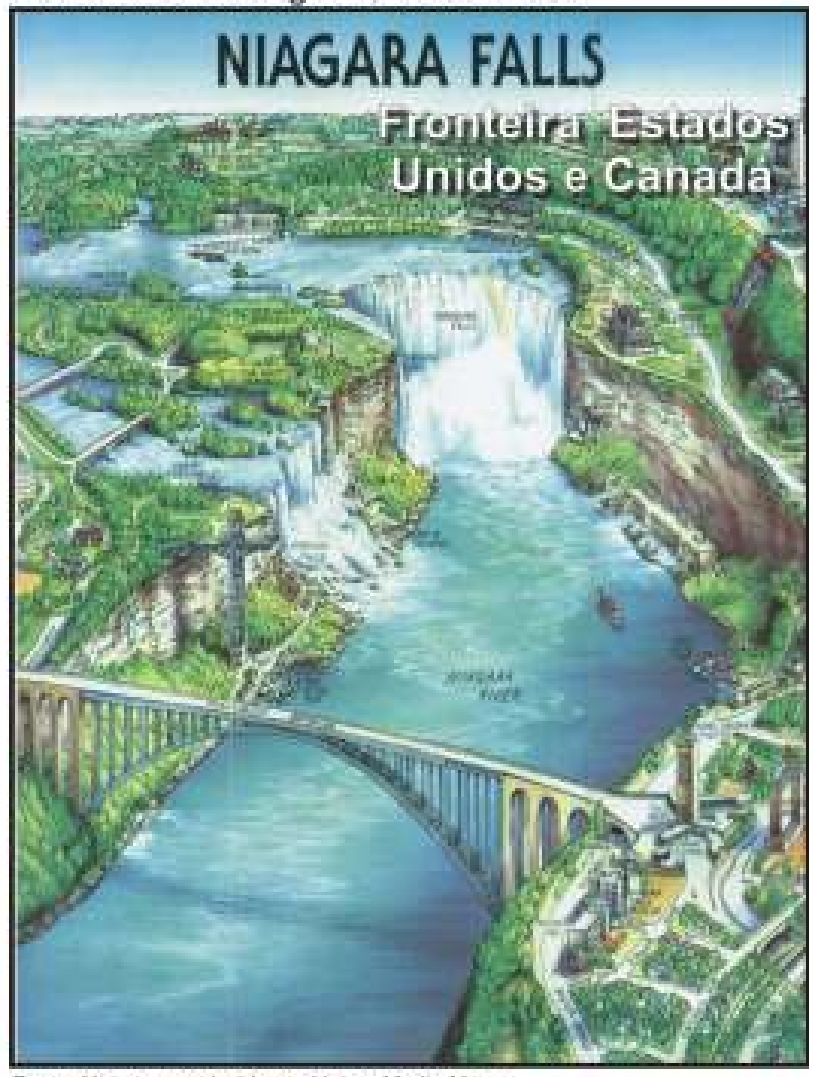

Fonte: Nagara, produzido por Uniquelladia Mags. 
Some-se ainda, uma junção entre as variáveis visuais de Bertin (1967), com atualização de MacEachren (1995), e os elementos visuais até agora descritos em suas qualidades sintático-semânticas. Todos esses recursos gráficos possibilitam representar o espaço por meio do mapa, proporcionando ao plano bidimensional uma aparente tridimensio-nalidade, como demonstrado na figura 68 .

Figura 68 - Composição de um mapa pictórico com variáveis e elementos visuais

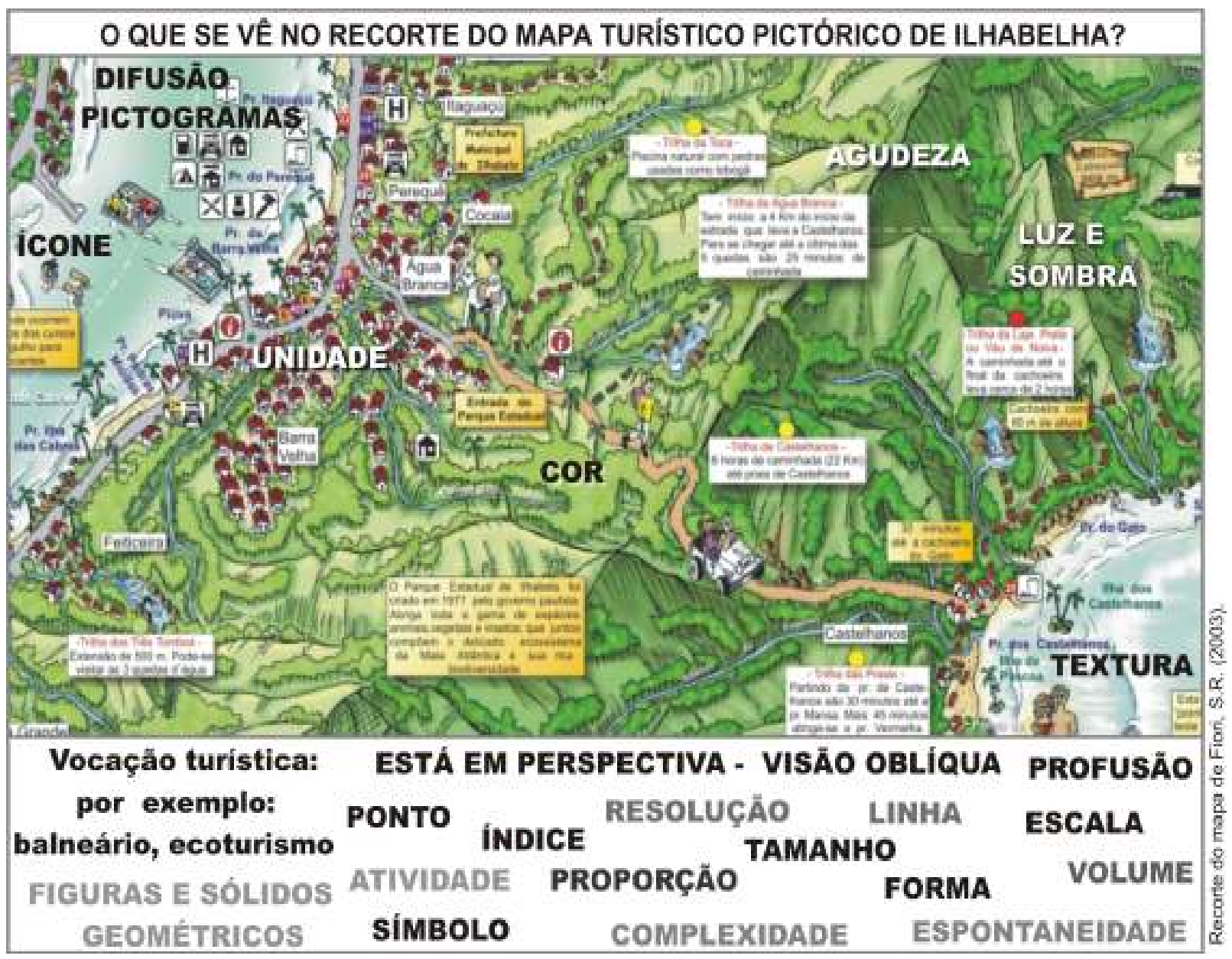

E, por se tratar de um mapa, não se poderia deixar de abordar que sempre haverá algum tipo de texto, pois a palavra escrita é um recurso eficiente e a articulação desenho / texto verbal constitui uma técnica importante para facilitar a decodificação de uma mensagem.

O texto verbal aparece, no mapa pictórico turístico, por exemplo, no título, em algumas legendas e etiquetas que apresentam um determinado assunto e são inseridos de forma natural à cena: uma folha de papel ou monitor do computador. No caso desta pesquisa, o código de expressão da mensagem é a língua portuguesa idioma oficial do país e compreendido pela imensa maioria das pessoas alfabetizadas, porém é importante frisar que o produto também será disponibilizado em inglês - de tal modo que, para que se compreendam plenamente as informações 
dispostas sobre o mapa, é necessário compreender o código de expressão da mensagem.

O texto usado no mapa turístico pictórico serve tanto para reforçar a representação pictórica quanto para enriquecê-la com outras informações complementares (Figura 69). Aliás, a divulgação pelo marketing turístico tem o poder de influenciar, direcionar, informar, facilitar a seleção ou escolha do usuário sobre uma determinada destinação, que conta com diferentes propostas paisagísticas ao turista, como rotas, lugares, áreas, atividades específicas da localidade.

Figura 69 - Articulação texto e imagem

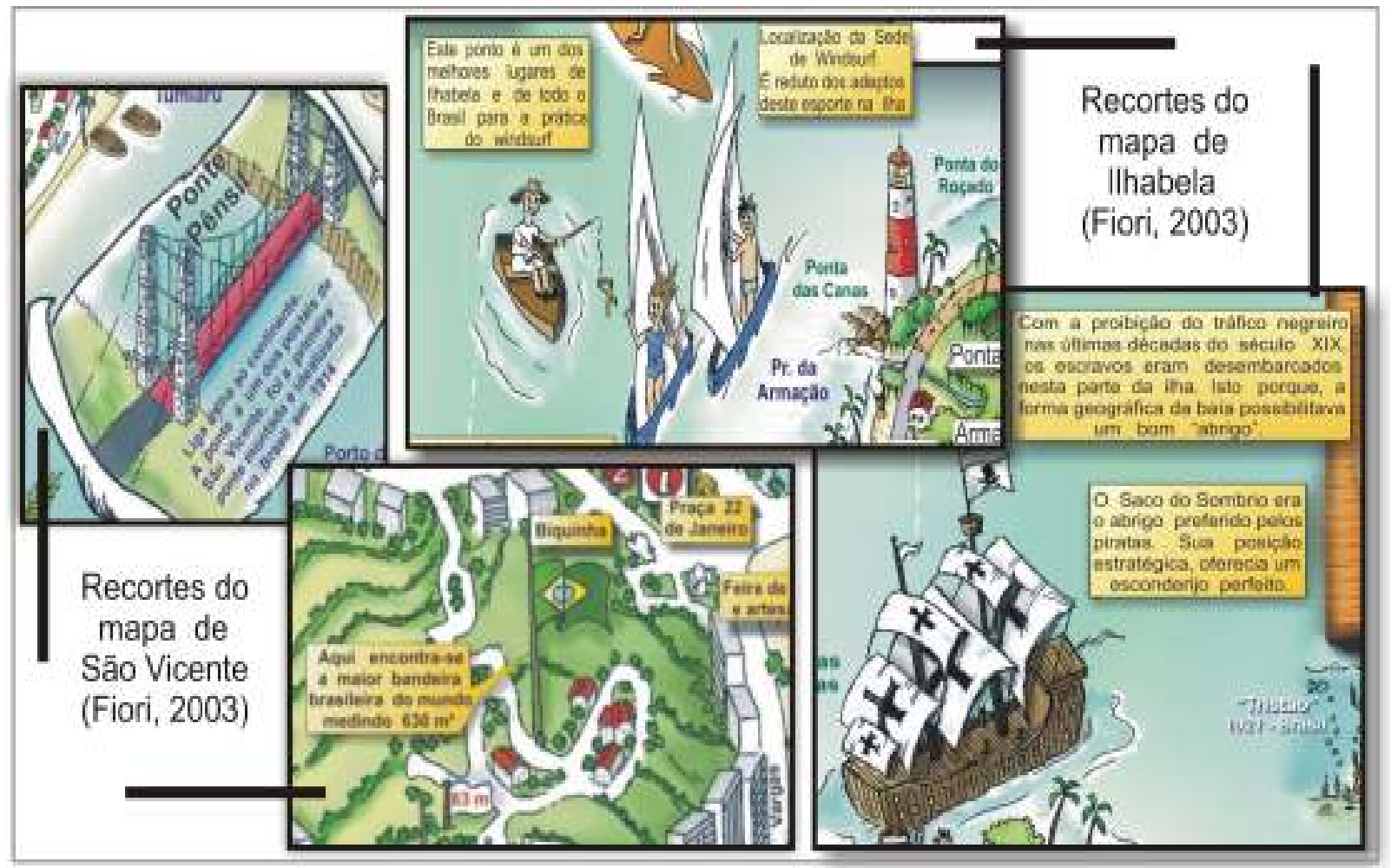

Moreira Leite (1998: 44) complementa que, embora habitualmente a linguagem visual seja considerada de transmissão direta, pode apresentar uma postura parasitária em relação à linguagem verbal. As imagens visuais precisam das palavras para que sejam transmitidas e, freqüentemente, a palavra já inclui em si um valor figurativo a ser considerado. Entretanto, em grande parte das vezes, as palavras não conseguem evocar exatamente o que a imagem propõe.

Barthes (1990: 33, 34) reitera que, de um lado, o texto verbal traz a possibilidade de o criador, e também de a sociedade, exercer um controle sobre a imagem: a fixação é o controle, detém uma responsabilidade sobre o uso da mensagem frente ao poder de projeção das ilustrações. Mostra-se como um valor repressivo em relação à liberdade dos significados da imagem. Por outro lado, a mensagem icônica possibilita que o leitor apressado não tenha que se incomodar com as descrições verbais, acreditando 
que as imagens constituem um sistema menos trabalhoso para assimilar a informação. Porto Alegre (1988: 80) complementa que, intuitivamente, um indivíduo é capaz de entender certas imagens sem passar à palavra e, mais do que isso, se tentar recorrer à fala, o sentido do que é puramente imagem não conseguirá existir, uma vez que se trata de um sentido irredutível.

Por tudo que foi exposto, pode-se estabelecer que não existe um tipo de mensagem lingüística, verbal, visual ou icônica absoluta. A idéia, então, é utilizar da melhor forma possível as três possibilidades de elaboração da mensagem: icônica codificada, icônica não-codificada e lingüística, apontadas por Barthes (1990: 28-40), para que, assim, o mapa pictórico se torne mais facilmente compreendido. Até porque os três tipos de mensagens apresentadas capacitam a trabalhar a redundância, podendo tornar o mapa mais informativo e esteticamente mais rico e agradável.

\section{2 - Símbolos de informação pública: pictogramas utilizados em mapas turísticos}

Até o momento, a pesquisa tratou particularmente do uso das representações pictóricas, objetivando justificar sua importância estética e informativa, onde todo o processo de design está essencialmente vinculado a um tipo de mapa preocupado em satisfazer as necessidades do setor do turismo.

Este setor de consumo ocorre em meio à infra-estrutura urbana ou rural, estando sujeito a condições de uma sinalização própria aos equipamentos, serviços e atrativos turísticos. Entre outras condicionantes, é importante que a destinação proporcione orientação ao turista, resultando em algum tipo de serviço de guia pela própria sinalização existente no local (Carneiro, 2001:5).

No caso do serviço aqui ressaltado, o mapa turístico, a comunicação almejada para os símbolos das legendas encerra-se em uma dualidade apresentada por Carneiro (2001:14): devem ser claros o bastante para serem globais, mesmo incorporando um certo grau de subjetividade; e personalizados, para atingirem os objetivos individuais do receptor, relacionando-se à atual tendência de uma comunicação plural de pessoas e gostos.

Como já visto anteriormente, o símbolo tem o poder de sugerir a parte de um todo, por exemplo, a cruz para a cristandade, a coroa para a monarquia, o círculo para a harmonia e perfeição. Um objeto, quando projetado traz à mente uma sucessão de idéias relacionadas entre si, analógica ou metaforicamente. O costume de estruturar o mundo em substâncias, cores, direções, animais e traços humanos, estimula uma visão simbólica do mundo (Tuan, 1980: 26).

Neste momento, discrimina-se uma grande variedade de símbolos, os quais denotam e conotam atividades, atrativos e serviços encontrados nas mais variadas destinações. 
De maneira geral, o simbolismo é utilizado corriqueiramente no dia-a-dia. Dondis (1991: 94), por exemplo, lembra que as datas festivas como o Natal, a Páscoa, o Dia dos Namorados, entre outras aproveitam os simbolismos sensíveis ao efeito publicitário (Figura 70). Até mesmo as empresas de grande porte adeririam aos símbolos visuais para representar sua identidade e seus objetivos.

Figura 70 - Os simbolismos cotidianos

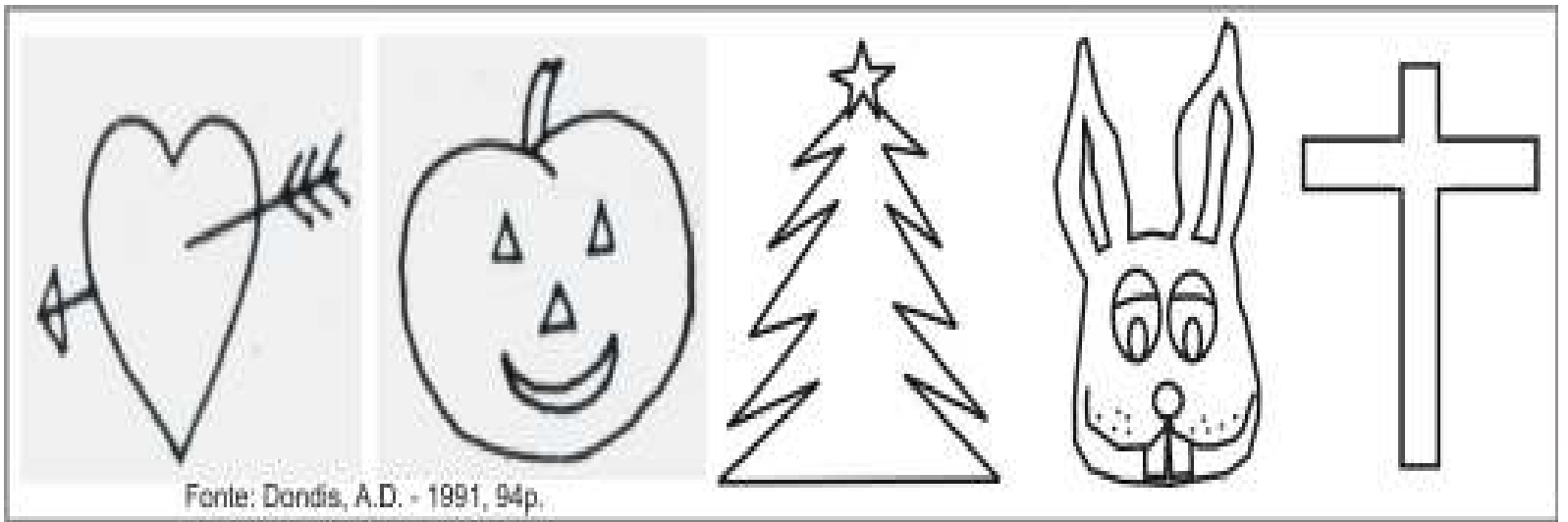

Portanto, o símbolo se configura como um meio de comunicação visual: deve ser simples, impregnado de informação de significado universal. Ele não existe apenas na linguagem verbal e visual: seu uso é muito mais abrangente, referindo-se a um grupo, idéia, atividade comercial, instituição ou partido político (Figura 71).

Figura 71 - Símbolo: meio de comunicação social

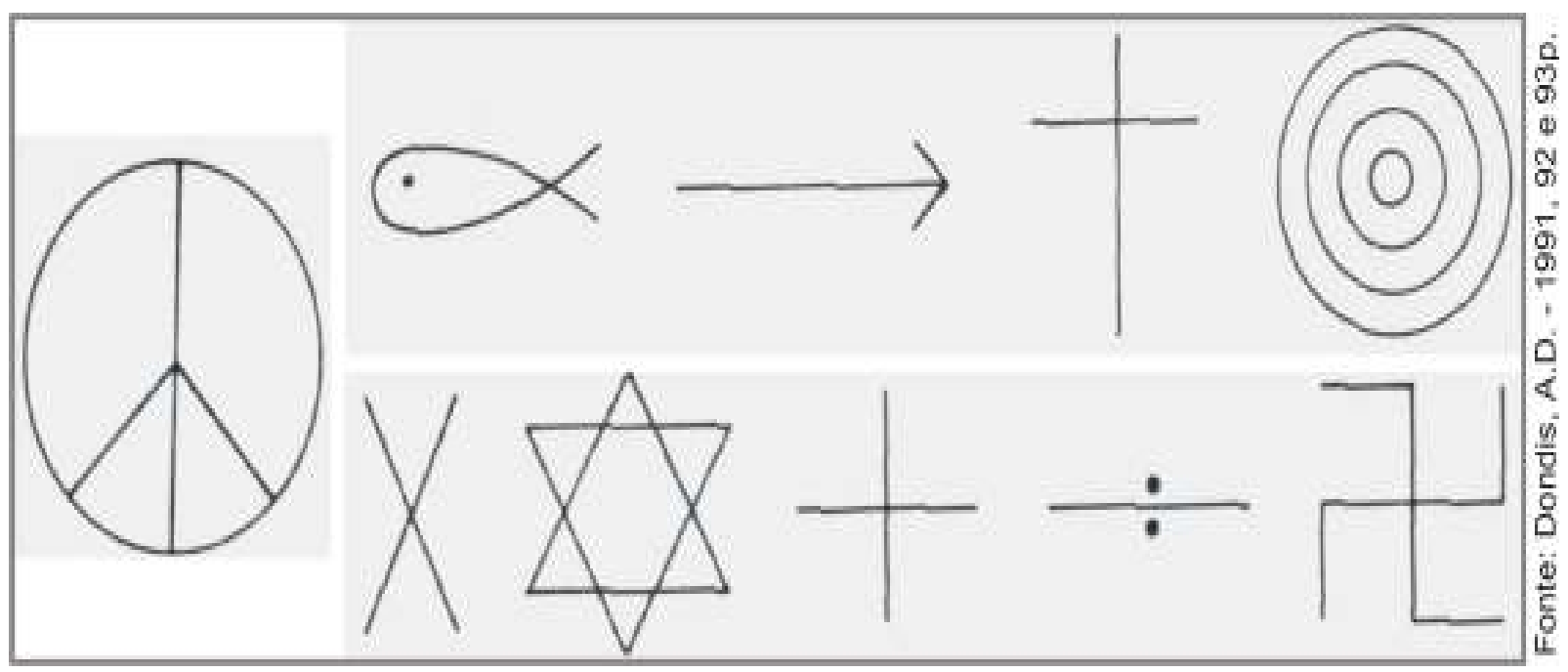

A interação entre propósito e composição de um lado e entre estrutura sintática e substância visual de outro deve ser mutuamente reforçada para que atinja uma maior eficácia em termos visuais. Constituem, em conjunto, a força mais importante de toda comunicação visual, a anatomia da mensagem (Dondis, 1991: 105). 
Isso posto, busca-se utilizar simbologias já existentes e desenvolver outras, quando necessário, que sejam bem aceitas e interpretadas em vários níveis e tipos de representação, pelo maior número de pessoas, as quais compõem o heterogêneo nicho de mercado relacionado ao setor do turismo.

Este momento focaliza e aprofunda os desenhos e símbolos pictóricos a serem dispostos nas legendas de mapas turísticos. O estudo empírico iniciado em Fiori (2003: 157 - 179) sobre a pictografia utilizada em símbolos de informação pública, somado às leituras de outros trabalhos - Forrest e Castner (1985), Clarke (1989), Forrest (1998), Gerber, Burgen \& Stanton (1990), Leung e Li (2002) - deixam claro o valor deste tipo de representação quando relacionado à compreensão da mensagem pelo usuário não especializado.

Muehrcke (1986:84) é relembrado ao afirmar que os símbolos pictóricos oferecem um maior apelo estético, além de serem lidos e apreciados mais facilmente por crianças e usuários não habituados a semântica cartográfica.

Em contrapartida, como também se firma desde o início desta pesquisa, é flagrante, principalmente às representações pictóricas, o contexto cultural que, por exemplo, gera e possibilita a escolha do estilo artístico; familiariza o usuário, capacitando-o a compreender a representação; valoriza certos elementos em detrimento de outros, etc. A preocupação está no olhar, que é condicionado por hábitos e expectativas, tanto que, ao se romper este vínculo, a comunicação tem grande possibilidade de falhar.

Em relação aos símbolos de informação pública (SIP), Carneiro (2001:14) ressalta que, devido ao momento histórico e econômico, torna-se cada vez mais necessária uma simbologia padronizada, na medida em que a qualidade do produto ou serviço passa a ser um atributo imprescindível à sua venda. $O$ público consumidor tende a ser por natureza frio e objetivo, exigindo a eficácia do produto e/ou serviço no qual está investindo seu tempo e dinheiro, não aceitando mais promoções mentirosas.

Conseqüentemente, a seleção e/ou desenvolvimento de SIPs e pictogramas ${ }^{57}$, dispostos em mapas turísticos impressos ou em meio digital, devem estabelecer um design eficiente e capaz de abranger o contexto mental de sociedades de diferentes tradições e culturas podendo ser consumidos, por exemplo, por brasileiros, europeus, australianos chineses ou japoneses.

Partindo do pressuposto de que o usuário só entende uma mensagem quando o repertório disponível é igual ao que ele conhece, até porque o contrário inviabiliza qualquer iniciativa de criação e implantação de um sistema de sinalização turística,

\footnotetext{
${ }^{57}$ A popularização do turismo e das viagens internacionais ocorreu principalmente após a Primeira Guerra Mundial, fazendo com que houvesse a necessidade de se criar um sistema de comunicação que não fosse limitado pela fronteira da língua. Gerou-se então, o interesse pela linguagem dos signos: o pictograma (Carneiro, 2001: 1), denominado por Frutiger (apud Carneiro, 2001: 25) como signo de segurança, possibilitando ao usuário apreender a informação com maior rapidez e facilidade.
} 
torna-se extremamente necessário o esforço continuado de um inventário, ordenação, padronização e divulgação, em escala internacional, de sistemas de sinalização. Assim, ao longo dos anos, poderá se vislumbrar a composição de um sistema único, normatizado, pelo menos no que se refere a ações, situações e locais de senso comum. A partir daí, os manuais de sinalização, ditos oficiais, reveriam suas posições, pois ser oficial não é uma qualidade imposta pelos órgãos ou entidades, mas sim uma condição legítima de uso e inteligibilidade (Carneiro, 2001:193).

Baseado em Souza (1992:2-5), inicia-se a discussão sobre os Símbolos de Informação Pública (SIP). As imagens dispostas na figura 72 são caracterizadas por sua funcionalidade, ou seja, são produzidas e criadas com um único intuito: a comunicação social. Devido a sua função sinalética ${ }^{58}$, excluem-se de sua natureza todas as imagens produzidas apenas com a intenção ornamental ou estética.

Esse tipo de imagem funcional, sinalética, gráfica, sem valor fonético, de natureza icônica é conhecida no âmbito da comunicação visual pelo nome de pictogramas, símbolos de sinalização, ou ainda, SIPs. Além disso, é auto-explicativo, devendo apresentar como características básicas a concisão gráfica, a densidade semântica e uma funcionalidade comunicativa que ultrapasse as barreiras comunicativas (Souza, 1992:6).

Entre os vários tipos de imagens gráficas já abordadas até aqui - representações pictóricas, mapas, plantas, etc - Souza (1992: 6) destaca os pictogramas como signos que comunicam mensagens primordiais à prática e a organização da vida pública, procurando superar as barreiras lingüísticas, reforçando, ampliando e, até mesmo, substituindo a palavra escrita e falada. De maneira simplificada, a autora (Souza, 1992: 141) conceitua pictograma como:

signos de comunicação visual, gráficos e sem valor fonético, de natureza icônica figurativa e de função sinalética. São auto-explicativos e apresentam como principais características: concisão gráfica, densidade semântica e uma funcionalidade comunicativa que ultrapassa as barreiras lingüísticas.

\footnotetext{
${ }^{58}$ Sinaléticos - compreende os signos gráficos - tais como: os pictogramas, os códigos gráficos de âmbito profissional, as marcas e logotipos institucionais, a sinalização viária (Souza, 1992: 132) - que transmitem informações essenciais a um grande número de pessoas, inclusive de línguas diferentes, para orientar o seu comportamento social.Tais imagens indicam reações comportamentais apropriadas em determinada situação social. Na tabela 72 podem-se classificar as imagens por sinais indicativos (fig. 3,14), designativos (fig. 1, 2, 4, 5, 6, 7, 8, 10, 11, 12, 13, 15, 16) e proibitivos (fig.9) (Souza, 1992: 5).
} 
Tabela 72 - 0 que representam e o que dizem essas formas gráficas?

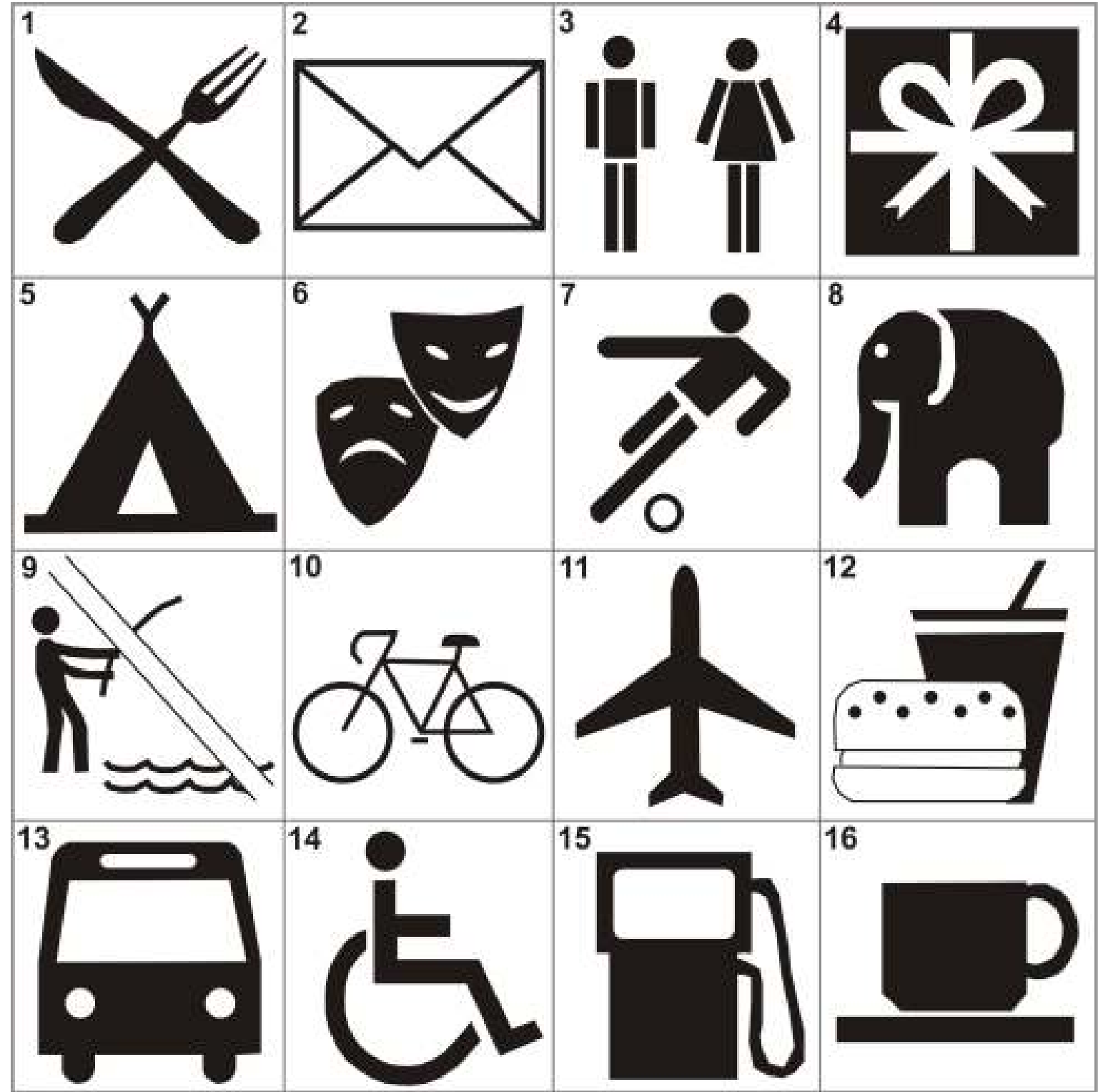

\begin{tabular}{|c|l|l|}
\hline $\begin{array}{c}\text { Forma } \\
\text { gráfica }\end{array}$ & \multicolumn{1}{|c|}{ Que representam ? } & \multicolumn{1}{|c|}{ Que dizem? } \\
\hline 1 & Garfo e faca & Restaurante \\
\hline 2 & Carta & Correio \\
\hline 3 & Homem, mulher & Porta de recinto (banheiro) \\
\hline 4 & Pacote decorado, presente & Local de compras (shopping) \\
\hline 5 & Tenda, cabana, barraca & Local para camping \\
\hline 6 & Duas máscaras (triste e alegre) & Teatro \\
\hline 7 & Jogando futebol & Evento esportivo, campo para esporte \\
\hline 8 & Elefante & Zoológico \\
\hline 9 & Homem pescando com barra diagonal & Proibido pescar \\
\hline 10 & Bicicleta & Ciclovia, aluguel de bicicleta \\
\hline 11 & Aviăo & Aeroporto \\
\hline 12 & Păo (hambürguer) e copo \{de suco, rétrigerante) & Lanchonete, fast-food \\
\hline 13 & Ónibus & Estação rodoviária, parada de ônibus \\
\hline 14 & Homem em uma cadeira de rodas & Local acessivel a deficientes fisicos \\
\hline 15 & Bomba de gasolina & Local de abastecimento, posto \\
\hline 16 & Pires e xícara & Local onde se encontra café \\
\hline
\end{tabular}


Já Carneiro (2001: 2) estabelece o pictograma por meio do conceito de ideograma, ou seja, desenho que representa uma idéia. Logo, o pictograma é uma espécie de ideograma que simboliza, representa uma idéia ou elemento em particular, sem que para isso necessite da palavra. Por exemplo, um objeto concreto - o telefone - ou um fato - alimentação - pode ser representado pelo pictograma, que estará no lugar do objeto, do fato. Esse tipo de comunicação é aplicado na maioria dos países, mesmo que seus traços gráficos sejam elaborados de maneiras e formas diversas (Figura 73 A). Some-se aqui que, quanto mais abstrata for uma imagem, maior será a necessidade de aprendizagem do seu significado, ou seja, o pictograma só se terá significado a partir do momento em que for reconhecido como sinal de comunicação Figura 73 B (Souza, 1992: 148).

\section{Figura 73 - 0 pictograma}

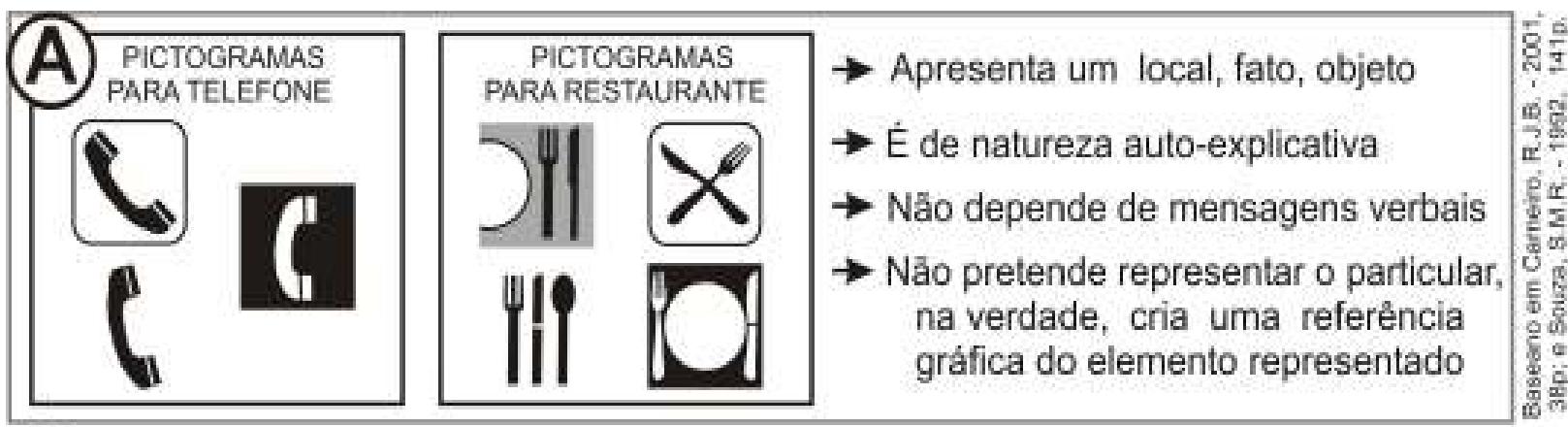

(B) Cinco graus de abstração dos pictogramas referentes a masculino e feminino
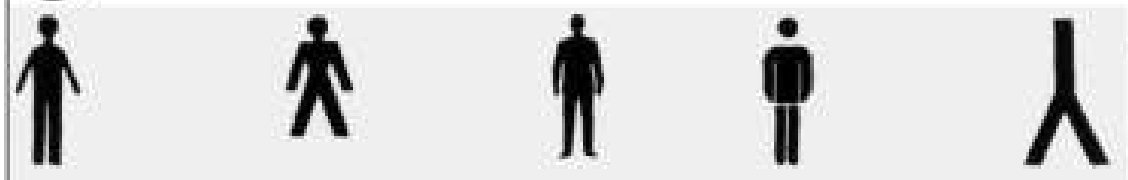

A natureza icônica dos pictogramas admite

graus de esquematização do desenho, correspondendo a diferentes graus

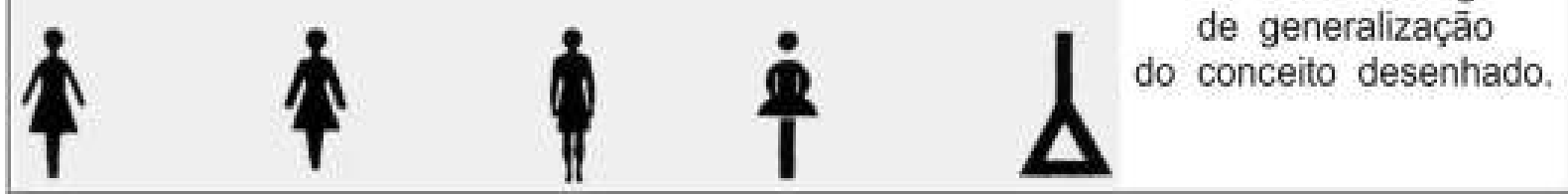

(1)

Os pictogramas têm ilustrado sinais ou mensagens de trânsito, os mais variados eventos esportivos, feiras mundiais, aeroportos entre outras atividades cotidianas. Encontra-se, por exemplo, em equipamentos eletrodomésticos, no zoológico, na sinalização turística, adaptando-se a distintas culturas e situações (Carneiro, 2001: 2). Existem, ainda, alguns símbolos que representam objetos e locais do cotidiano humano, como aqueles pictogramas utilizados para indicar locais públicos (hospital, banheiro, vestiários, restaurantes) e serviços (telefonia, transportes, informações, estacionamento). No entanto, tais pictogramas não são suficientes para garantir o aprendizado de toda gama de sinais inseridos na simbologia usada na comunicação visual (Carneiro, 2001:191). 
No que diz respeito ao programa de uma sinalização turística, a autora complementa (op.cit.: 2001:196) que se devem levar em conta as sinalizações (Figura 74):

$\checkmark$ Externas: inseridas em ambientes urbanos e rurais - referem-se aos equipamentos e serviços atrativos do cenário representado,

$\checkmark$ Internas: referem-se especificamente aos equipamentos, apontando as suas facilidades, serviços e locais especiais,

$\checkmark$ De uso comum: orientações de cunho genérico, dirigidas a turistas, como advertências, proibições e regulamentações.

Figura 74 - Estrutura inicial de um sistema de sinalização turística

\begin{tabular}{|c|c|c|c|c|}
\hline & & $\begin{array}{l}\text { Vias de } \\
\text { Acesso } \\
\text { em consonância } \\
\text { com Contran e }\end{array}$ & $\begin{array}{l}\text { Rodoviári } \\
\text { Ferroviári } \\
\text { Aérea }\end{array}$ & \\
\hline & EXTERNA & & & $\begin{array}{l}\text { Parques estaduais } \\
\text { Áreas de proteção }\end{array}$ \\
\hline & & Atrativos & Histórico- & culturais \\
\hline & & & Artificiais & $\begin{array}{l}\text { Parques temáticos } \\
\text { de diversão }\end{array}$ \\
\hline & & $\begin{array}{l}\text { Serviços/ Equi } \\
\text { Indicação e Or }\end{array}$ & $\begin{array}{l}\text { (Turisticos } \\
\text { ntaçäo). }\end{array}$ & e Näo-Turísticos \\
\hline SINALIZAÇÃO & INTFRNA & $\begin{array}{l}\text { Equipamentos } \\
\text { de apoio }\end{array}$ & $\begin{array}{l}\text { Hotéis } \\
\text { Eventos/F } \\
\text { Restaurar }\end{array}$ & $\begin{array}{l}\text { eiras } \\
\text { tes }\end{array}$ \\
\hline & & Serviços & $\begin{array}{l}\text { Todos os } \\
\text { não só os }\end{array}$ & $\begin{array}{l}\text { serviços, } \\
\text { turisticos }\end{array}$ \\
\hline & & Comunicaçōes & $\begin{array}{l}\text { Sinais de } \\
\text { em emb } \\
\text { produtos, }\end{array}$ & $\begin{array}{l}\text { advertência } \\
\text { alagens de } \\
\text { manuais, etc. }\end{array}$ \\
\hline & & Educação & $\begin{array}{l}\text { Sinais edu } \\
\text { escolas, b } \\
\text { museus, c }\end{array}$ & $\begin{array}{l}\text { Icativos em } \\
\text { ibliotecas, } \\
\text { ampus universitário }\end{array}$ \\
\hline & OUTRAS & Facilidades & $\begin{array}{l}\text { Médicas, } \\
\text { manutenç: } \\
\text { transporte }\end{array}$ & $\begin{array}{l}\text { nospitalares, } \\
\text { âo de } \\
\text { s, etc. }\end{array}$ \\
\hline & & $\begin{array}{l}\text { Segurança } \\
\text { Industrial }\end{array}$ & $\begin{array}{l}\text { Prevenção } \\
\text { incêndios, } \\
\text { saidas de }\end{array}$ & $\begin{array}{l}\text { e combate a } \\
\text { radioatividade, } \\
\text { emergência, etc. }\end{array}$ \\
\hline
\end{tabular}


A figura 75 refere-se ao fato de que, além do princípio básico de que todo pictograma deve ser compatível a várias culturas, faz-se ainda uma segunda ressalva: devido ao desenvolvimento natural da sociedade, correlacionado ao tempo e sua dinâmica, é bem provável que alguns símbolos necessitem de uma reavaliação periódica de suas representações. Por exemplo, citam-se as diferentes formas - reflexo do processo evolutivo - de representação para telefone, isto é, será que o pictograma elaborado para as Olimpíadas de 1968 no México não está ultrapassado? Até porque, atualmente, é raro se deparar com um telefone discado.

Figura 75 - As modificações das representações gráficas ao longo do tempo

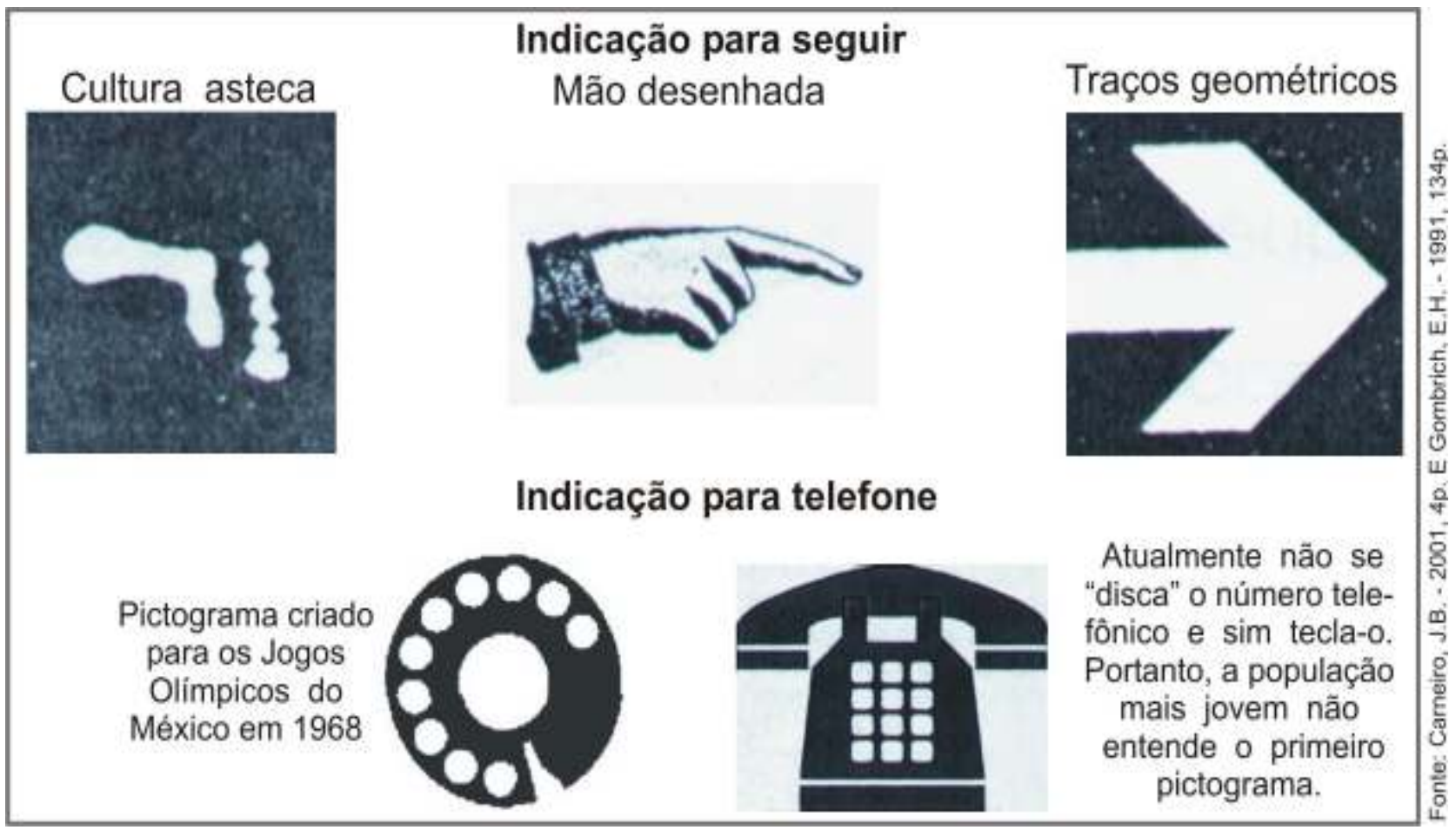

A figura 76 exemplifica o processo essencialmente dinâmico referente à evolução dos traços gráficos para os sinais de orientação.

Souza (1992: 178; 182) ainda lembra que, mesmo havendo um princípio normativo para a criação de pictogramas, é comum surgirem várias versões do mesmo conceito, isto é, o mesmo pictograma pode apresentar diferenças gráficas sem que isso altere sua significação (Figura 76A). Acrescente-se que, embora o plano de representação do pictograma seja preferencialmente frontal, ainda existem os pictogramas longitudinais e, mais raramente, os em perspectiva (Figura 76B). 
Figura 76 - Pictogramas: versões de um mesmo conceito

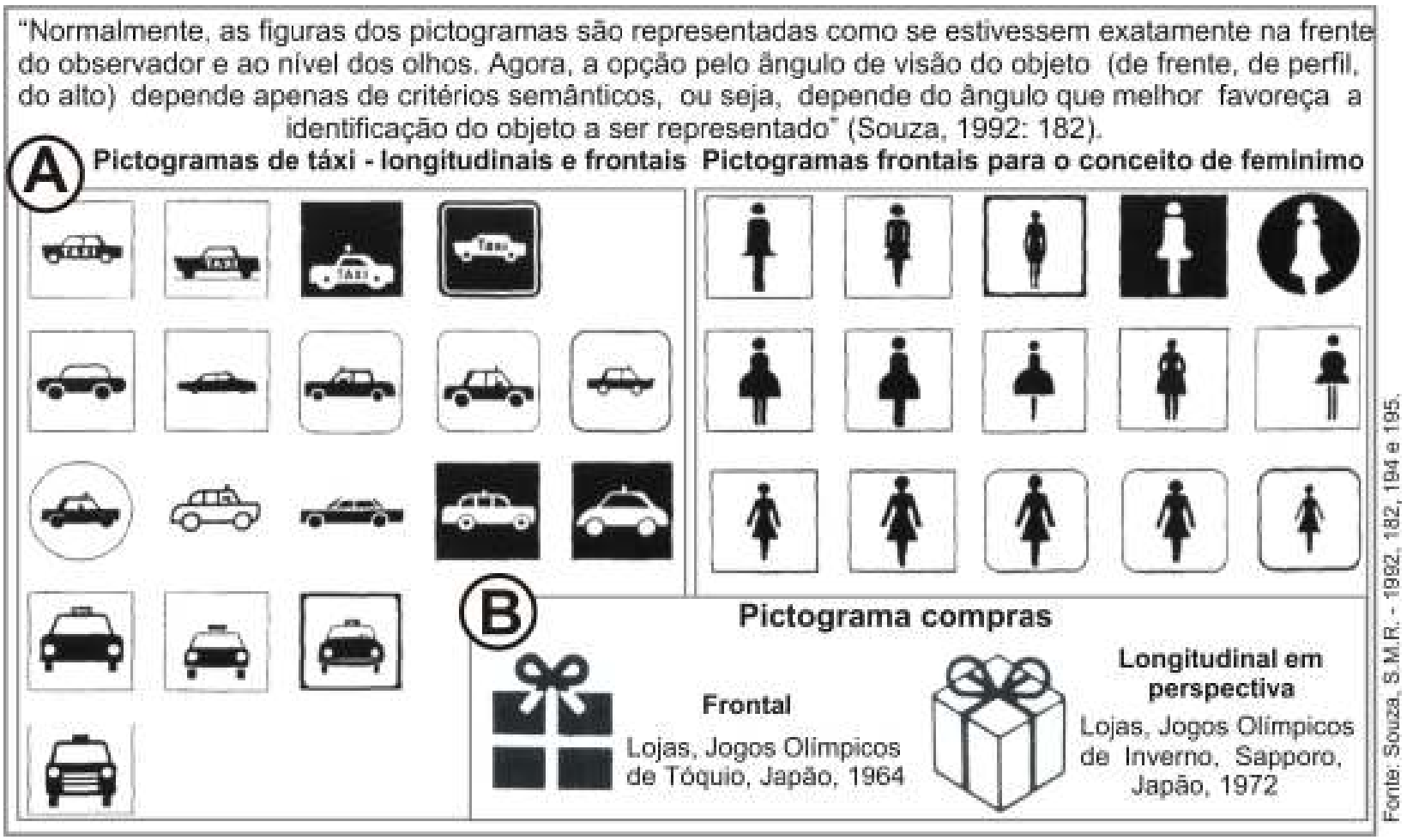

Carneiro, 2001:3) lista três tipos diferentes de pictogramas (Figura 77):

$\checkmark$ O figurativo - caracteriza-se pela vocação mimética de sua imagem, não deixando dúvidas quanto ao seu significado para o observador. Representa o objeto, ação ou idéia por meio de um desenho com peculiaridades aproximadas do elemento representado. Informa de maneira imediata; logo, não necessita de uma aprendizagem especial.

$\checkmark$ O semântico - abrange os esquemas cuja mensagem gráfica do objeto, ação ou idéia não é compreensível à primeira vista, exigindo um certo esforço de reflexão. O reconhecimento deste tipo de pictograma exige um período de aprendizagem específico. Logo, busca-se elaborar uma imagem gráfica por meio de contornos simples, suficientemente claros e inteligíveis na relação entre a representação e seu símbolo para que, assim, as pessoas entendam pelo aprendizado do uso constante.

$\checkmark$ O abstrato - compreende signos que possuem um alto grau de abstração, ou seja, não apresentam o objeto, ação ou idéia. É um código que será entendido apenas por aquelas pessoas que aprenderam como utilizá-lo. No entanto, quando incorporados ao conhecimento, sendo empregados de modo inconsciente, a informação que prestam é imediata e espontânea, tal como acontece aos signos alfabéticos. 
Figura 77 - Os três níveis de pictogramas

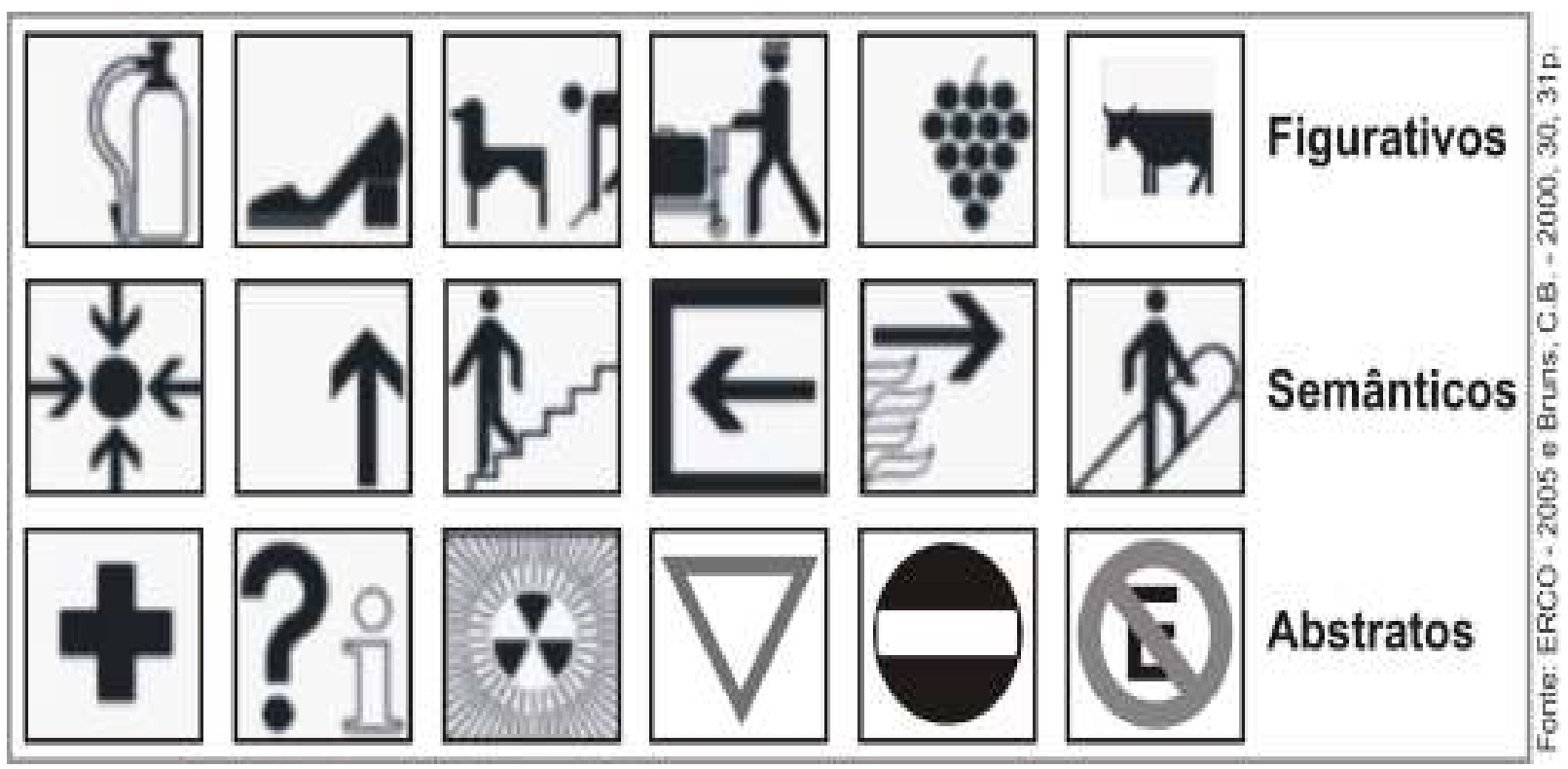

Para finalizar, Souza (1992:193) descreve as etapas do processo de categorização para a produção de pictogramas, que compreende as seguintes etapas:

a) reconhecer atributos (gestuais ou formais) invariantes distintivos que um ser, objeto ou situação possuem para pertencer a esta ou àquela classe; b) valorar os atributos reconhecidos; c) selecionar os atributos mais significativos para uma correta identificação semântica do ser, objeto ou situação; d) traduzir os atributos selecionados para a linguagem gráfica, observando as normas ou padrões sintáticos já estabelecidos pelo uso.

Carneiro (2001: 7) expõe a flagrante falta de estudos e pesquisas de caráter científico sobre a implantação, o uso e compreensão dos pictogramas em um sistema de sinalização turística ${ }^{59}$. E isso se traduz em uma escassa bibliografia disponível no Brasil e mesmo no exterior.

Como se pôde notar, a continuidade na elaboração de uma simbologia voltada aos mapas pictóricos turísticos conta com a valiosa dissertação de Carneiro (2001) intitulada: Sinalização Turística - diretórios e sistemas nacionais e internacionais, por desenvolver um trabalho apurado ao longo de quatro anos sobre o uso de pictogramas no setor turístico. A autora escolheu os diretórios (ou sistemas) do

\footnotetext{
${ }^{59}$ Compreende todo sinal gráfico (lingüístico, pictórico ou misto) que promova a correta orientação do usuário/ turista dentro de uma destinação ou equipamento turísticos (Carneiro, 2001: 11).
} 
Instituto Americano de Artes Gráficas ${ }^{60}$ (A/GA) e do japonês de Kuwayama ${ }^{61}$ Pictogramas e Fontes do Mundo Inteiro $n^{\circ}$. 2, por serem fontes bibliográficas constantes nos sistemas oficiais brasileiros e também por constituírem-se fontes referenciais em publicações nacionais e internacionais. Ao mesmo tempo, analisou alguns sistemas de sinalização turística, como o da Portland Oregon Visitors Association $^{62}$ (POVA), das cidades de Navarra, Ibiza (Espanha) e Alentejo (Portugal), da empresa alemã ERCO e das Olimpíadas de 2000 em Sidney, Austrália.

Quanto a fontes nacionais, a autora optou por aqueles sistemas elaborados por órgãos oficiais de turismo, federal e estadual: o CONTRAN (Conselho Nacional de Trânsito), a EMBRATUR (Instituto Brasileiro de Turismo) e a Secretaria Estadual de Esportes e Turismo do Estado de São Paulo (SEET), o sistema de sinalização do Código de Transito Brasileiro, além do Guia Quatro Rodas Brasil, reeditado anualmente pela Editora Abril.

Posto isso, concorda-se com Carneiro (2001: 30) no tocante ao desafio que os comunicadores têm quanto ao coeficiente de repetição da informação - no caso, os pictogramas - em um determinado tempo, ou seja, quanto mais um mesmo Símbolo de Informação Pública for usado, mais haverá a probabilidade de ser conhecido por um maior número de pessoas. Cresce, dessa forma, a inteligibilidade.

O desenvolvimento ou a escolha de uso de um pictograma já elaborado deve sempre respeitar as três dimensões de projeção de um signo e deixar-se guiar por elas: a sintática (como dizer ao usuário = técnicas e regras), a semântica (o que dizer ao usuário = clareza, influência da cultura) e a pragmática (para que dizer e a qual usuário dizer = enfatiza ou elimina elementos caracterizadores do signo para melhor entendimento), procurando sempre a maior eficiência do pictograma - detalhes sobre as três dimensões estão no item 1.5 .

Neste momento, apresenta-se o recolhimento de pictogramas utilizados em várias partes do mundo. As tabelas de 2 a 8 mostram uma série de símbolos de informação pública encontrados em publicações referentes a sistemas de sinalização turística, mapas turísticos e sites do Brasil e de outros países - mais aqueles já testados empiricamente em Fiori (2003) - demonstrando que se pode almejar uma possível

\footnotetext{
${ }^{60}$ Associação sem fins lucrativos fundada em 1914. Desenvolve nos E.U.A. um programa que inclui eventos, publicações, exposições e atividades educativas, com a finalidade de promover a qualidade e a excelência no terreno do desenho ou design gráfico. Ao longo deste tempo, elaboraram, por exemplo, sistemas gráficos de sinalização e programas de identificação para clientes na Europa, África, Ásia e Estados Unidos (Carneiro, op.cit.:46).

${ }^{61}$ Coletou e inventariou pictogramas ao longo de sete anos (1980 a 1987) em 76 cidades de 39 países da Europa, Ásia e Américas (incluindo São Paulo e Rio de Janeiro), resultando na publicação desse diretório. Em 1993, foi lançado o segundo diretório (Carneiro, op.cit.:65).

${ }^{62}$ Essa associação requisitou de Todd Pierce (presidente da empresa Design Pacifica International LLC) e sua equipe a criação e organização de um repertório de pictogramas. Em 1996, foi publicado um livro com a intenção de ser um indicador de sinalização completo para a cidade de Portland (E.U.A.).
} 
homogeneidade em relação aos pictogramas, mesmo havendo a factual heterogeneidade intercultural.

Ao término do inventário, percebeu-se que:

A mesma aparência gráfica de um pictograma é utilizada por diferentes culturas. Como é o caso, por exemplo, dos pictogramas de abastecimento, informação, café, hospital, aeroporto, natação, teatro, camping, entre outros.

> Implicações culturais puderam ser evidenciadas em alguns casos. Primeiro: todos os países já arrolados ilustram pictograficamente o item restaurante a partir de representações gráficas compostas por um garfo, uma faca, uma colher e/ou um prato. Contudo, no Japão, esse item é representado por meio de um "rashi". Outro caso: o Brasil é o único país que não utiliza a letra "P" (parking) para se referir a estacionamento, preferindo a letra "E". Talvez a solução seja colocar o pictograma de um "carrinho" (redundância ao lado da letra), como utilizado no mapa de Glasgow, Inglaterra. O mesmo fato acontece com o SIP para Hotel. Uma observação final refere-se aos países do norte europeu (Alemanha, Finlândia, Suécia) que utiliza um "olho" para representar correio.

Alguns pictogramas são mais facilmente compreendidos e interpretados que outros, ou seja, existem pictogramas potencialmente mais usados em mapas turísticos e, por conseguinte, pelos usuários enquanto outros se referem a atividades e atrações turísticas específicas e restritas a poucas destinações. $O$ exemplo pode ser retirado dos pictogramas de arquitetura histórica, tipos de templos religiosos (igreja, mesquita, sinagoga), ou de atividades esportivas não muito conhecidas como: paraglider, rafting, windsurfe ou rapel.

A terceira etapa da pesquisa, como já foi realizada em Fiori (2003), propôs um repertório maior de pictogramas a serem testados empiricamente por intermédio da aplicação de questionários, tendo como referencial os símbolos de informação pública das tabelas de 2 a 8.

A análise ocorre basicamente se averiguando a eficácia da representação gráfica de cada pictograma, ou seja, quantificando e qualificando a compreensão e aceitação pelo público potencial. 
Tabela 2 - Acomodaçāol Hospedagem

\begin{tabular}{|c|c|c|c|c|c|}
\hline Coluna 11 & $\begin{array}{l}\text { ఫ्ञّ } \\
\text { 呈 }\end{array}$ & 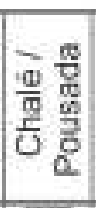 & 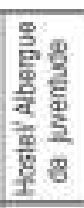 & $\frac{\frac{D}{E}}{\frac{C}{D}}$ & 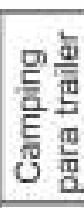 \\
\hline Fiori $(2003)^{*}$ & H] & 다 & & & \\
\hline $\begin{array}{l}\text { Secretaria do } \\
\text { turismo (Sáo Pauo) }\end{array}$ & & & & & \\
\hline CONTRAN & & & & & IF \\
\hline Guia 4 rodas & (6) & & & & \\
\hline IPHAN & & & & & \\
\hline ERCO & 10 & & & & \\
\hline Rügen & & & IR & & \\
\hline Dusseldorf & & & & & \\
\hline Buenos Aires & $\mathrm{H}$ & & & & \\
\hline Mendoza & $\theta$ & & & & \\
\hline Hull e Ottawa & & & & & \\
\hline Ottarwa & & & & & \\
\hline Chile & aㅣ & ill & & $\mathbf{A}$ & \\
\hline Cuba & TI & & & & \\
\hline Barcelona & $\mathrm{H}$ & & & & \\
\hline La Coruna & H] & & & & \\
\hline Madri & $\mathrm{H}$ & & & & \\
\hline Toledo & & & & & \\
\hline AIGA & 욜 & & & & \\
\hline Filadélfia & $|\mathbf{n}|$ & & & & \\
\hline $\begin{array}{c}\text { Williamsburg } \\
\text { (Vrginia) }\end{array}$ & & & & & \\
\hline Manhattan & & & & & \\
\hline Finlândia & 点 & $\mathbf{E}$ & If & $\mathbf{A}$ & 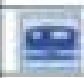 \\
\hline $\int_{\text {França }}^{\text {coshi }}$ & & & & & \\
\hline Milskolc & & & & & \\
\hline Budapeste & & & & & \\
\hline
\end{tabular}

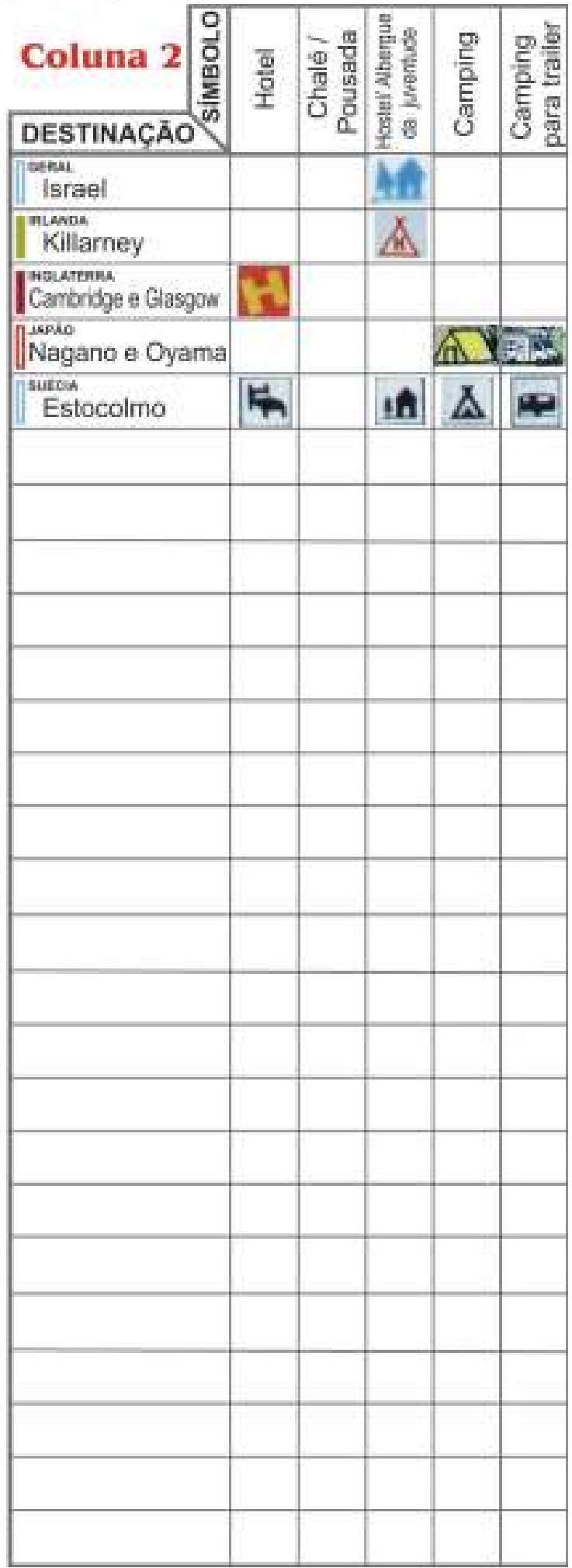


Tabela 3 - Serviços turísticos

\begin{tabular}{|c|c|c|c|c|c|c|c|c|c|c|c|c|c|c|}
\hline Coluna 11 & 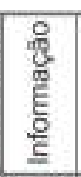 & 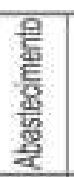 & : & & 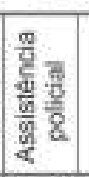 & $\begin{array}{l}\frac{\Phi}{0} \\
\frac{\delta}{\omega}\end{array}$ & 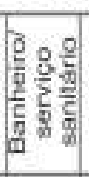 & $\begin{array}{l}\frac{8}{2} \\
\frac{\$}{2} \\
\frac{d}{2}\end{array}$ & 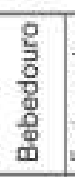 & 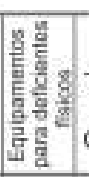 & 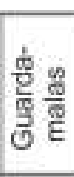 & 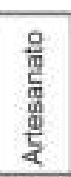 & 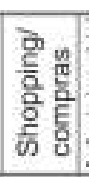 & 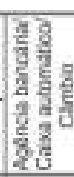 \\
\hline Fiori (2003)* & (4) & 믈 & 四 & 5 & $P$ & 6 & & 8 & & & & 8 & & \\
\hline $\begin{array}{l}\text { Secretaria do } \\
\text { turismo (Sso Pauto) }\end{array}$ & i & & & $=0$ & 2 & & 市章 & & & & & & 栗 & \\
\hline CONTRAN & (i) & 时 & & 후 & & & 先 & $>$ & & 5 & & 8 & & \\
\hline Guia 4 rodas & (i) & & $\mathbf{E}$ & 4 & & (6) & & & & & & & & S \\
\hline IPHAN & i & & S & 4 & & & a & $>$ & & & & 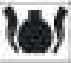 & & \$ \\
\hline ERCO & ? & & & $\infty$ & $\underline{z^{n}=}$ & & $\dot{\phi} \dot{t}$ & $\overline{\mathbf{T}}$ & & $\dot{\xi}$ & 0 & & (801 & 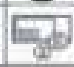 \\
\hline Rügen & & & & & & & & & & & & & & \\
\hline Dusseldorf & i & & (2) & $\boldsymbol{\theta}$ & 3 & & wC & & & 6 & & & & \\
\hline Buenos Aires & $\mathbf{1}$ & 是 & $\Delta$ & & & & & & & & & & Es & \\
\hline Mendoza & (i) & & & & & & & & & & & & 8 & \\
\hline Hull e Ottawa & $?$ & & & & & 6 & 60 & & $\mathrm{Na}$ & 5 & & & & \\
\hline Ottawa & $?$ & & & 4 & & & & & & & & & & \\
\hline Chile & in & Q & $\square$ & + & & 6 & & & & & & 3 & S & s \\
\hline Cuba & & 89 & 0 & Fis & & & & & & & & & हैं & 5 \\
\hline Barcelona & 17 & 19 & 四 & Da & 2 & t & & & & 5 & & & & \\
\hline La Coruña & F & B & 国 & 6 & & & & & & & & & & \\
\hline Madri & i & & & & & & & & & B. & & & & \\
\hline Toledo & (i) & & & & & & & & & & & & & \\
\hline AIGA & (2) & & $\theta$ & & & C & Wii & & $\mathrm{N}$ & & 亶 & & 酋苗 & 梿 \\
\hline Filadélfia & & & & $\mathrm{H}$ & & & & & & & & & & \\
\hline $\begin{array}{c}\text { Wililiamsburg } \\
\text { (Mirginia) }\end{array}$ & & & & & & $C$ & $+\phi$ & & 0 & 6 & & & & \\
\hline Manhattan & & & & & & & & & & & & & & \\
\hline Finlândia & & 6 & (a) & & & & & 1 & & & & & 1 & $\$$ \\
\hline França & & & & & & & & & & & & & & \\
\hline Milskolc & $\mathbf{1}$ & & & & & & & & & & & & & \\
\hline Budapeste & i & 9 & & $\boldsymbol{A}$ & & & & & & & & & & \\
\hline
\end{tabular}

\begin{tabular}{|c|c|c|c|c|c|c|c|c|c|c|c|c|c|c|}
\hline Coluna 2 DESTINAÇĀO & 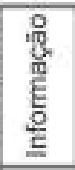 & $\begin{array}{l}\text { 을 } \\
\text { 댕. } \\
\text { 要 } \\
\frac{1}{2}\end{array}$ & $\begin{array}{l}\text { 융 } \\
\text { 응 }\end{array}$ & 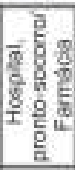 & 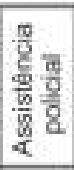 & 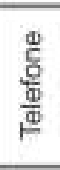 & 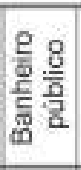 & 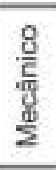 & 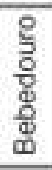 & 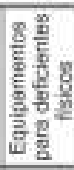 & 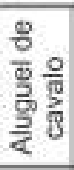 & $\begin{array}{l}\frac{8}{\mathrm{~T}} \\
\frac{\mathrm{c}}{\overline{8}} \\
\frac{\mathrm{s}}{2}\end{array}$ & 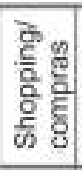 & \\
\hline Israel & & E & & & & & & & & & & & & \\
\hline $\begin{array}{l}\text { newno } \\
\text { Killarney }\end{array}$ & [ & & & & & & WC & & & & & & & \\
\hline Inauremen & $Z$ & & (2) & & & 6 & 훙 & & & 5 & & & & \\
\hline Nagano e Oyama & & 5 & & 7 & & 8 & W.C & & & & & & & \\
\hline $\begin{array}{l}\text { Sulciv } \\
\text { Estocolmo }\end{array}$ & $\mathbf{E}$ & & $\infty$ & + & 2 & & WC & & & & & & & \\
\hline
\end{tabular}


Tabela 4 - Alimentação e Abastecimento

\begin{tabular}{|c|c|c|c|c|c|c|c|}
\hline 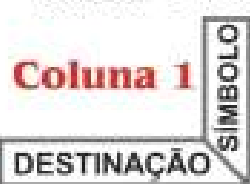 & 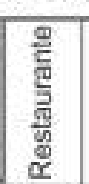 & లू & 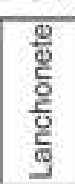 & 高 & $\begin{array}{l}\frac{\pi}{\frac{\pi}{2}} \\
\frac{\pi}{2} \\
\frac{d}{j}\end{array}$ & 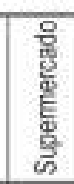 & 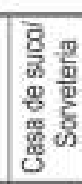 \\
\hline Fiori $(2003)^{*}$ & $x$ & & & - & & & \\
\hline $\begin{array}{l}\text { Secretaria do } \\
\text { turismo (Sao Paub) }\end{array}$ & IIP & III & $\theta$ & 1 & 而 & 쁄 & $\theta$ \\
\hline CONTRAN & $x$ & & & & & & \\
\hline Guia 4 rodas & $\%$ & & & & & & \\
\hline IPHAN & $x$ & & & & & & \\
\hline ERCO & 211 & 표 & $\rightarrow$ & E & D & तो & 8 \\
\hline Rügen & x & & & & & & \\
\hline Dusseldorf & & & & & & & \\
\hline Buenos Aires & 11 & & & $\mathbf{Y}$ & & & \\
\hline Mendoza & (6) & 8 & & & & & \\
\hline Hull e Ottawa & b] & E & & & & & \\
\hline Ottawa & & & & & & & \\
\hline $\int_{\text {Chan }}^{\text {Csile }}$ & 80 & 9 & & E & & & \\
\hline Cuba & $\mathbf{2}$ & $\square$ & & $\mathrm{I}$ & & & \\
\hline Barcelona & & & & & & & \\
\hline La Coruña & & & & & & & \\
\hline Madri & & & & & & & \\
\hline Toledo & & & & & & & \\
\hline AIGA & II & P & & $\boldsymbol{I}$ & & & \\
\hline Fliadélfia & & & & & & & \\
\hline $\begin{array}{c}\text { Williamsburg } \\
\text { (Virginia) }\end{array}$ & & & & & & & \\
\hline Manhattan & & & & & & & \\
\hline Finlândia & X & E & $I=$ & $I$ & & W. & \\
\hline$\llbracket$ França & & & & & & & \\
\hline Milskolc & & & & & & & \\
\hline Budapeste & & & & & & & \\
\hline
\end{tabular}

\begin{tabular}{|c|c|c|c|c|c|c|c|}
\hline Coluna 2 & 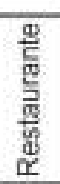 & $\frac{\Phi}{\tilde{N}}$ & 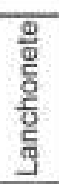 & 离 & 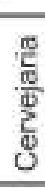 & 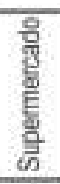 & 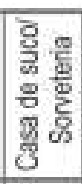 \\
\hline $\begin{array}{l}\text { oever } \\
\text { istael }\end{array}$ & & & & & & & \\
\hline Killamey & & & & & & & \\
\hline Cambridge & & & & & & & \\
\hline $\int_{\text {Naghano e Oyama }}^{1 \text { Nodo }}$ & (D. & -3 & & & & & \\
\hline
\end{tabular}


Tabela 5 - Transportes

\begin{tabular}{|c|c|c|c|c|c|c|c|c|c|c|c|}
\hline Coluna 1 DESTINAÇAO & 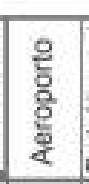 & 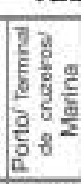 & & 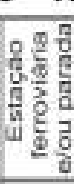 & 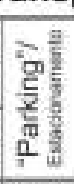 & $\stackrel{\mathrm{g}}{\mathrm{g}}$ & $\bar{x}$ & 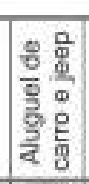 & 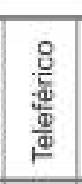 & $\frac{\text { g }}{\frac{5}{5}}$ & $\begin{array}{l}\frac{9}{\circ} \\
\frac{2}{9} \\
\frac{2}{1}\end{array}$ \\
\hline Fiori (2003) & & \pm & & & $E$ & & & A & & $\theta$ & \\
\hline $\begin{array}{l}\text { Secretaria do } \\
\text { turismo (Saso Pasulo) }\end{array}$ & I & & $\theta$ & 量 & & & 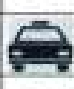 & $\sum_{0}^{\circ}$ & $\pi$ & 息 & E् \\
\hline CONTRAN & T & \pm & $=$ & & E & & & & & $t=$ & \\
\hline Guia 4 rodas & t & & exp & aㅛ & 国 & & & 成 & & & \\
\hline IPHAN & & & & & & & & & & & \\
\hline ERCO & & & & & & & & & & & \\
\hline Rügen & $\Psi$ & \pm & & & $\mathbf{P}$ & & & & & & \\
\hline Dusseldorf & & & & & $P$ & & & & & & \\
\hline Buenos Aires & $B=$ & & & & $P$ & & & & & & \\
\hline Mendonça & & & & & & & & & & & \\
\hline Hull e Ottawa & & & & & $\mathbf{P}$ & & & & & & \\
\hline Ottawa & & & & & & & & & & & \\
\hline Chile & & & & & & & & & & & \\
\hline Cuba & & & & & & & & & & & \\
\hline Barcelona & $t$ & $\theta$ & - & B & P & $\Leftrightarrow$ & & & en & & \\
\hline La Coruña & & $\underline{z}$ & $\Theta$ & $\theta$ & $\mathbf{P}$ & & $\mathrm{T}$ & & & & \\
\hline Madri & ] & & E & & $P$ & $\infty$ & & & & & \\
\hline Toledo & & & & & P & & & & & & \\
\hline AIGA & & & & & & & & & & & \\
\hline Filadelfia & (x) & & Ed & & P. & & & & & & \\
\hline $\begin{array}{c}\text { Williamsburg } \\
\text { (Nirginia) }\end{array}$ & & & & & & & & & & & \\
\hline Manhattan & & & & & & & & & & & \\
\hline Finlândia & $A$ & 2 & & & & & & & A & & \\
\hline França & t & & & & & & & & & & \\
\hline Milskolc & $\hat{1}$ & $\stackrel{2}{2}$ & & & & & & & & 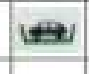 & \\
\hline Budapeste & & $\downarrow$ & 政 & & $\mathbf{P}$ & Q. & & & & & \\
\hline 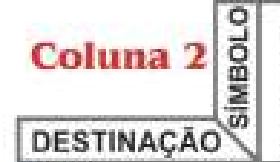 & \begin{tabular}{|l|}
8 \\
$\frac{8}{2}$ \\
$\frac{8}{2}$ \\
8 \\
8
\end{tabular} & 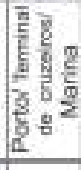 & 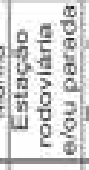 & 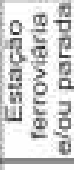 & 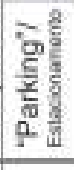 & $\frac{\mathrm{g}}{2}$ & 虔 & 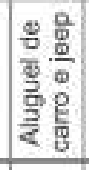 & 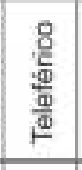 & 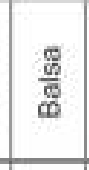 & 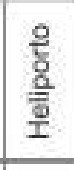 \\
\hline \begin{tabular}{|l|} 
oest \\
Israel \\
\end{tabular} & $\leftrightarrow$ & & & & & & & & & & \\
\hline \begin{tabular}{|l|} 
|runou \\
Killamey \\
\end{tabular} & & & & & (P) & & & & & & \\
\hline \multirow{2}{*}{\begin{tabular}{|l|} 
Casceskara \\
Carbridge e Glasgow \\
Napio \\
Nagano e Oyama
\end{tabular}} & (t). & 它 & = & & 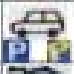 & & & & & & \\
\hline & & & & Geys & (P) & & & & & 8 & \\
\hline Estocolmo & & & & (J) & $P$ & (T) & & & & & \\
\hline
\end{tabular}


Tabela 6 - Atrativos turísticos e entretenimento

\begin{tabular}{|c|c|c|c|c|c|c|c|c|c|c|c|c|c|c|c|c|c|c|c|}
\hline Coluna 1 DESTINAÇAO & कू & & 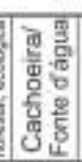 & 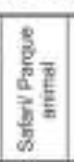 & $\begin{array}{l}\frac{8}{17} \\
\frac{8}{0} \\
N\end{array}$ & 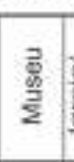 & 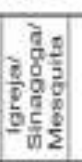 & 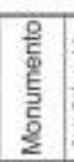 & 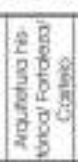 & 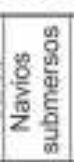 & $\frac{\sqrt{0}}{0}$ & 를 & 要 & 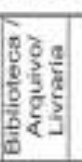 & 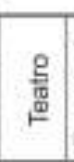 & 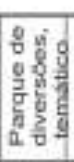 & $\begin{array}{l}\frac{8}{0} \\
\frac{8}{8} \\
\frac{8}{2}\end{array}$ & $\begin{array}{l}\text { 总 } \\
\frac{p^{2}}{I}\end{array}$ & 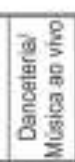 \\
\hline Fion $(2003)^{*}$ & & & [in & & (7) & (IIII) & $t$ & (1) & A & $\infty$ & $\lambda$ & TT & & $\theta$ & & & & $\Leftrightarrow$ & E- \\
\hline $\begin{array}{l}\text { Secretaria do } \\
\text { turismo }(\$ 860 \text { Postos) }\end{array}$ & & & & & & & & & & & & & & & te & Q & $\rightarrow$ & केe & \\
\hline CONTRAN & E: & 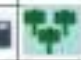 & & & 田 & IIII & 1. & 1 & A & & $\boldsymbol{\lambda}$ & 7 & $A$ & & & & & & \\
\hline Guia 4 rodas & 典 & & & & & & dit & & & & & & & & & & & & \\
\hline IPHAN & to & $(8 \%$ & 땔 & & P. & IIII & & 1 & 데레 & & $\lambda$ & $\overline{\mathbf{E}}$ & al & ㄴ] & 要 & sin & \% & $x$ & \\
\hline ERCO & & & & & & 变 & $1+9$ & & 口 & & & & & IIII & US: & & & & $a_{1}$ \\
\hline Rügen & 洸 & & & $\infty$ & एण्ण & IIII & की & & $\mathbf{H}$ & & & ic & & & & & & & \\
\hline Dusseldorf & & & & & & & $t$ & & & & & & & & & & & & \\
\hline Buenos Aires & & T) & & & $A$ & & Iod & & & & 2 & & & & & & & Ex & \\
\hline Mendoza & & & & & 200 & (1) & (9) & & & & & & & & 6 & & & & \\
\hline Hull e Ottawa & & & & & & Iiin & & & & & & & & & & & & & \\
\hline Ottawa & & & & & & & & & & & & & & & & & & & \\
\hline Chile & L & 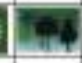 & & & min & & $A$ & & 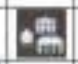 & & & & & & (2) & & & 8 & $\%$ \\
\hline Cuba & & & & & & [iii] & $\boldsymbol{\theta}$ & $\Omega$ & & & 5 & & & $\mathrm{\theta}$ & $\theta$ & & & & (1) \\
\hline Barcelona & 36 & & & & & $M$ & & & & & & & & B & & & & & \\
\hline La Coruña & & & & & & 0 & & & & & $\infty$ & & & & & & & & \\
\hline Madri & & & & & & & & & & & & & & & & & & & \\
\hline Toledo & & & & & & & & & & & & & & & & & & & \\
\hline AIGA & & & & & & & & & & & & & & & & & & & \\
\hline Filadélfia & & & & & & & $\pm \%$ & & & & & & & & & & & & \\
\hline $\begin{array}{c}\text { Williamsburg } \\
\text { (Nininie) }\end{array}$ & & & & & & & & & & & & & & & & & & & \\
\hline Manhattan & & & & & & & & & & & & & & & & & & & \\
\hline Finlândia & $*$ & & & & & $\mathbf{M}$ & $\mathrm{ba}$ & & & & & & & & $\mathbb{E}$ & & & & \\
\hline Franca & $\Delta !$ & & & $n^{\prime}$ & & & H & & $\mathbf{d}$ & & & & $n$ & & & 조 & & & \\
\hline Milskolc & 할 & 4: & & & & 業 & $M$ & $\Lambda$ & W & & & & $\Omega$ & & (ㄷ) & & & & \\
\hline Budapeste & & ㄴ. & & & & 요 & $\omega *$ & $\underline{1}$ & & & & & $\Omega$ & & $\theta$ & & & & \\
\hline Coluna 2 DESTINAC,AO O & 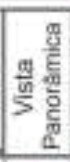 & & 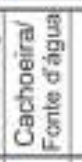 & 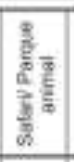 & $\begin{array}{l}\frac{8}{0} \\
\frac{8}{8} \\
\text { N }\end{array}$ & 焉 & 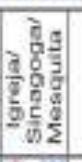 & 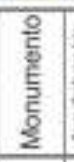 & 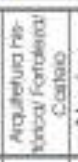 & 总 & $\frac{m}{2}$ & 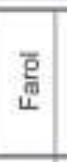 & $\begin{array}{l}\text { [ } \\
\text { है } \\
\text { o }\end{array}$ & 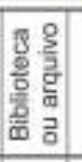 & 률 & 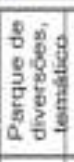 & है & 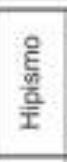 & 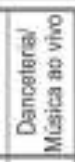 \\
\hline Israel & W & 9 & & & & $\mathrm{~m}$ & $E_{24}$ & & $y$ & & $\cong$ & & n & & & & & & \\
\hline Killamey & $\$ 1 / 6$ & 49 & & & & & + & & & & & & & & & & & & \\
\hline I Cambringe e Glasgow & & & & & & Givi & 60 & & & & & & & & 89 & & & & \\
\hline Nagano e Oyama & & & 2 a & & & & & & & & & & & & & & & & $a^{8}$ \\
\hline Estocolmo & $\%$ & & & B & & & & & & & & & & & (5) & & & & \\
\hline
\end{tabular}


Tabela 7 - Práticas desportivas e recreativas

\begin{tabular}{|c|c|c|c|c|c|c|c|c|c|c|c|c|c|c|c|c|c|c|c|c|c|c|c|c|c|}
\hline $\begin{array}{l}\text { Coluna } 1 \\
\text { DEstinacha }\end{array}$ & $\frac{5}{5}$ & $\frac{8}{2}$ & F & $\frac{2}{2}$ & है & है & & 害 & $\frac{3}{8}$ & & $\frac{E}{3}$ & 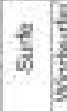 & & & $\frac{8}{2}$ & 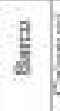 & & & & 离 & $\frac{b}{8}$ & & & & 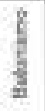 \\
\hline Fen l2003y & Rin & & & & 8 & (x) & $\$$ & 9 & (2) & (I) & & सा: & (A) & $\nabla$ & E & A & & 5 & [2] & & & 제 & & & \\
\hline 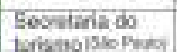 & & & & & & & $\bar{k}$ & & & $E$ & & & & & & & & & 3. & $\neq$ & $\bar{F}$ & & $M$ & & $\%$ \\
\hline Gua 4 rodas & a. & t & \#R & 9 & $\rho$ & & & & & & & $x$ & & & 14 & 1. & 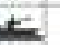 & & dito & & & & A & & \\
\hline OONTFAN & 2 & & & & & & & b) & & I & & ce. & $\Rightarrow$ & 5 & 5 & A & $x ?$ & $\$$ & & & & $h^{3}$ & & Pm & \\
\hline IFHAN & & $\not h$ & & & & 6 & $\$ 1$ & & & & & (t) & 3 & $\Rightarrow 1$ & 5 & A & & 3 & b & & & & & in & \\
\hline EACO & $m$ & $\not h$ & $\$$ & 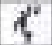 & $x$ & $y$ & E & 象 & & $z$ & 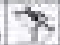 & $x$. & $P_{\mathrm{L}}$ & $\rightarrow$ & B. & $*$ & 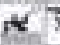 & 8 & dकी & ti & $\bar{\gamma}$ & & & & 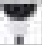 \\
\hline Fuger & & & & & & & & & & & & & & & & $\approx$ & & & & & & & & & \\
\hline Dusseditart & & & & & & & & & & & & & & & & & & & & & & & & & \\
\hline Buense Arou & & & & & & & & & & & & & & & & & & & & & & & & & \\
\hline Menososos & & & & & & & & & & & & & & & & & & & & & & & & & \\
\hline HAl c Otama & Ex & & & & & & & & & & & & & & & & & & & & & & & & \\
\hline Orawa & & & & & & & $\$$ & & & & $t$ & & & & & \pm & \pm & & \& & & & & & 五 & \\
\hline conde & & & & & & 量 & [E] & & & & \pm & & & & P & a & 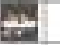 & & & & W & & & 풀 & \\
\hline Dostos & & & & & & & & & & & & & & 5.4 & 2 & & & & & & & & & & \\
\hline Barosibne & & & & & & & & & & & & & & & & & & & $\theta$ & & & & & & \\
\hline Lo chansts & & & & & & & & & & & & & & & & & & & (2) & & & & & & \\
\hline Masi & & & & & & & & & & & & & & & & & & & & & & & & & \\
\hline funto & & & & & & & & & & & & & & & & & & & & & & & & & \\
\hline$A B S A$ & & & & & & & & & & & & & & & & & & & & & & & & & \\
\hline Fiadefa & & & & & & & & & & & & & & & & & & & & & & & & & \\
\hline 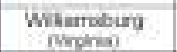 & & & & & & & & & & & & & & & & & & & & & & & & & \\
\hline Marhantan & & & & & & & & & & & & & & & & & & & & & & & & & \\
\hline Fîn'sinde & 스 & & & & & 6) & $M$ & & & & & & $a$ & & 2 & $\neq$ & s & & d) & $x$ & & s] & A & & \\
\hline Ftincus & & & & & & & & & & & & & & & & & & & & & & & & & \\
\hline Makoic: & & & & & & & & & & & 2 & & & & & & & & & & & & & & \\
\hline Butapeste & & & & & & & & & & & & & & & & & & & & & & & & & \\
\hline $\begin{array}{c}\text { Coluna } 2 \text {. } \\
\text { DESTINAC,AO }\end{array}$ & $\frac{\pi}{6}$ & $\frac{1}{5}$ & $\frac{\pi}{3}$ & in & है & 胥 & êt & $\frac{\pi}{3}$ & $\frac{8}{8}$ & $\frac{b^{3}}{y_{3}}$ & $\frac{\tilde{c}}{3} \frac{1}{3}$ & $\frac{2}{2}$ & 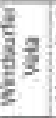 & 8 & $\frac{1}{2}$ & $\frac{9}{9}$ & & & 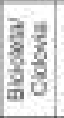 & $\begin{array}{l}8 \\
8 \\
8\end{array}$ & 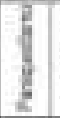 & $\frac{2}{2}$ & 8 & & $\frac{\xi}{3}$ \\
\hline ismal & & & & & & & & & & & 3 & & & 8 & & 3 & & & & & & & & 9 & \\
\hline Thamey & & & & & & & & & & & & & & & & & & & & & & & & & \\
\hline Cromisentaspow & & & & & & & & & & & & & & & & & & & dse & & & & & & \\
\hline 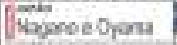 & 69 & & & & 2 & & a & & & & bi & & 1 & & 89 & & & & 30 & & & $8 \pi$ & & & \\
\hline Estoocomo & 1 & & & & & & & & & & & & & & & & & & & & & & & & \\
\hline
\end{tabular}


Tabela 8 - Pictogramas usados pelo site do Albergue da Juventude Internacional

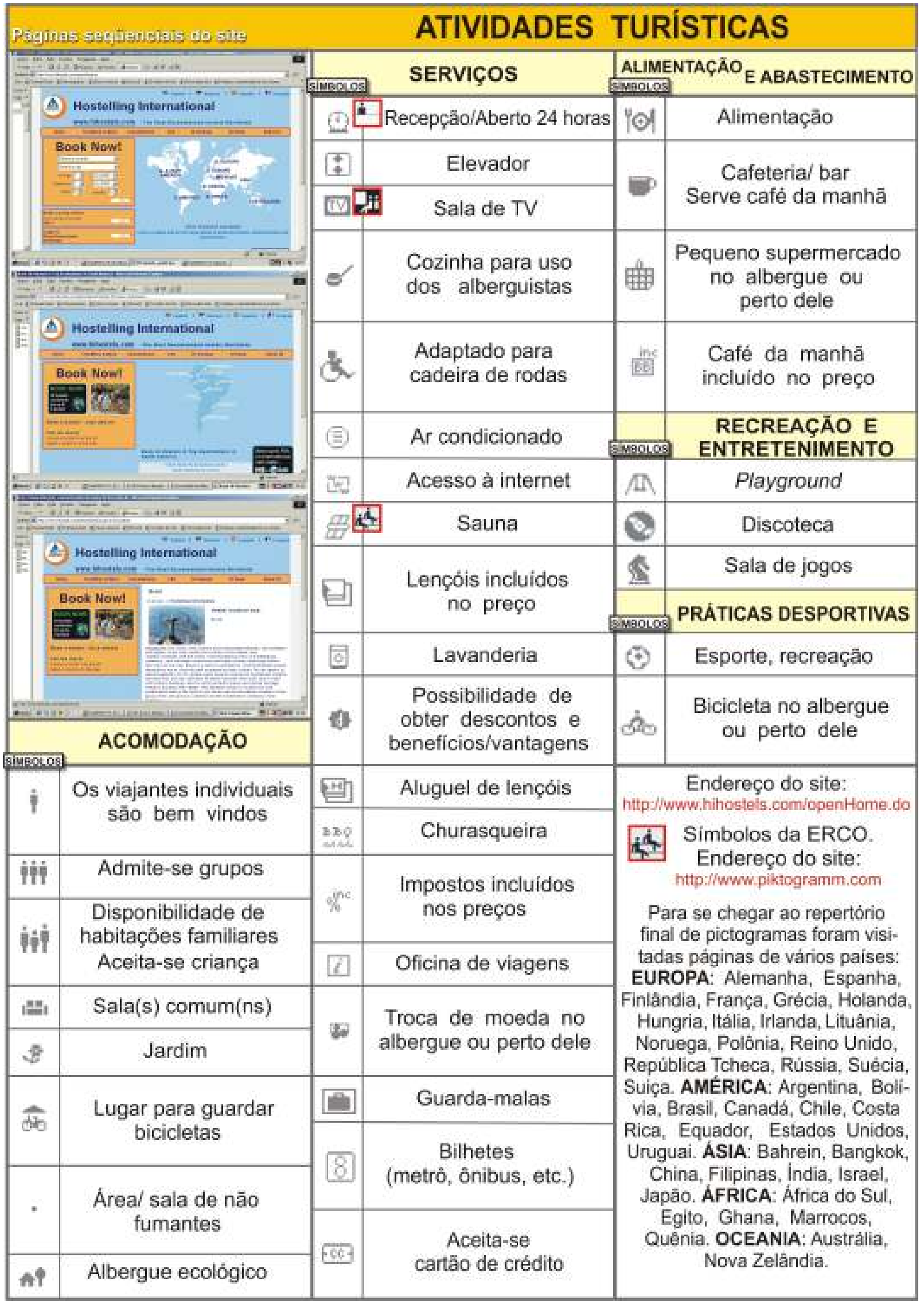




\section{3 - Elementos que compõem a multimídia interativa: aplicação em um mapa}

No setor do turismo, o mapa tradicional impresso é usado em conjunto com outros produtos gráficos, como guias e folhetos. Em geral, é um produto que ocupa pouco espaço físico como, por exemplo, o bolso da calça ou pequeno espaço na mochila. É de fácil manipulação, pois é dobrável, podendo ainda ser consultado em várias situações: ao andar, sentado no banco de uma praça, na areia da praia, em uma mesa, em pé, etc.

Entretanto, o mapa turístico em meio digital pode ser mais atrativo por poder incluir uma quantidade enorme de informações se comparado aos tradicionais mapas impressos, pois utilizar recursos como: vídeo clips, composição de vários layers camadas e possibilidade de representar uma mesma informação de diferentes formas - textos em pop up, que não poluem visualmente o mapa, indicação de links, entre outros recursos.

Apoiando-se na idéia de Emmer \& Worm (2001), um mapa turístico em multimídia interativa tem a capacidade de transformar um único mapa em muitos outros, sempre referenciado na mesma função inicial: o setor do turismo. Isso porque, um mesmo produto pode oferecer um mapa itinerário que se faz necessário às viagens de carro; o mapa da cidade e turístico, representando os cenários, as ruas, os hotéis, os restaurantes, os pontos atrativos, etc; o mapa rural, essencial para a viagem de férias no campo onde existam escaladas, caminhadas, ciclismo, etc neste seria interessante disponibilizar um mapa topográfico - e mais quantos mapas desejarem o planejador e o usuário.

Além disso, a multimídia interativa proporciona uma terceira opção, possibilitando que seus usuários "montem" e imprimam seus próprios mapas, personalizados, antes de saírem de casa (Brown, Emmer \& Worm, 2001).

Toda essa remodelação tecnológica ajudou a expandir, por exemplo, o uso dos bens patrimoniais e o campo da criatividade. Assim como o vídeo game tornou trivial as batalhas históricas, e alguns videoclipes ofereceram tendências experimentais à arte, os computadores e outros usos do vídeo facilitaram a obtenção de dados, a visualização e inovação gráfica. Isso permitiu simular o uso de novas peças e informações, reduziu a distância entre concepção e execução, conhecimento e aplicação, informação e decisão. Essa apropriação múltipla de produtos culturais abre as possibilidades originais de experimentação e comunicação (Canclini, 2003: 308). Entretanto, é necessário se fazer uma ressalva, apoiada no mesmo autor (Canclini, op.cit::150), que coloca a noção de público como sendo muito perigosa se caracterizada como um conjunto homogêneo e de comportamentos constantes. Deve-se levar em consideração que a sociedade está dividida em estratos econômicos e educacionais diversos, com hábitos de consumo 
cultural e disponibilidades diferentes para se relacionar com os bens oferecidos no mercado.

A partir daí, quem serão potencialmente os usuários dos produtos desenvolvidos nesta pesquisa? Pode-se supor que são aquelas pessoas com maior nível de educação tanto informal, isto é, aprenderam a lidar com o computador com os pais, amigos, filhos ou netos, quanto formal, por freqüentarem diversos graus e tipos de escolas, curso de computação, etc; além de possuir um poder aquisitivo para possuir, por exemplo, um computador e ter acesso à Internet.

O produtor de mapas em um site, então, terá dois grandes desafios: primeiro, desenvolver produtos no formato digital, de maneira que possam ser navegados de maneira simples e rápida. Em seguida, voltar-se para as preocupações primordiais abordadas por Gerber, Burgen \& Stanton (1990) sobre as oito características quanto à maior ou menor possibilidade de adquirir a informação cartográfica pelos usuários, que dependem de sua habilidade e percepção espacial, capacidade de leitura, idade, habilidade para desenhar mapas, experiência prévia quanto ao uso dos mapas, gosto pela leitura e a disponibilidade de mapas em casa no decorrer da vida de modo que eles não sejam vistos como objetos estranhos.

Posto isso, sabe-se que existe a possibilidade de reconhecer, identificar um novo caminho de ver a informação geográfica, fornecendo enfoques e pontos de vista diferentes e, assim, esperançosamente, assegurar que o vazio do entendimento geográfico possa ser preenchido com informações reunidas a partir de outras perspectivas, trazendo, dessa forma, uma compreensão mais completa da realidade (Cartwright \& Heath, 2002).

Ao se trabalhar com produtos disponibilizados em ambiente virtual, uma outra questão a ser abordada diz respeito à plataforma mínima necessária para que o produto possa ser acessado. Cartwright (1996) destaca que cada título em multimídia apresenta uma necessidade específica para sua confecção, que se conformam em:

$\checkmark$ Espaço suficientemente extenso para armazenamento no disco rígido (hard disk drives) ou CD.

$\checkmark$ Memória RAM que permita movimentos e manipulações eficazes de imagens digitais, animação e vídeo.

$\checkmark$ Uma unidade de CD.

$\checkmark$ CDs para usar na confecção dos protótipos e cópias short-run.

$\checkmark$ Interatividade, isto é, o usuário - que é o agente - determina por onde e como navegar. $O$ acesso às informações deve ser rápido e fácil. 
$\checkmark$ Provisão de uma estrutura eficiente, a partir da qual os usuários possam ao mesmo tempo transitar e fazer escolhas sensatas e criativas (Figura 78).

Figura 78 - Componentes típicos de um título em multimídia

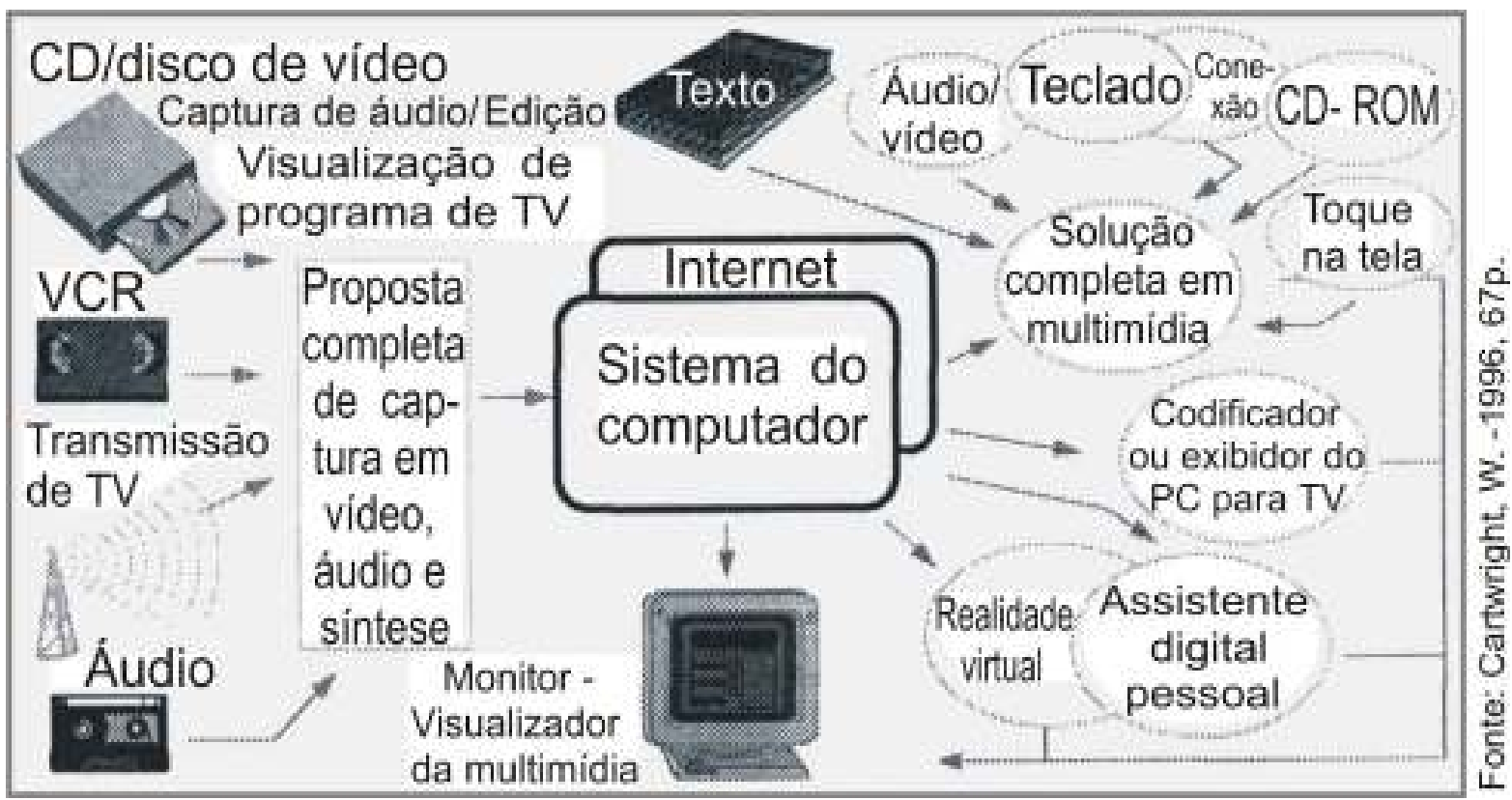

Inclui-se aos itens acima, um importante recurso não-material, ou seja, um conjunto de respostas emocionais que sejam o resultado das possibilidades de escolhas, caracterizando um acesso pessoal e personalizado com relação às diferentes mídias de um mesmo produto: a interação, ou seja, o controle da situação. Nos sistemas interativos, o espectador torna-se parte ativa da apresentação em vez de ser meramente um observador passivo. A interação possibilita ao usuário escolher o que fazer com o vídeo, o áudio e o texto. Com isso, os resultados da interatividade são mais individuais e imprevisíveis. Wolfgram (1994: 87) afirma que se você puder dar poderes à sua platéia, mesmo que seja da forma mais tímida, então poderá manter a sua atenção pelo tempo que precisar para transmitir a sua mensagem.

Romanov (apud Cartwright \& Heath, 2002) lembrou que, na Quarta Conferência Anual sobre World Wide Web, sustentou-se que a questão-chave na interatividade inteligente está no conteúdo emocional, que fundamenta a elaboração de produtos aos usuários. A promessa de novas tecnologias para artefatos cognitivos, como os mapas, tem proporcionado e aumentado a interação da comunicação contemporânea. Todavia, essas novas formas de representação e artefatos trarão novos questionamentos relacionados, por exemplo, ao entendimento e à eficácia da informação geográfica retratada, visualizada e percebida. A cartografia contemporânea precisa, então, encontrar maneiras de avaliar esse tipo de 
visualização, que dispõe de novas e diferentes ferramentas, providenciando representações inovadoras das imagens advindas da realidade.

Todavia se, de um lado, a grande variedade de recursos disponíveis como: ilustrações, áudio, vídeo, gráficos, textos, fotos, diferentes graus de representação da mesma informação, interatividade; num primeiro momento, fascina e dá a oportunidade de belas apresentações e possibilidades, de outro, traz também o problema da alta complexidade e imenso banco de dados. Logo, é papel do produtor desenvolver um material cartográfico e de multimídia-interativa eficaz em sua comunicação, ou seja, o usuário deve assimilar facilmente a informação, além de esta ser esteticamente motivadora. O consumidor não deve se sentir intimidado pela tecnologia, senão provavelmente não passará da demonstração inicial (Wolfgram, 1994).

Segundo Brown, Emmer \& Worm (2001) o grande negócio da interação é capacitar o usuário a encontrar e reagir às informações gráficas e textuais disponibilizadas. A cartografia, do mesmo modo que outras áreas do conhecimento, está sendo amplamente afetada pela revolução dos computadores e da Internet.

Desse modo, a produção de mapas turísticos interativos é um excitante desafio para o profissional em cartografia. Miller \& Pupedis (2002) afirmam que muitas vezes existe um enfoque maior nos aspectos técnicos (estruturação, integração e distribuição das bases de dados dos mapas) do que nos objetivos, necessidades e preferências dos usuários.

Entender como se trabalha com a tecnologia é fundamental, mas associações e contribuições da arte e da ciência para a cartografia são ainda mais importantes. $\mathrm{Na}$ opinião de Cartwright \& Heath (2002), a arte fornece a face pública da cartografia em multimídia (e a paixão, talvez a alma, do cartógrafo ao elaborar os produtos), e a ciência a complementa, garantindo a precisão e o rigor.

Sabe-se que, durante a elaboração do produto, agregam-se intrinsecamente técnicas e estéticas cartográficas, porém, para que se faça um produto esteticamente agradável, o talento artístico e o senso estético são de fundamental necessidade. Aliás, talento e senso estético não podem ser ensinados; por essa razão, alguns produtores de mapas são talentosos e outros, não (Brown, Emmer \& Worm, 2001).

Brown, Emmer \& Worm (2001) acrescentam serem poucas as vezes em que se encontram mapas que combinam elementos atrativos, de motivação e interativos. $E$ nos casos em que se aplica especificamente a interatividade, ela é, em sua maior parte, limitada a ações como zoom, pan e acesso a outros sites. Essas falhas ocorrem mesmo havendo programas que possibilitem a criação de uma grande variedade de formas interativas e de apresentação, trabalhadas por meio do design cartográfico. Especificamente, a produção de mapas para a Web, incluindo os turísticos, ainda continua muito restrito a reproduções feitas em papel, isto é, 
grande parte dos mapas turísticos disponíveis são simplesmente escaneados de outros já impressos.

Outro ponto a ser ressaltado sobre tipos de meios de apresentação no formato digital diz respeito à preocupação com o tempo de download do produto na Web. Isso porque, o desenvolvimento dos mapas turísticos precisa respeitar a qualidade da conexão - discada ou banda larga - que o usuário utiliza quando adquire a informação. Assim, o produto elaborado para a Web merece uma atenção redobrada quanto à funcionalidade das simbologias e à hierarquia visual da informação, por exemplo, buscando uma comunicação ágil e diminuindo a dificuldade em entender seqüências de acesso no site.

Wolfgram (1994) ratifica a proposta, a idéia de que o objetivo principal é não deixar que a apresentação pare de fluir, disponibilizando, por exemplo, recursos para informar ao usuário que o programa está rodando, ou para que ele saiba que, ao pressionar uma determinada tecla, aparecerá um determinado assunto. Deve-se evitar a demora no reconhecimento das informações: o usuário não pode, por exemplo, ficar parado por muito tempo em frente ao monitor do computador só para entender o que acontece no site. Todos esses fatores vão causando aborrecimento ao usuário, fazendo com que o produtor corra um sério risco de gerar perda das emoções e da motivação.

Miller \& Pupedis (2002), ao verificar outros sites, chegaram a algumas conclusões: normalmente, o produtor é muito técnico e, na maioria das vezes, faz suposições que generalizam o público alvo. Eles enfatizam que a implementação técnica, ou seja, acreditam que o produtor está muito mais preocupado com o tempo de download do que com a eficaz navegação do site pelo usuário. Além disso, devido ao custo, muitos produtores acabam desenvolvendo o site sem fazer um reconhecimento mais aprofundado e experimentado de seu usuário potencial.

Os autores (Miller \& Pupedis, 2002) ainda alertam para o fato de que pesquisas relacionadas ao uso dos mapas para $W e b$ - e, por que não dizer, os mapas interativos em geral - ligados às ciências geoespaciais estão normalmente focados em ferramentas de geovisualização voltadas àqueles usuários que já dominam o Sistema de Informação Geográfica (GIS). Por isso, os pesquisadores também precisam se preocupar com o uso do design daqueles sites elaborados para os usuários não-especializados, leigos em cartografia e/ou GIS. Os autores terminam a explanação, apontando alguns problemas de sites baseados em GIS:

$\checkmark$ Níveis inapropriados de generalização e escala.

$\checkmark$ Má elaboração do conteúdo temático dos mapas.

$\checkmark$ Precária legibilidade de leitura dos mapas.

$\checkmark$ Simbolização inconsistente. 
$\checkmark$ Uso confuso entre a escala e o zoom.

$\checkmark$ Uso de conceitos GIS não-familiares ao público em geral.

$\checkmark$ Procura confusa das estruturas espaciais.

$\checkmark$ Falta de clareza dos objetivos.

$\checkmark$ Excesso de níveis para obter a informação desejada.

$\checkmark$ Apresentação e navegação confusas.

$\checkmark$ Baixa motivação do usuário diante das informações oferecidas.

Em Cartwright \& Heath (2002) se acrescenta que a avaliação também deve envolver dimensões de interesse, que precisariam ser pensadas a partir dos projetos individuais, podendo incluir: a eficácia de aprendizado, o custo, a interatividade, os estilos de interação, a sincronicidade, a continuidade, a coesão, a qualidade na interface, a facilitação no uso, a disponibilidade, a facilidade de acesso, a natureza do produto, a fixação e a sustentação da informação, a eficácia na utilização da mídia e a complexidade dos elementos distribuídos.

Enfim, é óbvia a riqueza de conteúdo do novo meio de comunicação denominado hipermídia. Todavia, é prudente advertir sobre a enorme complexidade de elaboração desse tipo de produto, que necessita de um longo tempo para ser desenvolvido, é dispendioso e necessita de estudos que averigúem sua eficácia. Entretanto, estudos já apontam um inquestionável potencial de motivação do material disponibilizado em hipermídia, advindo tanto da diversidade de discursos disponíveis, como da flexibilidade dos percursos de exploração. Torna-se então necessário prever um mínimo de coerência pedagógica no projeto da correspondente navegação para que o usuário não se sinta perdido no hiperespaço (Rocha-Trindade, 1998: 169).

Faz-se justo afirmar que a boa transmissão da informação, além da alta tecnologia e suas respectivas facilidades técnicas, jamais deve dispensar um profissional especializado e competente preocupado em estabelecer um processo de desenvolvimento compatível com o produto idealizado.

Conseqüentemente, a concepção de todo o processo de design estará centrada no usuário, objetivando primordialmente que ele reconheça a idéia principal: no caso, a vocação turística (balneário, rural, estância, etc.) do município representado nos mapas turísticos interativos. O usuário-internauta deve se envolver a cada ação/clique no site, por meio dos botões, pop ups e outros recursos só existentes em meio digital.

O então mapa-site pode proporcionar a apresentação de atrativos, atividades e serviços, que é, por sua vez, atrelado a ciclos - grupos de temas distintos: 
arquitetura, esportes, acomodação, informações úteis, etc. - os quais em conjunto geram muitas e variadas informações sobre o destino. Some-se ainda a particularidade de que, por ser um produto constituído em ambiente virtual, tem a capacidade de ser renovado e realimentado, de tempos em tempos.

Escolhido a idéia principal e o público, inicia-se o processo desenvolvimento do produto. A primeira etapa é encontrar um estilo de arte mais condizente com as expectativas do usuário (Wolfgram, 1994: 103).

Desse modo, na elaboração dos mapas turísticos pictóricos interativos, é necessário que o produtor conheça as várias técnicas e formas de uso dos materiais já disponíveis. Wolfgram (op.cit:16) informa que as possibilidades de design incluem o projeto, o texto, as ilustrações, as animações, o vídeo, a música e, em alguns casos, a programação. Um bom projeto em multimídia deve sustentar uma boa apresentação, tendo como principais elementos a clareza, a simplicidade e a seqüência lógica e coerente. O autor (Wolfgram, op.cit.:122) ainda divide os componentes do projeto em: layout básico, cabeçalhos, texto principal, figuras adicionais, botões, tipografia, fundos e texturas.

O primeiro nível do conteúdo é formado pelo tema principal e os objetos interativos que podem ser, por exemplo, os símbolos acessíveis pelo mouse. O segundo nível refere-se à base da informação do mapa, muitas vezes consistindo em uma topografia simplificada. Pode conter também menus pop ups (com textos, filmes, tabelas, som, etc.), os quais fornecem informações adicionais sobre o tema principal. Existe ainda um terceiro nível, ligado às informações-suporte (aquelas não-diretamente relacionadas - marginais - ao tema principal) como legendas, bordas (moldura), ilustrações, gráficos ou menus pop up, como ilustra a figura 79 (Brown, Emmer \& Worm, 2001).

Wolfgram (op.cit::121) acrescenta que o projeto precisa buscar a união da arte, animação, ilustração e texto de forma que, efetivamente, comunique a mensagem. Cada linha, forma, fragmento de texto e cor precisa ter intenção e propósitos previamente direcionados. Fontes, estilos de fundo, e motivos musicais juntam-se aos já citados, proporcionando o impacto emocional e/ou auxiliar na comunicação. Trabalhar corretamente com estes parâmetros faz com que o projeto tenha uma possibilidade muito maior de eficácia.

Sendo assim, a elaboração dos mapas turísticos pictóricos e interativos apóia-se inicialmente na apresentação estilística (layout) do jogo SimCity ${ }^{\circledR}{ }^{63}$ (Figura 80), que parte de uma base - porção de terra - onde o jogador vai aos poucos construindo sua própria cidade. O SimCity ${ }^{\circledR}$ possui uma importante legenda

\footnotetext{
${ }^{63}$ Diferente da maioria dos jogos de computador, o SimCity 2000 ® não foi concebido com o intuito de vencer ou perder, pelo contrário; invoca um pensamento construtivo para educar o usuário sobre os conceitos geográficos e espaciais associados ao desenvolvimento urbano (Johnston \& Cartwright, 2000).
} 
Figura 79 - Os três níveis de conteúdo do mapa interativo

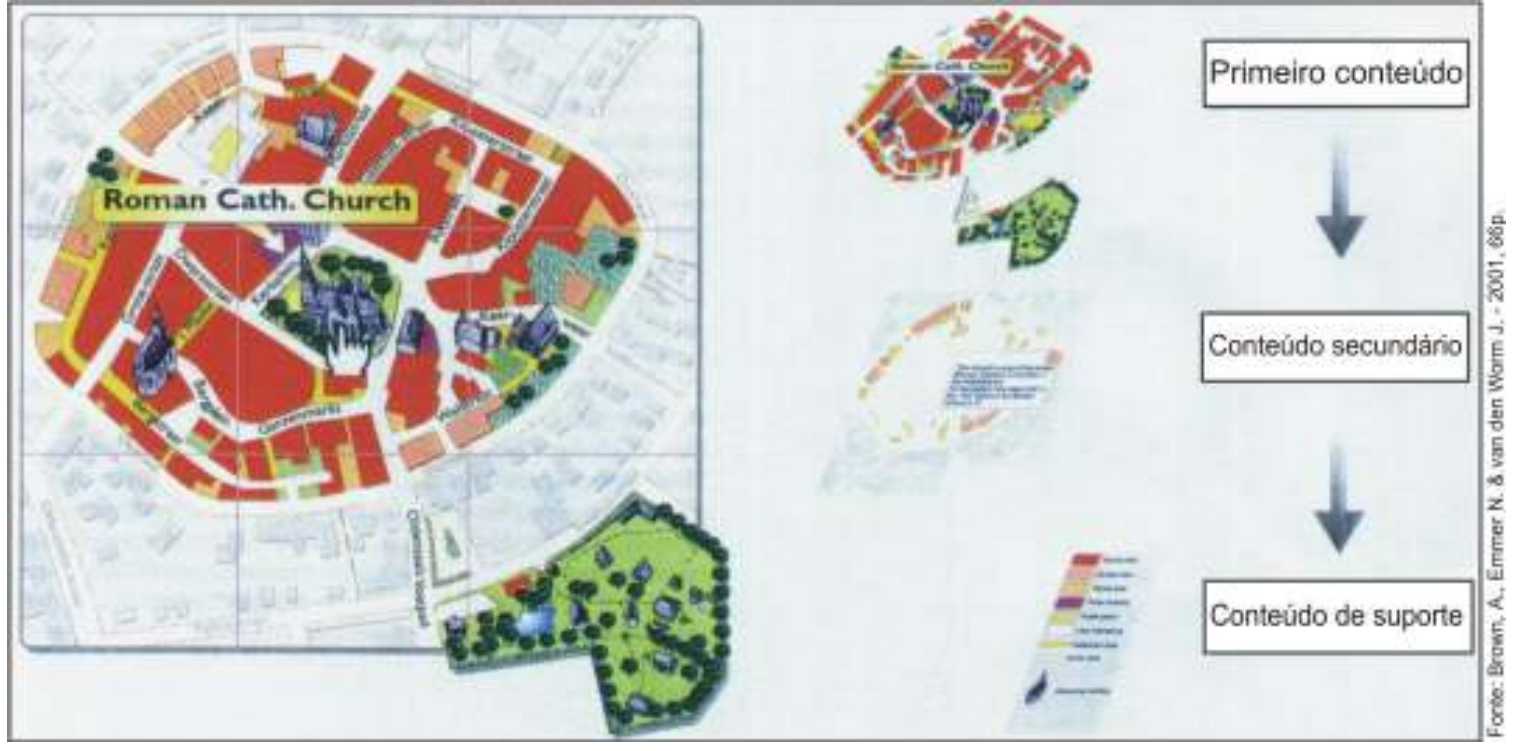

Figura 80: Simcity $®$ :referência para os mapas turísticos interativos

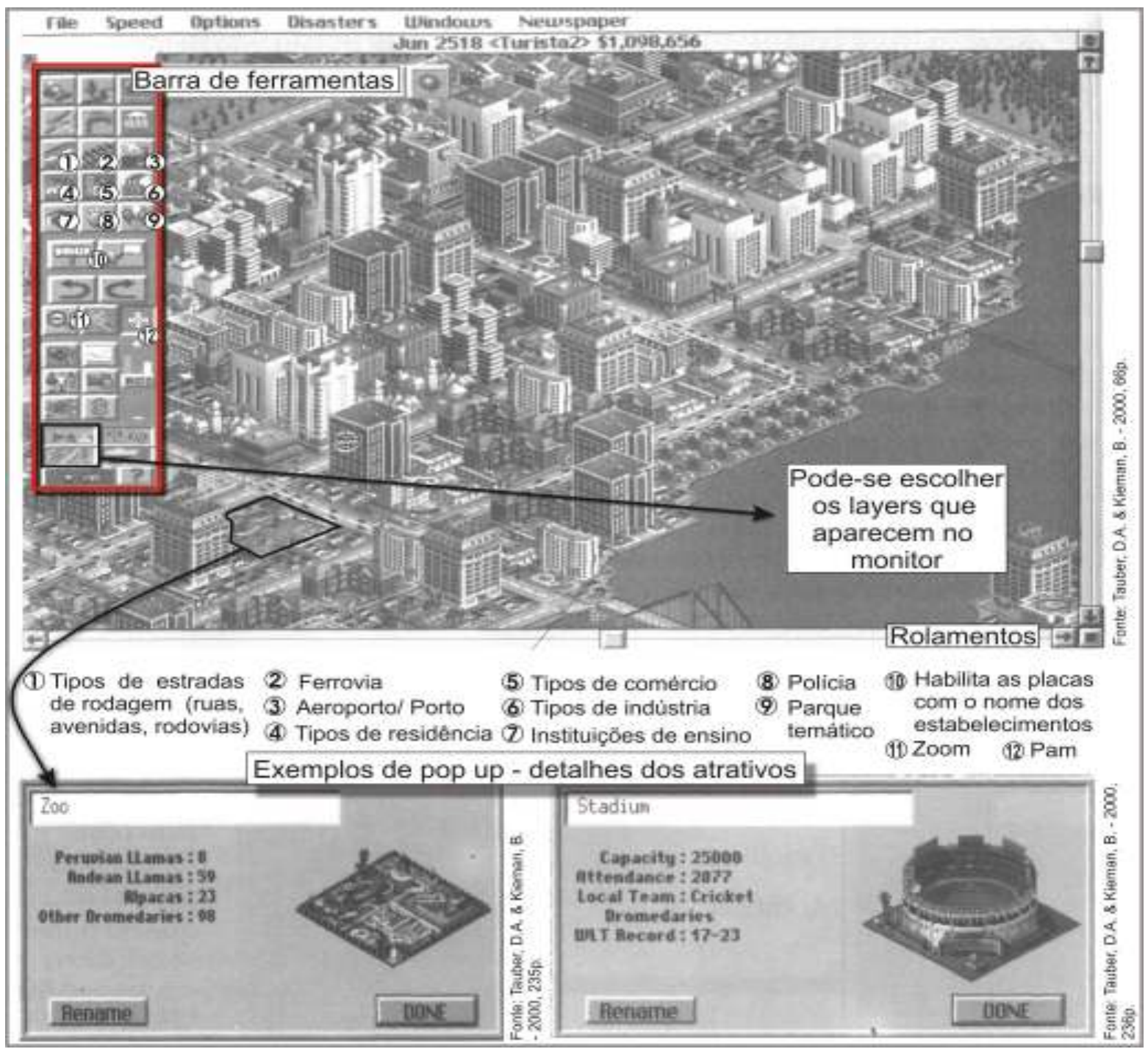


interativa que, entre seus inúmeros recursos, tem como principais elementos:

$>$ O zoom e o pan em vários níveis (sem escala formal).

> Uma rede de layers interativos que representam vários elementos espaciais de uma cidade como: residências, conglomerados comerciais (shoppings, restaurantes, parques de diversão) serviços (biblioteca, hospital, polícia), tipos de indústrias, meios de transporte, etc.

Acesso a informações importantes por meio de pop ups.

Todos esses recursos são facilmente habilitados e desabilitados pelo jogadorusuário.

Posto isso, a partir de agora são arroladas e exemplificadas as técnicas ainda não abordadas pelo item 2.1. Ao final, todas as técnicas apresentadas comporão um só conjunto que vão auxiliar no desenvolvimento dos mapas turísticos pictóricos interativos. Até porque, como enfatiza Dondis (1991: 24), as técnicas são os agentes do processo de comunicação visual e é por meio da sua energia que o caráter de solução visual adquire forma.

Referenciando-se na estrutura de projeto de Wolfgram (1994) e, até o momento, em autores como Menno-Jan \& Driel (1997), Brown, Emmer \& Worm (2001), detalham-se oito recursos de elaboração, transmissão e motivação de mensagens em multimídia interativa: o texto, o fundo-cenário, os elementos particulares (ilustrações, ícones e pictogramas), a animação, o áudio, o vídeo, a interatividade e o download e a impressão.

\subsection{1 - O texto}

Como já foi abordado anteriormente, mesmo com todas as novas tecnologias disponíveis para fazer uma boa apresentação, o texto ainda continua sendo um dos recursos mais importantes de comunicação. Entretanto, para que haja a transmissão da mensagem, ele deve ser representado de forma a provocar sua leitura.

Um bom texto deve sempre estar bem escrito, ser interessante e fácil de ler; precisa ainda prender a atenção, mesmo que não esteja acompanhado de animações ou efeitos de imagens. Na elaboração do mapa no formato digital, pontua-se que:

$\checkmark$ Trabalhe-se inicialmente com letras maiúsculas.

$\checkmark$ Mudem as dimensões das letras para explorar diferentes climas emocionais.

$\checkmark$ Usem-se fontes diferentes para transmitir a sensação de história, maciez, firmeza, ventos agitados e tundras congeladas. 
$\checkmark$ Cuide-se do tamanho dos caracteres que deve estar intrinsecamente ligado à escolha da fonte selecionada.

Já os textos referentes aos mapas disponibilizados para o computador distinguemse por duas aplicações principais:

$\checkmark \quad O$ texto aplicado nas bordas do mapa pode ser tratado como qualquer outro tipo de aplicação de texto em um mapa interativo ou página da Web. Deve haver precauções quanto ao controle do texto "flutuante" (onde e como localizá-lo nos pontos extremos do mapa), espaçamento e tamanho das letras, o tipo de fonte mais adequada, etc. Esse conjunto de texto comporá a(s) legenda(s), a(s) escala(s), o título, a borda (moldura) e outros itens complementares do mapa.

$\checkmark$ Em geral, o texto interno do mapa é usado para as informações geográficas, como os símbolos e uma série limitada de informações descritivas (rios, estradas, acidentes geográficos, etc.). As fontes devem buscar uma fácil legibilidade, principalmente aquelas relacionadas aos tamanhos menores $\mathrm{e}$, neste caso, os estilos simples, como a serifa e as fontes abertas são particularmente indicadas. $O$ texto em negrito pode melhorar a legibilidade, como também melhorar o espaçamento entre as letras. Uma regra é que a fonte não deve ter um tamanho menor que 10.

A quantidade de textos sobre o mapa deve se conservar baixa, porém, havendo a necessidade de grande uso deste recurso, a aplicação de um painel de controle habilita/desabilita para a legenda poderia permitir ao usuário mudar as camadas de texto ou desligá-los. Pode-se também utilizar o recurso do pop up: ele permite que, com um clique sobre uma determinada figura por meio do mouse, abra-se uma caixa de textos. Essa técnica permite ao produtor usar com freqüência, outros tamanhos e tipos de fontes, possibilitando uma leitura mais fácil e agradável (Figura 81).

O contraste entre a fonte e o fundo do mapa também afeta a legibilidade. Evita-se mais freqüentemente a seleção de texto claro sobre um fundo saturado (escuro) ou com muitas informações.

O contraste pode ser melhorado, se possível, pela adição de um fino contorno branco na fonte escura. Outra opção é aplicar uma sombra transparente projetada. Esta alternativa tem uma melhor aplicação em um texto importante e sóbrio, pois a sombra projetada pode gerar tanto um ruído quanto o aumento do tamanho do arquivo trabalhado.

\subsection{2 - O fundo-cenário}

E a maior ilustração do mapa pictórico interativo. Provém de um mapa-base topográfico em escala. $O$ fundo-cenário detalha pictograficamente e em visão 
oblíqua a morfologia do terreno da localidade turística, além de outros itens como vias de acesso (trilhas, ruas, avenidas, rodovias), rede hidrográfica (rios e córregos importantes) e caracterização de zonas urbanas, rurais e matas (figura 82).

Figura 81 - Legendas interativas pop up

As legendas interativas pop up podem ser utilizadas, por exemplo nas legendas secundárias, que são disponibilizadas quando o usuário seleciona ou passa o mouse por cima de um determinado objeto sobre o mapa

(Brown, Emmer \& Worm, 2001).

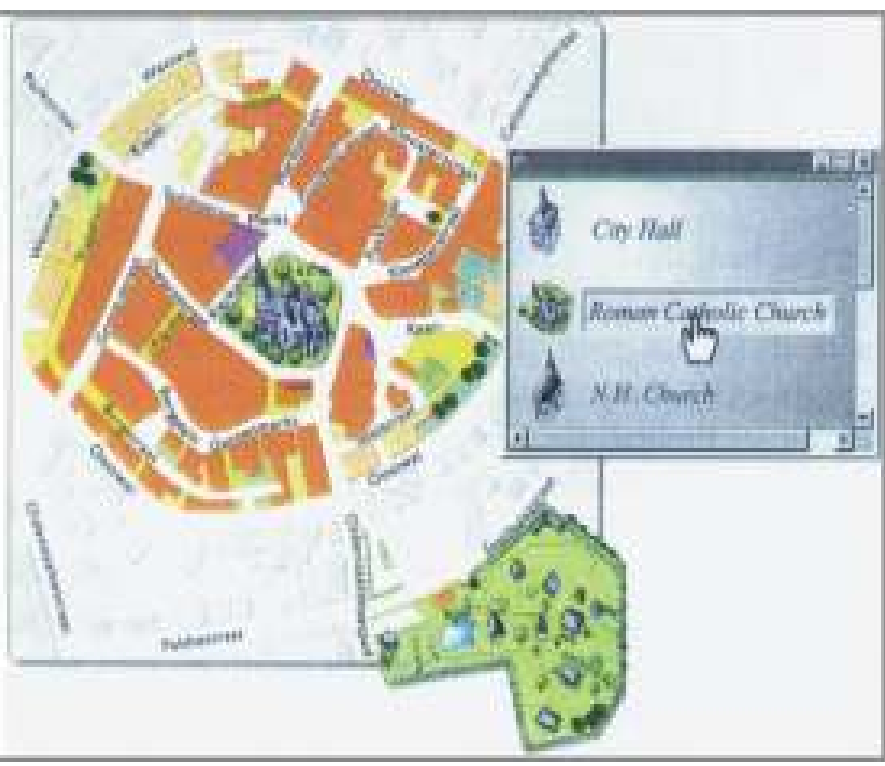

Figura 82 - Exemplo de um fundo-cenário: Caxambu

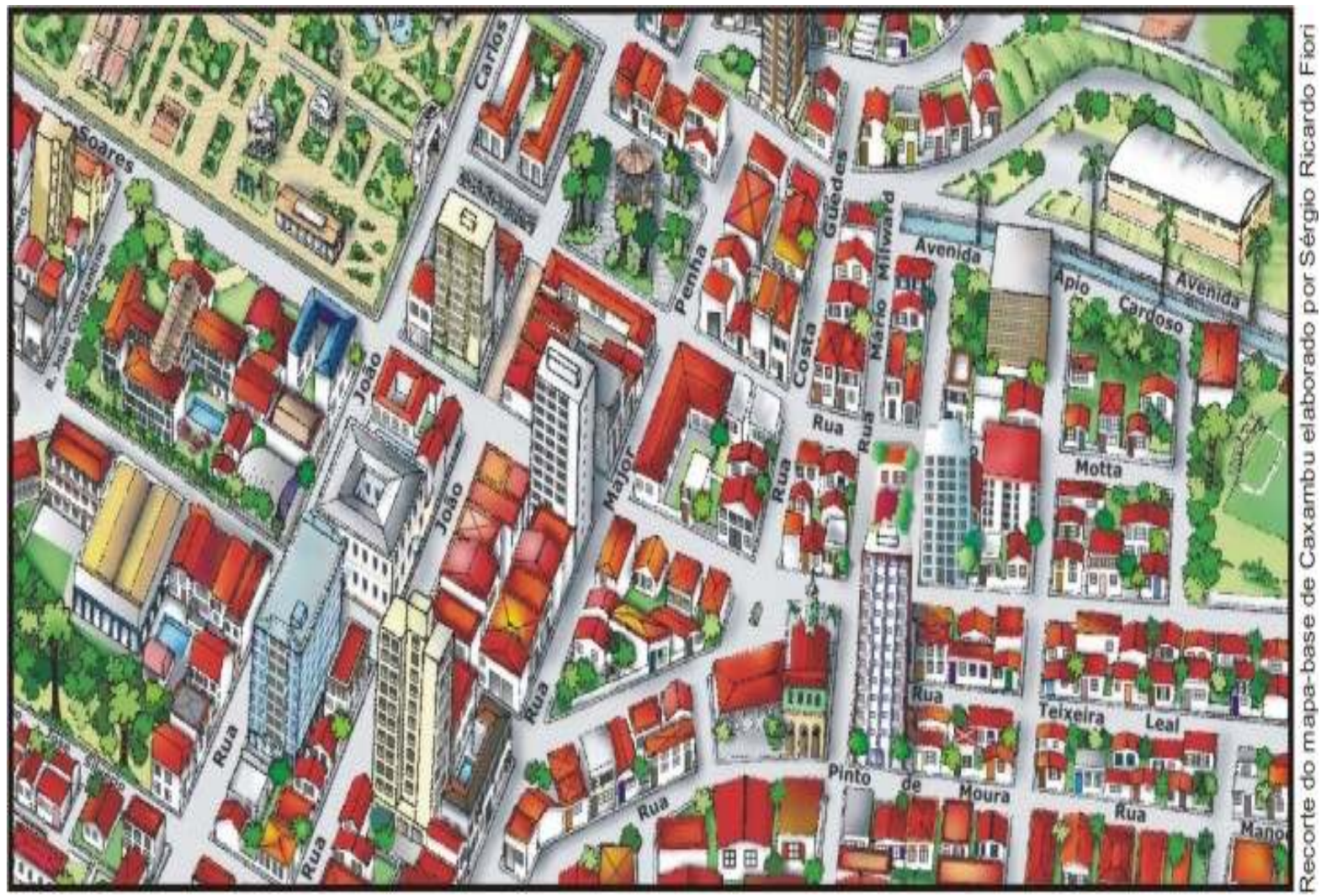

É primordial exemplificar pragmaticamente como se constrói este tipo de representação pictórica. 
Antes de iniciar o desenho, é preciso se preocupar com a proporção dos elementos dispostos na paisagem. Criam-se então alguns apoios, esquemas, utilizando as figuras geométricas básicas: o quadrado, o retângulo, o triângulo e a circunferência, que servem de guias para a construção das inúmeras figuras que compõem a paisagem, como exemplificado na figura $83 \mathrm{~A}$.

É aconselhável utilizar um lápis/grafite macio (6B, HB) em papel sulfite comum. Primeiramente, o ideal é traçar várias linhas sobre uma mesma área ainda não é importante atentar para o fato de as linhas estarem certas ou erradas; a preocupação maior deve estar na pressão que se faz com o lápis sobre a folha de papel, que deve ser leve. Até então não é necessário utilizar a borracha.

$\mathrm{Na}$ fase seguinte, deve-se procurar, entre as linhas desenhadas, o delineado mais preciso para a confecção do modelo. Agora, os movimentos das mãos são mais lentos e a pressão do lápis sobre o papel deve ser mais forte (ver figura 83 B).

$\mathrm{Na}$ finalização, utiliza-se uma borracha macia ou um limpa-tipo para apagar os traços em excesso. Pode-se passar uma caneta hidrográfica ou nanquim antes de apagar o excesso de linhas (Ver figura 83 final).

Figura 83 - Linhas e as figuras geométricas básicas para elaborar um cenário
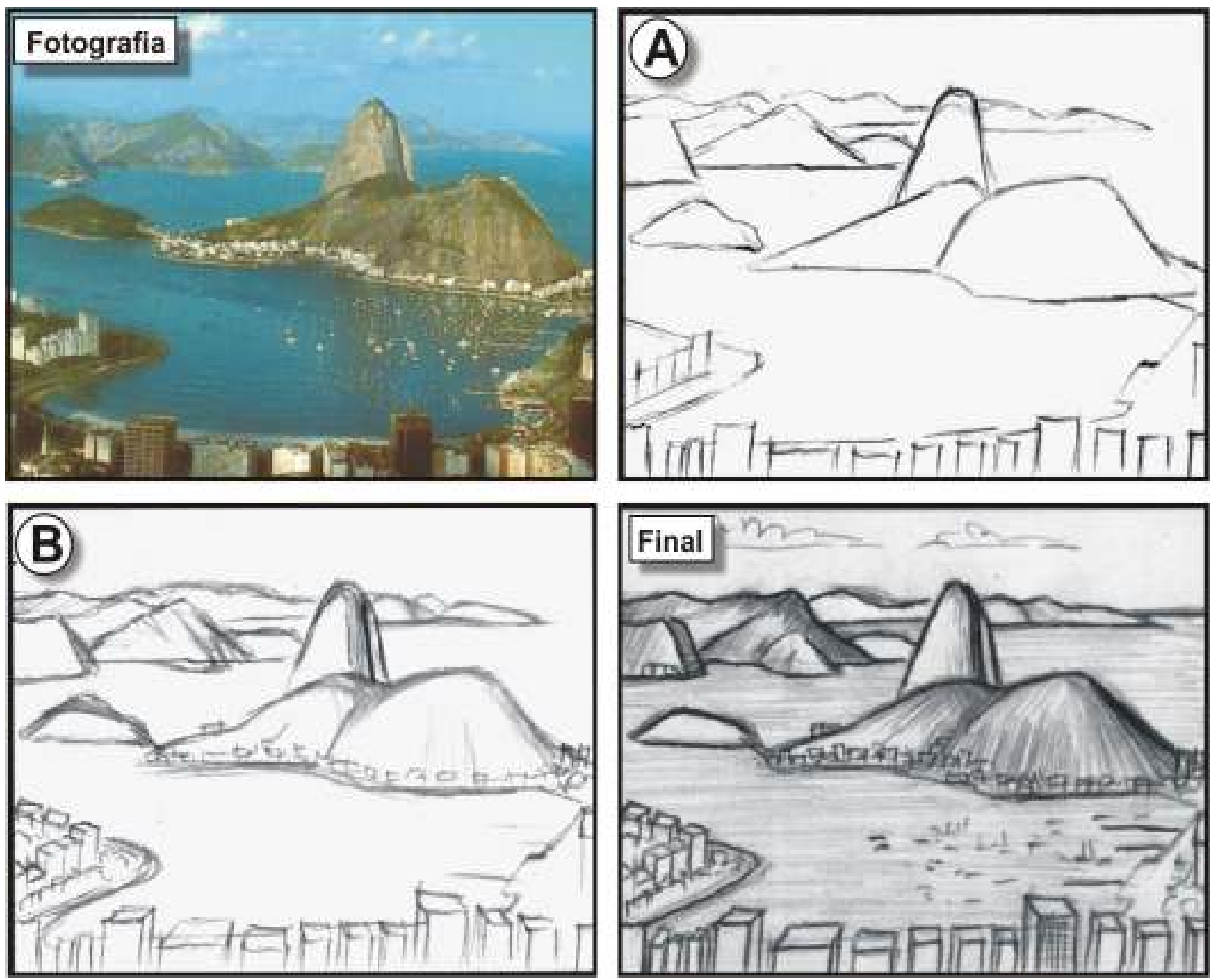
Neste momento, é imprescindível abordar o tema da perspectiva. Basicamente pode-se dividi-la em dois tipos distintos: paralela e cônica.

A perspectiva paralela acontece quando as arestas de um objeto formam feixe de linhas paralelas (figura 84 A). São subdivididas em: isométrica (figura 84 B) e cavaleira (figura $84 \mathrm{C}$ ). Ver também exemplo: figura 56.

Figura 84 - A perspectiva paralela isométrica e cavaleira

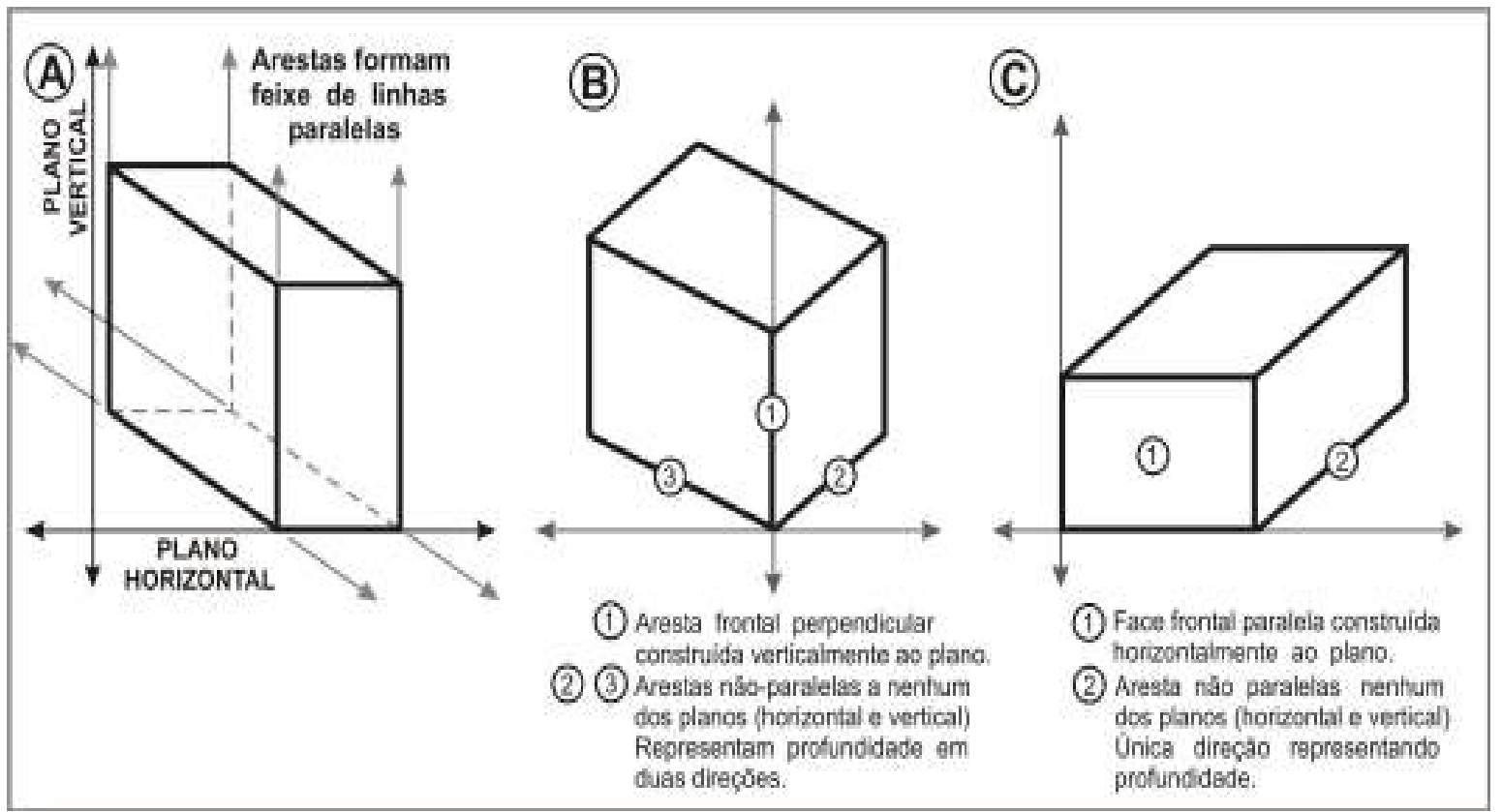

Já a perspectiva cônica é resultado das arestas de um objeto que convergem para um ponto pré-determinado, denominado ponto de fuga (PF) - Figura 85.

Figura 85 - A perspectiva cônica

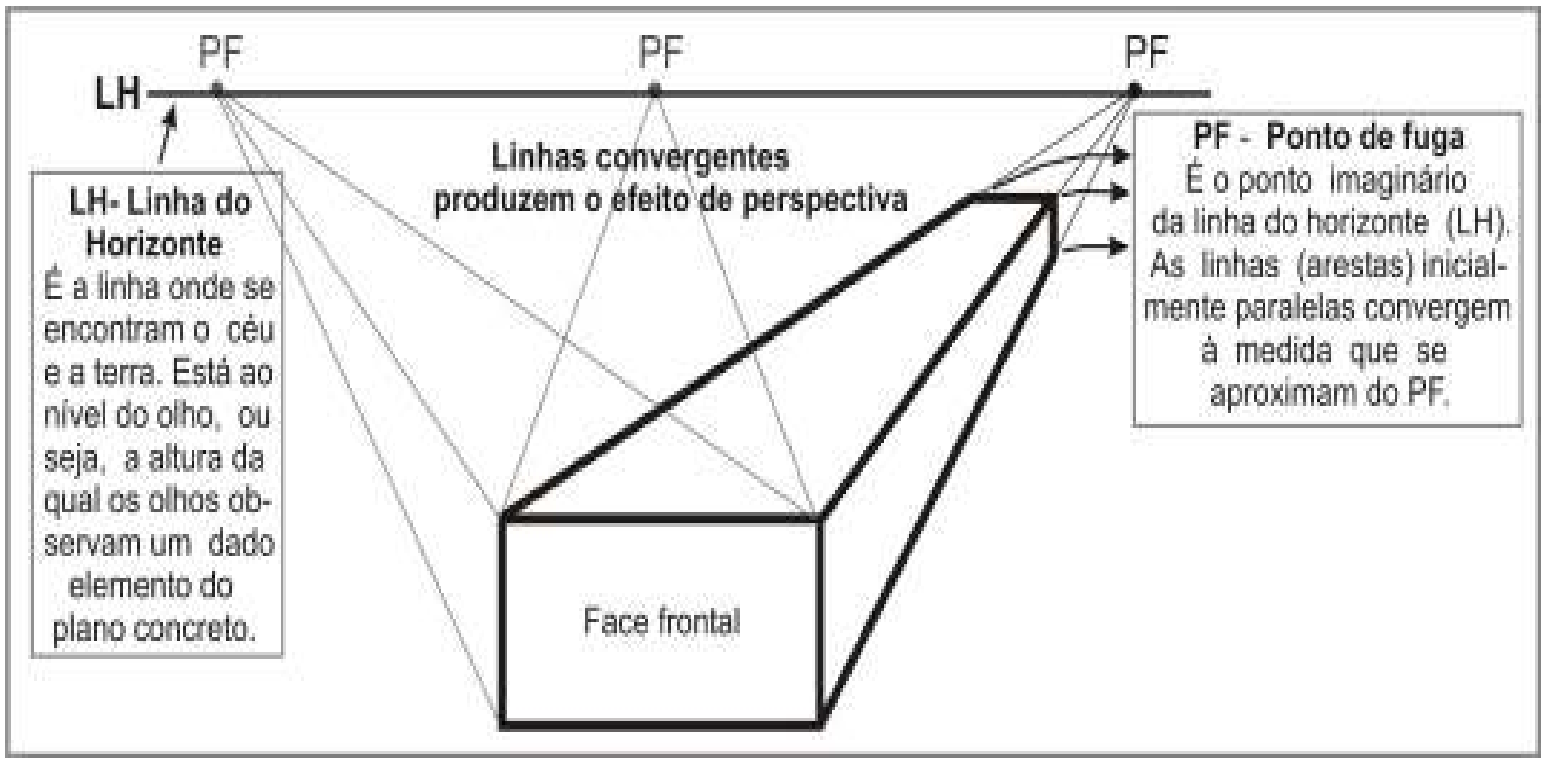


Qualquer forma em perspectiva é representada em três posições: acima, no nível e abaixo da linha do horizonte (LH), que são os níveis de visão de um observador. Cosgrove \& Daniels (1994:1) ensinam que a perspectiva busca transpor a superfície bidimensional à estrutura tridimensional do espaço, tal como o olho humano o percebe. Logo, a terceira dimensão (profundidade) tem que ser fingida pelo desenhista e pelo pintor. O que fica em primeiro plano na ilustração é o que está mais próximo do olho do pintor e do observador; portanto, deve ser representada em proporções maiores do que se desenha em segundo plano e assim por diante. Quanto mais distante estiver o objeto, menor será a figura representada e mais alta a sua base na tela (Figura 86). Já as imagens laterais devem estar acomodadas à pirâmide visual, cujo vértice coincide com o olho do pintor. O que está fora do campo de observação dos olhos (a cabeça deve estar imóvel e central - olhando para frente), não pode ser pintado, pois não existe naquele espaço.

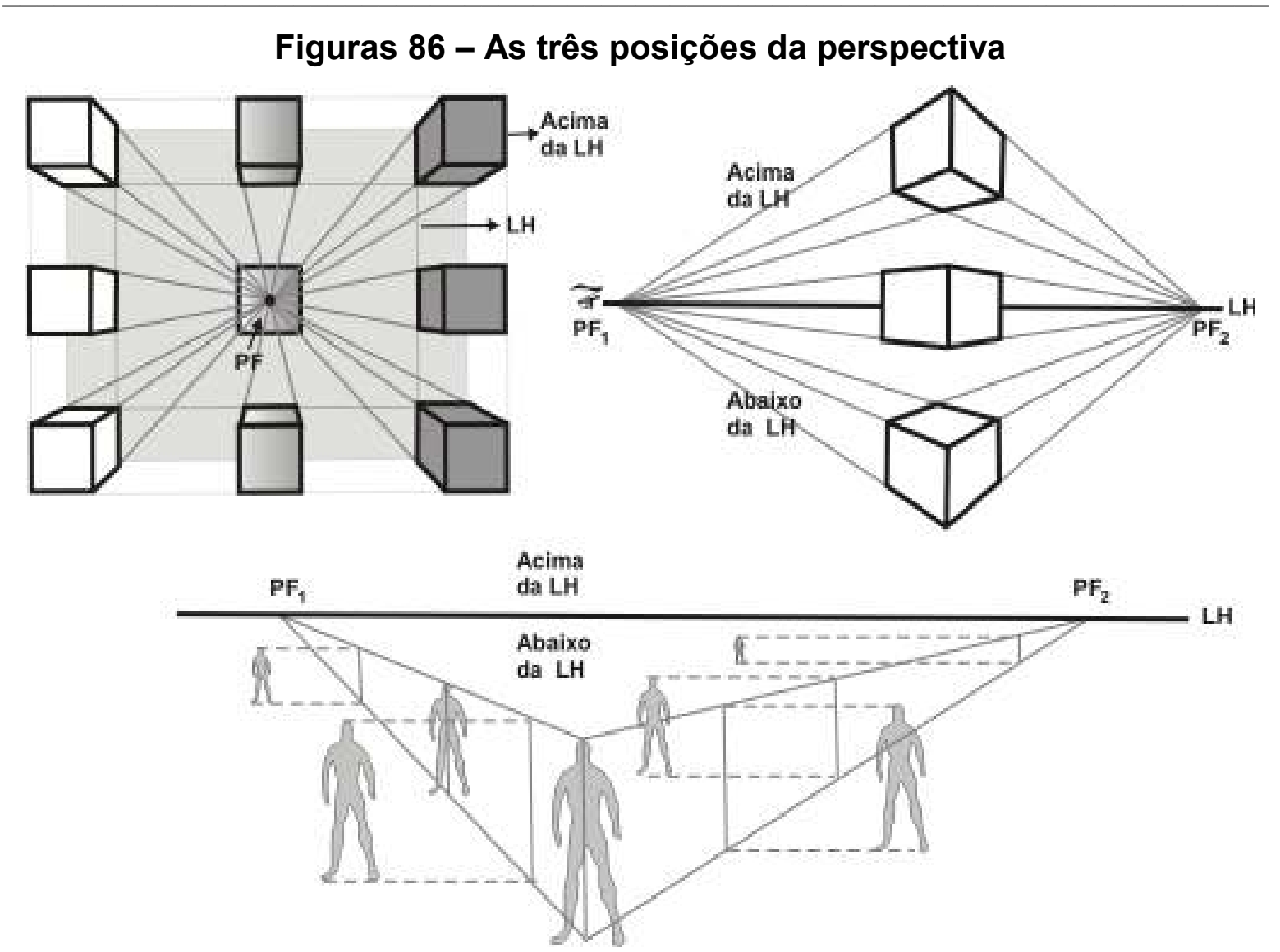

Os exemplos da figura 87 exemplificam ilustrações com um ou dois pontos de fuga.

Finalizando esta parte, ressalte-se que, muitas vezes, não é necessário utilizar a linha do horizonte e pontos de fuga para compor uma ilustração. A técnica da perspectiva paralela, além de ser mais simples, também proporciona bons efeitos visuais. A figura 88 demonstra que tanto os lados verticais como os horizontais são feitos a partir de linhas paralelas. 
Figura 87 - Desenhos com um ou dois pontos de fuga

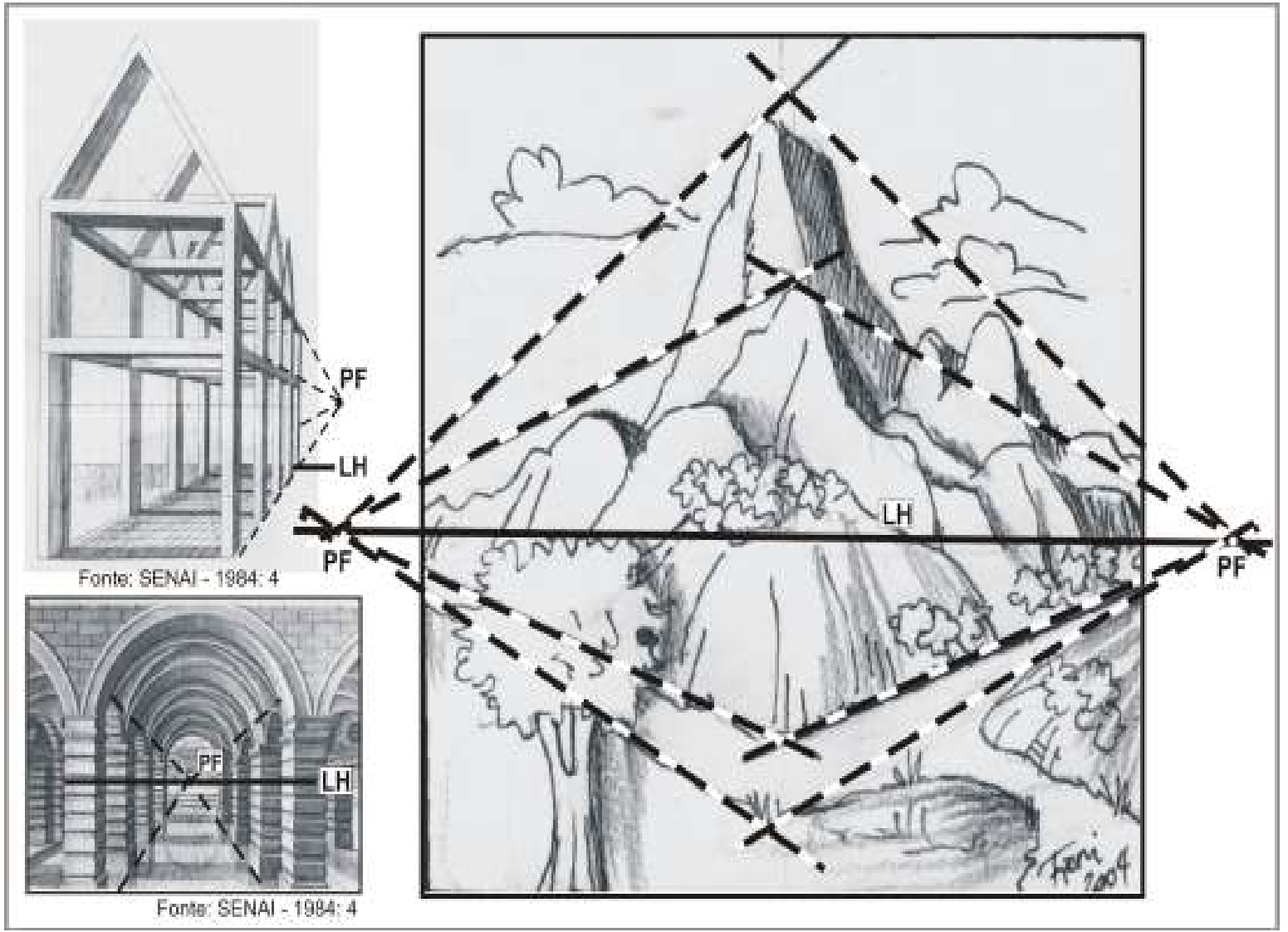

Figura 88 - São Vicente: desenho confeccionado em perspectiva paralela

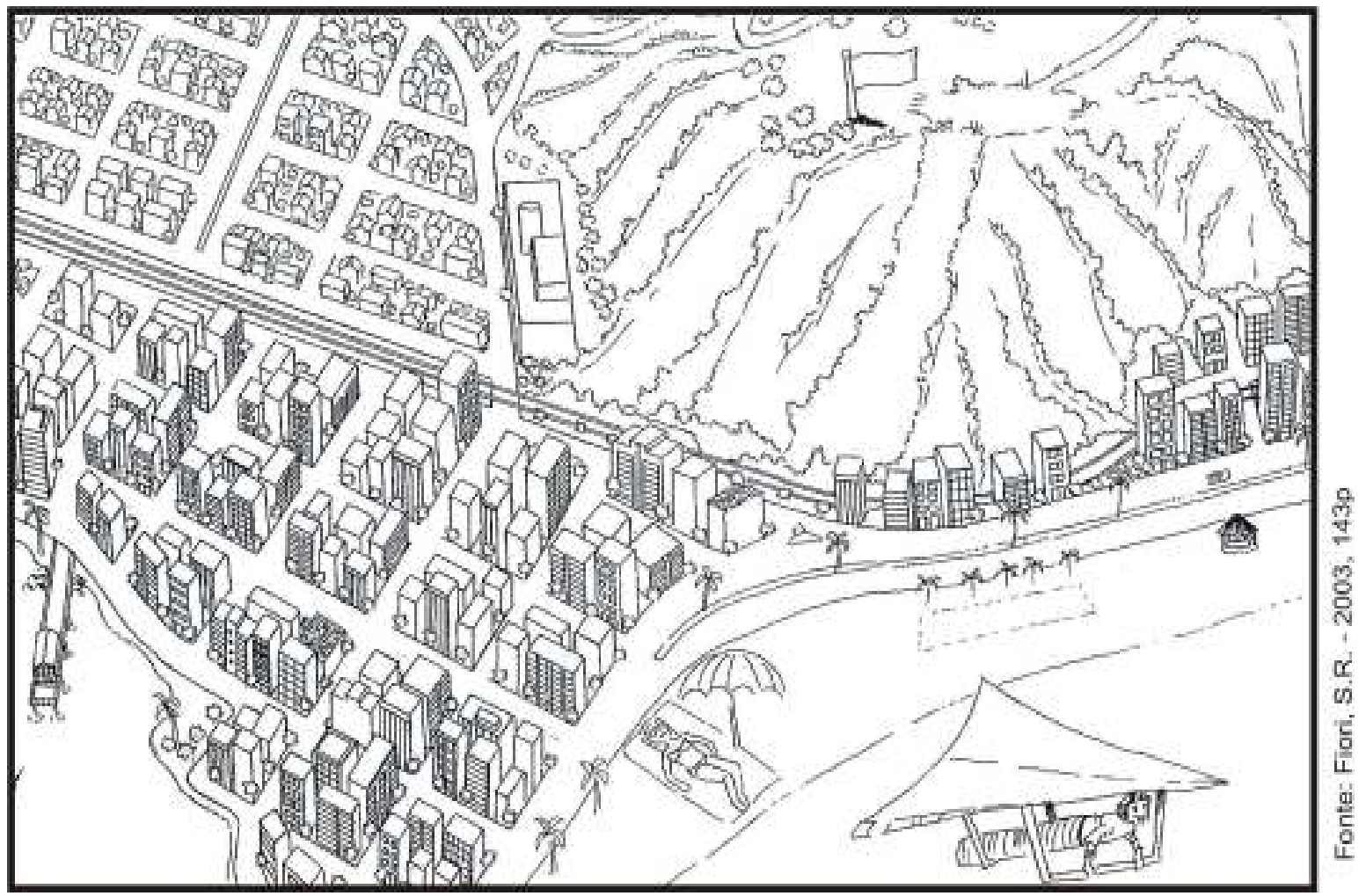




\subsection{3 - Elementos particulares}

Ao longo dos séculos, cartógrafos têm representado os fenômenos geográficos em mapas a partir de três formas básicas: o ponto, a linha e a área. Contudo, daqui para frente, serão destacados recursos de visualização ainda não abordados pela pesquisa de Fiori $(1999,2003)$, por se tratar de ferramentas elaboradas e utilizadas em ambientes interativos.

Nos mapas interativos, um ponto pode ser transformado em ícone ou símbolo, funcionando como um objeto que recebe uma ação graças ao clique do mouse, que permite funções, como, por exemplo, hiperlinks ou aberturas de menus pop up (Brown, Emmer \& Worm, 2001).

A interação em um mapa traz, então, um novo elemento complicador, atrelado ao trabalho do cartógrafo, porque o usuário pode perder uma informação por não perceber que alguns símbolos eram, na realidade, interativos. Assim, o mapa, ao ser manipulado, precisa deixar claro quais são os símbolos interativos e quais são os não-interativos.

Brown, Emmer \& Worm (2001) enfatizam que uma convenção parece estar se formando em torno dos símbolos pontuais interativos. Ela busca um efeito tridimensional para que eles pareçam flutuar sobre o fundo do mapa. O sombreamento é grandemente aplicado no desenvolvimento dos mapas interativos e da Web para criar objetos em 3D clicáveis, ou seja, acionados por meio de botões. O uso da sombra projetada sobre os objetos cria a impressão de estarem projetados sobre o fundo (Figura 89).

Figura 89 - Os diferentes tipos de símbolos pontuais interativos

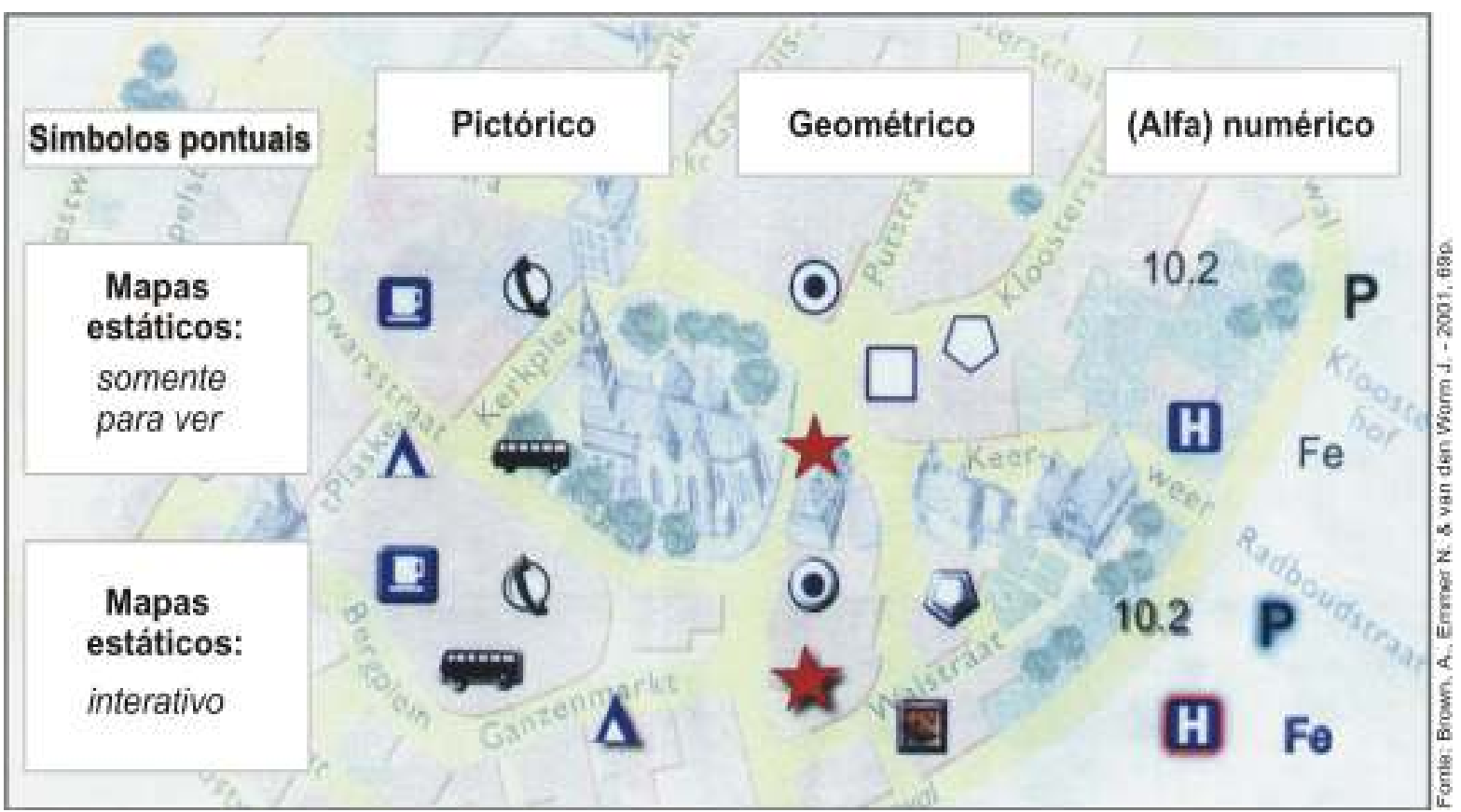


Os autores (Brown, Emmer \& Worm, 2001) ainda alertam para o cuidado em relação àquelas "legendas interativas" que são meramente escaneadas ao lado do mapa, não oferecendo nenhuma possibilidade de interação. Aliás, um dos grandes problemas associados à simples escanerização das legendas em mapas ocorre quando o usuário utiliza recursos como o zoom ou o pan e a legenda normalmente desaparece. Não se pode esquecer que a legenda é parte importante e fundamental do processo informativo de um mapa e, portanto, deve ser tratada como um objeto separado e móvel, o que possibilitará sempre seja vista na tela.

\subsection{4 - Animação}

Brown, Emmer \& Worm (2001) esclarecem que as animações podem ser aplicadas em símbolos:

$\checkmark$ Pontuais: rotacionar, pulsar, mudar de forma, alinhar símbolos, dar um efeito de algo movendo ao longo de uma linha, etc.

$\checkmark$ Areais: pequena mudança das cores do "verão" para o "inverno", movimento de setas ao longo de todos os itinerários de transporte ou o (um) modelo de uma suave ondulação azul para o mar.

A seguir, Wolfgram (1994) apresenta tipos de animações:

$\checkmark$ Personagem - busca a humanização de um desenho, isto é, significa que o personagem deve ter olhos, andar ou, de alguma forma, locomover-se como um ser humano faria, não havendo a necessidade de uma réplica perfeita. No caso de um mapa turístico, pode-se criar uma personagem que possua uma forte relação com o destino que ela representa, podendo ser naturalmente uma figura humana, como um pirata, um mártir; uma personagem típica - gaúcho, baiana, sambista, pantaneiro. Contudo, também pode ser uma personagem de uma lenda, um animal - jacaré ou o tuiuiú estilizado e usado para o Pantanal ou o golfinho para Fernando de Noronha - uma planta ou um objeto inanimado.

$\mathrm{Na}$ representação das personagens, devem ser ainda consideradas as emoções que possam caracterizá-las como tristeza, alegria, paixão, seriedade, etc.

A partir de pesquisas de gabinete e de campo, o produtor chega à conclusão de qual elemento seria o mais recomendado para representar a destinação.

$\checkmark$ Ping e pong - representam objetos em movimentos constantes, repetitivos, efeitos cintilantes e luminosos, capazes de destacar um objeto na imagem. Não devem prender a atenção por muito tempo; apenas o suficiente para que o produtor tenha a certeza de que público os percebeu. Como exemplos 
citam-se: o logotipo, diferentes tipos de botões - da legenda, de informações, da locomoção entre as páginas, etc.

A movimentação de objetos precisar ter sempre uma finalidade pré-estabelecida, ocorrendo somente se necessária, pois, quando uma apresentação é preenchida com movimentos sem sentido, os pontos-chave são perdidos e o usuário fica confuso. A movimentação da animação tem como finalidade acentuar o impacto emocional, melhorar a transmissão da mensagem, além de produzir uma transição eficaz entre um e outro segmento da apresentação.

\subsection{5 - Áudio}

Wolfgram (1994) divide-se o áudio em três categorias: música, efeitos sonoros e narrativa. Esses três elementos são parte importante do planejamento.

$\checkmark$ Música - é utilizada para criar um clima, uma atmosfera que deve envolver o espectador, influenciando a marcha das cenas seguintes. Tem diversas funções em uma apresentação, podendo determinar o início da exibição, enfatizar emoções ou ilustrar pontos particulares.

$\checkmark$ Efeitos sonoros - ranger de portas, chuva, sons de campainha são alguns exemplos desse tipo de áudio. Cada efeito sonoro precisa ter um propósito específico e deve ser adequado ao propósito do trabalho. Os efeitos sonoros nunca devem ser usados apenas para fazer um barulho de fundo, a menos que seja necessário.

$\checkmark$ Narrativa - usa a voz humana para apresentações em multimídia. O produtor que decide usar a voz deve ter cuidado com as possíveis reações a esse recuso. O sexo, a idade, a raça, a região e a atitude pessoal são características que se manifestam pela voz de uma pessoa. Nota-se, portanto, uma vez mais, a necessidade de conhecer bem o público-alvo e planejar a matéria de acordo com ele.

\subsection{6 - Interatividade}

É a forma como um usuário progride e se movimenta em uma apresentação nãolinear, não-seqüencial, ou seja, o usuário escolhe o seu próprio caminho quando utiliza o mapa. Logo, é importante considerar que tipo de usuário fará uso do produto e qual seu estado de ânimo nesse momento.

Segundo Wolfgram (1994:15), estatisticamente, as pessoas lembram-se apenas de cerca de $15 \%$ do que escutam, $25 \%$ do que vêem e mais de $60 \%$ das situações em que interagem. Em uma apresentação em multimídia, a interatividade aloca-se 
como a forma mais poderosa de provocar emoções, trazendo à tona todo um nível de controle implícito do produtor.

No entanto, esse recurso exige que o usuário sempre saiba onde está, como chegou ali e como deve proceder para ir de um lugar a outro; caso contrário, o produtor o perde. Portanto, a comunicação bem-sucedida sempre depende de manter a atenção do usuário ao assunto exposto.

A interatividade segue modelos diferentes, que podem ser previamente escolhidos. A forma mais comum de apresentações em multimídia ocorre por meio da estrutura hierárquica da organização dos dados. Normalmente, são utilizadas pequenas caixas retangulares em que se inserem palavras, porém, em geral, são pouco atrativas e não estimulam o interesse do usuário. Muitas vezes, botões de menu na forma de ícones contendo desenhos, sem legendas, são mais atraentes.

As aplicações em hipermídia - os hiperlinks, hipertextos e hipermapas - têm como princípio básico centenas de ligações cruzadas entre sessões sobre um mesmo assunto de forma que o usuário, tendo o controle interativo, pode pesquisar sem precisar passar por menus. De certa forma, uma apresentação em hipermídia é, na verdade, uma rede de informações com muitos caminhos por meio dos quais podese navegar.

Ao se abordar o tema principal desta pesquisa, o mapa pictórico turístico e interativo, a hipermídia habilita agregar e oferecer um grande e variado número de informações (Figura 90).

Baseado no exemplo de Menno-Jan \& Driel (1997), o turista, ao utilizar o hipermapa ${ }^{64}$, com sua coleção de mapas em diferentes escalas da destinação, tem a possibilidade de localizar todos os restaurantes num raio de dois quilômetros de seu hotel. Por exemplo, o mapa indica três: um de comida mineira, outro de comida internacional e um terceiro de comida árabe. O turista, então, ao clicar sobre o restaurante de sua preferência: o restaurante de comida mineira. Por meio do zoom, pode obter outras informações, como conhecer os diferentes ambientes (plantas) do edifício, fotografias do local e dos pratos, ver um vídeo da última festa de fim de ano, etc. Assim, todas as informações buscadas partem diretamente do hipermapa, definido como uma janela de procura dos elementos espaciais contidos na área representada, tendo como base o banco de dados já disponibilizado ao usuário.

\footnotetext{
${ }^{64} \mathrm{Na}$ literatura especializada, o termo hipermapa não é usado somente em sistemas de hipermídia geo-referenciada, mas também em mapas dinâmicos mais elementares, que apresentam uma exibição mais simples, com um número limitado de links. Já os mapas "clicáveis" são sistemas hierarquicamente orientados e proporcionam uma flexibilidade limitada, porém geo-referenciados. Menno-Jan, K. \& VAN DRIEL, R. (1997).
} 
Figura 90 - Conceito de hipermapa pela hipermídia geo-referenciada

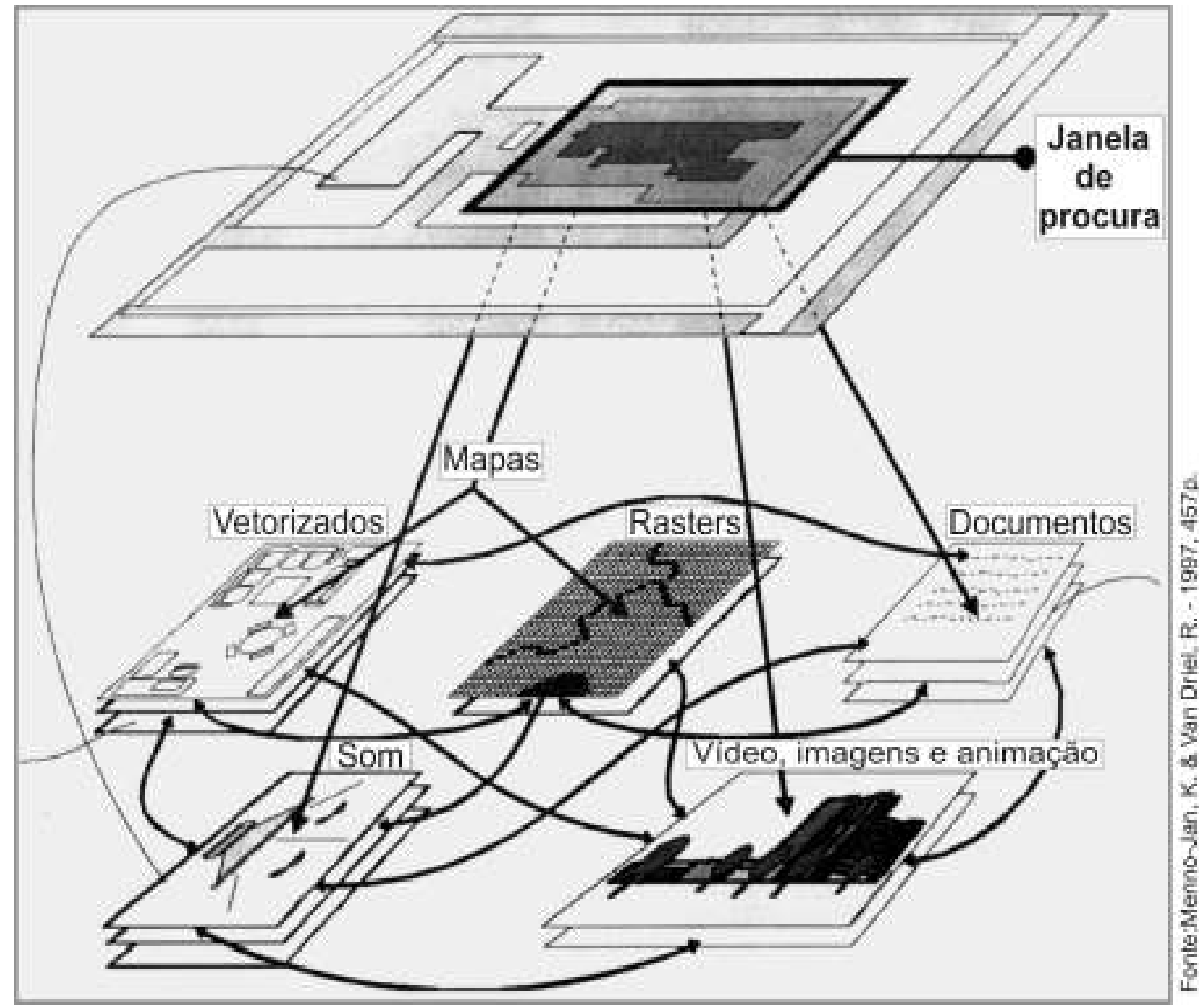

O tipo de acesso da informação exposto acima é conhecido como interno, porém existem outros links que se destacam fora da área do mapa, ou seja, o usuário pode clicar sobre um botão no site que está e este o liga a outros sites, fornecendo outras possibilidades de informação. Por exemplo, querendo saber mais informações sobre um hotel representado no mapa, o usuário pode ter acesso ao endereço/site do próprio hotel, que dará informações mais detalhadas sobre a acomodação: tipos de quartos e seus preços, planta de detalhamento de todos os serviços da instalação, a aceitação ou não de animais, tour virtual.

O site também pode ser enriquecido, se oferecer importantes informações sobre atividades e serviços que estão próximos ao destino representado, mas que não aparecem no mapa, como restaurantes na estrada, postos de gasolina e mecânicos, hospitais, parques de diversão, praias, monumentos históricos e arquitetônicos, entre outros. Este segundo tipo de acesso é conhecido como externo, ou seja, são aquelas informações obtidas além do site inicialmente acessado.

Os hipermapas são essencialmente constituídos pelo recurso do zoom, responsável por habilitar o usuário a focalizar ou ampliar, por meio de escalas, sua 
visão de um ou mais elementos dispostos no mapa. Desse modo, uma informação inicialmente dispersa e pequena no mapa, com o recurso zoom, pode ser ampliada, fazendo com que textos e ilustrações se tornem visíveis e compreensíveis. É claro que, para que uma informação seja bem transmitida, as mudanças de escala devem ser rápidas.

Comumente, encontram-se mapas na tela sem uma escala fixa, porém o produtor tem que decidir sobre alguns tipos de escalas "ideais", e isso depende da quantidade e precisão dos detalhes que quer apresentar. Brown, Emmer \& Worm (2001) distinguem três estratégias de zooms que podem ser aplicadas:

1) Zoom linear estático - Neste caso, a relação entre o zoom e o conteúdo do mapa é estática, sendo apenas ampliada ou reduzida linearmente, não havendo uma mudança de conteúdo do mapa. Pode-se conceber o processo de redução e ampliação do mapa a partir de dois tipos de comportamento:

$\checkmark$ Imagem raster - conforma-se no aumento ou diminuição de seus pixe/s, se caracterizam pelo formato analógico (folha de papel) e quando digitalizados são salvos em arquivos JPG, TIF, GIF, EPS.

$\checkmark$ Imagem vetorial - conserva seus detalhes em qualquer porcentagem de zoom, pois são elaborados em formato digital que, por exemplo, podem estar em arquivos DXF, DWG, CDR, Al (Figura 91).

Figura 91 - A escolha das imagens e o resultado no processo de zoom

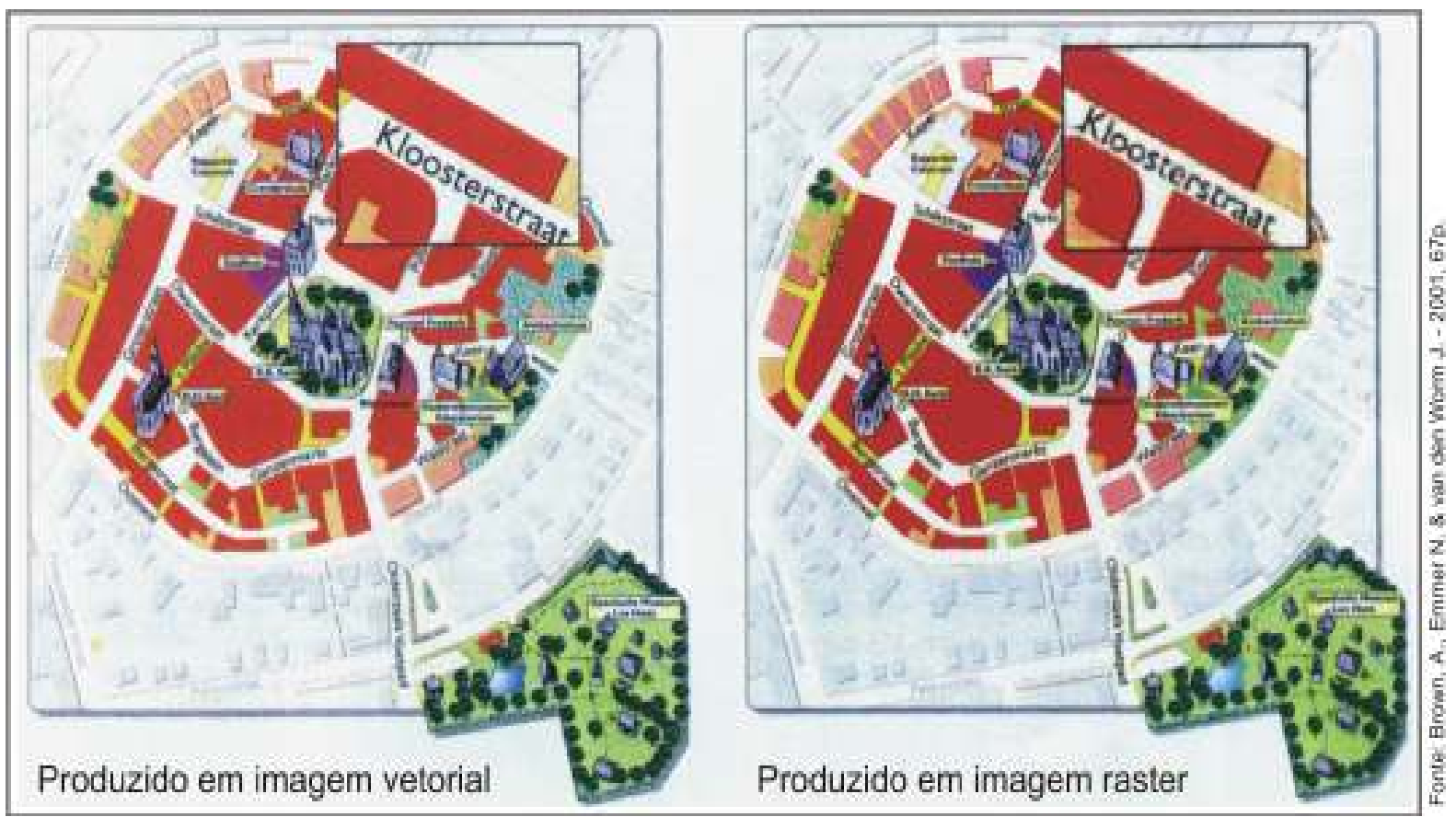


2) Zoom estático em etapas - Aqui se oferece uma série de mapas de um mesmo destino, os quais são armazenados em uma biblioteca de imagens gráficas, sendo cada mapa individualmente editado em seu conteúdo-escala, e desenvolvido a partir de imagens raster/vetorial reelaboradas para cada escala. Logo, quando o usuário utiliza o zoom (in ou out), há um processo de realocação, onde um mapa se sobrepõe ao outro, que o usuário havia inicialmente clicado. Este sistema é grandemente usado em sites de percursos projetados (Figura 92).

Figura 92 - Pré-estabelecendo os níveis de zoom

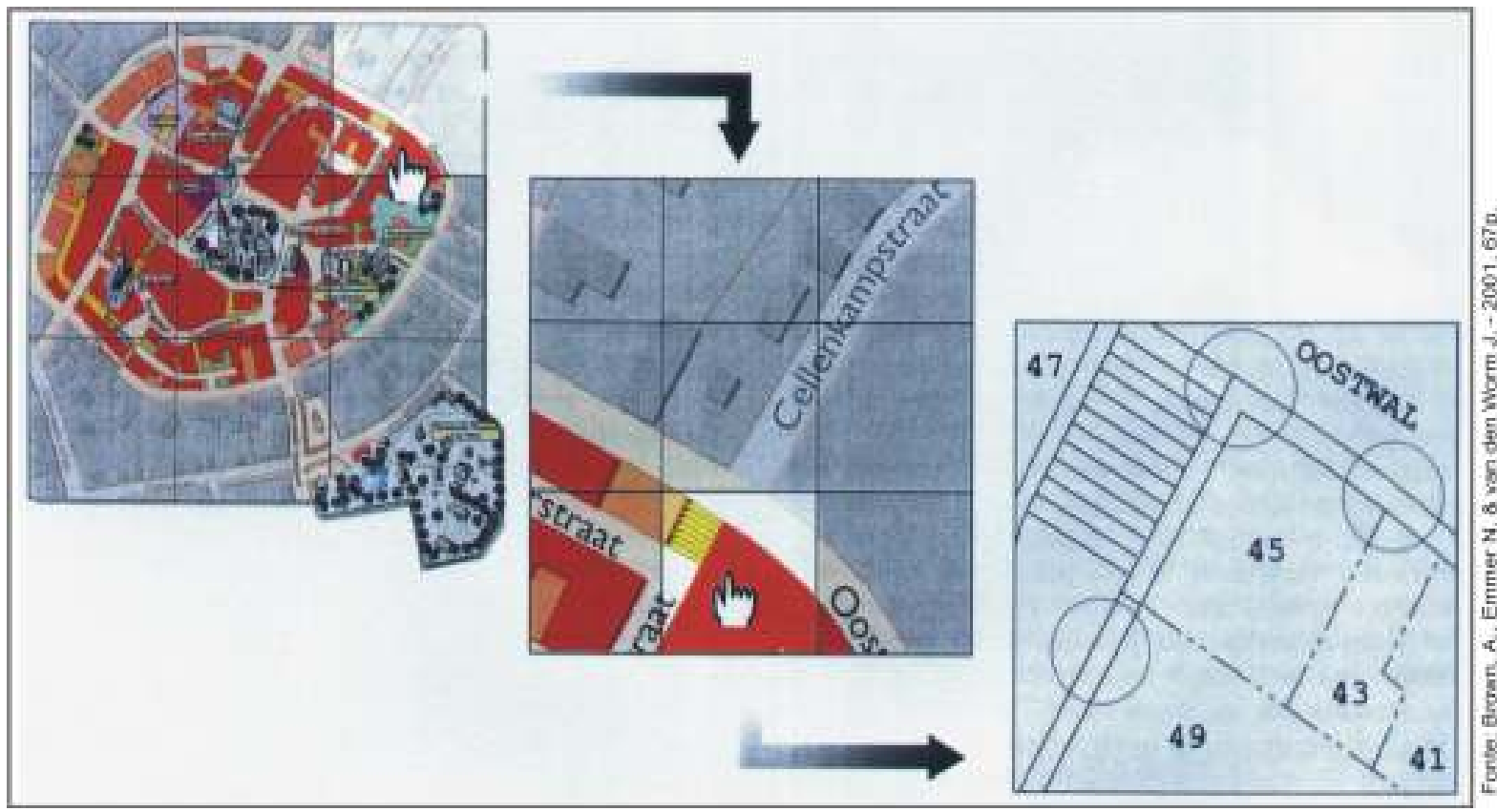

3) Zoom dinâmico (escala animada) - Este sistema apresenta um elo em tempo real entre a escala e o conteúdo do mapa; logo, quanto mais se aumenta a área de abrangência do mapa (zoom out), maior é o conteúdo automaticamente incluído. Para que isso ocorra são necessárias informações on-line da base de dados espaciais ligadas entre si. Como o tamanho do mapa não é fixo, a escala numérica não é o recurso mais recomendado para indicar a escala nos mapas confeccionados para Web. O mapa encontrado no site do departamento de Geografia da Universidade de São Paulo é um bom exemplo deste tipo de apresentação em zoom (Figura 93).

Aliás, ao abordar o tema escala, é necessário lembra que, historicamente e em uma grande variedade de aplicações, a hipermídia tem fornecido a seus usuários acesso a dados não-geo-referenciados. Em contrapartida, ao trabalhar fundamentalmente com mapas, abre-se essa nova fronteira. Nos campos de aplicação voltados às ciências da Terra, como o planejamento (cidades), o gerenciamento do meio ambiente e o setor do turismo, existe uma necessidade 
intrínseca de se combinarem dados geo-referenciados e não-geo-referenciados. Essa dualidade introduz o conceito de hipermapa, que permite ao usuário navegar por uma série de dados: não somente pelo tema, mas também espacialmente.

Figura 93 - O site do DG-USP: um exemplo de zoom dinâmico

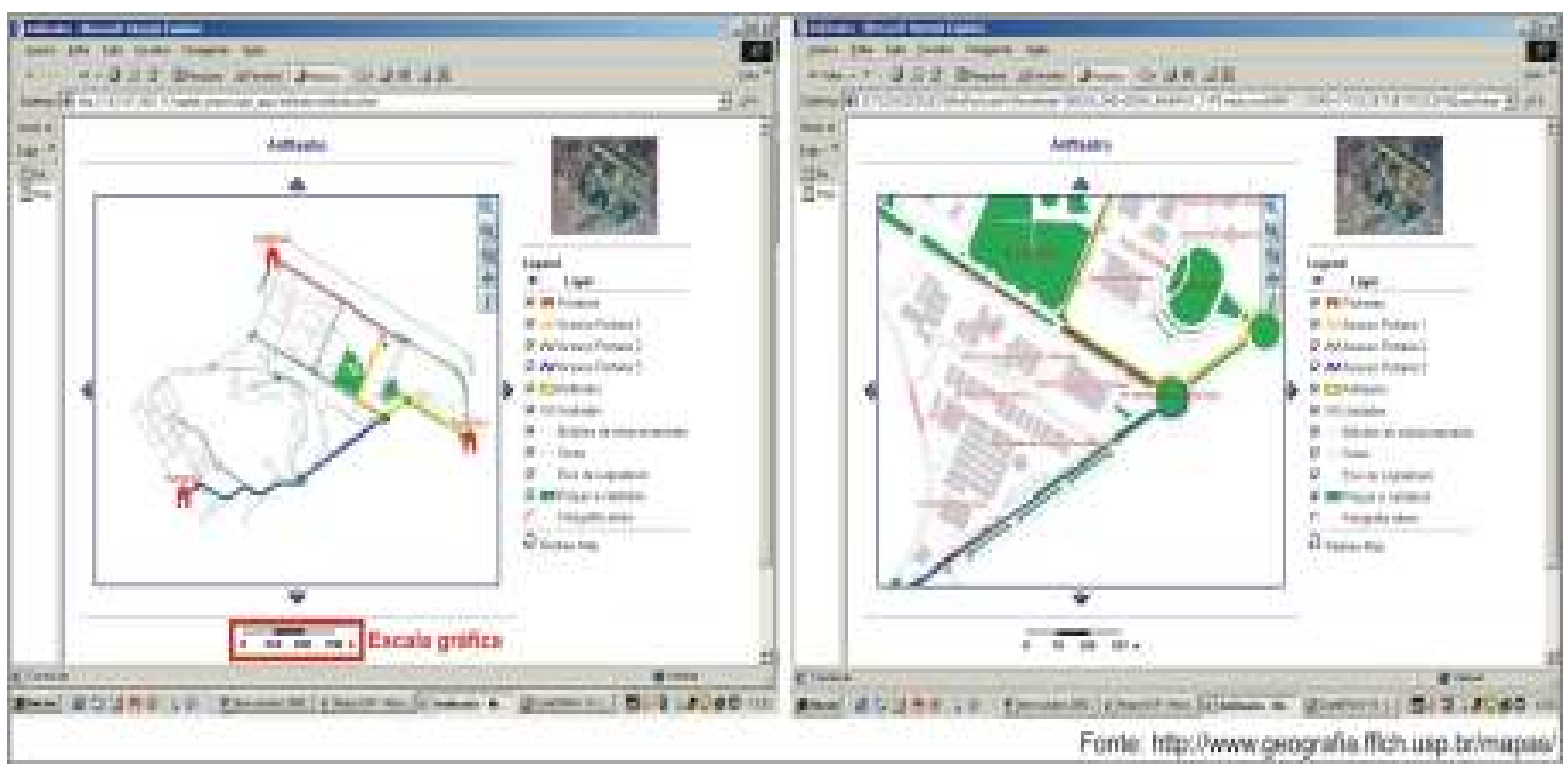

4) Pan - decorre da inserção de barras de rolagem no lado direito e/ou na parte inferior da tela. Estas barras surgem automaticamente toda vez que 0 tamanho da janela não suporta o seu conteúdo disponibilizado. A barra à direita é usada para deslocar o conteúdo da janela verticalmente, e a barra inferior para mover o conteúdo horizontalmente. Ao clicar nas setas das barras, o conteúdo da janela também é movimentado (Figura 94).

Figura 94 - As barras de rolagem: o recurso pan

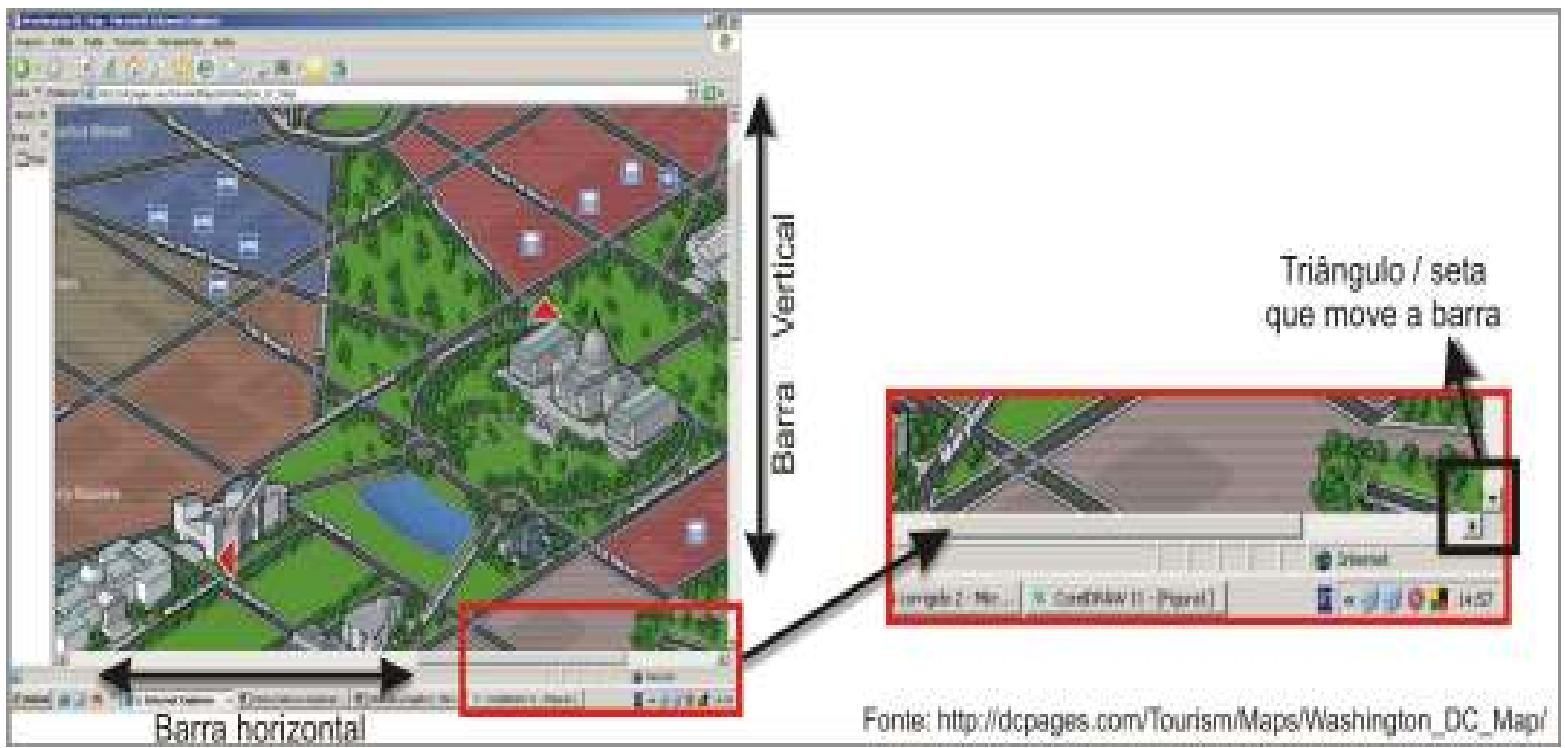


5) Pop up - é muito utilizado para solucionar o problema de acomodação de uma grande quantidade de links de navegação em um espaço reduzido. $O$ pop up surge e desaparece de maneira automática, rápida e temporária sobrepondo-se a pagina que se visualiza na tela do computador. Resulta da ação: clicar ou simplesmente passar o cursor em cima de algum elemento figura, texto, legenda, barra horizontal com submenus, etc. - com o auxílio mouse, liberando assim, a informação suplementar (Figura 95).

\section{Figura 95 - Tipos de pop up}

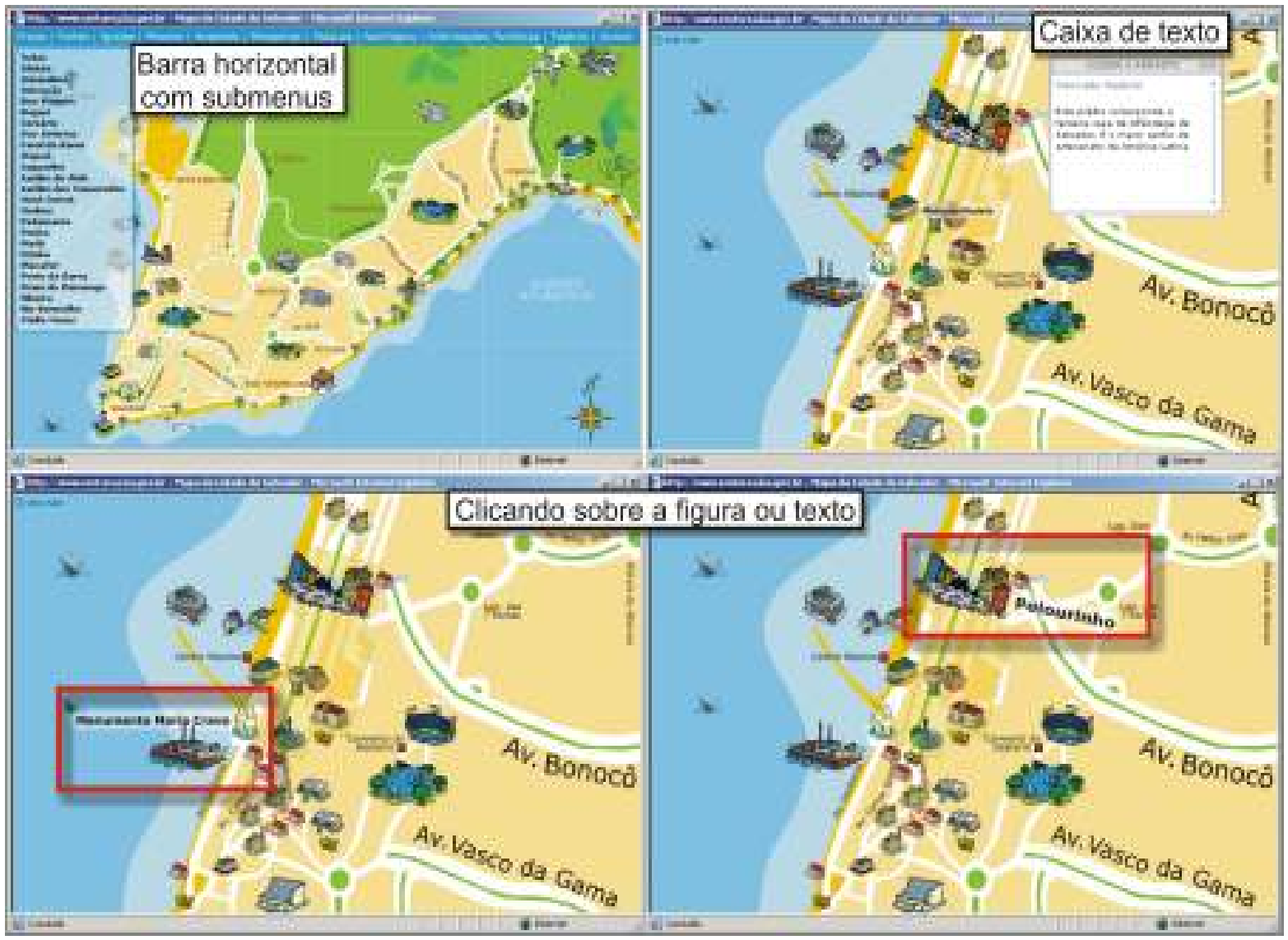

\subsection{7 - Download}

No caso dos mapas desenvolvidos especificamente para a Web, os cartógrafos precisam estar atentos a um item vital para seu sucesso: o tempo de download. Obviamente, o mapa deve motivar e ser cartograficamente eficaz, porém deve ter a obrigação de gerar apresentações, como páginas e animações, que sejam baixadas em um tempo que não as torne enfadonhas e desinteressantes. Inicialmente pela demora e posteriormente pelo custo da ligação telefônica, sobretudo a que se relaciona às conexões discadas ( $56 \mathrm{Kbps}$ ). Entretanto, mesmo a conexão em banda larga apresenta diferentes velocidades de downloads - 150, 250, 500 e $750 \mathrm{Kbps}, 1$ e 2 Mbps. 
Por isso, é importante levar em consideração o tipo de conexão de que o usuário faz uso. Em um levantamento da European Intelligence Unit (EIU), constatou-se que países como o Chile, Brasil, México e Argentina crescem rapidamente em número de internautas. No entanto, só o Chile possui penetração em banda larga superior a 3\% (IDG now!, 04/2005).

Em outra reportagem da IDG now! (06/2005), lê-se que, no Brasil, de cada dez internautas domésticos, quase cinco já possuem conexão em banda larga. A tendência é que, até 2009, por volta de 7,4 milhões de brasileiros estarão conectados a alta velocidade.

Diante dessas informações, fazem-se duas ressalvas: em primeiro lugar, mesmo com o crescimento apontado das conexões em banda larga, a porcentagem, ao se pensar no Brasil, país com mais de cento e oitenta milhões de habitantes, é muito pequena. Outra peculiaridade no que diz respeito à eficácia de um produto cartográfico feito para Web, é pensar que o download deve ser satisfatório a todos os usuários de Internet, sejam eles da conexão discada ou das várias possibilidades de conexões em banda larga.

Finaliza-se este capítulo com referências ao pensamento de Wolfgram (1994: 214), que aponta alguns itens que devem ser analisados ao finalizar o desenvolvimento de um trabalho em multimídia interativa:

$\checkmark$ Mensuração de quanto da memória do computador (CPU) é utilizada.

$\checkmark$ Qualidade das transições que devem acontecer de maneira suave e eficientemente.

$\checkmark$ Eficácia da comunicação da mensagem: o usuário deve compreender a mensagem desde a primeira vez que vê a apresentação.

$\checkmark$ Equilíbrio entre ritmo e andamento, ou seja, o trabalho interativo deve ser (está) lento o suficiente para ser confortável, mas não moroso e enfadonho.

$\checkmark$ Conteúdo da apresentação: todos os objetivos foram alcançados?

$\checkmark$ Satisfação do usuário: as mensagens estão sendo transmitidas do jeito que o cliente queria?

$\checkmark$ Preservação e/ou melhora da imagem do cliente.

$\checkmark$ Capacidade de medida: estão prontos os veículos que avaliarão o sucesso do projeto?

$\checkmark$ Expectativa dos usuários: Se os clientes gostaram do produto, o que mais os atraiu? 


\section{4 - Breve crítica e proposta para a elaboração dos mapas}

\section{e o protótipo de um mapa-site turístico do município de Caxambu}

Na última semana do mês de março de 2006, ocorreu um trabalho de campo no município de Caxambu, sul do estado de Minas Gerais. Durante a estada, foram travadas algumas conversas com funcionários da prefeitura, resultando na coleta de dados: o inventário turístico do município, folderes, fotos e visitas guiadas ao teleférico e Parque das Águas. Recolheu-se também o mapa turístico mais usado pela cidade (ver o mapa em CD - anexos - pasta 4), elaborado pela Editora Buz (C em 2003, sendo disponibilizado à Prefeitura Municipal de Caxambu. O produto era encontrado facilmente em hotéis, no Parque das Águas e no Posto de Informação Turística.

Levando-se em conta o momento histórico pelo qual a correção dos mapas convencio-nais se pauta - por exemplo, na geometria euclidiana e no atual desenvolvimento tecnológico - o mapa de Caxambu não se diferencia da grande parte dos "mapas" que prestam serviço ao setor do turismo / turista.

Apresenta muitas deficiências cartográficas, como: ausência de título, de escala e do sistema de referências ${ }^{65}$. A base cartográfica referente ao arruamento foi distorcida, e aparecem apenas poucos nomes de ruas - somente aquelas próximas ao Balneário. Além disso, a legenda poderia estar mais bem sinalizada, e não há citação sobre as fontes utilizada. Já os símbolos, sob o mapa-fundo, são poucos, mas claros, graficamente bem representados e de bom tamanho. É importante ressaltar que o fundo do mapa mantém relação harmônica com os símbolos, até porque o segundo elemento destacado deve sempre sobressair, não disputando a atenção com o fundo.

O mapa de Caxambu disponibiliza ainda um detalhe do Parque das Águas, o maior atrativo turístico da cidade. Contudo, seria muito oportuno existir também um mapa em menor escala, que indicasse acesso a rodovias e a localização de Caxambu entre outras cidades. Ainda poderia se fazer um pequeno mapa do Brasil, destacando o estado de Minas Gerais.

Por todos esses elementos inexistentes no mapa turístico do município de Caxambu, pode-se afirmar seguramente que o material não pode ser caracterizado como um mapa, mas sim como uma ilustração ou uma representação gráfica de uma parte do município.

Os cartunistas Gepp e Maia constituem um bom exemplo de profissionais que trabalham a arte como uma representação simbólica do espaço. No site www.geppemaia.com.br e em Gepp e Ferreira (2002), encontram-se ilustrações que representam o futuro Rodoanel, bairros como a Vila Madalena, Pinheiros,

\footnotetext{
${ }^{65}$ São as coordenadas geográficas e/ou UTM (Projeção Universal Transversa de Mercator) que revelam a latitude, longitude; indicação do Norte.
} 
Morumbi, região da Avenida Paulista, pontos históricos do centro da cidade de São Paulo, entre outras.

A figura 96 demonstra recortes de mapas turísticos ilustrados em diferentes escalas, que não apresentam nenhuma preocupação com as regras cartográficas essenciais. Outro item a ser observado é o espaço reservado à propaganda comercial, comum a esse tipo de representação, até porque, na grande maioria das vezes, são os comerciantes que custeiam a confecção do produto. Torna-se importante destacá-los, mas isso pode ser feito de uma maneira mais sutil e que não agrida a diagramação e o trabalho estético referente a compreensão do mapa.

A figura 96 exemplifica as deficiências cartográficas a partir de quatro mapas turísticos:

$\checkmark$ Não possuem escala,

$\checkmark$ O titulo é pequeno, sem destaque ou visualmente confuso em A e B;

$\checkmark$ Não há indicação de Norte em B e C;

$\checkmark$ Os mapas fazem uso de símbolos pictóricos; destaca-se o D, por sua visão oblíqua bem elaborada;

$\checkmark$ Os textos acompanham muitas ilustrações;

$\checkmark$ A legenda inexiste em $C$ e $D$, e é muito mal elaborada em A;

$\checkmark$ Todos possuem propaganda comercial; destaca-se o A pela poluição visual causada pelos anúncios que não estão nas bordas, mas inseridos dentro do próprio mapa.

O outro tópico é a discussão do mapa-site turístico de Caxambu, disponível no endereço: www.caxambu.mg.gov.br (Figura 97), que utiliza como apoio o material impresso ante-riormente citado: o mapa de Caxambu, ou seja, com todas as deficiências já relaciona-das. Ele é então adaptado ao meio digital e moldado como um mapa estático interativo.

A partir do fundo-mapa-base, são compostos símbolos e caixas de texto interativos, devido a alguns recursos "clicáveis", que possibilitam diferentes formas de apresentação visual do mapa. É de fácil acessibilidade, por ter um rápido download da página, mesmo em conexões de baixa velocidade. A navegação é simples e de boa compreensão por disponibilizar poucos símbolos pontuais. A legenda, em pop up, traz textos dos principais atrativos do município. Não é possível utilizar o recurso pan e não há uma rede de layers. O recurso zoom é disponível em um só nível - zoom em etapas com imagens raster. Há uma pequena animação em flash: o teleférico mas é esteticamente pobre.

A figura 97 ainda apresenta outros tipos de mapas-site encontrados na Internet. 
Figura 96 - Mapas turísticos e a despreocupação com as regras cartográficas
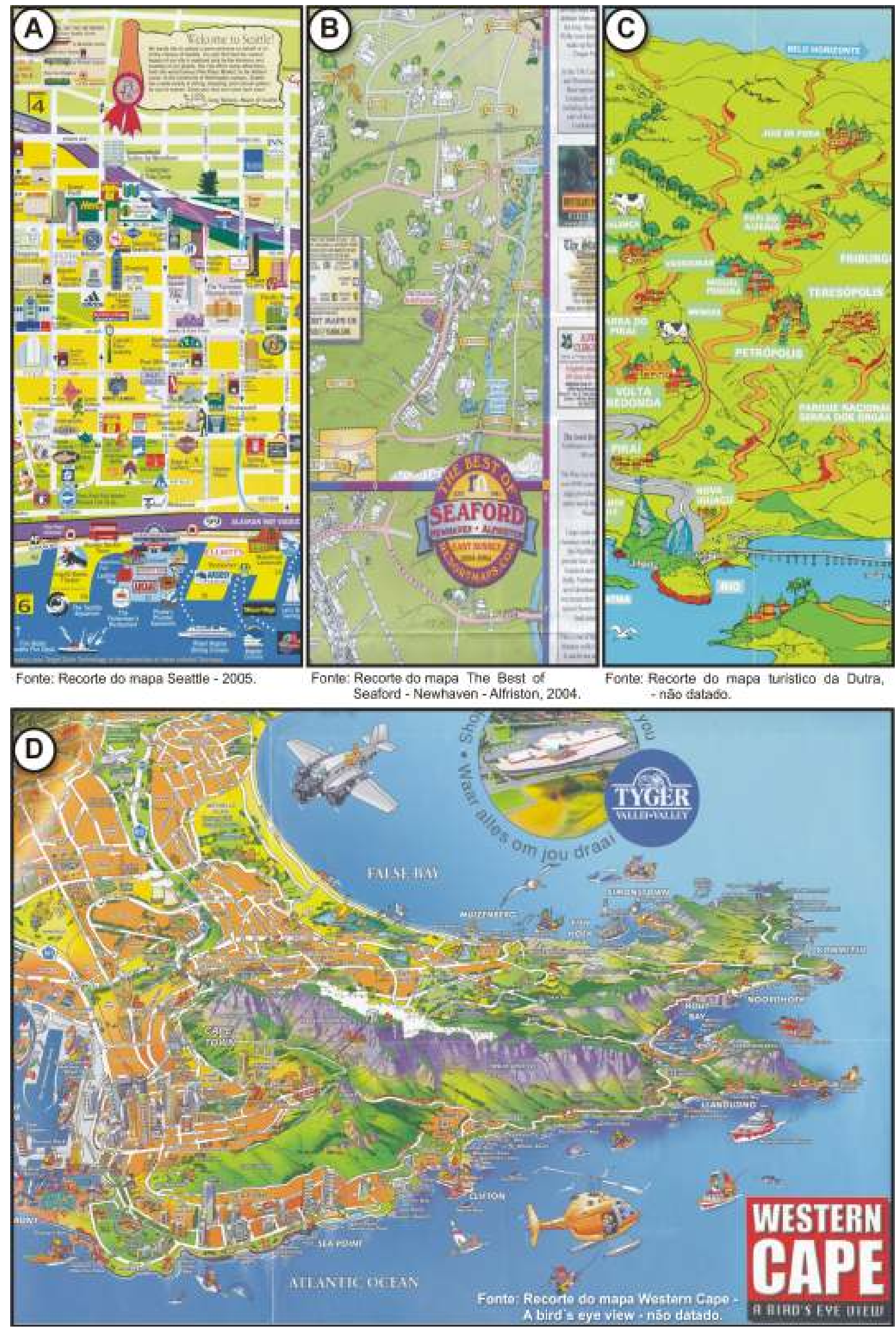
Figura 97 - O mapa-site turístico de Caxambu e alguns outros exemplos

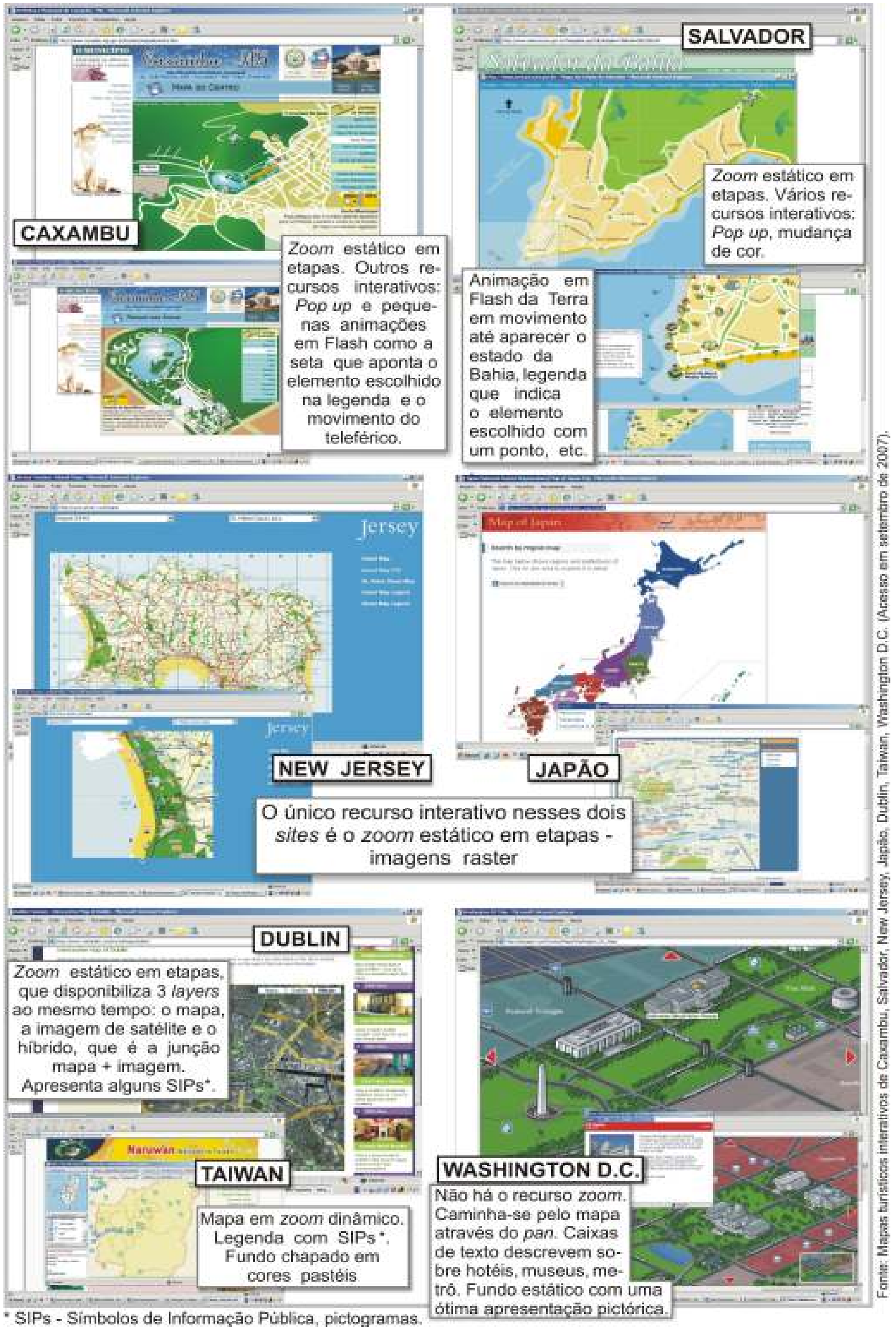


Todas essas observações refletem o desenvolvimento de vários tipos de mapas: convencionais, pictóricos e de mapas-site voltados ao setor do turismo.

Nesse momento, trabalha-se, na prática, o mapa híbrido, ou seja, aquele que tanto faz uso das regras cartográficas básicas, da semântica para iniciados e da semiologia gráfica de Bertin, quanto da teoria da comunicação, do senso comum e da pictografia.

É fundamental justificar que o mapa pictórico jamais conseguirá conceber uma linguagem finita, rigorosa, fisiológica e ordenada, como estabelece a semiologia gráfica. Até porque a teoria da comunicação estuda o signo lingüístico, que engloba o significante e o significado, e é caracterizado pela arbitrariedade por influencia das coordenadas histórico-culturais.

Em suma, a elaboração dos mapas convencionais tende a uma maior aproximação da semiologia gráfica: os denominados mapas para ver, enquanto os mapas pictóricos se configuram como mapas para ler (Bertin, 1983: 78).

Fiori $(1999,2003)$ e outros trabalhos empíricos evidenciam que, em geral, o público leigo em cartografia e o turista tendem a optar pelos mapas pictóricos, mesmo que a compreensão do conteúdo ocorra mais lentamente. Isso acontece devido ao melhor entendimento da informação, à atratividade e ao poder de sedução exercido pelo produto pictórico.

Ao se reportar ao tema central: diferentes tipos de usuários merecem diferentes tipos de mapas e, não ignorando o vertiginoso aumento dos "mapas" turísticos, resultado do crescimento das viagens pelo mundo, continua-se a pesquisa quanto à eficácia e eficiência de materiais cartográficos com grande apelo pictográfico.

Conseqüentemente, é proposital a elaboração de mapas para ler e não para ver, pois, considerando tudo que foi dito até aqui, o mapa para ler faz com que o usuário viaje à localidade representada antes mesmo de conhecê-la, possibilitando o devaneio, entre outras reações. O marketing turístico também pode tornar o mapa um suvenir.

Levando em conta a elaboração do mapa-site turístico pictórico e o acesso por pessoas de profissões, idades, mas principalmente culturas diferentes, é impossível não existir um rico questionamento quanto à maneira de representar a realidade, de modo que um maior número de pessoas possa ler e se interessar pelo material desenvolvido.

Como já se registrou anteriormente, os símbolos e ícones devem procurar uma feição simples, sem muitos traços. A legenda, textos e outros elementos ilustrativos são recursos que ajudam a aumentar a informação cartográfica. 
Faz-se aqui uma ressalva: os usuários que acessam o mapa-site turístico conhecem, sem mensurar o quanto, o meio digital e a Internet, supondo ainda conhecimentos formais e informais.

Além disso, é instigante pensar que o mapa pictórico possibilita uma maior visão do outro, ao enfatizar símbolos locais e nacionais, atrativos naturais e culturais, fornecendo ao usuário da Internet - "o turista virtual" - informações de que ele pode se apropriar e que é capaz de adaptar com o propósito de conceber um senso distinto de nacionalidade. Palmer (1999) afirma que a idéia de nação está poderosamente presente na linguagem do turismo patrimonial. A apropriação da identidade nacional para o turismo - e, por que não inserir o mapa turístico? - vai além do interesse comercial: perpassa o coração do povo e serve para definir uma identidade tanto para os que são representados quanto os que devem entender a representação.

A importância de um castelo vai além da estrutura física que atrai os turistas. Ele também significa a nação como anciã, poderosa, majestosa, forte e duradoura e, desse modo, representa tudo o que é apreciado sobre a nação (Palmer, 1999).

Assim, ao propor um mapa-site turístico, devem-se considerar não só os elementos essenciais de um mapa (título, escala, referências geográficas), mas ir além, estudando formas de representar graficamente alguns elementos característicos da identidade local e nacional.

\section{5 - Processo de elaboração dos mapas e do mapa-site turístico}

Elaboram-se dez mapas: cinco convencionais e cinco pictóricos de cinco municípios brasileiros. Os mapas em formato digital estão disponíveis CD - anexos - pasta 3.

\section{$1^{\circ}$ passo: o trabalho de campo}

Os trabalhos de campo foram realizados em Ilhabela (SP); em Foz do Iguaçu (PR), em fevereiro de 2006; Caxambu (MG), em março de 2006; Manaus (AM), em abril de 2006 e São Raimundo Nonato (PI), em junho de 2006. A estada nos municípios foi importante para recolher informações como: inventários turísticos, folderes, mapas, fotos, textos, entre outras fontes de dados.

\section{$2^{\circ}$ passo: a base cartográfica}

Utilizam-se cartas do IBGE em escalas 1:1.000.000, 1:250.000 e 1:50.000 (relacionadas na bibliografia), plantas cadastrais analógicas e digitais, Guia Brasil Quatro Rodas e os Atlas de Simielli (1993), Vasconcellos e Alves Filho (1999).

Entretanto, é necessário registrar que as cartas do IBGE foram produzidas há aproximadamente 20 anos, o que acarreta problemas quanto à defasagem das 
informações nelas dispostas. Por isso, foi necessário consultar outros materiais visando à atualização das bases, como imagens de satélite (Google Earth) e principalmente outros "mapas" sem escala, que forneceram subsídios para referências como hidrografia, estradas, curvas de nível, etc. As bases cartográficas, principalmente aquelas usadas nos mapas pictóricos, passaram por ampliações, com tamanho suficiente para a caracterização das ilustrações, símbolos e textos em geral.

Alguns mapas já vieram em formato digital (programa AutoCAD), mas a maioria foi escaneada e posteriormente digitalizada em AutoCAD ou CorelDraw.

O formato final do mapa temático turístico é o tamanho A1 (584 X $841 \mathrm{~mm})$.

\section{$3^{\circ}$ passo: a elaboração dos mapas}

A partir de uma mesma base cartográfica, elaboram-se dois mapas que, entretanto, apresentaram diferentes versões de representação para a mesma localidade: um mapa convencional e um mapa pictórico. A seguir, destacam-se os itens comuns às duas versões:

\section{1 - Um título com um tema em destaque disposto na parte superior do mapa}

Seguem-se os títulos: O arquipélago de llhabela; Foz do Iguaçu - Terra das Cataratas; Caxambu - A maior concentração de fontes carbogasosas do planeta; Manaus - Coração da Amazônia; e Parque Nacional Serra da Capivara - A maior concentração de sítios arqueológicos do mundo.

\section{2 - A base temática: o fundo do mapa}

Como se sabe, ao levar em conta o usuário, o fundo de um mapa nunca deve chamar mais a atenção do que as informações realmente importantes. Entretanto, devido à temática do turismo, fazem-se três ponderações:

$\checkmark$ Durante o processo de tematização, o produtor do mapa escolhe e adapta as informações contidas na base cartográfica. No caso desta pesquisa, as bases em escala menor são normalmente topográficas ou cadastrais (arruamento), e as bases em escala maior vêm fundamentalmente de guias e Atlas.

$\checkmark \mathrm{O}$ fundo do mapa turístico pode conter representações caracterizadas por espaços urbanos ou rurais e diferentes feições de morfologia do terreno. Contudo, a forma de representação visual desenvolvida pelos mapas convencionais é muito diferente se comparada aos mapas pictóricos. $\mathrm{O}$ primeiro tipo apresenta a vantagem de conseguir compor um mapa abstrato essencialmente por meio das cores, das linhas e do uso efetivo da visão vertical. O mapa convencional, referenciado no discurso da neutralidade, tende a ser visualmente mais claro, direto e possibilitar o domínio da 
informação de maneira mais rápida. São os mapas para ver.

$\checkmark$ Mesmo os mapas pictóricos sendo mais poluídos visualmente, apresentam a grande vantagem de compor representações que atraem o olhar da maioria das pessoas, em particular, os leigos em cartografia. Esse público, embora demore mais tempo para interpretar o que vê, consegue um melhor resultado quanto ao entendimento da informação. São os mapas para ler. Além disso, o recurso da ilustração e da visão oblíqua possibilita apresentar os temas de maneira mais lúdica, sedutora e atrativa, um aspecto a ser considerado quando se pensa desenvolver um mapa temático para o turismo.

A figura 98 demonstra o processo de elaboração dos mapas convencionais e pictóricos, referenciados em uma planta cadastral (98 A) e uma carta topográfica (98 B).

Para finalizar, é necessário que se faça uma ressalva quanto à elaboração das bases temáticas pictóricas. Mesmo que o grau de abstração da realidade seja menor, se comparado aos mapas convencionais, a base pictográfica continua sendo uma representação gráfica muito reduzida da realidade.

Ao olhar novamente para a figura $98 \mathrm{~A}$, pode-se afirmar que a representação é uma imagem genérica e geral dos quarteirões e suas construções. No caso do mapa de Caxambu, ainda devido à boa dimensão de sua escala foi possível até representar os principais prédios e atrativos do Parque das Águas, como as fontes e o Balneário. Todavia, é quase impossível compor ilustrações que representem o tamanho real ou apresentar todas as construções contidas em um quarteirão. $O$ que o mapa pictórico mantém são as distâncias, ou seja, as ilustrações consideram rigorosamente a base cadastral, topográfica.

O mesmo caso é percebido nas representações morfológicas do terreno, pois é impossível caracterizar a vegetação tal com ela é na realidade. Dessa forma, mesmo que a representação busque seguir as curvas de nível para moldar a morfologia do terreno, o modo como se caracteriza a vegetação é caricata. A figura 99 demonstra outro exemplo. Rever também as figuras $96 \mathrm{~B}, \mathrm{C}$ e D.

\section{3 - O sistema de referências}

Os mapas convencionais e ilustrados desenvolvidos possuem a indicação de Norte e a coordenada geográfica representando uma latitude e uma longitude.

Outro ponto de referência é conseguido graças à composição: mapa principal e outros mapas em escala menor. Os mapas-detalhe situam as cidades turísticas em relação a vias de acesso, a outras cidades e a capitais. Um pequeno mapa do Brasil ainda informa em qual estado brasileiro está a cidade representada. 
Figura 98 - A pictografia sob uma planta cadastral e uma carta topográfica
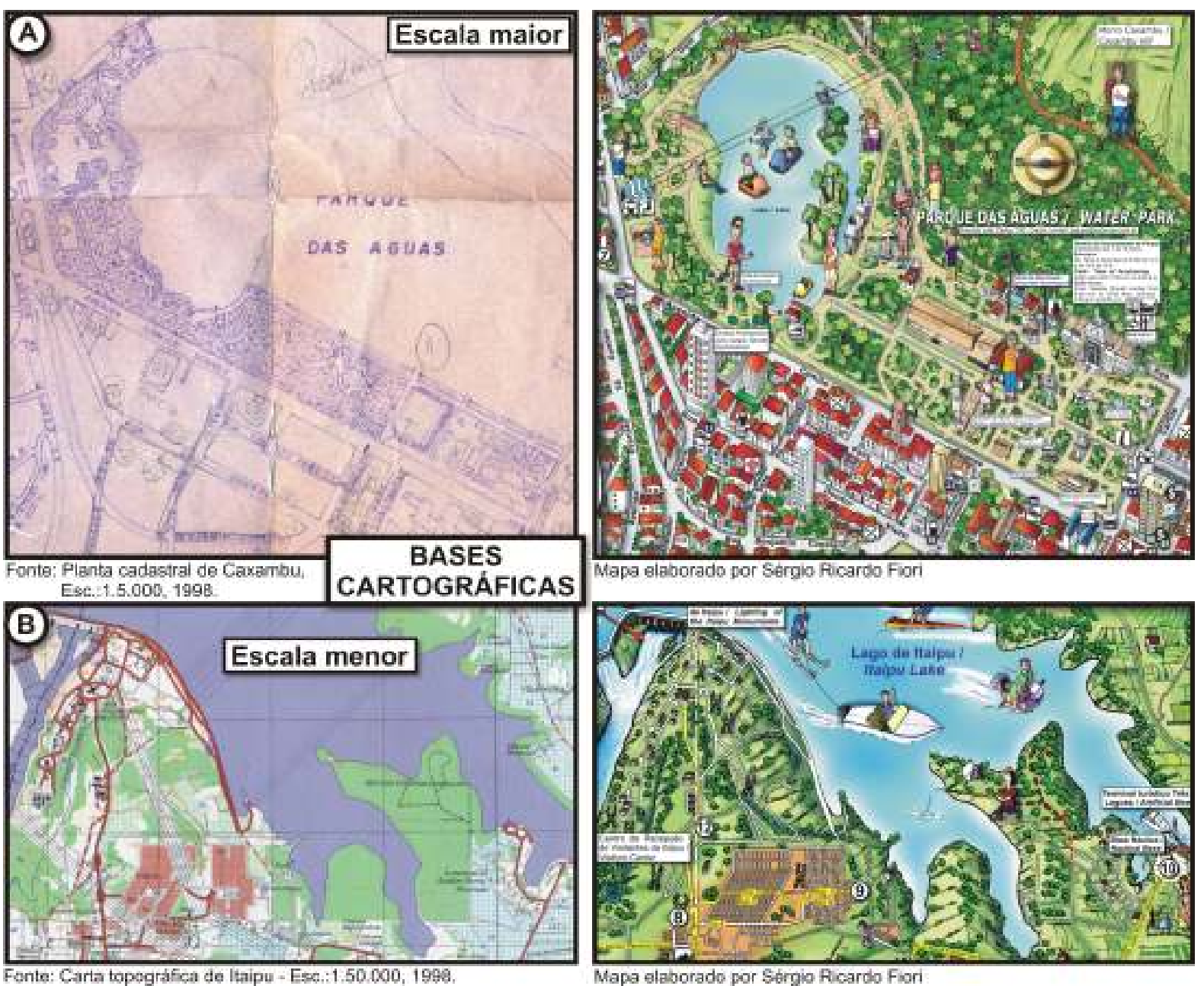

Figura 99 - A pictografia e a generalização da realidade física

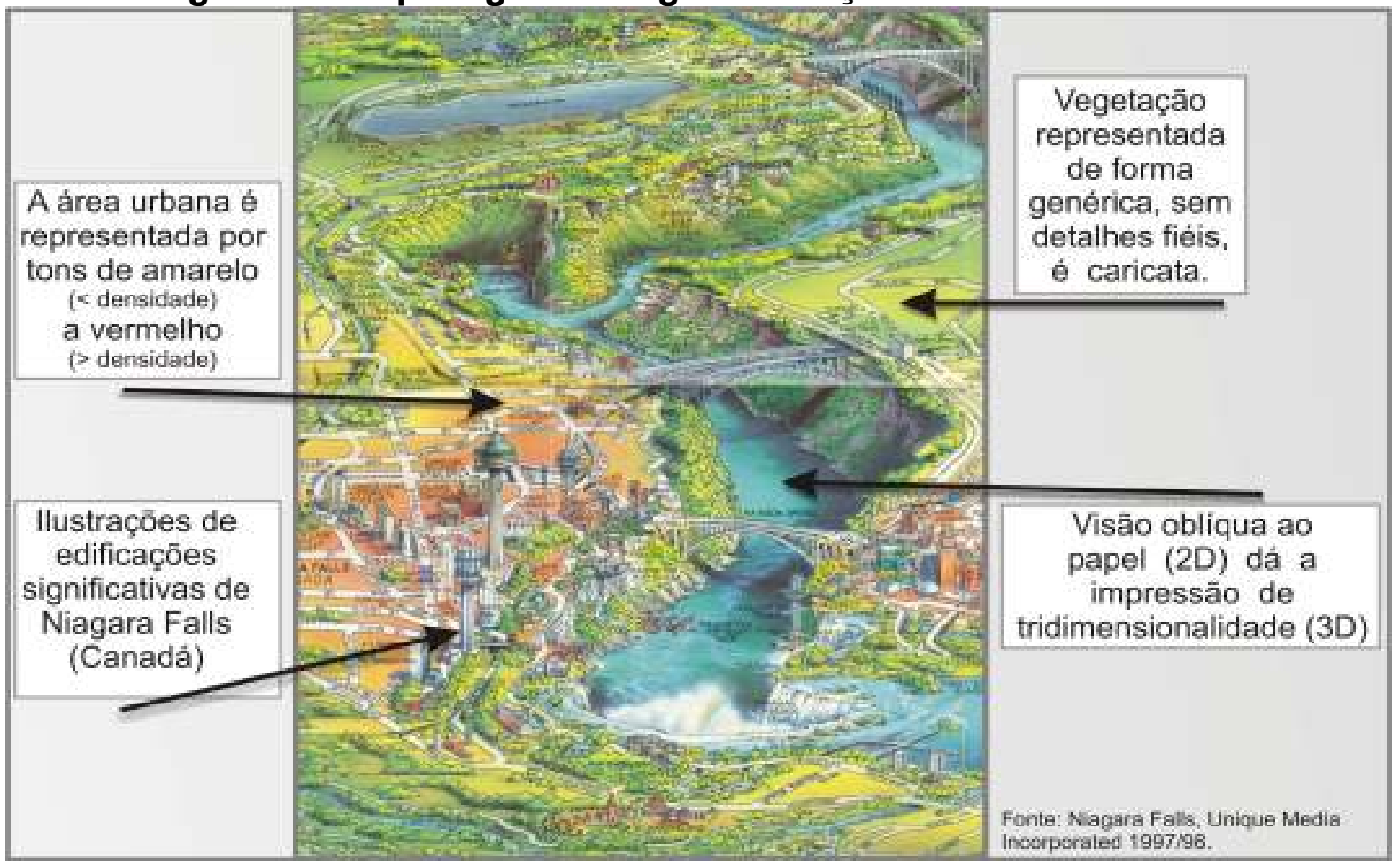




\section{4 - 0 símbolo}

A elaboração dos símbolos utiliza os mesmos fundamentos teóricos relatados no item 3.2 - base temática, ou seja, estão divididos em dois tipos: convencionais e pictóricos.

Os símbolos convencionais, também chamados de geométricos ou abstratos, caracterizam-se por círculos, quadrados, triângulos entre outras figuras, não conservando nenhuma relação com o elemento espacial representado.

Nos mapas temáticos turísticos convencionais, também é fundamental se representarem as vias de acesso (rodovias, ferrovias, ruas, trilhas, pontes) e a hidrografia (rios intermitentes e perenes). Esse é um tipo de simbologia de nível intermediário de abstração. Os símbolos são denominados de associativos (Gerber, Burden, Stanton, 1990) seminaturais (Oliveira, 1978:23) ou motivados (Forest e Castner, 1985).

Posto isso, os mapas convencionais tendem a uma simbologia voltada ao ver, à relação fisiológica da imagem. Mesmo assim, os mapas convencionais não estão livres de tradições, códigos e convenções estabelecidas a partir do tratamento gráfico da informação. Por exemplo, a cor: convencionou-se o verde para vegetação; o sépia para curvas de nível; o marrom para as maiores altitudes e o azul para hidrografia. Essa codificação resulta da cultura, ao empregar, no caso a cor, como uma metáfora natural, comum. Além disso, nos mapas com o grande uso de representações abstratas, a legenda é um elemento indispensável, mas o texto verbal também; logo, o usuário que desconhece aquela língua e sua escrita certamente terá problemas para decodificar as informações contidas no mapa.

Já os símbolos pictóricos exacerbam, em suas representações, os fatores tempo e cultura, porque as ilustrações sempre apresentam alguma semelhança física com o fenômeno representado. Como já foi visto anteriormente, é nesse instante que a arte e a cultura revelam uma importância preponderante, pois o ato da criação resulta de um conjunto de contextos mentais. Dessa forma, ao desenvolver os cinco mapas pictóricos (Ilhabela, Foz do Iguaçu, Caxambu, Manaus e São Raimundo Nonato), inúmeras figuras compõem, individualizam e ilustram os atrativos naturais (fauna, flora), culturais (arquitetura, artesanato) e alguns imateriais. Este último tipo de atrativo é bem mais complexo de ilustrar, pois, na maior parte das vezes, a compreensão do símbolo ultrapassa as referências físicas, necessitando de um conhecimento além da paisagem (Figura 100). Existem, ainda, símbolos e ilustrações que representam ações mais comuns, como personagens fazendo compras, praticando algum tipo de esporte ou serviço.

Registra-se aqui o cuidado que se deve ter quanto à concepção de ilustrações e imagens que, de apelo duvidoso, "venderiam" a destinação a qualquer preço. 
Figura 100 - llustrações dos atrativos

naturais, culturais e de ação nos mapas

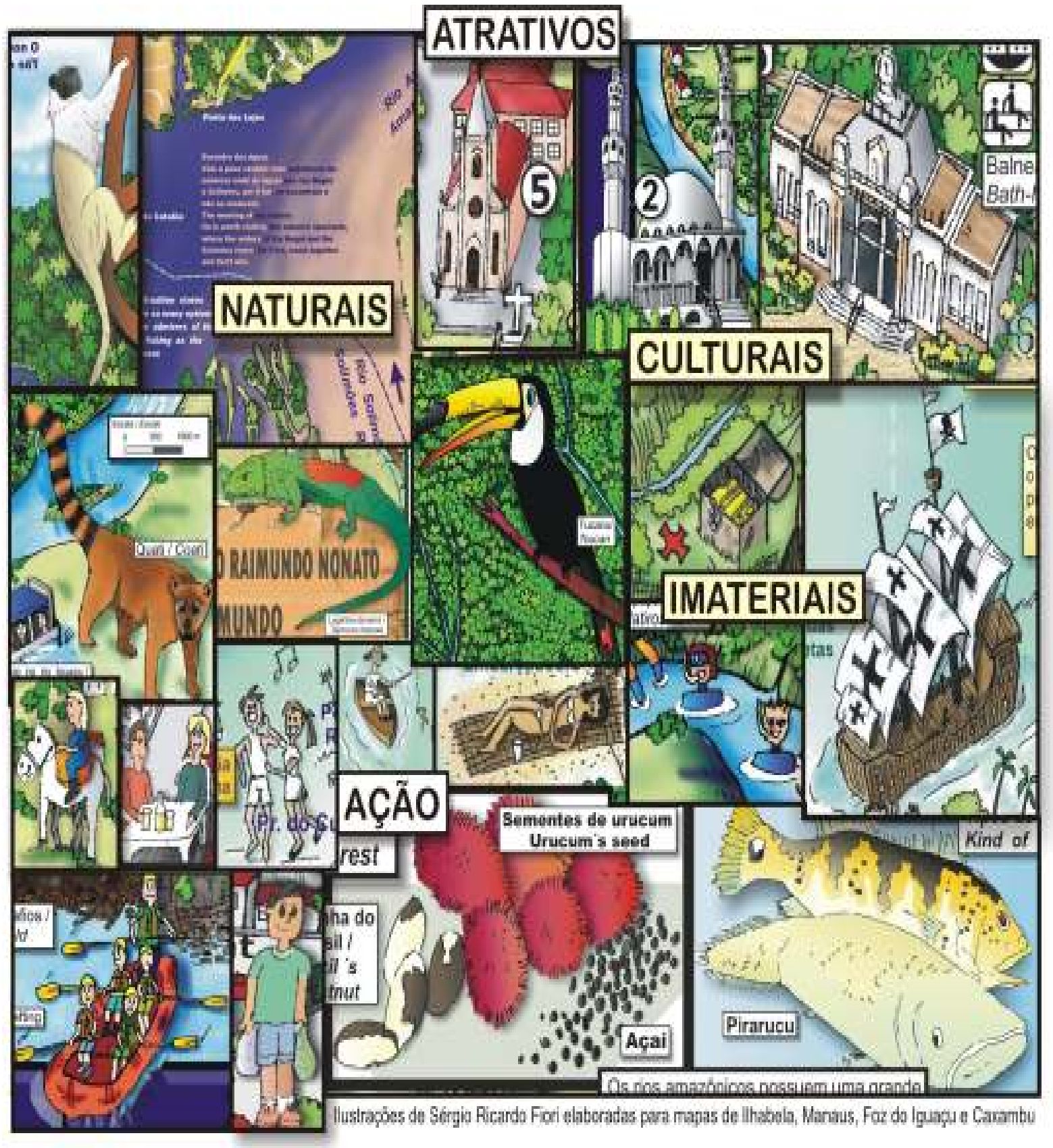

\section{5 - 0 texto}

O texto é um recurso fundamental a qualquer mapa. No caso particular dos turísticos convencionais e pictóricos, serve para compor o título, as caixas informativas - serviços, história, curiosidades - os nomes de praias, das serras, dos bairros, das ruas, dos rios, etc. Também é o elo entre a representação gráfica e a legenda - texto verbal. A harmonia estética e funcional entre os vários elementos gráficos e os textos possibilita composições com fontes de estilos e tamanhos diferentes, resultado de o que e como se quer informar (Figura 101). 
Figura 101 - Direcionamento da informação: ilustração e complemento texto

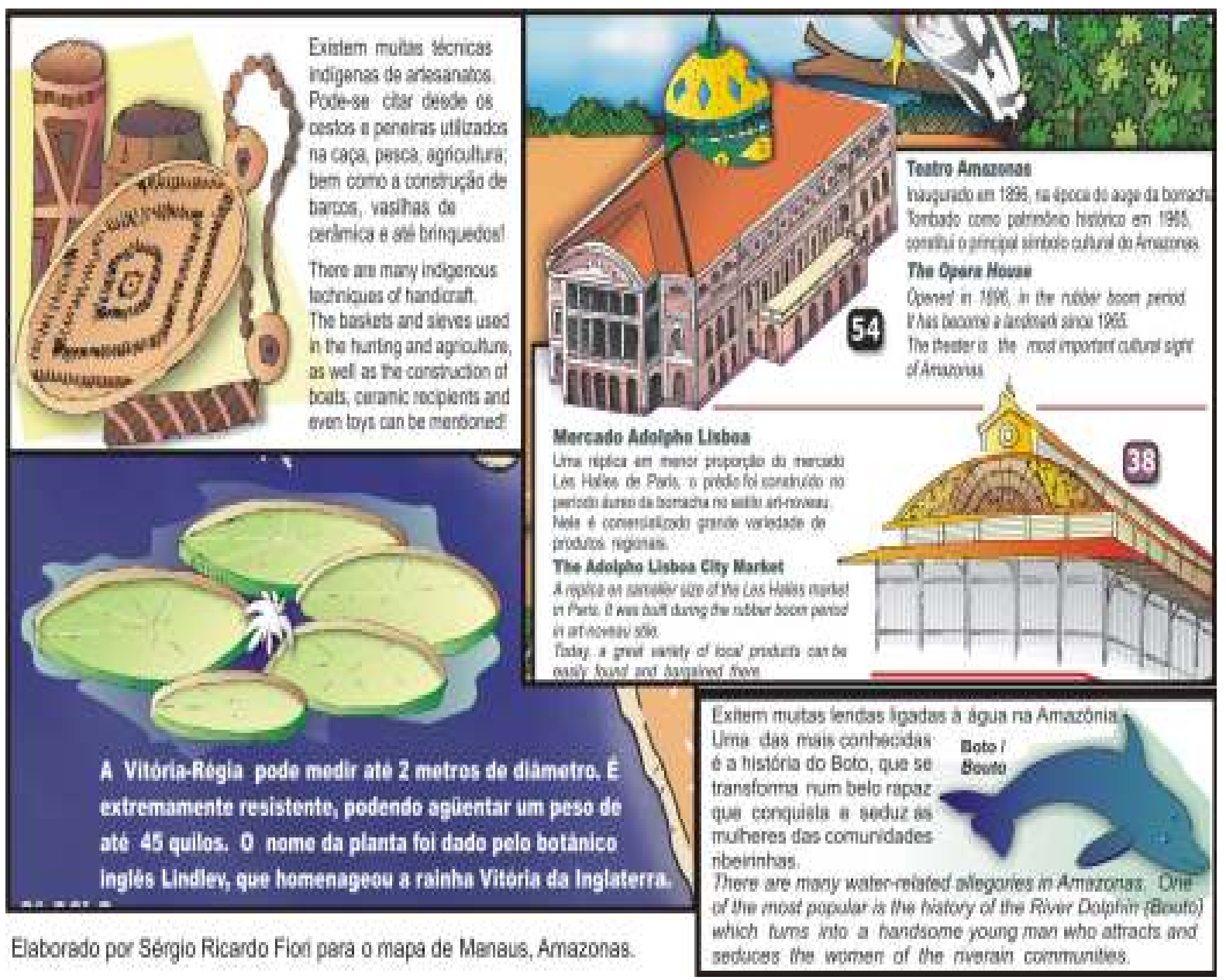

\section{6 - A legenda}

A legenda faz parte do processo de leitura, decodificação e compreensão do mapa. O maior ou menor uso desse recurso está intrinsecamente ligado à escolha do tipo de representação gráfica, pois, como visto no item 3.4, os mapas que contêm símbolos abstratos se caracterizam pela não referência ou semelhança com a informação que representam, pressupondo, assim, um uso maior da legenda.

O mapa turístico divide a legenda em dois tipos: geral, caracterizado por elementos usualmente encontrados em qualquer mapa como, por exemplo, o símbolo de capital, cidade, rodovia pavimentada ou sem pavimentação, hidrografia, limites municipal, estadual e federal entre outros do mesmo gênero. E a legenda turística, com símbolos relacionados à acomodação, alimentação, hospedagem, serviços, atrativos naturais e culturais, entretenimento, práticas desportivas, recreação e transporte (Figura 102).

Aliás, esta pesquisa continua o estudo de Fiori (2003), que propõe a elaboração de uma legenda para mapas turísticos, utilizando-se dos Símbolos de Informação Pública (SIPs). A escolha dos símbolos empregados nas legendas dos dez mapas desenvolvidos ao longo deste trabalho seguiu alguns critérios: 
102 - A legenda geral e turística

\begin{tabular}{|c|c|c|c|c|c|c|}
\hline$\bullet$ & $\begin{array}{l}\text { CAPITAL } t \\
\text { CAPITAL }\end{array}$ & 冓 & $\begin{array}{l}\text { Rodovia Federal I } \\
\text { Federal Highwway }\end{array}$ & Atrotivos Turisticase Ent & Eeterimento / Touristi & is Altractime and Estertainment \\
\hline & Cidade / City & $=0$ & Rodovia Estadual ? & mavestien: & vaver to & oonsen \\
\hline & Área urbana I & & State & 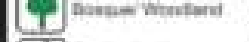 & Whesent & betions? \\
\hline & Urban area & & $\begin{array}{l}\text { Filo perene ' } \\
\text { Foremnial river }\end{array}$ & 8. 1 counoen: & Anens? & 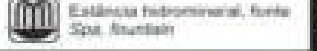 \\
\hline & $\begin{array}{l}\text { Rodovia I } \\
\text { Highwway }\end{array}$ & & $\begin{array}{l}\text { Flo intermitante } \\
\text { intermittent river }\end{array}$ & Servico / Servic & & \\
\hline & & & Represa / Dam & 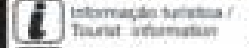 & 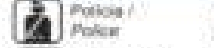 & 晋 \\
\hline & $\begin{array}{l}\text { pavimentachoo I } \\
\text { Street, Dirt land }\end{array}$ & & & 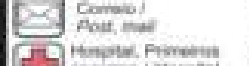 & Anacusis & 15) Duchas \\
\hline & $\begin{array}{l}\text { Caminho, tritha / } \\
\text { Way, path }\end{array}$ & & $\begin{array}{l}\text { apivara Mountain } \\
\text { ational Park }\end{array}$ & 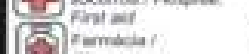 & & 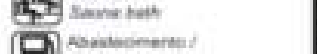 \\
\hline & Aeroporto / Airport & & Eloumdaries & 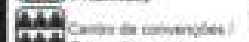 & thic: & \\
\hline & Limite de estado I & & $\begin{array}{l}\text { Satilios arqueológicos I } \\
\text { Archapological sites }\end{array}$ & Transporte/ Trans & art & Herane inatr \\
\hline & Informaçato turistic & & Information & (7) napoum 9 & $\Leftrightarrow$ & 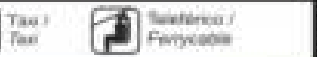 \\
\hline
\end{tabular}

$\checkmark$ Utilizar os SIPs que já aparecem usualmente em mapas nacionais e internacionais, guias turísticos como, por exemplo, o guia Quatro Rodas ou em padronizações (AIGA, ERCO, EMBRATUR); por apresentarem uma generalização pictográfica já estabelecida na sociedade, o que facilitaria a descoberta do significado, permitindo, ao turista, uma maior familiaridade com os símbolos.

$\checkmark$ Tomar como referência e utilizar alguns dos símbolos propostos em uma pesquisa realizada em 1987 e 1989 por Stanton (apud Gerber, Burgen \& Stanton,1990), que selecionou mapas turísticos da Austrália, Inglaterra, Suíça, Dinamarca, Nova Zelândia e Espanha. Depois disso, o autor desenvolveu uma série de SIPs, tendo como base um modelo australiano (AS 2342), que é equivalente ao modelo britânico (BS 6034) e ao da Organização Internacional (ISO 7001). Outra referência é o trabalho de Clarke (1989), que selecionou duas séries de símbolos comumente usados e disponíveis em mapas turísticos pertencentes às instituições da GrãBretanha ("Ordnance Survey") e dos Estados Unidos ("Estate Publications").

$\checkmark$ Havendo a necessidade de confeccionar um SIP, procurou-se elaborar uma representação gráfica que tendesse a concentrar um número pequeno de características gráficas da referência, simplificando ao máximo o código. A intenção é levar o usuário a recorrer à legenda somente para assimilar o novo ícone-símbolo, tornando-o tão natural quanto aqueles já usados pela mídia.

Durante o desenvolvimento dos mapas, foram elaborados alguns símbolos, como: rapel, pizzaria, jardim, confeitaria, vôos de trike, feira-mercado municipal, espaço cultural.

Proporcionar à identificação dos símbolos de uma maneira rápida e direta é muito importante; logo, é preciso que eles estejam emoldurados em um fundo chapado 
na cor branca. O intuito é permitir um destaque dos símbolos em relação ao fundo do mapa, tornando-os visualmente mais claros. A moldura deve ter o tamanho adequado para possibilitar que as figuras sejam facilmente identificadas.

Observa-se que os mapas convencionais tendem a ter um número maior de símbolos em suas legendas do que os mapas pictóricos. Quando isso não acontece, é porque o produtor do mapa opta por trabalhar a redundância, ou seja, representa a mesma informação mais de uma vez (Figura 103 A). As duas situações podem ser notadas em oito dos dez mapas produzidos, pois, naqueles de Ilhabela e Foz do Iguaçu, há uma redução do número de símbolos na legenda dos mapas pictóricos se comparado ao dos mapas convencionais. Já nos de Manaus e São Raimundo Nonato, a legenda é a mesma nas duas versões do mesmo mapa.

Rever novamente a figura 103 A, que exemplifica o porquê da ocorrência de menos SIPs nas legendas dos mapas pictóricos - as ilustrações falam por si. Já a figura 103 B demonstra a maneira enfática e sedutora de uma informação contida na legenda.

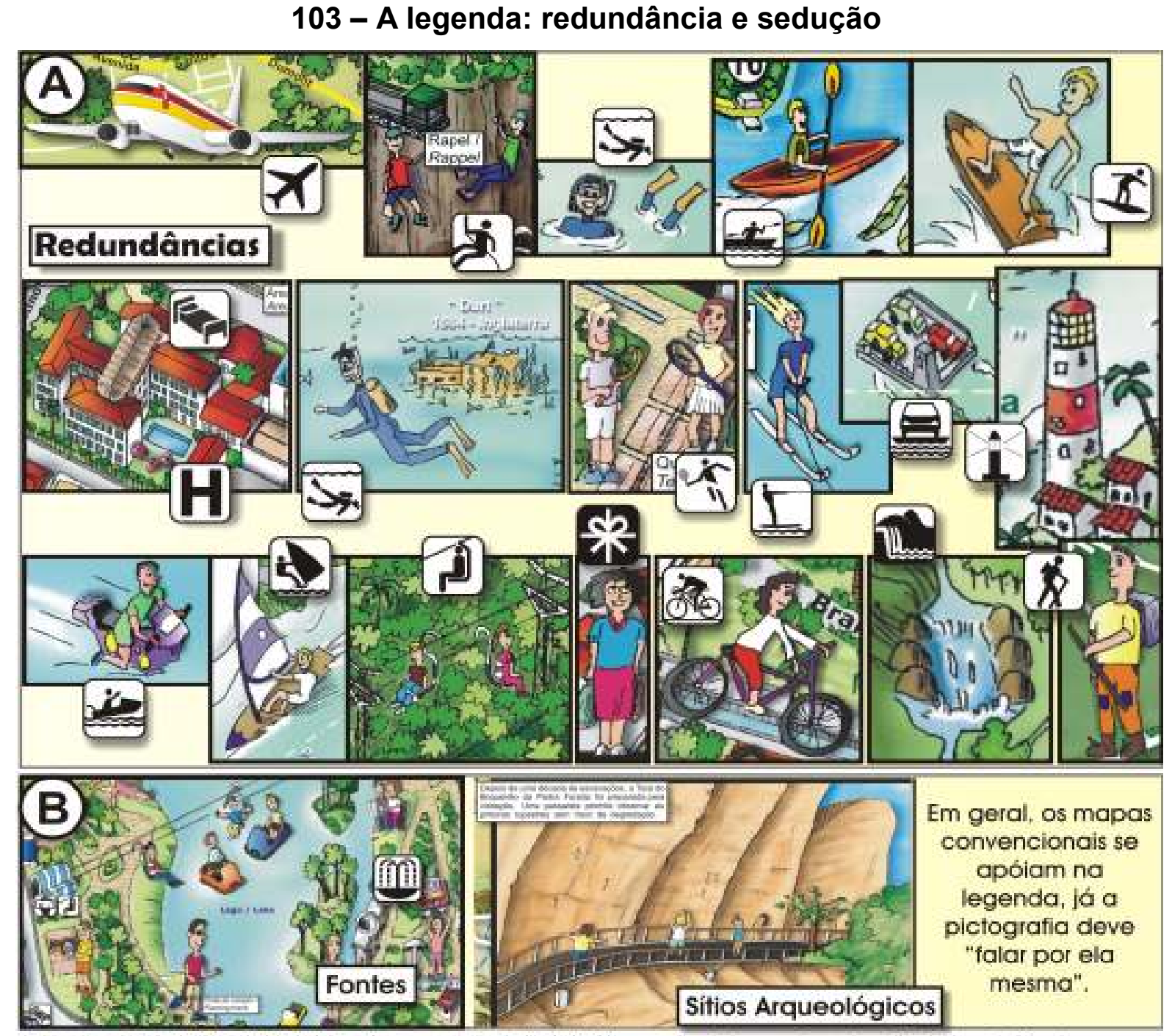

lilustraçọes de Sérgio Ricardo Fiori elaborados para mapas de llinabela, Manaus, Foz do lquaçu, Caxambu e São Raimundo Nonato 


\section{7 - A borda}

A borda em um mapa turístico serve para auxiliar o usuário que procura relacionar o item da legenda com sua localização no mapa. Por exemplo: como encontrar no mapa um hotel que se vê na legenda. Nesse caso, o simples e já usado processo de dividir a borda do mapa com letras e números resolve de maneira eficaz o problema (104 A).

Nos mapas pictóricos, as bordas recebem uma personalização, pois "encarna" algum tema referente à destinação turística (Figura 104 B). A idéia de confeccionar esse tipo de borda faz referência aos mapas do século XVII, quando os profissionais ilustravam as bordas das legendas com animais e produtos típicos da localidade mapeada.

Figura 104 - Bordas ilustradas

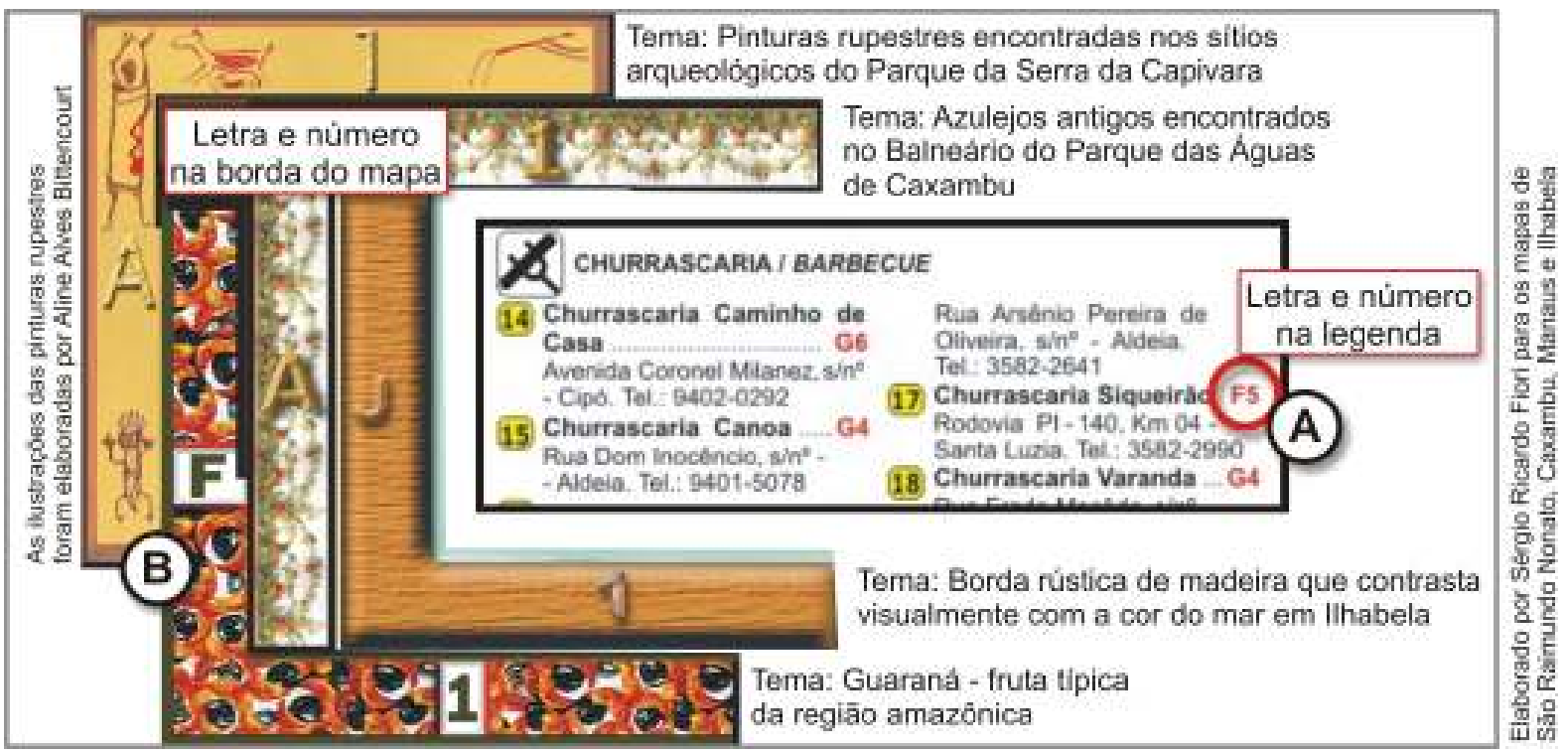

\section{8 - 0 processo de confecção dos mapas}

Inicialmente é necessário que todos os mapas recolhidos estejam em formato digital. Na maioria das vezes, a ação seguinte é unir e compor os vários mapas para que ocorra a atualização e eles fiquem adequados ao tamanho de folha A1 $(584 \times 841 \mathrm{~mm})$. A partir de então, tem-se a base cartográfica para o desenvolvimento dos mapas turísticos convencionais e pictóricos. As duas versões representativas da mesma localidade passam por um processo de confecção diferente:

Os mapas convencionais - transporta-se a base ao programa CorelDRAW, onde se realiza todo o processo de digitalização e diagramação das linhas, polígonos e manchas e textos dos vários elementos espaciais como, por exemplo, a indicação de área urbana ou rural, a hidrografia, a topografia, a rede viária, os diversos 
símbolos, etc. Cada elemento é ordenado em layers (camadas) - Figura 105. No caso específico da morfologia do terreno, levando em consideração a heterogeneidade do público alvo, opta-se por reduzir a quantidade do número de curvas de nível encontradas na base cartográfica. Utiliza-se uma seqüência monocromática de cor (verde) para obter uma impressão visual de altitude. Um símbolo geométrico (triângulo) marca os pontos mais altos (picos) da topografia.

Figura 105 - Os layers dos mapas

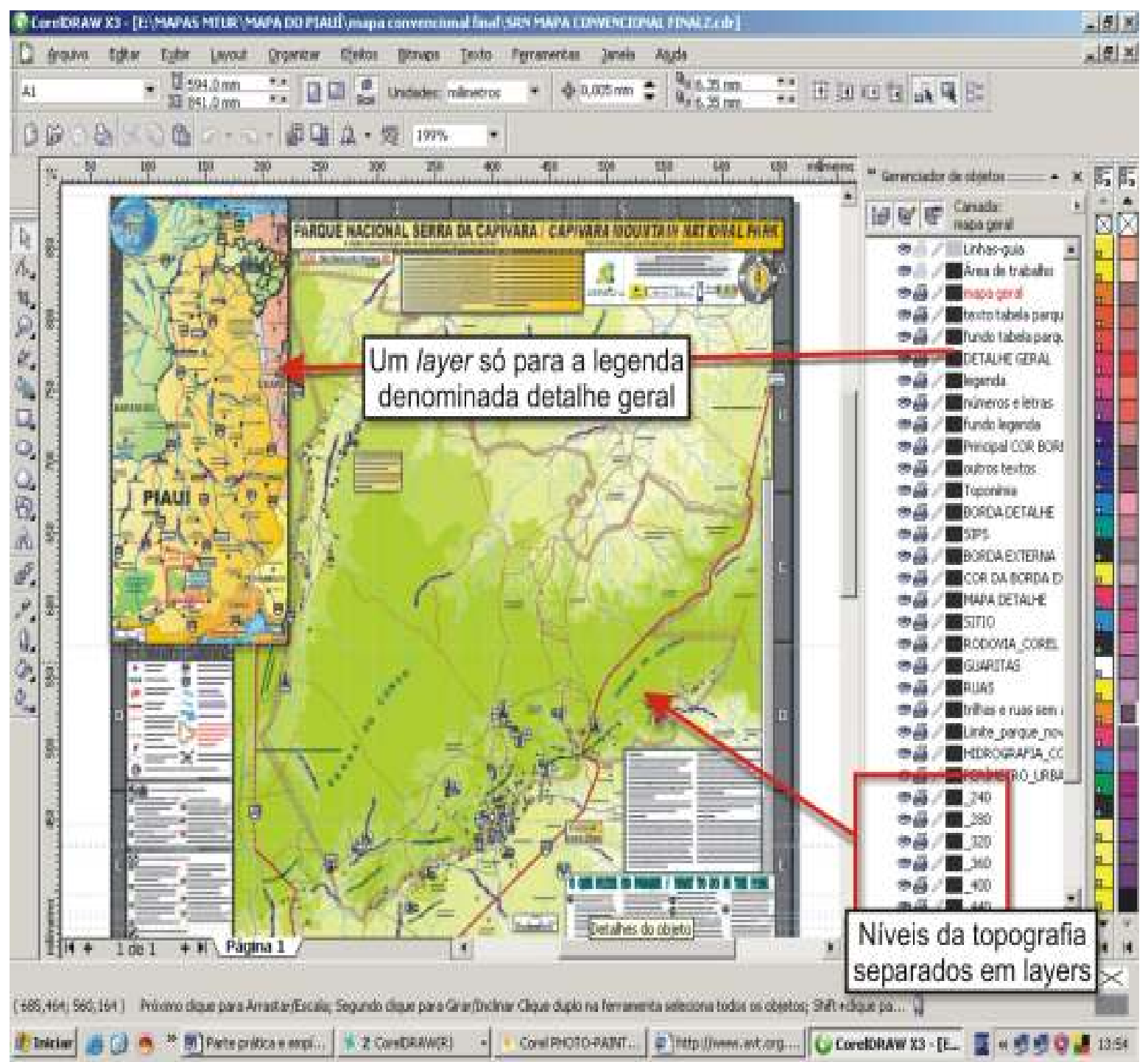

- Os mapas pictóricos - partem da base cartográfica (unida e atualizada) do mapa convencional, contudo, é necessário imprimi-la. Posteriormente, utiliza-se um papel vegetal para copiar linhas e áreas do mapa que servem de apoio ao processo ilustrativo (Figura $106 \mathrm{~A}$ ). Neste momento, pode-se escolher ou não copiar, no papel vegetal, elementos como o arruamento, a rodovia, a hidrografia, etc. Por exemplo, nos mapas pictóricos de llhabela e Caxambu, o arruamento foi copiado e transferido para o papel vegetal; já nos mapas de Manaus e São Raimundo Nonato, utilizam-se as bases digitalizadas do mapa convencional. 
Em seguida, transportam-se as informações coletadas no papel vegetal para uma folha de papel branca (preferencialmente verge ou canson). A confecção da base ilustrada apóia-se nas referências (linhas) transferidas, sendo que a ilustração é realizada a partir da técnica da visão oblíqua, que proporciona um aspecto de perspectiva ao desenho (Figura $106 \mathrm{~B}$ ).

É Importante ressaltar que, mesmo utilizando a visão oblíqua para a confecção dos mapas pictóricos, estes foram concebidos sobre uma base cartográfica em escala, o que possibilitou a inserção do sistema de referências geográficas (latitude, longitude e pontos cardeais).

Todo o processo de confecção nesta parte do trabalho é feito manualmente. $O$ desenho é concluído ao se passar a caneta nanquim sobre as linhas em grafite.

A próxima etapa é a digitalização da base ilustrada e seu transporte ao Adobe Photoshop. Parte-se então para o processo de colorização digital por meio da técnica da luz e sombra, o que possibilita o suposto volume; a tridimensionalidade. No programa, é realizado todo o processo de colorização, utilizando principalmente o recurso da ferramenta aerógrafo (Figura 106 C).

No final do processo de confecção, transporta-se o mapa ao CorelDRAW para sejam acrescidas as legendas, os mapas-detalhe e os textos. No mesmo programa, elaboraram-se ilustrações em outro layer, disposto acima do mapa-base. É o caso, por exemplo, das atividades esportivas, do imaginário local (lendas), curiosidades, construções históricas, etc (Figura 106 D). As ilustrações mais significativas dos mapas desenvolvidos são o centro de Ilhabela, a trilha das Cataratas em Foz do Iguaçu, o Parque das Águas de Caxambu, o centro de Manaus e a Toca do Boqueirão da Pedra Furada no Parque da Serra da Capivara.

- A legenda - grande parte dos símbolos de informação pública foi recolhida da Internet - ERCO, AIGA e GUIA BRASILEIRO DE SINALIZAÇÃO TURÍSTICA. A outra parte foi retirada e digitalizada do Guia Quatro Rodas, da apostila do Curso de Formação de Condutores (Bruns, 2000) e de vários mapas recolhidos e analisados ao longo da pesquisa (ver tabelas 2 a 8 ).

Os símbolos escolhidos para compor os mapas passaram por um processo de uniformização visual por meio do programa CoreIDRAW - Figura 107. 
Figura 106 - Seqüência de confecção da base ilustrada
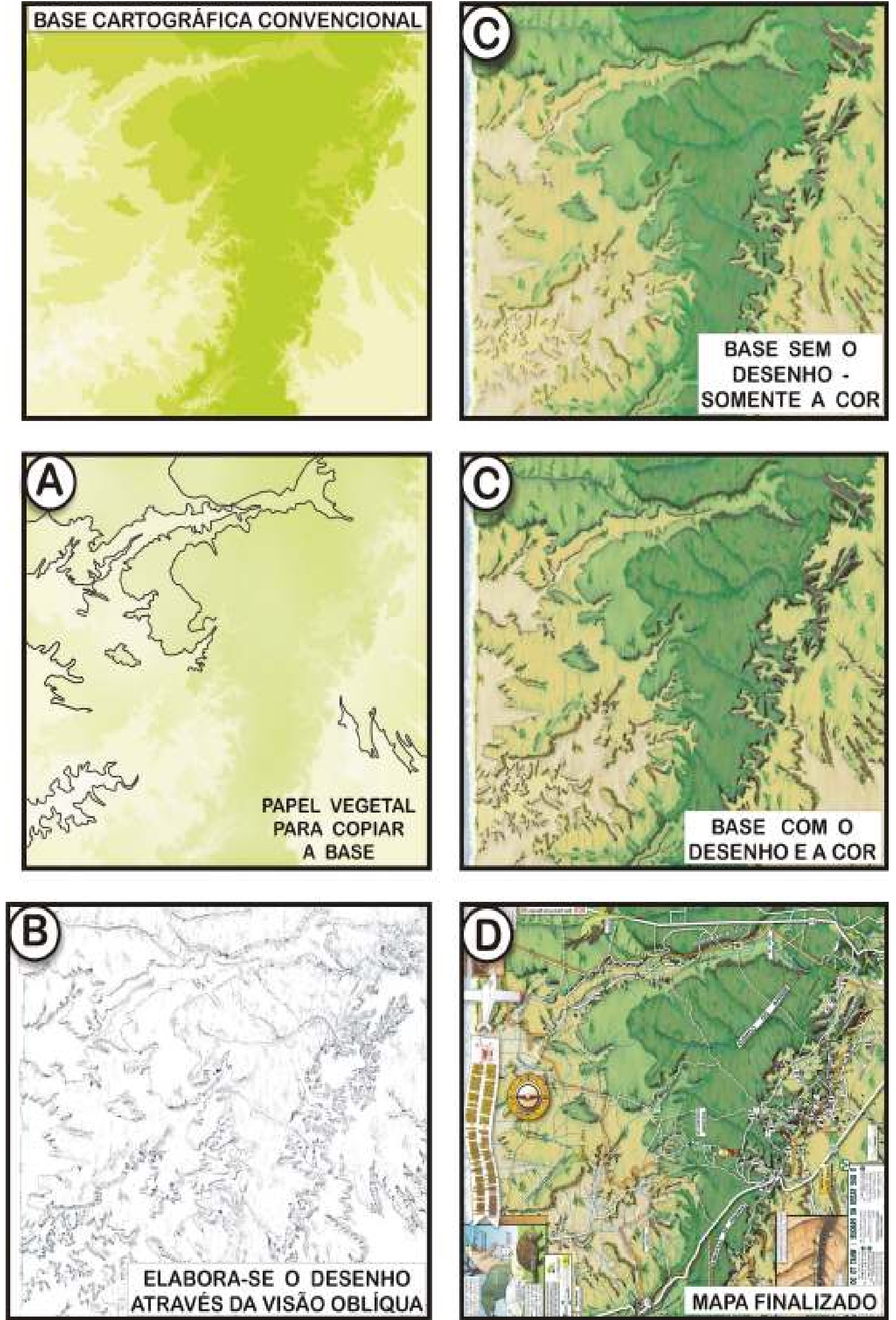
Figura 107 - Readequação gráfica e digitalização dos SIPs

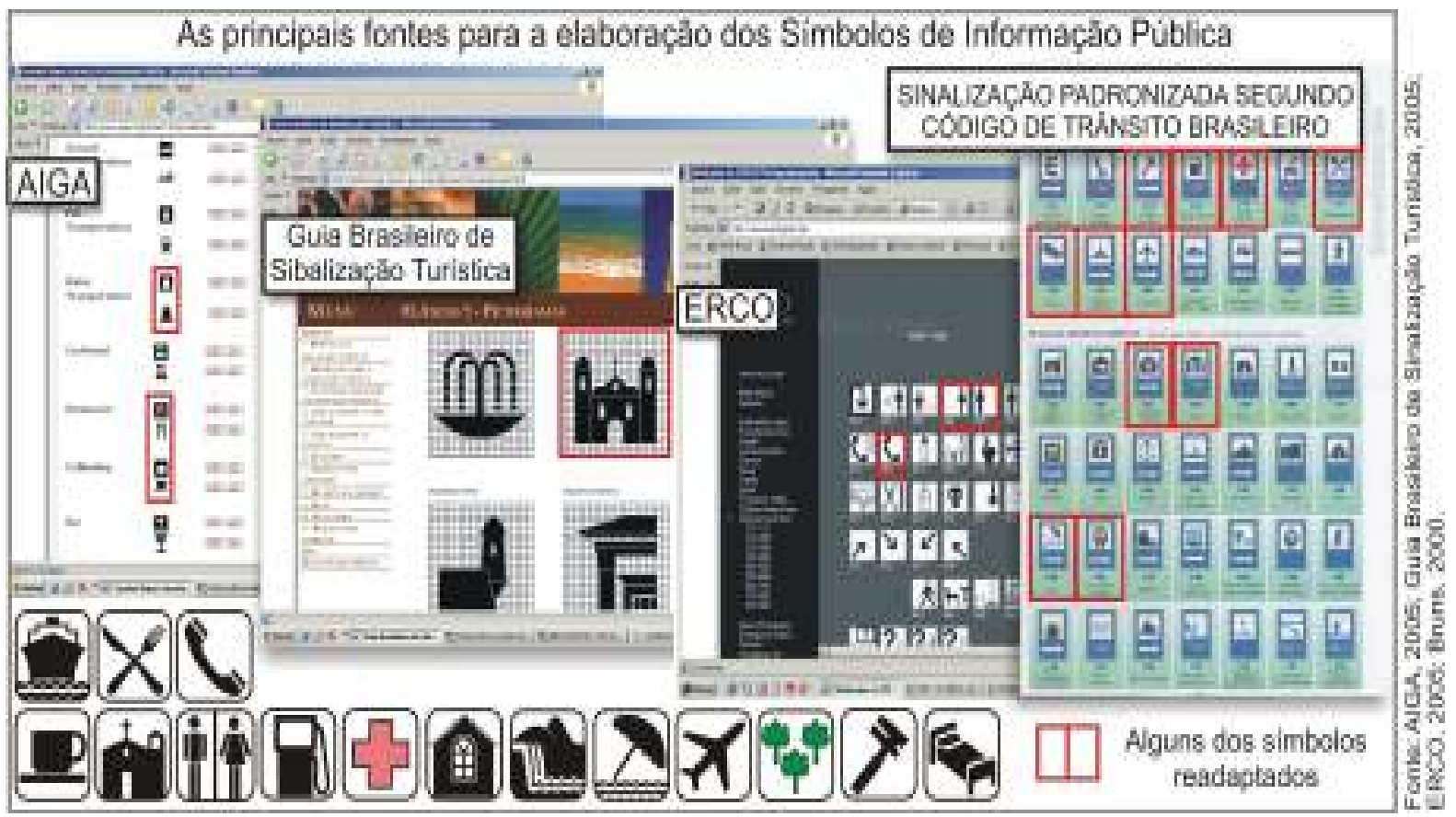

\section{$4^{\circ}$ passo: a elaboração do protótipo mapa-site turístico de Caxambu}

Após a confecção dos mapas turísticos de llhabela (SP), Foz do Iguaçu (PR), Caxambu (MG), Manaus (AM) e São Raimundo Nonato (PI): cinco convencionais e cinco pictóricos (ver mapas em CD - anexos - pasta 3), Caxambu foi selecionada para o desenvolvimento de um protótipo para um mapa-site turístico. A escolha se deve ao processo de elaboração dos dez mapas turísticos, ou seja, se comparado às outras cidades, Caxambu dispõe de uma maior quantidade de mapas convencionais e pictóricos e, ainda, escalas mais diversificadas, divididas em:

- Escala menor - globo terrestre focando a América do Sul, mapa da região Sudeste com destaque ao sul de Minas Gerai, e o mapa da Estrada Real.

- Escala intermediária - mapa do Circuito das Águas e do município de Caxambu.

- Escala maior - mapa do Parque das Águas.

O site foi confeccionado no programa Dreamweaver, sendo disponibilizado em dois idiomas: português e inglês. Compõe-se de quatro etapas em zoom estático com escalas gráficas pré-estabelecidas em imagem raster. As informações da legenda mudam, dependendo do mapa-zoom escolhido. Os mapas também oferecem ao usuário o recurso pan (Figura 108). 
Figura 108 - As quatro etapas de zoom do protótipo mapa-site de Caxambu

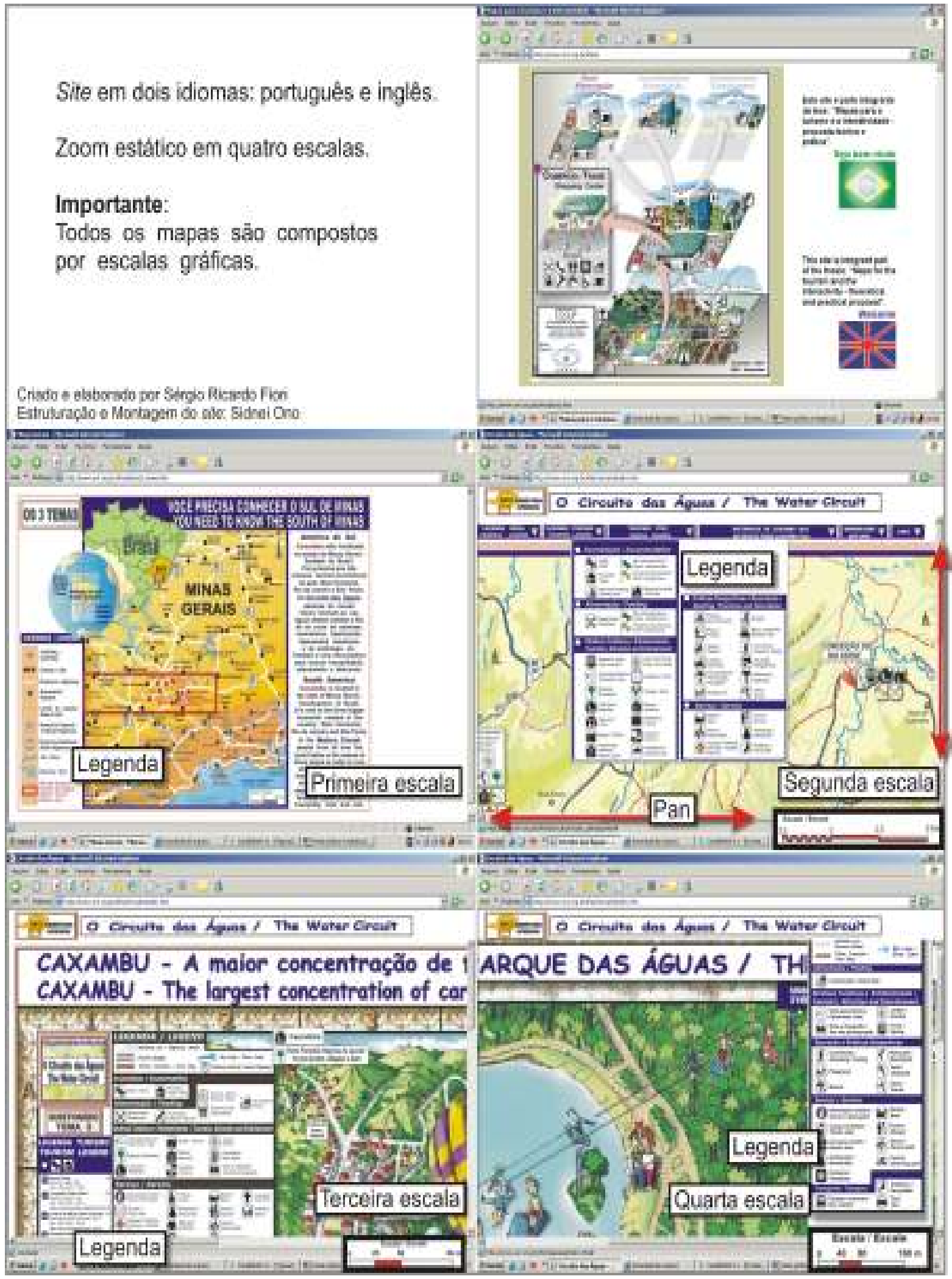

A interatividade do site aconteceu nos vários tipos de caixas de texto e botões que, ao serem clicados, abrem legendas, proporcionam informações direcionadas (entrar, ir até, voltar), apresentam alguns atrativos como as igrejas, o centro 
comercial de artesanato e o lago. Já os textos relatam sobre a história, a arquitetura, as fontes, horários de funcionamento do balneário e do Parque das Águas, curiosidades, etc. No mapa do Circuito das Águas, ainda se disponibilizam links para outros sites que se reportam a Caxambu e ao Circuito (Figura 109).

Figura 109 - Exemplos de elementos interativos do protótipo mapa-site de Caxambu

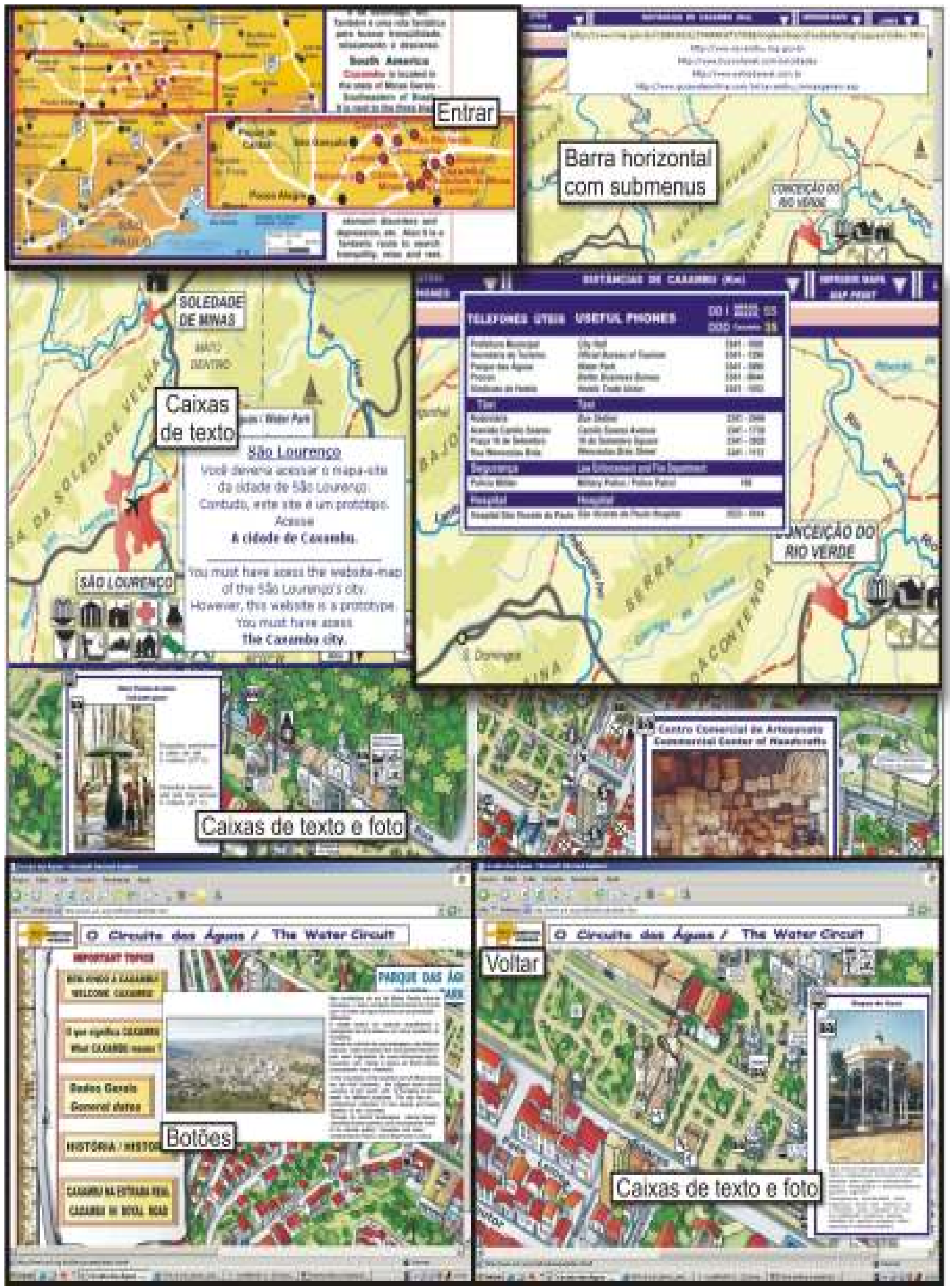




\section{CAPÍTULO 3}

Avaliação e análise dos mapas, dos símbolos de informação pública e do protótipo mapa-site turístico de Caxambu 


\section{1 - Desenvolvimento do estudo empírico}

Vários pesquisadores relacionados à produção cartográfica atestam que, durante a elaboração de um mapa, o qual comunica os inúmeros elementos materiais e imateriais contidos no espaço, é desencadeada uma problemática da informação, inicialmente representada / codificada para posteriormente ser lida / decodificada.

Portanto, a relação entre produtor e o receptor deve estar sempre harmonizada. Para que isto ocorra, deve-se respeitar uma regra básica da linguagem cartográfica: é imprescindível que o código construído pelo produtor seja captado de maneira plena pelo receptor, pois só desta maneira haverá a correta transmissão da informação e, conseqüentemente, a verdadeira comunicação.

A linguagem específica da cartografia é a linguagem gráfica e, com o auxilio de métodos próprios para a representação, se chega ao mapa, que terá a função de fazer o leitor retornar à realidade no seu sentido mais amplo. Assim, quanto melhor for representado o mapa e quanto mais adequado à clientela a que se destina, melhor será a visão do leitor sobre a realidade representada (Simielli, 1996).

Fica evidente, nesse sistema de informação visual, que, além da confecção de um mapa correto, segundo as tradições, normas e padrões cartográficos, deve-se satisfazer as expectativas do usuário potencial em relação ao material proposto.

E é por isso que esta pesquisa, fundamentada em Fiori (2003), apresenta uma dualidade crítica quanto a dois tipos distintos de mapas para o setor do turismo: o convencional e o pictórico, por proporcionarem graus diferentes de abstração e formas distintas de representar a informação. Portanto, três tópicos são averiguados:

1) Eficácia: identificar que tipo de mapa é mais eficaz para comunicar a informação representada.

2) Estética: qual dos mapas tem um maior grau de empatia - emotiva, sedutora - e atração quando expostos aos turistas.

3) Inteligibilidade: ao se propor a adaptação dos símbolos de informação pública em legendas de mapas temáticos para o setor do turismo, verifica-se quais símbolos possuem uma maior facilidade de leitura pelo usuário. Ressalta-se que os SIPs são elaborados para serem compreendidos sem a necessidade do ensino formal.

Os procedimentos e cuidados tomados até o momento em relação a um embasamento teórico, e posterior desenvolvimento prático - a elaboração dos mapas (convencionais e pictóricos) e do site - são discutidos e avaliados neste capítulo. 
A elaboração das questões empíricas leva em consideração o conceito de paisagem, ou seja, os mapas se pautam por uma realidade material, pela extensão de espaço que é vista, recortada, pictórica, oferecida ao olhar. Conseqüentemente, ao se pensar na elaboração dos mapas turísticos, o interesse está na visão do estrangeiro, que é aquele que interpreta superficialmente e esteticamente o que vê, dando significado ao mundo externo. Assim, os mapas são feitos para aquele indivíduo que não mora na cidade representada e que precisa ser atraído, motivado a querer conhecê-la, saber mais sobre a ela, para que, a partir daí, quem sabe, tenha vontade de visitá-la e indicá-la a outras pessoas.

Lowenthal (1985) afirma que cada indivíduo percebe diferencialmente a paisagem. Essa diferenciação se dá devido a fatores culturais, condições sócioeconômicas, crenças, sexo e idade. Além disso, ele aponta mais um item fundamental, pois o nativo do lugar adquire e assimila informações de forma diferente daquela pessoa que está em trânsito - aquele que viaja, o turista.

Gerber, Burgen \& Stanton (1990) identificam oito aspectos que atuam sobre as pessoas quando adquirem informação cartográfica: a habilidade espacial, a percepção espacial, a habilidade de leitura, a idade, a habilidade para desenhar, a experiência prévia quanto ao uso dos mapas, a atitude (pessoas que gostam de observar mapas) e a disponibilidade de mapas em casa ao decorrer da vida, ou seja, o mapa não é visto como um objeto estranho. A apreensão dessas características determinará o maior ou menor grau de abstração dos símbolos pelo usuário.

Somam-se ainda as preocupações sobre os problemas referentes à elaboração do site:

$\checkmark$ A diagramação e a facilidade de navegação.

$\checkmark$ A funcionalidade dos recursos zoom e pan, possibilitando vários ângulos e enfoques de uma mesma localidade.

$\checkmark$ A arte, o conteúdo e a motivação.

$\checkmark$ A objetividade, riqueza e não poluição visual do mapa possibilitada pelo recurso do pop up.

$\checkmark$ O tempo de download.

Enfim, a etapa empírica volta-se à dimensão pragmática, devendo se preocupar com o usuário-turista que, em geral, é o indivíduo caracterizado por ter pouco ou nenhum conhecimento cartográfico.

Em relação ao acesso / navegação do protótipo mapa-site turístico, o usuário necessita de um conhecimento mínimo do ambiente Windows e da Internet. Esse contexto é formado por um grupo de indivíduos com perfis muito heterogêneos, 
devido às diferentes idades, ao grau de escolaridade, à maior ou menor facilidade de abstração, à diversidade sócio-econômico-cultural, entre outros aspectos.

Devido a todos esses fatores, costuma-se estabelecer apenas uma idade mínima para a aplicação dos questionários: as pessoas deveriam ter uma idade acima dos quinze anos. Sem entrar no mérito da discussão, a escolha da idade mínima é apoiada em Cavalcanti (1996). Segundo o estudioso, somente aos onze, doze anos um indivíduo, uma pessoa é capaz de realizar abstrações que vão além dos significados ligados a suas práticas imediatas. Contudo, o autor ressalta ainda que essa competência não se consegue simplesmente pela idade: é preciso levar em conta a experiência do usuário. Isso quer dizer que, se o ambiente no qual o adolescente vive não oferece desafios e tarefas necessárias para estimular seu intelecto, seu raciocínio poderá não alcançar o nível adequado para sua faixa etária.

\section{2 - O material cartográfico em avaliação}

A pesquisa empírica conta com os seguintes produtos desenvolvidos para análise:

a) Um mapa convencional e um mapa turístico de Ilhabela, município do estado de São Paulo.

b) Um mapa convencional e um mapa turístico de Foz do Iguaçu, município do estado do Paraná.

c) Um mapa convencional e um mapa turístico da cidade de Caxambu, município do estado de Minas Gerais.

d) Um mapa convencional e um mapa turístico de Manaus, capital do estado do Amazonas.

e) Um mapa convencional e um mapa turístico de São Raimundo Nonato, município do estado do Piauí.

f) Um protótipo de um mapa-site turístico do município de Caxambu.

g) Uma relação de oitenta e dois símbolos de informação pública adaptados para a legenda de mapas turísticos.

A aplicação dos questionários ocorreu de duas maneiras:

$\checkmark$ O questionário in loco, referente aos oitenta e dois símbolos de informação pública, passou por um pré-teste em outubro de 2005. A aplicação efetiva ocorreu entre os meses de fevereiro de 2006 e setembro de 2007. 
$\checkmark$ Os questionários via Internet - site - dividem-se em três temas:

$\left.1^{\circ}\right)$ Duas maneiras de elaborar o mapa turístico.

$2^{\circ}$ ) Os oitenta e dois símbolos de informação pública.

$\left.3^{\circ}\right)$ Protótipo para um mapa-site turístico.

Os questionários não passaram por pré-testes. A aplicação ocorreu entre os meses de setembro e outubro de 2007.

\subsection{1 - Procedimentos}

\section{População}

Destaca-se o público pesquisado em dois grandes grupos:

- Os participantes das qualificações do Projeto Caminhos do Futuro ${ }^{68}$, divididos em professores do ensino fundamental e médio da rede pública e profissionais das secretarias da educação e turismo.

- Qualquer pessoa que tivesse tido acesso ao questionário do site da pesquisa (que se está em dois idiomas: português e inglês) no endereço: www. avt.org.br/sfiori.

A única ressalva quanto à aceitação do questionário preenchido esteve relacionada à idade do sujeito, que deveria ter, no mínimo, 15 anos, isto é, deveria ter nascido em 1992.

\section{Sujeitos}

Os sujeitos que responderam os questionários apresentam características muito heterogêneas. Discrimina-se, na tabela abaixo, somente o local de origem, a idade, o grau de escolaridade e a profissão - ver as tabelas 9 e 10.

68 O projeto Caminhos do Futuro é uma parceria do Ministério do Turismo com o Instituto de Academias Profissionalizantes (IAP), a Academia de Viagens e Turismo (AVT) e o Núcleo de Turismo da Universidade de São Paulo (USP). Essa parceria resultou em qualificações em 16 estados brasileiros, nos principais temas ligados ao turismo (Caminhos do Futuro, 2007). 
Tabela 9 - Discriminação dos sujeitos que responderam o questionário in loco segundo a idade, o grau de escolaridade e a profissão

\begin{tabular}{|c|c|c|c|c|c|c|c|}
\hline \multirow{2}{*}{ ESTADO } & \multicolumn{5}{|c|}{ Idade } & \multirow{2}{*}{$\begin{array}{l}\text { Escola- } \\
\text { ridade }\end{array}$} & \multirow{2}{*}{ Profissão } \\
\hline & $20-30$ & $31-40$ & $41-50$ & $>50$ & $\begin{array}{c}\text { Total } \\
\text { Sujeitos }\end{array}$ & & \\
\hline 1- ALAGOAS & 9 & 16 & 14 & 4 & 43 & \multirow{15}{*}{ Superior } & \multirow{15}{*}{$\begin{array}{c}\text { Professores } \\
\text { de escolas } \\
\text { públicas do } \\
\text { ensino } \\
\text { fundamental } \\
\text { e médio. } \\
\text { Outros } \\
\text { profissionais } \\
\text { ligados às } \\
\text { secretarias } \\
\text { da educação } \\
\text { e do turismo. }\end{array}$} \\
\hline 2- AMAZONAS & 6 & 9 & 18 & 12 & 45 & & \\
\hline 3- BAHIA & 4 & 16 & 14 & 6 & 40 & & \\
\hline 4- CEARÁ & 14 & 21 & 11 & 7 & 53 & & \\
\hline 5- DISTRITO FEDERAL & 5 & 15 & 6 & 8 & 34 & & \\
\hline 6- ESPÍRITO SANTO & 12 & 15 & 12 & 4 & 43 & & \\
\hline 7- GOIÁS & 6 & 22 & 8 & 10 & 46 & & \\
\hline 8- MARANHÃO & 20 & 18 & 8 & 2 & 48 & & \\
\hline 9- PERNAMBUCO & 13 & 10 & 13 & 8 & 44 & & \\
\hline 10- PIAUÍ & 11 & 15 & 16 & 10 & 52 & & \\
\hline 11- RIO GRANDE DO SUL & 8 & 8 & 15 & 9 & 40 & & \\
\hline 12- SANTA CATARINA & 12 & 9 & 13 & 6 & 40 & & \\
\hline 13- SERGIPE & 4 & 11 & 14 & 5 & 34 & & \\
\hline 14- TOCANTINS & 9 & 19 & 15 & 4 & 47 & & \\
\hline TOTAL GERAL & 133 & 204 & 177 & 95 & 609 & & \\
\hline
\end{tabular}

Municípios que participaram da pesquisa (in loco)

1- Maragogi (AL), Manaus (AM), Mata de São João (BA), Jijoca (CE), Brasília (DF), São Mateus (ES), Caldas Novas (GO), Barreinhas (MA), Cabo de Santo Agostinho $(\mathrm{PE})$, São Raimundo Nonato (PI), Pelotas (RS), Balneário de Camboriú (SC), Aracaju (SE) e Palmas (TO). 
Tabela 10 - Discriminação dos sujeitos que responderam o questionário pelo site segundo a idade, o grau de escolaridade e a profissão

\begin{tabular}{|c|c|c|c|c|c|c|c|c|c|c|c|}
\hline \multirow{2}{*}{\multicolumn{2}{|c|}{ PAís }} & \multicolumn{6}{|c|}{ Idade } & \multicolumn{3}{|c|}{ Escolaridade } & \multirow{2}{*}{$\begin{array}{c}\text { Profissão } \\
\text { Ver área de } \\
\text { atuação }\end{array}$} \\
\hline & & $<20$ & $\begin{array}{l}21 \\
30\end{array}$ & $\begin{array}{l}31 \\
40\end{array}$ & $\begin{array}{l}41 \\
50\end{array}$ & $>50$ & $\begin{array}{c}\text { Total } \\
\text { Sujeitos }\end{array}$ & Médio & Superior & $\begin{array}{c}\text { Pós- } \\
\text { graduado }\end{array}$ & \\
\hline \multicolumn{2}{|c|}{$\begin{array}{l}\text { BRASIL } \\
\text { (Total) }\end{array}$} & 7 & 20 & 15 & 9 & 5 & 56 & 5 & 32 & 19 & \multirow{8}{*}{1} \\
\hline \multicolumn{2}{|c|}{$\begin{array}{l}\text { Distrito } \\
\text { Federal }\end{array}$} & - & 2 & - & - & - & 2 & - & 2 & - & \\
\hline \multicolumn{2}{|c|}{ Mato Grosso } & - & 2 & - & - & - & 2 & - & 1 & 1 & \\
\hline \multicolumn{2}{|c|}{ Minas Gerais } & - & 1 & - & 3 & 1 & 5 & - & 3 & 2 & \\
\hline \multicolumn{2}{|c|}{ Pará } & - & 3 & - & 1 & - & 4 & - & 2 & 2 & \\
\hline \multicolumn{2}{|c|}{ Paraná } & - & 2 & 1 & - & 1 & 4 & - & 2 & 2 & \\
\hline \multicolumn{2}{|c|}{$\begin{array}{l}\text { Rio de } \\
\text { Janeiro }\end{array}$} & - & 1 & - & - & 1 & 2 & - & 1 & 1 & \\
\hline \multicolumn{2}{|c|}{ São Paulo } & 7 & 9 & 14 & 5 & 2 & 37 & 5 & 21 & 11 & \\
\hline \multicolumn{2}{|c|}{$\begin{array}{l}\text { ESTRANGEIROS } \\
\text { (Total) }\end{array}$} & - & 8 & 7 & 3 & 5 & 23 & - & 6 & 17 & 2 a 10 \\
\hline \multicolumn{2}{|c|}{ Alemanha } & - & 3 & 1 & - & - & 4 & - & 2 & 2 & 2 \\
\hline \multicolumn{2}{|c|}{ Áustria } & - & 2 & 1 & - & 1 & 4 & - & 1 & 3 & 3 \\
\hline \multicolumn{2}{|c|}{ Canadá } & - & - & 2 & - & - & 2 & - & 1 & 1 & 4 \\
\hline \multicolumn{2}{|c|}{ China } & - & - & - & 1 & - & 1 & - & 1 & - & 5 \\
\hline \multicolumn{2}{|c|}{ Espanha } & - & 1 & - & - & 1 & 2 & - & - & 2 & 6 \\
\hline \multicolumn{2}{|c|}{ E.U.A. } & - & 1 & 3 & - & 1 & 5 & - & 1 & 4 & 7 \\
\hline \multicolumn{2}{|c|}{ Holanda } & - & - & - & 1 & 2 & 3 & - & - & 3 & 8 \\
\hline \multicolumn{2}{|c|}{ México } & - & - & - & 1 & - & 1 & - & - & 1 & 9 \\
\hline \multicolumn{2}{|c|}{ Suíça } & - & 1 & - & - & - & 1 & - & - & 1 & 10 \\
\hline \multicolumn{2}{|c|}{ TOTAL GERAL } & 7 & 28 & 22 & 12 & 10 & 79 & 5 & 38 & 36 & 1 a 10 \\
\hline \multicolumn{12}{|c|}{ Área de atuação profissional daqueles que responderam os questionários } \\
\hline \multicolumn{12}{|c|}{$\begin{array}{l}\text { Estudante, química, artesanato, vendas, turismo, informática, marketing, setor } \\
\text { administrativo, geografia, pesquisa, magistério, psicologia, compras, consultoria, } \\
\text { odontologia, arquitetura, gestão ambiental, comércio, autônomo, designer gráfico. }\end{array}$} \\
\hline 2 & \multicolumn{11}{|c|}{ Cartografia, geo informática e mídia. } \\
\hline 3 & Cartograf & a, ge & info & mát & a e & nídia. & & & & & \\
\hline 4 & Cartograf & & & & & & & & & & \\
\hline 5 & Cartograf & & & & & & & & & & \\
\hline 6 & Geografia & e ca & togra & & & & & & & & \\
\hline 7 & Geografia & , cart & ografi & a, ps & colos & ia e c & onsultor & & & & \\
\hline 8 & Consulto & ia, ca & togra & fia e & nagi & tério & & & & & \\
\hline 9 & Magistéri & & & & & & & & & & \\
\hline 10 & Engenha & & & & & & & & & & \\
\hline
\end{tabular}


$\underline{\text { Instrumento de medida }}$

Nessa etapa da pesquisa, são reapresentadas e resumidas cinco questões importantes quanto à confecção dos mapas, tendo sempre como cuidado principal a adequação do usuário aos produtos finais desenvolvidos - mapas e mapa-site turístico de Caxambu:

1a.) A leitura do artigo de Kokkoken e Peltonen (1999) desafia a elaborar mapas, tendo o turista como usuário potencial. Castner (1987), ao trabalhar na elaboração de um Atlas para crianças (e pode-se pensar no leigo em cartografia), afirma que se deve diminuir a atenção dada aos elementos convencionais e estruturais dos mapas, enfatizando descobertas, descrições, classificações e símbolos de informações, pois o entretenimento passivo está por toda parte.

À preocupação de confeccionar um tipo de produto cartográfico funcional, que possibilite ao turista planejar e preparar suas atividades em seu tempo de descanso, soma-se a preocupação de um maior apelo estético. E é graças à pictografia que se dispõe do lúdico, tentando seduzir o turista tanto em relação ao destino turístico quanto ao produto-mapa.

O grau de abstração dos símbolos pictóricos apresenta um maior apelo estético e parece ser mais apreciado e lido por crianças e usuários que tenham pouco contato com materiais cartográficos (Muehrcke, 1986).

Para oferecer um contraponto e uma complementação ao material pictográfico, foram confeccionados mapas que fazem uso dos símbolos convencionais (abstratos, geométricos), devido à forma de representação mais objetiva e neutra.

É imprescindível frisar que, na proposta desenvolvida pela Semiologia Gráfica, as imagens necessitam somente de um momento de percepção; portanto, são imagens para "ver" - fisiológicas, entendidas à primeira vista - e não para "ler" condicionadas pela cultura, contexto, hábito, expectativas, etc. Contudo, o produto desenvolvido nesta pesquisa teve o propósito de enquadrar-se melhor na segunda opção, por objetivar propositalmente um produto de leitura mais lenta, levando o turista a viajar pelo mapa. Acredita-se que o intuito dos mapas turísticos não é obter uma resposta rápida, mas sim, permitir que o usuário compreenda e viaje pela informação.

2a.) Ao abordar mais especificamente o produto-mapa, deve-se estar constantemente preocupado com a percepção do usuário diante dos vários elementos gráficos representados no mapa. Robinson, Morrison, Muehrcke, Kimerling e Guptill (1995), e Fiori (2003) ressaltam quesitos como:

$\checkmark$ Legibilidade: uso de símbolos claros, familiares.

$\checkmark$ Contraste visual entre os símbolos e o fundo do mapa. 
$\checkmark$ Organização entre a figura e a base: saber distinguir entre a terra e a água, reconhecer contornos de cidades, ilhas, portos, etc.

$\checkmark$ Organização hierárquica: saber separar as características significativas, para poder descrever suas semelhanças, diferenças e inter-relações. Por exemplo, reconhecer diferentes espessuras de linhas, contrastes e tons das cores, hachuras, etc.

Esses itens são fundamentais na busca de um material cartográfico bem sucedido. Tem-se que é imprescindível facilitar e tornar atraente o processo visual de decodificação pelo usuário leigo em cartografia, possibilitando, assim, uma maior apreensão da informação e um menor esforço mental.

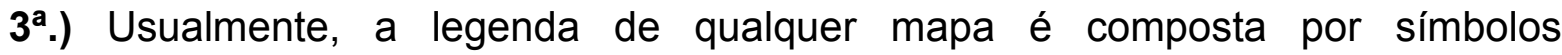
geométricos e intermediários, que representam elementos espaciais como cidades, rodovias pavimentadas ou sem pavimentação, hidrografia, limites municipal, estadual, federal, entre outros aspectos. Entretanto, durante a elaboração dos mapas para o setor do turismo, faz-se necessária a representação de outros tipos de elementos espaciais como: acomodação, alimentação, hospedagem, serviços, atrativos naturais e culturais, entretenimento, práticas desportivas, recreação e transporte. Aliás, na maior parte das vezes, os mapas analógicos e digitais para o setor representam todos esses itens por meio de símbolos pictográficos.

Propõe-se, então, um tipo de legenda para mapas turísticos que se baseie nos símbolos de informação pública. Para isso, é necessário adaptar, melhorar graficamente e avaliar, por pesquisas empíricas, os vários pictogramas já existentes. É preciso que se mantenha o esforço de formular um inventário, de ordenar, padronizar e divulgar, em escala internacional, um sistema de sinalização para o setor. Desse modo, pode-se vislumbrar a composição de um sistema único, normatizado, pelo menos no que se refere a ações, situações e locais de senso comum. Carneiro (2001:193) complementa que, ser oficial, não é uma qualidade imposta pelos órgãos ou entidades, mas sim a condição legítima de uso e inteligibilidade.

4a.) $O$ texto deve ser direto e objetivo, trazendo informações úteis - serviços, curiosidades, história, referências - aos turistas. A escala precisa ser adequada aos elementos que serão dispostos sobre o mapa-base. A orientação (pontos cardeais, latitude e longitude) é necessária, pois é um item que traz referências ao turista.

5.) O processo do desenvolvimento de mapas para o setor do turismo deve considerar o modo de adaptá-los ao meio digital interativo. A atenção se volta a itens como:

$\checkmark$ A facilidade de navegação e transição entre as páginas. 
$\checkmark$ O conteúdo e a apresentação visual (estética).

$\checkmark$ O equilíbrio entre ritmo e andamento, ou seja, a preocupação em gerar uma interatividade confortável (tempo de download) de recursos como o zoom, pan, pop up, etc.

Os itens acima constatam se as mensagens desenvolvidas pelo produtor ao longo do mapa-site foram transmitidas de maneira satisfatória. Verifica-se também a motivação, expectativas e a satisfação dos usuários, auxiliando na mensuração de que mais os atraiu e do que gostaram no produto.

Inicia-se o trabalho empírico, a partir da seguinte afirmação: fazendo uso da mesma base cartográfica e de outras informações comuns, elaboram-se duas formas de representação para um mapa turístico, possibilitando uma comparação entre os mapas convencionais e pictóricos, e uma posterior locação em meio digital e interativo, possibilitando uma situação de comparação, que:

$\checkmark$ Verifica as preferências do sujeito ao apresentar dois tipos de representação - convencional e pictórica - para um mesmo tema: o mapa turístico.

$\checkmark$ Verifica as preferências do sujeito quanto à utilização de símbolos convencionais e pictóricos.

$\checkmark$ Questiona a inserção de caixas de textos distribuídas sob o mapa.

$\checkmark$ Questiona a aceitação dos materiais cartográficos desenvolvidos.

$\checkmark$ Quantifica o grau de reconhecimento dos símbolos de informação pública.

$\checkmark$ Verifica a interatividade e a aceitação do mapa-site turístico de Caxambu por meio de itens como acesso, navegação, arte, conteúdo, motivação e o tempo de download.

Formularam-se questões com alternativas e outras dissertativas, com perguntas curtas, objetivas e de rápida compreensão, sempre levando em conta a heterogeneidade do usuário. É importante ressaltar a não-obrigatoriedade em se responder as questões dissertativas. 
Questionário 1 - in loco em quatorze municípios brasileiros

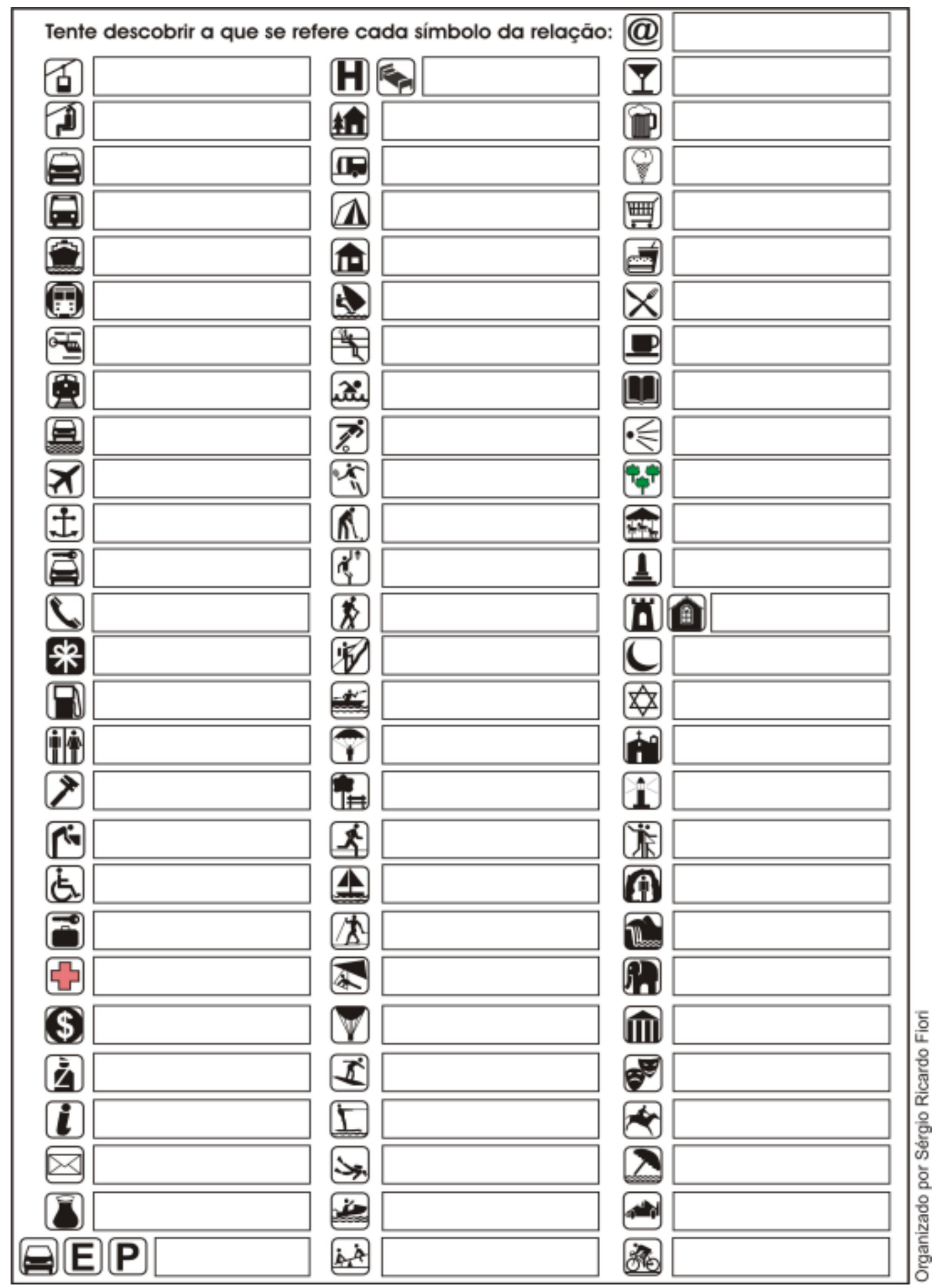


Questionário 2 - site (versão em português)

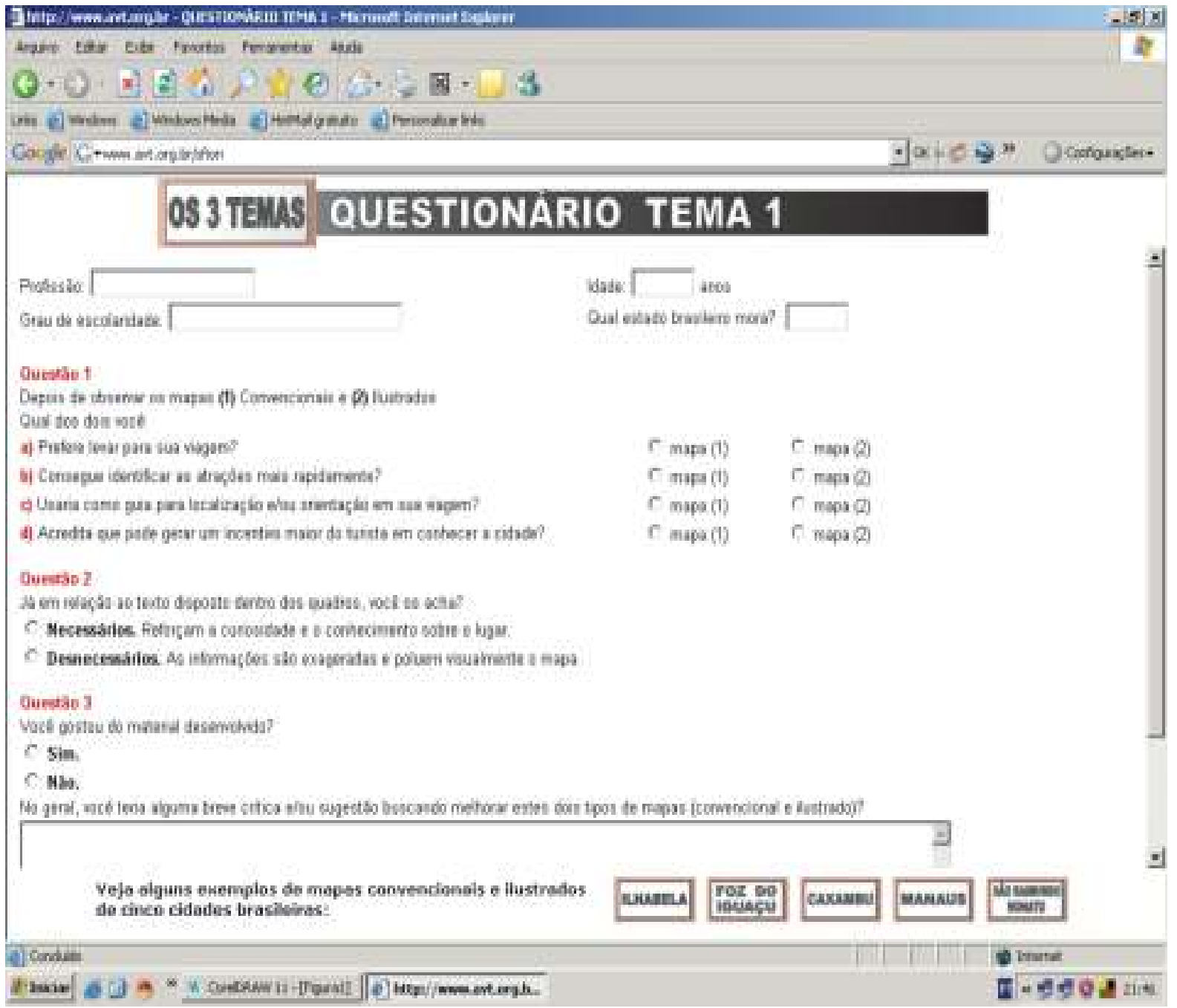

Elaborado por Sérgio Ricardo Fiori 
Questionário 3 - site (versão em português)

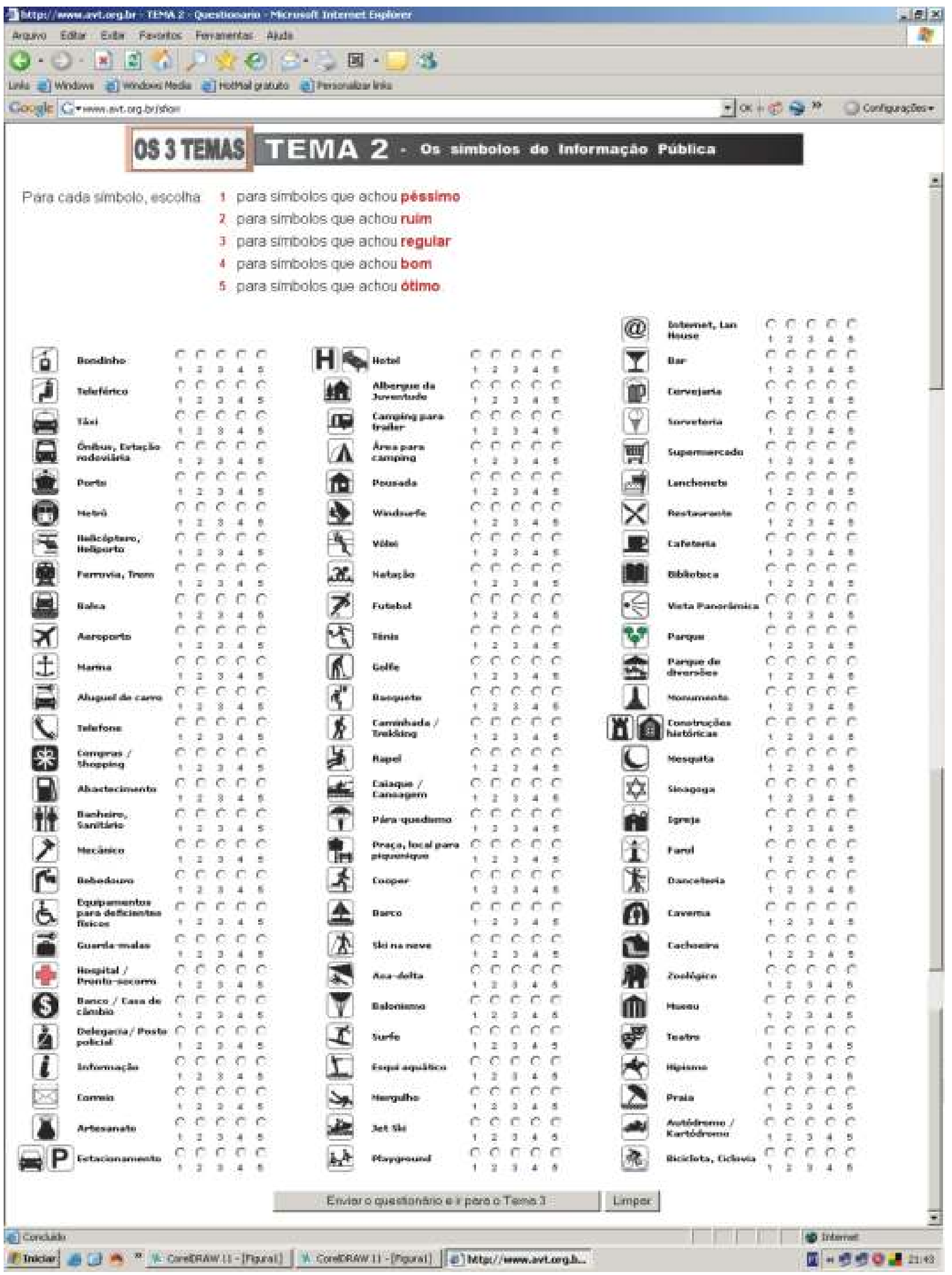


Questionário 4 - site (versão em inglês)

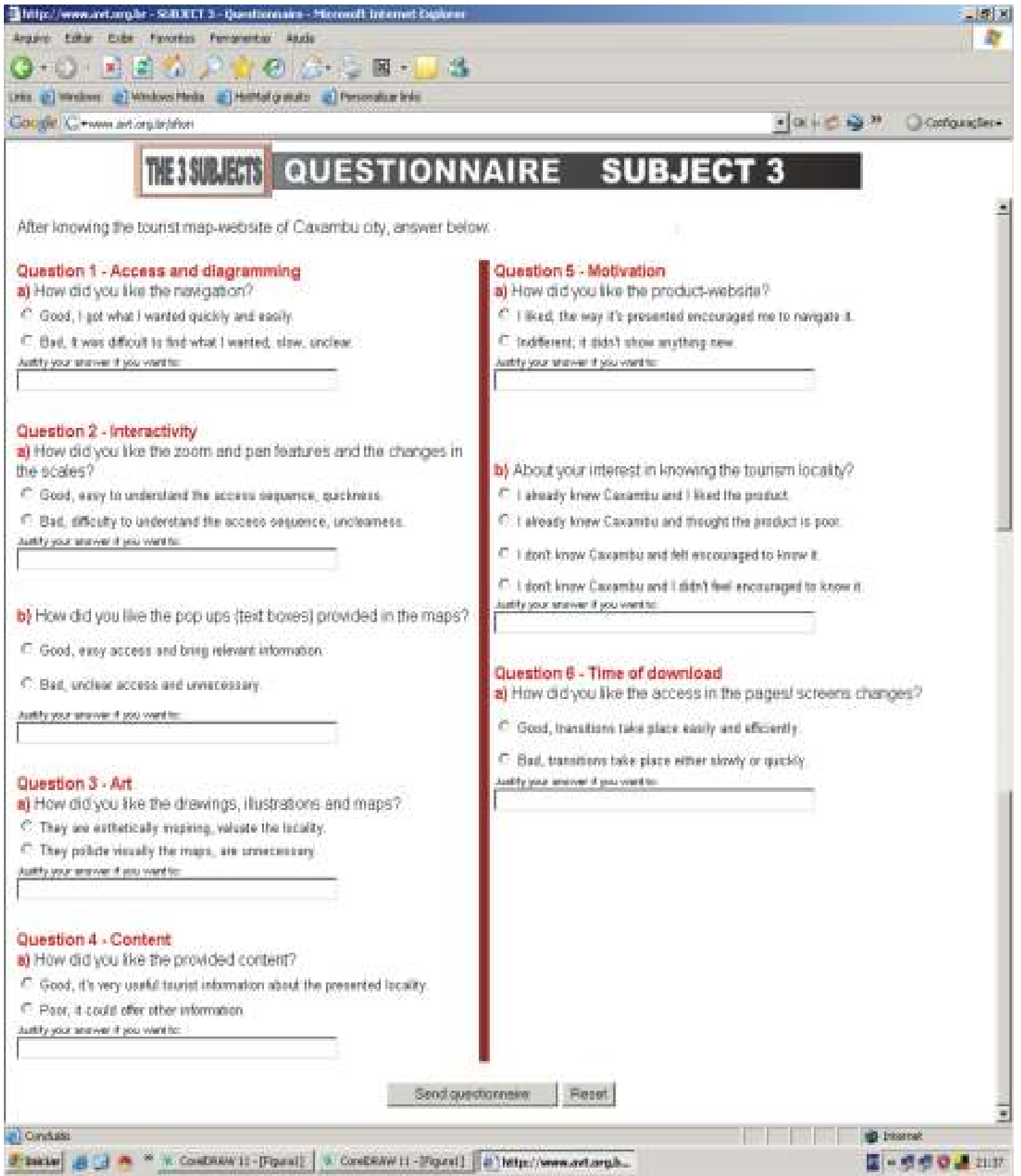


A aplicação dos questionários ocorreu de duas maneiras diferentes:

$\checkmark$ In loco - Entre as atividades de um curso de qualificação de professores, aplicou-se um questionário em que se utilizaram oitenta e seis símbolos de informação publica. O sujeito deveria olhar o símbolo (um por um) e, logo em seguida, escrever em um espaço em branco, na frente do próprio símbolo, o que aquilo significava, ou seja, qual a primeira palavra que vinha a sua mente ao se deparar com aquele símbolo.

$\checkmark$ Internet - Os outros três questionários (três temas distintos) eram respondidos quando o sujeito acessava o site da pesquisa no endereço: www. avt.org.br/sfiori. No tema 1, ele contava com dois mapas de cada destinação: um pictórico e um convencional, num total de dez mapas, indo logo em seguida ao questionário para responder três questões. No tema 2, o sujeito via a relação dos oitenta e seis símbolos de informação publica, mas, desta vez, contava com uma grade numérica para cada símbolo que ia de um a cinco, relacionados, em uma escala, aos conceitos, de péssimo a ótimo. O sujeito, então, avaliava cada um dos símbolos. E, no tema três, depois de navegar pela mapa-site turístico de Caxambu, dirigia-se ao questionário para responder seis questões.

\section{Atribuição de pontos}

$\checkmark$ O questionário que dispõe dos oitenta e seis símbolos de informação publica, respondido de forma dissertativa, resultou de uma avaliação em quatro níveis: símbolos que foram interpretados plenamente (sentido de coletivo); símbolos que foram interpretados fora do contexto (interpretação ao "pé da letra"); não foi respondido, e não se conseguiu interpretar o símbolo. Neste último caso, citam-se os casos mais relevantes para discussão.

$\checkmark$ Nos questionários do site: o Tema 1 e o Tema 3 se apresentaram em respostas optativas, ou seja, não corresponderam a respostas certas ou erradas, mas sim à escolha entre a primeira ou segunda preferência. Já as respostas dissertativas foram opcionais.

$\checkmark$ No questionário do site, o Tema 2 também utilizou os oitenta e seis Símbolos de Informação Publica respondidos, mas a aplicação do questionário ocorreu de forma alternativa. Na frente de cada símbolo, há uma grade numérica com números inteiros que vai de 1 (péssimo) a 5 (ótimo). Cada número inteiro equivale a um ponto. 


\subsection{2 - Coleta e processamento das informações}

Ao final dos 782 questionários aplicados, obtiveram-se os seguintes resultados:

$\checkmark 79$ sujeitos responderam sobre o tema Mapas convencionais e pictóricos.

$\checkmark 675$ sujeitos responderam sobre o tema Símbolos de Informação Pública; nesse caso, foram registradas 596 respostas dissertativas e 79 respostas alternativas.

$\checkmark 28$ sujeitos responderam sobre o tema Protótipo de um mapa-site turístico.

É fundamental registrar que, no caso das perguntas específicas ao site, o sujeito nem sempre respondeu os três temas propostos; na verdade, não era obrigado. A única condição para desconsiderar o questionário respondido ocorreu quando o sujeito não respondia as perguntas referentes à vida pessoal: profissão, idade, anos, grau de escolaridade e em qual estado brasileiro ou em qual país mora. As tabelas $11 \mathrm{~A}, 11 \mathrm{~B}$ e $11 \mathrm{C}$ mostram a diferenciação entre temas e divide os sujeitos em brasileiros e estrangeiros - sujeitos que moram em outros países.

As tabelas 12,13, 14 e 15 apresentam os dados brutos, ou seja, respostas dadas por cada sujeito referentes aos questionários 1 (in loco) e 2, 3 e 4 (os três temas encontrados no site).

Tabela 11 - Questionários respondidos e aceitos para a tabulação

\section{A) BRASIL}

\begin{tabular}{|c|c|c|c|}
\hline $\begin{array}{r}\text { TEMA } \\
\text { RESPOSTI }\end{array}$ & 1 & 2 & 3 \\
\hline Aceita & 56 & 56 & 28 \\
\hline Rejeitada & 3 & 8 & 0 \\
\hline TOTAL & 59 & 64 & 28 \\
\hline
\end{tabular}

B) ESTRANGEIROS

\begin{tabular}{|c|c|c|c|}
\hline $\begin{array}{l}\text { TEMA } \\
\text { RESPOSTA }\end{array}$ & 1 & 2 & 3 \\
\hline Aceita & 23 & 23 & 13 \\
\hline Rejeitada & 1 & 5 & 0 \\
\hline TOTAL & 24 & 28 & 13 \\
\hline
\end{tabular}

\begin{tabular}{|r|c|c|c|}
\hline \multicolumn{4}{|c|}{ C) BRASIL + ESTRANGEIROS } \\
\hline TEMA & $\mathbf{1}$ & $\mathbf{2}$ & $\mathbf{3}$ \\
\hline RESPOSTA & 56 & 56 & 28 \\
\hline Aceita & 56 & 8 & 0 \\
\hline Rejeitada & 3 & $\mathbf{6 4}$ & $\mathbf{2 8}$ \\
\hline TOTAL & $\mathbf{5 9}$ & & \\
\hline
\end{tabular}


Tabela 12 - Repostas ao se olhar os símbolos de informação pública (respostas dissertativas)

\begin{tabular}{|c|c|c|c|c|}
\hline Símbolo Resposta & $\begin{array}{l}\text { Acertaram o } \\
\text { Contexto }\end{array}$ & $\begin{array}{l}\text { Acertaram o } \\
\text { Símbolo }\end{array}$ & $\begin{array}{l}\text { Não } \\
\text { responderam }\end{array}$ & $\begin{array}{l}\text { Erraram os } \\
\text { dois }\end{array}$ \\
\hline 1) Bondinho & 254 & 0 & 37 & 305 \\
\hline 2) Teleférico & 456 & 0 & 93 & 47 \\
\hline 3) Táxi & 478 & 0 & 24 & 94 \\
\hline 4) Rodoviária & 58 & 355 & 30 & 153 \\
\hline 5) Porto & 281 & 225 & 27 & 66 \\
\hline 6) Metrô & 426 & 0 & 40 & 130 \\
\hline 7) Heliponto & 22 & 212 & 39 & 323 \\
\hline 8) Estação ferroviária & 67 & 271 & 25 & 233 \\
\hline 9) Balsa & 371 & 0 & 91 & 134 \\
\hline 10) Aeroporto & 513 & 66 & 5 & 12 \\
\hline 11) Marina / Atracadouro & 80 & 60 & 50 & 406 \\
\hline 12) Locação / Aluguel de carro & 256 & 0 & 86 & 254 \\
\hline 13) Telefone público & 87 & 387 & 1 & 121 \\
\hline 14) Shopping / Compras & 204 & 91 & 97 & 204 \\
\hline 15) Posto de gasolina / Abastecimento & 417 & 4 & 14 & 161 \\
\hline 16) Banheiro público / WC & 62 & 402 & 42 & 90 \\
\hline 17) Oficina mecânica / Mecânico & 303 & 18 & 109 & 166 \\
\hline 18) Bebedouro & 227 & 0 & 153 & 216 \\
\hline 19) Acesso para deficiente físico & 102 & 33 & 22 & 439 \\
\hline 20) Guarda malas / Volumes & 316 & 0 & 118 & 162 \\
\hline 21) Hospital / Pronto Socorro & 546 & 2 & 6 & 42 \\
\hline 22) Banco & 461 & 48 & 26 & 61 \\
\hline 23) Delegacia & 21 & 174 & 60 & 341 \\
\hline 24) Informação / Informação Turística & 252 & 0 & 161 & 183 \\
\hline 25) Correio & 559 & 11 & 3 & 23 \\
\hline 26) Artesanato & 260 & 3 & 201 & 132 \\
\hline 27) Estacionamento & 387 & 0 & 161 & 48 \\
\hline 28) Hotel & 492 & 4 & 8 & 92 \\
\hline 29) Albergue da juventude & 63 & 0 & 175 & 358 \\
\hline 30) Trailer & 361 & 0 & 138 & 97 \\
\hline 31) Camping & 322 & 38 & 29 & 207 \\
\hline 32) Pousada & 91 & 40 & 198 & 267 \\
\hline 33) Wind surf & 272 & 2 & 81 & 241 \\
\hline 34) Vôlei & 450 & 7 & 38 & 101 \\
\hline 35) Natação & 501 & 0 & 38 & 57 \\
\hline 36) Futebol & 521 & 0 & 18 & 57 \\
\hline 37) Tênis & 497 & 0 & 29 & 70 \\
\hline 38) Golfe & 500 & 0 & 24 & 72 \\
\hline 39) Basquete & 475 & 0 & 44 & 77 \\
\hline 40) Trekking / Caminhada & 127 & 0 & 140 & 329 \\
\hline 41) Rapel / Alpinismo & 407 & 5 & 61 & 123 \\
\hline 42) Caiaque / Canoagem & 272 & 0 & 94 & 230 \\
\hline
\end{tabular}


Tabela 12 - Repostas ao se olhar os símbolos de informação pública (continuação)

\begin{tabular}{|c|c|c|c|c|}
\hline Resposta & $\begin{array}{c}\text { Acertaram o } \\
\text { Contexto }\end{array}$ & $\begin{array}{l}\text { Acertaram o } \\
\text { Símbolo }\end{array}$ & $\begin{array}{c}\text { Não } \\
\text { responderam }\end{array}$ & $\begin{array}{l}\text { Erraram os } \\
\text { dois }\end{array}$ \\
\hline 43) Pára-quedismo & 326 & 130 & 54 & 86 \\
\hline 44) Praça / Área p/ piquenique & 460 & 0 & 45 & 91 \\
\hline 45) Cooper / Corrida & 334 & 0 & 54 & 208 \\
\hline 46) Barco / Barco a vela & 151 & 0 & 126 & 319 \\
\hline 47) Esqui na neve & 405 & 1 & 106 & 84 \\
\hline 48) Asa delta & 462 & 0 & 47 & 87 \\
\hline 49) Balonismo & 299 & 184 & 53 & 60 \\
\hline 50) Surfe & 411 & 4 & 75 & 106 \\
\hline 51) Esqui aquático & 416 & 0 & 115 & 65 \\
\hline 52) Mergulho & 378 & 72 & 98 & 48 \\
\hline 53) Jet Ski & 443 & 0 & 83 & 70 \\
\hline 54) Playground & 141 & 93 & 50 & 312 \\
\hline 55) Bar & 272 & 10 & 105 & 209 \\
\hline 56) Cervejaria & 62 & 58 & 20 & 456 \\
\hline 57) Sorveteria & 542 & 49 & 2 & 3 \\
\hline 58) Supermercado & 554 & 4 & 7 & 31 \\
\hline 59) Lanchonete & 477 & 41 & 19 & 59 \\
\hline 60) Restaurante & 572 & 0 & 4 & 20 \\
\hline 61) Cafeteria & 201 & 299 & 45 & 51 \\
\hline 62) Biblioteca & 301 & 240 & 28 & 27 \\
\hline 63) Vista panorâmica & 48 & 0 & 261 & 287 \\
\hline 64) Parque & 48 & 24 & 45 & 479 \\
\hline 65) Parque de diversão & 363 & 60 & 30 & 143 \\
\hline 66) Monumento & 204 & 1 & 165 & 226 \\
\hline 67) Construção histórica & 42 & 96 & 208 & 250 \\
\hline 68) Mesquita & 142 & 67 & 187 & 200 \\
\hline 69) Sinagoga & 208 & 38 & 172 & 178 \\
\hline 70) Igreja & 557 & 0 & 13 & 26 \\
\hline 71) Farol & 482 & 0 & 80 & 34 \\
\hline 72) Danceteria / Salão de dança & 333 & 2 & 28 & 233 \\
\hline 73) Caverna & 225 & 0 & 164 & 207 \\
\hline 74) Cachoeira & 495 & 2 & 38 & 61 \\
\hline 75) Zoológico & 383 & 58 & 63 & 92 \\
\hline 76) Museu & 116 & 0 & 91 & 389 \\
\hline 77) Teatro & 404 & 11 & 31 & 150 \\
\hline 78) Hipismo & 346 & 5 & 30 & 215 \\
\hline 79) Praia & 555 & 5 & 17 & 19 \\
\hline 80) Autódromo / Cartódromo & 296 & 48 & 77 & 175 \\
\hline 81) Ciclismo / Ciclovia & 417 & 32 & 11 & 136 \\
\hline 82) Internet * & 71 & 57 & 6 & 33 \\
\hline
\end{tabular}

* O símbolo Internet só foi utilizado em quatro dos quatorze municípios que se aplicou o questionário 
Tabela 13 - Respostas referentes a dualidade: convencional ou pictórico

\begin{tabular}{|c|c|c|c|c|}
\hline A) BRASIL & \multicolumn{3}{|c|}{} \\
\hline $\begin{array}{c}\text { QUESTÃO } \\
\text { TIPO DE } \\
\text { MAPA }\end{array}$ & a & B & c & d \\
\hline $\begin{array}{c}\text { Convencional } \\
\text { (1) }\end{array}$ & 15 & 6 & 23 & 4 \\
\hline $\begin{array}{c}\text { Pictórico } \\
\text { (2) }\end{array}$ & 41 & 50 & 33 & 52 \\
\hline $\begin{array}{c}\text { Total Geral } \\
(1+2)\end{array}$ & & & 56 & \\
\hline
\end{tabular}

B) ESTRANGEIROS

\begin{tabular}{|c|c|c|c|c|}
\hline $\begin{array}{c}\text { QUESTÃO } \\
\begin{array}{c}\text { TIPO DE } \\
\text { MAPA }\end{array}\end{array}$ & A & B & C & d \\
\hline $\begin{array}{c}\text { Convencional } \\
\text { (1) }\end{array}$ & 6 & 12 & 13 & 5 \\
\hline $\begin{array}{c}\text { Pictórico } \\
\text { (2) }\end{array}$ & 17 & 11 & 10 & 18 \\
\hline $\begin{array}{c}\text { Total Geral } \\
(1+2)\end{array}$ & \multicolumn{3}{|c|}{23} \\
\hline
\end{tabular}

\section{C) BRASIL + ESTRANGEIROS}

\begin{tabular}{|c|c|c|c|c|}
\hline QUESTÃO & \multicolumn{4}{|c|}{1} \\
\hline $\begin{array}{c}\text { TIPO DE } \\
\text { MAPA }\end{array}$ & a & B & c & d \\
\hline $\begin{array}{c}\text { Convencional } \\
\text { (1) }\end{array}$ & 21 & 18 & 36 & 9 \\
\hline $\begin{array}{c}\text { Pictórico } \\
(\mathbf{2})\end{array}$ & 58 & 61 & 43 & 70 \\
\hline $\begin{array}{c}\text { Total Geral } \\
(1+2)\end{array}$ & & \multicolumn{2}{|c|}{79} & \\
\hline
\end{tabular}

\section{QUESTÃO 2}

\begin{tabular}{l|l|l}
$\mathbf{N}$ & Dn & $\mathrm{N}=$ Necessário \\
$\mathbf{6 6}$ & $\mathbf{1 3}$ & $\mathrm{Dn}=$ Desnecessário
\end{tabular}

QUESTÃO 3

\begin{tabular}{l|l|l}
$\mathbf{N}$ & Dn & $\mathrm{N}=$ Necessário \\
$\mathbf{7 8}$ & $\mathbf{1}$ & $\mathrm{Dn}=$ Desnecessário
\end{tabular}

Tabela XX.2 - Disponibilidade de textos (total geral = Brasil + estrangeiros) 72 questionários aplicados

Tabela XX.2 - Aceitação do material (total geral = Brasil + estrangeiros) 72 questionários aplicados 
Tabela 14 - Repostas dadas aos símbolos de informação pública e a escala numérica (respostas alternativas)

\begin{tabular}{|c|c|c|}
\hline Resposta & $\begin{array}{l}\text { BRASIL - média } \\
\text { Total bruto - } 56 \text { sujeitos }\end{array}$ & $\begin{array}{l}\text { ESTRANGEIROS - média } \\
\text { Total bruto - } 23 \text { sujeitos }\end{array}$ \\
\hline 1) Bondinho & 4,2 & 4,2 \\
\hline 2) Teleférico & 4,2 & 4,3 \\
\hline 3) Táxi & 4,3 & 4,2 \\
\hline 4) Rodoviária & 4,3 & 4,2 \\
\hline 5) Porto & 4,2 & 4,3 \\
\hline 6) Metrô & 3,8 & 3,3 \\
\hline 7) Heliponto & 4,4 & 4,4 \\
\hline 8) Estação ferroviária & 4,2 & 3,6 \\
\hline 9) Balsa & 3,2 & 3,0 \\
\hline 10) Aeroporto & 4,7 & 4,9 \\
\hline 11) Marina / Atracadouro & 3,9 & 3,4 \\
\hline 12) Locação / Aluguel de carro & 3,2 & 3,5 \\
\hline 13) Telefone público & 4,6 & 4,6 \\
\hline 14) Shopping / Compras & 3,2 & 3,0 \\
\hline 15) Posto de gasolina / Abastecimento & 4,4 & 4,4 \\
\hline 16) Banheiro público / WC & 4,5 & 4,6 \\
\hline 17) Oficina mecânica / Mecânico & 3,5 & 3,4 \\
\hline 18) Bebedouro & 3,7 & 3,3 \\
\hline 19) Acesso para deficiente físico & 4,5 & 4,8 \\
\hline 20) Guarda malas / Volumes & 3,9 & 4,0 \\
\hline 21) Hospital / Pronto Socorro & 4,8 & 4,8 \\
\hline 22) Banco & 4,5 & 4,2 \\
\hline 23) Delegacia & 3,7 & 3,5 \\
\hline 24) Informação / Informação Turística & 4,2 & 4,4 \\
\hline 25) Correio & 4,4 & 4,5 \\
\hline 26) Artesanato & 3,1 & 2,8 \\
\hline 27) Estacionamento & 4,3 & 4,2 \\
\hline 28) Hotel & 4,4 & 4,4 \\
\hline 29) Albergue da juventude & 3,4 & 3,6 \\
\hline 30) Trailer & 3,6 & 3,9 \\
\hline 31) Camping & 4,3 & 4,0 \\
\hline 32) Pousada & 3,3 & 2,9 \\
\hline 33) Windsurf & 4,4 & 4,4 \\
\hline 34) Vôlei & 4,0 & 3,9 \\
\hline 35) Natação & 4,2 & 4,4 \\
\hline 36) Futebol & 4,5 & 4,6 \\
\hline 37) Tênis & 4,4 & 4,2 \\
\hline 38) Golfe & 4,4 & 4,3 \\
\hline 39) Basquete & 4,1 & 4,0 \\
\hline 40) Trekking / Caminhada & 3,8 & 3,8 \\
\hline 41) Rapel / Alpinismo & 4,1 & 3,7 \\
\hline 42) Caiaque / Canoagem & 4,3 & 3,9 \\
\hline
\end{tabular}


Tabela 14 - Respostas dos símbolos de informação pública e a escala numérica (continuação)

\section{Símbolo}

43) Pára-quedismo

44) Praça / Área p/ piquenique

45) Cooper / Corrida

46) Barco / Barco a vela

47) Esqui na neve

48) Asa delta

49) Balonismo

50) Surfe

51) Esqui aquático

52) Mergulho

53) Jet Ski

54) Playground

55) Bar

56) Cervejaria

57) Sorveteria

58) Supermercado

59) Lanchonete

60) Restaurante

61) Cafeteria

62) Biblioteca

63) Vista panorâmica

64) Parque

65) Parque de diversão

66) Monumento

67) Construção histórica

68) Mesquita

69) Sinagoga

70) Igreja

71) Farol

72) Danceteria / Salão de dança

73) Caverna

74) Cachoeira

75) Zoológico

76) Museu

77) Teatro

78) Hipismo

79) Praia

80) Autódromo / Cartódromo

81) Ciclismo / Ciclovia

82) Internet
BRASIL - média

Total bruto - 56 sujeitos

4,4

3,9

4,1

4,1

4,2

4,5

4,2

4,1

4,1

3,8

4,0

4,3

4,0

4,4

4,6

4,7

4,4

4,8

4,5

3,8

2,7

4,0

4,0

3,6

3,5

3,4

3,9

4,3

4,3

3,7

3,5

4,2

3,9

3,2

4,5

4,4

4,3

3,8

4,7

4,7
ESTRANGEIROS - média Total bruto - 23 sujeitos

4,3

3,8

3,6

3,9

3,9

4,2

4,1

3,3

3,9

3,3

3,3

4,2

3,8

4,0

4,8

4,6

4,3

4,8

4,6

3,8

2,7

3,8

3,8

3,5

3,3

3,2

3,9

3,9

4,3

3,5

3,3

3,3

3,8

3,3

4,2

3,8

4,5

3,5

4,3

4,5 
Tabela 15 - Respostas referentes ao protótipo mapa-site turístico de Caxambu

\begin{tabular}{|c|c|c|c|c|c|c|c|c|c|c|c|}
\hline \multicolumn{12}{|l|}{ A) BRASIL } \\
\hline \multirow{2}{*}{$\begin{array}{l}\text { QUESTÃO } \\
\text { RESPOSTA }\end{array}$} & \multirow[t]{2}{*}{1} & \multicolumn{2}{|c|}{2} & \multirow[t]{2}{*}{3} & \multirow[t]{2}{*}{4} & \multicolumn{3}{|c|}{5} & \multirow[t]{2}{*}{6} & \multicolumn{2}{|c|}{$\begin{array}{c}\text { Detalhe } \\
\text { Questão } 5 \mathrm{~b}\end{array}$} \\
\hline & & A & b & & & $\mathbf{a}$ & & & & 0 & 4 \\
\hline Positiva & 19 & 17 & 26 & 28 & 28 & 17 & I & II & 16 & & \\
\hline Negativa & 9 & 11 & 2 & 0 & 0 & 11 & III & IV & 12 & & \\
\hline $\begin{array}{c}\text { TOTAL } \\
\text { (Positiva + } \\
\text { negativa) }\end{array}$ & & & & & 28 & & & & & & \\
\hline
\end{tabular}

\section{B) ESTRANGEIROS}

\begin{tabular}{|c|c|c|c|c|c|c|c|c|c|c|c|}
\hline \multirow{3}{*}{$\begin{array}{l}\text { QUESTÃO } \\
\text { RESPOSTA } \\
\text { Positiva }\end{array}$} & \multirow[b]{3}{*}{5} & \multicolumn{2}{|c|}{2} & \multirow[t]{2}{*}{3} & \multirow[t]{2}{*}{4} & \multicolumn{3}{|c|}{5} & \multirow[t]{2}{*}{6} & \multicolumn{2}{|c|}{$\begin{array}{c}\text { Detalhe } \\
\text { Questão } 5 \text { b }\end{array}$} \\
\hline & & A & b & & & a & & & & & \\
\hline & & 6 & 7 & 12 & 12 & 10 & 1 & II & 6 & & \\
\hline Negativa & 8 & 7 & 6 & 1 & 1 & 3 & III & IV & 7 & & \\
\hline $\begin{array}{c}\text { TOTAL } \\
\text { (Positiva + } \\
\text { negativa) }\end{array}$ & & & & & 13 & & & & & & \\
\hline
\end{tabular}

\section{C) BRASIL + ESTRANGEIROS}

\begin{tabular}{|c|c|c|c|c|c|c|c|c|c|c|c|}
\hline \multirow{3}{*}{$\begin{array}{l}\text { QUESTÃO } \\
\text { RESPOSTA } \\
\text { Positiva }\end{array}$} & \multirow{3}{*}{$\begin{array}{c}1 \\
\\
24\end{array}$} & \multicolumn{2}{|c|}{2} & \multirow[t]{2}{*}{3} & \multirow[t]{2}{*}{4} & \multicolumn{3}{|c|}{5} & \multirow[t]{2}{*}{6} & \multicolumn{2}{|c|}{$\begin{array}{c}\text { Detalhe } \\
\text { Questão } 5 \text { b }\end{array}$} \\
\hline & & A & b & & & a & & & & 6 & 1 \\
\hline & & 23 & 33 & 40 & 40 & 27 & I & II & 22 & & \\
\hline Negativa & 17 & 18 & 8 & 1 & 1 & 14 & III & IV & 19 & & \\
\hline $\begin{array}{l}\text { TOTAL } \\
\text { (Positiva + } \\
\text { negativa) }\end{array}$ & & & & & 41 & & & & & & \\
\hline
\end{tabular}




\section{3 - Apresentação e discussão dos resultados}

A realização dos questionários procurou conhecer o ponto de vista dos usuários potenciais de um mapa temático para o setor do turismo. Buscou-se saber se a preferência recaía sobre a utilização de mapas convencionais ou de mapas pictóricos, com seus respectivos símbolos, com a inserção de textos - informativos, serviços, curiosidades, etc. Buscava verificar também se há ou não aceitação desse tipo de produto por turistas e pessoas leigas em cartografia. Além disso, analisou-se uma relação de oitenta e seis símbolos de informação pública e propôs-se um tipo de legenda que adaptasse tais símbolos aos mapas turísticos.

Foram utilizadas, como parâmetros duas visões distintas em relação ao material cartográfico elaborado: a do brasileiro e a do estrangeiro. Neste caso, requisitaramse sujeitos que moram em outros países.

A seguir, apresentam-se as tabelas 16, 17, 18 e 19 com as médias percentuais referentes aos quatro questionários (in loco e no site), realizados ao longo da pesquisa. 
Tabela 16 - Médias amostrais dos símbolos de informação pública in loco (\%)

\begin{tabular}{|c|c|c|c|c|}
\hline \multirow{2}{*}{ Símbolo } & \multirow[b]{2}{*}{$\begin{array}{c}\text { Acertaram o } \\
\text { Contexto }\end{array}$} & \multirow[b]{2}{*}{$\begin{array}{c}\text { Acertaram o } \\
\text { Símbolo }\end{array}$} & \multicolumn{2}{|c|}{ Pontuação mais alta } \\
\hline & & & $\begin{array}{c}\text { Não } \\
\text { responderam }\end{array}$ & $\begin{array}{l}\text { Erraram os } \\
\text { dois }\end{array}$ \\
\hline 1) Bondinho & 42,6 & 0 & 6,2 & 51,2 \\
\hline 2) Teleférico & 76,5 & 0 & 15,6 & 7,9 \\
\hline 3) Táxi & 80,2 & 0 & 4,0 & 15,8 \\
\hline 4) Rodoviária & 9,7 & 59,6 & 5,0 & 25,7 \\
\hline 5) Porto & 47,1 & 37,8 & 4,5 & 11,1 \\
\hline 6) Metrô & 71,5 & 0 & 6,7 & 21,8 \\
\hline 7) Heliponto & 3,7 & 35,6 & 6,5 & 54,2 \\
\hline 8) Estação ferroviária & 11,2 & 45,7 & 4,2 & 39,1 \\
\hline 9) Balsa & 62,2 & 0 & 15,3 & 22,5 \\
\hline 10) Aeroporto & 86,1 & 11,1 & 0,8 & 2,0 \\
\hline 11) Marina / Atracadouro & 13,4 & 10,1 & 8,4 & 68,1 \\
\hline 12) Locação / Aluguel de carro & 43,0 & 0 & 14,4 & 42,6 \\
\hline 13) Telefone público & 14,6 & 65,0 & 0,2 & 20,2 \\
\hline 14) Shopping / Compras & 34,2 & 15,3 & 16,3 & 34,2 \\
\hline 15) Posto de gasolina / Abastecimento & 70,0 & 0,7 & 2,3 & 27,0 \\
\hline 16) Banheiro público / WC & 10,4 & 67,4 & 7,0 & 15,2 \\
\hline 17) Oficina mecânica / Mecânico & 50,2 & 3,0 & 18,3 & 27,7 \\
\hline 18) Bebedouro & 38,1 & 0 & 25,7 & 36,2 \\
\hline 19) Acesso para deficiente físico & 17,1 & 5,5 & 3,7 & 73,7 \\
\hline 20) Guarda malas / Volumes & 53,0 & 0 & 19,8 & 27,2 \\
\hline 21) Hospital / Pronto Socorro & 91,6 & 0,3 & 1,0 & 7,1 \\
\hline 22) Banco & 77,4 & 8,0 & 4,4 & 10,2 \\
\hline 23) Delegacia & 3,5 & 29,2 & 10,1 & 57,2 \\
\hline 24) Informação / Informação Turística & 42,3 & 0 & 27,0 & 30,7 \\
\hline 25) Correio & 93,8 & 1,8 & 0,5 & 3,9 \\
\hline 26) Artesanato & 43,6 & 0,5 & 33,7 & 22,1 \\
\hline 27) Estacionamento & 64,9 & 0 & 27,0 & 8,1 \\
\hline 28) Hotel & 82,6 & 0,7 & 1,3 & 15,4 \\
\hline 29) Albergue da juventude & 10,6 & 0 & 29,4 & 60,1 \\
\hline 30) Trailer & 60,2 & 0 & 23,3 & 16,5 \\
\hline 31) Camping & 54,0 & 6,4 & 4,9 & 34,7 \\
\hline 32) Pousada & 15,3 & 6,7 & 33,2 & 44,8 \\
\hline 33) Wind surf & 45,6 & 0,3 & 13,6 & 40,4 \\
\hline 34) Vôlei & 75,5 & 1,2 & 6,4 & 16,9 \\
\hline 35) Natação & 84,1 & 0 & 6,4 & 9,5 \\
\hline 36) Futebol & 87,4 & 0 & 3,0 & 9,6 \\
\hline 37) Tênis & 83,5 & 0 & 4,8 & 11,7 \\
\hline 38) Golfe & 83,9 & 0 & 4,0 & 12,1 \\
\hline 39) Basquete & 79,7 & 0 & 7,4 & 12,9 \\
\hline 40) Trekking / Caminhada & 21,3 & 0 & 23,5 & 55,2 \\
\hline 41) Rapel / Alpinismo & 68,3 & 0,8 & 10,3 & 20,6 \\
\hline 42) Caiaque / Canoagem & 47,8 & 0 & 15,7 & 38,5 \\
\hline
\end{tabular}


Tabela 16 - Médias amostrais dos símbolos de informação pública in loco

$(\%)$ (continuação)

\begin{tabular}{|c|c|c|c|c|}
\hline Símbolo & $\begin{array}{l}\text { Acertaram o } \\
\text { Contexto }\end{array}$ & $\begin{array}{l}\text { Acertaram o } \\
\text { Símbolo }\end{array}$ & $\begin{array}{c}\text { Não } \\
\text { responderam }\end{array}$ & $\begin{array}{l}\text { Erraram os } \\
\text { dois }\end{array}$ \\
\hline 43) Pára-quedismo & 54,7 & 21,8 & 9,1 & 14,4 \\
\hline 44) Praça / Área para piquenique & 77,2 & 0 & 7,6 & 15,2 \\
\hline 45) Cooper / Corrida & 56,0 & 0 & 9,1 & 34,9 \\
\hline 46) Barco / Barco a vela & 25,4 & 0 & 21,1 & 53,5 \\
\hline 47) Esqui na neve & 68,0 & 0,2 & 17,7 & 14,1 \\
\hline 48) Asa delta & 77,5 & 0 & 7,9 & 14,6 \\
\hline 49) Balonismo & 50,2 & 30,8 & 8,9 & 10,1 \\
\hline 50) Surfe & 69,0 & 0,7 & 12,6 & 17,8 \\
\hline 51) Esqui aquático & 70,0 & 0 & 19,2 & 10,8 \\
\hline 52) Mergulho & 63,4 & 12,1 & 16,4 & 8,1 \\
\hline 53) Jet Ski & 74,4 & 0 & 13,9 & 11,7 \\
\hline 54) Playground & 23,7 & 15,6 & 8,4 & 52,3 \\
\hline 55) Bar & 45,6 & 1,7 & 17,6 & 35,1 \\
\hline 56) Cervejaria & 10,4 & 9,7 & 3,4 & 76,5 \\
\hline 57) Sorveteria & 91,0 & 8,2 & 0,3 & 0,5 \\
\hline 58) Supermercado & 93,0 & 0,7 & 1,1 & 5,2 \\
\hline 59) Lanchonete & 80,0 & 6,9 & 3,2 & 9,9 \\
\hline 60) Restaurante & 96,0 & 0 & 0,6 & 3,4 \\
\hline 61) Cafeteria & 33,7 & 50,2 & 7,5 & 8,6 \\
\hline 62) Biblioteca & 51,0 & 40,2 & 4,5 & 4,3 \\
\hline 63) Vista panorâmica & 8,1 & 0 & 43,8 & 48,1 \\
\hline 64) Parque & 8,1 & 4,0 & 7,5 & 80,4 \\
\hline 65) Parque de diversão & 61,0 & 10,0 & 5,0 & 24,0 \\
\hline 66) Monumento & 34,2 & 0,2 & 27,7 & 37,9 \\
\hline 67) Construção histórica & 7,0 & 16,1 & 34,9 & 42,0 \\
\hline 68) Mesquita & 23,8 & 11,2 & 31,4 & 33,6 \\
\hline 69) Sinagoga & 34,9 & 6,4 & 28,9 & 29,8 \\
\hline 70) Igreja & 93,4 & 0 & 2,3 & 4,3 \\
\hline 71) Farol & 80,9 & 0 & 13,4 & 5,7 \\
\hline 72) Danceteria / Salão de dança & 55,9 & 0,3 & 4,7 & 39,1 \\
\hline 73) Caverna & 37,8 & 0 & 27,5 & 34,7 \\
\hline 74) Cachoeira & 83,1 & 0,3 & 6,4 & 10,2 \\
\hline 75) Zoológico & 64,3 & 9,7 & 10,6 & 15,4 \\
\hline 76) Museu & 19,5 & 0 & 15,3 & 65,2 \\
\hline 77) Teatro & 67,8 & 1,8 & 5,2 & 25,2 \\
\hline 78) Hipismo & 58,1 & 0,8 & 5,0 & 36,1 \\
\hline 79) Praia & 93,1 & 0,8 & 2,9 & 3,2 \\
\hline 80) Autódromo / Cartódromo & 49,7 & 8,1 & 12,9 & 29,3 \\
\hline 81) Ciclismo / Ciclovia & 70,0 & 5,4 & 1,8 & 22,8 \\
\hline 82) Internet * & 42,6 & 34,2 & 3,7 & 19,5 \\
\hline
\end{tabular}


E quando o sujeito não acertava o contexto do símbolo de informação pública, quais foram as respostas mais freqüentes?

A estrutura é a seguinte:

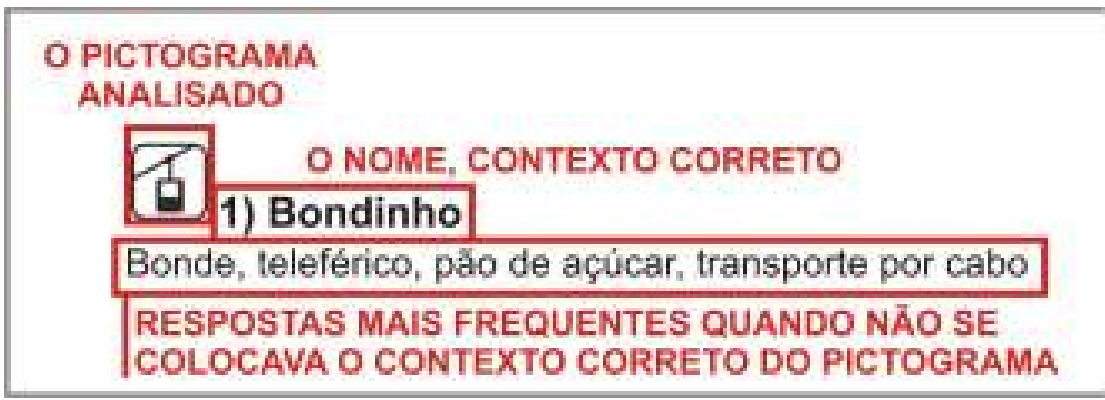

1) Bondinho

Bonde, teleférico, pão de açúcar, transporte por cabo.

\section{2) Teleférico}

Estação de esqui, poltrona, esqui, trem de esqui.

\section{3) Táxi}

Ponto de táxi, carro, polícia, ambulância, locação de veículos, parada de táxi.

\section{4) Rodoviária}

Ônibus, ponto de ônibus, transporte coletivo, transporte rodoviário.

\section{5) Porto}

Navio, embarcação, transporte fluvial, área portuária, transporte marítimo, viagem marítima, hidrovia.

\section{6) Metrô}

Estação de trem, trem-metrô, bonde, estação de metrô.

\section{7) Heliponto}

Helicóptero, heliporto, táxi aéreo, aeroclube, local de pouso.

\section{8) Estação ferroviária}

Trem, Ferrovia, Estação de trem, Linha de trem, linha férrea, locomotiva, metrô, trem de superfície.

\section{9) Balsa}

Carro, transporte fluvial, transporte aquático de carro, transporte por barca, carro na balsa. 
10) Aeroporto

Avião, transporte aéreo, aeroporto-avião.

11) Marina / Atracadouro

Âncora, porto, Marinha do Brasil, marinha, ancoradouro, cais.

12) Locação / Aluguel de carro

Chaveiro, garagem, oficina, estacionamento.

\section{3) Telefone público}

Telefone, orelhão, telecomunicações, cabine telefônica, posto telefônico.

\section{4) Shopping / Compras}

Presente, souvenir, loja comercial, conveniência, loja.

15) Posto de gasolina / Abastecimento

Posto, posto de combustível, gasolina.

\section{6) Banheiro público / WC}

Banheiro, ele-ela, toalete, unisex, maculino-feminino, sanitário.

\section{7) Oficina mecânica / Mecânico}

Oficina, borracharia, ferramenta, oficina de ferragem, chave, encanador.

18) Bebedouro

Lavatório, lixo, lixeira, pia, lavatório, limpeza, lavabo.

\section{9) Acesso para deficiente físico}

Cadeirante, deficiente, local para deficiente, vaga reservada para deficiente, cadeira de rodas, acessibilidade.

\section{0) Guarda malas / Guarda volumes}

Chaveiro, cofre, bagagem, viagem, armário, maleiro, porta bagagem. 
21) Hospital / Pronto Socorro

Ambulatório, primeiros socorros, saúde, posto de saúde, posto médico, cruz.

\section{2) Banco}

Dinheiro, empréstimo, câmbio, financeira, cifrão.

\section{3) Delegacia}

Policial, segurança, guarda de trânsito, área militar, posto policial, guarda, policiamento.

\section{4) Informação / Informação Turística}

Letra i, Internet, Itaú, banco Itaú, cyber café.

\section{5) Correio}

Correspondência, carta, serviço postal.

\section{6) Artesanato}

Cerâmica, utensílio, jarra, laboratório, vinho, louça, indústria química, artesanato-cerâmica, química, farmácia, ciência, pote, vaso.

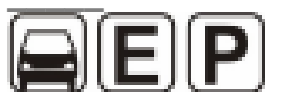

Permitido estacionar, parada, estacionamento proibido, permitido estacionar, estacionamento privado.

\section{H] 28) Hotel}

Hospedagem, dormitório, repouso, pernoite, hospital.

\section{29) Albergue da juventude}

Chalé, pousada, casa de campo, pousada nos Alpes, Natal.

\section{0) Camping para trailer}

Reboque, camping móvel, área de trailer, camping.

\section{1) Camping}

Acampamento, barraca, local para acampamento, cabana, área de camping.

\section{2) Pousada}

Chalé, casa de aluguel, casa, casa na praia, residência, guarita, moradia, área residencial.

\section{3) Windsurfe}

Velejar, barco a vela, vela, surfe, jangadeiro, regata, prática de iatismo. 


\section{4) Vôlei}

Quadra de vôlei, Pólo aquático, basquete.

\section{5) Natação}

Piscina, área para nadar.

\section{6) Futebol}

Quadra de Futebol, campo de futebol, jogo de futebol.

\section{7) Tênis}

Quadra de tênis, ping-pong.

\section{8) Golfe}

Campo de golfe.

39) Basquete

Quadra de basquete.

\section{0) Trekking / Caminhada}

Trilha, alpinismo, idoso, passagem para cegos, trilha de eco-turismo.

\section{1) Rapel / Alpinismo}

Escalada, montanhismo, escalar montanha, escalagem.

\section{2) Caiaque / Canoagem}

Remo, windsurfe, pescaria, iatismo, área de canoagem, regata.

\section{3) Pára-quedismo}

Pára-quedas, pára-quedista.

44) Praça / Área para piquenique

Parque, fazenda, pracinha, parque para recreação.

45) Cooper / Corrida

Atletismo, atleta, caminhar, pista de corrida, pista de Cooper, maratona.

46) Barco / Barco a vela

latismo, vela, marina, jangada, veleiro.

Esquiar, esqui no gelo, deficiente visual, trenó, patinador. 
48) Asa delta

Vôo livre, área de salto, ultra-leve.

49) Balonismo

Balão, pára-quedismo, balonista, baloagem.

\section{0) Surfe}

Surfista, skate, skatista.

51) Esqui aquático

Windsurfe, pescaria, esqui na água.

\section{2) Mergulho}

Mergulhador, área de mergulho, prática submarina, nadador.

53) Jet Ski

Lancha, bote, moto-náutica.

54) Playground

Gangorra, parque, parquinho, parque infantil, balanço.

55) Bar

Drink, taça, frágil, adega, bebida, taça de vinho.

56) Cervejaria

Choperia, chope, bar, milk shake, bar.

\section{7) Sorveteria}

Sorvete.

\section{8) Supermercado}

Carrinho de supermercado, mercado.

59) Lanchonete

Lanche, fast food, lancharia.

60) Restaurante

Refeição, talheres. 


\section{1) Cafeteria}

Café, casa de chá, café expresso.

\section{2) Biblioteca}

Livraria, leitura, livro, jornal.

\section{3) Vista panorâmica}

Farol alto, luz alta, luz, lanterna, autofalante, som, farol-sinaleiro, mirante, cinema, acenda o farol, buzina.

\section{4) Parque}

Floresta, árvores, bosque, reserva florestal, parque natural, campo, mata, área verde.

\section{5) Parque de diversão}

Carrossel, parque.

\section{6) Monumento}

Farol, marco, obelisco.

\section{iif 67) Construção histórica}

Castelo, patrimônio histórico, torre, patrimônio cultural, centro histórico.

\section{8) Mesquita}

Noite, lua, lua crescente, boate, templo islã, místico, lual, lua minguante, muçulmanos, símbolo do islã.

\section{9) Sinagoga}

Estrela de Davi, judaísmo, templo judeu, judeu, israelense, maçonaria, pentagrama.

\section{0) Igreja}

Catedral, cristão, igreja católica, igreja cristã, templo cristão.

\section{1) Farol}

Farol alto, porto, foguete.

\section{2) Danceteria / Salão de dança}

Dança, festa, baile, boate, pista de dança, clube, discoteca. 
Catarata, cascata, corredeira.

\section{5) Zoológico}

Animal selvagem, elefante, safári, selva, circo, cuidado: animais.

\section{6) Museu}

Circo, palácio, mesquita, teatro, ruínas, Grécia.

\section{7) Teatro}

Carnaval, museu, máscara do teatro, baile de máscara.

\section{8) Hipismo}

Hipódromo, rodeio, corrida de cavalo, hípica, jóquei, corrida de cavalo, equitação, festa de rodeio, haras.

\section{9) Praia}

Chuva, sombrinha, balneário, guarda-sol, área para banhista.

\section{0) Autódromo / Cartódromo}

Fórmula 1, automobilismo, pista de corrida, carte, corrida de automóvel.

\section{1) Ciclismo / Ciclovia}

Ciclista, bicicleta, velódromo, via de bicicleta.

\section{2) Internet}

Arroba, cyber café, e-mail, endereço eletrônico, informática, lan house, acesso a Internet.

Pelas respostas dissertativas de 596 sujeitos inventariadas na tabela 16, pôde-se averiguar que:

\section{Acertaram o contexto}

$\checkmark 11$ símbolos $(12,8 \%)$ foram identificados corretamente por mais de 500 sujeitos;

$\checkmark 32$ símbolos $(37,2 \%)$ foram identificados corretamente por mais de 400 sujeitos; 
$\checkmark 48$ símbolos $(55,8 \%)$ foram respondidos corretamente por mais de 300 sujeitos.

\section{Acertaram o contexto ou o símbolo}

$\checkmark 19$ símbolos $(23,2 \%)$ foram respondidos corretamente por mais de 500 sujeitos.

$\checkmark 45$ símbolos $(52,3 \%)$ foram respondidos corretamente por mais de 400 sujeitos.

$\checkmark 56$ símbolos $(68,3 \%)$ foram respondidos corretamente por mais de 300 sujeitos.

O próximo item merece destaque pela alta quantidade de respostas corretas acerto do contexto (sem contar o acerto do símbolo):

- Restaurante - 572; Correio - 559; Supermercado - 554; Igreja - 557; Praia - 555; Hospital, Pronto-Socorro - 546; Sorveteria - 542.

A partir dos 56 símbolos já inclusos, ainda restam 26 com índice menor de acerto que 300 sujeitos. Desses 26, 12 símbolos foram respondidos corretamente por menos de 200 sujeitos - acerto do contexto (incluindo-se o acerto do símbolo):

- Delegacia - 195; Marina, atracadouro - 140; Acesso para deficiente físico -135; Pousada - 131; Trekking, caminhada - 127; Barco, barco à vela - 151; Construção histórica - 138; Cervejaria - 120; Museu - 116; Albergue da juventude - 63; Parque - 72, Vista panorâmica - 48 .

Um dado curioso é que mais de $50 \%$ dos entrevistados interpretaram o símbolo Museu, mesmo sendo muito utilizado em placas de sinalização turística, como Circo. 
Tabela 17 - Valores amostrais quanto a preferência entre o mapa convencional ou pictórico

\begin{tabular}{|c|c|c|c|c|}
\hline A) BRASIL & \multicolumn{3}{|c|}{} \\
\hline $\begin{array}{c}\text { QUESTÃO } \\
\text { TIPO DE } \\
\text { MAPA }\end{array}$ & a & B & C & D \\
\hline $\begin{array}{c}\text { Convencional } \\
\text { (1) }\end{array}$ & 26,8 & 10,7 & 41,0 & 7,0 \\
\hline $\begin{array}{c}\text { Pictórico } \\
\text { (2) }\end{array}$ & 73,2 & 89,3 & 59,0 & 93,0 \\
\hline $\begin{array}{c}\text { Total Geral } \\
\text { (1+2) }\end{array}$ & & $\mathbf{1 0 0}$ & \\
\hline
\end{tabular}

\begin{tabular}{|c|c|c|c|c|}
\hline \multirow{2}{*}{$\begin{array}{l}\text { QUESTÃO } \\
\text { TIPO DE } \\
\text { MAPA }\end{array}$} & \multicolumn{4}{|c|}{$1(\%)$} \\
\hline & A & b & C & d \\
\hline $\begin{array}{l}\text { Convencional } \\
\text { (1) }\end{array}$ & 26,1 & 52,2 & 56,5 & 21,7 \\
\hline $\begin{array}{c}\text { Pictórico } \\
\text { (2) }\end{array}$ & 73,9 & 47,8 & 43,5 & 78,3 \\
\hline $\begin{array}{l}\text { Total Geral } \\
\quad(1+2)\end{array}$ & \multicolumn{4}{|c|}{100} \\
\hline
\end{tabular}

\begin{tabular}{|c|c|c|c|c|}
\hline C) BRASIL + ESTRANGEIROS \\
\hline $\begin{array}{c}|c| \\
\text { QUESTÃO }\end{array}$ & \multicolumn{4}{|c|}{$\mathbf{( \% )}$} \\
$\begin{array}{c}\text { TIPO DE } \\
\text { MAPA }\end{array}$ & A & B & C & d \\
\hline $\begin{array}{c}\text { Convencional } \\
\text { (1) }\end{array}$ & 26,6 & 22,8 & 45,6 & 11,4 \\
\hline $\begin{array}{c}\text { Pictórico } \\
\text { (2) }\end{array}$ & 73,4 & 72,2 & 54,4 & 86,6 \\
\hline $\begin{array}{c}\text { Total Geral } \\
\text { (1+2) }\end{array}$ & & 100 & \\
\hline
\end{tabular}
QUESTÃO 2 Tabela D - Valores amostrais: Disponibilidade de textos \begin{tabular}{cc|l} 
N & Dn & $\begin{array}{l}\mathrm{N}=\text { Necessário } \\
\text { Dn = Desnecessário }\end{array}$ \\
\hline $\mathbf{8 3 , 5}$ & $\mathbf{1 6 , 5}$ &
\end{tabular} (total geral $=$ Brasil + estrangeiros) $100 \%$

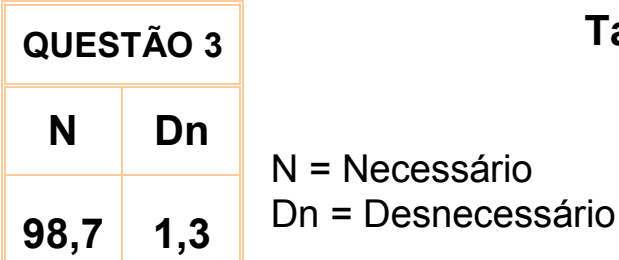
Tabela E - Valores amostrais: Aceitação do material (total geral $=$ Brasil + estrangeiros) $100 \%$ 
Ao observar as tabelas $17 \mathrm{~A}, \mathrm{~B}, \mathrm{C}, \mathrm{D}$ e $\mathrm{E}$, onde se registram os resultados dos questionários referentes ao tema 1 do site (ver site em CD - anexos - pasta 4), pôde-se averiguar que:

\section{Questão 1 (tema 1)}

Depois de observar os mapas (1) convencional e (2) ilustrado:

a) Qual dos dois prefere levar para sua viagem?

b) Em qual consegue identificar as atrações mais rapidamente? Note que a regência do verbo é diferente da dos demais.

c) Qual usaria como guia para localização e/ou orientação em sua viagem?

d) Qual você credita que pode gerar um incentivo maior ao turista que pretende conhecer a cidade?

$\left.1^{\circ}\right)$ As respostas dadas às questões formuladas com alternativas mostraram que, em resposta à questão $1 \mathrm{a}$ e $1 \mathrm{~d}, 80 \%$ dos entrevistados (brasileiros e estrangeiros) optaram pelos mapas pictóricos, que alcançaram os $93 \%$ na preferência dos brasileiros. Já na questão $1 \mathrm{~b}$, mesmo com a preferência geral dada aos mapas pictóricos, $52,2 \%$ dos estrangeiros optaram pelos mapas convencionais. A questão 1c apresentou os valores mais elevados a favor dos mapas convencionais $(45 \%)$, alcançando o pico de $56,5 \%$ entre os estrangeiros.

$\mathbf{2}^{\circ}$ ) As respostas dissertativas indicaram que os mapas convencionais são mais práticos, menos poluídos, preferidos quando em trânsito; proporcionam fácil localização, leitura imediata, melhor orientação no dia-a-dia. Já em relação aos mapas pictóricos, os termos usados para avaliá-los foram: oferecem ótima orientação, são atrativos, chamam mais a atenção, são preferidos quando já se está na localidade, são bons para planejar a viagem, aguçam a curiosidade e a querer conhecer o local, dão referências de localização, despertam o sentimento de pré-felicidade, são claros, confiáveis, dão uma visão mais aprofundada dos locais, permitem uma leitura mais lenta, são mais coloridos e adequados para os turistas.

Ressaltam-se a seguir algumas respostas dadas pelos entrevistados, que ilustram o que foi dito acima: "quando falamos de viagens turísticas, é claro que o mapa ilustrado é a melhor opção, pois te dá uma visão mais aprofundada dos locais a serem conhecidos, já os mapas convencionais tb são importantes, mas para localização do dia-a-dia" (Técnico em informática, 29, SP). "Map 2 is really colorful and perfect for tourists while Map 1 is much better for an overview or to orientate in the city. I think they are for different purposes..." (Engenheiro, 28, Suíça)."Para pedestres o ilustrado é interessante e motivador, porém a leitura é mais lenta, para motoristas o convencional permite uma leitura mais imediata" (Arquiteta, 43, SP). "Quality should be a main topic - especially in a time where computer tend to focus less on quality and loss of cartographic esthetics - type 1 has also its use in tourism, but would probably be better with a shaded relief in the background, then it could be 
perfect for hikink with the shown contour lines etc... there we need precise scales e.g. for measuring and suggesting the time for trips - type 2 seems to me being good for planning trips and getting to know the main features - told with pictures it attracts the visitors and helps the tourist in setting priorities. Maybe he sees which atractions are in a near surroundings and its importance for the family trip that could be made in a specific time - tourist maps should give a feeling of prehappyness of the upcoming trip" (geo informática e mídia, 30, Alemanha). "...em alguns momentos seria interessante levar os dois mapas...” (professora, 29, MT).

\section{Questão 2 (tema 1)}

Já em relação ao texto disposto dentro dos quadros, você os acha:

a) Necessários. Reforçam a curiosidade e o conhecimento sobre o lugar.

b) Desnecessários. As informações são exageradas e poluem visualmente o mapa.

$\left.1^{\circ}\right)$ As respostas baseadas nas questões apresentadas com alternativas revelaram que tanto os brasileiros quanto os estrangeiros vêem como necessária a disponibilidade de informações (caixas de texto) escritas sob o mapa turístico. A afirmação é ratificada por $83,5 \%$ dos entrevistados.

$2^{\circ}$ ) As respostas dissertativas mostraram que pode haver um excesso de informações. Leiam-se algumas declrações: "The text written in boxes is sometimes necessary, sometimes not. There is always some information obliterated by it. I like the material developed, but see it as additional information, not as a complete substitute" (cartógrafo, 64, Holanda). "O material é ótimo, o que pode ser melhorada levemente é a poluição visual, que, em certos casos, se faz presente, como em alguns trechos do mapa de Manaus, por exemplo. Mas é apenas em alguns casos" (Estudante, 15, SP). "... should be as attractive as possible but not overloaded with information - keep to details but don't get lost in them (geo informática e mídia, 30, Alemanha).

\section{Questão 3 (tema 1)}

\section{Você gostou do material desenvolvido?}

As respostas, dadas a questões baseadas em alternativas indicaram que tanto os brasileiros quanto os estrangeiros aprovaram de forma expressiva o material produzido para o setor do turismo (98,7 \%). Dos 79 entrevistados, houve apenas uma resposta negativa. 
Tabela 18 - Médias amostrais dos símbolos de informação pública e a escala numérica (\%)

Porcentagem igual ou menor que $70 \%$

\begin{tabular}{|c|c|c|}
\hline $\begin{array}{ll}\text { Símbolo } & \text { Resposta }\end{array}$ & $\begin{array}{c}\text { BRASIL } \\
\text { porcentagem (\%) }\end{array}$ & $\begin{array}{l}\text { ESTRANGEIROS } \\
\text { porcentagem (\%) }\end{array}$ \\
\hline 1) Bondinho & 84 & 84 \\
\hline 2) Teleférico & 84 & 86 \\
\hline 3) Táxi & 86 & 84 \\
\hline 4) Rodoviária & 86 & 84 \\
\hline 5) Porto & 84 & 86 \\
\hline 6) Metrô & 76 & 66 \\
\hline 7) Heliponto & 88 & 88 \\
\hline 8) Estação ferroviária & 84 & 72 \\
\hline 9) Balsa & 64 & 60 \\
\hline 10) Aeroporto & 94 & 98 \\
\hline 11) Marina / Atracadouro & 78 & 68 \\
\hline 12) Locação / Aluguel de carro & 64 & 70 \\
\hline 13) Telefone público & 92 & 92 \\
\hline 14) Shopping / Compras & 64 & 60 \\
\hline 15) Posto de gasolina / Abastecimento & 88 & 88 \\
\hline 16) Banheiro público / WC & 90 & 92 \\
\hline 17) Oficina mecânica / Mecânico & 70 & 68 \\
\hline 18) Bebedouro & 74 & 66 \\
\hline 19) Acesso para deficiente físico & 90 & 96 \\
\hline 20) Guarda malas / Volumes & 78 & 80 \\
\hline 21) Hospital / Pronto Socorro & 96 & 96 \\
\hline 22) Banco & 90 & 84 \\
\hline 23) Delegacia & 74 & 70 \\
\hline 24) Informação / Informação Turística & 84 & 88 \\
\hline 25) Correio & 88 & 90 \\
\hline 26) Artesanato & 62 & 56 \\
\hline 27) Estacionamento & 86 & 84 \\
\hline 28) Hotel & 88 & 88 \\
\hline 29) Albergue da juventude & 68 & 72 \\
\hline 30) Trailer & 72 & 78 \\
\hline 31) Camping & 86 & 80 \\
\hline 32) Pousada & 66 & 58 \\
\hline 33) Windsurf & 88 & 88 \\
\hline 34) Vôlei & 80 & 78 \\
\hline 35) Natação & 84 & 88 \\
\hline 36) Futebol & 90 & 92 \\
\hline 37) Tênis & 88 & 84 \\
\hline 38) Golfe & 88 & 86 \\
\hline 39) Basquete & 82 & 80 \\
\hline 40) Trekking / Caminhada & 76 & 76 \\
\hline
\end{tabular}




\begin{tabular}{|c|c|c|}
\hline $\begin{array}{ll} & \text { Resposta } \\
\text { Símbolo } & \end{array}$ & $\begin{array}{c}\text { BRASIL } \\
\text { porcentagem (\%) }\end{array}$ & $\begin{array}{l}\text { ESTRANGEIROS } \\
\text { porcentagem (\%) }\end{array}$ \\
\hline 41) Rapel / Alpinismo & 82 & 74 \\
\hline 42) Caiaque / Canoagem & 86 & 78 \\
\hline 43) Pára-quedismo & 88 & 86 \\
\hline 44) Praça / Área p/ piquenique & 78 & 76 \\
\hline 45) Cooper / Corrida & 82 & 72 \\
\hline 46) Barco / Barco a vela & 82 & 78 \\
\hline 47) Esqui na neve & 84 & 78 \\
\hline 48) Asa delta & 90 & 84 \\
\hline 49) Balonismo & 84 & 82 \\
\hline 50) Surfe & 82 & 66 \\
\hline 51) Esqui aquático & 82 & 78 \\
\hline 52) Mergulho & 76 & 66 \\
\hline 53) Jet Ski & 80 & 66 \\
\hline 54) Playground & 86 & 84 \\
\hline 55) Bar & 80 & 76 \\
\hline 56) Cervejaria & 88 & 80 \\
\hline 57) Sorveteria & 92 & 96 \\
\hline 58) Supermercado & 94 & 92 \\
\hline 59) Lanchonete & 88 & 86 \\
\hline 60) Restaurante & 96 & 96 \\
\hline 61) Cafeteria & 90 & 92 \\
\hline 62) Biblioteca & 76 & 76 \\
\hline 63) Vista panorâmica & 54 & 54 \\
\hline 64) Parque & 80 & 76 \\
\hline 65) Parque de diversão & 80 & 76 \\
\hline 66) Monumento & 72 & 70 \\
\hline 67) Construção histórica & 70 & 66 \\
\hline 68) Mesquita & 68 & 64 \\
\hline 69) Sinagoga & 78 & 78 \\
\hline 70) Igreja & 86 & 78 \\
\hline 71) Farol & 86 & 86 \\
\hline 72) Danceteria / Salão de dança & 74 & 70 \\
\hline 73) Caverna & 70 & 66 \\
\hline 74) Cachoeira & 84 & 66 \\
\hline 75) Zoológico & 78 & 76 \\
\hline 76) Museu & 64 & 66 \\
\hline 77) Teatro & 90 & 84 \\
\hline 78) Hipismo & 88 & 76 \\
\hline 79) Praia & 86 & 90 \\
\hline 80) Autódromo / Cartódromo & 76 & 70 \\
\hline 81) Ciclismo / Ciclovia & 94 & 86 \\
\hline 82) Internet & 94 & 90 \\
\hline
\end{tabular}

Ao observar a tabela 18, referente aos oitenta e dois Símbolos de Informação Pública (site), e a escala numérica, pôde-se averiguar o seguinte a partir das médias gerais (somadas todas as idades):

\section{1) Entre os brasileiros}

$\checkmark 15$ símbolos obtiveram uma média superior a $90 \%$ de aceitação.

$\checkmark 55$ símbolos obtiveram uma média superior a $80 \%$ de aceitação; 
$\checkmark 74$ símbolos obtiveram uma média superior a $70 \%$ de aceitação.

Neste item abaixo, merecem destaque os símbolos que obtiveram a média de aceitação igual ou superior a $92 \%$ :

- Restaurante - 96\%; Supermercado - 94\%; Ciclismo, ciclovia - 94\%; Internet - 94\%; Aeroporto - 94\%; Telefone público - 92\%; Sorveteria $92 \%$.

A partir dos 74 símbolos já inclusos, ainda restam 8 com índice de aceitação menor que $70 \%$ entre os sujeitos, a saber:

- Albergue da juventude - 68\%; Mesquita - 68; Pousada - 66\%; Shopping, compras - 64\%; Balsa - 64\%; Locação, aluguel de carro $64 \%$; Museu - $64 \%$; Artesanato - $62 \%$; Vista panorâmica - $54 \%$.

\section{2) Entre os estrangeiros}

$\checkmark 13$ símbolos obtiveram uma média superior a $90 \%$ de aceitação.

$\checkmark 40$ símbolos obtiveram uma média superior a $80 \%$ de aceitação.

$\checkmark 65$ símbolos obtiveram uma média superior a $70 \%$ de aceitação.

No item abaixo, merecem destaque os símbolos que obtiveram a média de aceitação igual ou superior a $92 \%$ :

- Aeroporto - 98\%; Restaurante - 96\%; Sorveteria - 96\%; Supermercado - 92\%; Banheiro público, WC - 92\%; Futebol - 92\%; Telefone público $92 \%$; Cafeteria - $92 \%$.

Dos 65 símbolos já inclusos, ainda restam 17 com índice de acerto menor que 70\% entre os sujeitos, a saber:

- Marina, atracadouro - $68 \%$; Oficina mecânica, mecânico - 68\%; Museu - 66\%; Bebedouro - 66\%; Surfe - 66\%; Mergulho - 66\%; Jet ski - 66\%; Construção histórica - 66\%, Caverna - 66\%; Cachoeira - 66\%; Metrô $66 \%$; Mesquita - 64\%; Balsa - 60\%; Shopping, compras - 60\%; Pousada $-58 \%$; Artesanato - $56 \%$; Vista panorâmica $-54 \%$. 
Tabela 19 - Respostas referentes ao protótipo mapa-site turístico de Caxambu

\begin{tabular}{|c|c|c|c|c|c|c|c|c|c|c|c|}
\hline \multicolumn{12}{|l|}{ A) BRASIL } \\
\hline \multirow{2}{*}{$\begin{array}{l}\text { QUESTÃO } \\
\text { RESPOSTA }\end{array}$} & \multirow[t]{2}{*}{1} & \multicolumn{2}{|c|}{2} & \multirow[t]{2}{*}{3} & \multirow[t]{2}{*}{4} & \multicolumn{3}{|c|}{5} & \multirow[t]{2}{*}{6} & \multicolumn{2}{|c|}{$\begin{array}{c}\text { Detalhe } \\
\text { Questão } 5 \text { b }\end{array}$} \\
\hline & & $\mathbf{a}$ & b & & & $\mathbf{a}$ & & & & \multirow{3}{*}{$\begin{array}{r}21,4 \\
53,6\end{array}$} & \multirow{2}{*}{14,3} \\
\hline Positiva & $\begin{array}{c}67 \\
6\end{array}$ & $\begin{array}{c}60 \\
7\end{array}$ & $\begin{array}{c}92, \\
9\end{array}$ & 100 & 100 & $\begin{array}{c}60 \\
7\end{array}$ & I & II & $\begin{array}{c}57 \\
1\end{array}$ & & \\
\hline Negativa & $\begin{array}{c}32 \\
1\end{array}$ & $\begin{array}{c}39, \\
3\end{array}$ & 7,1 & 0 & 0 & $\begin{array}{c}39, \\
3\end{array}$ & III & IV & $\begin{array}{c}42 \\
9\end{array}$ & & 10,7 \\
\hline $\begin{array}{c}\text { TOTAL } \\
\text { (Positiva + } \\
\text { negativa) }\end{array}$ & & & & & 100 & & & & & & \\
\hline
\end{tabular}

\section{B) ESTRANGEIROS}

\begin{tabular}{|c|c|c|c|c|c|c|c|c|c|c|c|}
\hline \multirow{3}{*}{$\begin{array}{c}\text { QUESTÃO } \\
\text { RESPOSTA } \\
\text { Positiva }\end{array}$} & \multirow[t]{2}{*}{1} & \multicolumn{2}{|c|}{2} & \multirow[t]{2}{*}{3} & \multirow[t]{2}{*}{4} & \multicolumn{3}{|c|}{5} & \multirow[t]{2}{*}{6} & \multicolumn{2}{|c|}{$\begin{array}{c}\text { Detalhe } \\
\text { Questão } 5 \text { b }\end{array}$} \\
\hline & & a & b & & & a & & & & 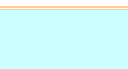 & 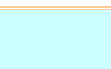 \\
\hline & $\begin{array}{c}38, \\
5\end{array}$ & $\begin{array}{c}46 \\
2\end{array}$ & $\begin{array}{c}53 \\
8\end{array}$ & $\begin{array}{c}92, \\
3\end{array}$ & $\begin{array}{c}92 \\
3\end{array}$ & 77 & 1 & II & $\begin{array}{c}46, \\
2\end{array}$ & 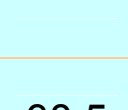 & 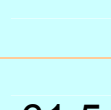 \\
\hline Negativa & $\begin{array}{c}61, \\
5\end{array}$ & $\begin{array}{c}53 \\
8\end{array}$ & $\begin{array}{c}46 \\
2\end{array}$ & 7,7 & 7,7 & 33 & III & IV & $\begin{array}{c}53, \\
8\end{array}$ & & \\
\hline $\begin{array}{l}\text { TOTAL } \\
\text { (Positiva + } \\
\text { negativa) }\end{array}$ & & & & & 100 & & & & & & \\
\hline
\end{tabular}

\section{C) BRASIL + ESTRANGEIROS}

\begin{tabular}{|c|c|c|c|c|c|c|c|c|c|c|c|}
\hline \multirow{2}{*}{$\begin{array}{l}\text { QUESTÃO } \\
\text { RESPOSTA }\end{array}$} & \multirow[t]{2}{*}{1} & \multicolumn{2}{|c|}{2} & \multirow[t]{2}{*}{3} & \multirow[t]{2}{*}{4} & \multicolumn{3}{|c|}{5} & \multirow[t]{2}{*}{6} & \multicolumn{2}{|c|}{$\begin{array}{c}\text { Detalhe } \\
\text { Questão } 5 \text { b }\end{array}$} \\
\hline & & $\mathbf{a}$ & b & & & a & & & & & \\
\hline Positiva & $\begin{array}{c}58, \\
5\end{array}$ & $\begin{array}{c}56 \\
1\end{array}$ & $\begin{array}{c}80 \\
5\end{array}$ & $\begin{array}{c}97, \\
6\end{array}$ & $\begin{array}{c}97 \\
6\end{array}$ & $\begin{array}{c}65 \\
9\end{array}$ & 1 & II & $\begin{array}{c}53 \\
7\end{array}$ & 14,0 & , \\
\hline Negativa & $\begin{array}{c}41 \\
5\end{array}$ & $\begin{array}{c}43 \\
9\end{array}$ & $\begin{array}{c}19 \\
5\end{array}$ & 2,4 & 2,4 & $\begin{array}{c}34, \\
1\end{array}$ & III & IV & $\begin{array}{c}46 \\
3\end{array}$ & 48,8 & 26,8 \\
\hline $\begin{array}{c}\text { TOTAL } \\
\text { (Positiva + } \\
\text { negativa) }\end{array}$ & & & & & 100 & & & & & & \\
\hline
\end{tabular}




\section{Questão 1 (tema 3) \\ O que achou da navegação? \\ Questão 2 (tema 3) \\ a) $\mathrm{O}$ que achou dos recursos zoom, pan e as mudanças de escalas? \\ b) $\mathrm{O}$ que achou dos pop ups (caixas de texto) contidos nos mapas?}

$\left.1^{\circ}\right)$ As respostas dadas às questões baseadas em alternativas mostraram que, na média geral, considerados brasileiros e estrangeiros, a navegação foi considerada positiva, mas apenas regular para $58,5 \%$ dos entrevistados, sendo que $61,5 \%$ dos estrangeiros acharam a navegação ruim. A reação não foi muito diferente quanto à interatividade. A questão $2 a$ recebeu uma média geral menor ainda $(56,1 \%)$. O melhor resultado conseguido entre os brasileiros não ultrapassou os $61 \%$. Os pop ups obtiveram uma média geral positiva, alcançando $80 \%$.

$\left.2^{\circ}\right)$ Quanto às dissertativas, apesar de respostas como "Adorei ver as fotos da cidade" (Assistente de diretoria, 40, SP), outros entrevistados apontaram falhas ocorridas durante o processo de navegação e interatividade: "Navegação não muito direta - confusa" (consultora, 37, SP); "I didn't know where to click, navigation to the other maps were strange" (cartógrafo, 30, Alemanha); "Alguns detalhes de navegação devem ser revistos"..."um pouco confuso para abrir os pop ups" (arquiteta, 43, SP); "Não foi possível ter uma visão geral do mapa na tela" (psicóloga, 35, SP).

\section{Questão 3 (tema 3) \\ 0 que achou dos desenhos, ilustrações nos mapas? \\ Questão 4 (tema 3) \\ O que achou do conteúdo disponibilizado?}

As respostas a essas questões evidenciaram que, mesmo com ressalvas, tanto brasileiros $(100 \%)$ quanto estrangeiros $(92,3 \%)$ aprovam categoricamente o uso das ilustrações e do tipo de conteúdo disponibilizado nos mapas turísticos.

\section{Questão 5 (tema 3)}

a) $O$ que achou do produto mapa-site?

b) Seu interesse em querer conhecer a localidade turística aumentou? 
$\left.1^{\circ}\right)$ As respostas alternativas revelaram que, na média geral, o produto mapa-site obteve uma aceitação de quase $66 \%$, sendo que as respostas positivas dos estrangeiros alcançaram os $77 \%$.

Já em relação aos entrevistados brasileiros que já conhecem a cidade e que gostaram do produto (questão $5 \mathrm{~b} I-21,4 \%$ ), somada a outra parcela que ficou motivada a conhecer Caxambu (questão $5 \mathrm{~b}$ III - 53,6) totalizam-se $75 \%$ de respostas positivas. Os estrangeiros também esboçaram um certo interesse em conhecer o destino (questões $38,5 \%$ ).

$2^{\circ}$ ) Das respostas dissertativas, uma exemplifica a reação esperada diante de um mapa-site: "Vou passar o carnaval de 2008 na cidade e já vou levar esse mapa comigo, achei tudo de bom e moderno. Aguçou minha curiosidade em conhecer a cidade" (Analista de Marketing, 21, SP).0

\section{Questão 6 (tema 3)}

a) $O$ que achou do acesso na mudança das páginas / telas? (download)

$\left.1^{\circ}\right)$ As respostas às questões formuladas com alternativas revelaram que este item também teve problemas, apresentando uma média geral positiva regular $(53,7 \%)$, sendo que entre os estrangeiros a rejeição chegou a quase $54 \%$.

$\left.2^{\circ}\right)$ Já as respostas dissertativas apontam falhas como: "achei o site um pouco pesado e olhe que tenho uma máquina core duo com 1 giga de memória" (Gestor ambiental, 46, SP). "Very slow through big file sizes" ... "slowly" (Cartógrafo, 30, Alemanha).

\section{4 - Análise dos resultados}

A amostragem estatística apresenta um total de setecentos e oitenta e dois questionários aplicados.

Os dados permitem fazer algumas afirmações quanto à eficácia, preferência e aceitação de três itens complementares, porém distintos, desta pesquisa:

Mapas temáticos para o setor do turismo.

S Símbolos de informação pública adaptados às legendas de mapas turísticos.

> Protótipo de um mapa-site turístico. 


\section{Primeira afirmação}

\section{Os entrevistados aprovaram os mapas desenvolvidos.}

\section{Houve uma maior aceitação dos mapas pictóricos em relação aos convencionais}

quanto à preferência do produto cartográfico direcionado ao setor do turismo

As respostas dadas às questões formuladas com alternativas e as dissertativas ratificam a pesquisa anterior de Fiori (2003:187), que estabelece o mapa pictórico como um produto mais apropriado ao setor do turismo que o mapa convencional. Inicialmente, a preferência resulta do menor nível de exigência de abstração do produto. Isto significa que a pictografia facilita o processo de leitura do conteúdo representado, em especial, para o público leigo em cartografia.

A representação pictórica também consegue obter maior sucesso quando comparada as representações convencionais, devido ao seu poder de sedução gráfica, ou seja, seu traço "menos técnico" e mais rico em detalhes proporciona uma maior atração estética e lúdica ao produto cartográfico. Esses recursos, sendo bem aproveitados, transformam o mapa em um produto de marketing para 0 turismo.

Kokkoken e Peltonen (1999) ressaltam que, ao promover uma destinação, a cartografia para o turismo deve estar atenta ao olhar do usuário, que vê a localidade como "produto". Logo, o cartógrafo deve fornecer impressões que possam ser convertidas em estímulo, trazendo concepções realistas sobre a qualidade do tipo de lugar e suas oportunidades para férias.

Sendo assim, além da funcionalidade (normas, regras, técnicas), o mapa turístico deve ter um visual prazeroso e remeter a emoções - vontade, curiosidade de conhecer as atrações propositalmente preparadas e ilustradas - permitindo que 0 turista planeje suas atividades em seu tempo de descanso. A pictografia permite formas de representação bem aceitas tanto pelo turista quanto pelos agentes de viagens. Atualmente, sabe-se que boa parte dos mapas utilizados pelo setor é pictórica. Portanto, pensar em formas de representação, referenciadas na cartografia e produzidas com um uso mais efetivo da pictografia, é uma necessidade.

É importante esclarecer que esta pesquisa não está preocupada em produzir mapas para ver e sim para ler (rever páginas 97-100). Mesmo os denominados mapas convencionais, elaborados ao longo do trabalho fazem uso, em menor grau, da pictografia, e por conseqüência, de padronizações e convenções não impostas pela fisiologia e pela alta abstração. 
No entanto, a aquisição mais lenta do conteúdo é proposital, pois, como já foi mencionado, o leitor precisa se envolver, e literalmente viajar pelo mapa. Todavia, deve compreender o que vê.

Para finalizar, mencione-se que Fiori (1999:106) vivenciou a utilização do recurso pictográfico em uma escola no ensino fundamental. Durante um teste com mapas, uma professora da sala relatou que os alunos demoravam mais tempo para responder o mapa pictórico porque, despendiam um tempo maior observando, admirando, lendo o material. Todavia, conseguiu-se o objetivo principal: atrair, seduzir o aluno à leitura do mapa, conseqüência de uma informação que estava mais próxima da realidade do público escolhido.

\section{Segunda afirmação}

\section{Quase $\mathbf{7 0 \%}$ dos oitenta e dois símbolos de informação pública foram respondidos corretamente (contexto + símbolo)}

Na média entre brasileiros e estrangeiros, 70 dos 86 símbolos de informação pública obtiveram uma média de aceitação superior a $70 \%$

As respostas dissertativas (questionário in loco nos quatorze municípios) e as dadas às questões formuladas com alternativas (questionário do site, dividido entre brasileiros e estrangeiros) permitem reflexões quanto referentes aos oitenta e dois símbolos de informação pública analisados.

Em geral, a relação de pictogramas que receberam os maiores ou menores níveis de acerto (questionário respostas dissertativas) e aceitação (questionário respostas alternativas) são os mesmos nos três questionários aplicados.

Fica evidente que o símbolo em conjunto com o texto proporciona um auxílio fundamental a boa parte dos pictogramas, basta comparar a pontuação obtida pelos questionários: in loco e os do site.

No entanto, pode-se afirmar que alguns pictogramas são eficazes, mesmo não utilizando o texto complementar. São eles os que representam o: aeroporto, restaurante, sorveteria, hotel, correio, supermercado, hospital, praia, telefone público, banco, vôlei, natação, futebol, tênis, golfe, basquete, asa delta, igreja, teleférico, táxi, posto de gasolina, lanchonete, e internet. Ao olhar as respostas dissertativas dadas a esses pictogramas, percebe-se que os poucos entrevistados, mesmo que não acertassem exatamente o contexto, chegaram muito próximos do significado pretendido pelo produtor. 
Já outros pictogramas, mesmo recebendo boa pontuação / aceitação, aproximamse mais do que se quer informar quando acompanhados do texto verbal (símbolo + texto $=$ redundância). Logo, o usuário vai a legenda para ler o que o pictograma significa, e posteriormente, não precisa mais do recurso para interpretar a informação, pois o símbolo de informação pública se faz claro e não é mais preciso voltar à legenda.

Nesse caso se destacam os pictogramas de rodoviária, porto, metrô, heliponto, estação ferroviária, balsa, estacionamento, praça / área para piquenique, acesso para deficiente físico, camping, pára-quedismo, balonismo, esqui na neve, cafeteria, mergulho, farol, danceteria / salão de dança, esqui aquático, surfe, caverna, teatro, hipismo, autódromo / cartódromo, ciclismo / ciclovia, cooper / corrida e biblioteca. Outros pictogramas como os que representam o bondinho, parque de diversão, cachoeira, zoológico, trailer, jet ski, parque, delegacia, informação turística, playground, banheiro público, cervejaria e bar encontram-se nesta relação mesmo recebendo uma pontuação menor, porque, com o efetivo auxilio do texto-legenda, recebem um esforço particular para que aconteça uma boa interpretação do símbolo.

Existem ainda os pictogramas específicos, cuja significação requer o conhecimento da cultura, atividade ou serviço que ele representa para que a informação possa ser compreendida. Nesse caso, o texto ao lado do símbolo é mais do que um tradutor, pois também esclarece o que significa o elemento representado. Relacionam-se aqui os pictogramas: rapel / alpinismo, caiaque / canoagem, windsurfe, trekking / caminhada. Já nos símbolos Mesquita e Sinagoga é visível a necessidade de referências culturais para a compreensão do grafismo. Ao ser referenciado no Ocidente, o pictograma Igreja atinge altos valores de compreensão $(93,4 \%)$ e aceitação (82\%) nos dois questionários usados (in loco e site). É seguido pelo pictograma Sinagoga, associado aos judeus, ao judaísmo, Estrela de Davi, Israel $(41,3 \%$ e $78 \%)$. Já o pictograma Mesquita é associado, em sua grande maioria, a lua e a noite, apresentando uma menor compreensão $(23,8 \%)$ e aceitação (66\%).

Por fim, mencionem-se os pictogramas que se referem a conceitos amplos e / ou um traçado distante daquilo que se pretende informar. Nesse caso, além do texto como apoio, dever-se-ia pensar em alguma alteração gráfica no pictograma que pudesse aprimorar seu teor informacional. Enquadram-se ali os símbolos locação / aluguel de carro, shopping / Compras, artesanato, oficina mecânica, guarda malas / guarda volumes, monumento, marina / atracadouro, bebedouro, pousada e barco / barco a vela. 
Quatro símbolos merecem uma consideração especial:

- Construção histórica - o produtor errou ao inserir, na mesma pergunta, dois símbolos que significavam a mesma coisa, mas em locais diferentes, isto é, a "torre" é usada para indicar construções históricas em alguns mapas europeus, enquanto a "casa" é utilizada em placas de sinalização turística no Brasil.

- Albergue da juventude - a confecção do pictograma foi inspirada no símbolo utilizado pela organização dos albergues da juventude, localizados em todo o mundo. Dessa forma, o símbolo não merece correção, mas que deve ser pelos usuários de albergues.

- Vista panorâmica - é um pictograma verdadeiramente ruim, como se pôde comprovar nas duas pesquisas trabalhadas. Os níveis de compreensão (10\%) e aceitação (54\%) foram muito baixos. Deve, portanto, ser elaborado um outro pictograma para o tema.

- Museu - também mereceria reformulação: mesmo sendo um pictograma mundialmente conhecido e utilizado em placas de sinalização turística, apresenta um nível de aceitação e compreensão baixo (65\% e $20 \%)$. Somese ao problema, o fato já mencionado de que mais de $50 \%$ dos entrevistados interpretaram o símbolo referente a museus como se representasse um circo.

Esta pesquisa confirma alguns resultados já registrados em Fiori (2003: 177-178) sobre a utilização dos símbolos de informação pública em legendas para mapas turísticos.

\section{Terceira afirmação}

Há interesse na utilização de textos em mapas turísticos

Corroborando a pesquisa empírica de Fiori (2003:189), a maioria dos entrevistados aprovou a utilização de textos verbais na parte inferior do mapa por proporcionarem informações complementares acerca dos atrativos turísticos. Entretanto, os quase $17 \%$ de rejeição desse recurso, somados aos comentários expostos nas respostas dissertativas, alertam para a necessidade de ter cuidado com a quantidade de caixas-texto, pois informações em demasia podem gerar um resultado inverso, já que a poluição visual é capaz de dificultar e até confundir o usuário, prejudicando a eficiência do produto cartográfico. 


\section{Quarta afirmação}

\section{Os entrevistados acharam o mapa-site regular}

\section{A navegação e a interatividade precisam ser melhoradas no protótipo mapa-site turístico}

Cabe aqui uma justificativa referente à baixa avaliação do protótipo mapa-site turístico. Desde o momento em que o site da pesquisa foi disponibilizado na Internet, percebeu-se que vários itens interativos poderiam e deveriam ser melhorados ou modificados. Entretanto, havia três fatores limitadores:

1) O tempo para o desenvolvimento do mapa-site foi curto (3 semanas).

2) A elaboração do produto necessitava de recursos técnicos e de um profissional mais adequado, o que elevaria o custo do projeto.

3) Não houve tempo suficiente para realizar um pré-teste.

Por exemplo, o modo como foram elaborados os pop ups, onde a informação (texto e/ou figura) só mantinha aberta se o cursor permanecesse sobre a caixa, ou então, a falta de indicações mais claras e diretas ao internauta, o que fez com que grande parte dos entrevistados não conseguisse ou tivesse dificuldades em acessar a seqüência dos quatro mapas em zoom (escala menor para maior) até chegar ao questionário do tema 3 . Essa limitação é flagrante quando se compara a quantidade de sujeitos que responderam os outros temas:1 e 2 (ver tabelas $11 \mathrm{~A}$, B e C).

O acesso ao tema 3 pôde ser melhorado quando foi inserida no site uma página de advertência sobre como prosseguir para chegar ao questionário (Figura 110).

Um último problema apontado foi o tempo de download para abrir principalmente às páginas do mapa-site turístico de Caxambu. $O$ que já se faz é disponibilizar o mesmo mapa em resoluções (dpi) diferentes, ou seja, na página do site (tela do computador), o mapa tem uma resolução menor do que quando disponibilizado para impressão. 
Figura 110 - A advertência para acesso no tema 3 do site

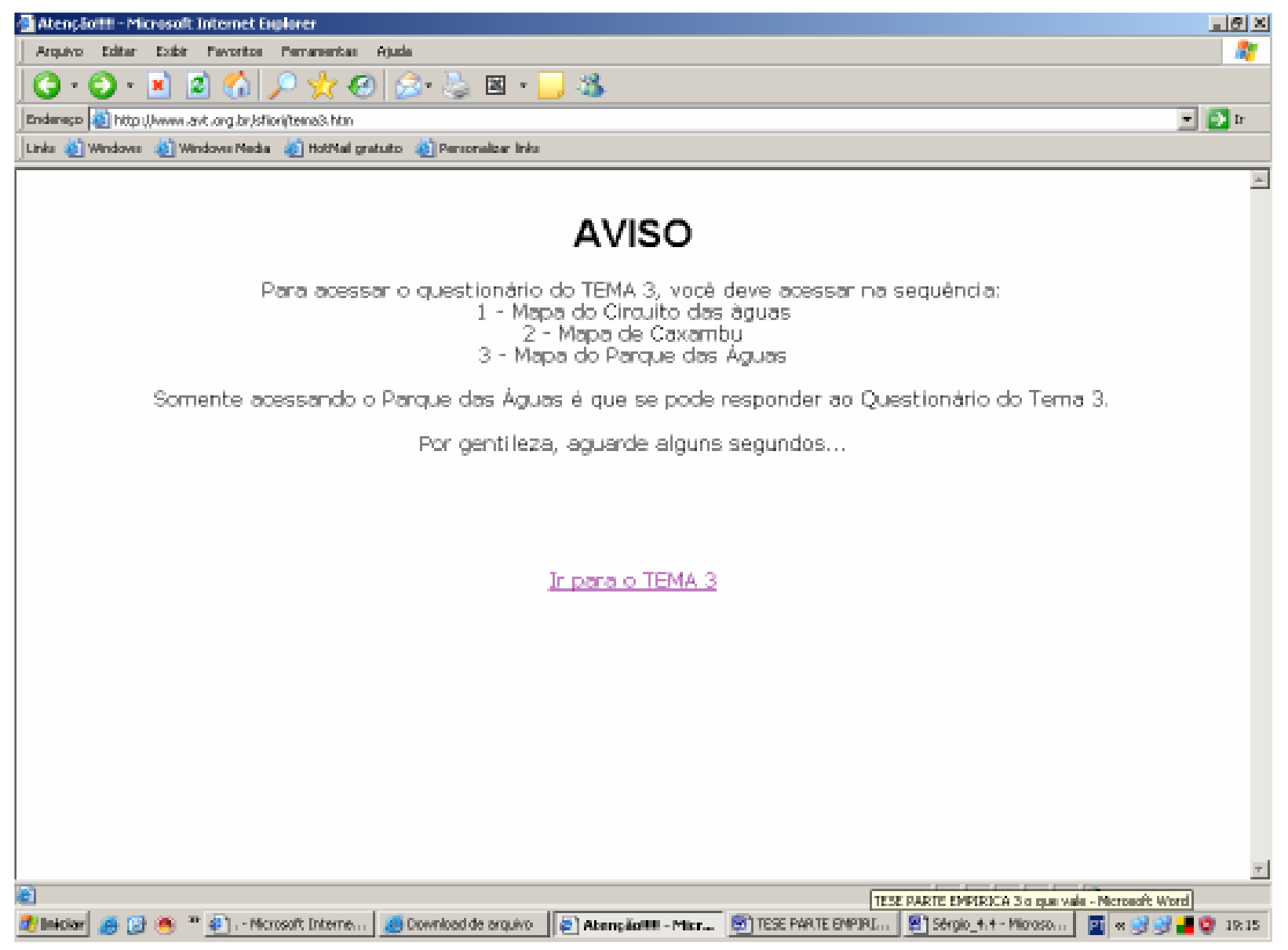

\section{Quinta afirmação}

Os entrevistados aprovaram as formas de

representação (arte) e o conteúdo do protótipo mapa-site

A média geral e particular (brasileiros ou estrangeiros) ultrapassou 90\% de aprovação. $O$ fato só reforça e legitima ainda mais a pictografia como recurso gráfico e visual muito importante em mapas temáticos para o setor do turismo (ver a segunda afirmação) e, neste caso, adaptada ao meio digital e interativo.

Mesmo com a alta aprovação dos itens, os entrevistados alertam para a grande quantidade de informação (textos, ilustrações), que, se reduzidas, podem melhorar ainda mais o produto.

Para serem mais eficientes, os mapas do protótipo mapa-site de Caxambu deveriam ter uma quantidade menor de informações dispostas sobre cada mapafundo. Essas informações poderiam ser distribuídas em pop ups e em uma legenda 
com layers (camadas, tópicos) que seriam habilitados segundo a vontade do usuário.

As cinco afirmações encerram mais uma etapa de pesquisas teórico-aplicadas que articula e analisa a cartografia temática e o uso da pictografia. A disposição e o aprofundamento nesta linha de discussão é decorrente do que autores como Oliveira (1993) e Taylor (1991) destacam ao afirmar que a avaliação do material cartográfico tem início em perguntas simples, porém fundamentais, como:

$\checkmark$ Para que ou por que esse mapa?

$\checkmark$ Que tipos de usuários têm necessidade dele?

$\checkmark$ Qual a finalidade do material a ser confeccionado?

Tais indagações permitem segmentar o público potencial para o material que é proposto, oferecendo orientações para o direcionamento do trabalho.

Kolacny (1994) pondera que o mapa só atinge seu objetivo quando o produtor considera a produção e o consumo como dois processos interligados. Por isso, desde a primeira pesquisa que nos propusemos fazer, sempre foram elaborados testes e análises empíricas após o planejamento e posterior confecção do material idealizado. Acredita-se se essa a maneira mais acertada de quantificar e qualificar a eficácia do produto finalizado. Colocam-se então, duas situações distintas, mas complementares, desenvolvidas durante o processo de comunicação elaborado por Board (1996):

Primeiro, como produtor - o profissional tem a obrigação de desenvolver uma abordagem teórico-metodológica cuidadosa e direcionada. Conseqüentemente, ao estabelecer o setor do turismo a ser atingido e o turista como público potencial, o produtor deve estar habilitado e preocupado (teoria e prática) em elaborar materiais o mais adequado possível ao grupo previamente selecionado.

Segundo, como usuário - auxiliado por questionários, o produtor busca se colocar no lugar do usuário. As análises das respostas ajudam a verificar qual o nível de eficácia obtido durante o processo que transmitiu a informação.

A decisão de privilegiar os símbolos pictóricos não foi tomada ao acaso. Os trabalhos desenvolvidos anteriormente (ver Fiori: 1999) com 120 alunos do ensino fundamental e com 160 pessoas divididas entre moradores locais e turistas (Fiori: 2003) apontam um instigante e desafiador campo de pesquisa: para uma maior discussão do uso da arte e, por conseqüência, da pictografia e da visão oblíqua em mapas para turistas e leigos em cartografia. Some-se ainda, a discussão sobre o mapa impresso e a sua adequação ao meio digital interativo. 


\section{CONSIDERAÇÕES}

FINAIS 


\section{4 - Considerações finais}

De acordo com a linha de estudo adotada, a história da cartografia, em todo registra inúmeras e distintas formas de representação do espaço; logo, é preciso dar à devida importância ao contexto cultural em que o mapa está inserido.

No caso da cultura ocidental, pode-se afirmar que os mapas sempre representaram o espaço com os olhos de um determinado tempo e de uma cultura. Isso ocorreu desde as primeiras representações espaciais feitas em pedra e barro na Antigüidade; passou pelos mapas com visões teocêntricas da Alta Idade Média; por aqueles que serviam como documento de legitimação e conquista de terras nos séculos XV e XVI; pelos utilizados nas guerras européias dos séculos XVIII e XIX, chegando finalmente ao sensoriamento remoto e ao geoprocessamento no século $\mathrm{XX}$.

Entretanto, durante um significativo período do século passado, os mapas de culturas não-européias só receberam alguma atenção da parte dos historiadores ocidentais quando possuíam certas semelhanças com os mapas europeus. Por exemplo: deveriam oferecer um sistema de orientação, escalas regulares e elementos da geometria euclidiana. Analisar o porquê destas diferenças não era uma tarefa cogitada.

Essa visão cientificista começou a mudar em 1987 com J. B. Harley e D. Woodward que, no primeiro dos quatro volumes da História da Cartografia, adotaram uma definição de mapa que permitia introduzir um possível relativismo no estudo histórico das cartas geográficas. A iniciativa fez com que se reconhecesse a diversidade das representações do espaço no grande mosaico da cultura humana universal.

Independentemente dos discursos e formalismos (suposta certeza e erro), cada mapa tem um porquê existencial, isto é, a forma está diretamente relacionada com a sua função. E é por isso que esta pesquisa discute e propõe a elaboração de mapas temáticos voltados ao setor do turístico, e posteriormente, sua adaptação ao meio digital, fazendo uso de recursos interativos. Aliás, a elaboração dos mapas turísticos não descarta a cartografia convencional e abstrata pautada nas convenções matemáticas e nas novas tecnologias do século XXI. Pelo contrário, todo esse conteúdo é utilizado e readaptado, procurando um resgate histórico, ou seja, o reviver daquela época em que se fazia uso mais freqüente da pictografia nos mapas.

Esse resgate acontece em um momento histórico em que as viagens a longas distâncias se tornaram rápidas e comuns, possibilitando que as pessoas conheçam outros atrativos naturais e culturais dentro ou fora de seu país. Portanto, ao pensar na elaboração de um mapa para o setor do turismo, deve-se ter em mente três perguntas essenciais: para que, para quem e como fazer o mapa temático turístico. 
Até porque é o público potencial que deve conduzir o produtor do mapa na escolha de quais representações devem ser mais usadas e eficazes do que outras.

A eficácia do mapa se resume a dois tópicos: conseguir alcançar o entendimento (boa leitura, compreensão) e as expectativas (sedução) do público para quem o mapa é elaborado.

Justifica-se, então, o tema e o problema quanto à elaboração e à eficácia dos mapas e do protótipo mapa-site turístico: diferentes tipos de usuários merecem diferentes tipos de mapas. Sendo assim, os produtos oferecidos (impressos e virtuais) devem ser adequados ao público potencial (turista e leigos na semântica cartográfica) e também servir à destinação turística como um produto de marketing.

O passo seguinte apresenta questões trabalhadas por Fiori (1999 e 2003), que são retomadas e aprofundadas nesta tese, cumprindo três etapas seqüenciais:

\section{O fundamento teórico}

O mapa turístico, seja na versão convencional seja na pictórica, traz reflexões sobre a relação tempo-natureza-cultura. O empirismo do relativismo relativista admite que os instrumentos e as cadeias de comunicação, criadas ao longo do tempo, estabelecem assimetrias e igualdades, hierarquias e diferenças. Logo, os mundos só parecem comensuráveis e incomensuráveis quando ficam presos a "medidas que puderam ser medidas". Essa linha de raciocínio possibilitou o enfoque interdisciplinar da pesquisa, principalmente entre os campos da Antropologia, da Lingüística, da Geografia, da Cartografia e do Turismo, e temas relacionados como o hibridismo, a comunicação, o espaço, a paisagem, a percepção, a leitura e interpretação do mapa, a arte e os símbolos, os atrativos naturais e culturais (material e imaterial), etc.

Em suma, a elaboração de mapas temáticos para o turismo apresentou diferentes graus de representação da mesma realidade selecionada, que se caracteriza por um maior ou menor nível de abstração dos símbolos. Além disso, a posterior elaboração do mapa-site turístico trabalhou a interatividade no meio digital, o que possibilitou a identificação de múltiplas escalas e uma grande quantidade de informações que podem ser habilitadas e desabilitadas por meio de botões, pop ups, entre outros recursos.

\section{O design e as técnicas}

A base teórica orienta o planejamento de como trabalhar o conteúdo, ou seja, o que se quer dizer; a forma, ou o meio de expressão a ser utilizado, graças ao controle exercido pela técnica. Inicialmente se apresentam os elementos visuais e gráficos indispensáveis à elaboração dos mapas, sejam eles convencionais sejam pictóricos, e do protótipo mapa-site como os tipos de linha, as figuras e os sólidos 
geométricos, os diferentes tipos de perspectivas, a cor, a luz e sombra, a textura, a proporção, o zoom estático em etapas, os recursos pop up, pan, etc.

O efetivo processo de representação dos mapas convencionais, dos elementos interativos do protótipo mapa-site turístico e de toda a diagramação final ocorre exclusivamente em meio digital. Já nos mapas pictóricos, a maior parte das ilustrações foram concebidas analogicamente, sendo posteriormente digitalizadas e colorizadas no computador. O procedimento possibilitou ao produtor mesclar técnicas analógicas e digitais na busca de um material diversificado, que permitisse diferentes tipos de representação e esteticamente mais atraente ao público potencial.

Os materiais utilizados vão desde lápis, papel vegetal, folha branca e caneta nanquim, até os recursos encontrados nos programas CorelDRAW, Photoshop e Dreamweaver.

\section{Avaliação empírica}

Após a finalização técnica e prática, partiu-se para a etapa de entrevistas, testes e análises dos mapas e do protótipo mapa-site turístico da cidade de Caxambu.

Os questionários foram desenvolvidos para averiguar três tópicos referentes à eficácia, preferência e aceitação de três itens complementares, porém distintos:

> Mapas temáticos para o setor do turismo.

> Símbolos de Informação Pública adaptados às legendas de mapas turísticos.

Protótipo de um mapa-site turístico.

A aplicação dos questionários ocorreu de duas maneiras diferentes:

> In loco - Durante uma das atividades oferecidas em um curso de qualificação de professores (Projeto Caminhos do Futuro) desenvolvido em 14 estados brasileiros.

$>$ Internet - Acesso ao site da pesquisa.

As três etapas acima ajudaram a investigar três hipóteses, estabelecidas no início da pesquisa, e permitiram fazer as seguintes afirmações:

1) Os mapas pictóricos têm maior aceitabilidade e preferência dos usuários durante a estada na destinação, além de serem mais adequados para incentivar o turismo. A hipótese, construída em trabalhos anteriores, (Fiori: 1990 e 2003), foi novamente confirmada o que estabelece a consistência e o interesse por esse tipo de produto.

2) O Símbolo de Informação Pública é um bom recurso gráfico de reconhecimento do conteúdo que se quer comunicar (atrativo, serviço, 
acomodação, etc), sendo possível uma simbologia padronizada em âmbito mundial. Além disso, pode ser habilmente utilizado e adaptado na elaboração de legendas para mapas turísticos.

3) A inserção dos mapas turísticos (convencionais e pictóricos) em meio digital interativo (protótipo mapa-site turístico) recebeu uma aprovação regular dos entrevistados. O grau de insatisfação pode ter ocorrido em conseqüência de uma finalização não-adequada do produto, que pode ser revisto $e$ reavaliado.

A pesquisa aponta para a necessidade de uma discussão maior do uso da arte e, como conseqüência, da pictografia, da visão oblíqua e dos Símbolos de Informação Pública em mapas turísticos impressos e em meio digital interativo. Até porque, atualmente, é indiscutível que boa parte dos mapas do setor do turismo são pictóricos ou utilizam a pictografia em grande quantidade.

Pensar formas de representação que resultem de uma composição referenciada nas bases e convenções cartográficas praticadas hoje, somada ao uso mais efetivo da pictografia é um fato que precisa continuar a ser investigado. 


\section{5 - Bibliografia}

ALBUQUERQUE, L. Curso de história náutica. Lisboa: Alfa. 1989.

ALCÂNTARA, M. L. B \& SADER, R. T. Paisagem e cultura. Imaginário. São Paulo, n.5, p.83-89. 1999.

ALMEIDA, R. A.; GUERRERO; A. L. e FIORI, S. R. Caminhos do Futuro. Geografia e cartografia para o turismo. São Paulo: Ministério do Turismo, 2007.

ALZUA, A., O'LEARY J.T. \& MORRISON A. M. Cultural and heritage tourism: Identifying niches for international travelers. The Journal of Tourism Studies, v. 9, n.2, p.2-13. 1998.

ANDRÄ, H. \& FALCÃO, E. C. América preterida eventa. São Paulo: Indústria de Papel Leon Feffer S.A., 1966.

ARNOLD, L. M. Western Australia's Pilbara touring map. Cartography, v.21, n.1, p.17-20. 1992.

ARROWSMITH, C. \& NTUWAH, W. Mapping Potencial for tourist segments. Cartography, v.31, n.1, p. 55-61, 2002.

BARBOSA, I. S. Propaganda e significação: do conceito à inscrição psico-cultural. In: CORRÊA, T. G. Comunicação para o mercado. 2.ed. São Paulo: Edicon, p.3150.1995.

BARTHES, R. Crítica e verdade. São Paulo: Editora perspectiva, 1970. . Elementos de Semiologia. São Paulo: Cultrix, Editora da USP, 1971.

O óbvio e o obtuso: ensaios críticos III, Rio de Janeiro: Nova Fronteira, 1990.

BELLUZZO, A. M. M. O Brasil dos viajantes: a construção da paisagem. São Paulo: Metalivros - Fundação Emílio Odebrecht, 1994.

BENI, M. C. Análise estrutural do turismo. São Paulo: Senac, 1998.

BENKENSTEIN, M.; YAVAS, U. \& FORBERGER, D. Emotional and Cognitive antecedents of customer satisfation in leisure services: the case of the Rostok Zoo. Journal of Hospitality \& Leisure Marketing, v.10 (3/4), p.173-184, 2003.

BERTIN, J. New look at cartography. In: D.R.F. Taylor (ed.) Graphic Communication and Design in Contemporary. E.U.A: John Wiley \& Sons, p. 69$86,1983$.

Sémiologie Graphique: les diagrammes, les réseaux, les cartes. Paris: Monton \& Gauthier-Villars, 1967.

. Teoria da comunicação e teoria da representação gráfica.

Geocartografia, n.13, p.1-11,1996. 
. Ver ou ler: um olhar sobre a cartografia. Seleção de textos - Associação dos Geógrafos Brasileiros, n.18, p. 45-53,1988.

BOARD, C. Comunicação e recuperação de informações espaciais de mapas temáticos. Geocartografia, n.7, p.1-9, 1996.

BOSI, A. Reflexões sobre a arte. 7.ed., São Paulo: Ática, 2000.

BOURDIEU, P. A economia das trocas simbólicas. São Paulo: Perspectiva, 1974. . As regras da arte: gênese e estrutura do campo literário. São Paulo: Companhia da Letras, 1996. . O poder simbólico. 3.ed., Rio de Janeiro: Bertrand Brasil, 2000.

BRILL, A. Da arte e da linguagem. São Paulo: Perspectiva, 1988.

BROWN, A.; EMMER, N. \& WORM, J. VAN DEN Cartographic design and production in the Internet Era: the example of tourist web maps. The Cartographic Journal, v.38, n.1, p. 61-72, 2001.

BRUNS, C. B. Curso de formação de condutores. São Paulo, Tecnodata: 2000.

CABANELLAS, I. Dibujo. 2.ed., Espanha: Editorial Magistério Español S.A, 1976.

CALVINO, I. As cidades invisíveis. $12^{\mathrm{a}}$ reimpressão, São Paulo: Companhia das Letras, 1999.

CANCLINI, N. G. A socialização da arte: teoria e prática na América Latina. 2.ed., São Paulo: Cultrix, 1984.

. Culturas híbridas: estratégias para entrar e sair da modernidade.

4.ed., São Paulo: EDUSP, 2003.

CARNEIRO, R. J. B. Sinalização turística: diretórios e sistemas nacionais e internacionais. (Dissertação de Mestrado). Escola de Comunicações e Artes, Programa de Pós-Graduação em Ciências da Comunicação, Universidade de São Paulo, São Paulo. 2001, 206p.

CARTWRIGHT, W. \& HEATH, G. Geography as seen from the window: exploration bout viewpoint-specific images of geography defined by tools of visualization. Cartography, v.31, n.2, p.103-117, 2002.

. Hardware, software and staffing requirements of multimedia cartography: an update. Cartography, v. 25, p.67-80, 1996.

. Multimedia and mapping. Cartography, v. 22, p.25-32. 1993.

CASTNER, H. W. Education throught mapping: a new role for the school Atlas. Cartographica, v.14, p.72-91, 1987. 
CAVALCANTI, L. S. A construção de conceitos geográficos no ensino: Uma análise de conhecimentos geográficos em alunos de $5^{a}$. e $6^{a}$. séries do ensino fundamental. (Tese de Doutorado) Faculdade de Filosofia, Letras e Ciências Humanas, Departamento de Geografia, Universidade de São Paulo, São Paulo. 1997, 118p.

$\mathrm{CHON}, \mathrm{K}$. Understanding recreational traveller's motivation, attitude and satisfation. The Tourist Review, n.1, p. 3-7, 1989.

CHRISTOFOLETTI, A. As perspectivas dos estudos geográficos. In: Perspectivas da Geografia. 2.ed. São Paulo: Difel, p.11-36, 1985.

CITELLI, A. Linguagem e persuasão. São Paulo: Ática, 1985. (série princípios)

CLARKE, L. M. An experimental investigation of communicative eficiency of point symbols on tourist maps. The cartographic Journal, v. 26, p.105-110, 1989.

COELHO, R. Da antropologia simbólica à antropologia cognitiva. Imaginário. n.1. p.11-39, 1993.

COLLINS-KREINER, N. Cartographic characteristics of current Christian pilgrimage maps of the Holy Land. Cartographica, v. 34, p. 45-53, 1997.

COMISSÃO PRÓ-ÍNDIO DO ACRE Atlas geográfico indígena do Acre. Acre: CPI/AC, 1996.

COSGROVE, D. \& DANIELS, S. Introduction: iconography and landscape. In: Theiconography of landscape: essays on the simbolic representation, design and use of past environments. Great Britain: Cambridge University Press, p.1-10, 1994.

. e JACKSON, P. Novos rumos da geografia cultural. In: CORREA, R. L. e ROSENDAHL, Z Geografia Cultural: um século (2). Rio de Janeiro: EdUERJ, p.15-32, 2000.

CROSHER, J. Os astecas. 15 ed., São Paulo: Melhoramentos, 2000.

CRUZ, O. Alguns conhecimentos básicos para fotointerpretação. Aerofotogeografia, v. 25, São Paulo: Instituto de Geografia-USP, p.1-13, 1981.

DACEY, M. F. Aspectos lingüísticos dos mapas e a informação geográfica. Boletim de Geografia Teorética, AGETEO, Rio Claro, v.8, n.15, p. 5-16, 1978.

DELANO-SMITH, C. Cartografia e imaginação. O correio da UNESCO. São Paulo: FGV, v.19, n.8, p.10-13, 1991. (Ed. em português)

DIENER, P. \& COSTA, M. F. A América de Rugendas: obras e Documentos. São Paulo: Kosmos, 1999.

Rugendas e o Brasil. São Paulo: Capivara, 2002.

DONDIS, A. D. (1991) Sintaxe da linguagem visual. São Paulo: Martins Fontes, 1991.

DREYER-EIMBCKE, O. O descobrimento da Terra: histórias da aventura cartográfica. São Paulo: Edusp e Melhoramentos, 1992. 
FALCÃO, G.M. Psicologia de aprendizagem. São Paulo: Ática, 1988.

FARINA, M. Psicodinâmica das cores em comunicação. 4. ed., São Paulo: Edgard Blücher Ltda e Modesto Farina, 1990.

FIORI, S. R. (2005a) Touristic maps: the challenge of using art in the digital era. In: XXII INTERNATIONAL CARTOGRAPHIC CONFERENCE. A Coruña. Mapping Approaches into a changing world. v.1. Espanha: International Cartographic Association, p.1-10, 2005.

- Atlas pictórico: proposta metodológica para a confecção e uso didático. (Trabalho de Graduação Individual) Faculdade de Filosofia, Letras e Ciências Humanas, Departamento de Geografia, Universidade de São Paulo, São Paulo, 1999, 130p.

- Confecção de mapas para o turismo: a "leitura" e as expectativas do público-alvo". Imaginário, n. 9, p.253-270, 2003b.

Mapas Turísticos: o desafio do uso da arte na era digital. (Dissertação de Mestrado) Faculdade de Filosofia, Letras e Ciências Humanas, Departamento de Geografia, Universidade de São Paulo, São Paulo. 204p, 2003a.

Técnicas de desenho e elaboração de perfis. In: VENTURI, L.A.B. Praticando Geografia: técnicas de campo e laboratório. 1. ed., São Paulo: Oficina de textos, p.211-223, 2005b.

FORREST, D. \& CASTNER, H. W. The design and perception of point symbols for tourism maps. The cartographic Journal, British Cartographic Society, London, v. 22, p.11-29, 1985.

. On the design of point symbols for tourist maps: enclosed or not enclosed is not the question! The cartographic Journal, v. 35, p. 79-81, 1998.

FRANKS, G. Landscapes: learn to drawn step by step. 3.ed. California: Walter Foster Publishing, Inc, 2003.

FURLAN, S.A. Lugar e cidadania: implicações sócio-ambientais das políticas de conservação ambiental - situação do Parque Estadual de Ilhabela na Ilha de São Vicente. (tese de doutorado - volume 1) Faculdade de Filosofia, Letras e Ciências Humanas, Departamento de Geografia, Universidade de São Paulo, São Paulo, 2000, 277p.

GALEFFI, R. Fundamentos da criação artística. São Paulo: Melhoramentos Edusp, 1977.

GALLARZA, M. G., SAURA, I. G. \& GARCíA, H. C. Destination image: towards a conceptual framework. Annals of tourism research, v. 29, p. 56-78, 2002.

GASPAR, M. (Manuscrito datado de 1594) Livro de Universal de derrotas, alturas, longetudes, e conhencenças. Códice 1507 da Biblioteca Nacional de Lisboa, 112 f. 
GEIGER, P. P. Turismo e espacialidade. In: Congresso Internacional de Geografia e Planejamento do Turismo "Sol e Território", 1995, São Paulo. Turismo e Geografia: reflexões teóricas e enfoques regionais. São Paulo: Hucitec, 1999.

GEPP, H. G. e FERREIRA, J. R. M de O. Um pouco de São Paulo. São Paulo: Imprensa Oficial do Estado, 2002.

GERBER, R.; BURDEN, P. \& STANTON, G. Development of public Information Symbols for tourism and recreational mapping. The cartographic Journal, v. 27: p.92-103, 1990.

GIRARDI, G. A cartografia e os mitos: ensaios de leituras de mapas. (Dissertação de Mestrado). Faculdade de Filosofia, Letras e Ciências Humanas, Departamento de Geografia, Universidade de São Paulo, São Paulo. 1997, 118p.

- Aventuras da leitura de mapas. In: SEEMANN, J. A aventura cartográfica: perspectivas, pesquisas e reflexões sobre a cartografia humana. Fortaleza: Expressão Gráfica e Editora, 2005, p. 61-72.

GNOTH, J, ZINS, A., LENGMUELLER, R. \& BOSHOFF, C. Emotion, mood, flow and motivation to travel. Journal of Travel \& Tourism Marketing, v. 9, n.3, p. 23-34, 2000.

GOLLEDGE, R. G.; JACOBSON, R. D.; KITCHINN, R., BLADES, M. Cognitive maps, spacial abilities, and humam wayfinding. Geographical Review of Japan, v. 73, n.2, p. 93-104, 2000.

GOMBRICH, E. H. Arte e ilusão: um estudo da psicologia da representação pictórica. 3 ed., São Paulo, Martins Fontes, 1995, 473p.

. La imagen y el ojo: nuevos estudios sobre la psicologia de la representación pictórica. 2.ed., Espanha: Alianza Editorial, 1991.

.; HOCHBERG, J. \& BLACK, M. Art, perception and reality. 5.ed.,

Baltimore and London: The Johns Hopkins University Press, 1992.

GOMES, P. C. C. Geografia e Modernidade. Rio de Janeiro: Bertrand Brasil, 1996.

GOOSSENS, C. Tourism information and pleasure motivation. Annals of Tourism Research, v.27, n.2, p.301-321, 2000.

GRELOT, J. P. Os agrimensores do espaço. O correio da UNESCO. São Paulo: FGV, 19(8):29-32, 1991.

GUERRERO, A. L. A. \& FIORI, S. R. A cartografia como elemento no turismo de aventura. In: UVINHA, R. R. Turismo de aventura: reflexões e tendências. São Paulo: Aleph, p.137-152, 2005. (Série turismo)

- A aprendizagem docente de conceitos elementares da

Geografia Física e da Cartografia de Base: um estudo de caso na região de Campo 
Limpo - SP. (Dissertação de Mestrado) Faculdade de Filosofia, Letras e Ciências Humanas, Departamento de Geografia, Universidade de São Paulo, São Paulo, 2004, 283p.

HALL, S. A identidade cultural na pós-modernidade. 8.ed., Rio de Janeiro: DP\&A editora, 2003.

HARLEY, J. B. A nova história da cartografia. O correio da UNESCO. São Paulo: FGV, v.19, n.8, p.4-9, 1991.

. e WOODWARD, D. - The History of Cartography. V.I-IV. Chicago:

The Chicago University Press, 1987.

. Maps, knowledge, and power. In: Cosgrove, D. \& Daniels, S. The iconography of landscape: essays on the simbolic representation, design and use of past environments. Great Britain: Cambridge University Press, p. 277-312, 1994.

INTERNATIONALE TOURISMUS BÖRSE Maps for tourists: a systematic approach to tourist cartography. In: International Tourist Fair, Berlin, p.163-168, 1987.

JOHNSTON, B. \& CARTWRIGHT, W. An historical overview of games and the spatial sciences within the learning environment. Cartography, v.29, n.2, p.65-73, 2000.

JOLY, F. A cartografia. Campinas: Papirus, 1990.

KEATES, J. S. Understanding maps. New York: Longman, 1982.

KOKKONEN, P. \& PELTONEN, A. Mapping lakelands: challenges $f$ map design for tourism. In: International Cartographic Conference, Ottawa, p.1-7, 1999.

KOLACNY, A. Informação cartográfica: conceitos e termos fundamentais na cartografia moderna. Geocartografia, n.2, p. 3-11, 1994.

KOZEL, S. Comunicando e representando: mapas como construções socioculturais. In: SEEMANN, J. A aventura cartográfica: perspectivas, pesquisas e reflexões sobre a cartografia humana. Fortaleza: Expressão Gráfica e Editora, p.131-149, 2005.

KRAAK, M-J. The cartographic visualization process: from presentation to exploration. The cartographic Journal, v. 35: p.11-15, 1998.

LATOUR, B. Jamais fomos modernos: Ensaio de antropologia simétrica. Rio de Janeiro: Ed. 34, 1994. (Coleção Trans)

LEUNG, L-F. \& LI, Z. Experimental evaluation of the effectiveness of graphic symbols on tourist maps. Cartography, v.31, p.11-20, 2002.

LEWIS, M. G. Rhetoric of the western interior: modes of environmental description in American promotional literature of the nineteenth century. In: Cosgrove, D. \& Daniels, S. The iconography of landscape: essays on the simbolic representation, design and use of past environments. Great Britain: Cambridge University Press, 
p.179-193, 1994.

LIMA, M. L. F. C. Eco(turismo) em áreas protegidas: um olhar sobre Fernando de Noronha. (Tese de doutorado) Faculdade de Filosofia, Letras e Ciências Humanas, Departamento de Geografia, Universidade de São Paulo, São Paulo. 2002, 306p.

LOWENTHAL, D. Geografia, experiência e imaginação em direção a uma epistemologia geográfica. In: CHRISTOFOLETTI, A. (Org.) Perspectivas da Geografia. 2.ed. São Paulo: Difel, p.103-141, 1985.

LUBBE B. Primary image as a dimension of destination image: an empirical assessment. Journal of travel \& tourism marketing, v.7, n.4, p.21-42, 1998.

MacEACHREN, A. M. How map work: representation, visualization and design. Guildford Press: New York, 1995.

Some Truth with Maps: a primer on Symbolization and design. Washington, D.C.: Association of American Geographers, 1994.

MACKAY, K. J. \& FESENMAIER, D. R. An exploration of cross-cultural destation image assessment. Journal of travel research, v.38, p.417-423, 2000.

Pictorial element of destination in image formation. Annals of tourism research, v.24, n.3, p.537-565, 1997.

MARTINELLI, M. Curso de cartografia temática. São Paulo: Contexto, 1991. (coleção: manuais contexto)

MAYHEW, D. J. Principles and guidelines in software user interface design. Englewood Cliffs: Prentice Hall, 1992.

MENNO-JAN, K. \& DRIEL, R. V. Principles of hipermaps. Computers \& Geosciences, v.23, n.4, p.457-464, 1997.

MILLER, S. \& PUPEDIS, G. Spatial interface design for the web - a question of usability. Cartography, v.31, n.2, p.119-134, 2002.

MONMONIER, M. How to lie with maps. 2.ed., Chicago and London: The University of Chicago Press, 1996.

MORAES, A. C. R. Ideologias geográficas. 4.ed., São Paulo: Hucitec, 2002. (Série Linha de Frente)

MOREIRA LEITE, M. L. Texto visual e texto verbal. In: FELDMAN-BIANCO, B. \& Desafios da imagem: fotografia, iconografia e vídeo nas ciências sociais. Campinas: Papirus, 1998, p. 37-49.

MOSCARDO, G. Making visitors mindful: principles for creating sustainable visitor experiences through effective communication. USA: Sagamore Publishing, 1999. (Advances in tourism applications series - volume two)

MUEHRCHE, P. C. Map use: reading, analysis, interpretation. 2.ed. Wisconsin: JP Publications, 1986. 
MUKAROVSKY, J. Escritos sobre a semiótica da arte. Lisboa: Editorial Estampa, 1981.

NORRILD, J. Las postales como geradoras de imagen de destino: El gaúcho y la identidad argentina. Estudios y Perspectivas en Turismo, v.10, p.113-130, 2001.

OLIVEIRA, C. Curso de cartografia moderna. Rio de Janeiro: IBGE, 1993.

OLIVEIRA, L. de Estudo metodológico e cognitivo do mapa. São Paulo: IGEOGUSP, 1978, 130p. (Série Teses e Monografias)

ORLANDI, E. P. As formas do silêncio: No movimento dos sentidos. 2.ed., Campinas: Ed. UNICAMP, 1997.

. Cidade dos sentidos. Campinas: Pontes, 2004.

. Discurso e texto: formulação e circulação dos sentidos. 4.ed.,

Campinas: Pontes, 2005.

OSBORNE, B. S. The iconography of nationhood in Canadian art. In: Cosgrove, D. \& Daniels, S. The iconography of landscape: essays on the simbolic representation, design and use of past environments. Great Britain: Cambridge University Press, p.162-178, 1994.

PADILLA, O. T. El Turismo: fenômeno social. 8.ed., México: Fondo de Cultura Económica, 1980.

PALMER, C. Tourism and the symbols of identity. Tourism Management, v.20, p.313-321, 1999.

PATIN, V. Tourisme et patrimoine. Paris: La documentation française, 2005.

PEDROSA, M. \& ARANTES, O. Forma e percepção estética: textos escolhidos II. São Paulo: Edusp, 1996.

PIRES, P. S. Ecoturismo no Brasil: uma abordagem histórica e conceitual na perspectiva ambientalista. (Tese de Doutorado), Faculdade de Filosofia, Letras e Ciência Humanas, Departamento de Geografia, Universidade de São Paulo, São Paulo. 1998. 218p.

Paisagem litorânea de Santa Catarina como recurso turístico. In: Congresso Internacional de Geografia e Planejamento do turismo "Sol e Território", 1995. Turismo - espaço, paisagem e cultura. São Paulo: Hucitec, 1996, p. 161-177.

PORTILLA, M. L. Os arquivos de Montezuma. O correio da UNESCO: São Paulo, FGV, n.8, p. 18-20, 1991.

PORTO ALEGRE M. S. Reflexões sobre iconografia etnográfica: por uma hermenêutica visual. In: FELDMAN-BIANCO, B. \& MOREIRA LEITE, M. L. Desafios da imagem: fotografia, iconografia e vídeo nas ciências sociais. Campinas: Papirus, p. 75-112, 1988. 
POTTER, S. R. () Illustrated maps on public display in Japan: geography and artistic tradition. Geographical Review of Japan, v.76, n.12, p.823-842, 2003.

PRINGLE, T. R. The privation of history: Landseer, Victoria and the highland myth. In: Cosgrove, D. \& Daniels, S. The iconography of landscape: essays on the simbolic representation, design and use of past environments. Great Britain: Cambridge University Press, p.142-161, 1994.

RAISZ, E. Cartografia Geral. 2.ed., Rio de Janeiro: Científica, 1969.

RAMIRES, R. R. Cartografia e cognição: aspectos de aprendizagem do mapa no início do processo de escolarização. (Dissertação de Mestrado) Faculdade de Filosofia, Letras e Ciências Humanas, Departamento de Geografia, Universidade de São Paulo, São Paulo, 1996. 175p.

RAMOS, F. P. Naufrágios e Obstáculos enfrentados pelas armadas da Índia portuguesa (1497-1653). São Paulo: Humanitas, 2000. (Série Iniciação)

REYES, M. C. Cibercartography from a modeling perspective. In: TAYLOR, D. R. F. Cybercartography: theory and practice. The Netherlands: Elsevier B.V., p. 63-97, 2005.

ROBINSON, A. H., MORRISON, J. L., MUEHRCKE, P. C.,KIMERLING, A. J. \& GUPTILL, S. C. Elements of cartography. 6.ed. E.U.A.: John Wiley \& Sons, Inc., 1995.

ROCHA-TRINDADE, M. B. Imagens e aprendizagens na sociologia e na antropologia. In: FELDMAN-BIANCO, B. \& MOREIRA LEITE, M. L. Desafios da imagem: fotografia, iconografia e vídeo nas ciências sociais. Campinas: Papirus, $p$. 159-171, 1988.

RODRIGUES, G. S. S. Representações da paisagem do Parque Nacional da Serra da Canastra - MG: o olhar do viajante, da população local e do geógrafo. (Dissertação de Mestrado) Faculdade de Filosofia, Letras e Ciências Humanas, Departamento de Geografia, Universidade de São Paulo, São Paulo. 2001, 110p.

SALVIA COELHO, L. M. Afinal o que é cognitivismo? Imaginário, n.1, p.41-72, 1993.

SAMAIN, E. Questões heurísticas em torno do uso das imagens nas ciências sociais. In: FELDMAN-BIANCO, B. \& MOREIRA LEITE, M. L. Desafios da imagem: fotografia, Iconografia e vídeo nas ciências sociais. Campinas: Papirus, p.51-62, 1988.

SANCHEZ, M. C. Conteúdo e eficácia da imagem gráfica. Boletim de Geografia Teorética, v.11, p.74-81, 1981.

SANTAELLA, L. O que é semiótica? 9.ed., São Paulo: Brasiliense, 1990.

SANTOS, M. A natureza do espaço: técnica e tempo, razão e emoção. São Paulo:

Edusp, 2002. 
SANTOS, M. Metamorfoses do espaço habitado. 4.ed., São Paulo: Hucitec, 1996. . Pensando o espaço do homem. 5.ed., São Paulo: Hucitec, 2004. . Por uma Geografia Nova: da crítica a geografia a uma gGeografia crítica. São Paulo: Edusp, 2002.

SEEMANN, J. Linhas imaginárias na cartografia: a invenção do primeiro meridiano. In: A aventura cartográfica: perspectivas, pesquisas e reflexões sobre a cartografia humana. Fortaleza: Expressão Gráfica e Editora, p.111-129, 2005.

SENAI - DIVISÃO DE MATERIAL DIDÁTICO. Desenho técnico e artístico. v.1, São Paulo: SENAI/SP, 1984.

SENAI - DIVISÃO DE MATERIAL DIDÁTICO. Perspectiva isométrica. v.4, São Paulo, SENAI/SP, 1984.

SENAI - DIVISÃO DE MATERIAL DIDÁTICO. Sólidos geométricos. v.3, São Paulo: SENAI/SP, 1984.

SEVERINO, A. J. Metodologia do trabalho cinetífico. 22.ed., São Paulo: Cortez, 2002.

SIMIELLI, M. E. Cartografia e ensino: proposta e contraponto de uma obra Didática. (Tese de livre docência) Faculdade de Filosofia, Letras e Ciências Humanas, Departamento de Geografia, Universidade de São Paulo, São Paulo, 1996. . Geoatlas. 12.ed., São Paulo: Ática, 1993.

.O mapa como meio de comunicação: implicações no ensino da geografia de $1^{\circ}$. Grau. (Tese de Doutorado) Faculdade de Filosofia, Letras e Ciências Humanas, Departamento de Geografia, Universidade de São Paulo, São Paulo, 1986. 205p.

SIRGY, M. J \& SU C. Destionation image, self-congruity, and travel behavior: toward an interative model. Journal of travel research, v.38, p.340-352, 2000.

SOUZA, S. R. M. Conteúdo, forma e função no design de pictogramas. In: CORRÊA, T. G. Comunicação para o mercado. São Paulo: Edicon, p.171-192, 1995.

. Do conceito à imagem: fundamentos do design de pictogramas. (Tese de doutorado) Escola de Comunicações e Artes, Programa de PósGraduação em Ciências da Comunicação, Universidade de São Paulo, São Paulo, 1992, 250p.

TANG, H. \& BISHOP, I. D. Integration methodologies for interative forest modeling and visualization systems. The Cartographic Journal, London, 39(1):27-35, 2002.

TAUBER, D. A. \& KIENAN, B. SIMCITY 2000: estratégias e segredos. São Paulo: Makron Books, 1995. 
TAYLOR, D. R. F. A conceptual basis for cartography: new directions for the information era. Cartographica, University Toronto Press, Toronto, 28(4):1-8, 1991.

. Challenge and response in cartographic deseign. In: KELLER,

C. H. \& WOOD, C.P. Cartographic design: theoretical and Practical perspectives. England: John Wiley \& Sons, p. 11-18, 1996.

The theory and practice of cybercartography: an introduction. In: Cybercartography: theory and practice. The Netherlands: Elsevier B.V., p.1-13, 2005.

THROWER, N. J. Uma nova imagem do mundo. O correio da UNESCO. São Paulo: FGV, n.8, p.25-28, 1991. (Ed. em português)

TUAN, Y. F. Topofilia: um estudo da percepção, atitudes e valores do meio ambiente. São Paulo: Difel, 1980.

TURNBULL, D. Maps are territories science is an atlas: a portfolio of exhibits. Austrália: University of Chicago Press, 1989.

VALDES, R. El acceso psicologico y la nocion de posicionamiento en el dominio del turismo. Estudios y Perspectivas en Turismo, v. 6, p. 53-76, 1997.

VASCONCELLOS, R. A cartografia tátil e o deficiente visual: uma avaliação das etapas de produção e uso do mapa. (Tese de doutorado volume I) Faculdade de Filosofia, Letras e Ciências Humanas, Departamento de Geografia, Universidade de São Paulo, São Paulo, 1993, 268p.

e ALVES FILHO, A. P. Novo Atlas geográfico ilustrado e comentado. São Paulo: FTD, 1999.

Tactile mapping design and the visually impaired user. In:

KELLER, C. H. \& WOOD, C.P. Cartographic design: theoretical and practical perspectives. England: John Wiley \& Sons, p.91-102,1996.

WAGNER, P. L. e MIKESELL, M. W. Temas da geografia cultural. In: CORREAA, R. L. e ROSENDAHL, Z. Geografia Cultural: um século (1). Rio de Janeiro: EdUERJ, p.111-167, 2000.

WOLFGRAM, D. E. Criando em multimídia. Rio de Janeiro: Campus, 1994.

WOLLHEIM, R. A pintura como arte. São Paulo: Cosac \& Naify, 2002.

WOOD, H. C. and KELLER, C. P. Design: Its pace in cartography. In: KELLER, C. H. \& WOOD, C.P. Cartographic design: theoretical and practical perspectives. England: John Wiley \& Sons, p.1-9, 1996.

WOOD, M. Visualization in historical context. In: MacEachren, A. M. \& D. R. F. Taylor Visualization in modern cartography. Pergamon, p.13-26, 1994. (Modern cartography, v. two) 
WURMAN, R. S. Ansiedade da informação: como transformar informação em compreensão. São Paulo: Cultura Editores e Associados, 1991.

\section{Sites}

AIGA. Disponível em: <http://www.aiga.org/content.cfm?content/D=147>. Acesso em: 2 set. 2005.

CAMINHOS DO FUTURO. Disponível em: <http://www.caminhosdofuturo.com.br/site/home/> Acesso em: 10 set. 2007.

CENTRO HISTÓRICO DE LA GRAN CIUDAD DE MÉXICO. Disponível em: <http://www.mapamex.com.> Acesso em: 12 dez. 2005.

CONHEÇA SALVADOR. Disponível em: <http://www.emtursa.ba.gov.br/Template.asp?nivel=00010001\&identidade=7>. Acesso em: 13 mar. 2007.

DESENHADOR VIRTUAL. Disponível em: < $<$ http://paginas.terra.com.br/arte/desenhadorvirtualcores/htm> Acesso em: 16 out. 2005.

ERCO. Disponível em <http://www.piktogramm.com> Acesso em: 2 set. 2005.

GEPP, H. G. e FERREIRA, J. R. M de O. Exposição dos mapas ilustrados da cidade de São Paulo. Disponível em: < http://www.geppemaia.com.br/mis/index. htm> Acesso em: 3 nov. 2004.

GUIA BRASILEIRO DE SINALIZAÇÃO TURÍSTICA. Disponível em: $<$ http://institucional.turismo.gov.br/sinalizacao/conteudo/principal.htm/> Acesso em: 28 set. 2005.

IDG NOW! Brasil cai três posições em ranking sobre web. Disponível em <http://idgnow.uol.com.br/AdPortalv5/InternetInterna_200405.htm/> Acesso em: 20 abr. 2005.

IDG NOW! Especial: qual a melhor tecnologia da banda larga? Disponível em: <http://idgnow.uol.com.br/AdPortalv5/Internet/nterna_060705.htm/> Acesso em: 6 set. 2005.

INPE-Manual do software Spring. Disponível em: <http://www.api.inpe.br/spring/teoria/ introd1/teoria1.htm> Acesso em: 25 de set. 2004.

MACMANIA.

$<$ http://www.terra.com.br/macmania/macmania/resenhas/resenhas_dtp.htm> Acesso: em 15 out. 2005.

MEC. Disponível em:<http://www.girus.com.br/noticias/visualiza.php?cod=3627> 
Acesso: em 5 set. 2007.

MAPA DO CENTRO DE CAXAMBU. Disponível em: <http://www.caxambu.mg.gov.br/turismo/mapadocentro.htm> Acesso em: 5 abr. 2006.

MAPA DO PARQUE DE CAXAMBU - Disponível em: <http://www.caxambu.mg.gov.br/turismo/mapadoparque.htm> Acesso em: 5 abr. 2006.

MAPA INTERATIVO DA BAHIA. Disponível em: $<h t t p: / / w w w . e m t u r s a . b a . g o v . b r / T e m p l a t e . a s p ?$ IdEntidade=7\&Nivel=00010001> MAPA INTERATIVO DE NEW JERSEY. Disponível em: <http://www.jersey.com/maps/> Acesso em: 15 set. 2007.

MAPA INTERATIVO DO DEPARTAMENTO DE GEOGRAFIA DA USP. Disponível em: <http://www.geografia.fflch.usp.br/mapas/> Acesso em: 26 jan. 2006.

MAPA INTERATIVO DO JAPÃO. Disponível em: <http://www.jnto.go.jp/eng/map/index_map.htm/\#> Acesso em: 15 set. 2007.

MAPA INTERATIVO DE TAIWAN. Disponível em: <http://202.39.225.132/jsp/Eng/html/map/index.jsp\#> Acesso em: 15 set. 2007.

MAPA INTERATIVO DE DUBLIN. Disponível em: http://www. visitdublin.com/travel/maps/dublin/ Acesso em: 15 set. 2007.

MAPA INTERATIVO DE WASHINGTON D.C.. Disponível em: <http://dcpages.com/cgi-bin/jump.cgi?/D=11576> Acesso em: 15 set. 2007.

UNESCO. Disponível em: <http://www.unesco.org.br/> Acesso em: 10 mai. 2007.

\section{Cartas}

FOLHA ASSUNCIÓN. Rio de Janeiro: IBGE, 1998. Mapa color, 75 x 60 cm, SG-21. Esc. 1:1.000.000.

FOLHA BARBACENA. Rio de Janeiro: IBGE, 1979. Mapa color, 75 x 60 cm, SF-23X-C. Esc. 1: 250.000.

FOLHA BARRAGEM. Recife: DSG, 1974. Mapa color, 72 x 62 cm, SC.23-X-B-VI, MI -1435, 1974, Esc. 1:100.000.

FOLHA CANTO DO BURITI. Recife: DSG, 1974. Mapa color, 72 × 62 cm, SC.23-XB-II, MI - 1356, Esc. 1:100.000.

FOLHA CARAGUATATUBA. Rio de Janeiro: IBGE, 1974. Mapa color, 75 x $60 \mathrm{~cm}$, SF-23-Y-D-VI-1. Esc. 1: 50.000. 
FOLHA CATARATAS DO IGUAÇU. Porto Alegre: DSG, 1997. Mapa color, 72 x 62 cm, SG.21-X-D-VI-1, MI - 2847/1, 1997, Esc. 1:50.000.

FOLHA CHAPADA DOS GERAIS. Recife: DSG, 1974. Mapa color, 72 × $62 \mathrm{~cm}$, SC.23-X-B-IV, MI - 1433, Esc. 1:100.000.

FOLHA CURITIBA. Rio de Janeiro: IBGE, 1998. Mapa color, 75 x 60 cm, SF-22. Esc. 1:1.000.000.

FOLHA FOZ DO IGUAÇU. Porto Alegre: DSG, 1997. Mapa color, 72 × $62 \mathrm{~cm}$, SG 21-X-D-V-2, MI - 2846/2, 1997, Esc. 1:50.000.

FOLHA GUARATINGUETÁ. Rio de Janeiro: IBGE, 1976. Mapa color, $75 \times 60 \mathrm{~cm}$, SF-23-Y-B. Esc. 1: 250.000.

FOLHA ITAIPU. Porto Alegre: DSG, 1998. Mapa color, 72 x 62 cm, SG.21-X-D-II-4, MI - 2831/4, Esc. 1:50.000.

FOLHA MANAUS. Brasília: DSG, 1999. Mapa color, 72 × $62 \mathrm{~cm}$, SA.20-Z-D-II, MI 0578, Esc. 1:100.000.

FOLHA MANAUS-E. Brasília: DSG, 1994. Mapa color, 72 x 62 cm, SA.21-Y-C-I, MI - 0579, Esc. 1:100.000.

FOLHA MANAUS-N. Brasília: DSG, 1994. Mapa color, 72 × $62 \mathrm{~cm}$, SA.20-Z-B-VI, MI - 0517, 1994, Esc. 1:100.000.

FOLHA RIO DE JANEIRO. Rio de Janeiro: IBGE, 1998. Mapa color, 75 x $60 \mathrm{~cm}$, SF-23. Esc. 1:1.000.000.

FOLHA RIO PRETO DA EVA. Brasília: DSG, 1994. Mapa color, 72 × 62 cm, SA.21Y-A-IV, MI - 0518, Esc. 1:100.000.

FOLHA SANTA TERESINHA DE ITAIPU. Porto Alegre: DSG, 1997. Mapa color, 72 x $62 \mathrm{~cm}$, SG.21-X-D- III-3, MI - 2832/3, Esc. 1:50.000.

FOLHA SÃO JOÃO DO PIAUÍ. Recife: DSG, 1974. Mapa color, $72 \times 62 \mathrm{~cm}$, SC.23X-B-III, MI - 1357, Esc. 1:100.000.

FOLHA SÃO RAIMUNDO NONATO. Recife: DSG, 1974. Mapa color, $72 \times 62 \mathrm{~cm}$, SC.23-X-C-V, MI - 1511, 1974, Esc. 1:100.000.

FOLHA SÃO VICENTE. São Paulo: EMPLASA, 1974. Mapa p\&b, $58 \times 81 \mathrm{~cm}$, SF23-Y-D-IV-3-SE-C, Esc. 1: 10.000.

FOLHA SERRA DO CONGO. Recife: DSG, 1974. Mapa color, 72 × $62 \mathrm{~cm}$, SC.23X-B-V, MI - 1434, Esc. 1:100.000.

FOLHA VARGINHA. Rio de Janeiro: IBGE, 1979. Mapa color, 75 × 60 cm, SF-23-VD. Esc. 1: 250.000.

FOLHA VOLTA REDONDA. Rio de Janeiro: IBGE, 1976. Mapa color, $75 \times 60 \mathrm{~cm}$, SF-23-Z-A. Esc. 1: 250.000. 
PLANTA DE REFERÊNCIA CADASTRAL DE CAXAMBU. 1990, Esc. 1:5.000.

PLANTA DE REFERÊNCIA CADASTRAL DE MANAUS. 1998. Esc. 1:5.000.

PLANTA DE REFERÊNCIA CADASTRAL DE SÃO RAIMUNDO NONATO. 1997, Esc. 1:4.000.

\section{Mapas turísticos}

BARCELONA CITY MAP. GREMI d'HOTELS de BARCELONA: Barcelona, 2005.

BARCELONA CITY MAP. PLAN de la ville. Ajuntament de Barcelona: Barcelona, Espanha, 1992.

BARCELONA. Plano Monumental. Rivadeneyra Geoproyectos S.A: España, 1989.

CARTE DE FRANCE. Maison de la France: France, 2000.

CENTER CITY PHILADELPHIA and PHILADELPHIA'S COUNTRYSIDE.

Philadelphia Convention and Visitors Bureau: Philadelphia, 2001.

CIUDAD DE LA HABANA. Mapa turístico. Ediciones GEO: Cuba, 1993.

GIRONA. Ajuntament de Girona: Girona, não datado.

GLASGOW EVENTS. City guide \& map. Mapmasters: Edinburgo, 2001.

GUIA T DE BARCELONA. Barcelona: Planografico - N.G. Ediciones, Espanha, 1992.

GUIA TURÍSTICO DE OYAMA. Oyama: Japão, não datado.

ISRAEL-TOURING MAP. Ministry of Tourism: Jerusalém, 2000.

KILLARNEY Area Guide. Cork Kerry Tourism: Ireland, [s.d.].

LANDESHAUPTSTADT DÜSSELDORF. City-karte. Vermessungs-und Katasteramt Düsseldorf, 1992.

MAPA DE BUDAPEST. Tourism Office of Budapeste: Hungria, 2003.

MAPA DE HULL E OTAWA: WHERE TM Magazine: Ottawa, [s.d.].

MAPA DE LA CIUDAD DE MENDOZA E ALTA MONTANA. Artes Gráficas Unión:

Mendonza, 2004.

MAPA DE MANAUS. Perspectiva: Manaus, 2003.

MAPA SANTIAGO TURÍSTICO. SERNATUR: Santiago do Chile, 2005.

MAPA TURÍSTICO DA REGIÃO DE NAGANO. Kem: Nagano: [s.d.]

MAPA TURÍSTICO DA DUTRA. RDE Empreendimentos Publicitários Ltda: Rio de Janeiro, [s.d.]

MAPA TURÍSTICO DE CAXAMBU. Tour Mapas. Editora Buz: Caxambu, 2003. 
MAPA TURISTICO NACIONAL. Ediciones GEO: Cuba, 1996.

MISKOLC. Borsod-Abaúj-Zemplén. Tourinform: Hungria, 2004.

NIAGARA FALLS (Buffalo, Hamilton). Unique Media Incorporated: Ontário: $1997 / 98$.

OTTAWA VALLEY-VALLÉE DE L'OUTAQUAIS. Canada Centre for mapping: Ottawa, 1993.

PLANO DE MADRID. Cartografia Digital Rugoma: Madrid, 2005.

PLANO JOVEM DE A CORUÑA. Ayuntamiento de La Coruña: Guzman Norte, 2004.

POHJOIS-SAVON VESIRETKEILYREITIT JA-PALVELUT: Karttaikkuna Ou, Finlândia, 1999.

RED CAMINERA PRINCIPAL. Automóvil Club argentino: Argentina, 1988.

RÜGEN. Topographisch-Touristische Karte 1: 100.000: Herausgegeben, 1991.

SEATTLE. Tourmap Company: Seattle, 2005.

SHOPPING MAP. Menzoza: Global Refund, Argentina, 2005.

STORA STOCKHOLMSKARTAN. Stockholm Information Service: Suécia, 1997.

THE BEST OF SEAFORD - NEWHAVEN - ALFRISTON. Resort Maps: United Kingdom, 2004.

THE CITY OF CAMBRIDGE. Map and guide for shoppers \& Tourists. AERO-PLAN: Cambridge, 1995.

THE GOLDEN MAP BUENOS AIRES. Golden Company S. R. L.: Argentina, 1998.

TOLEDO. Junta de Cominidades de Castilla-La Mancha: Espanha, 2004.

VISITOR'S COMPANION. Colonial Williamsburg. The colonial Williamsburg Foundation: Virginia, 2000.

WESTERN CAPE. A bird's eye view. Tyger Valley centre: Durbanville, [s.d.]. datado. 


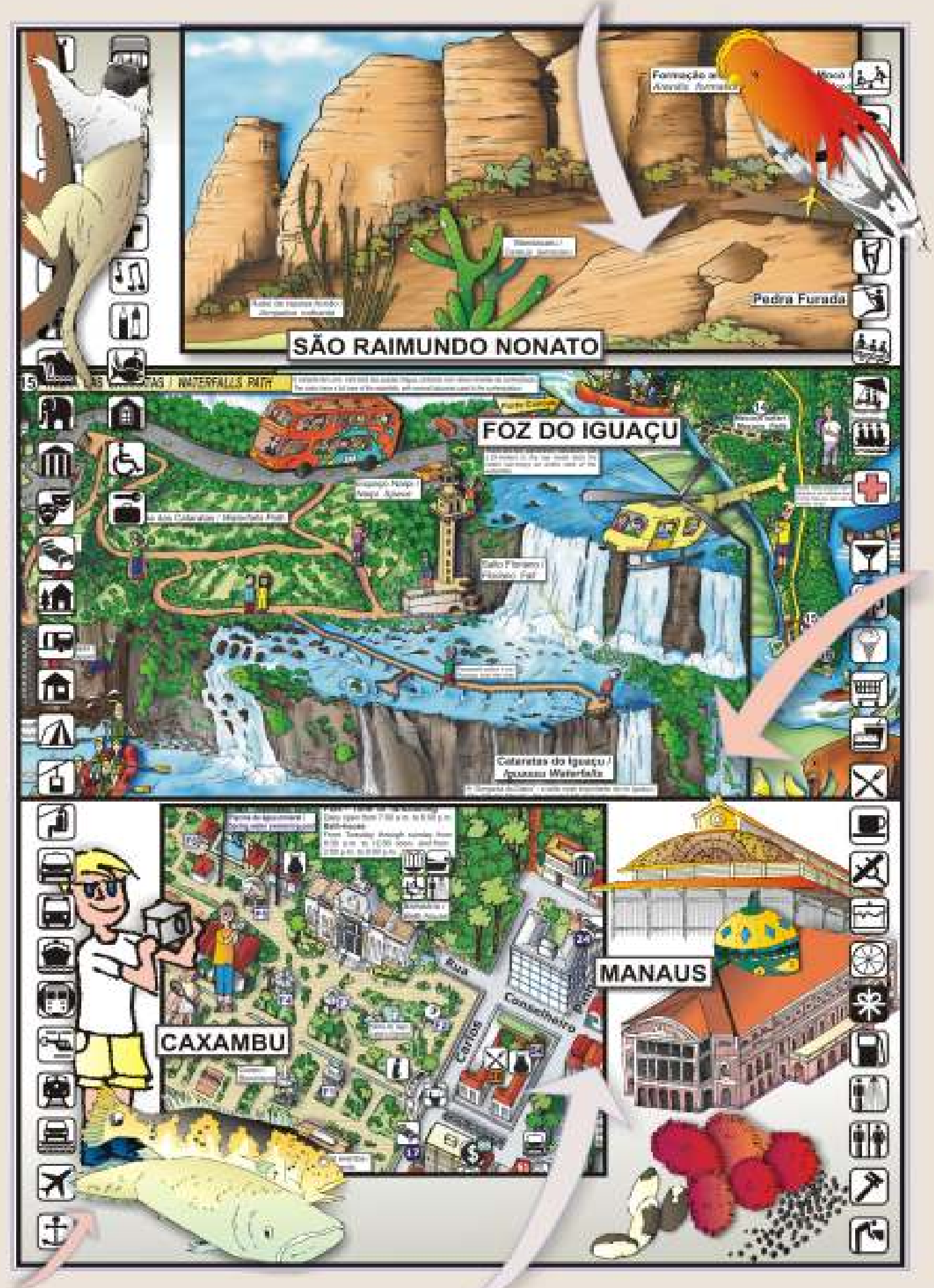

